DETMRTMENT OE THE INTEIIOR

INITHD STATES GEOLOCICAL STRVEY

EHAWIE- 6. WALCATT, HIERGTOR

\title{
CALIFORNIA HYDROGRAPHY
}

BY

TOSFPII BARLOW IMPPINCOTT

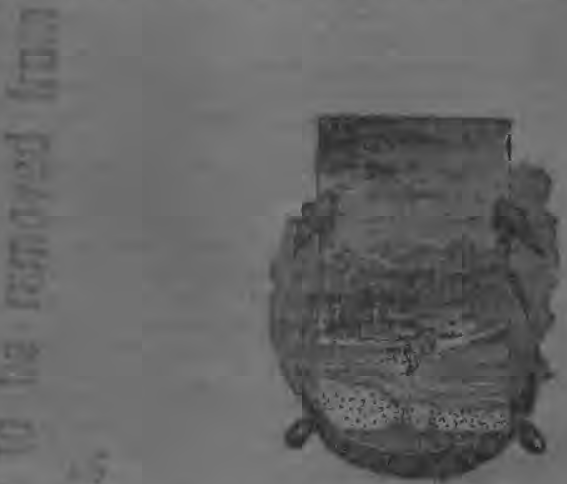

W A SHINGTON

GOSERNMTNT PRINTING OFFICE

1903 


\section{VBLICATIONS OF UNITED STATES GEOLOGICAL SURVEY.}

The publications of the tinited Stawn Genlogivel Sarvey consist of (1) Annual Reports; (2) Monographs; (3) Professional Papers; (2) Bulletins; (5) Mineral Resources; (6) Water-Supply and Irrigation Papers; (7) Topographic Atlis of Uniked kitakes, folios and separate shents thereof; (8) Geologio Atlas of United Statog, folios thereol. The classes numbered $2_{2} i_{1}$ and 8 are sold at cost of publication; the others are distributed free. A circulax giving complete lists may be had on application.

The Bulletins, Professional Papers, and Water-Supply Papers treat of a variety of subjects, and the total number issued is larEe. They have therefore been vlassified into the following series: A, Economic geology; B, Descriptive geology; C, Systematic geology and puleontology; D, Petrography and minoralogy; E, Chemistry and physices I, Geography; G. IMiscellaneous; H, Forestry; I, Irrigation; J, Water storage; I. Pumping water; I, Quality of water; M, Gencral bydrographic investigations; $N$, Water power; $O$, Underground waters; $P$, Hydrograpluic progress reports. Complete lists of papers relating to water supply and allied subjerts follow. ( $\mathbf{B}=$ Bulletin, $\mathbf{P P}=$ Profossional Paper, WS = Water-Supply Paper.)

\section{SERIES I-IRIUGANION.}

WS 2. Irrigation near Phnenix, Ariz, by A. P. Davis, 198\%. 98 pp, 31 pls, and maps.

WS 5. Irrigation practice on the Creat Plaing, by E. B. Cowgill. 189:. $32 \mathrm{pD}, 11$ pls.

WS 9. Irrigation near Greeley, Colo., by David Boyd. 189\%. 90 pp., 21 pls.

WS 10. Irrigation in Mesilla. Valley, New Mexico, by F. C. Barker. 1848, 51 pp., 11 pls.

WS 13. Irrigation systems in Texas, by W. F. Hutson. 1895. 68 pp., 10 pls.

WS 17. Irrigation near Bakersfield, Cal., by C. E. Grunsky. 1898. wi pp., 16 pls

WS 18. Irrigation near E' resno, Cal., by C. E. Grunsky. 1898. 94 pr., 14 pls.

WS 19. Irrigation near Merced, Cai, by C. E. Grunsky. 1699. 59 pp-, 11 pls.

WS 23. Water-right problems of Bighoru Mountains, by Elwood Merud. 1899. 62 yp., 7 pls.

WS 32. Water resources of Porto Rico, 1ry H. M. Wilsou, 1829.48 pp., 17 ple. and maps.

WS 43. Conveyance of water in irrigation cazals, flumes, and pipes, bv Samuel Fortier. 1901 $86 \mathrm{pp}, 15 \mathrm{pls}$

WS 70. Geology and water resources of the Patrick and Goshen Hole quadraogles, Wyoming, by G. I. Adams. 1902.50 pp., 11 pls.

WS 71. Irrigation systems of Texas, by T. U. Taylor. $190 \% .137$ pp., 9 pls.

WS 74. Water resources of the State of Colnado, by A. L. Fellows. 1900, 131 pp., 14 pls.

The following papers also relate especially to irrigation: Irrigation in India, by H. DI. Wilson, in Twelfth Annual, Part II; two papers on irrigation engineering, by H. M. Wilson, in Thirteenth Annual, Pqu't III.

\section{SERTES J-WATER STORAOE.}

WS 33. Storage of water on Gila River, Arizona, by J. B. Lippincott. 1900. 98 pp., 33 pls.

WS 40. The Austin dam, by Thomas U. Taylor. 19c0. 51 pp., 13 pls.

WS 45. Water starage on Cache Creeli, California, by A. I. Chratler. 1901, 48 pj, 10 pls.

WS 46. Physical eharacteristics of Kern River, California, by F. H. Olmsted and Reconnaissance of Yuba River, California, by Marsden Manson. 1903. 57 pp. 8 pls.

WS 58. Storage of water on Kings River, California, by J. B. Lippincott. 19012.100 pp, at2 pls.

WS 68. Water storage in Truckee Basin, California-Nevada, by L. H. Tarlor. 19k8. 90 pi, 8 pls.

WS 73. Water storage on Salt River, Arizona, by A. P. Davis. 1902. 54 pp. 25 pls.

The following paper also showld be noted under this heading: Reservoirs for irrigation, by J. D. Schuyler, in Eighteenth Annual, Part IV.

\section{SERTES K-PMMPtive Water.}

WS 1. Pumping water for irrigation, by Herbert M. Wilson. 1846.57 pp., 9 pla.

WS 8. Windmills for irrigation, by E. C. Murphy. 189\%. 49 pp., 8 pls.

WS 14. New tests of certain pumps and water lifts used in imigation, by Orni P. Hood. 1898. $91 \mathrm{pp}, 1 \mathrm{pl}$.

WS 20. Experiments with windmills, by T. O. Perry. 1899.97 pp., 12 ple.

WS 29. Wells and windrnills in Nebraska, by E. H. Barbour. $189 \% .85$ pp., 27 ply.

WS 41. The winamin; its efficieney and economic use, Part I, by E. C. Murphs, 1901. 72 pp., 14 pls.

WS 42. The pindmill, Part II (eantinuatiou of No. 41). 1901. 73-147 pp., 13-16 pls.

(Continued on third page of cover.)

$\operatorname{IRR} 81-2$ 
DEPAITIHET OF THE INTERIOR

UNITED N'TATES GEOLOGICAL SURVEY

GHAILLA D. WALCOTT, HIRECTOR

\section{CALIFORNIA HYDROGRAPHY}

$\mathrm{BY}$

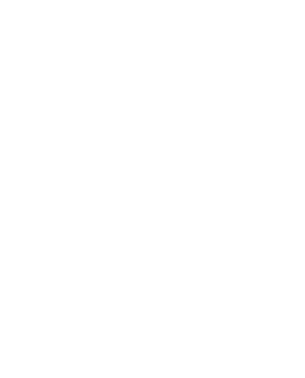

IVASIITNGTON

GOVERNMENT PRINTIN( 



\section{CONTENTS.}

Letter of transmittal

Introduction . . . . . . . . . . . . .

Relation of rainfall to run-off in California ........................ 14

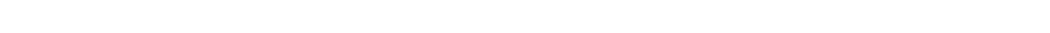

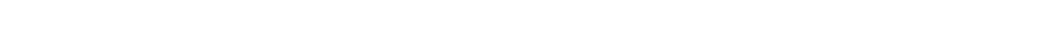

Sacramento River Basin . . . . . . . . . . . . . . . . . . . . . . . . 17

San Mateo Creek ... . . . . . . . . . . . . . . . . . . . . . . . . 18

Salt Springs Valley watersher _... $\ldots \ldots \ldots \ldots \ldots$

Stanislaus Rirer Basin . . . . . . . . . . . . . . . . . . . . . . . . . . 19

Tuolumne River Basin . . . . . . . . . . . . . . . . . . . . . . . . . . . 19

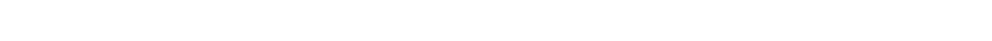

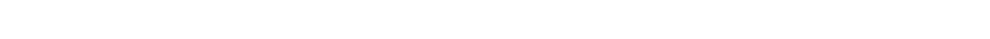

Cuyamaca reservoir watershed ... .................... 20

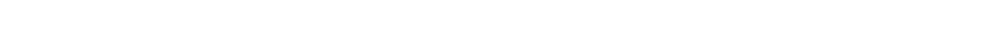

Evaporation . . . . . . . 20

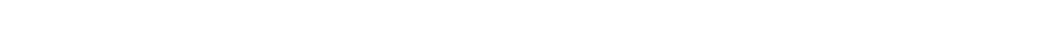

Reno, Nev . . . . . . . . . . . . . . . . . . . . . . . . . .

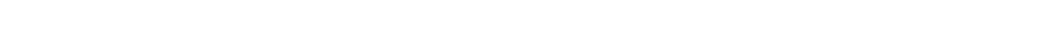

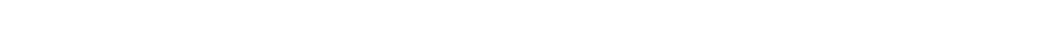

Clear Lake, Lakeport, Cal _... . . . . . . . . . . . . . . . . . . 31

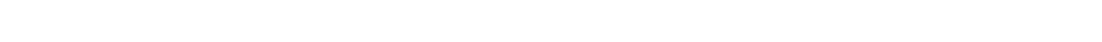

Aguilar Creek ............

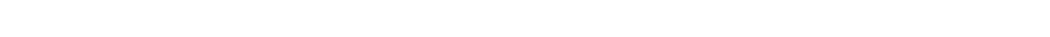

Alder Creek ... . . . . . . . . . . . . . . . . . . .

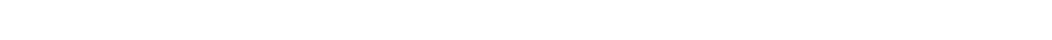

American River ....... . . . . . . . . . . . . . . . . . . . 40

Armas Creek ... ... . . . . . . . . . . . . . . . . . . . . . . . . . . 42

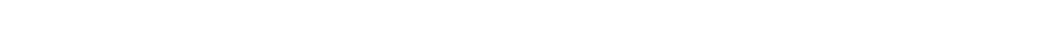

Arroyo Burro .... . . . . . . . . . . .

Arroyo Carnero _ . . . . . . . . . . . . . . . . . . . . . . . . . . . 43

Arroyo Grande . . . . . . . . . . . . . . . . . . . . . . . . . . . . . 4.43

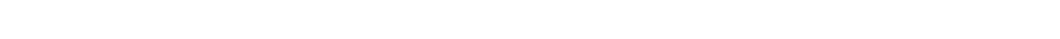

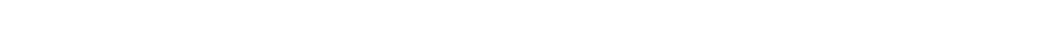

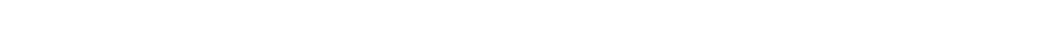

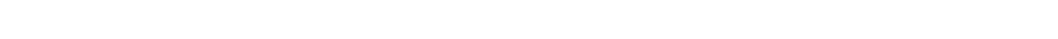

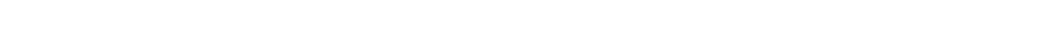

Big Rock Creek .... . . . . 50

Williams River . . . . . . . 50

Bloomington flume, San Bernardino County . . . . . . . . . . . . 50

Briscoe Creek, Glenn County _......................... 50

Burney Creek .... . . . . . . . . . . . . . . . . . . . . . . . . . . . 50

Butano Creek ...... . . . . . . . . . . . . 50

Cache Creek .......... . . . . . . . 51

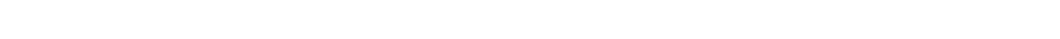

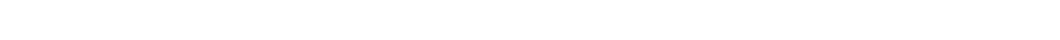

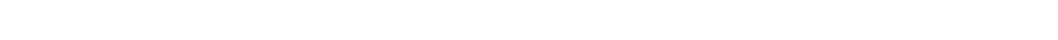

Calloway canal ............

Camp Carlton ditch, San Bernardino County ............. 59

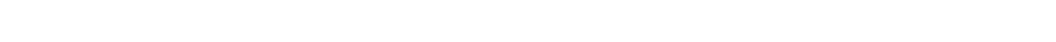


Discharge tables-Continued. Page.

Canyada Lares ... . . . . . . . . . . . . . . . . . . . . . . . . 60

Canyada Refugio . . . . . . . . 60

Canyada Verde ... . . . . . . . . . . . . 60

Capitan Creek ........ 60

Carpenteria Creek . . . 61

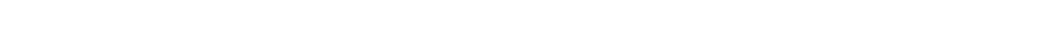

East Fork Carson River . . . 61

West Fork Carson River............................... 63

Cascade Creek, Tuolumne County .......................... 64

Cherry Creek, Tuolumne County . . . .

Chino Creek, Riverside County ................ 64

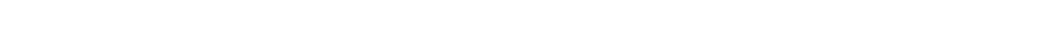

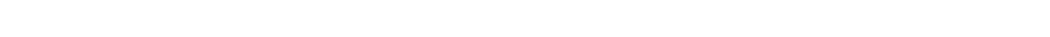

Cold Spring Canyon . . $\ldots \ldots$.

Coldwater Creek $\ldots \ldots \ldots$

Colorado River

Colton and Colton Terrace, San Bernardino County ............ 71

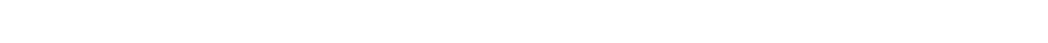

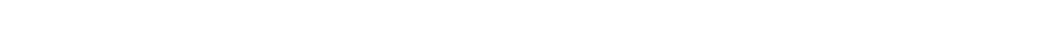

Cow Creek, Tuolumne County ................... 75

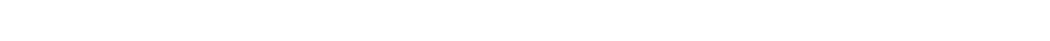

Daley ditch, San Bernardino County … $\ldots \ldots \ldots \ldots$

Deer Creek . . . . . . .

Dinsmore Creek $\ldots \ldots \ldots 1$

Dobbins Creek . .

Dos Pueblos Creek ......... 81

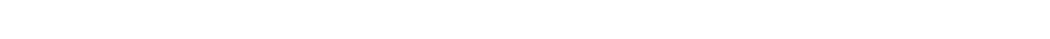

East Riverside Water Company, San Bernardino County .......... 85

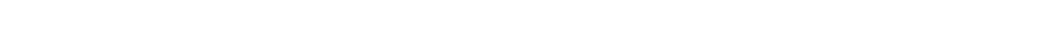

Eleanor Creek . .

Falls Creek .... $\ldots \ldots \ldots$

Fall River.......

Feather River ...

Ficay Creek $\ldots \ldots \ldots$

Fort Tejon Creek ............. 87

Fresno Creek .

Gage canal ....

Gato Creek ...

Gazoo Creek .......... 94

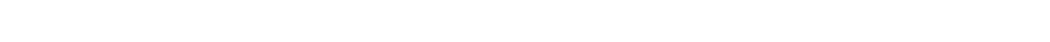

Green Spot pipe line ....

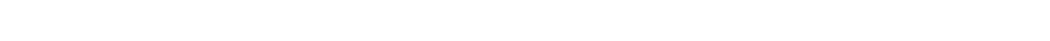

Gubernador Creek $\ldots \ldots \ldots$

Hat Creek $\ldots 4 \ldots$

Haws and Talmage ditch $\ldots \ldots \ldots$

Honey Lake . . .

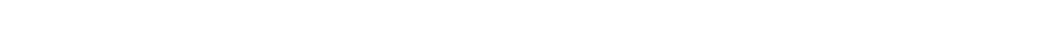

Kaweah River

Kern River. . . .

King River

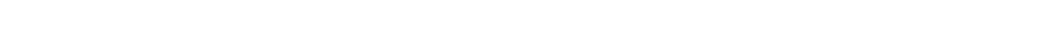

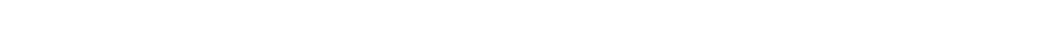

Logsdon and Farrel ditch, San Bernardino County .............. 120

Loma Abajo . . . . . 120 
Discharge tables-Continued.

Page.

Lopez Creek

123

Los Angeles River

Los Flores Canyon . . . . . . . . . . . . . . . . . . . . . . . . . . . . 13 .

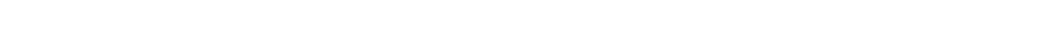

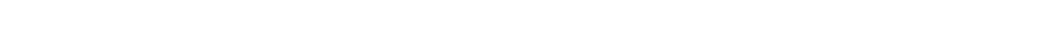

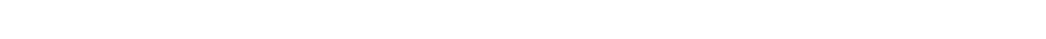

Mariposa Creek ... . . . . . . . . . . . . . . . . . . . . . . . . 149

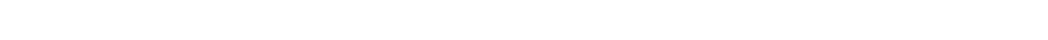

McCloud River . . . . . . . . . . . . . . . . . 152

McIntyre ditch ... . . . . . . . . . . . . . . . . . . . . . . . . . . 152

McKenzie ditch . . . . . . . . . . . . . . . . . . . . . .

Meeks and Daley ditch $\ldots \ldots \ldots$

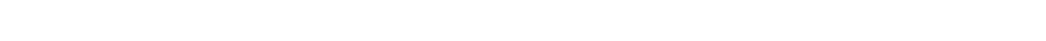

Mill Creek (King River) $\ldots \ldots \ldots \ldots \ldots$

Mill Creek (Santa Ana River) _. . . . . . . . . . . . . . . . . . . 158

Mill Creek, Green Spot pipe line . . . . . . . . 163

Mill Creek (Stanislaus River) _. . . . . . . . . . . . . . . . . . . . . . . . 163

Mill flume and pump, Riverside Water Company . . . . . . . . . . . . . 163

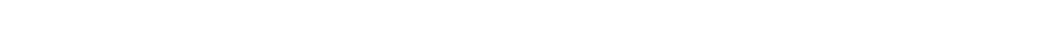

Mohave River .........

Mokelumne River. . . . . . . . . . . . . 168

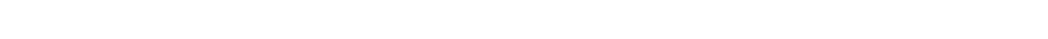

Niagara Creek .

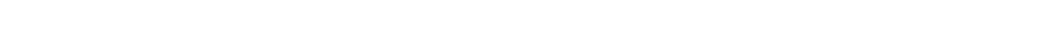

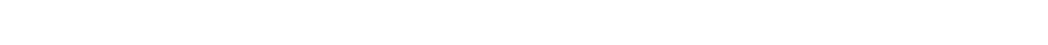

Padaro Creek $\ldots \ldots \ldots \ldots$

Pallett Creek .............

Pasadena Mesa ................. 174

Pastoria Creek

Pescadero Creek . . . .

Pilarcitos Creek ............ 181

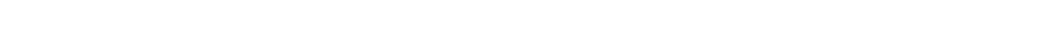

Pit River $\ldots \ldots \ldots \ldots \ldots$

Plunge Creek ... . . . . . .

Pomponio Creek . . . . .

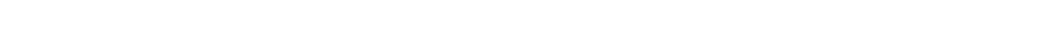

Purissima Creek. . . .

Putah Creek .... . . . . . 186

Rabel dam ditch, San Bernardino County $\ldots \ldots \ldots$

Ranchero ditch, San Bernardino County ...

Red Hills developments ...

Redlands canal _.... 186

Rincon Creek

Rubicon River.

Riverside Water Company, Upper Canal . . . . . . . $\ldots \ldots \ldots$

Sacramento River . . . . . . 186

Salinas River . . . . . . . . $\ldots \ldots \ldots \ldots$

Tributaries of Salinas River _... $\ldots \ldots \ldots 2$

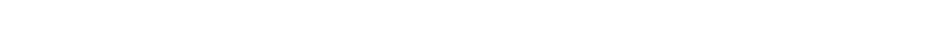

Nacimiento Creek .

Burnett Creek

San Antonio Creek

San Lorenzo Creek $\ldots$.

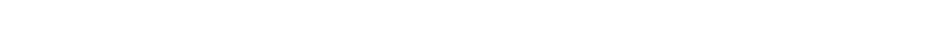


Discharge tables-Continued. Page.

San Antonio Creek .... . . . $\ldots \ldots \ldots$

San Bernardino Valley - . . . . . .

San Diemas Wash ..... . . . . . .

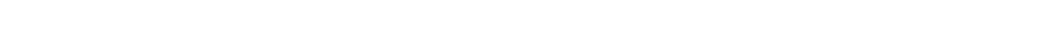

San Francisquito Creek ....... . . . . . . . . . .

San Gabriel River . . .

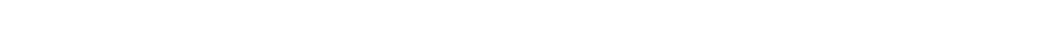

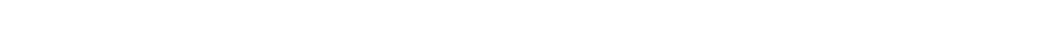

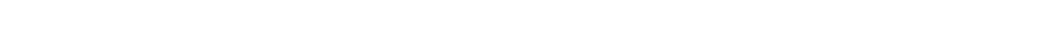

San Luis Rey River $\ldots \ldots \ldots \ldots \ldots \ldots$

San Mateo Creek ........ . . . . . . . . . . . . . . . . . . . . . . . 275

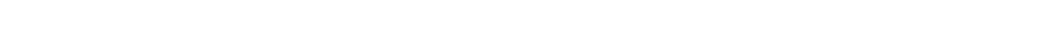

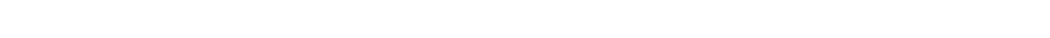

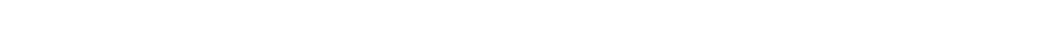

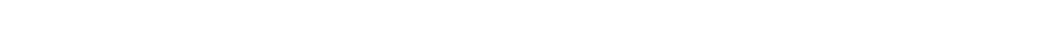

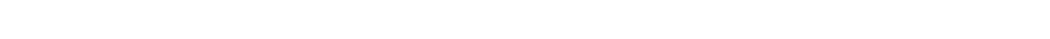

Santa Paula River ... . . . . . . . . . . . . . . $\ldots 24$

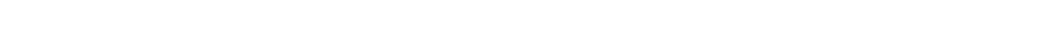

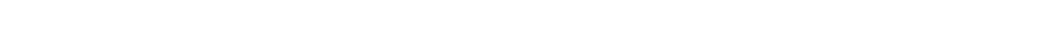

Sespe Creek .... . . . . . . . . . . . . . . . . . . . . . . . . . . . . . . . . 328

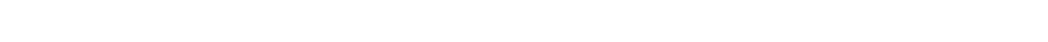

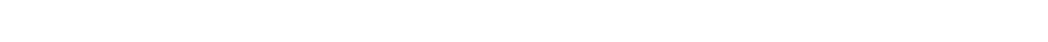

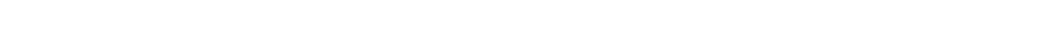

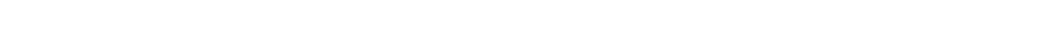

Stony Creek . . . . . . . . $\ldots \ldots \ldots \ldots$

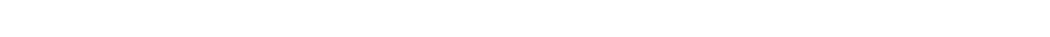

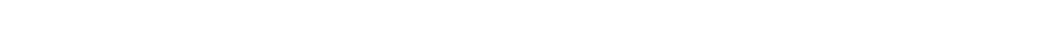

Sweetwater River $\ldots \ldots \ldots \ldots \ldots$

Tecolote Creek … $\ldots \ldots \ldots \ldots \ldots$

Tejon Creek $\ldots \ldots \ldots \ldots \ldots$

Tejon House Creek . . . . . . . . . . . . . . . . . . . . . . . . . . . . . . . . . 3

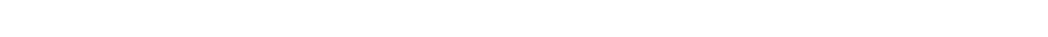

Toro Canyon . . $\ldots \ldots$

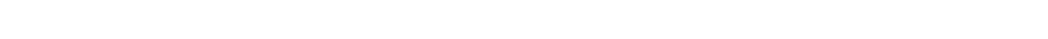

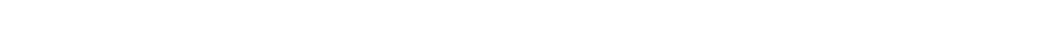

Tule River $\ldots \ldots \ldots \ldots \ldots$

Tumitus Creek ... $\ldots \ldots \ldots \ldots$

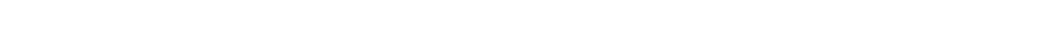

Tuolumne River . . . . . $\ldots \ldots \ldots$

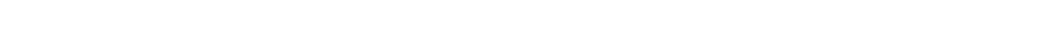

Walker River $\ldots \ldots \ldots \ldots \ldots$

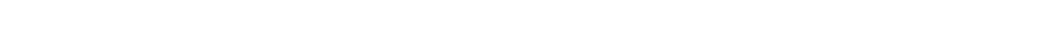

Warm Creek ......................................... 402

White Creek ..... . . . . . . . . . . . . . 403

Whitewater River ................................... 406

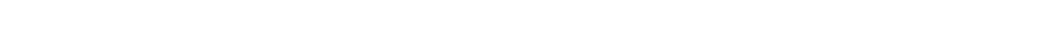

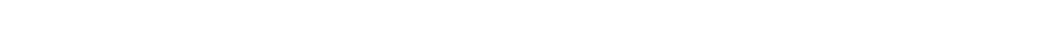

Yuba River ............. . . . . .

Maximum flood measurements .................................. 410

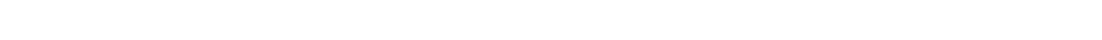

Rainfall tables ..................................................... 420 


\section{ILLUSTRATIONS.}

Pldte I. Map of Californi: . . . . . . . . . . . . . . . .

FIt. 1. Diagram showing increase of rainfall with rise in elevation over the Sierras in central California ...........................

2. Annual and mean run-off from California watersheds. based on several years' observations . . . . . . . . . . . . . . . . . . . . . . . . 17

3. Map showing location of wells near Pasadena ............... 175

4. Figure showing construction of weir ..................... 411 



\title{
LETTER OF TRANSMTTTAL.
}

\author{
DEPARTMENT OF THE INTERIOR, \\ United states Geological SURver, \\ DIVISION OF IIYDROGRAPHY, \\ Washington, D. C., January 15, 1903.
}

SIR: I have the honor to transmit herewith a paper entitled "California IIydrography," by Mr. .J. B. Lippincott, containing a summary of as much of the data concerning the water supply of California as is available from printed records and from observations of other engineers and investigations made by this Survey. The published records on the subject, hitherto much scattered, some of then out of print and difficnlt to secure, are here brought together, and the paper should therefore form a convenient and valuable book of reference for the use of engineers, irrigators, and all who are interested in the development of the valuable water resources of California.

For convenience in the use of the book the prominent drainage basins have been placerl in alphabetic order, and the minor tributaries of the larger streams have been arranged alphabetically under the name of the trunk stream into which they discharge. The minor tributaries and irrigation ditches have in addition been cross-entered in alphabetic place, so that they may be found independently under their local names. The discharge measurements include both lowwater and flood records and are arcompanied by useful precipitation data.

Very respectfully,

F. H. NeWELL, Hydrographer in Charge.

Hon. Charles D. Walcotot,

Director United States Geological S'urvey. 



\title{
CALIFORNIA HYDROGRAPHY.
}

\author{
By .JOSEPH BARLOW IIPPINCOTT.
}

\section{INTRO DUCTION.}

The purpose of this publication is to assemble under one corer as much of the data concerning the water supply of California as is available from printed records, observations of other engineers, and investigations made by this Survey. The greater portion of the data are obtained from the latter source. The records of striam flow that have been published by the Tnited States Geological Survey appear, first, in numerous Water-Supply Papers, which are published annually, soon after the end of the year's work, and contain a brief summary of the past year's operations, and, second, in large amnual reports, showing the average monthly discharge and other records of streams in all portions of the United States. Thus, while the published record is complete, it is distributed through many volumes, and numerous investigators do not have a complete set of these publications.

The methods of stream measurement practiced by the reological Survey are fully described in Water-Supply and Irrigation Paper No. 56. In brief, they usually consist of measuring the cross section of the stream with a tape and a sounding rod, and determining the velocity at numerous points in this cross section by means of a current meter, usually of the Price type. On large streams the meter measurements are usually made from cables. On small streams they are often made from foot bridges. The velocity observed is applied to each subdivision of the cross section where it is made, and the aggregate discharge of these cross sections is taken as the total discharge of the stream. On small streams weir measurements are often made.

When a record of daily flow is to be kept on any river a gage rod is established on the stream near the point of measurement, and the height of the water on this rod is observed and recorded at the time each measurement is marle. By properly selecting periods of high, low, and average water for the times of measurement it is possible to 
formulate a rating or discharge curve for the river in terms of volume discharged and water height on the rod. A local observer is employed to read the rod daily, and from these observed rod readings a statement of daily, monthly, and annual discharge is deduced.

Some of the data given were contributed by irrigation and power companies from daily records kept at their head works. In cases of this kind due credit is given.

The reports compiled and published by the California State engineering department between the years 1878 and $1884^{\circ}$ are now out of print and hard to obtain. The information contained in them is therefore included in this paper. The method of stream measurament most commonly practiced by the state engineering department consisted of stretching two wires across the stream at a fixed distance apart and noting the time of passage of floats through the section observed from the upper to the lower wire. Cross-sectional areas were measured and the velocities indicated by the floats were applied thereto, thus determining the discharge. Daily records of river heights on gage rods were kept on a number of the streams in a manner similar to that practiced by the United States Geological Survey. A rating ti.ble for the station was obtained from the discharge measurements, and, by applying it to the daily rod readings, monthly and annual discharge tables were determined. In several instances, however, where records have been kept on neighboring streams the State engineering department has prepared theoretical discharge estimates of other streams in the same locality by using the rate of run-off per square mile obtained from a measured stream and applying it in determining the probable run-off from the basin of a neighboring stream. In cases of this kind the discharge figures are marked with a star. In each instance the effort has been made to give the date of the measurement, the name of the observer, the volume discharged, and a description of the locality and stream.

The measurements have been grouped in the principel drainage basins, but it would obviously be impossible to adhere rigidly to this arrangement. For instance, all the streams of the San Joaquin Valley are, technically speaking, tributary to San Joaquin River, but it would be manifestly improper to include all the main rivers from the Sierras in this section under the head of San Joaquin River. The rule therefore has been adopted of giving each prominent drainage basin its place in alphabetic sequence; the minor tributar'es of these large streams are then arranged alphabetically under the name of the trunk stream into which they discharge. For instance, Tuolumne River is considered an independent stream, but Eleanor Creek, Falls Creek, etc., are considered minor tributaries and are arranged under the heading "Tuolumne River." The effort has been made, however,

a No measurements were made by the California State engineering department subsequent to 1884 , as the office was then discontinued. 
to cross-enter all these minor tributaries, so that they may be found independently under their local names, reference being made to the trunk stream into which they discharge.

Undoubtedly many measurements that are not available for this publication have been made for corporations and individuals by engineers of California. These data, if they could be obtained, would doubtless be of great value, and the suggestion is here made that it would be a public benefit to send this information to the United States Geological Survey, where it would be available for publication in subsequent bulletins of this nature.

The records of the Signal Service and Weather Buryau are also contained in annual reports extending over a long term of years, and the engineer who possesses a complete file of these publications is indeed fortunate.

The rain water which forms the source of the water supply for agriculture in California falls in large part upon the mountain ranges of the State. It is a well-known fact that within the State there are vast differences in rainfall with increase or decrease of elevation, particularly on the western slopes of the mountain ranges. Rainfall statistics have been compiled in great mass for the valley districts, where farming is actually carried on, but the engineer who is investigating plans for storage and power is much more interested in the rainfall of the mountains. An attempt has been made to include in this paper all available data relative to precipitation at the higher elevations. The Weather Bureau publishes its records of precipitation in calendar years, beginning with the 1st of January, which is the middle of the rainy season on the California coast. A record beginning on the 1st of January may show for that and following months conditions of excessive drought, while for the following November and December of the same calendar year it may give records of excessive rainfall, the result indicated for the calendar year being a mean rainfall, whereas there may have been a dry season followed by one of excessive precipitation. For this reason the rainfall records for the mountain districts have been classified in seasonal years, and it is bolieved that. their presentation in this form will avoid for the engineer many laborious retabulations of results. Particular effort has bsen made to collect and present new data.

Each table of precipitation is accompanied with a statement showing the approximate position of the station and its elevation, as well as the authority for the record. These records are in part taken from the annual reports of the Weather Bureau and rearranged in seasonal instead of calendar years, as stated above. All the regular stations of the United States Weather Bureau are situated at relatively low elevations with the exception of Mount Tamalpais, but some voluntary observers report to the Weather Bureau from mountain sta- 
tions. 'These observers use a variety of measuring devices. Some use glass graduates, with various-sized catchment cups, and some employ more primitive implements. The records of mountain precipitation, however, are so scarce that they are all given here, because it is believed that any information tending to throw light on this subject is of value.

All the records that are credited to the Southern Pacific Raihroad were obtained from Mr. William Hood, chief engineer of the system. The rain gages used by the railroad company are small gages with 3-inch catchment cups, usually set on posts about 6 feet ir height, and the observations are made by the local railroad agents. Their reports are sent in promptly to San Francisco and are there tabulated by a corps of clerks whose time is devoted entirely to this subject.

In many places in the high mountain districts, particularly at the greatest elevations, the gages have been lately furnished by the hydrographic branch of the United States Geological Survey. The gages used in these places are of the standard type, with an 8-inch measuring cup. Snow observations are made by melting the snow and reporting the resultant water.

\section{RELATION OF RAINEALL TO RUN-OFF IN CALIFORNIA.}

\section{DIAGRAMS AND TABLES.}

The arcompanying diagrams and tables are presented as the result of a study of the available rainfall and run-off data for Cahifornia watersheds.

As the run-off diagram was to be used in estimating the water supHy available for various storage reservoirs for irrigation, it was thought best to represent the run-off in acre-feet per square mile. The majority of the discharge reports give the depth of run-off in inches. The accompanying table has been made for converting depth of run-off in inches to run-off in acre-feet per square mile, the following formula being used:

Depth of run-off in inches $\times(0.0833 \times 640)=$ run-off in acre-feet per square mile. 
Table for converting depth of run-off in inches into acre-feet per squere mile.

\begin{tabular}{|c|c|c|c|c|c|c|c|}
\hline $\begin{array}{l}\text { Depth of } \\
\text { run-off. }\end{array}$ & $\begin{array}{c}\text { Acre-feet } \\
\text { per square } \\
\text { mile. }\end{array}$ & $\begin{array}{l}\text { Depth of } \\
\text { run-off. }\end{array}$ & $\begin{array}{c}\text { Acre-feet } \\
\text { per square } \\
\text { mile. }\end{array}$ & $\begin{array}{l}\text { Depth of } \\
\text { run-off. }\end{array}$ & $\begin{array}{c}\text { Acre-feet } \\
\text { per square } \\
\text { mile. }\end{array}$ & $\begin{array}{l}\text { Depth of } \\
\text { run-off. }\end{array}$ & $\begin{array}{c}\text { Acre-feet } \\
\text { per square } \\
\text { mile. }\end{array}$ \\
\hline Inches. & & Inrhes. & & Inches. & & Inches & \\
\hline 0.01 & 0.533 & 0.26 & $13.86 \pi$ & 0.51 & $2 \pi .200$ & 0.76 & 40.533 \\
\hline .02 & $1.06 i$ & $.2 \pi$ & 14.400 & .52 & $2 \pi .733$ & .7 & $41.06 \pi$ \\
\hline .03 & 1.600 & .28 & 14.933 & .53 & $28.26 \pi$ & .78 & 41.600 \\
\hline .04 & 3.133 & .29 & $15.46 \pi$ & .54 & 28.800 & .79 & 42.133 \\
\hline .05 & 2.667 & .30 & 16.000 & .55 & 29.333 & .80 & $42.66 \%$ \\
\hline .06 & 3.200 & .31 & 16.533 & .56 & 29.867 & .81 & 43.200 \\
\hline $.0 \%$ & 3.733 & .32 & $1 \% .06 \%$ & $.5 \%$ & 30.400 & .82 & 43.733 \\
\hline .08 & 4. $26 \%$ & .33 & 17.600 & .58 & 30.933 & .83 & $44.26 \%$ \\
\hline .09 & 4.800 & .34 & 18.133 & .59 & $31.46 \%$ & .84 & 44.800 \\
\hline .10 & 5.333 & .35 & $18.66 \%$ & .60 & 32.000 & .85 & 45.333 \\
\hline .11 & $5.86 \%$ & .36 & 19.200 & .61 & 32.533 & .86 & $45.86 \%$ \\
\hline .12 & 6.400 & $.3 r$ & 19. 733 & .62 & $33.06 i$ & $.8 i$ & 46.400 \\
\hline .13 & 6.933 & .38 & $20.26 \pi$ & .63 & 33.600 & .84 & 46.983 \\
\hline .14 & $\tau .46 \pi$ & .39 & 20.800 & .64 & 34.133 & .89 & $4 \pi .46 \%$ \\
\hline .15 & 8.000 & .40 & 21.333 & .65 & $34.66 \pi$ & .90 & 48.000 \\
\hline .16 & 8.533 & .41 & $21.86 i$ & .66 & 35.200 & .91 & 48.533 \\
\hline .17 & $9.06 \%$ & .42 & 22.400 & .67 & 35. $\% 33$ & .92 & $49.06 \pi$ \\
\hline .18 & 9.600 & .43 & 22.933 & .68 & 36.267 & .93 & 49.600 \\
\hline .19 & 10.133 & .44 & 23.467 & .69 & 36.800 & .94 & 50.133 \\
\hline .20 & $10.66 \%$ & .45 & 24.000 & .70 & $3 \pi .333$ & .95 & $50.66 \%$ \\
\hline .21 & 11.200 & .46 & 24.533 &.$\tau 1$ & $3 \pi .86 \pi$ & .96 & 51.200 \\
\hline .22 & 11. 733 & $.4 \%$ & $25.06 \tau$ & .22 & 38.400 & .97 & 51.733 \\
\hline .23 & $12.26 \%$ & .48 & 25.600 & .73 & 38.933 & .98 & $52.96 \%$ \\
\hline .24 & 12.800 & .49 & 26.133 & .74 & 39.467 & .99 & 52.800 \\
\hline .25 & 13.333 & .50 & 26.667 & .75 & 40.000 & 1.00 & 53.333 \\
\hline
\end{tabular}

At the outset many difficulties presented themselves. The most serious one was that of obtaining measurements of rainfall at the higher elevations. The streams having the largest run-off, and on which discharge records had been kept, have their sources on the western slopes of the high Sierra Nevada, where there are few or no inhabitants above 7,000 feet, and consequently no observers of rainfall; but the valuable rainfall records of the Pacific Railway system along the line of railway from Sacramento to the summit of the Sierra Nevada at Railroad Pass offered a solution of this difficulty. In fig. 1 the mean rainfall and the elevation of the station are plotted as ordinates, and the distance inland of the station as abscissas.

The rate of increase of precipitation from Sacramento to Cisco, at the elevation of 6,000 feet, the point of maximum rainfall, seems to 
be 0.6 inch per 100 feet of rise. The precipitation above the $6,000-$ foot point decreases with the elevation approximately at the rate of 0.4 inch per 100 feet of rise.

Fortunately, in Tuolumne River Basin, about midway between American and King river basins, there is another series of rainfall stations, including Lagrange, elevation 293 feet above sea level; Sonora, elevation 1,824 feet; Second Garrote, elevation 2,900 feet, and Crockers, elevation 4,453 feet. The mean rainfall of these stations, plotted as in the above diagram, indicates the rate of incrase from Lagrange to Crockers to be $0.8 \pm$ inch per 100 feet of rise. This rate of increase has been taken to hold good up to an elevation of 6,000 feet, and above this the rate of decrease of rise to be 0.4 inch per 100 feet to an elevation of 9,000 feet. Probably the rate of increase and

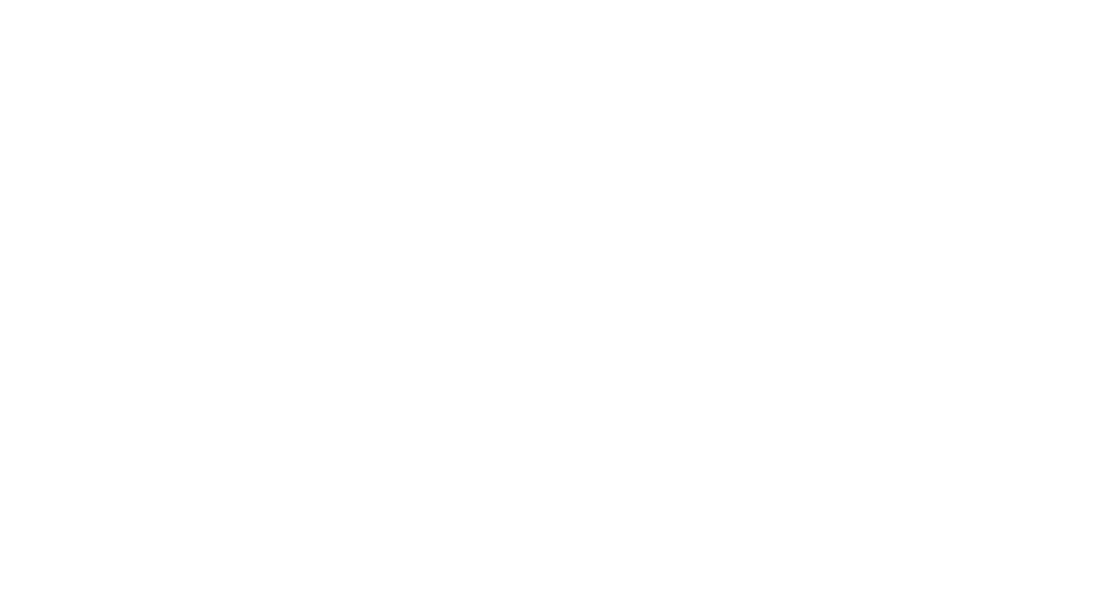

FIG. 1.-Diagram showing increase of rainfall with rise in elevation over the Sierras in central California.

decrease would be more correctly represented by a curved line, but the data are not sufficient to warrant such representation.

At these rates of increase and decrease, the mean precipitation for the years 1896-1899, at an elevation of 9,000 feet in the Tuolumne River Basin, would be 49.8 inches; if snow converts into water at the ratio of 8 to 1 , the snowfall would be 33.2 feet at this elevation.

It was found impossible to use the run-off data of Kern River Basin-though that stream is without doubt more closely watched than any other stream in the state and the record is the oldest for any large stream in the State-because of the exposure of the watershed and because of the scarcity of rainfall data. This watershed is bounded on the west for almost its entire length by a high mountain range. Concerning the precipitation on the eastern slope of this range, little is known beyond the fact that it is very much less than on the western slope. 
and flows over the top of the walls of the dam on the side, so that the large flood measurements that have been computed contain considerable elements of error. The measurements of smaller volumes, however, are doubtless more accurate. The Spring Valley Water Company, of San Francisco, has a pumping station which is supplied from an intake above the Niles dam, so that the amount of water pumped, as given in the following tables, should be added to the amount of water passing over the weir, in order to get total discharge.

During a term of years the Spring Valley Water Company kept observations at this weir dam of the height of water on the weir and the length of weir, and also of the amount of water pumped. These data were presented as Exhibit 11 in a certain suit entitled "Clough $r$. Crystal Springs Water Company of San Francisco," involv. ing water rights to Alameda Creek, tried in the Alameda County superior court in the fall of 1901 .

The record is not entirely complete, but the available data were assembled and computations of discharge were made by this office, and average monthly flow is given in the following tables. In some instances uncertainty exists as to the proper length of weir. This matter has been taken up, however, with the Spring Valley Water Company, and all corrections have been made for which the data are available. While the record is not considered perfect, it is the best obtainable, and in view of the extent of the data it is deemed to be worthy of publication.

Discharge measurements of Alameda C'reek, Alameda C'ounty.

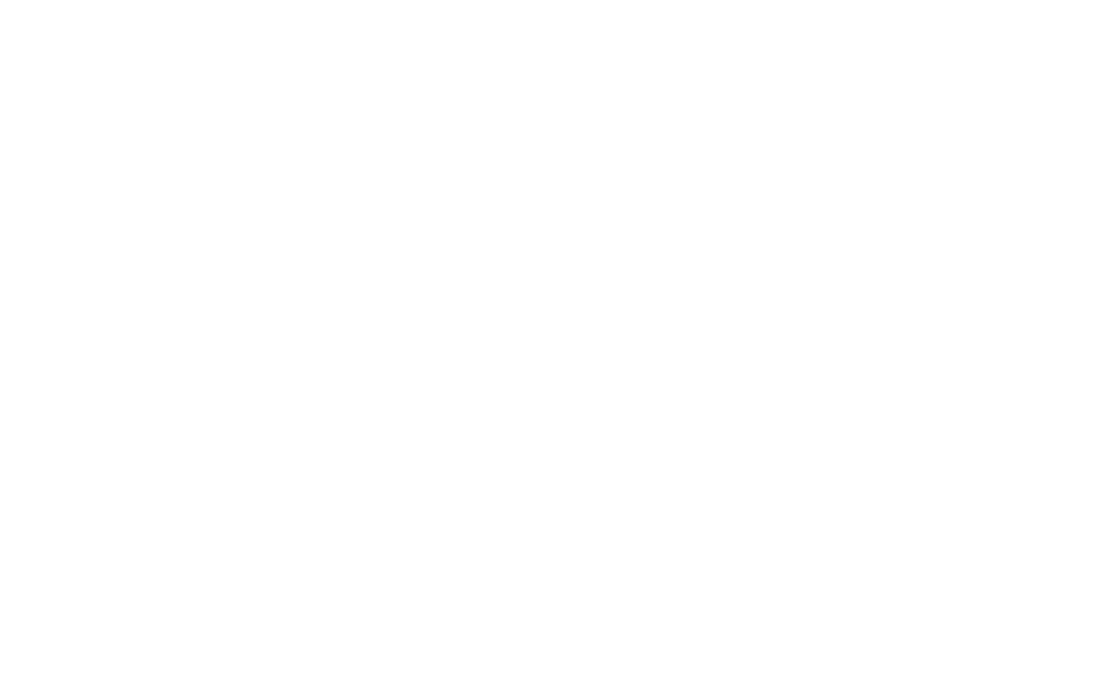

IRR $81-03-3$ 
Estimated monthly discharge of Alameda Creek at Niles dam.

\begin{tabular}{|c|c|c|c|c|}
\hline \multirow{2}{*}{ Month. } & \multicolumn{3}{|c|}{ Discharge over weir. } & \multirow{2}{*}{$\begin{array}{l}\text { Quantity } \\
\text { of watel } \\
\text { pumped. }\end{array}$} \\
\hline & Maximum. & Minimum. & Mean. & \\
\hline 1889. & second-feet. & Second-feet. & Second-feet. & Sec.feet. \\
\hline January . . . . & $\ldots \ldots$ & $\begin{array}{l}\ldots \ldots \\
\ldots\end{array}$ & …... & 12 \\
\hline February .... & $\ldots$. & & $\ldots$ & 11 \\
\hline March ..... . & $\ldots \ldots$ & . . . . . . & $\ldots \ldots$ & 8 \\
\hline April & $\ldots$ & . . . . . & ....... & 13 \\
\hline May ........ & $\ldots \ldots$ & & $\ldots$. & 13 \\
\hline June . . . . . . . & $\ldots \ldots$ & $\ldots$. & $\ldots \ldots \ldots$ & 12 \\
\hline July _... . . . & $\ldots \ldots$ & $\ldots \ldots$ & $\ldots \ldots$ & 11 \\
\hline August ...... & $\ldots . .$. & $\ldots \ldots$ & $\ldots$ & \\
\hline September ..... & $\ldots$ & . . . . . . . & $\ldots$. & \\
\hline October . . . . . & $\ldots \ldots$ & $\ldots \ldots$ & $\ldots$ & \\
\hline November . . . . . & $\ldots$ & $\ldots$. & $\ldots$. & \\
\hline December ... . & 2,577 & . . . . . & 996 & \\
\hline The year & ..... & $\ldots .$. & ....... & 9.25 \\
\hline 1890. & & & . & \\
\hline January . . . . . . & 7,792 & 412 & 1,654 & \\
\hline February .... & 2,813 & 237 & $1,00 \pi$ & \\
\hline March ....... & 1.353 & 324 & 646 & \\
\hline April ........ & 412 & 176 & 242 & \\
\hline May ......... & $2 ; 3$ & 82 & 144 & \\
\hline June . . . . . . . & 88 & 41 & 62 & $\ldots$ \\
\hline July . . . . . . & $4 \pi$ & 22 & 31 & 7 \\
\hline August $\ldots .$. & 22 & 16 & 20 & 13 \\
\hline September & 38 & 16 & 17 & 12 \\
\hline October . . . . . & 28 & 16 & 17 & 12 \\
\hline November . . . . & 22 & 16 & 19 & 12 \\
\hline December .... & 293 & 31 & 49 & 10 \\
\hline The year. & & $\ldots$. & 326.5 & 5.7 \\
\hline
\end{tabular}


Estimated monthly discharge of Alameda Creek at Niles dam-Continned.

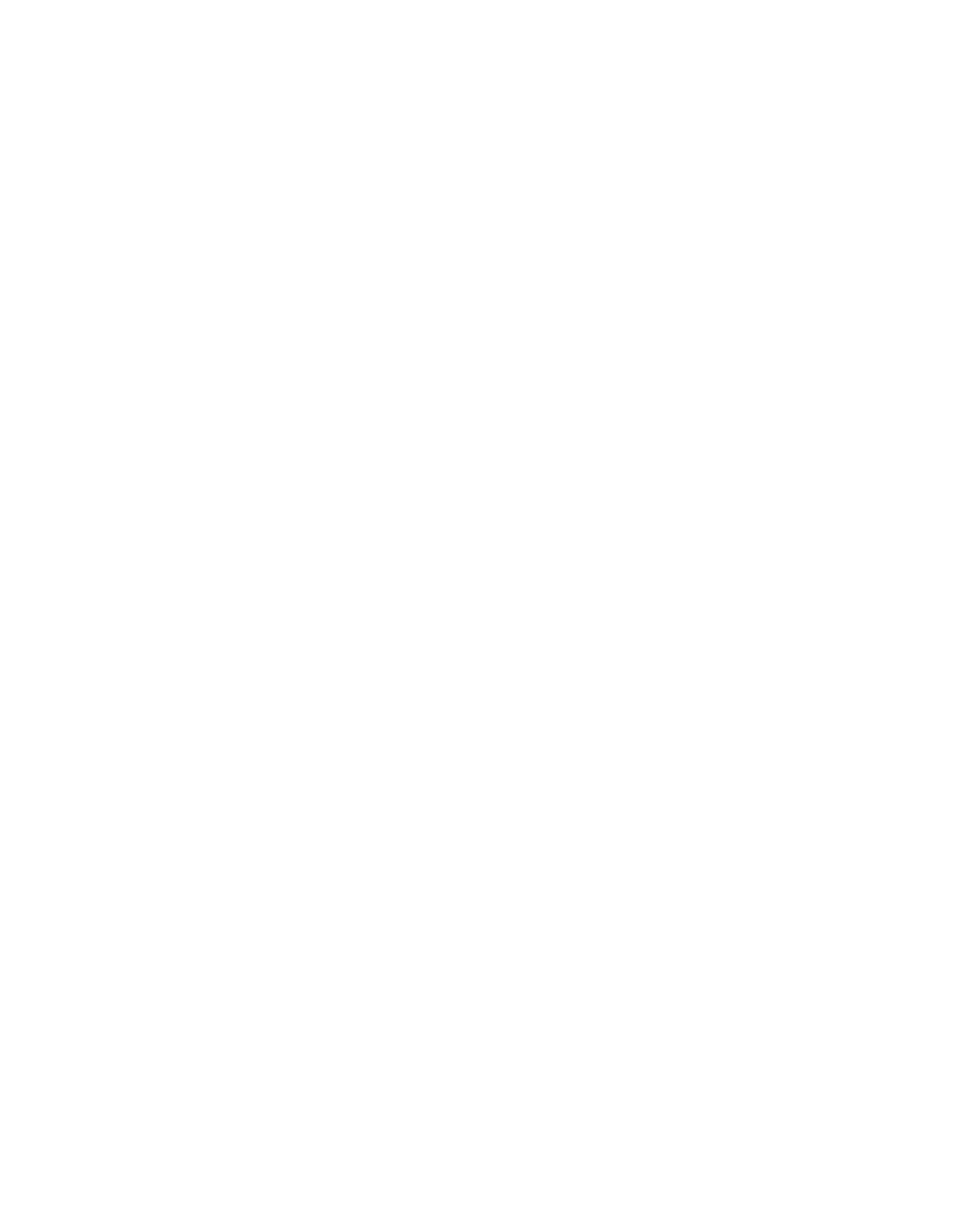


Estimated monthly discharge of Alameda Creek at Niles dam-Continued.

\begin{tabular}{|c|c|c|c|c|c|}
\hline & \multirow{2}{*}{ Month. } & \multicolumn{3}{|c|}{ Discharge over weir. } & \multirow{2}{*}{$\begin{array}{l}\text { Quantity } \\
\text { of water } \\
\text { pumped. }\end{array}$} \\
\hline & & Maximum. & Minimum. & Mear. & \\
\hline & 1893. & Second-feet. & Second-feet. & Second-feet. & Sec.feet. \\
\hline January . . . . . . & & 2,016 & 120 & 437 & \\
\hline February $a \ldots$ & & $2,57 \%$ & 237 & 743 & \\
\hline March ....... & & & & & \\
\hline April & & & & & \\
\hline May & & & & & \\
\hline June ...... & & & & & \\
\hline July _..... & & & & & 12 \\
\hline August . . . . . & & & & - & 12 \\
\hline September - - & & & & $\ldots$ & 9 \\
\hline October ..... & & & & & 8 \\
\hline November.... & & & & & 8 \\
\hline December .... & & & & $\ldots$ & $\tau$ \\
\hline The year & & & & ${ }^{b} 590$ & 5.3 \\
\hline & 1894. & & & & \\
\hline January . ... & & & & & \\
\hline February $\ldots .$. & & & & & \\
\hline March ...... & & & & $\ldots$ & \\
\hline April ....... & & & ... & - . & \\
\hline May .......... & & & $\ldots$ & $\ldots$ & \\
\hline June ........ & & & & & \\
\hline July ....... & & & & & \\
\hline August ... & & & & & \\
\hline September - & & & & & \\
\hline October ...... & & & & & 8 \\
\hline November...... & & & & & 2 \\
\hline December 9 to 31 & & $c 3,700$ & 79 & 659 & - - - \\
\hline . The year & & & & -... & 5.2 \\
\hline
\end{tabular}

a No record for rest of year. b'Two months mean. c No record prior to December 9. 
Estimated monthly discharge of Alameda Creek at Niles dam-Continued.

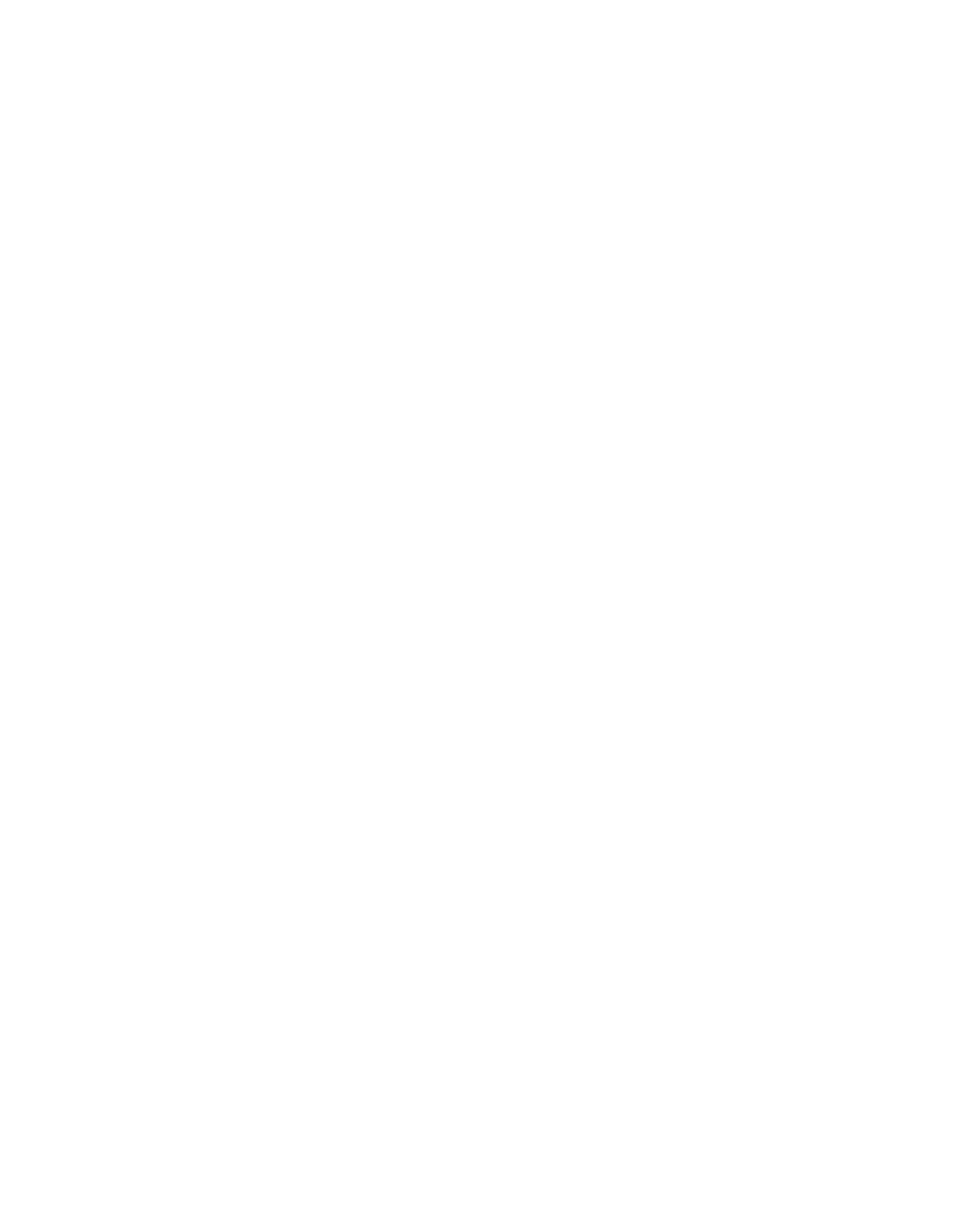

a Record missing February 15 to 28 , inclusive.

$b$ No record previous to July.

$c$ Record missing September 16 to 3 ), inclusize.

d Six months mean. 
Fstimated monthly dischurge' of Alameda Creek at Niles dam-Cortinued.

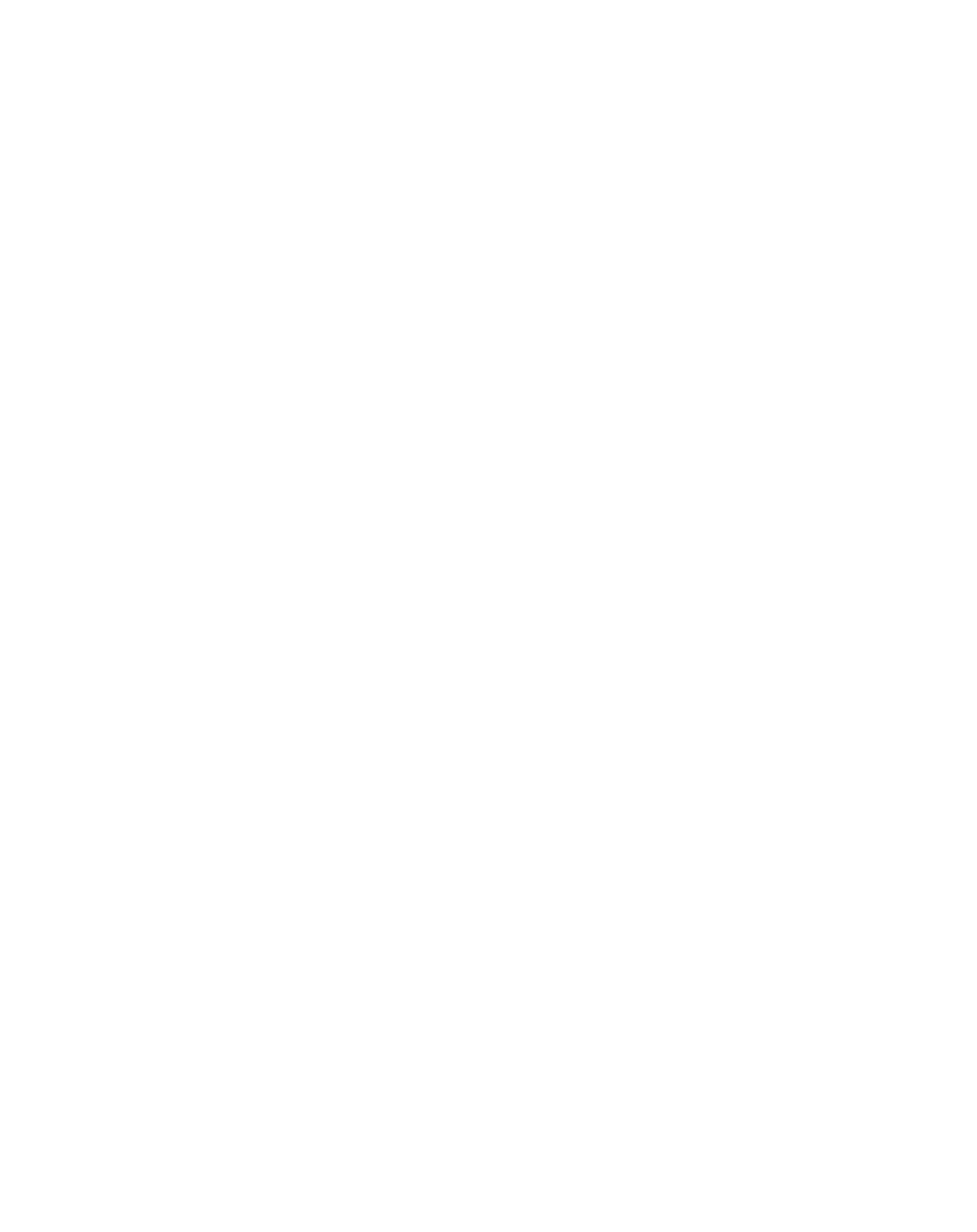

a Mean of July 1 to 15 , inclusive. No record for remainder of montl .

b No record from July 16 to November 15 , inclusive.

c No record from December 1, 189\%, to May 22, 1898, inclusive.

a No record from December 1, $189 \%$, to May 22,1898 , inclusive.

$e$ June 18 to October 22 , inclusive, water helow crest.

$f$ Nolength of weir given from October 23 to November 18 , inclusive. 
Estimated monthly discharge of Alamedu C'reek at Niles dam-Continued.

\begin{tabular}{|c|c|c|c|c|}
\hline \multirow{3}{*}{ Month. } & \multicolumn{3}{|c|}{ Discharge over weir. } & \multirow{3}{*}{$\begin{array}{l}\text { Quantity } \\
\text { of water } \\
\text { pumped. }\end{array}$} \\
\hline & & & $-\quad-$ & \\
\hline & Maximum. & Minimum. & Mean & \\
\hline $1 \times 99$. & | Second-feet. & second-feet. & second-feet. & Sere-feet. \\
\hline January - - & 431 & 0 & 41 & 8 \\
\hline February & 4 & 0 & 2 & 11 \\
\hline March" ... & & $\cdots$ & $\ldots$ & 6 \\
\hline April ......... & 200 & 21 & 54 & 10 \\
\hline May .......... & 19 & 6 & 12 & 11 \\
\hline June ........... & 8 & 2 & 4 & 12 \\
\hline July ... . . . . . & 1 & 0 & 1 & 12 \\
\hline August ..... & 0 & 0 & 0 & 12 \\
\hline September .. & & & & 11 \\
\hline October & & . & -. & 10 \\
\hline November . - & b38 & 8 & $4 r$ & 6 \\
\hline December .... & 565 & 14 & 101 & 7 \\
\hline The year . & & & & 9.67 \\
\hline 1900 & & & & \\
\hline January ... & 3,700 & 41 & 2.97 & 5 \\
\hline February $\ldots \ldots \ldots$ & 47 & 25 & 34 & 12 \\
\hline 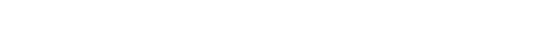 & 306 & 25 & 112 & $\gamma$ \\
\hline April .............. & $r 1$ & 25 & 35 & 12 \\
\hline May $\ldots \ldots \ldots$ & 31 & $\tau$ & 17 & 12 \\
\hline 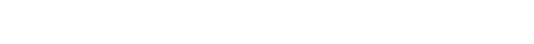 & 6 & 1 & 4 & 12 \\
\hline July ........... & 1 & 0 & 0 & 12 \\
\hline August $\ldots \ldots \ldots$ & 1 & 0 & 0 & 12 \\
\hline September ... - & $\| 17 !$ & 0 & 4 & 10 \\
\hline October .... & & & & 12 \\
\hline November ... & & & & $d 9$ \\
\hline December . . . . . & & & & -........ \\
\hline The year. & & & & ค 10.45 \\
\hline
\end{tabular}

"Record incomplete.

"August 17 to November 15 , inclusive, water below crest.

"No record from June $1 \tau$ to 24 , inclusive.

"IEnd of record.

e Eleven months mean. 


\section{ALDER CREEK.}

Alder ('reek is a tributary of the Santa Ana, in San Bernardino ('ounty. (See Santa Ana River, Alder Creek.)

\section{ALISO CREEK.}

Aliso Creek rises in the Fernando hills. It is normally dry at the points of measurement. During the night preceding the measurements there had been 0.65 inch of rain. At the point of first measurement it is 1.5 miles from the foothills. The measurements show the manner in which the creek sinks. Just below the point of second measurement the water all disappears.

Discharge measurements of Aliso Creek, San Fernando Valley.

\begin{tabular}{|c|c|c|c|}
\hline Date. & Hydrographer. & $\begin{array}{c}\text { Dis- } \\
\text { charge. }\end{array}$ & Locality. \\
\hline 1901. & & Sec.-foot. & \\
\hline January 28 . & J. B. Lippincott . . & 0.60 & At Chatsworth road crossing. \\
\hline Do $\ldots$ & $\ldots$ do _........... & .32 & 2 miles below roat crossing. \\
\hline
\end{tabular}

\section{AMERICAN RIVER.}

Discharge measurements of American River, Sacramento County.

\begin{tabular}{|c|c|c|c|}
\hline Date. & Hydrographer. & Discharge. & Locality. \\
\hline & & sec'-feet. & \\
\hline Sept. - 1898 & J. B. Lippincott . & 34.5 & Folsom. \\
\hline Ang. 3,1901 & C. W. Landis . ... & 619 & Do. \\
\hline Sept. 18,1901 & J. B. Lippincott. & 23 & Eldorado flume at Riverton. \\
\hline Sept. 16,1899 & S. G. Bennett ... & 86 & $\begin{array}{l}\text { Main river. } 1 \text { mile above South } \\
\text { Fork. }\end{array}$ \\
\hline Sept. 14,1900 & $\ldots$ do & 235 & Do. \\
\hline Sept. 16,1899 & . do & 20 & $\begin{array}{l}\text { North Fork ditch, } 2 \frac{1}{2} \text { miles above } \\
\text { Folsom. }\end{array}$ \\
\hline Sept. 14,1900 & do & 12 & Do. \\
\hline Dec. 28.1878 & $\begin{array}{l}\text { State engineering de- } \\
\text { partment. }\end{array}$ & $5 \% 0$ & 4 miles above Folsom. \\
\hline July 14,1879 & $\ldots$ do $\ldots \ldots$........ & 4,000 & Do. \\
\hline Jan. 24,1879 & $\ldots$ do $\ldots . . . .$. & 13,000 & $\begin{array}{l}\text { Sacramento, Twelfth street } \\
\text { bridge. }\end{array}$ \\
\hline Feb. 23,1879 & ..... do & 10,000 & Near month. \\
\hline May 21,1879 & $\ldots$ do $\ldots . . . . . .$. & 10,000 & Do. \\
\hline
\end{tabular}


Discharge measurements of South Fork of American River, Eldorato County.

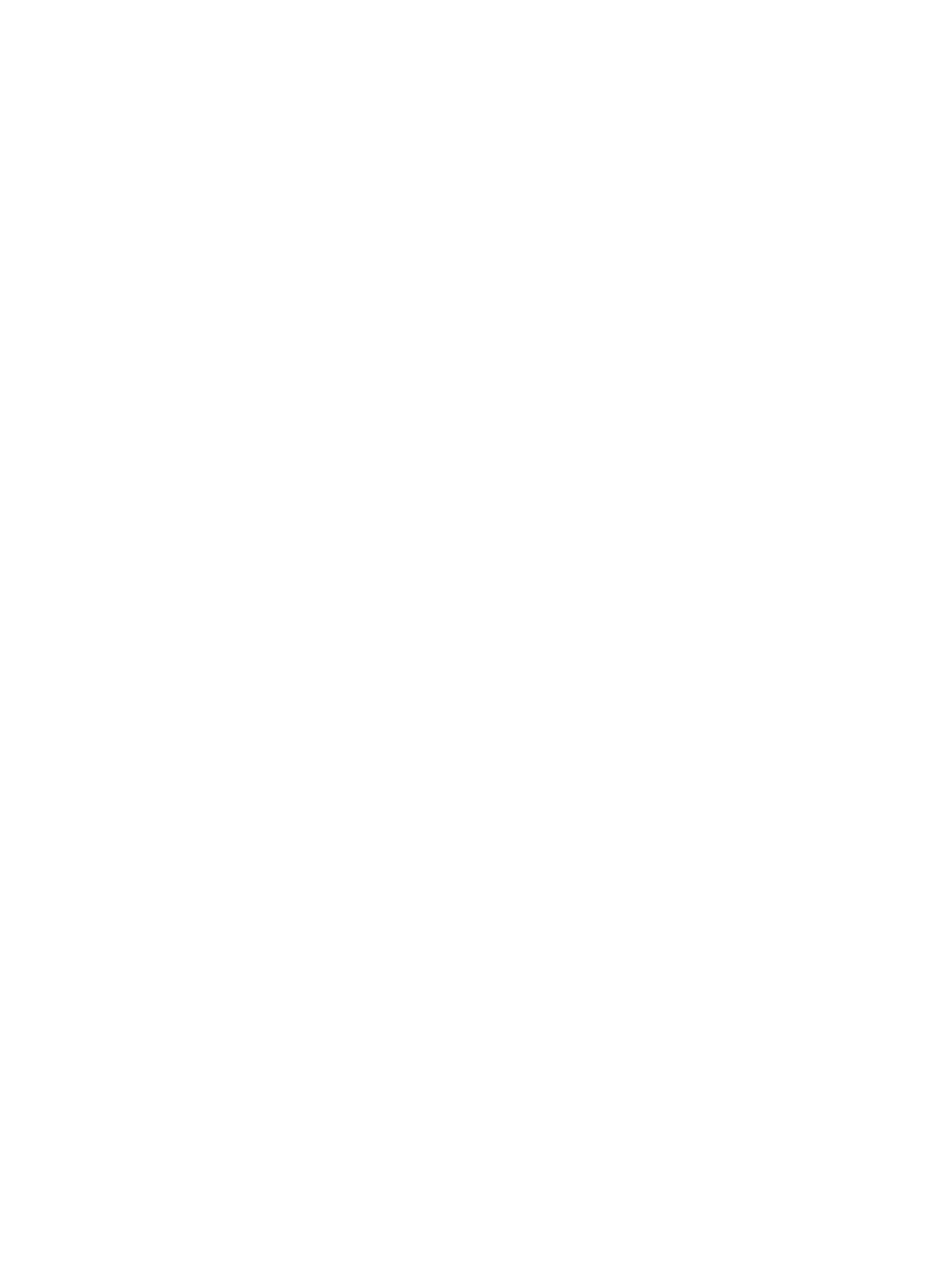


Discharge mertsurements of North Fork of American River.

\begin{tabular}{|c|c|c|c|}
\hline Date. & Hydroglapher. & $\begin{array}{c}\text { Dis- } \\
\text { charge. }\end{array}$ & Locality. \\
\hline Aug. 25, 1902 & S. G. Bennett & $\begin{array}{r}\text { sec.ft. } \\
59\end{array}$ & $\begin{array}{l}200 \text { feet above Colfax. Iowa Hill } \\
\text { road hridge. }\end{array}$ \\
\hline Do. & $\ldots$..... do & 3.5 & $\begin{array}{l}\text { South Yuba Water Company's } \\
\text { new power canal. }\end{array}$ \\
\hline Ang. 21, 1902 & Chas. A. Miller & 204 & $\begin{array}{l}\text { Above junction with South } \\
\text { Fork. }\end{array}$ \\
\hline Aug. 23, 1902 & $\ldots$ do ... & 145 & $\begin{array}{l}1 \text { mile above mouth of South } \\
\text { Fork. }\end{array}$ \\
\hline Ang. $2 \pi, 1902$ & .... do & 121 & Do. \\
\hline Aug. 28, 1902 & .....do . . & 78 & $\begin{array}{l}2 \frac{1}{2} \text { miles from Auburn above } \\
\text { mouth Middle Fork. }\end{array}$ \\
\hline Aug. 26,1902 & $\ldots$.... do & 14 & $\begin{array}{l}\text { North Fork Canal, second cross- } \\
\text { ing of ditch from Folsom. }\end{array}$ \\
\hline
\end{tabular}

Discharge measurements of Middle Fork of American River.

\begin{tabular}{|c|c|c|c|}
\hline Date. & Hydrographer & is & Locality. \\
\hline Ang. 26,1902 & S. G. Bennett ... & $\begin{array}{r}\text { Sec.ft. } \\
25\end{array}$ & $\begin{array}{l}\text { North Fork of Middle Fork, } 300 \\
\text { feet above junct:on. }\end{array}$ \\
\hline Do . . ..... & $\ldots$. . do _. & 11 & $\begin{array}{l}\text { North Fork of ] iiddle Fork, } \\
\text { mining ditch. }\end{array}$ \\
\hline & & 18 & $\begin{array}{l}300 \text { feet above junction with } \\
\text { Rubicon River. }\end{array}$ \\
\hline Do .... & $\ldots$....do & 42 & $\begin{array}{l}\text { Rubicon River, } 300 \text { feet above } \\
\text { junction with Middle Fork of } \\
\text { American River. }\end{array}$ \\
\hline Aug. 28, 1902 & $\ldots$ do $\ldots . . .$. & 110 & Middle Fork above mouth. \\
\hline
\end{tabular}

ARMAS CREEK.

Discharge measurements of Armas C'reek, Santa Barbara County.

\begin{tabular}{c|c|c|c}
\hline Date. & Hydrographer. & $\begin{array}{c}\text { Dis- } \\
\text { charge. }\end{array}$ & Locality. \\
\hline Aug. _, 1889 & G. F. Wright _........ & $\begin{array}{r}\text { Sec.ft. } \\
0.08\end{array}$ & \\
\hline
\end{tabular}

\section{AKMITAS CREEK.}

Discharge measurements of Armitas C'reek, Sunta Burbara County.

\begin{tabular}{c|c|c} 
Date. & Hydrographer. & $\begin{array}{c}\text { Dis- } \\
\text { charge. }\end{array}$ \\
\hline Aug.,- 1889 & G. F. Wright ....... & $\begin{array}{r}\text { Sec.ft. } \\
0.04\end{array}$ \\
\hline
\end{tabular}


ARROYO BURRO.

Discharge measurements of Arroyo Burro," Santa Barbara County.

\begin{tabular}{|c|c|c|c|}
\hline Date. & Hydrographer. & $\begin{array}{l}\text { Dis- } \\
\text { charge. }\end{array}$ & Lorality. \\
\hline Ang. - $18 \times 9$ & G. F. Wright & $\begin{array}{l}\text { sec.feet. } \\
0.23\end{array}$ & \\
\hline June $21,190 ?$ & J. B. Lippincott & .0036 & 100 feet below Moore's north line. \\
\hline June $1 \%, 1900$ & J. Harrington ... & .03 & San Roqui Creek. above tunnel. \\
\hline Do $\ldots . . .$. & $\ldots$ do ....... & .03 & San Roqui Creek, below tunnel. \\
\hline May 2,1900 & $\ldots$. . . do & .04 & $\begin{array}{l}\text { San Roqui Creek, station } 6 \text {, op- } \\
\text { posite tunnel. }\end{array}$ \\
\hline Do... & $\ldots$ do $\ldots$ & .02 & $\begin{array}{l}\text { San Roqui Creek, station } 8 \text {, op- } \\
\text { posite tunnel. }\end{array}$ \\
\hline Do - . & . . . do & .08 & $\begin{array}{l}\text { Tunnel of Pacific Improvement } \\
\text { Co. }\end{array}$ \\
\hline June 21.1902 & J. B. Lippincott & .009 & San Roqui Creek, below tunnel. \\
\hline Do $\ldots . .$. & .... do ........ & .25 & $\begin{array}{l}\text { Tunnel of Pacific Improvement } \\
\text { Co. }\end{array}$ \\
\hline Do $\ldots$ & $\ldots$ do ..... & .011 & $\begin{array}{l}\text { San Roqui Creek at station } 44 \text {, } \\
\text { opposite tunnel. }\end{array}$ \\
\hline Do _.. & _... do & .0063 & $\begin{array}{l}\text { San Roqui Creek at station } 65 \text {, } \\
\text { opposite tunnel. }\end{array}$ \\
\hline
\end{tabular}

ARROYO CARNERO.

Discharge measurements of Arroyo Camero. Santa Barbara County.

\begin{tabular}{c|c|c|c}
\hline Date. & Hydrographer. & $\begin{array}{c}\text { Dis- } \\
\text { eharge. }\end{array}$ & Locality. \\
\hline Ang. - 1889 & G. F. Wright _........ & $\begin{array}{c}\text { Sec.feet } \\
0.08\end{array}$ \\
\hline
\end{tabular}

\section{ARROYO GRANDE.}

Discharge measurements of Arroyo Grande, San Luis Obispo County.

\begin{tabular}{|c|c|c|c|}
\hline Date. & Hydrographer. & $\begin{array}{c}\text { Dis- } \\
\text { charge. }\end{array}$ & Locality. \\
\hline Nov. $20,189 \pi$ & W. W. Brier . . . & $\begin{array}{l}\text { Sec.-feet. } \\
7.80\end{array}$ & Arroyo Grande. \\
\hline
\end{tabular}

ARROYO LEON.

Discharge measurements of Arroyo Leon, San Mateo County.

\begin{tabular}{c|c|c|c} 
Date. & Hydrographer. & $\begin{array}{c}\text { Dis- } \\
\text { charge. }\end{array}$ \\
\hline Oct. $17,1,893$ & W. W. Brier .......... & $\begin{array}{l}\text { Sec.-feet. } \\
0.63\end{array}$ \\
\hline
\end{tabular}

a The upper mountainous portion of this stream is alled the San Roqui and the lower part the Arroyo Burro. 


\section{ARROYO SECO.}

This stream is a tributary of Los Angeles River, which it joins at the city of Los Angeles. Its basin is small, draining 21 square miles of the sierra Madre. The river issues from the mountains on the west side of Pasadena Mesal, passes through an opening in a granite spur known as Devils Gate, and joins Los Angeles River at Los Angeles. Between the point where the water issues from the mountain and Devils Gate lies a broad river bottom 2 miles in length, composed of coarse material. In passing over this the water sinks rapidly, diminishing in volume of flood water from the mouth of the canyon to Devils Gate. It is believed that a large portion of the underflow from the gravels above Devils Gate passes to the east of Devils (Gate and flows toward the San Gabriel Valley. (See also Pasac'sna Mesa.)

Discharge measurements of Amoyo Seco, at cable station terminal quarries, Los Angeles County.

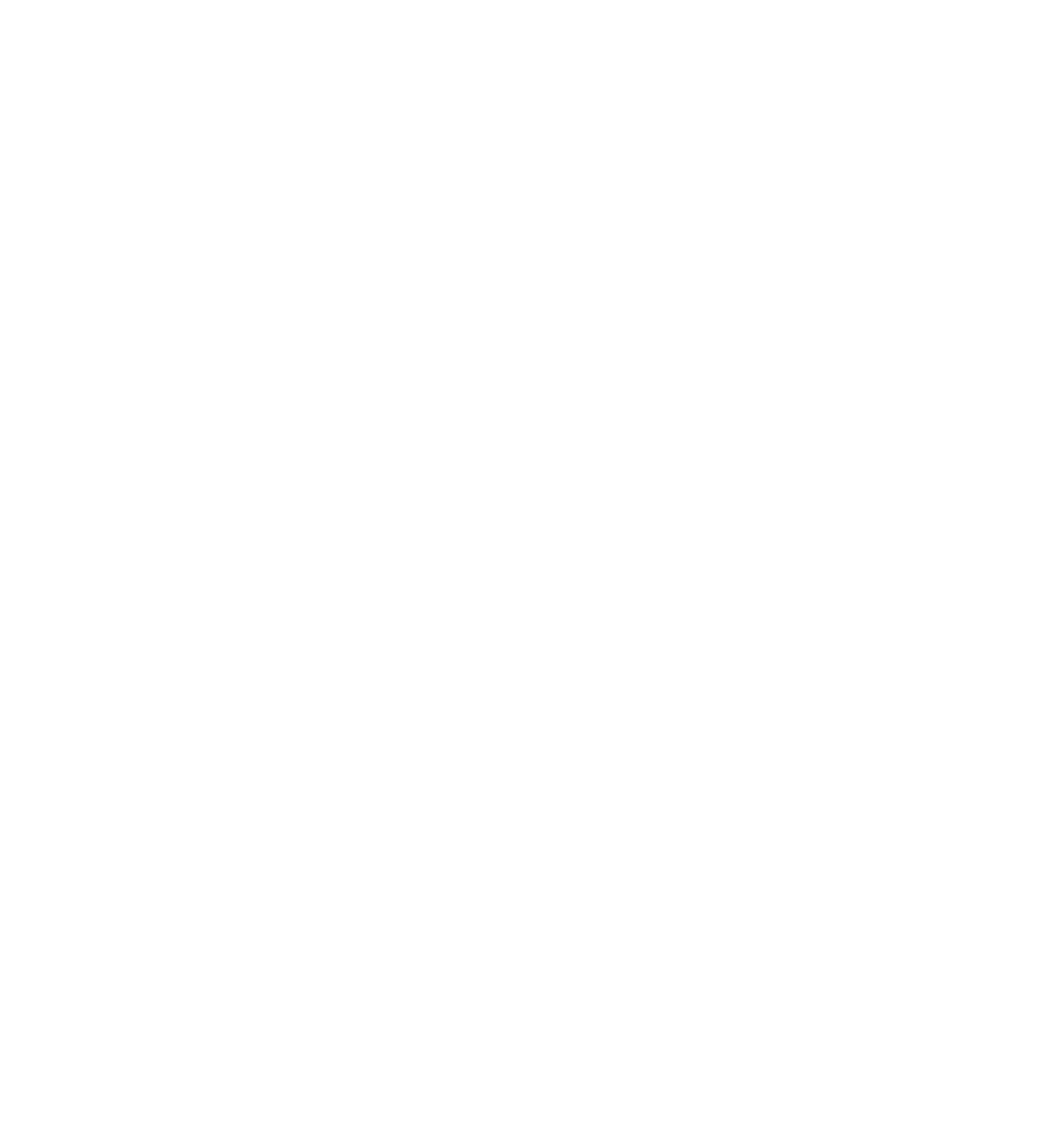


Discharge measurements of Arroyo Seco, etc.-Continued.

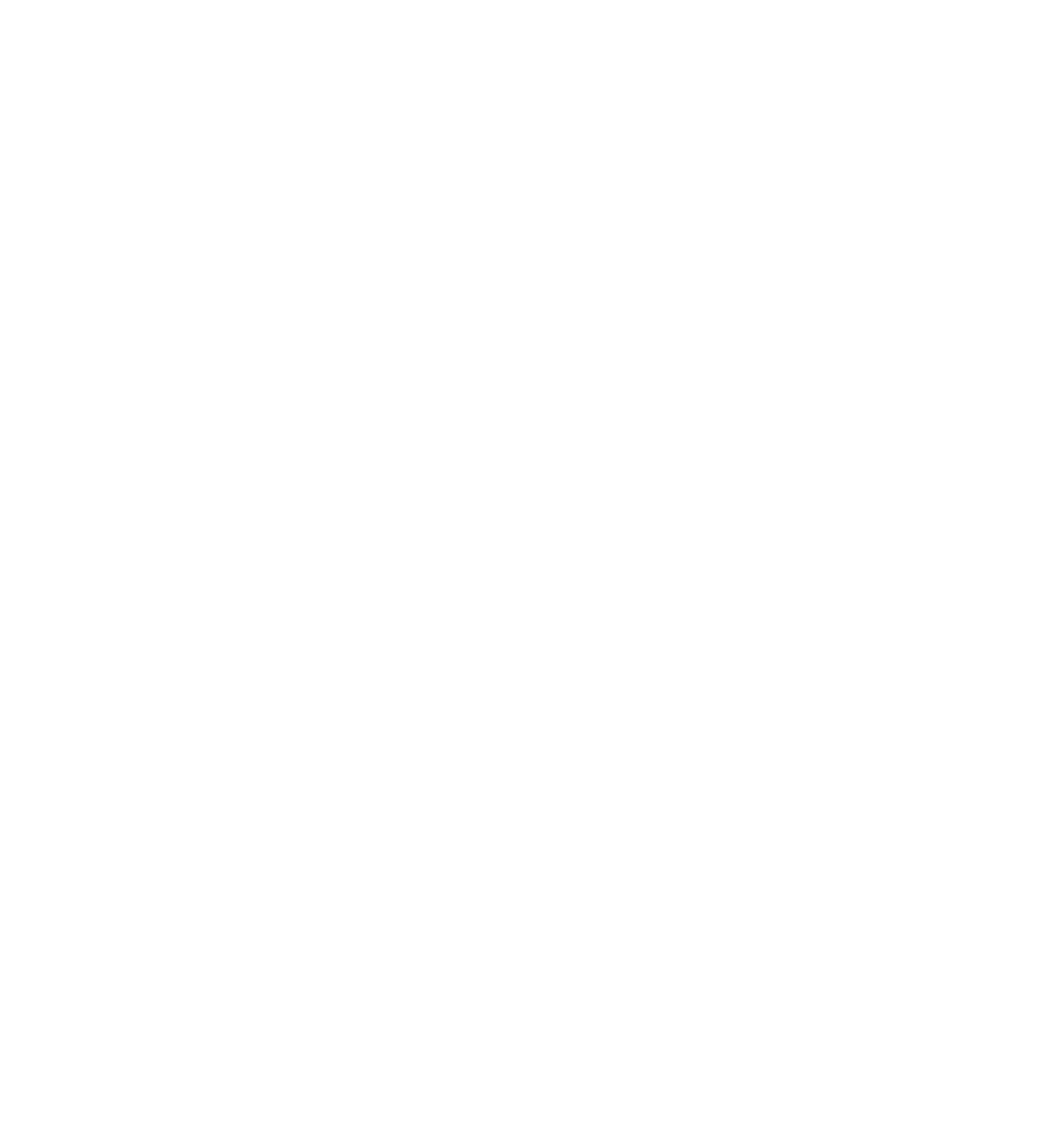

Discharge measurements of Arroyo Seco near Devils Gate. Los Angeles County.

\begin{tabular}{|c|c|c|}
\hline Date. & Hydrographer. & $\begin{array}{c}\text { Dis- } \\
\text { charge. }\end{array}$ \\
\hline & & Sec.-feet. \\
\hline June 14,1899 & T. D. Allen ... & a 5.17 \\
\hline July $12,189 \tau$ & .. . do ...... & a 5.12 \\
\hline Aug. 9,1897 & $\ldots$ do ...... & $a 4.63$ \\
\hline Oct. 11,1897 & $\ldots$. . do . . . & $a 4.13$ \\
\hline Nov. 8,1897 & $\ldots$. do $\ldots . . . .$. & a 4.16 \\
\hline May $3^{1}, 1899$ & $\ldots$ do $\ldots \ldots$ & a 3.17 \\
\hline July 10,1899 & W. B. Clapp .... & $a 2.87$ \\
\hline Sept. 17, 1900 & _. do . . . . . . . & $a 3.55$ \\
\hline Sept. 16,1898 & F. H. Olmsted $\ldots$ & a 3.60 \\
\hline Oct. 12,1898 & J. B. Lippincott $\ldots$ & a 3.44 \\
\hline
\end{tabular}


Dischurge measurements of Arroyo Seco, Los Angeles County.

\begin{tabular}{|c|c|c|c|}
\hline Date. & Hydrographer. & $\begin{array}{c}\text { Dis- } \\
\text { charge. }\end{array}$ & Locality. \\
\hline & & Sec.-ft. & \\
\hline Jan. 11.1899 & W. B. Clapp $\ldots$ & 4.17 & Loughery dam site. \\
\hline Oct. 13,1898 & J. B. Lippincott. & .08 & Painter pipe-line diversion. \\
\hline Sept. 16,1898 & F. H. Olmsted ... & 1.69 & Sheep corral, total. \\
\hline Oct. 24,1898 & J. B. Lippincott ... & 1.48 & Do. \\
\hline May 29,1899 & W. B. Clapp ..... & 1.43 & Do. \\
\hline June 3,1899 & $\ldots$ do _...... & 1.36 & Do. \\
\hline June 21,1899 & $\ldots$ do $\ldots \ldots$. . & 1.62 & Do. \\
\hline July 1,1899 & $\ldots$ do ..... & 1.33 & Do. \\
\hline July 13,1899 & $\ldots$ do _... . . . . . & 1.30 & Do. \\
\hline Sept. 19,1900 & W. W. Cockins, jr & 1.94 & Do. \\
\hline Sept. 21,1900 & J. B. Lippincott & 1.37 & Do. \\
\hline Feb. $\quad 6,1901$ & S. G. Bennett ... & 270 & $\begin{array}{l}\text { Avenue } 26 \text { bridge (flood meas- } \\
\text { urement). }\end{array}$ \\
\hline
\end{tabular}

\section{BEAR CREEK.}

See Santa Ana, Bear Creek.

\section{BEAMS DITCH.}

See San Bernardino Valley, Beams ditch.

BEAR RIVER.

Discharge measurements of Bear River, Iuba County.

\begin{tabular}{|c|c|c|c|}
\hline Date. & Hydrographer: & $\begin{array}{c}\text { Dis- } \\
\text { charge. }\end{array}$ & Locality. \\
\hline Sept. 17,1900 & S. G. Bennett ...... & $\begin{array}{l}\text { Sec.-ft. } \\
11.7\end{array}$ & $\begin{array}{l}\text { Wagon bridge } 1 \text { mile south of } \\
\text { Wheatland. }\end{array}$ \\
\hline Dec. 16,1878 & $\begin{array}{l}\text { State engineering de- } \\
\text { partment. }\end{array}$ & 10 & Wire bridge. \\
\hline Sept. $\quad 6,1879$ & . do & 15 & Do. \\
\hline Feb. 22,1879 & $\ldots$....do _... & 6,500 & Do. \\
\hline Sept. $\quad 6,18 \% 9$ & 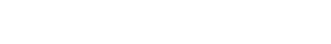 & $1 \tilde{5}$ & Wheatland. \\
\hline Oct. $\quad 20,1879$ & . do _.......... & 12 & 1 mile below wire bridge. \\
\hline Aug. 25, 1902 & S. G. Bennett . . . . . . & 16 & $\begin{array}{l}\text { Below waste from old mining } \\
\text { ditch. }\end{array}$ \\
\hline Do .... & . . do ........ & 33 & $\begin{array}{l}\text { Old mining ditch of South Yuba } \\
\text { Water Company, one-fourth } \\
\text { mile below head works. }\end{array}$ \\
\hline Aug. 26,1902 & Charles A. Miller...... & 28 & $\begin{array}{l}\text { Wooden flume of South Yuba } \\
\text { Water Company, near Au- } \\
\text { burn. }\end{array}$ \\
\hline
\end{tabular}


Estimuted monthly discharge of Bear River, Merced County, at base of foothills. ${ }^{a}$ [Drainage area, 16t square miles.]

\begin{tabular}{|c|c|c|c|c|c|c|}
\hline \multirow[b]{2}{*}{ Month. } & \multirow[b]{2}{*}{ Maximum. } & Discharge. & & \multirow[b]{2}{*}{$\begin{array}{l}\text { Total dis- } \\
\text { charge. }\end{array}$} & \multicolumn{2}{|c|}{ Pun-off. } \\
\hline & & Minimum. & Mean. & & $\begin{array}{l}\text { Per } \\
\text { square } \\
\text { mile. }\end{array}$ & Depth. \\
\hline 1878. & sec.-feet. & Sec.-fect. & sec-feet. & Acrefoet. & Nec.feet. & Inches. \\
\hline November ... & 0 & 0 & 0 & 0 & 0 & \\
\hline Decemiber & 0 & 0 & 0 & 0 & 0 & \\
\hline January $18 i 9$. & 0 & 0 & 0 & 0 & 0 & \\
\hline February . . . . & 312 & 0 & 95 & 1.388 & 0.15 & 0.16 \\
\hline March ........ & $5 \% 0$ & 0 & $5 \pi$ & 3.505 & .34 & .39 \\
\hline April . . . . . . & 197 & 5 & 54 & 3,213 & .33 & .37 \\
\hline May .......... & 0 & 0 & 0 & 0 & 0 & \\
\hline June .......... & 0 & 0 & 0 & 0 & 0 & \\
\hline 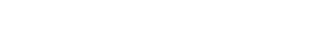 & 0 & 0 & 0 & 0 & 0 & \\
\hline August $\ldots \ldots \ldots$ & 0 & 0 & 0 & 0 & 0 & \\
\hline September . . . & 0 & 0 & 0 & 0 & 0 & \\
\hline October $\ldots . . .$. & 0 & 0 & 0 & 0 & 0 & \\
\hline November .... & 0 & 0 & 0 & 0 & 0 & \\
\hline December ....... & $25 \%$ & 0 & 18 & $1,10 \%$ & .11 & .13 \\
\hline The year ....... & $5 \% 0$ & 0 & 13 & 9,213 & .08 & 1. 35 \\
\hline $\begin{array}{ll} & 1880 . \\
\text { January }\end{array}$ & $21 \%$ & 0 & 25 & $1,5: 3 \pi$ & .15 & .17 \\
\hline February _.......... & 700 & 0 & 61 & 3,509 & $.3 \%$ & .40 \\
\hline 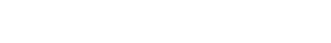 & 85 & 10 & 31 & 1.906 & .19 & .22 \\
\hline April ......... & $\stackrel{2}{2,080}$ & 25 & 321 & 19,101 & 1.93 & 2.15 \\
\hline May ... . . . . . & 47 & 0 & $2: 3$ & 1,414 & .14 & .16 \\
\hline June .......... & 0 & 0 & 0 & 0 & 0 & \\
\hline July _... . . . . & 0 & 0 & 0 & 0 & 0 & \\
\hline August . . . . . . & 0 & 0 & 0 & 0 & 0 & \\
\hline September ..... & 0 & 0 & 0 & 0 & 0 & \\
\hline October . . . . . & 0 & 0 & 0 & 0 & 0 & \\
\hline November & 0 & 0 & 0 & 0 & 0 & 0 \\
\hline December . . . . . . & 421 & 0 & 115 & $\tau, 071$ & .69 & .80 \\
\hline The year ....... & 2,080 & 0 & 48 & 34.538 & .29 & 3.90 \\
\hline
\end{tabular}

"Authority, State engineering department. 
Estimated monthly discharge of Bear River, etc.-Continued.

\begin{tabular}{|c|c|c|c|c|c|c|}
\hline \multirow[b]{2}{*}{ Month. } & \multicolumn{3}{|c|}{ Discharge } & \multirow[b]{2}{*}{$\begin{array}{l}\text { Total dis- } \\
\text { charge. }\end{array}$} & \multicolumn{2}{|c|}{ Run-off. } \\
\hline & Maximum. & Minimum. & Mean. & & $\begin{array}{l}\text { Per } \\
\text { square } \\
\text { rile. }\end{array}$ & Depth. \\
\hline January 1881. & $\begin{array}{r}\text { Sec.'feet. } \\
1,920\end{array}$ & $\begin{array}{r}\text { Sec. feet. } \\
20\end{array}$ & $\begin{array}{c}\text { Sec-feet. } \\
169\end{array}$ & $\begin{array}{r}\text { Acre-feet. } \\
10,391\end{array}$ & $\begin{array}{c}\text { Sec.feet. } \\
1.02\end{array}$ & $\begin{array}{l}\text { Inches. } \\
1.18\end{array}$ \\
\hline February & 1,423 & 47 & 214 & 11,885 & 1.29 & 1.34 \\
\hline March .... & 197 & 13 & 48 & 2,951 & .29 & .33 \\
\hline April . & 20 & 0 & 6 & 357 & .04 & .04 \\
\hline May ..... & 0 & 0 & 0 & 0 & 0 & 0 \\
\hline June . . . . . & 0 & 0 & 0 & 0 & 0 & 0 \\
\hline July .... & 0 & 0 & 0 & 0 & 0 & 0 \\
\hline Angust .... & 0 & 0 & 0 & 0 & 0 & 0 \\
\hline September ... & 0 & 0 & 0 & 0 & 0 & 0 \\
\hline October .... . & 0 & 0 & 0 & 0 & 0 & 0 \\
\hline November. ... & 0 & 0 & 0 & 0 & 0 & 0 \\
\hline December .... & 0 & 0 & 0 & 0 & 0 & 0 \\
\hline The year & 1,920 & 0 & 36 & 25,584 & .22 & 2.89 \\
\hline $1882 . a$ & & & & & & \\
\hline January ..... & 0 & 0 & 0 & 0 & 0 & 0 \\
\hline February ... & 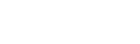 & $\ldots$ & 33 & 1,833 & .20 & .21 \\
\hline March ..... & $\ldots$ & $\ldots$ & 100 & 6,149 & .60 & .69 \\
\hline April ..... & $\ldots$ & $\ldots$ & 130 & 7,736 & .78 & .87 \\
\hline May .... & 0 & 0 & 0 & 0 & 0 & 0 \\
\hline June ........ & 0 & 0 & 0 & 0 & 0 & 0 \\
\hline July .. & 0 & 0 & 0 & 0 & 0 & 0 \\
\hline Angust ..... & 0 & 0 & 0 & 0 & 0 & 0 \\
\hline September & 0 & 0 & 0 & 0 & 0 & 0 \\
\hline October ... & & $\ldots$ & 17 & 1,045 & .10 & .12 \\
\hline November. & & 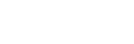 & 25 & 1,488 & .15 & .17 \\
\hline December ... & & $\ldots \ldots$ & 17 & 1,045 & .10 & .12 \\
\hline The year & & $\ldots$ & 27 & 19,296 & .16 & 2.18 \\
\hline
\end{tabular}

a Run-off for 1882,1883 , and 1884 , estimated from previous measurements or from run off of neighboring streams. 
Estimated monthly discharge of Beur River, ete.-Continued.

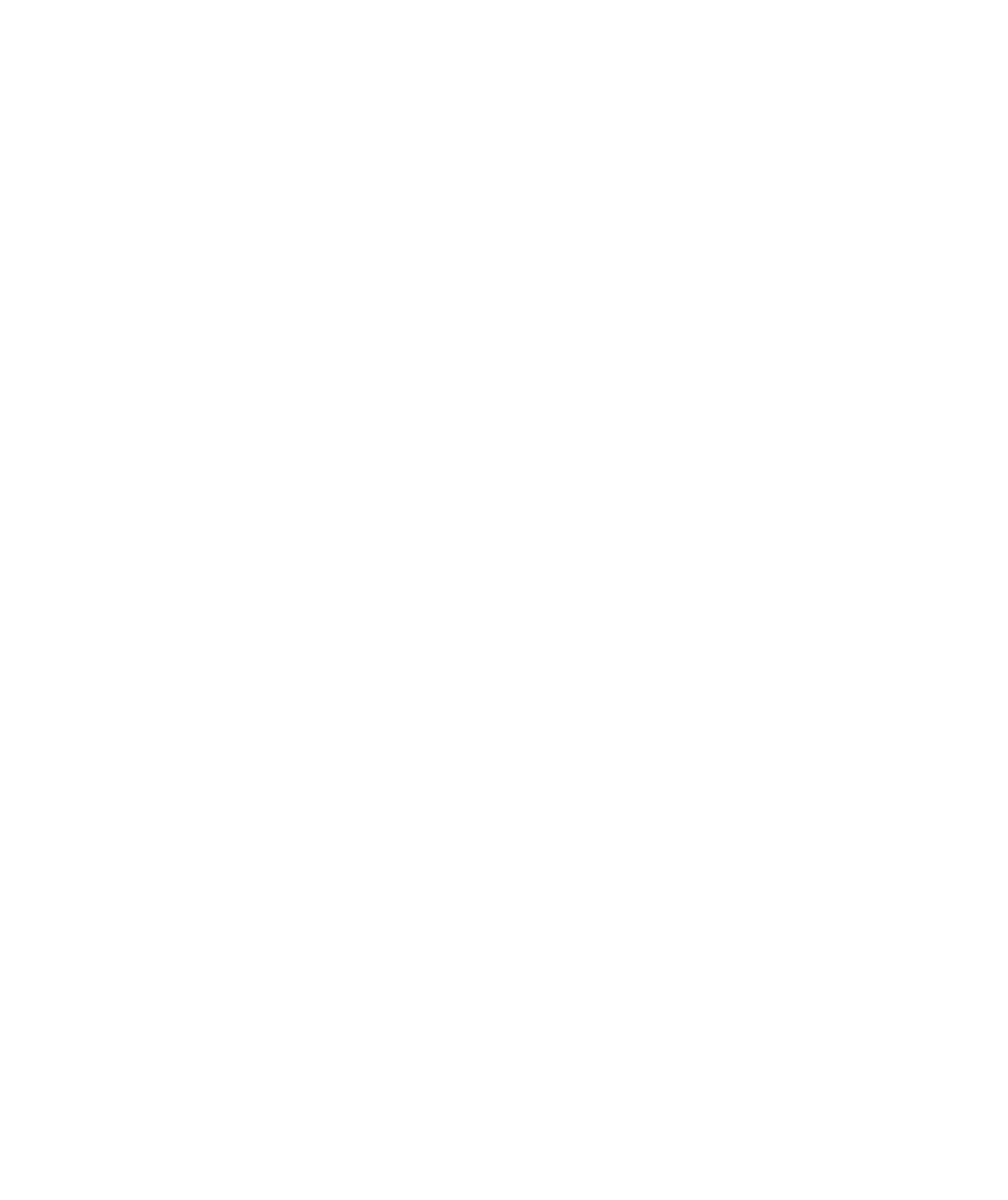

a Run-off for 1882,1883 , and $18 \% 4$, estimated from previous measurements or from run-off of neighboring streams.

IRR $81-03-4$ 


\section{BIG ROCK CREEK.}

Discharge measurements of Big Rock ('reek. Los Angeles C'ounty.

\begin{tabular}{|c|c|c|c|c|}
\hline & Date. & Hydrographer. & $\begin{array}{l}\text { Dis- } \\
\text { charge. }\end{array}$ & Loralit:r. \\
\hline Jan. & 4,1898 & J. B. Lippincott & $\begin{array}{c}\text { Sec, feet. } \\
5.2 \pi\end{array}$ & $\begin{array}{l}\text { Dam site above development } \\
\text { tunnel. }\end{array}$ \\
\hline Jan. & 4,1898 & $\ldots$ do $\ldots . . . . . .$. & 1.27 & Diversion to tunnel. \\
\hline Jan. & 4,1898 & $\ldots$. . do _... . . . & 1. 33 & Developed in tunrel. \\
\hline Jan. & 4,1898 & $\ldots$ do . . . . . . . & .78 & Cienega on Pallett tributary. \\
\hline
\end{tabular}

\section{WILLIAMS RIVER.}

Discharge meusurement of Williams River, Fumu C'ounty, Ariz.

\begin{tabular}{|c|c|c|c|}
\hline Date. & Hydrographer. & $\begin{array}{c}\text { Dis- } \\
\text { charge, }\end{array}$ & Locality. \\
\hline & & Sec. feet. & \\
\hline 1,1902 & J. B. Lippincott . & 4 & Mouth of river. \\
\hline Oct. 28,1902 & E. T. Perkins _- & 4 & Do. \\
\hline
\end{tabular}

\section{BLOOMINGTON FLUME, SAN BERNARDINO COUNTY.}

See San Bernardino Valley.

\section{BRISCOE CREEK, GLENN COUNTY.}

See Stony Creek, Briscoe tributary.

\section{BURNEY CREEK.}

See Pit River, Burney tributary.

\section{BUTANO CREEK.}

Discharge measurement of Butano Creek, San Mateo Cointy.

\begin{tabular}{|c|c|c|c|}
\hline Date. & Hydrographer. & $\begin{array}{c}\text { Dis- } \\
\text { charge. }\end{array}$ & Locality. \\
\hline Oct. 17,1893 & W. W. Brier & $\begin{array}{c}\text { Sec. feet. } \\
2.05\end{array}$ & $\begin{array}{l}5 \text { miles above junction with } \\
\text { Pescadero Cree }\end{array}$ \\
\hline
\end{tabular}




\section{CACHE CREEK. $a$}

This stream is the oullet of Clear Lake, in Lake County, Cal., and is described in Water-Supply Paper No. 51, p. 453.

On account of the great importance of Clear Lake as a storage reservoir, a gaging station was established at the wagon bridge across Cache Creek, one-half mile north of the town of Lower Lake, January 1, 1901. Gage rods were put in at this point and an obsarver was employed by Mr. P. N. Ashley, of Woodlands, for the Ag 'icultural Department, about October, 1900, but no meter measurements were made.

In order to determine the evaporation from the surface of Clear Lake an evaporation pan and gage were placed in a cove near Lakeport in January, 1901, and the observations for evaporation were begun Febiuary 1 by Capt. D. C. Rumsey. The pan is not exposed to the full force of the wind, as the waves often run high.

Discharge measurements of Cache Creek. Lake County.

\begin{tabular}{|c|c|c|c|c|}
\hline Date. & Hydrographer. & $\begin{array}{c}\text { Gage } \\
\text { height. }\end{array}$ & $\begin{array}{c}\text { Dis- } \\
\text { charge. }\end{array}$ & Locality. \\
\hline Sept. 24,1900 & S. G. Bennett & Feet. & $\begin{array}{r}\text { Sec.ffeet. } \\
3.8\end{array}$ & Lower Lake Bridge. \\
\hline Dec. 16,1900 & ... _do ...... & 1.18 & 123 & Do. \\
\hline Jan. 25,1901 & ... -do & 3.60 & 675 & Do. \\
\hline Apr. 13,1901 & .... do .... . & 3.80 & 673 & Do. \\
\hline June $1 \tau, 1901$ & S. Matthews & 2.85 & 333 & Do. \\
\hline July 15,1901 & . . do .... & 2.45 & 236 & Do. \\
\hline Ang. 13, 1901 & ... do ... & $2.0 \pi$ & 144 & Do. \\
\hline Sept. $\quad 4.1901$ & J.R. Anderson & 1.72 & 84 & Do. \\
\hline Uct. 5,1901 & $\ldots$ do .... . . & 1.45 & 34 & Do. \\
\hline Nov. 9,1901 & $\ldots . .$. & 1.20 & 20 & Do. \\
\hline Nov. 29,1901 & $\ldots$ do .... & 1.60 & 69 & Do. \\
\hline Dec. 30,1901 & ... - do & 1.60 & 65 & Do. \\
\hline Jan. $29.190^{\circ}$ & $\ldots$.... do ... & 1.60 & ro & Do. \\
\hline Feb. 13,1902 & $\ldots$ do .... & 2.50 & 260 & Do. \\
\hline Mar. 3,1902 & $\ldots$.... do ... & 6.50 & 1,151 & Do. \\
\hline Mar. 19,1902 & ... do & 7.70 & 1,866 & Do. \\
\hline Apr. $\quad 5.1902$ & .. do & 6.5 & $1,39 \%$ & Do. \\
\hline Apr. 24,1902 & . . . do & 5.9 & 1,212 & Do. \\
\hline May 3,1902 & .....do ... & 5.2 & 1,042 & Do. \\
\hline May 19,1902 & $\ldots$ do ... & 4.5 & 853 & Do. \\
\hline May 31,1902 & .. do & 4.0 & 720 & Do. \\
\hline June 14,1902 & $\ldots$ do . . . . . & 3.6 & 629 & Do. \\
\hline July 12,1902 & $\ldots$. do _.... & 3.1 & 422 & Do. \\
\hline
\end{tabular}

a For a detailed statement concerning the hydrography of Cache Creek, see Wrater-Supply Paper No. 45, by A. E. Chandler. 
Discharge mersurements of C'ache' ('re'ek. Lake County-C'ontinued.

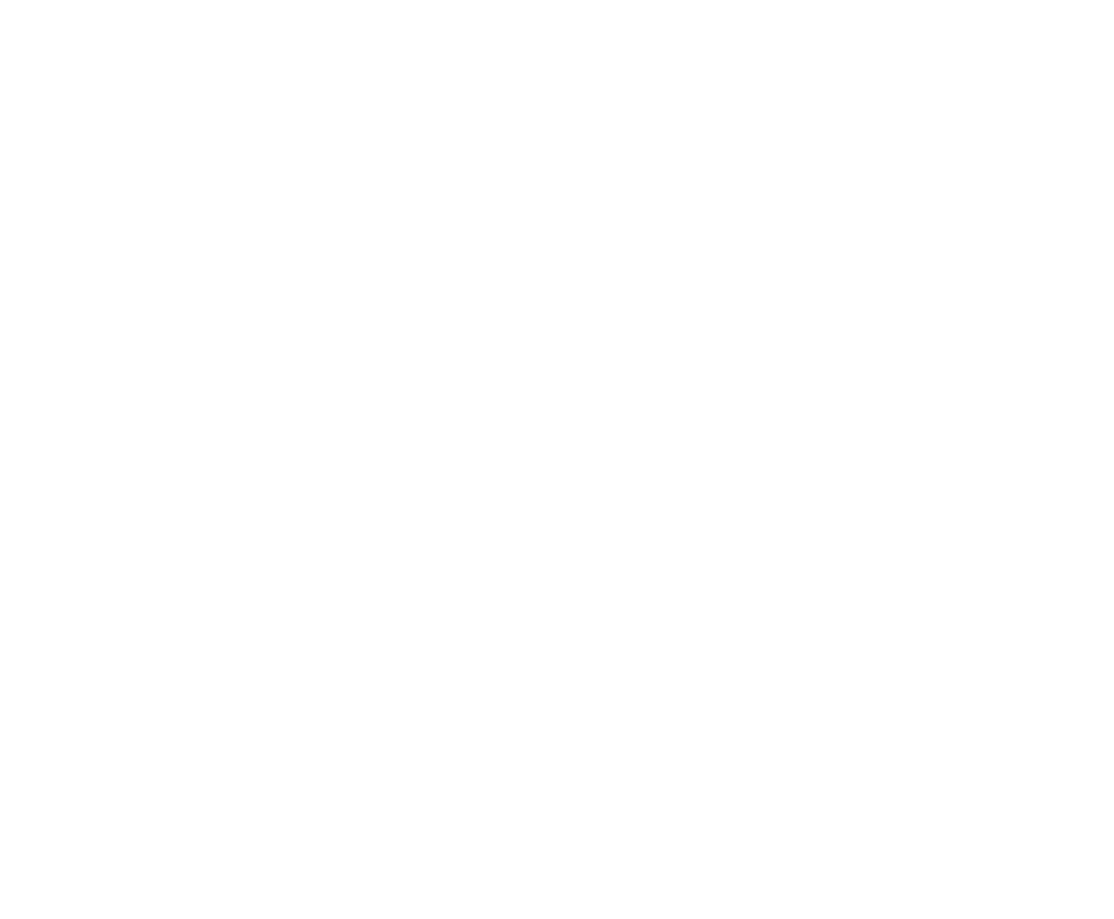

Estimated monthly dischargo of Cache ('reek at Lowe'r Lake.

[Drainage area, 510 square miles.]

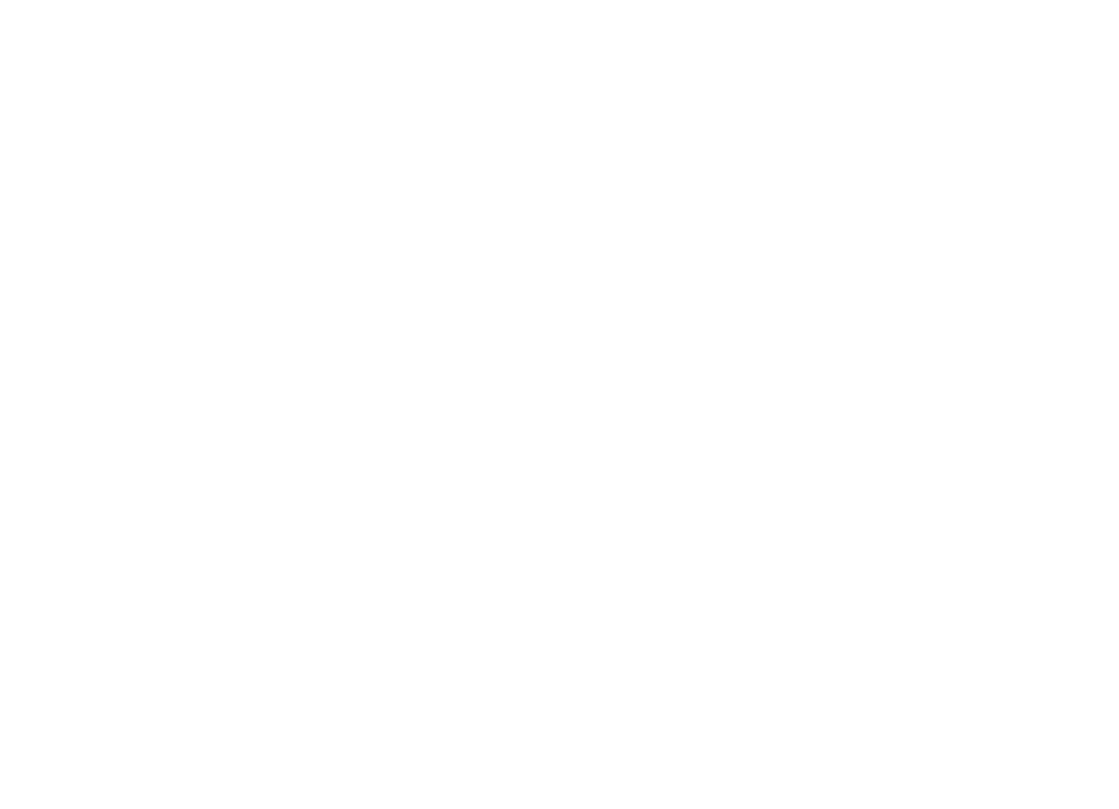


Estimated monthly discharge of C'ache ripek at Louer Lake-Continued.

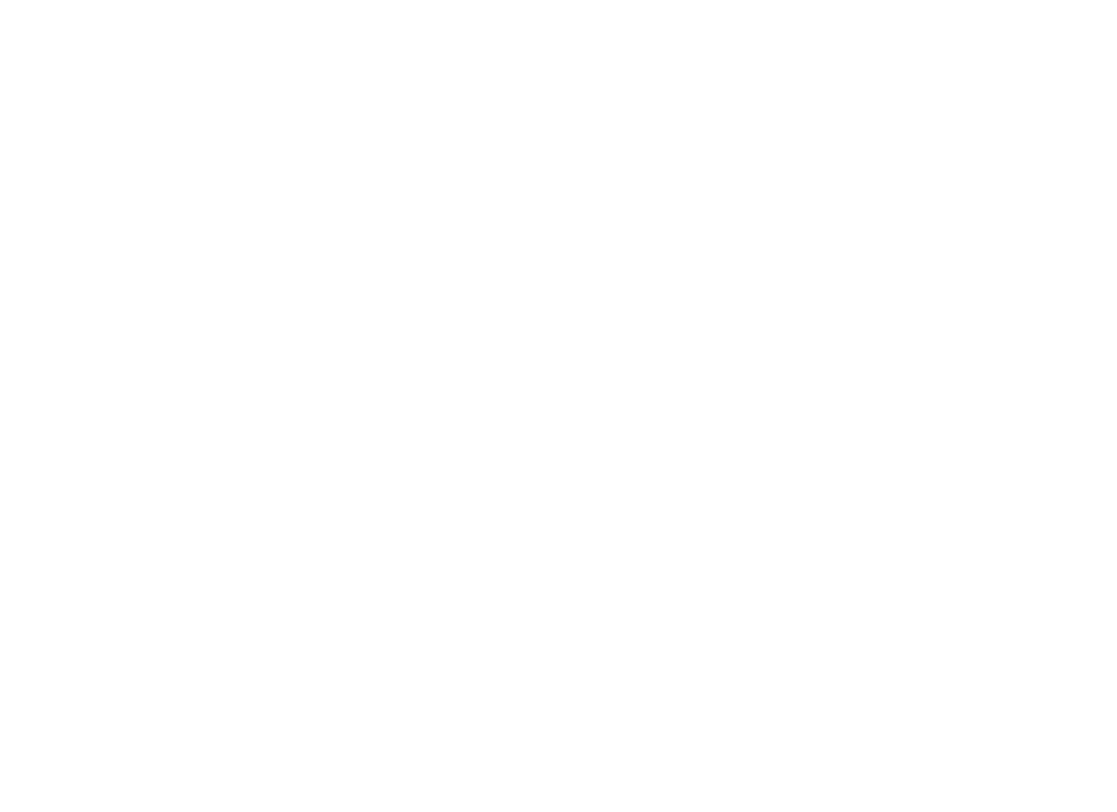

\section{CAJON CREEK.}

Discharge measurements of Cajon Creek, Sam Bernardino County.

\begin{tabular}{|c|c|c|c|}
\hline Date. & Hydrographer. & Discharge. & Lorality. \\
\hline June $\&, 1900$ & S. G. Bennett ... & $\begin{array}{l}\text { sec.feet. } \\
1.37\end{array}$ & Keenebrook station. \\
\hline
\end{tabular}

\section{CALAVERAS RIVER.}

Discharge measurements of C'alaveres River, Calaveras ('ounty.

\begin{tabular}{c|c|c|c|c}
\hline \multicolumn{2}{c}{ Date. } & Hydrographer. & Discharge. & Locality \\
\hline Sept. 6,1899 & S. G. Bennett _........ & Dry ..... & San Andreas, Jackson road. \\
\hline
\end{tabular}


Estimated monthly discharge of Calaveras River at Bellota."

[Drainage area, 491 square miles.]

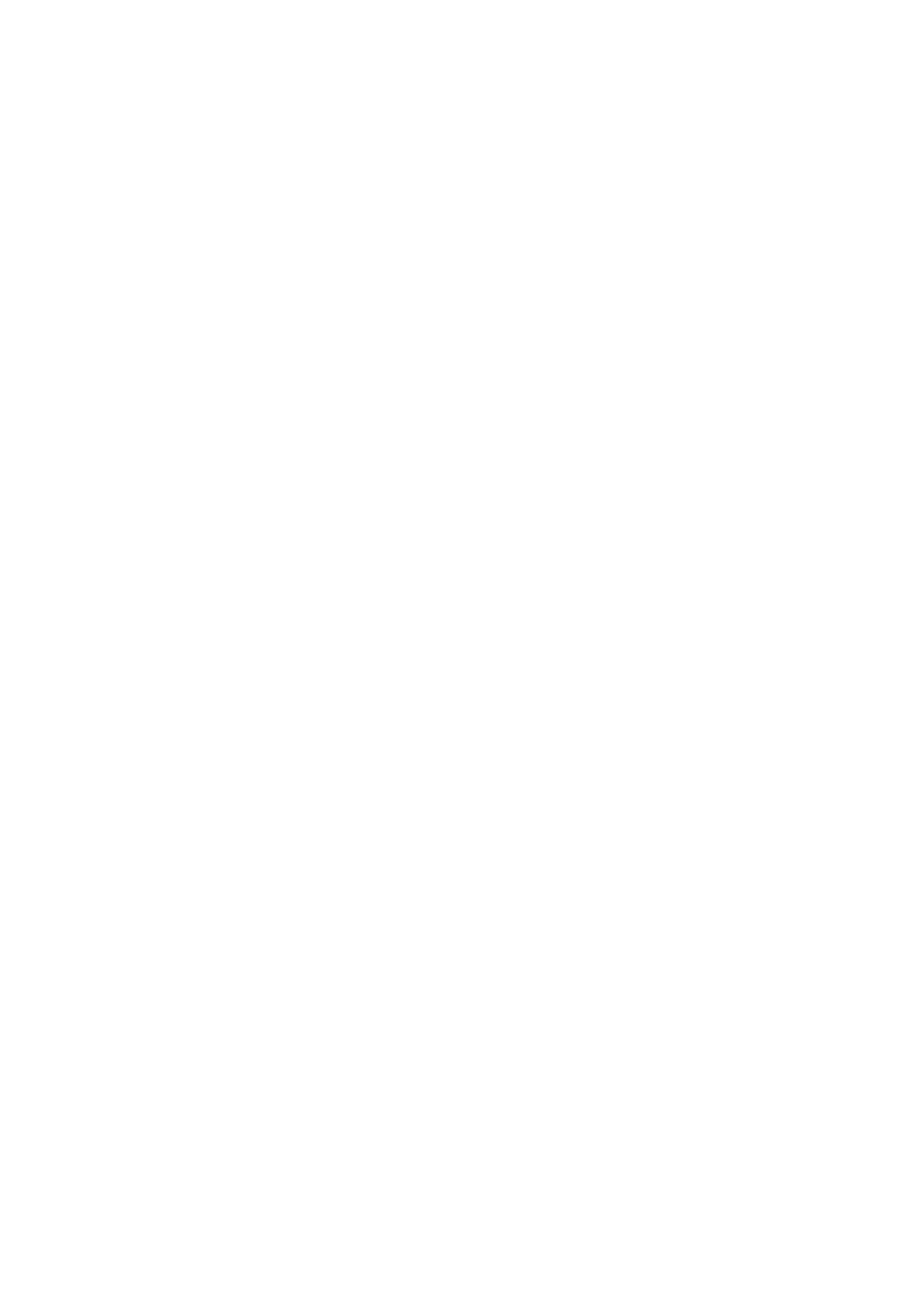

a Authority, California State engineering department

$b$ For November and December. 1878 , and trom June, 15i9, to October, 1884, estimated from run off of nelghboring stream.

c Estimated from run off of neighboring stream. 
Estimated monthly discharge of Calaveras River at Bellota-Continned.

\begin{tabular}{|c|c|c|c|c|}
\hline \multirow[b]{2}{*}{ Month. } & \multirow[b]{2}{*}{$\begin{array}{l}\text { Mean dis- } \\
\text { charge. }\end{array}$} & \multirow[b]{2}{*}{$\begin{array}{l}\text { Total dis- } \\
\text { rharge. }\end{array}$} & \multicolumn{2}{|c|}{ P.un-off } \\
\hline & & & $\begin{array}{l}\text { Per squa.re } \\
\text { mile. }\end{array}$ & Depth. \\
\hline $1881 . " 1$ & sec.feet. & tore-feet. & sect-feet. & luches. \\
\hline January . . . . . . . . . & 1,473 & 90,571 & 3.00 & 3.46 \\
\hline February ........... & 2.700 & 149,950 & 5.90 & 5.73 \\
\hline March $\ldots \ldots \ldots \ldots$ & 982 & 60,381 & 2.00 & 2.31 \\
\hline April .............. & 989 & $.88,433$ & 2.00 & 2.23 \\
\hline May . . . . . . & 196 & 12,052 & .40 & .46 \\
\hline June . ... & 74 & 4,403 & .15 & .17 \\
\hline July . . . . . & 49 & 3,013 & .101 & .12 \\
\hline August ....... & 0 & 0 & 0 & 0 \\
\hline September ... . & 0 & 0 & 0 & 0 \\
\hline October ...... & 0 & 0 & 0 & 0 \\
\hline November...... & 0 & 0 & 0 & 0 \\
\hline December ....... & $\% 4$ & 4,550 & .15 & .17 \\
\hline The year .... & 544 & 383,353 & 1.11 & 14.65 \\
\hline 1882. $a$ & & & & \\
\hline January ............. & 344 & 21,152 & .70 & .81 \\
\hline February $\ldots \ldots \ldots \ldots \ldots$ & 442 & 24,547 & .90 & .94 \\
\hline March $\ldots \ldots \ldots \ldots \ldots$ & 1,719 & $105,69 \tau$ & 3.50 & 4.04 \\
\hline April $\ldots \ldots \ldots$ & 1,719 & 102,288 & 3.50 & 3.90 \\
\hline May $\ldots \ldots \ldots$ & 2.946 & 181,142 & 6.00 & 6.92 \\
\hline June $\ldots \ldots \ldots \ldots \ldots \ldots \ldots$ & 246 & 14,638 & .50 & .56 \\
\hline July $\ldots \ldots \ldots$ & 0 & 0 & 0 & 0 \\
\hline Angust $\ldots \ldots \ldots$ & 0 & 0 & 0 & 0 \\
\hline September $\ldots$ & 0 & 0 & 0 & 0 \\
\hline 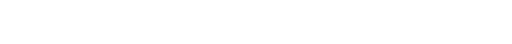 & 98 & 6,026 & .20 & .23 \\
\hline November _ . . . . . . & 147 & 8,747 & .30 & .33 \\
\hline December .... & $14 \tau$ & 9,039 & .30 & .35 \\
\hline The year . .... & 651 & 473,276 & 1.33 & 18.08 \\
\hline
\end{tabular}

" Estimated from run-off of neighboring stream. 
Estimated monthly discharge of ('alaceras River at Bellota-Continued.

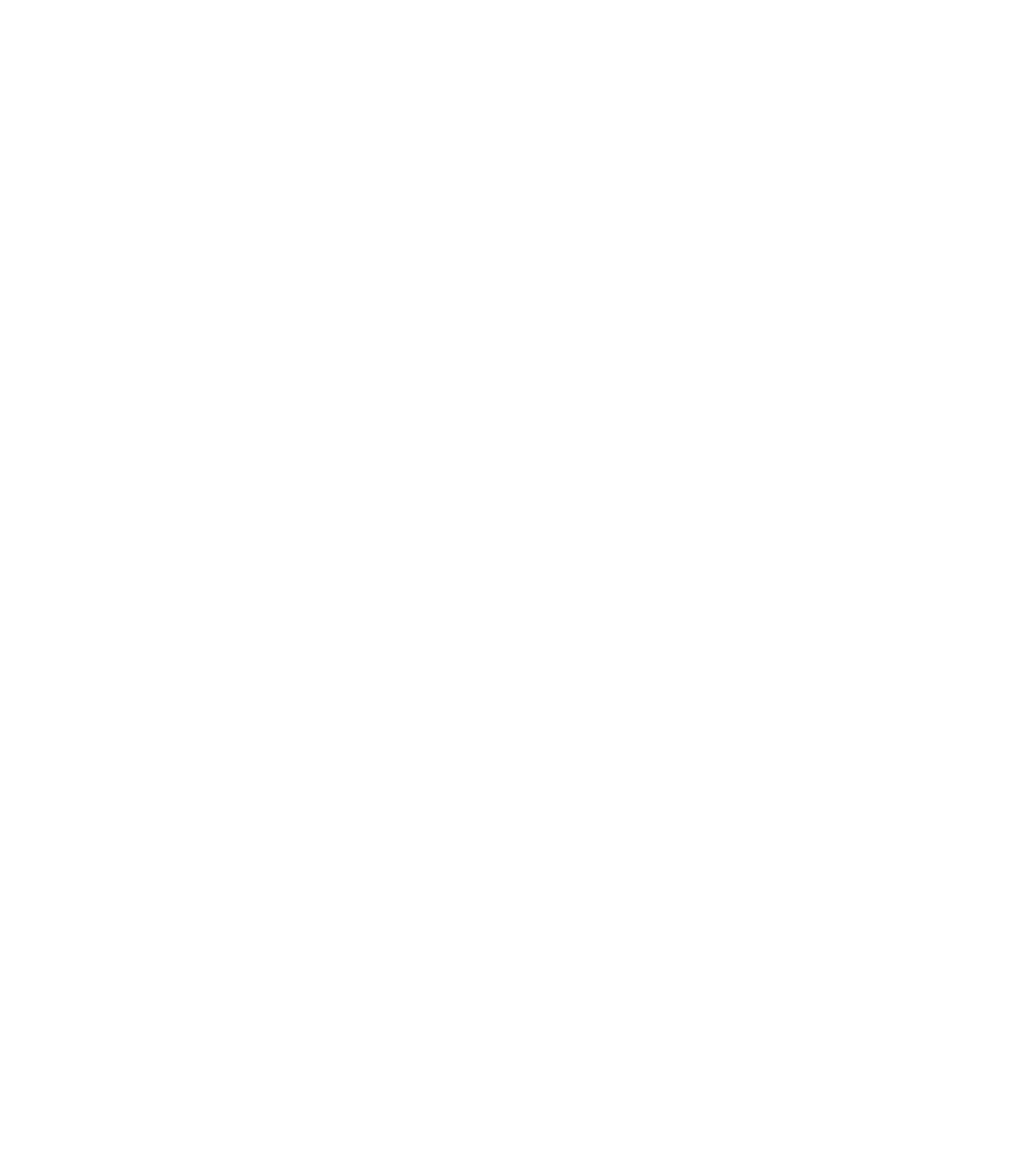

a Estimated from run-off of neighboring stream.

\section{CALIENTE CREEK."}

Discharge measurements of Caliente Creek, Kern County.

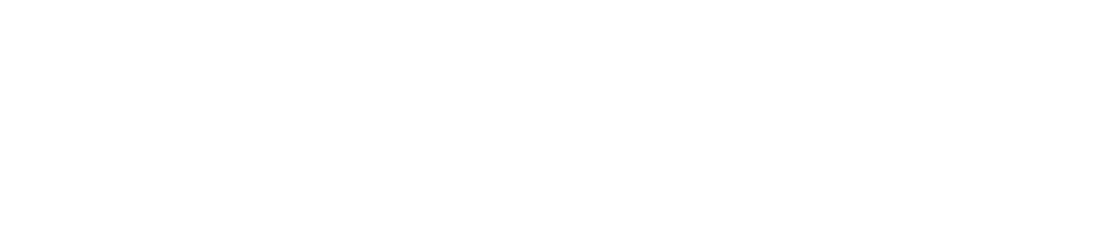


Estimated monthly discharge of Caliente Creek, Kern C'ounty, at base of foothills." [Drainage area, 423 square miles.]

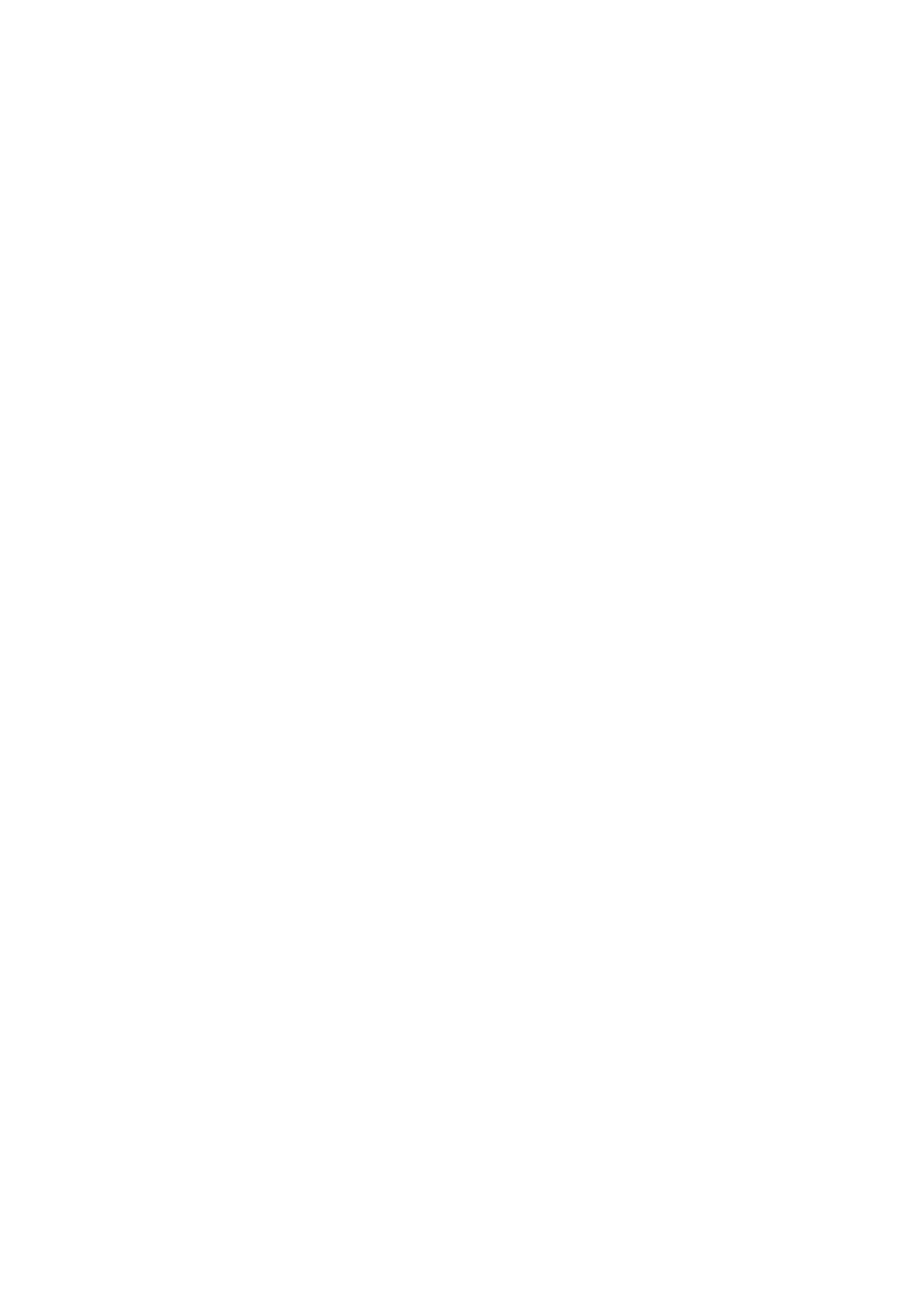

a Estimated from run-off of neighboring streams. Authority, California State engineering department. 
Estimated monthly discharge of ('aliente Creeh', etc.-Continued.

\begin{tabular}{|c|c|c|c|c|}
\hline \multirow[b]{2}{*}{ Month. } & \multirow[b]{2}{*}{$\begin{array}{l}\text { Mean dis- } \\
\text { rharge. }\end{array}$} & \multirow[b]{2}{*}{$\begin{array}{l}\text { Total dis- } \\
\text { charge. }\end{array}$} & \multicolumn{2}{|c|}{ Run-off. } \\
\hline & & & $\begin{array}{l}\text { Per square } \\
\text { mill } 3 .\end{array}$ & Depth. \\
\hline - - - - - & & $\cdots$ & $------\mid$ & $\cdots \cdots$ \\
\hline 1881 & seci-feet. & Arreffet. & ser.feet. & Inches. \\
\hline January ..... & 212 & 13,035 & 0.50 & 0.58 \\
\hline February ... & 4:2:3 & 23,492 & 1.00 & 1.04 \\
\hline March ....... & 423 & 26.009 & 1.00 & 1.15 \\
\hline April . & 493 & 25,170 & 1.00 & 1.12 \\
\hline May ......... & $4: 3$ & 26,009 & 1.00 & 1.15 \\
\hline June ........ & 212 & 12.615 & .50 & .56 \\
\hline July $\ldots \ldots . . .$. & 0 & . $\quad 0$ & 0 & \\
\hline August $\ldots \ldots \ldots$ & 0 & 0 & 0 & \\
\hline September $\ldots \ldots \ldots \ldots \ldots \ldots$ & 0 & 0 & 0 & \\
\hline October & 0 & $0^{-}$ & 0 & \\
\hline November . . . . . . . . & 0 & 0 & 0 & \\
\hline December ... . & 51 & 3,136 & .12 & .14 \\
\hline The year. & 181 & 129,466 & .43 & 5.74 \\
\hline 1882. & & & & \\
\hline January . . . . & 51 & 3,136 & .12 & .14 \\
\hline February ..... & 63 & 3,499 & .15 & .16 \\
\hline March ........ & 212 & 13,035 & .50 & .58 \\
\hline April $\ldots \ldots$ & 212 & 12.615 & .50 & .56 \\
\hline May ............. & 42 & 2,582 & .10 & .12 \\
\hline June ......... & 0 & 0 & 0 & \\
\hline July ......... & 0 & 0 & 0 & \\
\hline August ...... & 0 & 0 & 0 & \\
\hline September . . . & 0 & 0 & 0 & 0 \\
\hline Oetober ....... & 0 & 0 & 0 & 0 \\
\hline November . & 63 & 3,749 & .15 & .17 \\
\hline December. & 63 & 3,874 & .15 & .17 \\
\hline The year & 59 & 42,490 & .14 & 1.90 \\
\hline
\end{tabular}


Estimated monthly discharge of c'aliente ('reek, ete.-Continued.

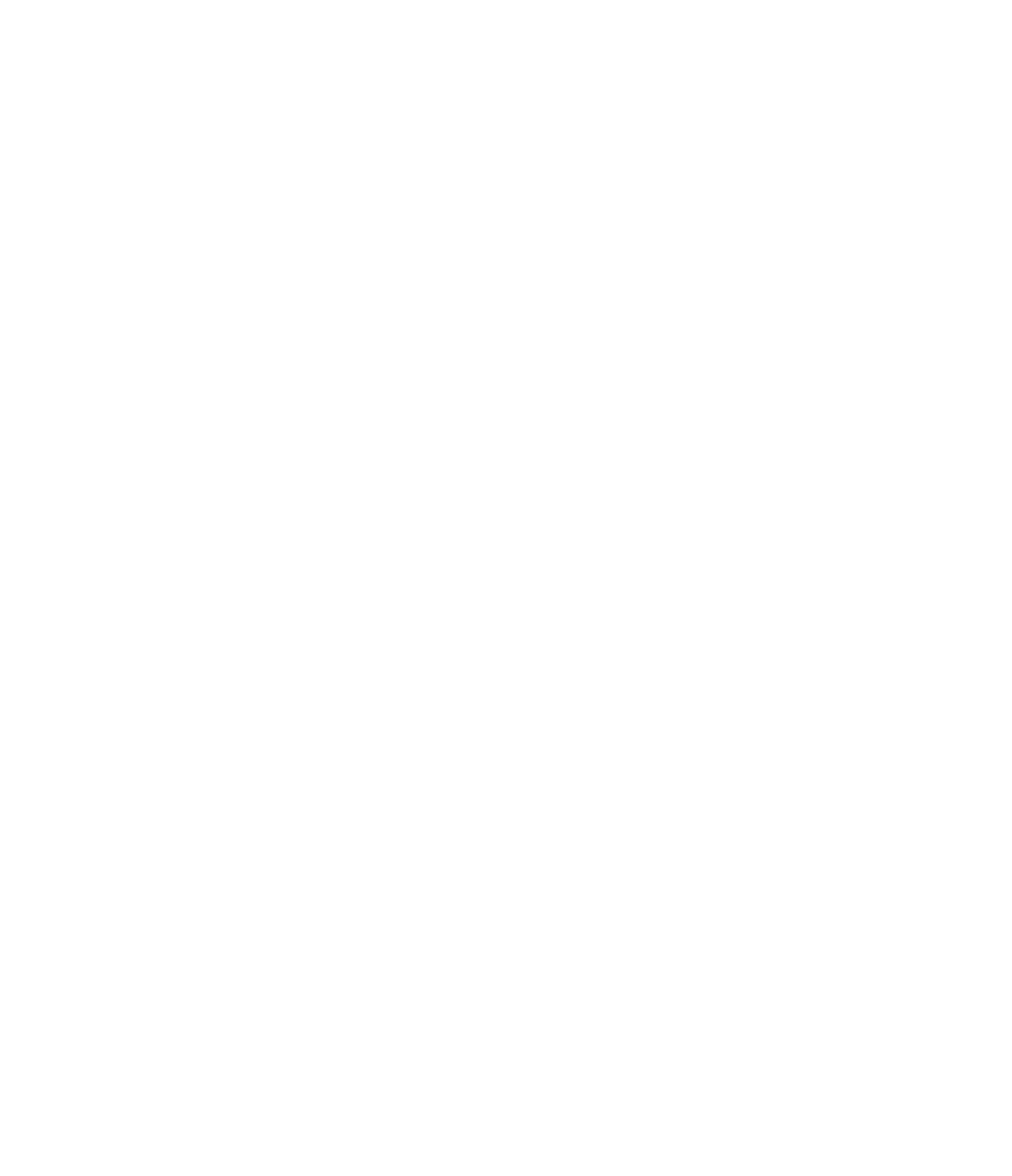

CALLOWAY CANAL.

See Kern River, Calloway canal.

CAMP CARLTON DITCH, SAN BERNARDINO COUNTY.

See San Bernardino Valley, Camp Carlton ditch. 


\section{CANYADA DEL CORRAL.}

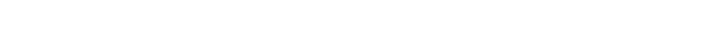

Date.

Hydrographer. \begin{tabular}{l|l} 
Aug. $\rightarrow, 1889$ & G. F. Wright .
\end{tabular}

Dis-

rharge.

Sire.-feret.
0.15 Santa Barbara County.

\section{CANYADA LARES.}

Discharge measurement of c'amyada Iaress Creek.

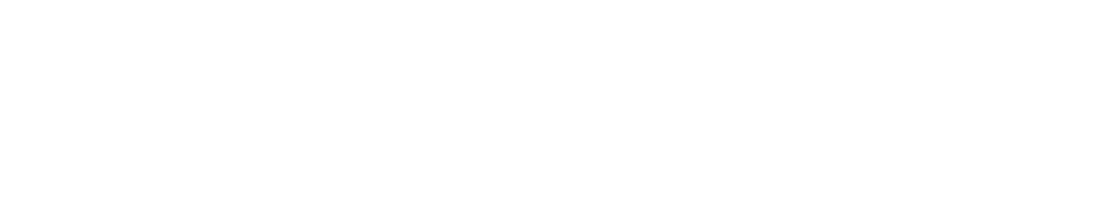

CANYADA REFUGIO.

Discharge measurement of C'anyarla Refugio C'reek.

\begin{tabular}{|c|c|c|c|}
\hline Date. & Hydrographer. & $\begin{array}{l}\text { Dis- } \\
\text { charge. }\end{array}$ & Locality. \\
\hline Ang. -,$- 18 \times !)$ & G. F. Wright..... & $\begin{array}{c}\text { ser.-feet. } \\
0.31\end{array}$ & Santa Barbara County. \\
\hline
\end{tabular}

\section{CANYADA VERDE.}

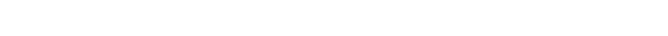

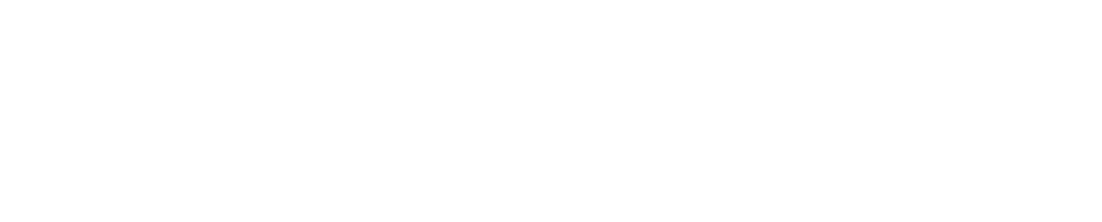

\section{CAPITAN CREEK.}

Discharge measurement of C'apitan (E7) Creok.

\begin{tabular}{|c|c|c|c|}
\hline Date. & Hydrographer. & $\begin{array}{l}\text { Dis- } \\
\text { charge. }\end{array}$ & Locality. \\
\hline Aug. --. 1889 & G. F. Wright $\ldots \ldots \ldots$ & $\begin{array}{c}\text { sec-feet. } \\
0.23\end{array}$ & Santa Barbara County. \\
\hline
\end{tabular}


CARPENTERIA CREEK.

Discharge measurement of C'arpenteria Creek.

\begin{tabular}{c|c|c|c} 
Date. & Hydrographer. & $\begin{array}{c}\text { Dis. } \\
\text { charge. }\end{array}$ & Loeality. \\
\hline Aug. -.1889 & G. F. Wright ....... & 0.08 & $\begin{array}{c}\text { Santa Barbara County. 1 mile } \\
\text { above Placitas Roed. } \\
\text { Do. }\end{array}$ \\
\hline
\end{tabular}

CARSON RIVER.

EAST FORK C'ARSON RIVER.

This branch of Carson River has its source in the high Sierra of California, and flows northward, crossing the Nevada-California boundary line and entering Carson Valley at Rodeubar's ranch, about 20 miles from Carson, a little east of south. There it turns to the northwest, and a short distance above the town of Genoa unites with the West Fork, forming Carson River. The drainage area above Rodenbah's is 414 square miles in extent, and is mapped on the Markleeville and Dardanelles atlas sheets of the United States Geological Survey. This gaging station was established by L. H. Taylor on October 17, 19(), at the place where measurements were made in the years 1890, 18:1, and 1892. The rol was an inclined timber securely fastened to posts set in the right bank of tre stream. The bench mark was on a basalt rock at the edge of the stream, 20 feet from the gage, and was at an elevation of 6.3 feet above gage datum. The channel at the station is straight and the banks are high. The stream bed is of tobhles and gravel, and is quite stable. Measurements are made from a cahle and suspended car. On August 2, 1 1!01, a loose rock dam was raised a short distance below the gaging station, which affected the velocity at the latter point. The dam was partly washed out by a freshet on December 4, 1901. On March 10, 1901, a new gage was established a short distance downstream from the original one, which had been destroyed. It consists of a vertical timber driven into the stream bed at the right bank and spiked to a cottonwood tree. A bench mark was also established on a large granite bowlder 20 feet south of the gage, under the cable from which the measurementis are made. Its elevation is 8.10 feet above the datum of the gage. 
Discharge measurements of East Fork Carson River, near Garlnemille, Nev.

\begin{tabular}{|c|c|c|c|}
\hline Date. & Hydrographer, & $\begin{array}{c}\text { Gage } \\
\text { height. }\end{array}$ & $\begin{array}{c}\text { Dis- } \\
\text { eharge. }\end{array}$ \\
\hline & & Feet. & Ser.feet. \\
\hline Mar. 10,1901 & L. H. Taylor - & 4.00 & 459 \\
\hline Apr. 30,1901 & $\ldots$. & 4.55 & $" 864$ \\
\hline June $\quad 4.1901$ & . . . do & 5.85 & 1,868 \\
\hline June 9.1901 & .... do & 5.40 & 1.356 \\
\hline Sept. 29,1901 & . . . . do & 3.70 & ${ }^{a} 127$ \\
\hline Nov. $\quad 7.1901$ & . . . do & 3.70 & $a 117$ \\
\hline Dec. 19,1901 & i.... do .... & 3.40 & 156 \\
\hline
\end{tabular}

"Approximate.

Estimated monthly discharge of East Fork Carson River, at Gurdnerville (Rodenbah), Nex.

[Drainage area, 1,519 square miles.]

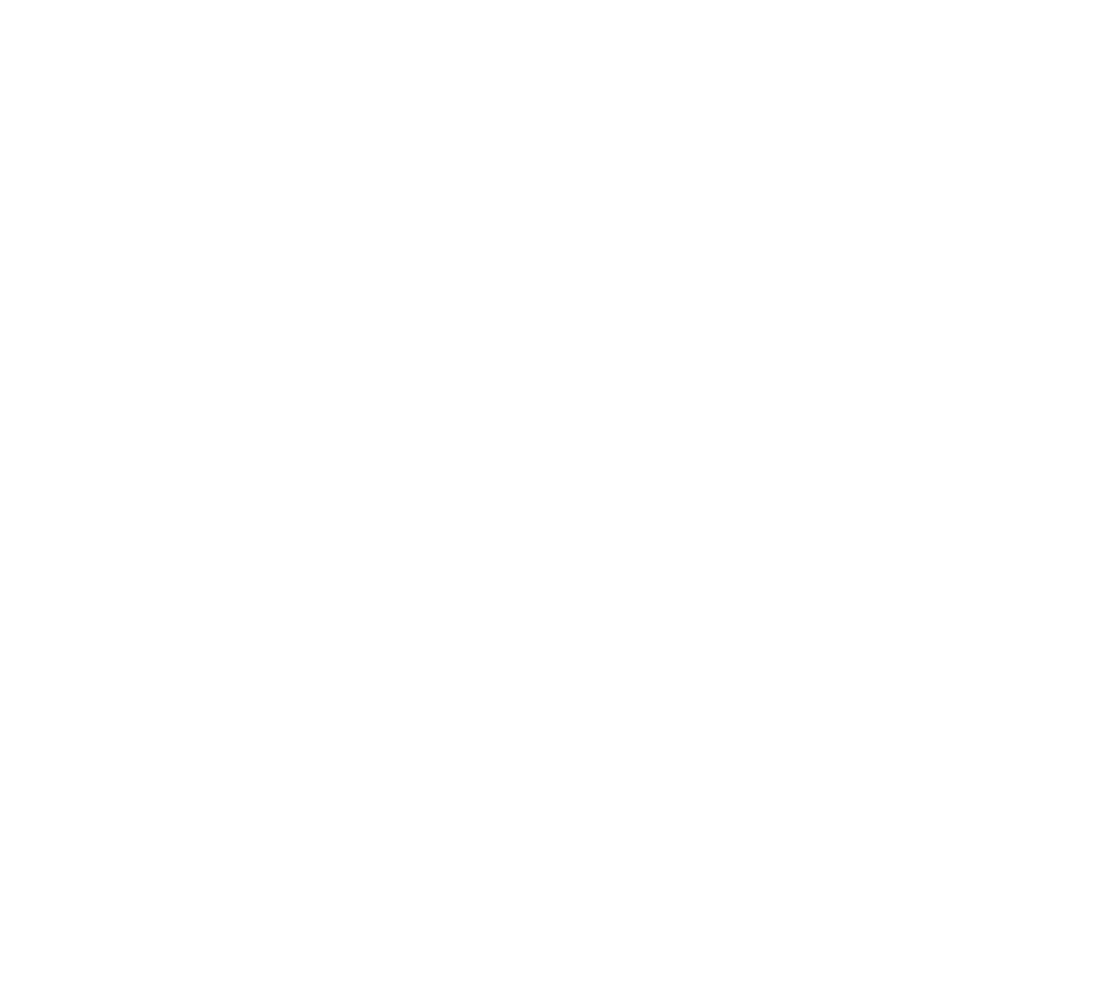


For further details of the flow of East and West forks of Carson River, see the TweIfth Annual Report of the United States Geological Survey, Pt. II, page 351 .

\section{WEST FORK, CARSON RIVER.}

'This stream rises on the eastern slope of the Sierra Nevada in ca1ifornia, immediately sontheast of the source of Truckee River, and, flowing in a general northeast direction, crosses the State line into Nevada and joins the East Fork near Genoa, in Carson Valley. The drainage area is mapped on the Markleeville atlas sheet of th o United States Geological Survey. This gaging station, established by L. IH. Taylor on October 18, 1910, is about three-fourths of a mile above the post-office at Woodfords, near the point where measurements were made in 1890,1891 , and 1892 . The gage at present in use is a vertical timber, but it is only temporary, the equipment of the station being incomplete. The channel at the station is straigh1, the banks are high and rocky, and the bed is of rock and gravel and not likely to shift. Measurements are made from a car suspended on a steel cable across the stream.

Discharge measurements of West Fork, Carson River, near Woodfords, C'al.

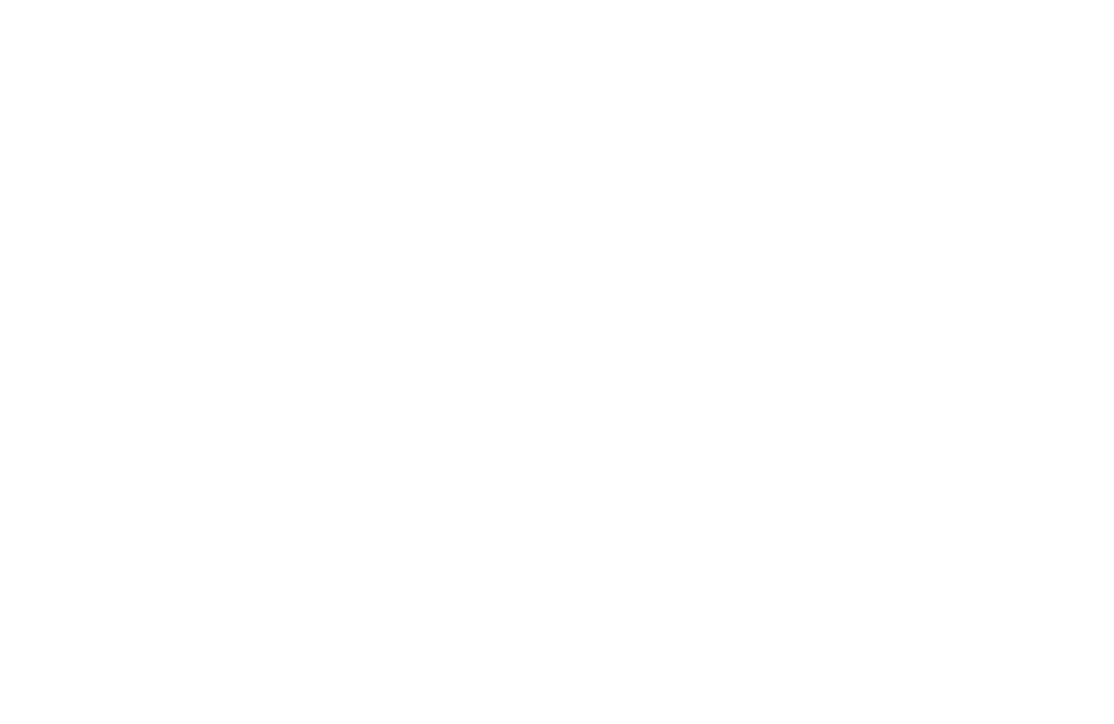


Estimated monthly discharge' of West Fork ('arson River, at Woodfords, Cal.

[Drainage area, \%) square miles.]

\begin{tabular}{|c|c|c|c|}
\hline Month. & $\begin{array}{l}\text { Mean dis- } \\
\text { charge. }\end{array}$ & Month. & $\begin{array}{l}\text { Mean dis- } \\
\text { charge. }\end{array}$ \\
\hline April . . . . . & $\begin{array}{l}\text { Ser.-ft. } \\
\quad 284\end{array}$ & $\begin{array}{c}1891 \text {-Continued. } \\
\text { May } \ldots \ldots \ldots\end{array}$ & $\begin{array}{r}\text { Sec.-ft. } \\
534\end{array}$ \\
\hline May ....... & $6 \tilde{3} 7$ & June .......... & 338 \\
\hline June ...... & 614 & July . . . . . . & 130 \\
\hline July .......... & 380 & August ................ & 65 \\
\hline August $\ldots \ldots$ & 135 & September . . . . & 41 \\
\hline September & 75 & October ... & 48 \\
\hline October - & 67 & November & 43 \\
\hline November - & 49 & December & 47 \\
\hline December . & 53 & The year... & 128 \\
\hline January ... & 52 & January & \\
\hline February & 48 & February & \\
\hline March ..... & 61 & & \\
\hline April - & 127 & & \\
\hline
\end{tabular}

Discharge measurements in C'arson River Basin.

\begin{tabular}{|c|c|c|c|}
\hline Date. & Hydrographer. & $\begin{array}{c}\text { Dis- } \\
\text { charge. }\end{array}$ & Location. \\
\hline Aug. $\quad 6,190) 2$ & C. V. Taylor. & $\begin{aligned} \text { Sec. } f t .7 \\
0.72\end{aligned}$ & Indian Creek and Harvey's ditch. \\
\hline Do ........ & $\ldots$ do _.... & 1.18 & $\begin{array}{l}\text { Hawkins Creek, one-fourth mile } \\
\text { above Hawkins's ho'tse. }\end{array}$ \\
\hline 9,1902 & L. L. Richards . & 1.10 & Do. \\
\hline 6.1902 & C. V. Taylor & 1.27 & Petersons Creek, near old sawmill. \\
\hline Sept. 9.1902 & L. L. Richards.. & .42 & $\begin{array}{l}\text { Petersons Creek, above Cohn's } \\
\text { meadow. }\end{array}$ \\
\hline Aug. $\quad 6,190^{\circ}$ & C. V. Taylor & 2.84 & Bruns Creek. mouth of canyon. \\
\hline 9,1902 & L. L. Richards _. & 3.48 & Do. \\
\hline
\end{tabular}

CASCADE CREEK, TUOLUMNE COUNTY.

See Stanislaus River, Cascade Creek.

CHERRY CREEK, TUOLUMNE COUNTY.

See 'Tuolumne River, Cherry Creek.

CHINO CREEK, RIVERSIDE COUNTY.

See Santa Ana River, Chino Creek. 


\section{CHOWCHILLA CREEK.}

Estimated monthly discharge of Chouchilla Creek at base of foothills."

[Drainage area, 2 tis square miles.]

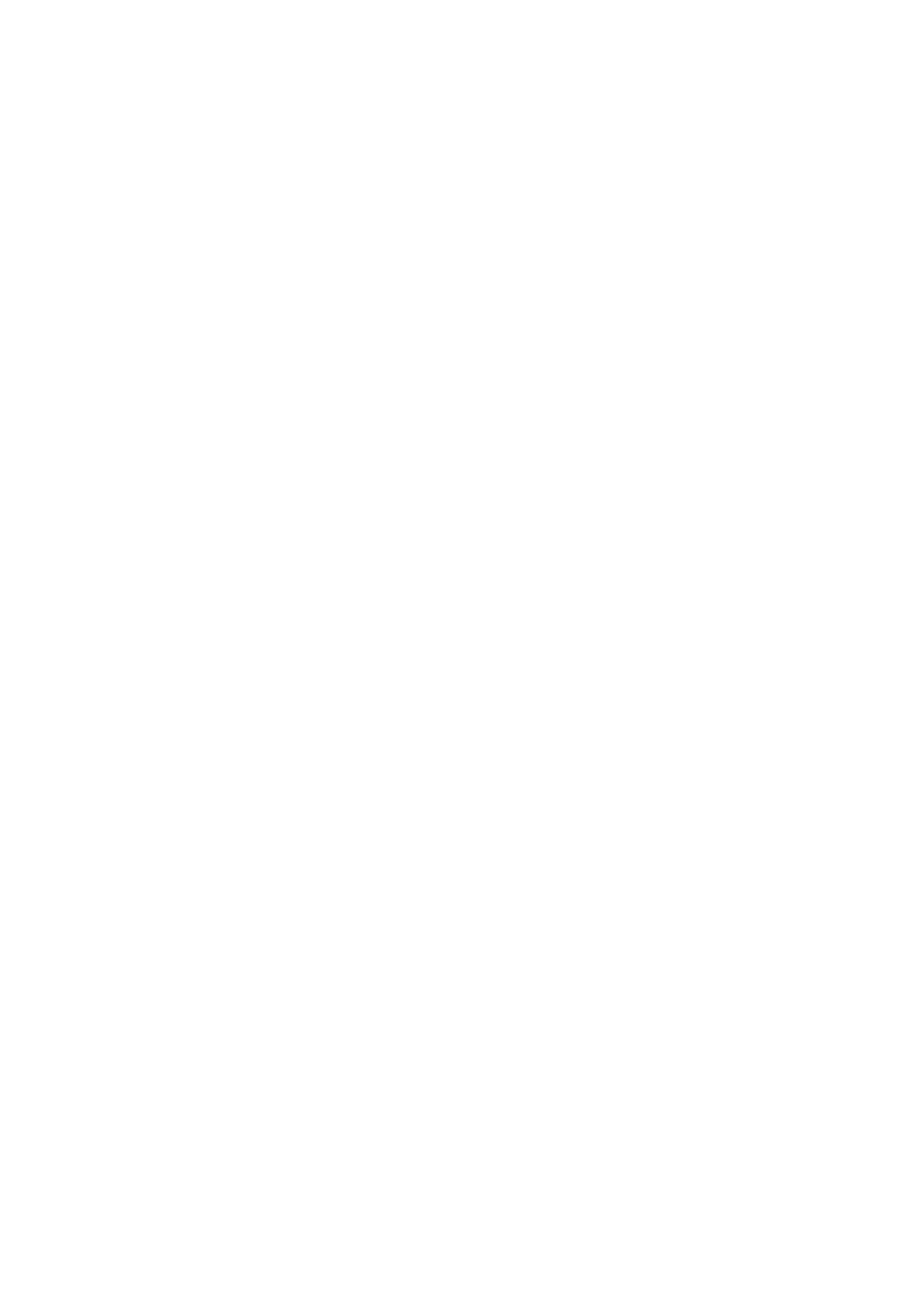

"Authority, California State engineering depastment

$b$ Estimated from previous measurement

IRR $S^{\prime} 1-11: 3-5$ 
Estimated monthly rliseharge' of chonechilla creek at bese of foothills-continued.

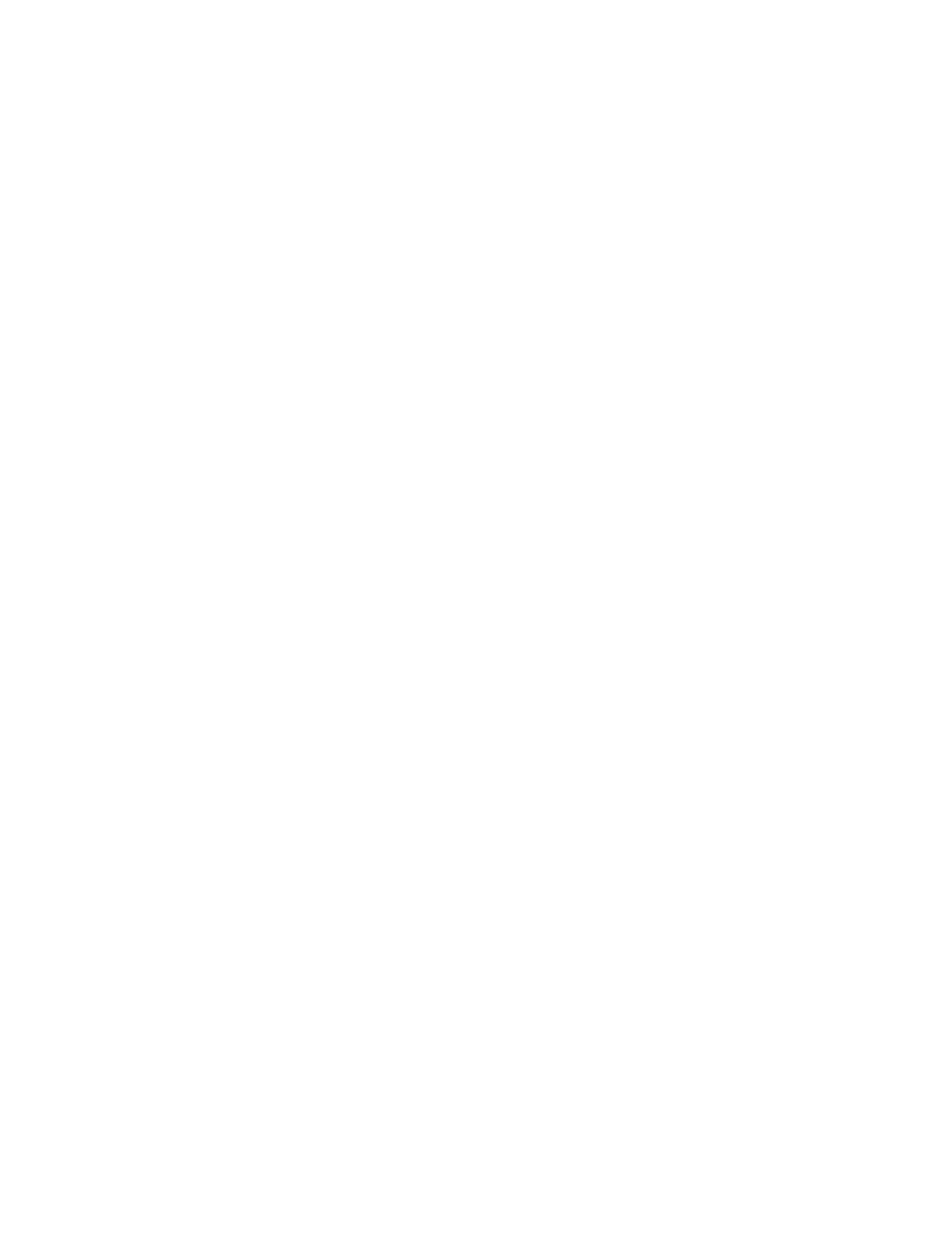

a Estimated from previous measuremont ${ }$, or flom run-off of neighborng stream. 
Est imatrd morthly discharge of Chourhilla croek at betse of foothills-Continned.

\begin{tabular}{|c|c|c|c|c|c|c|}
\hline & & Discharge. & & & Run- & -off. \\
\hline Month. & Maximum. & Minimum. & Mean. & $\begin{array}{l}\text { Total dis- } \\
\text { eharge. }\end{array}$ & $\begin{array}{c}\text { Pev: } \\
\text { square } \\
\text { mils. }\end{array}$ & Depth. \\
\hline $1883 . " 1$ & Siece-fret. & siec-feet. & see-feet. & Acre-feet. & sec-feet. & Inches. \\
\hline January ..... . . . & $\ldots \ldots$ & & 80 & 4,919 & 0.30 & 0.35 \\
\hline Fehruary _..... & $\ldots$ & $\ldots$ & 53 & 2,943 & .20 & .21 \\
\hline March _. _ - & - & & 268 & 16,479 & 1.00 & 1.15 \\
\hline April ... ... & & & 134 & $7,9 \pi 4$ & .50 & .56 \\
\hline May .... . & $\ldots$ & - & $10 \%$ & 6.579 & .40 & .46 \\
\hline June ..... . . . . . . & 0 & 0 & 0 & 0 & 0 & 0 \\
\hline July _......... & 0 & 0 & () & 0 & 0 & 0 \\
\hline August ..... . . . & () & 0 & 0 & 11 & () & 0 \\
\hline September .. . . . . & (1) & 0 & 0 & 0 & 0 & 0 \\
\hline October $\ldots \ldots$ & $1)^{1}$ & 0 & 0 & 1) & 0 & 0 \\
\hline November. . . . . . . . & () & ) & 0 & 0 & 0) & 0 \\
\hline December - . . . . . . & 0 & () & 0 & 0 & 0 & 0 \\
\hline The year & & & 54 & 38,894 & .20 & 2.73 \\
\hline $1884 . " 1$ & & & & & & \\
\hline January . . . . . . & & & $2 \pi$ & 1,660 & .10 & .12 \\
\hline February ..... & & & 1,340 & ז.0\% & 5. 00 & 5.39 \\
\hline March ... . . .... & & & 1.608 & 98,872 & 6.00 & 6.92 \\
\hline April ........ & & & $1,0 \div 2$ & 63. & 4.00 & t. 46 \\
\hline May . & & & 804 & 49,436 & 3.00 & 3.46 \\
\hline Jume . - & & & 8114 & $4 \pi .841$ & 3.00 & 3.35 \\
\hline July . . . . . . . . & & & 268 & 16,479 & 1.00 & 1.15 \\
\hline August . . . . . . & & & $2 \%$ & 1,660 & .10 & .12 \\
\hline September . . . . & & & 0 & 0 & 0 & 0 \\
\hline October.......... & & $\ldots$ & 0 & 0 & () & 0 \\
\hline
\end{tabular}

a Estimated from previous measurements, or from run-roff of neighboring stream. 


\section{CITY CREEK.}

Inischenefe medsurements of c'ity ('reed at month of amyon, Sall Bernardino ('ounty.

\begin{tabular}{ll:l} 
Hydrographer. & $\begin{array}{c}\text { Dis- } \\
\text { charge. }\end{array}$ \\
\hline
\end{tabular}

Sec-feet.

Jume 11,1898 ,

J. B. Lippincott

3.03

Sept. 9,1898 . do

Mar. 25, 1899

S. G. Bemnett

8.80

Ang. 25, 1899

Oct. 1,1900

W. W. Cockins, jr

Apr. $\quad$ ‘, 1902

S. G. Bennett

Sept. 4.1902

W. B. Clapp

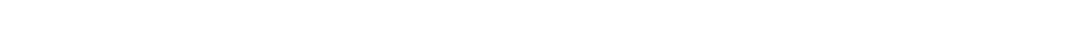
seo Santa Ana River near ('otton. Detailed deseriptions given in Water-supply Paper No. 59.

\section{COLD SPRING CANYON.}

Discharge measurements of cold syring ('anyem). Senter Barbare county.

\begin{tabular}{|c|c|c|c|}
\hline Date. & Hydrographer'. & $\begin{array}{l}\text { Dis- } \\
\text { (harge. }\end{array}$ & Locality. \\
\hline- & ---- & sec-feet. & {$[-$} \\
\hline Aug. 13,$189 ;$ & Montecito Water Co. & 0.66 & City tumnel. \\
\hline Do ...... & ....do .. & .08 & Creek at falls. \\
\hline Sept. $6,189 \%$ & $\ldots d n \ldots$ & .81 & City tumnel. \\
\hline Do . . . . . . & $\ldots$ do ......... & .06 & Creek at falls. \\
\hline Sept. $12,189 \tau$ & $\ldots$. & .31 & City tumnel. \\
\hline Do $\ldots . . . .$. & $\ldots d o \ldots$. & .09 & Creek at falls. \\
\hline Oct. $\quad 2.1897$ & $\ldots$. . do .... & .28 & City tumnel. \\
\hline Do $\ldots . .$. & $\ldots$. do _.. & .09 & Creek at falls. \\
\hline Dec. $\quad 8,189 \%$ & do & .92 & City tumnel. \\
\hline Do $\ldots . . .$. & $-d_{0}$ & .09 & Creek at falls. \\
\hline Jan. $26.1 \times 98$ & . do & .22 & City tunnel. \\
\hline Do $\ldots . . .$. & $\ldots d v \ldots . .$. & .11 & Creek at falls. \\
\hline June 14.1900 & R. Moyer . . . . . . & .02 & City tumnel, station $29+9 \%$. \\
\hline Do...... & $\ldots(d) \ldots .$. & .04 & $\begin{array}{l}\text { City tumnel. } 100 \text { feet from head. } \\
\text { station } 29+2 \pi \text {. }\end{array}$ \\
\hline Apr. 19.1 1 & Montecito Water Co. & .22 & City tumnel. \\
\hline June 10.1900 & J. B. Lippincott - & .41 & City tunnel at Portal. \\
\hline Do & $\ldots d 0 \ldots \ldots$ & Dry. & Creek at falls. \\
\hline Mar. 2a.18mi & Montecito Water Co & .06 & City tumnel. \\
\hline Do ...... & $\ldots d \theta \ldots \ldots$ & Dry. & Creek at falls. \\
\hline Aug. - $-1 \times 89$ & G. F. Wright .... & .23 & \\
\hline
\end{tabular}


COLDWATER CREEK.

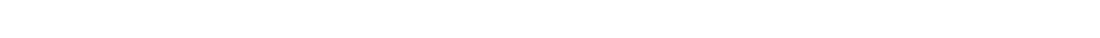
alooere derme.

\begin{tabular}{|c|c|c|}
\hline Date. & Hydrugrapher. & $\begin{array}{l}\text { Dis- } \\
\text { charge. }\end{array}$ \\
\hline$\ldots \ldots$ & $-\quad \ldots-\ldots-\cdots, \ldots, \cdots$ & sere-fert. \\
\hline 4,1899 & F. Rolfe & $0.8:$ \\
\hline Jan. $1 \times, 1 \leqslant 99$ & - $(30 \quad-$ & 1. 48 \\
\hline Jan. $2 \pi .1899$ & -do & \\
\hline Feb. $\quad 3,1899$ & . do ... & . \\
\hline Feh. 11,1899 & do ............. & .9 \\
\hline Fel). 18,1899 & do & .8 \\
\hline Feb. 24.1899 & do _ . . . . . & . \\
\hline Mar. $1.1 \times 99$ & $\left.d_{1}\right) \ldots \ldots$ &. \\
\hline Mar. $12.1 \times 99$ & do .... .... & .7 \\
\hline Mar. 17.1899 & 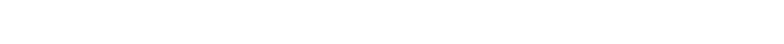 & 1.1 \\
\hline Mar. 25. 1899 & $\ldots \ldots$ & 1.1 \\
\hline Mar. 81,1899 & $\ldots \ldots$ & . \\
\hline Apr. 14.1899 & . $10 \ldots \ldots$ & \\
\hline Apr. 15,1899 & $\ldots \ldots \ldots$ & . \\
\hline Apr. 21.1899 & do $\ldots . . . .$. & . \\
\hline Apr. 26.1899 & (d) ... .... & \\
\hline May 5. 1899 & . $\quad \ldots \ldots$ & $\therefore$ \\
\hline May 13,1899 & $\ldots \ldots$ & \\
\hline May 17,1899 & - do & . \\
\hline May 29.1899 & do & $\therefore$ \\
\hline May 31.1899 & do $\ldots \ldots \ldots$ & $\therefore$ \\
\hline Do....... & 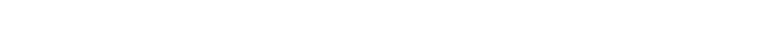 & .2 \\
\hline Jume 5.1899 & $\ldots$ do $\ldots . . . . .$. & .30 \\
\hline June $\quad$ i. 1899 & $\ldots \ldots d u \ldots \ldots$ & \\
\hline
\end{tabular}

\section{COLORADO RIVER.}

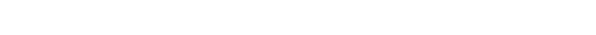

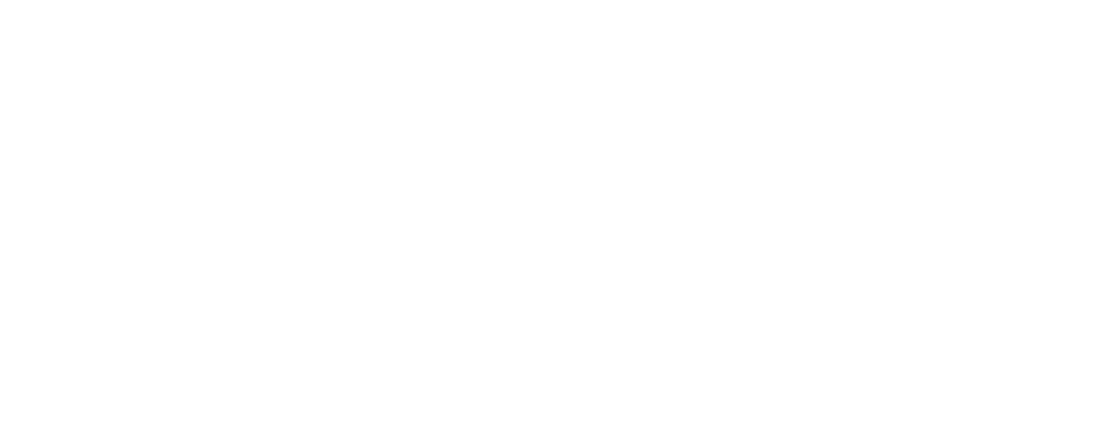


Dischurge measurements af Colorado River-Continned.

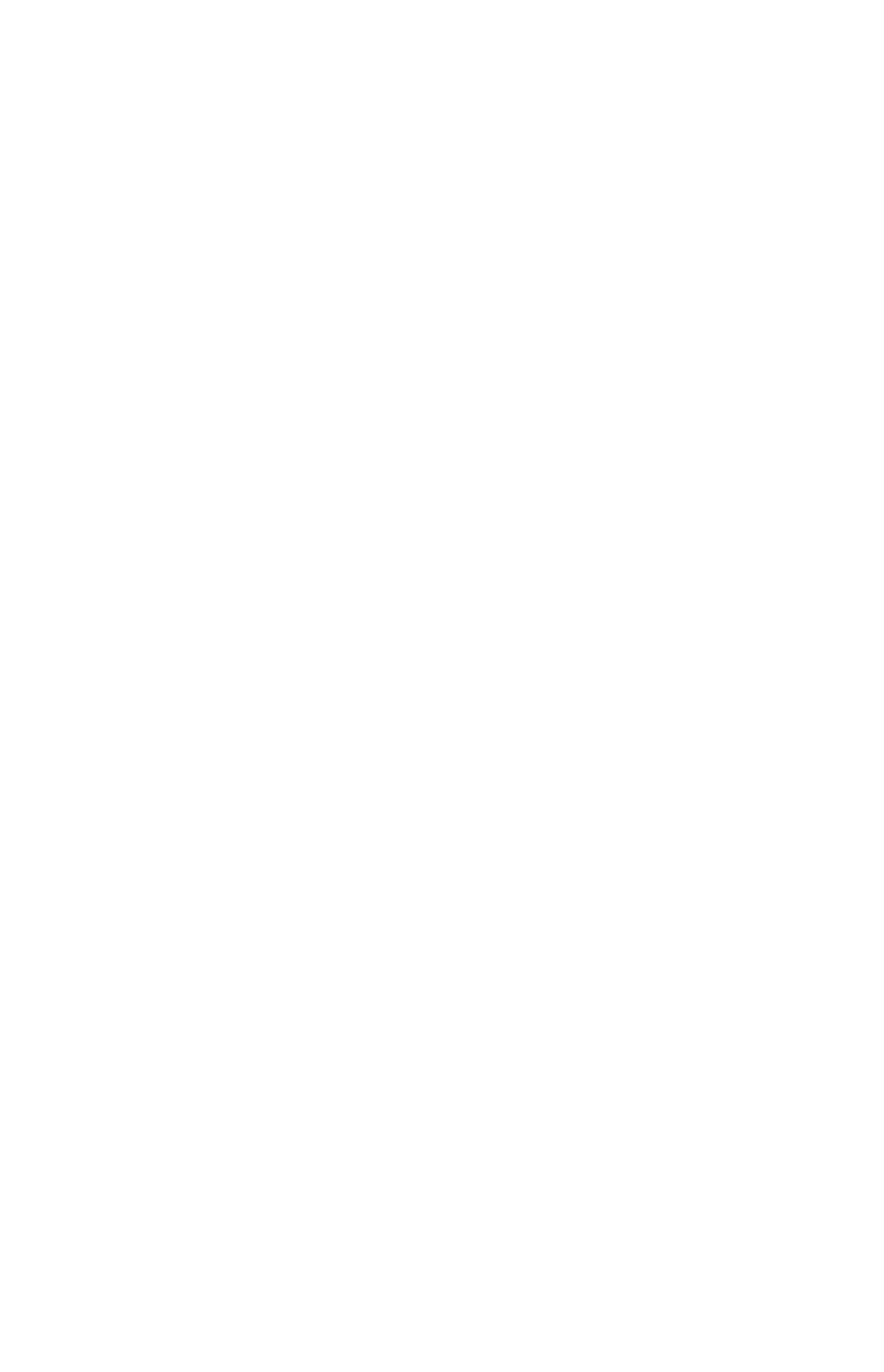


Estimated monthly discharge of C'olorado River at I'uma.

[Drainage area,

\begin{tabular}{|c|c|c|c|c|c|c|}
\hline \multirow[b]{2}{*}{ Month. } & \multicolumn{3}{|c|}{ Discharge. } & \multirow{2}{*}{$\begin{array}{l}\text { Total dis- } \\
\text { charge. }\end{array}$} & \multicolumn{2}{|c|}{ Run-off. } \\
\hline & Maximum. & Minimum. & Mean. & & $\begin{array}{c}\text { Per } \\
\text { square } \\
\text { mile. }\end{array}$ & Depth. \\
\hline 1902. & I suefoet. & Sere-fort. & serefferet. & Acre-feet. & ser-feet. & morhess. \\
\hline January .... & 4,590 & 3. 280 & $3,72 \%$ & 329,164 & 0.017 & 0.020 \\
\hline February ... & 4,720 & 3,300 & $3,9 \pi$ i & $219,6,50$ & .018 & .019 \\
\hline March ... & 5,340 & 4,340 &,+ 903 & 301,474 & .022 & .025 \\
\hline April ... . . . . & 11,400 & 4,340 & 6.179 & 365,656 & $.02 \%$ & .030 \\
\hline May .... . . . . & 59.900 & 11.400 & 35,961 & $2,211,170$ & .160 & .184 \\
\hline June . . . . . . . . . & 56,200 & 29,000 & 42,520 & $2,530,115$ & .189 & .211 \\
\hline 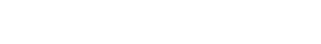 & $2 \pi, 000$ & 5,130 & 12,527 & 70,255 & .056 & .065 \\
\hline August ....... & 5,560 & 3,230 & 4,183 & 257.203 & .019 & .092 \\
\hline September & 8,360 & 3,050 & 3,819 & $22 \%, 246$ & $.01 \tau$ & .019 \\
\hline October ...... & 6,600 & 3,140 & 4,299 & 264,335 & .019 & $.0 \% 2$ \\
\hline November. & 5.540 & 3,140 & $4,18 i$ & 249,144 & .019 & .021 \\
\hline December. . & 12,600 & 3,590 & 5.412 & 332,771 & .02 .5 & .028 \\
\hline The year...... & $.59,200$ & 3,050 & $10,9 \pi 3$ & ₹.960,189 & .049 & .666 \\
\hline
\end{tabular}

Discharge measmements of Colorado River at Bulls Head ranyon.

\begin{tabular}{|c|c|c|c|}
\hline Date. & Hydrographer. & $\begin{array}{l}\text { Gare } \\
\text { height. }\end{array}$ & $\begin{array}{l}\text { Dis- } \\
\text { charge. }\end{array}$ \\
\hline & & Fiet. & sec.feet. \\
\hline Dec. 5,1902 & J.T. Whistler & 3 & 5,786 \\
\hline Dec. 10,4902 & L. M. ¿armes _.. & 2.6 .5 & 4,051 \\
\hline Dec. 13,1902 & d... do . . . . & $2 . \therefore 5$ & 3,222 \\
\hline Dec. $1 \%, 1902$ & $\ldots d v$ & 2.95 & 4,138 \\
\hline Dec. 20,1902 & ..... do ... & 3.50 & 4,792 \\
\hline Dec. 24,1902 & ...do .. & 3.23 & 4.939 \\
\hline Dec. 29,1902 & !.... do .. & 2.45 & 3,366 \\
\hline Dec. $31,190^{\circ}$ & , do & 2.20 & $\mathcal{Q}, 913$ \\
\hline
\end{tabular}

COLTON CITY AND COLTON TERRACE, SAN BERNARDINO COUNTY.

See San Bernardino Valley.

\section{CONVIC'T CREEK.}

See Owens River, ('onvict Creek. 
COSUMNES RIVER.

IDischarge measurements of C'osumnes River', Eldomallo ('ounty.

\begin{tabular}{|c|c|c|c|}
\hline Date & Hydrographer. & $\begin{array}{c}\text { Dis- } \\
\text { charge. }\end{array}$ & Locality. \\
\hline- & & Sentert & - n \\
\hline Sept. 16,1899 & S. G. Bennett & 2 & $\begin{array}{l}\text { Bridge near Latrobe, Jackson } \\
\text { road. }\end{array}$ \\
\hline Do. & $\ldots$ do ... & 2 & $\begin{array}{l}\text { Ditch on sonth side of Latrobe, } \\
\text { Jackson road. }\end{array}$ \\
\hline Sept. 12,1900 & _... do & 1.7 & $\begin{array}{l}\text { Bridge near Latrobe. Jackson } \\
\text { road. }\end{array}$ \\
\hline Do & ... no & 3.7 & Ditch on south side. \\
\hline
\end{tabular}

Estimated monthly dischargr of Cosumnes River at Live Oah Suspensiom Bridge, Sacromento County.

[Drainage area, iko square miles.]

\begin{tabular}{|c|c|c|c|c|}
\hline \multirow[b]{2}{*}{ Month. } & \multirow[b]{2}{*}{$\begin{array}{l}\text { Mean dis } \\
\text { charge }\end{array}$} & \multirow[b]{2}{*}{$\begin{array}{c}\text { Total dis } \\
\text { charge. }\end{array}$} & \multicolumn{2}{|c|}{ Run-off. } \\
\hline & & & $\begin{array}{c}\text { Per square } \\
\text { mil }\end{array}$ & Depth. \\
\hline November . . . . . $18 \pi$. . . & $\begin{array}{r}\text { See -feet. } \\
29\end{array}$ & $\begin{array}{l}\text { Acre-feet. } \\
1 . \approx 26\end{array}$ & $\begin{array}{l}\text { sece feet. } \\
\quad 0.05\end{array}$ & $\begin{array}{l}\text { mehes. } \\
0.06\end{array}$ \\
\hline December ..... . & 29 & 1,783 & .05 & .06 \\
\hline 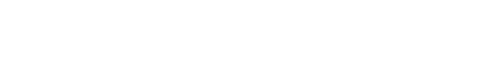 & 290 & $1 \pi, 831$ & .50 & .58 \\
\hline February $\ldots \ldots \ldots \ldots \ldots$ & 1,218 & $6 \tau, 644$ & $\therefore .10$ & 2.19 \\
\hline 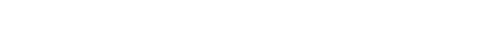 & 1.740 & 106,988 & $\because$ & 3.46 \\
\hline April $\ldots \ldots \ldots \ldots$. & 3,132 & $180,36 \%$ & 1. 40 & 6.03 \\
\hline May $\ldots \ldots \ldots$....... & $3.24 k$ & 199.712 & 5.60 & 0. 46 \\
\hline June _ _.... & 3,480 & $20 \pi, 0 \pi 4$ & c & 6.69 \\
\hline July $\ldots . . . .$. & 422 & $2 \tilde{5}, 948$ & .73 & .84 \\
\hline August ... . & 116 & $\tau, 133$ & .30 & .33 \\
\hline September . . . . . . . . . . & 23 & 1,369 & .04 & .04 \\
\hline October ..... & $1 \tau$ & 1,045 & .03 & .03 \\
\hline November. . ... & 52 & 3,094 & .09 & .10 \\
\hline December $\ldots \ldots \ldots$ & 406 & 24,964 & .70 & .81 \\
\hline The year & 1,179 & 849,169 & 2.03 & $2 \pi .46$ \\
\hline
\end{tabular}

a Authority, California state engineering department Estimated from rum-eft of weighloring drainage lasins. 
Estimated monthly dissharge of ('ostmmuses River, ate.-Continued.

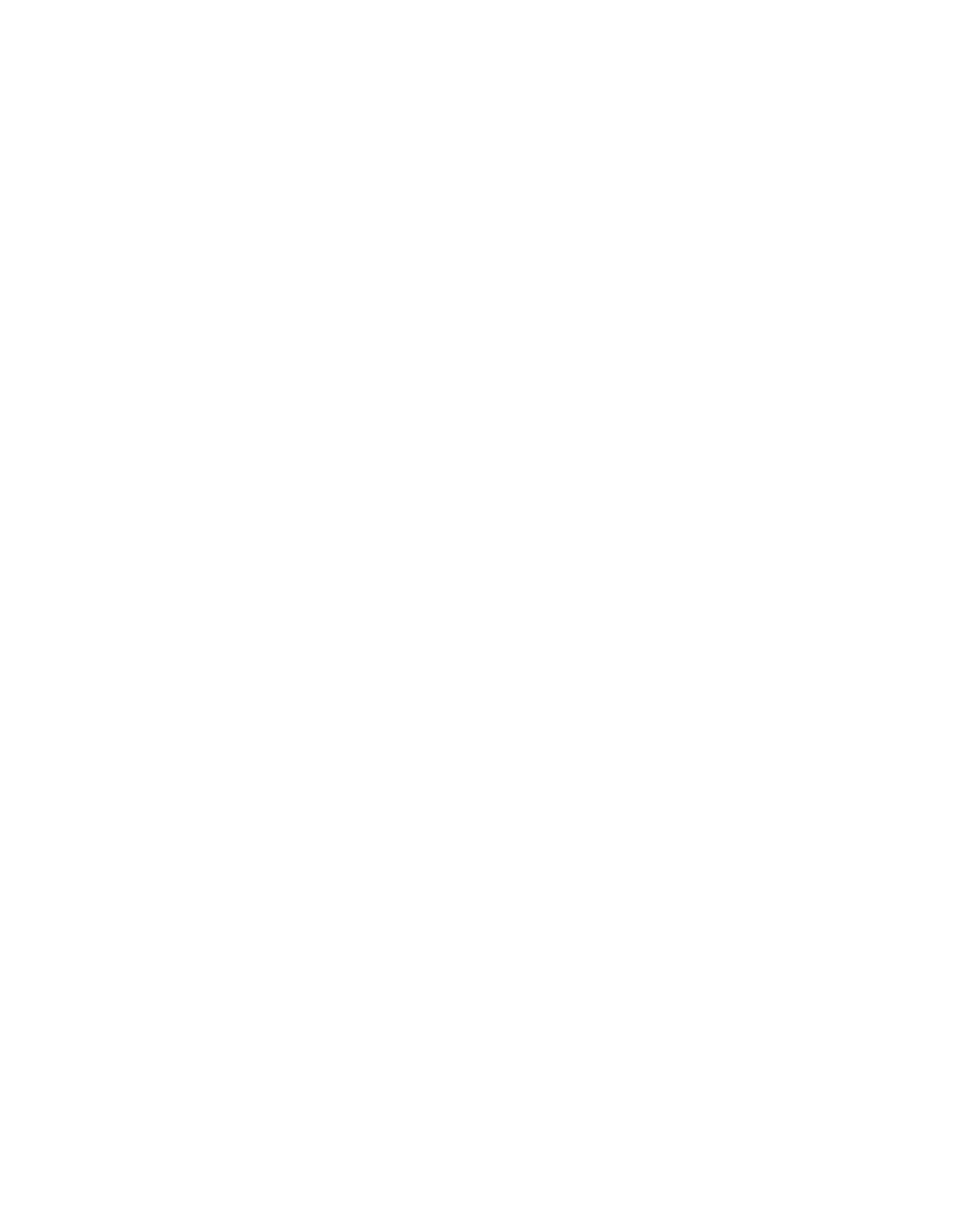


Estimeted monthly dischary" "ff cosummes River, ete-Continnert.

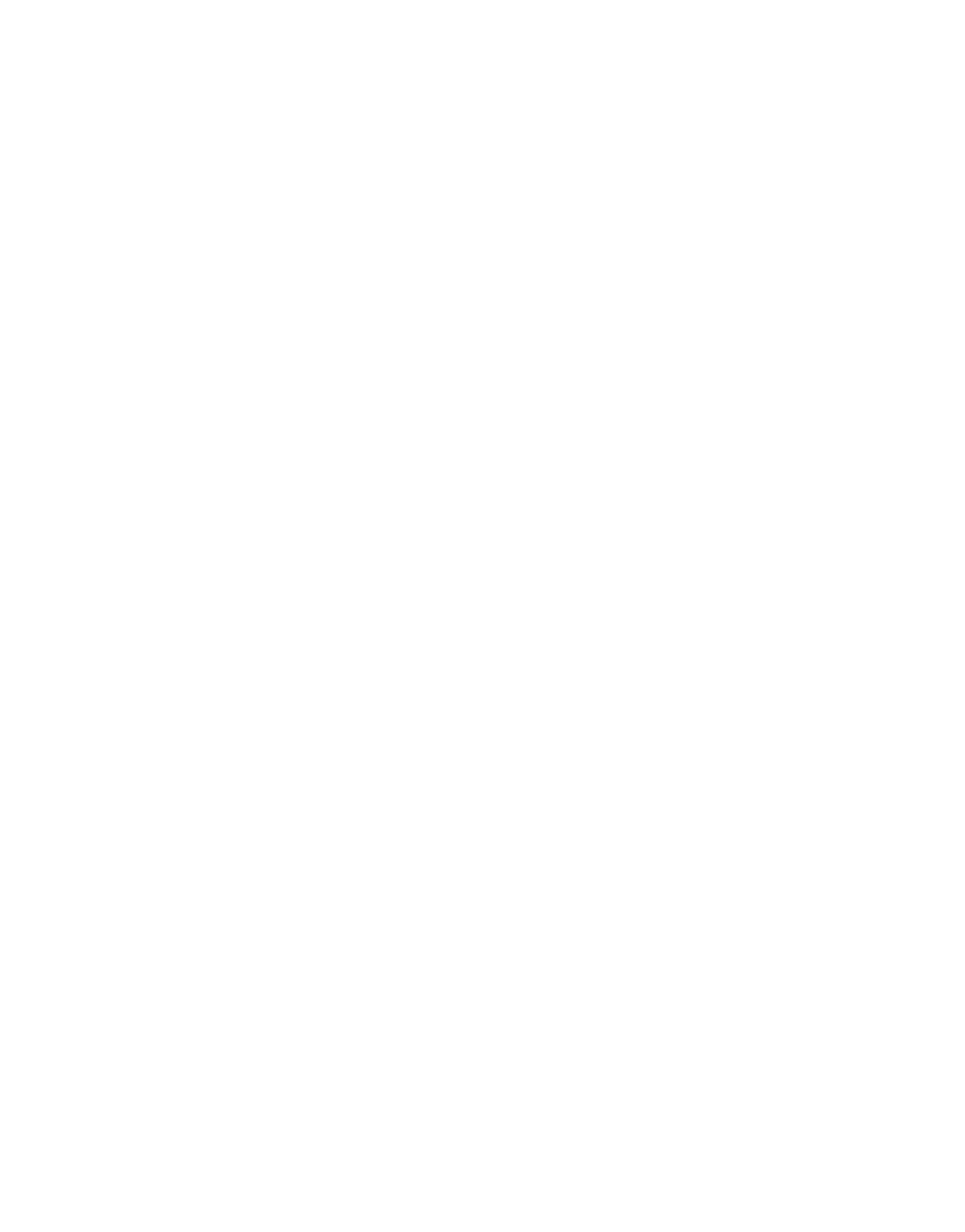


Tistimated monthly discharge of ('astmus's River, ete.-Contimued.

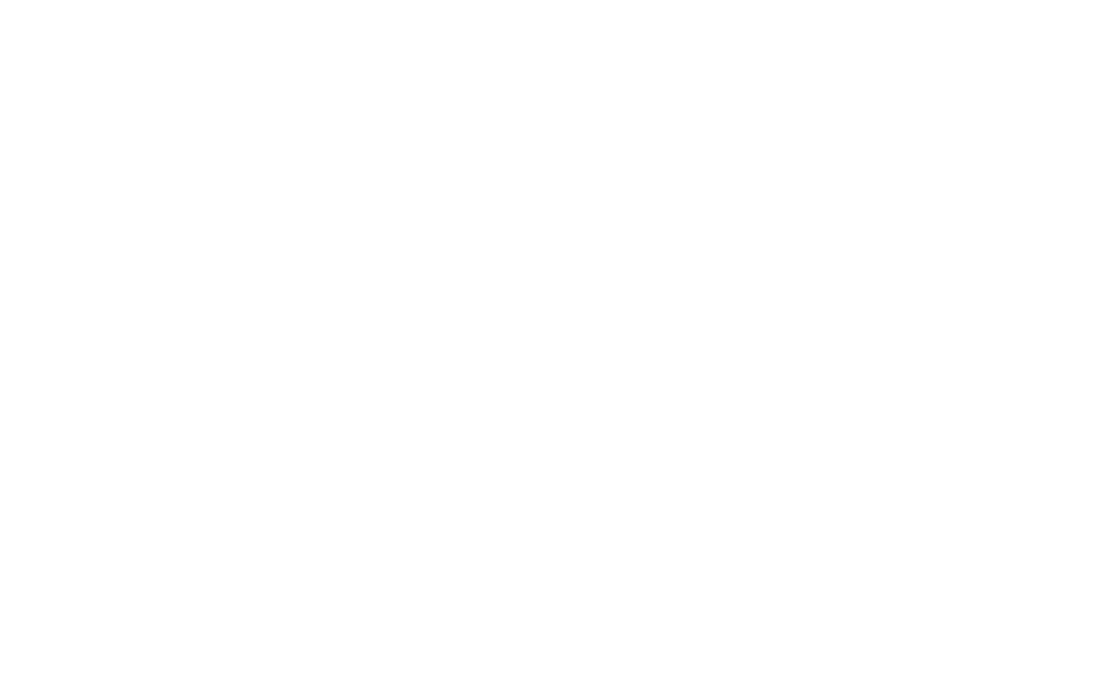

COW CREEK, TUOLUMNE COUNTY.

See Stanislaus River, Cow Creok.

\section{CUCAMONGA CREEK.}

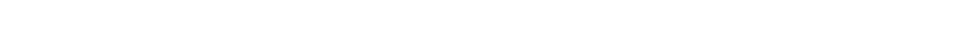

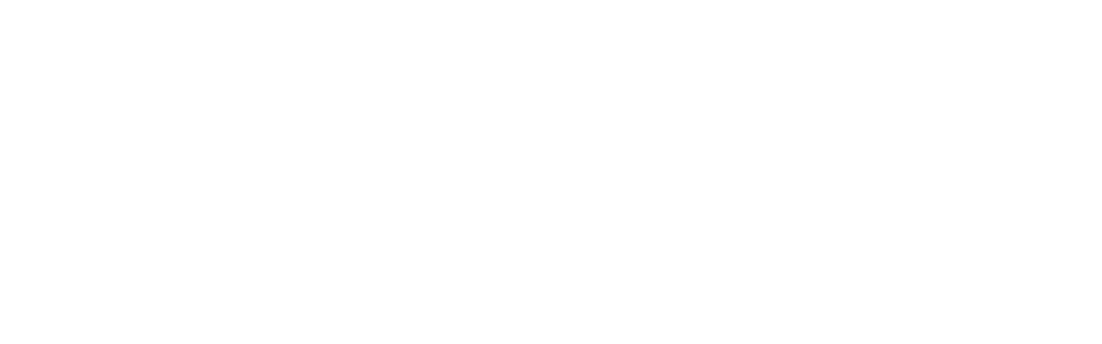




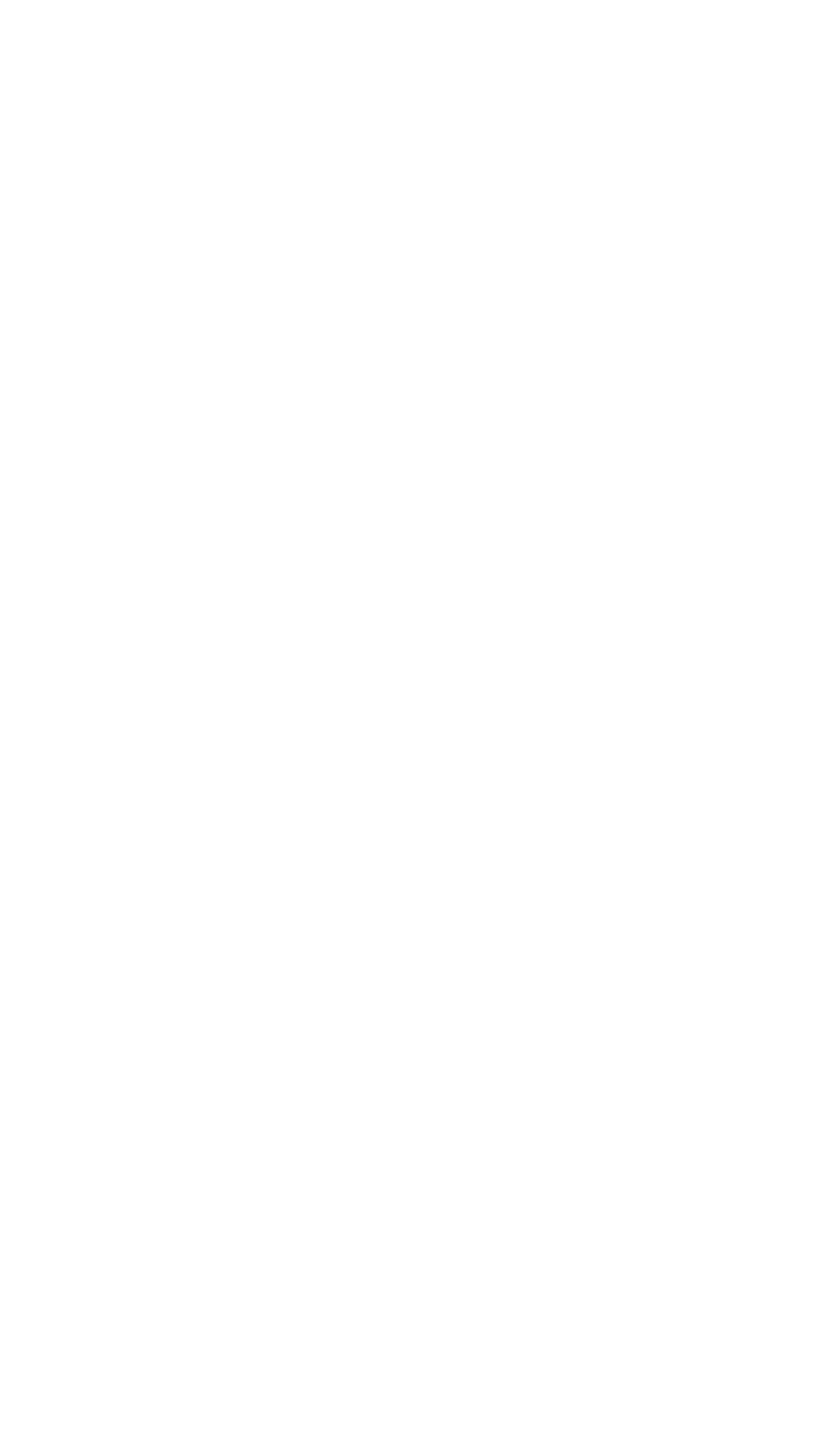




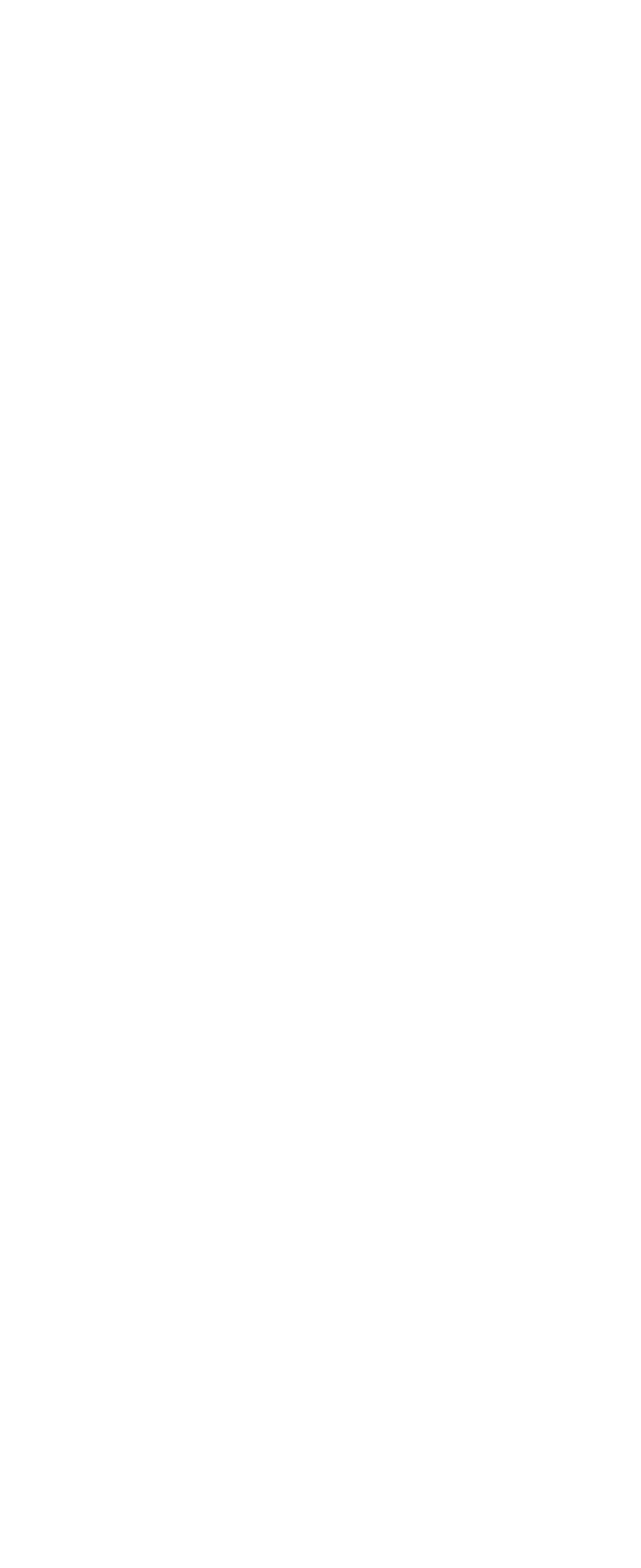




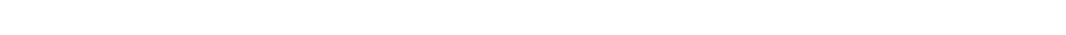

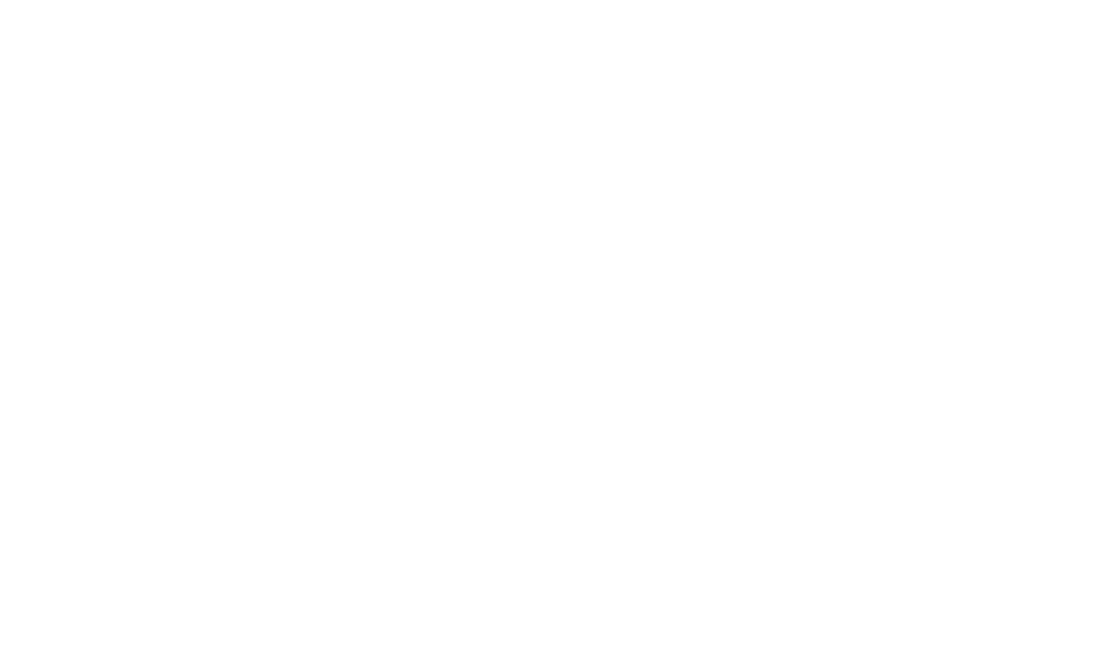

DALEY DITCH, SAN BERNARDINO COUNTY.

See San Bernardino Talley, Daley ditch.

\section{DEER CREEK.}

Estimated monthly discharge of Deer C'reek, Tulare C'ounty, at hase of foothills." [Drainage area, 110 square miles.]

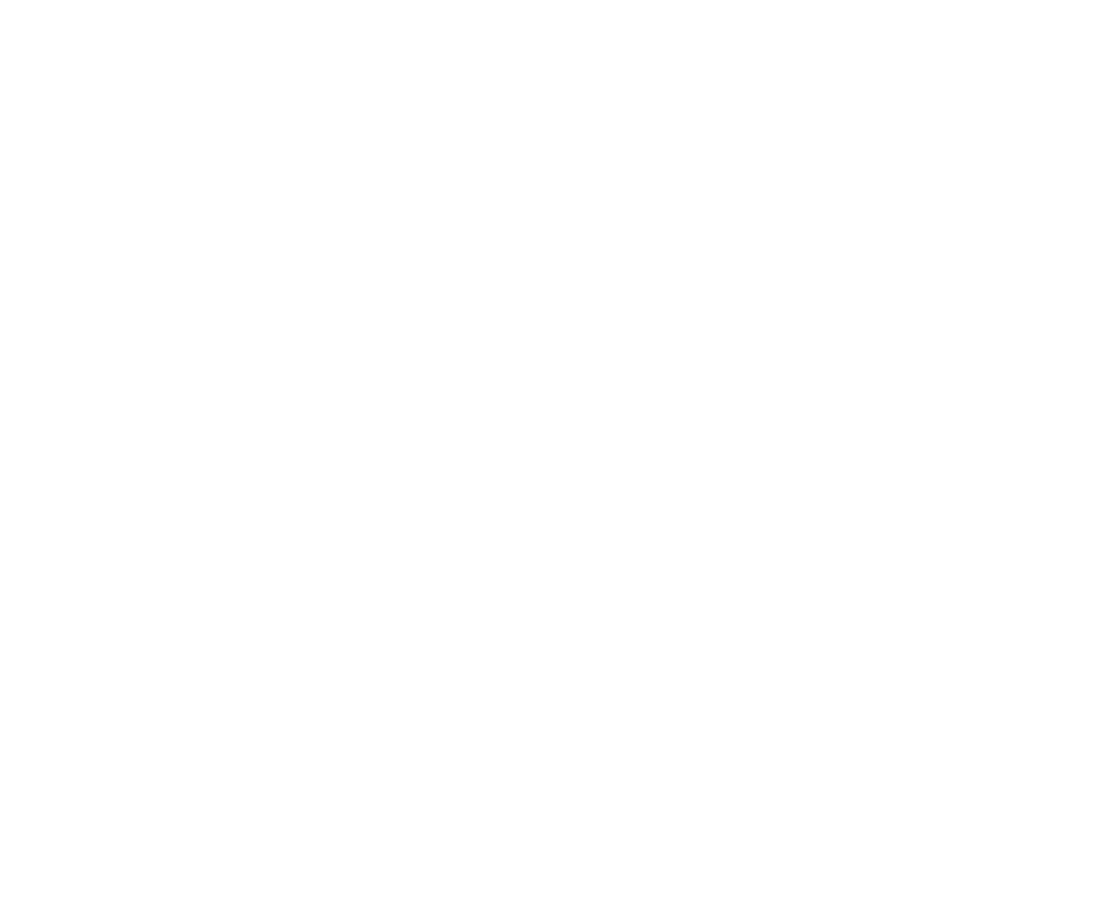

a Anthority, California State engineering department. Estimated from 1'mu-off of neighhoring streams. 


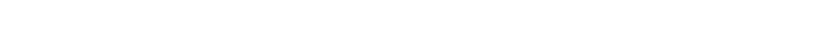

\begin{tabular}{|c|c|c|c|c|}
\hline \multirow[b]{2}{*}{ Montli. } & \multirow[b]{2}{*}{$\begin{array}{l}\text { Mean dis- } \\
\text { charge. }\end{array}$} & i & \multicolumn{2}{|c|}{ Rull-ı)ั̆. } \\
\hline & & $\begin{array}{l}\text { Total dis- } \\
\text { charge. }\end{array}$ & $\begin{array}{l}\text { Per square } \\
\text { mile. }\end{array}$ & Deptli. \\
\hline$-\cdot--$ & i & $-\cdots$ & $-\cdots$ & $--\ldots$ \\
\hline \begin{tabular}{c}
\multicolumn{3}{c}{$1 \mathrm{k} \times(0}$. \\
January .
\end{tabular} & $\begin{array}{r}\text { sectred-feet. } \\
132\end{array}$ & $\begin{array}{r}\text { Acre-pert } \\
8,116\end{array}$ & secend-fert. & $\begin{array}{l}\text { Inches. } \\
1.38\end{array}$ \\
\hline February $\ldots \ldots$ & $25: 3$ & $14.5,53$ & 2.30 & 2.48 \\
\hline March . . . . . . . . & 286 & 17,585 & $\therefore .60$ & 3.00 \\
\hline April $\ldots \ldots \ldots$ & 319 & 18,982 & 2.90 & 3.24 \\
\hline May .... & 290 & 13.527 & 2.00 & 2.31 \\
\hline June $\ldots \ldots$. $\ldots \ldots$. $\ldots$. & 55 & 3.283 & .50 & .56 \\
\hline July $\ldots \ldots \ldots$ & 6 & 369 & .05 & .06 \\
\hline Augnst $\ldots \ldots \ldots \ldots$ & 0 & 0 & 0 & 0 \\
\hline 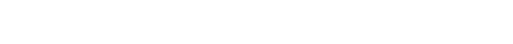 & 0 & () & (1) & 0 \\
\hline October $\ldots \ldots \ldots$ & 0 & 0 & 0 & 0 \\
\hline November $\ldots \ldots \ldots \ldots \ldots$ & 29 & 1,309 & .20 & $\therefore 2$ \\
\hline December . . . . . . & 5.5 & 3.382 & .50 & . is \\
\hline The year & 112 & 81,096 & 1.02 & 13.83 \\
\hline $18 \$ 1$. & & & & \\
\hline January . . . . . . . . & $5 \overline{5}$ & 3,382 & .50 & .58 \\
\hline February . . . . & 110 & 6.109 & 1.00 & 1.04 \\
\hline March $\ldots \ldots \ldots$ & 110 & 6.764 & 1.00 & 1.15 \\
\hline April $\ldots \ldots \ldots$ & 110 & 6.545 & 1.00 & 1.12 \\
\hline May ................... & 110 & 6.764 & 1.00 & 1.15 \\
\hline June ... . . . . . . . . . . & $5 \tilde{5}$ & 3.223 & .50 & .56 \\
\hline July $\ldots \ldots \ldots$ & 0 & 0 & 0 & 0 \\
\hline August .... & () & () & 0 & 0 \\
\hline September ......... & 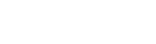 & 0 & (1) & 0 \\
\hline October $\ldots \ldots$ & 0 & 0 & 0 & 0 \\
\hline November ... . . . . . & 0 & 0 & 0 & 0 \\
\hline December. & $2: 3$ & 1.41. & .21 & .24 \\
\hline The year . ...... & tri & 34,251 & .43 & $\pi .81$ \\
\hline
\end{tabular}


Estimated monthly discharge' of Deer- ('peesk, etc.-Continued.

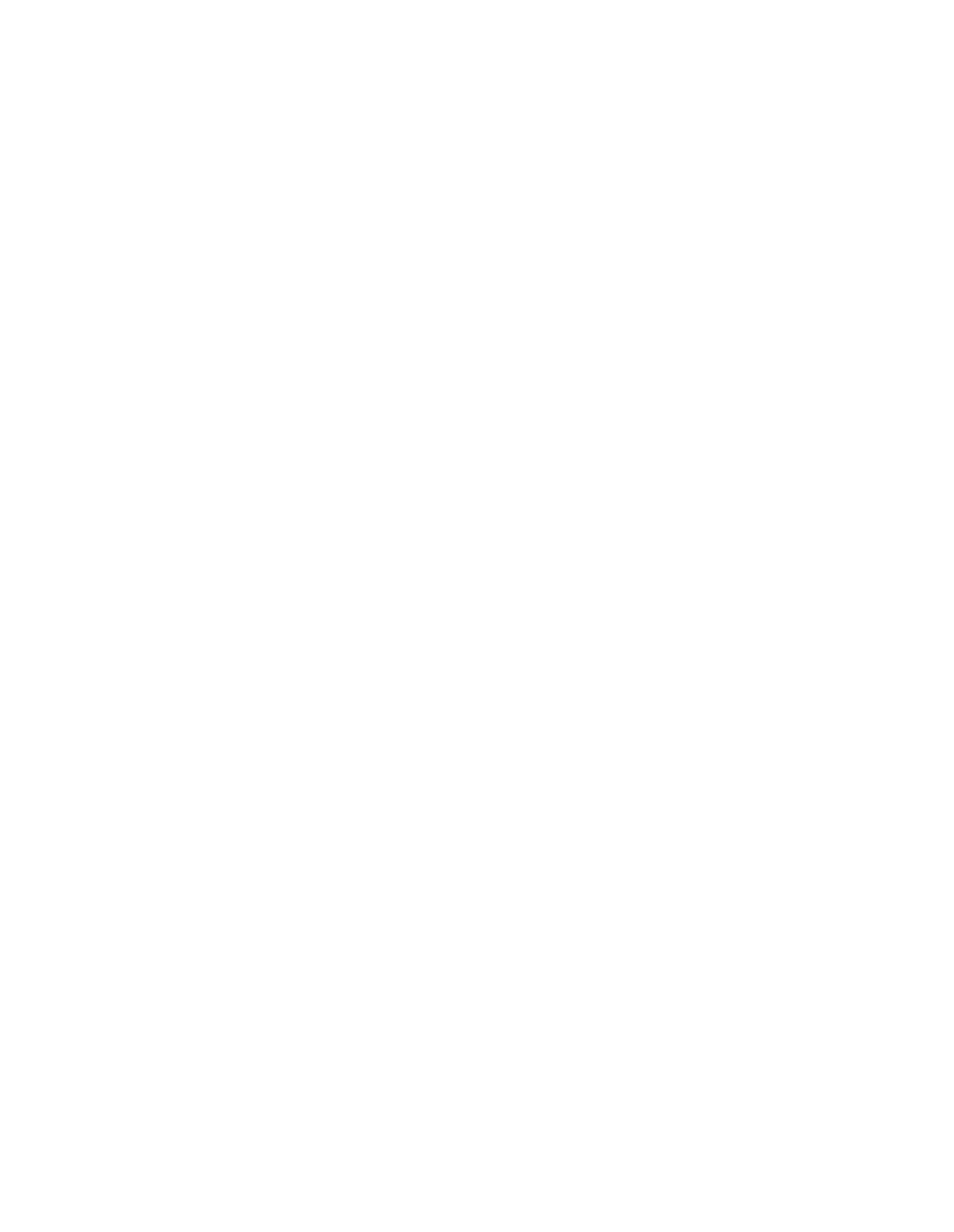


Estimated monthly rischerge of Deer Creek, etc.--Continued.

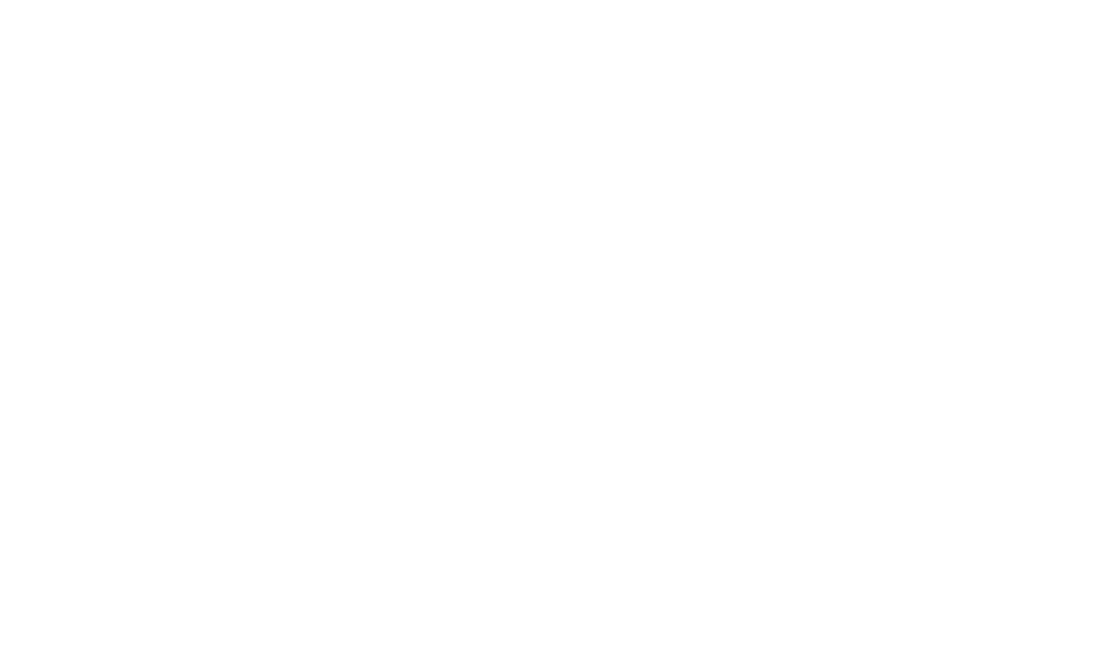

\section{DINSMORE CREEK.}

Discharge measurement of Dinsmore Creek, Santa Barbara County.

\begin{tabular}{|c|c|c|}
\hline Date. & Hydrographer. & $\begin{array}{c}\text { Dis- } \\
\text { charge. }\end{array}$ \\
\hline Aug. - -1889 & G. F. Wright $\ldots \ldots \ldots$ & $\begin{array}{r}\text { sec-feet. } \\
0.23\end{array}$ \\
\hline
\end{tabular}

\section{DOBBINS CREEK.}

Discharge measurement of Dobbins Creek, Fuba County.

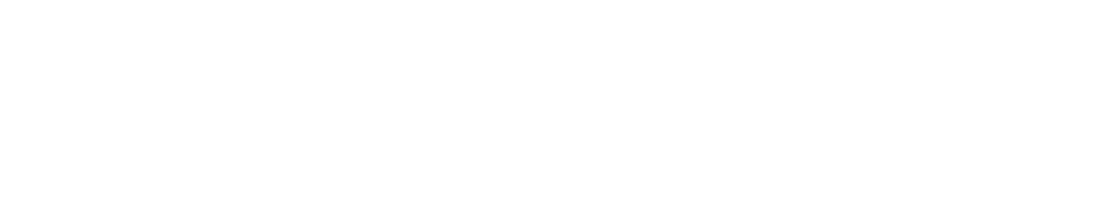

a Estimated, at dam.

\section{DOS PUEBLOS CREEK.}

Discharge measurement of Dos Pueblos C'reek, Santa Barbara Connty.

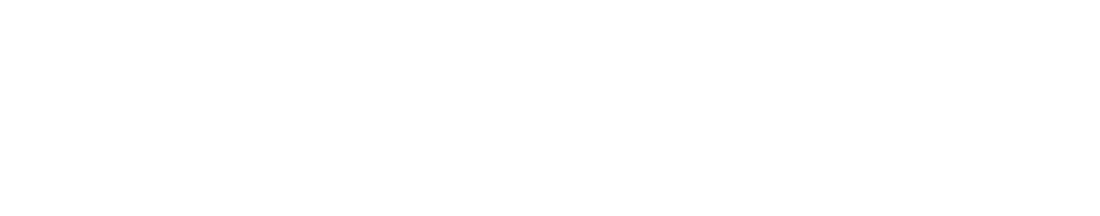

IRK $81-03-6$ 


\section{DRY OR JACKSON CREEK.}

Estimated monthly discharge of Dry C'reek, San Joaquin C'ounty, at berse of foothills."

[Drainage area, $2 \times 3$ square miles.]

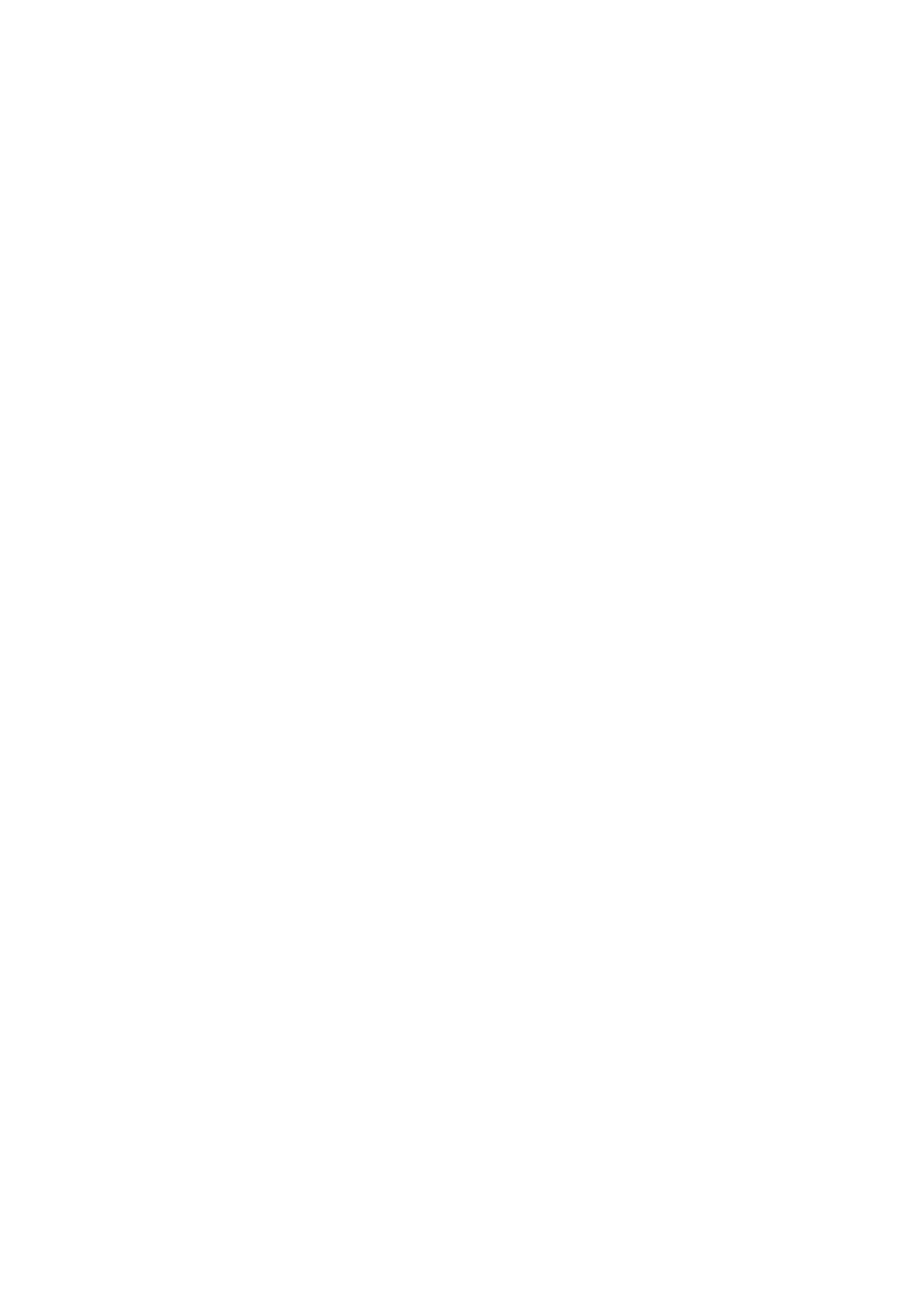

a Authority, California State engineering department. Estimated from rur off of neighboring streams. 
Estimated monthly discharge of Dry Creek, ete.-Continued.

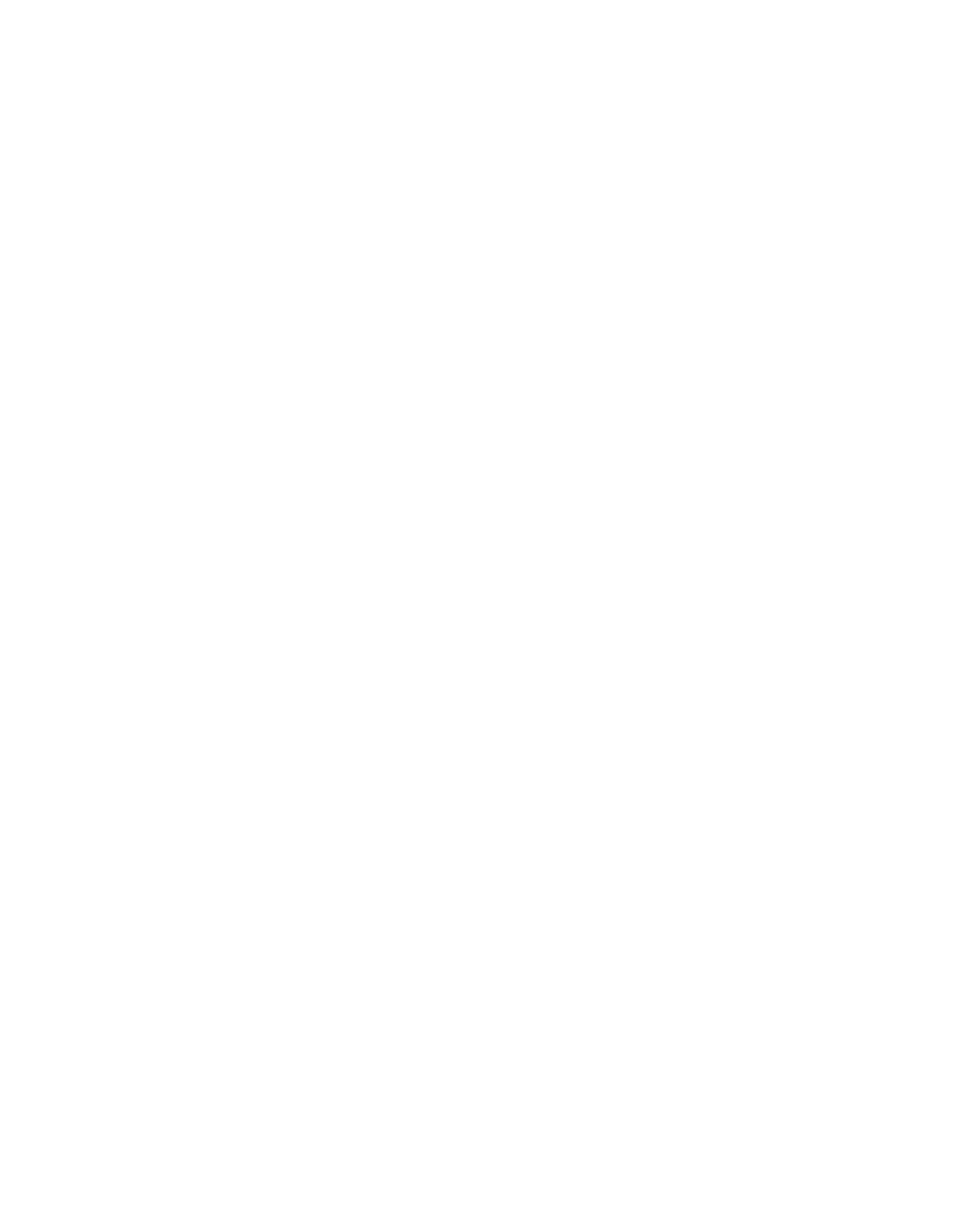


Estimuted momthly alischargr of Dry Creek, etc.-Continned.

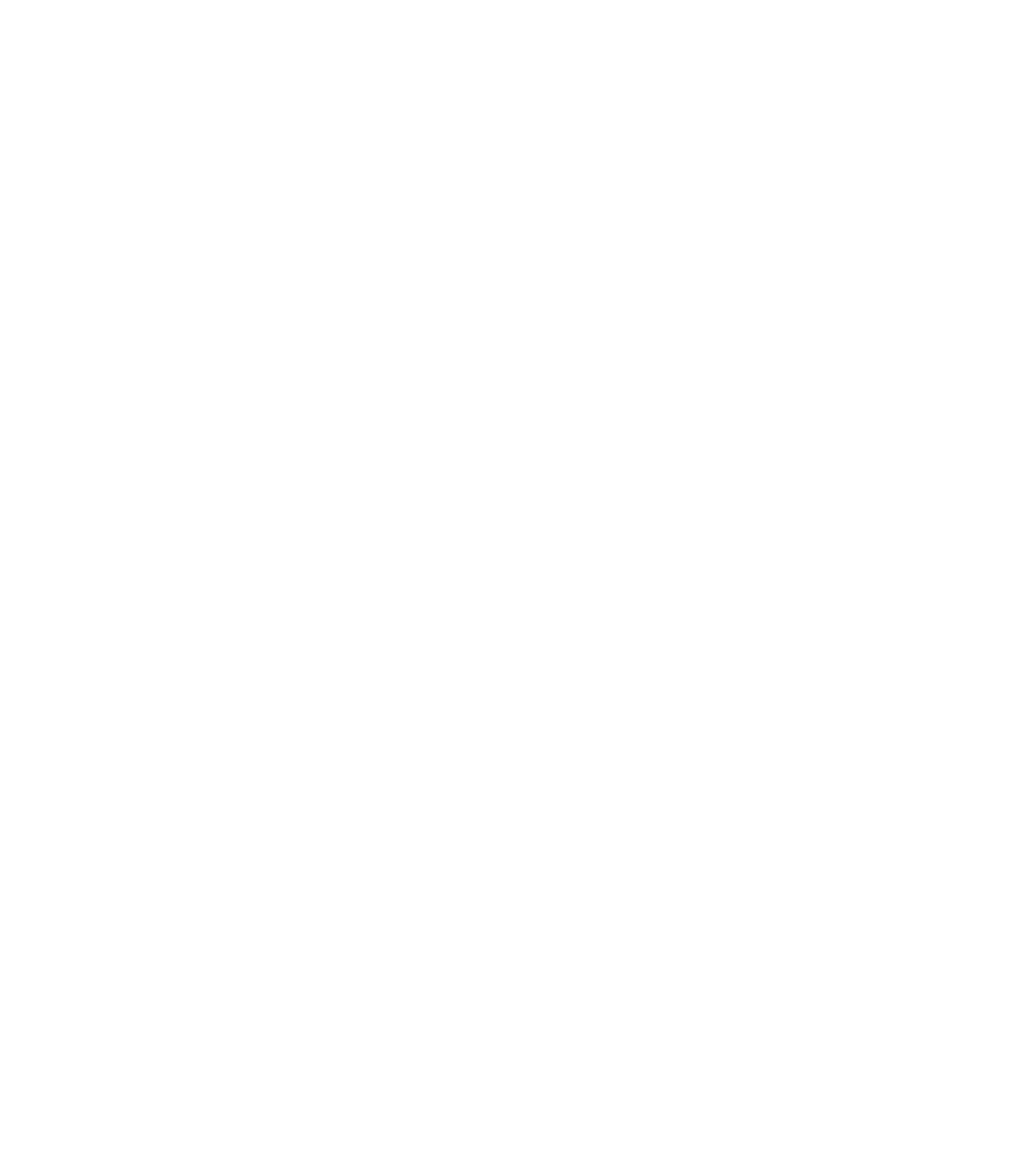


EAST RIVERSIDE WATER COMPANY, SAN BERNARDINO COUNTY.

See San Bermardino Valley.

EATON CANYON.

Discharge measurements of Eaton c'anyon. Los Angeles County.

\begin{tabular}{|c|c|c|c|}
\hline Date. & Hydrographer. & Discharge. & Lowalit:". \\
\hline & & I ser-fpet. & \\
\hline Jan. 11.1899 & E. P. Dewey . . . . . . . & | $\quad 0.50$ & Near falls. \\
\hline Oct. 18.1898 & J. B. Lippincott_ _ - - I & $1.8 i$ & $\begin{array}{l}\text { Water from large wells in Ea- } \\
\text { ton Wash. }\end{array}$ \\
\hline Do $\ldots$ & ... do & .04 & $\begin{array}{l}\text { Around superintendent's house } \\
\text { and barns. }\end{array}$ \\
\hline Do . . & do & .10 & San Gabriel water. \\
\hline Do.... & do & .10 & Dairy well. \\
\hline lov. 14,1898 & .... do & 2.11 & \\
\hline
\end{tabular}

ELEANOR CREEK.

See Tuolumne River, Eleanor Creek.

FALLS CREEK.

See Tuolumne River, Falls Creek.

FALL RIVER.

See Pit River, Fall River.

FEATHER RIVER.

Discharge measurements of Feather River, Butte County.

\begin{tabular}{|c|c|c|c|c|}
\hline Date. & Hydrographer. & $\begin{array}{c}\text { Gage } \\
\text { height. }\end{array}$ & $\begin{array}{c}\text { Dis- } \\
\text { charge. }\end{array}$ & Locality. \\
\hline Feb. $18,18 \% 9$ & $\begin{array}{l}\text { State engineering } \\
\text { department. }\end{array}$ & Feet. & $\begin{array}{l}\text { Sec-feet. } \\
21,000\end{array}$ & Hennesseys. \\
\hline May 13,1879 & . do do . . . . & & 15,000 & Do. \\
\hline Feb. 19,1879 & $\ldots$. do .... & & 12,000 & Burts Ferry. \\
\hline Aug. 31,1879 & $\ldots$ do .... & & 1,200 & Do. \\
\hline Nov. 12,1879 & . do .... & & 2. 700 & Do. \\
\hline Mar. $\quad 6.18 \% 9$ & ...do & & 56.000 & Marysville. \\
\hline Sept. 1,1879 & $\ldots$ do $\ldots$ & & 1,200 & Do. \\
\hline July 16,18 ; 9 & $\ldots$. & & 1,900 & Near mouth. \\
\hline Aug. $2 \%, 18 \% 9$ & . . do & & 1,200 & Oroville. \\
\hline Sept. $\quad 1,1879$ & $\ldots$ do ...... & & 1.800 & Below mouth of Yuba. \\
\hline Sept $\quad 7,1901$ & S. G. Bennett. & & 34 & $\begin{array}{l}\text { West Branch of NorthFork, } \\
\text { Cherokee Pipe Crossing. }\end{array}$ \\
\hline Sept, 18,1900 & $\ldots$ do & & 1.123 & Oroville Bridge. \\
\hline Sept. $\quad 6,1901$ & ....do do & & 1,220 & Do. \\
\hline
\end{tabular}




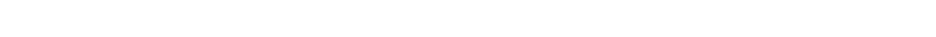

\begin{tabular}{|c|c|c|c|c|}
\hline Date. & Hydrographer. & $\begin{array}{l}\text { Giage } \\
\text { height. }\end{array}$ & $\begin{array}{l}\text { Dis- } \\
\text { charge. }\end{array}$ & Locality. \\
\hline-- & - & Fert. & Ser-fert. & $-\ldots$ \\
\hline an. $99,190 \%$ & S. (*. Bennett & & 1.960 & Oroville Bridge. \\
\hline ept. $\div .1901$ & . do . . & & 946 & North Fork. Huffs Bar. \\
\hline Lar. $\quad 1,190 \%$ & $\ldots d o \ldots . . .$. & 8.7 & 15,294 & Oroville Bridge. \\
\hline May $\%, 1902$ & ... do . ........ & $\therefore . \pi$ & $15.4 \pi 6$ & Do. \\
\hline ept. $\quad 4,1902$ & Chas. A. Miller & .96 & 1, & Do. \\
\hline ept. 111.1902 & $\ldots$. & .99 & 1,890 & Dn. \\
\hline Dec. $1 \times, 1902$ & S. G. Bennett ... & 3.6 .5 & $: 3.298$ & Do. \\
\hline Sept. 3,1902 & ..... do ...... & & 1 & $\begin{array}{l}\text { Sunth Fork at Little (*ra } \\
\text { Valley. }\end{array}$ \\
\hline ept. $\quad 6.190 \%$ & ('hats. A. Miller & & 1 & $\begin{array}{l}\text { Sonth Fork at bridge at } \\
\text { Enterprise. }\end{array}$ \\
\hline Do $\ldots$ & $\ldots(10$ & & 216 & $\begin{array}{l}\text { South Fork at Birlwell Bar } \\
\text { Bridge. }\end{array}$ \\
\hline Do & . (1) & & 30 & $\begin{array}{l}\text { Tork Palermo Canal } \\
\text { terprise. }\end{array}$ \\
\hline ept. 4,1902 & S. G. Bennett & & 92 & $\begin{array}{l}\text { Middle Fort, below mouth } \\
\text { of Nelson Creek. }\end{array}$ \\
\hline Do .... & do & & 33 & $\begin{array}{l}\text { Middle Fork, Nelson Creek } \\
\text { above mouth. }\end{array}$ \\
\hline Do . - & $\ldots$ & & 28 & $\begin{array}{l}\text { Middle Fork, Spanish Creek } \\
\text { at Pocket Bridge, lower } \\
\text { end of American Valley. }\end{array}$ \\
\hline ept. $5,190 \%$ & ... do & 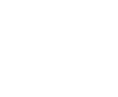 & 22 & $\begin{array}{l}\text { North Fork, Indian Creek } \\
\text { at Indian Valley on Tay- } \\
\text { lorsville road. }\end{array}$ \\
\hline Do & $\ldots d o \ldots$ & & $60 \%$ & $\begin{array}{l}\text { North Fork at lower end } \\
\text { Big Meadows. }\end{array}$ \\
\hline ept. $\quad \times, 1902$ & $\ldots$.... do .. & & 669 & $\begin{array}{l}\text { North Fork at Bidwell's } \\
\text { sawmill. }\end{array}$ \\
\hline Do & do & & 163 & $\begin{array}{l}\text { East Branch North Fork at } \\
\text { Hamilton's bridge. }\end{array}$ \\
\hline ept. 9,1902 & ... do & & 64 & $\begin{array}{l}\text { Big Spring Branch of East } \\
\text { Fork of ITorth Fork at } \\
\text { point } 1 \text { mile below boat- } \\
\text { house. }\end{array}$ \\
\hline Do . . & do & & 109 & $\begin{array}{l}\text { Dotta or Lower Big Spring } \\
\text { Branch of North Fork at } \\
\text { mouth. }\end{array}$ \\
\hline $\mathrm{D}(1 \ldots$ & .... de ... & & $32 i$ & $\begin{array}{l}\text { West Brancl of North Fork } \\
\text { near Prattville. }\end{array}$ \\
\hline Sept. $\quad$. 1900 & .... & & 27 & $\begin{array}{l}\text { Butte Valley Creek, North } \\
\text { Fork, at Butte Valley } \\
\text { post-office. }\end{array}$ \\
\hline Sept. $9,1911^{\circ}$ & C'has. A. Miller .. & - & 59.3 & North Fork, Hnffs Bar. \\
\hline Sept. 12.1902 & .... r r & & 315 & $\begin{array}{l}\text { Big Bend Tunnel on North } \\
\text { Fork. at portal of tumel. }\end{array}$ \\
\hline Sept. $9,190 \%$ & $\ldots$..... & -.. & 27 & $\begin{array}{l}\text { West Fork of North Fork } \\
\text { at Yankee Hill Bridge. }\end{array}$ \\
\hline
\end{tabular}


Estimated monthly discharge of Feather River at Oroville, cral.

[Drainage area, 3,3511 square miles.]

\begin{tabular}{|c|c|c|c|c|c|c|}
\hline \multirow[b]{2}{*}{ Nonth. } & \multicolumn{3}{|c|}{ Discharge. } & \multicolumn{3}{|c|}{ Run-uff. } \\
\hline & Maximum. & Minimum. & Mean. & $\begin{array}{l}\text { Total dis- } \\
\text { rharge }\end{array}$ & $\begin{array}{c}\text { Per } \\
\text { senuare } \\
\text { mile. }\end{array}$ & Depth. \\
\hline 1902. & sierefert. & I Nerfeft. & sueceferet. & screffeet. & I ser-jeet. & morkss. \\
\hline Jannary & $2,32 \pi$ & $1,97.5$ & $1,9 ! 4$ & $122,8.52$ & 0.60 & 0.69 \\
\hline February ... & 3R. 680 & $1,97.5$ & 19.545 & $1,085,474$ & 5.83 & 6.07 \\
\hline March .... & 24,420 & 7.000 & 11.148 & 68. & 3.33 & 3.84 \\
\hline April & 39.600 & 8,300 & 19. 48.5 & $1,159.43 \%$ & 5.82 & 6.50 \\
\hline May & 16,600 & 9,020 & 12.110 & 744.615 & 8.61 & 3.74 \\
\hline June & 10.900 & 2.750 & 5. 6009 & $3333.7 .5 !$ & $1.6 \%$ & 1.86 \\
\hline July & 2.550 & 1,620 & 2,094 & 129,001 & $.6 i 3$ & .72 \\
\hline Angust & 1,620 & 1,400 & $1.53 \%$ & $94,3 \times 33$ & .46 & .53 \\
\hline September & 1,400 & 1., 300 & 1.399 & is, 2QS & $.40^{1}$ & .45 \\
\hline October & 3.150 & 1,300 & $1,50: 3$ & $92,47 \%$ & .45 & .52 \\
\hline November & 14.400 & 1,510 & $3,4,81$ & $30 \% .134$ & 1.04 & 1.08 \\
\hline December - & $25.8(30)$ & 1,565 & $6,2 \times i$ & 386.573 & 1.88 & 3.17 \\
\hline The yea & 39,600 & 1,300 & 7,17 & 万. 119,893 & ?. 14 & 28.57 \\
\hline
\end{tabular}

\section{FICAY CREEK.}

Discharge mersurement of Ficaly C'reek. Senta Barbara C'onenty.

Date.
Aug. $\ldots, 1889 \ldots \ldots$

FORT TEJON CREEK.

Discharge measurement of Font Tejon Creek, in fonthills, Kern ('ounty.

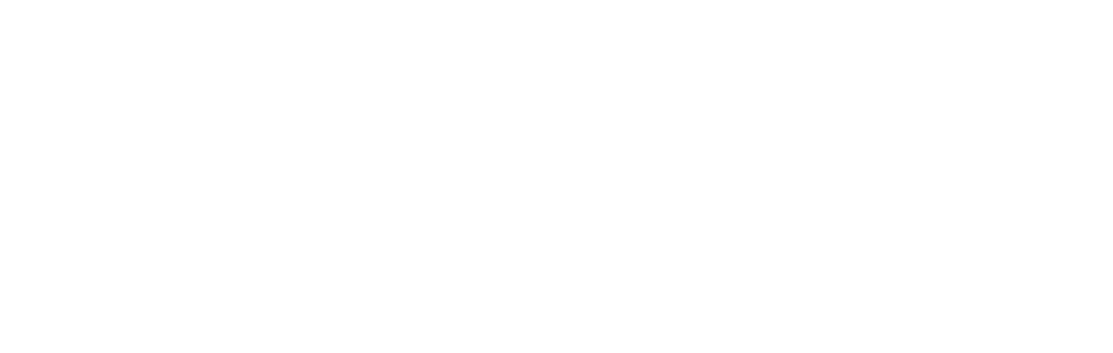


FRESNO CREEK.

Estimated monthly dischurge of Fresuo ('reek, Mardera c'onnty, at base of foothills."

[Drainage area, zo nquare miles.]

\begin{tabular}{|c|c|c|c|c|c|c|}
\hline \multirow[b]{2}{*}{ Month. } & \multirow[b]{2}{*}{ Maximum. } & \multirow[b]{2}{*}{ Minimum. } & \multirow[b]{2}{*}{ Mean. } & \multirow[b]{2}{*}{$\begin{array}{l}\text { Total dis- } \\
\text { charge. }\end{array}$} & \multicolumn{2}{|c|}{ Run-off. } \\
\hline & & & & & $\begin{array}{l}\text { Per } \\
\text { square } \\
\text { mile. }\end{array}$ & Depth. \\
\hline $18 \% 8$. & Ster.feet. & Nec-feet. & Sec-feet. & Acrefeet. & Sece-fret. & Theless. \\
\hline November ${ }^{b}$. & & $\ldots \ldots$ & 0 & 0 & 0 & \\
\hline December ${ }^{\prime \prime}$.. & & $\ldots$ & 0 & 0 & 0 & 0 \\
\hline 1879 & & & $=-$ & - & & - \\
\hline January c ... & 80 & 0 & $2 \pi$ & 1,660 & 0.10 & 0.12 \\
\hline February" .... & $11 \tau$ & 66 & $x_{0}$ & 4,443 & 29 & .30 \\
\hline March $c \ldots . . .$. & 202 & 66 & 118 & 7.256 & .43 & .50 \\
\hline April ${ }^{\prime} \ldots \ldots$ & 202 & 124 & 156 & 9,283 & .57 & .64 \\
\hline May' ....... & $10 \stackrel{2}{2}$ & 66 & 79 & 4,858 & .29 & .33 \\
\hline Juner ...... & 54 & 0 & 15 & 893 & .06 & $.0 \%$ \\
\hline July $c^{c} \ldots \ldots$ & 0 & 0 & 0 & 0 & 0 & \\
\hline Auguste .... & 0 & 0 & 0 & 0 & 0 & \\
\hline September $r$ & 0 & 0 & 0 & 0 & 0 & \\
\hline October" .... & 0 & 0 & 0 & 0 & 0 & \\
\hline November ${ }^{\prime \prime} \ldots$ & 0 & 0 & 0 & 0 & 0 & \\
\hline December ${ }^{\prime \prime} .$. & & -...... & 109 & 6,702 & .40 & .46 \\
\hline The year & & & 49 & 35,095 & .18 & 2.42 \\
\hline $1880 . "$ & & - ニニニ =-- & & & & \\
\hline January .... - & & & 5 & $30 \%$ & .02 & .02 \\
\hline February ... & & . & 150 & 8,628 & .55 & .59 \\
\hline March ..... & & & 16 & 984 & .06 & .07 \\
\hline April ..... & & & 1,088 & 64,740 & 4.00 & 4.46 \\
\hline May ..... . & & & 54 & 3,320 & .20 & .23 \\
\hline June ..... & & . & $2 \tau$ & $1,60 \tau$ & .10 & .11 \\
\hline July _... . . & & & 0 & 0 & 0 & \\
\hline Angust .... & & - & 0 & 0 & 0 & \\
\hline September . & & & 0 & 0 & 0 & \\
\hline October ..... & & & 0 & 0 & 0 & \\
\hline November . & & & 0 & 0 & 0 & \\
\hline December ... & & & 218 & 13,404 & 80 & .92 \\
\hline The year - & & & 130 & 92,990 & .48 & 6.40 \\
\hline
\end{tabular}

a Authority, Calufornia State engineering department.

$b$ November and December, 1878, and from November, 18\%9, to October, 18\%4, inclusire, estimated from run -off of neighboring streams.

$c$ Measured. 
Estimated monthly discharge of Fresno Creek, ite.-Contirned.

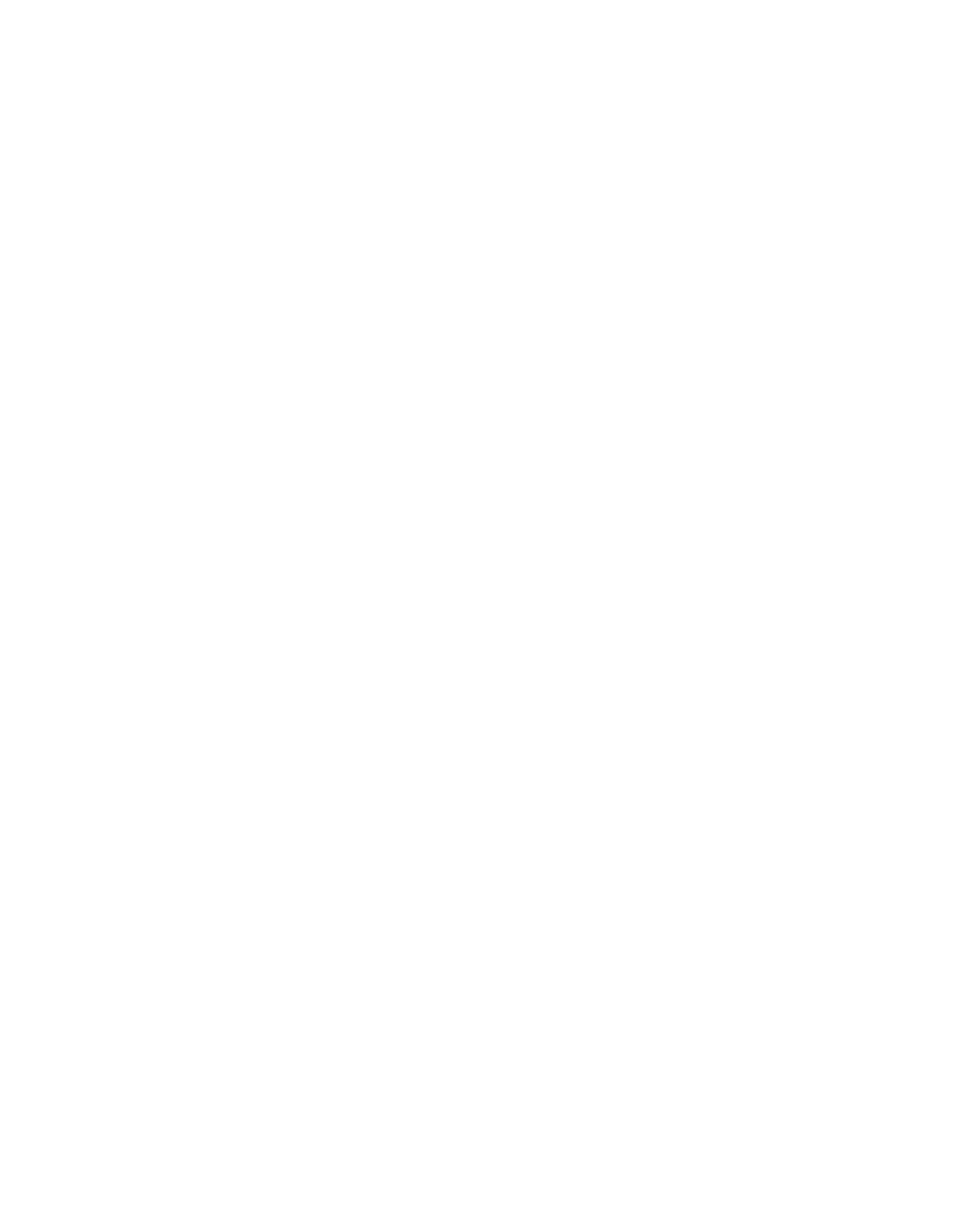

a November and December, $18 \% 8$, and from November, 18\%9, to Octoher, 1884, inclusive, estimated from run-off of neighboring streams. 
Extimutul monthly discharge of Fresno Creek, etc.-Continued.

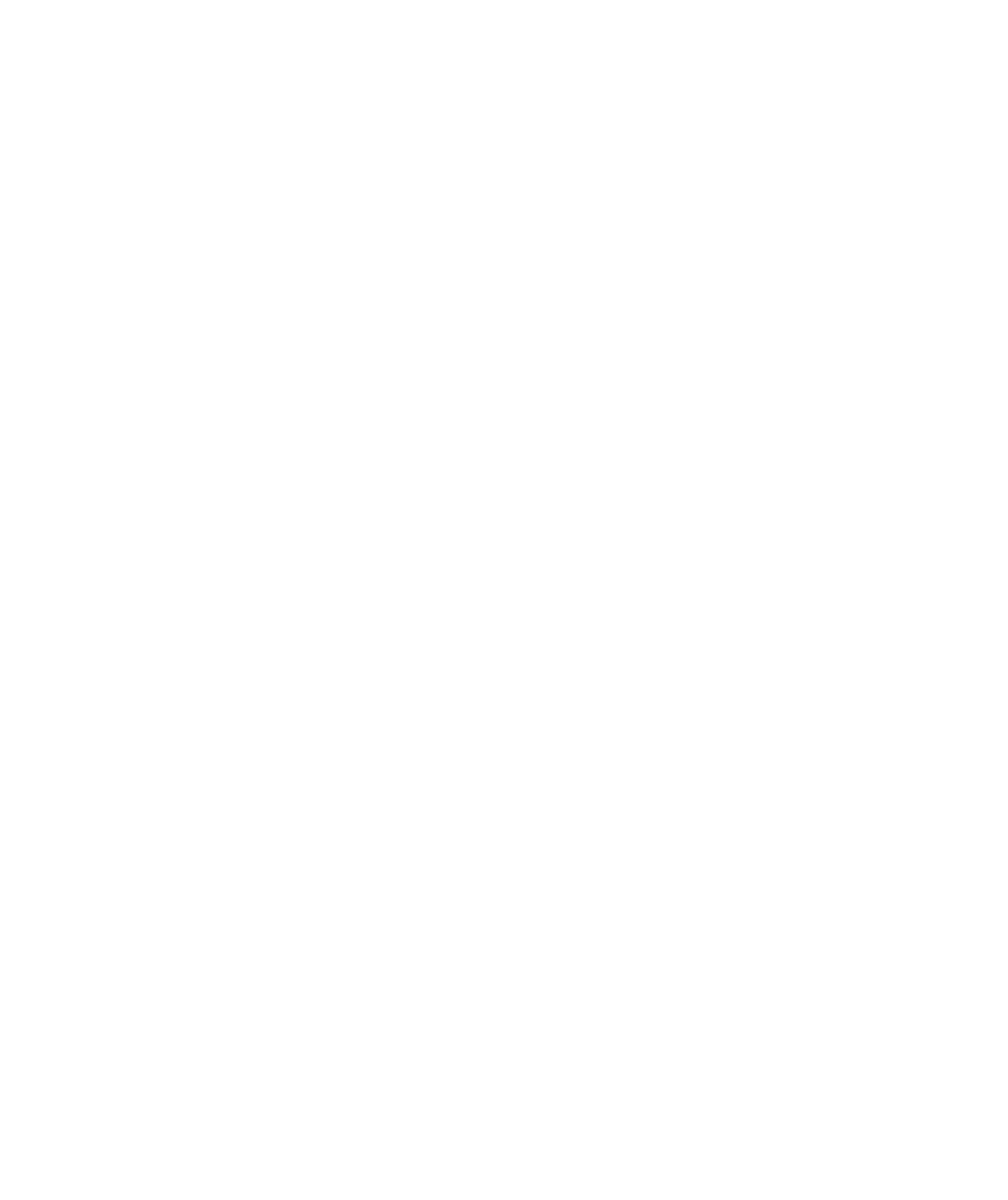

aNorember and December, $18 \%$, and from November, 1s\%a, to October, 1484. molusive, estimated from run-off of neighboring streams.

GAGE CANAL.

Ser San Bermarlino Valley, Gage canal. 


\section{GATO CREEK.}

Gato Creek was measured by (harles .I. Johansen for the Pacific Improvement Company, as given below. It was gaged a short dislanee above its junction with the Loma Abajo, and at the time of its measurement no water was heing comvered in the pipe line situated along this streant

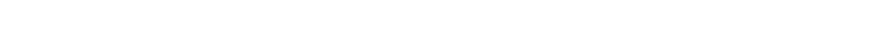

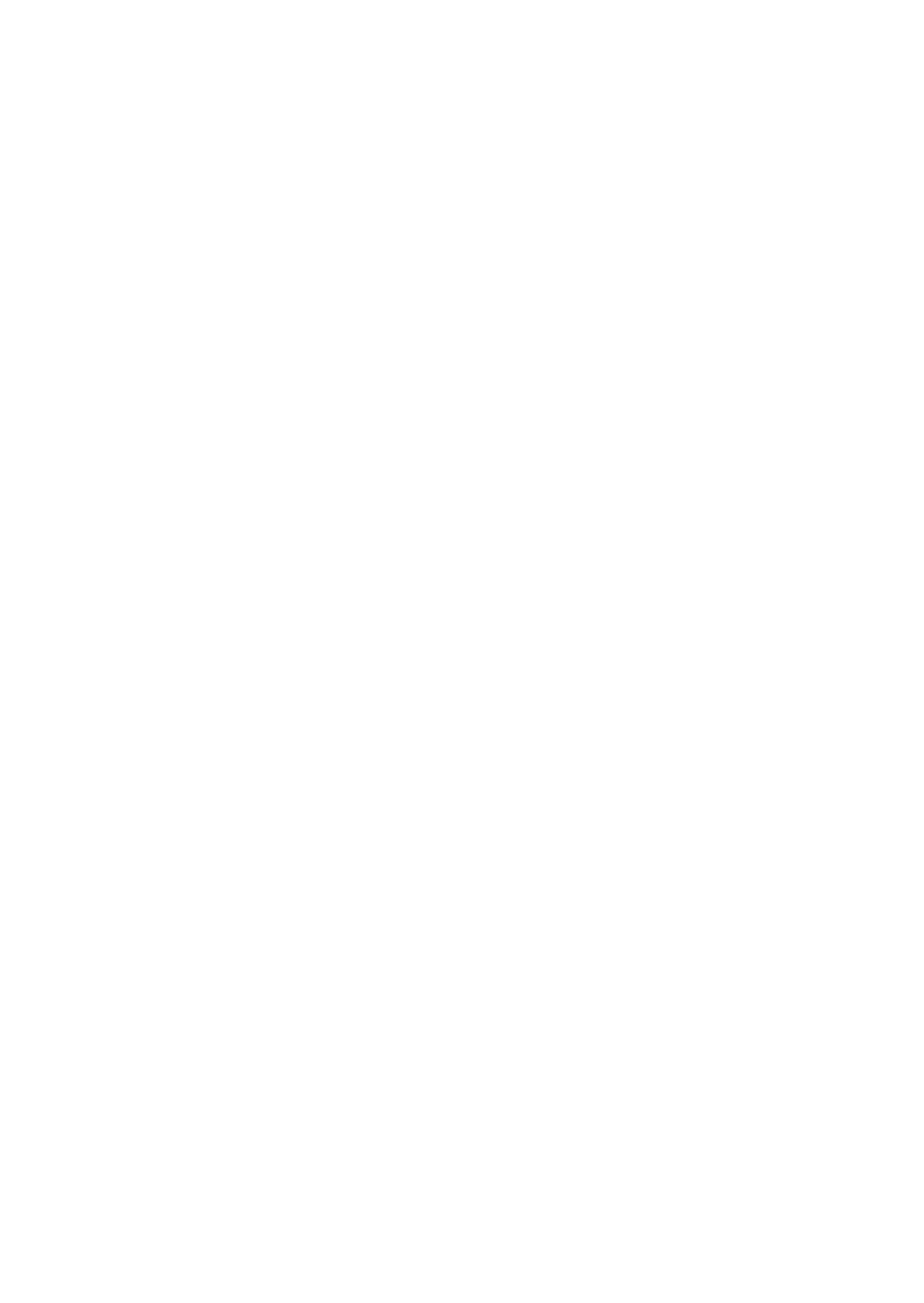


Discharge measurements of Gato ('reek. Santa Barbara r'ounty-Continued.

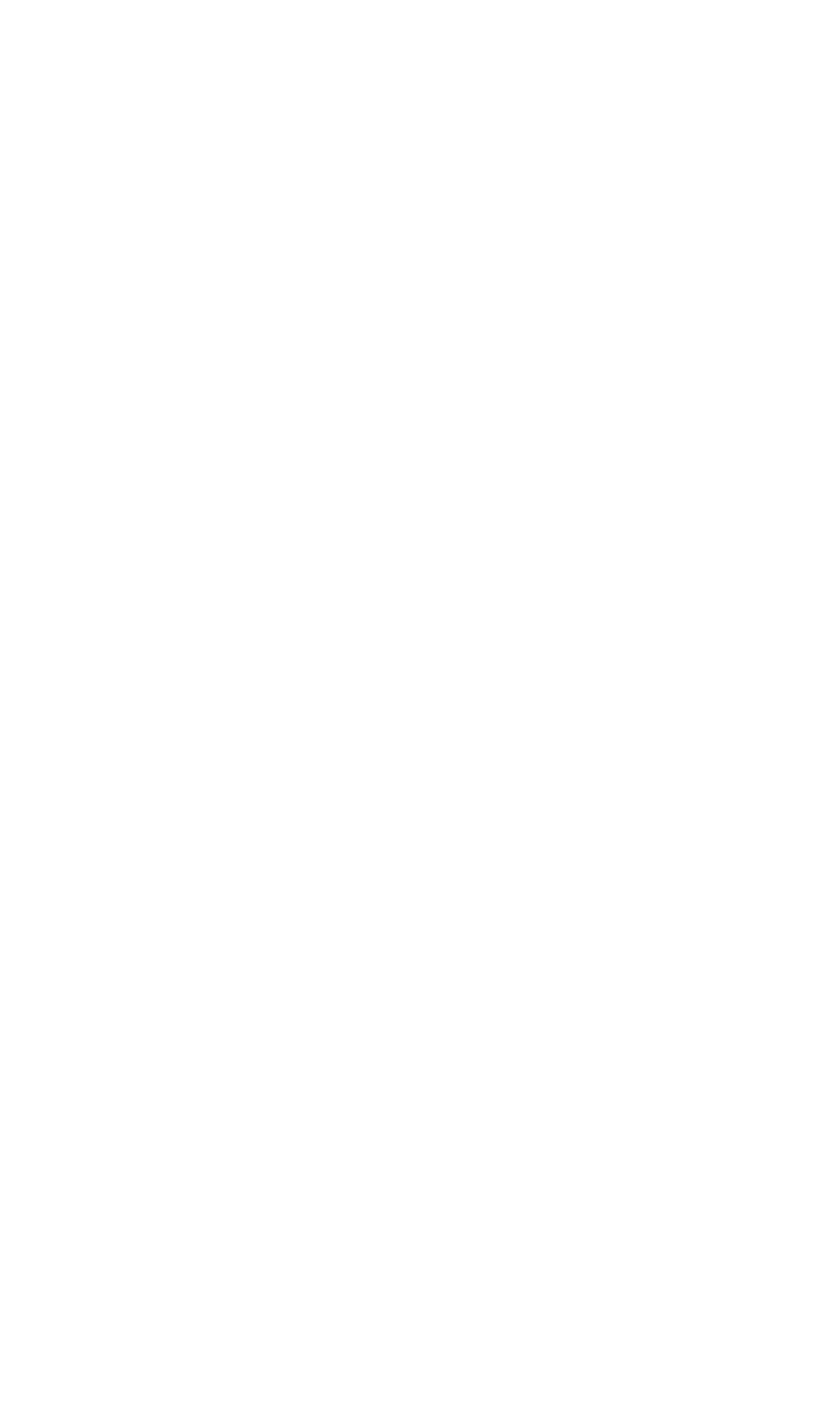


Discharge measurements of Gato Creek, Santa Barbara County-Continned.

\begin{tabular}{|c|c|c|c|c|}
\hline & Date. & Hyitrographer. & $\begin{array}{l}\text { Dis- } \\
\text { charge. }\end{array}$ & Locality. \\
\hline & & & Sec-feet. & \\
\hline July & 25,1890 & Charles J. Johansen & 0.26 & At mouth. \\
\hline July & 27,1890 & $\ldots$ do $\ldots . . .$. & .32 & Do. \\
\hline July & 29,1890 & .... do ... & .34 & Do. \\
\hline July & 31,1890 & .... do ... & .34 & Do. \\
\hline Aug. & $\cdot 2,1890$ & . . . do . . . & .34 & Do. \\
\hline Ang. & . 4,1890 & ..... do ... & .34 & Do. \\
\hline Aug. & 6,1890 & .... do ... & .29 & Do. \\
\hline Aug. & 8,1890 & $\ldots$. . do _. & .27 & Do. \\
\hline Aug. & 10,1890 & $\ldots$ do .... & .32 & Do. \\
\hline Ang. & 12,1890 & $\ldots$.... do ... & .35 & Do. \\
\hline Aug. & 14,1890 & ..... do _. & .30 & Do. \\
\hline Aug. & 15,1890 & $\ldots$. . . do . . & .27 & Do. \\
\hline Aug. & 17,1890 & $\ldots$. . do _... & .26 & Do. \\
\hline Aug. & 19,1890 & ..... do _.... & .28 & Do. \\
\hline Ang. & 21,1890 & .... do ... & .35 & Do. \\
\hline Aug. & 23,1890 & $\ldots$. do . . . & .28 & I \\
\hline Ang. & 25,1890 & $\ldots d_{0} \ldots$ & .30 & Lis. \\
\hline Aug. & 27,1890 & .... do ... & .30 & Io. \\
\hline Aug. & 29,1890 & $\ldots$ do .... & .28 & Io. \\
\hline Aug. & 31,1890 & $\ldots$ do ..... & .26 & Lo. \\
\hline Sept. & $\quad 2,1890$ & ....do ... & .22 & Io. \\
\hline Sept. & - 4,1890 & $\ldots$. . do . . . & .22 & Do. \\
\hline Sept. & 6,1890 & $\ldots$ do ..... & .26 & Io. \\
\hline Sept. & 8,1890 & .... do .... & .26 & Do. \\
\hline Sept. & 10,1890 & $\ldots$. do _... & .26 & Do. \\
\hline Sept. & 12,1890 & .... . do .... & .26 & Do. \\
\hline Sept. & 14,1890 & . . _ do .... & .22 & Do. \\
\hline Sept. & 16.1890 & $\ldots$.. do ... & .22 & Do. \\
\hline Sept. & 18,1890 & 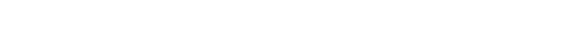 & .26 & Do. \\
\hline Sept. & 21,1890 & $\ldots$. do ... & .30 & Do. \\
\hline Sept. & 22,1890 & .....do .... & .22 & Do. \\
\hline Sept. & 24,1890 & $\ldots$. . do .... & .22 & Do. \\
\hline Sept. & 26.1890 & ... do . . . & .22 & Do. \\
\hline Sept. & 28,1890 & $\ldots$... do .... & .37 & Do. \\
\hline Sept. & 30,1890 & _. . do & .60 & Do. \\
\hline Oct. & 2,1890 & $\ldots$ do ...... & .42 & Dr. \\
\hline Oct. & 4,1890 & $\ldots$ do $\ldots . . .$. & .35 & D. \\
\hline Oct. & 6,1890 & $\ldots$. do ...... & .30 & $\mathrm{Do}$ \\
\hline Oct. & $\tau, 1890$ & 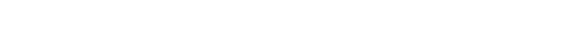 & .30 & D). \\
\hline
\end{tabular}




\section{GAZOO CREEK.}

Discharge measurements of Gazoo Creek, San Mateo ('ounty.

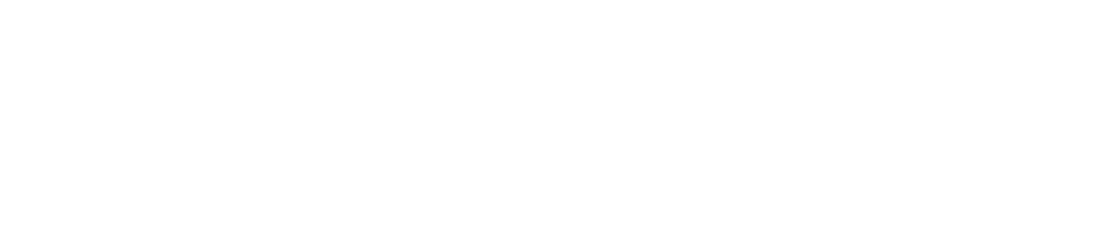

\section{GORMAN CREEK.}

See l'iru creek, Gorman Creek.

\section{GREEN SPOT PIPE LINE.}

Sec Santa Ana River, Green spot pipe line.

\section{GRINDSTONE CREEK.}

Sere Stomy Greek, Girindstome ('reek.

GUBERNADOR CREEK.

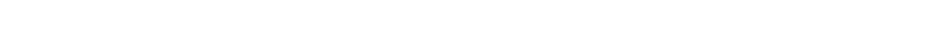

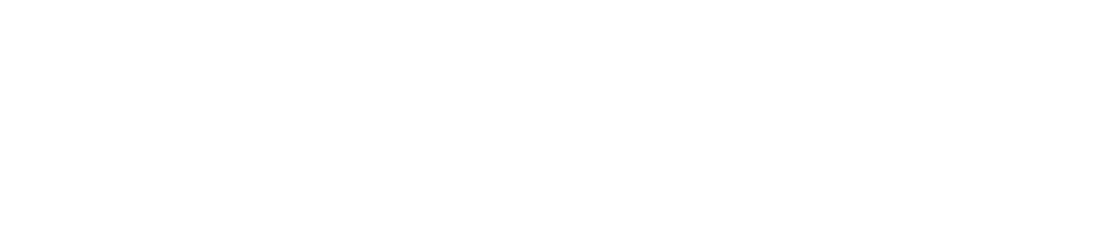

\section{HAT CREEK.}

Ser Pit River, IIat creek.

\section{HAWS AND TALMAGE DITCH.}

See tan Bermardino Valley, IIaws and Talmage ditch.

\section{HONEY LAKE.}

Annual inflow estimated by State engineering department 200,000 acre-fect.

\section{HOUSE CREEK.}

See 'Tejon Ilonse ('reek. 
KAWEAH RIVER.

Dischurge medestrements of Kunerell River, Tulure comnty.

\begin{tabular}{|c|c|}
\hline Date. & Hydrographer. \\
\hline Nov. 20, $18: 15$ & J. B. Lippincott . \\
\hline Sept. $1,1 s 9 s$ & $\ldots d 0 \quad \ldots \ldots$ \\
\hline Sept. $\quad 6,1899$ & S. G. Bennett .... \\
\hline Sept. 3,1900 & ... do . . . . . . . \\
\hline Nov. $20,180 \pi$ & J. B. Lippincott. . - \\
\hline Aug. :31.1898 & $\ldots$ do $\ldots \ldots . . . . .$. \\
\hline Sept. 1.18!s & $\ldots d o$ \\
\hline Sept. 6,1899 & S.G. Bennett - \\
\hline Sept. :3.1900 & $\ldots$ do $\ldots \ldots$ \\
\hline Do . ...... & $\ldots$. 10 _. . . . . \\
\hline Oct. 20,1901 & $\ldots d_{0} \ldots \ldots$ \\
\hline Do $\ldots .$. & $\ldots$ do $\ldots . . . . . .$. \\
\hline Aug. 31,1894 & J. B. Lippincott . . \\
\hline Sept. $\quad 6,1849$ & S.G. Benmett.... \\
\hline Sept. 3,1900 & 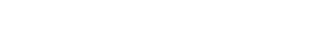 \\
\hline Do $\ldots . . .$. & $\ldots$ do $\ldots \ldots$ \\
\hline Aug. 311898 & J. B. Lippincott _. \\
\hline Sept. $\quad 6,1899$ & s. G. Bemmett.... \\
\hline Sept. 3,1900 & $\ldots$ do . . . . . \\
\hline Sept. $1,189 \mathrm{~s}$ & J. B. Lippincott . . \\
\hline Sept. 6,1899 & S. G. Bemnett.... . \\
\hline Sept. 1,1898 & J. B. Lippincott \\
\hline Sept. $\quad 6,1899$ & S.G.Bennett . ... \\
\hline Sept. 25,1902 & E.T. Perkins ..... \\
\hline Do - & 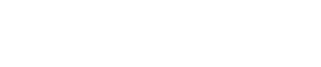 \\
\hline Serii. 20,1902 & .....do. \\
\hline Sept. $2 i, 1902$ & ... do .. \\
\hline Do ... & ـ.... \\
\hline Do & $\ldots$ do ............. \\
\hline Do - & . . . do \\
\hline
\end{tabular}

Dis-

charge

wireginet

io, Healworks alouve njerer large power canal.

3,5

$\pm 1$

Do.

is.5 Do.

(1) Irombloridge, wagom load.

0 Southern Pacific lorench railroad bridges.

is Iron bridge, wagon road.

:3: Do.

i: 1.000 feet below irom hivlge.

1j Watmona ('anal at head-eatr.

i⿱

5) Watumua C'amal.

ห.j Kaweah irrigation and power ditcll (Pogues lower ditch).

1.j Do.

S. 1 Do.

1

Myers ditelo ahove Pogruts mper ditch.

4.j) Pognes.uplere ditr.h.

4.9 Do.

6. $\%$ Do.

:3 North Fork at woruth.

1.1 Do.

(1) Sinth Fork canals.

ir Do.

4.: North Fork at lower end Davis ranch.

. midge on road to Visalia.

29 Middle Fork, ${ }_{4}$ mile above Sequoia National Part line.

20) Midale Fork, I00 yaris ahove junction with Marble Fork.

4 Marble Fork. 100 yards above junction with Midrlle Fork.

$1 . \overline{5}$

East Fork, ! mile above lieadworks Mount Whitney power plant.

1.5.5 East Fork, 200 feet loelow headworks Mount Whitney power plant.

Sept. 28, 1902 do
East Fork, 100 yards below trail from Soldiers" CamptoTarGap. 
Mischurge measurements of Krweeh River, Tulare County-Continued.

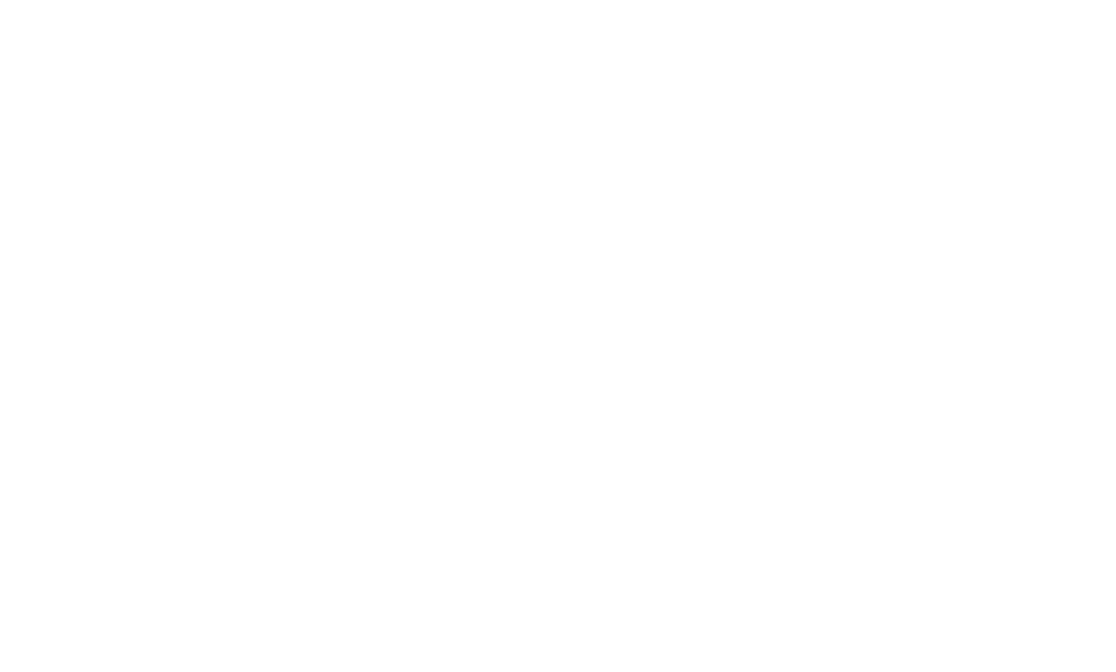

Estimated monthly discharge of Kaueah River at Wachumna Hill, Tulare County. ${ }^{a}$

[Drainage area, b19 square miles.]

\begin{tabular}{|c|c|c|c|c|}
\hline \multirow[b]{2}{*}{ Month. } & \multirow{2}{*}{$\begin{array}{l}\text { Mean dis- } \\
\text { charge. }\end{array}$} & \multirow[b]{2}{*}{$\begin{array}{l}\text { Total dis- } \\
\text { charge. }\end{array}$} & \multicolumn{2}{|c|}{ Run-off. } \\
\hline & & & $\begin{array}{c}\text { Per square } \\
\text { mile. }\end{array}$ & Depth. \\
\hline 1878. & second-feet. & Acre-feet. & Second-feet. & Inches. \\
\hline November $"$. . . . . . . & 155 & 9,223 & 0.25 & 0.28 \\
\hline December $" \ldots \ldots$ & 155 & 9,531 & .25 & .29 \\
\hline 1879. & & & & \\
\hline January $c . . .$. & 248 & 15,249 & .40 & .46 \\
\hline February ${ }^{\prime} \ldots \ldots$ & 279 & 15,495 & .45 & .47 \\
\hline March $c \ldots \ldots$ & 402 & 24,718 & .65 & .75 \\
\hline April $c_{\ldots} \ldots \ldots$ & 867 & 51,590 & 1.40 & 1.56 \\
\hline May c . . . . . . & 774 & 47,591 & 1.25 & 1.44 \\
\hline June $c \ldots .$. & 557 & 33,144 & .90 & 1.00 \\
\hline July c........ & 124 & 7,624 & .20 & .23 \\
\hline August ".... & 31 & 1,906 & .05 & .06 \\
\hline September " - . & 31 & 1,845 & .05 & .06 \\
\hline October ${ }^{b} \ldots$ & 62 & 3,812 & .10 & .12 \\
\hline November $" \ldots \ldots . . . .$. & 124 & 7,379 & .20 & .22 \\
\hline December $c \ldots \ldots$ & 279 & 17,155 & .45 & .52 \\
\hline The year.... . . & 315 & 227,508 & .51 & 6.89 \\
\hline
\end{tabular}

a Authority, California State engineering department.

$b$ Estimated in part from run-off of neighboring streams.

c Based in part on measurements and rod records near Three Rivers. 
Estimated monthly discharge of Kareah River, cte.-C'ontinued.

\begin{tabular}{|c|c|c|c|c|}
\hline \multirow[b]{2}{*}{ Month. } & \multirow[b]{2}{*}{$\begin{array}{l}\text { Mean dis- } \\
\text { charge. }\end{array}$} & \multirow[b]{2}{*}{$\begin{array}{l}\text { Total dis- } \\
\text { charrge. }\end{array}$} & \multicolumn{2}{|c|}{ Run-offi. } \\
\hline & & & $\begin{array}{l}- \\
\text { Per scuare } \\
\text { mile. }\end{array}$ & Depth. \\
\hline $\begin{aligned} & 1880 . \\
\text { Jannary } 九 \ldots \ldots & \ldots\end{aligned}$ & $\begin{array}{r}\text { Secromet-feet. } \\
2 \pm 8\end{array}$ & $\begin{array}{l}\text { Acr-feet. } \\
15,249\end{array}$ & $\begin{array}{c}\text { Shrond-feet. } \\
0.40\end{array}$ & $\begin{array}{l}\text { Inches. } \\
0.46\end{array}$ \\
\hline February $"$. & 310 & 17,831 & .50 & .54 \\
\hline$\ldots \ldots \ldots$ & $\Varangle 64$ & 28,530 & .75 & .86 \\
\hline$\ldots \ldots \ldots$ & 2,352 & 139,954 & 3.80 & 4.24 \\
\hline$\ldots$ & 2,780 & 171,304 & 4.50 & 5.19 \\
\hline$\ldots \ldots \ldots$ & 3,900 & $3: 32,066$ & 6.30 & 7.02 \\
\hline July $a_{\ldots} \ldots \ldots \ldots$ & 743 & $45,68.5$ & $1 .: 0$ & 1.38 \\
\hline August $b \ldots \ldots$ & 1.5 .5 & 9,531 & .25 & .29 \\
\hline September ${ }^{b} \ldots$ & 99 & 5,891 & .16 & .18 \\
\hline$\ldots \ldots \ldots$ & 50 & 3.074 & $.0 \mathrm{~s}$ & .09 \\
\hline November $b \ldots \ldots$ & 74 & 4,403 & .12 & .13 \\
\hline December $b \ldots \ldots \ldots$ & $3 ; 1$ & 22,812 & .60 & .69 \\
\hline The year ... & $96: 3$ & 696,330 & 1.56 & $21.0 \%$ \\
\hline 1881 & & & & \\
\hline January $b \ldots \ldots$ & $5 \supseteq 6$ & 32,342 & .8 .5 & .98 \\
\hline February $"$. $\ldots \ldots \ldots \ldots$ & $\pi 4$ & 42,986 & 1.25 & 1.30 \\
\hline March ${ }^{\prime}{ }_{-} \quad \ldots \ldots \ldots$ & 619 & 38.061 & 1.00 & 1.1 .5 \\
\hline April ${ }^{\prime}, \quad \ldots \ldots \ldots \ldots$ & $1,39: 3$ & 82,889 & 2.25 & 2.51 \\
\hline May ${ }^{\prime} \ldots \ldots \ldots$ & 1. $2: 38$ & 76,122 & 2.00 & 2.31 \\
\hline June ${ }^{\prime \prime} \ldots \ldots \ldots$ & 990 & $.58,909$ & $1 .(60)$ & 1.79 \\
\hline July" _ _ $\ldots \ldots \ldots$ & $3 \% 1$ & $22, \times 12$ & .60 & .69 \\
\hline August $" \ldots \ldots \ldots \ldots$ & 15.5 & $9,5: 31$ & .25 & .29 \\
\hline September $\iota^{\prime} \ldots \ldots \ldots \ldots$ & 43 & $2,5.59$ & $.0 \%$ & .04 \\
\hline October ${ }^{a} \ldots \ldots \ldots \ldots$ & 74 & 4.550 & .12 & .14 \\
\hline November $" \ldots \ldots \ldots$ & $1: 4$ & 7,379 & $\therefore 0$ & .22 \\
\hline December" $"$. & 279 & $1 \%, 15 j$ & $.4 ;$ & .50 \\
\hline The year $\ldots \ldots \ldots$ & 549 & $39 \% .29 \%$ & .89 & 11.98 \\
\hline
\end{tabular}

a Based in part on measurenents and rod records near Three Rivers. b Estimated in part from run-off of neighboring streans.

IRR S $1-(1) ;-7$ 
Estimaterl monthly discharye of Kaneroh River, etc-Continned.

\begin{tabular}{|c|c|c|c|c|}
\hline \multirow[b]{2}{*}{ MIonth. } & \multirow[b]{2}{*}{$\begin{array}{l}\text { Mrean dis- } \\
\text { charge. }\end{array}$} & \multirow[b]{2}{*}{$\begin{array}{l}\text { Total dis- } \\
\text { charge. }\end{array}$} & \multicolumn{2}{|c|}{ Run-off. } \\
\hline & & & & Depth \\
\hline 1882. & recond-feet. & Acre-feet. & Second-feet. & Inches. \\
\hline January ${ }^{\prime} \ldots \ldots$ & 155 & 9,531 & 0.25 & 0. 29 \\
\hline February $t_{-}$. & 310 & $17.21 \%$ & .50 & .59 \\
\hline March".... & 464 & 28,530 & .75 & .86 \\
\hline April $" \ldots \ldots$ & 1,393 & 82.889 & 2.25 & 2.51 \\
\hline May $" \ldots \ldots$ & 2,228 & 136.994 & 3.60 & 4.15 \\
\hline June $"$. . . . . . & 929 & 55.299 & 1.50 & $1.6 \pi$ \\
\hline July ${ }^{l} \ldots \ldots$ & 743 & 45,685 & 1.20 & 1.38 \\
\hline August $b \ldots$ & 198 & 12,175 & .32 & .37 \\
\hline September " & 93 & .5 .534 & .15 & .17 \\
\hline October " & $8 i$ & 5,349 & .14 & .16 \\
\hline November $"$ & 124 & 7,379 & .20 & .22 \\
\hline December $"$... & 93 & 5,718 & .15 & .17 \\
\hline The year & 568 & 412,280 & .92 & 12.47 \\
\hline $1883 . b$ & & & & \\
\hline January . . & 155 & $9,5: 31$ & .25 & .29 \\
\hline February ... & 124 & $6.88 \%$ & .20 & .21 \\
\hline March ...... & 619 & 38.061 & 1.00 & 1.15 \\
\hline April ...... & 805 & $4 \pi .901$ & 1.30 & 1.45 \\
\hline May _........ & 1,021 & $62, \pi \%$ & 1.65 & 1.90 \\
\hline June . . . . . . & 990 & 58,909 & 1.60 & 1. 79 \\
\hline July ........ & $40^{\circ}$ & 94,715 & $.6 \pi$ & .75 \\
\hline August .... & 99 & $6.08 \%$ & .16 & .18 \\
\hline September ... & 74 & $4.40: 3$ & .12 & .13 \\
\hline October & 62 & 3,512 & .10 & .12 \\
\hline November & $i 4$ & $4.40: 3$ & .12 & .13 \\
\hline December ... . . . . & 74 & $4,5.50$ & .12 & .14 \\
\hline The year & $3 \pi 5$ & 272,041 & .61 & 8.24 \\
\hline
\end{tabular}

a Based in part on measurements and rod records near 'Tlnee Rivers. $b$ Estimated in part from rum-off of neighboring streams. 


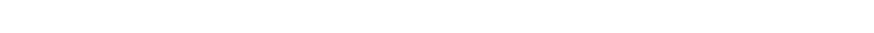

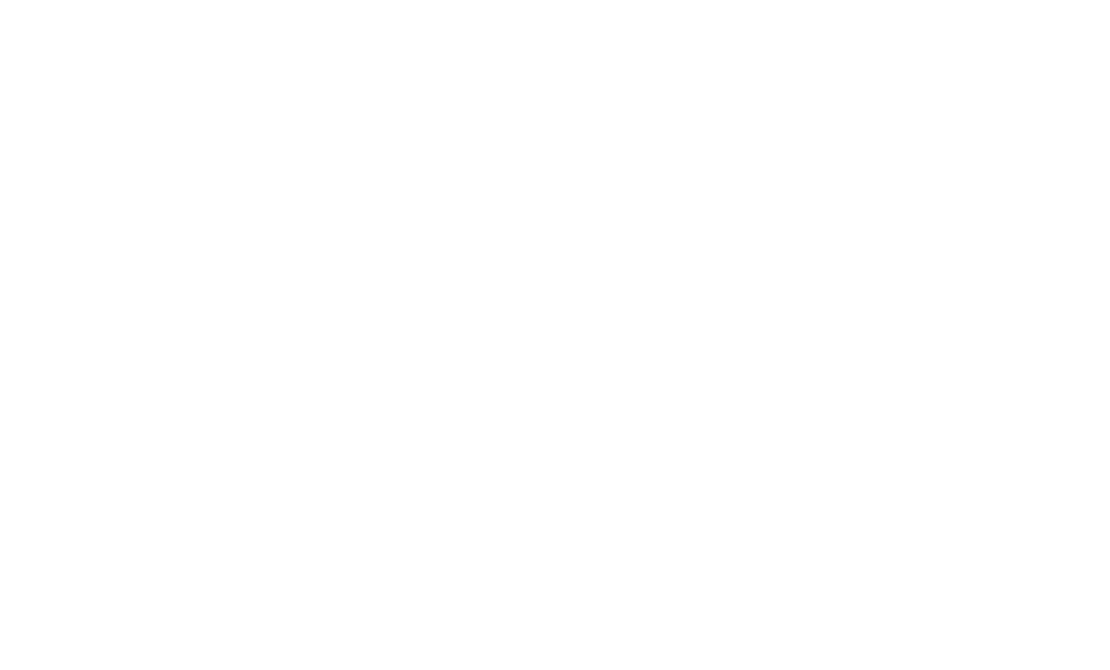

"Estimated in part from run-off of neighboring streams.

\section{KERN RIVER.}

The Eaging station on Kern River, established in 1 s.93 hy Mr. Waller Jones, ehief engineer of the Kern County Land Company, is located at what is known as first point of measurement, 5 miles ahove Bakersfield. Meter moasurements are taken once a week and an automatic gage records daily fluctuations of the river heights. Mr. A. K. Warrest, the engineer in charge of this work for the Kern County Land Company, attends to the discharge measurements with much areduracy and precision, and furnishes the survey with the final results.

Discharge mensurements of Rern River. Fern county.

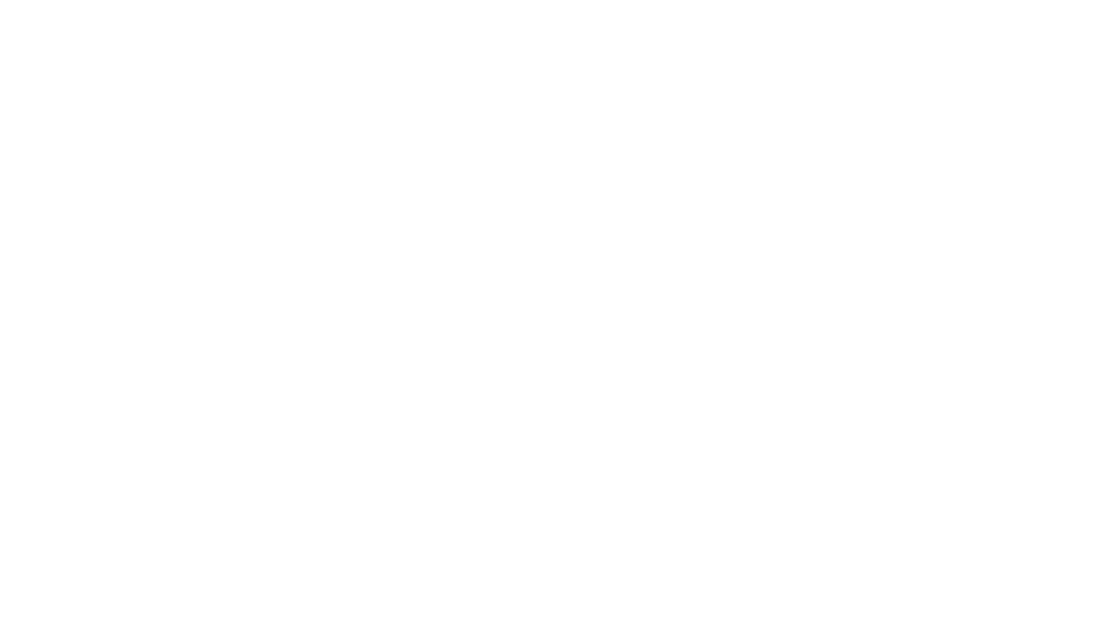


Dischorge measurements af Kern River, Kern Connty-Continued.

Date.

Sept. 2,1899 S. G. Bennett ... ...

Aug. 30.1900 A. K. Warren ......

Oct. $\quad$ i,1902 L. M. Lawsom ......

Feb. 11,1к9\% , J.B. Lippinentt ....

Sept. :2, 1к99 $\mid$ F.H. Olmster

Jume $19,1900, \ldots$
June 20,1900

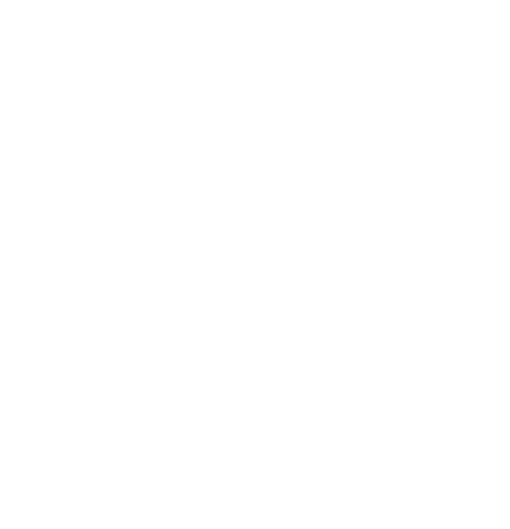

Do ............ (2)

June $25,1900 \mid \ldots$. . $10 \ldots$.

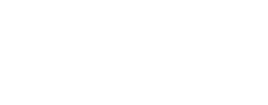

Do .......... do

Do ...... do

Junt $28,1900 \ldots$

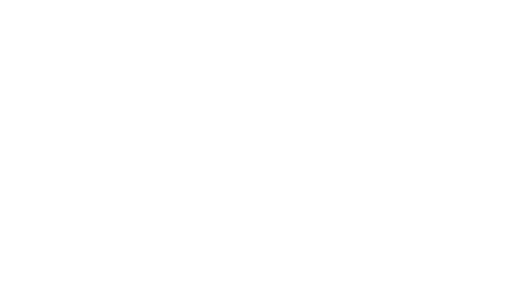

Discharge.

Locality

Sir counctiferet.

$9 !$

First point of mes.surement.

103 Do.

$1 \% 1$

322

Do.

Callosway Canal at first point of measurement.

99. 22 Kern River, first point of measurement.

1.32 i Basin Creek, Rankin"s ranch, Walker's basin.

14.18 South Fork of Kern River, 700 feet above junction.

1.333.1\% North Fork of Kern River, Hooper's Mill Bridge.

2.:30 Bull Rum Creek near mouth.

3. 9: Tobias Creek neas mouth.

.15 Ant Creek at mouth; elevation. 3,200 feet.

3.4 .5 Salmon Creek at mouth.

.32 Corral Creek near mouth.

5.82

South Needles Creek at Needles Peak: elevation, 4,550 feet.

5. 19 Clark Creek. Dry Meadows.

5.74 Jackson Creek, Dry Meadows.

. 07 Wade Creek, Dry Meadows.

4. 26 North Needles Creek at Needles Peak.

81

Little Kern River: at junction with Kern River.

2.87 Tibbetts Creek, 1 mile above mouth.

s. 4.5 Harris Creek at mouth.

4. 87 One Mile Creek, 1 mile below Kern Lake.

1.154.90 North Fork of Kern River, 3, 000 feet above junction with Little Kern River.

4. 22 Whitney Creek at tumnel in divide.

39.11 Whitney Creek at Lava britge.

1\%.64 Creek south of Bald Mountain; elevation, 6,560 feet.

939.60 North Fork of Kern River, 800 feet above Kern Lake.

3.6\% South Fork of Kern River, Manache Meadows.

1. 80 Tibbetts Creek: elevation, 8,300 feet. 
Discharge messuremonts of Kern Riwe, Kern romnty-Continued.

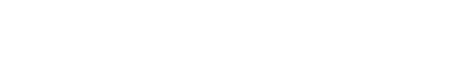

June 29, 1900

Do

di)

June :3(1, 1901)

(1)

Do

do

July $2,1900, \ldots . . .20$

Do . . . . . . . . do

July : :, 1900) ..... do

Do.

(li)

Oct. 4. 1912 E. T. Perkins

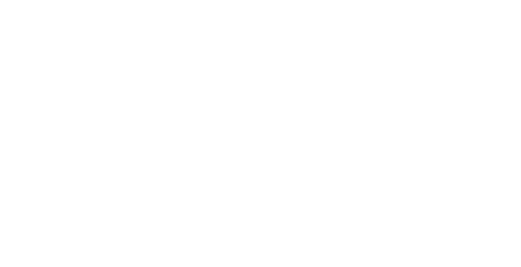

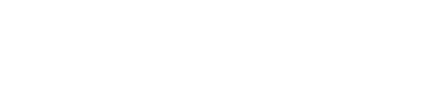

Oct. $\quad$ ¿ $19012 \ldots \ldots d 0$

Do........... do

Do - . $\mid-.$. do

Oct. $\times, 1902, \quad$ do

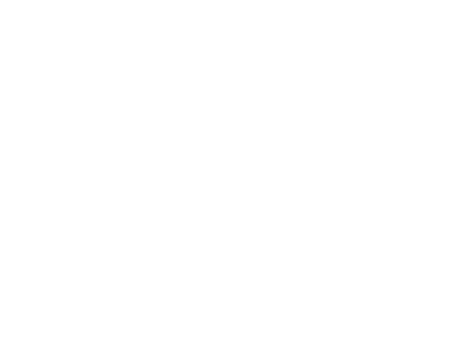

Dir-chargr.

Locality. veremet-fert.

1.04 North Fork of Brush Creek: elevation, 5,900 feet.

४. 22 $\mid$ Brush Creek above N'orth Fork; elevation, 5.600 feet.

42.5. 25 North Fork of Kern River. 4.000 feet above junction with South Fork.

4.0,5 Salmon Creek, Horse Meadows; elevation, r,700 feet.

11.05) South Fork of Kern River, T. 2.; S., R. 3.5 E., Mount Diablo meridian; elevation, 2.920 feet.

2.28 Powers Ditch near hear.

1.90 Neil's Ditch, Isabella.

i.s1 Hooper's Mill Ditch at gaging station on Kern River.

14 Little Kerm 100 yards above junction.

1is 100 yards above jumetion with Little Keru.

.j Brown's upper ditch at road crossing to Hot Springs.

$\tau$ Brown's main ditch at entrance to weir.

1.j Stafford \& Neal ditch above Kernville.

7.9 Brown's lower ditch above dairy.

160 Power Company's diversion, Kernville.

$224 \quad \frac{1}{4}$ mile above month of Salmon Creek.

.5 Salmon Creek 50 yords ahove junction.

Above gaging station, Kern River Power Co.

188 I mile above powerhouse, Kern River Power Co.

236 Below Clear Creek.

201 200 yards below junction South Fork.

18 South Fork above junction.

\begin{tabular}{l|l|l}
202 & 350 yards below bridge from
\end{tabular} Isabella to Kernvill?.

$9 \quad$ Honper ditch at bridge from Isabella to Kernvill:.

.6 Lower Stafford ditch mile north of Staffords ranch. 


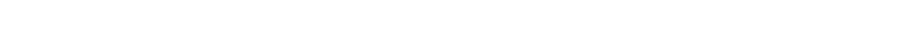

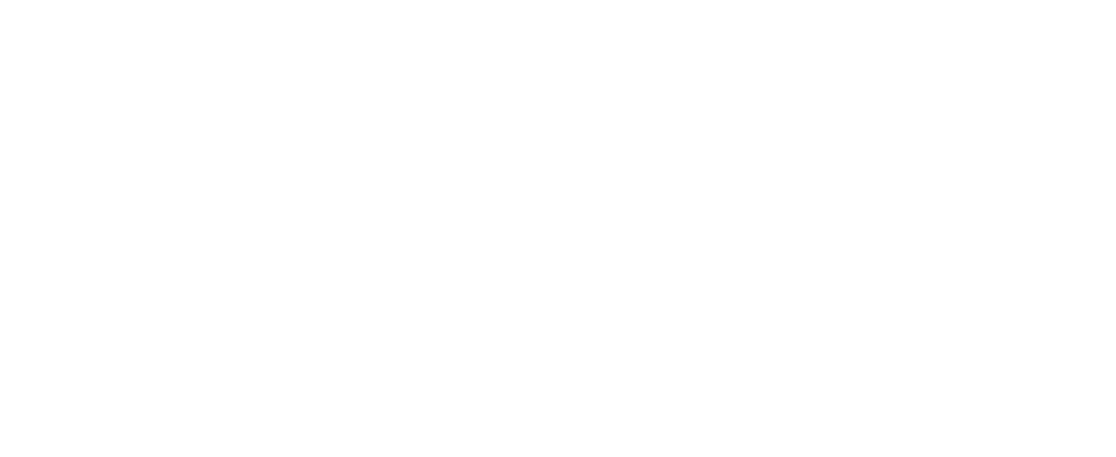

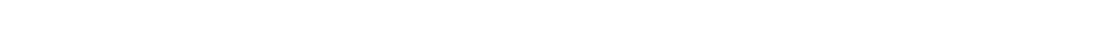
[Drainage area, 2.;34., scuare miles.]

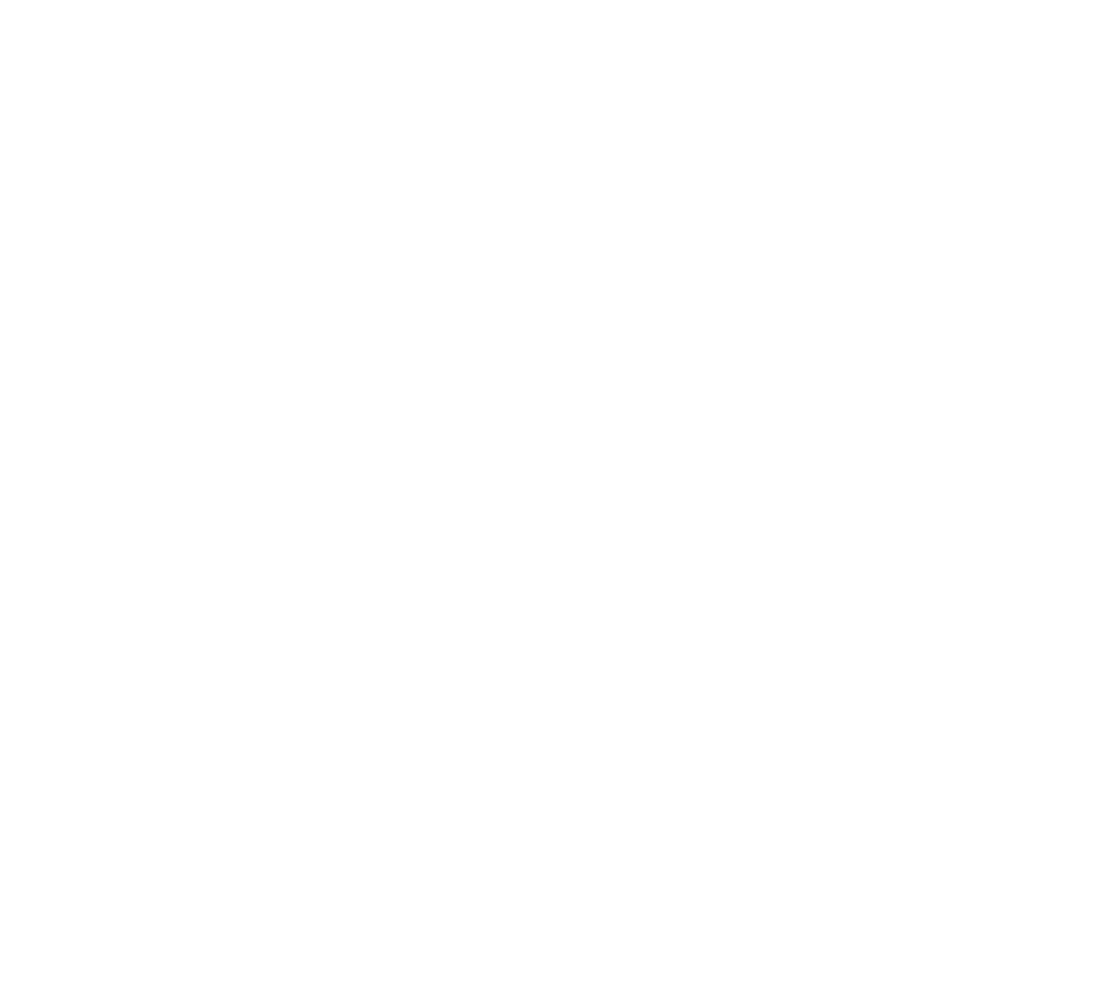

a Authority. ('ilifornia State engineering department, from November, 18 's to October, 1sst, inclusive. 
Estimated monthly aischarge of Kern River, etr.-Continued.

\begin{tabular}{|c|c|c|c|c|c|c|}
\hline \multirow{2}{*}{ IIonth. } & \multicolumn{3}{|c|}{ Discharge. } & \multicolumn{3}{|c|}{ Run-off. } \\
\hline & Maximum. & Minimum. & Meau. & $\begin{array}{l}\text { Total dis- } \\
\text { charge. }\end{array}$ & $\begin{array}{c}\text { Per } \\
\text { square } \\
\text { mile. }\end{array}$ & Depth. \\
\hline $18,80$. & Sier feet. & sere-fiet. & serefert. & Acir-feet. & sire-feet. & Inches. \\
\hline January & 410 & 315 & $35 t$ & $21,76 \pi$ & 0.15 & 0.17 \\
\hline February & 340 & 31.5 & $3 \% 0$ & 21,283 & .16 & ז'1 \\
\hline March .......... & $3 \times 5$ & 349 & 389 & 23,919 & .17 & .20 \\
\hline April ....... & 3,320 & 39.5 & $1,5 \%$ & $92,6 \pm x$ & .66 & .74 \\
\hline May ........ & 3,560 & 1.615 & 2,659 & 163,496 & 1.13 & 1.30 \\
\hline June . . . . . . . . & 4,$0 ; 0$ & จ. & $3.31 \%$ & $19 \% .3 \%$ & 1.41 & $1.5 \%$ \\
\hline July . . . . . . ... & 3,141 & 1.550 & 2,196 & 135,027 & .94 & 1.08 \\
\hline August ... . . . . . & 1,500 & 840 & 1,060 & $6 \pi .1 \%$ & .45 & .52 \\
\hline September . .... & 846 & $\approx 10$ & $\tau 6 \tau$ & $4,5,640$ & .33 & .37 \\
\hline October ..... & $\% 94$ & 72: & אis & 46.608 & .32 & .37 \\
\hline November. . . . . & 830 & 69.5 & $\tau 6 \tau$ & $4.5,640$ & .33 & $.3 \%$ \\
\hline December . . . . . . . & 1.480 & 790 & 1,063 & 65,361 & .45 & .52 \\
\hline The year & $4,0 \% 0$ & $31 \%$ & $1,2 \% 1$ & 923,941 & .54 & $\tau .38$ \\
\hline 1881. & & & & & & \\
\hline January ..... & 1,640 & 950 & $1.0 \% 8$ & 66,284 & .46 & .53 \\
\hline February .... & $2.9 \% 0$ & 1.430 & 1.763 & 98,467 & .76 & .79 \\
\hline March ........ & 2.100 & 1.400 & $1,5 \% 0$ & 96,536 & $.6 \%$ & $.7 \%$ \\
\hline April . . . . . . & $\stackrel{2}{\sim} 61 \stackrel{2}{\sim}$ & $2,100^{\prime}$ & 2,288 & 136.145 & .98 & 1.09 \\
\hline May ......... & 2,710 & 2.060 & 9. 362 & 145. 234 & 1.01 & 1.16 \\
\hline June ......... . & 2.390 & $1.4 \% 5$ & 1.890 & 112,463 & .81 & .90 \\
\hline July . . . . . . & 1,520 & 氵10 & 1,126 & 69,235 & .48 & .55 \\
\hline August ...... & 1.200 & 420 & $62 \pi$ & $38,5.53$ & $.2 \%$ & .31 \\
\hline September . . . . . . & 420 & 320 & 361 & 21.481 & .15 & .17 \\
\hline October & 360 & 310 & 333 & $20.4 \% 5$ & .14 & .16 \\
\hline November $\ldots \ldots$ & 360 & 300 & $33 \%$ & 20,053 & .14 & .16 \\
\hline December . . . . . . & 410 & 320 & 350 & 21,521 & .15 & .17 \\
\hline The year. & $2,9 \div 0$ & 300 & 1,175 & $846,44 \tau$ & .50 & 6.76 \\
\hline
\end{tabular}


Estimaterl monthly discharge of Kern River, ete.-Contirned.

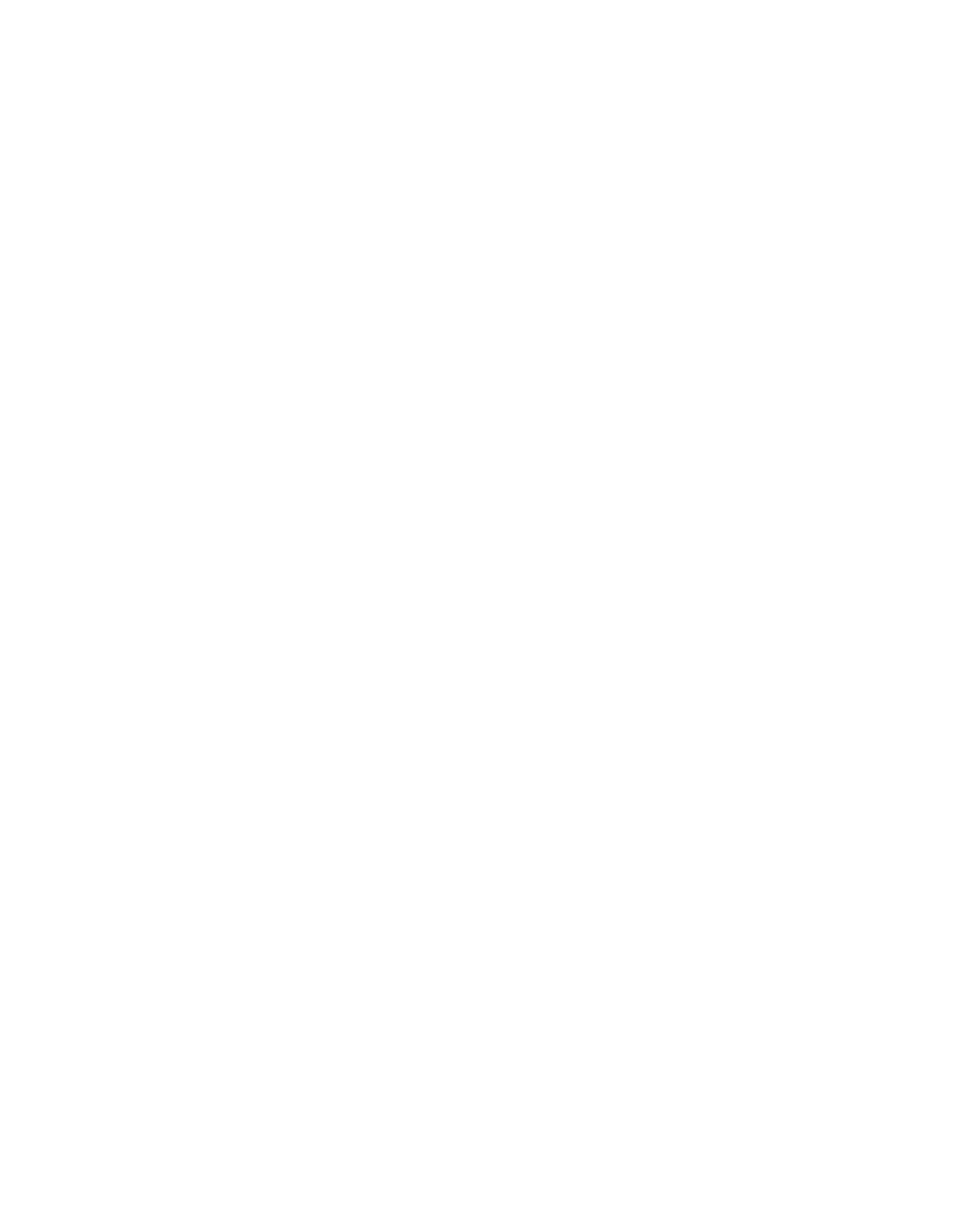

a Estimated from previous measurements and from lun-off of neighboring steams. 
Estimated monthly discharge of Kern Rier', ets.-Continued.

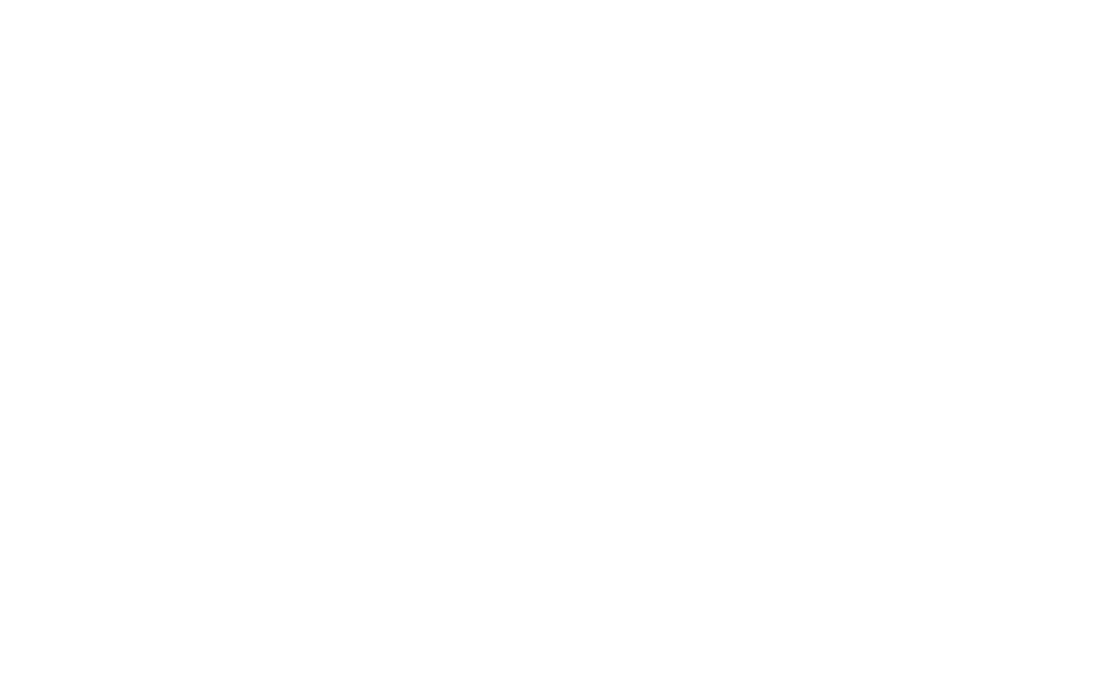

a Estimated from previous measurements and from run-off of neighloring stroams.

Estimated mouthly discharge "f Kern River at first point of measurement. [Drainage area, 2:345 square miles.]

\begin{tabular}{|c|c|c|c|c|c|c|}
\hline \multirow[b]{2}{*}{ Month. } & \multicolumn{3}{|c|}{ Discharge. } & \multicolumn{3}{|c|}{ Run-riff. } \\
\hline & Maximum. & Minimun. & Mean. & $\begin{array}{l}\text { Total dis- } \\
\text { rharge. }\end{array}$ & $\begin{array}{l}\text { Per } \\
\text { square } \\
\text { mile. }\end{array}$ & Depth. \\
\hline 1893. & secefeet. & Sece-fert. & Ner-seet. & Acre-fert. & sere-fuet. & Inchers. \\
\hline October . . .... & 5.54 & $51 \%$ & 534 & 32,861 & 0.23 & 0.26 \\
\hline November & 559 & 467 & 518 & 30,827 & .20 & .24 \\
\hline December ... . . . . & 590 & 430 & 516 & $31.75 \%$ & .29 & .25 \\
\hline 1894. & & & & & & \\
\hline January ..... & $r+1$ & 562 & ricis & $4(1,644$ & .29 & .32 \\
\hline February ........ & 1,114 & 604 & $71 \%$ & $39,81 \%$ & .30 & .32 \\
\hline March ....... & 1,443 & 762 & 1.001 & $61,5+1$ & .43 & .65 \\
\hline April ...... & 1.892 & 1,209 & $1,49.5$ & 88,952 & .64 & .71 \\
\hline May ....... & 2,208 & 1,228 & $1,60 \%$ & 98,798 & .60 & .79 \\
\hline June ...... & 1,719 & $8 \% 1$ & $1,08.5$ & $04.55 \%$ & .46 & .51 \\
\hline July ....... . & 1,$0 ; 1$ & 400 & 700 & 43,036 & .30 & .34 \\
\hline August & 549 & 256 & 335 & 20,565 & .14 & .16 \\
\hline September .... & 382 & 172 & 248 & 14.756 & .11 & .12 \\
\hline October -.. & 263 & 224 & $2 \pi 9$ & $1 \pi, 1 \pi R$ & .12 & .14 \\
\hline November & 268 & 230 & 244 & 14,500 & .10 & .11 \\
\hline December . - & 805 & 234 & $4 \% 0$ & 28.908 & .20 & .23 \\
\hline The year & 2,208 & $1 \% 2$ & 737 & 533,252 & .31 & 4.40 \\
\hline
\end{tabular}


Estimuted monthly discharge of Kem River. atr.-Continued.

\begin{tabular}{|c|c|c|c|c|c|c|}
\hline \multirow[b]{2}{*}{ Month. } & \multicolumn{3}{|c|}{ Diselharge. } & \multicolumn{3}{|c|}{ Run-off. } \\
\hline & Maximum. & Minimum. & Mean. & $\begin{array}{c}\text { Total dis- } \\
\text { charge. }\end{array}$ & $\begin{array}{c}\text { Per } \\
\text { square } \\
\text { mile. }\end{array}$ & Depth. \\
\hline $189 . \overline{5}$ & Sereffect. & sure-fret. & Sisc-fuet. & I tere-fret. & Sirr.feet. & Inches. \\
\hline Jannary ..... & 1.616 & $4 \%$ & 809 & 49.762 & 0.34 & 0.40 \\
\hline February _... & 4.762 & 67.5 & 1.252 & 69,536 & $. \pi: 3$ & .55 \\
\hline March ........ & 3,004 & 94 & $1.3 \% 4$ & $84,4: 3$ & .59 & $.6 \%$ \\
\hline April ......... & $3,89 \%$ & 1.911 & 9.724 & $169,0 \div 6$ & 1.16 & 1.29 \\
\hline May - & 5,384 & 3,100 & 4.369 & $268.60 \mathrm{~s}$ & 1.80 & 2.14 \\
\hline June ..... & 3.721 & $2,1 \pi 4$ & 2,906 & $1 \% 2.919$ & 1.24 & 1.37 \\
\hline July ..... . & 2.063 & R6r & $1,48^{2}$ & 91,113 & .63 & .73 \\
\hline Augnst - & 1.073 & 3.54 & 629 & 38,$60 ;$ & .27 & .31 \\
\hline September & 676 & 290 & 344 & 20,469 & .15 & $1 \tau$ \\
\hline October & 612 & $2 \pi 6$ & $32 \pi$ & 20,106 & .14 & .16 \\
\hline November & 436 & 308 & 346 & 20,588 & .15 & .17 \\
\hline December. & 44 & 368 & 403 & 24,759 & .17 & .20 \\
\hline The year & 5.384 & $2 \% 6$ & 1,413 & $1,023,058$ & .60 & 8.16 \\
\hline $1 \times 96$. & & & & & & \\
\hline Jamiary .... & 3.101 & $37 \%$ & 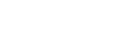 & 45,931 & .32 & .37 \\
\hline February $\ldots$ & 798 & 559 & $61 \tau$ & 35.489 & .26 & .28 \\
\hline March ....... & 2.089 & 652 & $9 \pi 1$ & $\pi 8,4 \pi$ & .41 & $.4 i$ \\
\hline April ....... & 1.203 & 766 & 972 & 57,838 & .41 & .46 \\
\hline May ... .... & $3,3 \% 0$ & $93+1$ & 1,401 & 86,144 & .60 & .69 \\
\hline June ........ & 3,611 & 1. 244 & $2,4,56$ & 146.142 & 1.0. & 1.17 \\
\hline July ....... & 2,210 & $i 41$ & 1,316 & 82,762 & ris & .66 \\
\hline August ... & $i+1$ & 353 & $4 \times 6$ & $29,8 \times 3$ & .21 & .24 \\
\hline September - & 473 & 234 & 304 & 18,089 & .13 & .14 \\
\hline October...... & 425 & $22: 3$ & $26 \pi$ & $16.41 \%$ & .11 & .13 \\
\hline November & 416 & 288 & $3,5,5$ & 21.124 & .15 & $.1 \tau$ \\
\hline December . ... & 426 & 313 & $34 \pi$ & 21.836 & .15 & .11 \\
\hline The year & 3,611 & 223 & 854 & 619,630 & .36 & 4.95 \\
\hline
\end{tabular}


Estimaled monthly diseharge of Kern Rivere, etc.-Continued.

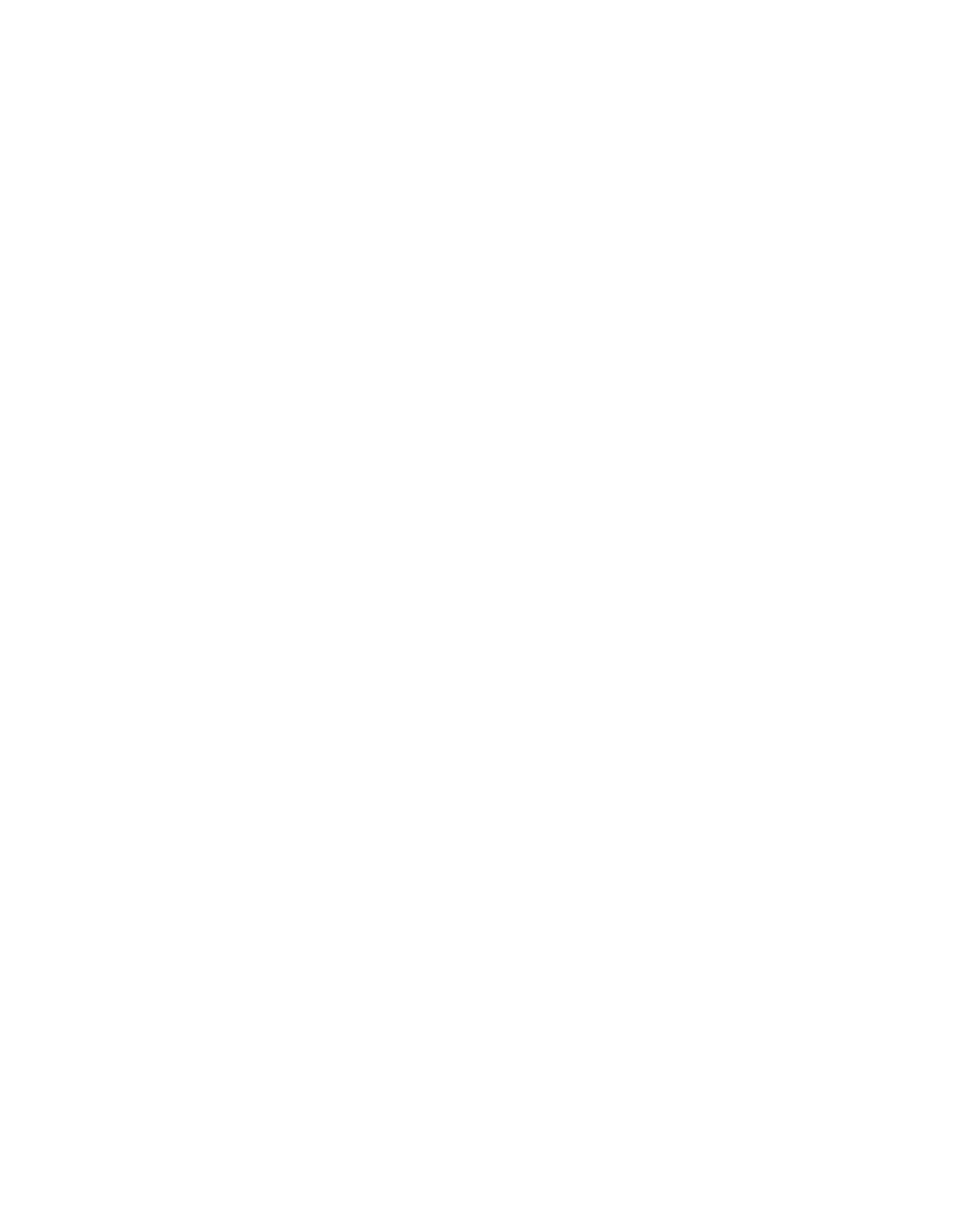


Extimated monthly rlischetrye of Kern River, ete.-Continuterl.

\begin{tabular}{|c|c|c|c|c|c|c|}
\hline \multirow[b]{2}{*}{ Mronth. } & \multicolumn{2}{|r|}{ Discharge. } & & \multicolumn{2}{|c|}{ Run-off. } \\
\hline & Maximum. & Minimum. & Mean. & $\begin{array}{l}\text { Tutal dis- } \\
\text { rharge. }\end{array}$ & $\begin{array}{l}\text { Per } \\
\text { square } \\
\text { mile. }\end{array}$ & Depth. \\
\hline tret9. & sereffert. & Sien-fiet. & sien fiest. & Aretefert. & Sureffert. & Inclues. \\
\hline Jannary - & 361 & $1 \times 2$ & 263 & 16,172 & 0.11 & 0.13 \\
\hline February . ...... & 365 & 258 & 302 & 16,772 & .13 & .14 \\
\hline March . ....... & 4,932 & 247 & 590 & $36.2 \pi$ & .25 & .29 \\
\hline April $\ldots \ldots$ & $1,16 \%$ & 593 & 893 & 53.138 & .38 & .43 \\
\hline May ... . . ...... & 1,302 & $5 \% 6$ & $83 \pi$ & $51,3+2$ & .36 & .41 \\
\hline June . . . . . . . . & 2,230 & 809 & 1,331 & 79.200 & $.5 \pi$ & .63 \\
\hline July . . . . . . & 894 & 299 & $4 \times 9$ & $30,05 \%$ & .21 & .24 \\
\hline August .. ... & $340^{1}$ & 99 & 150 & 9,792 & .01 & .08 \\
\hline September ..... & 117 & 89 & 10.5 & $0 i, 25 i$ & .04 & .05 \\
\hline October - & 299 & $800^{2}$ & 160 & 9.438 & $.0 \%$ & .08 \\
\hline Norember. & זיה & $1 \times 3$ & 221 & 13.151 & .09 & .10 \\
\hline Decemliner.... . - & in1 & 182 & $2 \%$ & $1 \%, 032$ & $1.1 \mathrm{~s}$ & 1.36 \\
\hline The year. & 4,932 & 86 & 468 & $.338,829$ & .29 & 3.94 \\
\hline 1900. & & & & & & \\
\hline January ........ & $1,04 R$ & 266 & 362 & 22,259 & .15 & .17 \\
\hline February ...... & 329 & 238 & 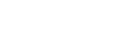 & $15,5.50$ & .12 & .12 \\
\hline March ..... & 502 & $30 \%$ & 413 & 25,394 & .18 & .21 \\
\hline April & 592 & $38 \%$ & 472 & $2 \times, 0 \times 6$ & .20 & .22 \\
\hline May. & 1,969 & 449 & 1.111 & $6 \times, 312$ & $.4 \pi$ & .54 \\
\hline June ........ . & $1,8,8$ & 841 & 1,283 & 76.344 & .5 .5 & .61 \\
\hline July ....... & $\times 50$ & 202 & 392 & 24.103 & $.1 \%$ & .20 \\
\hline August ......... & $21 i$ & 101 & 144 & 8,854 & .06 & $.0 \tau$ \\
\hline September & | & 106 & 166 & $9, \times, 8$ & $.0 \pi$ & .08 \\
\hline October .......... & 186 & $13 i$ & 160 & 9.838 & $.0 \tau$ & .08 \\
\hline November. . . . . . & 1,389 & 161 & $3+9$ & 20,765 & .15 & .17 \\
\hline December - & 445 & $25 x$ & $3 ; 3$ & 22,934 & .16 & .18 \\
\hline The year. & 1,969 & 101 & 459 & 332,319 & .20 & 2.65 \\
\hline
\end{tabular}


Estimated monthly discharge of Kern River, ete.-Continued.

\begin{tabular}{|c|c|c|c|c|c|c|}
\hline \multirow[b]{2}{*}{ Month. } & \multicolumn{3}{|c|}{ Discharge. } & \multirow[b]{2}{*}{$\begin{array}{l}\text { Total dis- } \\
\text { eharge. }\end{array}$} & \multicolumn{2}{|c|}{ Run-off. } \\
\hline & Maximnu. & Minimum. & Mean. & & $\begin{array}{l}\text { Per } \\
\text { square } \\
\text { mile }\end{array}$ & Depth. \\
\hline 1901 & Nece-feet. & sereffeet. & seec-fect. & Aterefert. & Siec-fent. & Inches. \\
\hline Jannary - ....... & 2,049 & 226 & 493 & $30.31: 3$ & 0.21 & 0.24 \\
\hline Februmry ... & 1,963 & 342 & 860 & $4 \pi, \pi 62$ & $.3 \%$ & .39 \\
\hline March ........ . . & 1.658 & 901 & $1,2 \div 0$ & 78,089 & .54 & .62 \\
\hline April ........ & 2,632 & $63 \%$ & 1.398 & 83.187 & .60 & .67 \\
\hline May . . . . . . . . & 4,419 & 2.0911 & 3.0132 & $180,+330$ & 1.29 & 1. 49 \\
\hline June $\ldots \ldots \ldots$ & $4,3: 3: 2$ & 2.45 & $3,324^{1}$ & 197.792 & 1.42 & 1.58 \\
\hline July ............ & $3 . \times 56$ & 1.120 & 1,864 & 114.16:; & .80 & .92 \\
\hline August .......... & 1.804 & 505 & 968 & 59.520 & .41 & .47 \\
\hline September . . . . . . . & 526 & $24 !$ & 345 & 30.529 & .15 & .17 \\
\hline October ............ & 756 & 259 & $31 \%$ & 19,492 & .14 & .16 \\
\hline Novemher ... & 421 & 343 & 3 :3 & 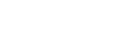 & .16 & .18 \\
\hline December . & $4 \pi \tau$ & $\because 68$ & 393 & 19,860 & .14 & .16 \\
\hline The year ...... & 4.419 & 220 & 1. 216 & 880.020 & .52 & $\tau .05$ \\
\hline
\end{tabular}

KING RIVER.

This river rises on the western slope of the Sierra Nevada in Fresno county, Cal. The waters coming from the high atehment basin are probably of greater value for irrigation purposes than those of any other stream in central California, being used exclusively for the raising of grapes and deciluous fruits in the neighlorhood of Fresno, Selma, and Hanford. The summer flow of this river is now entirely diverted, and during the dry season of the last few years the scarcity of water has worked many hardships. There is a large surplus of water in this river in the spring, due to the melting of snows, which is now going to waste, and which, if stored in suitable reservoirs, would bring larger areas moler cultivation. The mountainoms basin of this river has been systematically explored for reservoir siter For a detailed statement concerning the hydrography of King River, see Water-Supply Paper No. 5s, by J. B. Lippineolt. 'Jwo gaging stations were formerly maintained on the river, one al Red I Iountain and the other at Kingsburg, Cal. The station at Red Mountain, established September $3,1 \times 95$, is located 15 miles east of Sanger, Cal., and southwest of Red Mountain. The station is on what is ealled "the lower section of No. "t" of the lumber flume. It is located at the mouth of the eanyon, above all diversions. The bed of the stream is of gravel, and few changes have been noticed in the cross section since the establishment of the station. 
Inischarge meresnrements af King River, Fresun county.

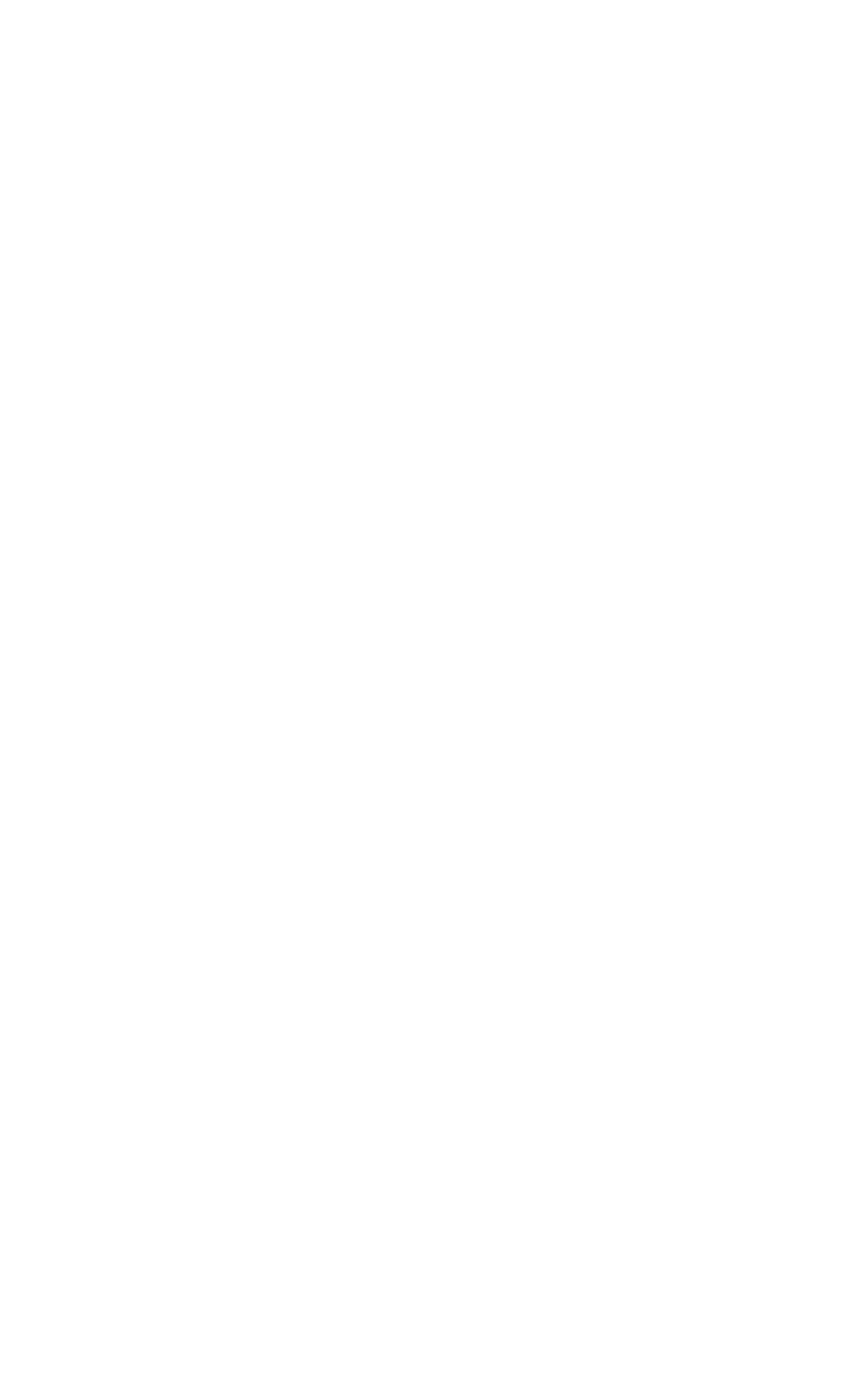




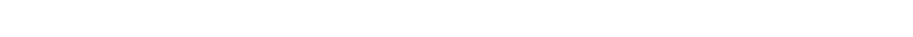

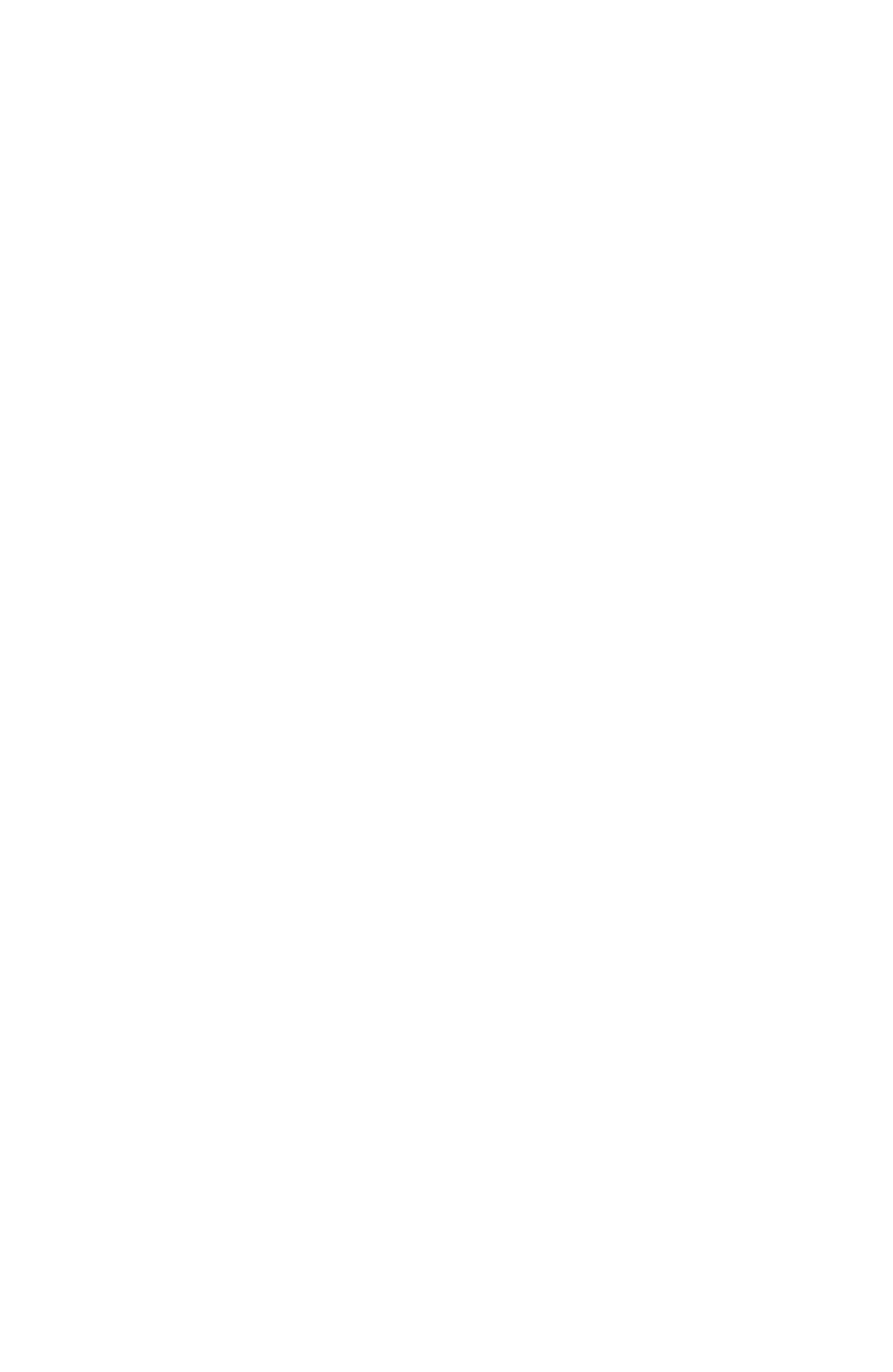

a Grade of river at Kingshurg affected by diversion dam of Last Chan e. ('mmpany, : miles below. 
Jischerge mersmements uf King River. Fresno county-Continued.

\begin{tabular}{|c|c|c|c|c|}
\hline Date. & Hydrographer. & $\begin{array}{c}\text { Gage } \\
\text { height. }\end{array}$ & Discharge. & Locality. \\
\hline & & Feet. & sec.-feet. & \\
\hline Nov. $1,189 \pi$ & A. Q. Campliell .... & $4.5 i$ & 552 & Red Mountain. \\
\hline Dec. 22,1897 & J. B. Lippincott ... & 4.7 & 515 & Do. \\
\hline Apr. 20,1898 & $\ldots d o . \ldots . . .$. & 8.55 & 4,943 & Do. \\
\hline May 29,1898 & $\ldots$. & 7.14 & $2.6 \% 2$ & Do. \\
\hline July $2 \pi, 1898$ & $\ldots$ do ....... & 4.32 & 503 & Do. \\
\hline Aug. 31,1898 & $\ldots$ do ......... & $3.7 \%$ & 244 & Do. \\
\hline Dec. 21,1898 & do ........ & Ћ.0 & 2,444 & Do. \\
\hline Apr. 19,1899 & S. G. Bennett .... & 8.8 & 5,409 & Do. \\
\hline May 15,1899 & $\ldots$ do $\ldots . . . . .$. & 8.15 & 4,422 & Do. \\
\hline June $\quad 3,1899$ & $\ldots$. 30 & 7.85 & 3.9 .4 & Do. \\
\hline June $: 6,1899$ & $d 0 \ldots \ldots$ & 7.23 & 3,049 & Do. \\
\hline Aug. : :. 1899 & . do ......... & 4.66 & 608 & Do. \\
\hline Sept. $\quad 4,1899$ & $\ldots d \theta \ldots . . . . . .$. & 3.80 & 206 & Do. \\
\hline Dec. $\quad$ ґ, 1899 & J. B. Lippincott - . & 4.36 & 458 & Do. \\
\hline Apr. $\quad 4,1900$ & S. G. Bennett .... . & 6. 54 & $\stackrel{?}{?}, 0335$ & Do. \\
\hline May 16,1900 & $\ldots$ do ....... & $9 .: 2$ & 6,436 & Do. \\
\hline June 19,1900 & ... do & 8.59 & $5,0 \% 2$ & Do. \\
\hline Aug. 10.1900 & .... do .... & 4.3 & 497 & Do. \\
\hline Sept. 4.1900 & $\ldots$ do $\ldots . . . .$. & 4.28 & $40 . \overline{5}$ & Do. \\
\hline Sept. $2 \pi, 1900$ & $\ldots$ do _........ & 3.82 & 220 & Do. \\
\hline Dec. 29,1900 & . do ........ & 4.65 & 576 & Do. \\
\hline Jan. 31,1901 & .... do & 5.4 & 991 & Do. \\
\hline Feb. 98,1901 & 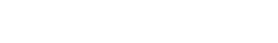 & 7.90 & $3,59: 3$ & Do. \\
\hline Apr. $\quad 4.1901$ & $\ldots$ do ............ & 6.40 & 1.915 & Do. \\
\hline May 21.1901 & J. B. Lippincott & 10.5 & 10.869 & Do. \\
\hline July 30.1901 & S. G. Bennett ... & 7.54 & 3,179 & Do. \\
\hline Oct. 17,1901 & $\ldots$. do _....... & 4.1 & 301 & Do. \\
\hline Sept. 21.1902 & $\ldots$ do $\ldots . .$. & $\ldots$ & $21 \%$ & Do. \\
\hline Oct. 20,1900 & H. E. Green - . & & 346 & $\begin{array}{l}\text { South Fork, just below } \\
\text { junction of Middle Fork. }\end{array}$ \\
\hline Sept. $\quad 4,1899$ & S. G. Bennett & & Dry. & $" \approx 6 "$ ditch at head. \\
\hline Sept. $\quad 4.1900$ & $\ldots$. . do ........ & $\ldots$ & Dry. & Do. \\
\hline June 2.j, 1895 & J. B. Lippincott & 13.9 & $10.30 \tau$ & Suspension bridge. \\
\hline Sept. $2.189 \pi$ & A. P. Davis ..... & 9.5 & 525 & Do. \\
\hline Dec. יㅗ. $189 \pi$ & J. B. Lippincott - . & 4.9 & 522 & Do. \\
\hline
\end{tabular}




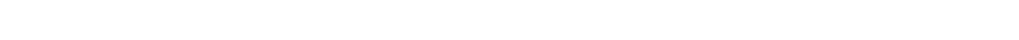

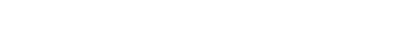

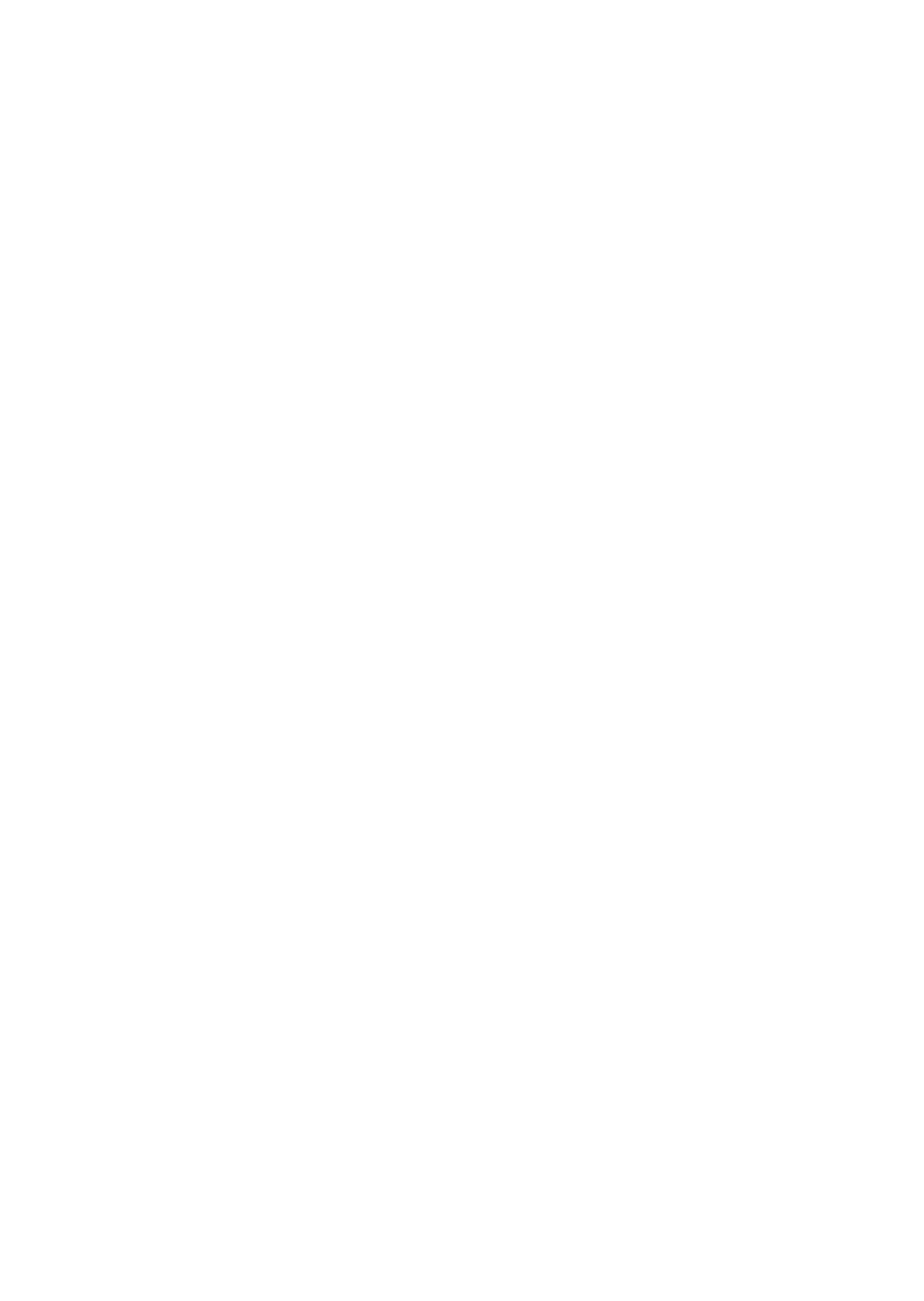

T Authority, ('aliformia State engineer.

IRR 81 - $1: 3-S$ 
Estimeter monthly discharge of King River, cte.-Continued.

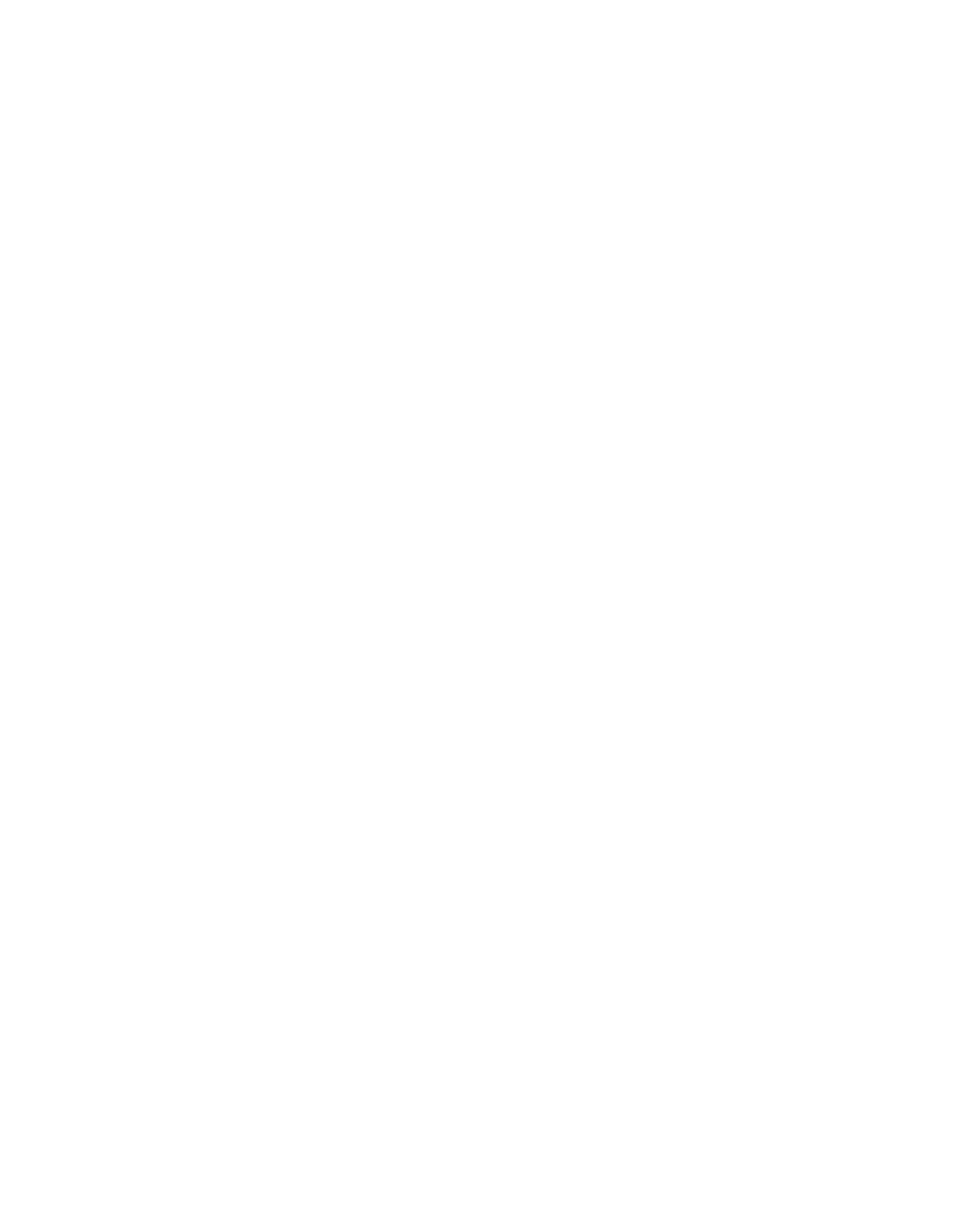


Estimated monthly discharge of King River, etc.-Continued.

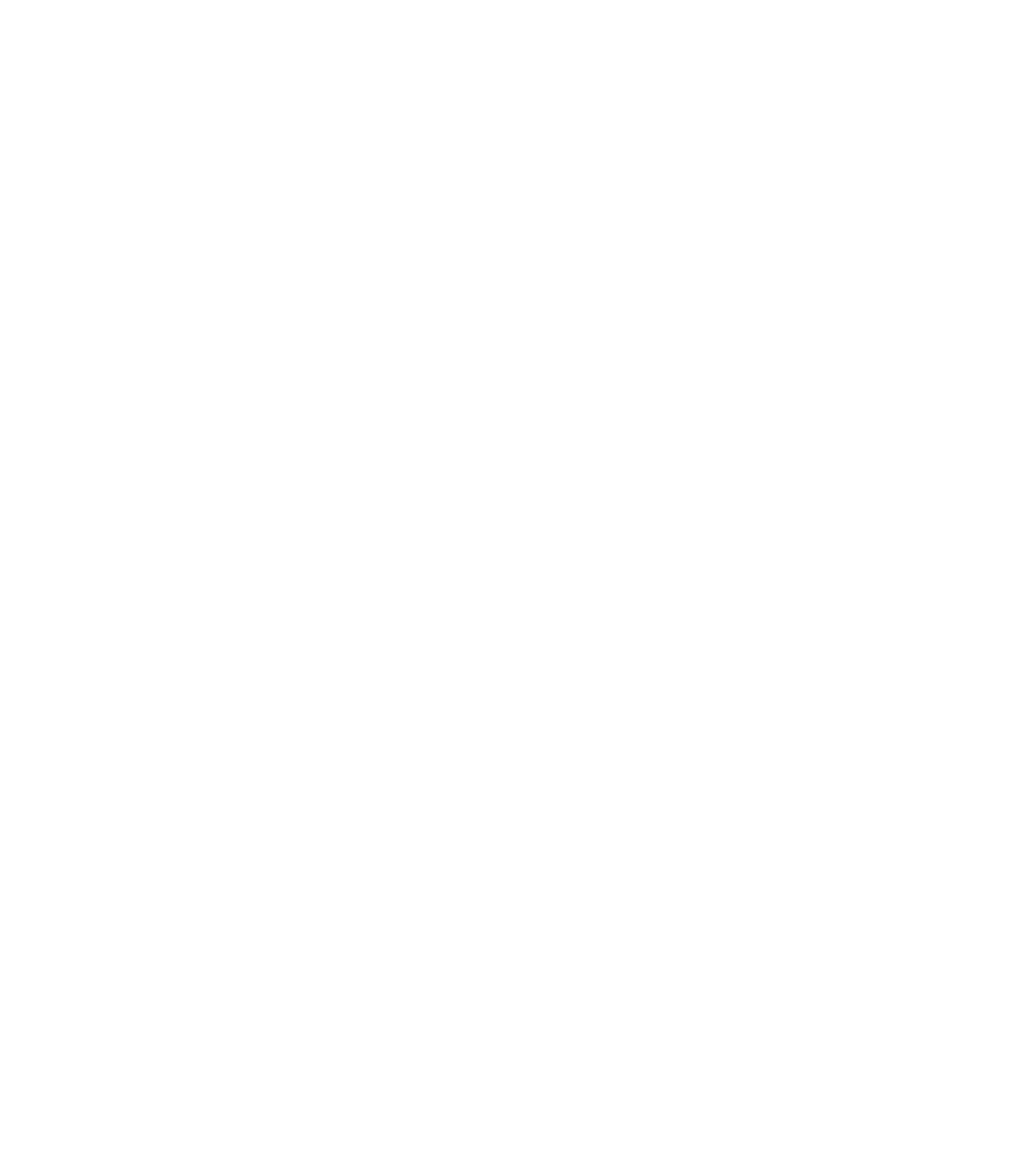


Estimeted monthly discharye af' King River at Red Mountain, Fresues C'onnty."

[Drainage area, 1,74: square miles.]

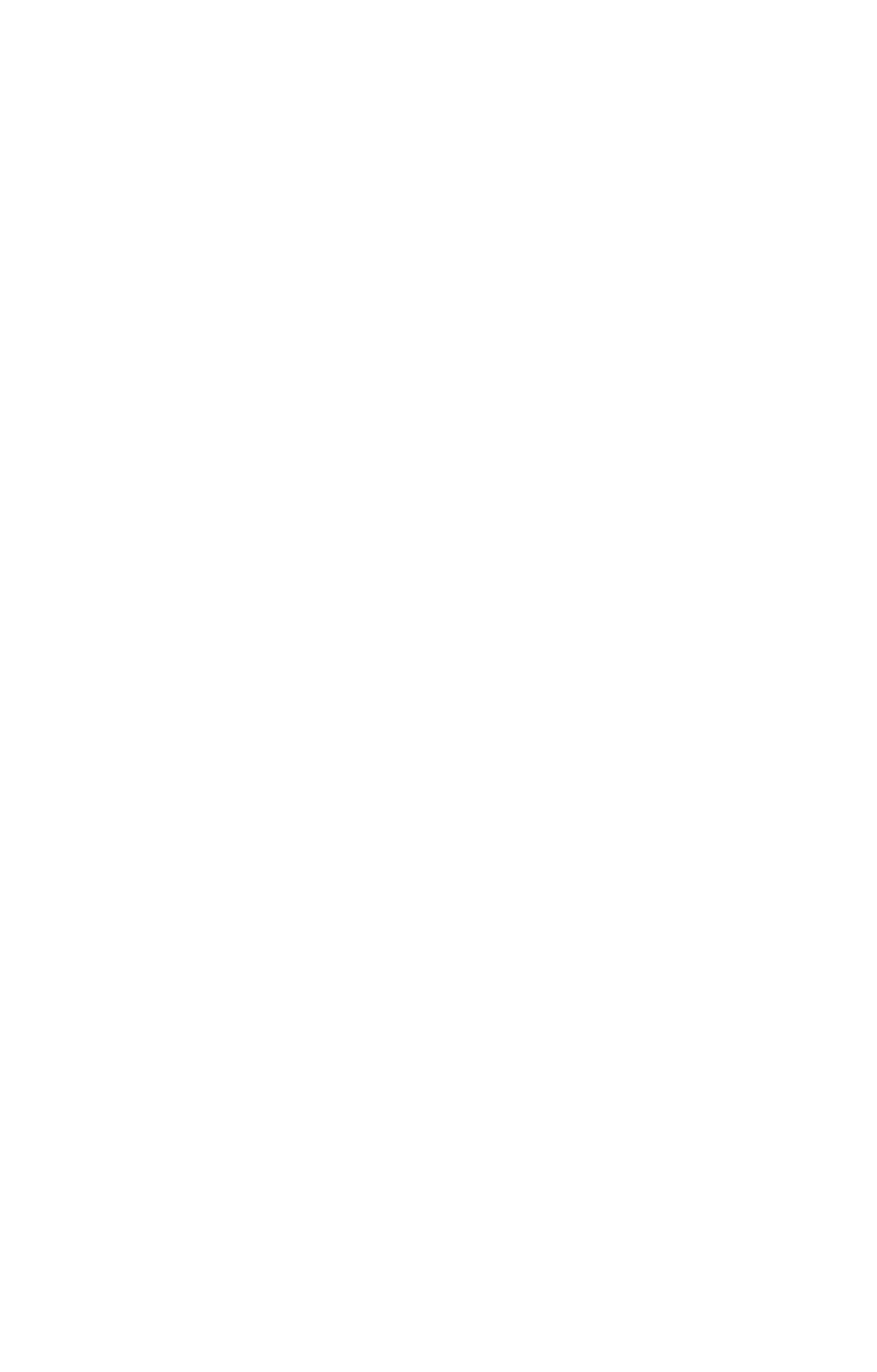

a Authority, United States Geological Survey. 
Estimated monthly discharge of King River, ete.-Centinued.

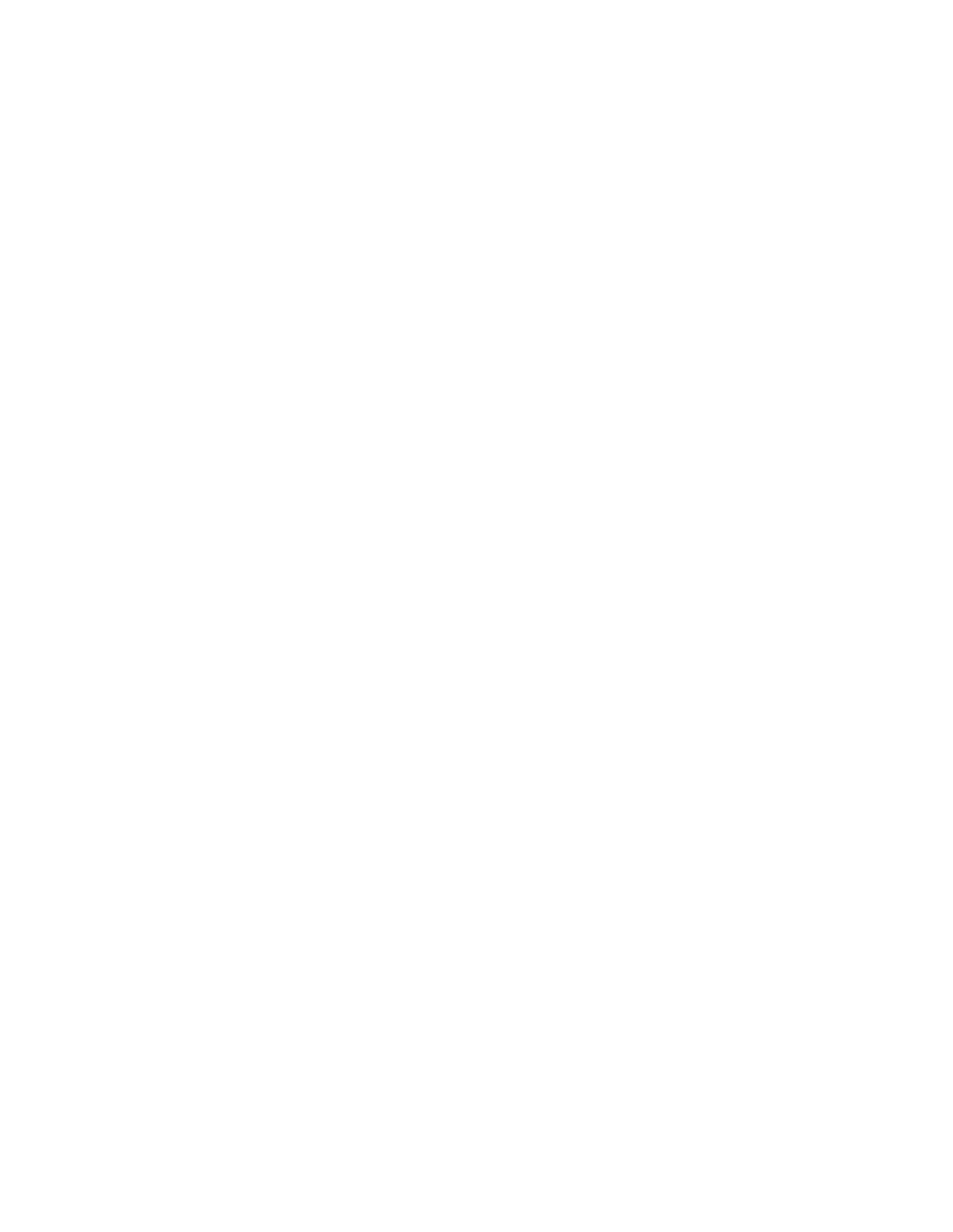




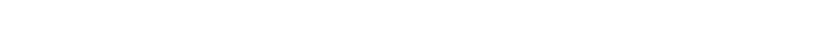

\begin{tabular}{|c|c|c|c|c|c|c|}
\hline \multirow[b]{2}{*}{ Month. } & \multicolumn{3}{|c|}{ Diurharger. } & \multirow[b]{2}{*}{$\begin{array}{c}\text { Total dis } \\
\text { rharge }\end{array}$} & \multicolumn{2}{|c|}{ Rum off } \\
\hline & Maximum, & Minimum & Mean. & & $\begin{array}{l}\text { Per } \\
\text { square } \\
\text { mile. }\end{array}$ & Depth. \\
\hline 1901$).$ & Sirefort & Sier.fert. & sec foet. & derefoet. & - serejoet & Inches. \\
\hline January ... . . . & 12.700 & 849 & 1,689 & $103,55: 3$ & 0.97 & 1.12 \\
\hline February ..... & $\cdot 849$ & $6 r 6$ & $\tau 48$ & 41.542 & .43 & .45 \\
\hline March ...... & 2,584 & $72 R$ & 1,712 & $10.5,26 \pi$ & .96 & 1.13 \\
\hline April ........ & $2.8 \pi 2$ & 1,546 & $\stackrel{2}{2}, 098$ & 124.840 & 1. 20 & 1.34 \\
\hline May - & 9.400 & $1,9: 30$ & 5,881 & 361,609 & 3.38 & $: 3.90$ \\
\hline June - & 5.900 & $?, 986 \mathrm{i}$ & 5,127 & $30.5,078$ & 2.94 & $3.2 \%$ \\
\hline July ..... & 2,54 & $5 \% 2$ & $1,2 \pi$ & TS. 541 &.$\pi 3$ & .84 \\
\hline Angust... . & 624 & 250 & 398 & 24,422 & $.2: 3$ & .26 \\
\hline September: & 520 & $21 \pi$ & $: 301$ & 17,911 & .17 & .19 \\
\hline Octoler ... ... & 440 & 215 & 300 & 19.000 & .18 & .21 \\
\hline November - & 1.). 200 & 9.50 & 1,310 & $\approx \pi, 950$ & .75 & .83 \\
\hline Derember - - & 972 & $5 \% 2$ & 726 & $44.6+1)$ & .42 & .48 \\
\hline The year & 15,700 & 215 & 1,898 & $1,304,7.4: 3$ & $1.0: 3$ & 14.02 \\
\hline 1901 & - & & & & & \\
\hline Jannary & $4: 3,9330$ & 520 & 4,3334 & $266,66^{2}$ & $\because 49$ & 2.87 \\
\hline February & 7.040 & 1,040 & 8,319 & 190,392 & 1.90 & 2.00 \\
\hline March _.. .. & 4,490 & $2,0.34$ & $? 96.1$ & 182,311 & $1 . \%()$ & 1.96 \\
\hline April ..... & $10, \times 40$ & $1,6 \pm 2$ & 4.492 & $265,29: 3$ & 2.58 & 2.87 \\
\hline May ...... & 21.830 & 5,545 & 11,0993 & $682,0 \times 2$ & 6. $3 i$ & ז. 36 \\
\hline June ........ & $\because 1,1 \leqslant 0$ & $\tau, 040$ & 14.363 & $\$ 54,658$ & ห.25 & 9.20 \\
\hline July -.. - & 13,240 & 3,280 & $6,2.88$ & $384,7 \times 9$ & 3.59 & 4.14 \\
\hline August .... & 6.260 & 724 & 2,292 & $140,9: 30$ & 1.32 & 1.52 \\
\hline September - & isio & $4+1)$ & .534 & $31,7.5$ & .81 & .35 \\
\hline Octoher .... & $\because, 034$ & 360 & 53.5 & 39,890 & .31 & .36 \\
\hline November - & 1.450 & 480 & 694 & 41,296 & .10 & .45 \\
\hline December .... & 1.170 & 440 & $66 \mathrm{~s}$ & $41.0 \% 3$ & $.3 \times$ & .44 \\
\hline The year & & 360 & 4.296 & $16 \%$ & $2.4 \pi$ & .52 \\
\hline
\end{tabular}


Estimetad monthly discharge of King Rivere, ete. - Continued.

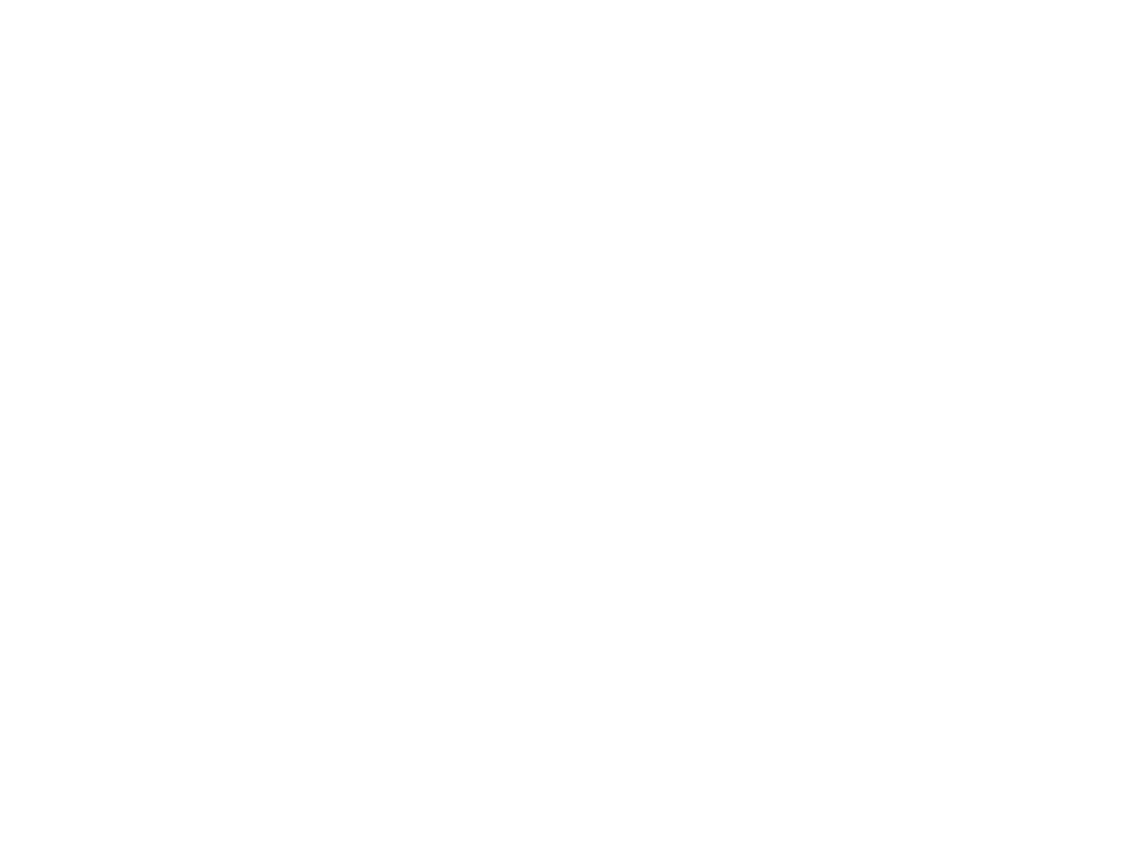

\section{LITTLE ROCK CREEK.}

J)ischury' metsurnements of' Little Rock ('reek, Los Angeles c'ounty.

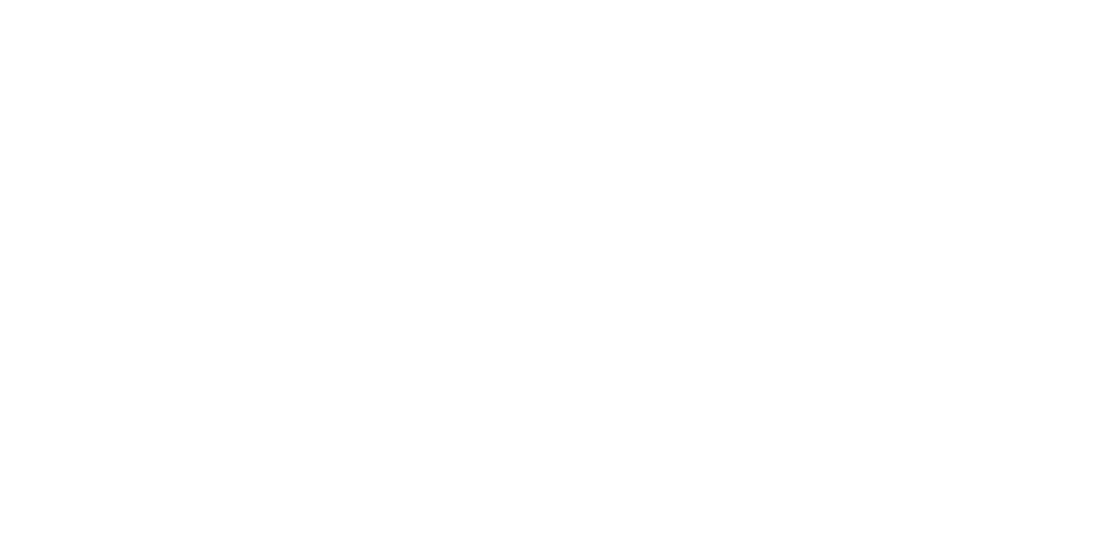

LOBETUS CREEK.

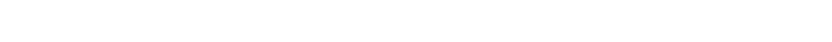

\begin{tabular}{c|c|c|c}
\hline Date. & Hydrographer. & $\begin{array}{r}\text { Dis } \\
\text { (harge. }\end{array}$ \\
\hline Oct. $1 \%, 1893$ & W. W. Brier ......... & $\begin{array}{r}\text { Sec.-feet. } \\
0.18\end{array}$ & 1 mile above mouth. \\
\hline
\end{tabular}




\section{LOGSDON AND FARREL DITCH, SAN BERNARDINC COUNTY.}

See San Bernardino Valley, Jogestom amel Farrel diteh.

\section{LOMA ABAJO.}

The Loma Abajo was measured hy (tharles J. Johansen for the Pacifir. Improvement ('ompany, as indicated below. The point of measmement, was a short distance above the junction with the Gato. At the time of these measurements no water was flowing in the pipe line from the Ioma Abajo to the ontare ranch.

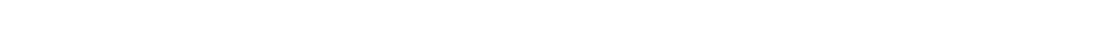

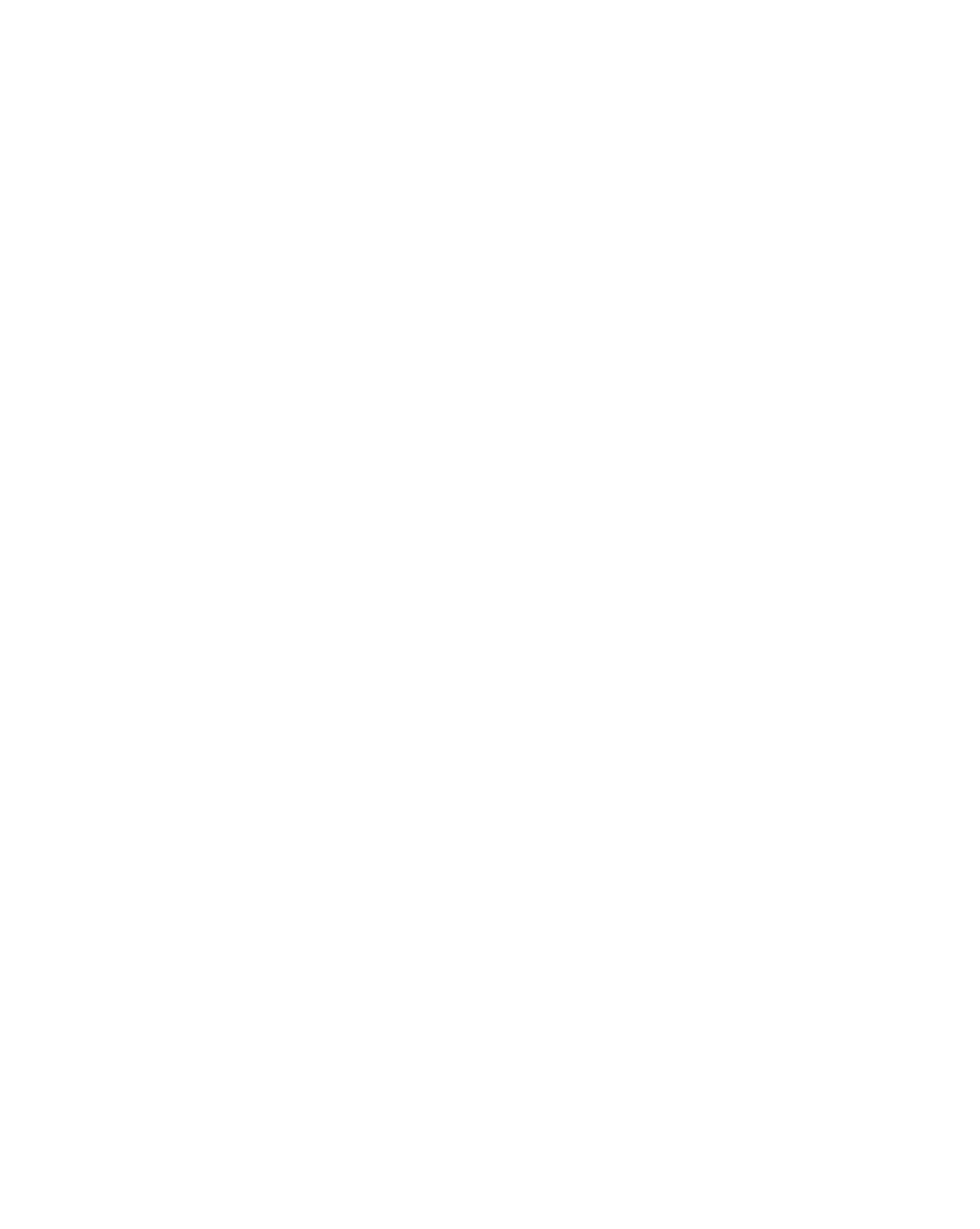


List of disclearge messmemenis of Loma Abajo Rin r, str.-C'omtinned.

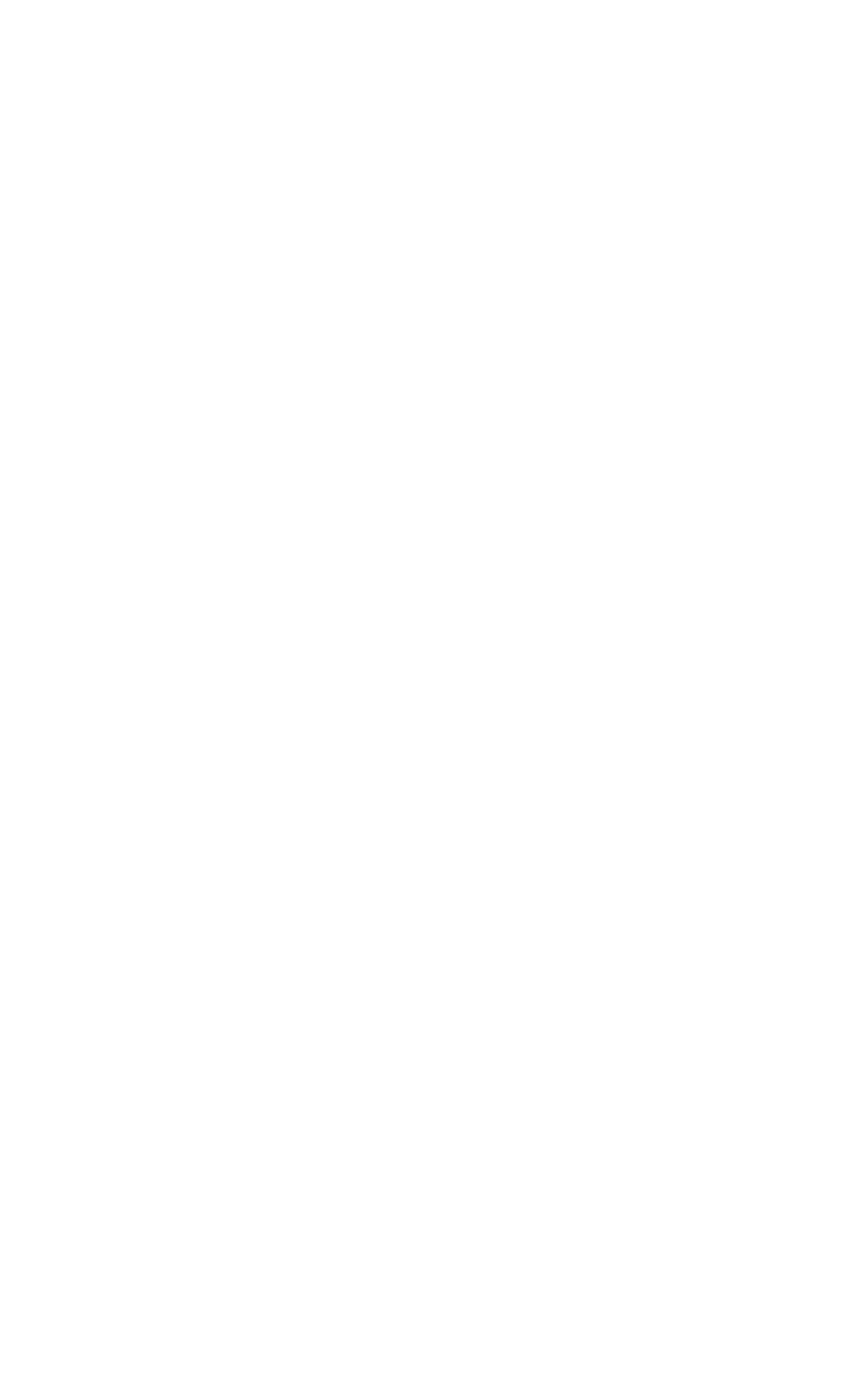




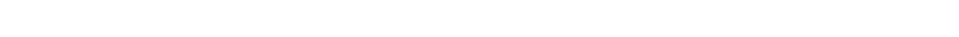

Inate.

July 1.), 1s9o (harles.J.Jolnansen

July 1\%, 1590! .... do

July $19,1890 \mid \ldots$ do

July 21,1890

July 2:3, 1890)

July 2.5, 1к90

July :\%, 1890

July 29,1890

July 31,1890

Ang. $\stackrel{2}{2} 1890$

Ang. 4.1890

Ang. 1i, 1890

Ang. R. 1890

Ang. 10, 1890

Ang. 12, 1890

Ang. 14, 1890

Ang. 1\%,1890

A11‥ 19, 1890

Alug. 21, 1890

А11: 2:3, 1890

Aug. 2.), 1890

Ang. 2\%, $1 \times 90$

A11s. 29, 1890

Ang.: :1. 1890

Sept. $2,1 \times 90$

Sept. 4, 1890

Sept. (i. 1א90

Sept. $\leftarrow, 1890$

Sept. 10,1r90

Sept 12,1890

Sept. 14, 1890

Sept. 16, 18̄90

Sept 18, 1890

Sept. 20,1890

Sept. 22,1890

Sept. 24, 1890

Sept. 26,1890

Sept. 28, 1890

Sept. 30, 1890

Oct. $\quad 2,1890$
1 Iyatrontalyher.

(1)

(i)

(Ir)

(li)

(ro)

ilo

. . . do

ito

.... do

.... do

.... do

do

.....

小is

do

(d)

(1)

.....do

lo

..... din

in

b....do

..... do

...

-..... 10

..... 110

- . do

- . - d to

do

do

..... do

-.... do

lo

do

do

do

do

do

do
1..... do
Dis-

charge.

Itxality

sireffect.

0. 24 i Aluse junction with rato.

$.20 \mid$ Do.

$.2: 3$ - Do

$.1 \%$ Do.

.20) Do.

$.18^{\prime}$ Do.

.21 । Do.

.21 Do.

.233 Do.

.24 Do.

$.30, \quad$ Do.

$\therefore 0$ Do.

18 Do.

.24 Do.

$.2 \%$ Do.

.30): Do.

.12 Do

.13 Do.

$.1 \%$ Do.

.11 i Do.

.12 Do.

.12 Do.

.11 Do.

.09 Do.

.07 Do

.08 Do.

.12 Do

.06 Do

.09 Do.

$.0 \%$ Do

$.00 ;$ Do.

.09 i Do.

.11 Do.

.

.09 Do.

.12 Do.

.13 j Do.

.14 Do.

.30 Do.

$.20 \quad$ Do. 


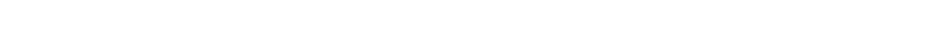

\begin{tabular}{|c|c|c|c|}
\hline Date. & Hydrograpliter. & $\begin{array}{c}\text { Dis- } \\
\text { charge. }\end{array}$ & Lou'dity. \\
\hline & & Nereffert. & \\
\hline oct. $1.1890 \ldots$ & Charles.T. Tohansen & 0.14 & Alore junction with rato. \\
\hline ()et. $0,1<90 \ldots$ & . . do _........ & .14 & Do. \\
\hline Ang. 18, 1s90, a.m & ....do & $.0 \%$ & Below Upuner Forks. \\
\hline Ang. $18,1890.1 . m$ & 1. . do ........ & $.0 \frac{1}{4}$ & Do. \\
\hline Ang. 21, 1890. a. mL . & $\ldots d_{0}$ & .11 & Do. \\
\hline Ang. $21,1 \times ! 0, p \cdot m$ & $\ldots$ do $\ldots$. & .04 & Do. \\
\hline May 21.1890 & . . do $_{10} \ldots \ldots$ & .46 & Upper Forks-Esst Fork. \\
\hline Do $\ldots . .$. & $\ldots \quad d o \ldots . . .$. & $.0 \%$ & Upper Forks-West Fork. \\
\hline Junie 4. 1א90 & . . do & .31 & Upper Forks-East Fork. \\
\hline Do $\ldots \ldots$ & $\ldots d 0 \ldots . .$. & .00 & ITper Forks-West Fork. \\
\hline
\end{tabular}

LOPE $Z$ CREEK.

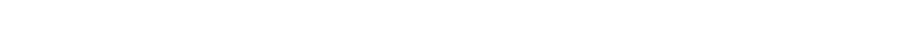

\begin{tabular}{|c|c|c|c|}
\hline Irate. & Hydrugrapher. & $\begin{array}{c}\text { Dis- } \\
\text { rharge. }\end{array}$ & Lurality. \\
\hline$\cdots$ & ----- & $-\ldots$ & -. \\
\hline Nov. $19,1 \times ! r$ & W. W. Brier & 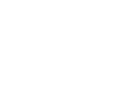 & 10 miles al nove Arroyo Grande. \\
\hline
\end{tabular}

LOS ANGELES RIVER.

Los Angeles River heads immediately south of Santa Clara River, its various tributaries receiving their supply from the mountains surrounding the San Fermando Plains. It passes out of the lower end of the plain through a narrow valley known as The Narrows, at the lower end of which is the eity of Los Angeles. The streams entering San Fernando Valley have brought down immense quantities of sand and gravel from the montainous apea, and thes have formed the san Fernando Ilains. This coarse deposit acts as a natural regulator, absorbing 1 he floed waters, which gradually appear lower down. The rainfall of southern California has been deficient for the last few year's, but the discharge of Los Angeles River at 'The Narrows has been exceptionally constant, the decrease in 1900 being not more than 2 () $\mathrm{per}^{\mathrm{e}}$ cent of the average. On arcount of the numerous lawsuits which have arisen regarding water rights on this ricer, a thorough study of its discharge has been instituted by the city of Los Angeles, the work being under the direction of .J. B. Lippincott, as consulting 
enginere for the city. The majority of the measurements have been mate hy ( $\therefore$. A. Miller, although a number of them were made by F. II. Olmstert, city (angincer. Several woirs have heen placed in the river where the measurements are made. The points of measurement are as follows, in order downstream:

Weir A. at the intersection of Paroima avenne with Los Angeres River, in the Lankershim Rancho sublivision.

Weir B. at the intersection of Vineland arenne with Los Angeles River.

Weir ('. at the intersection of Fernando avenue with Los Angeles River.

Weir $E$, at the sonthwest corner of llock $\%: 3$. Providencia Ranc'w.

Weir (x. at the intersection of the east line of block 71 . Providencia Rancho, with Los Angeles River.

Weir L, rro feet above weir $H$.

Weir $H$, approximately 300 feet east of the intersection of Buena Vista street with Los Angeles River.

Weir $I, 2,5+3$ feet below weir $H$.

Weir J. 600 feet east of the west line of llock 69, Providencia Pancho.

Weir K, in blork as. Provillencia Rancho, 300 feet west of center.

Measuring hridge P. near the sonthwest corner of hlock \&1, Providencia Rincho, in the headworks site of the city of Los Angeles. (onmmonly known as the Pomeroy \& Honker tract. where river tmons to the east at angle of 90 .

Measuring bridge $Q$, abont for feet ahove the junction of the Verdngo Wash with Los Angeles River.

Measuring hriclge No. 2, ahout 600 feet ahove the head of the power ditch of the Los Angeles City Water Conpany. in the sn-called Crystal Springs tract.

Weir No. r. 1 mile below the heal, in the main supply ditch, sometimes called the Woolen Mill ditch, in the headworks site.

Measuring point No. $z$ B. at a 3 -foct cement pipe in the sam ditch, west of bridge No. $\therefore$ and at the Los Felix ranch house.

Weir No. 17, opposite bridge No. ?. (m what is called the Glass 11 tributary.

To get the total flow of river at bridge No. 2. there should be combined the flow at bridge No. 2, weir No. 1\%. and measuring point No. iB. Jn case measurements were not taken on the main supply ditch at No. iB. tr measurement observed at weir No. 5 , above No. $\approx B$ on the main supply ditch, was used, and the loss between No. $\tau$ and No. ;B. 2.49 second-feet, was deducted. This is shown in detail in the table for bridge No. 2. For brilge $Q$ a similar pro.ess is followed, omitting No. 1\%. For bridge $\mathrm{P}$ the olserved flow at the bridge is combined with either the flow at No. $\tau$ or at No. rB.

Weir No. 9. at the month of Tnjunga Creek, near the western end of the headworks site, and near the intersection of Bnena Vista street with Los Angeles River.

Weir No. 10, approximately 200 feet west of weir No. 9, at the ontlet of a small cut which was run into the gravel bed for the development of water.

Weir M. block 6i. Providencia Rancho, on a small stream entering the river in the headworks tract. 
Discherge mesesmements of Less atugeles River.

A'T WEIR A.

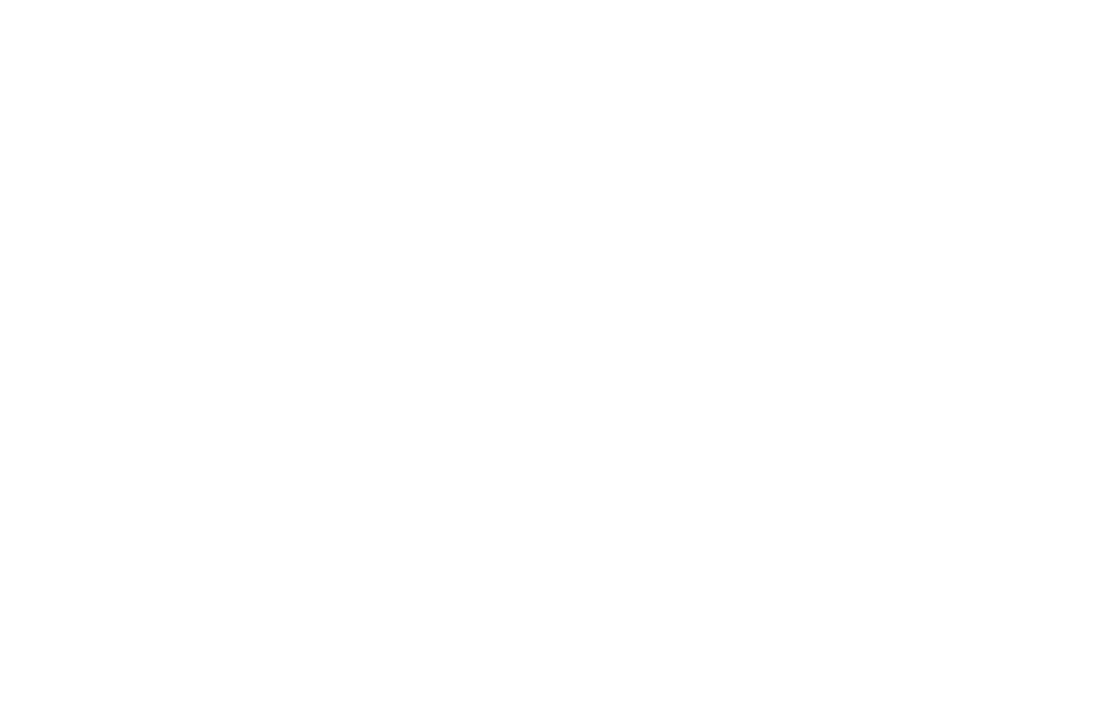

AT WFIR B.

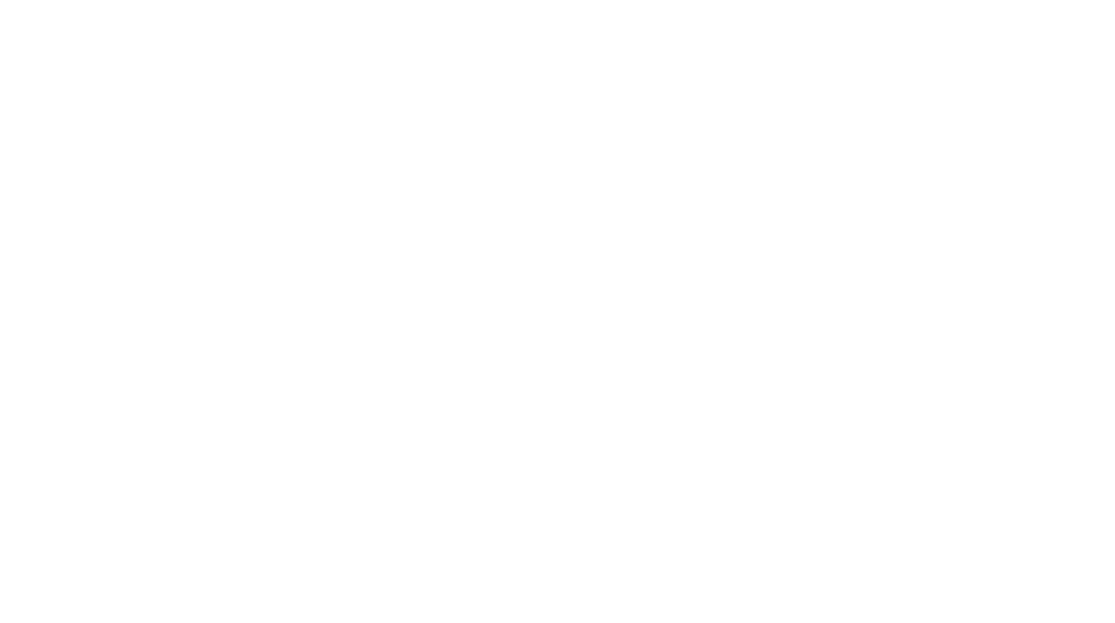


Hischarge mersurements of Las Angeles River-Continued.

AT WEIR (

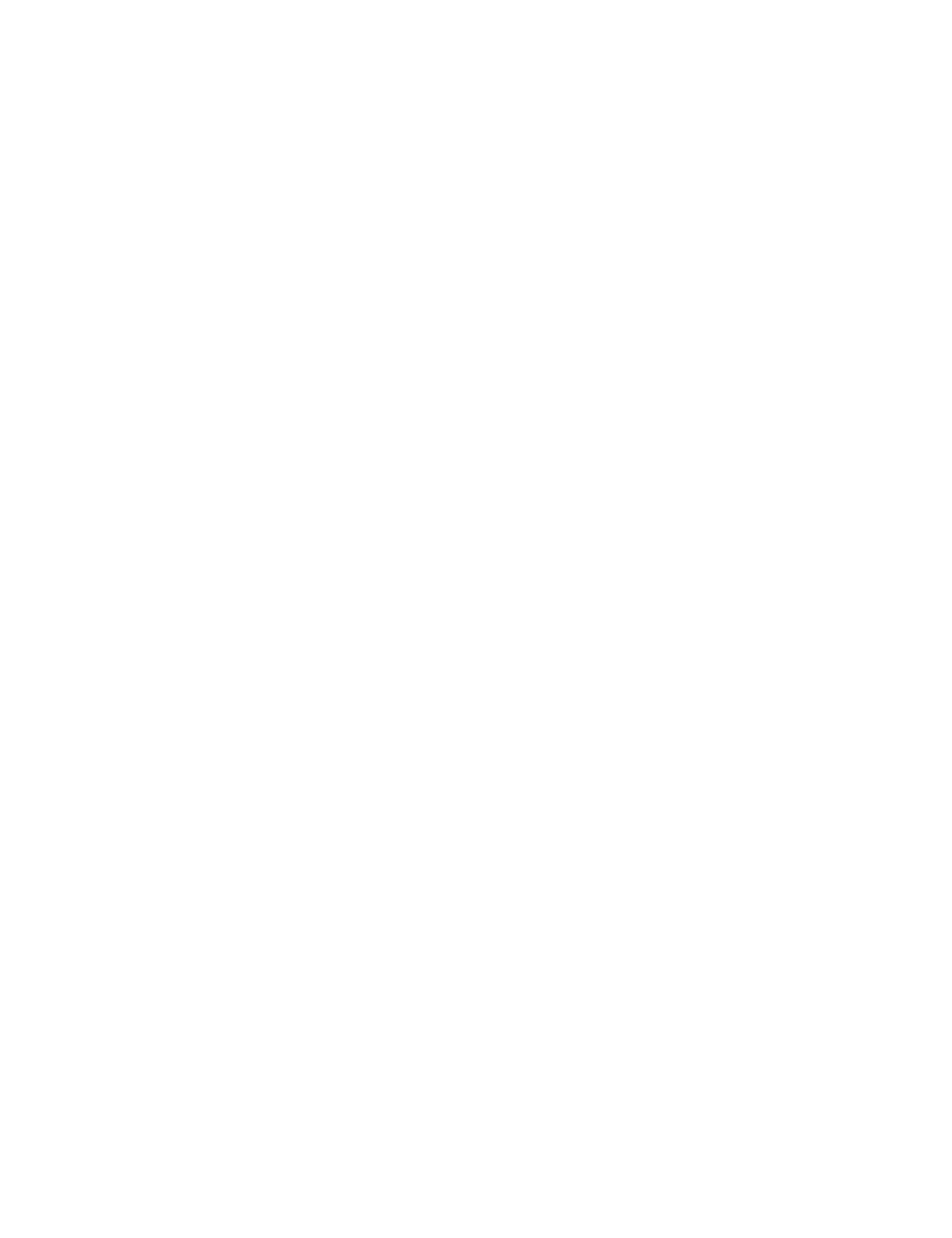


I hischarge mosurements of Los alugeles River-Continued.

AT WEIR ( $\mathrm{T}$.

\begin{tabular}{|c|c|c|c|c|c|}
\hline Date. & $\begin{array}{l}\text { Dis- } \\
\text { charges. }\end{array}$ & $\begin{array}{c}\text { Arerage } \\
\text { for } \\
\text { month. }\end{array}$ & Date. & $\begin{array}{c}\text { Dis- } \\
\text { charge. }\end{array}$ & $\begin{array}{c}\text { Arerage } \\
\text { for } \\
\text { month. }\end{array}$ \\
\hline 1899. & sirefefed. & sere-fert. & 1900. & | iser-feet. & sire-feet. \\
\hline Angust $14 \ldots \ldots$ & ז.9. & & May $1 \bar{x} \ldots$ & 7.94 & ร.94 \\
\hline Angust $24 \ldots . . .$. & $\approx .93$ & . & June $12 \ldots$ & 7.63 & $\approx 91$ \\
\hline September $:(0, \ldots \ldots$ & 7.60 & $\sim 0$ & June $29 \ldots . .$. & 7.00 & 1.51 \\
\hline September $26 \ldots \ldots$ & 7.60 & 1.00 & July $2 \tau, \ldots$ & 6.45 & 6.45 \\
\hline October 9 & 7.66 & 413 & Angust $1 \ldots \ldots \ldots$ & 6.45 & \\
\hline October 2.5 & 8.60 & 8.13 & August 15..... & 6.80 & 6.70 \\
\hline November $1 i$ & 9.17 & 4.0 & Angust:31 ... & $6.8 \%$ & \\
\hline November $2 ১$. . . . & 8.99 & 3.00 & September $\$$ & 6.72 & \\
\hline December $13 \ldots$ & 8.90 & & September $11 \ldots$ & 7.00 & 6.80 \\
\hline December $21 \ldots$ & $\$ .90$ & $\therefore .90$ & September $2 \tau \ldots$ & 6.68 & \\
\hline December $26 \ldots$ & 8.92 & & November $1: 3 \ldots$ & (6.99 & 6.99 \\
\hline Mean & & S.:3:3 & Mean & & 7.03 \\
\hline
\end{tabular}

AT WEIR L.

\begin{tabular}{|c|c|c|c|c|c|}
\hline 1К9!. & & \multirow{3}{*}{11.100} & 1900. & & \multirow{3}{*}{$\therefore .7$} \\
\hline August $14 \ldots \ldots \ldots$ & 9.08 & & May $1 \delta_{\ldots} \ldots . .$. & 8.85 & \\
\hline 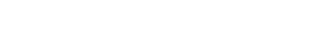 & 4.93 & & May $23 \ldots \ldots \ldots$ & 8.73 & \\
\hline September $20 \ldots$ & 8.59 & \multirow{2}{*}{ S. 74} & Tune $12 \ldots$ & 8.62 & \multirow{2}{*}{8.46} \\
\hline September $20 \ldots$. & S. 80 & & June 29 . & s. 30 & \\
\hline October $9 \ldots$ & 8.59 & \multirow{3}{*}{9.29} & July $2 \tau_{\ldots} \ldots \ldots$ & 7.53 & 7.53 \\
\hline October $2 \pi \ldots \ldots$ & $9.5 \mathrm{~N}$ & & Angust 1 _ .. & 7.53 & \multirow{4}{*}{$i . \% 1$} \\
\hline October $2 \pi$ & $9.4 N$ & & August $8 . \ldots$. & 7.59 & \\
\hline Norember $17 \ldots$ & 10.15 & \multirow{2}{*}{10,114} & August $15 \ldots . .$. & โ.69 & \\
\hline November 28. & $9.9: 3$ & & Angast:31 . $\ldots \ldots$ & 8.02 & \\
\hline December 13.. & 10.102 & \multirow{4}{*}{10.11} & September $\triangleleft$..... & $i, 8$ & \\
\hline December 21 & $10.0 \%$ & & September 11 . & 8.20 & 7.92 \\
\hline December $: 0$ & 10.80 & & September $2 \pi$ - & 7.76 & \\
\hline & & & November $10 \ldots . . .$. & 8.34 & $\therefore .34$ \\
\hline Mean & & 9.42 & Mean & & 8.12 \\
\hline
\end{tabular}


Discharge medsmerments of Los Angeles River-Continued.

A'T WEIR H.

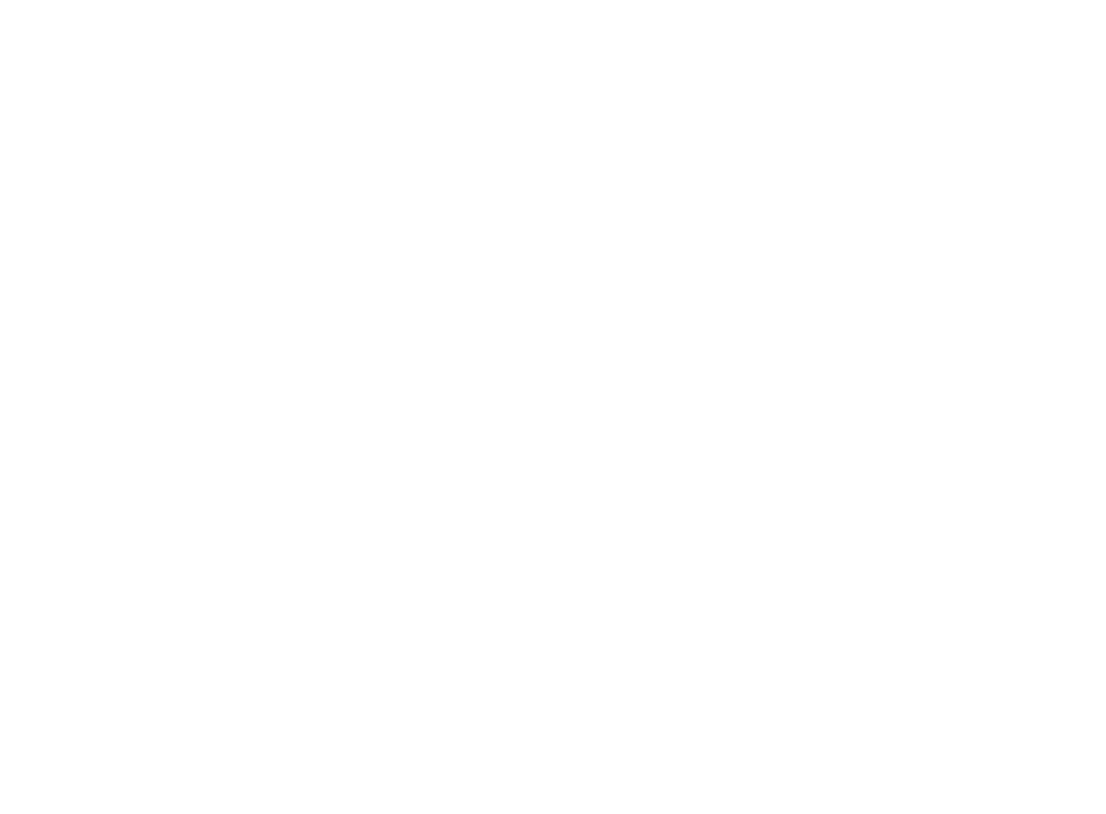

AT WEIR I.

\begin{tabular}{|c|c|c|c|c|c|}
\hline 1899. & & & 1900. & & \\
\hline August $14 \ldots \ldots \ldots$ & 17.18 & & May $15 \ldots \ldots$ & 16.25 & \\
\hline August $2 x_{\ldots} \ldots \ldots$ & 16.91 & i 1.04 & May $2: \ldots \ldots \ldots$ & 16.05 & 16.10 \\
\hline September : 20. & 17.15 & & June $12 \ldots \ldots \ldots$ & 15.66 & 155 \\
\hline September $26 \ldots$ & 17.32 & $\gamma^{10.25}$ & June $29 . \ldots$ & 15.49 & L \\
\hline October 9 & $1 \tau .19$ & 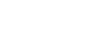 & July $12 \ldots \ldots$ & 15.58 & $1-1$ \\
\hline October 25 & $18.3: 3$ & 10.60 & July $2 \tau \ldots \ldots$ & 14.74 & 11.). 10 \\
\hline November $1 r_{\ldots} \ldots \ldots$ & 19.04 & $18 x y$ & August 1.... & 14.37 & \\
\hline November $2 N_{-}$ & $1 \mathrm{R} .72$ & (10.00 & August $8 \ldots \ldots$ & 14.94 & $1+2$ \\
\hline December 13 & 18.93 & 159 & August 15. & 14.69 & $1+.61$ \\
\hline December $: 6$. & 18.99 & 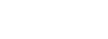 & Angust $31 \ldots$ & 14.80 & \\
\hline & & & September $8 \ldots \ldots$. & 14.54 & \\
\hline & & & September $11 \ldots \ldots$ & 14.74 & 14.53 \\
\hline & & & September $2 \gamma_{\ldots} \ldots$ & 14.31 & \\
\hline & & & November $10 \ldots \ldots$ & 14.92 & 14.92 \\
\hline Mean & & 17.97 & Mean & & 15.17 \\
\hline
\end{tabular}


Discharge measmentments of Less Angeles River-Continned.

AT WEIR J.

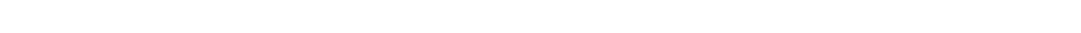
$+\mathrm{No} \cdot \mathrm{B}+2.49$.

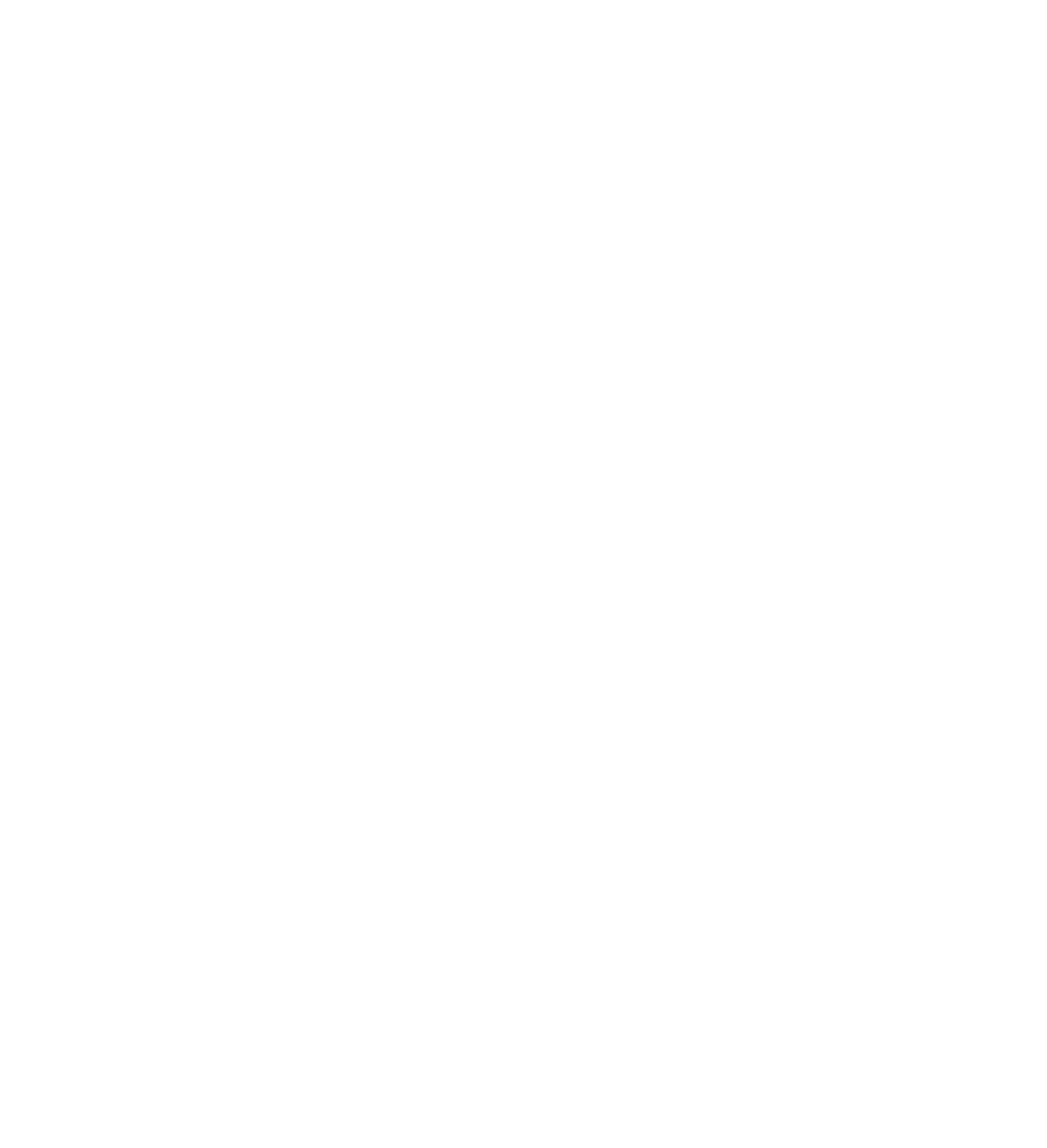

IRR $: 1-(1: 3-?$ 
Inischurge measurements of Los Angeles River-Continned.

AT WEIR $\mathrm{K}$.

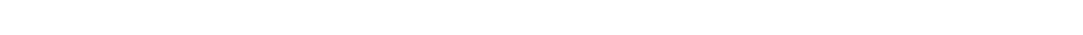
$+\mathrm{N} r . \mathrm{B}+241$.

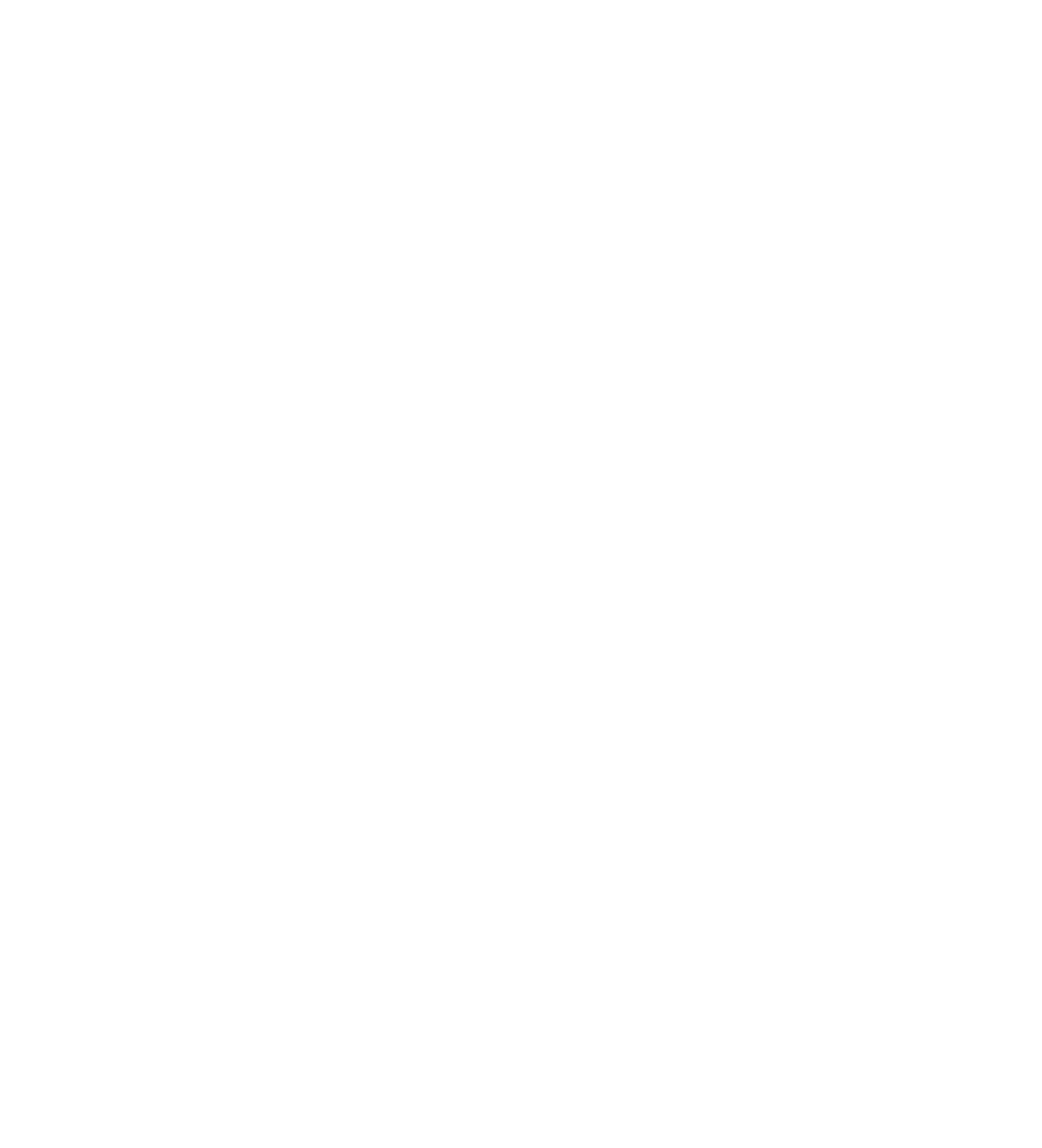


Discharge measmoments of las . Lugeles River-Continued.

AT BRIDUE P.

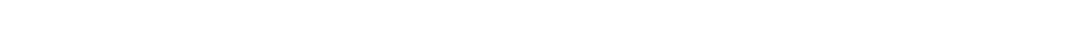
+ disi-harge at No. זB.

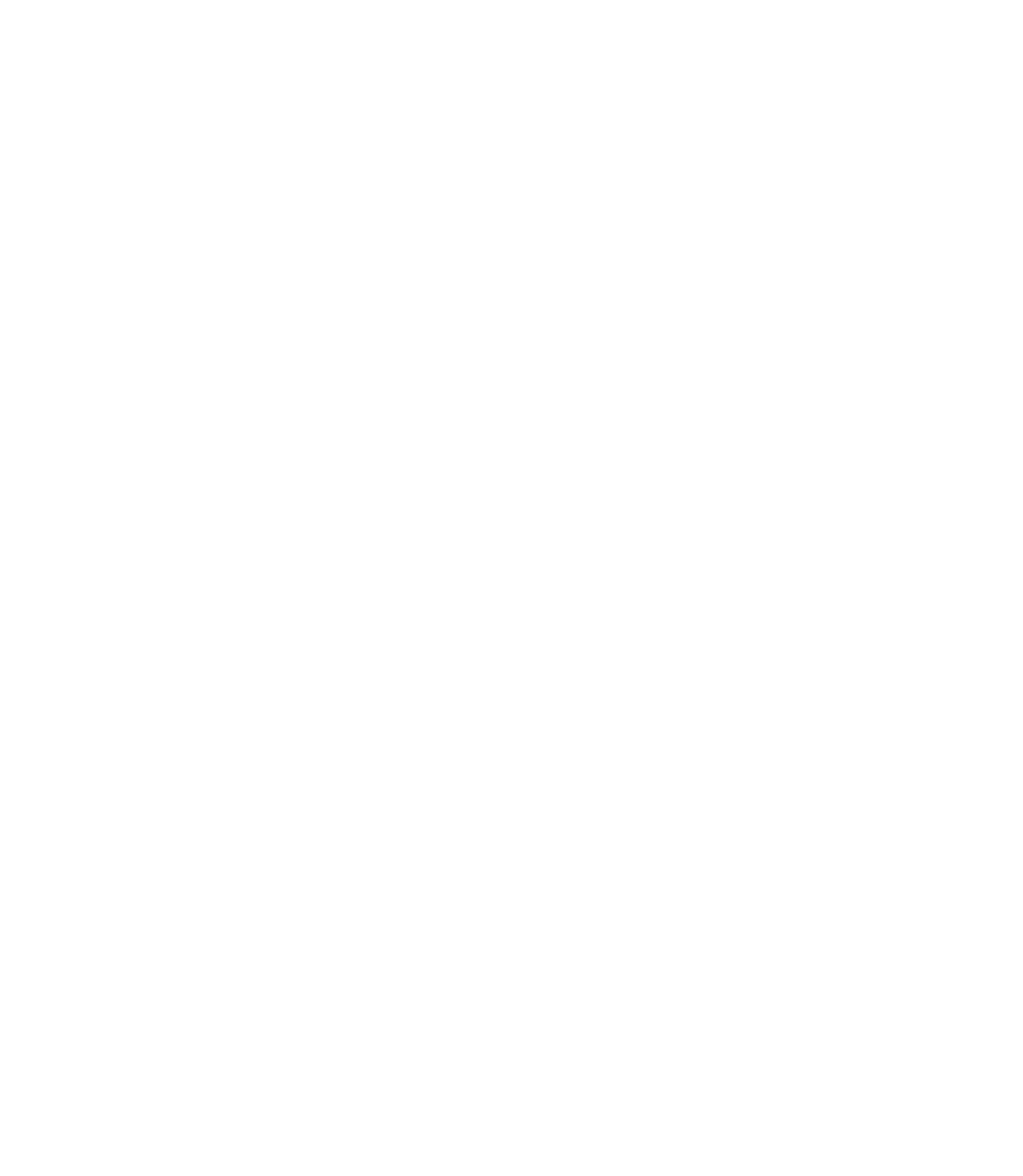




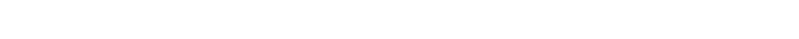

\section{AT BRIDGE $Q$.}

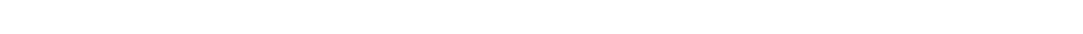
or $i$ N.,. 6 B.

\section{Date}

1899.

September $\geqslant 0$.

September $\approx$.

October 10

October 25

October 28

November $1 \%$

November 29

December 18

December :

Mean

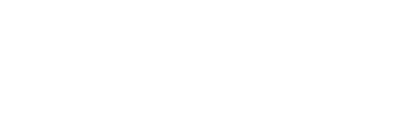

1900 .

May 15

May 2:3

June 12

July 2 .

July 1:

August 1

September 8

Septemluer 11

September :8

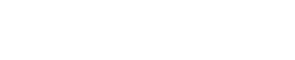

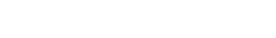

\begin{tabular}{c|c} 
Total dis- & Arerage \\
charge at & for month. \\
bridge. &
\end{tabular}

-

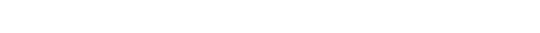

\begin{tabular}{|c|c|c|c|}
\hline $15 .+1$ & 98.12 & 43.53 & \multirow{2}{*}{$4: 3.84$} \\
\hline $16.1 \%$ & 27.99 & 44.16 ' & \\
\hline 1.5 .59 & $2 \% . \%$ & 4:3.:36 & \multirow{3}{*}{41.31} \\
\hline$x .21$ & 27.66 & $35 . \times 5$ & \\
\hline S. 23 & $3(i .48$ & 44.11 & \\
\hline 9.36 & $: 34 . \sim 1$ & $49.0 \%$ & \multirow{2}{*}{$4 \pi .58$} \\
\hline 12.20 & 33.89 & $46.09 \quad$ & \\
\hline 11.41 & 3.5 .99 & \pm 7.40 & \multirow{2}{*}{ tij. 21} \\
\hline $11.1 \%$ & 31.86 & $4: 3.0: 31$ & \\
\hline
\end{tabular}

44.49

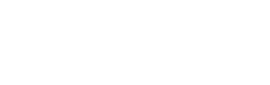

$1 \% .60$

13.88

28.42

46. $00^{\circ}$

41.85

43). 93

$1 \% .32$

$2 \pi .9 \pi$

44.96

$\pm 1.96$

1:3. $8: 3$

22.64

40.03

14. 00

26.20

24.59

38.79

39. 41

14.00

24.48

38.45

38. 18

27.119

20.23

1\%.32

?!1. :3:3

43. 54

$4+43$

ti3. 98 
Discharge merssurements of Los Angeles Rirer, Los Angeles comnty. ne'ur bridge No. $\therefore$

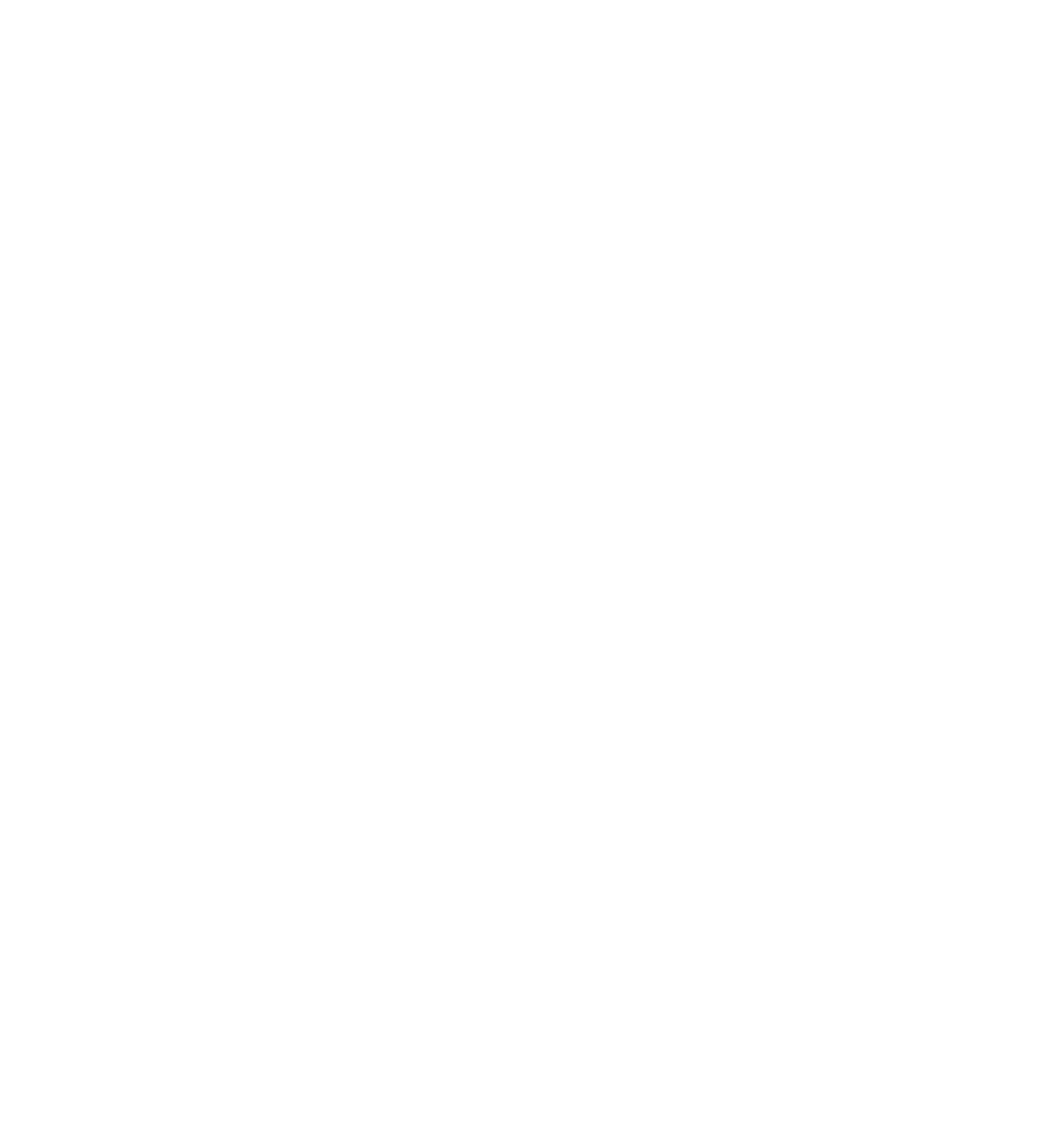


Inischarge measurements of Los Angeles River at bridge No. ?.

Notw.-Total discharge of river at bridge No. 2 equals discharge at $\mathrm{No} .2+$ discharge at No. iB, (1) No. $2+\mathrm{No}, 72.49$.

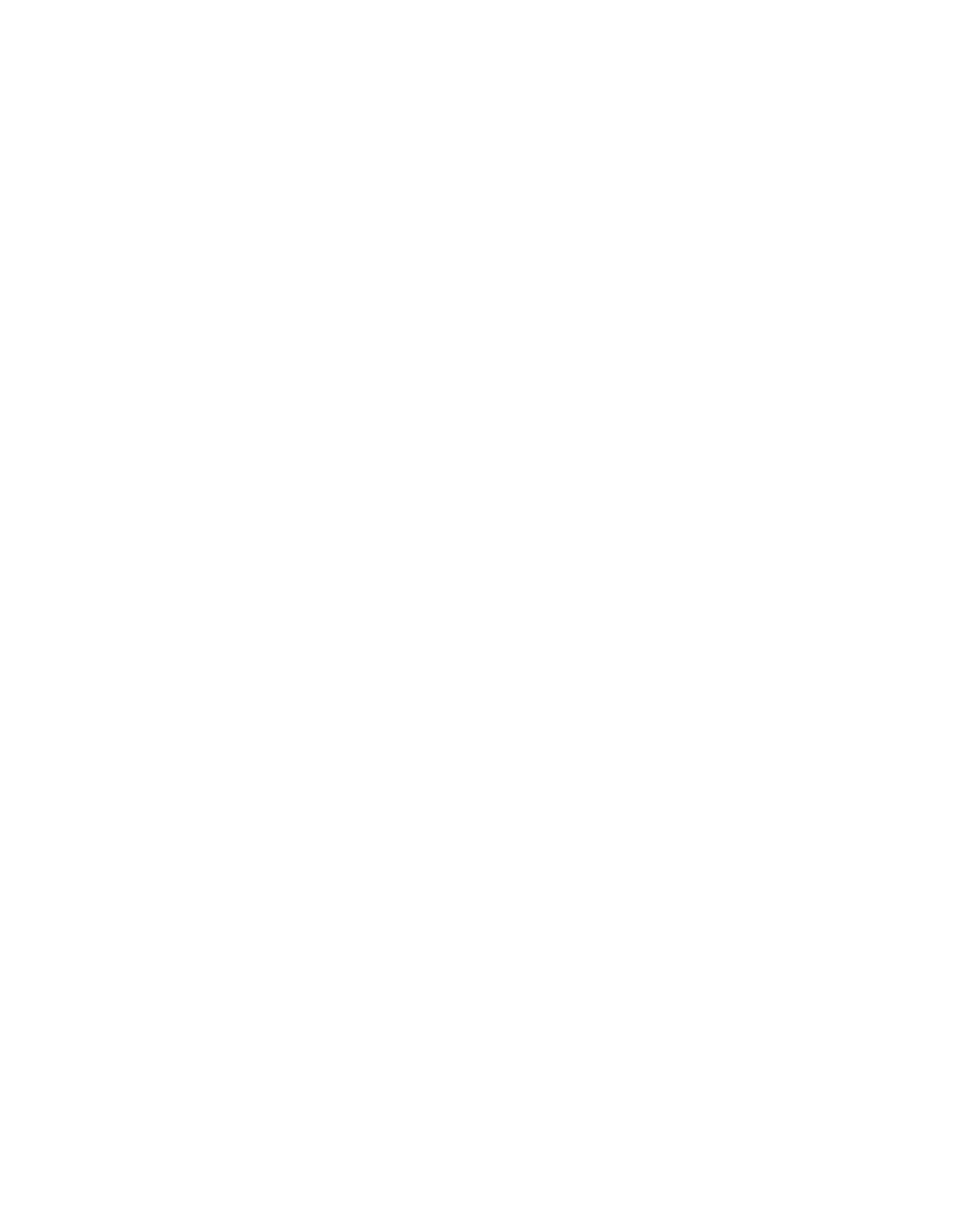


Axerage discharge af Las Angelo's River at weir Wo. ?.

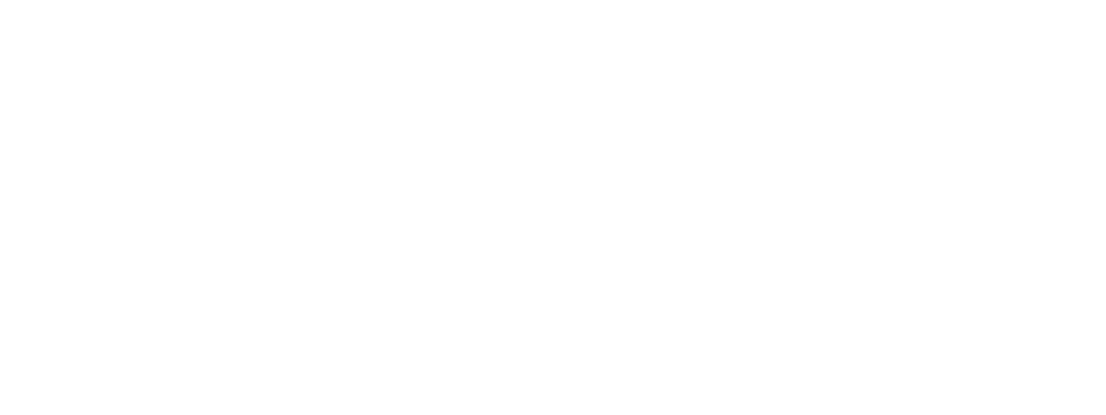

Arerage discharge of developed water at weir No. Wh.

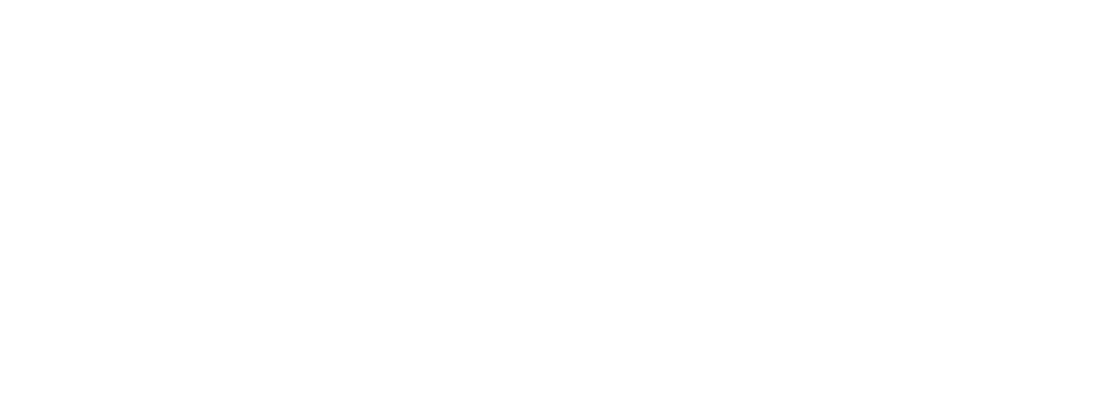

Arerage discharge of smell tributary of Los Angeles River at worir $\mathbf{M}$.

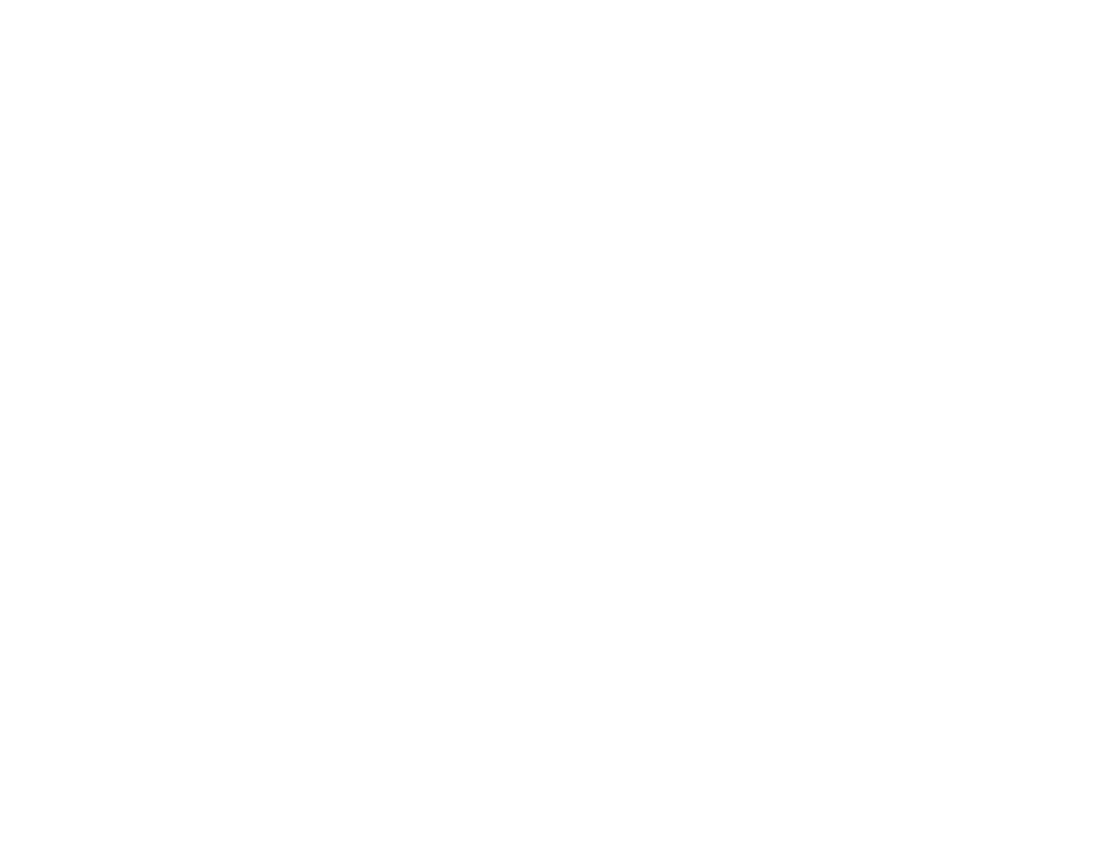


Averaye tischerye of Los Angeles River.

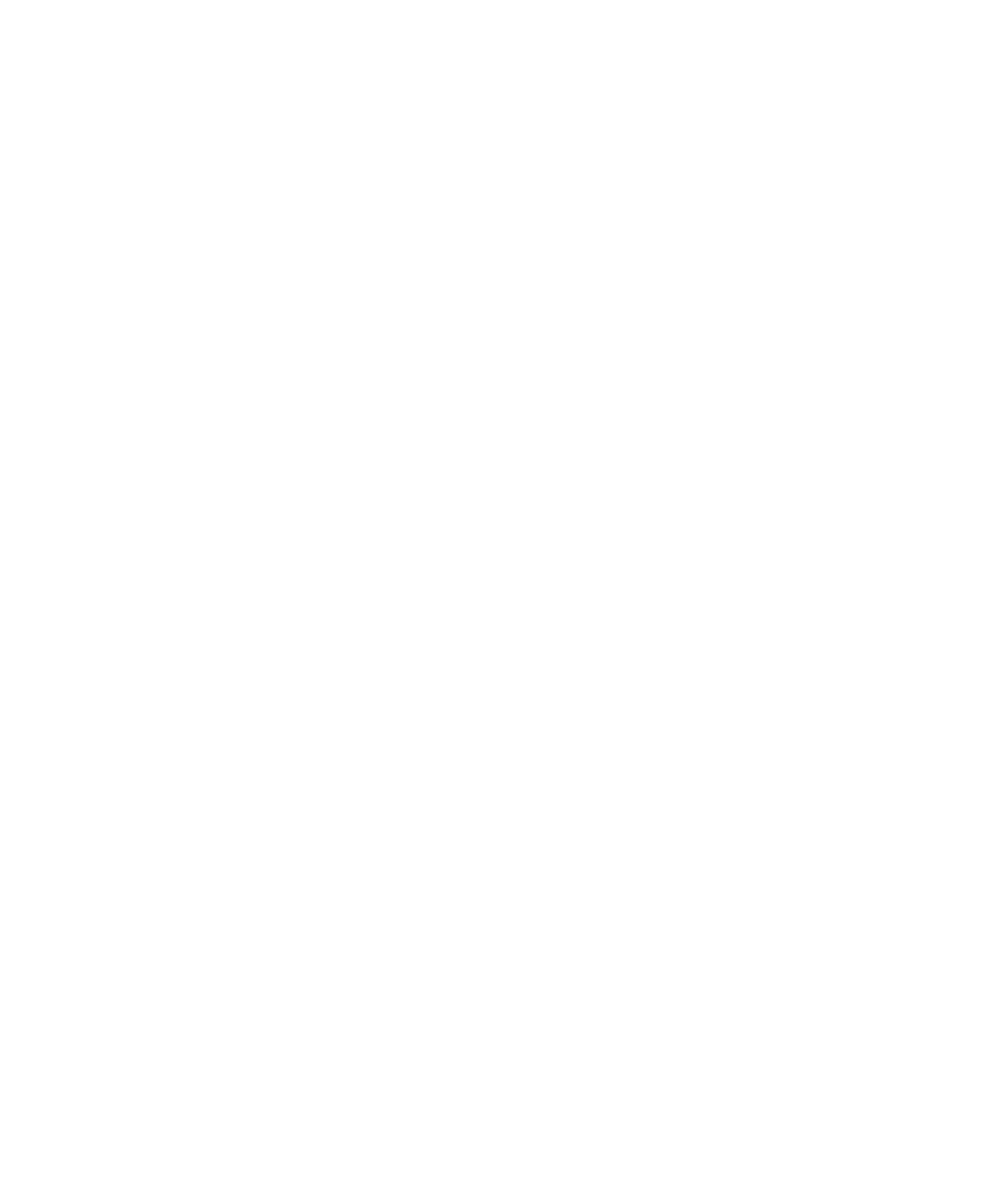


Discharge measurements of Los Augeles River, Los Angeles County.

Inate.

IIydrographer.

Aug. $\approx 1.1899$

Jan. 9,1901

Sept. 20,1901

Ang. 21, 1899

Oct. $\quad 9,1900$

Sept. 21,1901

W. W. Cockins

Nov. 22, 1900

Do

Do

S. G. Bennett

Aug. 21, 1899

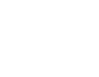

(harge

Siere-jt.

0.0 Pacoima, month of canyon.

.50 .0

0.0

.44 Tujunga. Headworls Monte Vista C'anal.

.19 Do.

.22 Do.

1.. $\approx$ Tujunga Railroar, moin line.

. (15) Tujunga, 3 miles below above measurement.

10.60) Tujunga Railroad. main line, flood marks.

0.0 Tujunga-littlı.

Discharge measurements of Ios Angcles River at pumping stations in San Fermudo Valley.

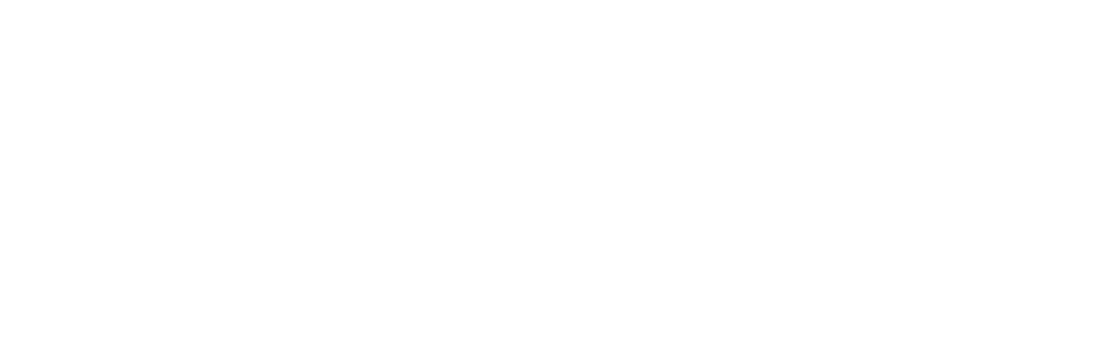

a Reduced to continuous flow for summer months.

\section{LOS FLORES CANYON.}

Ios Flores Canyon is situated on the southern slope of the Sierra Madre, in Los Angeles County. The araa of the drainage basin above the line of township 1 north, above which all diversions ocemr, is 0.35 square mile. The canyon is in granite, largely shattered, with prevailing lines of cleavage extending northwest to southeast, but with other distinct lines bearing northeastward. Below the mouth of the canyon are the beautiful Pasadena Mesa lands. The scarcity of water, coupled with the general desirability of these lands, has causer much "development work" to be donc for the purpose of increasing the water supply. Twelve tunncls in all have been run into this granite rock. The experience has been that as the fissures and cracks of the rock are opened a consirlerable discharge has resulted for a period of a few weeks, after which the flow decreased, and the tumnels would then again be extended or new ones run. 
Following is a list of 1 her 1 ummols, showing their lengths:

Los Flores tumnel:

Feet.

No. 1

No. 2

No. 3

No. 4

Mining tunnel

Twaddell tunnel

MeNally tunnel

Los Flores tumnel:

No. 5

No. 6

No. 7

No. 8

Total length.

From the nature of the drainage basin and the data obtainet from neighboring streams a reasomable natural run-off from this clrainage basin, including flood waters, of from 0.111 to 0.15 second-foot might be expected in arerage years.

The granite bed rock in the drainage basin is covered with a few feet of coarse, disintegrated, granitic soil, very absorbent of water. Rain falling upon this is rapidly absorbed, and the tunnels show within a few weeks the effect of rainfall. During the years when measurements of the tunnels were marle the rainfall was, as a rule, much beiow normal. In the following discharge measurements all the water which is diverted, both developed and natural flow, is included, but probably a few winter storms occurred that produced greater runoff than the rapacity of the diversion pipes, and consequently some of the water must have escaped nnmeasured.

The lesson to be drawn from this particular ase is that the expenditure of the large amount of money required to construct these tunnels was ill advised, the water supply having been not materially, if at all, increased beyond the normal flow of the canyon prior to the construction of the tummels. A similar experience is the result of like work in Eaton canyon, which adjoins the Isos Flores to tle east.

Dischurge morsurements of Los Flores C'anyon, Los Angeles Connty.

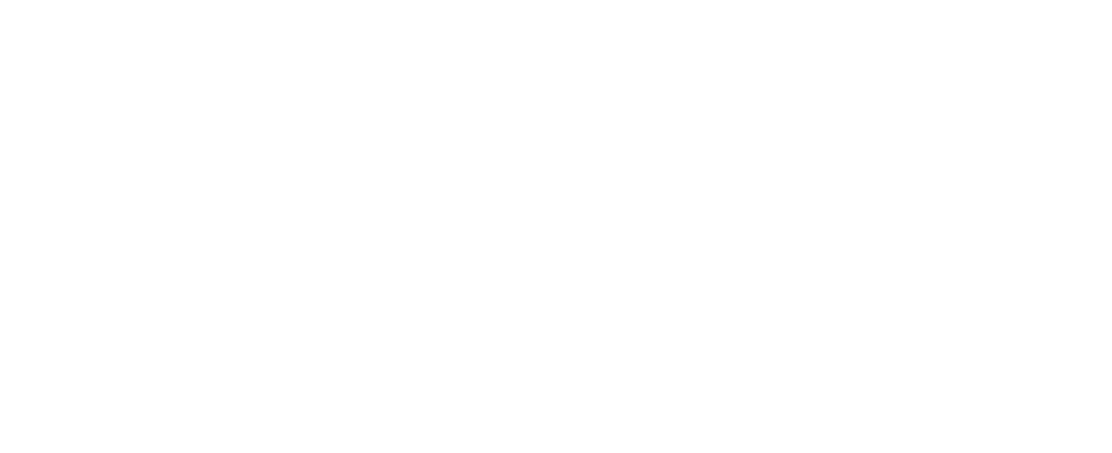




\section{LYTLE CREEK.}

This smatl streant drains the souther't slope of the Sierra Martre and discharges its waters on the plains northwest of Sall Bernordino. Although it drains a comparatively small area of 50 square niles, at the mouth of the cancon its waters are inportant for irrigation purposes. Owing to the controversies which have arisen orere its diversions, a number of lawsuits for thesettlement of the rlaims have been instituterl from time to time. A number of measurements of this stream at the mouth of the "anyon from $18 ! 2$ to 1896 , inclusive, are given below. They aro copied from court records of procesedings in which the water supply of this creck was incoherl. These cares were tried in the san bernardino courts by Jurlge J. W. MeKinley. The

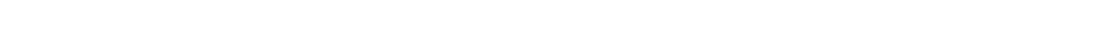
weir's, and are believed to be ac*urate.

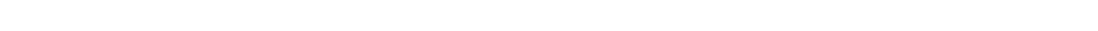
cromenty. r'al.

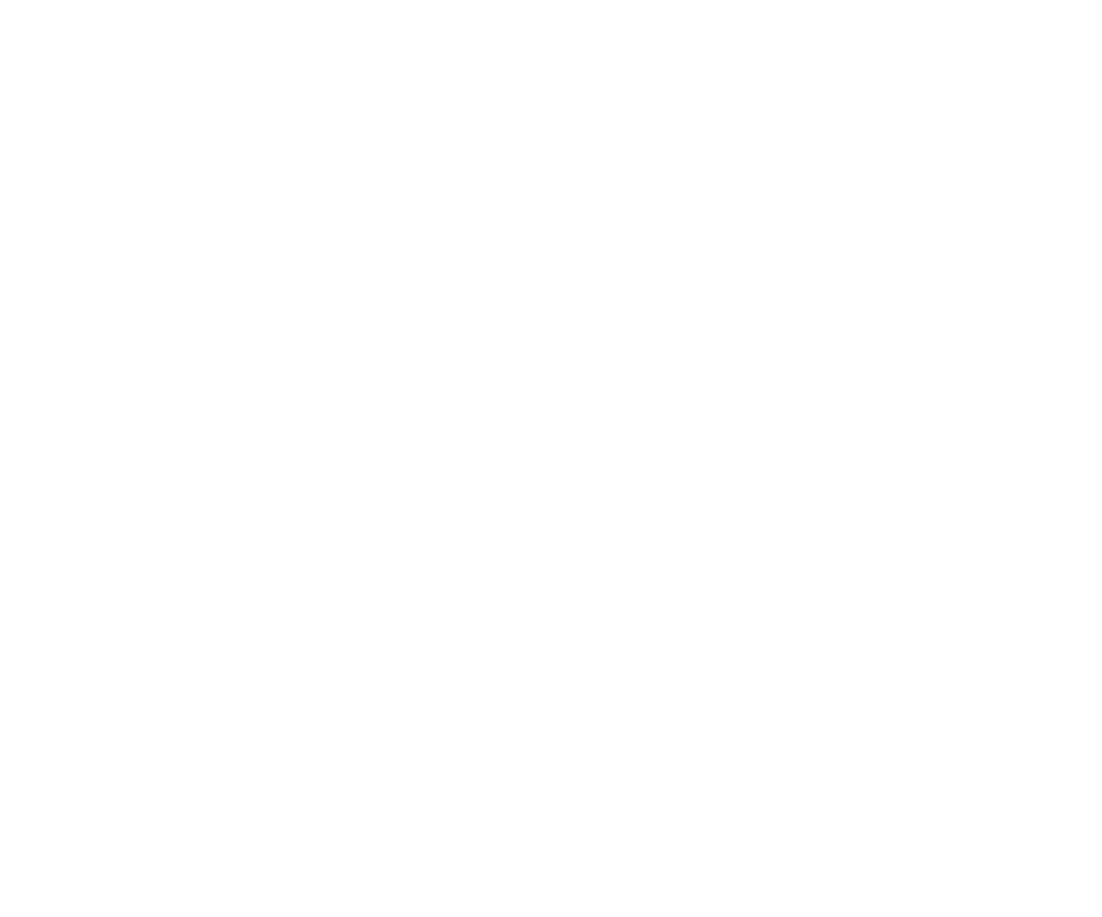


Berginning in 18:4, measurements of Lytle Creek were also made by II. I). Nibley, who was zanjero of the Iytle ('reck canals at that time. The measurements were usually male because the discharge of the stream was below normal. In the winter and spring only the amount of water needed for irrigation was turned into the ditches, but later in the summer the entire flow was diverted. These measurements also were made over weirs and are helieved to be fairly accurate. During 1898 tronble was experienced through miners' taking the water from the natural chamnel and turning it into dry channels, sluice boxes, weirs, mill races, etc., thereby cansing an alleged loss of from 20 to 25 per cent of the total flow of the creek. Only a portion of these latter diversions were returned to the creek. The measurements of Mr. Sibley would not show the full flow of Iytle Creek at all times, and sometimes show less than the full discharge, for the reasons mentioned above. During 1899 the amount of water which was diverted into the main canal was measured daily by the Anglo-American Canaigre Company, at a weir erected near the head of its cement ditch. The rolumes given have been occasionally checked by risiting the canal and making meter measurements. It is believed that ruring 1899 practically all the water of the stream was diverted into the canal. 
Discharge. in secoml-fert, of Lytle creck main canal above Rialto, San Bernardino ('ounty. C'al.

[I)rainage area, is square miles.]

1 1.44.

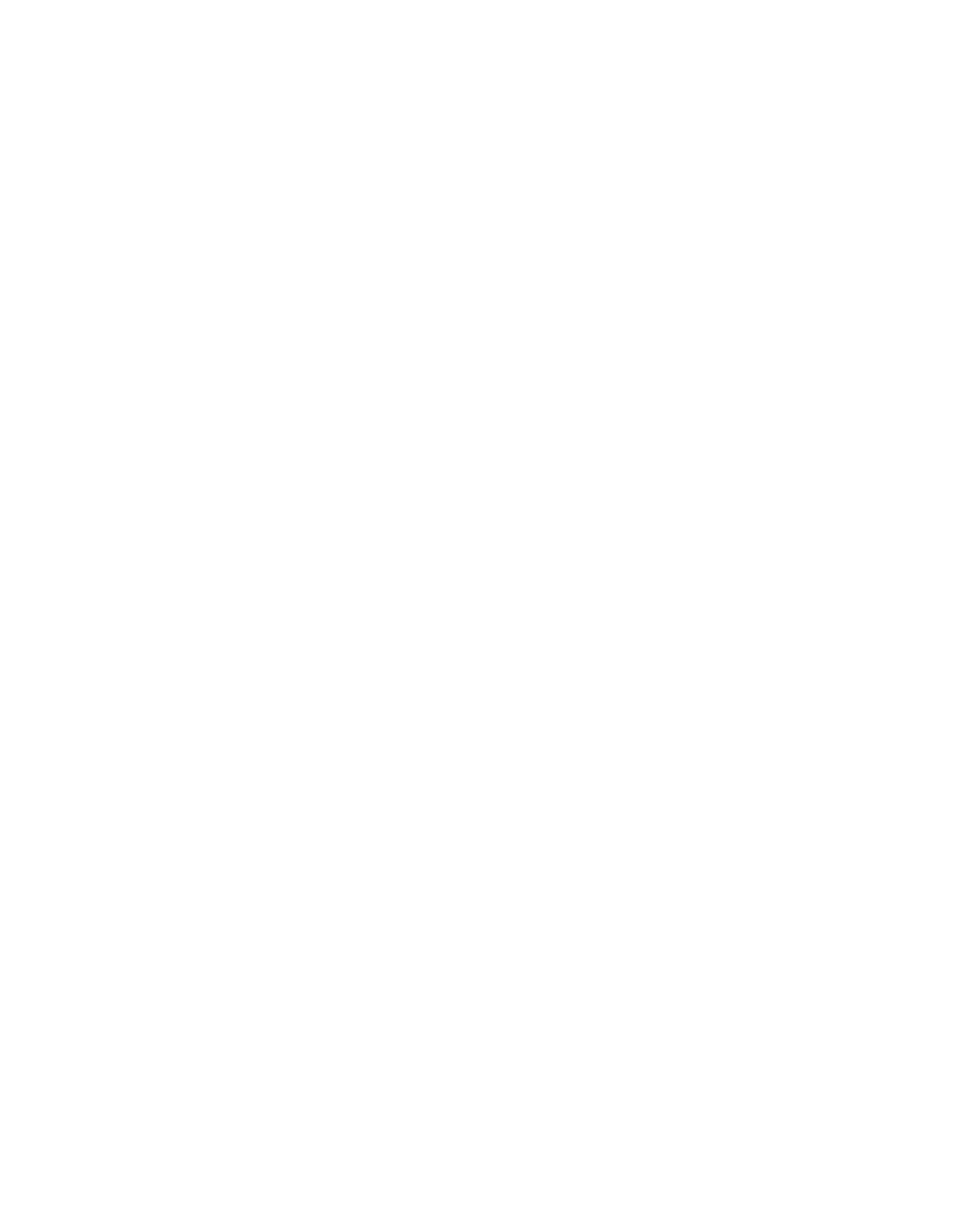




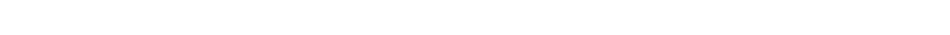

1 15.

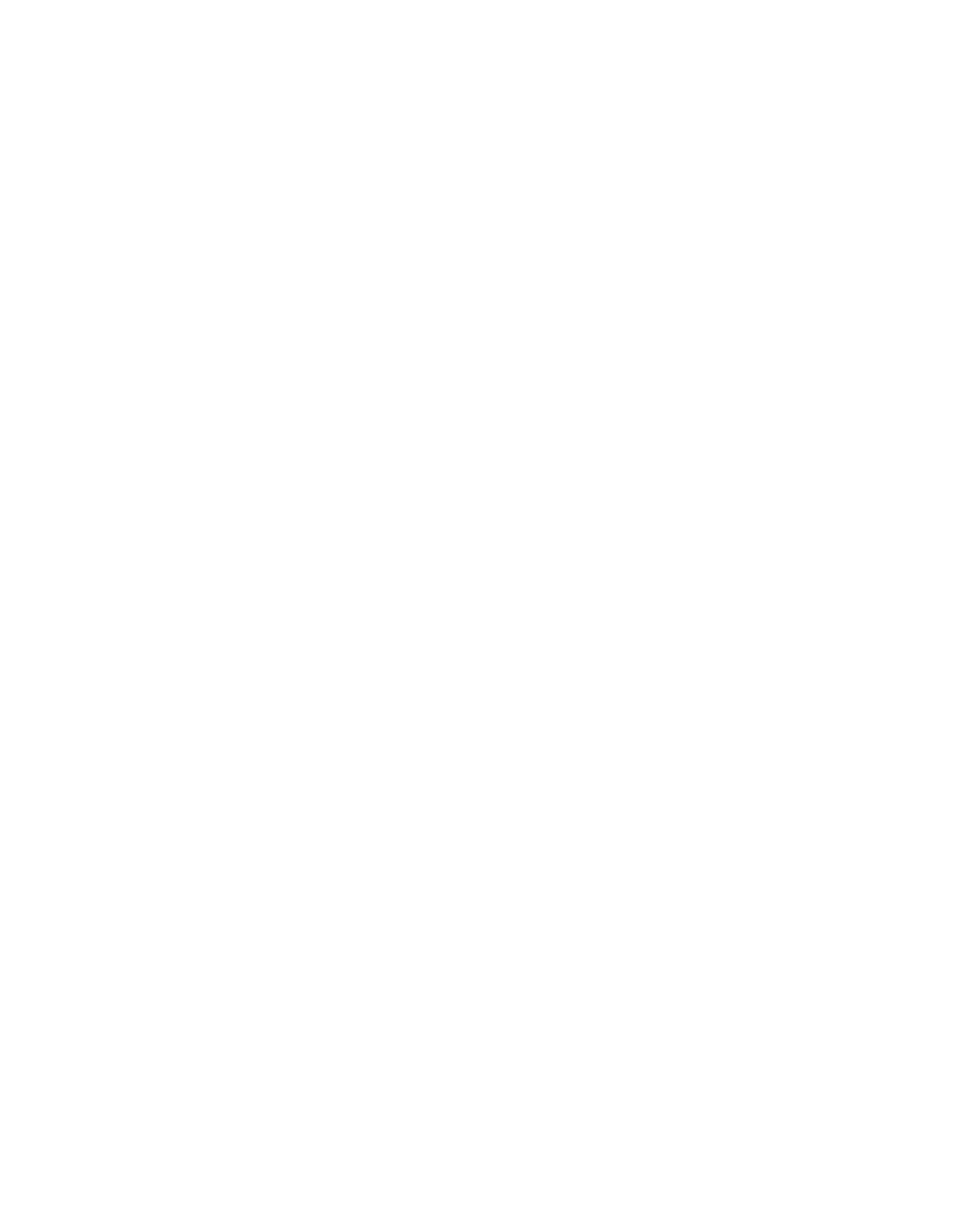

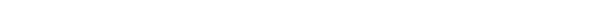




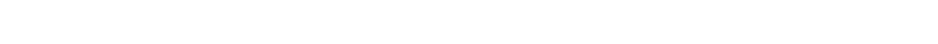

1Niki.

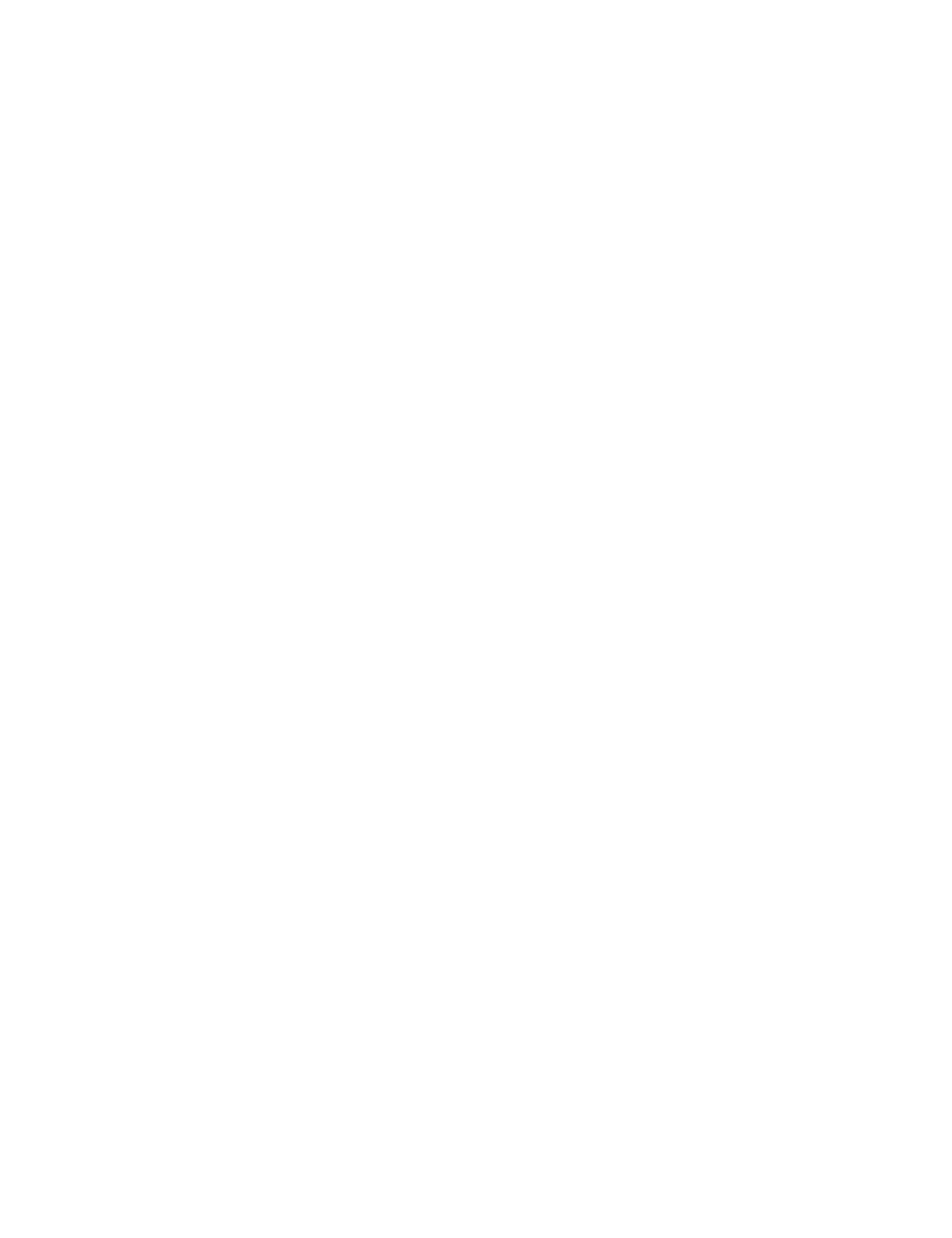

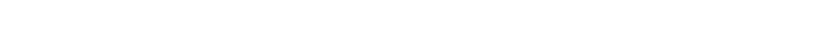


Dischary', in secomel-fert, of Lytle' C'reek main cancel, ete.-Continued.

$1 \times 9 \%$

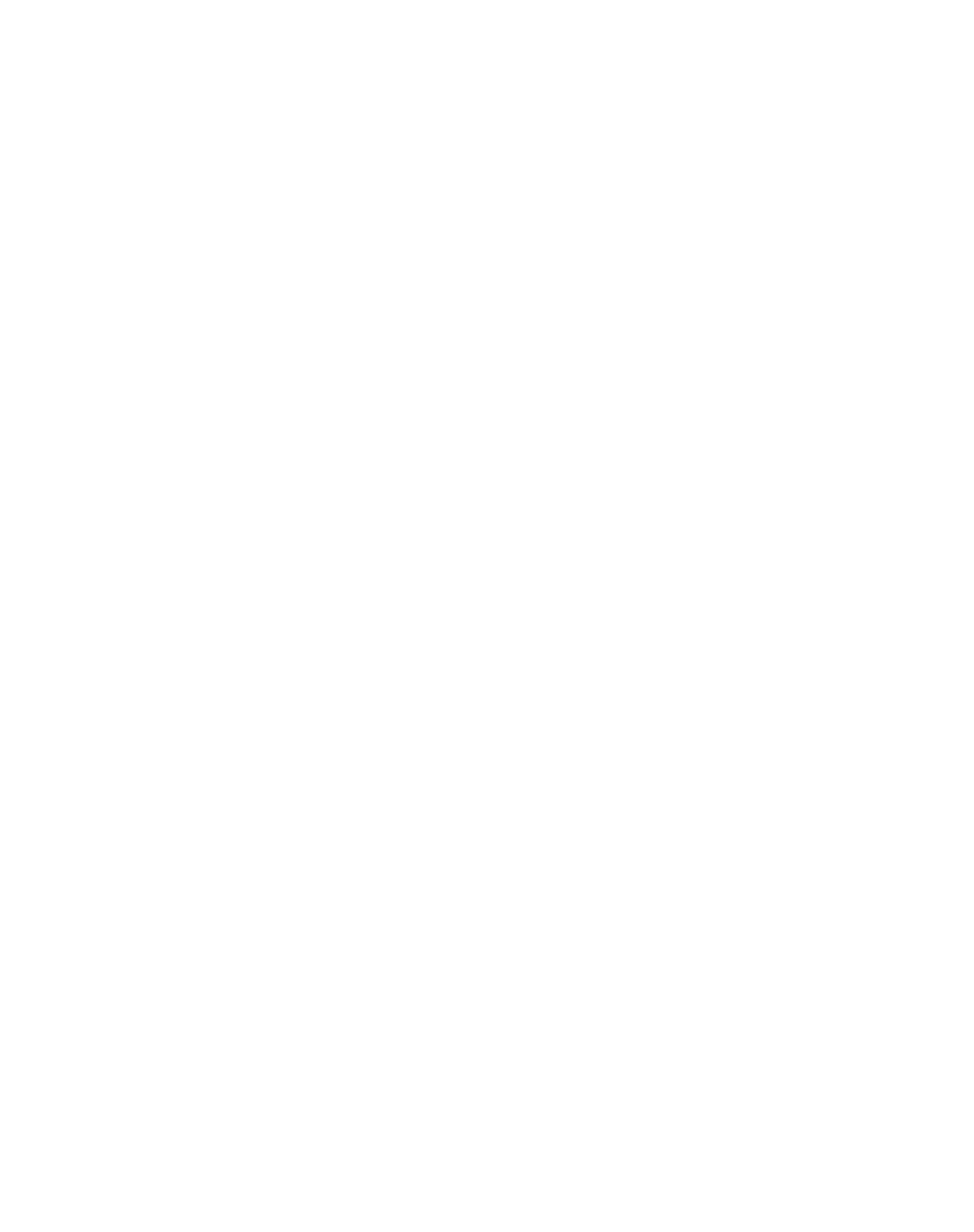

Heary rains February 3 and 18, March 2s, september 1t. Chicala Water Company towk "bargo of station June 1 . 


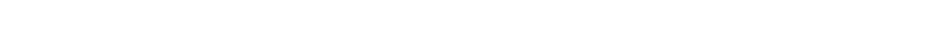
1 1.t.

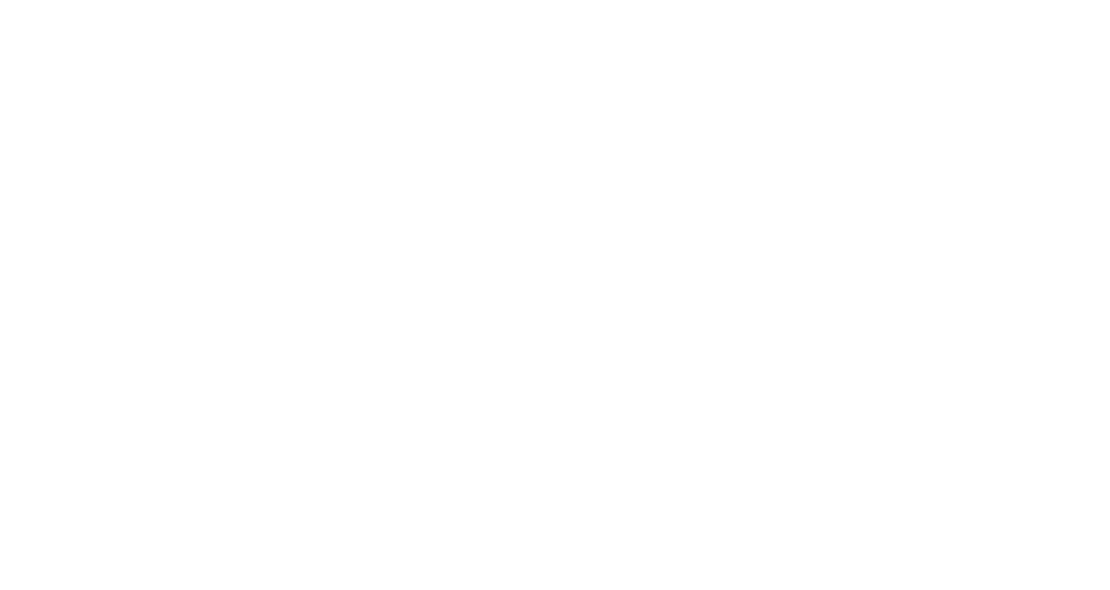

No measurments for January to April, inelusive, and August to Decomber, inclusive.<smiles>[Y10][As][As][W]</smiles> 


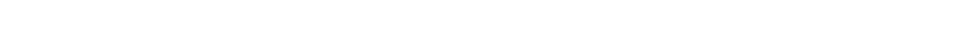

1년

\begin{tabular}{|c|c|c|c|c|c|c|c|c|c|c|c|c|}
\hline Day. & Ja11. & Feb. & Mar. & Apr. & May & June. & $\begin{array}{c}\text { July. } \\
-\end{array}$ & Aus & Sept. & Oet. & Nov. & Dee. \\
\hline 1 & 11.1 & $11 . x$ & 11.2 & $9 . \tilde{7}$ & 11.2 & 12.2 & 6.3 & 9.4 & 14.5 & 10.9 & 10.5 & 11.1 \\
\hline 2 & 11.1 & 12.1 & 11.1 & 8.9 & 10.9 & 10.4 & 6.8 & 10.4 & 1.5. 1 & 10.8 & 10.3 & 11.8 \\
\hline 3 & 12.1 & 12.1 & 11.2 & 8.5 & 10.9 & $9 . \tau$ & 6.4 & 9.6 & 16.6 & 10.8 & 10.3 & 11.4 \\
\hline 4 & 11.4 & 12.4 & 11.1 & 12.6 & 10.5 & 9.5 & 6.4 & $10 . \tau$ & 16.7 & 10.8 & 10.6 & 11.1 \\
\hline j & $11 . \tau$ & 12.4 & 10.8 & 12.5 & 10.5 & 9.4 & 6.4 & 12.2 & 16.0 & $10 . \tau$ & 10.5 & 11.3 \\
\hline 6 & 11.6 & 12.5 & 10.6 & 12.1 & 10.5 & 9.6 & 6.4 & 11.0 & 16.0 & 10.6 & 10.6 & 11.3 \\
\hline 7 & 11.6 & 12.6 & 10.4 & 11.9 & 10.5 & 9.2 & 6.3 & 10.8 & 16.6 & 10.1 & 10.6 & 11.3 \\
\hline 8 & 11.6 & 12.4 & 10.4 & 11.8 & 10.2 & 9.0 & 6.2 & 11.0 & 15.9 & 9.9 & 9.9 & 11.6 \\
\hline 9 & 11.6 & 12.1 & 10.9 & $11 . \tau$ & 11.8 & 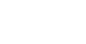 & 6.2 & 11.0 & 16.5 & 10.2 & $\$ .9$ & 11.4 \\
\hline 0 & 12.0 & 11.8 & 10.6 & 11.9 & 9.5 & 7.2 & 6.0 & 8.7 & 16.1 & 10.8 & 10.0 & 11.5 \\
\hline 1 & 16.1 & 11.8 & 10.6 & 11.7 & 9.5 & 7.5 & 5. 9 & 12.0 & 16.0 & 11.7 & 10.2 & 11.4 \\
\hline 12 & 13.1 & 11.8 & 10.6 & $11 . \tau$ & 9.2 & 8.2 & 6.0 & 12.0 & 15.8 & 72.1 & 10.5 & 11.3 \\
\hline 13 & 12.2 & 11.8 & 10. & 11.0 & 9.6 & ^. 1 & 5.9 & 12.2 & 15.3 & 12.4 & 10.9 & 11.2 \\
\hline 14 & 12.0 & 11.6 & $10 . \tau$ & 10.6 & 9.5 & 7.8 & 5.9 & 12.1 & 15.4 & 13.5 & 11.0 & 11.1 \\
\hline 15 & 11.9 & $11 . \pi$ & $10 . \tau$ & 10.6 & 9.8 & $\ldots$ & 6.0 & 12.3 & 16.0 & 12.7 & $11 . \dot{3}$ & 11.2 \\
\hline 16 & 12.0 & 11.5 & 15.3 & $10 . \tau$ & 9.4 & 7.6 & 6.0 & 12.3 & $1 . \overline{5}$ & 13.0 & 11.7 & 12.9 \\
\hline 17 & 12.0 & 11.5 & 14.7 & 10.6 & 9.4 & 7.8 & 5.8 & 12.2 & 15.3 & 13.0 & 11.5 & 11.8 \\
\hline 18 & 12.0 & 11.3 & $13 . \tau$ & 10.7 & 9.4 & 7.9 & 5.4 & 12.6 & 14.3 & 12.3 & 12.0 & 11.8 \\
\hline $19 \ldots$ & 11.9 & 11.4 & 12.3 & 10.2 & 9.7 & $\pi . \tau$ & 5.6 & 13.0 & 15.7 & $: 2.0$ & 11.9 & 11.6 \\
\hline 20 & 11.8 & 11.3 & 13.7 & 10.8 & 9.8 & 7.3 & 5.6 & 13.0 & 14.9 & 11.4 & 11.8 & 11.6 \\
\hline 21 & $11 . \tau$ & 11.3 & 13.1 & 9.9 & 9.5 & 7.5 & 5. 8 & 12.5 & 15.2 & 11.2 & 12.2 & 11.3 \\
\hline $22 \ldots$ & 11.8 & 11.3 & 19.9 & 9.9 & 9.4 & . 6 & 7.2 & 12.4 & 16.1 & 11.6 & 12.7 & 11.1 \\
\hline 23 & 11. & 11.3 & 12.8 & 10.3 & 9.4 & 7.4 & 8.6 & 12.4 & 10.8 & 11.9 & 12.1 & 11.1 \\
\hline 24 & 11.6 & 11.8 & 13.2 & 10.6 & 9.2 & $\tau .1$ & 9.3 & 12.5 & 10.4 & 10.3 & 12.0 & 11.1 \\
\hline 25 & 11.6 & 11.4 & 14.8 & 10.5 & 9.2 & 7.2 & 8.9 & 12.4 & 10.3 & 10.7 & 13.8 & 10.9 \\
\hline 26 & 11.6 & 11.4 & 13.5 & 10.4 & 9.0 & 7.4 & 9.2 & 12.6 & 10.3 & 11.4 & 11.7 & $1 \mathrm{i} .2$ \\
\hline $2 \%$ & 11.6 & 11.3 & 13.4 & 10.4 & 9.0 & 7.3 & 9.4 & 12.5 & 10.5 & 11.3 & 11.5 & 11.1 \\
\hline 28 & 11.6 & 11.3 & 13.6 & 10.4 & 9.0 & 7.2 & 9.5 & 12.2 & 10.5 & 11.1 & 11.5 & 11.1 \\
\hline 29 & 11.6 & & 13.6 & 11.0 & 9.4 & 6.7 & 9.7 & 12.3 & 10.6 & 11.0 & 11.4 & 11.2 \\
\hline & 11.6 & & 13.5 & 11.2 & 9.3 & 6.4 & 9.6 & 12.2 & 10.6 & 11.4 & 11.2 & 11.1 \\
\hline & 11.7 & & 13.5 & $\ldots$. & $\cdots$ & & 10.0 & 12.1 & $\cdots$ & 11.3 & $\ldots$ & 11.3 \\
\hline Mean & 11.9 & $11 . \tau$ & 12.2 & 10.8 & 9.8 & 8.1 & $\tau .1$ & 11.8 & 14.3 & 13.3 & 112 & 11.3 \\
\hline
\end{tabular}

a Rain in mountains. 
The summer of 1 b!s was one during which the smallest steam flow mecurred in southern California of which wo have record. The perion of smallest summer flow was during the month of september. During "his minimum period the Edison Electric ('ompany had certain measmements made on Lytle creek at half hour intervals, to determine "Tre diurnal fluctuations. The discharge of the stream was as follows:

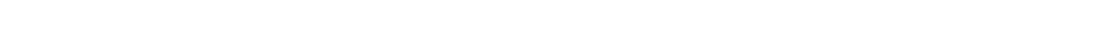
('ounty.

\begin{tabular}{|c|c|c|c|c|c|}
\hline Date. & Time. & $\begin{array}{l}\text { Dis- } \\
\text { eharge. }\end{array}$ & Date. & Time. & $\begin{array}{l}\text { Dis- } \\
\text { charge. }\end{array}$ \\
\hline & & Sier'-feet. & & & Siere-freet. \\
\hline Sept. 15, 1 k98 & \% a. $111 \ldots \ldots$. & 9.16 & Sept.15, $189 \mathrm{x}$ & $10.30 \mathrm{p} . \mathrm{m}-$ & 8.88 \\
\hline Do ..... & ז.30 a. $\mathrm{mL} \ldots$ & 9.16 & Do ..... & $11 \mathrm{p} . \mathrm{m} \ldots$ & К. 88 \\
\hline Do. . & \&a. $11 \ldots \ldots$ & 9.16 & Do . - & $11.30 \mathrm{p} . \mathrm{mI}$ & 4.88 \\
\hline Do - & 8.30 a. $1 \mathrm{~m} \ldots \ldots$ & 9.16 & Do ...... & 12 midnight & 9 \\
\hline Do. & 9 a. $1 \mathrm{n} \ldots \ldots .$. & 9.100 & Sept.16, 1898 & 12.:30 a. $\mathrm{m}$ & 9 \\
\hline Do . & 9.30 a. $1 \mathrm{n} \ldots \ldots$ & ¿.94 & Do $\ldots$. & 1 a. $\mathrm{m} . .$. & 9 \\
\hline Do . . & 10 a. $111 \ldots \ldots$ & 8.02 & Do - & 1.30 a. $\mathrm{m}$ & 9.16 \\
\hline Do . . & 10.30 a. $1 \mathrm{~m} \ldots$ & 8.02 & Do . & 2 a. $111 \ldots$ & 9.16 \\
\hline Do .. & 11 a. $\ln \ldots \ldots$ & 8.02 & Do . . & 2.30 a. $1 \mathrm{n}$ & 9.16 \\
\hline Do .... & 11.30 a. $\mathrm{m}_{\ldots} \ldots$ & 7.74 & Do - & 3 a. $\mathrm{m} \ldots$ & 9.16 \\
\hline Do ... & $12111 \ldots \ldots$ & ร. 46 & Do - & 3.30 a. 111 & 9.16 \\
\hline Do $\ldots$ & $12: 30$ p. $\mathrm{m} \ldots$ & 7. 34 & Do & 4a. $\mathrm{m} \ldots$ & 9.16 \\
\hline Do . . & $1 \mathrm{p} . \mathrm{m}_{\ldots} \ldots \ldots$ & $\div 20$ & Do . & 4.30 a. $1 n$ & 9.16 \\
\hline Do - & 1.30 p. $\mathrm{m} \ldots$. & $\tau .20$ & Do . & 5 a. m.... & 9.16 \\
\hline Do . & 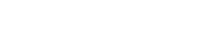 & r. 20 & Do & 5.30 a. 11 & 9.16 \\
\hline Do - & $2.30 \mathrm{p.} \mathrm{m} \mathrm{...}$ & ז.20 & Do - & 6 a. $\mathrm{m}_{\ldots} \ldots$ & 9.16 \\
\hline Do .. & 3 p. m. $\ldots \ldots$ & $\tau .06$ & Do - & 6.30 a. $\mathrm{m}$ & 9.16 \\
\hline Do . & $3.30 \mathrm{p} . \mathrm{m} \ldots$ & $\tau .106$ & & 12-honr mean & 8.86 \\
\hline Do .. & 4 p. m. . . . . & 6.94 & & & $=$ \\
\hline Do . . & $4.3010 \mathrm{p} \ldots \ldots$ & ז.06 & Sept.16, 1898 & ז & 9.28 \\
\hline Do . . & jp. $\mathrm{m}_{\ldots} \ldots \ldots$ & โ.06 & Do .... & 7.80 a. $\mathrm{m}$ & 9.28 \\
\hline Do . & $5.30 \mathrm{p} . \mathrm{m} \ldots$ & $\tau .34$ & Do & ía. 1 m.... & 9.16 \\
\hline Do . & $6 \mathrm{p} . \mathrm{m} \ldots$ & 7.46 & Do . . & 8.30 a. $1 \mathrm{~m}$ & 9 \\
\hline Do _. & $6.30 \mathrm{p} . \mathrm{m} \ldots$ & โ.46 & Do . & 9 a. $\mathrm{m}$ & 9 \\
\hline & 1:-hour mean & $\pi . \tau$ & Do . & 9.30 a. $111 \ldots$ & 8.02 \\
\hline Sept. 15,1898 & $\tau_{1} 1.111 \ldots . . .$. & ก. 46 & Do _. & 10.30 a. $\mathrm{mm} \ldots$ & $\tau .74$ \\
\hline Do $\ldots$. & $\tau .301 . \mathrm{m} \ldots$ & 7.74 & Do . . & 11 a. $\mathrm{m}_{\ldots} \ldots$ & 7.74 \\
\hline Do...... & 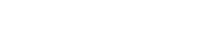 & 8.40 & Do . . & 11.30 a. $\mathrm{mm} \ldots$ & ז. 46 \\
\hline Do . . & ↔.:30 p. $1111 \ldots$ & 8.58 & Do _. & $12 \mathrm{~m} \ldots \ldots$ & $\tau .20$ \\
\hline Do ...... . & 9 p. $\mathrm{m} . \ldots \ldots$ & 8.52 & Do _. . & 12.30 p. $\mathrm{m} \ldots$ & $\tau .20$ \\
\hline Do ....... & 9.30 p. $1 \mathrm{~m} \ldots$ & 8.72 & Do _. & 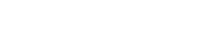 & 7.06 \\
\hline Do . . . . . . & 10 p. m . . . . . & 8.88 & Do ....... & 1.30 p. m . . . & 6.94 \\
\hline
\end{tabular}




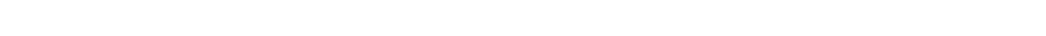

\begin{tabular}{|c|c|c|c|c|c|}
\hline Date. & Time. & $\begin{array}{l}\text { Dis- } \\
\text { eharge. }\end{array}$ & Date. & Time. & $\begin{array}{l}\text { Dis- } \\
\text { elharge. }\end{array}$ \\
\hline & -- -- & secefeet. & & & sec-feet. \\
\hline Sept. 16,1898 & $2 \mathrm{p} . \mathrm{m}_{-}$ & 0.80 & Sept.16,189s & $10.30 \mathrm{p} . \mathrm{m}$ & 9 \\
\hline Do . . . & $2.30 \mathrm{p} . \mathrm{m} \ldots$ & 6.94 & Do $\ldots$ & 11 p. $\mathrm{m}_{\ldots} \ldots$ & 9 \\
\hline Do & 3 p. m $\ldots$. & $\therefore 20$ & Do ..... & $11.30 \mathrm{p} . \mathrm{m} \ldots$ & 9 \\
\hline Do ... & 3.30 p. $11 \mathrm{I}$ & โ:0 & Do . . . . & 12 midniglnt . . & 9 \\
\hline Do - & $\pm \mathrm{p} . \mathrm{m} \ldots$ & ก.:34 & Sept.17,189s & 12.30 a. 111. & 9.16 \\
\hline Do & $4.30 \mathrm{p} . \mathrm{m} \ldots$ & $\pi .34$ & Do .... & 1 a. $\mathrm{m} \ldots \ldots$ & 9.16 \\
\hline Do .... & jp. $\mathrm{m} \ldots$ & $\therefore 46$ & Do & 1.30 a. $\mathrm{m} \ldots \ldots$ & 9.16 \\
\hline Do... & $5.30 \mathrm{p.} .111$ & \%. 46 & Do _ & 2 a. $\mathrm{m}_{\ldots} \ldots \ldots$ & 9.16 \\
\hline Do. & $61 \% \mathrm{~m} \ldots$ & 7.60 & Do . & $2.30 \mathrm{a} . \mathrm{mL} \ldots$ & 9.10 \\
\hline Do . . . & 6.30 1. $\mathrm{m}$ & 7.60 & Do . . & ; a. $1 \mathrm{~m} \ldots \ldots$ & 9.16 \\
\hline & 1:-hour mean & 7.75 & Do. & 3.30 a. $111 \ldots$ & 9.16 \\
\hline & & $\ldots$ & Do - & 4 a. $\mathrm{m}_{\ldots} \ldots$ & 9.16 \\
\hline Sept. 16.1898 & ร1. $\mathrm{m} \ldots$ & 8.02 & Do . & 4.30 a. $\mathrm{mm} \ldots$ & 9.06 \\
\hline Do $\ldots$ & 7.30 1). $\mathrm{ml} \ldots$. & 8.88 & Do & 5a. $11 \mathrm{I}_{\ldots} \ldots \ldots$ & 9.28 \\
\hline Do .... & $8 \mathrm{p} . \mathrm{m} \ldots \ldots$ & 8.88 & Do & 5.30 a. $\mathrm{mm}$ & 9.28 \\
\hline Do ....... & $8.30 \mathrm{p} . \mathrm{m}$ & 8.88 & Do .. & 6 a. $\mathrm{m} \ldots$ & 9.28 \\
\hline Do ..... & 9 p. $\mathrm{m}_{\ldots} \ldots \ldots$ & 8.88 & Do ... & 6.30 at. $111 \ldots$ & 9.28 \\
\hline Do & $9.30 \mathrm{p.} \mathrm{m} .$. & 8.88 & & 12-hour inean & 9.04 \\
\hline Do . ... & 10 p. $\mathrm{mL}$ & 9 & & & \\
\hline
\end{tabular}

The following measurements were made by the United States Geological survey:

Discharge measturements of Lytle C'reck at month of canyou. Sran Bernardino Count!).

\begin{tabular}{|c|c|c|c|c|c|}
\hline Date. & Hydrographer. & $\begin{array}{l}\text { Dis- } \\
\text { charge. }\end{array}$ & Date. & Hydrographer. & $\begin{array}{l}\text { Dis- } \\
\text { charge. }\end{array}$ \\
\hline & & seci-feet. & & & sec.-feet. \\
\hline July $2 \pm, 1896$ & J. H. Quinton- & $15 . \%$ & June 8,1900 & S. G. Bennett ... & 6.2 \\
\hline June 10,1898 & J. B. Lippincott & 10.7 & Sept.29, 1900 & W.W.Cockins, jr & 4.6 \\
\hline Aug. 27,1898 & F.H.Olmsted & 10.0 & Apr. 1,1902 & S.G. Benuett ... & 19.9 \\
\hline Aug. 29,1899 & S. G. Bennett & 12.5 & Sept. $5,19(12$ & W. B. Clapp .... & 5.0 \\
\hline
\end{tabular}

MAMMOTH CREEK.

See Owens River, Mammoth Creek.

\section{MARIA IGNACIA CREEK.}

Inischarge measurement of Maria Igmacia C'reek, S'antu Barbara County.

\begin{tabular}{|c|c|c|}
\hline Date. & Hydrographer. & $\begin{array}{l}\text { Dis- } \\
\text { eharge. }\end{array}$ \\
\hline Aug. - -1899 & Geo. F. Wright. - & $\begin{array}{r}\text { Sec. feet. } \\
-\quad 0.23\end{array}$ \\
\hline
\end{tabular}




\section{MARIPOSA CREEK.}

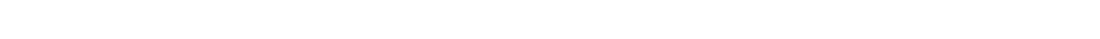
county."

[I)raintug area, 1:2: squar' miles.]

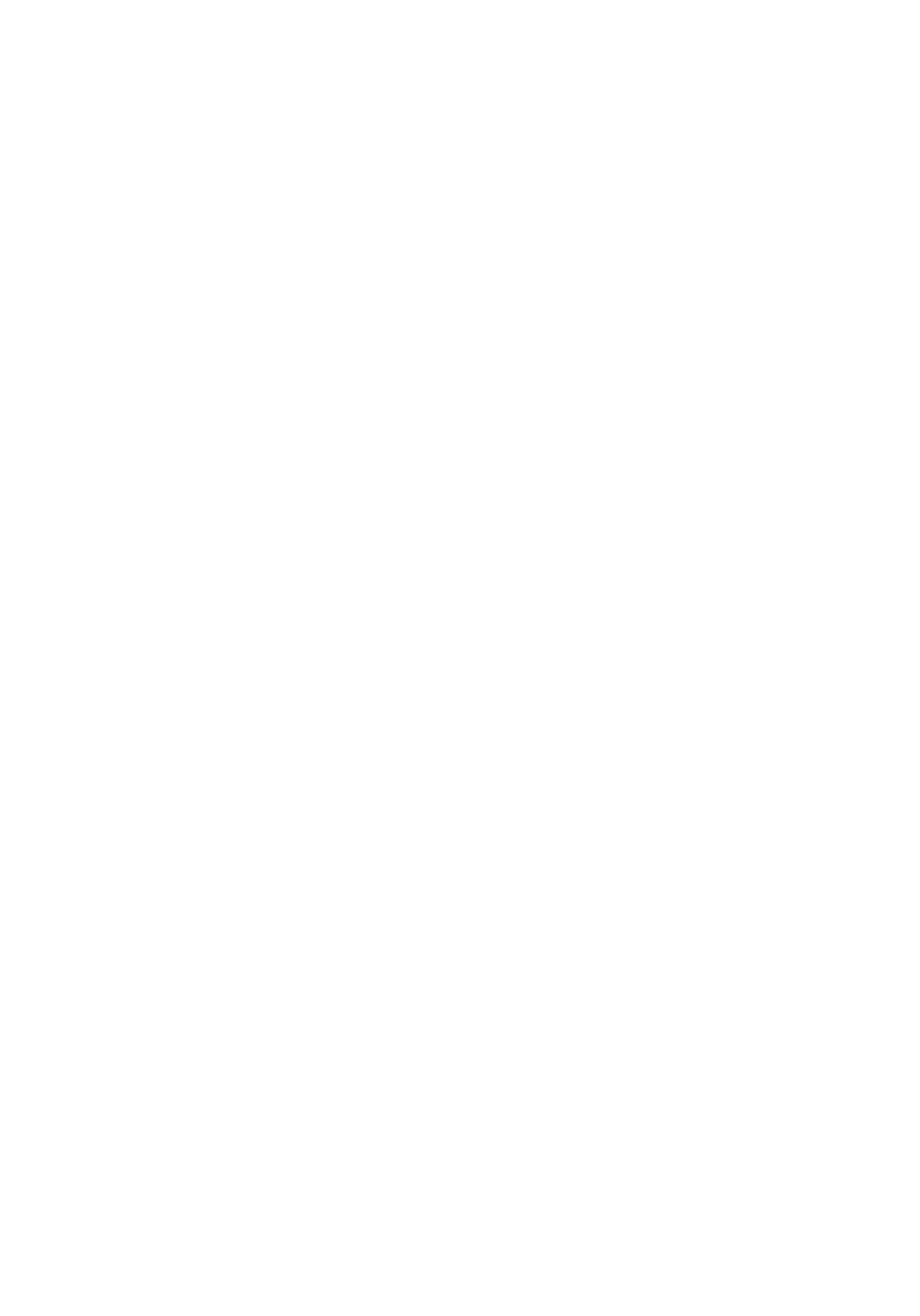

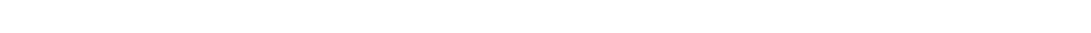
ing stroams. 


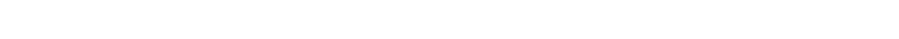

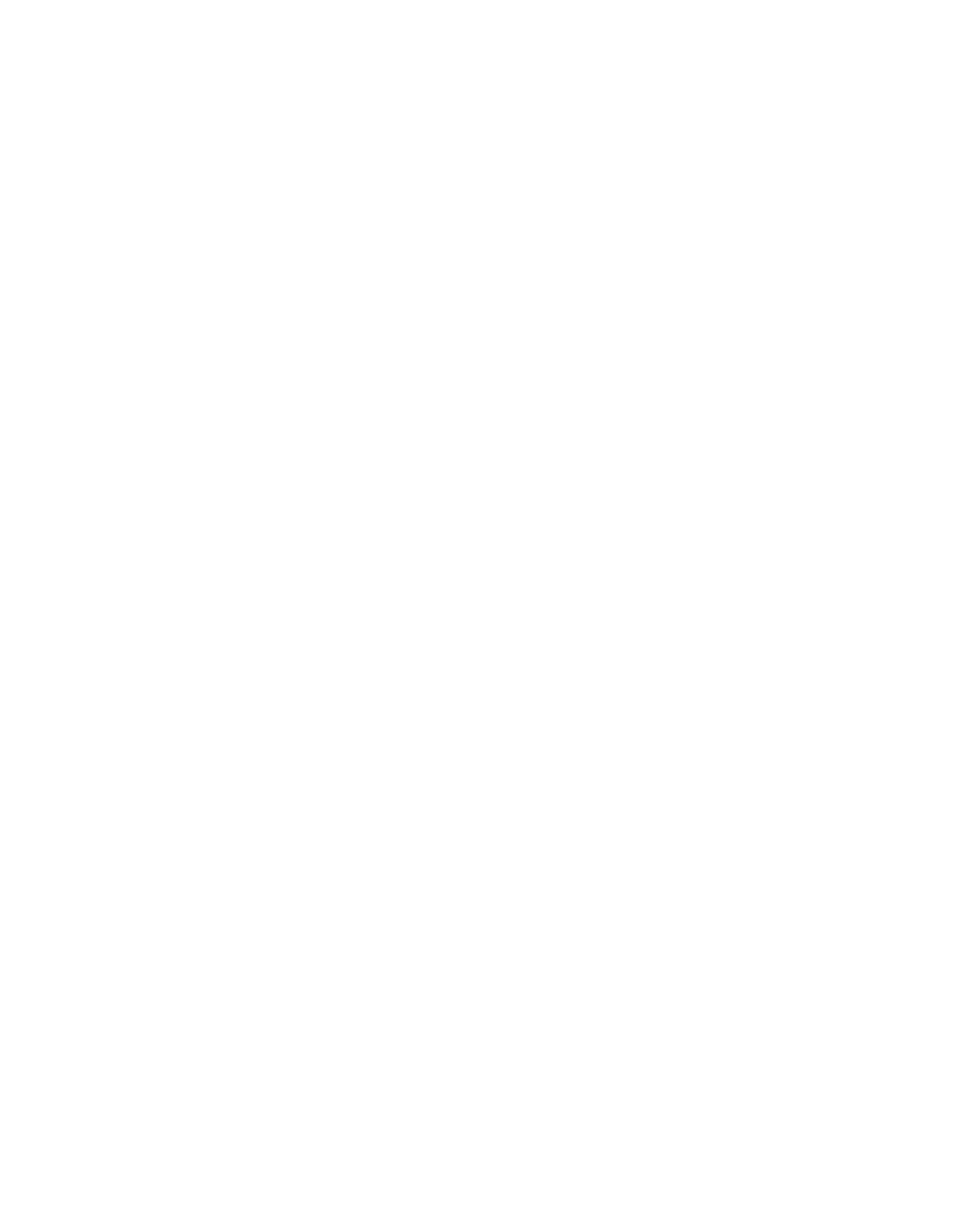


Estimated monthly discharge of LIariposed Creek, ete.-Continned.

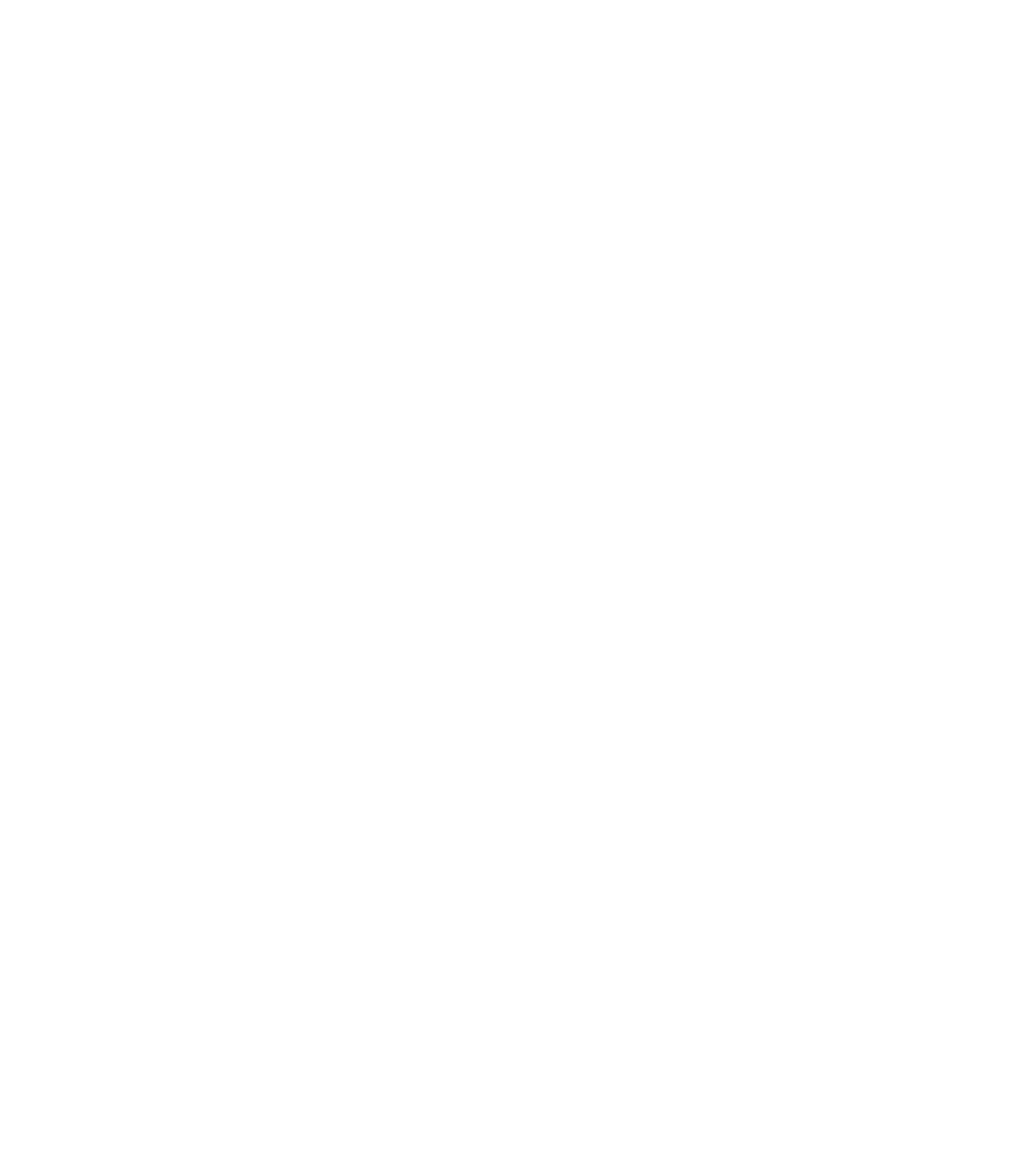


MAYBERRY CANYON.

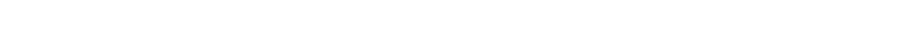

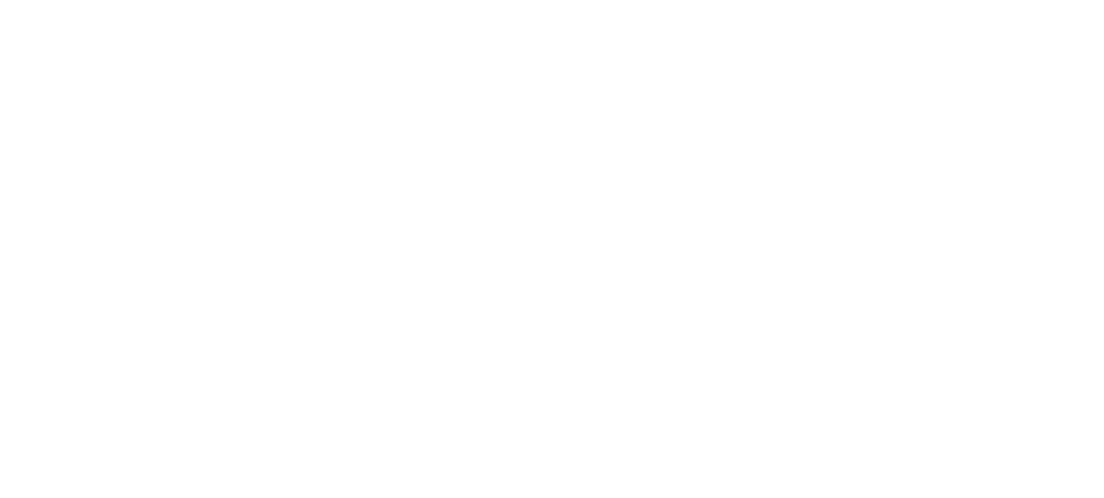

MCCLOUD RIVER.

Discharge merasurements of Hoclomed River. Shasta rounty.

\begin{tabular}{|c|c|c|c|}
\hline Date. & Hydingrapher. & $\begin{array}{l}\text { Dis- } \\
\text { charge. }\end{array}$ & Iucality. \\
\hline & -- & ser.-ft. & 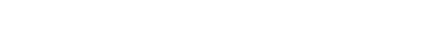 \\
\hline Sept. 9.1901 & S. G. Bennett. & 1.096 & $\begin{array}{l}\text { One-fourth mile alove Tnit. } \\
\text { States fishery. }\end{array}$ \\
\hline Sept. 23,1902 & $\ldots$ - do _... & $1,2 \% 2$ & At Hirze Mountain. \\
\hline Sept. 24,1902 & Chas. A. Miller. & 1,325 & 1 mile ab ive Squaw Creek. \\
\hline Sept. 26.1902 & $\ldots$. . . . . . . . & 1.356 & United States fishery. \\
\hline Sept. 94,1902 & . & $6 \tau$ & $\begin{array}{l}\text { Squaw Creek at bridge above } \\
\text { mouth. }\end{array}$ \\
\hline
\end{tabular}

MCINTYRE DITCH.

Ser San Bernardino Valley, MeIntyre ditch.

MCKENZIE DITCH.

Sec San Iormardino Valley, McKenzie ditch.

\section{MEEKS \& DALEY DITCH.}

Ser San Bornarlino Valley, Meeks \& Daley ditch.

\section{MERCED RIVER.}

Merced River above Mereed Falls drains approximately 1,090 square miles of the western slopes of the Sierra Nevada. Included in the asstern portion of its (lrainage area are a large number of high peaks, the highest, Mount Lyell, reaching an elevation of 13,090 feet. 
The midsummer flow of this stream is larger in proportion to its drainage area than that of the Tuolumne River, which aljoins it on the north.

In their plunge into the Yosemite Valley the water's of the Merced River and its tributaries form most beautiful waterfalls.

The measurement and record of this stream was undertaken in response to numerous requests from persons interested in mining and irrigation. The midsummer flow of the stream is less than the combined capacity of the irrigation and power canals taking water in the vicinity of Snelling. The owners of these canals offered to pay $\$ 100$ toward the expenses of equipping and maintaining the gaging station for the first year. Mr. II. II. Menderson, county surveyor of Merced County, established a gaging station at a point 1 mile albove Merced Falls, April 6, 1901. Meter measurements are marlo from a cable. The olserver is Mr. ('harles Niegfeldt.

Discharge measurements of Merced Rivel. Meroed C'ounty.

\begin{tabular}{|c|c|c|c|c|}
\hline Date. & Hydrographer. & $\begin{array}{c}\text { Gage } \\
\text { height. }\end{array}$ & $\begin{array}{c}\text { Dis- } \\
\text { charge. }\end{array}$ & Remar'ks. \\
\hline Sept. 11.1899 & S. C. Bennett _. & Fret. & $\begin{array}{l}\text { Sec,-feet. } \\
35\end{array}$ & $\begin{array}{l}\text { River. } 1 \text { mile above hear } \\
\text { works Crocker-Hoffman } \\
\text { Canal." }\end{array}$ \\
\hline Do ....... & $\ldots$. $10 \ldots$ & . & j & Old Mill Valley ditch. \\
\hline Do . ... & $\ldots$.... do .... & 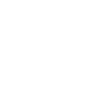 & 16.5 & $\begin{array}{l}\text { Crocker-Hoffman Canal, } \\
300 \text { feet below head- } \\
\text { works. }\end{array}$ \\
\hline Sept. 10,1900 & $\ldots$ do ....... & 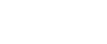 & $6 . j$ & Do. \\
\hline Sept. 4.1002 & L. M. Lawson & & $3 \pi$ & $\begin{array}{l}\text { Crocker-Hofiman Canal, } 3 \\
\text { miles helow snelling. }\end{array}$ \\
\hline Nov. $2 \pi, 1895$ & J. B. Lippincott. & & 125 & Merced Falls. \\
\hline Sept. 10,1900 & S. G. Bennett - . & & 63 & Do. \\
\hline Apr. $\quad 6.1901$ & $\ldots$ do ......... & $10 .: ?$ & 1,379 & Do. \\
\hline June 11,1901 & J. B. Lippincott. & 12 & 4,139 & Do. \\
\hline Aug. 2.1901 & S. G. Bennett & 10.05 & 1,122 & Do. \\
\hline Aug. 31, 1901 & $\ldots$. do $\ldots . . .$. & 8.6 & 220 & Do. \\
\hline Mar. $\quad 6,1902$ & $\ldots$ do ....... & 10.1 & $1,30^{\circ}$ & Do. \\
\hline May 13,1902 & $\ldots$ do ........ & 12.15 & i. $41: 3$ & Do. \\
\hline Sept. 3,1502 & L.M. Lawson - & & 109 & Do. \\
\hline Sept. 10,1900 & S. G. Bennett .. & & $2 \tau$ & $\begin{array}{l}\text { Merced River Mills Canal, } \\
22 \text { miles lelow Snflling. }\end{array}$ \\
\hline Do ... & .... do & & 2.1 & Snelling ditch. \\
\hline Aug. 22,1890 & J. B. Lippineott & & 89 & $\begin{array}{l}\text { Yosumite Valley. Stone- } \\
\text { man Honse. }\end{array}$ \\
\hline
\end{tabular}

"Leveral small ditelhes are taken out of Mered River ahure this point. 


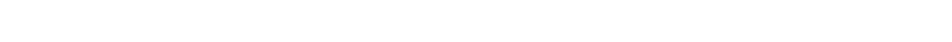

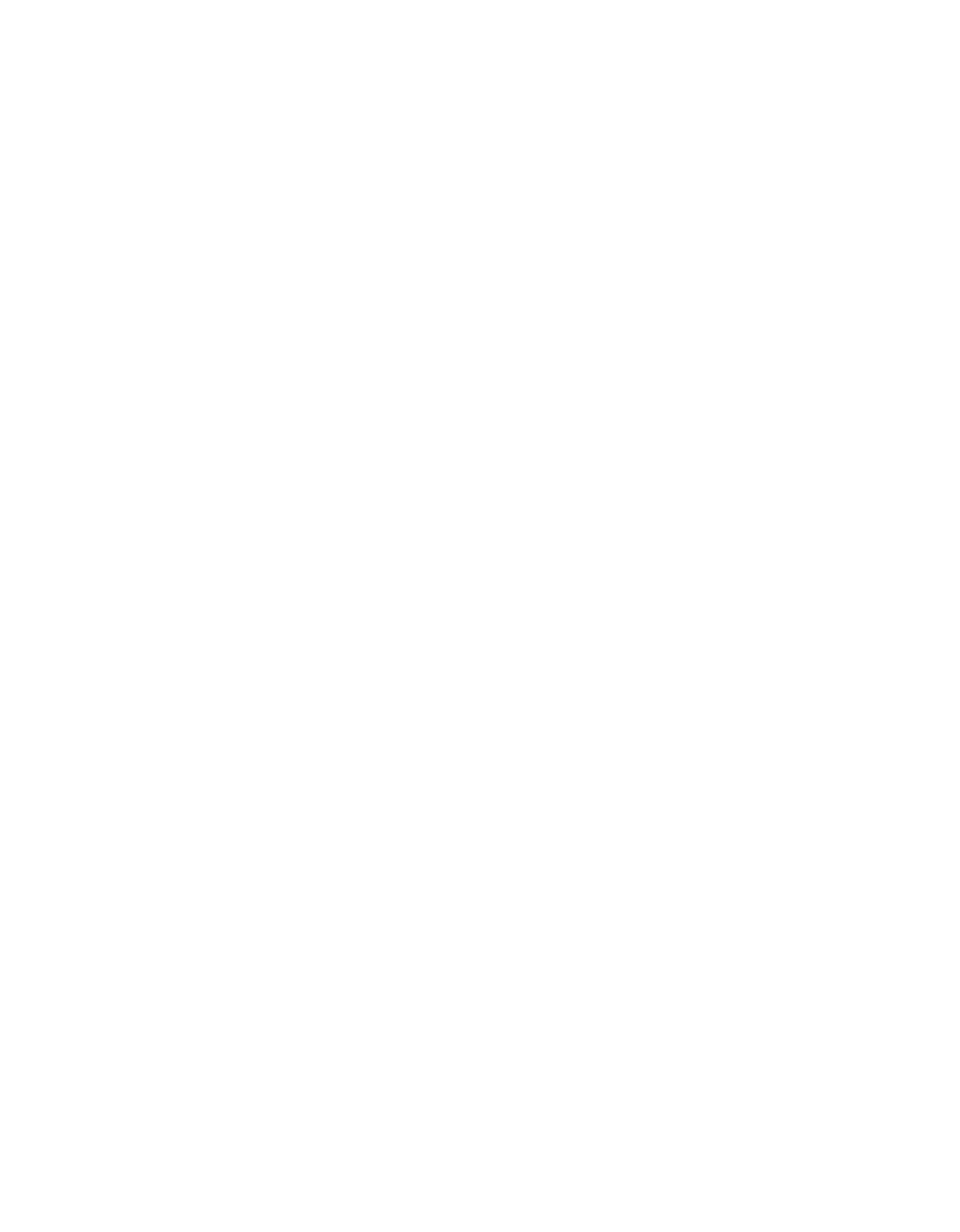




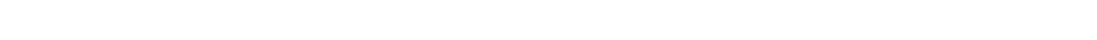

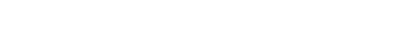

\section{Ibisharge.}

Menth.

Maximum. Minimum. Mrean.

$18 \% 9$.

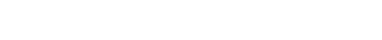

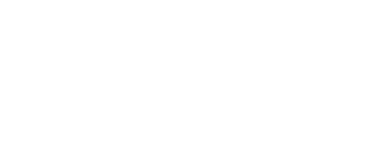

fropyet. serejeet. Imelhes.

354

$21 . \% 6 \%$

(1.. $3: 3$

0.38

1. 506

s.3. 639

1. 41)

1.46

$\therefore$. 099

$139,0(11$

1.9 .5

2. 95

3,120

$185,65)$

‥ 90

3), 24

$3,: 330 ; \quad 20,12,12: 3$

3. 10

$3.5 \%$

:3. :336

198.5016

3. 10

2. 46

$96 \mathrm{~s}$

.)9. 500

.90

1.04

$1 \div 2$

$10.5 \%$

.16

.18

i.)

$4,46: 3$

$.11 \%$

.08

แ)

$+, 612$

.

.08

$12: 2$

10, 2:35)

.16

.18

$6+6$ । 39.721

.60

.69

1. $: 301$

95) 81

1. $2: 3$

16. 61

$1 \times 80$

Jannary -

35

(5)is

$2: 3,296$

$\therefore 3$

.42

February

$811 \%$

4:3, 313

.50

.75

March

4. 250

49,621

. 55

.86

April

$+8.82$

25) 89:3

3. 95

+. 41

May

.), 111

$29 \%, 73$

4.50

ร. 19

2, 74

304,126

$4.7 \%$

$\bar{\pi} .30$

July

$18 \times,+20$

2.5

2. .94

ins

46,300

.70

.81

:123

19. 20

.30

.23

209

16,540

. 25

. 29

$2: 3$

14,10 )

. 22

.

1. 291

\%9, 3र0

1. $: 0$

1.38

$1.81+{ }^{\prime} 1.31 \pi .736{ }^{\prime} \quad 1.69 \quad 22.93$

The year

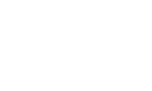

Figures for Januiry, Febrnary, and

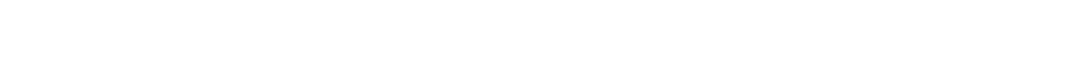

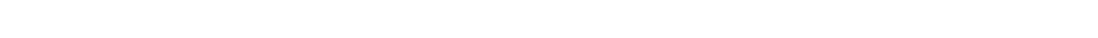

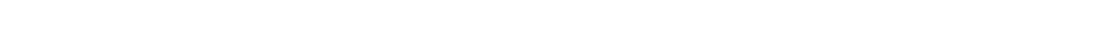




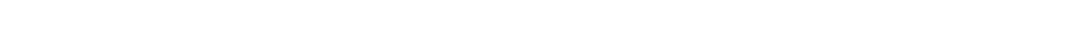

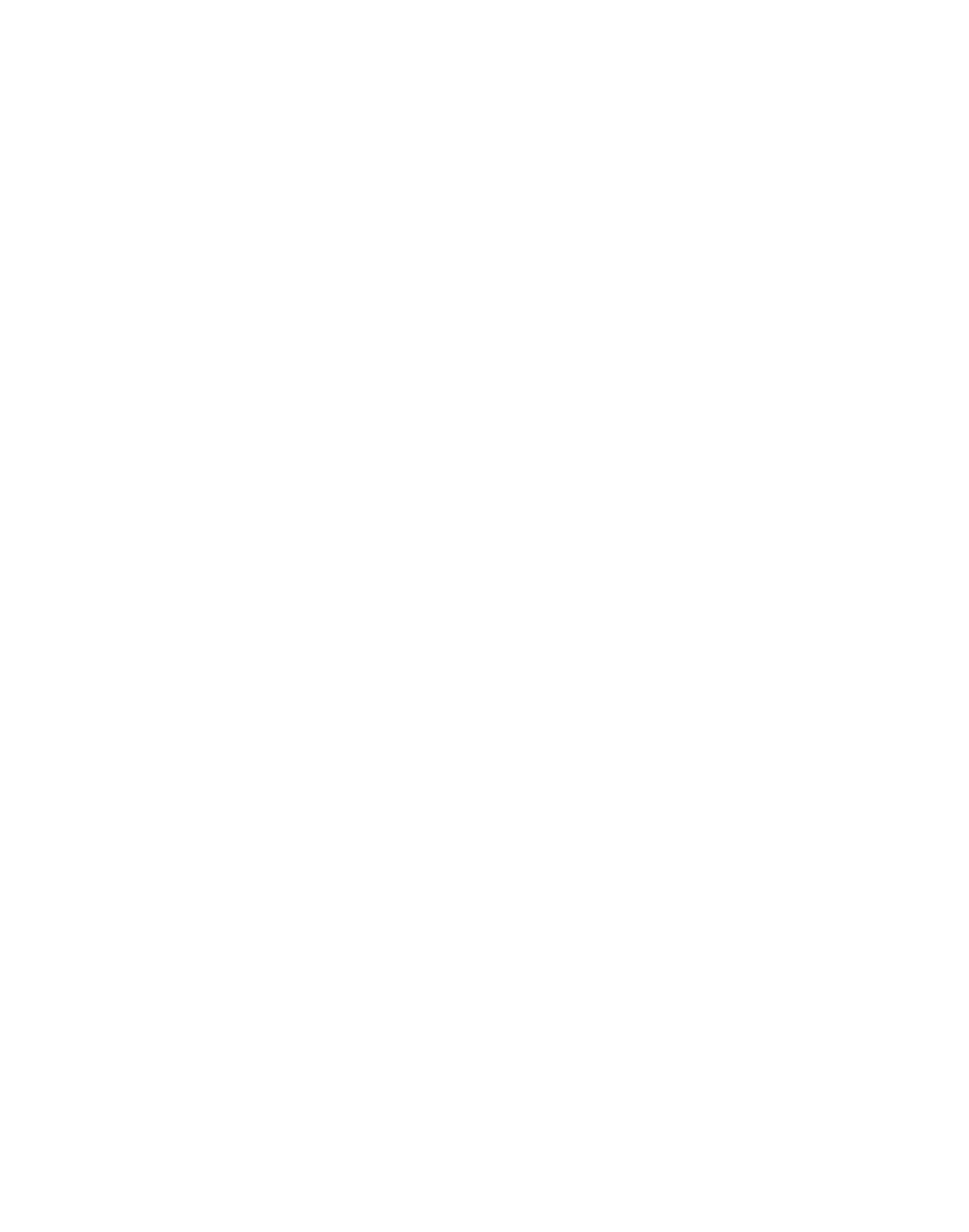




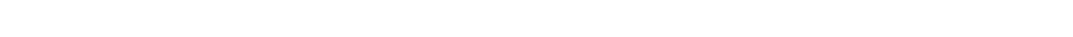

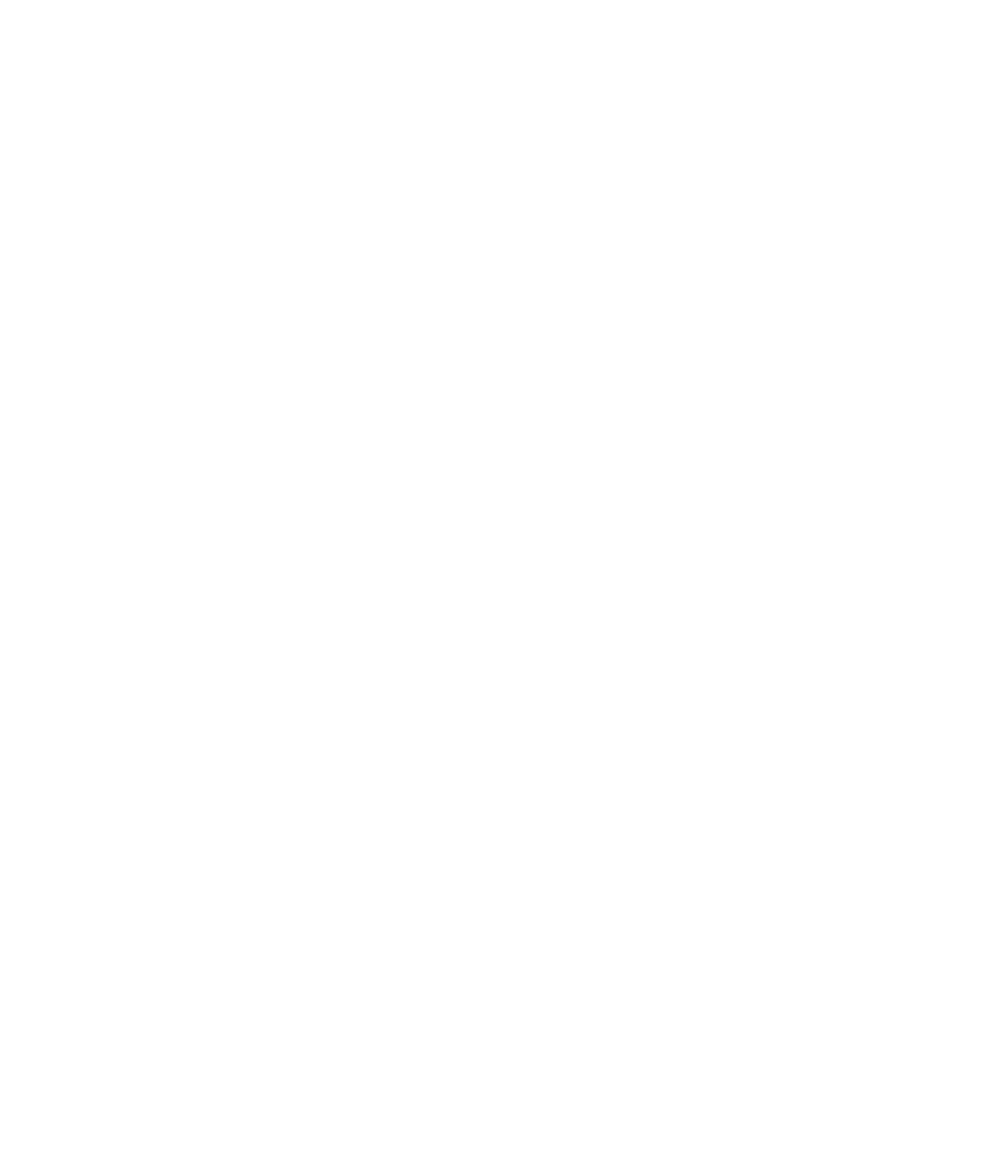




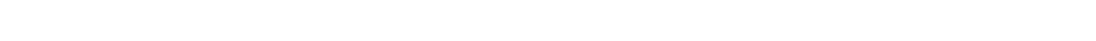
ilened Fulls."

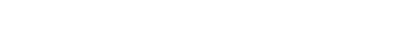

\begin{tabular}{|c|c|c|c|c|c|c|}
\hline \multirow{2}{*}{ Month. } & \multirow[b]{2}{*}{ Muximumu. } & \multicolumn{2}{|l|}{ J hiseharge. } & \multirow{2}{*}{$\begin{array}{l}\text { Total dis- } \\
\text { charge. }\end{array}$} & \multicolumn{2}{|c|}{ Run-off. } \\
\hline & & Minimum. & Mrain. & & $\begin{array}{l}\text { Pere } \\
\text { squares } \\
\text { mile. }\end{array}$ & Deptl. \\
\hline 1901. & hreefert. & sereffert. & Sect-fect. & Acre-feet. & Sece-fret. & lineles. \\
\hline April ..... & 5.000 & 1. 090 & 2,687 & $13: 3,240$ & 1.55 & 1.73 \\
\hline Iay - & 9,450 & 2,7011 & $\bar{\pi}, 419$ & 333,201 & $4.9 \pi$ & $5.8 \%$ \\
\hline June . - & $\therefore 2.200$ & $3.3 \times 10$ & 5.389 & 320,678 & 4.94 & 5.51 \\
\hline July ............... & 4.560 & 1,090 & 2.096 & 128,828 & 1.92 & 2.21 \\
\hline August .......... & $?, 1090$ & $2: 20$ & 204 & 43,284 & (ii) & $\pi$ \\
\hline September . . . . . . . & 2.50 & $1: 30$ & 183 & 10. $\$ 89$ & $.1 \tau$ & 19 \\
\hline October ............ & 990 & 15) & 26.5 & 16,291 & .24 & 6) \\
\hline November . . . . . . . & $2: 30$ & $0^{\prime}$ & 399 & $: 3, \pi 42$ & .3 & .41 \\
\hline December . ........ & $\therefore 090$ & $2: 20$ & 58 & $35,4 i 8$ & .53 & 61 \\
\hline$i 9(0)$ & & & -- & & & \\
\hline January ..... & 410 & 19.5 & 236 & 14,511 & .22 & .25 \\
\hline ebruary ....... & 4,020 & 170 & $\lceil 49$ & $41.59 \%$ & .69 &.$\%$ \\
\hline Iarch ...... & 5,220 & 460 & $1.36 \pi$ & 84.0 .54 & 1.25 & 1.4 \\
\hline April & 5.460 & 830 & 2,45 & 146,202 & 2.25 & 2.5 \\
\hline May & 6,240 & 2.180 & 3.79 .5 & 2333,345 & 3.48 & +.01 \\
\hline Junt . . . . . . & 5.460 & 1. 220 & 3.142 & 186.962 & 2.88 & 3.21 \\
\hline July ..... . & 1.110 & $2 \times 0$ & $4 \times 1$ & 39,576 & .44 & .5 \\
\hline Angust ... .... & 320 & 110 & 191 & $11,74 t$ & .18 & .2 \\
\hline September ............. & 110 & 65 & sis & $\therefore, 236$ & .08 & .0 \\
\hline October ... $\ldots . . .$. & 280 & 6.5 & 90 & $\pi, 5: 34$ & .18 & .0 \\
\hline Norember & 1,110 & 90 & 246 & $14,6: 34$ & .23 & .2 \\
\hline December & 1,340 & $19 . \overline{5}$ & $3(1: 3$ & $1 \aleph, 631$ & .28 & .8 \\
\hline 'The yerr' & 6,240 & 6.5 & $1,09 \pi$ & 792,030 & 1.01 & 10.0 \\
\hline
\end{tabular}

$a[T$. S. (xeol. Survery.

MILL CREEK.

See King River, Mill Creek.

\section{MILL CREEK.}

This stream is one of the larger tributaries of Santa Ana River, although on areount of its importance for irrigation it is generally considred as an independent stream. It rises on the western slope of the San Bernardino Momntains, draining the area immediately south of the headwaters of Santa Ana River. Mill Creek appears from its canyon about 5 miles east of Rerllands. The Crafton Water 
Company diverts all the water of this ereek at the momth of the anyon, particularly in the summel. The water passes over a weir, and the rolume is therefore determined with considerable acemary.

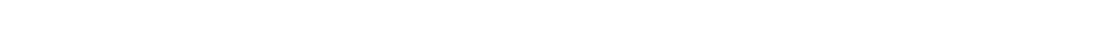
diven Comut!!

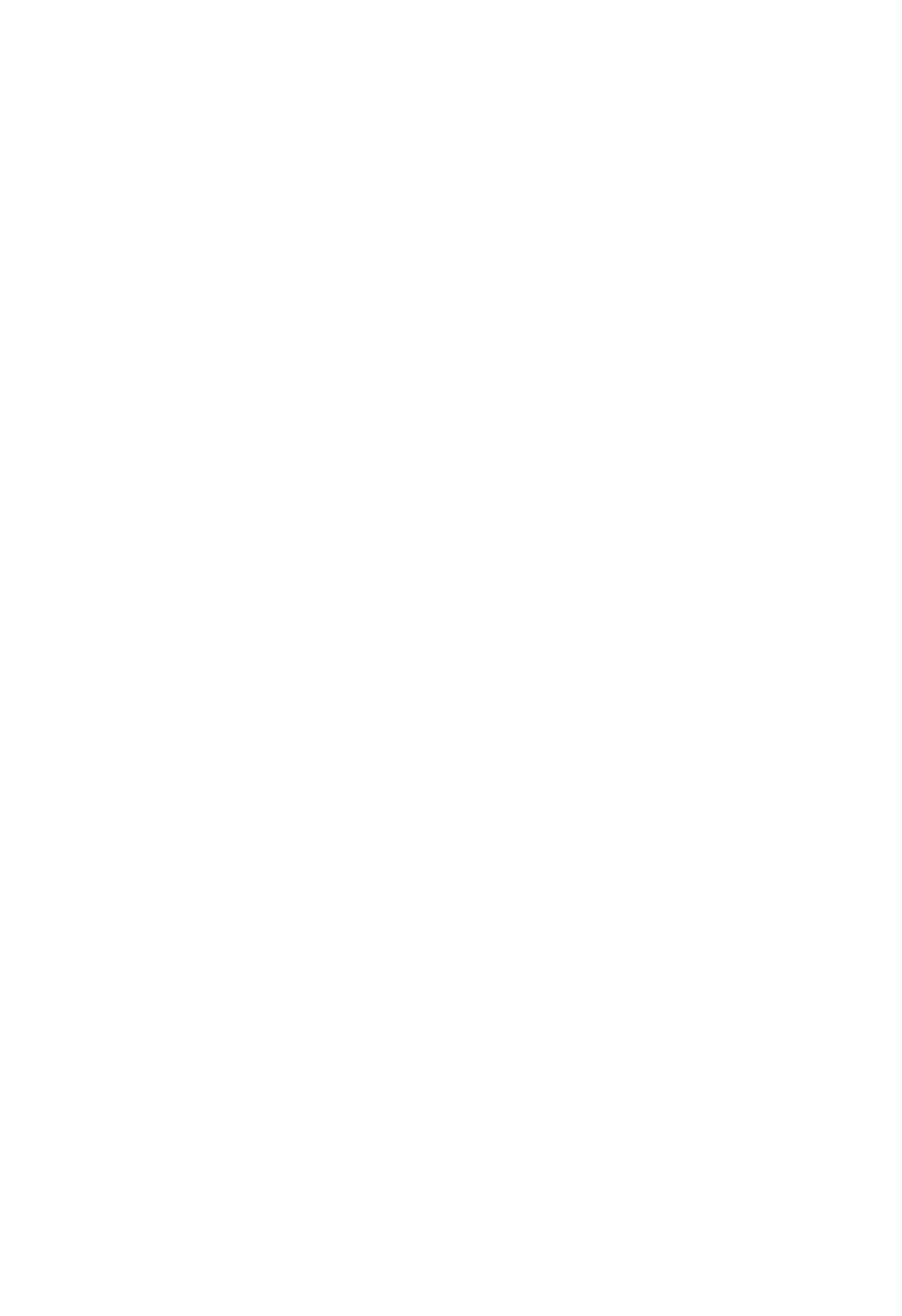




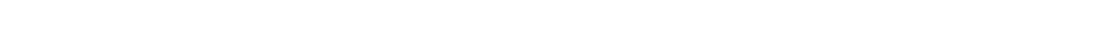
('ounty.

[Measurements noule hy Edison Electric ('ompany.]

\begin{tabular}{|c|c|c|c|}
\hline Date. & $\begin{array}{c}\text { Dis- } \\
\text { charge. }\end{array}$ & Date. & $\begin{array}{l}\text { Dis- } \\
\text { charge. }\end{array}$ \\
\hline Sept. 15, 18ys: & Sherefeet. & Sept. 16, 1898: & Sec.-feet. \\
\hline ร a. $111 \ldots$ & 11.74 & $12.30 \mathrm{a} . \mathrm{m}$ & 10.78 \\
\hline 7..30 i. $111 \ldots$ & 11.74 & 1 a. $\mathrm{m} \ldots .$. & 11.08 \\
\hline sa.m....... & 11.58 & 1.30 a. $\mathrm{m} \ldots \ldots$ & 11.08 \\
\hline 8.30 a. $m \ldots$ & 11.74 & 2a. $m \ldots \ldots$ & 11.08 \\
\hline 9 a. $111 \ldots \ldots \ldots$ & 11.74 & 2.30 a. $\mathrm{m} \ldots \ldots$ & 11.26 \\
\hline 9.30$)$ & 11.42 & 3 a. m... & 11.26 \\
\hline 10 a. $11 \ldots \ldots$ & 11.26 & 3.30 a. $\mathrm{m} . \ldots$ & 11.26 \\
\hline 10.30 a. $11 \ldots$ & 11.26 & 4 a. $m \ldots . .$. & 11.26 \\
\hline 11 a. $111 \ldots$. & 11.08 & 4.30 a. $1 \mathrm{~m}$ & 11.26 \\
\hline $11.30 \mathrm{d.} \mathrm{mL}$ & 10.78 & ja. $\mathrm{m}$ & 11.42 \\
\hline $12 \mathrm{~m} \ldots . .$. & 10.48 & 5.30 a. $\mathrm{m} \ldots \ldots$ & 11.26 \\
\hline $12.301, .111 \ldots$ & 10.32 & 6 a. $\mathrm{m} \ldots \ldots$ & 11.42 \\
\hline $1 \mathrm{p.m} \ldots \ldots$ & 10 & $6.30 \mathrm{a} . \mathrm{m} \ldots$ & 11.42 \\
\hline $1.30 \mathrm{p} . \mathrm{m} \ldots \ldots$ & 9.84 & 12-hour mean & 10.72 \\
\hline$\approx \mathrm{p} . \mathrm{m} \ldots$ & 9.54 & & 10.8 \\
\hline $2.30 \mathrm{p} . \mathrm{m} \ldots$ & 9.40 & Sept. 16, 1898: & \\
\hline 3 p. m . . . . & 9.24 & โ a. $\mathrm{m} \ldots$ & 11.26 \\
\hline 3.30 p. in ... & 9.24 & $7.30 \mathrm{a} . \mathrm{m}$ & 11.26 \\
\hline \pm p. $111 \ldots \ldots$ & 9.24 & 8 a. $\mathrm{m} \ldots$ & 10.94 \\
\hline $4.30 \mathrm{p} . \mathrm{m} \ldots$ & 9.24 & 8.30 a. $\mathrm{ml}$ & 11.08 \\
\hline $5 \mathrm{p} . \mathrm{m} \ldots$ & 9.24 & 9 a. $\mathrm{m} \ldots . .$. & 11.08 \\
\hline 5.30 p. $\mathrm{m} \ldots$ & 9.24 & 9.30 a. $\mathrm{m}$ & 10.78 \\
\hline 6 p. $\mathrm{m} \ldots \ldots$ & 9.54 & 10 a. $\mathrm{m} \ldots . .$. & 10.48 \\
\hline 6.30 p. $\mathrm{m} \ldots$ & 9.54 & 10.30 a. $\mathrm{m}$ & 10.48 \\
\hline 12-hour mean . ...... & 10.35 & 11.30 a. $\mathrm{m}$... & \\
\hline Sept. 15, 189s: & & $12 \mathrm{~m} \ldots . .$. & 10.00 \\
\hline 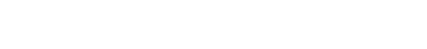 & 9.54 & 12.30 p. m ... & 9.84 \\
\hline $7.30 \mathrm{p} .111 \ldots$ & 9.42 & 1 p. m............. & 9.68 \\
\hline $8 p . \mathrm{m} \ldots . .$. & 9.84 & 1.30 p. $\mathrm{mm}$ & 9.54 \\
\hline 8.30 p. $111 \ldots$ & 9.84 & $2 \mathrm{p} . \mathrm{m} \ldots \ldots$ & 9.40 \\
\hline 9 p. m..... & 10 & 2.30 p. $\mathrm{m} \ldots$ & 9.24 \\
\hline $9.30 \mathrm{p} . \mathrm{m} \ldots$ & 10.16 & 3 p. m............. & 9.10 \\
\hline $10 \mathrm{p} .1 \mathrm{n} \ldots .$. & 10.36 & 3.30 p. m . . & 9.24 \\
\hline 10.30 p. $\mathrm{m} \ldots \ldots$ & 10.48 & $4 \mathrm{p} . \mathrm{m}_{\ldots} \ldots$ & 8.9 \\
\hline 11 p. m. . . . . . & 10.48 & 4.30 p. m . . . . . . . & 8.9 \\
\hline $11.30 \mathrm{p} . \mathrm{m} \ldots$ & 10.78 & $5 \mathrm{p} . \mathrm{m} \ldots \ldots$ & 8.9 \\
\hline 12 midnight & 10.62 & $5.30 \mathrm{p} . \mathrm{m} \ldots .$. & 8.9 \\
\hline
\end{tabular}




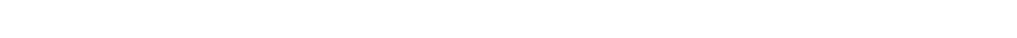

\begin{tabular}{|c|c|c|c|}
\hline Ibate. & $\begin{array}{c}\text { Dis- } \\
\text { charge. }\end{array}$ & Date. & rharge. \\
\hline Sept. 16. 1sak: & sereffeet. & Sept. 1\%, 189x: & sier-fient. \\
\hline fip.m & 9.08 & 12.30 a. $\mathrm{me}$ & 10. 48 \\
\hline$(6.30 \mathrm{p}, \mathrm{m}$ & 9.40 & 1 a. $\mathrm{m}_{\ldots} \ldots \ldots$ & 10.48 \\
\hline 12-hom mean & 9.92 & 1.30 a. $\mathrm{m} \ldots \ldots . .$. & 10.64 \\
\hline & & $\because$ a. $m \ldots \ldots$ & 10.78 \\
\hline sept. 16. 18, & & 2.80 a. $m \ldots \ldots$ & 11). is \\
\hline ip.m $\ldots$ & 9.54 & ; a. m $m$ & 10.78 \\
\hline \%.311 p. m & 9.68 & 3.30 a. $\mathrm{m} \ldots \ldots$ & 10.78 \\
\hline sp.m........ & 9.68 & ta. $\mathrm{m} \ldots \ldots \ldots$ & 10.78 \\
\hline$\$ .30 \mathrm{p} \cdot \mathrm{m} \ldots$ & 9.84 & 4.30 a. $m \ldots$ & 11.08 \\
\hline $9 \mathrm{p} \cdot \mathrm{m}, \ldots$ & 9.84 & ja. $m \ldots$ & 11.08 \\
\hline $9.30 \mathrm{P} . \mathrm{m} \ldots$ & 9.84 & .3 .30 a. $\mathrm{mm} \ldots \ldots$ & 11.08 \\
\hline $10 \mathrm{p} \cdot \mathrm{m} \ldots$ & 10.16 & 6 a. $\mathrm{m} \ldots \ldots . .$. & 11.26 \\
\hline 10.30 p. $\mathrm{m} \quad \ldots \ldots \ldots$ & 10.16 & $6.30 \mathrm{a} . \mathrm{m}$ & 11.26 \\
\hline $11 \mathrm{p} . \mathrm{m} \ldots \ldots$ & 10.32 & & -- \\
\hline $11.30 \mathrm{p} . \mathrm{m} \ldots \ldots$ & 10.32 & 12-hour mean . . . . & 10.46 \\
\hline 12 midnight $\ldots \ldots$ & 10.32 & & \\
\hline
\end{tabular}

Discharge merswements of Mill C'reek, San Beruardina ('onuty.

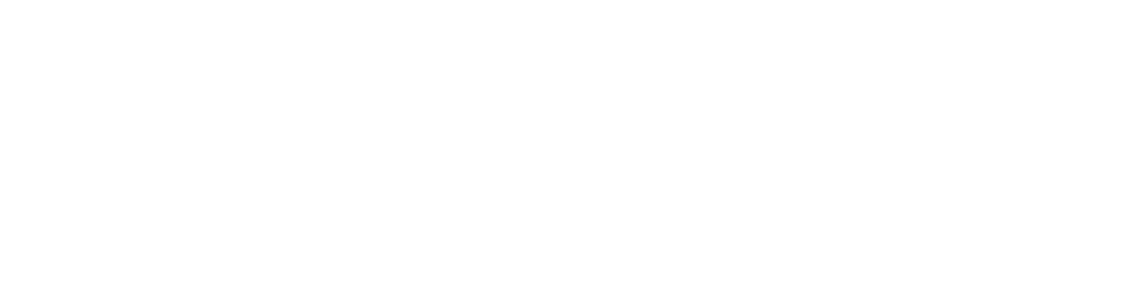

"Loss from this intak" to head of Grafton Canal, 1.4 second-feet.

IRR $\times 1-(1): 3-11$ 


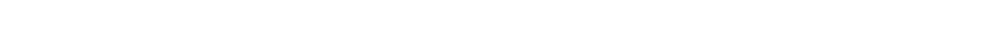

[Drainage area, $4 \%$ square iniles.]

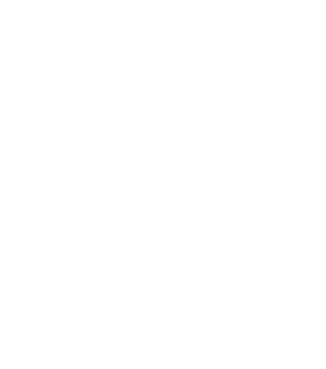

$1 \times 96$.

May

lune

July

Angust

September

October

1899.

February ..........

March

April

May

June

July

August

September

October.

November

December

\section{$1900 . " 1$}

Jantuary

February

March

April

May

June

July

August

September

Octoler

November 1 to 17

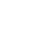

-

.

Inisroharge.

Maximum. Minimum. Mean.

Secr-feet ser-feet sec-feet $2 \% .6$ 26.5

$$
24.0
$$

19.5

24.5

22.0

24.5

$1 \% .0$

19.6

9. 4

13.4

5. 1

10.3

6. 1

11.5

8.7

11. 6

13.2

ก. 4

11.5

15.0

13.1

9.0

10.5

13.0

16.0

13.0 :

12.0

1 . 0

․ 2

i.

$5 . \%$

8.

11.

14.6 


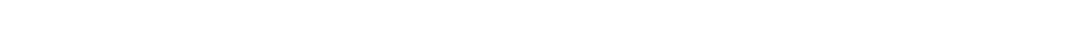

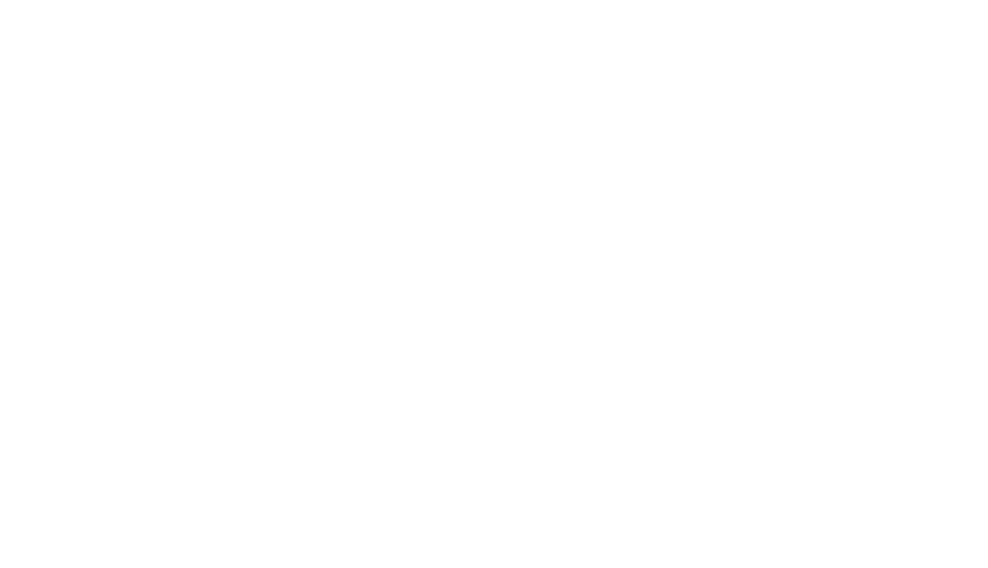

"On August 1ti a rloudburst in Mill Creek canyom and ('rafton Hills filled zanjer and supply a ral with sand. No record from A ugust 16 to 23 , inclusive.

\section{MILL CREEK, GREEN SPOT PIPE LINE.}

See santa Ana River, Green spot pipe line.

\section{MILL CREEK.}

See Stanislaus River, Mill Creset.

MILL FLUME AND PUMP, RIVERSIDE WATER COMPANY.

See sian Bernatelino Valley.

\section{MISSION CREEK.}

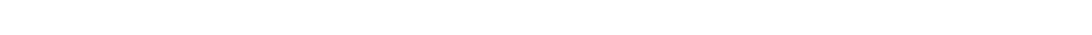
above dam.

I)ate.

ㄴ. 1.5. $1 \mathrm{kNS}$

c n. 21.1868

(5.). \%.18

Far. 16.18xy

-uly 20,1888

1) ly 13,1889

1g. - . $1 \times 89$

ient. $1.18 \times 9$

wine $11,189 \%$

une 17,1900
Hydrographer

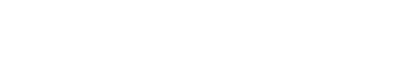

Sere-fret

A. Poett

(). 93

2. 80

1.37

2. 23

.36

.43

G. F. Wright . . . . . . . . . . . . . 46

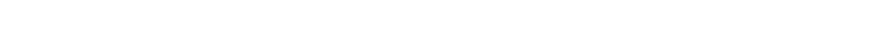

la

.36

a. 05 


\section{MOHAVE RIVER.}

The streams forming the headwaters of this river have their sondee on the northern slope of the Sierra Madre and flow northerly, the river finally disappearing in the sands of the Mohave Dessert. At Victorville, a station on the Itrhison, Topeka and santa lis Railroad, the river passes through a narrow gorge, locally known as The Narrows. This place has been under investigation as a possible dam site, and soundings for the tepth of bed rock were marle by the United States Geologinal survey during the season of 1899. The greatest depth of bed rock was found to be 54 feet. The diamond drill showed the rock to bo a fine-grained granite." Above The Narrows the valley broadens into a large reservoir site, and at the 145-foot flow line is said to cover 7,71 s acres. In order to determine the amount of water arailable for storage for this reservoir, a gaging station was established February 27,1899 . The rod is a 2 by ; inch timber, bolted to a vertical cliff on the right hank of the river, 600 feet upstream from the wagon brilge. The bench mark is top of east rail of the Santa lir track, 75 fret south of center of wagon bridge orer track. The zero mark of rorl is $12.8+$ feet below bench mark.

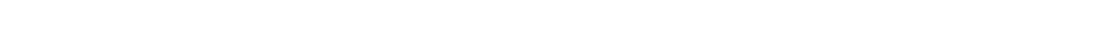
(")int!).

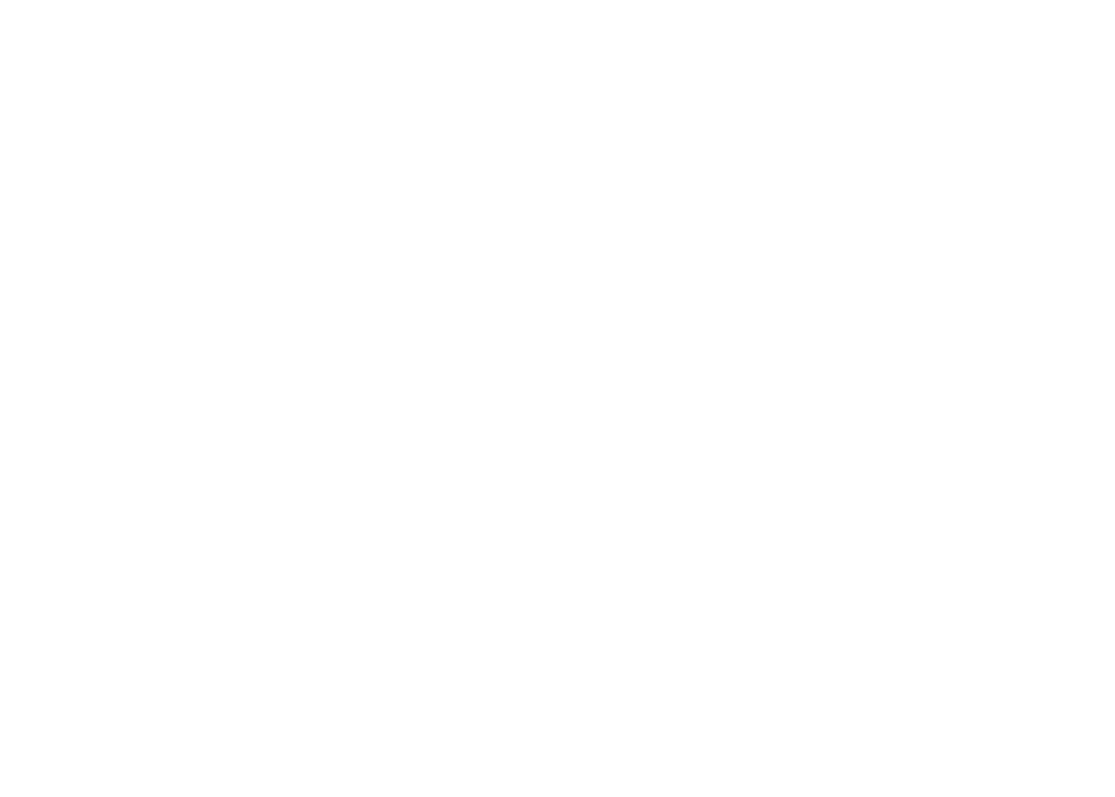

a Twenty-first Ann. Rej,t. L. A. ( teol. Survey, pt. 4, 1901, p. 4\%. 


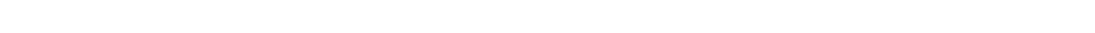

Date.

1901.

Feb. 11

Mar. 4

Mar. 25

Apr. 9

Apr. 27

May 10

May

Jume 10

Jume 2.;

July 12

July as

Ang. \&

Aug. 31

Sept. 6

Sept. 20

Oct. 5

oct. : 24

Nov. 6

Nov. 2.t

Dec. 10

Dec. 25

190 ․․

Jan. 4

Jan. 21

Feb. 1

Feh. 25

Mar. i

Mar. 29

Apr. 5

Apr. 19

Apr. 26

May 10

May 2.5

June 8

June $2 \%$

July is

July 26

Ang. 9

Ang. 15

Oct. 20

Oct. :30

Nov. 10

Nov. 27

Dec. 11

Dec. 19

Dec. $2 \%$
Hydrographer.

S. Cr. Bemmett .

P. H. Leahy

do

(l)

(1)

do

do.

do

do

ro

di)

do

.. do

... de

....do

do

do

(d)

do)

(d)

dis

- do

do

do

di)

dis

do

. . . do

. . do

... . do

. . . do

. . . do

do

(1)

do

do

-

Gage
height.

Feet. rece-fect.

$1.4 \quad 664$

$1.3 \quad .12$

$.9 \quad 50$

$.9 \quad 39$

() $\quad 48$

. 85 t 45

.85) 51

.8. 43

.942

.9 40

. 142

.9) 45

.9 5

.9) 49

.) 61

.9 57

$.9 \quad 82$

\begin{tabular}{l|l}
.9 & 78
\end{tabular}

.) 76

$.9 \quad 76$

$\begin{array}{ll}.9 & 69\end{array}$

$.9 \quad 4 i$

$.9 \quad 53$

.9 58

.) 63

\begin{tabular}{l|l}
.9) & 66
\end{tabular}

.9 66

.! $6 r$

\begin{tabular}{l|l}
.9 & 62
\end{tabular}

47

$3 \pi$

49

53

$4 \%$

38

41

48

33

49

4.5

43

5)

$6 \mathrm{x}$

69

5.) 
Estimated monthly alise-harge of Mohare River at Firtorville.

[Drainage area $\psi(n)$ square miles.]

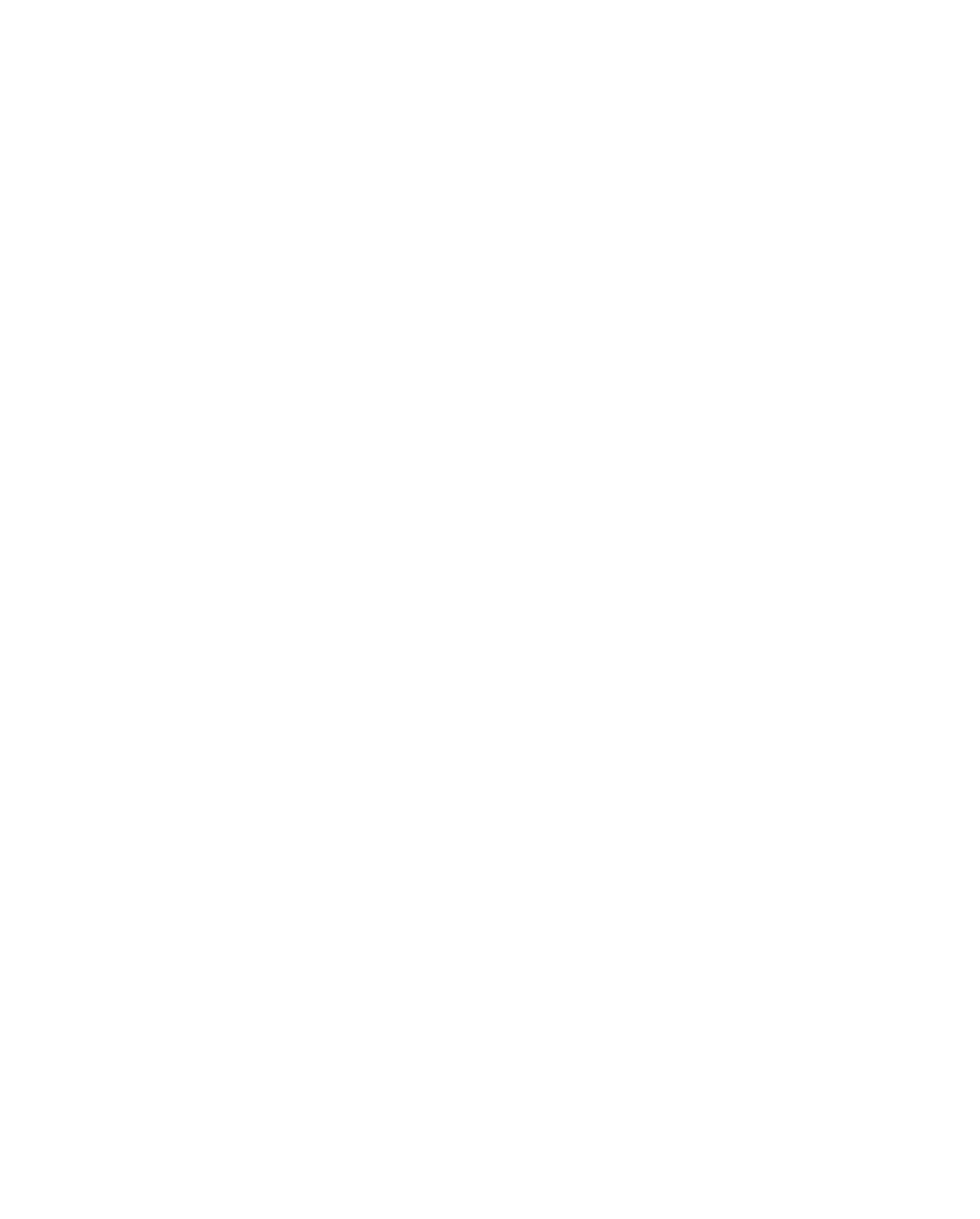


Estimated monthly discharge of Moharer Rives at Tietoreville-Continued.

\begin{tabular}{|c|c|c|c|c|c|c|}
\hline \multirow[b]{2}{*}{ Month. } & \multicolumn{3}{|c|}{ Diseharge. } & \multirow[b]{2}{*}{$\begin{array}{l}\text { Total dis- } \\
\text { charge. }\end{array}$} & \multicolumn{2}{|c|}{$R-n-\cap f f}$. \\
\hline & Maximum. & Minimum. & Mean. & & $\begin{array}{c}\text { Per } \\
\text { square } \\
\text { mile. }\end{array}$ & Depth. \\
\hline 1901. & siteffeet. & Sice-fect. & sereffeet. & Acre-feet. & I. Sere-foet. & Inehes. \\
\hline January ... & 4,180 & 50 & 183 & 11,252 & 0.46 & 0.53 \\
\hline February ... & 4.820 & 50 & 925 & $51,3 \% 2$ & 2. 31 & $\stackrel{2}{2} 41$ \\
\hline 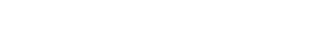 & 660 & $\pi)$ & 178 & 10, & .45 & .52 \\
\hline April .... . . . . & 44 & 44 & 44 & $\stackrel{2}{2}, 61 x$ & .11 & .12 \\
\hline 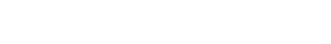 & 49 & 49 & 49 & 3.013 & .12 & .14 \\
\hline June . . . . . . . . & 42 & 42 & 42 & 2,499 & .11 & .12 \\
\hline July _.......... & 40 & 40 & 40 & 2,460 & .10 & .12 \\
\hline Auguist .......... & 50 & 30 & 50 & $3,0 i 4$ & .13 & .15 \\
\hline September ... . . & $\pi$ & i.) & 55 & 3,273 & .14 & .16 \\
\hline October ............... & 69 & 69 & 69 & 4,243 & .17 & .20 \\
\hline November . & $\pi$ & $\pi$ & $r$ & $4,5 \times 2$ & .19 & .21 \\
\hline December....... & $\% 3$ & 73 & 73 & 4,489 & .18 & .21 \\
\hline The year ..... & $4,8: 0$ & 40 & 149 & 103,820 & $.3 i$ & 4.89 \\
\hline 1902. & & & & & & \\
\hline Jantuary ....... & 53 & $4 \tilde{\imath}$ & 50 & 3,074 & .13 & .15 \\
\hline February ........... & 63 & 58 & 60 & 3.332 & 1i & .16 \\
\hline March .. . . . . & 66 & 66 & 66 & $4,0.58$ & $.1 \%$ & .20 \\
\hline 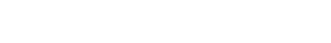 & $6 i$ & $4 \pi$ & 59 & 3.511 & .15 & .17 \\
\hline 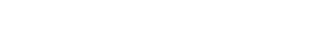 & 49 & $3 \pi$ & 43 & $\stackrel{2}{2}, 644$ & .11 & .13 \\
\hline June ..... & 53 & $4 \tau$ & 50 & $2,97,5$ & .13 & .14 \\
\hline July . . . . . . . & 41 & $3 \pi$ & 40 & 2,460 & .10 & .12 \\
\hline August & $4 n$ & 33 & 40 & 2,460 & .10 & 12 \\
\hline September ........ & (a) & $(a)$ & $($ (i) & 2,618 & .11 & .12 \\
\hline October $\ldots \ldots \ldots$ & 49 & 45 & $4 i$ & 2,890 & .12 & .14 \\
\hline November ........ & 50 & 43 & 46 & $2,73 \%$ & .12 & .13 \\
\hline December . . . . . . . & 69 & i.) & 65 & $3,99 \tau$ & .16 & .18 \\
\hline The year & 69 & 33 & 51 & 36,756 & .13 & 1.76 \\
\hline
\end{tabular}


MOKELUMNE RIVER.

The Mokelumne River drains 537 square miles of the western slopes of the Sierra Nevada above Electra, Cal. A gaging station was established at this point by Burr Bassell, C. E., while employed by the Standard Electric Company. Daily gage readings were taken from January 1 to June 30, 1901, and numerous meter measurements were marle.

Discharge measurements of Mokelumne River. Amador ('onnty.

\begin{tabular}{|c|c|c|c|c|}
\hline Date. & Hydrographer. & $\begin{array}{l}\text { Gage } \\
\text { height. }\end{array}$ & Discharge. & Locality \\
\hline$--\cdot$ & $\ldots--\ldots \ldots$ & $\ldots$ & $\ldots$ & $-\quad-$ \\
\hline 1900 & & Feet. & second-feet & \\
\hline Sept. 12 & S. G. Bennett & & $3 i$ & $\begin{array}{l}\text { Amador ditch at Camp Ta } \\
\text { beaud. }\end{array}$ \\
\hline $\begin{array}{c}\text { Sept. 12 } \\
1901 .\end{array}$ & - do - & & 4.8 & Butte ditch ahove Electra. \\
\hline Jan. « & B. Bassell & ว. 9 & $1 . \pi 1 \%$ & Electra. \\
\hline Feb. 4 & $\ldots d o \quad \ldots$ & 4.2 & $60 \mathrm{~s}$ & Do. \\
\hline Eeb. 1. & $\ldots d n$ & 4.8 & 966 & Do. \\
\hline Feb. 19 & $\ldots d o \ldots$ & 11.0 & 13,213 & Do. \\
\hline Feb. 22 & $\ldots$ do ..... & 8.6 & $6,3: 30$ & Do. \\
\hline Feb. 26 & $\ldots$ do $\ldots . .$. & $\pi .4$ & 3.846 & Do. \\
\hline Mar. 4 & $\ldots$ do ..... & 6.6 & $2,72: 3$ & Do. \\
\hline May & $\ldots d 0 \ldots . . .$. & 6.2 & 2,232 & Do. \\
\hline $\begin{array}{c}\text { May } 21 \\
1902 .\end{array}$ & $\ldots$ do .... & 6.7 & 3,016 & Do. \\
\hline Aug. 14 & E.T.Perkins & & 51 & Do. \\
\hline Ang. 14 & - do ........ & - - & 30 & Electra power plant discharge. \\
\hline 189.5. & Total $\ldots$ & & 81 & \\
\hline Jan. 6 & J.B. Lippincott. & 12.25 & 1,063 & Lodi." \\
\hline Mar. 20 & $\ldots$ do ........ & 8.0 & 1,068 & Do. \\
\hline $\begin{array}{c}\text { Ang. } 27 \\
1899 .\end{array}$ & $\ldots$.... do ...... & 1.3 & 91 & De. \\
\hline Aug. 20 & $\ldots$ do $\ldots . .$. & & 56 & Do. \\
\hline Sept. 14 & S. G. Bennett . & & 33 & Mokelumme Hill. \\
\hline
\end{tabular}

a Capacity of ditch, 64 second-feet: 25 second-feet carried ont of basin to Jackron and sutter. Authority, Burr Bassell.

$b$ The Woudbridge diversion dam, 2 miles below Lodi, affects guge heights 
Discharye messurements of Dokelumue River, Amator C'ounty-('ontinued.

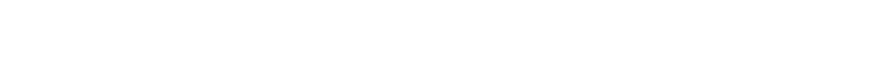

1900 .

Sept. 12 S.G. Bennett

fieet. $\mid$ sire tert.

1.) Mokelumne Hill.

$190 \%$.

Ang. 10

Ang. 16

. do

2.4

40 Wordbridge canal at head.

Aug. 1:

L. Lawson

3.0

Do.

Ang. 1:3

S. G. Bennett

29

33

At Woodbridge.

Ang. 14 do

1.0

67

$\frac{1}{6}$ mile below Lancha Plana dam.

51

Amador ditch. ! mile above tunnel.

Aug. $14 \quad \ldots$... du

ij) Standard Power Canal at flume No. 59, near Electra.

Ang. 1, ..... do

21 Mokelumne ditch in flume. South Fork Mokelnmme River.

Ang. 15, ..... d

1.7 Middle Fork, 150 feet below bridge near West Puint.

Aug. 15 .... do

(i) North Fork, $\frac{3}{3}$ mile alove bridge near West Point.

Aug. 16 ..... rho

t. $s$ Mokelumne ditch, 2 miles sontheast Fort Mountain, South Fork.

Ang. 14

L. Lawson

(i.) Clements.

Ang. 1.j

(lo)

$126 \quad \frac{1}{4}$ mile below Lancha Plana dam. 
Estimated monthly dischargr of Hokehumne River at Lome Star Mills."

[Drainage areal bri square miles.]

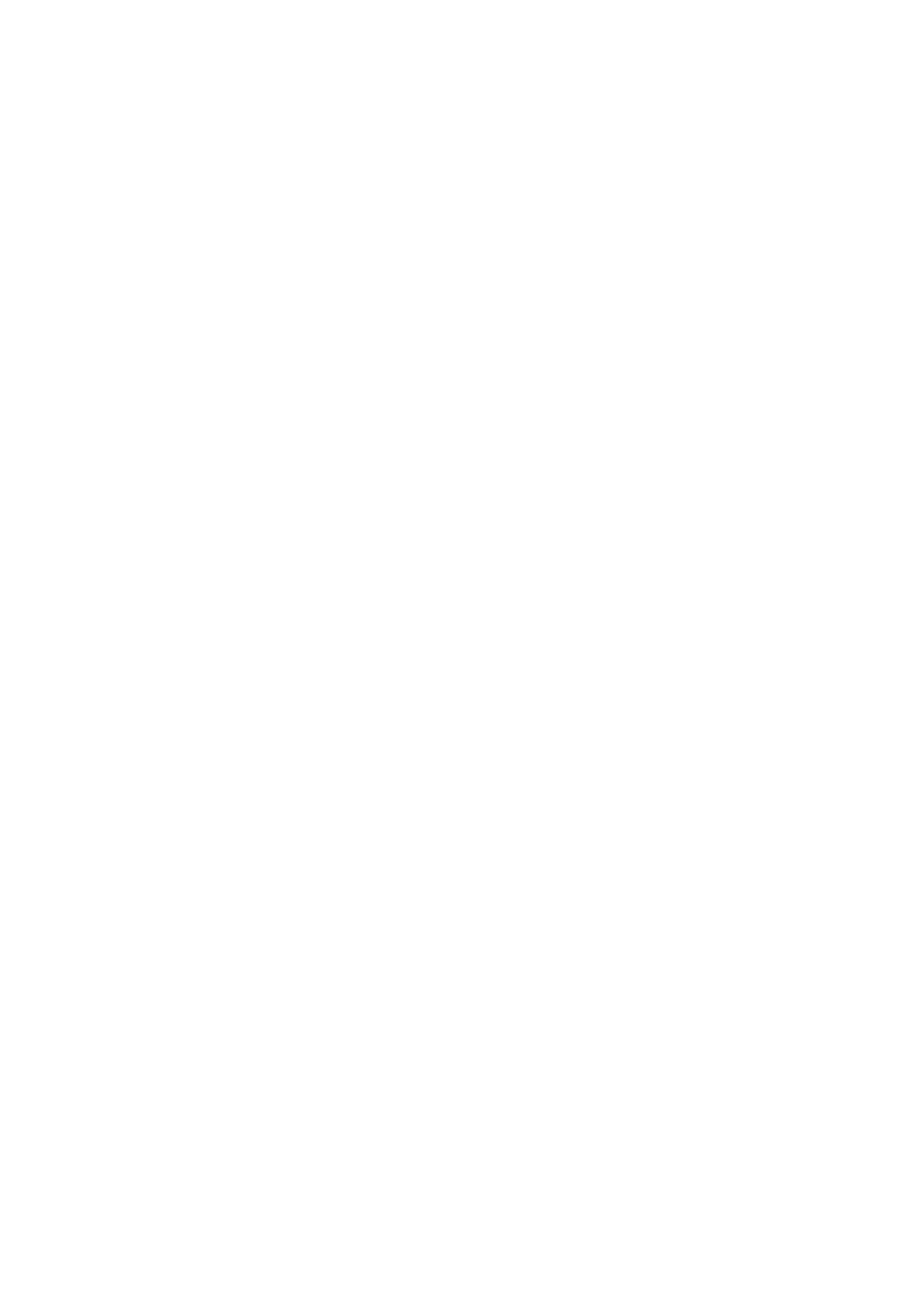

"Authority, California State engineering department.

b Estimated from r'un-off of neighboring streams and from provious measurements. 
Estimated monthly discharge of Mohelumme River at Lome Star Mills-Cont"d.

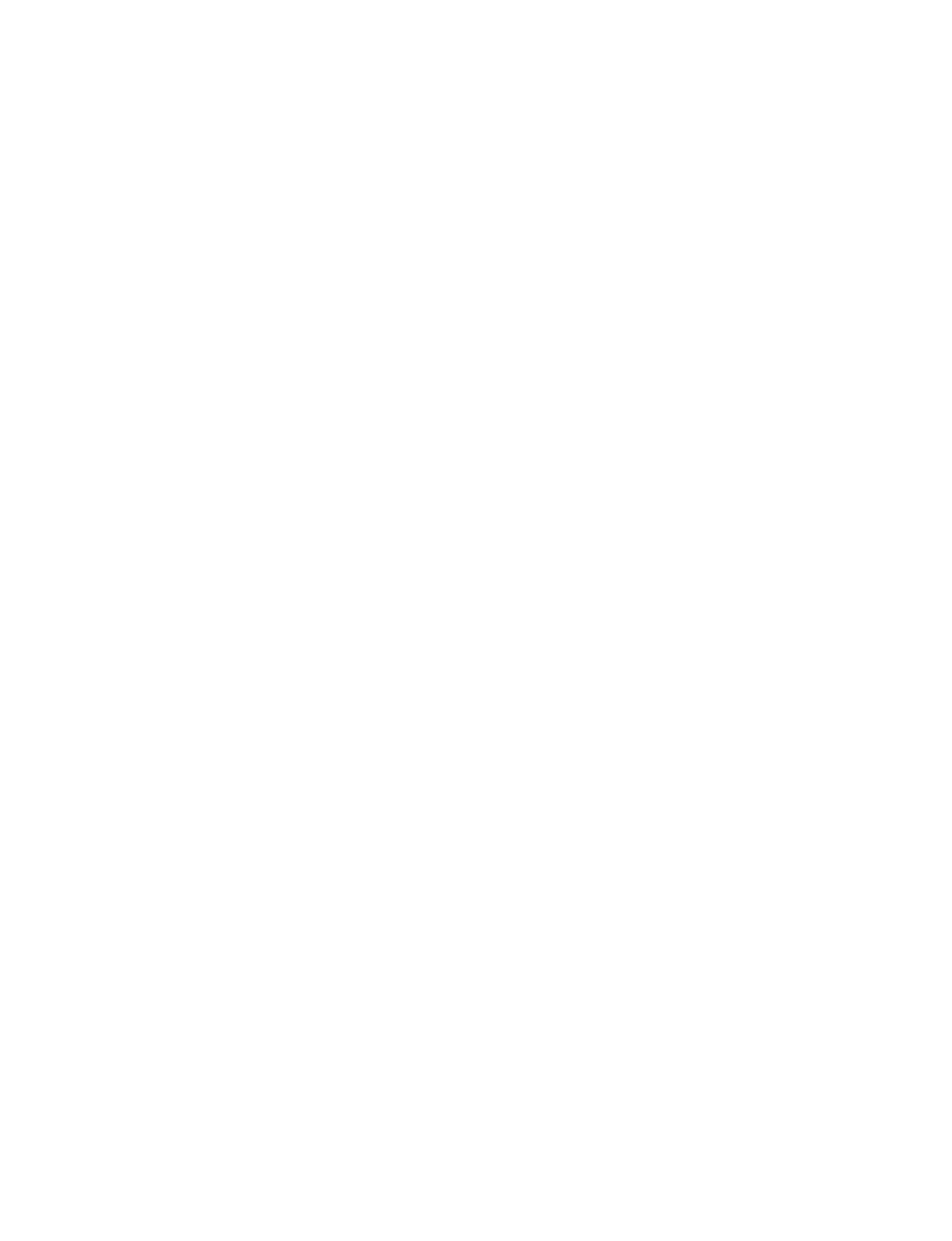

¿ Fstimated from run-off of neigllboring streams and from previous measurements 


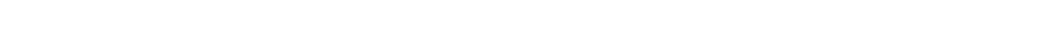

\begin{tabular}{|c|c|c|c|c|c|c|}
\hline \multirow[b]{2}{*}{ Month. } & \multicolumn{3}{|c|}{ Discharge } & \multirow[b]{2}{*}{$\begin{array}{l}\text { Total dis- } \\
\text { eharge. }\end{array}$} & \multicolumn{2}{|c|}{ Run-off. } \\
\hline & & Minimtum & Mean. & & $\begin{array}{l}\text { Per } \\
\text { siluare } \\
\text { mile. }\end{array}$ & Deptl.. \\
\hline 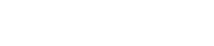 & sicer-fied. & sieregfeet. & Shereforet. & frefefeet. & strefert. & Iuches. \\
\hline January . .... & & & 414 & 35,456 & $0.6: 3$ & 1). .3 \\
\hline February - & & & $3: 8$ & 18,216 & .50 & .52 \\
\hline March ....... & & & 591 & 36,339 & .90 & i. 104 \\
\hline April ....... & & & 1.91 & 117.243 & 3.00 & 3.35 \\
\hline May ... _. & & & 3.948 & 242,384 & 6. 00 & 6.92 \\
\hline June . . . . . . & & .. & $\because 628$ & 156.374 & 4.00 & 4. 46 \\
\hline July _... . . & & $\ldots \ldots$ & (65) & $40,39 \pi$ & 1.00 & 1.15 \\
\hline Angust . . - & & $\cdots$ & 263 & 16,171 & .40 & .46 \\
\hline September .... & & $\cdots$ & 98 & $\bar{\pi}, 8: 31$ & .1 .7 & .17 \\
\hline October .... & & $\ldots$ & 9 & 4,026 & .15 & .17 \\
\hline November.... & & - & $13:$ & 5.8 .5 .5 & .90 & .22 \\
\hline December.... & & & 132 & 8.116 & .20 & .23 \\
\hline The year & & & 938 & $6 \$ 0,451$ & $1.4: 3$ & 19.42 \\
\hline $1884 . "$ & & & & & & \\
\hline Jannary . . - & & & 164 & 10,084 & .25 & .29 \\
\hline February & & & $1.9 \% 1$ & $113,33 \%$ & $: 3.00$ & 3. 24 \\
\hline March . ... & & & 3.949 & 942.384 & (i. 100 & 6.92 \\
\hline April ...... & & & 3.942 & $2: 34,565$ & (i. 110$)$ & 6. 69 \\
\hline May ..... & & & 3,245 & ב 201, & 5.00 & 5.76 \\
\hline June....... & & & 2.95 & 175,954 & 4.50 & 5.12 \\
\hline July - - & & . & 2,628 & 161, ואיאו & 4.00 & 4.61 \\
\hline August ... - & & . & $6 . \pi$ & $40.39 \%$ & 1.00 & 1.15 \\
\hline September ... & & ...... & 131 & 7.79 .5 & .20 & .22 \\
\hline Octoher & & & 98 & 6,026 & .15 & .17 \\
\hline
\end{tabular}




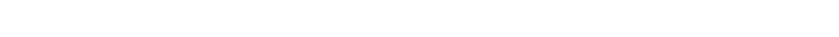

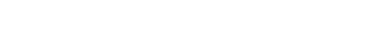

$$
\text { Diselharge. }
$$

Month.

(11)1.

January

Februar.

March

April

May

Trune

July

Augunt

Septemher

October

November.

\section{Maximum.}

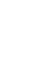

$$
\text { 4. }(i 00)
$$

13. 210

+. 0201

3.16()

5.

(i. $2 \div 10$
Minimu

Yrating
Toutal dirharge.

\section{1}

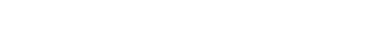

Rui:-riti.

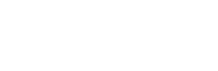

lerentiof. Sire-fuet. Inteles$$
3: 311
$$

$1 .(1)(1)$

61. 4is

1. 86

$\because 14$

(i10

3.3012

$1+3: 3,384$

(i. 1.5

(i. 41$)$

1. $1: 31)$

2,0104

123. 291

:3. 203

1. 30

(1), ()

?. () $4(1$

1:1.

:3.

4. 24

1. 9601

4, (i2)

254, 30 ,

‥ 62

9.93

1. 3.30

:1, $5: 3: 3$

29.145

. 14

ร. $9 \%$

200

1 1.,

$.4 x$

. .).

190

11. 643

.35

.40

(i)

3. $5 \%$

.1

. 12

76

210

4. 67:3

.16

12. 496

.44

"Authority. Lnited Siatestreolugu'al Surver.

MONO LAKE DRAINAGE.

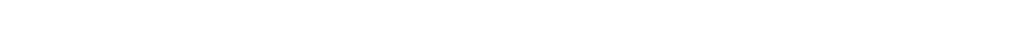

Date.

Hỵdrospaphe'r

Discharge

Sireforte

July :9. 1!n: F. H. (1husted

July :30. 190! _ _ do

Aug. 1. 1910: -.. - ilo.

Do . . . . . do

Do . . . . . . . d d
46. i.) Mill Creek, just below Lumrly Lake and above all diversions.

ห!). 101 Leevining, just ahove Rhinerlollar Lake.

26.30; Walker Creek, wasterly from Blondy Canyom.

21.65.j Parker (reek.

(i2. 40 Rukh (reek, alowe ,ilver Lake,

\section{NIAGARA CREEK.}

Sire Nianislaus Rivor, Nianara crook.

\section{OWENS RIVER.}

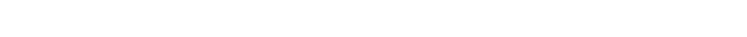

Dite. Hydrographer. 'Dischargi. Luratity.

Aug. f. 1901 F. H.(1)msterd -.

Do (1) 


\section{PACOIMA CANYON.}

See Ios Amgelos River, Patroima.

PADARO CREEK.

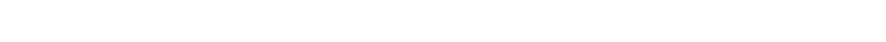

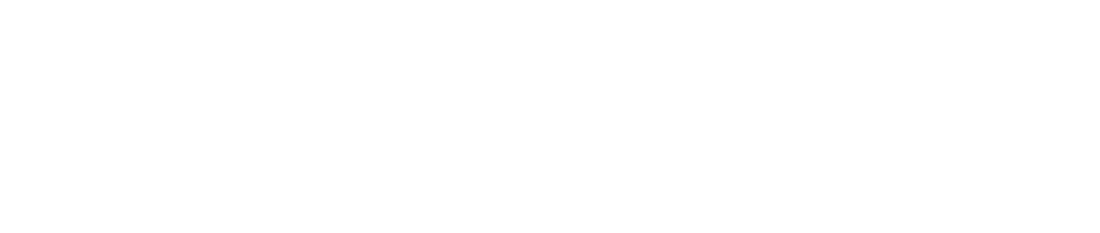

PALLETT CREEK.

See Big Rock Creek, Pallett Creek.

PASADENA MESA.

UNDERGROUND WATER OBTAINED FROM THE BED OF ARROYO SECO AND PASADENA MESA.

An examination of the underground water supply in the vicinity of Pasadend was made by Mr. .T. B. Lippincott in October, 1898, the results of which are given in the following paragraphs:

Pasadena Mesa, lying south of the Sierra Madre, is bounded on the west, along the eastern bank of Arroyo Seco, by a low ringe of granite and clay hills; on the south by Raymond Hill, which is of sandstone, and by a dike, the capping of which apparently consists of adobe or clay. This dike extends from Raymond Hill, on the south side of the city of Pasarlena, in a direction a little north of east, throngh Sumy Slope and Baldwin ranches to the base of the Sierra Madre near the mouth of Santa Anita Canyon. The mesa proper consists of leposits of sand, gravel, and bowlders, the larger bowlders lying near the monntains and the finer material near the sonthern slope. The voids in this absorbent material act as a storage reservoir, being filled by the flood waters issuing from the steep slopes on the southern face of the Sier": Madre. The underground waters are reenforced by the return water from irrigation on the mesa. From 1893 to 1902, inclusive, was a period of unusual drought, but most of the developments were new in 1898.

Arroyo Seco, llaining 21 square miles of the Sierra Tadre, issues from these momtains on the north side of Pasadena Mesa, passes through an opening in a granite spur known as Derils Gate, and joins Los Angeles Rivar at Ios Angeles. between the point where the water from this basin issues from the momtains and Derils Gate lies a broad river botioun 2 miles in length, composed of coarse material. In passing over this the water sinks rapidly, diminishing in volume from the mouth of the canyon to Devils Gate. 
Pasadena water companies have built (xtensive development tunnels above Devils Gate, cross cutting beneath the eastern bank and under the mesa land. A submerged dam at Devils Gate assists the tunnel developments by intercepting the underflow. An examination of these tumnels shows that no imperviou: stratum is encountered after the granite ledge at Devils (tate is passed. Of the water obtained from these development works, 6! per cont is gained from the portion of the tumnel which is beneath the mesa. A well about

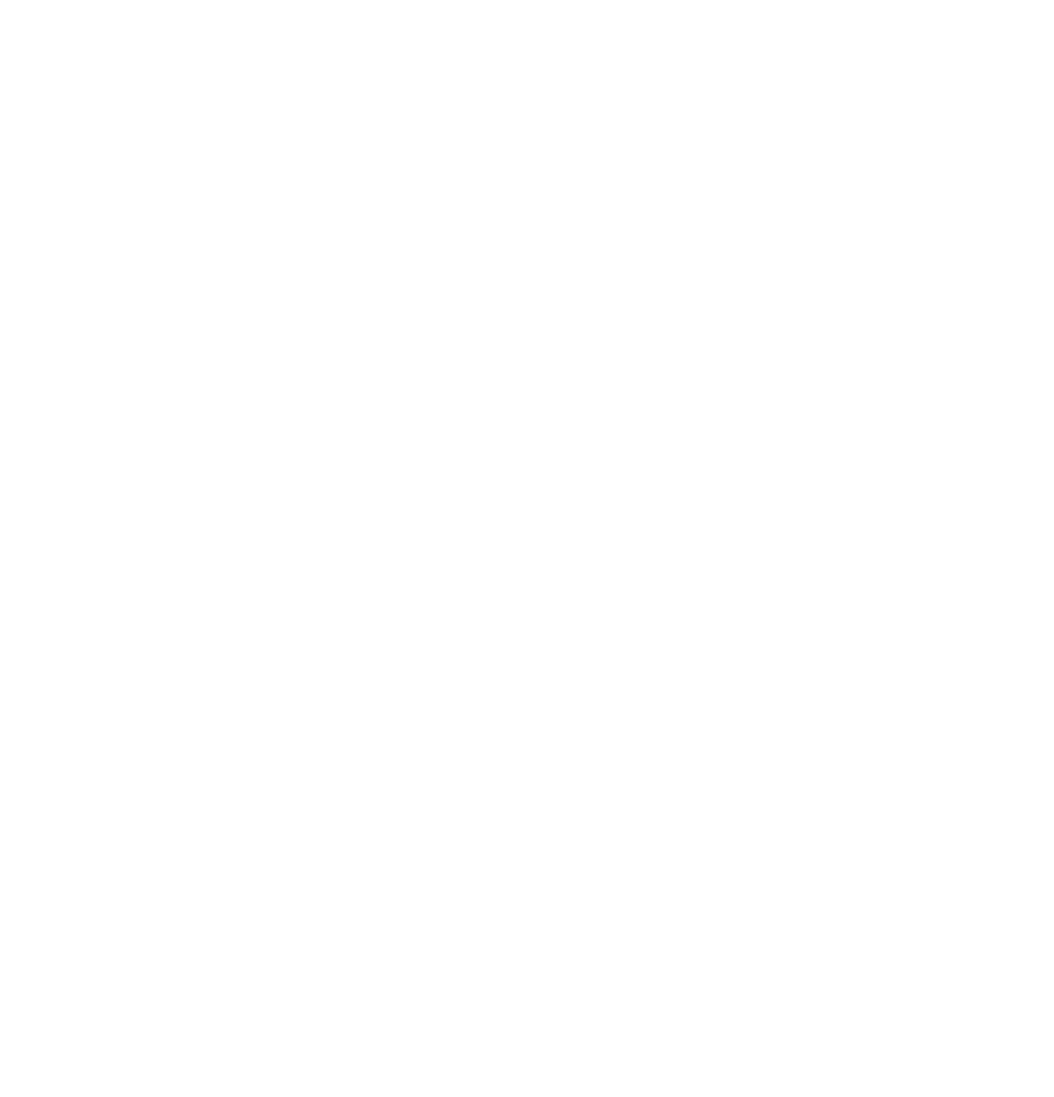

Fıg. 3.--Map showing location of wells near Pasadena.

4,000 feet upstrean from the tumnel and 200 feet doxp, in the bed of the wash near the mouth of the mountain canyon of the Arroyo seco, was drained hy the extension of this line of tunnels maler Pasadena Mesa.

From the investigations the conchusion is reached that to water from Arroyo seco which sinks brtween the mouth of the ranyon proper and Devils (tate passes nucler the eastern hank of Arroyo Seco between these points and augments the underground water of 
lasadena Mesa. (otherwise it would be difficult to aceonut for the large amount of water whirh is obtained from the lower development workis at the southern dike of Pasadena Mesa. This mesa is underlain throughout with a sheet of water extending from the foot of the mouniains, where its depth below the surface is from 150 to 200 feet, to the dike at its soithern exposure, where the water is practically at the surface, making itself manifest in numerous small springs which rise in drainage lines on the southern face of the dike. With the exception of the Arroyo Seco developments, which in the tabulaticns are classified by themselves, tho principal water product of this mesa is obtained along these drainage lines from the springs. Numerous wells from which water is pumped have been sunk and tumnels have been run through the dike into the water-bearing gravel.

An interesting feature of these development works is the constant strife axisting between the various tunnel and well owners along the dike. For instance, the owner of a certain piece of property discovered by a tumnel the presence of a considerable body of water on his land; his neighbor to the south, whose land is at a lower elevation, drained the first tumel by digging another on a lower grade and extending it to his northern property line. This has been done repeatedly, in some aases the water having been so diverted hy two or three owners in succession.

The wells aro usually bored and are lined with 7 -inch r.sing. South of the santa Fe Railroad a (harge of 50 cents a foot is mate for completing the first 5 () feet in depth of the well, with an increase of 50 cents per foot for each additional 50 feet in depth. North of the railroad, where the bowlders are larger, a charge of from 10 to 20 per cent more is marle for boring. These prices do not include the cost of casing. The data given below concerning depth of wells and depth of water werr in nearly all cases obtained from statements made by the owners.

()n the following pages is given a compilation of facts with reference to the depth of water in wells through the district and a summary of the water crop from the principal development works. It has heen imposibible to form an exact estimate of the amount of water taken for domestic use and for minor irrigation purposes from the larese number of small wells on the mesa, but the water from the larger developments has been arenrately measured and included in this summary.

JUSCRIPTION OF WELLS IN PANADEXA MESA."

1. Gidding: on colorado street between Hollister and Chester streets: elevation. 815 feet; depth to water, 103 feet; dug mostly throngh gravel with no hardpan: digging cost $\$ 1$ per foot and 25 cents extra for every 25 feet additional: 109 feet deep, with 6 feet of water: elevation of water, $r 12$ feet.

"The unit of measurement is the california miner's inch, which is (I.t) of 1 enbic foot per second. 
2. McCallum; Colorado street, in McCallum wash; elevation, 785 feet; 151 feet deep; was dug originally 83 feet: at 90 feet sandstone for 10 feet; 101 feet from surface to water: 50 feet of water; elevation of water, 684 feet; water raised by windmill.

3. Hoover; a bored well with windmill: 115 feet deep, with $1 \tau$ feet of water; eleration, $7 \% 5$ feet; water elevation, 67 feet.

4. Moses; bored well; 200 feet deep; elevation 790 feet; water elevation, 684 feet; origi: ally 100 feet of water, now 94 feet, commencing 106 feet from the surface; $1 \frac{1}{2}$-horsepower gasoline engine with 8-inch stroke, 3-inch cylinder, pumping 1,000 gallons an hour.

5. King: $22 \%$ feet deep; elevation, 800 feet: water elevation, 678 feet; originally 117 feet of water, now about 10.5 feet; water raised by an engine with 12 -inch stroke and 4-inch cylinder, pumping 2.500 gallons per hour.

6. Stevens; 121 feet deep; 31 feet of water; 90 feet to water surface: elevation, 781 feet; water elevation, 691 feet; was dug thirteen years ago.

7. McAdam; 150 feet deep; 5 ; feet from surface to water: elevation, 740 feet; water elevation, 683 feet.

8. Merwin: 95 feet deep; 55 feet to water; elevation, 735 feet; water elevation, 680 feet; pump capacity, 20 gallons per minute: costs $3 \frac{1}{2}$ to 4 cents an hov $r$ to run engine with gasoline.

9. Butler: bored well; 93 feet deep; 48 feet from surface to water, orig nally $\mathbf{4 0}$ feet; elevation, 718 feet: water elevation, $6 \tau 0$ feet.

10. Hutchinson; bored well; 230 feet deep; 36 feet from surface to water; elovation. 713 feet; water elevation. $6 \%$ feet: well bored throngh clay; pressure comes from below.

11. Daniels; $10 \tau$ feet deep; 40 feet from surface to water; water 6 i feet deep; elevation, 71.5 feet; water elevation, 675 feet; strata of clay and bowlders with coarse gravel at bottom were encountered.

12. Hodge; 169 feet deep; 33 feet to water; elevation, 20 feet; water elovation, 692 feet.

13. Miles; bored well: 225 feet deep: 143 feet to water; elevation, $81 \%$ feet; water elevation. 674 feet.

14. Wilkeson: 1 i千 feet deep: 30 feet from surface to water; elevation, 720 feet; water elevation, 690 feet: Jack Butler, well borer, says that wells during 1898 were 15 feet lower than in previous years.

15. Ackerman; bored well: 149 feet deep: 7.5 feet from surface to water: elevation. 710 feet; water elevation, 63.) feet.

16. Thorndyke; 2.5 feet deep; 30 feet from surface to water; elevation, 705 feet; water elevation. 67.5 feet: fine clay encountered at 69 feet and $\% 3$ feet from surface, the remainder being gravel strata.

17. Lamanda Park; 180 feet deep; originally 80 feet from surface to water: elevation, it0 feet; present water elevation, 680 feet.

18. Titus; 558 feet deep; from surface to water. 12 feet, originally 4 feet; elevation, 690 feet: water elevation, 6r8: several strata of cement 1 inch thick were encountered.

19. Butler: 1\%j feet deep; 75 feet from surface to water; elevation, 720 feet; water elevation, 64.) feet.

20 . Graves: 88 feet deep; 40 feet from surface to water; elevation, 20 feet; water elevation, 680 feet.

21. Krouser; 113 feet deep: 15 feet from surface to water: elevation, 700 feet; water elevation, 68.5 feet.

22. Wakefield: 00 feet deep: originally 20 feet to water, now 30 feet; elovation, 703 feet: water elevation, 6 ; 3 feet.

IRR $81-0.3-12$ 
23. Pavey: 360 feet deep: water elevation, $6 \% 0$ feet; origimally flowed 16 miner's inches of water: still flowing, but in less volume.

24. Chapman: flowing well: 17.5 feet deep. There are about 12 wells flowing on this ranch.

25. Hassleys; 500 feet deep; elevation. 600 feet; originally artesian. but now cut by a tunnel at a lower elevation.

26. Raymond; 40 feet to water. which is 4 feet deep: water fell 2 feet during season of 1898; 91 miner's inches of water were pumped from this well during October, 1898; well is brick lined and 12 feet in diameter.

2\%. Marengo tunnel; run into Raymond's hill at Terminal Railway, Fair Oaks station; it is discharging 18 miner's inches. This tumnel draine 1 a small tunnel on the west side of Fair Oaks avenue.

28. Fluer; dug well, Ipswich street; depth, 48 feet; water, 12 feet: dug in October, 189\%; at first there was a supply of 50 miner's imches, but the supply las diminished to 30 miner's inches; a 6 -inch centrifugal promp. with 20 -horsepower engine, pumps out the well in 1.5 hours.

29. Stoneman tumnel; was first rum in 1890, 178 feet, and in surmer of 1898 was extended 164 feet; flows 14.4 miner's inches.

30. Graves tunnel; 530 feet of tumnel and about 100 feet of ditch: water 26 feet below the surface of the ground at the upper end: 20 miner's inches of water obtained.

31. Oak Knoll: about the same class as Rhodes well and discharging the same amount of water, 4 miner's inches.

32. Brickyard well; mear Lake aveme, northeast from Oak Knoll; 40 feet of well are through clay, $\gamma$ feet throngh sand and gravel; $r$ miner's inclres of water is obtained: this is a brick-lined dug well.

33. Rhodes well; near corner of Lake avenue and Hawkeye st"eet: 49 feet deep and water approximately 8 feet in depth: steam plant, 15-horsepower boiler. with Smith valve pump: a continuous flow of 4 miner's inches is obtained.

34. Alhambra water, in Maybərry Canyon; 64 miner's inches is obtained, which is not the full capacity of the plant. There are six wells, from 350 to 750 feet deep, of which five are being pumped and one flows.

35. Patton tunnel, near Kewen Lake: produces $\gamma$ miner's inchas.

36. Surface water; Patton water in West Canyon, 2 miner's inclres.

3\%. Patton water. East Canyon; 24 miner's inches. (San Gabriel water not included in this.)

38. San Gabriel Mission; 24.9 miner's inches; comes from tha same canyon as Patton water in East Canyon; it is surface water and has been reduced by development works.

39. Shorb water: from tunmel under orange grove on Shorb place; approximately 2 miner's inches is obtained. In small canyon northwest of house there is a stream. approximately 5 miner's inches; there are three artesian wells (No. $42)$ southeast of the ranch house, from which 17 miner's inches is obtained.

60. Lower Painter well; dng in 1894; 96 feet deep: water, 79 feet from surface; elevation. 1.040 feet; water elevation, 961 feet; this is a 4 -foot by $\%$-foot dug well. the material passed through being large bowlders.

61. Upper Painter well; dug well much resembling No. 60: 162 feet deep; 132 feet to water: elevation, 1,129 feet; water elevation, 997 feet.

62. Becker; 200 feet deep: depth to water. as measured in May, 1898, 173 feet; a 6-horsepower gasoline engine is used which has pumped 5 miner's inches; it is a bored well; cost $\$ 250$. including casing (\$1 per foot plus 25 cents additional for each 50 feet additional depth); elevation, 825 feet; water elevation. 652 feet.

63. Stafford: bored well; 241 feet deep; deptl to water. 173 feet; elevation, 825 feet; water elevation, 652 feet. 
64. Krank; 30) feet deep; 290 feet to water: elevation, 1.070 feet; water elevation. 780 feet.

65. Meers; on E street; 300 feet deep; 75 feet of water in August, 1897; elevation. 1,060 feet; water elevation, 835 feet.

66. Stone; 100 feet deep; 85 feet to water: elevation, 1.040 feet; water elevation, 955 feet; approximately 15 miner's inches is obtained when pump is run. This is a dug and timbered well and cost for excavation $\$ 1.75$ per vertical foot until water was struck: passed through. say, 65 feet of gravel, 15 feet of sand, and 12 feet of clay.

6r. Called Painter well: 170 feet to water; 14 feet lower ground than No. 11; water elevation, $8: 30$ feet.

50. Hurlbut; bored well, about 1,300 feet deep; 95 feet through clay; bit little water; elevation, 816 feet; water elevation, 745 feet.

26. Olmsted: 39 feet deep; elevation. 750 feet; water elevation, 740 feet; the usual depth of water from the surface is 8 feet, but in October. 1898 , vas 10.5 feet.

51. Pasadena and Pacific power-house well: elevation, 750 feet; water stands 11 feet from original surface of ground: water elevation. 739 feet.

52. Baker; 35 feet deep; elevation, 740 feet; water elevation, 734 feet; supply is said to come from northeast.

53. Pasadena West Side Water Company; about ;0 feet deep and 3 feet to water; elevation, 718 feet; water elevation, 715 feet; water comes from northeast.

68. Morehouse; cesspool at this point of 70 feet and no water is encountered; surface elevation, $\% 90$ feet.

69. On top of a hill 500 feet east of No. 53; 60 feet deep and no water: found; surface elevation, 825 feet.

74. In Arroyo Seco, at mouth of canyon: 250 feet deep and dry.

Amomnt of water acveloped in Pasadena Mesa. October, 1898.

[1 miner's inch is 0.02 of 1 cubic foot per second.]

27. Raymond Improvement Company's tunnel at Fair Oaks avenue . . . . . . . 18

26. Marengo well, near Atchison, Topeka and Santa Fe station, Raymond _.. 91

26. Surface water in Marengo Canyon, near railroad crossing (Southern Pacific)

28. Fluer well on Ipswich street, near Santa Fe Raymond station; intermic-

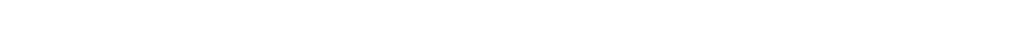

29. Las Roebles Water Company, near new Graves tunnel _............. 14

29. Stoneman Canyon heads, near Fluer well . . . . . . .

30. Walter Graves's new or upper tunnel _... . . . . .

31. Oak Knoll well $\ldots \ldots \ldots \ldots \ldots$

32. Brickkiln well

33. C. H. Rhodes's well, near Lake avenue and Hawkeye street . . . . . . . . 4

34. Allambra water, artesian wells and air-compressing plant _......... 64

35. Patton tunnel, near Kewen Lake .............................. 7

36. Patton water in west canyon

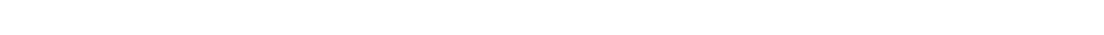

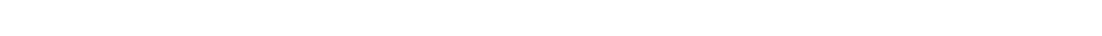

39. Shorb water northwest from ranch house ...................... 5

39a. Shorb water in timnel southwest of ranch hoise $\ldots \ldots \ldots \ldots \ldots \ldots \ldots$

40. Graves's lower tunnel (dry) _..... . . . . . . . . . . . . . .

41. Richardson's two tunnels, near Kewin Lake _. . . _ . . . . . . . . . . 18

42. Shorb's three artesian wells southeast of honse _.. . . . . . . . . . . . . . . 17

43. Pump, 13 inches; artesian, 3 inches; tunnel, 22 inches; all belong to Shorb. 38 
44. Rose well, east side Santa Anita avenue . . . . . . . . . . . . . . . . . . . . 20

45. Winston wells. Santa Anita avenue . . . . . . . . . . . . . . . . . . . . _ 12

46. Alexander water, east of Santa Anita avenue . . . . . . . . . . . . . 25

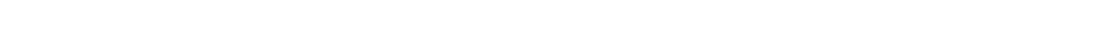

48. Sunny Slope developments . . . . . . . $\ldots \ldots \ldots \ldots$

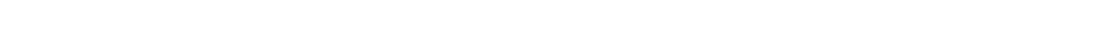

Total $\ldots \ldots \ldots 1$

Developments near Devils Gate by the United IHater Ciompanies.

56. Pumped from well below Devils Gate, but entering tunnel above sand box - 7

5\%. Weir at mouth of northeast tunnel _... . . . . . . . . . . . . . . . . . 8

58. Weir at mouth of northwest tunnel .......... . . . . . . . . . . . . 123

Total from Devils Gate ... . . . . . . . . . . . . . . . . . 138

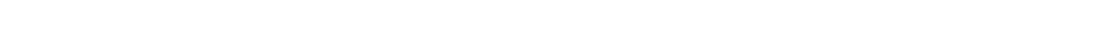

Total from submerged dam and from under arroyo above dam ....... 5

Flow from the 900-foot tunuel, east bank of arroyo, or six-tenths of whole

Devils Gate flow from tunnels . . . . . . . . . . . . . . . . . . . . . . . 77

70. Richardson tunnel below Devils Gate . . . . . . . . . . . . . . . . . . .

71. Wilson tunnel below Devils Gate . . . . . . . . . . . . . . . . . . . . . . . . . 10

Developed at Devils Gate . . . . . . . . . . . 138

Total upper arroyo development ...................... 172

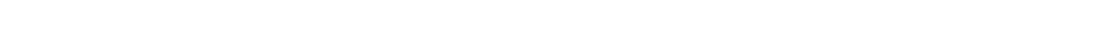

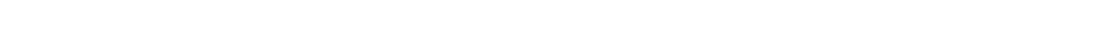

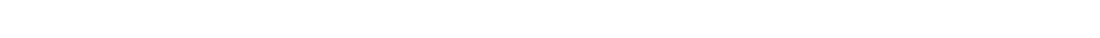

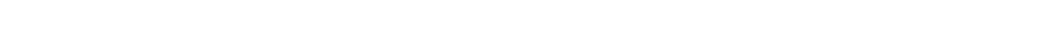

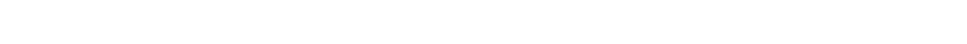

72. Sheep Corral Springs, in development cut _... . . . . . . . . . . . . . . 74

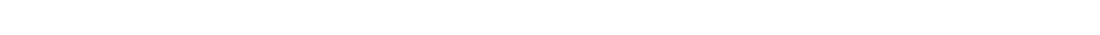

Summary of water development from Pasadena Mesa.

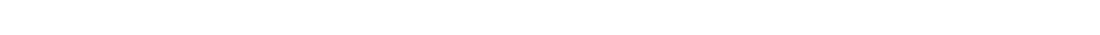

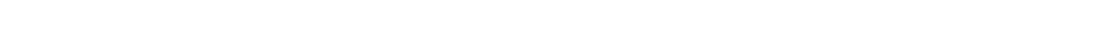

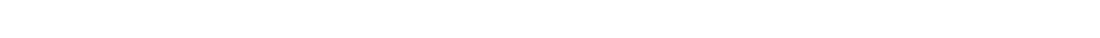

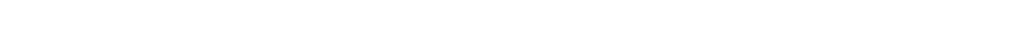

PASTORIA CREEK.

Discharge measurement of Pastoria C'reek, Kern County.

\begin{tabular}{|c|c|c|c|}
\hline Date. & Hydrographer. & $\begin{array}{l}\text { Dis } \\
\text { (harge. }\end{array}$ & Locality. \\
\hline $\begin{array}{l}\text { Nov. } 13,189.5 \\
\text { Dec. } 15,1896\end{array}$ & J. B. Lippincott . . & $\begin{array}{c}\text { see feet. } \\
0.04 \\
0.00\end{array}$ & $\begin{array}{l}\text { Mouth of canyon. } \\
\text { Road crossing. }\end{array}$ \\
\hline
\end{tabular}




\section{PESCADERO CREEK.}

Discharge measurement of Iescadern ('reek. San Mateo County.

\begin{tabular}{|c|c|c|c|c|c|}
\hline & Date. & Hydrographer. & $\begin{array}{l}\text { Dis- } \\
\text { ،harge. }\end{array}$ & & Iscality. \\
\hline Oct. & $1 \% .1893$ & & $\begin{array}{c}\text { Ser.feet } \\
\quad 4.6 \text { ir }\end{array}$ & 6 miles abov & Pescadero. \\
\hline
\end{tabular}

\section{PILARCITOS CREEK.}

Discharge measurement of Pilareitos Creek, San Mateo County.

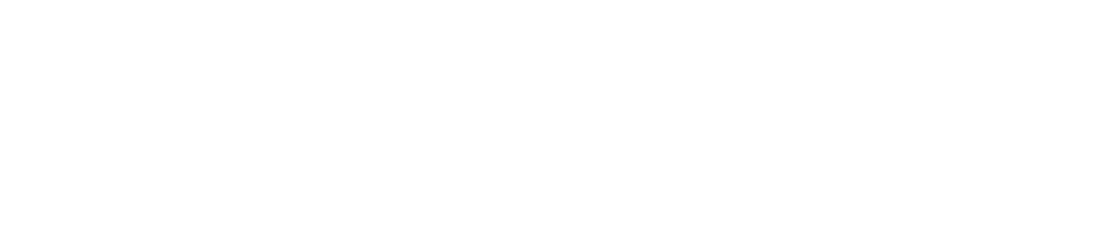

\section{PIRU CREEK.}

Discharge measurements of Pine creek. Tentura County.

\begin{tabular}{|c|c|c|c|c|}
\hline Date. & Hydrographer. & $\begin{array}{l}\text { Gage } \\
\text { height. }\end{array}$ & $\begin{array}{l}\text { Dis- } \\
\text { rharge. }\end{array}$ & Lorality. \\
\hline & & Feet. & ser-gect. & \\
\hline Mar. 111.1895 & J. B. Lippincott . & 0.27 & 3.54 & Robertson Mill. \\
\hline Jan. 21,1896 & S. Stewart ....... & & 18.00 & Smith:s. \\
\hline Jan. 31,1896 & J. B. Lippincott . . - & $1 . \pi$ & 13.30 & Do. \\
\hline Aug. $11,189 \times$ & F. H. Olmsted ... & & 0.92 & French House. \\
\hline Dec. 15, 1896 & J. B. Lippincott . - & & .20 & $\begin{array}{l}\text { Gorman Creek below Gor- } \\
\text { man Station. }\end{array}$ \\
\hline Mar. 16.1899 & S. (x. Bemnett .... & $\ldots$. & 101.00 & $\begin{array}{l}\text { At Pirn City, wagon road } \\
\text { crossing. }\end{array}$ \\
\hline Tar, 17.1899 & do & & 1152.00 & Do. \\
\hline Tar. 14.1899 & $\ldots$ do . . . . . . . & & $\pi .00$ & Narrows, near Dutton`s. \\
\hline Aug. 19.1899 & ... & & 1.30 & Head of Pirn pipe line. \\
\hline $8,19(10)$ & W. W. Cockins, jr & . & 2.20 & $\begin{array}{l}\text { Lower Pirn ('reek, ditches } \\
\text { from. }\end{array}$ \\
\hline
\end{tabular}




\section{PIT RIVER.}

Inischarge measurements of Pit River. Shasta C'ounty.

\begin{tabular}{|c|c|c|c|}
\hline Date. & Hydrographer. & $\begin{array}{c}\text { Dis- } \\
\text { charge. }\end{array}$ & Locality. \\
\hline 1901. & & sec.feet. & \\
\hline Sept. - & Robt. McF. Doble_ & 2,230 & Peck`s Bridge. \\
\hline Sept. 9 & S. G. Bennett ......... & 2,682 & Silverthorn Ferry. \\
\hline Sept. - & Roht. McF. Doble.... . . & $17 \%$ & $\begin{array}{l}\text { Burney Creek, tributary of Pit } \\
\text { River. }\end{array}$ \\
\hline Sept. - & $\ldots$ do _ . . . _ n & $1,44 i$ & Fall River, near month. \\
\hline Sept. - & $\ldots$ do .............. & $62 \%$ & Hat Creek, Carbon luridge. \\
\hline $\begin{array}{l}\text { Sept. } 9 \\
1902 .\end{array}$ & S. G. Bennett . . . . . . & 23 & $\begin{array}{l}\text { Squaw Creek, near Copper City } \\
\text { bridge. }\end{array}$ \\
\hline Sept. 17 & $\ldots$ do $\ldots . . . . .$. & 208 & $\begin{array}{l}\text { Pit River above month of Fall } \\
\text { River, at Fall River Mills. }\end{array}$ \\
\hline Sept. 16 & $\ldots$.... do _ & 1,543 & Fall River, at bridge. \\
\hline Do _.. & do & $58: 3$ & Hat Creek, at Carbon bridge. \\
\hline Sept. 15 & $\ldots$. do _..... & 2,350 & Peck's bridge. \\
\hline Do _.. & $\ldots$ do $\ldots . . . . .$. & 209 & $\begin{array}{l}\text { Burney Creek, } \frac{1}{2} \text { milo below Burney } \\
\text { Falls. }\end{array}$ \\
\hline Sept. 27 & Chas. A. Miller & 2,508 & Silverthorn Ferry. \\
\hline Do $\ldots$ & . . do do $_{2} \ldots . .$. & $3 \tau$ & $\begin{array}{l}\text { Squaw Creek. near Copper City } \\
\text { bridge. }\end{array}$ \\
\hline
\end{tabular}

\section{PLUNGE CREEK.}

Discharge measurements of Plinge Creek, at headuorts in amyon. San Bernardino County.

\begin{tabular}{|c|c|c|}
\hline Date. & Hydrographer. & $\begin{array}{c}\text { Dis- } \\
\text { charge. }\end{array}$ \\
\hline & & Sec.feet. \\
\hline June 12,1898 & J.B. Lippincott & 2.30 \\
\hline Sept. $\quad 9.1898$ & $\ldots$. . . . . . . . . & .20 \\
\hline Mar. 25, 1899 & S. G. Bennett . . $\ldots$ & 10.90 \\
\hline Aug. 25, 1899 & do & .50 \\
\hline July 12,1900 & do & .34 \\
\hline Apr. $\quad 7,1902$ & $\ldots$ do $\ldots$. & 12.40 \\
\hline \multirow[t]{2}{*}{ Sept. $\quad 4,1902$} & W. B. Clapp $\ldots \ldots \ldots$ & .31 \\
\hline & POMPONIO CREEK. & \\
\hline \multicolumn{3}{|c|}{ Discharge measurement of Pemponio C'reck, san Maten County. } \\
\hline Date. & Hydrographer. $\quad$ Dis- & \\
\hline 1893. & Sec.feet. & \\
\hline Oct. 17 & W. Brier . . . . . . . $0.2 \tau \mid 2$ sniles above montr. & \\
\hline
\end{tabular}




\section{POSO CREEK.}

Estimated monthly discharge of Poso Creek at base of foothills. ${ }^{a}$

[Drainage area, 289 sunare miles.]

\begin{tabular}{|c|c|c|c|c|}
\hline \multirow[b]{2}{*}{ Menth } & \multirow[b]{2}{*}{$\begin{array}{l}\text { Mean dis- } \\
\text { charge. }\end{array}$} & \multirow[b]{2}{*}{$\begin{array}{l}\text { Total dis- } \\
\text { charge. }\end{array}$} & \multicolumn{2}{|c|}{ Run off. } \\
\hline & & & $\begin{array}{l}\text { Per square } \\
\text { mile. }\end{array}$ & Depth. \\
\hline $18 \pi 8$. & Seefoet. & Acrefeet. & Ser.feet. & Inches. \\
\hline November . . . . . . . . & 0 & 0 & 0 & 0 \\
\hline December . & 0 & 0 & 0 & 0 \\
\hline $18 \% 9$ & & & & $=$ \\
\hline January $\ldots \ldots \ldots$ & 23 & 1,414 & 0.08 & 0.09 \\
\hline February ........... & 40 & 2,221 & .14 & .15 \\
\hline March . . . . . . . . . . . & 20 & 1,230 & $.0 \%$ & .08 \\
\hline April $\ldots \ldots \ldots \ldots \ldots$ & $i^{2}$ & 4,284 & .25 & .28 \\
\hline May .............. & 52 & $3,19 \pi$ & .18 & .21 \\
\hline June . . . . . . . . . . . & 17 & 1.012 & .06 & .07 \\
\hline July $\ldots \ldots \ldots \ldots \ldots$ & 0 & 0 & 0 & 0 \\
\hline August $\ldots \ldots \ldots \ldots \ldots \ldots$ & 0 & 0 & 0 & 0 \\
\hline September $\ldots \ldots \ldots \ldots \ldots$ & 0 & 0 & 0 & 0 \\
\hline October ..... & 0 & 0 & 0 & 0 \\
\hline November $\ldots{ }_{1}, \ldots \ldots \ldots \ldots$ & i5 & 4.463 & .26 & .29 \\
\hline December _. . . . . . . . . & 145 & $\$, 916$ & .50 &. .88 \\
\hline The year ..... & $3 i$ & $26,73 \%$ & $\overline{13}$ & 1. 万人 \\
\hline $1 \times \times 0$. & & & & \\
\hline January $\ldots . . . . .$. & $34 \pi$ & 21,336 & 1. 20 & 1.38 \\
\hline February ........... & 66.5 & $3 \times .251$ & 2.30 & 2.48 \\
\hline March ..... & 51 & $46,1 \%$ & 2.60 & 3.00 \\
\hline April $\ldots \ldots \ldots \ldots \ldots$ & $x+34$ & 49.864 & 9.90 & 3.24 \\
\hline May ............ & 58 & 35, 5.50 & 2.00 & 2.31 \\
\hline June $\ldots \ldots \ldots$ & 14.) & R, $62 \mathrm{X}$ & .50 & .56 \\
\hline July ... . . . . . . . & 14 & 861 & .05 & .06 \\
\hline August . $\quad \ldots \ldots$ & 0 & 0 & 0 & 0 \\
\hline$\ldots \ldots \ldots$ & () & 0 & 0 & 0 \\
\hline October $\ldots \quad \ldots \ldots \ldots$ & 0 & ) & 0 & 0 \\
\hline November $\ldots \ldots \ldots \ldots \ldots$ & 58 & 3,451 & .20 & .22 \\
\hline December & 145 & 8,918 & .50 & .58 \\
\hline The year. & 294 & 213,024 & 1.02 & 13.53 \\
\hline
\end{tabular}

"Authority, state engineer. Estimater from run-off of neighbering streams. 
Estimated momthly discharge of Poso ('reek at base of foothills--Continned.

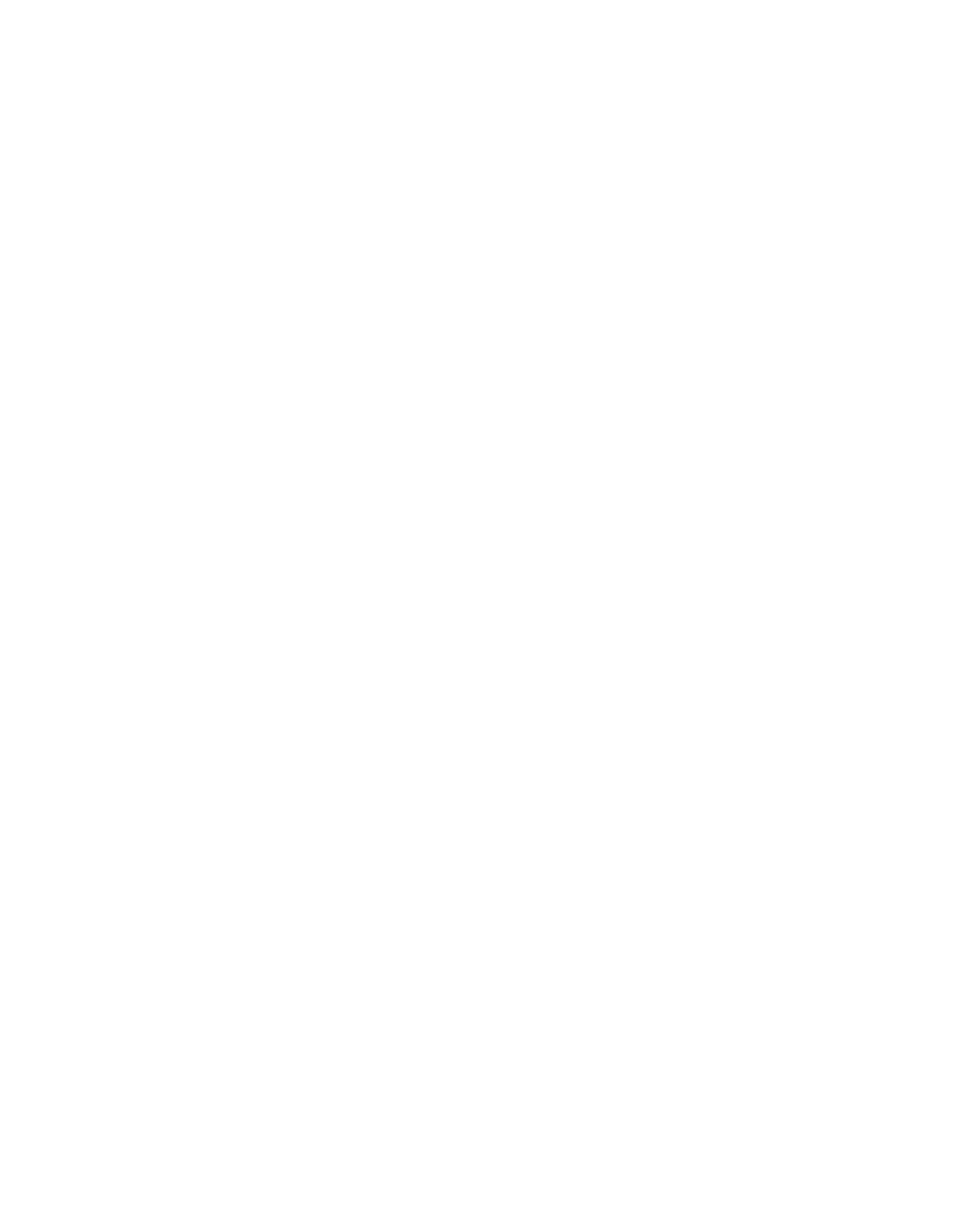

u Estimated from run-off of neighboring stream. 
Estimated monthly discharge of Pose ('resk ut base of foothills-Contimerl.

\begin{tabular}{|c|c|c|c|c|}
\hline Month. & $\begin{array}{l}\text { Mean di- } \\
\text { charge. }\end{array}$ & $\begin{array}{l}\text { Total dis- } \\
\text { charge. }\end{array}$ & $\begin{array}{c}\text { Per square } \\
\text { mile. }\end{array}$ & Depth. \\
\hline $18 \times: 3 . "$ & siecefert. & wrefeet. & Seet-feet. & Inckes. \\
\hline January ....... & 43 & 2,644 & 0.15 & 0.17 \\
\hline February $\ldots \ldots \ldots$ & 43 & 2.388 & .15 & .16 \\
\hline March . . . . . . & 231 & 14,204 & .80 & .92 \\
\hline April $\ldots \ldots \ldots$ & 145 & 8,628 & .50 & .56 \\
\hline May $\ldots \ldots \ldots \ldots$ & 119 & $7,31 \%$ & .41 & $.4 \pi$ \\
\hline June . . . . . & 0 & () & () & 0 \\
\hline July ... $\ldots \ldots \ldots$ & 0 & () & $\theta$ & 0 \\
\hline August $\ldots \ldots \ldots \ldots$ & 0 & 0 & 0 & 0 \\
\hline September . . . ......... & 0 & 0 & 0 & 0 \\
\hline October $\ldots \ldots \ldots$ & 29 & 1.783 & .10 & .12 \\
\hline November $\ldots \ldots \ldots$ & 29 & 1,726 & .10 & .11 \\
\hline December ... $\quad$. & 43 & 2,644 & .15 & .17 \\
\hline The year $\ldots \ldots \ldots$ & $\pi$ & $\begin{array}{r}41,334 \\
-\quad-\ldots=\end{array}$ & .19 & 2.68 \\
\hline 1884."t & & & & \\
\hline January . . . . . . . . & $14 \pi$ & 8.916 & .50 & .58 \\
\hline February ............ & $86 \%$ & 49.870 & 3.00 & 3.24 \\
\hline March ............ & $86 \%$ & $5: 3.310$ & 3.00 & 3.46 \\
\hline April $\ldots \ldots \ldots \ldots$ & 578 & 34,393 & 2.00 & 2.23 \\
\hline May ... ... & 119 & $\tau, 31 \tau$ & .41 & $.4 \pi$ \\
\hline June $\ldots \ldots \ldots \ldots \ldots$ & 14.5 & $8,6 \gtrsim 8$ & .50 & .56 \\
\hline 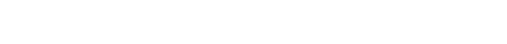 & 0 & (1) & 0 & 0 \\
\hline August $\ldots \begin{array}{ccccc} & \ldots & \ldots & \ldots & \ldots\end{array}$ & 0 & & 01 & 0 \\
\hline Sepitember - ...... & 0 & 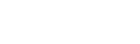 & 0 & 0 \\
\hline Octoher .. & 0 & . . - . - & () & 0 \\
\hline
\end{tabular}

"Estimated from run-eff of neighboring stream.

PURISSIMA CREEY.

Discharge measureme'nt of Purissima ('reek, San Mateo ('ounty.

\begin{tabular}{|c|c|c|c|}
\hline Date & & $\begin{array}{l}\text { Dis } \\
\text { charge. }\end{array}$ & Lorality. \\
\hline $1 \times 93$. & & Sec.feet. & \\
\hline Oct. $1 \pi$ & W. W. Brier . & 2.03 & 1 $\frac{1}{2}$ miles above Purissima. \\
\hline
\end{tabular}




\section{PUTAH CREEK.}

Discharge measurement of Putah Creek, Napa County.

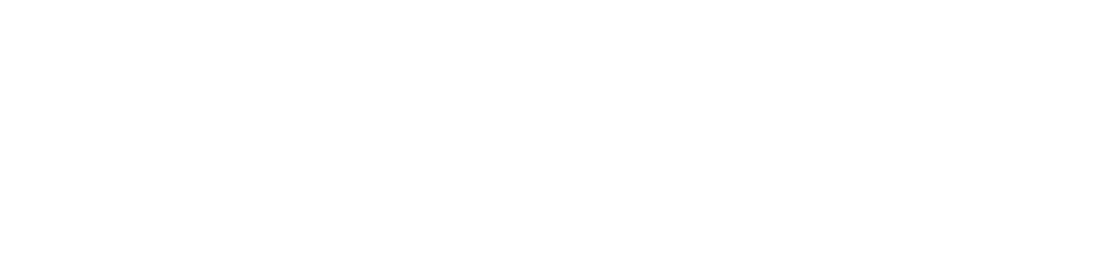

RABEL DAM DITCH, SAN BERNARDINO COUNTY.

See San Bemarlino Valley, Rahel dam diteh.

RANCHERO DITCH, SAN BERNARDINO COUNTY.

See San Bernardino Valley, Ranchero ditch.

RED HILLS DEVELOPMENTS.

See C'ucamongra ('reek, Red Ilills.

\section{REDLANDS CANAL.}

See Santa Ana River, Redlands aanal.

\section{RINCON CREEK.}

Discharge measurements of Rincon Creck. Santa Barbara County.

\begin{tabular}{|c|c|c|c|}
\hline Date. & & Hydrographer. & $\begin{array}{c}\text { Dis- } \\
\text { charge. }\end{array}$ \\
\hline & & & Sec.-feet. \\
\hline Aug. -, 1889 & G. F. Wright & & 0.12 \\
\hline June 16,1900 & R. Moyer .... & $\ldots \ldots \ldots$ & .03 \\
\hline
\end{tabular}

RUBICON RIVER.

Sies Middle Fork American Rivere.

RIVERSIDE WATER COMPANY, UPPER CANAL.

Sec San Bermarlino Valley.

\section{SACRAMENTO RIVER.}

This river rises in the extreme northeastern corner of California and flows in a general southerly direction, draining a large area in northern Califoruia between the Coast Range on the west and the Sierra Nevada on the east. It clischarges into San Franciseo Bay. A num- 
ber of storage reservoirs have been construrted on the various tributaries of the river, and are used for hydraulic mining purposes and to a less extent for irrigation. The gaging station of the Geological Survey, established April 30, 1895, is located 12 miles above the town of Red Bluff at the crossing of the country road at Jellys Ferry. The gage consists of a rertical rod made in three sections and nailed firmly to trees near the ferry landing. A second rod is located 1,206 feet above the gage, and a third one 350 feet below the main rod, in order to determine the slope of the water surface. The three rods are referred to the same datum. Bench mark No. 1 is on an oak tree on the left bank of the river 300 feet below the cable, and is 22.429 feet above gage datum. The ferry cable is used in the discharge measurements. The channel for 1,000 fect above and below the station is nearly straight. The right bank is high, but the left bank is liable to overflow when the water rises above the 25 -foot mark. 'The bed of the stream consists of gravel and changes only slightly. The gaging station of the State enginerring department was at the month of the river.

Discharge measurements of Sacramento River.

\begin{tabular}{|c|c|c|c|}
\hline Date. & Hydrographer. & $\begin{array}{l}\text { Dis- } \\
\text { charge. }\end{array}$ & Lor'ality. \\
\hline$--\cdots$ & $-c_{-}-c_{-}-c_{1}$ & $-\ldots$ & $-\cdots-$ \\
\hline $18 \% 8$ & & Seci-fcet. & \\
\hline $\begin{array}{l}\text { Oct. - } \\
1879 .\end{array}$ & United States Engineers & 6,495 & Sacramento. \\
\hline May 12 & $\begin{array}{l}\text { State engineering de- } \\
\text { partment. }\end{array}$ & 16.000 & Knights Landing. \\
\hline July 16 & $\ldots$.... do _....... & 5,000 & Sacramento Slough. \\
\hline May 16 & $\ldots d(r) \ldots . . . . . .$. & 38,000 & Gray \& Shaws. \\
\hline May 21 & $\ldots d 0 \ldots$ & $26.000)$ & Ahove mouth of American River. \\
\hline July 14 & $d_{0} \ldots \ldots$ & 13.000 & Do. \\
\hline May 22 & $\ldots d 0 \ldots$ & 39,000 & Sacramento, foot of $T$ stroet. \\
\hline July 14 & . do _ . . . . . & 15,000 & Do. \\
\hline Mar. 3 & .....(n) & 40.0000 & Freeport. \\
\hline Mar. 20 & do & 56.000 & Do. \\
\hline Jan. 24 & do & 12,000 & Brannan Slough. \\
\hline
\end{tabular}


Estimated monthly discharge of sateramento River at Collinstille."

[Drainage area. : औ,1s square miles.]

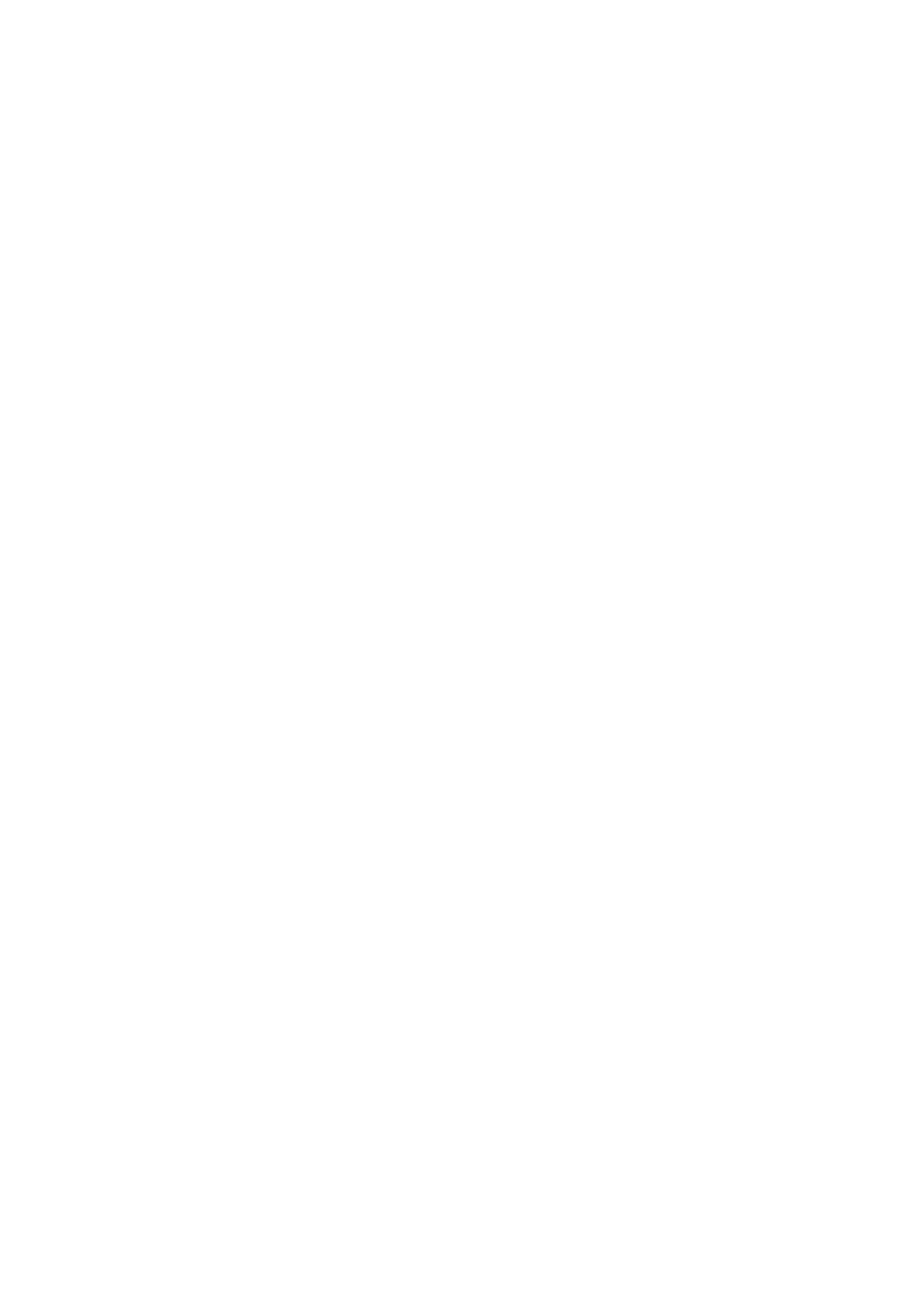

a Authority, State engineer. 
Estimated monthly discharge of Sacramento River at Collinsville-Continued.

\begin{tabular}{|c|c|c|c|c|}
\hline \multirow[b]{2}{*}{ Month. } & \multirow{2}{*}{$\begin{array}{l}\text { Mean dip- } \\
\text { charge. }\end{array}$} & \multirow{2}{*}{$\begin{array}{l}\text { Total dis- } \\
\text { charge. }\end{array}$} & \multicolumn{2}{|c|}{ Run-off. } \\
\hline & & & $\begin{array}{l}\text { Per square } \\
\text { mile. }\end{array}$ & Depth. \\
\hline 1881. & Siece-feet. & Acre-feet. & sreefeet. & Inches. \\
\hline January ... & 9.5 .000 & $5,841,3 \approx 2$ & 3.63 & 4.18 \\
\hline February $\ldots \ldots \ldots \ldots$ & 115,000 & $6,386,7 \approx 6$ & 4.39 & 4.57 \\
\hline March $\ldots \ldots \ldots \ldots$ & 7.000 & 4.734 .545 & 2.94 & 3.39 \\
\hline April ....... & 90,000 & $\pi, 355,3 \% 2$ & 3.44 & 3.84 \\
\hline May ... . . . . & 70.000 & $4,304,132$ & 2.67 & 3.08 \\
\hline June .... . - & $2 \pi, 000$ & $1.48 \pi, 603$ & .95 & 1.06 \\
\hline$\ldots \ldots \ldots$ & 14,000 & 860,826 & .531 & .61 \\
\hline August $\ldots \ldots \ldots \ldots$ & $\therefore, 000$ & 491,901 & .39 & .35 \\
\hline September $\ldots \ldots \ldots \ldots \ldots$ & 6.500 & $386, \pi \% 7$ & $.2 \pi$ & .28 \\
\hline October ..... & $\tau .000$ & 430,413 & .27 & .31 \\
\hline November _. & 8,200 & $48 \pi, 934$ & .31 & .35 \\
\hline December . . . . . . & 16,000 & 983,802 & .61 & .70 \\
\hline The year ...... & 44,308 & $31,751,403$ & $1.6 ?$ & 22.72 \\
\hline $188^{\circ}$ & & & & \\
\hline January .... & 24.000 & $1,475.602$ & .93 & 1.06 \\
\hline February .- & 22,000 & $1,221.818$ & .84 & .87 \\
\hline March ...... & 55.000 & $3,381,818$ & 2.10 & 2.42 \\
\hline April ....... & 90.000 & $5,355,372$ & 3.44 & 3.84 \\
\hline May ......... & 92.000 & $5,656,859$ & 3.51 & 4.05 \\
\hline June ....... & $\tau 4.000$ & $4,403,306$ & 2.83 & 3.15 \\
\hline July ...... & 17,000 & $1,045,289$ & .65 & .75 \\
\hline August ..... & 8.000 & 491.901 & .31 & .35 \\
\hline September .. & 6,500 & $386,77 \%$ & $2 \pi$ & .28 \\
\hline October..... & 10,000 & 614,876 & $.3 ?$ & .44 \\
\hline November ... & 14,000 & 833,058 & $.5 \%$ & .59 \\
\hline December ... & 11,000 & 676,364 & .42 & .48 \\
\hline The year & 35,292 & $25,543,140$ & 1.35 & 18.28 \\
\hline
\end{tabular}


Estimated monthly discharge of Sacramento Rirer at ('ollinsville-Continued.

\begin{tabular}{|c|c|c|c|c|}
\hline \multirow{3}{*}{ Month. } & \multirow[b]{2}{*}{$\begin{array}{l}\text { Mean dis- } \\
\text { charge. }\end{array}$} & \multirow[b]{2}{*}{$\begin{array}{l}\text { Total dis- } \\
\text { charge- }\end{array}$} & \multicolumn{2}{|c|}{ Run-off. } \\
\hline & & & $\begin{array}{l}\text { Per square } \\
\text { mile. }\end{array}$ & Depth. \\
\hline & Sien-feret. & Acre-feet. & seceffert. & Inelers. \\
\hline January $\ldots \ldots \ldots \ldots$ & 12.000 & 735.851 & 0.46 & $0.5 j$ \\
\hline February $\ldots \ldots \ldots$ & $1 \%, 000$ & 944,132 & .65 & .68 \\
\hline$\ldots \ldots \ldots$ & 21,000 & $1,291,240$ & .80 & .92 \\
\hline April $\quad-\quad \ldots \ldots \ldots$ & 20.000 & $4,343,801$ & 2.79 & 3.11 \\
\hline May _. . _ . . . . . . . . & 80.000 & $4,919,008$ & 3.05 & 3.52 \\
\hline June $\ldots \ldots \ldots \ldots$ & 32.000 & $1,904,132$ & 1. 22 & 1.36 \\
\hline July _..... $\ldots \ldots$ & 12,000 & $73 \%, 851$ & .46 & .53 \\
\hline$\ldots \ldots \ldots \ldots$ & $\tau, 000$ & 430,413 & .27 & .31 \\
\hline September .. & 6.500 & 386.776 & .25 & .28 \\
\hline October _ $\quad \ldots \ldots$ & $\tau, 000$ & 430,413 & $.2 \%$ & .31 \\
\hline November & $\tau, 500$ & 446,281 & .99 & .32 \\
\hline December . . & $\tau, 400$ & 455,008 & .28 & .32 \\
\hline The year ... & 23,533 & $17,026,906$ & .90 & 12.19 \\
\hline 1884. & & & & \\
\hline January ......... & 12.000 & $73 \% .851$ & .46 & .63 \\
\hline February _... & 24,000 & $1,380,496$ & .92 & 1.01 \\
\hline March ..... & 80,000 & $4,919,008$ & 3.05 & 3.52 \\
\hline April ..... & 105.000 & $6,247,934$ & 4.01 & $4.4 \pi$ \\
\hline May . ....... & 111,000 & $6.89 .5,124$ & 4.23 & 4.88 \\
\hline June ...... & 90,000 & $5,35 \overline{5}, 3 \pi^{2}$ & 3.44 & 3.84 \\
\hline July _. . . . & 31,000 & $1,906,116$ & 1.18 & 1.36 \\
\hline August .... . & 12.000 & $73 \%, 8.51$ & .46 & .53 \\
\hline September & $\tau .500$ & 446.281 & .29 & .32 \\
\hline October & 8,000 & 491.901 & .80 & .35 \\
\hline
\end{tabular}


Discharge measurements of Sacramento River. Iron C'anyon, it miles abone Red Bluff, Tehama County. Cal.

\begin{tabular}{|c|c|c|c|}
\hline Date. & Hydrographer. & $\begin{array}{c}\text { Gage } \\
\text { height. }\end{array}$ & $\begin{array}{c}\text { Dis- } \\
\text { charge. }\end{array}$ \\
\hline 1901. & & Feet. & Sec-feet. \\
\hline Oct. 30 & S. G. Bennett. & 1.02 & 5,187 \\
\hline $\begin{array}{c}\text { Dec. } 13 \\
1902 .\end{array}$ & ... do . ........ & 2.69 & 9,651 \\
\hline Jan. 28 & do $\ldots . . . . . . .$. & 1.35 & 5.912 \\
\hline Feb. 12 & Wm. F. Luning . . . . . . . . . . & 20.6 & "110,824 \\
\hline Mar. 3 & S. G. Bennett $\ldots \ldots$ & 10.6 & $41,5 \% 0$ \\
\hline May 10 & do & 5.5 & 18,927 \\
\hline Sept. 13 & Chas. A. Miller . .. & .84 & 4,425 \\
\hline Dec. 31 & S. G. Bennett ..... & 3.20 & 9,858 \\
\hline
\end{tabular}

"Float measurement

Discharge measurements of Sacromento River at Red Bluff, Trhama C'omuty, C'al.

\begin{tabular}{|c|c|c|c|}
\hline Date. & Hydrographer. & $\begin{array}{l}\text { Gage } \\
\text { height. }\end{array}$ & $\begin{array}{c}\text { Dis- } \\
\text { charge. }\end{array}$ \\
\hline 1894. & & Feet. & seci-feet. \\
\hline $\begin{array}{c}\text { Dec. } 20 \\
1895 .\end{array}$ & A. P. Davis and J. B. Lippincott $\ldots$. & $10 . \tau$ & 45.000 \\
\hline Mar. 19 & J. B. Lippincott .... & 4.8 & 15,461 \\
\hline $\begin{array}{c}\text { Apr. } 27 \\
1896 .\end{array}$ & $\ldots$ do $\ldots . . . . . . .$. & $x .4$ & 36,181 \\
\hline Jan. 21 & $\ldots$ do $\ldots . . . . . .$. & 20.8 & 109,432 \\
\hline Jan. $\stackrel{2}{2}$ & do $\ldots$. & $1 \% . \tau$ & 83,558 \\
\hline
\end{tabular}


Estimated monthly discharge of Sacromento River at Red Bluff, Tehama County."

[Drainage area, 9,355 square miles.] $b$

\begin{tabular}{|c|c|c|c|c|c|c|}
\hline \multirow[b]{2}{*}{ Montli. } & \multicolumn{3}{|c|}{ Discharge. } & \multirow[b]{2}{*}{$\begin{array}{l}\text { Total dis- } \\
\text { charge. }\end{array}$} & \multicolumn{2}{|c|}{ Run-off. } \\
\hline & Maximum. & Minimum. & Mean. & & $\begin{array}{l}\text { Per } \\
\text { square } \\
\text { mile. }\end{array}$ & Depth. \\
\hline January & $\begin{array}{l}\text { sec.-feet. } \\
123,000\end{array}$ & $\begin{array}{l}\text { rec.feet. } \\
15,220\end{array}$ & $\begin{array}{c}\text { Sec.feet. } \\
47,26 \%\end{array}$ & $\begin{array}{c}\text { Acre-feet. } \\
2,906,320\end{array}$ & $\begin{array}{l}\text { sec.-feet. } \\
5.052\end{array}$ & $\begin{array}{l}\text { Inches. } \\
5.824\end{array}$ \\
\hline February & 65,600 & 13,860 & 26,792 & $1,487.940$ & 2.864 & 2.982 \\
\hline March ... & 85,360 & 15,220 & 32,517 & $1,999,418$ & 3.475 & 4.007 \\
\hline April . & 33,880 & 26,670 & 29,566 & $1,759,300$ & 3.160 & 3.526 \\
\hline May ....... & 48,600 & 16,840 & 30,238 & 1.859 .250 & 3.232 & 3.726 \\
\hline June ....... & 18,600 & 9,040 & 12,764 & 759.510 & 1.717 & 1.522 \\
\hline July & 9,040 & 6,150 & 7,235 & 444,863 & 1.364 & .892 \\
\hline August ... & 6,150 & 5,990 & 6,057 & 372,436 & .647 & .746 \\
\hline September & 10,820 & 5.830 & 6,321 & 376,106 & $.6 \pi 6$ & .754 \\
\hline October ... & 6,285 & 5,910 & 5,989 & 368,261 & .640 & .738 \\
\hline November . & 6,690 & 5.910 & 6,046 & 359,792 & .646 &.$\tau 11$ \\
\hline December ........ & 36,880 & 6,150 & 10,095 & 620,760 & $1.0 \% 9$ & 1. 244 \\
\hline Per annum ..... & 123,000 & $\tilde{5}, 830$ & 18,390 & $13,313,956$ & 1.9656 & 26.672 \\
\hline \multicolumn{7}{|l|}{1896.} \\
\hline January ...... . & 140,000 & 6,150 & $\tilde{51 . \tau 02}$ & $3,179,032$ & 5.53 & 6.41 \\
\hline February .... & 46.860 & 9,040 & 15,231 & 876,120 & 1.63 & 1.76 \\
\hline March ...... & 74,050 & 9,700 & 25,533 & $1,569,981$ & 2.73 & 3.15 \\
\hline April ........... & T2.910 & 16,370 & 30.708 & $1,827,271$ & 3.28 & 3.61 \\
\hline May ........ & 81,030 & 19,660 & $3.5,019$ & $2,153,252$ & 3.74 & 4.35 \\
\hline June .... & 21,150 & 8,600 & 13,599 & 809,215 & 1.45 & 1.62 \\
\hline July - & 8,380 & 5,990 & 6,907 & 424,694 &.$\pi t$ & .85 \\
\hline August ... . & 5,910 & 5,660 & 5.738 & 352,858 & .61 & .70 \\
\hline September & 5.830 & 5,660 & $\tilde{5}, 696$ & $338,97 \tau$ & .61 & .68 \\
\hline October ..... & 6,555 & 5,660 & 5,730 & 352,336 & .61 & .70 \\
\hline November...... & $5 \% .200$ & 5,660 & 11,260 & 670,058 & 1.20 & 1.34 \\
\hline December ... & 106,880 & 11,380 & 33,316 & $2,048,546$ & 3.56 & 4.09 \\
\hline The year . . . . & 140,000 & 5,660 & 20,037 & $14,602,340$ & 2.14 & 29.26 \\
\hline
\end{tabular}

a Authority, United States Geological Survey.

$b$ Drainage areas were measured from maps of United States Geolog ical survey. 
Discharge measurements of Sacramento River at Jellys Ferry. Tehama Cominty.

\begin{tabular}{|c|c|c|c|}
\hline Date. & Hydrosrapher. & $\begin{array}{l}\text { Gage } \\
\text { height. }\end{array}$ & $\begin{array}{l}\text { Dis- } \\
\text { charge. }\end{array}$ \\
\hline 1895. & & Feet. & Sec.-ft. \\
\hline Apr. 30 & J.B. Lippincott . . & 12 & 27,255 \\
\hline June 30 & $\ldots$ do $\ldots \ldots$ & 6.75 & 8,456 \\
\hline Ang. 25 & A. P. Davis and J. B. Lippincott & 5.55 & 5.452 \\
\hline $\begin{array}{c}\text { Oct. j } \\
1896 .\end{array}$ & J. B. Lippincott . . . . . & 5.5 & 6,046 \\
\hline Jan. 21 & J. B. Lippincott ... & 25.9 & 105,000 \\
\hline Jan. 29 & $\ldots$ do . . . . . . . & $22 . \tau$ & 82,000 \\
\hline July 7 & C. C. Babb ..... & 6.6 & 6,924 \\
\hline $\begin{array}{c}\text { Nov. } 1 \\
1897 .\end{array}$ & Richard Gernon .. & j. 9 & 6. $\% 73$ \\
\hline Mar. 29 & Fred Lemstrom & 14.4 & 28.319 \\
\hline Mar. 13 & $\ldots$. do _........ & 10.3 & 18,568 \\
\hline Apr. 3 & J.B. Lippincott & 10.85 & 21,519 \\
\hline Apr. 16 & Fred Lemstrom ............. & 12.2 & 25,806 \\
\hline Apr. 30 & $\ldots$ do $\ldots . . .6$. & 10.3 & 18,514 \\
\hline May 11 & . do $\ldots . . .$. & 9 & 14,719 \\
\hline May 28 & $\ldots$ do $\ldots . . . .$. & $\pi .5$ & 10,193 \\
\hline June 11 & $\ldots$ do _....... & 6.5 & 7,277 \\
\hline June 28 & $\ldots$. & 6.42 & 6,493 \\
\hline July 13 & do ...... & 5.95 & 5,032 \\
\hline July 28 & do $\ldots . . .$. & 5. 7 & 5,082 \\
\hline Aug. 13 & 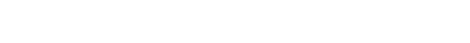 & 5.6 & 4,285 \\
\hline Ang. 28 & $\ldots$ do .... & 5.5 & 4,490 \\
\hline ept. 13 & $\ldots$ do . . . . . . . & 5.5 & 4,257 \\
\hline Sept. 28 & _ & 5. & 4,418 \\
\hline Oct. 13 & $\ldots$ do _. . . . . & & 4,591 \\
\hline Oct. 28 & 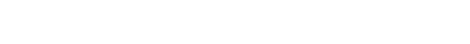 & 5.7 & 4,202 \\
\hline Nov. 13 & $\ldots$ do _... & 5.7 & 4,196 \\
\hline Nov. 28 & $\ldots d o \ldots . . . .$. & 5. 95 & 6,179 \\
\hline Dec. 13 & $\ldots$ do & $\tau .4$ & 10,151 \\
\hline Dec. $1 \%$ & J. B. Lippireott $\ldots$ & 6.85 & 8,802 \\
\hline Dec. 28 & Fred Lemstrom . . . . . . . . & 5.95 & 6,10 \\
\hline
\end{tabular}

IRR $81-0 ; 3-13$ 
Discharge measurements of Sacramento River at Jellys Ferry, etc.-Continued.

\begin{tabular}{|c|c|c|c|}
\hline Date. & Hydrographer. & $\begin{array}{c}\text { Gage } \\
\text { h?ight. }\end{array}$ & $\begin{array}{c}\text { Dis- } \\
\text { charge. }\end{array}$ \\
\hline $\begin{array}{c}1898 . \\
\text { Jan. } 28\end{array}$ & Fred Lemstrom & $\begin{array}{r}\text { Feet. } \\
5.7\end{array}$ & $\begin{array}{l}\text { Sec.-ft. } \\
5,578\end{array}$ \\
\hline Feb. 21 & . & 8.3 & 13,118 \\
\hline Feb. 28 & do. & 15.32 & 42,020 \\
\hline Mar. 13 & do . . & 6.95 & 9,495 \\
\hline Mar. 28 & $\ldots$... do ... & 6.1 & 7,155 \\
\hline Apr. 13 & $\ldots$. . do ... & 6.1 & 7,216 \\
\hline Apr. $2 \pi$ & $\ldots$. . do ... & 6.2 & 7,606 \\
\hline May 13 & $\ldots$ do ... & 5.5 & 5,473 \\
\hline May 28 & . do _ . . . . . & 7.92 & 12,477 \\
\hline June 3 & J. B. Lippincott & 7.1 & 9,048 \\
\hline June 13 & Fred Lemstrom & 5.9 & 6,162 \\
\hline June 28 & ... do ..... & $\overline{5} .45$ & 5,093 \\
\hline July 13 & _ do ... & 5.2 & 4,625 \\
\hline July 28 & .... do .. & 5.1 & 4,520 \\
\hline Aug. 13 & do .. & 5 & 4,324 \\
\hline Aug. 27 & $\ldots$ do ... & 5 & 4,089 \\
\hline Sept. 13 & . . . do . & 5 & 4,160 \\
\hline Sept. 28 & $\ldots$ do $\ldots$ & 5.1 & 4,322 \\
\hline Oct. 12 & .... do . . . & 5.15 & 4,380 \\
\hline Oct. 28 & .... do . . & 5.15 & 4,271 \\
\hline Nov. 28 & $\ldots$ _ do .... & 5.2 & 4,662 \\
\hline Dec. 13 & do ....... & 5.2 & 4,367 \\
\hline $\begin{array}{c}\text { Dec. } 28 \\
1899 .\end{array}$ & $\ldots$. & 5.3 & 4,462 \\
\hline Jan. 14 & Fred Lemstrom & 11.4 & 21,211 \\
\hline Jan. 28 & . . do . . . . . . & 7.5 & 10,299 \\
\hline Feb. 13 & . do _ _ & 5.9 & 5,848 \\
\hline Feb. 28 & .... do .. & 6.1 & 6,380 \\
\hline Mar. 13 & . . do ... & 6.15 & 6,644 \\
\hline Mar. 29 & $\ldots$... do ... & 11.5 & 21,985 \\
\hline Apr. 13 & $\ldots$. . do .... & 7.8 & 10,659 \\
\hline Apr. 28 & . . . do . . . . . & 7.3 & 7,813 \\
\hline May 13 & $\ldots$ do $\ldots \ldots$. & 6.65 & 7,630 \\
\hline June 3 & $\ldots$ do $\ldots . . .$. & 6.9 & 8,409 \\
\hline June 13 & _... do do ....... & 5.9 & 6,104 \\
\hline June 28 & $\ldots$ do _....... & 5.5 & 4,866 \\
\hline July 13 & $\ldots$. . do ... & 5.25 & 4,276 \\
\hline July 28 & $\ldots$. . do _... & 5.05 & 4,025 \\
\hline Aug. 13 & . . do . . . . . & 5.0 & 3,969 \\
\hline Aug. 28 & . . do ..... & 5.0 & 3,764 \\
\hline Sept. 13 & ... do ........ & 5.0 & 4,087 \\
\hline Sept. 28 & $\left.\right|_{\ldots .}$. do $\ldots \ldots$ & 5,0 & 4,009 \\
\hline
\end{tabular}


Discharge moctsurements of Sacramento River at Jellys Ferry, etc.-Continned.

\begin{tabular}{|c|c|c|c|}
\hline Date. & Hydrographer. & $\begin{array}{c}\text { Gage } \\
\text { height. }\end{array}$ & $\begin{array}{c}\text { Dis- } \\
\text { charge. }\end{array}$ \\
\hline 1900. & & Feet. & Sec.-ft. \\
\hline Feb. 17 & Richard Gernon ... & 6.8 & 8,374 \\
\hline Apr. 29 & $\ldots$. do _ . . . . & 7.1 & 9,586 \\
\hline May 28 & $\ldots$.... do ....... & 6.4 & $\tau, 173$ \\
\hline Sept. 20 & S. G. Bennett $\ldots$ & 5.0 & 4,105 \\
\hline Dec. 18 & _. _ _ do _ _ . . . & 10.0 & 18,361 \\
\hline 1901. & & & \\
\hline Jan. 27 & S. G. Bennett - & 9.46 & 15,908 \\
\hline Apr. $\quad 9$ & $\ldots$. . . do ....... & 7.8 & 11,112 \\
\hline Sept. 2 & $\ldots$. . do & 4.9 & 4,390 \\
\hline
\end{tabular}

Estimated monthly discherge of Sacramento River at Jellys Ferry, Tehama County.

[Drainage area, 9,134 square miles.]

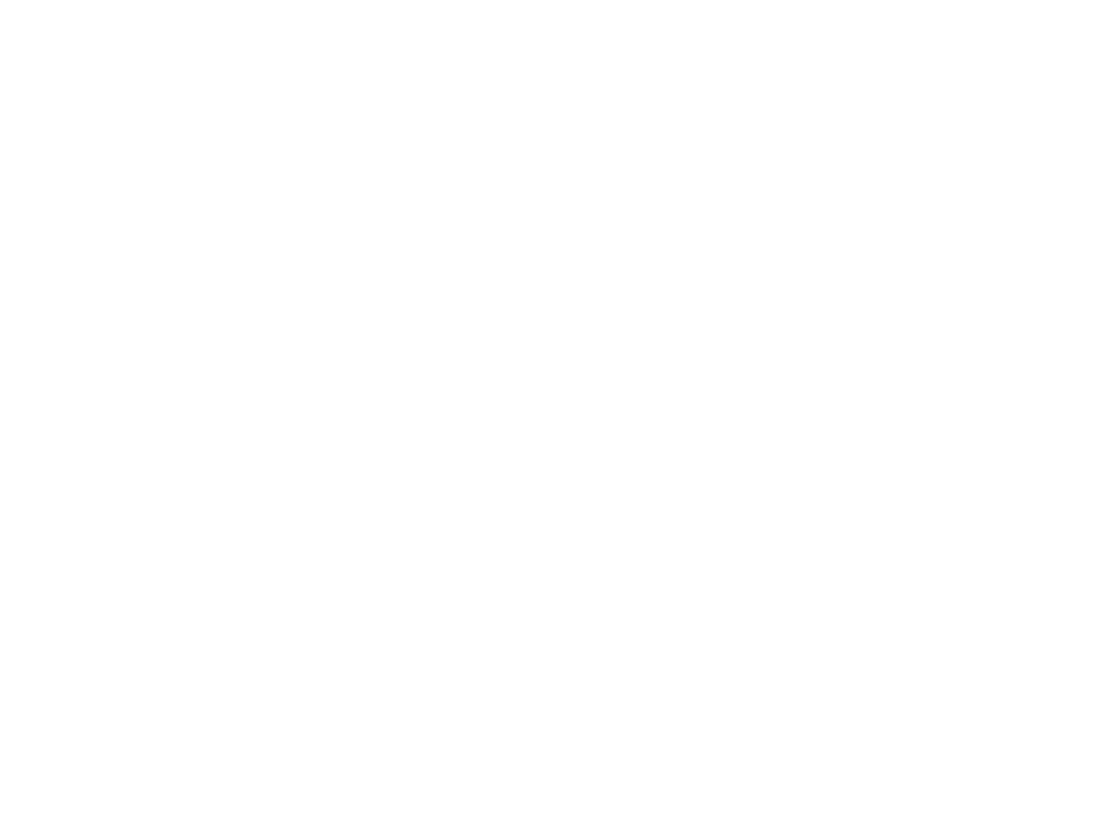


Estimated monthly discharge of Sacramento River at Jellys Ferry, etc.-Cont'd.

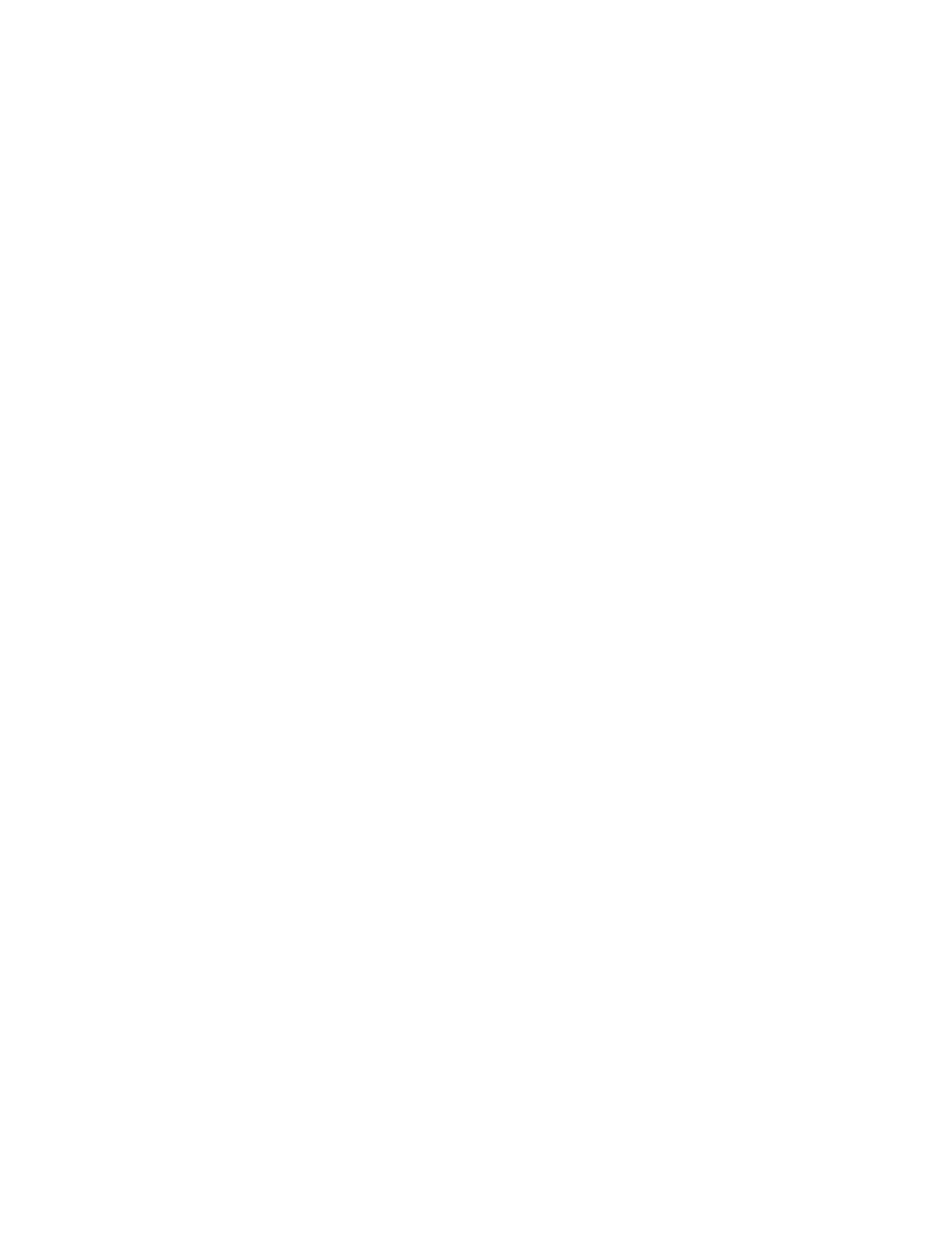


Estimated monthly discharge of Sacramento River at Jellys Ferry, etc.-Cont'd.

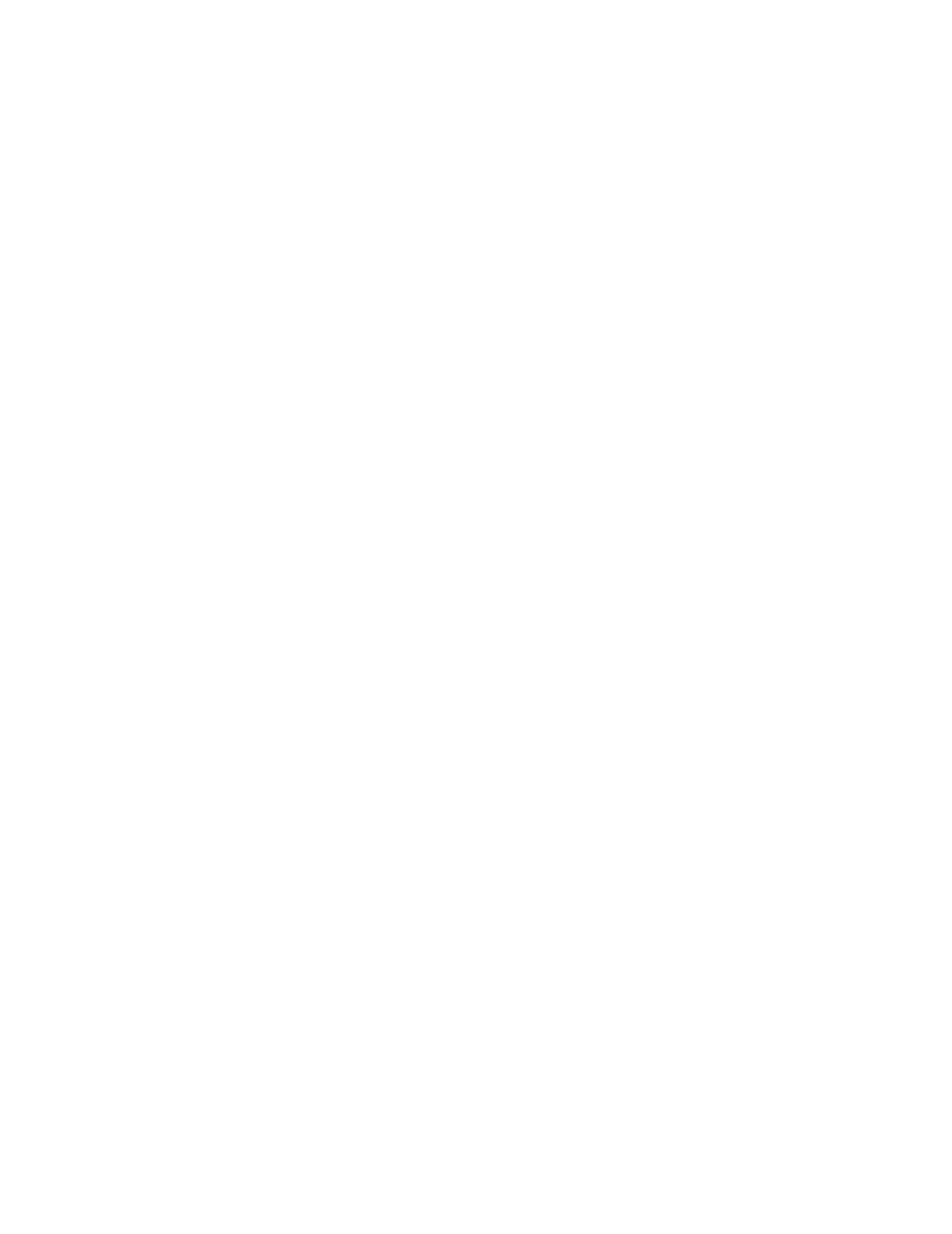


Estimated monthly discharge of Sacramento River at Jellys Ferry, etc.-Cont'd.

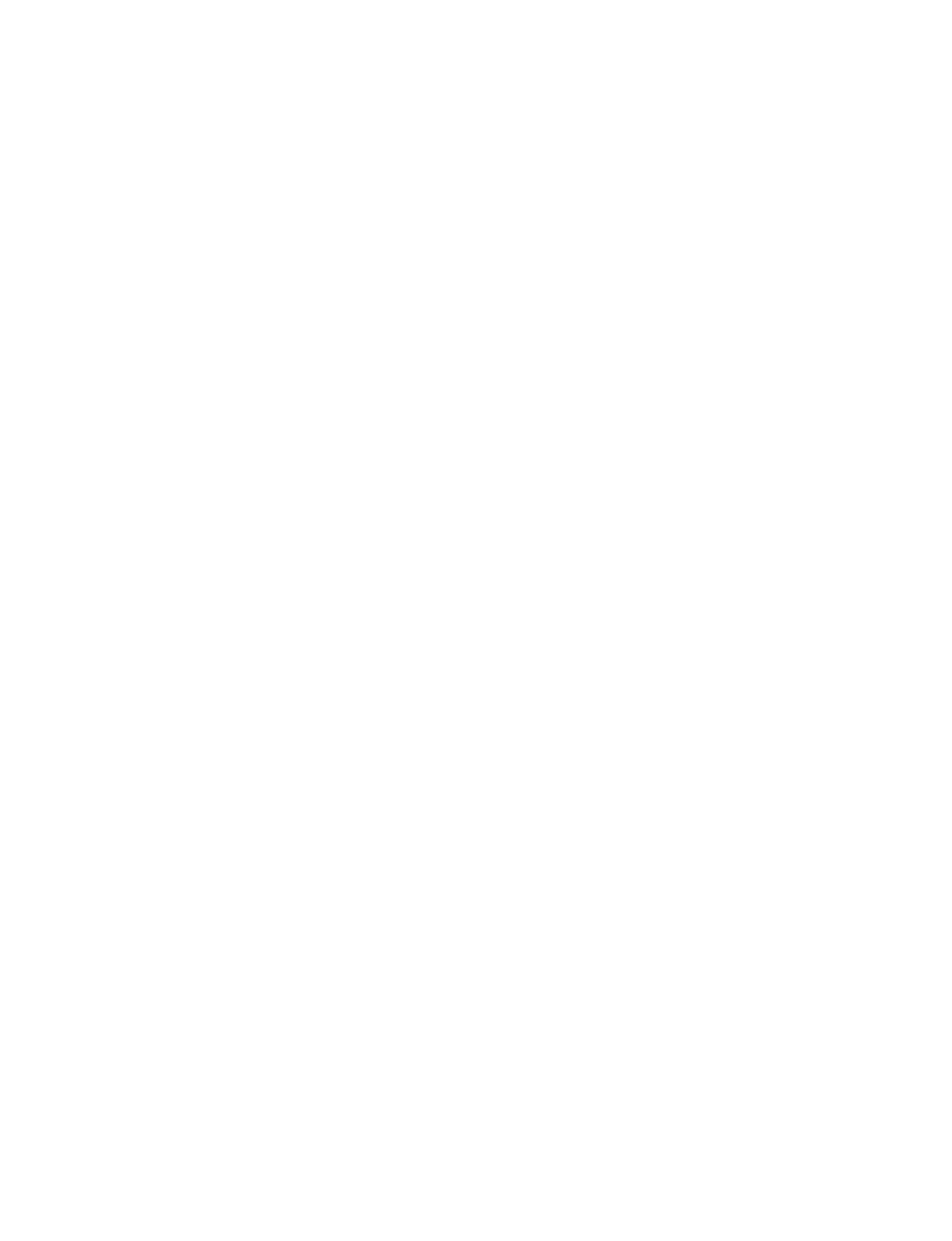

Discharge measurement of Upper Sacramento River. Shaster County. 1 mile above junction with Pitt River.

\begin{tabular}{|c|c|c|c|}
\hline Date. & Hydrographer. & $\begin{array}{c}\text { Gage } \\
\text { height. }\end{array}$ & $\begin{array}{c}\text { Dis- } \\
\text { charge. }\end{array}$ \\
\hline 1901. & & Feet. & Sec.-feet. \\
\hline Sept. 10 & S. G. Bennett & - & 242 \\
\hline
\end{tabular}


Discharge measurements of Sacramento River.

\begin{tabular}{|c|c|c|c|c|}
\hline Date. & Hydregrapher. & $\begin{array}{c}\text { Gage } \\
\text { height. }\end{array}$ & $\begin{array}{c}\text { Dis- } \\
\text { charge. }\end{array}$ & Locality. \\
\hline 1902. & & Feet. & Sect-feet. & \\
\hline Sept. 22 & Charles A. Miller & & 384 & Castle Crags, Shasta County. \\
\hline Do & S. G. Bennett ... & & 286 & Bards Station. Shasta Cunnty. \\
\hline Do ... & Charles A. Miller & & 15 & $\begin{array}{l}\text { Soda Creek at Castle Crags, } \\
\text { Shasta County. }\end{array}$ \\
\hline Sept. 14 & ..... do & & $4,45 \overline{5}$ & Balls Ferry, Tehama County. \\
\hline Sept. 1.j & $\ldots d u \ldots$ & & 313 & $\begin{array}{l}\text { Battle Creek, near Bills Ferry, } \\
\text { Tehama County. }\end{array}$ \\
\hline Do $\ldots$ & & & 27 & $\begin{array}{l}\text { Ditch from Battle Creek, near } \\
\text { Balls Ferry, Teham a County. }\end{array}$ \\
\hline & Total & & 340 & \\
\hline Sept. 26 & S. G. Bennett & $\therefore 22$ & 5,848 & Sacramento,Sacramento County. \\
\hline
\end{tabular}

SALINAS RIVER.

Salinas River rises in San Luis Obispo County, flows in a northwesterly direction through Salinas Valley, and discharges into the Bay of Monterey. The crest of the Coast Range, locally known as the Santa Lucia Mountains, forms the boundary of the watershed on the sonth and west; the crest of the Gabilan Mountains and the Mount Diablo Range forms the eastern boundary of the watershed. The total area drained is $t, 7 \mathrm{SO}$ square miles. The principal tributaries of the river, Nacimiento and san Antonio creeks and Arroyo. Seco, drain the eastern slopes of the Santa Lueia Mountains. The only important stream entering from the east is San Lorenzo (reek, which drains the western slopes of the Mount Diablo Range.

A reconnaissance survey for reservoir sites on Salinas Piver and its tributaries was made during the period from May 28 to Angust 31, 1900, under the direction of Prof. Charles D. Marx, of Stanford University. These studies were continued by Mr. Homer IIamlin during the years 1901 and 1900 , and the results are being prepared for publication.

A gaging station was established on the river January 8 , 190(), by D. A. Porter. On account of the shifting nature of the channel cluring floods, four gage rods were set between January $\&$ and April 2, 1900 , and each was referred to a different datnm. On June 8, 1900, a permanent station was established at the county bridge, $3 z^{3}$ miles south of Salinas. The gage, which is vertical, is attached to one of the piers of the bridge. The bench mark is a nail in the washer in the top of a redwood post, 13 inches by 15 inches in size, on the north bank of the river, at an elevation of 20 feet above gage datum.

On account of the continual shifting of the stream bed and the improbalility of its water being used for either power or irrigation purposes, the record on this stream was discontinued Angust. 3, 1901. 
Discharge measurements of Salinas River, near Salinas, Monterey County.

\begin{tabular}{|c|c|c|c|c|}
\hline Dats. & Hydrographer. & $\begin{array}{l}\text { Gage } \\
\text { height. }\end{array}$ & $\begin{array}{l}\text { Dis- } \\
\text { charge. }\end{array}$ & Femarks. \\
\hline 1900 & & Fret. & sere-feet. & - - \\
\hline Aprr. 9 & S. G. Bennett ...... & 4. 20 & 25.51 & \\
\hline Apr. $\quad 9$ & D. A. Porter ....... & 4. 20 & 26.04 & \\
\hline Apr. 12 & 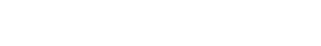 & 4.15 & 15.44 & Strong wind upstream. \\
\hline Apr. 15 & $\ldots$ do ........... & 4.10 & 13.10 & Do. \\
\hline Apr. 19 & . do ........... & 4.10 & 17.04 & No windl. \\
\hline Apr. 22 & ... do & 4.25 & 33.85 & Do. \\
\hline Apr. 25 & $\ldots$ do .......... & 4.15 & 18.91 & Strong wind upstream. \\
\hline May 1 & ... do ........... & 4.10 & 18.02 & No wind. \\
\hline May $t$ & .. do & 4.10 & 16.40 & Do. \\
\hline May $\tau$ & . do _ . . . . & 4.10 & $1 \% .50$ & Do. \\
\hline May 12 & $\ldots$ do ......... & 4.10 & $1 \pi .8 \pi$ & Do. \\
\hline May 16 & $\ldots$ do ..... & 4.10 & 17.94 & Light wind. \\
\hline May 19 & $\ldots d o \ldots . .$. & 4.10 & 16.23 & Do. \\
\hline May 24 & ... do ........ & 4.1 & 17.20 & No wind. \\
\hline May 29 & .... do ..... & 4.1 & $1 \% .43$ & Do. \\
\hline June 2 & . do .......... & 4.05 & 13.32 & Windy. \\
\hline June i' & ... do ........ & 4.05 & 15.29 & No wind. \\
\hline Juale $\&$ & . do do . . . . . . . & 4.0 & $14.0 . \bar{j}$ & Do. \\
\hline June 12 & . do $\ldots \ldots \ldots$ & 4.05 & $15 . \div 9$ & Do. \\
\hline June 15 & $\ldots$. . do ............... & 4.05 & 15.32 & Light wind. \\
\hline June 18 & . . Io .......... & 4.0 & 13.93 & Do. \\
\hline June 22 & .... do $\ldots$..... & 4.0 & 12.91 & No wind. \\
\hline June 26 & $\ldots$... do ........ & 4.0 & 11.47 & Light wind upstream. \\
\hline June 30 & ... do ......... . & 3.9 & 10.50 & No wind. \\
\hline July 3 & 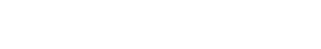 & 3.65 & 9.96 & Fresh wind upstream. \\
\hline July 16 & $\ldots$. do . . . ... & 3.70 & 9.56 & No wind. \\
\hline Ang. 1 & .... do & 3. 70 & 9.83 & Do. \\
\hline Aug. 18 & .... do & 3.6 .5 & 9.89 & Light breeze downstream. \\
\hline Sept. 1 & $\ldots$ do $\ldots . . .$. & 3.6 .5 & 10.10 & No wind. \\
\hline Sept. 26 & S. G. Bennett ..... & 3.45 & $1 . \tau$ & \\
\hline Oct. 23 & J. B. Lippincott - - & 3.45 & 1.7 & \\
\hline Oct. $: 26$ & W. W. Cockins, jr. & $\ldots \ldots$ & 1.1 & 1 mile below sugar factory. \\
\hline Nov. 14 & . . do ......... & $3 . \tau$ & 8.6 & \\
\hline Nov. 16 & $\ldots$... do $\ldots . . .$. & 4.2 & 31.6 & \\
\hline Nov. 19 & .... do ....... & $6 . \tau$ & 2.056 & \\
\hline Nov. 20 & .... do -. & 5.9 & $\checkmark 29$ & \\
\hline Nov. 21 & $\ldots$ do $\ldots . . .$. & 5.6 & 743 & \\
\hline Nov. 22 & $\ldots$ do ...... & 1.5 .6 & 33,600 & Float. \\
\hline Nov. 23 & $\ldots$ rlo ........ & 9.7 & 12,851 & Do. \\
\hline
\end{tabular}


Discharge measurements of Salinas River, near Salinas, eic.-Continned.

\begin{tabular}{|c|c|c|c|c|}
\hline Date. & Hydrographer. & $\begin{array}{c}\text { Gage } \\
\text { height. }\end{array}$ & $\begin{array}{c}\text { Dis- } \\
\text { charge. }\end{array}$ & Remarks. \\
\hline 1901 & & Heet. & theceffeet. & \\
\hline Ja11. 1.5 & S. C. Bemmett & 6.4 & 2,142 & \\
\hline Jan. 22 & d ख0. & 5. $K$ & 1.335 & \\
\hline Ja11. 24 & W. W. Cockins, jr & 5.9 & $1.59 \kappa$ & \\
\hline Feb. 9 & S. G. Bennett ... & $\therefore .9$ & 4.982 & \\
\hline Feb. 19 & $\ldots$ do $\ldots \ldots \ldots$. & 6.0 .5 & 1.561 & \\
\hline Apr. 12 & W. W. Cockins, jr & 4.7 & 342 & \\
\hline Mar. 1 i & - do & 5.6 & 1,204 & \\
\hline Mar. 24 & ....do & 5.2 & $66 \mathrm{~s}$ & \\
\hline Mar. 30 & $\ldots$. do _ & 4.9 & 541 & \\
\hline Apr. 6 & $\ldots d 0 \ldots$ & 4.75 & 512 & \\
\hline
\end{tabular}

Estimated monthly dischrerge of Salines River at a point 4 miles south of Saliuas. Monterey county.

[Drainage area, 4,(k4 squ are miles.]

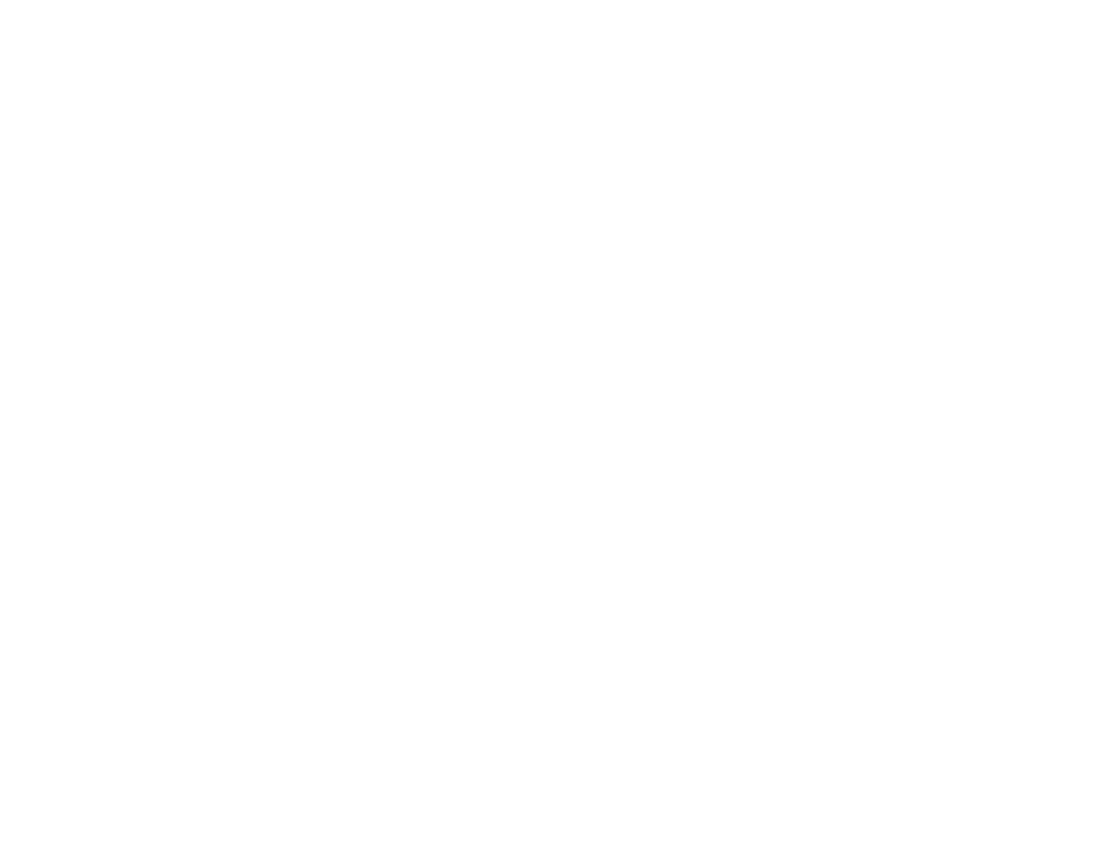


Estimated monthly discharge of Salinas River, etc.-Continued.

\begin{tabular}{|c|c|c|c|c|c|c|}
\hline \multirow[b]{2}{*}{ Montl. } & \multicolumn{3}{|c|}{ Discharge in ser.ond-feet. } & \multirow[b]{2}{*}{$\begin{array}{c}\text { Total in acre- } \\
\text { feet. }\end{array}$} & \multicolumn{2}{|c|}{ Run-off. } \\
\hline & Maximum. & Minimum. & Mean. & & $\begin{array}{l}\text { Second- } \\
\text { feet per } \\
\text { square } \\
\text { nile. }\end{array}$ & $\begin{array}{l}\text { Depth in } \\
\text { inches. }\end{array}$ \\
\hline \multicolumn{7}{|l|}{1901.} \\
\hline January . . . . & 35,162 & 380 & 4,921 & 302,580 & 1. 21 & 1.39 \\
\hline February & $20,92 \pi$ & 540 & $4,1 \% 2$ & 231.701 & 1.02 & 1.06 \\
\hline March ... & $1, \% 2$ & 430 & 1,063 & 65,361 & .26 & .30 \\
\hline April _. & 405 & 160 & $2 \pi 0$ & 16,066 & $.0 \tau$ & .07 \\
\hline May - & 2,012 & 160 & 533 & 32,773 & .13 & .15 \\
\hline June - & 160 & 30 & 56 & 3,332 & .01 & .02 \\
\hline July . . . . & 30 & 25 & $2 \%$ & 1,660 & .01 & .01 \\
\hline
\end{tabular}

Discharge measurements of Salinas River at bridge, Bralley, Monterey County.

\begin{tabular}{|c|c|c|c|c|}
\hline & Date. & Hydrographer. & $\begin{array}{c}\text { Gage } \\
\text { height. }\end{array}$ & $\begin{array}{c}\text { Dis- } \\
\text { charge. }\end{array}$ \\
\hline & 1901. & & Feet. & sec-feet. \\
\hline Feb. 14 & & S. G. Bennett .... & $\ldots$ & 1,424 \\
\hline
\end{tabular}

TRIBUTARIES (IF SALINAS RIVER.

ARROYO SECO.

This stream rises on the eastern slope of the Santa Lucia Mountains, flows eastward, and empties into Salinas River at soledad, Cal. A gaging station was established December 30, 1900, by $\mathrm{IT}^{*}$. W' Cockins, jr., at Foster's ranch, near Piney, Cal. The high water of January, 1901, enlarged the old channel, and the gaging station was removed to Pettit's ranch, 4 miles below.

The purpose of establishing these gaging stations vras to get the maximum flood discharge and the amount of water available for storage.

The total area of watershed drained above Pettit's ranch is 215 square miles. 
Discharge measurements of Arroyo Seco, a tributary of Salinas River.

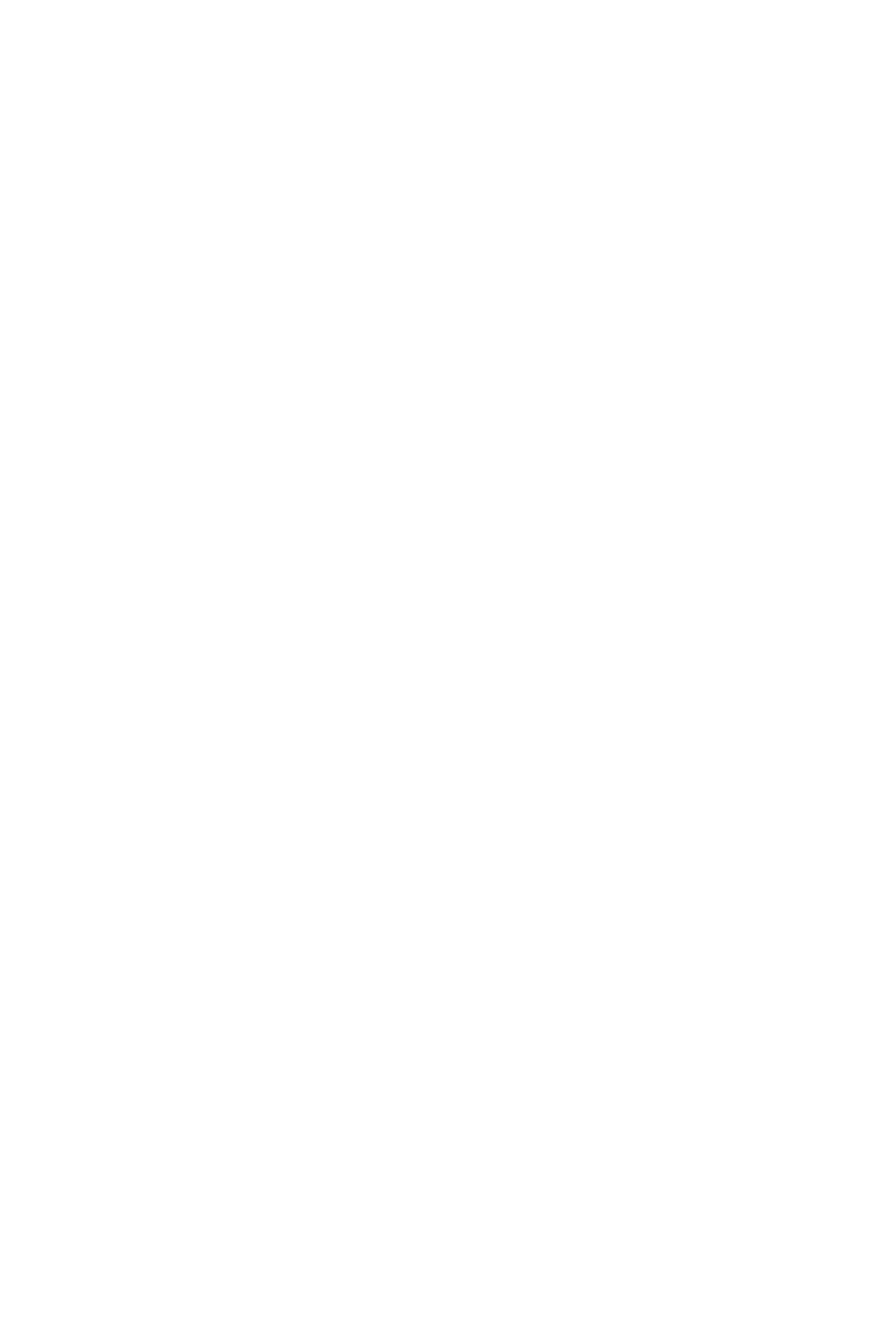

a Float measurements. 
Estimated monthly discharge of Arroyo Seco, a tributary of Salinas River. at Piney. Monterey County.

[Drainage area, 215 square miles.]

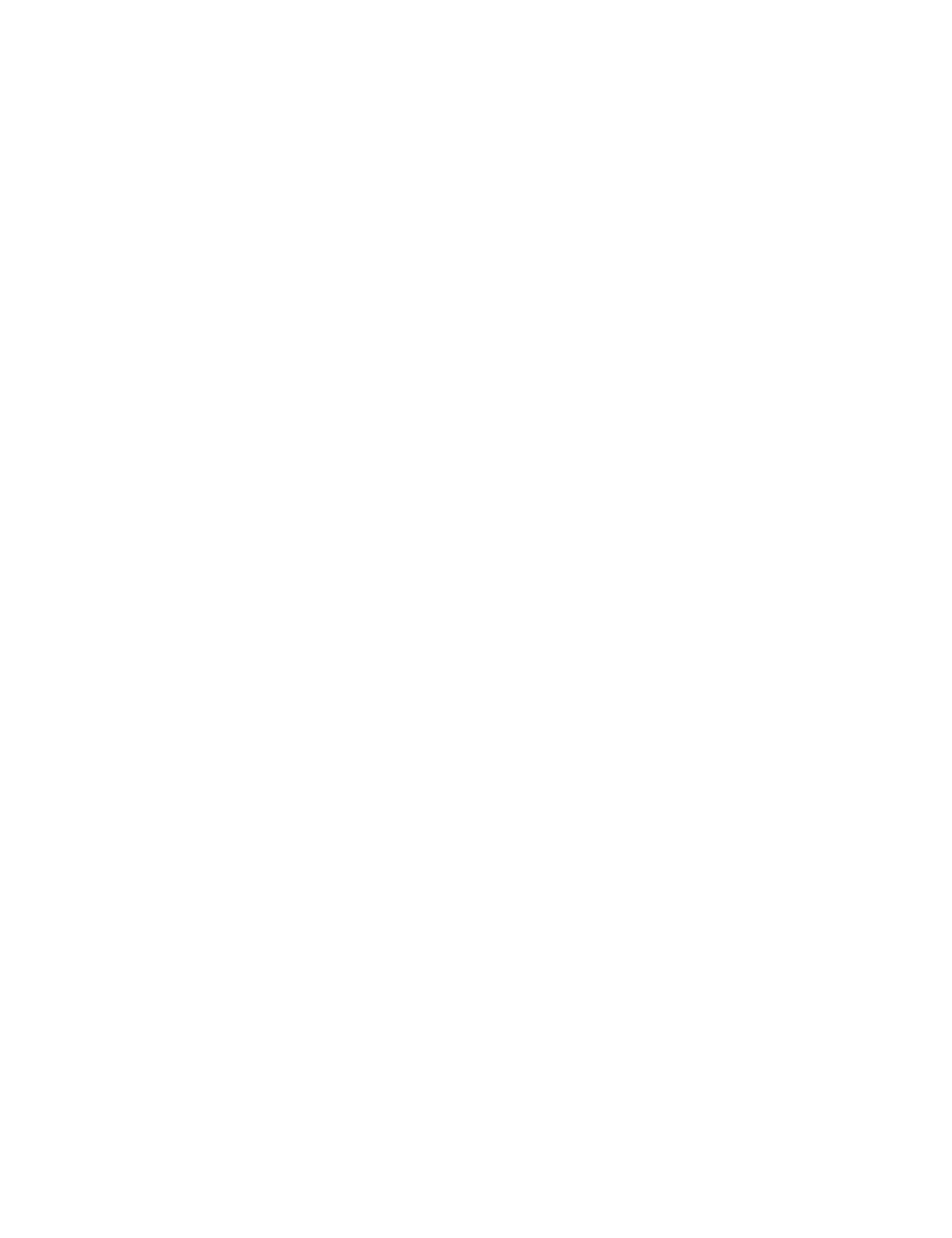


NACIMIENTO CREEK.

This stream drains the eastern slopes of the Santa Lucia Mountains and enters Salinas River 5 miles above Bradley, Cal. A gaging station was established on this stream at Harris ranch, near Bryson, Cal., by S. G. Bennett, on February 17, 1901. The record on this stream was discontinued April 30, 1901. The total area drained above the gaging station is 171 square niles.

Discharge measurements of Nacimiento Creek, a branch of Salinas River, at point near Bryson, Monterey County.

\begin{tabular}{|c|c|c|c|c|}
\hline Date. & Hydrographer. & & $\begin{array}{c}\text { Gage } \\
\text { height. }\end{array}$ & $\begin{array}{c}\text { Dis- } \\
\text { charge. }\end{array}$ \\
\hline 1901. & & & Feet. & Sec.-feet. \\
\hline Feb. 17 & S. G. Bennett ....... & & $6.1 \%$ & 284 \\
\hline Mar. 25 & 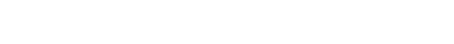 & $\ldots \ldots$ & 5.3 & 105 \\
\hline Apr. 3 & do & & 5.3 & 121 \\
\hline
\end{tabular}

Discharge measurements of Nacimiento Creek, a branch of Salinas River, near Newhall Ranch house, San Migulito ranch, Monterey County.

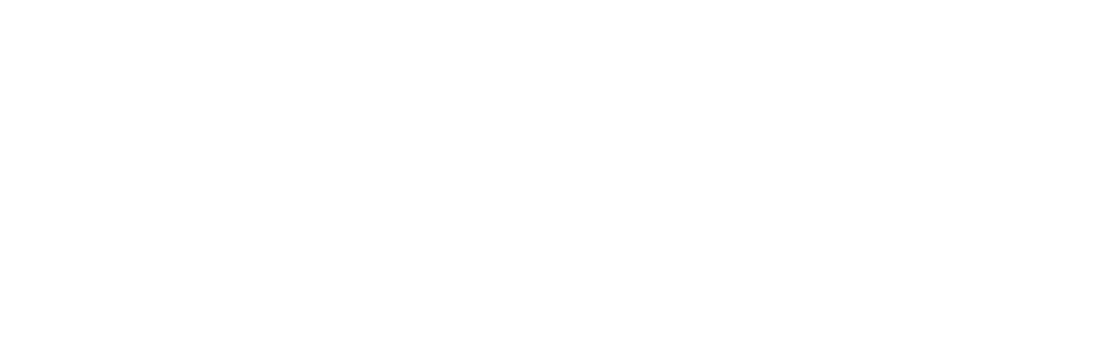

Estimated monthly discharge of Nacimiento Creek, a tributary of Saliras River, at Bryson, Monterey County.

[Drainage area, $1 \% 1$ square miles.]

\begin{tabular}{|c|c|c|c|c|c|c|}
\hline \multirow[b]{2}{*}{ Month. } & \multicolumn{3}{|c|}{ Discharge. } & \multirow[b]{2}{*}{$\begin{array}{l}\text { Total dis- } \\
\text { charge. }\end{array}$} & \multicolumn{2}{|c|}{ Run-off. } \\
\hline & Maximum. & Minimum. & Mean. & & $\begin{array}{l}\text { Per } \\
\text { square } \\
\text { mnile. }\end{array}$ & Depth. \\
\hline February $1 \%$ to $28 \ldots$ & $\begin{array}{r}\text { sicr-feet. } \\
3,300\end{array}$ & $\begin{array}{r}\text { Sec-feet. } \\
295\end{array}$ & $\begin{array}{r}\text { Sec.-feet. } \\
855\end{array}$ & $\begin{array}{l}\text { Acre-feet. } \\
\quad 20,350\end{array}$ & $\begin{array}{c}\text { Ser.feet. } \\
5.00\end{array}$ & $\begin{array}{l}\text { Inches. } \\
5.21\end{array}$ \\
\hline March ............. & 365 & 110 & 184 & 11,314 & 1.08 & 1.24 \\
\hline April & 670 & 87 & 99 & 5,891 & .58 & .65 \\
\hline
\end{tabular}

Discharge measurements of Nacimiento C'reek, a tributary of Salinas River, it miles above mouth, San Luis Obispo County.

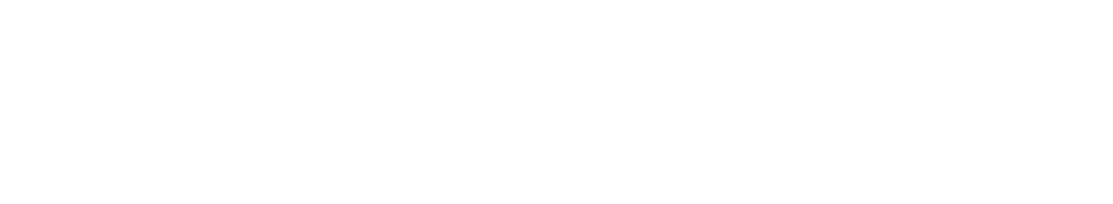


BIRNETT CREEK.

Discharge measurements of Burnett ('reek, tributary of Nacimiento Creek, a branch of Salinas River. San Luis Obispo County.

\begin{tabular}{|c|c|c|c|}
\hline Date. & Hydrographer. & $\begin{array}{c}\text { Gage } \\
\text { height. }\end{array}$ & $\begin{array}{c}\text { Dis- } \\
\text { charge. }\end{array}$ \\
\hline 1901. & & Feet. & sec-feet. \\
\hline Apr. $4 \ldots \ldots$ & W. W. Cockins. jr & $\ldots \ldots$ & 21 \\
\hline
\end{tabular}

SAN ANTONIO CREEK.

This stream drains the eastern slopes of the Santa Lucia Mountains and enters the Salinas River at Bradley, Cal. A gaging station was established near Jolon, Cal., December 15, 1900, by Wr. Wr. Cockins, jr. The total area drained is 161 square miles. The record on this stream was discontinued April 30, 1901.

Discharge measurements of San Autonio Creek, Salinas River, near Jolon, Monterey County.

\begin{tabular}{|c|c|c|c|}
\hline Date. & $\mathrm{H}_{y}$ rlrographer. & $\begin{array}{c}\text { Gage } \\
\text { height. }\end{array}$ & $\begin{array}{c}\text { Dis- } \\
\text { charge. }\end{array}$ \\
\hline 1901. & & Feet. & Sec--feet. \\
\hline Jan. 19 & S. G. Bennett & 4.45 & 185 \\
\hline Feb. 12 & $\ldots$. $\ldots$ do _.... & 4.8 & 242 \\
\hline Mar. 18 & W. W. Cockins, jr & 4.5 & 148 \\
\hline Mar. 26 & $\ldots$ do _ _........ & 4.3 & 76 \\
\hline Apr. 5 & .....do .... . & 4.3 & 76 \\
\hline Apr. 18 & $\ldots$ do $\ldots . . .$. & 4.1 & 59 \\
\hline July 11 & H. Hamlin . . . . . & $\ldots$. & .64 \\
\hline
\end{tabular}

Discharge measurement of San Antonio Creek, Salinas River, Los Ojitos Dam site, Monterey County.

\begin{tabular}{|c|c|c|c|}
\hline Date. & Hydrographer. & $\begin{array}{c}\text { Gage } \\
\text { height. }\end{array}$ & $\begin{array}{c}\text { Dis- } \\
\text { charge. }\end{array}$ \\
\hline 1901. & & Feet. & sec.feet. \\
\hline Apr. 17 & J. B. Lippincott... & & 50 \\
\hline
\end{tabular}

Discharge measurement of Sam Antonio Creek. Salinas River, Pinkerton Dam site, Monterey County.

\begin{tabular}{|c|c|c|c|}
\hline Date. & Hyllrographer. & $\begin{array}{c}\text { Gage } \\
\text { height. }\end{array}$ & $\begin{array}{c}\text { Dis- } \\
\text { charge. }\end{array}$ \\
\hline 1901. & & Feet & sec.feet. \\
\hline Apr. 17 & J. B. Lippincott. . . . . . & 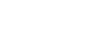 & 37 \\
\hline
\end{tabular}


Estimated monthly alischarge of San Antomin (reek, a tributary of Salinas River, at Jolon. Monterey County.

[Drainage area, 161 square miles.]

\begin{tabular}{|c|c|c|c|c|c|c|}
\hline \multirow[b]{2}{*}{ Month. } & \multicolumn{3}{|c|}{ Discharge. } & \multirow{2}{*}{$\begin{array}{l}\text { Total dis- } \\
\text { charge. }\end{array}$} & \multicolumn{2}{|c|}{ Run-off. } \\
\hline & Maximum. & Minimum. & Mean. & & $\begin{array}{l}\text { Per } \\
\text { square } \\
\text { mile. }\end{array}$ & Depth. \\
\hline 1900 . & Sereffect. & siecefeet. & Sec-feet. & Arrefeet. & Ner'-feet. & Inches. \\
\hline December 1 is to 28 & 200 & 170 & 184 & 5. 109 & 1.14 & 0.59 \\
\hline 1901. & & & & & & \\
\hline January _... . . . . . & 3.700 & 64 & $52: 3$ & 32.158 & 3.25 & 3.55 \\
\hline February .......... & $1, \pi 00$ & 110 & 509 & 28,268 & 3.17 & 3.31 \\
\hline March ............. & 400 & 84 & $1 \% 1$ & $10, \pi 14$ & 1.06 & 1.22 \\
\hline April & 740 & 39 & $8: 3$ & 4,939 & .52 & .5 \\
\hline
\end{tabular}

S.AN JURENZU ('REFK.

This strean drains the western slojes of the Gavilan Mountains and enters the Salinas River noar Kings (ity, Cal. There is a reservoir and dam site on the stream 5 miles above its mouth. The stream is entirely dry during the summer months. The flood waters are used for winter irrigation. I gaging station was established December 16 , igou, hy W. W. Cockins, jr., at Ilollonberk's ranch, a quarter of a mile helow the dam site.

The area of the watersherl drained is was square miles.

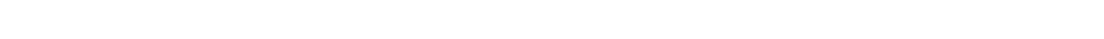
above king ('ity. Monterey County.

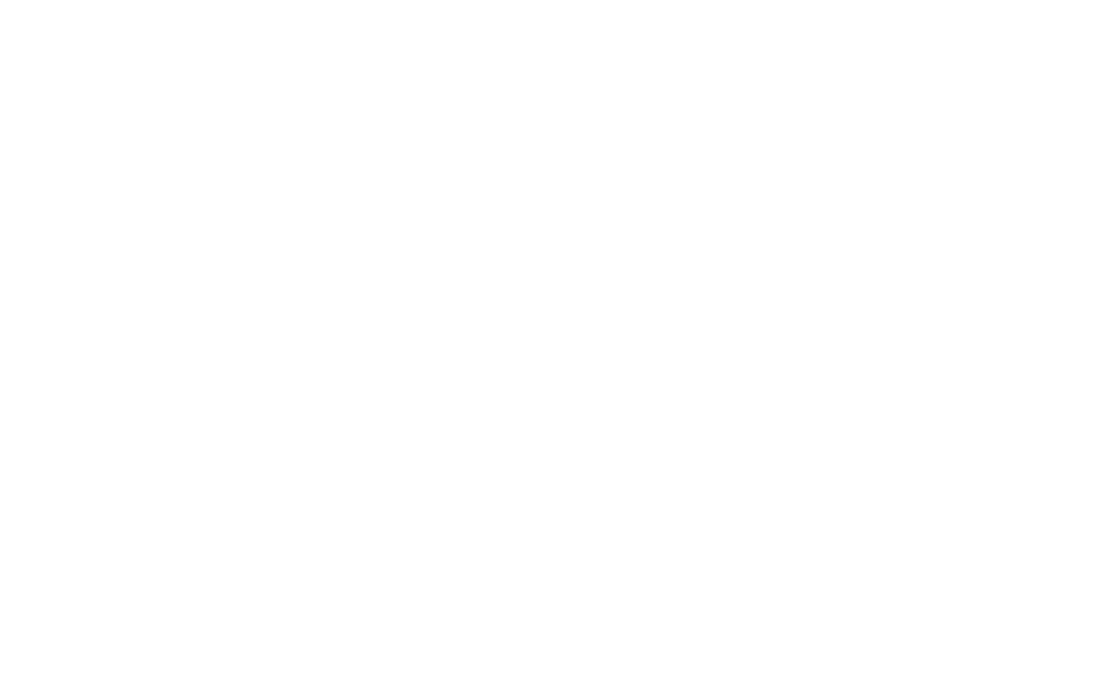


Estimated monthly discharge of San Lorenzo Creek, a tributary of Salinas Rizer, at King City. Monterey County.

[Drainage area, 235 square miles.]

\begin{tabular}{|c|c|c|c|c|c|c|}
\hline \multirow[b]{2}{*}{ Month. } & \multicolumn{3}{|c|}{ Discharge. } & \multirow[b]{2}{*}{$\begin{array}{l}\text { Total. } \\
\text { discharge. }\end{array}$} & \multicolumn{2}{|c|}{ Run-off. } \\
\hline & Maximum. & Minimum. & Mean. & & $\begin{array}{l}\text { Per } \\
\text { square } \\
\text { mile. }\end{array}$ & Deptr \\
\hline 1900. & Sec.-feet. & sec-feet. & Sec-feet. & Acre-feet. & Sec-feet. & Inches. \\
\hline December 16 to 31 & 13 & 9 & 9 & 286 & 0.04 & 0.0 \\
\hline 1901 & & & & & & \\
\hline January ..... & $2, \dot{3} 40$ & 9 & $1 \pi 1$ & 10,514 & .73 & \\
\hline February - . & 9,200 & 9 & 725 & 40,264 & 3.09 & 3.2 \\
\hline March ... & 27 & 9 & 17 & 1,045 & .07 & . \\
\hline April & 13 & 6 & 8 & 476 & .03 & \\
\hline
\end{tabular}

Estimated monthly discharge of San Lorenzo Creek at King City.

[Drainage area, 235 square miles.]

\begin{tabular}{|c|c|c|c|c|c|c|}
\hline \multirow[b]{2}{*}{ Month. } & \multirow[b]{2}{*}{ Maximum. } & arge. & \multirow[b]{2}{*}{ Mean. } & \multirow[b]{2}{*}{$\begin{array}{l}\text { Total dis- } \\
\text { eharge. }\end{array}$} & \multicolumn{2}{|c|}{ Run-off. } \\
\hline & & Minimum. & & & $\begin{array}{l}\text { Per } \\
\text { square } \\
\text { mile. }\end{array}$ & Depth. \\
\hline 1902. & Sec-feet. & Sec.feet. & Ser-fett. & Acre-feet. & sec.-feet. & Inches. \\
\hline January .... & 15 & 5 & 6 & 369 & .03 & .03 \\
\hline February .. & 79.5 & 5 & 69 & 3,832 & .29 & .30 \\
\hline March .... & 875 & j & 81 & 4,980 & .34 & .39 \\
\hline April . & 5 & 3 & 4 & 238 & .02 & .02 \\
\hline November..... & 200 & 15 & 85 & 5,057 & .36 & .40 \\
\hline December ... . & 15 & 5 & $r$ & 430 & .03 & .03 \\
\hline
\end{tabular}

SALT SPRING VALLEY.

Estimated scasomal discharge into Salt Spring Valley reservoir near Milton, C'alareras County, Cal.a

[Drainage area, 25 square miles.]

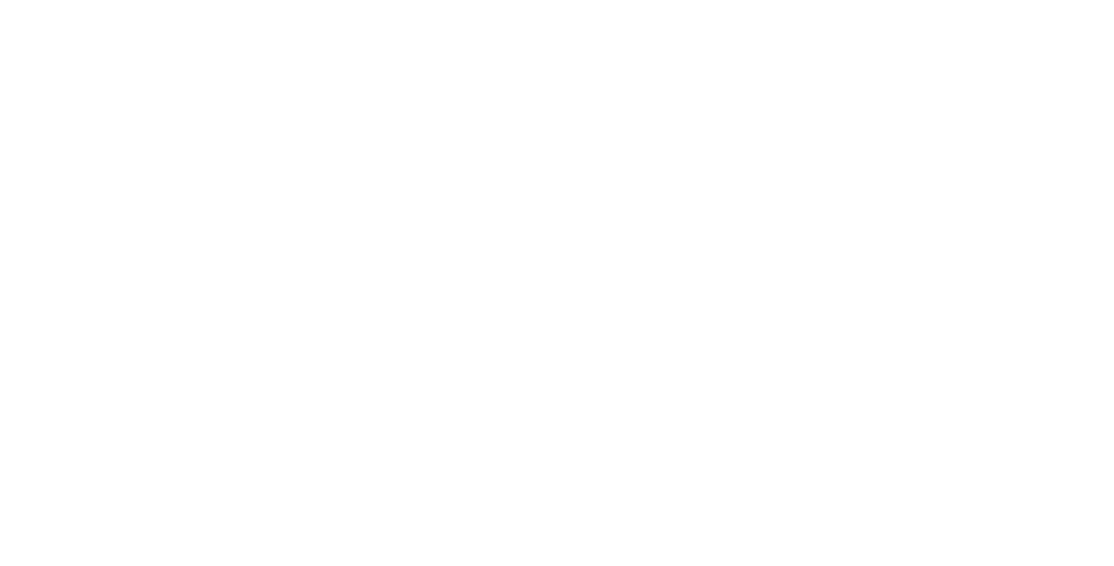




\section{SAN ANTONIO CREEK.}

The discharge of the streams of southern California was unusually low in september, 1898 , and these measurements were made by the Edison Electric Company to determine the minimum. with its hourly fluctuation.

Diseharge measurements of Sam Antonio Creek, at Water C'ompany's ueir, San Beruardino County.

[Measurements by Edison Electric Co.]

\begin{tabular}{|c|c|c|c|}
\hline Late. & $\begin{array}{l}\text { Dis- } \\
\text { charge. }\end{array}$ & Date. & $\begin{array}{l}\text { Dis- } \\
\text { clarge. }\end{array}$ \\
\hline$\cdots--$ & - - - & - & $-\ldots$ \\
\hline September 15, 1898: & Sereffeet. & September $15.1898-$ Cont d. & Sier.feet. \\
\hline \% a. $\mathrm{m}_{\ldots} \ldots \ldots$ & ร. 60 & 9 p. $\mathrm{m}_{\ldots} \ldots$ & 5.44 \\
\hline 7.30 a. $\mathrm{m} \ldots$ & 5.60 & 9.30 p. $\mathrm{m} \ldots \ldots$ & 5.60 \\
\hline sa. $\mathrm{m} \ldots \ldots$ & 5.60 & $10 \mathrm{p} . \mathrm{m}_{\ldots} \ldots \ldots$ & 5.60 \\
\hline 8.30 a. $m \ldots$. & 5.60 & 10.30 p. m $\ldots$ & 5.60 \\
\hline 9 a. $m \ldots . . .$. & 5.58 & 11 p. m...... & 5.60 \\
\hline 9.30 a. $\mathrm{m} \ldots$ & 5.58 & $11.30 \mathrm{p} . \mathrm{m} \ldots \ldots$ & 5.70 \\
\hline 10 a. $\mathrm{m} \ldots \ldots$ & 5.58 & 12 midnight $\ldots . .$. & 5.70 \\
\hline 10.30 a. $\mathrm{m}$ & 5.44 & September 16, 1898: & \\
\hline 11 a. $\mathrm{m} \ldots . .$. & 5.32 & 12.30 a. $\mathrm{m}$ & 5.70 \\
\hline 11.30 a. $\mathrm{mn}$. & 5.32 & 1 a. $\mathrm{m}_{\ldots} \ldots \ldots$ & 5.70 \\
\hline $12 \mathrm{~m} \ldots \ldots$ & 5.32 & 1.30 a. $\mathrm{m} \ldots .$. & 5.70 \\
\hline 12.30 p. $\mathrm{ml} \ldots$ & 5.32 & 2 a. $\mathrm{m}_{\ldots} \ldots \ldots \ldots$ & 5.70 \\
\hline 1 p. m... . . . & .). 06 & 2.30 a. $\mathrm{m} \ldots \ldots$ & 5.70 \\
\hline $1.30 \mathrm{p} . \mathrm{m} \ldots . .$. & 5.06 & 3 a. $\mathrm{m} \ldots$ & 5.70 \\
\hline 2 p. $m_{\ldots} \ldots \ldots$ & 5.06 & 3.30 a. $\mathrm{m} \ldots$ & 5.70 \\
\hline 2.30 p. $\mathrm{m} \ldots \ldots$ & 5.06 & 4 a. $\mathrm{m} \ldots \ldots . . .$. & 5.70 \\
\hline 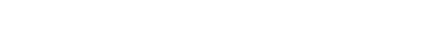 & 4.94 & 4.30 a. $\mathrm{m} \ldots$ & 5.70 \\
\hline $3.30 \mathrm{p} . \mathrm{m} \quad \ldots$. & 4.94 & 5 a. $\mathrm{m}_{\ldots} \ldots \ldots$ & 5.70 \\
\hline 4 p. m $\ldots \ldots$. & 4.94 & 5.30 a. $\mathrm{m} \ldots \ldots$ & 5.70 \\
\hline 4.30 p. m . . . . . . . . & 4.80 & 6 a. $\mathrm{m} \ldots$ & 5.60 \\
\hline 5 p. $\mathrm{m}_{\ldots} \ldots \ldots \ldots \ldots$ & 4.80 & 6.30 a. $\mathrm{m} \ldots$ & 5.60 \\
\hline $5.30 \mathrm{p}, \mathrm{m} \ldots \ldots \ldots$ & 4.80 & 12-hour mean & $5.5 \%$ \\
\hline $6 \mathrm{p} . \mathrm{m} \ldots$. & 4.92 & & \\
\hline $6.30 \mathrm{p} . \mathrm{m} \ldots$ & 5.06 & September 16, 1898: & \\
\hline 12-hour mean & 5.22 & ' a. m... & 5.60 \\
\hline Septenuber 15, 1898: & & 8 a. $m \ldots$ & 5.60 \\
\hline$\tau p \cdot \mathrm{m}_{\ldots} \ldots \ldots$ & 5.06 & 8.30 a. $\mathrm{m} \ldots \ldots$ & 5.60 \\
\hline 7.30 p. $\mathrm{m} . . . . . .$. & 5.06 & 9 a. $m \ldots$ & 5.60 \\
\hline 8 p. m. . . . . . & 5.06 & 9.30 a. $\mathrm{m}$ & 5.60 \\
\hline 8.30 p. $\mathrm{m} \ldots \ldots$ & 5.44 & $10 \mathrm{a}, \mathrm{m} \ldots \ldots \ldots$ & 5.44 \\
\hline
\end{tabular}


I Discharge measurements of San Antonio Creek, etc.-Continued.

\begin{tabular}{|c|c|c|c|}
\hline Date. & $\begin{array}{l}\text { Dis- } \\
\text { charge. }\end{array}$ & Date. & $\begin{array}{l}\text { Dis- } \\
\text { charge. }\end{array}$ \\
\hline September 16,1898 -Cont'd. & rec.feet. & September 16, 1898-Ccnt'd. & Sec.-feet. \\
\hline 10.30 a. $10 \ldots \ldots \ldots$ & & 9 p. $\mathrm{m}$ & 5.44 \\
\hline 11 a. m .............. & 5. 18 & $9.30 \mathrm{p.m}$ & 5.44 \\
\hline 11.30 a. $\mathrm{m}$ & 5.06 & 10 p. $\mathrm{m} \ldots$ & 5.44 \\
\hline $12 \mathrm{~m} \ldots \ldots \ldots$ & 5.06 & 10.30 p.m & 5.60 \\
\hline 12.30 p. $\mathrm{m}_{\ldots} \ldots$ & 4.94 & 11 p.m . . . . . & 5.60 \\
\hline 1 p. m........... & 4.94 & 11.30 p.m $\ldots$ & 5.60 \\
\hline $1.30 \mathrm{p} . \mathrm{m}$. & $\tilde{5.06}$ & 12 midnight .... & 5.60 \\
\hline $2 \mathrm{p} . \mathrm{m} \ldots$ & 5.06 & September $1 \%, 1898:$ & \\
\hline $2.30 \mathrm{p.m}$ & 5.06 & 12.30 a. $\mathrm{m}$ & 5.60 \\
\hline $3 \mathrm{p} . \mathrm{m} \ldots$ & 5.06 & $1 \mathrm{a} . \mathrm{m} \ldots$ & 5.60 \\
\hline 3.30 p. m ... & 4.80 & $1.30 \mathrm{a} . \mathrm{m}$ & 5.60 \\
\hline 4 p. m . . . . & 4.80 & 2 a.m $\ldots$ & 5.60 \\
\hline $4.30 \mathrm{p} . \mathrm{m}$. & 4.56 & $2.30 \mathrm{a} . \mathrm{m}$ & 5.60 \\
\hline 5 p. $\mathrm{m}_{\ldots} .$. & 5.06 & $3 \mathrm{a} . \mathrm{m} \ldots$ & 5.60 \\
\hline $5.30 \mathrm{p} . \mathrm{m} \ldots$ & 5.06 & $3.30 \mathrm{a} . \mathrm{m}$ & 5.70 \\
\hline $6 \mathrm{p} . \mathrm{m} \ldots$ & 5.06 & 4 a.m ... & 5.70 \\
\hline $6.30 \mathrm{p.m} \ldots \ldots$ & 4.92 & $4.30 \mathrm{a} . \mathrm{m}$ & 5.70 \\
\hline 12-hour mean . .... & 5.16 & $5 \mathrm{a} . \mathrm{m} \ldots$ & 5.70 \\
\hline September 16,1898 : & & $\begin{array}{l}5.30 \mathrm{a} . \mathrm{m}- \\
6 \mathrm{a} . \mathrm{m} \ldots\end{array}$ & \\
\hline † p.m $\ldots . . .$. & 5.06 & 6.30 a. $\mathrm{m}$ & 5.60 \\
\hline 7.30 p. $\mathrm{m} \ldots$ & i). 06 & & \\
\hline 8 p.m $\ldots$ & 5.06 & 12-hour mean & 5.5 \\
\hline 8.30 p.m $\ldots \ldots$ & 5.06 & & \\
\hline
\end{tabular}

Discharge measurements of San Antonio Creek, San Bernardino County.

\begin{tabular}{|c|c|c|c|}
\hline Date. & Hydrographer. & $\begin{array}{c}\text { Dis- } \\
\text { charge. }\end{array}$ & Locelity. \\
\hline & & Sec.feet. & \\
\hline July 23,1896 & J. H. Quinton ... & 7.9 & Month of canyon. \\
\hline July $2,1898 \ldots$ & F. H. Olmsted. & 6.59 & Do. \\
\hline Aug. 26, 1898 & $\ldots$ do $\ldots \ldots$ & 5.18 & Division weir. \\
\hline Aug. $25,1899_{-1}$ & S. G. Bennett - - & 4.48 & Mouth of canyon. \\
\hline July 11,1900 _ & $\ldots$ do $\ldots \ldots \ldots$ & 4.07 & Do. \\
\hline Sept. 25, 1900 & W. W. Cockins, jr. & 3.72 & Division weir. \\
\hline April $3,1902 \ldots$ & S. G. Bennett ...... & 11.40 & Do. \\
\hline July 23,1896 & J. H. Quinton ... & 1.88 & Ontario water from tunnel. \\
\hline July $2,1898 \ldots$ & F. H. Olmsted ... & 3.36 & In creek at Pierce's camp. \\
\hline
\end{tabular}


The water of San Antonio ('reek is utilized to a large extent. The Pacific Electrie Light and Power Company, commonly called the San Gabriel Electric Company, has a power plant in the canyon at an elevation of 3,250 feet. The water from the tailrace of this power house passes over a measuring weir and is discharged into the pipe line of the San Antonio Water Company's power plant. It is carried in this conduit on the right bank of the canyon to a point opposite the old division weir between the San Antonio Water Company and the Pomoua Land and Water Conpany, from which point it is discharged through the power house of the San Antonio Water Company. The portion of the water which goes to the San Antonio Water Company is again diverted through a pipe line and nsed at a third power house, at an elevation of about 1,!100 feet, near the left bank of the canyon. In addition there is a tunnel in the mouth of the canyon run through the bowlders and gravels of the river bed to bed rock, up to and near the old division box mentioned above. This tunnel water together with all other water after it has been used for power is used for irrigation near Ontario and Pomona.

The second power plant on the river was constructed by the San Antonio Water Company during the year 1902, and before tre water was diverted into the concluits of this corporation a board of engineers was appointed by the San Antonio Water Company to make measurements of the water in various portions of the canyon in order to determine what effect, if any, would result from the diversion of the stream which they contemplated from the upper power house of the San Gabriel Electric Company to the old division box. This board of engineers consisted of W. Il. Saunders, chief engineer, F. E. Trask, Samuel Storrow, and J. B. Lippincott, consulting engineer. suitable weirs were erected, and automatic river-height-recording devices were installed on most of these weirs. The San Gabriel Electric Company's power-house weir was located in the tailrace of the power house, and measured the main volume of water in the river at that point. The "Fountain of Life" spring is a small steady flow of water issuing from a spring near the San Gabriel Electric Company's power house, but the water is not included in that measured in the power-house weir. A small amount of water was flowing in the bed of the stream opposite the San Gabriel Electric Company's power house, and was not included in either the power-house weir or the "Fountain of Life" spring measurements.

The Spring Hill weir was located in the main river below the San Gabriel Elertric Company's power house and measured total flow.

The "Baby Ruth" weir was also in the main stream below the San Gabriel Electric Company's power house, and above the division weir, and measured the full stream.

The division weir was located in the main stream opposite the power house of the San Antonio Water Company. At this point the 
water is divided between the San Antonio Water Company and the Pomona Land and Water Company, but before the division occurs a certain amount of water, known as gird water, is talen out of the stream and not included in the measurement of the main division weir.

The water measured in the san Antonio tumnel is picked up from the sands and gravels of the river bed below all the above-mentioned points of measurements, and this water is not includerl in any other measurement.

All these measurements were made prior to the time when the diversion occurred through the new pipe line and power plant of the San Antonio Water Company.

All these measurements were made for the San Antonio Water Company by the engineers in question. They were supplemented by further continuous records obtained from the automatic registers; but these records are not now available for publication.

Discharge measurements of Sren Antonio Creek.

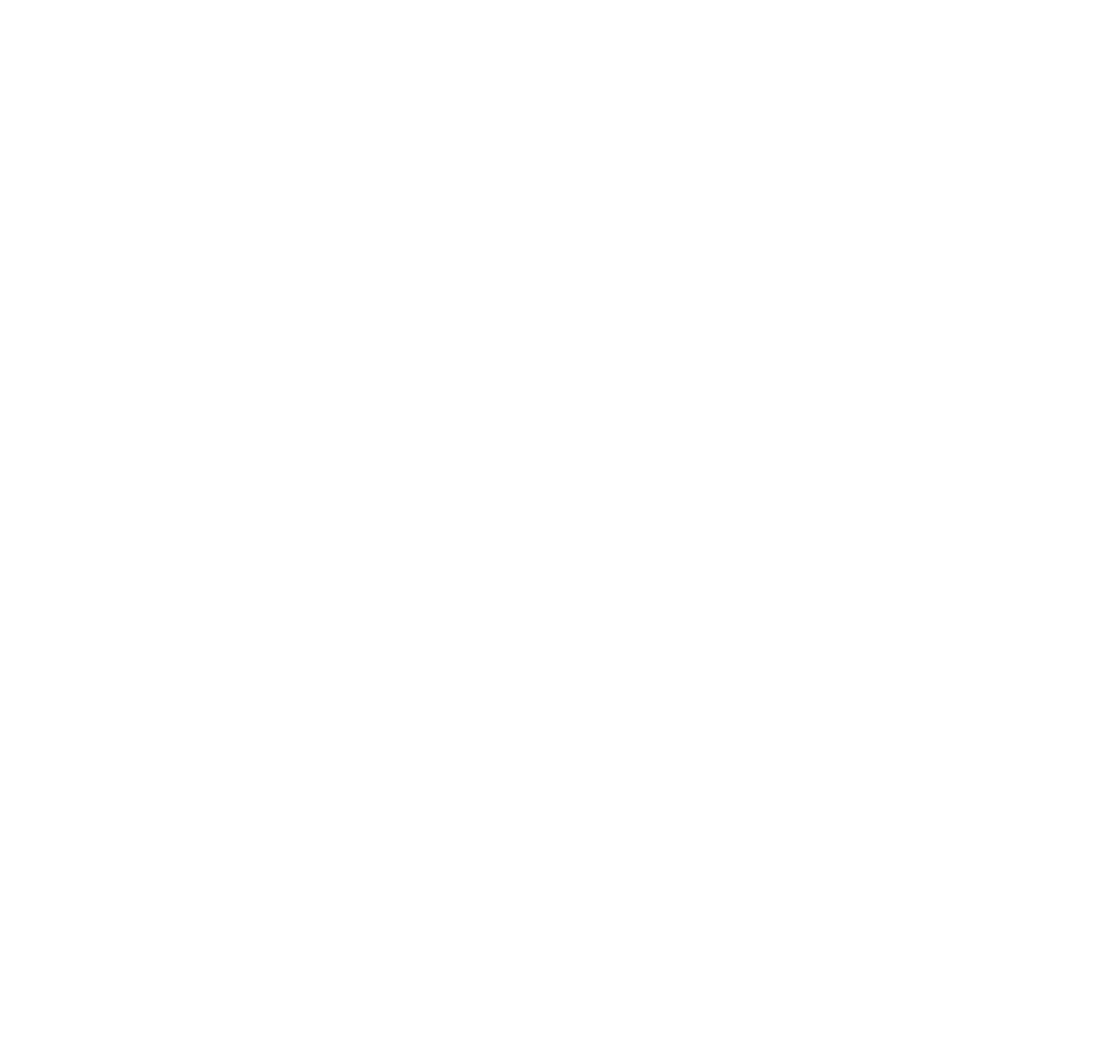


Discharge measurements of San Antonio Creek-Continued.

\begin{tabular}{|c|c|c|c|}
\hline Date. & Hydrographer. & $\begin{array}{c}\text { Dis- } \\
\text { charge. }\end{array}$ & Locality. \\
\hline & & Sec.feet. & \\
\hline \multirow{3}{*}{$\begin{array}{l}\text { Ang. } 2,10.30 \text { a. m } \\
\text { Do }\end{array}$} & J. B. Lippincott & 4.83 & Division weir. \\
\hline & 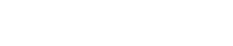 & .36 & Gird water. \\
\hline & & 5.19 & Total. \\
\hline \multirow{3}{*}{$\begin{array}{l}\text { Aug. } 2.2 .30 \text { p. } \mathrm{m} \\
\text { Do } \ldots . . .\end{array}$} & $\ldots$ do. & 4.35 & Division weir. \\
\hline & $\ldots d o \ldots$ & .36 & Gird water. \\
\hline & & $4 . \% 1$ & Total. \\
\hline \multirow{3}{*}{$\begin{array}{r}\text { Aug. } 9,10.18 \text { a. m } \\
\text { Do } \ldots \ldots\end{array}$} & $\ldots$ do .... & 4.76 & Division weir. \\
\hline & _ do & .35 & Gird water. \\
\hline & & 5.11 & Total. \\
\hline \multirow{3}{*}{$\begin{array}{r}\text { Aug. 9. } 2.40 \mathrm{p} \mathrm{m} \ldots \\
\text { Do } \ldots\end{array}$} & .... do ........ & 4.18 & Division wejr. \\
\hline & $\ldots$ do $\ldots . . . . .$. & .35 & Gird water. \\
\hline & & 4.53 & Total. \\
\hline \multirow{3}{*}{\multicolumn{2}{|c|}{$\begin{array}{c}\text { Aug 29. } 10.55 \text { a. } \mathrm{m} \ldots \\
\text { Do } \ldots \ldots\end{array}$}} & 4.26 & Division weir. \\
\hline & & .38 & Gird water. \\
\hline & & 4.64 & Total. \\
\hline \multirow{3}{*}{$\begin{array}{r}\text { Aug. } 29,2.2 \% \text { p. m }- \\
\text { Do } . . . .\end{array}$} & .... do .... & 3.55 & Division weir. \\
\hline & ...do & .38 & Gird water. \\
\hline & & 3.93 & Total. \\
\hline \multirow{3}{*}{$\begin{array}{r}\text { Sept. } 2 \pi .10 .30 \mathrm{a} . \mathrm{m} \\
\text { Do } \ldots \ldots \ldots\end{array}$} & .. do & 4.00 & Division weir. \\
\hline & do & .33 & Gird water. \\
\hline & & 4.33 & Total. \\
\hline \multirow{3}{*}{$\begin{array}{l}\text { Sept. } 2 \pi, 2.15 \mathrm{p} . \mathrm{m} \\
\text { Do } \ldots \ldots \ldots\end{array}$} & $\ldots$ do & $3.5 \%$ & Division weir. \\
\hline & . _ _ do . . & .33 & Gird water. \\
\hline & & 3.90 & Total. \\
\hline \multirow{3}{*}{$\begin{array}{l}\text { Oct. 18. 10.55 a.m } \\
\text { Do }\end{array}$} & ... do . . & 3.98 & Division weir. \\
\hline & $\ldots$ do $\ldots$ & .38 & Gird water. \\
\hline & & 4.36 & Total. \\
\hline June $28 \ldots$ & . . do _.. & .34 & $\begin{array}{l}\text { Fountain of Life spring- } \\
\text { weir measurement. }\end{array}$ \\
\hline July $12,12.15$ p. m & $\ldots$ do .... & .34 & Do. \\
\hline Aug. 2, 12.05 p.m & . do _.... & .30 & Do. \\
\hline
\end{tabular}


Discharge measuremeuts of San Antonio Creek-Continued.

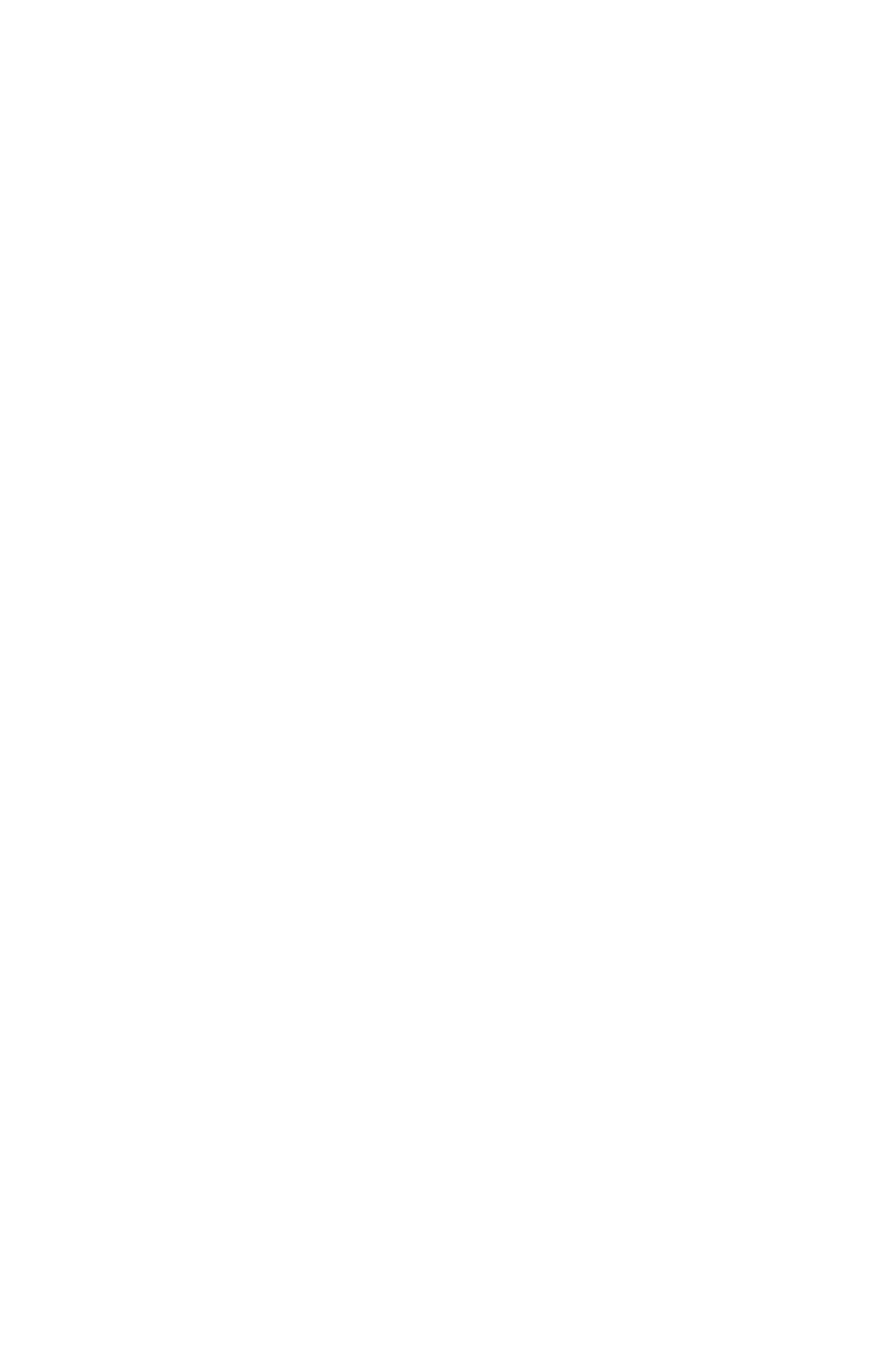


SAN BERNARDINO VALLEY.

Discharge measurements of San Bernardino Valley, betueen San Bernardino and Riverside.

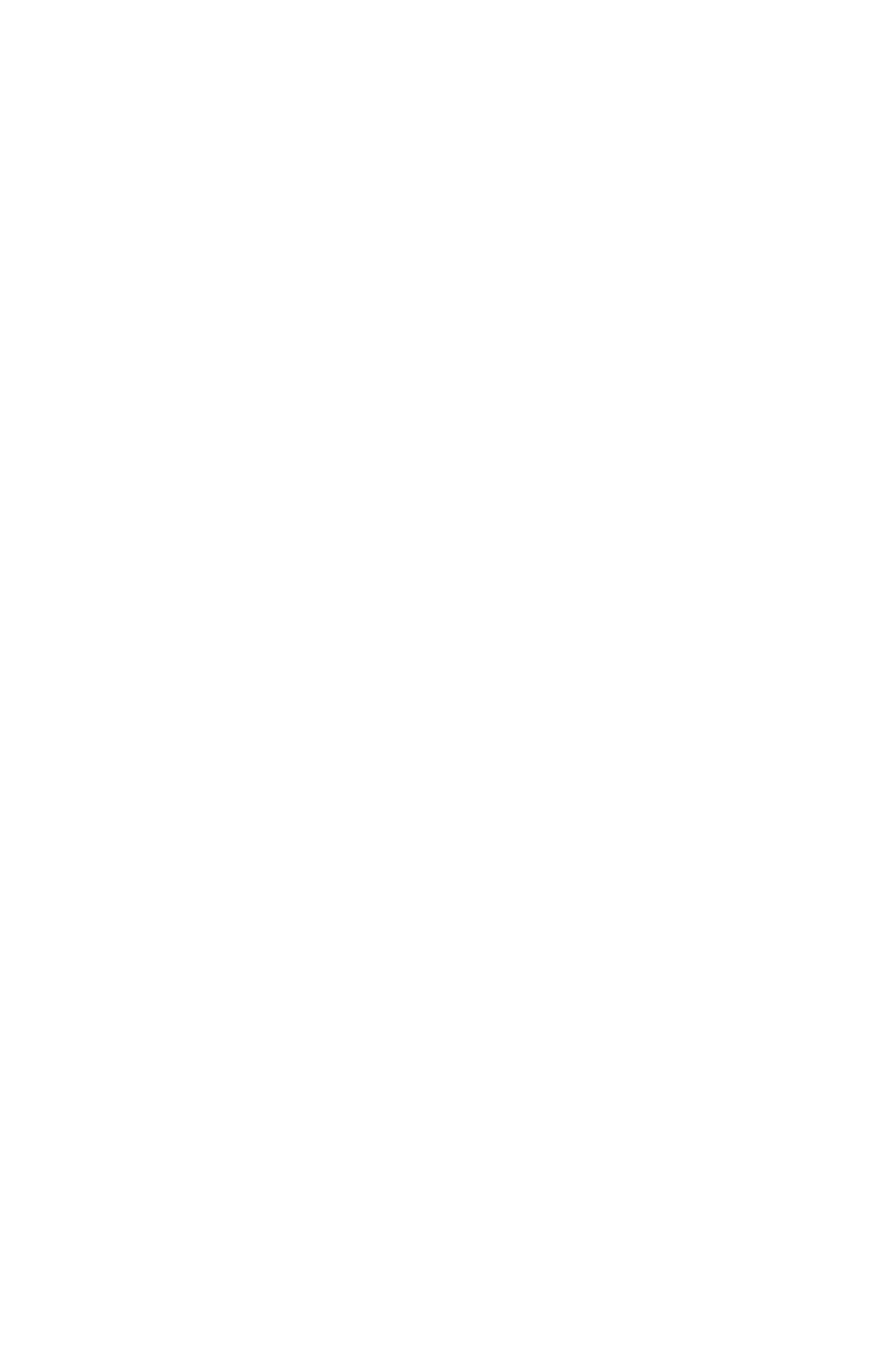


Discharge measurements of San Bernardino Valley, etc.-Continued.

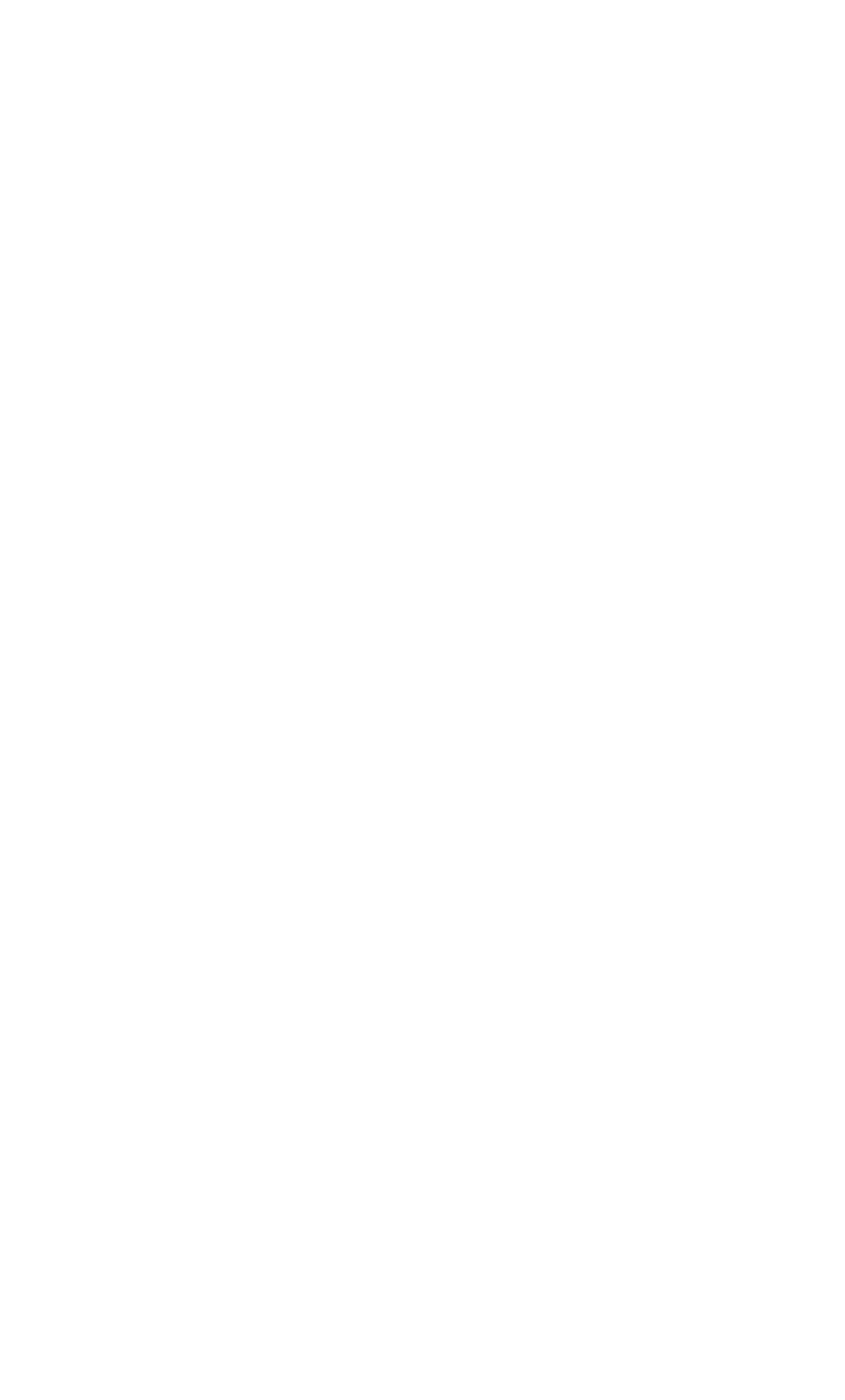


Discharge measurements of San Bernardino Valley, etc.-Continued.

\begin{tabular}{|c|c|c|}
\hline Date & $\begin{array}{c}\text { Dis- } \\
\text { rharge }\end{array}$ & Locality. \\
\hline & Sec $\cdot$ feet & \\
\hline September, 1900 & 27.85 & Gage canal, Palm avenne weir. developerl water. \\
\hline October 11,1902 & 30.17 & Do. \\
\hline June, $1898 \ldots \ldots$. . . . & .84 & Haws and Talmadge ditch, natural water. \\
\hline September. 1898 ... . & .00 & Do. \\
\hline March. 1899 _. . . & .28 & Do. \\
\hline June, $1899 \ldots$ & .00 & Do. \\
\hline August. $1899 \ldots . .$. & .00 & Do. \\
\hline March, 1900 ...... & .00 & Do. \\
\hline June, $1900 \ldots . . .$. & .00 & Do. \\
\hline September, $1900 \ldots$ & .00 & Do. \\
\hline September $30,1902 \ldots$ & .00 & Do. \\
\hline June, $1898 \ldots . .$. & .72 & Logsdon and Farrell ditch, natural water. \\
\hline September, $1898 \ldots$ & .63 & Do. \\
\hline March, $1899 \ldots$ & 1.61 & Do. \\
\hline June, $1899 \ldots \ldots$. & 1.15 & Do. \\
\hline August, 1899 .. & .54 & Do. \\
\hline March. $1900 \ldots$ & 1.26 & Do. \\
\hline June, $1900 \ldots \ldots$ & .49 & Do. \\
\hline September. 1900 & .20 & Do. \\
\hline October $13,1902 \ldots$ & .00 & Do. \\
\hline June, $1898 \ldots \ldots$ & .37 & McIntyre ditch, natural water. \\
\hline September, $1898 \ldots$ & .038 & Do. \\
\hline March, 1899 ....... & .82 & Do. \\
\hline June, $1899 \ldots \ldots$ & .15 & Do. \\
\hline August, 1899 & .00 & Do. \\
\hline March. $1900 \ldots$ & .14 & Do. \\
\hline June, $1900 \ldots \ldots$ & .01 & Do. \\
\hline Septembęr, $1900 \ldots$ & .00 & Do. \\
\hline October 7,1902 & .00 & Do. \\
\hline June, $1898 \ldots \ldots$ & 2.54 & McKenzie ditch, natural water. \\
\hline September, 1898 & 2.08 & Do. \\
\hline March, $1899 \ldots$. & 9.40 & Do. \\
\hline June, $1899 \ldots \ldots$. . . . . . & 3.86 & Do. \\
\hline August, $1899 \ldots \ldots$ & 2.00 & Do. \\
\hline March, $1900 \ldots . .$. & 2.30 & Do. \\
\hline June, $1900 \ldots \ldots$. & 1.5 & Do. \\
\hline September, $1900 \ldots$ & 1.69 & Do. \\
\hline September 30,1902 & .00 & Do. \\
\hline June, $1898 \ldots . . . .$. & 8.42 & Meeks and Daley ditch, natural water. \\
\hline September, 1898 . . . & $1 \% .00$ & Do. \\
\hline
\end{tabular}


Discharge measurements of San Bernardino Valley, etc.-Continued.

\begin{tabular}{|c|c|c|}
\hline & & \\
\hline Date. & & Locality \\
\hline & Sec. feet & \\
\hline March, 1899 . . . . & 17.00 & Meeks and Daley ditch, natural water. \\
\hline June, 1899 . . . . . . . . & 15.48 & Do. \\
\hline August, $1899 \ldots \ldots$ & 10.45 & Do. \\
\hline March, 1900 & 13.94 & Do. \\
\hline June, $1900 \ldots \ldots$ & 13.78 & Do. \\
\hline September, $1900 \ldots$ & 14.68 & Do. \\
\hline September $30,1902 \ldots$ & 13.40 & Do. \\
\hline June, $1898 \ldots \ldots \ldots$ & 1.94 & Mill pump, developed water. \\
\hline September, $1898 \ldots$ & 2.04 & Do. \\
\hline March, $1899 \ldots$. & .00 & Not rumning. \\
\hline June, $1899 \ldots \ldots$ & $1 . \pi$ & Mill pump, developed water. \\
\hline August, 1899 & $1.6 \pi$ & Do. \\
\hline Mar'ch, 1900 & .00 & Not running. \\
\hline June, $1900 \ldots \ldots$. . . & 1.88 & Mill pump. developed water. \\
\hline September, $1900 \ldots$ & 1.52 & Do. \\
\hline September $30,1902 \ldots$ & 1.20 & Do. \\
\hline June, $1 \times 98 \ldots \ldots$ & 5. 37 & Rabel dam ditch, natural water. \\
\hline September, 1898 & $3.0 \%$ & Do. \\
\hline March.1899 _...... & 2.26 & Do. \\
\hline June, $1899 \ldots .$. & 1.54 & Do. \\
\hline August, $1899 \ldots .$. & .94 & Do. \\
\hline March, $1900 \ldots$ & .54 & Do. \\
\hline June, $1900 \ldots \ldots . . . .$. & .35 & Do. \\
\hline September, $1900 \ldots$ & $.0 \%$ & Do. \\
\hline September $30,1902 \ldots$ & .00 & Do. \\
\hline June. 1898 ... . . . . . . & 1.75 & Ranchero ditch, natural water. \\
\hline September, 1898 . & 1.64 & Do. \\
\hline March, $1899 \ldots \ldots$ & 1.64 & Do. \\
\hline June, 1899 & 1.00 & Do. \\
\hline August. $1899 \ldots$ & .41 & Do. \\
\hline March, $1900 \ldots \ldots$ & .24 & Do. \\
\hline June, $1900 \ldots \ldots$ & .55 & Do. \\
\hline September, $1900 \ldots$ & 1.33 & Do. \\
\hline Do $\ldots . . . . . .$. & .80 & Ranchero ditch, developed water. \\
\hline June, $1898 \ldots \ldots$ ! & 3.12 & Riverside Water Company, natural water. \\
\hline September, 1898 . . . . & 3.36 & Do. \\
\hline March, 1899 . . . . . . & 5.30 & Do. \\
\hline June, $1899 \ldots \ldots$ & 7.29 & Do. \\
\hline Angust, $1899 \ldots \ldots$. . . & 2.56 & Do. \\
\hline March, $1900 \ldots \ldots$ & $2.6 r$ & Do. \\
\hline
\end{tabular}


Discharge measurements of San Bernardino Ialley, etc.-Continued.

\begin{tabular}{|c|c|c|}
\hline Date. & $\begin{array}{c}\text { Dis- } \\
\text { charge. }\end{array}$ & Locality. \\
\hline & Ser-feet. & \\
\hline June. $1900 \ldots .$. & 2.17 & Riverside Water Company, natural water. \\
\hline September. 1900 & .94 & Do. \\
\hline September 30.1902. & .50 & Do. \\
\hline June, $1898 \ldots \ldots$ & 2.30 & Shay or Stout dam ditch, natural water. \\
\hline September, $1898 \ldots$. & 2.08 & Do. \\
\hline March, $1899 \ldots$. & 2.23 & Do. \\
\hline June, $1899 \ldots \ldots$ & 1.13 & Do. \\
\hline August, $1899 \ldots$ & .90 & Do. \\
\hline March, $1900 \ldots \ldots$ & $.50 \tau$ & Do. \\
\hline June, $1900 \ldots \ldots$ & .40 & Do. \\
\hline September, $1900 \ldots$ & .16 & Do. \\
\hline September 30,1902 & .00 & Do. \\
\hline June, $1898 \ldots \ldots \ldots$ & 1.00 & Swamp ditch, natural water. \\
\hline September, 1898 .. & 1.02 & Do. \\
\hline March, $1899 \ldots \ldots$ & .85 & Do. \\
\hline June, $1899 \ldots \ldots . . . .$. &.$\%$ & Do. \\
\hline August, $1899 \ldots \ldots$ & .69 & Do. \\
\hline March, $1900 \ldots \ldots$ &.$\% 0$ & Do. \\
\hline June, $1900 \ldots \ldots$. . . . & .89 & Do. \\
\hline September, $1900 \ldots$ & .86 & Do. \\
\hline October $14,1902 \ldots$ & .93 & Do. \\
\hline June, $1898 \ldots \ldots . . .$. & 1.60 & Ward and Warren ditch. developed water. \\
\hline Do $\ldots \ldots \ldots$ &.$\%$ & Ward and Warren ditch, natural water. \\
\hline September. $1898 \ldots$ & 1.60 & Ward and Warren ditch. developed water. \\
\hline Do $\ldots \ldots \ldots$ & .72 & Ward and Warren ditch, natural water. \\
\hline March, $1899 \ldots \ldots$ & 1.60 & Ward and Warren ditch. developel water. \\
\hline Do ......... & 1.49 & Ward and Warren ditch. natural water. \\
\hline June. $1899 \ldots \ldots$ & .615 & Ward and Warren ditch. developed water. \\
\hline August, $1899 \ldots$ & 1.56 & Do. \\
\hline March, $1900 \ldots$. & 1.60 & Do. \\
\hline Do $\ldots . . . . .$. & .95 & Ward and Warren ditch. natural water. \\
\hline June, $1900 \ldots \ldots$ & 1.60 & Ward and Warren ditch, developed water. \\
\hline Do .............. & .10 & Ward and Warren ditch, natural water. \\
\hline September. $1900 \ldots$ & .53 & Ward and Warren đitch. developed water. \\
\hline October 14,1902 . & .30 & Do. \\
\hline Do............. & 1.58 & Ward and Warren ditch, natural water. \\
\hline June, $1898 \ldots \ldots$ & .26 & Whiting ditch, natural water. \\
\hline September, 1898 & .01 & Do. \\
\hline March, $1899 \ldots \ldots \ldots$ & .76 & Do. \\
\hline June, $1899 \ldots \ldots$. . . . . . & .246 & Do. \\
\hline
\end{tabular}


Discharge measurements of San Bernardino Valley, etr.-Continned.

\begin{tabular}{|c|c|c|}
\hline Date. & $\begin{array}{c}\text { Dis- } \\
\text { charge. }\end{array}$ & Loca.ity. \\
\hline August, 1899 & $\begin{array}{c}\text { Sec-feet } \\
0.01\end{array}$ & Whiting ditch, natural water. \\
\hline March, 1900 & 1.12 & Do. \\
\hline June, $1900 \ldots \ldots$ & .13 & . Do. \\
\hline September, 1900 & .00 & Do. \\
\hline October 13,1902 & .00 & Do. \\
\hline June, $1898 \ldots \ldots$ & .34 & Whitlock ditch, natural water. \\
\hline September, 1898 & .38 & Do. \\
\hline March, $1899 \ldots$ & $.4 \pi$ & Do. \\
\hline June, $1899 \ldots \ldots$ & .28 & Do. \\
\hline August, $1899 \ldots$ & .09 & Do. \\
\hline March, $1900 \ldots$ & .23 & Do. \\
\hline June, $1900 \ldots$ & .00 & Do. \\
\hline September, 1900 & .00 & Do. \\
\hline October 13,1902 & .00 & Do. \\
\hline
\end{tabular}

List of discharge measurements of San Bernardino Valley betueen San Bernardino and Colton.

\begin{tabular}{|c|c|c|}
\hline Date. & $\begin{array}{c}\text { Dis- } \\
\text { charge. }\end{array}$ & Remarks. \\
\hline & Sec.-feet. & \\
\hline June, 1898 & 18.00 & Riverside Water Co., upper canal, developed water. \\
\hline Do $\ldots$ & 41.04 & Riverside Water Co., upper canal, natural water. \\
\hline September, 1898 . & 17.54 & Riverside Water Co., upper canal, ceveloped water. \\
\hline Do _....... . & 43.80 & Riverside Water Co., upper canal, natural water. \\
\hline March, $1899 \ldots$ & 18.04 & Riverside Water Co. upper canal, ceveloped water. \\
\hline Do $\ldots . .$. & 42.49 & Riverside Water Co., upper canal, natural water. \\
\hline June, $1899 \ldots$ & 17.50 & Riverside Water Co., upper canal, developed water. \\
\hline Do . .... & 36.42 & Riverside Water Co., upper canal, natural water. \\
\hline August, 1899 . & 27.50 & Riverside Water Co., upper canal, ceveloped water. \\
\hline Do $\ldots \ldots$ & 24.54 & Riverside Water Co., upper canal, natural water. \\
\hline March, $1900 \ldots$ & 24.54 & Riverside Water Co., upper canal, ceveloped water. \\
\hline Do . . . . . . . & 37.40 & Riverside Water Co., upper canal, natural water. \\
\hline June, $1900 \ldots$ & 32.36 & Riverside Water Co., upper canal, developed water. \\
\hline & 20.58 & Riverside Water Co., npper canal, natural water. \\
\hline September, 1900 & 27.00 & Riverside Water Co., upper canal, developed water. \\
\hline Do .............. & 34.02 & Riverside Water Co., upper canal, natural water. \\
\hline September 30,1902 & 26.08 & Riverside Water Co., upper canal, developed water. \\
\hline Do .............. & 21.89 & Riverside Water Co., upper canal, natural water. \\
\hline
\end{tabular}


Discharge measurements of return unters belou silover Mountain, above Riverside Narrous. San Bernardino Valley, between San Bernardino and Riverside.

\begin{tabular}{|c|c|c|}
\hline Date. & $\begin{array}{c}\text { Dis- } \\
\text { charge. }\end{array}$ & Remarks. \\
\hline 1902. & Sec.-feet. & \\
\hline September 29 & 5.94 & West Riverside pumping plant, developed water. \\
\hline October $11 \ldots$ & 4.38 & Rogers pumping plant, developed water. \\
\hline Do $\ldots$ & 2.95 & $\begin{array}{l}\text { Riverside Water Co., pumping plant No. 1, Santa } \\
\text { Ana River flume, developed water. }\end{array}$ \\
\hline Do $\ldots$ & 2.08 & $\begin{array}{l}\text { Riverside Water Co.. pumping plant No. 2, Santa } \\
\text { Ana River flume, developed water. }\end{array}$ \\
\hline September 29 & $3.10 \%$ & $\begin{array}{l}\text { Riverside Water Co., flume head of lower canal, } \\
\text { natural water. }\end{array}$ \\
\hline Do & ז.19 & Roubidoux Canal, natural water. \\
\hline Do ... & 2.17 & $\begin{array}{l}\text { Evans ditch at north line Riverside Connty line, } \\
\text { natural water. }\end{array}$ \\
\hline Do _ _ & .53 & $\begin{array}{l}\text { Evans ditch } 1 \text { mile south Riverside Connty line, } \\
\text { natural water. }\end{array}$ \\
\hline Do . ..... & 5.35 & $\begin{array}{l}\text { Evans Island ditch, west end of West Riverside } \\
\text { bridge, natural water. }\end{array}$ \\
\hline Do _ - & 1.96 & $\begin{array}{l}\text { Alvetriz ditch at east end West Riversids bridge, } \\
\text { natural water. }\end{array}$ \\
\hline October 10 & 43.25 & Santa Ana River at Riverside Narrows. \\
\hline Total & 63.52 & \\
\hline
\end{tabular}




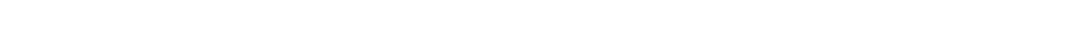

\begin{tabular}{|c|c|c|c|c|c|c|c|c|c|}
\hline Name of ditch. & $\begin{array}{l}\text { June, } \\
\text { 1s98. }\end{array}$ & $\begin{array}{l}\text { Sept.. } \\
1 \times 9 \mathrm{x} .\end{array}$ & $\begin{array}{l}\text { Mar., } \\
1 \mathrm{~s} 99 .\end{array}$ & $\begin{array}{l}\text { June, } \\
1899 .\end{array}$ & $\begin{array}{l}\text { Aug., } \\
1899 .\end{array}$ & $\begin{array}{c}\text { Mar. }_{1900 .}\end{array}$ & $\begin{array}{l}\text { Jure, } \\
19 r^{\prime}\end{array}$ & $\begin{array}{l}\text { Sept., } \\
19(k) .\end{array}$ & $\begin{array}{l}\text { Sept., } \\
\text { 1912. }\end{array}$ \\
\hline Haws \& Talmage & 0.84 & 0.00 & 0.98 & 0.00 & 0.00 & 0.00 & 0.00 & 0.00 & 0.00 \\
\hline Rabel dam. & $5.3 \%$ & $3.0 \%$ & 2.36 & 1.54 & .94 & .54 & .35 & $.0 \tau$ & .00 \\
\hline Shay or Stout dam & 2.30 & 2.08 & $9.23^{\prime}$ & 1.13 & .90 & $.50 \%$ & .40 & .16 & .00 \\
\hline McKenzie ....... & 2.54 & 2.08 & 9.40 & 3.86 & 2.00 & 2.30 & $1.5 \%$ & $1.69^{\prime}$ & .00 \\
\hline Meeks \& Daley & 8.42 & 117.00 & $1 \% .00$ & 15.48 & 10.45 & 13.94 & 13.78 & 14.68 & 13.40 \\
\hline Beam . . . . . . . & $.6 \%$ & $b .65$ & .72 & .52 & .40 & .68 & .50 & .33 & .22 \\
\hline $\begin{array}{l}\text { Riverside Water } \\
\text { Co., upper ca- } \\
\text { nal }\end{array}$ & 59.04 & 61.34 & 60.53 & 53.92 & 52.04 & 61.94 & 52.94 & 61.02 & 47.97 \\
\hline Timber . ...... & .00 & .00 & .00 & .00 & .00 & .00 & .00 & $.00^{\prime}$ & .00 \\
\hline $\begin{array}{c}\text { Gage canal, Santa } \\
\text { Ana River.... }\end{array}$ & 1.16 & 1.16 & .72 & .24 & .64 & .395 & .29 & .17 & .00 \\
\hline $\begin{array}{l}\text { Gage canal.Palm } \\
\text { avenue }\end{array}$ & 26.26 & $25.0 \%$ & e26.68 & 625.22 & $23.4 \%$ & 21.96 & (222.23 & $c 27.85$ & 30.17 \\
\hline $\begin{array}{l}\text { Logsdon \& Far- } \\
\text { rell }\end{array}$ & .72 & .63 & 1.61 & 1.15 & .54 & 1.26 & .49 & .20 & .00 \\
\hline Whitlock $\ldots . .$. & .34 & .38 & .47 & .28 & .094 & .23 & .00 & .00 & .00 \\
\hline Daley ...... & .63 & .67 & .71 & .51 & .51 & .72 & 1.12 & .54 & .00 \\
\hline McIntyre . & .37 & .038 & .82 & .15 & .00 & .14 & .01 & .00 & .00 \\
\hline Whiting . . & .26 & .01 & .76 & .246 & .01 & 1.12 & .13 & $.00^{\circ}$ & .00 \\
\hline Swamp . . & 1.00 & 1.02 & $.85^{\circ}$ &.$\pi$ & .69 & .70 & .89 & .86 & .93 \\
\hline Ranchero... & $a_{1.75}$ & 1.64 & $1.64^{\prime}$ & 1.00 & .41 & .24 & $.5 \pi$ & 1.33 & 2.28 \\
\hline Ward \& Warren & 2.32 & 42.32 & $3.09^{\prime}$ & .615 & 1.56 & 2.55 & 1.70 & .53 & 1.88 \\
\hline $\begin{array}{l}\text { Mill flume of Riv- } \\
\text { erside Water Co. }\end{array}$ & 3.12 & 3.36 & $.5 .30^{1}$ & $\tau .29$ & 2.56 & 2.67 & 2.17 & .94 & .50 \\
\hline $\begin{array}{l}\text { Mill pumpof Riv- } \\
\text { erside Water Co. }\end{array}$ & 1.94 & 2.04 & (d) & 1.77 & $1.6 \pi$ & (d) & 1.88 & 1.52 & 1. 20 \\
\hline Camp Carlton .... & .61 & 1.20 & 2.13 & 1.62 & 1.02 & 2.55 & 2.60 & $1.6 \%$ & 1. 70 \\
\hline East Riverside ... & 4.40 & 4.43 & $4.2 \pi$ & 2.08 & 2.00 & 6.59 & 5.38 & 3. 70 & … \\
\hline $\begin{array}{c}\text { Colton Terrace } \\
\text { Water Co..... }\end{array}$ & 1.97 & 1.61 & 1.69 & 1.30 & 1.30 & 1.69 & 1.54 & 1.53 & 1.08 \\
\hline City of Colton . . - & 6.82 & 7.40 & 3.20 & 5.49 & 3.89 & 4.94 & 3.21 & 3.54 & 3.53 \\
\hline $\begin{array}{l}\text { Bloomington } \\
\text { flume }\end{array}$ & 5.26 & ร. 49 & $(d)$ & 5.93 & 3.05 & 3.80 & 3.68 & 3.28 & .00 \\
\hline $\begin{array}{l}\text { West Riverside } \\
\text { 350-inch pump- } \\
\text { ing plant }\end{array}$ & & & 1 & 1 & & & & & 5.94 \\
\hline $\begin{array}{l}\text { Rogers pumping } \\
\text { plant }\end{array}$ & & & & & & & & & 4.38 \\
\hline $\begin{array}{l}\text { Santa Ana River } \\
\text { flume: River- } \\
\text { side pumping } \\
\text { plants Nos. } 1 \\
\text { and } 2\end{array}$ & & & & & & & & & 5.03 \\
\hline Total & 138.11 & 14.69 & 146.44 & 132.11 & 110.14 & 131.46 & $11 \% .41$ & 125.61 & 120.21 \\
\hline
\end{tabular}

a Interpolated. ${ }^{u}$ Above Slover Mountain. $\quad$ River water not included. $a$ Pumps not run. 
Return uater. natural flow in second-feet, compared with developed water in San Bernardino Talley above Colton.

\begin{tabular}{|c|c|c|c|c|c|c|c|c|}
\hline \multirow[b]{2}{*}{ Name of ditch. } & \multicolumn{2}{|c|}{ June, 1s9k. } & \multicolumn{2}{|c|}{ September. 1895.} & \multicolumn{2}{|c|}{ March, 1899.} & \multicolumn{2}{|c|}{ Jure, 1899.} \\
\hline & $\begin{array}{l}\text { Devel- } \\
\text { oped. }\end{array}$ & $\begin{array}{l}\text { Natu- } \\
\text { ral. }\end{array}$ & $\begin{array}{l}\text { Devel- } \\
\text { oped. }\end{array}$ & $\begin{array}{c}\text { Natu- } \\
\text { ral. }\end{array}$ & $\begin{array}{l}\text { Devel- } \\
\text { oped. }\end{array}$ & $\begin{array}{l}\text { Natu- } \\
\text { ral. }\end{array}$ & $\begin{array}{l}\text { Devel } \\
\text { oped. }\end{array}$ & $\begin{array}{c}\text { Natu- } \\
\text { ral. }\end{array}$ \\
\hline Haws \& Talmage . . & & 0.84 & & 0.00 & & $0.2 K$ & & 0.00 \\
\hline Rabel dam . ... & & $5.3 \%$ & & $3.0 \%$ & & 2.36 & & 1.54 \\
\hline Shay or Stont dam & & 2.30 & & 2.08 & & 2.23 & & 1.13 \\
\hline McKenzie ... & . & 2.54 & $\ldots$ & 2.08 & & 9.40 & & 3.86 \\
\hline Beam _......... & 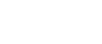 & $.6 \pi$ & - & .65 & & .72 & - & .52 \\
\hline $\begin{array}{c}\text { Riverside WaterCo.. } \\
\text { upper canal ... }\end{array}$ & 18.00 & 41.04 & 17.54 & 43.80 & 18.04 & 42.49 & 17.50 & 36.42 \\
\hline $\begin{array}{l}\text { Gage canal, Santa } \\
\text { Ana River. }\end{array}$ & & 1.16 & & 1.16 & & .72 & & .24 \\
\hline $\begin{array}{l}\text { Gage canal, Palm } \\
\text { avenue weir .. }\end{array}$ & 26.26 & & 25.07 & & 26.68 & $\ldots$. & 25.22 & . \\
\hline Logsdon \& Farrell _. & $\ldots .$. & .72 & .. & .63 & & 1.61 & $\ldots \ldots$ & 1.15 \\
\hline Whitlock ......... & $\ldots \ldots$ & .34 & $\ldots$ & .38 & $\ldots \ldots$ & $.4 i$ & & .28 \\
\hline Daley . . . . . . . . & $\ldots$ & .63 & $\ldots$ & $.6 \pi$ & ..... &.$\tau 1$ & $\ldots$ & .51 \\
\hline McIntyre ...... & $\ldots$ & $.3 \pi$ & - & .038 & - & .82 & $\ldots$ & .15 \\
\hline Whiting ....... & $\ldots$ & .26 & $\ldots$ & .010 & $\ldots \ldots$ &.$; 6$ & & .246 \\
\hline Swamp _...... & $\ldots$ & 1.00 & $\ldots \ldots$ & 1.020 & $\ldots \ldots$ & .85 & & .77 \\
\hline Ranchero ..... & $\ldots$ & 11.75 & $\ldots \ldots$ & 1.640 & $\ldots$ & 1.64 & $\ldots$. & 1.00 \\
\hline Ward \& Warren... . & 1.60 & .72 & 1.60 & .720 & 1.60 & 1.49 & $.61 \tilde{\jmath}$ & $\ldots$ \\
\hline $\begin{array}{l}\text { Mill flume of River- } \\
\text { side Water Co. }\end{array}$ & $\ldots \ldots$ & 3.12 & & 3.360 & & 5.30 & & 7.25 \\
\hline $\begin{array}{l}\text { Mill pump of River- } \\
\text { side Water Co... }\end{array}$ & 1.94 & & 2.04 & & $\left\{\begin{array}{l}\text { Not } \\
\text { run. }\end{array}\right.$ & & $1 . \%$ & \\
\hline Camp Carlton ditch. & .61 & & 1.20 & & 2.13 & & 1.62 & \\
\hline $\begin{array}{l}\text { East Riverside dis- } \\
\text { trict, or Riverside } \\
\text { Highland Water } \\
\text { Co ............... }\end{array}$ & 4.40 & & 4.43 & & 4.25 & & 2.08 & \\
\hline $\begin{array}{c}\text { Colton Terrace } \\
\text { Water Co } \ldots . . . .\end{array}$ & 1.97 & & 1.61 & & 1.69 & & 1.30 & \\
\hline $\begin{array}{l}\text { City of Colton pump- } \\
\text { ing plant. }\end{array}$ & 6.82 & & 7.40 & & 3.20 & & 5.49 & \\
\hline Bloomington flume & 5. 26 & & 5.49 & & .00 & & 5.93 & $\ldots \ldots$ \\
\hline Meeks \& Daleyditch _ & & 8.42 & $\ldots$ & 117.00 & - n... & $1 \% .00$ & 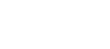 & 15.48 \\
\hline Total & 66.86 & i1.25 & 66.38 & 78. 31 & $5 \% .5^{9}$ & 88.85 & 61.525 & 70.59 \\
\hline
\end{tabular}

$a$ Interpolated. 
Return uater. natural flow in second-feet, etc.-Continued.

\begin{tabular}{|c|c|c|c|c|c|c|c|c|c|c|}
\hline \multirow{2}{*}{ Name of diteh. } & \multicolumn{2}{|c|}{ August, 1899.} & \multicolumn{2}{|c|}{ March. 19xl. } & \multicolumn{2}{|c|}{ June, 1900.} & \multicolumn{2}{|c|}{$\begin{array}{l}\text { September, } \\
1900 \text {. }\end{array}$} & \multicolumn{2}{|c|}{$\begin{array}{c}\text { September, } \\
1902 \text {. }\end{array}$} \\
\hline & $\begin{array}{c}\text { Devel- } \\
\text { oped. }\end{array}$ & $\begin{array}{l}\text { Natu- } \\
\text { ral. }\end{array}$ & $\begin{array}{l}\text { Dercl- } \\
\text { oped. }\end{array}$ & $\begin{array}{l}\text { Natu- } \\
\text { ral. }\end{array}$ & $\begin{array}{l}\text { Devel- } \\
\text { oped. }\end{array}$ & $\begin{array}{l}\text { Natu- } \\
\text { ral. }\end{array}$ & & $\begin{array}{c}\text { Natu- } \\
\text { ral. }\end{array}$ & $\begin{array}{l}\text { Devel- } \\
\text { oped. }\end{array}$ & $\begin{array}{l}\text { Natu- } \\
\text { ral. }\end{array}$ \\
\hline Haws \& Talmage. & & 0.00 & & 0.000 & 0.00 & 0.00 & & 0.00 & & 0.00 \\
\hline Rabel dam & & .94 & & .540 & & .35 & & $.0 \%$ & & .00 \\
\hline Shay or Stout dam. & & .90 & & $.50 \pi$ & & .40 & & .16 & & .00 \\
\hline McKenzie & & 2.00 & & 2.300 & & $1.5 \%$ & & 1.69 & & .00 \\
\hline Beam & & .40 & & .680 & & .50 & & .33 & & .22 \\
\hline $\begin{array}{c}\text { Riverside Wate } \\
\text { upper canal }\end{array}$ & $2 \pi .50$ & 24.54 & 24.54 & $3 \pi .40$ & 32.36 & 20.58 & $2 \pi .00$ & .02 & 26.08 & 21.89 \\
\hline $\begin{array}{l}\text { Gage canal, Santa } \\
\text { Ana River }\end{array}$ & & .64 & & . 395 & & .29 & & .17 & & .00 \\
\hline $\begin{array}{l}\text { Gage canal, Palm } \\
\text { avenue weir }\end{array}$ & $23.44^{\prime \prime}$ & $\ldots$ & 21.96 & & 22.23 & & 27.85 & & $30.1 \%$ & \\
\hline Logsdon \& Farrell & & .54 & & 1. 26 & & .49 & & .20 & $\ldots$ & .00 \\
\hline Whitlock & $\ldots \ldots$ & .09 & & .23 & & .00 & & .00 & $\ldots$ & .00 \\
\hline Daley - & & 51 & & .72 & & 1.12 & & .54 & $\ldots$ & .00 \\
\hline McIntyre & & .00 & & .11 & & .01 & & .00 & & .00 \\
\hline Whiting $\ldots \ldots$ & $\ldots$ & .01 & & 1.12 & & .13 & & .00 & & 00 \\
\hline Swamp & & .69 & & .70 & & .89 & & .86 & $\ldots$ & .93 \\
\hline Ranchero & $\ldots$ & .41 & $\ldots \ldots$ & .24 & $\ldots$ & .55 & .80 & .53 & 2.28 & \\
\hline Ward \& Warren & 1.56 & & 1.60 & .95 & 1.60 & .10 & .53 & & .30 & 1.58 \\
\hline $\begin{array}{l}\text { Mill flume of River- } \\
\text { side Water Co... }\end{array}$ & & 2.56 & & $2.6 i$ & & 2.17 & - - & .94 & & 50 \\
\hline $\begin{array}{l}\text { Mill p } \\
\text { side }\end{array}$ & 1.67 & & & $\left\{\begin{array}{l}\text { Not } \\
\text { run. }\end{array}\right.$ & 1.88 & & 1.52 & & 1.20 & \\
\hline Camp Carlton ditch. & 1.02 & & 2.55 & & 2.60 & & $1.6 \%$ & & 1.70 & \\
\hline $\begin{array}{c}\text { East Riverside dis- } \\
\text { trict, or Riverside } \\
\text { Highland Water } \\
\text { Co }\end{array}$ & 2.00 & & 6.59 & & 5.38 & & 3.70 & & & \\
\hline $\begin{array}{l}\text { Colton Terr } \\
\text { ter Co } \ldots\end{array}$ & 1. 30 & & 1.69 & & 1.54 & & 1.53 & & 1.08 & \\
\hline $\begin{array}{l}\text { City of Colt } \\
\text { ing plant }\end{array}$ & 3.89 & & 4.94 & & 3.21 & & 3.54 & & 3.53 & \\
\hline Bloomington flume & 3.05 & $\ldots$ & 3.80 & . & 3.68 & & 3.28 & $\ldots$ & .00 & $\ldots$ \\
\hline Meeks \& Daley ditch & & 10.45 & & 13.94 & & 13.78 & & 14.68 & $\ldots$ & 13.40 \\
\hline $\begin{array}{l}\text { West Rivers } \\
\text { inch pu } \\
\text { plant.... }\end{array}$ & & & & & & & & & 5.94 & \\
\hline $\begin{array}{c}\text { Rogers pump } \\
\text { plant }\end{array}$ & & & & & & & & & 4.38 & \\
\hline $\begin{array}{l}\text { Santa Ana River } \\
\text { flume; Riverside } \\
\text { pumping plant } \\
\text { Nos. } 1 \text { and } 2 . . . .\end{array}$ & & & & & & & & & 5. 03 & 3 \\
\hline Total & 65.46 & 44.68 & 67.67 & 63.79 & 74.48 & 42.93 & 71.42 & 54.18 & 81.69 & 38.52 \\
\hline
\end{tabular}


From the two preceding tables it will be noted that despite severe droughts which existed flom 18 s to 190, inclusive, the output of water from the gravel berls alove colton has but slightly diminisherl, the total being 14t.6!) second-feet in september, 1ses, as compared with 120.21 second-fest in septemler, 1!n.2. The amount of deroloped water in september, 1s\%s, was lit.:3n second-feet, and in September, 1902 , s1.69) second-feet. while the natural returu water between the same dates decreaser from 75.31 serond-fret to $3 \$ .52$ second-feet. During this period much development work was done, and while these new supplies do not mean an absolute aldition to the ontput from the district, the farct that the total supply was maintained notwithstanding the drought is a clecided achierement.

\section{SAN DIENAS WASH.}

See San Gabriel River, miscellaneons measurements, Fan I)iemas Wash.

\section{SAN FERNANDO CREEK.}

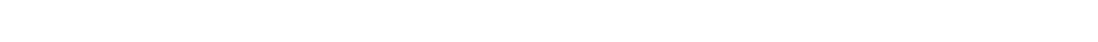

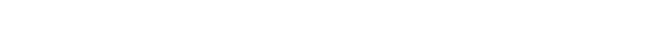

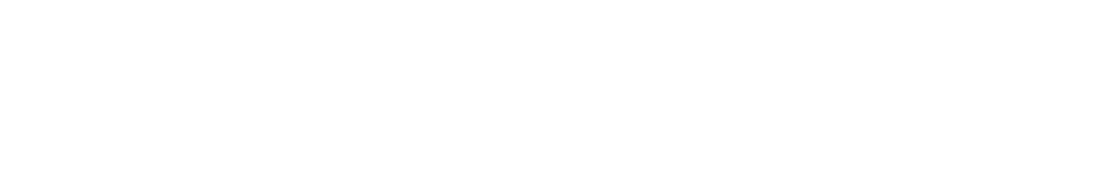

SAN FRANCISQUITO CREEK.

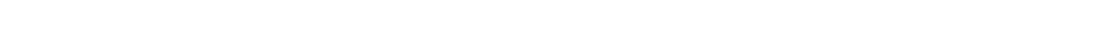
River, Los Angeles ("ounty.

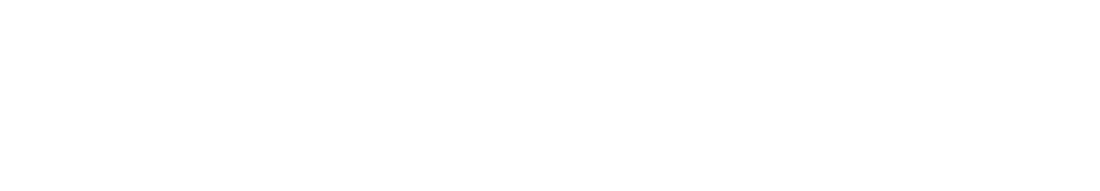

\section{SAN GABRIEL RIVER.}

The drainage hasin of this river lies on the southern slope of the Sierra Madre, the watersherl heing includerl in Los Angeles county, (al. The varions tributaries join the river hefore it anters its lowest canpon, whence it alpears finally on the platin in the vicinity of Azusa. The seepage waters aplear lower down in the valley. The

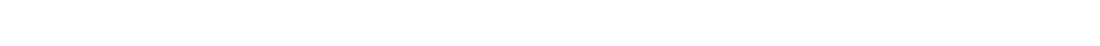
difined storm rhammels. All the smmmer flow of this stream is now used for irrigation purposes in the vicinity of Azusa. ()wing to the numerous diversions, it has been difficult to olstain aromate discharge measurements, hut during lons the san Gabriel Electup: Company completed its system, and measurements are now obtained with greater ease, and hence with greater accuracy. The head works of this company are located alout $(\mathrm{i}$ miles above the month of the canyon, the water is carried along the left side by a series of tunnels and

IRR $S: 1-(1: 3-15$ 
concluits, and a hoad of $t^{\prime \prime \prime) ~ f e e t ~ i s ~ o b t a i n e d ~ w h e r e ~ t h e ~ e l e c t r i c ~ p o w e r ~}$ is gencrater. Weirs are placed on the conduit of the electric compauy, and the low water is measured at this point. The capacity of the conduit is 90 second-feet. The gaging station on the main river is located at the mouth of the canyon. The equipment consists of a rod, a cable, a car, and a tagged wire.

Discharye measmements of $S a n$ Gabriel River at point near month of canyon near Azusa. Los Augeles C'ounty, Cal.

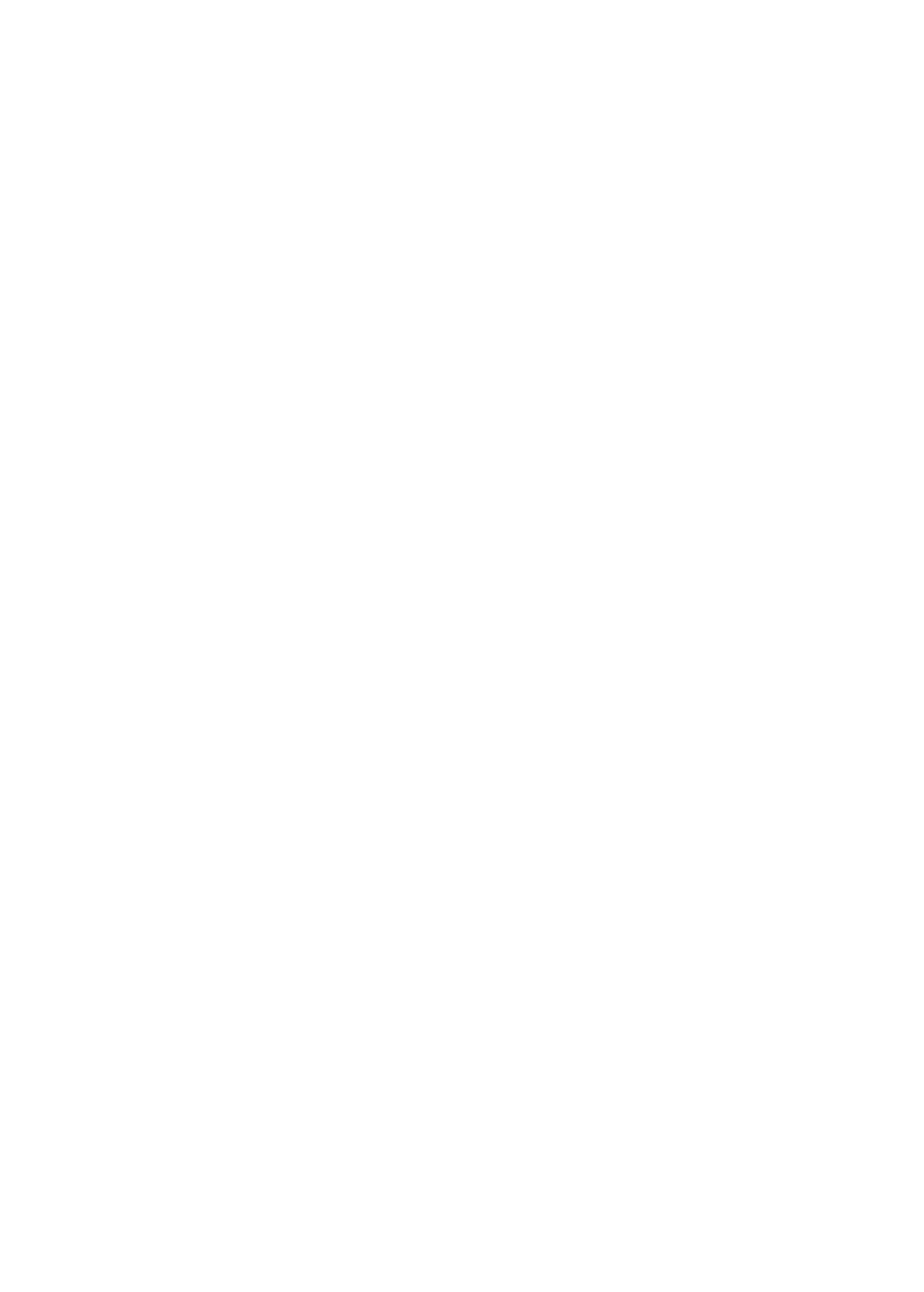


I Mischarge measurements of San Gabriel River, etc._Continu-d.

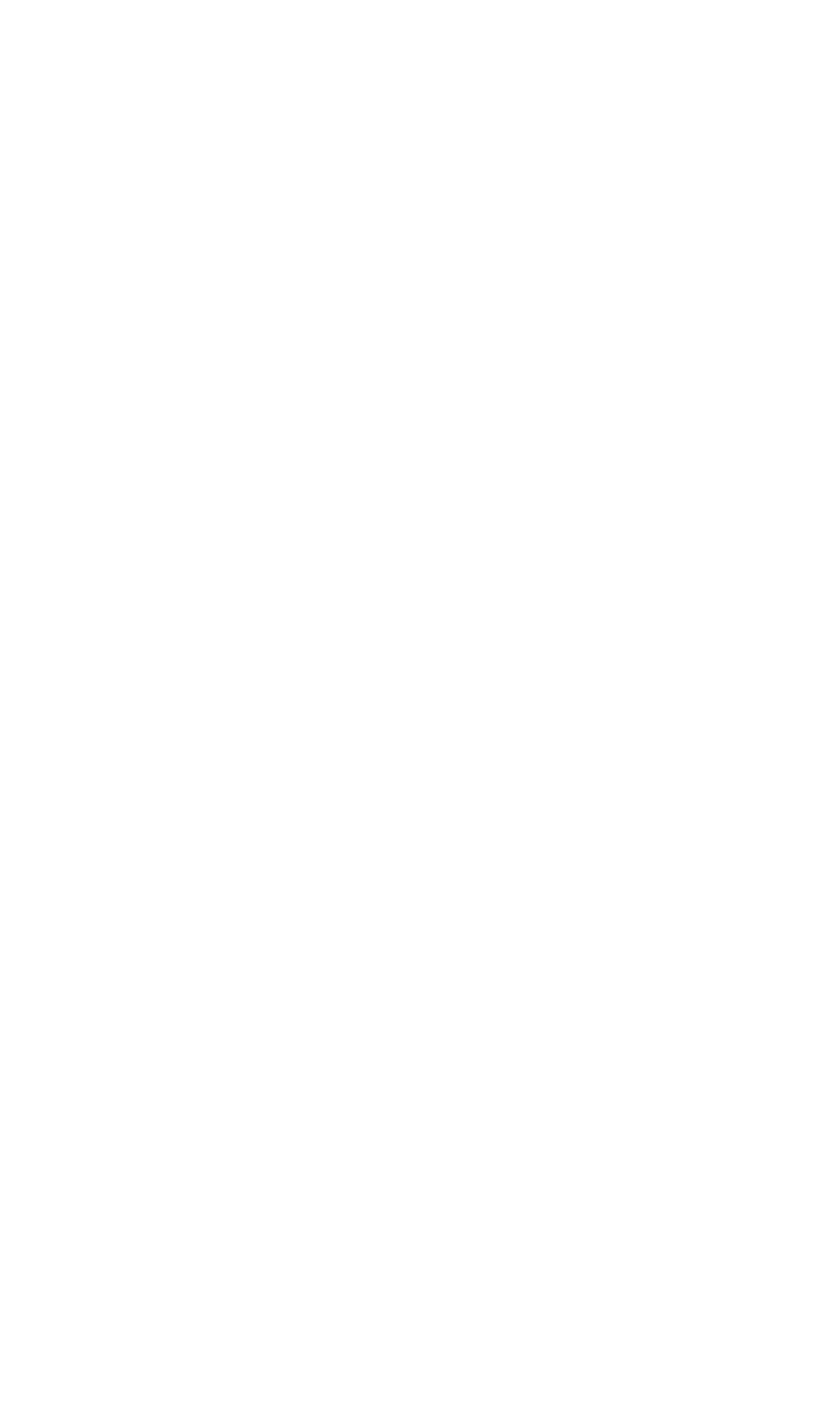




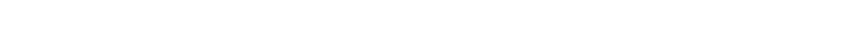

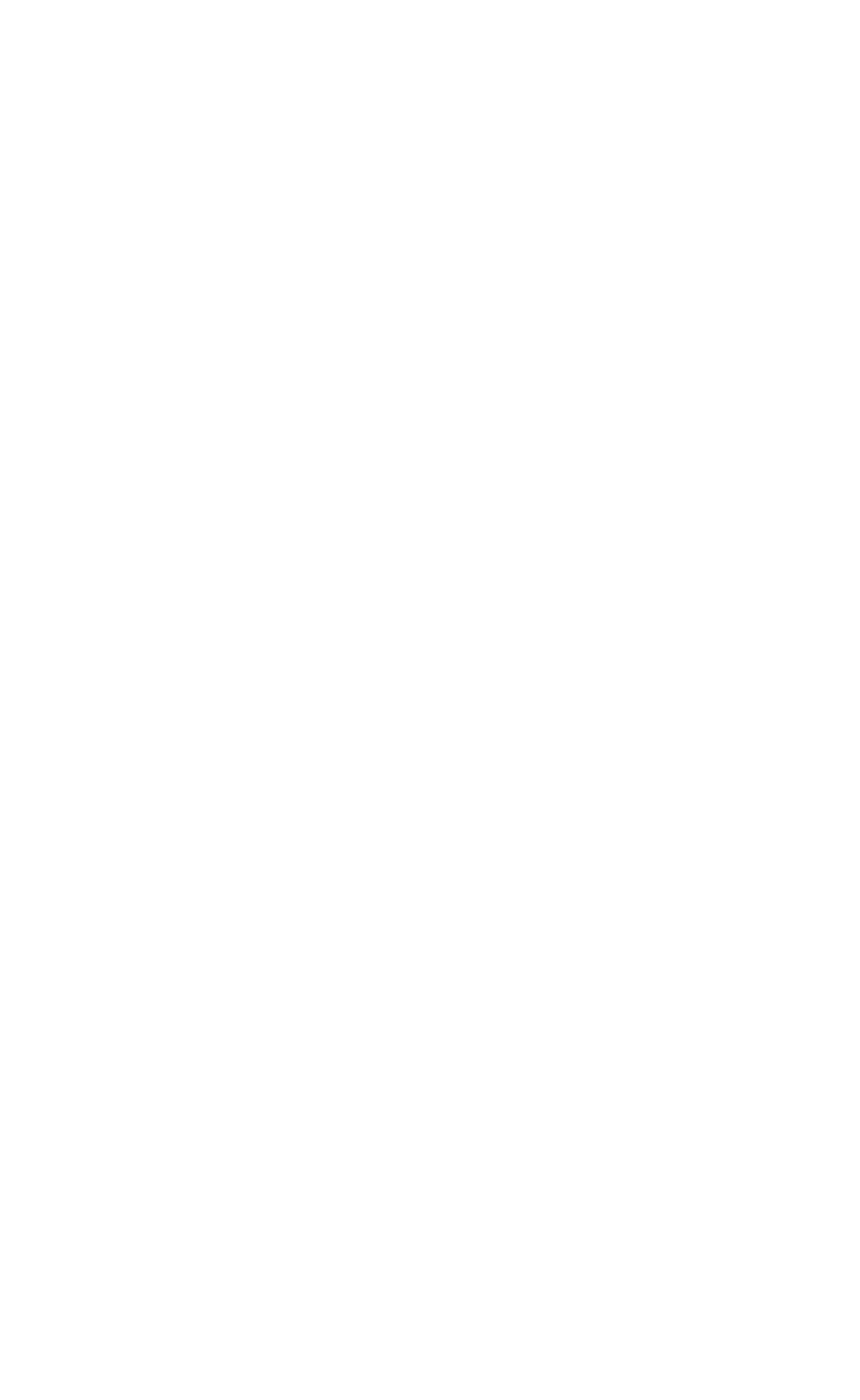




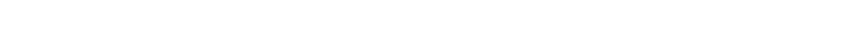

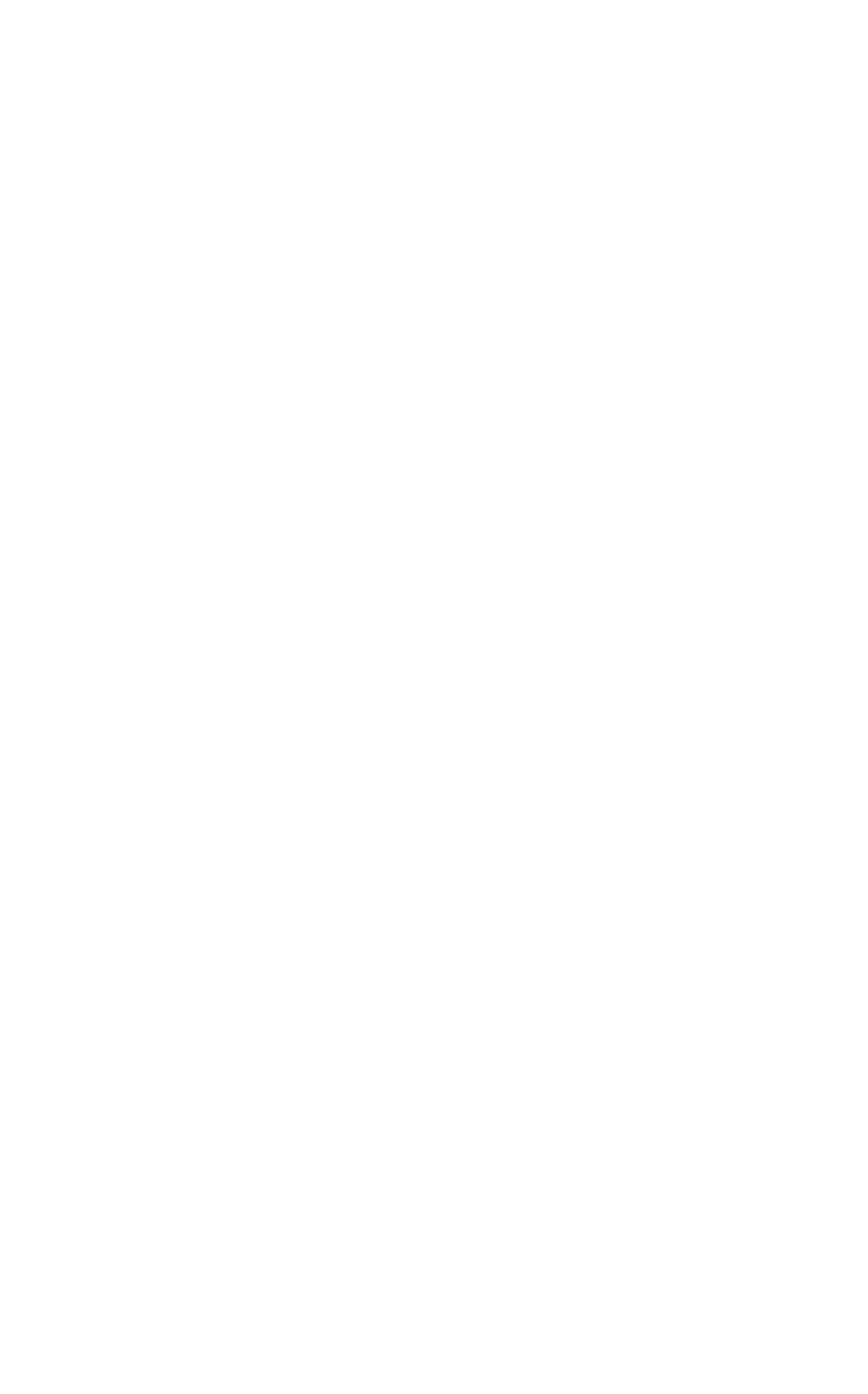


Discharge measmements of san rableiel River.ete.-Continned.

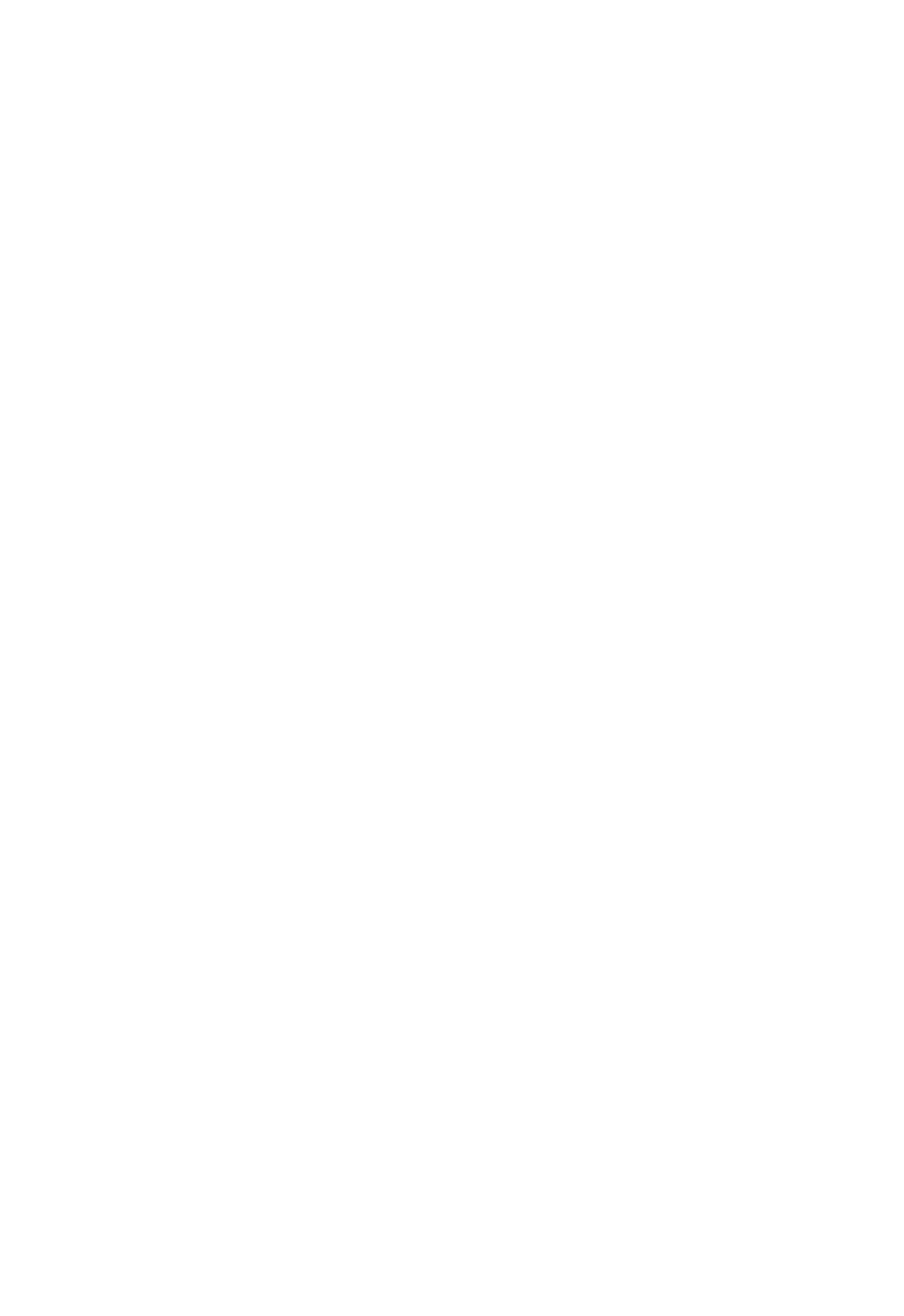


Dischurge measurements of San Gabriel River. Azusa, Los Angeles C'onitiy.

\begin{tabular}{|c|c|c|c|}
\hline Date. & Hydrographer. & $\begin{array}{c}\text { Dis- } \\
\text { charge. }\end{array}$ & Locality. \\
\hline & & Sereffert. & \\
\hline June 17,1896 & J. B. Lippinentt . & 1.54 & Mouth of Yineland tumeI. \\
\hline Do $\ldots . . .$. & $\ldots \quad$ do ......... & 9.11 & Same: pump running. \\
\hline Apr. $29,189 \%$ & ..... do ... & 2.23 & Mouth of Vineland tumel. \\
\hline Do . ....... & $\ldots$.... do .. & 2.11 & Same: shaft No. 2 \\
\hline Do . . . . . & $\ldots . . . d_{n} \ldots . . .$. & 2.13 & $\begin{array}{l}\text { Same: at head of flume. hetween } \\
\text { shafts Nos. } 3 \text { and } 4 .\end{array}$ \\
\hline Do ...... & $\ldots$.... do ....... & 1.07 & $\begin{array}{l}\text { Same; right fork, ahove shaft } \\
\text { No. } 4 \text {. }\end{array}$ \\
\hline May 24,1897 & $\ldots$ do. & $1.8 s$ & Mouth of Vineland Tunnel. \\
\hline
\end{tabular}

Discharge measurements of San Gabrin Riwe at intake of San Gabrin Poner Company. Los Angeles C'ounty.

[Measurements by Edison Electric Company. The flow was nuusually small in September, 189k, and these measurements were made to determine this minimum and its hourly fluctuation.]

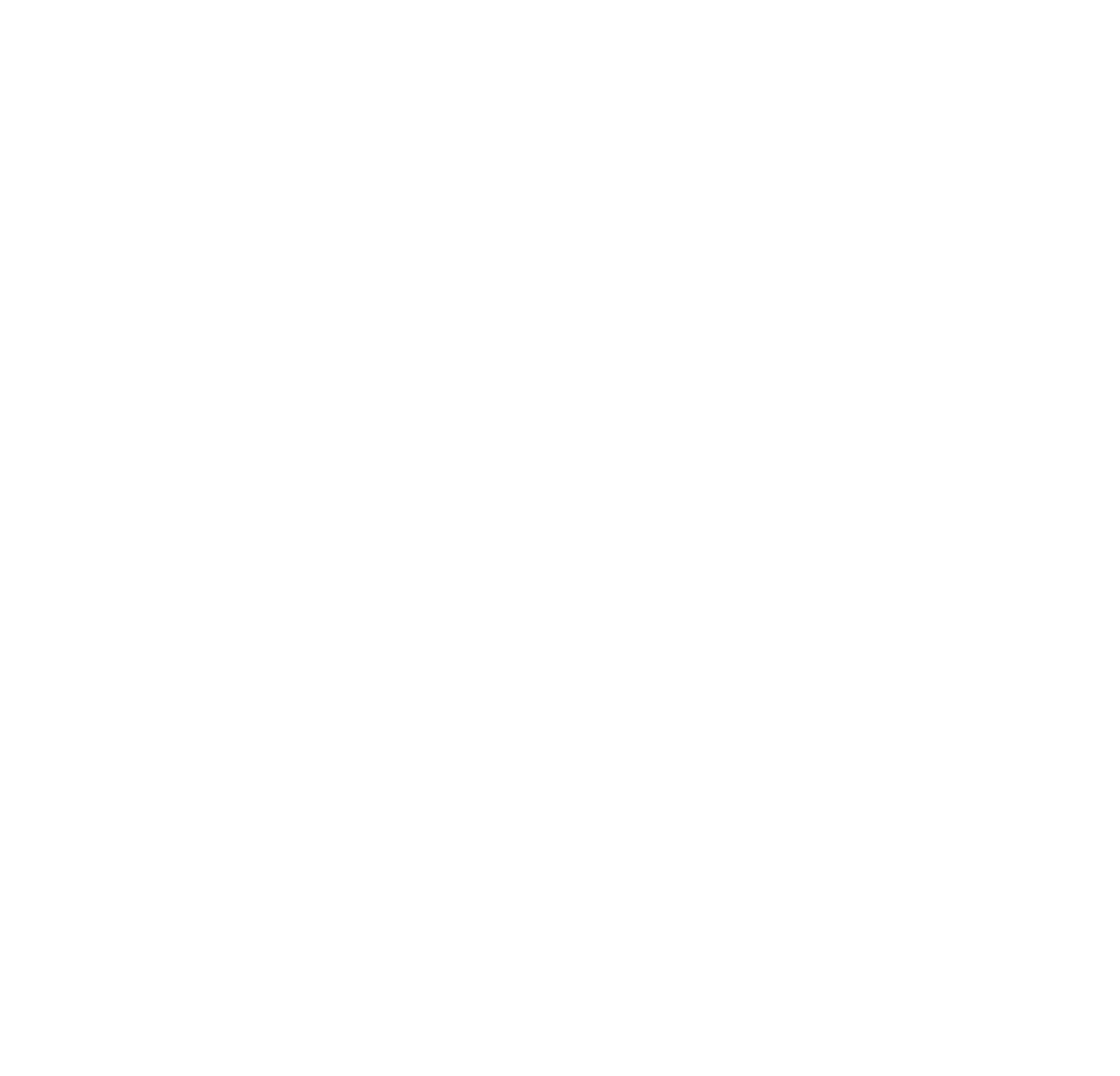




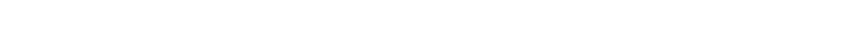

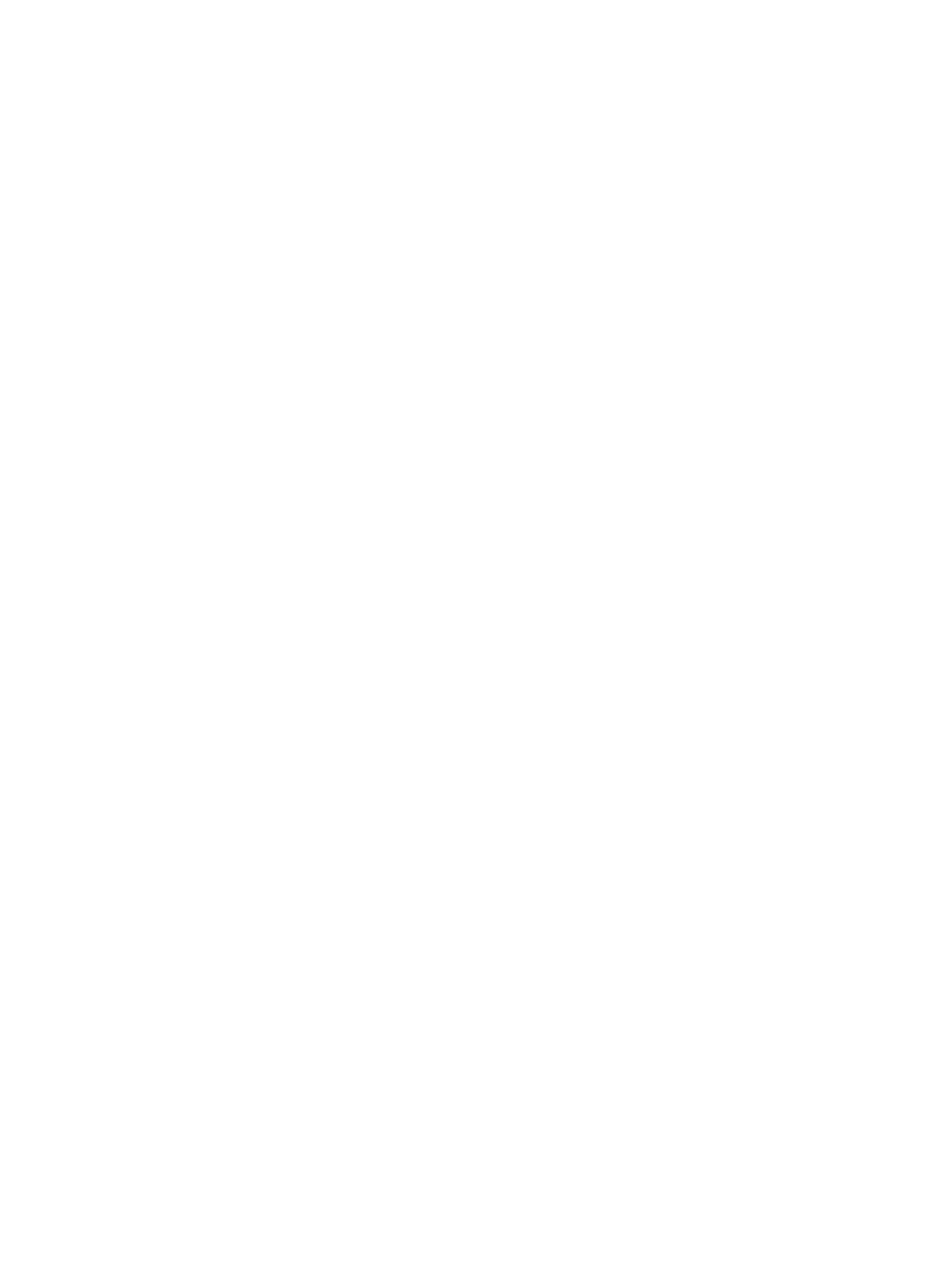


The following table is prepared from measurements made three times daily for the San Gabriel Electric Company, and filed in a suit before the United States land office at Los Angeles, Cal. The mean of the three daily measurements is here given.

Estimated daily discharge, in second-fet, of San Gabriel River over woir on West Branch of North Fork, at sycamore Flat, for 1 suo.

[Observer, San Gabriel Power Company.]

Day.$$
1
$$$$
2 .
$$$$
3 .
$$$$
4
$$$$
5 .
$$$$
6 .
$$

ז.

8

9

10

11

12

13

14

15

16

17

18

19.

20

21

22

23

24

25

26

27

28

29

30

31

Total
Tuly.

(1.

.27

.27

.26

- 28

.24

.23

.25

.23

. 2i

. 25)

.22

$.2 \pi$

.27

.31

.31

. 2

.31

.39

.39

. 24

. 26

. 26

.28

$3 r$

.84

. 26

. 23

. 23

. 23

August. September.' Octoher.

(1. 23

0.19

0.20

.23

.19

.12

.23

.18

$.1 \%$

.18

.26

.22

.23

.11

.12

.23

.12

.19

.23

.22

.19

.18

.19

.20

.19

.22 ,

. $2 \mathrm{~N}$

.19

.22

.19

.

.22

.18

.18

.1:

.12

.

.15

.13

.15

.12

.15

.22

.27

. 26

. 26

.22

.20

18
.25

.20

.17

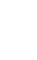

.28

.21 
Estimated daily discharge, in second-feet, of San Gabriel River over weir on North Branch of North Fork, at Sycamore Flat, for 1900.

[Observer, San Gabriel Power Company.]

\begin{tabular}{|c|c|c|c|c|}
\hline Day. & July. & August. & September. & Octob $=$ \\
\hline 1. & -... & 0.89 & 0.62 & 0.65 \\
\hline $2 \ldots \ldots$ & 0.92 & .89 & .62 & .72 \\
\hline $3 \ldots \ldots \ldots$ & .92 & .89 & .62 & .68 \\
\hline $4 \ldots \ldots$ & .92 & .95 & .62 & .68 \\
\hline$\tilde{\sigma}_{\ldots} \ldots \ldots \ldots$ & .89 & .95 & 60 & .68 \\
\hline $6 \ldots \ldots \ldots$ & .89 & .74 & .65 & .68 \\
\hline - . . & .89 & .74 & .61 & .56 \\
\hline$\ldots \ldots \ldots \ldots$ & .82 & .74 & .61 & .56 \\
\hline $9 \ldots \ldots \ldots$ & .80 & .78 & .83 & .56 \\
\hline $10 \ldots \ldots \ldots \ldots \ldots \ldots$ & .70 & $.7 \%$ & .61 & $.5 \%$ \\
\hline $11 \ldots \ldots \ldots \ldots$ & .81 & .74 & .61 & .59 \\
\hline $12 \ldots \ldots \ldots \ldots$ & .83 & .74 & .63 & .59 \\
\hline $13 \ldots \ldots \ldots \ldots$ & .86 & $.7 \%$ & .61 & .59 \\
\hline $14 \ldots \ldots \ldots$ & .95 & .68 & .63 & $\ldots$ \\
\hline $15 \ldots \ldots \ldots$ & .97 & .74 & .63 & $\ldots$. \\
\hline 16 . & .97 & .62 & .59 & $\ldots \ldots$ \\
\hline $17 \ldots \ldots \ldots$ & .97 & .65 & .59 & $\cdots$ \\
\hline $18 \ldots \ldots \ldots$ & .97 & .65 & .59 & $\ldots \ldots$ \\
\hline 19 & .97 & .62 & .59 & $\ldots$. \\
\hline 20 & .97 & .60 & .59 & ... \\
\hline $21 \ldots \ldots$ & $.9 \tau$ & .60 & .53 & $\ldots \ldots$ \\
\hline 22. & .96 & - . & .53 & $\ldots \ldots$ \\
\hline 23. & $1.0 \pi$ & $.5 i$ & .53 & ...... \\
\hline $24 \ldots \ldots \ldots$ & .95 & .12 & .81 & $\ldots \ldots$ \\
\hline $25 \ldots \ldots \ldots$ & .9 .5 & .52 & .68 & $\ldots \ldots$ \\
\hline $26 \ldots \ldots \ldots$ & .96 & .56 & .65 & ......... \\
\hline 27. & .68 & .57 & .65 & $\cdots$ \\
\hline $28 \ldots$ & .68 & $.5 \%$ & .68 & $\cdots$ \\
\hline $29 \ldots \ldots \ldots$ & .89 & .54 & .68 & $\ldots$ \\
\hline $30 \ldots \ldots \ldots \ldots$ & .86 & .74 & .68 & $\ldots-\ldots \ldots$ \\
\hline $31 \ldots \ldots \ldots$ & .68 & $\cdots$ & $\cdots$ & $\ldots \ldots$ \\
\hline Total & .89 & .70 & .63 & .62 \\
\hline
\end{tabular}


Estimated daily discharge, in second-feet, of Sam Gabriel. River over weir on West Fork above wouth of North Fork for 1900.

[Observer, San Gabriel Power Company.]

\begin{tabular}{|c|c|c|c|c|}
\hline Day. & July. & August. & September: & October. \\
\hline $1 \ldots \ldots \ldots$ & 0.5 .5 & $0.0 \pi^{l}$ & 0.12 & 0.16 \\
\hline $2 \ldots$ & .62 & .02 & .12 & .16 \\
\hline 3 & .68 & $\ldots$ & .12 & .16 \\
\hline $4 \ldots \quad \ldots \quad \ldots \ldots \ldots 1$ & .62 & $\ldots \ldots \ldots$ & .12 & .16 \\
\hline 5 & .53 & $\ldots \ldots$ & .08 & .10 \\
\hline $6 \ldots \ldots \ldots \ldots$ & .i.j & & .11 & .20 \\
\hline$\tau_{\ldots \ldots \ldots} \ldots \ldots \ldots \ldots$ & .55 & $\left.\ldots\right|^{\prime}$ & .16 & .20 \\
\hline $8 \ldots \ldots \ldots$ & .55 & $\ldots$ & .12 & .16 \\
\hline $9_{1}$ & .44 & $\ldots-1$ & .12 & .16 \\
\hline $10 \ldots \ldots \ldots$ & .34 & $\ldots$ & .16 & .13 \\
\hline $11 \ldots \ldots \ldots$ & .29 & $\cdots$ & .16 & .20 \\
\hline $12 \ldots \ldots \ldots$ & .26 & .08 & .12 & .20 \\
\hline $13 \ldots \ldots \ldots$ & .24 & $.0 \%$ & .12 & .20 \\
\hline $14 \ldots \ldots \ldots$ & .20 & .08 & .16 & $\ldots$ \\
\hline $15 \ldots \ldots \ldots \ldots \ldots$ & .13 & .08 & .16 & $-\cdots$ \\
\hline $16 \ldots \quad-\quad \ldots \ldots \ldots \ldots$ & .12 & .12 & .16 & $\ldots$ \\
\hline $1{ }^{1}$ & .16 & .10 & .16 & $\ldots$ \\
\hline $18 \ldots \quad \ldots \ldots-\ldots \ldots \ldots \ldots$ & .16 & .12 & .11 & $\ldots$. \\
\hline $19, \quad \ldots \ldots \ldots$ & .12 & .10 & .12 & $\ldots$ \\
\hline $20 \ldots \ldots \ldots \ldots$ & .12 & .12 & .12 & $\ldots$ \\
\hline $21 \ldots \ldots \ldots \ldots$ & $.0 \tau$ & .12 & .16 & -.. \\
\hline $22 \ldots \ldots \ldots \ldots$ & .12 & .10 & .16 & $\ldots$ \\
\hline 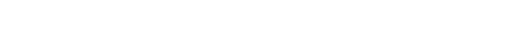 & $\ldots$ & $.0 \%$ & - - & \\
\hline $2_{4} \quad-\ldots \ldots \ldots$ & $\ldots$ & .08 & $\ldots$ & $\ldots$ \\
\hline $25 \ldots \ldots \ldots$ & .08 & .08 & $\begin{array}{l}.12 \\
.20\end{array}$ & - \\
\hline $2 i \quad \ldots \ldots \ldots$ & $\cdots$ & .08 & .16 & . . . . . \\
\hline 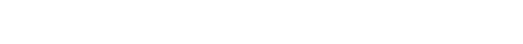 & .0 .5 & .08 & .16 & ........ \\
\hline $29 \ldots \ldots \ldots$ & .08 & .10 & .13 & $\ldots$ \\
\hline $30 \ldots$ & $.0 . \overline{3}$ & .12 & .14 & -... \\
\hline $31 \ldots \ldots \ldots \ldots$ & .0 .5 & .10 & $\cdots$ & $\ldots$ \\
\hline Totai ....... & .29 & .09 & .14 & .17 \\
\hline
\end{tabular}


Estimated daily discharge, in second-feet of San Gabriel River over weir on ('olduater creek. id miles above mouth, for 1900.

[Observer, San Gabriel Power Company.]

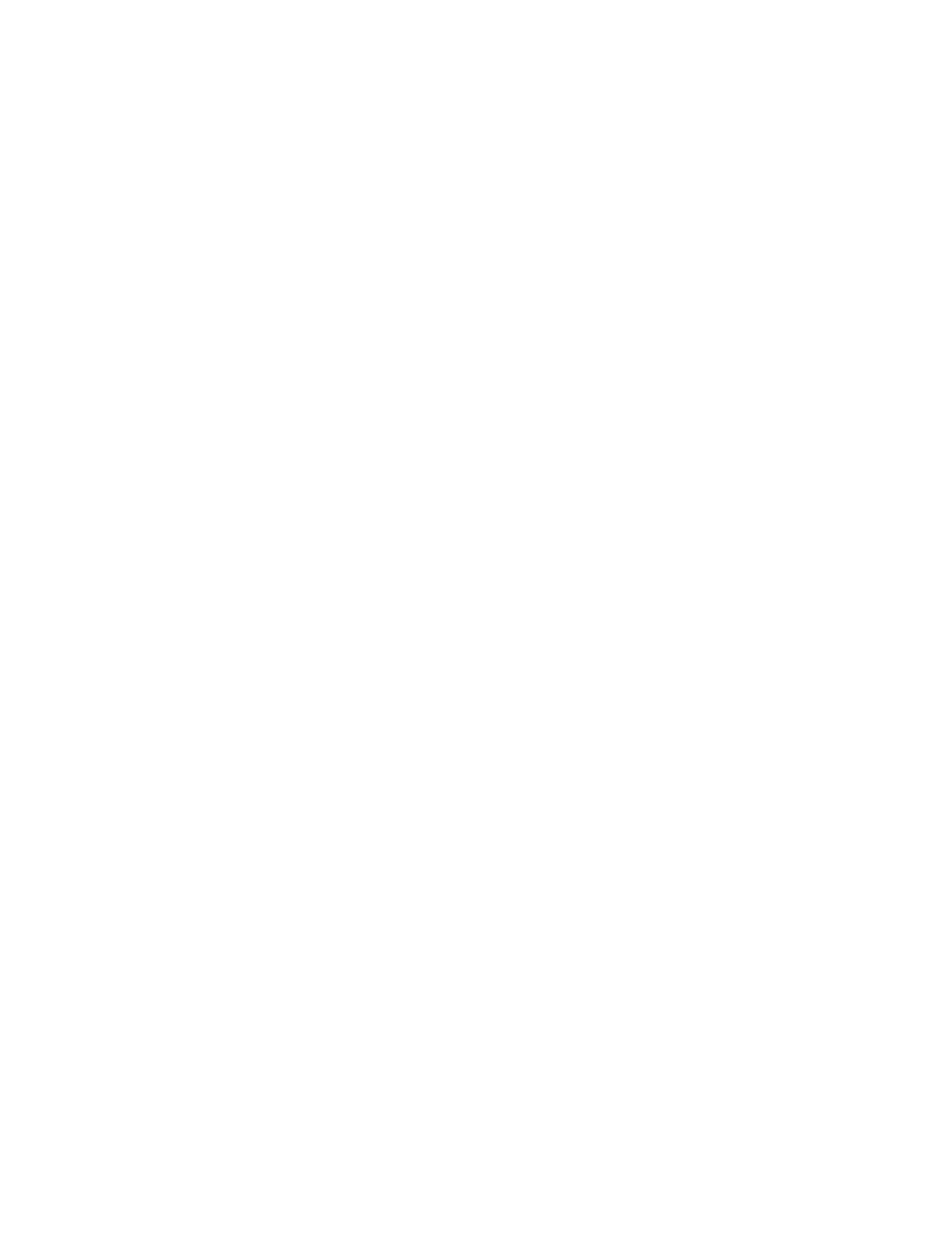


Est imated daily discharge, in se'smd-feet, of San Gabriel River over weir 1'm yards "lowe Fish Fork, for 19 mo.

[Observer, San Gabriel Power Company.]

Day.

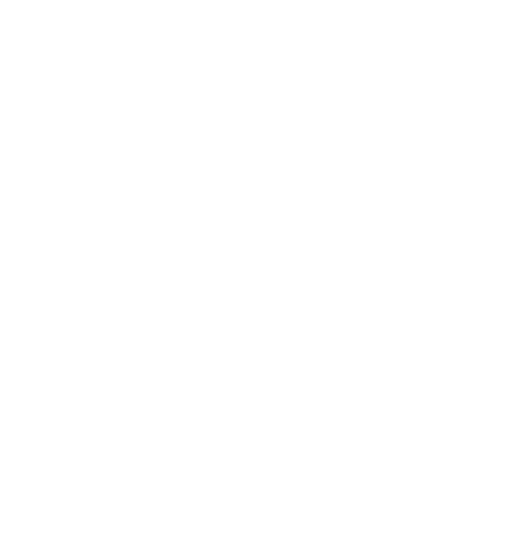

14.

15

16

17

18

19

20

21

22

23

24

25

26

$2 \tau$

28

29

30

31
July. Angust. Neptember. October.

2. 24

1.67

2. 48

1.67

2. 48

2.42

1. 2

1. 71

2. 33

1.80

1.84

2.97

1.80

1.84

2. 06

1. 80

1.80

2.12

1.80

1. $\%$

?. (0)

2. 15

2. 09

2. 1.5

2. 15

2. 03

2. 03

2. 12

1. 80

1. 67

1.80

1.84

1. 7

1.80

1.80

1. 7

1.80

1. 22

1. 5

$1.9 \%$

1. 26

[. 76

1.92

1. 22

1.89

2. 00

1.4 .5

1. $\% 6$

1.80

1. 68

1. 76

2.00

1. 76

1. 80

1.9 ז

1. 68

1. 71

1.97

2.00

2.00

2.00)

$1.9 \pi$

2.18

1.68

1. 2.

1.64

1. 22

1.68

1.68

1.68

1.59

1. 68

1. 63

1.68

1. 79

2.00

1. $\% 6$

1. 89

1.68

1.84

2. 00

1.60

1.84

1.95

1. 60

1.67

1. $1 \%$

1.68

1. 63

1.75

1.68

1.97

$1.6 \%$

1. 79

1. $\% 5$

1. 14

1. .5

2.09

Total

1.


Estimated derily discharge, in second-feet, of San Gabriel River over weir on Fish Fork. 100 yards from mouth, for 1900.

[Ohwerver, Lin (tal)riel Power Company.]

\begin{tabular}{|c|c|c|c|c|}
\hline Day. & July. & August. & September. ${ }^{1}$ & Octoher. \\
\hline$\ldots \ldots$ & 1.42 & & & 0.95 \\
\hline$\ldots \ldots \ldots \ldots$ & 1.66 & & $\ldots$ & .9 \\
\hline $3 \ldots \ldots \ldots$ & 1.68 & 0.99 & $\ldots$ & .9 \\
\hline $4 \ldots \ldots \ldots \ldots$ & 1.66 & .96 & $\ldots$ & .9 \\
\hline $5_{\ldots}$ & 1.28 & 1.02 & -. & .9 \\
\hline 6 & 1.25 & 1.06 & $\ldots \ldots$ & .9 \\
\hline $7 \ldots \ldots-\ldots$ & 1.16 & 1.06 & $|-\ldots \ldots|$ & .93 \\
\hline $8 \ldots \ldots$ & 1.18 & .92 & $\ldots$ & .9 \\
\hline 9 & 1.08 & .95 & 1.52 & .90 \\
\hline $10 \ldots$ & .98 & 1.02 & .92 & .8 \\
\hline $11 \ldots$ & .96 & .99 & .96 & .9 \\
\hline . & .98 & 1.11 & 1.13 & .9 \\
\hline $13 \ldots$ & .98 & 1.11 & 1.10 & 1.0 \\
\hline $14 \ldots \ldots \ldots \ldots \ldots$ & 1.04 & 1.02 & .99 & \\
\hline $15 \ldots \ldots$ & 1.02 & .99 & 1.08 & \\
\hline $16 \ldots \ldots$ & 1.25 & .90 & .94 & \\
\hline 17 . & .93 & .90 & .93 & \\
\hline (n. & 1.00 & .84 & .89 & \\
\hline$\ldots \ldots \ldots+\ldots$ & 1.00 & .84 & .86 & \\
\hline $20 \ldots \ldots+\ldots, \ldots \ldots$ & 1.00 & .95 & .84 & \\
\hline - & 1.12 & .89 & .84 & \\
\hline 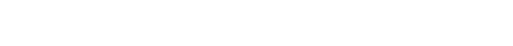 & 1.12 & .90 & .80 & \\
\hline $23 \ldots \ldots \ldots \ldots \ldots$ & 1.13 & .90 & .98 & \\
\hline $24 \ldots \ldots \ldots \ldots$ & 1.06 & .90 & 1.02 & \\
\hline$\ldots+\ldots \ldots \ldots+\ldots$ & 1.02 & .92 & 1.01 & $\cdots$ \\
\hline ' & .90 & .92 & .98 & \\
\hline $27 \ldots \ldots \ldots \ldots \ldots$ & .90 & .92 & .78 & \\
\hline $28 \ldots \ldots \ldots$ & .90 & .92 & .80 & \\
\hline $29 \ldots \ldots \ldots \ldots \ldots \ldots$ & $.8 \tau$ & .99 & .81 & \\
\hline ( & .87 & .95 & .84 & \\
\hline $31, \ldots \ldots \ldots$ & $\ldots$ & 1.08 & & \\
\hline Total & 1.11 & .96 & .96 & \\
\hline
\end{tabular}


Estimated daily discharge, in second-feet, of San Gubriel River over ucir on Iron Fork, 100 yards from mouth, for 1901.

[Observer, San Gabriel Power Company.]

\begin{tabular}{|c|c|c|c|c|}
\hline Day. & July. & August. & September. & October. \\
\hline $1 \ldots$ & 1.97 & & & 1.05 \\
\hline $2 \ldots \ldots$ & 1.97 & 0.87 & $-\ldots$ & 1.08 \\
\hline $3 \ldots \ldots \ldots \ldots \ldots$ & 2.03 & 1.05 & $\ldots \ldots$ & 1.05 \\
\hline $4 \ldots \ldots$ & 2.09 & 1.09 & -.... & 1.12 \\
\hline $5 \ldots \ldots \ldots . . . . .5$ & 1.89 & 1.16 & - & 1.20 \\
\hline $6 \ldots \ldots$ & 1.91 & 1.16 & & 1.12 \\
\hline$\tau \ldots \ldots . . . . . .$. & 1.83 & .62 & - . - & 1.09 \\
\hline $8 \ldots \ldots$ & 1.66 & 1.16 & $\ldots . .$. & 1.16 \\
\hline$\ldots, \ldots, \ldots$ & 1.55 & 1.12 & 1.09 & 1.12 \\
\hline $10 \ldots \ldots \ldots \ldots \ldots$ & 1.58 & 1.16 & 1.12 & 1.09 \\
\hline 11 & 1.50 & 1.24 & 1.12 & 1. 20 \\
\hline $12 \ldots \ldots \ldots$ & 1.39 & 1.06 & 1.09 & 1. 20 \\
\hline $13 \ldots \ldots \ldots$ & 1.42 & 1.09 & 1.09 & 1. 23 \\
\hline $14 \ldots \ldots \ldots . . . .140$ & 1.42 & 1.20 & 1.12 & 1.31 \\
\hline $15 \ldots \ldots$ & 1.44 & 1.24 & 1.16 & $\ldots$ \\
\hline $16 \ldots \ldots \ldots \ldots$ & 1.42 & 1.12 & 1.09 & $\ldots$ \\
\hline $17 \ldots \ldots \ldots \ldots$ & 1.42 & 1.12 & 1.16 & $--\cdots$ \\
\hline $18 \ldots \ldots \ldots$ & 1.37 & 1.09 & 1.09 & $\ldots$ \\
\hline $19 \ldots$ & 1.37 & 1.09 & 1.09 & -..... \\
\hline $20 \ldots \ldots \ldots \ldots$ & 1.42 & 1.16 & 1.05 & $\ldots$ \\
\hline $21 \ldots \ldots \ldots$ & 1.31 & 1.12 & .91 & ...... \\
\hline $22 \ldots \ldots \ldots \ldots$ & 1.34 & 1.12 & .87 & ...... \\
\hline 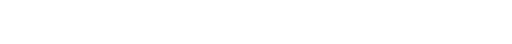 & 1.37 & 1.02 & 1.12 & $-\ldots$ \\
\hline $24 \ldots \ldots \ldots \ldots$ & 1.24 & 1.02 & 1.27 & ...... \\
\hline $25 \ldots \ldots \ldots \ldots$ & 1.29 & .95 & 1.20 & -...... \\
\hline $26 \ldots \ldots \ldots$ & 1.24 & .95 & 1.20 & $\ldots \ldots$ \\
\hline $27 \ldots \ldots \ldots \ldots \ldots \ldots \ldots$ & 1.26 & .95 & $1.0 \tilde{5}$ & $\ldots \ldots$ \\
\hline 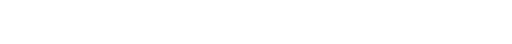 & 1.21 & 1.02 & 1.01 & ............. \\
\hline $29 \ldots \ldots \ldots$ & 1.09 & 1.09 & 1.01 & $\cdots$ \\
\hline $30 \ldots \ldots \ldots \ldots$ & 1.14 & 1.09 & 1.16 & - . .... \\
\hline 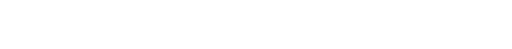 & 1.24 & 1.12 & $\ldots \ldots$ & (............ \\
\hline Total & 1.50 & 1.07 & 1.09 & . 1.14 \\
\hline
\end{tabular}


Inscharge mensurements of 'san cabriel River at point abow Iron Fork.

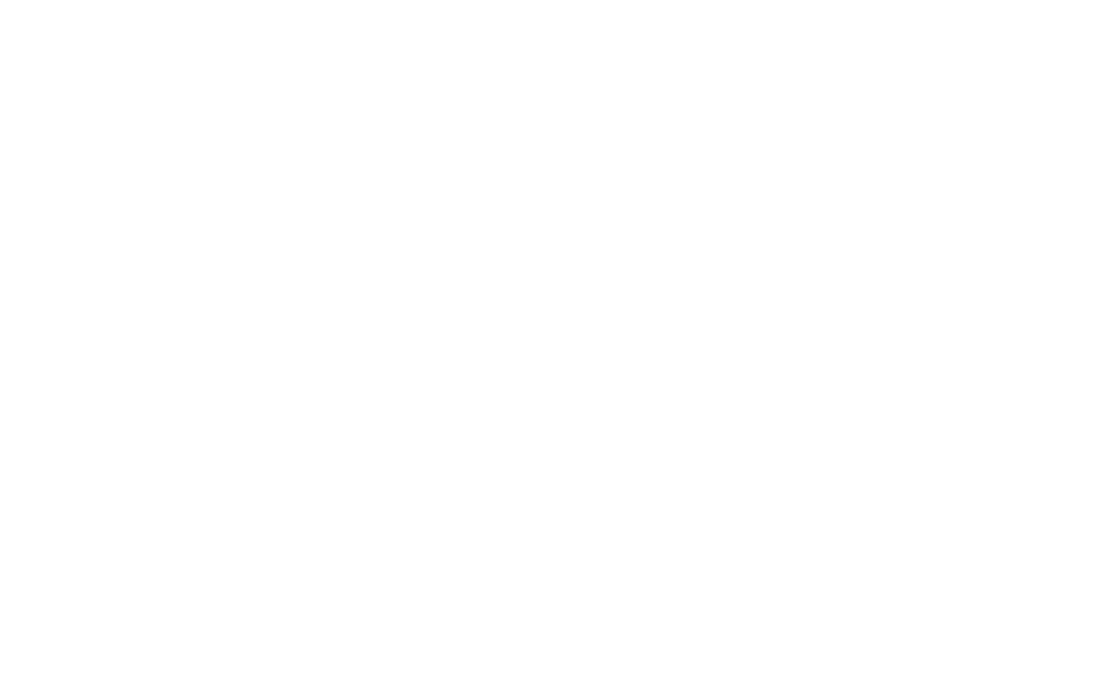

Discharge measurements of Iron Fork of san Gabriel River at month.

\section{Date.}

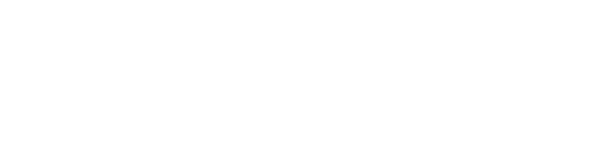

November, 1896

F. C. Finkle

Sier.-ficet.

December, 1896

January, $189 \%$ do

do

do

February, $189 \pi$

do

March, 189 ז do

April, $189 \%$

May, 1897

June, 1897

July, 1897

August, 1897

September, $189 \%$

April, 1900

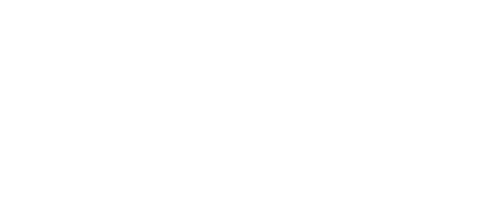

5. 6

3.0

10.1

18.3

18.9

10. 2

8.9

ก.

8.6

3.9

4.1

1. 69 
Discharge mensurements of North Fork of San Galurich River.

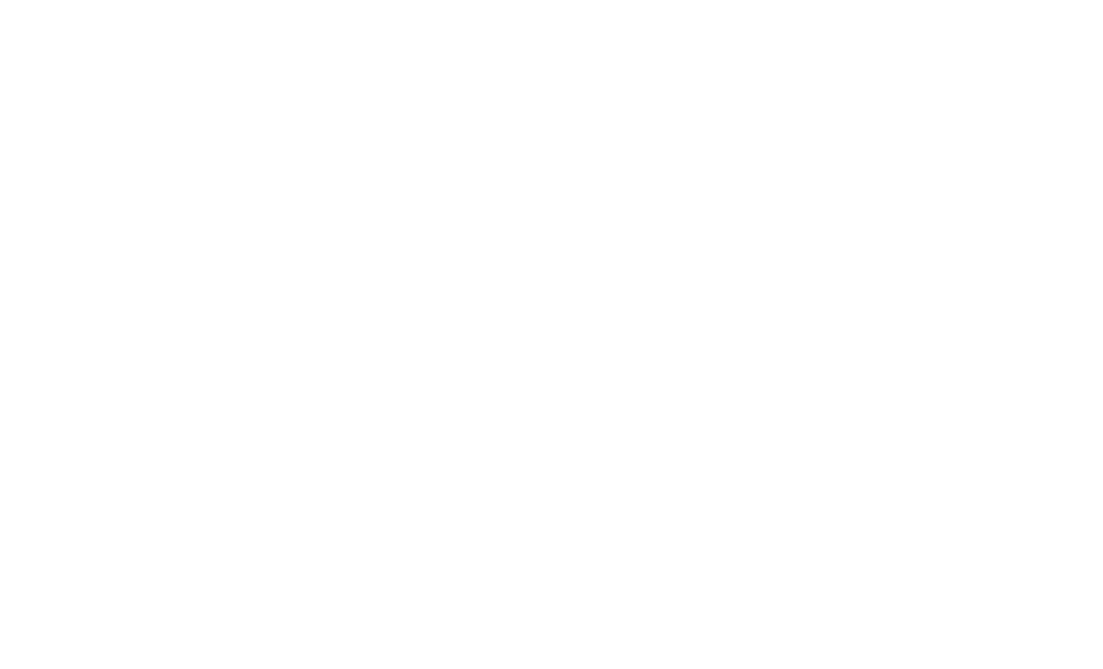

Discharge measurements of Colduater Creek, Sun Gabricl River. Las; angeles County, Crel.

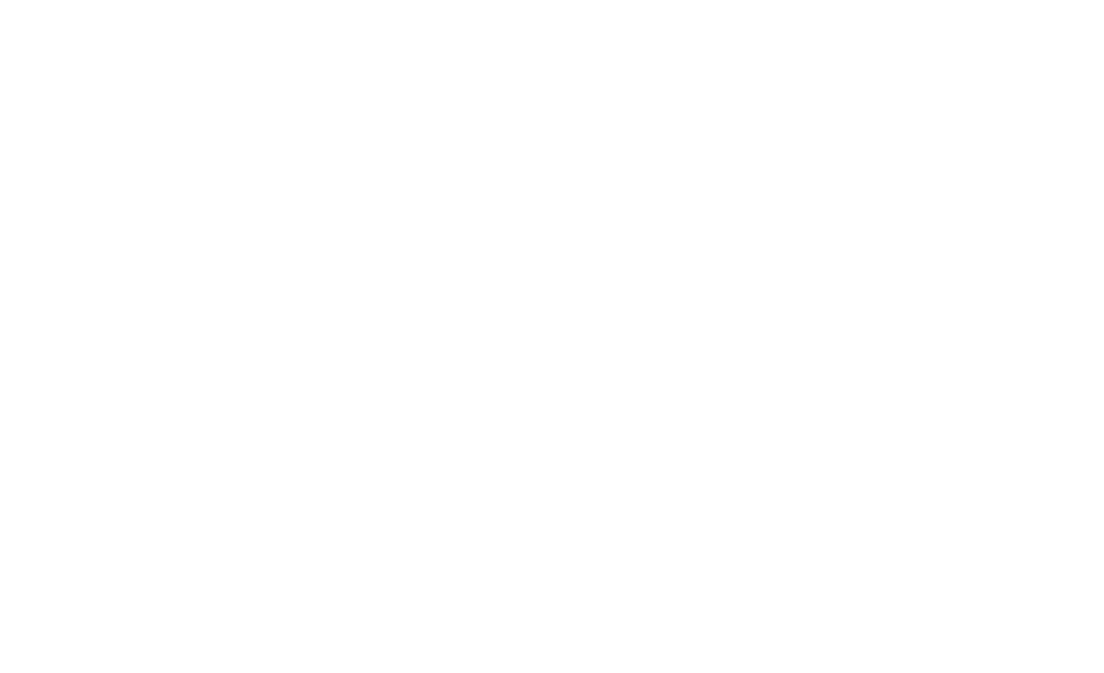

IRR $\$ 1-0: 3-16$ 


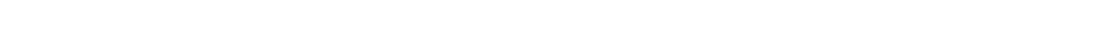
(torl.
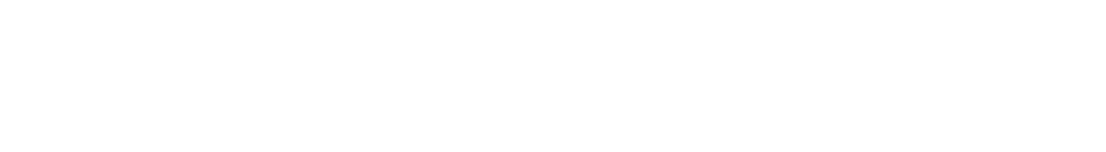

\begin{tabular}{|c|c|}
\hline November, 1896 & F. ('. Fincle $\ldots . . . . \quad \ldots \ldots \ldots \ldots$ \\
\hline December, 1896 . & . - do $\ldots$. \\
\hline January, 1897 & do $\ldots \ldots \ldots$ \\
\hline February, 1897 & . do ............... \\
\hline March, $189 r \ldots$ & do ............ \\
\hline April, $1897 \ldots$ & $\ldots$. . . . . . . . . . . . . \\
\hline May, $189 \tau$... . . & do \\
\hline
\end{tabular}

Discharge measurements of Bear Creek, San Gabriel River, at point near mouth, Los Angeles County. Cal.

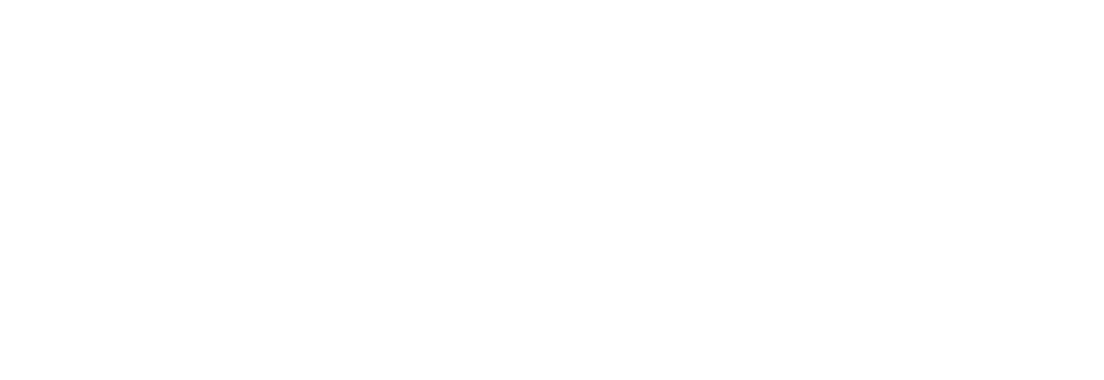

Discharge measurement of West Fork of San Gabriel River above Bear Creek, Los Angeles C'ounty, Cai.

\begin{tabular}{|c|c|c|}
\hline Date. & Hydrographer. & $\begin{array}{l}\text { Dis- } \\
\text { charge. }\end{array}$ \\
\hline April, 1900 . & B. Lippincott et al & $\begin{array}{r}\text { Sec.feet. } \\
1.80\end{array}$ \\
\hline
\end{tabular}

Discharge measurement of Thest Fork of San Gabriel above junction uith East Fork, or Main River, Los Angeles County, Cal.

\begin{tabular}{|c|c|c|}
\hline Date. & Hydrographer. & $\begin{array}{c}\text { Dis- } \\
\text { charge. }\end{array}$ \\
\hline August 23,1898 . & J. B. Lippincott _. & $\begin{array}{r}\text { ser.feet. } \\
\text { 2. } 67\end{array}$ \\
\hline
\end{tabular}




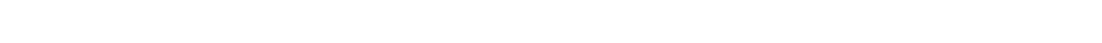
I'orl, Less Angoles county. Cal.

Date.

August 23, 1895
Hỹdrographer.

J. B. Lippincentt
Discharge. :irr:-ficet.

\%. 11

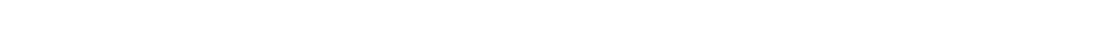

Date.

Hydrographer.

\section{Ingust 23. 1 R9s.}

-

Do.....

J. B. Lippincott

| Sier. feet.

do

9.78

18.42

1.36

"San Gabriel River at headworks of San (iabriel Power C'onpany.

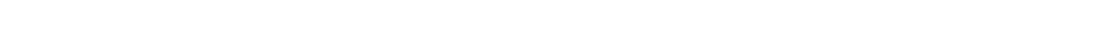
Los Angeles Cominty. C'rll.
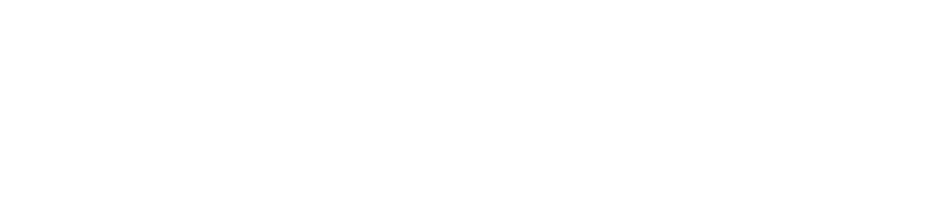

April, 1900

J. B. Lippinentt et al

0.32

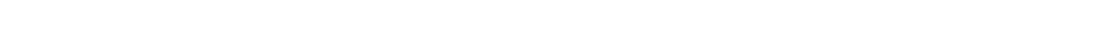
belou El Monte Narrous.

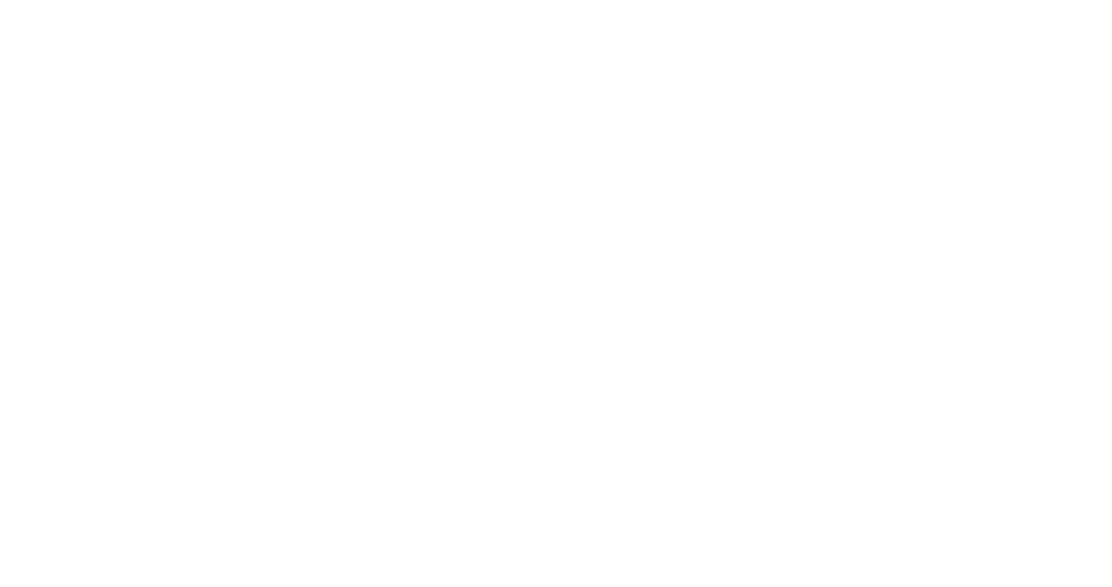


Discharge measurenents of San Gabiel River at various points in watershed.

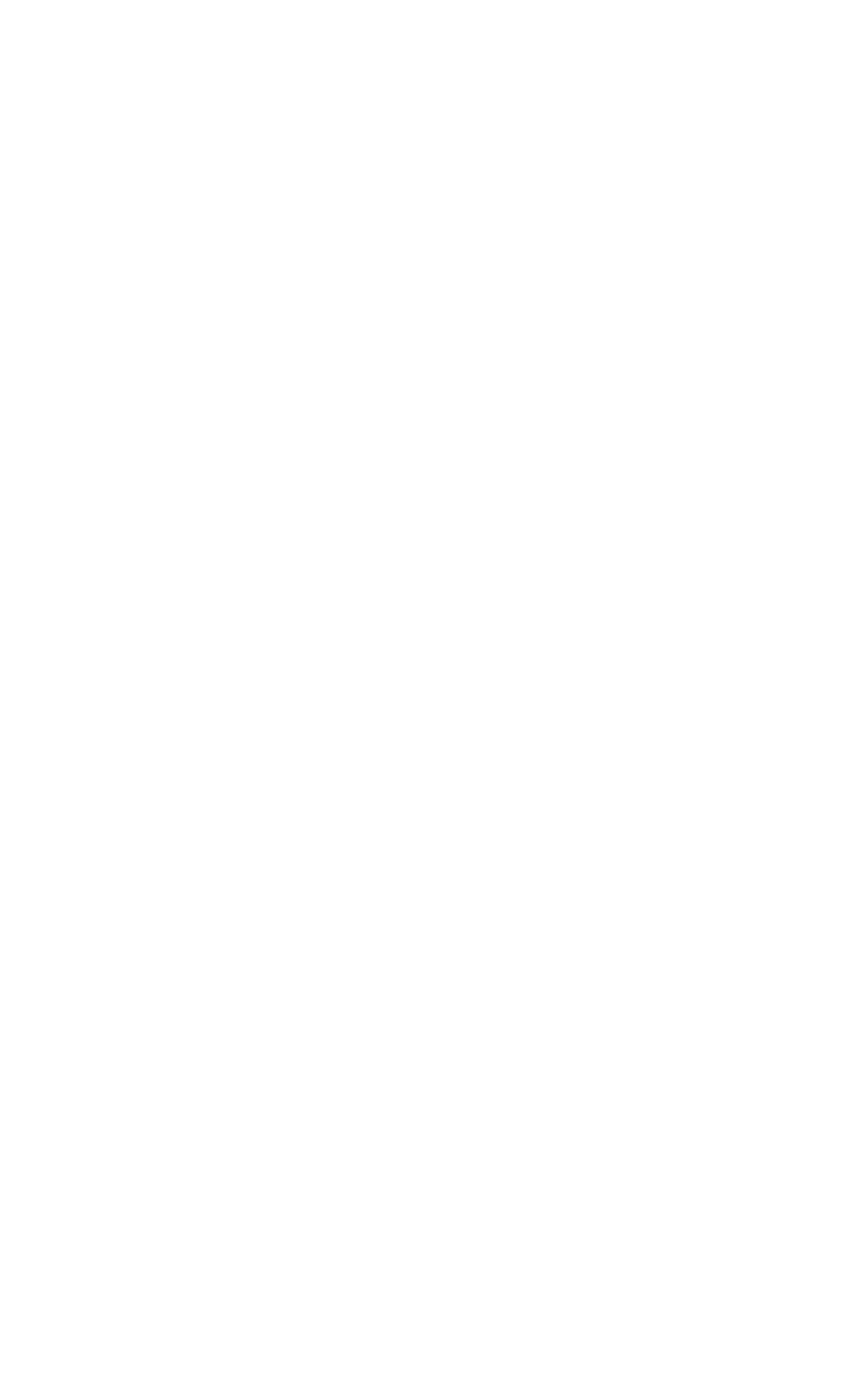


Discharge measurements of Son Grobriel River, ete.-Continued.

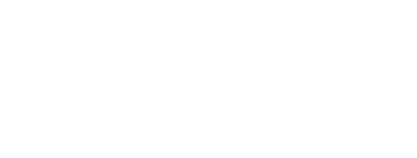

Sept. 20 W. W. C'x'rin:;

Sept. 2

$-17$

(1)

Sept. 24

Sept. 24

(1)

Sept. $24 !$ (1)

Sept. 18 - d .

Sept. $24 \mid \ldots$.

Sept. 21

do

Sept. 21 di

Sept. 13) di

Seyt. 13

do

Sept. 13 .. do

Sept. $13 \ldots$ do

Sept. 13

dis

Sept. 14

do

Sept. 14

do

Sept. 14 do

Sept. $14 \ldots$. . do

Sept. 1\%
Locality.

Area uf Mean IJissection. Delocity, rharge.

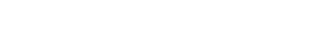

Alhambra Water Co..

2. 58 weir No. 1.

Alhambra Water Co.. weir No.?.

Total

2.92

Santa Anita Canyon, natural flow.

Sierra Madre Water Co. (weir).

Remamettes east of Sierra Madre.

Monrovia Water Co.. is wells pumped.

Momrovia Canyon, to Monrovia Water Co. (weirs).

To Bradbury .116

Total

3. 24

.428

$-$

Duarte Mutual Inprovement and Canal Co.

Beardskey Water Co

Morengo Water Co. Southern Pacific Co.'s Garfield station (weir).

Morengo Water Co.'s weir in Morengo Canyon (weir).

Los Robles Water Co. is reservoir (weir).

Reservoir at junction of Glenarm and Los Robles avenues. Pasadena (weir).

Graves \& Bean tunnel

2.06

Brick kiln between Molino and Hope streets, Pasadena.

Oak Knoll Park. Pasadena.

Patton tunnel. near Kewen Lake.

Patton's east canyon .

Patton's east canyon, natural flow; pump not running.
5.34

1.10

1.82

.096

3.53

.34

$.04 \% \quad 3.80$

.18

$.8 \%$

1. 70

1. 48

.30

1.03

.37 
I)ischarge measurements af San Gabriel River. ete.-Continued.

Date. Hyrtrographler.

1900 .

Sept. 1\% W. W. Co.kin::

Sept. $14 \ldots$... do

Sept. $14 \ldots$ do

Sept. 15 . . do ....

Sept. 15 ... do

Sept. 15 ... do

Sept. 15

Sept. 15: - ilo

Sept. $2 \tau^{\prime} \ldots$ do

Sept. $2 \pi$ ' Irwin F. Daniels

Sept. $2 \tau^{\prime} \ldots$. do

Sept. 25 do

Sept. $2 \pi$ r

Sept. $2 \pi \mid$ - do

Sept. $2 \%$ _ do

Sept. $2 \pi \mid \ldots$ do

Sept. $27 \mid \ldots .$. do

Sept. $2 \pi$

Sept. $2 \pi$, . do

Sept. $2 r^{\prime}-d o$

Sept. $2 \pi$ do

Sept. $2 \pi$

Sept. 2 T $^{2}$.... do

Sept. 27 . . . do
Lorality.

Mission ditch, Patton ranch.

Winston ranch

Shorbes ranch (weir)

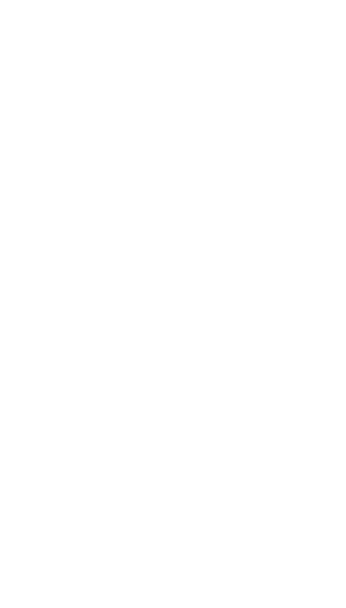

Morningside ranch
(weir).

Glendora, Azusa Irrigation Co.:

Massey well

1.50

Paine well

Total

2. 40

Wells in San Diemas wash:

Daty \& Sons

San Diemas Irrigation Co.. F, D. Smith well

Thacker well

Sinith well (jrivate).

Chapman well .......... .... . . 50

Ruddock well _............. . . . .50

Artesian Belt Co., 2 wells.

Azusa city well .............. . .

Walker's well _..... . . . . . _ ... $\quad .90$

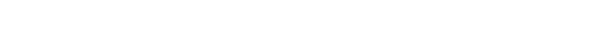
(Covina).

Covina plant. Deacon well.

Natural flow, San Diemas Canyon.

Spark"s well

Total 
Discharge measurements of San Gabriel River at uells on Lordsburg hese.

\begin{tabular}{|c|c|c|c|c|c|}
\hline Date. & Hydrograpler. & Locality. & $\begin{array}{l}\text { Area of } \\
\text { section. }\end{array}$ & $\begin{array}{l}\text { Mean } \\
\text { velocity. }\end{array}$ & $\begin{array}{l}\text { Dis- } \\
\text { charge. }\end{array}$ \\
\hline & & & q. $f+4$ & & ser.-feet. \\
\hline Sept. $2 \%$ & Irwin F. Daniels. & Richards, \& wells. & & & 1.52 \\
\hline Sept. $2 \tau$ & $d o$ & Sumner & & - & .48 \\
\hline Sept. $\approx \tau$ & - 10 - & Sheldon Bros ..... & - . - & & .30 \\
\hline Sept. $2 \%$ & do $\ldots . .$. & $\begin{array}{l}\text { La Ferne Land and } \\
\text { Water Co. }\end{array}$ & & & .70 \\
\hline Sept. $2 \%$ & do & Rodgers . . . . . . . . . & & & .10 \\
\hline Sept. $2 \tau$ & rlo .......... & True (5 days in 30 ) .. & $\cdots$ & 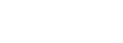 & .16 \\
\hline Sept. 27 & do $\quad \ldots$ & Rodney Soper ..... & . & & .24 \\
\hline Sept. $2 \pi$ & -.10 & Hayes \& Stratton. - & - & & .20 \\
\hline Sept. $2 r$ & do & Wallace.......... & $\ldots$ & & .16 \\
\hline Sept. 27 & $\ldots$ do ... . . . & Mrullard ........... & $\cdots$ & & .30 \\
\hline Sept. $2 \tau$ & $-\ldots d 0 \ldots . .$. & Douglas \& MeQuilly .. & $\cdots-$ & & .76 \\
\hline Sept. $2 r$ & $\ldots$ do ........ & Norris .. ........ & $\cdots$ & & .30 \\
\hline Sept. $2 \tau$ & ..... do ....... & Williams Bros ... . . . & & & .80 \\
\hline Sept. $\stackrel{2}{2}$ & $\ldots d 0 \ldots$ & $\begin{array}{l}\text { Kulp (intermittent), } \\
\text { south of Mesa avenue. }\end{array}$ & & & .20 \\
\hline Sept. $2 \tau$ & $\ldots$. . rlo $\ldots . . . . .$. & D. Fulton .......... & $\cdots$ & & .50 \\
\hline Sept. 27 & $\ldots$ do $\ldots . . .$. & Steves............ & & & .20 \\
\hline Sept. 27 & $\ldots$.... do ... & Daniels \& Overholtzer & & & 1.34 \\
\hline Sept. $2 \pi$ &.$- d o$ & Massey, 2 wells...... & & & .54 \\
\hline Sept. 27 & do ..... & Hauser Bros. . . . . & $\ldots$ & & .76 \\
\hline Sept. $2 \pi$ & $\ldots$ do ...... & Moorwaw \& Son... & & & .50 \\
\hline Sept. 27 & $\ldots$ do $\ldots . . .$. & Sleider .......... & & & .88 \\
\hline Sept. $2 \pi$ & ....do... & Rutherford \& $\mathrm{Co} \ldots .$. & ….... & $\ldots$ & .40 \\
\hline Sept. 27 & $\ldots$ do $\ldots$ & New Deal Water Co... & 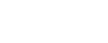 & & .40 \\
\hline \multirow[t]{2}{*}{ Sept. 27} & $\ldots$. & Kiser .......... & $\ldots$ & & .90 \\
\hline & & Total & & & 12.64 \\
\hline
\end{tabular}


Estimaterl monthl!y dischurge of San Gabriel River at Azusa, Los Angeles comnty.

[Drainage area, 2:2: square miles.]

\begin{tabular}{|c|c|c|c|c|c|c|}
\hline \multirow[b]{2}{*}{ MIonth. } & \multicolumn{3}{|c|}{ Discharge. } & \multirow[b]{2}{*}{$\begin{array}{l}\text { Total dis- } \\
\text { charge. }\end{array}$} & \multicolumn{2}{|c|}{ Run-off. } \\
\hline & Maximum. & Minimum. & Mean. & & $\begin{array}{l}\text { Per } \\
\text { square } \\
\text { mile. }\end{array}$ & Lepth. \\
\hline $1 \times 94$. & Sireffeet. & Sec-fert. & sise-feet. & Acreffeet. & Sec-fect. & Iuches. \\
\hline May & 50 & $2 \tilde{}$ & 32 & 1.968 & 0.14 & 0.16 \\
\hline June & $2 \pi$ & $1 \%$ & 23 & 1.369 & .10 & .11 \\
\hline July $\ldots \ldots \ldots$ & $1 \tau$ & 9 & 12 & 738 & .05 & .06 \\
\hline August ........... & $2 \pi$ & 10 & 14 & 861 & .06 & $.0 \%$ \\
\hline September ......... & 23 & 13 & 15 & 893 & $.0 \%$ & .08 \\
\hline October ........... & 16 & 13 & 14 & 861 & .06 & $.0 \%$ \\
\hline November 1 to $15 . .$. & 14 & 13 & 13 & $38 \pi$ & .06 & .03 \\
\hline 1895 & & & & & & \\
\hline August 8 to $81 \ldots$. & $4 i$ & 38 & 42 & 1.999 & .19 & .15 \\
\hline September ....... & 39 & 29 & 32 & 1.904 & .14 & .16 \\
\hline Octoher ................ & 32 & 27 & 29 & 1. 283 & $.1: 3$ & .15 \\
\hline November ........ & 50 & 29 & 40 & 2.380 & .18 & .20 \\
\hline December ........ & 45 & 37 & 42 & $2,5 \times 2$ & .19 & .22 \\
\hline 1896. & & & & - & 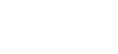 & - \\
\hline January . . . . . & 25 & $0^{\prime}$ & 11 & $6 \% 6$ & 0.05 & 0.06 \\
\hline February .......... & 28 & 3 & 12 & 690 & .0 .5 & .06 \\
\hline March ...... & 134 & $2 \pi$ & 75 & 4,612 & .34 & .39 \\
\hline April ........ & 46 & 0 & 11 & 655 & .05 & .06 \\
\hline May ........ & 0 & 0 & 0 & 0 & 0 & 0 \\
\hline June .......... & 0 & 0 & 0 & 0 & 0 & 0 \\
\hline July $\ldots \ldots \ldots$ & 0 & 0 & 0 & 0 & 0 & 0 \\
\hline August .... . . & 0 & 0 & 0 & 0 & 0 & 0 \\
\hline September......... & 0 & 0 & 0 & 0 & 0 & 0 \\
\hline October ......... & $1 \pi$ & 0 & 12 & 738 & .05 & .06 \\
\hline November. . . . & 16 & 0 & 3 & 179 & .01 & .01 \\
\hline December ... & 12 & 0 & 2 & 123 & .01 & .01 \\
\hline The year ... & $1 \%$ & 0 & 11 & 7,673 & .05 & 6.5 \\
\hline
\end{tabular}

Note.-During the summer months all this water is diverted by the canals. For 1894 and 1895 the above table is for the total discharge from the drainage basin. Subseunent to 1895 the table shows the separate flow in river and canals, except where combined and so stated. 
Estimated menthly discharge of San Gabriel River at Azusa, etc.-Cortinned.

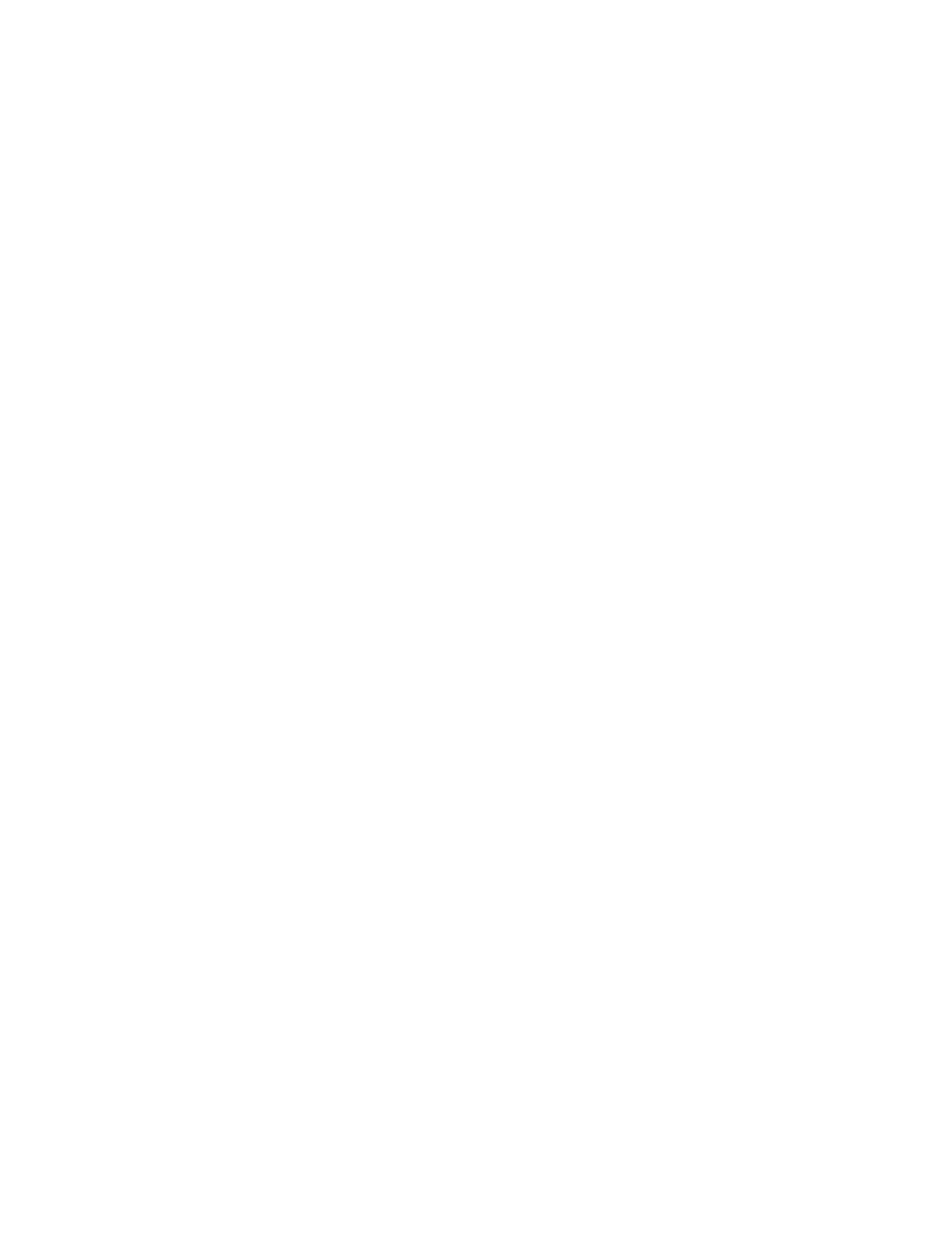


Estimated monthly discharge of San Gabriel River at Azusa, etr.-Continued.

\begin{tabular}{|c|c|c|c|c|c|c|}
\hline \multirow[b]{2}{*}{ Month. } & \multicolumn{3}{|c|}{ Discharge. } & \multirow[b]{2}{*}{$\begin{array}{l}\text { Total dis- } \\
\text { charge. }\end{array}$} & \multicolumn{2}{|c|}{ Run-off. } \\
\hline & Maximum. & Minimum. ' & Mean. & & $\begin{array}{l}\text { Per } \\
\text { square } \\
\text { mile. }\end{array}$ & Depth. \\
\hline 1899. & sereffeet. & sec-feet. & Sec.-feet. & Acrefert. & Sec.feet. & Inches. \\
\hline January .... & 16 & 0 & 1.2 & 74 & 0.00 .5 & 0.00 \\
\hline Fehruary ......... & 0 & 0 & 0 & 0 & 0 & 0 \\
\hline March ........... & 0 & 0 & 0 & 0 & 0 & 0 \\
\hline April .. & 0 & 0 & 0 & 0 & 0 & 0 \\
\hline 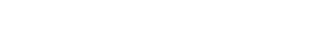 & 0 & 0 & 0 & 0 & 0 & 0 \\
\hline June ........... & 0 & 0 & 0 & 0 & 0 & 0 \\
\hline July . . . . . . . & 0 & 0 & 0 & 0 & 0 & 0 \\
\hline August $\ldots \ldots \ldots$ & 0 & $0 !$ & 0 & 0 & 0 & 0 \\
\hline September ..... & 0 & 0 & 0 & 0 & 0 & 0 \\
\hline October ........... & 13 & 0 & .42 & 26 & $0.00^{\circ}$ & .002 \\
\hline November & 0 & 0 & 0 & 0 & 0 & 0 \\
\hline December ... . & 0 & 0 & 0 & 0 & 0 & 0 \\
\hline The year - & 16 & 0 & .13 & 100 & .007 & .007 \\
\hline 1900 & & & & & & \\
\hline Jantary _........ & 49 & 0 & 2 & $12: 3$ & 0.01 & 0.01 \\
\hline Febrnary ........... & 0 & $n$ & 0 & 0 & $n$ & 0 \\
\hline March .............. & 0 & 0 & 0 & 0 & 0 & 0 \\
\hline April ................ & 0 & 0 & 0 & 0 & 0 & 0 \\
\hline May ....... & 38 & 0 & 2 & 123 & .01 & .01 \\
\hline June ...... & 0 & 0 & 0 & 0 & $1)$ & 0 \\
\hline July ... . . & 0 & 0 & 0 & 0 & 0 & 0 \\
\hline August .... & 0 & 0 & 0 & 0 & 0 & 0 \\
\hline Septenber .. & 0 & $n$ & 0 & 0 & 0 & 0 \\
\hline October .... & 0 & 0 & 0 & 0 & 0 & 0 \\
\hline November ... & 5,169 & 0 & $1 \% 2$ & 10. 25i & o ii & 0.85 \\
\hline December ....... & 0 & 0 & 0 & 0 & 0 & 0 \\
\hline The year & 5.168 & 0 & 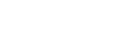 & 10481 & $.0 i$ & .87 \\
\hline
\end{tabular}


Estimated monthly discharge of San Gabriel River at Azusa. etc.-Continued.

\begin{tabular}{|c|c|c|c|c|c|c|}
\hline \multirow[b]{2}{*}{ Month. } & \multicolumn{3}{|c|}{ Distharge. } & \multirow[b]{2}{*}{$\begin{array}{l}\text { Total dis- } \\
\text { charge. }\end{array}$} & \multicolumn{2}{|c|}{ Rù-off. } \\
\hline & Maximum. & Minimum. & Mean. & & $\begin{array}{l}\text { Per } \\
\text { square } \\
\text { mile. }\end{array}$ & Depth. \\
\hline 1901. & Sereffert. & Ser.ffept. & Sece-feet. & Acre-feet. & Sece-feet. & Turhes. \\
\hline January .... . . . . & 1.450 & 0 & 111 & 6,825 & 0.50 & 0.58 \\
\hline February .......... & $\stackrel{2}{2}, 600$ & \%0 & 613 & 34,044 & 2. 56 & 2.87 \\
\hline March _. . . .... & $3 \pi 0$ & 80 & 158 & 9,715 & .71 & .82 \\
\hline April ............... & $i 5$ & 13 & 43 & 2,559 & .19 & .21 \\
\hline May ............ & 200 & 18 & $\tilde{5} 5$ & 3,382 & .25 & .29 \\
\hline June . ............ & $2 \tau$ & 0 & 7 & 417 & .03 & .03 \\
\hline July _.............. & 0 & 0 & 0 & 0 & 0 & 0 \\
\hline August .. $\ldots \ldots$ & 0 & 0 & 0 & 0 & 0 & 0 \\
\hline September ..... & 0 & 0 & 0 & 0 & 0 & 0 \\
\hline October . . . . . . . & 70 & 0 & 3 & 184 & .01 & .01 \\
\hline November ... & 0 & 0 & .0 & 0 & 0 & 0 \\
\hline December ... .... & 0 & 0 & 0 & 0 & 0 & 0 \\
\hline The y+ar .... & $\stackrel{2.600}{\sim}$ & 0 & 83 & $5 \%, 126$ & .37 & 4.81 \\
\hline 1902. & & & & & & \\
\hline January _........ & 0 & 0 & 0 & 0 & - & \\
\hline February $\ldots \ldots \ldots$ & $\pi$ & 0 & 3 & $16 \%$ & & \\
\hline March ... $\ldots$ & 318 & 4 & 38 & 2.337 & & $\ldots$ \\
\hline April $\ldots \ldots \ldots$ & $3 i$ & 0 & $i$ & 417 & $\ldots$. & $\ldots$ \\
\hline May .... .... . . . & 0 & 0 & 0 & 0 & & \\
\hline June .... . . . ... & 0 & 0 & 0 & 0 & & \\
\hline July . . . . . . . . & 0 & 0 & 0 & 0 & $\ldots$ & \\
\hline August .......... & 0 & 0 & 0 & 0 & -. & $\ldots$ \\
\hline September ........ & 0 & 0 & 0 & 0 & 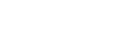 & -. \\
\hline October ............ & 0 & 0 & 0 & 0 & & \\
\hline November . . . . . . . & 0 & 0 & 0 & 0 & & $\ldots$ \\
\hline December ... ... ... & 0 & 0 & 0 & 0 & & \\
\hline The year... & 318 & 0 & 4 & 2,921 & & \\
\hline
\end{tabular}


Estimated monthly discherefe of San Crabriel canals at Azusa, Lo: Angeles County.

[Drainage area, 222 square miles.]

\begin{tabular}{|c|c|c|c|c|c|c|}
\hline \multirow[b]{2}{*}{ Month. } & \multicolumn{3}{|c|}{ Discharge. } & \multirow[b]{2}{*}{$\begin{array}{l}\text { Total dis- } \\
\text { charge. }\end{array}$} & \multicolumn{2}{|c|}{ Run-off. } \\
\hline & Maximum. & Minimum. & Mean. & & $\begin{array}{l}\text { Per } \\
\text { square } \\
\text { mile. }\end{array}$ & Depth. \\
\hline 1896. & Seerefeet. & sec.-feet. & Sec-feet. & Acre-fert. & ser.feet. & Inches. \\
\hline January _. . . . . . . . & 26 & 26 & 26 & 1, 599 & 0.12 & 0.14 \\
\hline Febrcary ........ & 34 & 26 & 30 & 1,726 & .14 & .15 \\
\hline 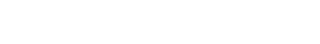 & 43 & 35 & 36 & 2,214 & .16 & .18 \\
\hline 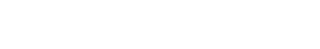 & 45 & 40 & 43 & $2,5.59$ & .19 & .21 \\
\hline May ....... & 42 & 29 & 36 & 2.214 & .16 & .18 \\
\hline June ........ . & $2 \pi$ & 13 & 19 & 1.131 & .09 & .10 \\
\hline July .............. & 15 & 9 & 12 & 738 & $\cdot .05$ & .06 \\
\hline August.... . & 36 & 9 & 14 & 861 & .06 & $.0 \%$ \\
\hline Septcmber .... & 19 & 11 & 13 & $\pi \% 4$ & .06 & .07 \\
\hline Octobe: ... & $1 \%$ & 10 & 11 & $6 \% 6$ & .05 & .06 \\
\hline November..... & 24 & 15 & 17 & 1,012 & .08 & .09 \\
\hline December .... . & 25 & 18 & 20 & 1,230 & .09 & .10 \\
\hline The year - & 45 & $\overline{9}$ & 23 & 16,734 & .10 & 1.41 \\
\hline $189 \%$ & & & & & & \\
\hline January ..... . & 22 & 13 & 17.56 & $1,0 \% 2$ & 0.079 & 0.091 \\
\hline February ... & 20 & 3 & 13.10 & 726 & .059 & .061 \\
\hline March ... & 21 & 0 & $1 \% .14$ & 1,051 & $.0 \% 7$ & .089 \\
\hline April & 60 & 15 & 35.30 & 2,102 & .159 & $.17 \%$ \\
\hline May ........ & 68 & 55 & 62.97 & 3,810 & .284 & .328 \\
\hline Jun $\ldots \ldots \ldots$ & $r 1$ & .54 & 63.20 & 3,759 & .285 & .317 \\
\hline 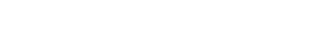 & 52 & $2 \pi$ & 38.13 & 2,343 & .171 & $.19 \pi$ \\
\hline Angnst $\ldots . .$. & 34 & 22 & 26.45 & 1,613 & .118 & .136 \\
\hline September $\ldots$ & 23 & 18 & 20.66 & 1,226 & .088 & .098 \\
\hline October ...... & 26 & 10 & 18.03 & 1,106 & .081 & .093 \\
\hline November . . . . & 39 & 16 & 23.30 & 1,385 & .105 & .109 \\
\hline December .... & 29 & 25 & 26.84 & 1,648 & .121 & .139 \\
\hline The year & $\tau 1$ & 0 & 30.20 & 21,831 & .136 & 1,835 \\
\hline
\end{tabular}


Estimated monthly discharge of San Gabriel canals at Azusa, ete.-Continued.

1898.

January

Februar:

March

April

May

June

July

August

Septemher

October

November

December

The year 1899.

January

February

March

Apri

May

June

July

August

September

October

November

December

The year

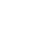

......

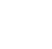

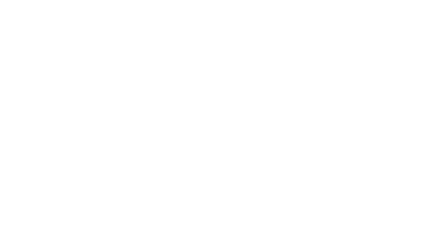

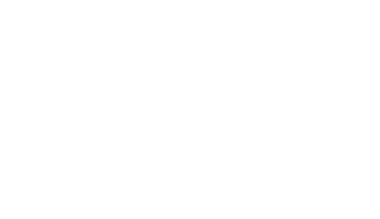

32 23

26

1, 591

0.12

0.14

34

10

48

37

45

30

$$
28
$$

29

35

$25.3 \quad 33$

20.0 । 32

\begin{tabular}{l|l}
14.5 & 19
\end{tabular}

14

9

10

9.

19

5.0 \%

6. 1 8

10

11

18

\section{5}

8.0

9

10

11. $7 ~ 14$

.

......

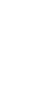

$2 \pi$

$1,618 \quad .13$

.14

\begin{tabular}{l|l|l}
2,129 & .16 & .18
\end{tabular}

\begin{tabular}{l|l|l}
1,950 & .15 & .17
\end{tabular}

$1,947 \quad .14 \quad .16$

\begin{tabular}{ll|l}
1,159 & .09 & .10
\end{tabular}

$\begin{array}{lll}672^{\prime} & .05 & .06\end{array}$

\begin{tabular}{ll|l}
456 & .03 & .03
\end{tabular}

\begin{tabular}{ll|l}
$46 \tau$ & .04 & .04
\end{tabular}

$533 ! .04, .04$

$580 \quad .04 \quad .04$

$832 \quad .06 \quad .07$

1.17

\begin{tabular}{l|lll|l}
15 & 21.8 & 1,340 & 0.098 & 0.115
\end{tabular}

\begin{tabular}{l|l|l|l|l|}
20 & 22.0 & $1,244^{\prime}$ & .102 & .106
\end{tabular}

\begin{tabular}{l|l|l|l|l|}
\hline 18 & 26.0 & 1,623 & .119 & .137 \\
\hline
\end{tabular}

\begin{tabular}{ll|l}
1,262 & .096
\end{tabular}

.107

$842, .062 \quad .071$
48

$\overline{\overline{1}}$

$$
=
$$

$5 . 0 \longdiv { 1 9 . 4 }$

$2 \pi$

40

28

17

22

4

4

6

6

6

24

24
39

39

40

16

21.0

5.0

4.0

14.0

20.0

14.4

$\begin{array}{lll}565 & .043 & .048\end{array}$

\begin{tabular}{l|l|l|l}
221 & .016 & .018
\end{tabular}

295.022 .025

\begin{tabular}{l|l|l}
220 & .019 & .021
\end{tabular}

$683 \quad .050$

.058

$\begin{array}{lll}847 & .064 & .071\end{array}$

$1,247 \quad .091$

.105

.882 
Fstimated monthly discharge of sall crabriel canals at Azusa, etc.-Continued.

\begin{tabular}{|c|c|c|c|c|c|c|}
\hline \multirow[b]{2}{*}{ Month. } & \multicolumn{2}{|r|}{ Discharge. } & & \multicolumn{2}{|c|}{ Run-off. } \\
\hline & Maximum. & Minimum. & Mean. & $\begin{array}{l}\text { Total dis- } \\
\text { charge. }\end{array}$ & $\begin{array}{c}\text { Per } \\
\text { square } \\
\text { mile. }\end{array}$ & Depth. \\
\hline 1900. & Sereffect. ! & ! sier.-feet. & sece-feet. & Acrefeet. & | Sec.-feet. & Inches. \\
\hline January .... & 50 & 22 & $30^{\prime}$ & 1,845 & 0.14 & 0.16 \\
\hline February . . . . . . & 23 & 18 & 20 & 1,111 & .09 & .09 \\
\hline March . . . . . . & 30 & 16 & 20 & 1,230 & .09 & .10 \\
\hline April ........... & 26 & 13 & 17 & 1,012 & .08 & .09 \\
\hline May ............ & 56 & 16 & 35 & 2,152 & .16 & .18 \\
\hline June ........... & 22 & 8 & 15 & 893 & $.0 \pi$ & .08 \\
\hline July .... . . . . & 10 & $t$ & 6 & 369 & .03 & .03 \\
\hline August ..... & $\tilde{5}$ & 4 & 4 & 246 & .02 & .02 \\
\hline Septembe: . & 6 & 3 & 4 & 238 & .02 & .02 \\
\hline October . . . . . & 6 & 4 & $5 !$ & $30 \pi$ & .02 & .02 \\
\hline November...... & 5.5 & 5 & 14 & 833 & .06 & $.0 \%$ \\
\hline December 1 to $16 \ldots$ & 53 & 31 & 40 & 1,269 & .18 & .11 \\
\hline The year & 55 & 3 & 18 & 11,505 & .08 & .97 \\
\hline 1901. & & & & & 1 & \\
\hline January .... & - 90 & 0 & 58 & 3,566 & $0.26^{\prime}$ & 0.30 \\
\hline February ... & 70 & 5 & $67^{\prime}$ & 3,721 & .30 & .31 \\
\hline March ..... & $r 0$ & $3 \tilde{n}$ & 63 & $3.8 \pi 4$ & $.28 \mid$ & .32 \\
\hline April . . . . . & 84 & 55 & $6 \tau$ & 3,987 & .30 & .33 \\
\hline May . . ....... & 72 & 59 & 66 & 4,058 & .301 & .35 \\
\hline June ... . . . . . & 66 & 41 & 56 & 3,332 & .25 & .28 \\
\hline July ........ & 41 & 24 & 30 & 1,845 & .14 & .16 \\
\hline August ..... & $2 \tau$ & 15 & 20 & 1,230 & .09 & .10 \\
\hline September . . ... & 20 & 15 & 17 & 1,012 & .08 & .09 \\
\hline October . . . . . & 64 & 0 & 21 & 1,291 & .09 & .10 \\
\hline November. ..... & 50 & 29 & 32 & 1,904 & .14 & .16 \\
\hline December . . . . . . . . & 30 & 26 & 27 & 1,660 & .12 & .14 \\
\hline The year. & 90 & 0 & 44 & 31,480 & .20 & 2.64 \\
\hline
\end{tabular}


Estimated monthly rischarge of San Gabriel cauds at Azusa. ete.-Continuet.

\begin{tabular}{|c|c|c|c|c|c|c|}
\hline \multirow[b]{2}{*}{ Month. } & \multicolumn{3}{|c|}{ Discharge. } & \multirow[b]{2}{*}{$\begin{array}{l}\text { Total dis- } \\
\text { charge. }\end{array}$} & \multicolumn{2}{|c|}{ Run-off. } \\
\hline & Maximum. & Minimum. & Mean. & & $\begin{array}{c}\text { Per } \\
\text { square } \\
\text { mile. }\end{array}$ & Depth. \\
\hline 1902 & sec.-feet. & Sec.-feet. & sec-feet. & Acre-feet. & Sec-feet. & Inches. \\
\hline January _...... & 51 & 24 & 28 & 1,722 & & \\
\hline February .... . . . & 63 & 27 & 34 & 1,888 & & \\
\hline March $\quad \ldots . . . .$. & 62 & 55 & 61 & 3,750 & & \\
\hline April & 62 & 46 & 59 & 3,510 & & \\
\hline May ....... & 48 & 30 & 39 & 2,398 & & \\
\hline June ........ & $29 . \overline{5}$ & 13.5 & 20 & 1,190 & & \\
\hline July ... ..... & 17 & 7.5 & 11 & 676 & & \\
\hline August ..... & 8.5 & 6 & $\tau$ & 430 & & \\
\hline September ......... & $6 \quad$ & 4.5 & 5 & 298 & & - . \\
\hline October . . . . . & 10.5 & 5.5 & 7 & 430 & & \\
\hline November. . . . . . . . & 62 & 7.5 & 19 & 1,131 & & \\
\hline December $\quad \ldots . . .$. & 68 & 16 & 32 & 1,968 & & \\
\hline The year ....... & 68 & 4.5 & $2 \pi$ & 19,391 & & \\
\hline
\end{tabular}

Estimated monthly discharge of San Gabriel River and cangls at Azusa, Los Angeles County.

[Drainage area, 222 square miles.]

\begin{tabular}{|c|c|c|c|c|c|c|}
\hline \multirow[b]{2}{*}{ Month. } & \multicolumn{3}{|c|}{ Discharge. } & \multirow[b]{2}{*}{$\begin{array}{l}\text { Total dis- } \\
\text { charge. }\end{array}$} & \multicolumn{2}{|c|}{ Run-off. } \\
\hline & Maximum. & Minimum. & Mean. & & $\begin{array}{c}\text { Per } \\
\text { square } \\
\text { mile. }\end{array}$ & Depth. \\
\hline 1896. & ser.feet. & sec:-feet. & Seer-feet. & Acre-feet. & Secr-feet. & Inches. \\
\hline January .... & 51 & 26 & 37 & 2,275 & 0.17 & 0.20 \\
\hline February $\ldots . . . .$. & 61 & 36 & 41 & 2,358 & .18 & .19 \\
\hline March ..... . . . . . & 169 & $3 \pi$ & 111 & 6.825 & .50 & .58 \\
\hline April $\ldots \ldots \ldots \ldots$ & 91 & 40 & 54 & 3,213 & .24 & .27 \\
\hline May ... - ... . . & 40 & 29 & 36 & 2,214 & .16 & .18 \\
\hline June ...... . . . . . . & $2 \pi$ & 13 & 19 & 1,131 & .09 & .10 \\
\hline July _ _ . . . . & 15 & 9 & 12 & 738 & .05 & .06 \\
\hline August $\ldots .$. & 36 & 9 & 14 & 861 & .06 & .07 \\
\hline Septemiber. & 19 & 11 & 13 & 774 & .06 & $.0 \%$ \\
\hline October ..... & 188 & 10 & 24 & 1,476 & .11 & .13 \\
\hline November . . . . . & 40 & 15 & 19 & 1,131 & .09 & .10 \\
\hline December . . . . . . . & $3 \pi$ & 17 & 22 & 1,353 & .10 & .12 \\
\hline The year. & 188 & 9 & 34 & 24,349 & .15 & 2.07 \\
\hline
\end{tabular}


Estimated momthly aischarge if sin' Crabrial River and canals at Azusa, Los Alugek: comty-Continued.

\begin{tabular}{|c|c|c|c|c|c|c|}
\hline \multirow[b]{2}{*}{ Montli. } & \multicolumn{3}{|c|}{ Discharge. } & \multirow[b]{2}{*}{$\begin{array}{l}\text { Total dis- } \\
\text { charge. }\end{array}$} & \multicolumn{2}{|c|}{ Run-off. } \\
\hline & Maxinum. & Minimum. & Mean. & & $\begin{array}{l}\text { Per } \\
\text { squarc } \\
\text { mile. }\end{array}$ & Depth. \\
\hline $189 \%$ & serefect. & Sece-feet. & Ser.-feet. & Acrefert. & Soc-fcet. & Tuches. \\
\hline Jannary .......... & 147 & 25 & $\tilde{5} .0$ & 3,617 & 0.260 & 0.292 \\
\hline February ....... . . & 1,713 & 64 & 344.8 & 19,146 & 1.503 & $1.5 \% 9$ \\
\hline March . . . . & 1,765 & 294 & 465.6 & $28,62: 3$ & 2.097 & ․ 418 \\
\hline April ..... & $3 \% 0$ & 201 & 294.4 & 17,519 & 1.325 & 1.478 \\
\hline May ........ & 196 & 94 & 145.0 & 8.8 .51 & .653 & .748 \\
\hline June ...... . & 91 & 54 & 67.8 & $4.0: 33$ & .306 & .341 \\
\hline July $\ldots \ldots \ldots$ & 52 & $2 \tau$ & 38.1 & 2.343 & $.1 \% 1$ & .197 \\
\hline August . . . . . . . . & 34 & 22 & 26.4 & 1,613 & .118 & .136 \\
\hline September ....... & 23 & 18 & 20.7 & 1,226 & .088 & .098 \\
\hline October ........... & 1.640 & 22 & 90.5 & $5 . \tilde{5} 64$ & .408 & .465 \\
\hline November .. & 34 & 31 & 33.3 & 1,860 & .141 & .149 \\
\hline December & 34 & 28 & 30.5 & $1,8 \pi i 5$ & $.13 \pi$ & .158 \\
\hline The year & 1,765 & 18 & 134.6 & 96,270 & .604 & 8.0 .59 \\
\hline 1898. & & & & & & \\
\hline January . . . . . . . . & 63 & 28 & 40 & 2,453 & 0.18 & 0.20 \\
\hline February ........... & 70 & 32 & 40 & 2,241 & .18 & .19 \\
\hline March ............ & 48 & 28 & 35 & 2,131 & .16 & .18 \\
\hline April .............. & $3 i$ & 25.3 & 33 & 1.950 & .15 & .17 \\
\hline May _........... & 83 & 25.0 & 36 & 2. 223 & .16 & .19 \\
\hline June ............. & 30 & 14.5 & 19 & 1,159 & .09 & .10 \\
\hline July ................ & 14 & 9.0 & 11 & 672 & .05 & .06 \\
\hline August ...... & 9 & 5.0 & ז & 456 & .03 & .04 \\
\hline September ........ & 10 & 6.1 & 8 & $46 r$ & .04 & .04 \\
\hline October ...... & 10 & 5.5 & 9 & 533 & .04 & .05 \\
\hline November ... & 11 & 8.0 & 10 & 580 & .04 & .05 \\
\hline December ..... & 18 & $11 . \tau$ & 14 & 832 & .06 & .07 \\
\hline The year & 83 & 5.0 & 22 & 15,697 & .10 & 1.34 \\
\hline
\end{tabular}


Estimated monthly discharge of San Gabriel Rives and canals at Azusa, Los Angeles County-Continued.

\begin{tabular}{|c|c|c|c|c|c|c|}
\hline$-\cdots$ & -- & Discharge. & 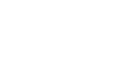 & & & uff. \\
\hline Month. & Maximum. & Minimum. & Mean. & $\begin{array}{l}\text { Total dis- } \\
\text { charge. }\end{array}$ & $\begin{array}{l}\text { Per } \\
\text { scluare } \\
\text { mile. }\end{array}$ & Depth. \\
\hline 1899. & Ser-feet. & ser-feet. & Sereffeet. & srresfeet. & sier-ficet. & Inches. \\
\hline January . . . . . & 33 & 1.5 & 23 & 1. 414 & 0.104 & 0.120 \\
\hline February .... & 28 & 20 & 29 & 1. 244 & .102 & .106 \\
\hline March ... & 40 & 18 & 26 & 1.623 & .119 & .137 \\
\hline April . & 28 & 16 & 21 & 1.262 & .096 & $.10^{\prime}$ \\
\hline$\ldots$ & $1 \tilde{i}$ & 12 & 14 & 842 & .062 & $.0 \%$ \\
\hline June . . . . . . . . . . . & 22 & 5 & 10 & 565 & .043 & .048 \\
\hline July ........... & 4 & 3 & 4 & 221 & .016 & .018 \\
\hline August ........... & 6 & 4 & j) & 295 & .022 & .025 \\
\hline September ....... & 6 & 3 & 4 & 220 & .019 & .021 \\
\hline October ........... & 96 & 4 & 11 & \%0! & .050 & .05 \\
\hline November ...... & 24 & 10 & 14 & 847 & .064 & .07 \\
\hline December ... . . . . & 30 & 16 & 20 & $1,24 \tau$ & .091 & .10 \\
\hline The year .... & 41) & 3 & $\check{5}$ & 10. 489 & .065 & .887 \\
\hline 1900 . & & & & & & \\
\hline January ....... & $\times 9$ & 22 & 32 & 1.968 & 0.14 & 1). 16 \\
\hline February ....... & 23 & 18 & 20 & 1.111 & .09 & .09 \\
\hline March ......... & 30 & 16 & 20 & 1,230 & .09 & .10 \\
\hline April .... . . . & $? 6$ & 13 & 17 & 1.012 & .08 & .09 \\
\hline May ... . . . . . . . . & 86 & 16 & 36 & 2.975 & .17 & .20 \\
\hline June ............ & $2: 2$ & 8 & 15 & 893 & $.0 \%$ & .08 \\
\hline July ... . . . . . & $10 !$ & 4 & i & 369 & .03 & .03 \\
\hline August . . . . . . . . &.$j$ & 4 & 4 & 246 & .02 & .02 \\
\hline September $\ldots \ldots$. & 6 & $: 3$ & 4 & :3s & .12 & .02 \\
\hline October ....... & 6 & 4 & 5 & $30 \%$ & .02 & .02 \\
\hline November . . . . . & 5. 200 & 5 & 186 & 11.068 &.$\$ 4$ & .93 \\
\hline December 1 to 16 & 53 & 31 & 40 & 1. 269 & .18 & .11 \\
\hline The year - & $\overline{5}, 200$ & 3 & 32 & 21,986 & .15 & 1.45 \\
\hline
\end{tabular}


Estimated mouthly discharge of San Gabriel River and canals at Azusa, Los Angeles County-Continued.

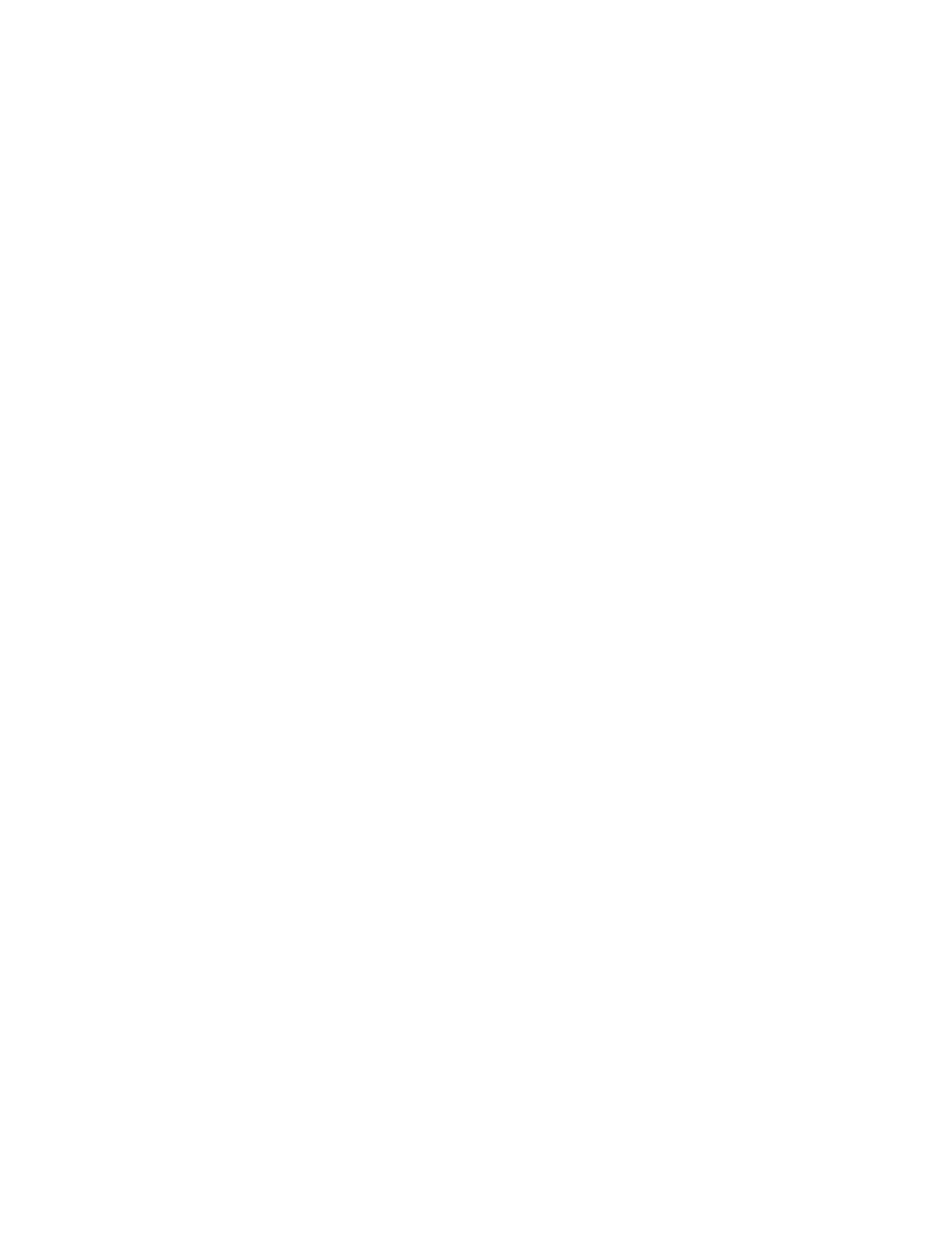




\section{SAN GREGORIO CREEK.}

Discharge measurement of San Gregorio Creek. San Mateo county.

\begin{tabular}{|c|c|c|c|}
\hline Date. & Hydrographer. & $\begin{array}{c}\text { Dis- } \\
\text { charge. }\end{array}$ & Louality. \\
\hline $\begin{array}{c}1893 . \\
\text { Oct. } 1 \%\end{array}$ & W. W. Brier. & $\begin{array}{r}\text { Sec. } f t . \\
6.49\end{array}$ & One-third mile above San Gregorio. \\
\hline
\end{tabular}

SAN JOAQUIN RIVER.

The headwater tributaries of this river receive the drainage from the crests of the Sierra Nerada north of Mount Whitney. The fall of the river is rapid, with many favorable locations for power derelopment, and in one case alvantage has been taken of the fall on the North Fork, and a power plant constructed, developing electric power for transmission to Fresno and IIanford, Cal. During 1899 a second storage reservoir was under course of construction on the North Fork, which will tend further to regulate the flow of the river. No permanent diversions above the gaging station are made, but the water is extensively used below for irrigation purposes. The gage rod at the station was established by the Sonthern Pacific Railway Company in 1879. The old trestle bridge was torn down by the railroad company during 1899 and a new iron structure was ererted in its place. This necessitated a new gage rod, which was set to the datum of the old gage and bolted to the western side of the central concrete pier. The bench mark is a nail in a post at the south end of the bridge on the west side, 0.2 foot above the ground and marked "B. MI." It is at an elevation of 24.12 feet above gage datum. The channel for some distance above and below the bridge is straight, and the water has a uniform velocity. The right bank is high, rocky, and steep. The bed of the stream is of sand and gravel.

Discharge meaxurements of San Jocruin River at Herndon, Fresno Comnty, C'al.

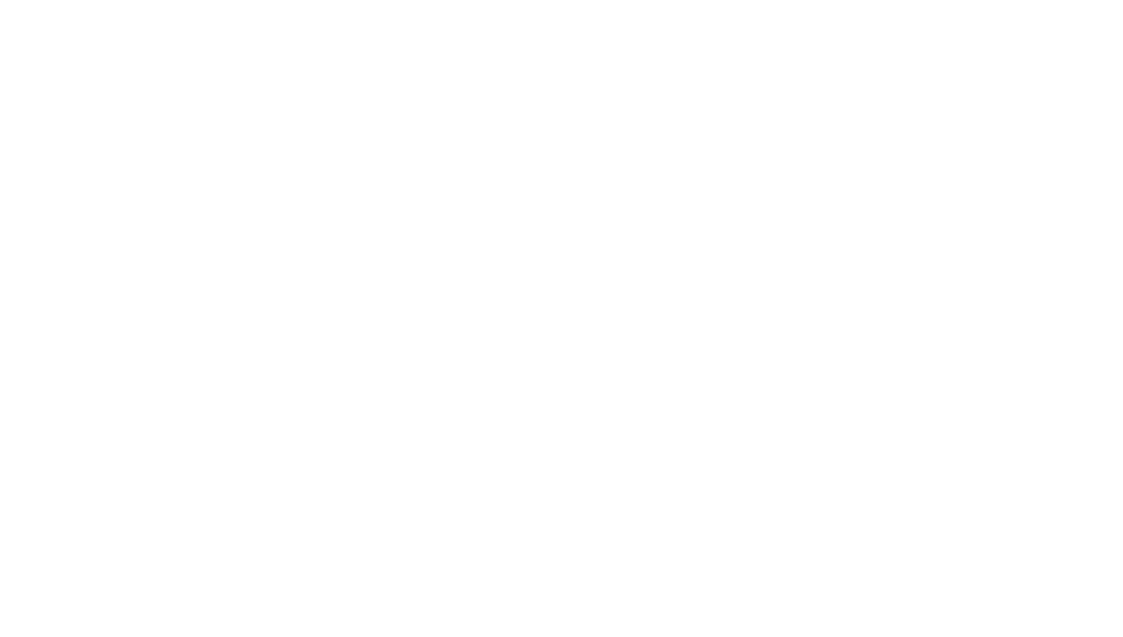


Dischorge mersurements of Sall .Jocumin River at Herndon. etc.-Continued.

Date.

$1 \times ! \%$.

Feb. 14

May 31

July 16

Sept. 8

Nov. 2

Dec. 21

J. B. Lippinceott

1 N98.

Apr. 19

May 30

Tuly 28

Sept. 2

Dec. 20

1899.

Mar. 5

Apr. 18

May 13

June 2

June 27

Aug. 1

Sept. 8

1900.

Feb. 2

Apr. 3 !

J. B. Lippincott

May 15

S. G. Bennett

June 18 ..... do

Aug. 9 ..... do

Sept. 1 .... do

Sept. 28

Dec. 30

1901.

Jan. 30

Mar. :

Apr. 3

July 31

Oct. 16

S. G. Bennett

do

Hyrtrographer

A. Q. Camplell

do

incott

J. B. Lippincott

S. G. Bennett

do

do

do

.. . do

do

1902.

May 14

Sept. 11

\begin{tabular}{c|r}
$\begin{array}{r}\text { Gage } \\
\text { height. }\end{array}$ & \multicolumn{1}{c}{$\begin{array}{c}\text { Dis- } \\
\text { charge. }\end{array}$} \\
\hline Feet. & sec.feet. \\
3.58 & 1,117 \\
8.60 & 10,500 \\
4.5 & 3,223 \\
2.66 & 271 \\
2.92 & 515 \\
3.00 & 699 \\
& \\
& \\
5.42 & 4.162 \\
4.58 & 2.235 \\
3 & 611 \\
2.52 & 328 \\
2.5 & 287
\end{tabular}

3.25

786

6. 34

$.5,310$

" 7

\%. 435

5. 76

$4,1 \%$

4.90

2,922

3. 32

i43

2. $6 \pi$

196

3. 25

1,003

4.66

2. 641

.). 91

4,448

5. 67

3. 710

2. 83

466

2.50

246

2. 33

197

3.33

614

4

1,357

6.8

6,179

5

3,357

5.67

3,909

2.25

352

ร. 35

โ, 381

323 
Discherge measurements of Sam. Jorumin River. Fresuo County.

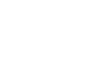

Sept. \& S. ( 7 . Bennett

$1900)$.

Sept. 2ֻ

Sept. $2 \%$

1901.

Oct. 16 ... (*. Bennett ......

1910.

Aug. 31 $\mid$ E. G. Hamilton ...

$190 \%$.

Sept. 2r

Sept. i E. T. Perkins

Sept. $\quad$ i . .

Sept. 7 do

Sept. \& .. do.

Sept. 10

Sept. 111

Sept. 10)

Sept. $\leftrightarrow$

Sept. 9

\begin{tabular}{|r|r} 
L. M. Lawson ..... & 309
\end{tabular}

Sept. 10

do

do

do

do

188

315
Dis-
charge.

siec. fient.

$269 \quad 500$ feet ahove Pullasky Bridge.

Do.

At Pollasky Ford.

\$1 South Fork at Blaney Meadows.

589 Above railroad britge near Lathrop, San .Toaquin Comnty.

.7 (tranite Creek 100 feet helow sheep bridge.

34: 1.N yards below junction Jackass ('reek.

3 Jackass Creek no feet above junction with San Joaquin.

14 Middle Fork 100 yards ahowe Miller Bridge.

51 Mono Creek at Trail ('rossing.

10i South Fork at Trail Crossing.

9 Big Creek at dam site of .T.S. Eastwood.

309 Pollasky.

18 Canal at Reservoir, North Fork, at San Joaquin power honse.

310 'San Joaquin Electric C'o.'s power honse.

25) Below dam at Mendota.

260 Miller and Lnx Canal at small dam.

20i Miller and Lux canal at bridge near dredger. 
Fistimater monthly discharge of Sam Joaquin River at Homptomeille. Fresno County.

[Drainage area. 1,637 square miles.]

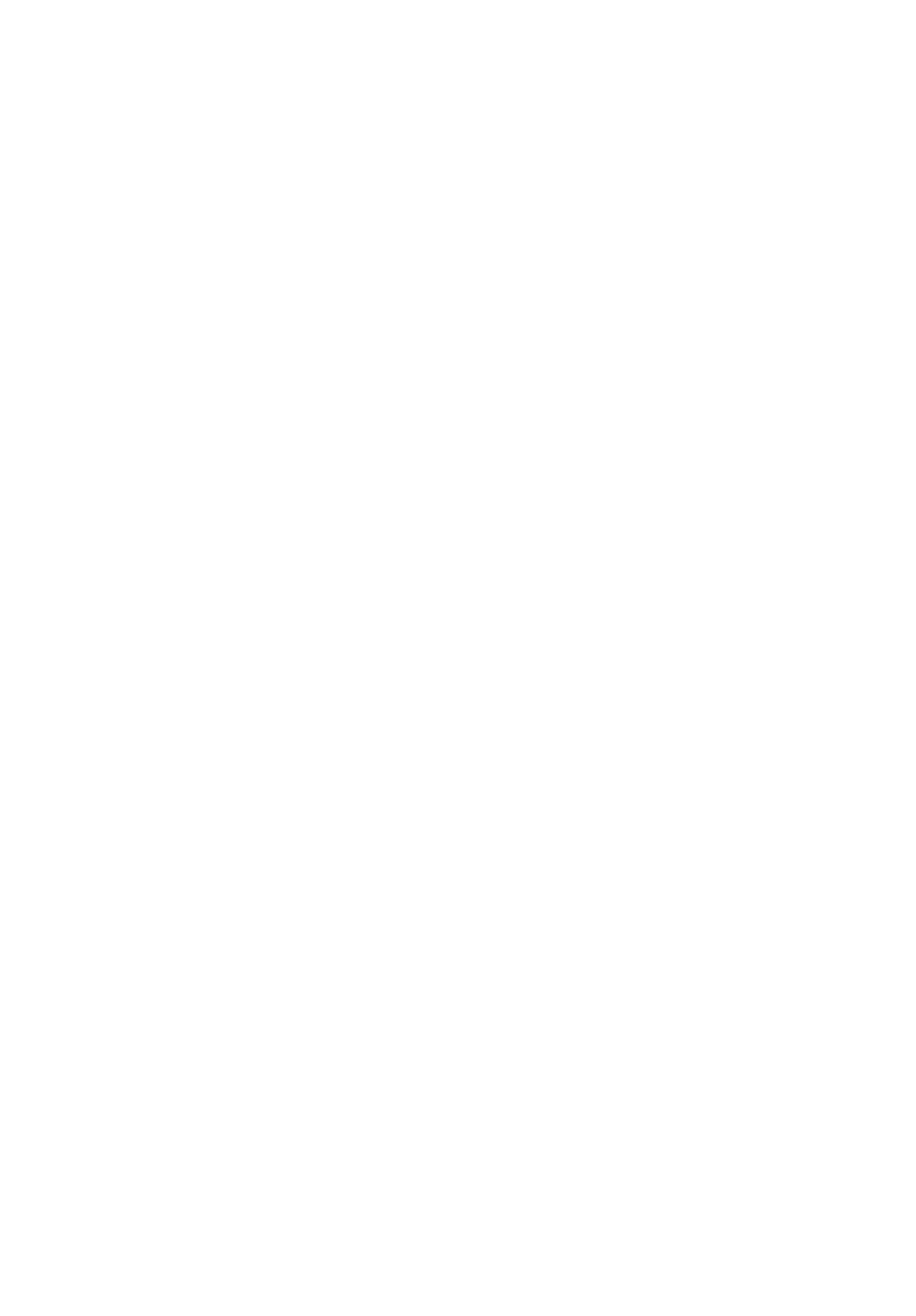

a Authority, California State engineering department. 
Estimated monthly discharge of San Joaquin River at Hamptonville, Fresno County-Continued.

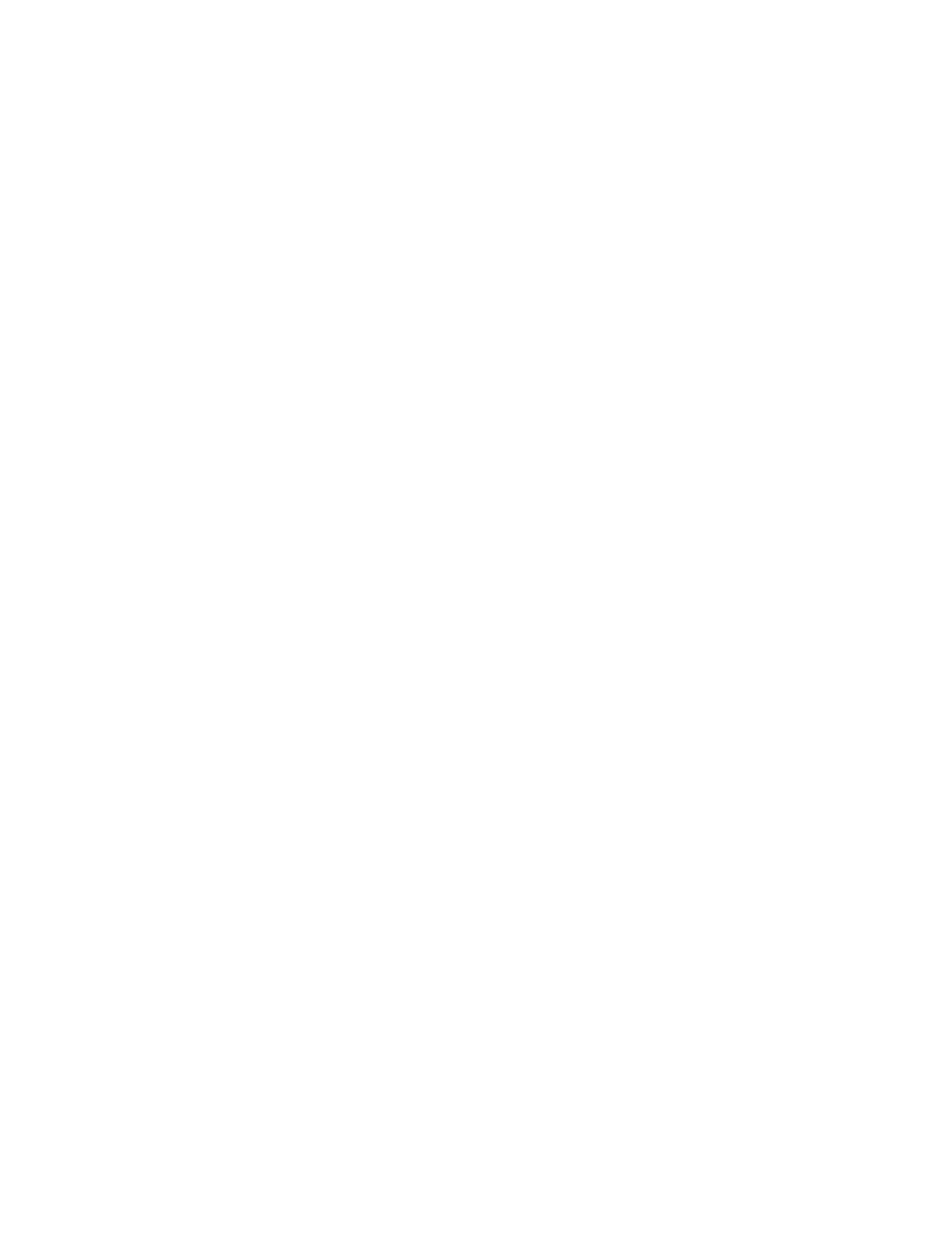

a Authority, California State engineering department.

$\checkmark$ Estimated from previous measurements and neighboring streams. 


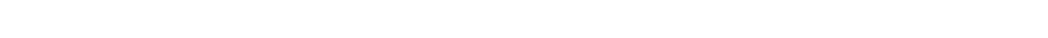
('ounty-Continued.

\begin{tabular}{|c|c|c|c|c|c|c|}
\hline \multirow[b]{2}{*}{ Month. } & \multicolumn{3}{|c|}{ Discharge } & \multirow[b]{2}{*}{$\begin{array}{l}\text { Total dis- } \\
\text { charge. }\end{array}$} & \multicolumn{2}{|c|}{ Run-off. } \\
\hline & Maximum. & Minimum. & Mean. & & $\begin{array}{c}\text { Per } \\
\text { square } \\
\text { mile. }\end{array}$ & Depth. \\
\hline$-{ }^{-}-{ }^{-}$ & --- & & ---1 & $-\ldots-$ & sec-feet & Inches \\
\hline January ${ }^{b} \ldots$ & Sere-feet. & sece-feet. & $\begin{array}{r}320 \\
320\end{array}$ & $19,6 \% 6$ & $\begin{array}{r}0.21 \\
0.21\end{array}$ & 0.23 \\
\hline February" & & & 320 & $1 \% . \% 1$ & .21 & .21 \\
\hline March $7, \ldots$ & & & 1,150 & $70, \pi 11$ & .70 & .81 \\
\hline April ${ }^{b} \ldots$ & & & 2.130 & 126.744 & 1.30 & 1.45 \\
\hline May ${ }^{\prime} . . . .$. & & & $\tau .370$ & 453.164 & 4.50 & 5.19 \\
\hline June $^{b} \ldots$ & & & 6.220 & $3 \% 0.116$ & 3.80 & 4.24 \\
\hline July ${ }^{\prime} \ldots$ & & & 1,470 & $90,38 \%$ & .90 & 1.04 \\
\hline Angust "... & & $\ldots$ & 490 & 30.129 & .30 & .35 \\
\hline Septemher " & & $\ldots$ & 410 & $24,39 \tau$ & .25 & .28 \\
\hline Octoher ${ }^{\prime}$..... & & $\ldots$ & 330 & 20,291 & .20 & .23 \\
\hline November" & & $\ldots$ & 250 & $14,8 \% 6$ & .15 & $.1 \%$ \\
\hline December ${ }^{7}$ & & & 250 & $15.3 \% 2$ & .15 & $.1 \%$ \\
\hline The year & & & 1.726 & $1,253,634$ & 1.05 & 14.37 \\
\hline 1nst." & & & & & & \\
\hline January $" \ldots$ & & & 410 & 25,210 & 0.25 & 0.29 \\
\hline Febrnary & & & 2.460 & $1+1.501$ & 1.50 & 1.62 \\
\hline March" .. - & & 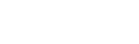 & 4.090 & 251.484 & 2.50 & 2.88 \\
\hline April ${ }^{\prime} \ldots \ldots$ & & ...... & 3,270 & 194.578 & 2.00 & 2.23 \\
\hline $\operatorname{May}^{b} \ldots \ldots$ & & & 8.190 & 503,583 & 5.00 & 5.76 \\
\hline June ${ }^{b} \ldots . . .$. & & $\ldots . . .$. & 16.400 & 975.868 & 10.02 & 11.18 \\
\hline July ${ }^{b} \ldots \ldots$ & & - . . . . & 13.100 & $80.5,488$ & 8.00 & 9.22 \\
\hline August $" . . .$. & & & 3.270 & 201,064 & 2.00 & 2.31 \\
\hline September $"$ & & $\ldots$ & 980 & $.58,314$ & .60 & .67 \\
\hline October" & & & $820^{1}$ & 50.420 & .50 & .58 \\
\hline
\end{tabular}

"Authority, California state engineering department.

? Estimated from previous measurements and neighboring streams. 
Estimated monthy discharge of San Joaquin River at Herndon. Fresno ('ounty.

[Drainage area, 1,63\% square miles.]

\begin{tabular}{|c|c|c|c|c|c|c|}
\hline \multirow[b]{2}{*}{ Montb. } & \multicolumn{3}{|c|}{ Discharge. } & \multirow[b]{2}{*}{$\begin{array}{l}\text { Total dis- } \\
\text { charge. }\end{array}$} & \multicolumn{2}{|c|}{ Rur-off. } \\
\hline & Maximum. & Minimum. & Mean. & & $\begin{array}{l}\text { Per } \\
\text { suuare } \\
\text { mile. }\end{array}$ & Depth. \\
\hline $\begin{array}{c}1895 . \\
\text { January } \ldots . . .\end{array}$ & $\begin{array}{l}\text { sec.fuet. } \\
\quad 11,225\end{array}$ & $\begin{array}{r}\text { sece-feet. } \\
\quad 1.260\end{array}$ & $\begin{array}{c}\text { Sec.-feet. } \\
2,881\end{array}$ & $\begin{array}{l}\text { Are-feet. } \\
1 \% \pi, 146\end{array}$ & $\begin{array}{c}\text { Ser.ffeet } \\
1.76\end{array}$ & $\begin{array}{l}\text { Inches. } \\
2.03\end{array}$ \\
\hline February ... & 8,500 & 909 & 2,568 & 142,619 & $1.5 i$ & 1.63 \\
\hline March ........ & 9.318 & $1,5.54$ & $2,7 \% 9$ & 170.874 & 1. 70 & 1.96 \\
\hline April ....... & 9,863 & 3,354 & $\tilde{3}, 834$ & $34 \pi, 14 \pi$ & 3.50 & 3.97 \\
\hline May ....... . & 19,960 & $\pi, 100$ & 13.124 & 806,963 & $\times .02$ & 9.24 \\
\hline June . . . . . . . & 14,250 & 7.2 .00 & $10.67 t$ & $635,14 \%$ & 6.52 & 7.27 \\
\hline July . & 8.000 & 2,148 & 4,528 & 278,416 & $2 . \%$ & 3.20 \\
\hline Augrust & 2,301 & 793 & $1,41 \tau$ & 87,128 & $.8 \%$ & 1.00 \\
\hline September ... . . ... & 8.500 & 260 & $1,0 \times 5$ & 64,562 & .66 & .73 \\
\hline Octoher ............. & 1,260 & 260 & 420 & 25,825 & .26 & .30 \\
\hline November... & 426 & 260 & $: 362$ & 21,540 & .22 & .24 \\
\hline Decemher - & 6ĩ & 260 & $3+3$ & 22,935 & .23 & .26 \\
\hline The year & 19,960 & 260 & $3.83 \%$ & $2,780,302$ & 2.85 & 31.83 \\
\hline 1896. & & & & & & \\
\hline Jannary ..... ... & 12,800 & 250 & 2. 119 & $1301,33 \pi$ & 1.29 & 1.49 \\
\hline February -... & 1.7 .50 & 950 & $1.17 \%$ & $6 \pi, 696$ & .72 & $.7 \%$ \\
\hline March ..... & 12.176 & 1,180 & 2,612 & 160,649 & 1.60 & 1.84 \\
\hline April ..... & 5,648 & 1,920 & 2.67 .5 & $1.59,192$ & 1.64 & 1.83 \\
\hline May . & 18,800 & $\stackrel{2}{2}, 560$ & 5.394 & $: 31,700$ & 3.30 & 3.81 \\
\hline June ....... & 16.920 & 6.544 & 11, $\approx 99$ & 702,106 & $\because 21$ & 8.00 \\
\hline July ... . . . . & 8,080 & 1,600 & $4.1 \%$ & 256,865 & 2.55 & 3.04 \\
\hline August ..... & 1.300 & $\tau 00$ & 1,048 & 64.463 & .64 & .74 \\
\hline September .. & 1.180 & 80 & .334 & $31.81 \%$ & .33 & .37 \\
\hline October..... & 700 & 80 & $16 i$ & 10,275 & .10 & .12 \\
\hline November.... & $\stackrel{2}{2}, 390$ & 430 & $69 r$ & 41,492 & .43 & .48 \\
\hline December...... & 1,750 & 430 & 666 & $40,95 \pi$ & .41 & .45 \\
\hline The year - & 18,800 & 80 & 2,756 & $1,99 \pi, 54 \tau$ & 1.69 & .96 \\
\hline
\end{tabular}


Estimated monthly discharge of San Joaquin River at Herndon. Fresno County-Continued.

\begin{tabular}{|c|c|c|c|c|c|c|}
\hline \multirow[b]{2}{*}{ Month. } & \multicolumn{3}{|c|}{ Discharge. } & \multirow[b]{2}{*}{$\begin{array}{l}\text { Total dis- } \\
\text { charge. }\end{array}$} & \multicolumn{2}{|c|}{ Run-off. } \\
\hline & Maximum. & Minimum. & Mean. & & $\begin{array}{l}\text { Per } \\
\text { square } \\
\text { mile. }\end{array}$ & Depth. \\
\hline 1897 & I Siec.-feet. & see-feet. & reco-feet. & Acre-feet. & Ser.feet. & Inches. \\
\hline January ... . . & 1,180 & 535 & 655 & 40,275 & 0.40 & 0.46 \\
\hline February & 15,660 & 1,180 & 2,598 & 144,286 & 1.59 & 1.66 \\
\hline March ..... & 4,600 & $1,6 \% 5$ & 2,325 & 142,960 & 1.42 & 1.64 \\
\hline April $\ldots . .$. & 11,708 & 2,305 & 6,541 & 389,216 & 4.00 & 4.46 \\
\hline May ....... & 18,600 & $9,56.5$ & 13,545 & $832.8 \overline{5} 5$ & 8.27 & 9.54 \\
\hline June ...... & 12,332 & 2,390 & 5,862 & 348,812 & 3.57 & 3.98 \\
\hline July ..... & 4,300 & 1,300 & 2,493 & 153,290 & 1.52 & 1.75 \\
\hline August ... & 1,300 & 590 & 898 & 55.216 & .55 & .63 \\
\hline September ... & 535 & 10.5 & $22 \tau$ & 13.507 & .14 & .16 \\
\hline October ...... & $8: 0$ & 10.5 & 279 & 17,155 & .17 & .20 \\
\hline November & 4,300 & 120 & 872 & $51.88 \pi$ & .53 & .59 \\
\hline December & 4,000 & ( $51: 3$ & 995 & 61,180 & .61 & .70 \\
\hline The year & 18,600 & $10 \overline{5}$ & 3,108 & $2,250,639$ & 1.90 & $25 . \%$ \\
\hline 1898. & & & & & & \\
\hline January - . - & 763 & 530 & 658 & 40,459 & 0.40 & 0.46 \\
\hline February - & 1,425 & 530 & 842 & 46,762 & .51 & .54 \\
\hline March ... & 1,242 & 763 & 908 & 55,831 & .56 & .64 \\
\hline April . . . . & 5,846 & 1. 018 & 2,944 & 175,180 & 1.80 & 2.01 \\
\hline May ....... & 5.141 & 2,262 & 3,206 & $19 \%, 131$ & 1.96 & 2.26 \\
\hline June $\ldots \ldots$ & 3,744 & 1,730 & 2,718 & 161,732 & 1.66 & 1.85 \\
\hline July ..... & 1,730 & 530 & 959 & $58.96 \%$ & .59 & .68 \\
\hline Angust - & 610 & 350 & 480 & 29,514 & .29 & .33 \\
\hline September & 1,882 & 220 & 363 & 21,600 & .22 & .24 \\
\hline October $\ldots$ & $r 63$ & 350 & 509 & $31,29 \tau$ & .31 & .36 \\
\hline November. & 350 & 290 & 308 & $18,32 \tau$ & .19 & .21 \\
\hline December. & 1,181 & 240 & 384 & 29,611 & .24 & .26 \\
\hline The year & 5,846 & 220 & 1.190 & 860,411 & .73 & 9.84 \\
\hline
\end{tabular}

a Minimum of 60 second-feet given in Nineteenth Ann. Rept. is error. 
Estimated monthly discharge of San Joaquin River at Hernaton. Fresno County-Continued.

\begin{tabular}{|c|c|c|c|c|c|c|}
\hline \multirow[b]{2}{*}{ Month. } & \multirow[b]{2}{*}{ Maximum. } & \multicolumn{2}{|l|}{ Discharge. } & \multirow[b]{2}{*}{$\begin{array}{l}\text { Total dis- } \\
\text { charge. }\end{array}$} & \multicolumn{2}{|c|}{ Run-off. } \\
\hline & & Minimum. & Mean. & & $\begin{array}{l}\text { Per } \\
\text { square } \\
\text { mile. }\end{array}$ & Depth. \\
\hline 1899. & Seci-feet. & Sere-fuet. & scc.-feet. & Acrefeet. & ser-feet. & Inches. \\
\hline January .... & 1,170 & 170 & 463 & 28,469 & 0.28 & 0.32 \\
\hline February _......... & 1,060 & 350 & 645 & 35,821 & .39 & .41 \\
\hline March ........... & 16. 206 & 692 & $\stackrel{2}{2}, 689$ & $16 \overline{5}, 341$ & 1.64 & 1.89 \\
\hline April $\ldots \ldots \ldots$ & 7.354 & 2,030 & 4,233 & 251,880 & 2.59 & 2.88 \\
\hline May ....... & $\tau, 090$ & 1,830 & 3,730 & 229,350 & 2.28 & 2. 63 \\
\hline June ........ & $9,0 \% 0$ & 2.620 & $\overline{5}, 700$ & 339,173 & 3.48 & 9.88 \\
\hline July .... - & 3,105 & 955 & 1,664 & 104,284 & 1.02 & 1. 18 \\
\hline August ... . . . . & T4.5 & 250 & 428 & 26,31 i & .26 & .30 \\
\hline September ... & 220 & ro & 152 & 9,045 & .09 & .10 \\
\hline October . & $7 \% 6$ & 69 & 214 & 13,158 & .13 & .15 \\
\hline November & 1,175 & 130 & 565 & 33,620 & .34 & .39 \\
\hline Derember - . - & 4,275 & 220 & $1,018 \mathrm{i}$ & $62,59 \check{\jmath}$ & .62 & .71 \\
\hline The year - & 16,206 & 69 & 1,792 & $1,299,053$ & 1.09 & 14.84 \\
\hline \multicolumn{7}{|l|}{1900} \\
\hline Jantuary ... . . . & 15.932 & 745 & 2,244 & $13 \pi, 978$ & 1.37 & 1.58 \\
\hline February ........ & T4\% & 355 & 534 & $29,6.5 \%$ & .33 & .34 \\
\hline March ... .... & 2.780 & 640 & 1,748 & $10 \tau, 480$ & $1.0 \tau$ & 1.23 \\
\hline April $\quad \ldots \ldots$ & 2,780 & 1,520 & 2,060 & $122,5 \% 8$ & 1.26 & 1.41 \\
\hline$\ldots \ldots$ & 9,730 & 2,170 & 5,725 & 352,016 & 3.50 & 4.04 \\
\hline June . . . . . . . . & 8,674 & 3,620 & 5,728 & 340,840 & 3.50 & 3.90 \\
\hline July .. . . . . . . . & 3,445 & 630 & 1,642 & 100,962 & 1.00 & 1.15 \\
\hline August ......... & 630 & 240 & 390 & 23,980 & .24 & .28 \\
\hline September _.... & 240 & 180 & 204 & 12,139 & .13 & .14 \\
\hline October . . . . & 990 & 180 & 451 & $2 \pi, 730$ & .28 & .32 \\
\hline November _.... & 20,780 & 240 & 1,834 & 109,130 & 1.12 & 1.25 \\
\hline December .. _ _ & 1.285 & $\tau 45$ & 1,033 & 63,517 & .63 & .72 \\
\hline The year ..... & $20, i 80$ & 180 & 1,966 & $1,428,00 \%$ & 1.20 & 16.36 \\
\hline
\end{tabular}


Estimaterl monthly discharge of San Joaquin River at Herndon, Fresno f culuty-Continued.

\begin{tabular}{|c|c|c|c|c|c|c|}
\hline \multirow[b]{2}{*}{ Month. } & \multicolumn{3}{|c|}{ Discharge. } & \multirow[b]{2}{*}{$\begin{array}{l}\text { Total dis- } \\
\text { eharge. }\end{array}$} & \multicolumn{2}{|c|}{ Run-off. } \\
\hline & Maximum. & Minimum. & Mean. & & $\begin{array}{c}\text { Per } \\
\text { square } \\
\text { mile. }\end{array}$ & Depth. \\
\hline 1901. & Sec-fret. & secefeet. & sec-feet. & Acrefeet. & Sec.-feet. & Thehes. \\
\hline Jantuary . . . . & $21,3 \% 2$ & 810 & 3.506 & 215,576 & 2. 14 & 2.4 \\
\hline February ... & 12,940 & 1,550 & 4,983 & $2 \tau 6, \tau 42$ & 3.04 & 3.17 \\
\hline March & 6,830 & 2,480 & 4,191 & 357,695 & 2.56 & 2.9 \\
\hline April - & 12,400 & 1,930 & 4.680 & 278.479 & 2.86 & 3.1 \\
\hline$\ldots \ldots$ & $1 \%, 870$ & 4.775 & 10,935 & $6 \tau 2,36 \%$ & 6.68 & $\pi .71$ \\
\hline June ......... . . & 15,662 & ז.882 & 11,998 & 713,930 & 7.33 & 8.17 \\
\hline July _......... & 14.294 & 3,110 & 3,466 & 213,116 & 2.12 & 2.48 \\
\hline August $\ldots . .$. & 5.850 & 500 & 2,373 & 145,910 & 1.45 & 1.6 \\
\hline September .... & 500 & 360 & 399 & 33,742 & .24 & .2 \\
\hline Octoher ..... & 2,480 & 340 & 489 & $30.06 \%$ & .30 & \\
\hline November ... & 1,550 & 500 & 702 & $41,7 \% 2$ & .43 & .48 \\
\hline December. & 2,060 & 460 & 872 & 53,617 & .53 & .6 \\
\hline The year . . . . & 21,372 & 340 & 4,050 & $2,923,013$ & 2.47 & 33.4 \\
\hline
\end{tabular}

Discharge measurements of ('hiquita San Joaquin River, Madera C'ounty.

\begin{tabular}{|c|c|c|}
\hline Date. & Hydrographer. & $\begin{array}{c}\text { Dis- } \\
\text { charge. }\end{array}$ \\
\hline Sept. $2 \%, 1900$ & J. S. Eastwood ....... & $\begin{array}{r}\text { see-feet. } \\
22.6\end{array}$ \\
\hline
\end{tabular}

\section{SAN JOSE CREEK.}

Discharge measurements of Sun Jose Creek, Santa Barbara County.

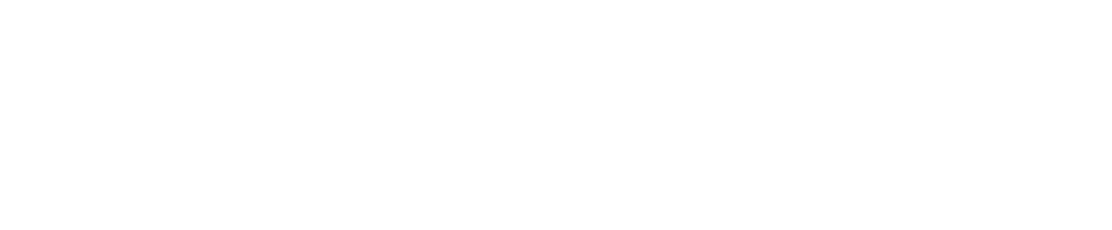

The following measurements of San Jose Creek were made by Charles J. Johansen for the Pacific Improvement Company. The pipe line along the West Fork of San Jose Creek was not earrying water in the year 1 s.tr. 
The point of measurement of the West Fork was a short distance above its junction with the East Fork, or main stream. The main stream, or East Fork, of San Jose Creek was gaged a short distance above its junction with the West Fork, and the pipe line along this stream was not carrying water in the year 1890 .

List of discharge measurements of San Jose C'reek, Santa Barbara County.

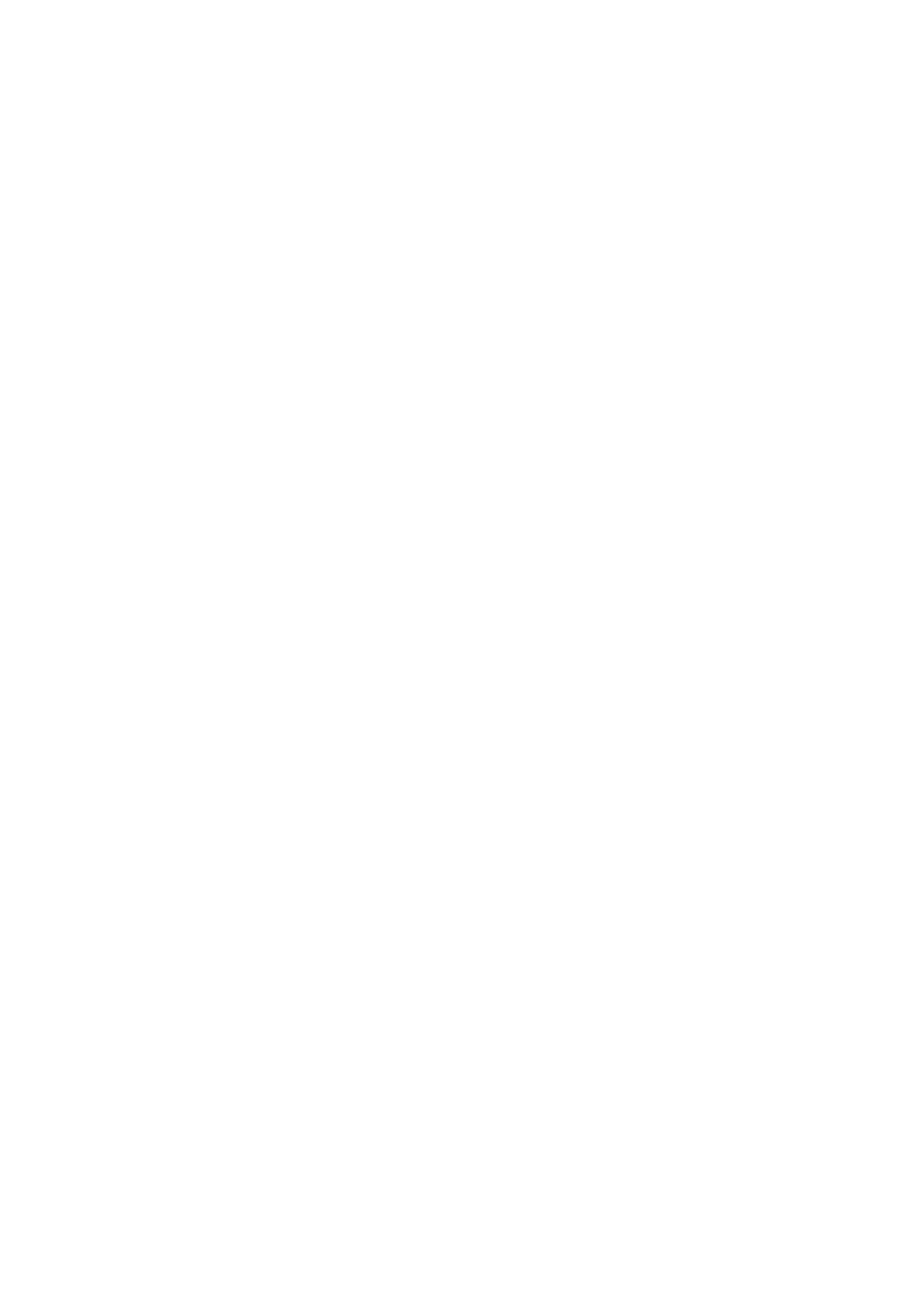


List of dischurge measurements of San Jose Creek, ete.-Continued.

\begin{tabular}{|c|c|c|c|c|}
\hline \multirow{2}{*}{\multicolumn{2}{|c|}{$\begin{array}{c}\text { Date. } \\
--- \\
1890 .\end{array}$}} & Hydrographer. & $\begin{array}{c}\text { Dis- } \\
\text { charge. }\end{array}$ & Locality. \\
\hline & & & sec-feet. & \multirow[b]{2}{*}{ West Fork at moutl. } \\
\hline May & 1 & Charles J. Johanson ... & 0.32 & \\
\hline May & 3 & ... do do . . & .26 & Do. \\
\hline May & 5 & $\ldots$... do ... & .32 & Do. \\
\hline May & $\tau$ & $\ldots$..... do .... & .32 & Do. \\
\hline May & 9 & $\mid \ldots$ do $\ldots \ldots$. & .26 & Do. \\
\hline May 1 & 11 & 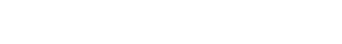 & .26 & Do. \\
\hline May & 12 & ..... do .... & .23 & Do. \\
\hline May & 13 & $\ldots$ do $\ldots . .$. & .26 & Do. \\
\hline May & 15 & $\ldots$ do ...... & .23 & Do. \\
\hline May & 17 & .... do ... & .26 & Do. \\
\hline May & 19 & ..... do ... & .26 & Do. \\
\hline May & 21 & .... do $\ldots$ & .23 & Do. \\
\hline May & 23 & $\ldots$ do $\ldots . .$. & .23 & Do. \\
\hline May & 25 & .... do .... & .23 & Do. \\
\hline May & $2 t$ & ....do . . & .23 & Do. \\
\hline May & 29 & . . . do . . . . . . . . . . & .23 & Do. \\
\hline May : & 31 & 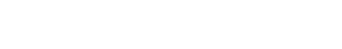 & .21 & Do. \\
\hline June & 2 & .... do .................... & .21 & Do. \\
\hline June & 4 & 1... do ... & .21 & Do. \\
\hline June & 6 & $\mid \ldots$... do ... & .21 & Do. \\
\hline June & 8 & .... do . . . . & .18 & Do. \\
\hline June 1 & 10 & $\ldots$ do ................. & .23 & Do. \\
\hline June 1 & 12 & $\ldots$ do ..... & .21 & Do. \\
\hline June 1 & 14 & .... do .... & .21 & Do. \\
\hline June 1 & 16 & $\ldots d_{0} \ldots . .$. & .27 & Do. \\
\hline June 1 & 18 & - . do do . & .21 & Do. \\
\hline June : & 20 & - & .19 & Do. \\
\hline June : & 22 & $\ldots$ do $\ldots \ldots$ & .21 & Do. \\
\hline June : & 24 & $\ldots$ do $\ldots \ldots \ldots$ & $.1 \tau$ & Do. \\
\hline June : & 26 & $\ldots$ do ...... & .19 & Do. \\
\hline June : & 28 & $\ldots$ do ....... & .20 & Do. \\
\hline June : & 30 & .... do ...... & .20 & Do. \\
\hline July & 2 & ... do . . . & .17 & Do. \\
\hline July & 4 & .... do . . . . & .17 & Do. \\
\hline July & 6 & - do $\ldots$. & .18 & Do. \\
\hline July & 8 & 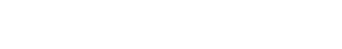 & .17 & Do. \\
\hline July & 10 & 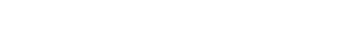 & .17 & Do. \\
\hline July & 12 & . do $\ldots . . . . . . . . .$. & .17 & Do. \\
\hline July & 14 & $\mid \ldots$ do $\ldots \ldots \ldots \ldots$ & .16 & Do. \\
\hline
\end{tabular}


List of discharge measurements of San Jose Creek, etc.-Continued.

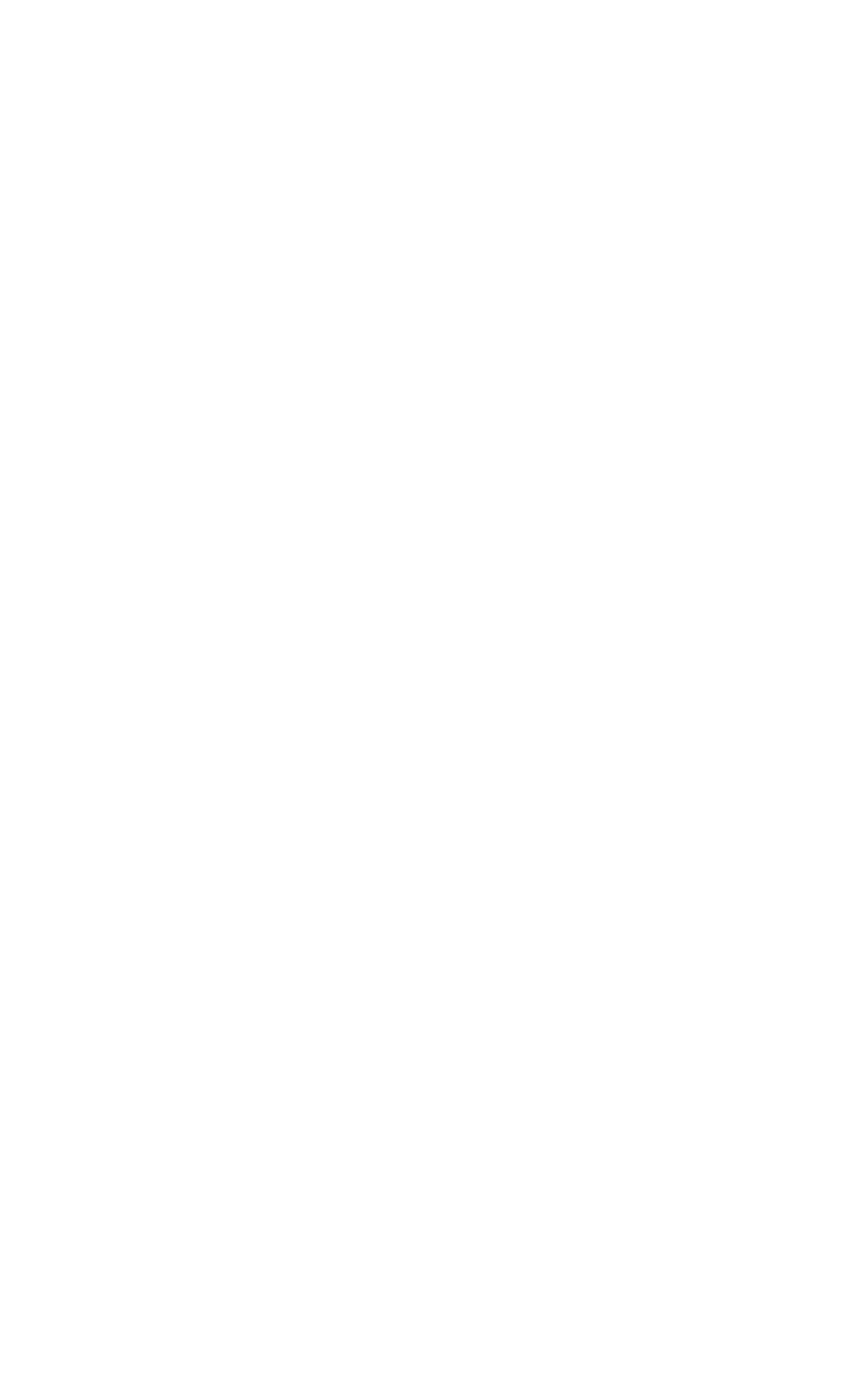


List of discharge measurements of San Jose C'reek, etc._Continued.

\begin{tabular}{|c|c|c|c|}
\hline Date. & Hydrographer. & $\begin{array}{l}\text { Dis- } \\
\text { rharge. }\end{array}$ & Locality. \\
\hline 1890. & & Sisc.feret. & \\
\hline Apr. 19 & Charles J. Johansen ... & 2.10 & East Fork above West Fork. \\
\hline Apr. $: 21$ & $\ldots$ do _............... & 2.10 & Do. \\
\hline Apr. 23 & $\ldots$......... & 1.97 & Do. \\
\hline Apr. 25 & , _ & $1.97^{1}$ & Do. \\
\hline Apr. $2 \pi$ & $\ldots$ do ................. & $1.9 \tau$ & Do. \\
\hline Apr. $\quad 29$ & 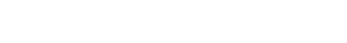 & 2.10 & Do. \\
\hline May 1 & $\ldots$ do .... & 1.97 & Do. \\
\hline May 3 & $\ldots$ do $\ldots . . . .$. & $1 . \% 2$ & Do. \\
\hline May 5 & ـ do & 1. 72 & Do. \\
\hline May $\tau$ & 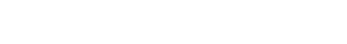 & 1.72 & Do. \\
\hline May 9 & _. do _ _ _ _ _ n & 1. $\tilde{\tau}^{2}$ & Do. \\
\hline May 11 & $\ldots$... do ....... & 1. 22 & Do. \\
\hline May 12 & .... & 1.18 & Do. \\
\hline May 13 & $\ldots$ do $\ldots \ldots$ & 1.59 & Do. \\
\hline May 15 & _. _ do _............ & $1.4 \pi$ & Do. \\
\hline May $1 \gamma$ & . . . do _. . . . . . . . . . & $1.4 \pi$ & Do. \\
\hline May 19 & _ & 1.47 & Do. \\
\hline May 21 & $\ldots$. $10 \ldots \ldots$ & 1.19 & Do. \\
\hline May 23 & ' & 1.19 & Do. \\
\hline May 25 & $\ldots$ do $\ldots \ldots \ldots$ & 1.25 & Do. \\
\hline May $2 r$ & . & 1.19 & Do. \\
\hline May 29 & $\ldots$ do . . . . & 1.19 & Do. \\
\hline May 31 & 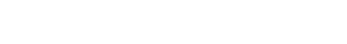 & 1.19 & Do. \\
\hline June 2 & . . do ...... & 1.12 & Do. \\
\hline June $t$ & $\ldots$.... do ... . ........ & .94 & Do. \\
\hline June 6 & $\ldots$. do _. . . . - . . . & .88 & Do. \\
\hline June 8 & $\ldots$ do ..... & .91 & Do. \\
\hline June 10 & 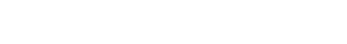 & .91 & Do. \\
\hline June 12 & $\ldots$. & .94 & Do. \\
\hline June 14 & $\ldots$. . do . . . . . . . . . & 1.00 & Do. \\
\hline June 16 & $\ldots$. $d o \ldots . . . . . . . .$. & 1.12 & Do. \\
\hline June 18 & $\ldots$ do ..... & 1.06 & Do. \\
\hline June 20 & $\ldots$. . do . . . . . . . . . . . . & 1.00 & Do. \\
\hline June 22 & $\ldots$ do & .82 & Do. \\
\hline June 24 & ... . do ... & .82 & Do. \\
\hline June 26 & $\ldots$.... do ..... & .88 & Do. \\
\hline June 28 & $\ldots$ do $\ldots \ldots \ldots \ldots$ & .94 & Do. \\
\hline June 30 & $\ldots$ do $\ldots \ldots$ & .82 & Do. \\
\hline July 2 & _... do ........ & .76 & Do. \\
\hline
\end{tabular}


List of discharge measurements of sim. . Jose lreek, ete.-C'ontinued.

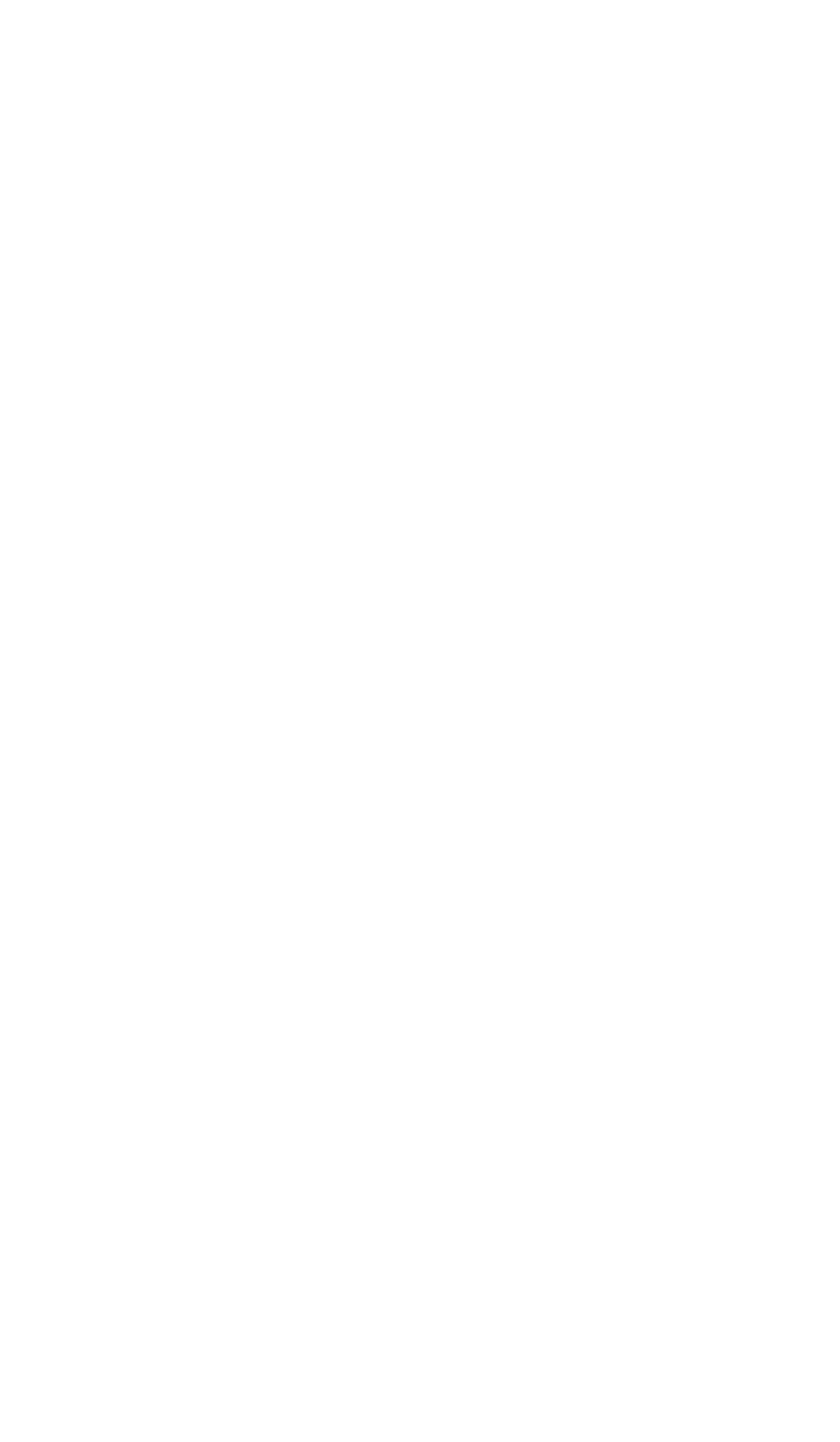

IRR $\mathrm{a} 1-03-1 \mathrm{~B}$ 
List of discharge measurements of San Jose Crepk, citc.-Continued.

\begin{tabular}{|c|c|c|c|}
\hline Date. & Hydrographer. & $\begin{array}{c}\text { Dis- } \\
\text { charge. }\end{array}$ & Locality \\
\hline 1890. & & sace-feet. & \\
\hline Sept. 15 & 'Charles J. Johansen & 0.60 & East Fork above West Fork. \\
\hline Sept. 18 & .... do ............ & .60 & Do. \\
\hline Sept. 20 & $\ldots$ do $\ldots \ldots \ldots$ & .65 & Do. \\
\hline Sept. 22 & $\ldots$ do $\ldots \ldots . . . .$. & .60 & Do. \\
\hline Sept. 24 & .... do ........... & .71 & Do. \\
\hline Sept. 26 & |....do ............ & .71 & Do. \\
\hline Sept. 28 & $\ldots$ do $\ldots \ldots$ & .82 & Do. \\
\hline Sept. 30 & $\ldots$ do $\ldots \ldots \ldots$ & .71 & Do. \\
\hline Oct. 2 & . . do ........... & .71 & Do. \\
\hline Oct. 4 & .... do .......... & .68 & Do. \\
\hline Oct. 6 & ... do . . . . . . & .60 & Do. \\
\hline Oct. $\tau$ & $\ldots$.... do ......... & .61 & Do. \\
\hline
\end{tabular}

SAN LUIS REY RIVER.

Discharge measurements of San Luis Re'y River, San Diego Connty.

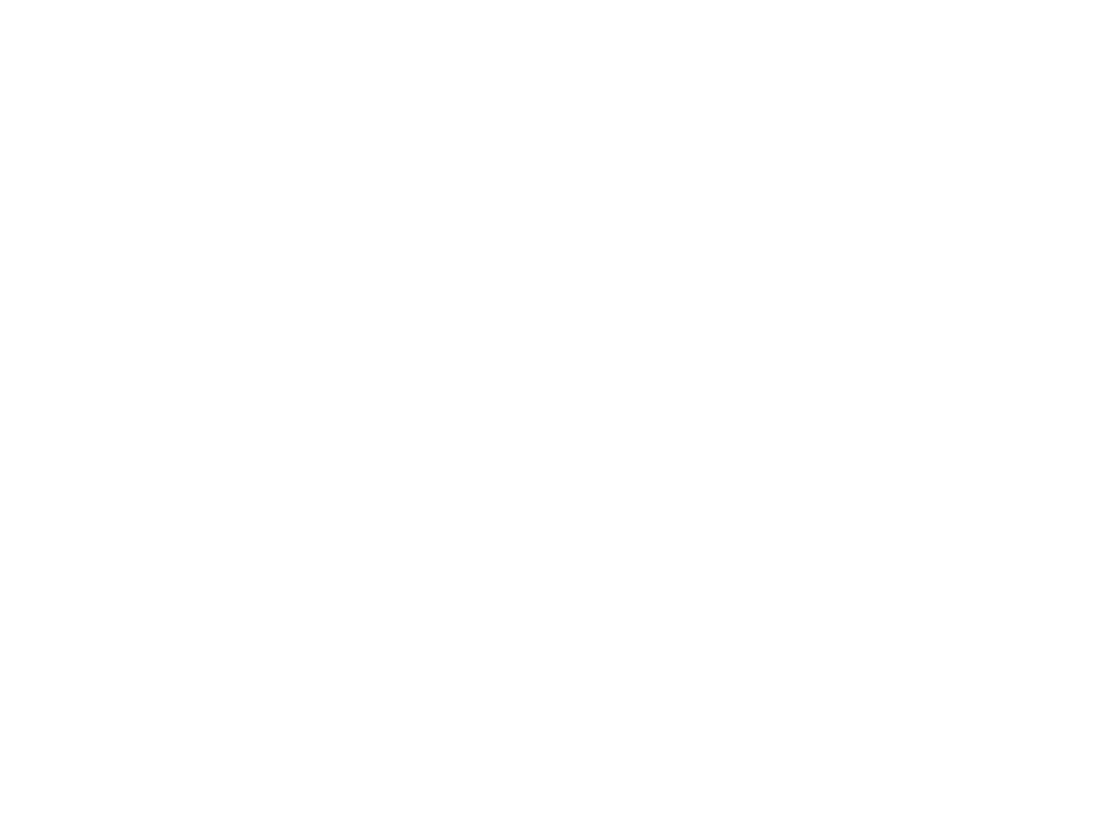

“ H. N. Savage states this to be minimum prior to September, 1899. 


\section{SAN MATEO CREEK.}

San Francisco obtains its domestic water supply from a series of impounding reservoirs located in the southern portion of the peninsula between San Francisco Bay and the Pacific Ocean. The drainage basin of these reservoirs ranges in elevation from 250 to 1,800 feet, rith an average of about 750 feet. The hills are undulating. There is a limited growth of timber on the northern slopes near the summit, but a large amount of brush covers other portions of the basin. On the southern slopes and crests the hills are frequently bare of brush, but are covered with grasses. The spring Valley Water Corpany rwns the entire area of the drainage basin and protects the forest covering, not even permitting grazing within its limits. Mr. IIerman "shussler, chief engineer of the water company, has furnished this rffice with a statement of the rainfall and run-off of the drainage basins which contribute to the water supply unler the control of the company. The table given below extends from 1869 to 1899, and shows the seasonal rainfall, together with the percentage collected in the rescrvoirs. The record is therefore thirty years in length. th is by far the oldest 1able of run-off in the state, and for this eason is of unusual value. The seasonal year rather than the calenar is given. Column No. 1 shows the year; column No. 2 the inches of rainfall in the respective basins; column No. 3 the percentage of this rainfall which is caught and delivered, the evaporation beng reducted. The portion of the discharge table marked "Southeasterly jortion of the watershed southeast of old ram," ete., refers to the \& rea above the reservoir, which was constructed at an early date. At a later period, at a point lower down the stream, the Crystal springs ram was constructed and flooded water over the top of the original am and into the valleys of other streams. This explains the change in the description of the drainage basin which occurs in 1888. The jortion of the table marked "Above southeasterly and northeasterly portion of peninsula watershed, total crystal Lake drainage," is for the entire area above the (rystal springs gage datum. The remarkchle variation in percentage strikingly illustrates the necessity for storing water from the drainage basins in order to provide for priods of drought. In the western portion of the drainage basin there was practically no run-off in the seasou of $1876-77$, and in the easterly por1 ion of the basin there was practically no run-off in the seasons of 881-82, 1882-83, and 1897-98. It would therefore be necessary to store enough water in the reservoirs to furnish a supply for two :ummers and at least one winter. Another feature of interest in this table is that while the run-off in the seasons of 1881-82 and 882-83 was practically nothing from the easterly portion of the basin, the percentage of rainfall in the western portion of the watershed was $\therefore 9.4$ and 23 , respectively. 
Shinfall and run-off from basin of San Mateo C'reek, California.

\begin{tabular}{|c|c|c|c|c|c|}
\hline Year. & Rainfall. & Run-off. & Year. & Rainfall. & Run-off. \\
\hline$-\ldots-\ldots$ & $\ldots$ & - & -- & & \\
\hline $\begin{array}{l}\mathrm{W} \text { tern portion of penin- } \\
\text { :aid watershed: }\end{array}$ & Imolles. & Percent. & $\begin{array}{l}\text { Southeasterly portion cf } \\
\text { peninsula watershed }\end{array}$ & & \\
\hline $1869-70 \ldots \ldots$ & +1.95 & 206 & (southeast from old dam): & Inches. & Per cent. \\
\hline $18 \% 0-71 \ldots \ldots$ & 34.70 & 9.8 & $18 \% 78 \ldots$ & 57.70 & 29.3 \\
\hline $1861-62 \ldots \ldots \ldots$ & (4). 42 & 31.4 & $1878-69$ & 43.12 & 12.2 \\
\hline $1862-63 \ldots$ & 39.31 & 28.4 & $1879-80$ & 48.01 & 15.1 \\
\hline $1873-\dddot{4} \ldots$ & 48.88 & 29.5 & $1880-81 \ldots$ & 38.78 & 34.1 \\
\hline $18,4-75 \ldots$ & 44.26 & 21.2 & $1881-82$ & 25.02 & .9 \\
\hline $1875-76 \ldots$ & 69. 24 & 39.2 & $188 \%-83$. & 23.06 & .0 \\
\hline $1866-7 \%$ & 23.83 & .7 & $18833-84$ & 40.32 & 26.8 \\
\hline $18 \pi \tau-j \mathrm{~s} . .$. & $\because 2.51$ & $3 i .8$ & $1884-85 \ldots$ & 25.67 & 13.1 \\
\hline $18 \pi x-79 . .$. & 56.10 & 29.2 & 1885-86 - & 35.58 & 25.4 \\
\hline $1879-401$. & 56.14 & 35.0 & $1826-8 x^{2} \ldots$ & 28.61 & 9.7 \\
\hline $188(1-\times 1$ & 53. 81 & 43.11 & $188 \pi-8 x$ & 32.96 & 5.3 \\
\hline $18 \times 1-42$ & 34.23 & 29.4 & $1 \times 48-89$ & 35.60 & 7.4 \\
\hline $188^{20}-83 . \ldots . . . .$. & 33.89 & 23.0 & Total_ & 434.53 & 179.5 \\
\hline $1883-84 \ldots \ldots \ldots$ & 54.99 & 33.2 & Mean. . & 36.21 & 14.94 \\
\hline $1884-x, \pi \ldots \ldots$ & 38.25 & $31) .0$ & & & $-\ldots$ \\
\hline $1885-86 . \ldots$ & 51.90 & 43.9 & Above southeasterly and & & \\
\hline $18 \times 6-8 \%$ & 34.44 & 29.1 & $\begin{array}{l}\text { northeasterly portions of } \\
\text { peninsula watershed, to- }\end{array}$ & & \\
\hline $188 i-88 \ldots$ & $3 \pi .53$ & 29.2 & talCrystal Lake drainage: & & \\
\hline $1888-89 \ldots$ & 11.17 & 28.1 & $1889-90$ & 72.68 & 53.2 \\
\hline $1889-90 \ldots$ & $33.6 \%$ & $44 . \%$ & $1890-91$ & 31.92 & 24.4 \\
\hline $1890-91 \quad \ldots$ & 31.69 & 28 & $1891-92$. & 24.16 & 8.0 \\
\hline $1891-92^{2} \ldots$ & 43.10 & 13.3 & $1892-93$ & $47.0 \%$ & 34.3 \\
\hline $1 \times 92-43$. & 58.25 & 24.4 & $1893-94 \ldots$ & 33.08 & 29.0 \\
\hline $1393-94 \ldots$ & 54.90 & 21.8 & $1894-95$ & 55.76 & 33.8 \\
\hline $1894-95$ & 66.93 & 25.2 & $1895-96$ & 32.62 & 16.2 \\
\hline $1 \times 95-96$. & 49.45 & 21.0 & $1896-97 \ldots \ldots \ldots$ & 35.62 & 19.3 \\
\hline $1896-96 \ldots \ldots$ & 50.47 & 34.0 & $189 i-98 \ldots$ & 18.17 & 0.0 \\
\hline $1897-9 t_{2} \ldots$ & 26.26 & 9.6 & $1898-99 \ldots \ldots$ & 30.36 & 11.0 \\
\hline $1898-99 \ldots \ldots$ & $4 \% .56$ & $1 \%$ & Total .................. & $: 381.46$ & 930.1 \\
\hline Total $\ldots \ldots \ldots$ & $1,450.83$ & 818.2 & Mean $\ldots \ldots \ldots \ldots$ & 38,15 & 23.01 \\
\hline Mean...... & 48.36 & $26 i .94$ & & & \\
\hline
\end{tabular}

\section{SAN ROQUI CREEK.}

San Roqui (reek was measured during the year 1890 by Charles J. Johansen for the Pacific Improvement Company. The point of measurement was a short distance below the San Roqui tumnel, which was being built from 1899 to 1901 , the point of measurement being near an old dam in the stream. This drainage line is called San Roqui Creek in its mountainous portions, but lower down and south of the Sonthern Pacific Railroad it is called the Arroyo Burro. 
List of discharge measurements of San Roqui Creek, Santa Barbara County.

\begin{tabular}{|c|c|c|c|}
\hline Date. & Hydrographer. & $\begin{array}{c}\text { Dis- } \\
\text { ('harge. }\end{array}$ & Locality \\
\hline 1890. & & sise-foet. & \\
\hline Feb. 13 & Charles J. Johansen ... & +.96 & At old diversion box below tunnel. \\
\hline Feb. 19 & $\ldots$ do $\ldots \ldots \ldots$ & $5.70^{\prime}$ & Do. \\
\hline Feb. 21 & do ............ & $9.61^{\prime}$ & Do. \\
\hline Feb. 26 & do $\ldots \ldots . . . . . .-1$ & 11.03 । & Do. \\
\hline Mar. 1 & $\ldots$ do $\ldots$........ & 6.91 & Dr. \\
\hline Mar. 3 & $\ldots$ do $\ldots . . .6 . . .6$ & 6.28 & Do. \\
\hline Mar. 5 & $\ldots$ do $\ldots . . . . . . . . .$. & 5.67 & Do. \\
\hline Mar. 6 & $\ldots$ do .......... & $\bar{j} .6 \pi$ & Do. \\
\hline Mar. 8 & $\ldots$ do $\ldots . .$. & 5.20 & Do. \\
\hline Mar. 10 & $\ldots$ do ........... & 5.20 & Do. \\
\hline Mar. 12 & .... do ....... & 4.96 & Do. \\
\hline Mar. 14 & 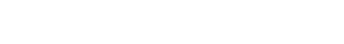 & 4.96 & Do. \\
\hline Mar. 16 & $\ldots$ do $\ldots \ldots \ldots$ & $4.2 \pi$ & Do. \\
\hline Mar. 18 & $\ldots$ do ........... & $4.2 \%$ & Do. \\
\hline Mar. 20 & $\ldots$ do $\ldots . . . . . . .$. & 4.73 & Do. \\
\hline Mar. 22 & do $\ldots . . . . .$. & 4.73 & Do. \\
\hline Mar. 24 & . . do . . . . . . . . . & $4.2 \%$ & Do. \\
\hline Mar. 26 & $\ldots$ do $\ldots . .$. & 3.84 & Do. \\
\hline Mar. 28 & ... no & 3.84 & Do. \\
\hline Mar. 30 & $\ldots d o \quad \ldots$. & 3.84 & Do. \\
\hline Apr. 1 & $\begin{array}{cccc}-. & -d o & \ldots & \end{array}$ & 3.42 & Do. \\
\hline Apr. 3 & $\ldots d v \quad \ldots . . .$. & 3.42 & Do. \\
\hline Apr. $\quad \tilde{j}$ & $\ldots d o \quad \ldots .$. & 3.42 & Do. \\
\hline Apr. $\quad \tilde{i}$ & $\ldots d_{0} \ldots \ldots \ldots$ & 3.21 & Do. \\
\hline Apr. $\quad 9$ & $\ldots \quad d o \quad \ldots \ldots$ & 3.21 & Do. \\
\hline Apr. 11 & $\ldots$. & 3.00 & Do. \\
\hline Apr. 18 & $\ldots d o \ldots . . . . .$. & 2.80 & Do. \\
\hline Apr. 15 & $\ldots$ do $\ldots . . . . . . . .$. & 2.62 & Do. \\
\hline Apr. 17 & $\ldots$ do $\ldots . . . . . . .$. & 2.62 & Do. \\
\hline Apr. 19 & $\ldots d_{1} \ldots \ldots \ldots$ & 2.42 & Do. \\
\hline Apr. 21 & $\ldots d_{1} \ldots \ldots \ldots . . . .$. & 2.15 & Do. \\
\hline Apr. 23 & $\ldots$ do ........ & 1.86 & Do. \\
\hline Apr. 25 & $\ldots d 0 \quad \ldots . . .6$. & 1.8() & Do. \\
\hline Apr. $2 \gamma$ & $\ldots d d_{1} \ldots \ldots$ & 1.80 & Dı. \\
\hline Apr. 29 & $\ldots d o d_{0} \ldots . . . . .$. & $1.5 \pi$ & Do. \\
\hline May 1 & $\ldots$ do $\ldots . . . . .$. & $1,5,5$ & Do. \\
\hline May 3 & $\ldots$ do $\ldots . . . . . . .$. & 1.39 & Do. \\
\hline May 5 & $\ldots$ do ........... & 1.39 & Do. \\
\hline May $\gamma$ & 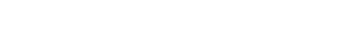 & 1.39 & Do. \\
\hline May 9 & $\ldots$ do $\ldots \ldots \ldots . . . . . . .$. & 1. $2: 3$ & Do. \\
\hline May 11 & ! . . do . . . . _........ & 1.23 & Do. \\
\hline
\end{tabular}


List of 'Tischarge Hertsurements of San Roqui Creek. str.-Continued.

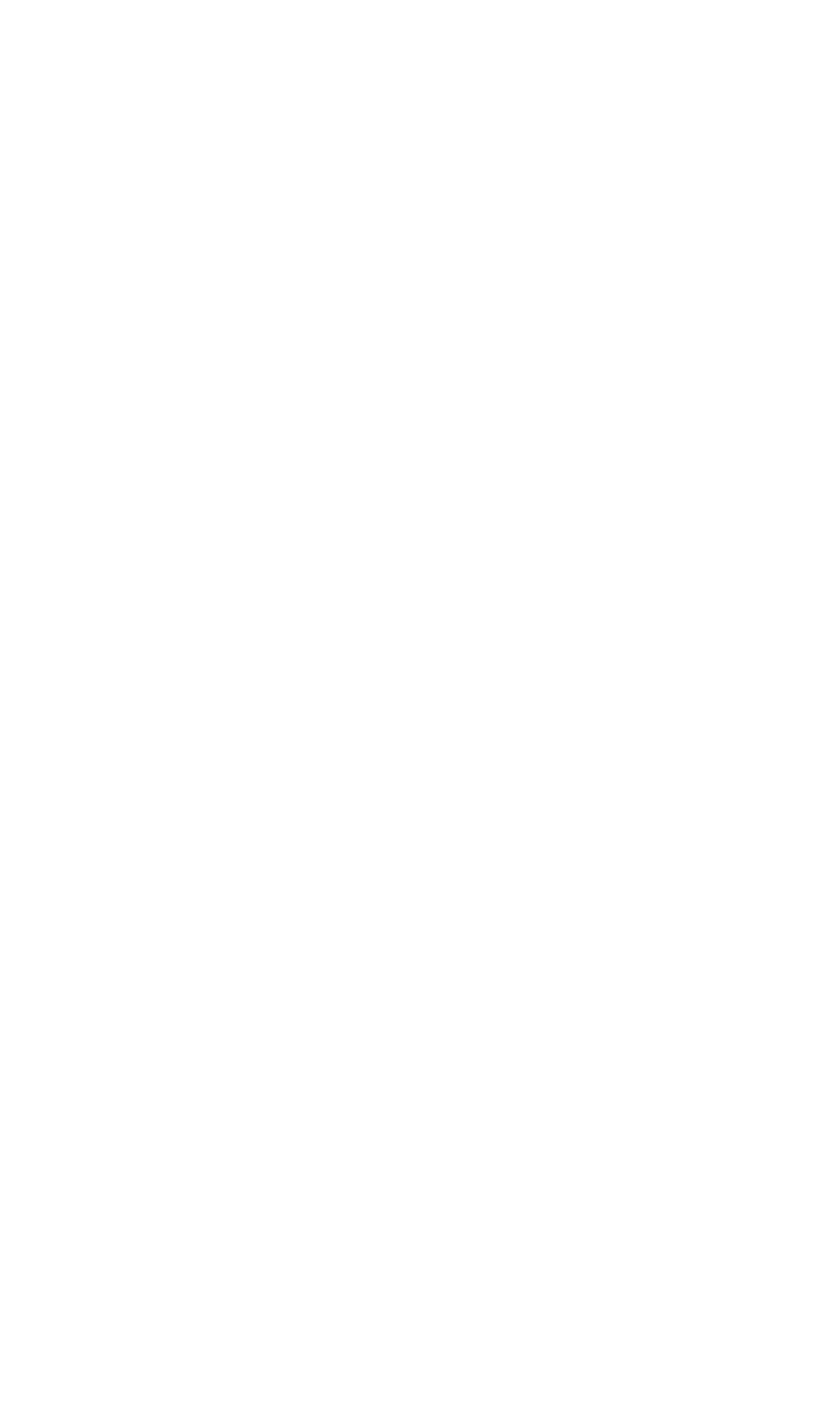


LIPPINCott.] SAN ROQUI CREEK AND SANTA ANA RIVER.

List of discharge measurements of Sun Roqui ('reek, etc.-C'ontinued.

\begin{tabular}{|c|c|c|c|}
\hline Date. & Hydrographer. & $\begin{array}{l}\text { Dis- } \\
\text { charge. }\end{array}$ & Locality. \\
\hline$\ldots$ & , $\quad \ldots-$ & $\cdots$ & $-\cdots+\ldots-\cdots$ \\
\hline 1890 & & Nece-fiet. & \\
\hline Aug. $\quad 2$ & Charles J. Johansen & $0.2 t$ & At old diversion box below tunnel. \\
\hline Aug. 4 & $\ldots$ do $\ldots . . . . . . . . .$. & .24 & Do. \\
\hline Aug. 6 & .... do & .24 & Do. \\
\hline Aug. 8 & $\ldots$ do .... & .26 & Do. \\
\hline Ang. 10 & $\ldots$..... do ... & .26 & Do. \\
\hline Aug. 12 & $\ldots$.... do ... & .26 & Do. \\
\hline Aug. 14 & $\ldots$. . do $\ldots$ & .23 & Do. \\
\hline Aug. 16 & $\ldots$ do $\ldots .$. & .23 & Do. \\
\hline Aug. 18 & $\ldots$.... do $\ldots$ & .20 & Do. \\
\hline Aug. 19 & .... do ... & .20 & Do. \\
\hline Aug. 22 & ..... do. & $.1 \%$ & Do. \\
\hline Sept. 2 & ... do ... & .19 & Do. \\
\hline Sept. 3 & ....do do .. & .19 & Do. \\
\hline Sept. 4 & $\ldots$. & .19 & Do. \\
\hline Sept. is & .....do - & .19 & Do. \\
\hline Sept. 6 & .... do ... & .19 & Do. \\
\hline Sept. $\tau$ & $\ldots$ do & .19 & Do. \\
\hline Sept. 8 & .... do . . . & .19 & Do. \\
\hline Sept. 10 & $\ldots . . . d o \ldots$ & .19 & Do. \\
\hline Sept. 11 & ... do . . & .19 & Do. \\
\hline Sept. 12 & ..... do ... & .19 & Do. \\
\hline Sept. 13 & $\ldots$ do .... & .19 & Do. \\
\hline Sept. 14 & $\ldots$. . do ... & .19 & Do. \\
\hline Aug. 26 & $\ldots$ do $\ldots .$. & .09 & Below old diversion box. \\
\hline Aug. 28 & $\ldots$ do $\ldots$ & .09 & Do. \\
\hline Aug. 30 & $\ldots$..... do ... & .07 & Do. \\
\hline Sept. 2 & do . . & .04 & Do. \\
\hline Sept. 4 & $\ldots$ do $\ldots$ & .04 & Do. \\
\hline Sept. 6 & $\ldots . \mathrm{d} o \ldots$ & $.0 . \overline{5}$ & Do. \\
\hline Sept. 8 & $\ldots$ do .... & .04 & Do. \\
\hline Sept. 10 & - _ do ........ & .04 & Do. \\
\hline Sept. 12 & $\ldots$ do $\quad \ldots \ldots c c c$ & .04 & Do. \\
\hline Sept. 14 & $d_{0} \ldots \ldots \ldots$ & .04 & Do. \\
\hline
\end{tabular}

SANTA ANA RIVER.

The river has its source on the sonthwestern slope of the San Bernardino Mountains and flows west, appearing from its canyon 6 miles northeast of Redlands. Its waters are completely used in San Bernardino Valley. At the lower part of the valley the water appears again in the vicinity of Rincon, where the river passes through a 
comparatively narow gorge, amel the stream flows thence in a general southwesterly direction, emptying into the Pacific Ocean. The station, established June, 189t, is located 5 miles northeast of Mentone, Cal., three-fourths of a mile below the head works of the Santa Ana canal and opposite the warm springs in the canyon. The gage is an inclined timber fastened to a large bowlder and posts set in the bank of the river. (n) Octoler 16, 18!8, owing to some local legal complications, an unusually large volume of water was turned into the santa Ana canal by the bear Talley Company. This water was wasted from the canal at a point below the old gage rod, necsssitating the establishmeit of a new gage ron upon this stream at a point below where the waste from the canal was turned into the river. The new gage was put in November 9, 189s, and since that date daily observations have been kept on the lower gage, which is a 2 by 6 inch timber firmly bolted to a granite eliff, which forms the left banl of the river, and is situated soo feet below the mouth of Warmsprings Canyon and 100 feet above a ford on the canyon road. A landslide occurred below the gage rod April 16, 1899, which changed the condition of the rating for the station. Owing to the shifting nature of the stream bed it has not been possible to construct perfectly satisfactory rating curves, but the tables as presented are based on the best information that could be obtained. This river is one of the most difficult streams in the State to accurately gage. The Edison Electric Company diverts the greater portion of the water of Santa Ana River above the gaging station, but also returns all of it above the station. Only limited portions of the water are allowed to pass out of the conduits during certain hours of the lay, the water being held back for the purpose of obtaining additional power when the greatest demand exists. An effort is being made to arrange with this company to obtain a record of the number of gates, the sizes of the openings, and the hours at which the various wheels are r'm, in order to more accurately determine the volumes of water. The Santa Ana canal, as mentioned above, also diverts water from Santa Ana River above the station, but the greater part of it is returned to the channel of the stream before passing the point of measurement.

It was found that this slation conld not be used during high water, and on January 1, 1901, observations were resumed at the old station and on Santa Ana Canal near the river station.

From June 1 to December 31, 1901, and for the entire rear 1909, except from February 26 to April 23 , inclusive, the discharge of sinta Ana River was obtained by observations on the weirs at the head works of Green Spot pipe line, Highlands canal, and Redlands canal. The flow from Redlands tunnel and Morton Canyon was assumed to offset the loss by evaporation between the old gaging station and the mouth of the canyon.

The drainage area used prior 101902 was obtained from Land Office maps. Subsequently the Geologioal survey completer its contonr 
map of this basin and an area of 1s: square miles above the gaging "tatiou was obtained therefrom and was accepted.

Discharge measurements of Alder Creek, a branch of Santa Ana River. St:n Bernardino County.

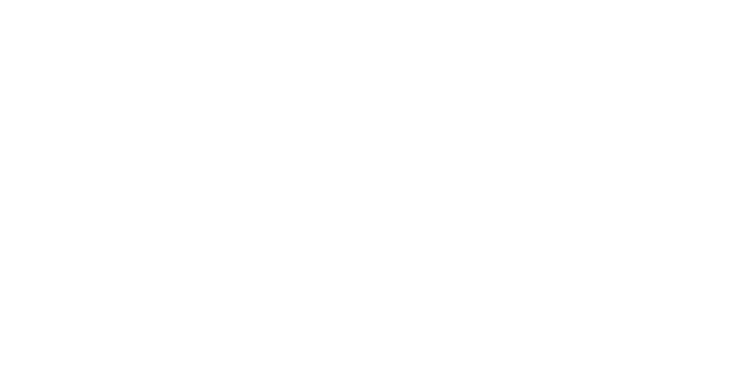

Discharge measurements of Santa Ana River above month of Bear. Creek, San Bernardino County.

August $8,189 \%$

August 31, 1897

"Tovember 14.189\%

April 14, 1900

Detober 8,1901 do
0.88

1.00

.00

.90

89
July $2 \pi, 1 \times 96$

$\therefore$ ugust 31.1897

'Tovember $14.189 \pi$.
J.H. Quinton Hydrographer.

A. Q. Campbell

J. B. Lippincott
Discharge.

Sac. feet.

14.2

17.9

17.5

The discharge of the streams of southern California was unusually 'ow in September, 18!9, and these measurements were made to determine this minimum with its hourly fluctuation.

Discharge measurements of Sunta Ana River above mouth of Bear Creek.

[Measurements by Edison Electric Company.]

\begin{tabular}{|c|c|c|c|}
\hline Date. & $\begin{array}{l}\text { Dis- } \\
\text { charge. }\end{array}$ & Date. & $\begin{array}{c}\text { Dig- } \\
\text { charge. }\end{array}$ \\
\hline :ept. 1\%, 1898: & sec.feet. & Sept. 15, 1898-Continued. & Sec-feet. \\
\hline ז a.m.... & 8.22 & $1.30 \mathrm{p} . \mathrm{m} \ldots$ & \%.12 \\
\hline $7.30 \mathrm{a} . \mathrm{nr}$ & 8.22 & 2 p. $\mathrm{m} \ldots \ldots$ & $\tau .20$ \\
\hline 8 a.m... & 8. 22 & 2.30 p.m $\ldots$ & \%.06 \\
\hline 8.30 a.m & 8.22 & 3 p.m. & 6.92 \\
\hline 9 a. $\mathrm{m} \ldots$ & ห. 22 & $3.30 \mathrm{p.m}$. & 6.86 \\
\hline 9.30 a.m & 4. 22 & $4 \mathrm{p} \cdot \mathrm{m}$ & 6.66 \\
\hline 10 a.m $\mathrm{m}$ & 8.46 & $4.30 \mathrm{p} . \mathrm{m}$ & 6.98 \\
\hline $10.30 \mathrm{a} . \mathrm{m} \ldots \ldots \ldots$ & ४. 10 & $5 \mathrm{p} . \mathrm{nl} \ldots \ldots$ & 6.44 \\
\hline 11 a.m ... & $\tau .98$ & $5.30 \mathrm{p.m}-$ & 6. 22 \\
\hline $11.30 \mathrm{a} . \mathrm{m}$ & 7.86 & 6 p.m ...... & 6.22 \\
\hline $12 \mathrm{~m} \ldots \ldots$ & $\tau .76$ & $6.30 \mathrm{p} . \mathrm{m}$ & 6.10 \\
\hline $19.30 \mathrm{p} . \mathrm{m} \ldots \ldots$ & 7.48 & 12-hour mean. & 7.43 \\
\hline $1 \mathrm{p} . \mathrm{m} \ldots$ & 7.54 & & \\
\hline
\end{tabular}


Discharge measurements of Santa Ana River, etc.-Continued.

\begin{tabular}{|c|c|c|c|}
\hline Date. & $\begin{array}{l}\text { Dis- } \\
\text { charge. }\end{array}$ & Date. & $\begin{array}{c}\text { Dis- } \\
\text { charge. }\end{array}$ \\
\hline Sept. 15. 1898-Continued. & Sec-feet. & Sept. 16,1898-Contirued. & Sec.-feet. \\
\hline 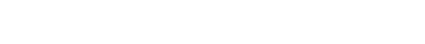 & 6.10 & 1.30 p. m $\ldots$ & 7.32 \\
\hline $7.30 \mathrm{p.m}$. & 6.10 & $2 \mathrm{p} . \mathrm{m} \ldots .$. & 7.20 \\
\hline sp.m..... & 6.10 & 2.30 p. $\mathrm{m}$ & 7.06 \\
\hline 8.30 p. m . . . & 6. 02 & 3 p.m.... & 6.86 \\
\hline 9 p. in $\ldots \ldots$ & 6.02 & 3.30 p. m ... & 6.66 \\
\hline 9.30 p. m $\ldots \ldots$ & 6.02 & 4 p. $\mathrm{m}$ & 6.44 \\
\hline 10 p. m $\ldots$ & 6.02 & 4.30 p. m ... & 6.32 \\
\hline 10.30 p. m . . . & 6.02 & 5 p. $m \ldots$ & 6.22 \\
\hline 11 p. m.... & 6. 32 & 5.30 p. m .. & 6.10 \\
\hline 11.30 p. $\mathrm{m} \ldots \ldots$ & 6.96 & 6 p. m.... & 6.02 \\
\hline 12 midnight $\ldots \ldots \ldots$ & 6.60 & 6.30 p. in - & 6.02 \\
\hline $\begin{array}{l}\text { Sept. } 16,1898: \\
12.30 \text { a. } \mathrm{m}\end{array}$ & 6.66 & 12-hour mean. .. & $\begin{array}{r}7.23 \\
\end{array}$ \\
\hline $1 \mathrm{a} . \mathrm{m} \ldots$. & 6.66 & $\tau \mathrm{p} . \mathrm{m}_{\ldots} \ldots$ & 6.20 \\
\hline 1.30 a. $\mathrm{m} \ldots$ & 6.86 & T.30 p. m $\ldots$ & 6. 20 \\
\hline 2 a. m... & 6.92 & 8 p. m.... & 6.20 \\
\hline 2.30 a. $\mathrm{m} \ldots$ & 7.06 & 8.30 p. $\mathrm{m} \ldots$ & 6. 20 \\
\hline $3 \mathrm{a} . \mathrm{m} \ldots \ldots$ & 7.20 & 9 p. m $\ldots$ & 5.76 \\
\hline 3.30 a. $\mathrm{m} \ldots$ & $\tau .32$ & 9.30 p. $\mathrm{m}_{-}$ & 5.92 \\
\hline 4 a. $m \ldots \ldots$ & 7.54 & 10 p. m ... & 5.92 \\
\hline 4.30 a. $\mathrm{m}$ & ז.66 & 10.30 p. m . & 6.02 \\
\hline 5 a. $\mathrm{m} \ldots . . . .$. & ז.66 & 11 p. $\mathrm{m} \ldots$ & 6.22 \\
\hline 5.30 a. $\mathrm{m} \ldots \ldots$ & 7.86 & $11.30 \mathrm{p.m}$. & 6.32 \\
\hline 6 a. $\mathrm{m} \ldots$ & 7.76 & 12 midnight & 6.32 \\
\hline 6.30 a. $\mathrm{m}_{\text {.- }}$ & $\div 76$ & Sept. $17,1898:$ & \\
\hline 12-hour mean. . & 6.80 & 12.30 a. $\mathrm{m}$. & 6.44 \\
\hline 7a.m. ... & 7.76 & 1 a. m... & 6.66 \\
\hline 7.30 a. $\mathrm{n} \ldots \ldots$ & $\pi . \% 6$ & 1.30 a. $\mathrm{m}$. & 6.76 \\
\hline 8 a. $\mathrm{m}_{\ldots} \ldots .$. & 8.10 & 2a. $\mathrm{m} \ldots$ & 6.86 \\
\hline 8.30 a. $\mathrm{m}$ & 7.98 & 2.30 a. $\mathrm{m}$ & 6.92 \\
\hline 9 a. $\mathrm{m} \ldots \ldots \ldots$ & 8.04 & 3 a. $\mathrm{m} \ldots$ & $\begin{array}{l}7.06 \\
7.90\end{array}$ \\
\hline 9.30 a. $\mathrm{m} \ldots .$. & 8.10 & 3.30 a. $\mathrm{m} \ldots$ & $\begin{array}{l}7.20 \\
7.32\end{array}$ \\
\hline 10 a. $\mathrm{m} \ldots \ldots$ & 7.82 & $\begin{array}{l}\text { 4 a. } \mathrm{m} \ldots \\
4.30 \text { a. } \mathrm{m}\end{array}$ & $\begin{array}{l}7.32 \\
7.32\end{array}$ \\
\hline 10.30 a. $\mathrm{ml} \ldots . .$. & $\tau .98$ & 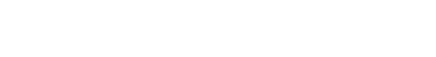 & $\begin{array}{l}7.52 \\
7.54\end{array}$ \\
\hline 11 a. $\mathrm{m}_{\ldots} \ldots$ & 7.86 & $5.30 \mathrm{a} . \mathrm{m}$ & 7.54 \\
\hline 11.30 a. $\mathrm{m} \ldots$ & 7.76 & 6 a. $\mathrm{m}$ & 7.66 \\
\hline $12 \mathrm{~m} \ldots \ldots$ & 7.48 & 6.30 a. $\mathrm{m} \ldots$ & 7.76 \\
\hline $12.30 \mathrm{p.m}$ & $\pi .44$ & 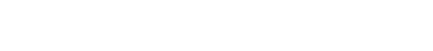 & \\
\hline $1 \mathrm{p} \cdot \mathrm{m} \ldots \ldots$ & 7.32 & 12-nour mean. - & 6.68 \\
\hline
\end{tabular}


Discharge measurements of Beur Creek above Sunta Ana River, San Bernardino County.

[Measurements by Edison Electric Co.]

\begin{tabular}{|c|c|c|c|}
\hline Date. & $\begin{array}{c}\text { Dis- } \\
\text { charge. }\end{array}$ & Date. & $\begin{array}{c}\text { Dis- } \\
\text { charge. }\end{array}$ \\
\hline Sept. 15, 1898: & Sec-feet. & Sept. 16, 1898: & Sec.feet. \\
\hline ז a. m... & 23.30 & $12.30 \mathrm{a} . \mathrm{m}$ & 19.74 \\
\hline 7.30 a. $\mathrm{m}$ & 23.30 & 1 a. $\mathrm{m} \ldots \ldots$ & 19. 74 \\
\hline 8 a. $\mathrm{m}_{\ldots} \ldots$ & 23.30 & 1.30 a. $\mathrm{m}$ & 19.54 \\
\hline 8.30 a. $\mathrm{m}$. & 25.94 & $2 \mathrm{a} \cdot \mathrm{m} \ldots$ & 19.34 \\
\hline 9 a. $\mathrm{m} \ldots$ & 23.30 & $2.30 \mathrm{a} . \mathrm{m}$ & 19.14 \\
\hline 9.30 a. $\mathrm{m}$ & 23.30 & $3 \mathrm{a} . \mathrm{m} \ldots \ldots$ & 18.72 \\
\hline 10 a. $\mathrm{m}_{\ldots} .$. & 23.30 & $3.30 \mathrm{a} . \mathrm{m}$ & $18 . \% 2$ \\
\hline 10.30 a. $\mathrm{m}$ & 23.10 & 4 a. m .... & 18.32 \\
\hline 11 a. $m$ & 23.10 & $4.30 \mathrm{a} . \mathrm{m}$ & 18.32 \\
\hline $11.30 \mathrm{a} . \mathrm{m}$ & 22.84 & 5 a.m & 18.12 \\
\hline $12 \mathrm{~m} \ldots \ldots$ & 22.66 & $5.30 \mathrm{a} . \mathrm{m} \ldots$ & 18.12 \\
\hline $12.30 \mathrm{p}, \mathrm{m}$ & 22.66 & 6 a.m $\ldots$ & $1 \% .92$ \\
\hline 1 p. m.... & 22.66 & 6.30 a.m $\mathrm{m}$ & 17.80 \\
\hline 1.30 p. m & 22.66 & 19-hour $m$ & 19.84 \\
\hline 2 p. m .... & 22.66 & 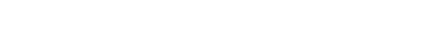 & \\
\hline $2.30 \mathrm{p.} \mathrm{m}$ & 22.66 & $7 \mathrm{a}: \mathrm{m} \ldots$ & 17.92 \\
\hline 3 p. m $\ldots$ & 22.66 & $7.30 \mathrm{a} . \mathrm{m} \ldots$ & 17.92 \\
\hline 3.30 p. m & 22.44 & sa.m ... & 17.80 \\
\hline 4 p. m.... & 92.44 & $8.30 \mathrm{a} . \mathrm{m}$ & 16.94 \\
\hline 4.30 p. m & 22.44 & 9 a.m $\ldots . .$. & 17.34 \\
\hline 5 p. m.... & 22.02 & $9.30 \mathrm{a} \cdot \mathrm{m}$ & 17.24 \\
\hline 5.30 p. m & 22.02 & $10 \mathrm{a} \cdot \mathrm{m}$ & $1 \% .12$ \\
\hline $6 \mathrm{p} . \mathrm{m} \ldots$ & 22.02 & $10.30 \mathrm{a} . \mathrm{m}$ & 17.12 \\
\hline 6.30 p. m & 21.80 & $11 \mathrm{a} \cdot \mathrm{m}$ & 16.84 \\
\hline 12-hour mean & 22.86 & 11.30 a. $\mathrm{ml}$. & \\
\hline รp. m.... & 21.60 & 12.30 p. $\mathrm{m}$ & 16.94 \\
\hline $7.30 \mathrm{pem}, \ldots$ & 21.60 & 1 p. m........ & 16. $\% 6$ \\
\hline $8 \mathrm{p} \cdot \mathrm{m}$ & 21.60 & $1.30 \mathrm{p} . \mathrm{m} \ldots$ & 16. 76 \\
\hline 8.30 p. $\mathrm{ml} \ldots$ & 21.40 & 2 p. $\mathbf{m}$ & 16.56 \\
\hline $9 \mathrm{p} . \mathrm{m} \ldots \ldots \ldots$ & 21.06 & $2.30 \mathrm{p} . \mathrm{m} \ldots$ & 16.56 \\
\hline $9.30 \mathrm{p}, \mathrm{m}_{\mathrm{L}}$. & 21.18 & $3 \mathrm{p} . \mathrm{m}_{-}$ & 16.56 \\
\hline $10 \mathrm{p} . \mathrm{m} \ldots \ldots$ & 20.98 & 3.30 p. $\mathrm{m}$ & 16.56 \\
\hline 10.30 p. $\mathrm{m} \ldots$ & 20.98 & 4 p.m................... & 16.38 \\
\hline 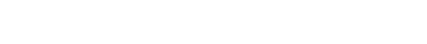 & 20.78 & $4.30 \mathrm{p} . \mathrm{m}$ & 16.38 \\
\hline 11.30 p. m & 21.60 & 5 p. $\mathrm{m} \ldots \ldots$ & 16.38 \\
\hline 12 midnight $\ldots \ldots \ldots$ & 19.94 & $5.30 \mathrm{p} . \mathrm{m} \ldots$ & 16.38 \\
\hline
\end{tabular}


Inischarge measureme'nts of Bear Creek, etc.-Continued.

Date.

Sept. $16.1 \times 98-C o n t i n u e d$.

6 p. $\mathrm{m}$

6.30 p. $\mathrm{m}$

12-hour mean

ז p.m.

\%. 30 p.m

8 p. m.

8.30 p. m

9 p. m

9.30 p. $\mathrm{m}$

10 p. $\mathrm{m}$

10.30 p. $\mathrm{m}$

11 p. $\mathrm{m}$

$11.30 \mathrm{p.} \mathrm{m}$.

12 midnight

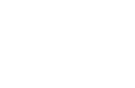

Ser.feet.

16.38

16.38

16.86

16.38

16.28

16.28

16.28

16.18

16. 38

16.38

16.38

16.38

16.38

16. 38

\begin{tabular}{|c|c|}
\hline Date. & $\begin{array}{l}\text { Dis- } \\
\text { charge. }\end{array}$ \\
\hline Sept. 17, 1898: & Sec-feet. \\
\hline 12.30 a. $\mathrm{m} .$. & 16.38 \\
\hline 1 a. $\mathrm{m} \ldots \ldots$ & 16.38 \\
\hline 1.30 a. $\mathrm{m}_{\ldots} \ldots$ & 16.38 \\
\hline a. $\mathrm{m} \ldots \ldots$ & 16.38 \\
\hline $2.30 \mathrm{a} . \mathrm{m} \ldots$ & 16.38 \\
\hline 3 a. $m \ldots \ldots \ldots$ & 16.38 \\
\hline 3.30 a. $\mathrm{m} \ldots$ & 16.38 \\
\hline 4 a. $m_{\ldots} \ldots$ & 16.38 \\
\hline 4.30 a. $\mathrm{m} \ldots \ldots$ & 16.38 \\
\hline 5 a. $111 \ldots . .$. & 16.38 \\
\hline 5.30 a. $\mathrm{m} \ldots$ & 16.38 \\
\hline 6 a. $\mathrm{m}_{\ldots} \ldots$ & 16.38 \\
\hline 6.30 a. $\mathrm{m}$ & 16.38 \\
\hline 12-hour mean. . . . . . . & 16.36 \\
\hline
\end{tabular}

Discharge measurements of Bear Creek above Santa Ana River, San Bernardino County.

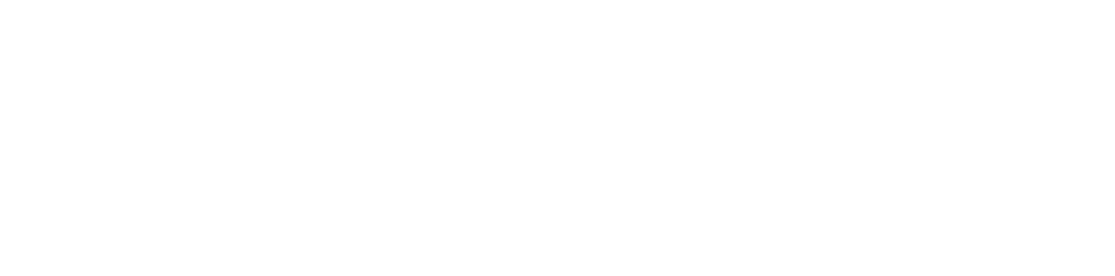

Discharge measurements of areen Spot Pipe Line, Santa Ana River, San Bernardino County.

\begin{tabular}{|c|c|c|}
\hline Date. & Hydrographer. & $\begin{array}{c}\text { Dis- } \\
\text { charge. }\end{array}$ \\
\hline 1896. & & ser-feet. \\
\hline $\begin{array}{c}\text { Nov. } 21 \\
1898 .\end{array}$ & J. B. Lippincott & 0.40 \\
\hline Jan. 8 & J. B. Lippincott _. - & .38 \\
\hline Apr. 12 & $\ldots$ do .......... & a 1.89 \\
\hline Apr. 12 & $\ldots$. . do & b 1.74 \\
\hline Apr. 29 & $\ldots$.... do ...... & 2.94 \\
\hline June 12 & .... do & .63 \\
\hline July 23 & ( & 2.20 \\
\hline Sept. 8 & 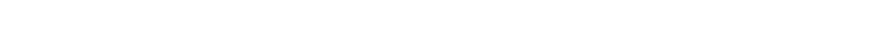 & 0.00 \\
\hline Oct. 18 & F. H. Olmsted $\ldots \ldots \ldots \ldots$ & 1.36 \\
\hline Nov. 9 & (2, & .50 \\
\hline Dec. & . . . . do & .50 \\
\hline Dec. & $\ldots$ & b. 15 \\
\hline
\end{tabular}


Discharge measurements of Green Spot Pipe Line. ete.-Continned.

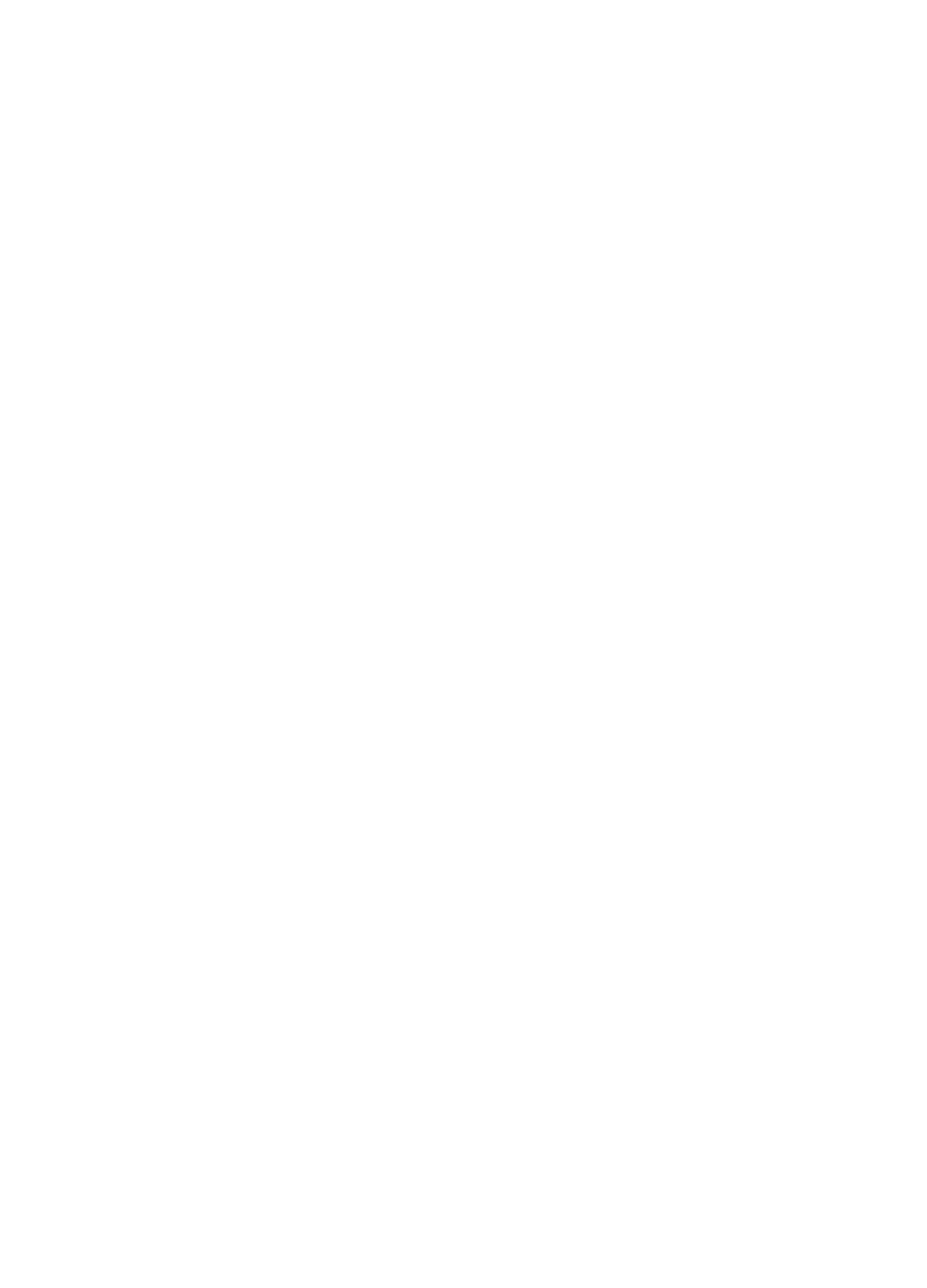


Estimated monthly discharge of Bear. Talley Water, Green Spot Pipe Line. Santa Ana River, at hearl of C'rafton ditch, San Bernardino County.

\begin{tabular}{|c|c|c|c|}
\hline Montb. & $\begin{array}{l}\text { Mean dis- } \\
\text { charge. }\end{array}$ & Month. & $\begin{array}{l}\text { Mean dis } \\
\text { charge. }\end{array}$ \\
\hline $1 \times 9 \%$ & sec feet. & 1899. & ser-feet. \\
\hline August & 21.5 & July & 5.8 \\
\hline September ....... & 15.8 & August...... & 5.8 \\
\hline October 1 to $21 \ldots \ldots$ & 13.2 & September . & 4.1 \\
\hline 1898. & & October .... & 6.6 \\
\hline April ...... & 17.0 & November . & 8.6 \\
\hline May ..... & $1 \% .2$ & December .. & 9.5 \\
\hline June $\ldots \ldots \ldots$ & 13.2 & 1900. & \\
\hline July . . . . . . . . & 9.1 & January .... & 2.1 \\
\hline August.... & 9.1 & February & 2.5 \\
\hline September ............ & S. 2 & March .... & 1.5 \\
\hline October .... ...... & 9.0 & April ..... & 2.3 \\
\hline November . . . . . . . . . . & 10.0 & May $\ldots . .$. & 1.9 \\
\hline December ... $\quad \ldots \ldots \ldots$ & 10.7 & June . . . . . . . & .4 \\
\hline 1899. & & July 1 to $15 \ldots \ldots$ & 1.1 \\
\hline January 1 to $9 \ldots \ldots$ & 11.0 & August $\ldots \ldots \ldots \ldots$ & 0 \\
\hline February ........ & 11.6 & September $\ldots \ldots \ldots$ & 0 \\
\hline March ... & 12.2 & October $\ldots \ldots$ & 0 \\
\hline April.... & 11.8 & November ... $\ldots \ldots$ & 0 \\
\hline$\ldots \ldots \ldots$ & 11.2 & December & 0 \\
\hline 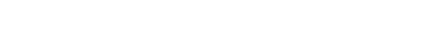 & 5.4 & & \\
\hline
\end{tabular}

Estimated monthly discharge of Green Spot Pipe Line, Santa Ana River, at Headworks Weir, San Bernardino Connty.

\begin{tabular}{|c|c|c|c|}
\hline Month. & $\begin{array}{l}\text { Mean dis- } \\
\text { charge. }\end{array}$ & Month. & $\begin{array}{l}\text { Mean dis- } \\
\text { charge. }\end{array}$ \\
\hline 1901. & Sec.feet. & 1901-Continued. & Sec-feet. \\
\hline June ...... & 1.5 & October $\ldots \ldots$ & 5.7 \\
\hline July ..... & 2.3 & November $\ldots \ldots$ & 1.7 \\
\hline August.... & 2.7 & December & 1.2 \\
\hline September & 5.5 & & \\
\hline
\end{tabular}


Discharge measurements of Highlands or North Fork Canal at intake ueir. Santa Ana River. San Bernardino County.

\begin{tabular}{|c|c|c|}
\hline Date. & Hydrographer. & Discharge. \\
\hline 1896. & & Sec.feet. \\
\hline Nov. 21 & J. B. Lippincott & 8.50 \\
\hline 1898. & & \\
\hline Jan. 8 & J. B. Lippincott. & 11.91 \\
\hline Mar. 9 & H. Crowe ....... & 10.76 \\
\hline Apr. 12 & J. B. Lippincott . - & 12.40 \\
\hline Apr. 29 & . . do . . . . . . & 17.03 \\
\hline June 12 & . . do ...... & 11.37 \\
\hline Sept. 8 & $\ldots$ do ...... & 13.29 \\
\hline Oct. 18 & F.H.Olmsted & 9.85 \\
\hline Nov. 9 & . . do ...... & 8.12 \\
\hline Dec. 8 & $\ldots$ do...... & 6.95 \\
\hline 1899. & & \\
\hline Feb. 18 & S. G. Bennett. . . & 8.07 \\
\hline Mar. 23 & $\ldots$ do .......... & 11.78 \\
\hline May 6 & $\ldots$ do $\ldots . . . . .$. & 7.70 \\
\hline May 31 & $\ldots d o \ldots \ldots$ & 6.74 \\
\hline June 15 & $\ldots$ do $\ldots \ldots \ldots$ & 10.30 \\
\hline July 15 & - do $_{-} \ldots \ldots \ldots \ldots . . . .$. & 13.14 \\
\hline July $2 \%$ & do $\ldots$............ & 11.92 \\
\hline Aug. 24 & $\ldots$ do ............ & 4.28 \\
\hline 1900 & & \\
\hline Apr. 14 & S. G. Bennett $\ldots \ldots \ldots \ldots$ & 7.48 \\
\hline July 13 & 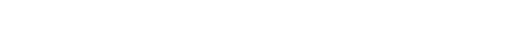 & (a) \\
\hline Oct. 2 & W. W. Cockins. jr $\ldots \ldots \ldots \ldots$ & 5.61 \\
\hline 1901. & & \\
\hline July 6 & S. G. Bennett . - & 13.28 \\
\hline Aug. 20 & do & 15.79 \\
\hline Oct. 8 & $\ldots$ do . . . . . . . . . & 14.30 \\
\hline Dec. $\bar{\delta}$ & $\ldots$ do $\quad \ldots . . . . .$. & 8.53 \\
\hline May 31 & do do $_{2} \ldots \ldots \ldots \ldots$ & 7.90 \\
\hline 1902. & & \\
\hline July 10 & S. G. Bennett..... & 11.50 \\
\hline Sept. 3 & W. B. Clapp $\ldots \ldots$ & 11.10 \\
\hline Nov. $\quad \tilde{5}$ & S. G. Bennett. . . . . . . . & 10.02 \\
\hline
\end{tabular}

"Water not going through weir basin: weir was being repaired. 
Dischurge measurements of Suntu Ana River above Keller Crek, San Bernardino County."

[Measurements by Edison Electric Company.]

\begin{tabular}{|c|c|c|c|}
\hline Date. & $\begin{array}{c}\text { Dis- } \\
\text { charge. }\end{array}$ & Date. & $\begin{array}{l}\text { Dis- } \\
\text { charge. }\end{array}$ \\
\hline ept. 15. 189x: & seci-feet. & Sept. 16, 1898: & Sec-feet. \\
\hline ז a. $111 \ldots$ & 29.30 & $12.30 \mathrm{a} . \mathrm{m}$ & $2 \pi .08$ \\
\hline $7.30 \mathrm{a} . \mathrm{m}$. & 30.44 & 1 a. $\mathrm{m}_{\ldots} \ldots$ & $2 \pi .08$ \\
\hline 8 a. m.... & 28.30 & $1.30 \mathrm{a} . \mathrm{m} \ldots \ldots$ & $3 \pi .08$ \\
\hline 8.30 a. $\mathrm{m} \ldots \ldots$ & 30.44 & 2 a.m.... & $2 \pi .08$ \\
\hline 9 a. $\mathrm{m} \ldots \ldots$ & 30.44 & $2.30 \mathrm{a} . \mathrm{m} \ldots \ldots$ & 26.02 \\
\hline 9.30 a. $\mathrm{m}$ & 30.44 & a. $\mathrm{m} \ldots$ & 26.0 \\
\hline 10 a. in ..... & 30.44 & $3.30 \mathrm{a} . \mathrm{m}$ & 26.02 \\
\hline $10.30 \mathrm{a}, \mathrm{m} \ldots$ & 30.44 & a. $\mathrm{m} \ldots$ & 26.02 \\
\hline 11 a. $11 \ldots \ldots$ & 30.44 & $4.30 \mathrm{a} . \mathrm{mr} \ldots \ldots$ & 26.02 \\
\hline 11.30 a. $\mathrm{m} \ldots \ldots$ & 30.44 & 5 a. $\mathrm{m} \ldots \ldots$ & 24.9 \\
\hline $12 \mathrm{~m} \ldots \ldots$ & 29.30 & .30 a. $\mathrm{nI}$ & 24.9 \\
\hline 12.30 p. $\mathrm{m} \ldots \ldots$ & 29.80 & 6 a. $\mathrm{m} \ldots$. & 24.92 \\
\hline 1 p. $\mathrm{m} \ldots \ldots$ & 29.30 & 30 a. $\mathrm{m} \ldots \ldots$ & 24.92 \\
\hline 1.30 p. $\mathrm{m} \ldots \ldots$ & 29.30 & & \\
\hline 2 p. m $\ldots \ldots$ & 29.30 & $1 \sim$ & $--=-$ \\
\hline 2.30 p. $\mathrm{m} \ldots$ & 29.30 & ร a. $\mathrm{m} \ldots$ & 24.92 \\
\hline $3 \mathrm{p} . \mathrm{m} \ldots \ldots$ & 39.30 & 7.30 a. $\mathrm{m} \ldots$ & 24.92 \\
\hline 3.30 p. $\mathrm{m}_{\ldots}$ & 28.20 & 8 a. $m \ldots . .$. & 24.92 \\
\hline $\pm p . m \ldots$ & 28.20 & $8.30 \mathrm{a} . \mathrm{m}_{-}$ & 24.92 \\
\hline $4.30 \mathrm{p} . \mathrm{m} \ldots \ldots$ & 28.20 & 9 a. $m \ldots$ & 24.92 \\
\hline j $p, \mathbf{m} \ldots \ldots \ldots \ldots$ & 28.20 & .30 a. $\mathrm{m} \ldots$ & 24.9 \\
\hline 5.30 p. $\mathrm{m} \ldots \ldots$ & 28.20 & 10 a. $\mathrm{m} \ldots \ldots$ & 24.9 \\
\hline $6 \mathrm{p} . \mathrm{m} \ldots \ldots$ & 28.20 & 10.30 a. $\mathrm{m}$ & 94.9 \\
\hline 6.30 p. $\mathrm{m} \ldots$ & 29.30 & 11 a. $\mathrm{m} \ldots \ldots$ & 24.4 \\
\hline 12-hour mean. & 29.16 & 列 & \\
\hline ; p. m. & 29.30 & $12.30 \mathrm{p.} \mathrm{m}$ & 23.84 \\
\hline $7.30 \mathrm{p} . \mathrm{m} \ldots$ & 28.22 & 1 p. m.... & 93.8 \\
\hline 8 p. m...... & 28.20 & $1.30 \mathrm{p.} \mathrm{m}$ & $9 ? 8$ \\
\hline $8.30 \mathrm{p.m} \ldots$ & 28.20 & $2 \mathrm{p} \cdot \mathrm{m}_{\ldots} \ldots \ldots$ & 22.8 \\
\hline 9 p. m . .... & 28.20 & 2.30 p. m . . . . & 29.8 \\
\hline 9.30 p. m .... & 28.20 & $3 \mathrm{p} . \mathrm{m} \ldots \ldots$ & 22.8 \\
\hline 10 p. m...... & 28.20 & 3.30 p. m - & 22.8 \\
\hline 10.30 p. m ... & 28.20 & \pm p. $\mathrm{m} \ldots$ & 22.8 \\
\hline $11 \mathrm{p} . \mathrm{m} \ldots$ & 28.20 & 4.30 p. m . & 21.8 \\
\hline 11.30 p. m . & 28.20 & sp. $\mathrm{m}_{\ldots} \ldots \ldots$ & 21.8 \\
\hline 12 midnight & 28.20 & $5.30 \mathrm{p} . \mathrm{m} \ldots$ & \\
\hline
\end{tabular}

a The discharge of the streams of southern California was unusually low in September, $18 \% k$. anc? these measurements were made by the Edison Electric Company to deternine this minimum with its hourly fluctuation. 
Discharge measurements of Santa Ana River, etc.-Continued.

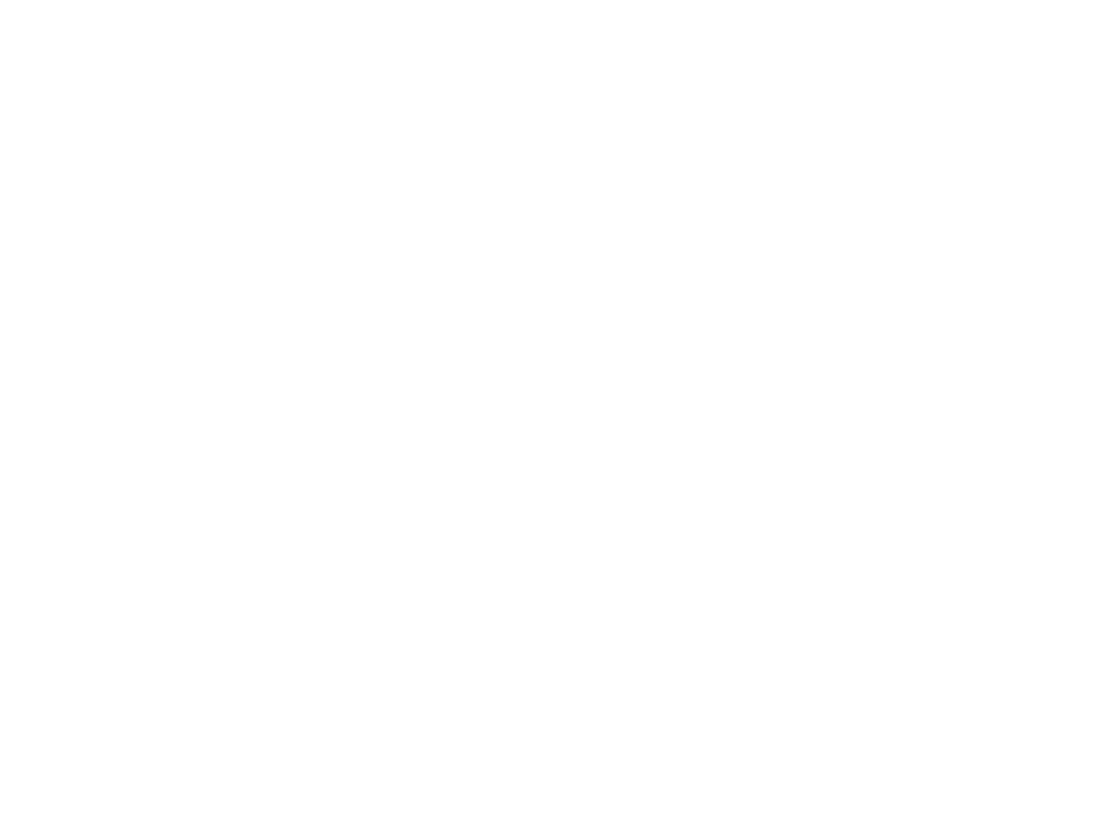

Discharge measurements of Keller Creek, a tributary of Santa Ana River.

\begin{tabular}{|c|c|c|}
\hline Date. & Hydrographer. & $\begin{array}{c}\text { Dis- } \\
\text { charge. }\end{array}$ \\
\hline 1897. & & Sec.-feet. \\
\hline $\begin{array}{c}\text { Nov. } 14 \\
1900 .\end{array}$ & A. Q. Campbell ...... & 1.00 \\
\hline Apr. 14 & S. G. Bennett. $\ldots \ldots \ldots \ldots$ & .67 \\
\hline
\end{tabular}

IRR $81-03-19$ 
Discharge measurements of Morton Canyon Water, tributary to Santa Ana River.

\begin{tabular}{|c|c|c|}
\hline Date. & Hydrographer. & $\begin{array}{c}\text { Dis- } \\
\text { charge. }\end{array}$ \\
\hline 1898. & & Sec feet. \\
\hline Apr. 12 & J. B. Lippincott & 0.20 \\
\hline Apr. 29 & .... do ........... & .20 \\
\hline $\begin{array}{c}\text { June } 12 \\
1899 .\end{array}$ & $\ldots$ do $\ldots . . . . . . . .$. & .12 \\
\hline May 31 & S. G. Bennett & .23 \\
\hline June 15 & - do & .17 \\
\hline July 15 & 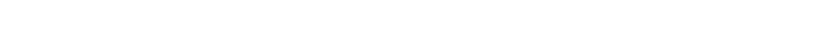 & .12 \\
\hline $\begin{array}{c}\text { Aug. } 24 \\
1900 .\end{array}$ & 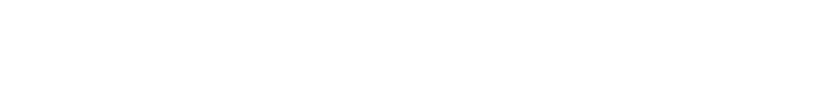 & .11 \\
\hline Apr. 14 & S. G. Bennett & .29 \\
\hline July 13 & 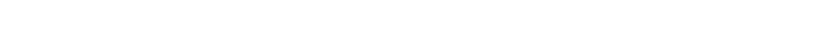 & .09 \\
\hline Oct. 2 & W. W. Cockins, $\mathbf{j r} \ldots \ldots \ldots \ldots$ & .12 \\
\hline
\end{tabular}

Discharge measurements of Redlands or South Fork ramal weir at Sambl Box. tributary to Santa Ana River.

\begin{tabular}{|c|c|c|}
\hline Date. & Hydrographer & $\begin{array}{l}\text { Dis- } \\
\text { charge. }\end{array}$ \\
\hline 1896. & & Sec.feet. \\
\hline July 29 & J. H. Quinton ....... & 40.62 \\
\hline $\begin{array}{c}\text { Nov. } 21 \\
1898 .\end{array}$ & J. B. Lippincott .......... & 12.00 \\
\hline Jan. 8 & J. B. Lippincott ....... & 21.32 \\
\hline Mar. 9 & H. Crowe . . . . . . . & 22.22 \\
\hline Apr. 12 & J. B. Lippincott ........ & 16. 70 \\
\hline Apr. $\quad 29$ & $\ldots d o \ldots \ldots$ & 13.00 \\
\hline June 12 & , _ & 18.40 \\
\hline July 23 & $\ldots$. do . . . . . . & 15.00 \\
\hline ept. 8 & do $\ldots \ldots \ldots$ & 15.40 \\
\hline Oct. 18 & F. H. Olmsted ....... & 7.26 \\
\hline Nov. 9 & . . . do . . . . . . . . . . & 10.20 \\
\hline $\begin{array}{c}\text { Dec. } 8 \\
1899 .\end{array}$ & 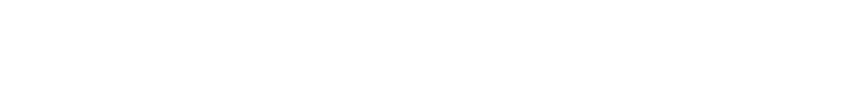 & 12.00 \\
\hline Jan. 12 & S. G. Bennett. & 15.10 \\
\hline Feb. 18 & .... do. & 15. 70 \\
\hline Mar. 23 & . . do. ............ & 17.00 \\
\hline May 6 & $\ldots$. . do .... & 15.49 \\
\hline May 31 & $\ldots$ & 14.67 \\
\hline June 15 & - & 7.76 \\
\hline June $2 \tau$ & .... do ...... & 12.40 \\
\hline July 15 & 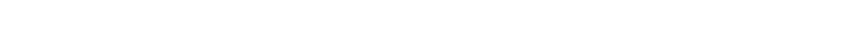 & 12. 70 \\
\hline Aug. 24 & $\ldots \ldots \ldots \ldots \ldots \ldots$ & 5.7 \\
\hline
\end{tabular}


Discharge measurements of Redlands or South Fork canal weir. ete.-C'ontil.

\begin{tabular}{|c|c|c|}
\hline Date. & Hydrographer. & $\begin{array}{l}\text { Dis- } \\
\text { charge. }\end{array}$ \\
\hline 1900. & & setefert. \\
\hline Apr. 14 & S. G. Bennett ........ & 12.10 \\
\hline July 13 & $\ldots$... do . . . . . . . . . & $10.6 \tilde{5}$ \\
\hline $\begin{array}{c}\text { Oct. } \quad 2 \\
1901 .\end{array}$ & W. W. Cockins, jr & 6.25 \\
\hline Mar. 30 & S. G. Bennett & $: 30.00$ \\
\hline May 31 & ..... do ...... & 19.60 \\
\hline July 6 & $\ldots$... do.......... & 19.91 \\
\hline Aug. 20 & $\ldots$ do $\ldots \ldots \ldots$. & 16.75 \\
\hline Oct. 8 & $\ldots$ do & 24.10 \\
\hline $\begin{array}{c}\text { Dec. } \quad 5 \\
1902 .\end{array}$ & , do & 14.27 \\
\hline July 10 & S. G. Bennett ..... & 10.06 \\
\hline Sept. 3 & W. B. Clapp & 14.60 \\
\hline Nov. 5 & S. G. Bennett $\ldots \ldots \ldots \ldots$ & $\tau .55$ \\
\hline
\end{tabular}

Discharge measurements of Reallamds or Bolen tumnel, tributary to Santa Ana River.

\begin{tabular}{|c|c|c|}
\hline Date. & Hydrographer. & $\begin{array}{c}\text { Dis- } \\
\text { (-harge. }\end{array}$ \\
\hline 1896. & & sec-feet. \\
\hline Nov. 21. & J. B. Lippineott & 1.00 \\
\hline 1898. & & \\
\hline June 12 & J. B. Lippincott. & 1.24 \\
\hline Sept. $\quad \forall$ & 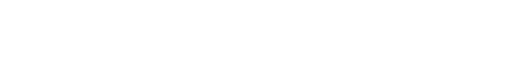 & 1.24 \\
\hline 1899. & & \\
\hline June 15 & S. G. Bennett . . . . & .67 \\
\hline July 15 & $\ldots$ do . . . . . . . & 1.03 \\
\hline $\begin{array}{c}\text { Aug. } 24 \\
1900 .\end{array}$ & - . . do ............... & 1.10 \\
\hline Apr. 14 & S. G. Bennett & .88 \\
\hline July 13 & $\ldots$ do $\ldots . . . . . .$. & .84 \\
\hline $\begin{array}{c}\text { Oct. } \quad 2 \\
1901 .\end{array}$ & 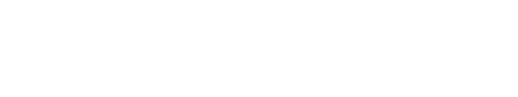 & .85 \\
\hline July 6 & S. G. Bennett & 1.40 \\
\hline $\begin{array}{c}\text { Dec. } 5 \\
1902 .\end{array}$ & $\ldots$ do $\ldots . . . . . . . . .$. & .90 \\
\hline July 10 & - do & .90 \\
\hline
\end{tabular}


Discharge measmements of Santa . Lua Canal, San Bernardino County. a

\begin{tabular}{|c|c|c|}
\hline Date. & Hydrographer. & $\begin{array}{c}\text { Dis- } \\
\text { charge. }\end{array}$ \\
\hline 1896. & & sec-feet. \\
\hline June 20 & J. B. Lippincott & 18.28 \\
\hline July 28 & J. H. Quinton ... & 14.98 \\
\hline Nov. 21 & J. B. Lippincott - & 3.50 \\
\hline $189 \%$ & - & \\
\hline Jan. $2 \pi$ & J. B. Lippincott & 4.00 \\
\hline Mar. 4 & _. _ do . . . . . . & 5.00 \\
\hline June 15 & $\ldots$. _ do . . . . & 19.00 \\
\hline July 1 & $\ldots$. $d o \ldots \ldots$ & 18.50 \\
\hline July 6 & A. Q. Campbell & 12.42 \\
\hline July 6 & $\ldots$ do . . . . . & 11.02 \\
\hline Aug. 8 & $\ldots . . . d o \ldots$ & 18.68 \\
\hline Aug. 31 & $\ldots$. . . do . . & 18.49 \\
\hline Sept. 30 & $\ldots$. . do _..... & 22.95 \\
\hline $\begin{array}{c}\text { Nov. } 14 \\
1898 .\end{array}$ & . . . do . . . . . & ๆ.29 \\
\hline Jan. 8 & A. Q. Campbell & 8.72 \\
\hline Mar. 9 & $\ldots$ do $\ldots \ldots \ldots \ldots$ & 7.04 \\
\hline Apr. $\quad 2$ & J. B. Lippincott. . . . . & 12.66 \\
\hline Apr. 12 & ... do _ . . . & 7.67 \\
\hline June 12 & $\ldots$.... do ..... & 3.92 \\
\hline July 23 & $\ldots$. & 5.34 \\
\hline Sept. 8 & $\ldots$ do . . . . . . . & 1. 66 \\
\hline Oet. 18 & F. H.Olmsted & 7.92 \\
\hline Nov. 9 & $\ldots$. . do ........ & 19.50 \\
\hline $\begin{array}{c}\text { Dec. } \quad 8 \\
1899 .\end{array}$ & $\ldots$ do ........ & 20.60 \\
\hline Jan. 12 & S. G. Bennett ... & .00 \\
\hline Feb. 18 & $\ldots$ do _........ & 4.00 \\
\hline Mar. 23 & $\ldots$ do $\quad \ldots \ldots$ & 7.60 \\
\hline May 6 & $\ldots$ & 3.40 \\
\hline May 31 & do & 1.10 \\
\hline June 15 & $\ldots$. & .20 \\
\hline July 15 & ............... & .00 \\
\hline July 27 & $\ldots d 0, \ldots \ldots$ & .00 \\
\hline Aug. : 24 & 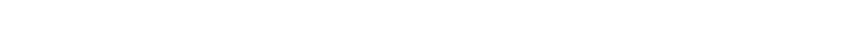 & .00 \\
\hline
\end{tabular}

a For total flow of river and canal see Santa Ann River, total flow. 
Discharge measurements of Santu ina ('anal, etc.-Continned.

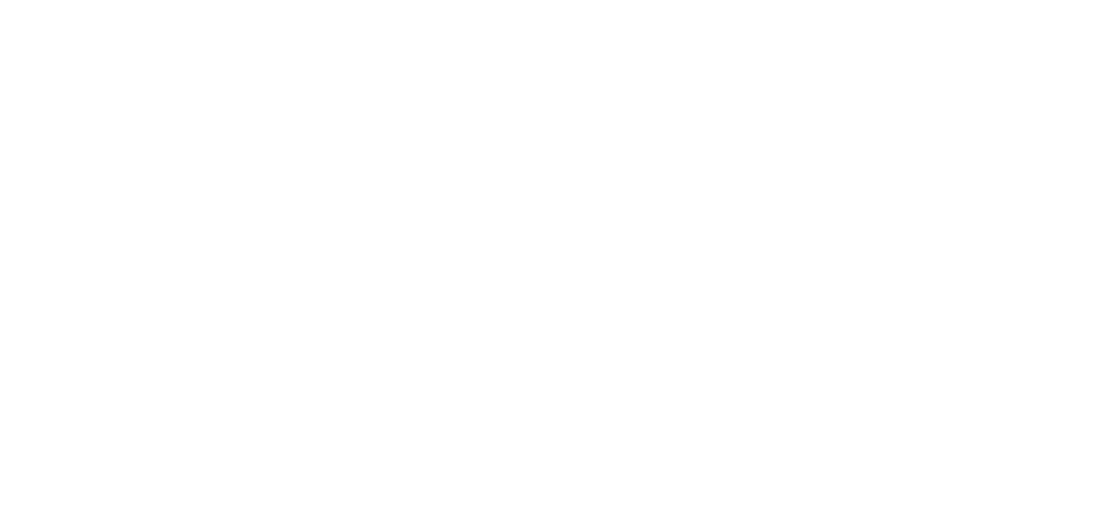

Discharge measurements of Santa Alua River and Canal at Warm spring. San Beruardino Connty.

\begin{tabular}{|c|c|c|c|}
\hline Date. & Hydrographer. & $\begin{array}{c}\text { Gage } \\
\text { height. }\end{array}$ & $\begin{array}{l}\text { Dis- } \\
\text { ،harge, }\end{array}$ \\
\hline 1896. & & Feet. & Siec-feet. \\
\hline Apr. 27 & J. A. Vogleson _... & & 51.00 \\
\hline July :25 & J. H. Quinton ....... & & 7.00 \\
\hline June 20 & J. B. Lippincott $\ldots \ldots$ & & $" 61 . \%$ \\
\hline \multirow[t]{2}{*}{ Do } & _. _. do _ _ _ _ _ _ _ & & b18.28 \\
\hline & Total _... & & 80.05 \\
\hline 1896. & & & $\cdots$ \\
\hline \multirow{3}{*}{$\begin{array}{c}\text { July } 28 \\
\text { Do }\end{array}$} & J. H. Quinton . & 1.29 & 459.72 \\
\hline & $\ldots$. $\|_{0} \ldots \ldots \ldots$ & & 714.98 \\
\hline & Total & & $\tau+. r 0$ \\
\hline \multirow{3}{*}{$\begin{array}{r}\text { Nov. } 21 \\
\text { Do }-\end{array}$} & J. B. Lippineott & .98 & a31.68 \\
\hline & $\ldots d 0 \ldots . .$. & & 13.50 \\
\hline & Total & & $3 \pi .18$ \\
\hline Nov. 21 & J. B. Lippincott & & $c 2 \pi .40$ \\
\hline 1897. & & & \\
\hline \multirow{3}{*}{$\begin{array}{r}\text { Jan. } 2 \tau \\
\text { Do } . .\end{array}$} & J. B. Lippincott . ... & & $a 43.58$ \\
\hline & $\ldots$ do ...... & & $b 4.00$ \\
\hline & Total - & & $4 \pi .58$ \\
\hline \multirow{3}{*}{$\begin{array}{c}\text { Mar. } 4 \\
\text { Do } .\end{array}$} & J. B. Lippincott .. & & $a 100.70$ \\
\hline & $\ldots$ do _.......... & & b.5.00 \\
\hline & Total & & 105.70 \\
\hline
\end{tabular}


Discharge measurements of Santa Ana River and Canul, etc.--Continued.

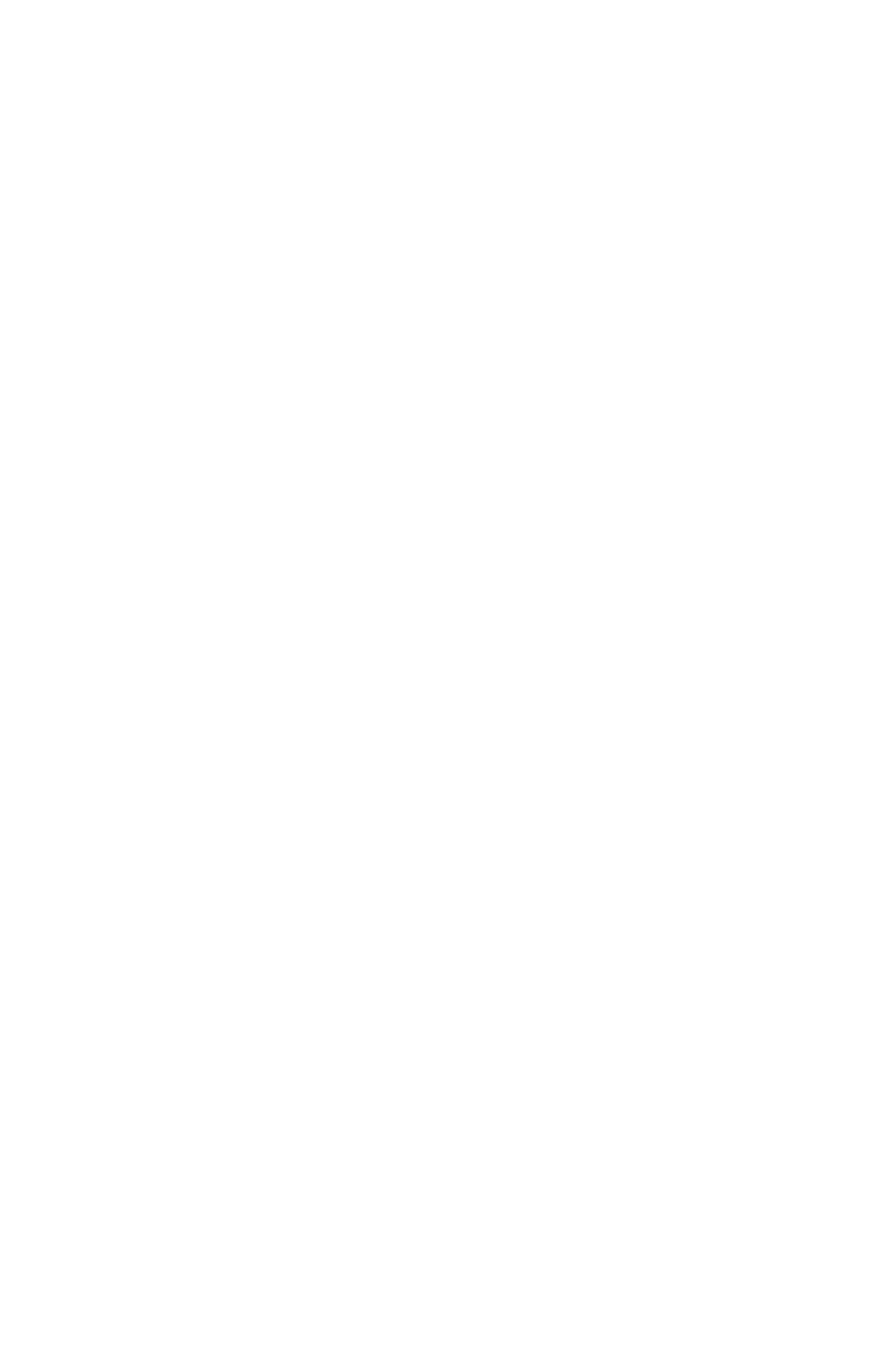


Discharge measurements of Santa Ana River and Canal, etc.-Continued.

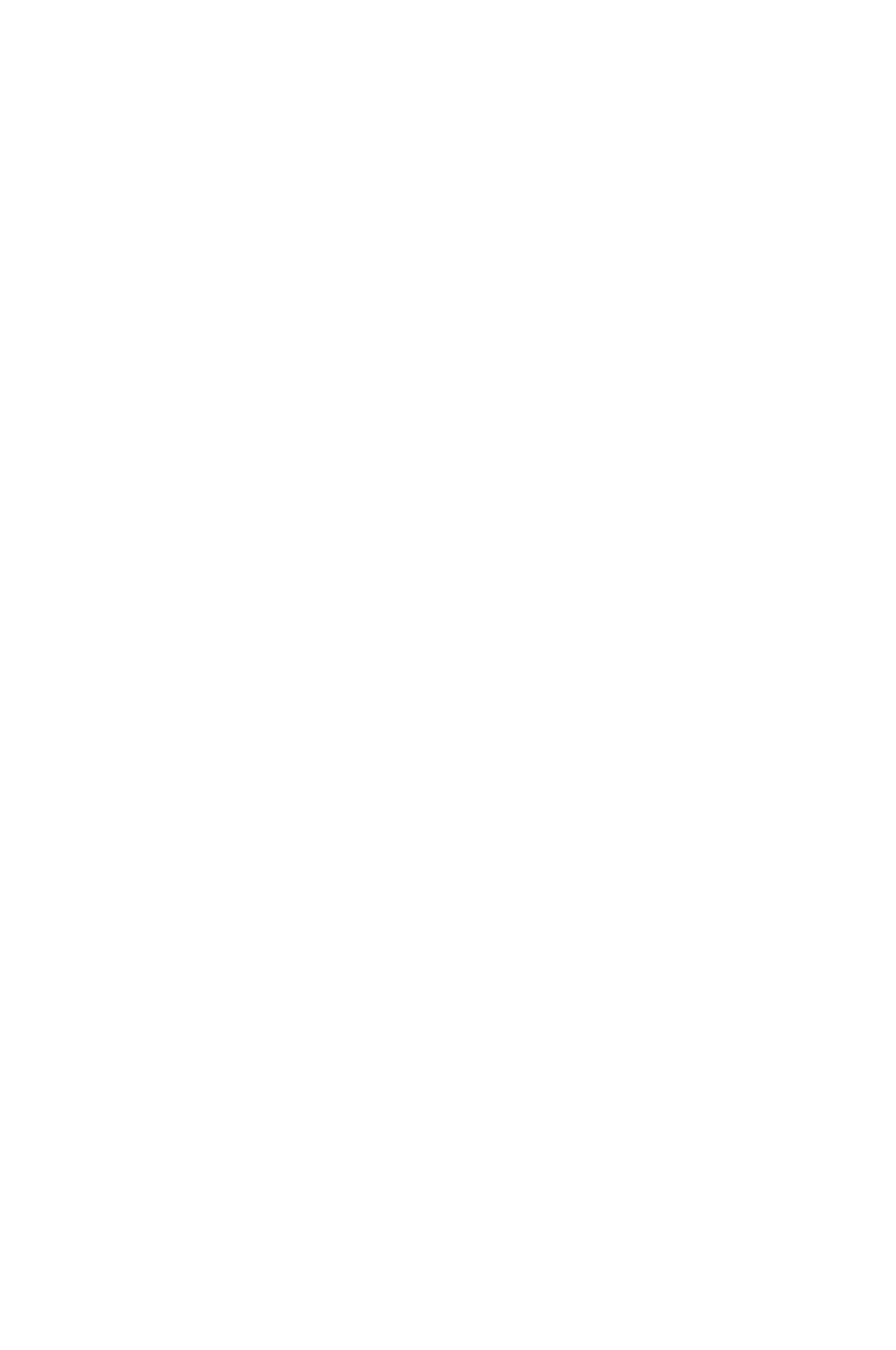

a Abore Santa Ana Canal intake.

$b$ River.

"Canal.

"Total water from sianta Aua (anal wasted above gaging station.

e New rod. 
Discharge measurements of Santa Ana River and Canal, "te-Continued.

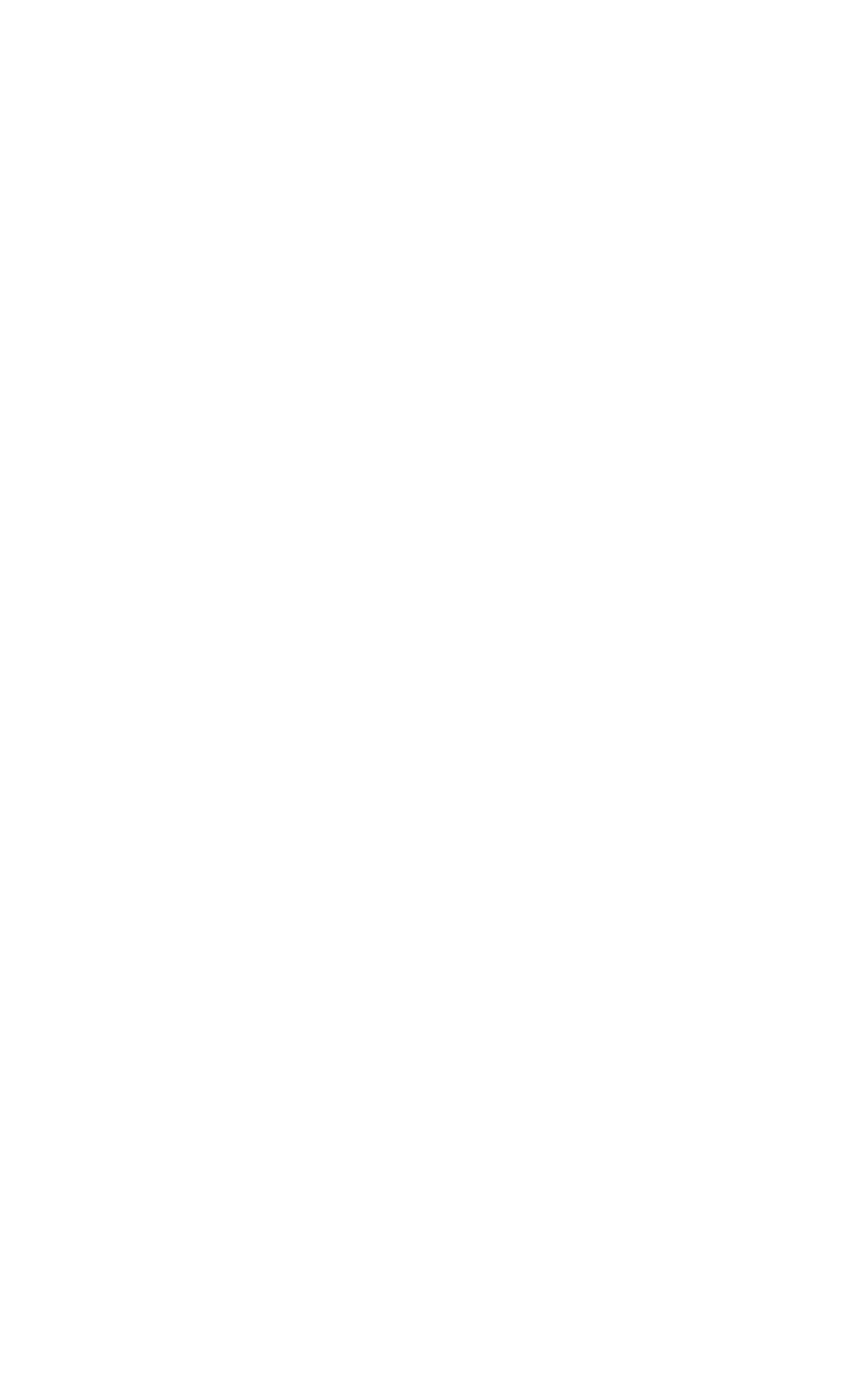


Discharge measurements of Santr Ana River and Canal, etc.-Continned.

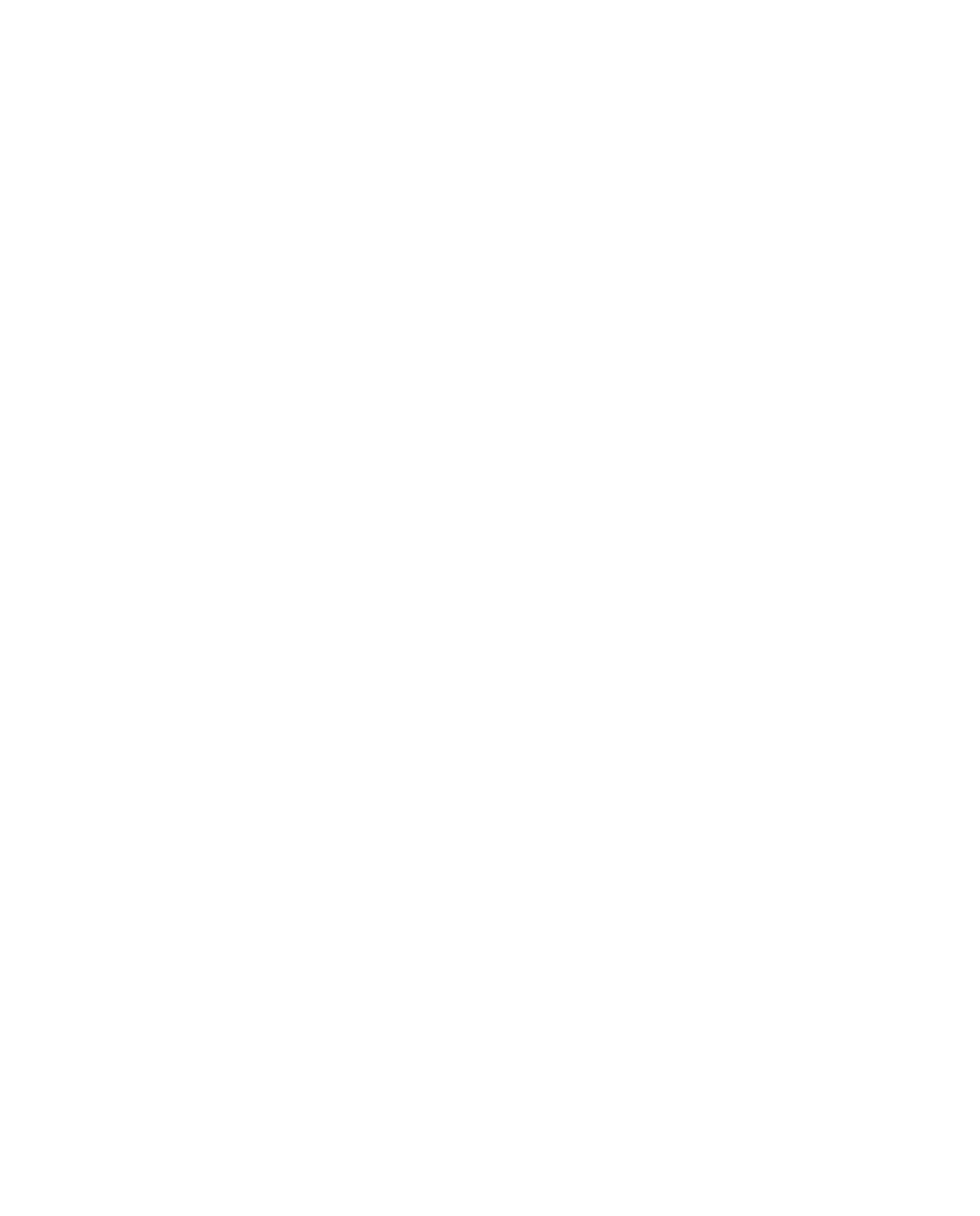




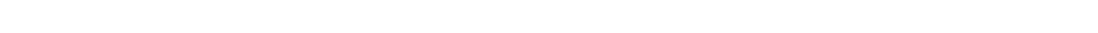
('ounty.

\begin{tabular}{|c|c|c|c|}
\hline Date. & 'grapher. & & $\begin{array}{l}\text { Dis- } \\
\text { charge. }\end{array}$ \\
\hline 1896. & & Feet. & Sec-feet. \\
\hline une 20 & J. B. Lippincott_ & & 61.77 \\
\hline July 28 & $\ldots \ldots \ldots$ & & 59.7 \\
\hline $\begin{array}{c}\text { Nov. } 21 \\
189 \pi .\end{array}$ & $\ldots$ & 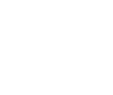 & 31.6 \\
\hline an. 27 & J. B. Lipl & & 43.5 \\
\hline Mar. 4 & -d & & $100 . \%$ \\
\hline June 15 & $\ldots$ do & 1.15 & 3.7 \\
\hline July 1 & $\ldots \ldots$ & 1.20 & ร2.2 \\
\hline July 6 & . . do .... & 1.11 & 60.3 \\
\hline ng. 8 & ... do & & 56.2 \\
\hline pt. 30 & $\ldots \ldots \ldots$ & 1.13 & 2.5 \\
\hline $\begin{array}{l}\text { fov. } 14 \\
1898 .\end{array}$ & $\ldots \ldots \ldots \ldots$ & 1.25 & 39.9 \\
\hline Jan. 8 & A. Q. C & 1.00 & 25.5 \\
\hline Mar. 9 & - & 1.05 & 43.7 \\
\hline Apr. 11 & $\ldots \ldots \ldots \ldots$ & .98 & 31.6 \\
\hline Apr. $\quad 29$ & . . do & .90 & 29.6 \\
\hline June 12 & $\ldots$ & 1.10 & 35.1 \\
\hline July 23 & $\ldots \ldots \ldots \ldots \ldots$ & 1.10 & 42.2 \\
\hline ept. 8 & $\ldots \mathrm{do} \ldots \ldots \ldots$ & $1.0 \%$ & $3 \tilde{.} .0$ \\
\hline Oct. 18 & F.H. Olmsted $\ldots \ldots \ldots \ldots$ & .95 & 22.7 \\
\hline ov. 9 & do & 1.10 & 21.7 \\
\hline $\begin{array}{c}\text { Dec. } \quad 8 \\
1899 .\end{array}$ & 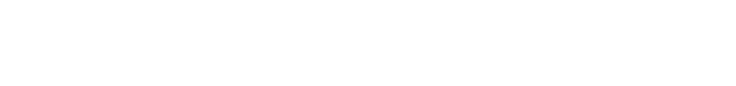 & 1.13 & 24.7 \\
\hline Jan. 12 & . & 1.07 & 38.0 \\
\hline eb. 18 & $\ldots \ldots \ldots \ldots \ldots$ & a2.16 & 8.1 \\
\hline Iar. 23 & $\ldots \ldots \ldots \ldots \ldots \ldots$ & 2.30 & 29.1 \\
\hline May 6 & $\ldots$ do $\ldots \ldots \ldots \ldots$. & 2.45 & 25. \\
\hline May 31 & $\ldots$ do $\ldots \ldots$. & 2.27 & 21.0 \\
\hline June 15 & -do $\ldots \ldots \ldots \ldots$ & 2.21 & 19.6 \\
\hline July 15 & 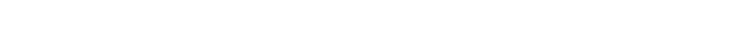 & 2.30 & 25.9 \\
\hline July 27 & 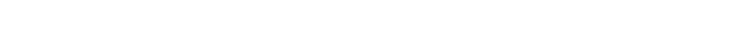 & 2.30 & 23.5 \\
\hline $\begin{array}{c}\text { Aug. } 24 \\
1900 .\end{array}$ & $\ldots \ldots \ldots \ldots \ldots$ & 1.85 & 10.8 \\
\hline Apr. 14 & S. G. & 2.25 & 22.6 \\
\hline May 5 & . . do & 2.20 & 24. \\
\hline aly 13 & $\ldots \ldots \ldots$ & & 22. \\
\hline ov. 20 & 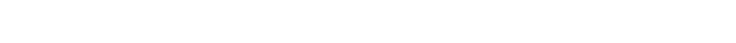 & $31 . \% 0$ & 102. \\
\hline . & 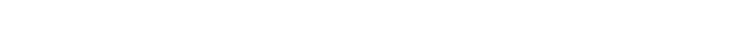 & ..... & $c 15$. \\
\hline
\end{tabular}


Discharge measmements of Sonta Aur River at Warm Spring. ete.-Continued.

$$
\text { Date. }
$$

Mar. 4 S. G. Bemett

Mar. 30

Feb. 5

Eeb. 23

July 6

Aug. 20

Oct. 8

Dec. 5 1902.

May 31

July 10

Sept. 3

Nov. ,j
Hydrographer.

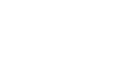

Discharge measurements of Santu tha River, Alsetrez ditch, in vicinity of Colton and Riverside, San Bernardino and Ricerside counties.

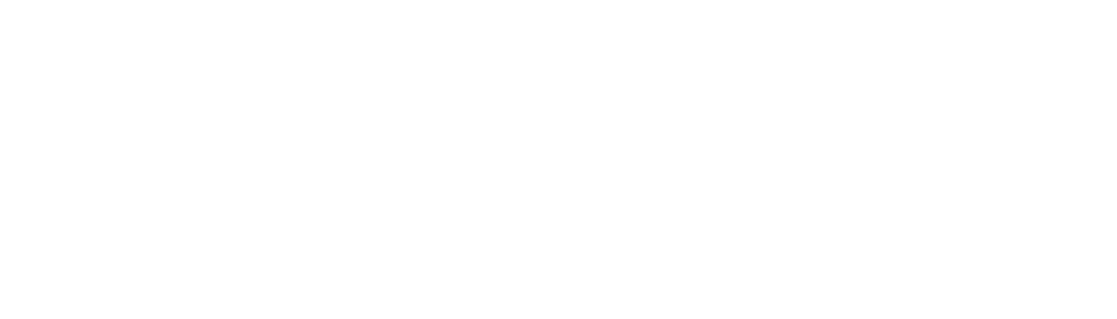

Discharge measurements of Euams loner ateh, Riverside rounty.

\begin{tabular}{|c|c|c|}
\hline Date. & Hydrographer. & $\begin{array}{c}\text { Dis- } \\
\text { charge. }\end{array}$ \\
\hline 1898. & & Sere-feet. \\
\hline June 19 & F.H. Olmsted & 5.68 \\
\hline $\begin{array}{c}\text { Aug. } 28 \\
1899 .\end{array}$ & 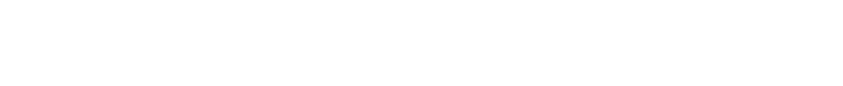 & 4.87 \\
\hline $\begin{array}{c}\text { Aug. } 30 \\
1900 .\end{array}$ & S. G. Bennett ... . . . & 4.48 \\
\hline July $2 \pi$ & S. G. Bennett $\ldots \ldots \ldots \ldots$ & $5.2 \pi$ \\
\hline $\begin{array}{c}\text { Oct. } 25 \\
1902 .\end{array}$ & K. Sanborn $\ldots \ldots \ldots$ & 4.36 \\
\hline Sept. 29 & K.Sanborn $\ldots \ldots \ldots \ldots \ldots \ldots$ & 5.35 \\
\hline
\end{tabular}


Discharge measurements of Evans upper ditch, Riverside County.

Date.

Hydrographer.

Dis-

charge.

1900.

July $2 \pi$

S. G. Bemnett.

Oct. 25

K. Sanborn

1901.

Aug. 30

J. B. Lippincott.

1902.

Sept. 29

K. Sanborm

Sept. 29 ido

a At north line Riverside County.

¿One mile south of north line $\mathrm{K}$ iverside County.

Estimated monthly aischarge of Santa Ana River at ITarm Spring, San Bernardino County, exclusive of Santa Ana canxl.

[Drainage area, 188 square miles.]

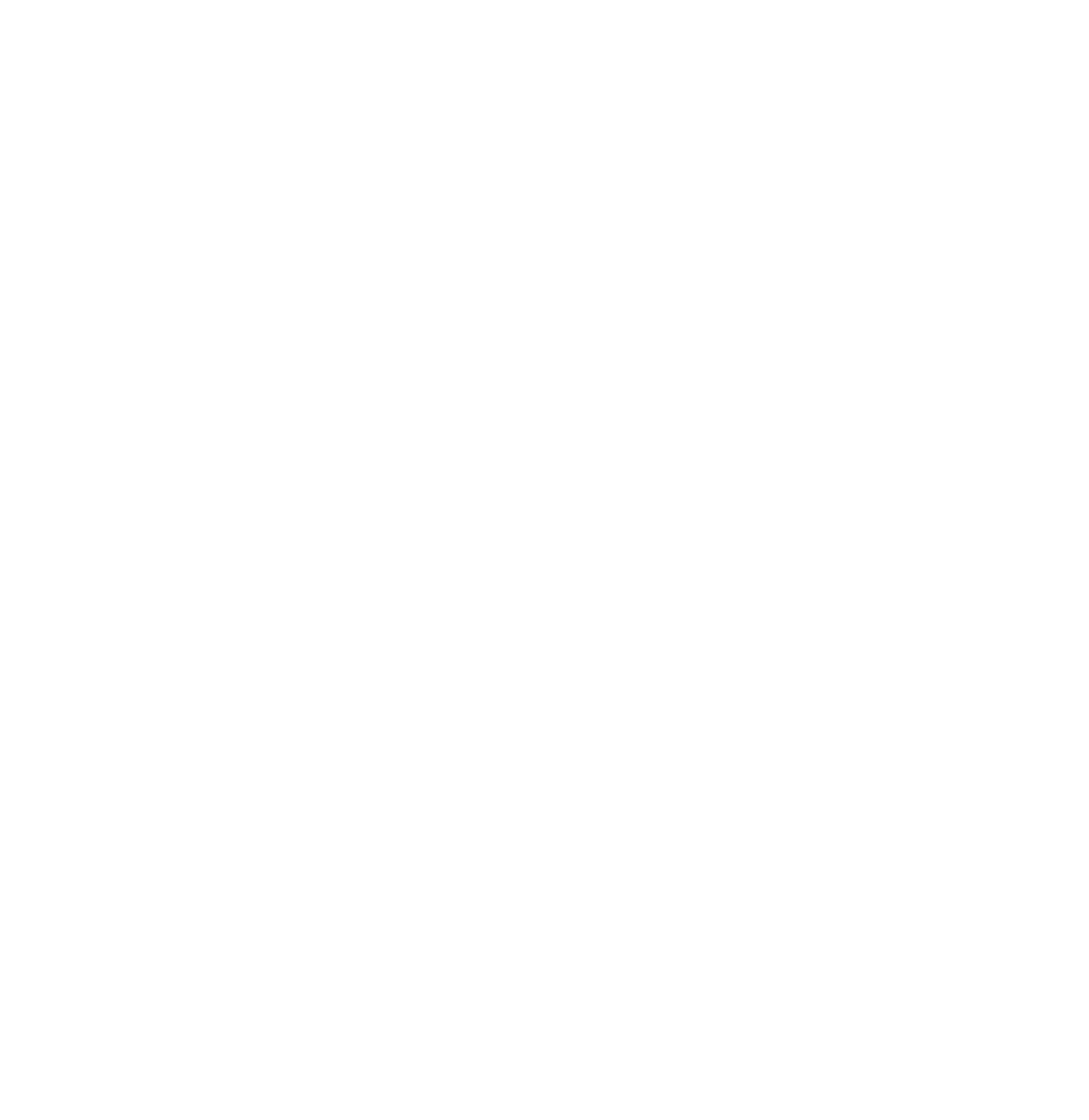


Estimated monthly discharge of Santa Ana River at 11 arm Spring. S'an Bernardino County, etc.-Continued.

\begin{tabular}{|c|c|c|c|c|c|c|}
\hline \multirow[b]{2}{*}{ Month. } & & Discharge. & \multirow[b]{2}{*}{ Mean. } & \multirow[b]{2}{*}{$\begin{array}{l}\text { Total dis- } \\
\text { charge. }\end{array}$} & \multicolumn{2}{|c|}{ Run off. } \\
\hline & Maximum. & Mininumu. & & & $\begin{array}{c}\text { Per } \\
\text { square } \\
\text { mile. }\end{array}$ & Depth. \\
\hline $1 \kappa 98$. & Sicemed feet. & secomd-feet. & secrefeet. & Acre-feet. & sec-feet. & Inches. \\
\hline January .... & .58 & 33 & 40 & 2,460 & 0.21 & 0.24 \\
\hline Tebruary & 76 & 33 & 40 & 2,221 & .21 & .22 \\
\hline 'Tarch ... & 40 & 25 & 32 & 1,968 & .17 & .20 \\
\hline April . & 34 & 28 & 31 & 1,845 & .16 & .18 \\
\hline ‘ay ........ & 149 & 26 & $5 \tilde{5}$ & 3,382 & .29 & .33 \\
\hline June $\ldots \ldots \ldots$ & 58 & 36 & 44 & 2,618 & .23 & .26 \\
\hline Tuly _....... & 53 & 33 & 41 & 2,521 & .22 & .25 \\
\hline August ... & 38 & 33 & 41 & 2,521 & .22 & .25 \\
\hline September. . . . . & 45 & 28 & 36 & 2,142 & .19 & .21 \\
\hline October ....... & 36 & 19 & 26 & 1,599 & .14 & .16 \\
\hline Tovember. ... & 34 & 18 & $2 \mathfrak{2}$ & 1,309 & .12 & .13 \\
\hline Jecember & 28 & 22 & 22 & 1,353 & .12 & .14 \\
\hline The year. & 149 & 18 & 36 & 25,939 & .19 & 2.57 \\
\hline 1901. & & & & & & \\
\hline Tanuary ...... & 600 & 31 & 78 & 4,796 & 0.41 & 0.47 \\
\hline Tebruary .. & 540 & 48 & 194 & 10.774 & 1.03 & 1.07 \\
\hline Iarch ...... & 114 & 45 & 68 & 4,181 & .36 & .41 \\
\hline April ......... & 107 & 39 & 43 & 2,559 & .23 & .26 \\
\hline 'Tay ........ & 68 & 35 & 42 & 2,582 & .22 & .25 \\
\hline Tune . . . . . . & 44 & 30 & $3 \pi$ & 2,202 & .20 & .22 \\
\hline Tuly _.... & 42 & 34 & $3 r$ & $\stackrel{2}{2} 337$ & .20 & .23 \\
\hline August & 200 & 31 & 50 & $3,0 \pi 4$ & .27 & .31 \\
\hline September & 60 & 42 & 49 & 2,916 & .26 & .29 \\
\hline October & 96 & 24 & 48 & 2,951 & .26 & .30 \\
\hline Tovember _... & 36 & $2 \mathfrak{2}$ & 26 & $1,54 i$ & .14 & .16 \\
\hline December ... & 25 & 21 & 24 & $1,4 \% 6$ & .13 & .15 \\
\hline The year & 600 & 21 & is & 41,395 & .31 & 4.12 \\
\hline
\end{tabular}


Extimated monthly discharge "f Sarta Ana canel at H'arm Spring, San Bernardino County.

[Drainage area, 188 square miles.]

\begin{tabular}{|c|c|c|c|c|c|c|}
\hline & & Discharge. & & & Run- & \\
\hline Month. & Maximum. & Minimum. & Mean. & $\begin{array}{l}\text { Total dis- } \\
\text { charge. }\end{array}$ & $\begin{array}{c}\text { Per } \\
\text { square } \\
\text { mile. }\end{array}$ & Depth. \\
\hline $\begin{array}{c} \\
\text { July } \ldots 96 . \\
\end{array}$ & Ser-fiet. & sec-feet. & $\begin{array}{c}\text { Sect-fert. } \\
14\end{array}$ & $\begin{array}{r}\text { Aere-feet. } \\
861\end{array}$ & $\begin{array}{c}\text { sec-feet. } \\
0.0 \%\end{array}$ & $\begin{array}{l}\text { Inches. } \\
0.08\end{array}$ \\
\hline August . . . . . . . & & & 14 & 861 & .07 & .08 \\
\hline September ... . & & & 14 & 833 & .07 & .08 \\
\hline October . . . . . & $\ldots$ & (n...... & 16 & 984 & .09 & .10 \\
\hline November. . . . . . . & & & 3.5 & 2,083 & .02 & .02 \\
\hline December ........ & & & 4.2 & 2,582 & .02 & .02 \\
\hline $189 \pi$ & & & & & & \\
\hline January _........ & 8.5 & 3.2 & 5.6 & 344 & 0.03 & $0.0: 3$ \\
\hline Februar: . . $\ldots \ldots \ldots$ & 6 & 0 & 4 & 222 & .02 & .02 \\
\hline March ............ & 6 & .5 & 5.2 & 320 & .03 & .03 \\
\hline April $\ldots \ldots$ & 12 & 0 & 3.8 & 226 & .02 & .02 \\
\hline May ........ . . . & 20 & 0 & 15 & 922 & .08 & .09 \\
\hline June . . . . . . . & 19 & 0 & 16.6 & 988 & .09 & .10 \\
\hline July ........... & 18.5 & 10.6 & 15.6 & 960 & .08 & .09 \\
\hline Angust ....... & 20 & 17.4 & 18.3 & 1,125 & .10 & .12 \\
\hline September ... & & $\ldots .$. & 20 & 1,190 & .11 & .12 \\
\hline October ...... & & & 12.4 & r6ะ & .07 & .08 \\
\hline November......... & & $\ldots$ & $\tilde{\imath}$ & 417 & .04 & .04 \\
\hline December .... . & & $\ldots$ & $\tau$ & 430 & .04 & .04 \\
\hline The year . & & $\ldots$ & 10.9 & 7,906 & .06 & .78 \\
\hline 1898 & & & & & & \\
\hline January .... . . . & & & 9 & 553 & 0.05 & 0.06 \\
\hline February ....... & & .. & 8 & 444 & .04 & .04 \\
\hline March ......... & & $\cdots$ & 8 & 492 & .04 & .04 \\
\hline April $\ldots . . . . . .$. & & $\ldots \ldots$ & 8 & $4 \% 6$ & .04 & .04 \\
\hline May . . . . . . & & $\ldots$ & 6 & 369 & .03 & .03 \\
\hline June . . . . . . . . . & $\ldots$ & $\ldots$ & 4 & 258 & .02 & .02 \\
\hline July . . . . . . & $\ldots \ldots$ & $\cdots$ & 2 & 123 & .01 & .01 \\
\hline August $\ldots \ldots \ldots$ & 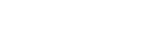 & $\ldots$ & 2 & 123 & .01 & .01 \\
\hline September ....... & $\ldots .$. & $\ldots$ & 2 & 119 & .01 & .01 \\
\hline October .......... & $\ldots . .$. & $\ldots \ldots$ & 0 & 0 & 0 & 0 \\
\hline November .... . . . & - n..... & $\mid \cdots \ldots \ldots$ & 0 & 0 & 0 & 0 \\
\hline December ... . . . . & $\ldots \ldots \ldots$ & …....... & 0 & 0 & $0^{\prime}$ & 0 \\
\hline The year & & $\ldots . .$. & 4 & $2,93 i$ & .02 & .26 \\
\hline 1901 & & & & & & \\
\hline March $\ldots \ldots$ & 6 & 0 & 2.71 & $16 i$ & 0.01 & 0.01 \\
\hline April ... . . . . . . & 4.62 & 0 & 2.34 & $13 \mathrm{C}$ & .01 & .01 \\
\hline May .. . . . & 4.62 & 3.8 & 3.96 & 245 & .01 & .01 \\
\hline
\end{tabular}


Estimated monthly discharge of Santa Ana River and canals at Warm spring, San Bernardino County."

[Drainage area, 188 square miles.]

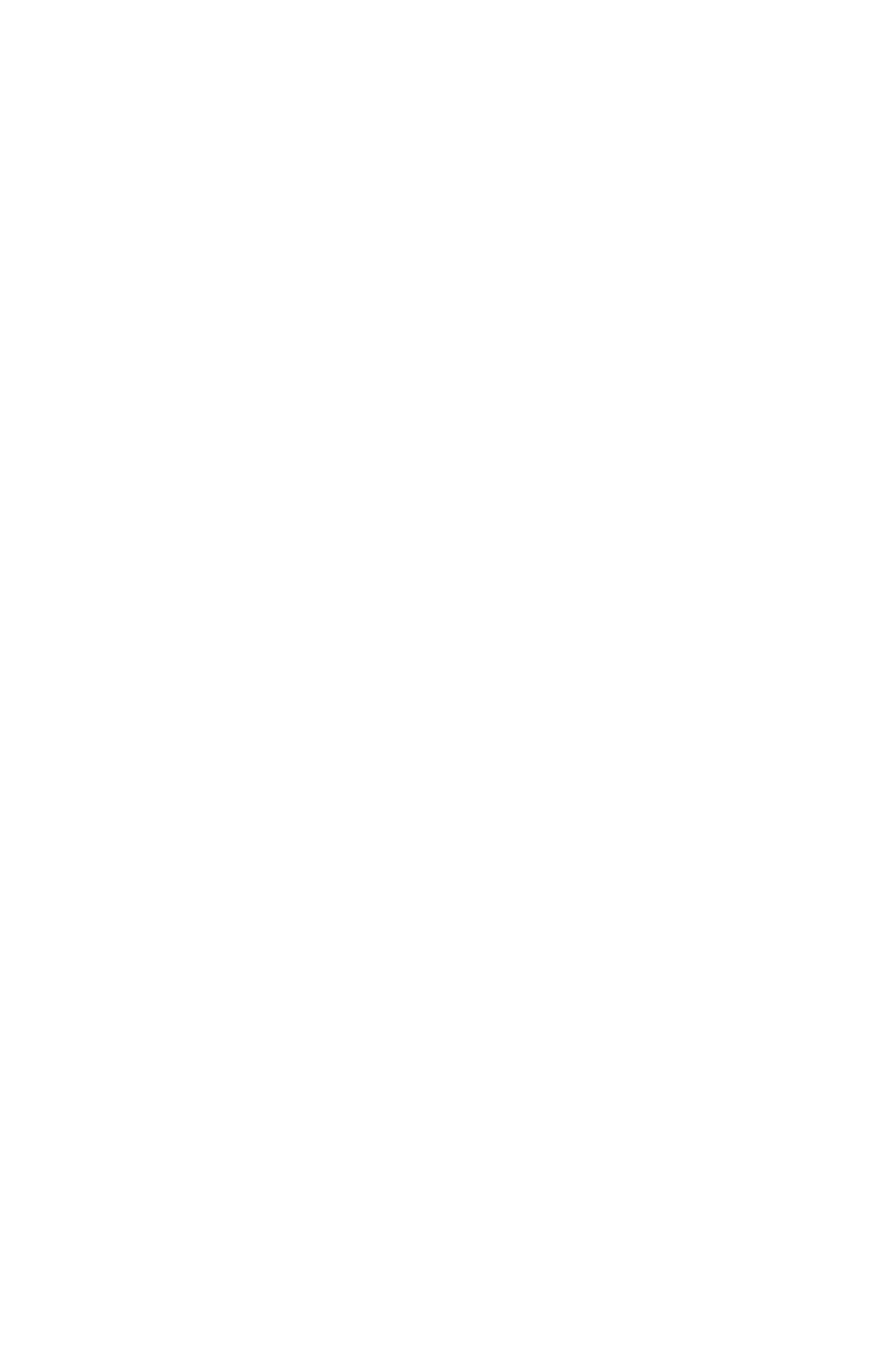

"Total flow. 
Estimated monthly discharge of Santa Ana River and canals at Warm Spring, San Bernardino County-Continued.

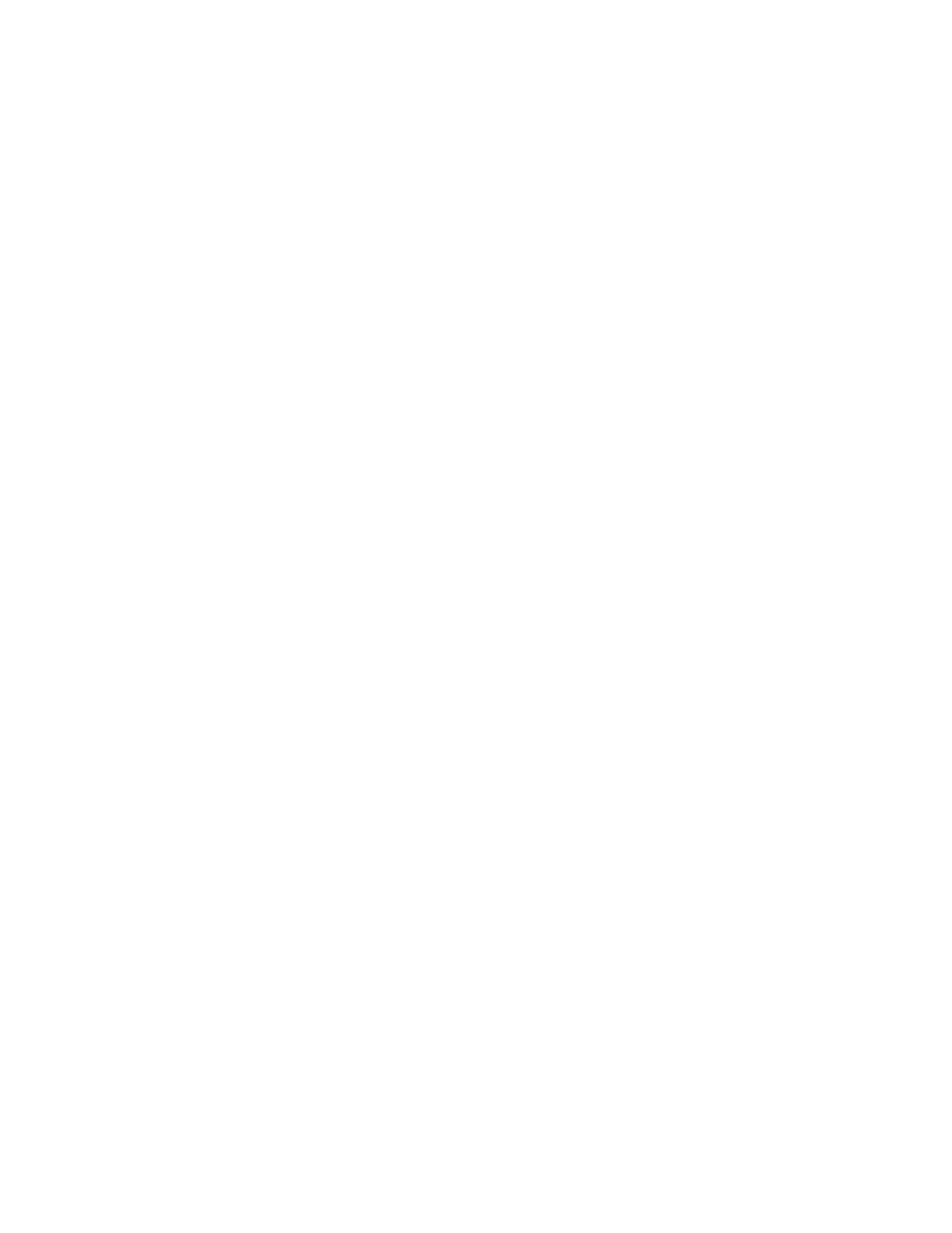


sstimated monthly discharge of Santa Ana River aud canals at Warm Spring, San Bernardino County-Continued.

\begin{tabular}{|c|c|c|c|c|c|c|}
\hline \multirow[b]{2}{*}{ Month. } & \multicolumn{3}{|c|}{ Discharge } & \multirow[b]{2}{*}{$\begin{array}{l}\text { Total dis- } \\
\text { charge. }\end{array}$} & \multicolumn{2}{|c|}{ Run-off. } \\
\hline & Maximum. & Minimum. & Mean. & & $\begin{array}{c}\text { Per } \\
\text { square } \\
\text { mile. }\end{array}$ & Depth. \\
\hline 1901. & Sec.-feet. & Sec:-feet. & Sec.feet. & Acre-feet. & Sec.feet. & Inchess. \\
\hline 「anuary ..... . . . & 600 & 31 & 78 & 4,796 & 0.41 & 0.47 \\
\hline Tebruary _...... & 540 & 48 & 194 & 10, $\approx \pi 4$ & 1.03 & 1.07 \\
\hline March ... & 114 & 45 & 68 & 4,181 & .36 & .41 \\
\hline April ... & 107 & 39 & 43 & 2,559 & .23 & .26 \\
\hline May ..... & 68 & 35 & 42 & 2,582 & .22 & .25 \\
\hline Iune .... & 44 & 30 & 37 & $2,20^{2}$ & .20 & .22 \\
\hline July _......... & 42 & 34 & 38 & 2,337 & .20 & .23 \\
\hline August . . . . . . . & 200 & 31 & 50 & 3,074 & .27 & .31 \\
\hline September _. . . . . . & 60 & 42 & 49 & 2,916 & .26 & .29 \\
\hline Jctober ............ & 96 & 24 & 48 & 2,951 & .26 & .30 \\
\hline November........ & 36 & 22 & 26 & $1, \overline{5} 4 \%$ & .14 & .16 \\
\hline December ..... . . & 25 & 21 & 24 & 1,476 & .13 & .15 \\
\hline The year .... & 600 & 21 & 58 & 41,395 & .31 & 4.12 \\
\hline 1902 & & & & & & \\
\hline January ... . . . . . . . & 45 & 20 & 24 & 1,476 & 0.13 & 0.15 \\
\hline February ........ & 240 & 20 & 38 & 2.110 & .21 & .22 \\
\hline March ............ & 485 & 41 & 79 & 4,858 & .43 & .50 \\
\hline April $\ldots \ldots \ldots$ & 71 & 43 & s1 & 3,035 & .28 & .31 \\
\hline Tay ....... & 45 & 31 & 36 & 2,214 & .20 & .23 \\
\hline June $\ldots \ldots \ldots$ & 47 & 23 & 33 & 1,964 & .18 & .20 \\
\hline Tuly $\ldots \ldots$ & 32 & 33 & 26 & 1,599 & .14 & .16 \\
\hline August ....... & 30 & 22 & 25 & 1,537 & .14 & .16 \\
\hline September ... . . . . & 29 & 22 & 24 & 1,428 & .13 & .15 \\
\hline October ..... . . . . . . & $\tilde{5} 5$ & 30 & 40 & 2,460 & .22 & .25 \\
\hline 'Tovember... . . . . & 43 & 19 & 24 & 1,428 & .13 & .15 \\
\hline Jecember . . . . . . . & 27 & 19 & 22 & 1,353 & .12 & .14 \\
\hline The year...... & 485 & 19 & 35 & 25,462 & .19 & 2.62 \\
\hline
\end{tabular}

IRR $81-03+20$ 
Inischarge measurements of Santa Ana River at head of Gage canal, a

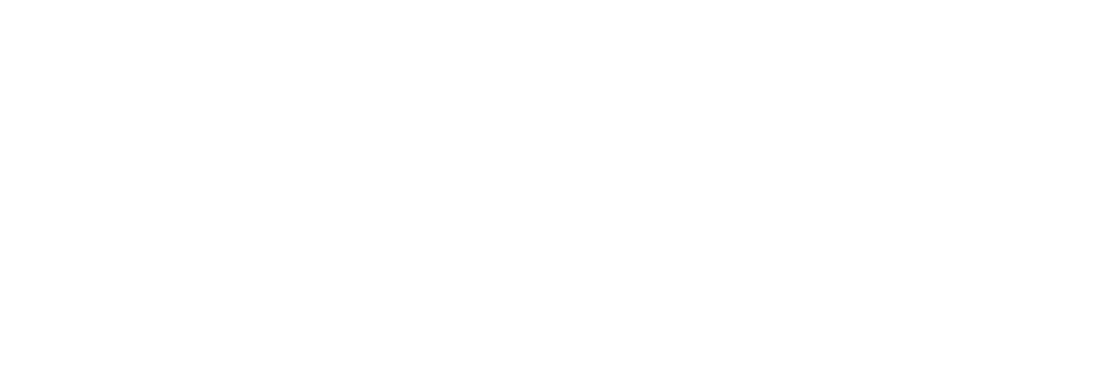

a See San Bernardino Valley, Gage canal.

$b$ Flood. Since that time floods as great as 4,000 second-feet have been observed.

Discharge measurements of Jurupa ranat.

\begin{tabular}{|c|c|c|}
\hline Date. & Hydrographer. & $\begin{array}{c}\text { Dis- } \\
\text { charge. }\end{array}$ \\
\hline 1898. & & Sec-feet. \\
\hline June 1 r & F.H. Olmsted & 13.83 \\
\hline July 1 & J. B. Lippincott and K. Samborn _ . $\ldots \ldots \ldots$ & $\gamma .11$ \\
\hline Aug. $2 r$ & F.H. Olmsted $\ldots \ldots$ & 10.18 \\
\hline Sept. 22 & J. B. Lippincott & 5.41 \\
\hline May 31 & S. G. Bennett . . . . . . . & 6.74 \\
\hline July 15 & . do $\ldots \ldots \ldots \ldots . . . . . . .$. & 13.14 \\
\hline 1899. & & \\
\hline Aug. 24 & S. G. Bemnett ...... & $" 4.28$ \\
\hline July 26 & $\ldots d o \ldots \ldots \ldots$ & $" 5.11$ \\
\hline 1900 & & \\
\hline July $2 \%$ & G. S. Bennett & 14.42 \\
\hline Oct. 19 & (2. & 14.05 \\
\hline
\end{tabular}

a Submerged flume above Colton bridge.

Discharge measurement of Santu Ana River below Jurupa ditch.

\begin{tabular}{|c|c|c|}
\hline Date. & Hydrographer. & $\begin{array}{l}\text { Dis- } \\
\text { charge. }\end{array}$ \\
\hline & & sec-feet. \\
\hline June $1 \%, 1898$ & F. H. Olmsted....... & $\begin{array}{r}9.74 \\
\end{array}$ \\
\hline
\end{tabular}

Discharge measurements of Santa Ana River belou Roubidoux, Evans Upper, and Trujillo ditches.

\begin{tabular}{|c|c|c|c|}
\hline \multicolumn{2}{|r|}{ Date. } & \multirow[t]{2}{*}{ Hydrographer. } & $\begin{array}{c}\text { Dis- } \\
\text { charge. }\end{array}$ \\
\hline & & & Sec.feet. \\
\hline July & 27,1900 & S. G. Bennett & 0.44 \\
\hline Oct. & 25,1900 & K. Sanborn ......... & .56 \\
\hline
\end{tabular}


Discharge measurements of Santa Ana River in vicinity of Colton and Riverside, San Bernardino and Riverside Connties.

RIVERSIDE WATER COMPANY'S LOWER CANAL.

\begin{tabular}{|c|c|c|}
\hline Date. & Hydrographer. & $\begin{array}{c}\text { Dis- } \\
\text { chargat. }\end{array}$ \\
\hline & & Sec-feet. \\
\hline June,- 1898 & K. Sanborm $\ldots \ldots$ & $10.2 \gamma$ \\
\hline Sept. - 1898 & - do $\quad$ do & 7.70 \\
\hline Mar.,-- 1899 & 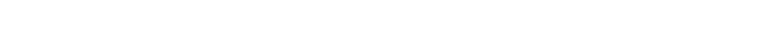 & 16.20 \\
\hline June,- 1899 & - do $\ldots \ldots-\ldots$ & 9.09 \\
\hline Aug. - 1899 & $\ldots$.... & ז.38 \\
\hline Mar. -, 1900 & $\ldots$ do ..... & 8.00 \\
\hline June,- 1900 & K. Sanborn _ . . . . . . $\ldots$ & 7.16 \\
\hline Sept. - 1900 & 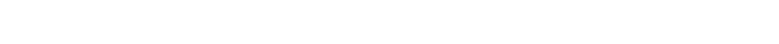 & 6.6 \\
\hline June 17,1898 & F. H. Olmsted & 9.27 \\
\hline June 18,1898 & do $\ldots$. & 11.27 \\
\hline & & $" 10.27$ \\
\hline July $2 \%, 1900$ & S. G. Bennett & 7.13 \\
\hline Aug. 30,1901 & J. B. Lippincott . . . & $b 4.52$ \\
\hline Sept. 30,1902 & K. Sanborn . . . . . . . & $3.0 \pi$ \\
\hline
\end{tabular}

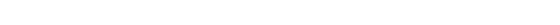

Aug. 30, 1899

S. (*. Bennett

$15 \% .4$

July 26,1900

do

" 43.3

ROUBIDOUX MITCH.

June 19. 1898

Ang. 28, 1898

July $2 \%, 1900$

Oct. 25,1900

Aug. 30, 1901

Sept. 30,1902
F. H. Olmsted

8.94

do

8.50

S. G. Bennett.

8.18

K. Samborn

\%. 80

J. B. Lippincott

8.75

K. Sanborn . . . . . . . . . . . . . . . . . . . . . . 19

SANTA ANA RIVER 1

Aug. 27, 1898 F. H. Olmsted.

0.50

a Mean for June 17 and 18.

b One-fourth of a nule below headworks; 10.4 second-feet wasted below point of measurement into river for Roubidoux Canal.

c See also Riverside Water Company s upper cunal, under san Bernardino Valley.

dIn flume above tunnel near Riverside Mesa. 


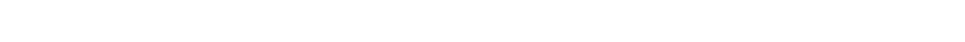
Riverside, re.-Continued.

SPRINA BREOK BELOW WHST RIVERSIDE BRIDGE.

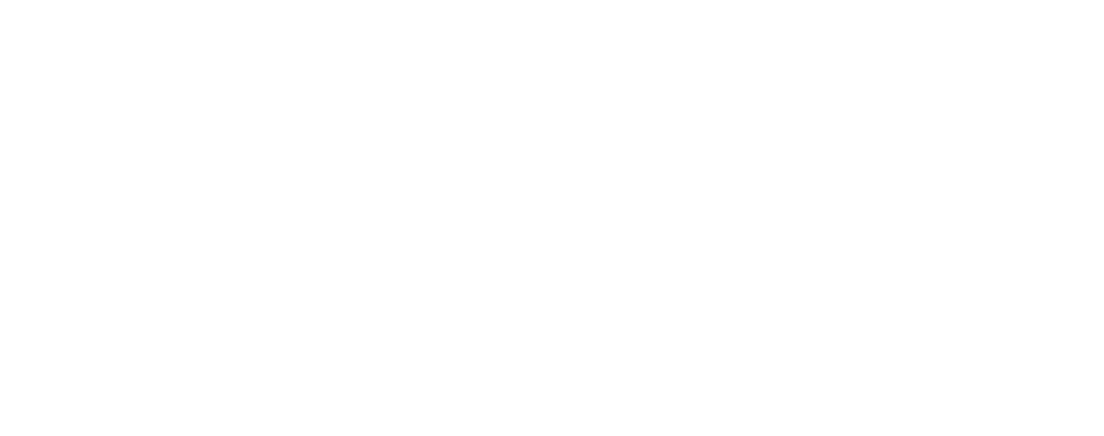

SANTA ANA RIVER BHLOW WHS' RIVERSIDE BRIDGE.

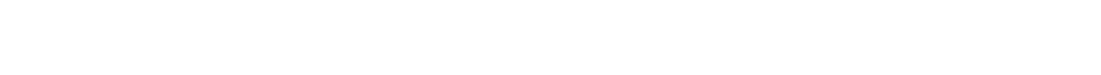

Aug. :30. 1901 . .. B. Lippincott . . . . . . . . . . . . . . . . . . . . $\quad 1.19$

NANTA ANA RIVER AT GALIIGERS FORD, I MLES BELOW WEST RIVERSHE BRIJGR.

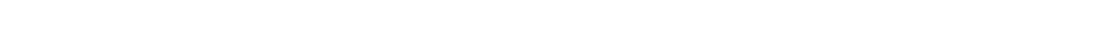

"Santa Ana River, West Riverside Bridge.

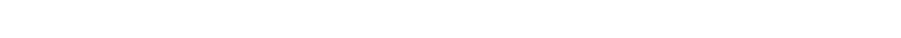

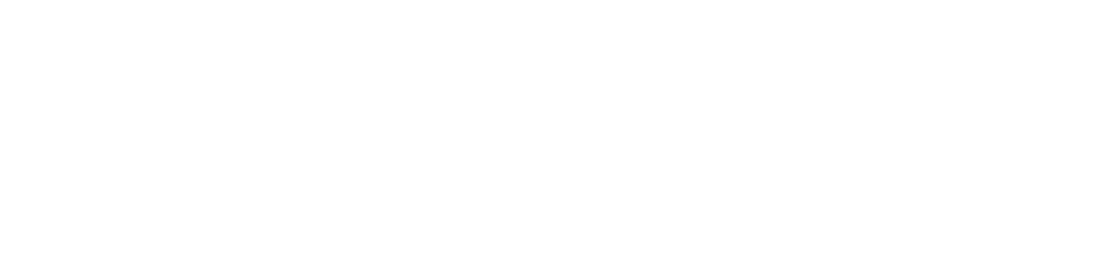

Discharge measurement of Santa Ana River 1, fun feet belou Poubidoun ditch intake.

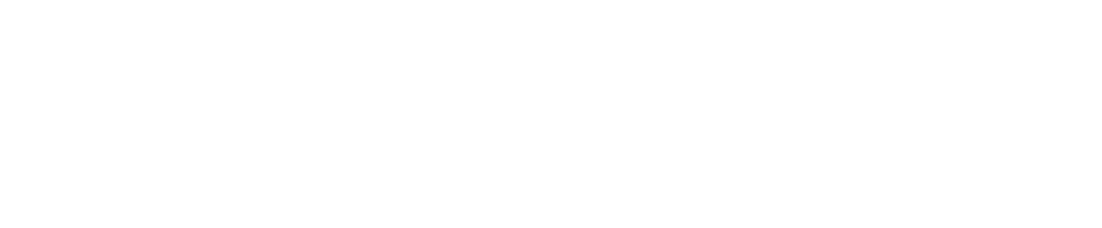


Discharge measurements of Santa Ana River in nicinity of Rincon. Riverside County.

ANAHEIM UNION CANAL.

\begin{tabular}{|c|c|c|c|}
\hline Date. & Hydrographer: & $\begin{array}{c}\text { Dis- } \\
\text { charge. }\end{array}$ & Remarks. \\
\hline- & - & Ner-feet. & 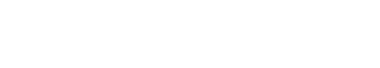 \\
\hline June $22,1 \times 98$ & F. H. Olmsted ....... & 34.74 & imiles below division box. \\
\hline Sept. 15,1899 & J. B. Lippincott . . . . & $2 \pi .92$ & \\
\hline Oct. 26,1899 & ... do ......... & $1 \% .14$ & 1 mile below Esperanza. \\
\hline Ang. 1.), 1900 & W.P.Sear'cy .... & $1 \times .3 \pi$ & \\
\hline Sept. $\quad 3,1900$ & . do $\ldots . . . . .$. & 18.22 & \\
\hline Ang. 31,1901 & $\ldots$ do .......... & 23.11 & \\
\hline
\end{tabular}

NANTA ANA RIVER AT AITBLRNDAIE BRIDGK.

July $1 \%, 18 \times 8$

Aug. 22, 1888

Sept. 15, 1888

Ang. 14, 1889

Sept. 28,1889

Ang. 13, 1890

Sept. 10.1891

Sept. 11, 1892

June 21, 1898

Aug. 30,1899

Sept. 12,1899

July 28,1900

Oct. 5,1900

Aug. 2\%, 1901

Aug. 31.1901
F. C. Finkle

do

do

do

do

do

do

do

F.H.Olmsted

S. G. Bennett

J. B. Lippincott . . . . . . .

S. G. Bennett

W. W. Cockins. jr

J. B. Lippincott.

do
14.6

13.3

14.2

1.5 .6

16.

22.3

25. 6

43.4

60. 00 Including ditches.

53.10 $\quad$ Do.

59.83

54.45 Do.

69.70 Do.

43. 70 Above Roberts ditch.

28.54 Do.

CASTILLO DITGH BELOW RIVERSIDH NARROWA.

Ang. 30, 1901

J. B. Lippincott

1.19

CHINO CREEK NEAR RINCON.

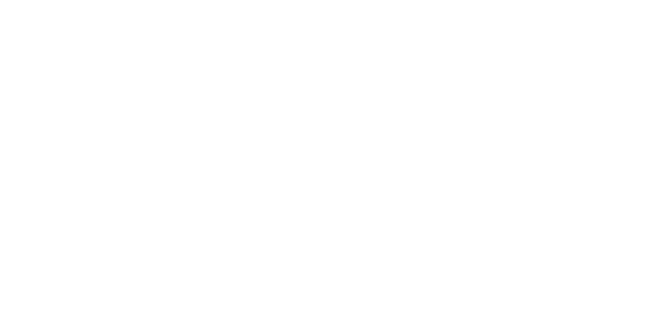


Discharge measurements of Santr Alua River in vicinity of Rincon, etc.-Cont'd.

CHINO CREEK NEAR RINCON-continued.

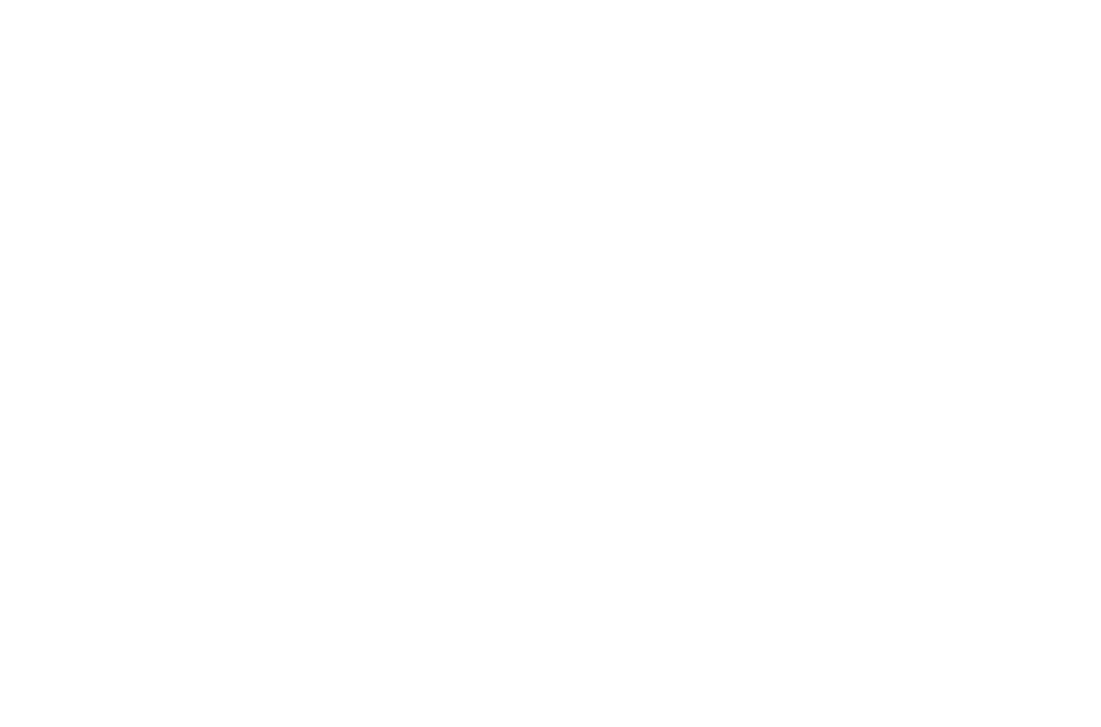

DTVISION BOX SANTA ANA ANI ANAHRIM CANALS.

June 22, 1898

Aug. 30, 1898

Ang. 30, 1899

Sept. 1.5, 1899

Oct. 25,1899

July 28,1900

Oct. 5,1900

Aug. 2\%, 1901

Aug. 31, 1901
F. H. Olmsted. do

S. G. Bennett

J. B. Lippincott do

S. G. Bennett

W. W. Cockins, jr ....

J. B. Lippinentt do
67.5

52.9

59.6

$71 . \%$

144. 7

49.7

T5. 1

64.5

5. 4

DURKEF DITCH.

Sept. 3, 1899

Sept. 13, 1899 July 28, 1900 Aug. 27. 1901 Aug. 31, 1901
J. B. Lippincott do

S. G. Bennett

J. B. Lippincott do
1.38 Near ranch honse.

6.14 Newberry east line.

1.80 At ranch house.

3.98

8. 24

SANTA ANA RIVER, OPPOSITE FSPERANZA STATION.

Oct. $26,1 \times 99$

J. B. Lippincott

49. 2 
Discharge measurements of Santa Ana River in vicinity of Rincon, ete.-Cont'd. FULLER DITCH.

\begin{tabular}{l|l|l|l}
\hline \multicolumn{1}{c|}{ Date. } & \multicolumn{1}{|c}{ Hydrographer. } & $\begin{array}{c}\text { Dis- } \\
\text { charge. }\end{array}$ \\
\hline & & $\begin{array}{r}\text { Ser.-feet. } \\
13.00\end{array}$ Said by Fuller to be carrying \\
this amount at intake.
\end{tabular}

SANTA ANA RIVER, ABOVE FUIJLR'S DIT'H,

\begin{tabular}{l|l|l|l|}
\hline Aug. 30,1901 & J. B. Lippincott . . . . . & 24.34 & Intake. \\
\hline
\end{tabular}

GIIIILAND's DITCH, AUBURNDALE BRTHUE.

Discharge measurement of Santa Ana River, Neuberry's east line.

Aug. 31,$1901 ;$ J. B. Lippincott ....... $\left|\begin{array}{c}\text { Hydrographer. } \\ \text { Dec.-feet. } \\ 40.7\end{array}\right|$ Remarks.

Discharge measurements of Newberry ditch.

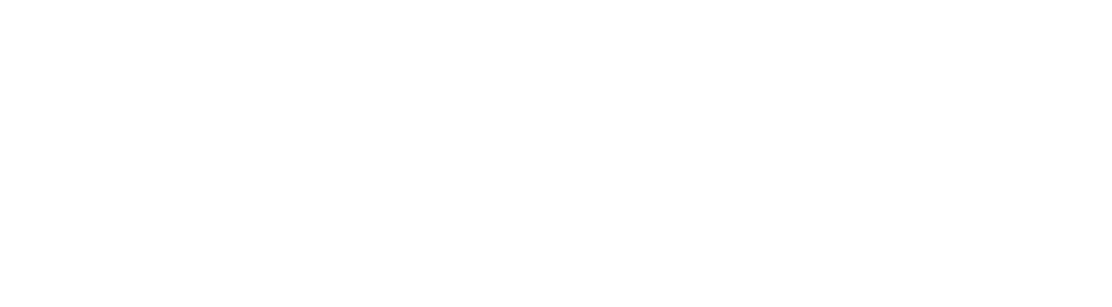

Discharge measurement of Newton ditch, below Narrou's.

\begin{tabular}{c|c|c|c}
\hline \multicolumn{1}{c}{ Date. } & Hydrographer. & $\begin{array}{c}\text { Dis- } \\
\text { charge. }\end{array}$ & Remarks. \\
\hline Aug. 30.1901 & J. B. Lippincott....... & $\begin{array}{r}\text { Sec.feet. } \\
7,04\end{array}$ \\
\hline
\end{tabular}


Discharge measurements of Santa Ana River 1 mile below railroad bridge, Rincon, Cal.

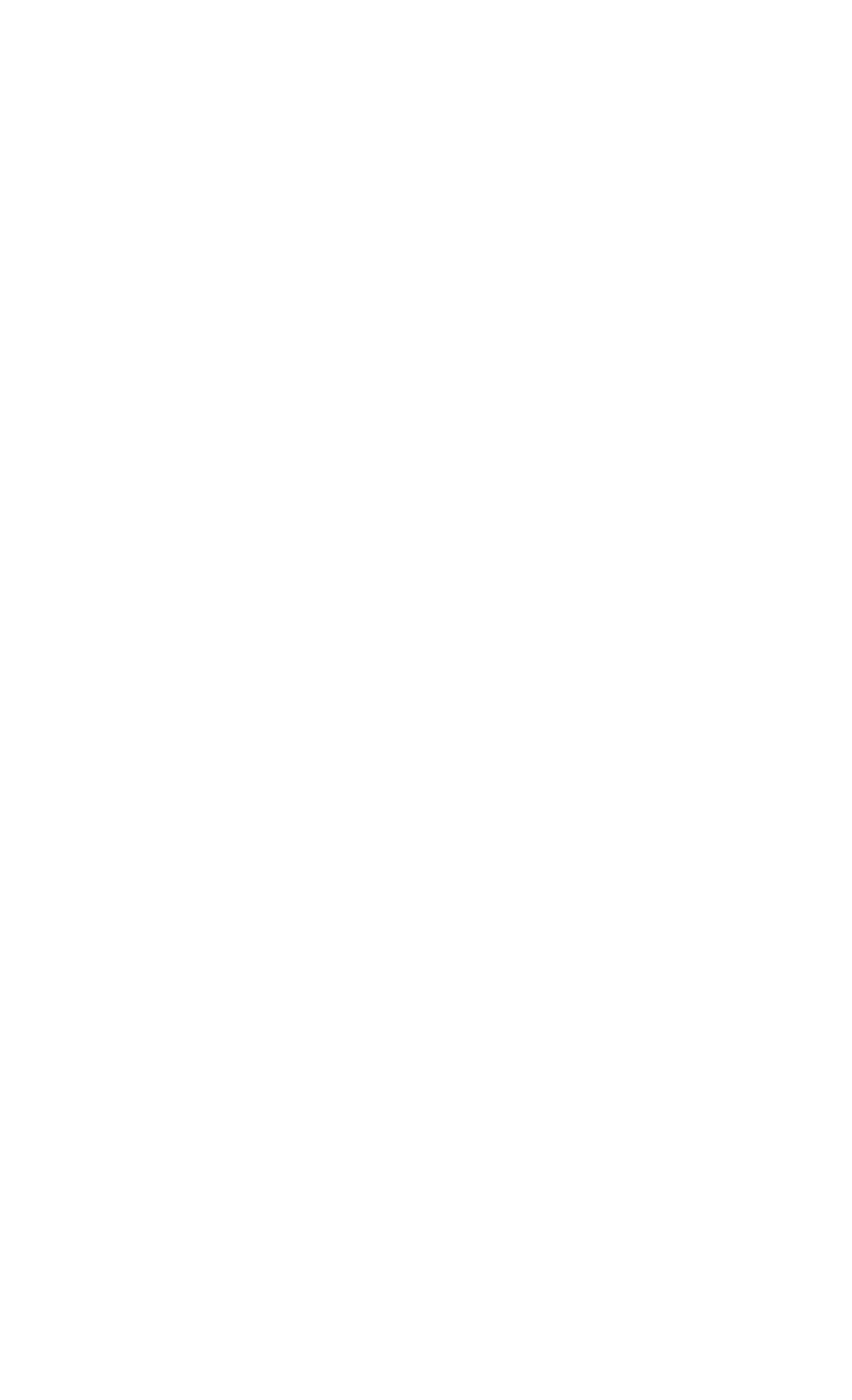


Discharge measurements of Santa Ana River, etr.-Continued.

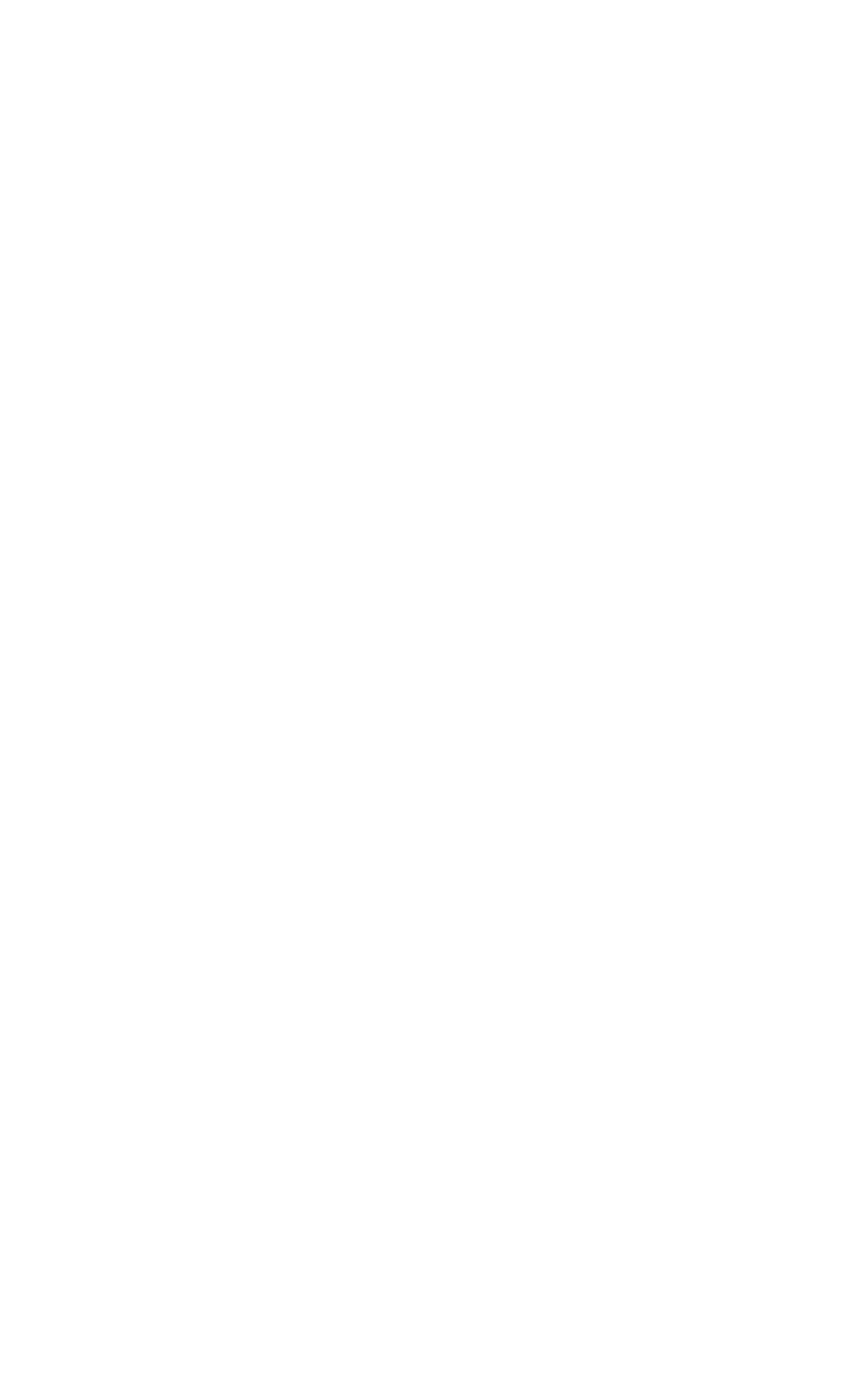


Ihisaluere measurements of Santa Ana River at Rincon ungon bridge.

\begin{tabular}{|c|c|c|}
\hline Date. & Hydrographer. & $\begin{array}{l}\text { Dis- } \\
\text { charge. }\end{array}$ \\
\hline 1899. & & Sec.-feet. \\
\hline Sept. 13 & J. B. Lippincott .... & 79.58 \\
\hline Oct. 25 & $\ldots$. & 130.32 \\
\hline Oct. $\quad 26$ & $\ldots$..... & 146.53 \\
\hline $\begin{array}{c}\text { Dec. } 28 \\
1900 .\end{array}$ & 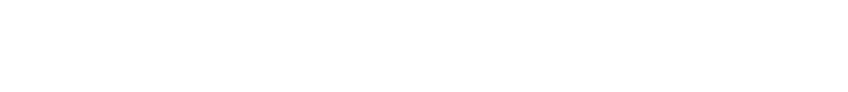 & 165.05 \\
\hline Apr. $1 \%$ & W.P.Searc. & 101.60 \\
\hline June 24 & $\mid-\ldots$ do & 69.20 \\
\hline July $\tau$ & $\ldots d 0, \ldots \ldots \ldots \ldots$ & 84.47 \\
\hline July 28 & S. G. Bennett . . & 60.76 \\
\hline Aug. 15 & W.P.Searcy $\quad \ldots \ldots \ldots$ & 87.10 \\
\hline Sept. 3 & : ndo & 88.20 \\
\hline $\begin{array}{c}\text { Det. is } \\
1901 .\end{array}$ & W. W. Coxkins, jr $\ldots \ldots \ldots \ldots \ldots \ldots$ & 74.20 \\
\hline Ang. $2 \pi$ & , T. B. Lippineott . . & $\because 8.60$ \\
\hline $\begin{array}{c}\text { Aug. } 31 \\
1902 .\end{array}$ & $\ldots$ do $\ldots . . . . . .$. & 65. 30 \\
\hline Sept. 2 & W. B. Clapp ........... & 74.90 \\
\hline
\end{tabular}

Discharge mensurements of Sante Ana River at Riverside Narrou's.

\begin{tabular}{|c|c|c|}
\hline Date. & Hydrographer. & $\begin{array}{c}\text { Dis- } \\
\text { charge. }\end{array}$ \\
\hline $18 \times 8$. & & Sec.-feet. \\
\hline July 16 & F. C. Finkle...... & 10.1 \\
\hline July 17 & - do & 10.5 \\
\hline Aug. 21 & . & 8.5 \\
\hline $\begin{array}{c}\text { Sept. } 14 \\
1889 .\end{array}$ & $-\ldots$ do & 9.5 \\
\hline Aug. 13 & ـ & 11.0 \\
\hline $\begin{array}{c}\text { Sept. } 2 \pi \\
1890 .\end{array}$ & $\ldots d 0 \ldots$ & 11.2 \\
\hline $\begin{array}{c}\text { Aug. } 12 \\
1901 .\end{array}$ & do & 18.8 \\
\hline $\begin{array}{c}\text { Sept. } 9 \\
1892 .\end{array}$ & 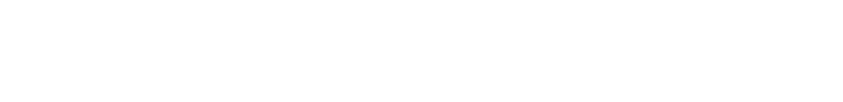 & 15.5 \\
\hline Sept. 10 & .... & 29.4 \\
\hline
\end{tabular}


Discharge measurements of Santre Alla River at Riverside Narrous-Continued.

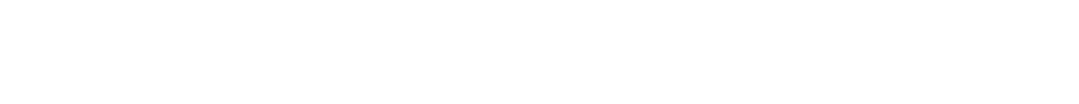

1898.

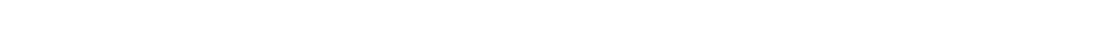

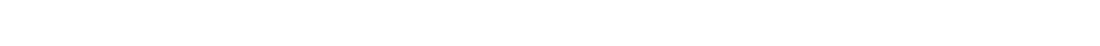

1899.

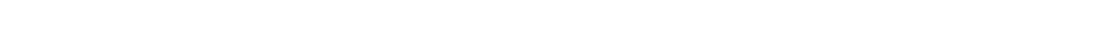

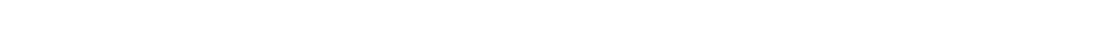

1900.

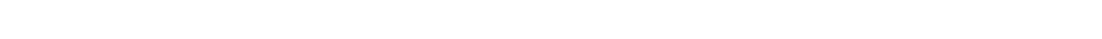

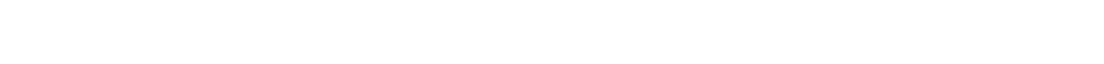

1901.

\begin{tabular}{l|l|l|r} 
Ang. 30 & .T. B. Lippincott & 33.87
\end{tabular}

1902.

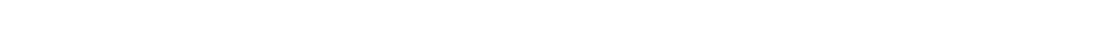

Discherrge measurements of canals and ditches of Santer Amer Riner system near Rincon, Riverside C'ounty.

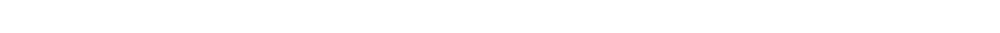

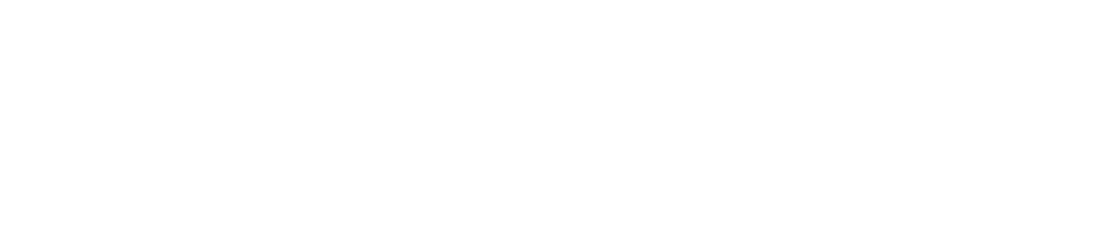

DTTCH ON RIGHT BANK OH SANTA ANA RIVER 5 MILFA BELOW RIVRIRIDH NARJOWS, ON QRTFFITH'S PLACK.

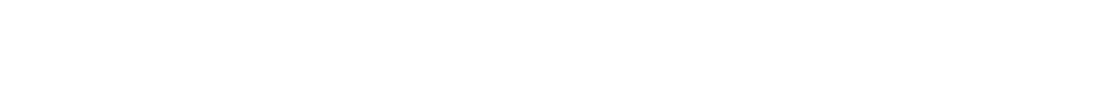

ROBERTS DITCH.

1901.

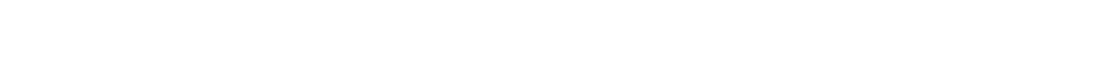

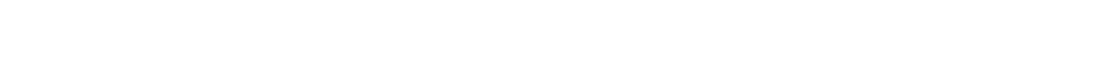


Discharge measurements of canals and ditches, etc.-Continued.

SANTA ANA YALLEY IRKHGATION COMPANY'S GANAL, ORANGH COUNTY, CAI.

Date.

1898.

June 92

F. H.Olmsted

Sec, feet. $\because 28.99$

Aug. :31

1899.

May 26 F. Rolfe

b 43.98

Sept. 1i

J. B. Lippincott

.30 .26

Oct. $\quad 26$

do

( 47.19

1900.

Sept. 3 , W.P.Searcy

Aug. 15

.... do

1901.

Ang. 31

J. B. Lippincott

SEECHER DITCH, AT RINCON BRIDGE

\begin{tabular}{c|c}
\hline $\begin{array}{c}1901 . \\
\text { June 24 }\end{array}$ & W.P.Searcy \\
\hline
\end{tabular}

SOWNSEND DITCH.

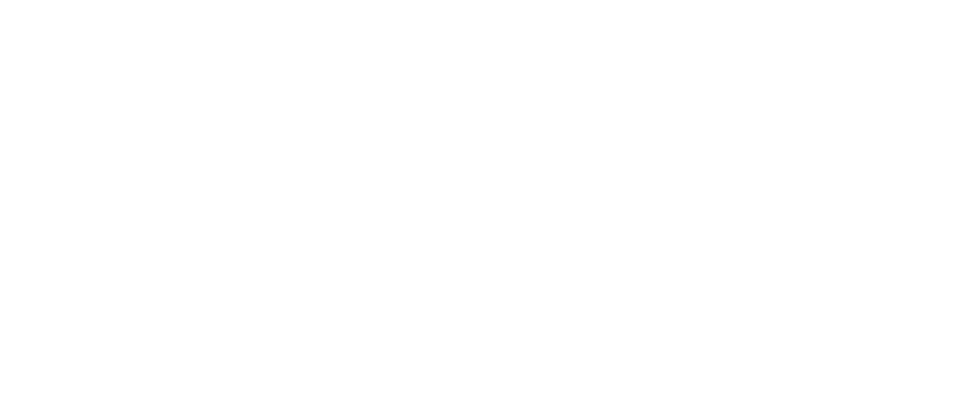

YORBA DITCH

1899.

Oct. 26 J. B. Lippincott .

1900.

Aug. 15

W. P. Searcy .

Sept. 3

1901.

Aug. 31

J. B. Lippincott

a Near 1)ridge to Yorba. $b$ Three miles alove ()live c. First road r'rossing.
"At road (rossing at bead of cement luning. - Estimated above drop from Anaheim ditrb aud opposite Esperanza. 
Hiscellameous ion-uater measurements ma?e in uatersher of Semta Ama River, Los Angeles, Sum Bernardino, Riverside. and Orange counties.

$$
\text { Date. }
$$

1900

jept. 25

Do... Phillips's ranch, near Sparlia (weir)

jept. 27 C.L. Lancaster. Mesa avenut, Lordsburg (weir)

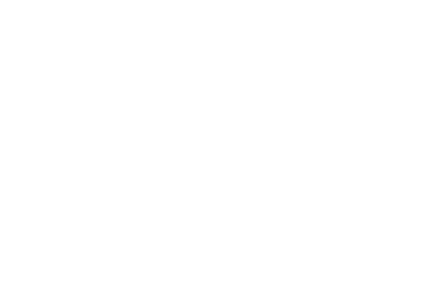

3.58

3.34 . 1595 . and 9.02 second-feet on Sept. $6,189 \tilde{\tau}$ (weir)." ... REJ) HILL, CUC'AMION(*A.

July 11 Cucamonga Land and Water Co.. Cucanonga Creek. 30)-inch pipe line (weir)

diar Hill t mile north of Poyndin College (weir)

of Pomona Cand and Water The discharge from San Antonio Canyon was T.53 second-feet Sept.

Do .... Cucamonga Land and Water Co..

Do .... Cucamonga Land and Water Co.. (weir)

Do. . - C'ncamonga Land and Water Co.. "Y ${ }^{*}$ tumnel (weir)

Do.... Stowell water from $9(1-a c r e$ tract: west side part to Ontario (weir)

Do .... San Antonio Water Co., Haskell well (weir)

Do .... San Antonio Water Co., Sixteenth street, pumping plant (weir)

\section{Total}

.26

.96

.09

3.72

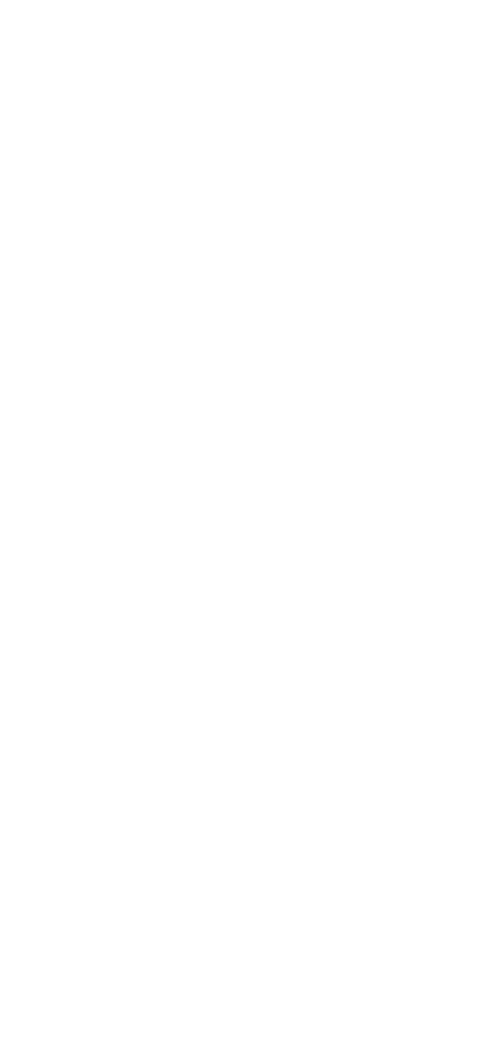

1.15

13

1.72

0.85

a July 11, 1960, measurenent made of water in San Antonio Canyon by S. (\%. Bennett; discharge, $4.0 \%$ second.feet. 
Miscellaneoms lon-uater measurements made, etc.-Continued.

\begin{tabular}{|c|c|c|c|c|}
\hline Date. & Lecality. & $\begin{array}{l}\text { Area of } \\
\text { section. }\end{array}$ & $\begin{array}{l}\text { Mean } \\
\text { velocity. }\end{array}$ & Discharge. \\
\hline 1900. & RED HLL, CUCAMONA.A-continned. & & & \\
\hline July 11 & $\begin{array}{l}\text { Natural surface flow of Cucamonga } \\
\text { Creek in canyon (Iomosa Water } \\
\text { Co.) }\end{array}$ & $\begin{array}{r}\text { Sig. feet. } \\
0.22\end{array}$ & $\begin{array}{l}\text { Feet perser: } \\
\qquad .10\end{array}$ & $\begin{array}{l}\text { Sec:-fert. } \\
0.90\end{array}$ \\
\hline & Developed by bed-rock tunnel & & & .18 \\
\hline & Total & & & 1.08 \\
\hline Aug. $\quad 1$ & $\begin{array}{l}\text { Cucamonga Land and Water Co., } \\
\text { Lone Star Spring prumping plant } \\
\text { (weir) }\end{array}$ & & & 1.02 \\
\hline June $\&$ & $\begin{array}{l}\text { Lytle Creek at intake of Rialto Canal } \\
\text { (weir) }\end{array}$ & & & 6.19 \\
\hline Sept. $\approx 9$ & $\ldots$ do $\ldots . . . . . .$. & & & 4.62 \\
\hline June \& & $\begin{array}{l}\text { Cajon Creek Canyon in flume. (ppor- } \\
\text { site Keenbrook station }\end{array}$ & 1.49 & .92 & 1.37 \\
\hline July 12 & West Twin Creek in flume......... & .084 & 2.66 & .22 \\
\hline Oct. 1 & 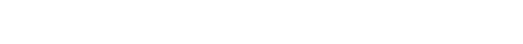 & $\ldots$ & & .16 \\
\hline July 12 & $\begin{array}{l}\text { East Twin Creek, Del Rosa rement } \\
\text { canal }\end{array}$ & .40 & 1.55 & .62 \\
\hline Oct. 1 & $\ldots$ do _ . _ . . . & & & .36 \\
\hline July 12 & $\begin{array}{l}\text { East Twin Creek. Kansas ('ity Syndi- } \\
\text { cate development }\end{array}$ & .44 & 3.45 & .15 \\
\hline Oct. 1 & $\ldots \quad d 0 \ldots \ldots \ldots \ldots$ & & $\cdots$ & .17 \\
\hline July 12 & $\begin{array}{l}\text { City Creek measurement in cement } \\
\text { canal }\end{array}$ & .32 & . & .16 \\
\hline Oct. 1 & City Creek, at head of pipe line .... & .24 & .88 & .21 \\
\hline July 12 & Plunge Creek at intake of ditch (weir) & & & .34 \\
\hline July 13 & Below wasteway of Santa Ana Canal & 9.29 & $\approx 404$ & $\stackrel{22.34}{2}$ \\
\hline Do & $\begin{array}{l}\text { South Fork or Redlands Canal, water } \\
\text { not going over weir into North } \\
\text { Fork or Highlands Canal on ac- } \\
\text { count of repairs (weir) ......... }\end{array}$ & & & 10.65 \\
\hline Do . & Redlands tunnel (weir) & & & .81 \\
\hline Do .... & Morton Canyon (weir) & & & .09 \\
\hline Oct. $\quad 2$ & Sonth Fork or Redlands Canal (weir) & & & 6.25 \\
\hline Do .... & North Fork orHighlands Canal (weir). & & & 5.61 \\
\hline Do . & Green Spot pipe line (weir) & & & .12 \\
\hline Do . . . & Redlands tunnel (weir) $\ldots \ldots \ldots$ & & $\ldots$ & .85 \\
\hline Do .... & Morton Canyon (weir) ........ & & & .20 \\
\hline July 13 & Water in Mill Creek zanja (weir) & & & 5.35 \\
\hline Do & $\begin{array}{l}\text { Mill Creek. Water is being pumped } \\
\text { by Crafton Water Co.et al. in Mill } \\
\text { Creek Canyon and Yucipe Valley } \\
\text { (weir) }\end{array}$ & & & 3.44 \\
\hline & Total. & & & 8.79 \\
\hline
\end{tabular}


Hiscellaneous lou-unter measurements made, etc.-Continued.

\begin{tabular}{|c|c|c|c|c|c|}
\hline Date. & & Locality. & $\begin{array}{l}\text { Area of } \\
\text { section. }\end{array}$ & $\begin{array}{c}\text { Mean } \\
\text { velocity. }\end{array}$ & Discharge. \\
\hline 1900. & & RFD HILI. CUCAMGNGA-continned. & & & \\
\hline Oet. & & $\begin{array}{l}\text { Crafton Water Co.'s pumping plant. } \\
\text { Mill Creek Canyon (weir) }\end{array}$ & siq. feet. & Feet perser. & $\begin{array}{l}\text { Sec.-feet. } \\
1.35\end{array}$ \\
\hline Do - & - - & At mouth of Mill Creek Canyon (weir) & & & T.21 \\
\hline & & Total & & & 8.56 \\
\hline July & 14 & $\begin{array}{l}\text { San Timoteo Canyon ditch at Bick- } \\
\text { nell Station }\end{array}$ & 1.00 & 1.50 & 1.50 \\
\hline June - & - & Haws \& Talmadge . . . . . . . . . . & & $\ldots$ & .00 \\
\hline June - & - & Rabel ditch $\ldots$ & & $\ldots$ & .35 \\
\hline June - & - & Shay ditch ............ & & $\ldots \ldots$ & .40 \\
\hline June - & - & McKenzie ditch . ..... & & -1 & $1.5 \%$ \\
\hline June - & - & Meeks \& Daley ditch ... & & $\cdots$ & 13.78 \\
\hline June - & - & Beams ditch $\ldots . . .$. & $\ldots$ & - . & .50 \\
\hline Tune & $\ldots$ & Riverside Water Co.. npper canal & & $\ldots$ & 52.94 \\
\hline June & - & Riverside Water Co.. lower canal & & ... & 7.16 \\
\hline June & - & 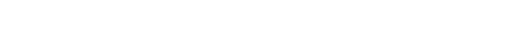 & 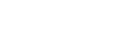 & $-\cdots$ & .00 \\
\hline Jume - & - & Gage Canal. Santa Ana River.... & - & $-\cdots$ & .29 \\
\hline Tune - & - & Gage Canal, Palm avenut . . . . . & ... & $\ldots$ & 22.52 \\
\hline Junt & - & Logsdon \& Farrel ditch $\quad . .$. & & $\ldots-$ & .49 \\
\hline Jume - & 一 & Whitlock ditch.................... & .. & & .00 \\
\hline June - & -- & Daley ditch .................. & -. & $\ldots$ & 1.12 \\
\hline June - & -- & McIntyre ditch .. ... & & & .01 \\
\hline June . & - & Whiting ditch $\ldots \ldots$ & & $\ldots$ & .13 \\
\hline June - & - & Swamp ditch . . . . . . . & & & .89 \\
\hline June - & - & Ranchero ditch ................... & .. & $\ldots$ & .55 \\
\hline June - & - & Ward \& Warren ditch............ & $\ldots$ & $\ldots$ & 1.70 \\
\hline june & - & Mill flume, Riverside Water C'o... & 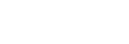 & & 2.17 \\
\hline June - & - & Mill pump. Riverside Water Co.... & . & $\ldots$ & 1.88 \\
\hline June - & - & Camp Carlton ditch .......... & & & 2.60 \\
\hline . Tune - & - & East Riverside ditch & & & 5.38 \\
\hline June - & - & Colton Terrace Water Co ....... & & & 1.54 \\
\hline June - & 一 & City of Colton $\ldots \ldots$ & & & 3.21 \\
\hline June - & - & Bloomington flume - & & & 3.68 \\
\hline July 2 & 26 & $\begin{array}{l}\text { Riverside Water Co.'s upper canal in } \\
\text { flume } 150 \text { feet above tunnel River- } \\
\text { side Mesa....................... }\end{array}$ & $1 \% .48$ & $2.4 \%$ & 43.30 \\
\hline July : & 27 & $\begin{array}{l}\text { North Riverside and Jurupa Canal } \\
\text { in flume near Beckstead's house... }\end{array}$ & 6.94 & $2.07 \%$ & 14.42 \\
\hline July & 27 & Riverside Water Co. \&s lower caul ... & 3.35 & 2.128 & 7.13 \\
\hline July : & 27 & Roubidoux ditch .................. & 6.21 & 1.317 & 8.18 \\
\hline July : & 27 & Trujillo ditch,$\ldots \ldots \ldots$ & .75 & .61 & .46 \\
\hline
\end{tabular}


Miscellancons lon-uater mersurements made, etc.-Continued.

\begin{tabular}{|c|c|c|c|c|}
\hline Date. & Isocality. & $\begin{array}{l}\text { Area of } \\
\text { section. }\end{array}$ & $\underset{\text { velocity. }}{\text { Mean }}$ & Discharge. \\
\hline 1900. & RED HILL, CUCAMON(tA-continued. & sit. feet. & Feet per sec. & Ser. feet. \\
\hline July $2 \%$ & i5 feet below intake of Trujillo ditch. & 0.38 & 1.17 & 0.44 \\
\hline July 27 & $\begin{array}{r}\text { Evans upper ditch } \\
\text { Total flow Santa Ana at Roubi- } \\
\text { doux ditch intake }\end{array}$ & .95 & 1.10 & $\begin{array}{r}1.04 \\
10.12\end{array}$ \\
\hline July 27 & $\begin{array}{l}\text { Alsetrez ditch from Spring Brook, } 100 \\
\text { feet below West Riverside bridge }\end{array}$ & 1.95 & $1.42^{\circ}$ & 2.77 \\
\hline July 27 & 200 feet below West Riverside bridge & $1.7 \tau$ & .65 & 1.16 \\
\hline July 27 & $\begin{array}{l}\text { West Riverside bridge, Roubidoux } \\
\text { Mountain }\end{array}$ & 2.85 & 1.85 & 5.27 \\
\hline July 27 & At Riverside Narrows . . . . . . . . . . . & 26.54 & 1.443 & 38.41 \\
\hline Sept. 13 & Riverside Water Co. 's lower canal ... & 3.36 & 1.99 & 6.69 \\
\hline Oct. 19 & North Riverside and Jurupa canal .. - & 6.69 & $\stackrel{2.10}{10}$ & 14.05 \\
\hline Oct. $\quad 25$ & Roubidonx ditch $\ldots . \ldots \ldots \ldots$ & 5.95 & 1.31 & 7.80 \\
\hline Oct. 25 & Trujillo ditch $\ldots \ldots \ldots \ldots$ & 1.10 & .48 & .53 \\
\hline Oct. 25 & 20 feet below intake of Trujillo ditch & .80 & .70 & .56 \\
\hline Oct. 25 & $\begin{array}{r}\text { Evans's upper ditch } \ldots \ldots \\
\text { Total }\end{array}$ & 2.42 & 1.37 & $\begin{array}{r}3.32 \\
12.21\end{array}$ \\
\hline Oct. & $\begin{array}{l}\text { Alsetrez ditch from Spring Brook, } \\
\text { West Riverside bridge ... }\end{array}$ & 1.75 & .87 & 1.53 \\
\hline Oct. 25 & At West Riverside bridge ............ & 5.50 & 1.54 & 8.45 \\
\hline Oct. $\quad 25$ & Evans`s ditch, West Riverside bridge. & $\stackrel{2.52}{2}$ & 1.75 & 4.36 \\
\hline Oct. 25 & At Riverside Narrows . . . . . . . . . . . & 43.3 & $1.6: 3$ & 70.64 \\
\hline July 28 & 300 feet above Auburndale bridge . . . & 28.65 & 1.576 & 45.16 \\
\hline July 28 & Newberry ditch. Auburndale bridge . & 5.32 & 1.03 & 5.47 \\
\hline July 28 & $\begin{array}{l}\text { Ditch south of Newberry ditch, An- } \\
\text { burndale bridge }\end{array}$ & 1.58 & 1.47 & 2.32 \\
\hline July & $\begin{array}{c}\text { Gilliland ditch, Auburndale bridge } \\
\text { Total }\end{array}$ & 1.49 & $\ldots . . .$. & $\begin{array}{r}1.40 \\
54.35\end{array}$ \\
\hline Oct. & Auburndale bridge ................ & 40.50 & $1.5 \% 7$ & 63.9 \\
\hline Oct. & Townsend ditch, Auburndale bridge & 6.10 & $.95 \%$ & 5.84 \\
\hline Oct. & Fuller's ditch, near schoolhouse . . . . & 5.10 & $1.2 \% 4$ & 6.50 \\
\hline July 28 & Rincon bridge $\ldots \ldots \ldots \ldots \ldots$ & 35.55 & 1. 704 & 60.76 \\
\hline July 28 & 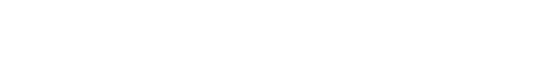 & 3.66 & .60 & 2.20 \\
\hline Oct. & Rincon bridge ................... & 4.3 .90 & 169 & 74.20 \\
\hline Oct. & 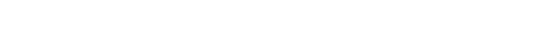 & 1.90 & 2.63 & 5.00 \\
\hline July 28 & Durkee ditch, near ranch house $\ldots$ & 1.40 & 1.30 & 1.80 \\
\hline July 28 & $\begin{array}{l}\text { At Anaheim and Santa Ana division, } \\
\text { box } \ldots \ldots \ldots \ldots \ldots \ldots\end{array}$ & 23.64 & 2.103 & 49.72 \\
\hline Oct. 5 & . do & 29.00 & 2.59 & \%5. 10 \\
\hline
\end{tabular}

For tabulation of a large number of water measurements in the San Bernardino Valley aliove Riverside Narrows and in the basin of the Santa Ana River, see san Bernardino Valley 
SANTA ANA RIVER, MILL CREEK.

See Mill Creck (page 15S).

SANTA ANA RIVER, LYTLE CREEK.

See Lytle (reek (page 13!).

SANTA ANA RIVER, SAN ROQUE CREEK.

See Arroyo Burro (page 43 ).

SANTA BARBARA COUNTY.

Miscellaneous measurements of streams east of Santa Barbara City. Santa Barbara County, made in .July and August, 18s9, by George F. Wright.

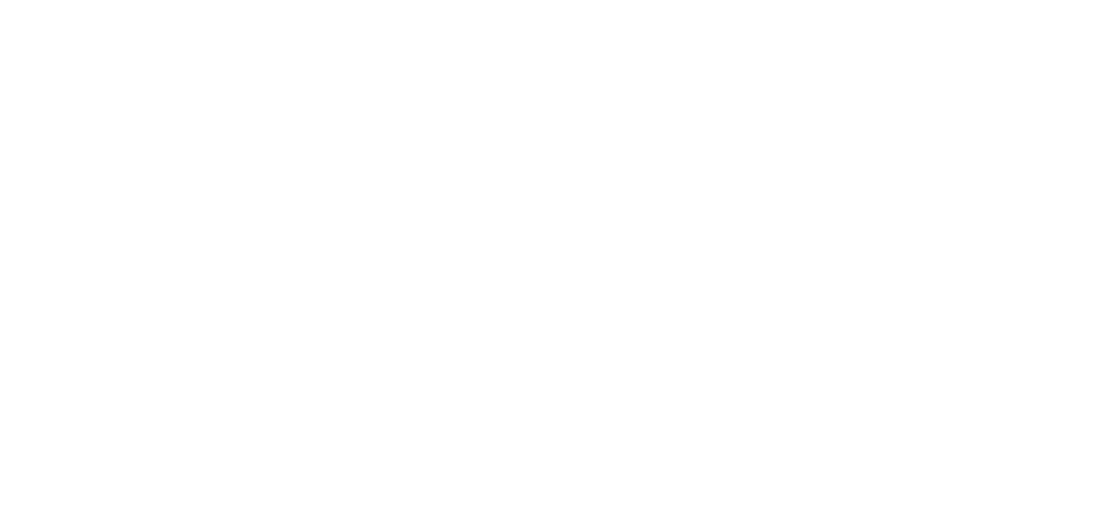

Miscellaneous measurements of streams uest of Santa Barbara City, Santa Barbara County, made in July and August, 1889, by George F. Wright.

\begin{tabular}{|c|c|c|}
\hline Stream. & $\begin{array}{c}\text { Dis- } \\
\text { charge. }\end{array}$ & $\begin{array}{c}\text { Area of } \\
\text { water- } \\
\text { shed. }\end{array}$ \\
\hline & Sec.feet. & Sq. miles. \\
\hline Arroyo Burro & 0.23 & 2.5 \\
\hline Maria Ignacia . . & .28 & 16.5 \\
\hline San Jose .................. & .27 & $\ldots \ldots . .$. \\
\hline San Pedro ... & .08 & 3.0 \\
\hline Arroyo Carnero . . . . . . . . . . . & .08 & 1.0 \\
\hline Armas $\ldots \ldots$. & .08 & 1.0 \\
\hline Tecolote.. ..... & .27 & 2.0 \\
\hline Aguilar $\ldots \ldots \ldots \ldots \ldots$ & .12 & 2.0 \\
\hline Dos Pueblos $\ldots \ldots \ldots \ldots$ & .54 & 3.25 \\
\hline Canyada Verde.... . . . . . . . . . & .08 & 2.00 \\
\hline Canyada Llaces ... . . . . . . . . . & .08 & 1.50 \\
\hline El Capitan _............ & .28 & 1.50 \\
\hline 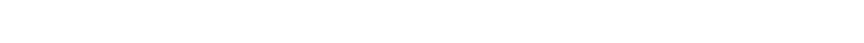 & .15 & 1.00 \\
\hline Canyada Refugio ........................ & .31 & 2.00 \\
\hline
\end{tabular}


Ihisehrorg measurements of San Pedro Creek. Santu Barbara County, Cal.

\begin{tabular}{c|c|c|c} 
Date. & Hydrographer. & $\begin{array}{r}\text { Dis- } \\
\text { charge. }\end{array}$ \\
\hdashline Aug. -.1889 & G. F. Wright _........ & $\begin{array}{r}\text { Rec.feet. } \\
0.08\end{array}$ & Drainage area, 3 square miles. \\
\hline
\end{tabular}

Discharge measurements of San. Timoteo Creek, Riverside County.

\begin{tabular}{c|c|c|c}
\hline Date. & Hydrographer. & $\begin{array}{c}\text { Dis- } \\
\text { charge. }\end{array}$ & Remarks. \\
\hline July 14,1900 & S. G. Bennett ......... & $\begin{array}{r}\text { Sec.feet. } \\
1.50\end{array}$ & Bicknel station. \\
\hline
\end{tabular}

Discharge measurements of San Fsidro Creek, Santa Barbara County, Cal., above dam.

\begin{tabular}{|c|c|c|c|}
\hline Date. & Hydrographer. & $\begin{array}{c}\text { Dis- } \\
\text { charge }\end{array}$ & Remarks. \\
\hline & & Sec.feet. & \\
\hline Nov. $\quad 2,1899$ & Greenheld . & 0.06 & \\
\hline Dec. 3,1899 & $\ldots \mathrm{d} o \ldots \ldots$ & .15 & \\
\hline Mar. $\quad 6,1900$ & $\ldots$ do $\ldots . . .$. & 1.00 & \\
\hline Mar. 19,1900 & $\ldots$ do .... & .35 & \\
\hline June 16,1900 & R. Moyer & .07 & \\
\hline
\end{tabular}

SANTA CLARA RIVER.

Discharge measurements of Santa Clara River at point below mouth of San Francisquito Creek, on Newhall ranch, Los Angeles County.

\begin{tabular}{|c|c|c|c|c|}
\hline & Date. & Hydrographer. & $\begin{array}{c}\text { Dig- } \\
\text { charge. }\end{array}$ & Remarks. \\
\hline & & & sec-feet. & \multirow{10}{*}{$\begin{array}{l}\text { East channel. } \\
\text { West channel. } \\
\text { Newhall ditcl. }\end{array}$} \\
\hline Aug. & 9,1898 & F. H. Olmsted & 10.83 & \\
\hline Ang. & 19,1899 & S. G. Bennett . & 3.38 & \\
\hline Ang. & 19,1899 & .... do ...... & 1.65 & \\
\hline \multirow[t]{2}{*}{ Aug. } & 19,1899 & .... do . & 3.37 & \\
\hline & & Total & 8.40 & \\
\hline Oet. & 8,1900 & W. W. Cockins, jr. & 3.64 & \\
\hline Oct. & 8.1900 & . . do ........... & 3.25 & \\
\hline \multirow[t]{2}{*}{ Oct. } & \multirow[t]{2}{*}{8.1900} & ... do . & 3.35 & \\
\hline & & Total ... & 10.24 & \\
\hline
\end{tabular}


ischarge measurements of Santa Clara River at point a miles east of C'amulos, Tentura County.

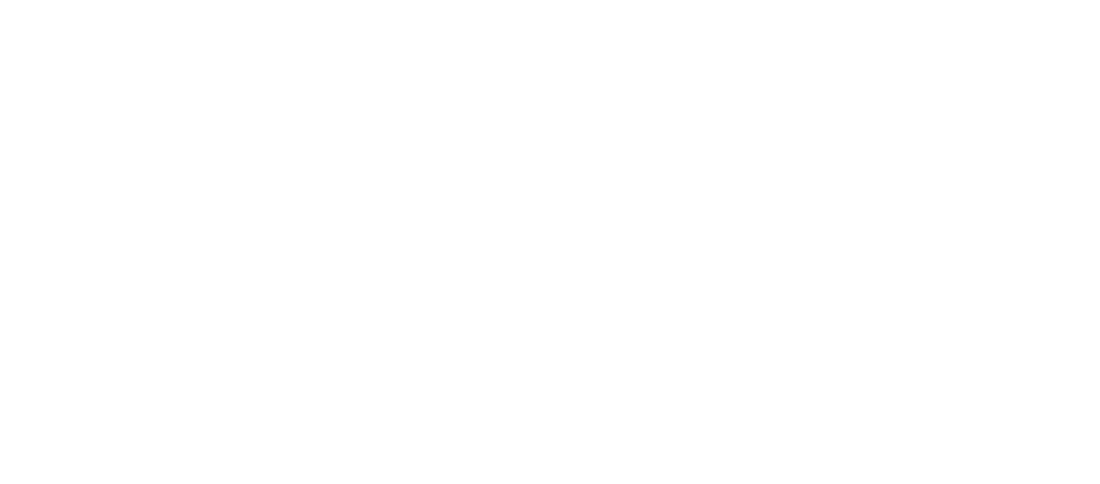

Discharge measurements of Santa Clara River in Cienega, 1 mile east of Fillmore, Ventura County.

\begin{tabular}{c|c|c|c}
\hline Date. & Hydrographer. & $\begin{array}{c}\text { Dis- } \\
\text { charge. }\end{array}$ \\
\hline Mar. 15,1899 & S. G. Bennett .......... & $\begin{array}{c}\text { Sec.feet. } \\
3.60\end{array} \mid$ \\
\hline
\end{tabular}

Discharge measurements of Santa Clara River near Santa Paula. Ventura County.

\begin{tabular}{|c|c|c|c|}
\hline Date. & Hydrographer. & $\begin{array}{c}\text { Dis- } \\
\text { charge. }\end{array}$ & Remarks. \\
\hline & & Ser.-feet. & \\
\hline Aug. 18, 1899 & S. G. Bennett. & 16.00 & Farmers ditch. \\
\hline Aug. 18,1899 & $\ldots$... do .... & 8.60 & Grease or Santa Clara litch. \\
\hline Aug. 18.1899 & .... do .... & 5.80 & $\begin{array}{l}\text { Ditch taken out on east side of } \\
\text { river. }\end{array}$ \\
\hline \multirow[t]{2}{*}{ Aug. 18,1899} & ... do & 10.30 & River. \\
\hline & Total & 40.70 & \\
\hline
\end{tabular}

\section{SANTA MONICA CREEK.}

Discharge measurements of Santa Monica Creek, Santa Burbara County.

[Drainage, 4.3 square miles.]

\begin{tabular}{|c|c|c|c|}
\hline Date. & Hydrographer. & $\begin{array}{c}\text { Dis- } \\
\text { charge. }\end{array}$ & Remarks. \\
\hline & & Sec.feet. & \\
\hline Aug. 一, 1889 & G. F. Wright $\ldots$ & 0.23 & $\frac{1}{4}$ mile above Fithian's house. \\
\hline June 16,1900 & R. Moyer.... & .11 & \\
\hline
\end{tabular}


SANTA PAULA RIVER.

Discharge measurement of Santa Paula River above Neep"r schoolhonse, near Santa Paula, Ventura County, Cal.

\begin{tabular}{|c|c|c|c|}
\hline Date. & Hydrographer. & $\begin{array}{c}\text { Dis- } \\
\text { charge. }\end{array}$ & Locality. \\
\hline Ang. 18, 1899 & S. G. Bennett & $\begin{array}{c}\text { Sec.feet. } \\
0.85\end{array}$ & \\
\hline
\end{tabular}

SANTA YNEZ RIVER.

As determined from Geological Survey maps the area of the drainage basin of this stream above Juncal dam site is 13.4 square miles. E. J. S. Purslow stated in a report to the Santa Barbara Water Company in 1896 that the Santa Ynez River at the Juncal reservoir site was measured during the "past winter and spring;" further details are not given. The discharge stated was $800,000,000$ gallons $=2,455$ acre-feet. The rainfall for season at Santa Barbara, was 13.77 inches and the mean from 1867 to date is 16.82 inches. The period of stream observations probably extended from November 1, 18.5, to July 1, 1896. This includes Alder Creek water below Juncal.

During the winter of 1902-3 the city of Santa Barbara cooperated with the United States Geological Survey in determining the run-off from portions of the drainage basin of the Santa Ynez River, as given below.

Measurements were first made of the main Santa Ynez River above its junction with the Mono tributary. The drainage area above this point is 71 square miles. Measurements were also made of the discharge of the Mono tributary of the Santa Ynez River at its mouth. The drainage area above this point is 119 square miles. Both of these streams flow from the mountains of the Coast Range, the elevations of their basins ranging from 1,400 to 7,000 feet.

The estimated average rainfall in these drainage basins is 22 inches, and during the season of $1902-3$ the mean rainfall was probably exceeded by about 2 inches. The precipitation, however, occurred in gentle slow storms until the latter part of March, when there were heavier rains. It is locally stated that the stream flow is not up to the average. This probably could be explained by the fact of the gentle rains referred to above, and to the further fact that the season of 1902-3 was preceded by years of protracted drought. 
ist of discharge measmements of Senta Shez River abow junction with Mono.

\begin{tabular}{|c|c|c|c|}
\hline Date. & Hyrtrographer. & $\begin{array}{c}\text { Gage } \\
\text { height. }\end{array}$ & $\begin{array}{c}\text { Dis- } \\
\text { charge. }\end{array}$ \\
\hline $\begin{array}{l}1903 . \\
\text { an. } 12\end{array}$ & Howard Rankin & $\begin{array}{l}\text { Feet. } \\
1.10\end{array}$ & $\begin{array}{r}\text { Sec.feet. } \\
1.79\end{array}$ \\
\hline an. 25 & ... do . . . . . . . & 1.10 & 1.93 \\
\hline an. $2 \pi$ & $\ldots$ do $\ldots . .$. . & 1.20 & 3.30 \\
\hline [an. 28 & $\ldots$ do $\ldots \ldots$ & 3.55 & 457.24 \\
\hline Tan. 29 & $\ldots$ do . . . . & 1.70 & 49.75 \\
\hline 「an. 30 & . do .............. & 1.50 & 22.45 \\
\hline Jan. 31 & do _........... & 1.48 & 17.90 \\
\hline eb. 1 & . do _... . . & 1.50 & 22. 18 \\
\hline eb. 2 & $\ldots d o \ldots \ldots$ & 1.4 .5 & 16.01 \\
\hline eb. 3 & do $\ldots \ldots$ & 1.42 & 14.61 \\
\hline eb. 4 & $\ldots$ do & 1.45 & 15.31 \\
\hline Feb. 5 & - do & 1.45 & 14.92 \\
\hline Teb. & - do & 1.45 & 15.63 \\
\hline Feb. & . do _ & 1.58 & 24.74 \\
\hline Feb. 9 & $\ldots$........ & 1.50 & 18.38 \\
\hline Teb. 10 & $\ldots$ do . . . . . . & 1.49 & 17.63 \\
\hline Seb. 11 & .....do & 1.46 & 16.15 \\
\hline Teb. 12 & $\ldots$. & 1.45 & 15.54 \\
\hline Teb. 13 & . . . do & 1.44 & 14.92 \\
\hline Teb. 14 & $\ldots$. . do _ . . . . & 1.44 & 14. $\% 2$ \\
\hline Teb. 16 & $\ldots$ do & 1.40 & 10.85 \\
\hline Teb. 17 & $\ldots$... do _... & 1.40 & 11.34 \\
\hline Teb. 18 & $\ldots$ do $\ldots \ldots$. & 1.40 & 11.11 \\
\hline Teb. 19 & .... do & 1.40 & 11.05 \\
\hline Teb. 20 & . . do & 1.39 & 10.75 \\
\hline Teb. 21 & $\ldots$ do & 1.39 & 10.98 \\
\hline Teb. 23 & ..... do & 1.38 & 10.11 \\
\hline Teb. 24 & $\ldots$ do & $1.3 \%$ & 9.05 \\
\hline Feb. 25 & .. do & $1.3 \pi$ & 9.07 \\
\hline Feb. 26 & ......do & 1.36 & 8.58 \\
\hline Teb. $2 \%$ & $\ldots$ do & 1.35 & 8.72 \\
\hline Teb. 28 & - . . do & 1.35 & 8.32 \\
\hline Lar. 1 & .....do & 1.35 & 8.16 \\
\hline Tar. & $\ldots$.... do & 1.35 & 8.01 \\
\hline Lar. 3 & $\ldots$ do . & 1.35 & ז.91 \\
\hline Tar. 4 & $\ldots d o \ldots . . .$. & 1.45 & 14.78 \\
\hline "Tar. $\overline{1}$ & do $\ldots \ldots$. & 1.65 & 31.60 \\
\hline Tar. 6 & do $\ldots \ldots \ldots \ldots$ & 1.50 & 20.19 \\
\hline Tar. i & $\ldots$ do $\ldots$. & 1.50 & 19.95 \\
\hline Lar. 9 & $\ldots d 0$ & 1.43 & 13.52 \\
\hline "Lar. 10 & $\ldots$ do $\ldots . . .$. & 1.42 & 13.20 \\
\hline Tar. 11 & $\ldots d o$ & 1.42 & 13.42 \\
\hline
\end{tabular}


List of discharge measurements of Santa Inez River, etr.-Continued.

\begin{tabular}{|c|c|c|c|}
\hline Date. & Hydrographer. & $\begin{array}{c}\text { Gage } \\
\text { height. }\end{array}$ & $\begin{array}{c}\text { Dis- } \\
\text { charge. }\end{array}$ \\
\hline 1903 & & Feet. & Sec.feet. \\
\hline Mar. 12 & Howard Rankin & 1.41 & 12.70 \\
\hline Mar. 13 & . do . . . . . & 1.42 & 13.24 \\
\hline Mar. 14 & $\ldots$........... & 1.43 & 12.84 \\
\hline Mar. 15 & . do _ & 1.43 & 13.11 \\
\hline Mar. 16 & . do & 1.43 & 12.85 \\
\hline Mar. 17 & do & 1.42 & 11.63 \\
\hline Mar. 18 & . do .. & 1.41 & 11.27 \\
\hline Mar. 19 & . do . & 1.40 & 11.08 \\
\hline Mar. 20 & $\ldots d o \ldots . .$. & 1. 40 & 10.88 \\
\hline Mar. 21 & $\ldots$ do . . . . & 1.40 & 10.55 \\
\hline Mar. 22 & $\ldots d o \ldots$ & 1.40 & 10.48 \\
\hline Mar. 23 & ... do _... & 1.40 & 10.60 \\
\hline Mar. 25 & $\ldots$. & 1.67 & 29.26 \\
\hline Mar. 26 & ... do & 1.55 & 19.58 \\
\hline Mar. 27 & $\ldots d o \ldots$. & 1.50 & 17.15 \\
\hline Mar. 28 & $\ldots$ do $\ldots$ & 1.49 & 16.91 \\
\hline Mar. 29 & $\ldots$ do $\ldots . . . .$. & 1.50 & 18.05 \\
\hline
\end{tabular}

List of discharge measurements of Mono Creek at wouth.

\begin{tabular}{|c|c|c|c|}
\hline Date. & Hydrographer. & $\begin{array}{c}\text { Gage } \\
\text { height. }\end{array}$ & $\begin{array}{c}\text { Dis- } \\
\text { charge. }\end{array}$ \\
\hline $\begin{array}{c}1903 . \\
\text { Jan. } 28\end{array}$ & Howard Rankin & $\begin{array}{l}\text { Feet. } \\
2.95\end{array}$ & $\begin{array}{l}\text { Sec.-feet. } \\
295.00\end{array}$ \\
\hline Jan. 29 & do & 1.55 & 20.23 \\
\hline Jan. 30 & . do & 1.30 & 12.51 \\
\hline Jan. 31 & do. & 1.25 & 9.03 \\
\hline Feb. 1 & do ... & 1.35 & 14.83 \\
\hline Feb. $\quad 2$ & do & 1.30 & 10.12 \\
\hline Feb. $\quad 3$ & $\ldots$. do ........... & 1.20 & 6.93 \\
\hline Feb. 4 & $\ldots$. . do . . . & 1.28 & 8.82 \\
\hline Feb. $\quad 5$ & $\ldots$....... & 1.28 & 8.25 \\
\hline Feb. 6 & $\ldots$ do .... & 1.21 & 8.08 \\
\hline Feb. 8 & $\ldots$.... do ... & 1.35 & 11.96 \\
\hline Feb. 9 & $\ldots$. do .... & 1.29 & 8.81 \\
\hline Feb. 10 & $\ldots$. . do ... & 1.28 & 8.42 \\
\hline Feb. 11 & $\ldots$... do .... & 1.27 & 8.77 \\
\hline Feb. 12 & $\ldots$.... do ..... & 1.26 & 8.23 \\
\hline Feb. 13 & $\ldots . .$. do ....... & 1.25 & 7.61 \\
\hline Feb. 14 & 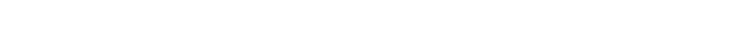 & 1.20 & 4.89 \\
\hline Feb. 16 & .... do .... & 1.20 & 5.10 \\
\hline Feb. 17 & do $\ldots \ldots \ldots$ & 1.20 & 5.04 \\
\hline
\end{tabular}


List of discharge measurements of Mono Creek at mouth-Continued.

\begin{tabular}{|c|c|c|c|}
\hline Date. & Hydrographer. & $\begin{array}{c}\text { Gage } \\
\text { height. }\end{array}$ & $\begin{array}{c}\text { Dis- } \\
\text { charge. }\end{array}$ \\
\hline 1903. & & & Secr-feet. \\
\hline Feb. 18 & Howard Rankin & 1.20 & 5.14 \\
\hline Feb. 19 & .... do - & 1.20 & 5.17 \\
\hline Feb. 20 & .. do & 1.19 & 4.75 \\
\hline Feb. 21 & do & 1.19 & 4.74 \\
\hline Feb. 23 & .... do ... & 1.17 & 4.65 \\
\hline Feb. 24 & $\ldots$. do .... & 1.15 & 4.60 \\
\hline Feb. 25 & $\ldots$ do & 1.15 & 4.56 \\
\hline Feb. 26 & . . do & 1.15 & 4.45 \\
\hline Feb. 27 & _ do & 1.14 & 3.79 \\
\hline Feb. 28 & ... do & 1.14 & 3.81 \\
\hline Mar. 1 & .. do & 1.12 & 3.61 \\
\hline Mar. 2 & . . . do do & 1.12 & 3.62 \\
\hline Mar. 3 & $\ldots$ do ..... & 1.12 & 3.64 \\
\hline Mar. 4 & .... do . & 1.30 & 10.99 \\
\hline Mar. 5 & ... - do & 1.60 & 25.85 \\
\hline Mar. 6 & $\ldots$. . do ....... & 1.37 & 13.57 \\
\hline Mar. $\%$ & $\ldots$ do $\ldots$ & 1.35 & 13.28 \\
\hline Mar. 9 & $\ldots$ do & 1.30 & 9.77 \\
\hline Mar. 10 & - do & 1.25 & 6.58 \\
\hline Mar. 11 & . - do & 1.22 & 6.32 \\
\hline Mar. 12 & _. do & 1. 22 & 6.56 \\
\hline Mar. 13 & . . do & 1.22 & 6.49 \\
\hline Mar. 14 & - _do & 1.27 & 9.22 \\
\hline Mar. 15 & . do & 1.25 & 7.52 \\
\hline Mar. 16 & . do . & 1.30 & 9.83 \\
\hline Mar. 17 & _ do & 1.32 & 9.94 \\
\hline Mar. 18 & _ do & 1.26 & 8.19 \\
\hline Mar. 19 & do & 1.25 & 7.99 \\
\hline Mar. 20 & . . do & 1.24 & 7.08 \\
\hline Mar. 21 & .... do - & 1.24 & $\tau .0 \%$ \\
\hline Mar. 22 & . . . do . . . . . & 1.23 & ‘. 18 \\
\hline Mar. 23 & .... do & 1.23 & $\tau .17$ \\
\hline Mar. 25 & - do . & 2.50 & 1.53 .23 \\
\hline Mar. 26 & do & 1.90 & 62.52 \\
\hline Mar. 27 & do & 1.70 & $36.2 \pi$ \\
\hline Mar. 28 & do & 1.60 & 26.63 \\
\hline Mar. 29 & $\ldots$ do & 1.61 & 29.54 \\
\hline Mar. 30 & $\ldots$ do $\ldots . .$. & 2.65 & 177.46 \\
\hline Mar. 31 & $\ldots$ do . . . . . . & 2.80 & 227.31 \\
\hline Apr. 1 & 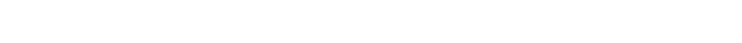 & 4.50 & $\tau 10.58$ \\
\hline Apr. 2 & ( & 3.00 & 269.83 \\
\hline
\end{tabular}


SAWPIT CREEK.

Discharge measurement of Saupit 'reek at Dirision Box. Los Angeles Comuty. C'al.

\begin{tabular}{c|c|c|c} 
Date. & Hydrographer. & $\begin{array}{c}\text { Dis- } \\
\text { charge. }\end{array}$ \\
\hline July 1,1898 & F. H.Olmsted & Locality. \\
\hline
\end{tabular}

\section{SESPE CREEK.}

Discharge measurements of Sespe Creek, Santa Clara River, Tentura County. C'ul.

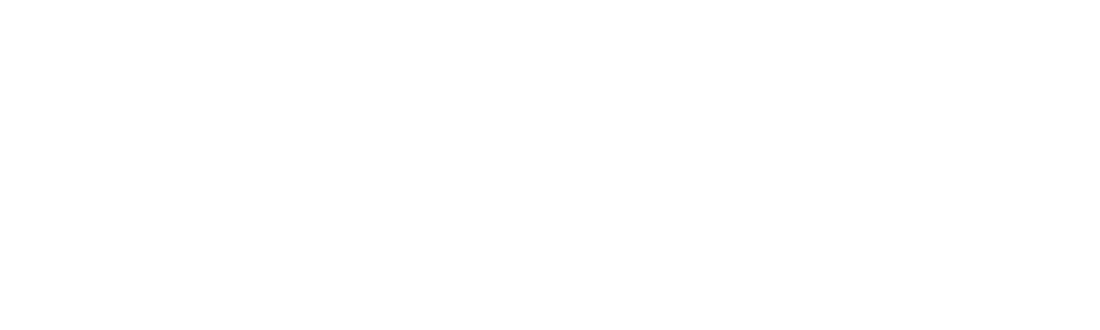

SHASTA RIVER.

Discharge measurement of Shasta River.

\begin{tabular}{c|c|c|c} 
Date. & Hydrographer. & $\begin{array}{c}\text { Dis- } \\
\text { charge. }\end{array}$ & Locality. \\
\hline Aug. -. 1899 & M. M. O'Shaughnessy - & $\begin{array}{r}\text { Sec.feet. } \\
279\end{array}$ & $\begin{array}{c}\text { Wagon bridge 1 mile south of } \\
\text { Montague railroad station. }\end{array}$ \\
\hline
\end{tabular}

\section{SNOW CREEK.}

Discharge measurement of Snow Creek, Palm Valley, Riverside County, Cal.

\begin{tabular}{c|c|c|c}
\hline Date. & Hydrographer. & $\begin{array}{c}\text { Dis- } \\
\text { charge. }\end{array}$ \\
\hline Feb. 22, 1898 & J. B. Lippincott........ Locality. \\
\hline
\end{tabular}

\section{SPRING VALLEY WATER COMPANY.}

See San Mateo Creek, Water Supply and Irrigation Paper No. 51, page 390 . 
STANISLAUS RIVER.

The river has its source on the western slope of the Sierra Nevada in California. It drains a country lying between the basins of Mokelumne River on the north and 'Tuolumne River on the south, and flows in a general southwesterly direction, entering San Joaquin River 23 miles above stockton. A number of canals divert water from this stream on either side, the principal one being the canal of the Stanislaus and San Joaquin Water Company, which irrigates lands in the vicinity of Oakdale and between Knights Ferry and stockton.

The canal of the Stanislaus and San Joaquin Water Company diverts water from stanislaus River at a point 3 miles above $I$ nights Ferry, or approximately 15 miles above Oakdale. The rolume of this canal at what is known as section 3, was rated on Jume 1, 1898, by turning in various amounts of water and measuring the sare with a meter. It was found on June 6 , 1899, that silt had accumulated in the bottom of the flume at the old gage, and a new station was adopted. This point was rated similarly to the one of the year previous.

The record at this station was discontinued February 16, 1901.

Discharge measurements of Stanislaus River at Oakdale, Stanislaus County.

\begin{tabular}{|c|c|c|c|}
\hline Date. & Hydrographer. & $\begin{array}{c}\text { Gage } \\
\text { height. }\end{array}$ & $\begin{array}{c}\text { Dis- } \\
\text { charge. }\end{array}$ \\
\hline 1895. & & Feet. & Sec.-feet. \\
\hline May 3 & J. B. Lippincott_. . & 8.85 & 7,744 \\
\hline July 1 & .. do _........ & $6.1 \%$ & 3,754 \\
\hline Aug. $2 x$ & $\ldots$ do . ........ & 2.40 & 279 \\
\hline Oct. 10 & $\ldots$. . do . . ..... & 2.11 & 192 \\
\hline Nov. 29 & .....do . . & 2.12 & $14 \pi$ \\
\hline 1896. & & & \\
\hline Apr. 17 & J. A. Vogleson ... & 5.40 & 2,801 \\
\hline July 5 & C. C. Babb..... & 4.80 & 2,061 \\
\hline Sept. 7 & H. Crowe ...... & 2.50 & 304 \\
\hline Oct. $\quad 29$ & J. B. Lippincott. . & 2.40 & 210 \\
\hline 1897. & & & \\
\hline Feb. 16 & J. B. Lippincott . . . . . . . & 4.22 & 1,346 \\
\hline June 30 & J. B. Lippincott and B. Cole .... & 8.60 & 6,754 \\
\hline July 14 & A. Q. Campbell . . . . . . & 3.20 & 1,015 \\
\hline Sept. 5 & $\ldots$ do .......... & 2.00 & 144 \\
\hline Oct. $\quad 29$ & $\ldots$ do _.............. & 2.40 & 223 \\
\hline Dec. 19 & J. B. Lippincott $\ldots \ldots$ & 3.00 & 429 \\
\hline
\end{tabular}


Discharge measurements of Stan islaus River at Oakdale, etc.-Continued.

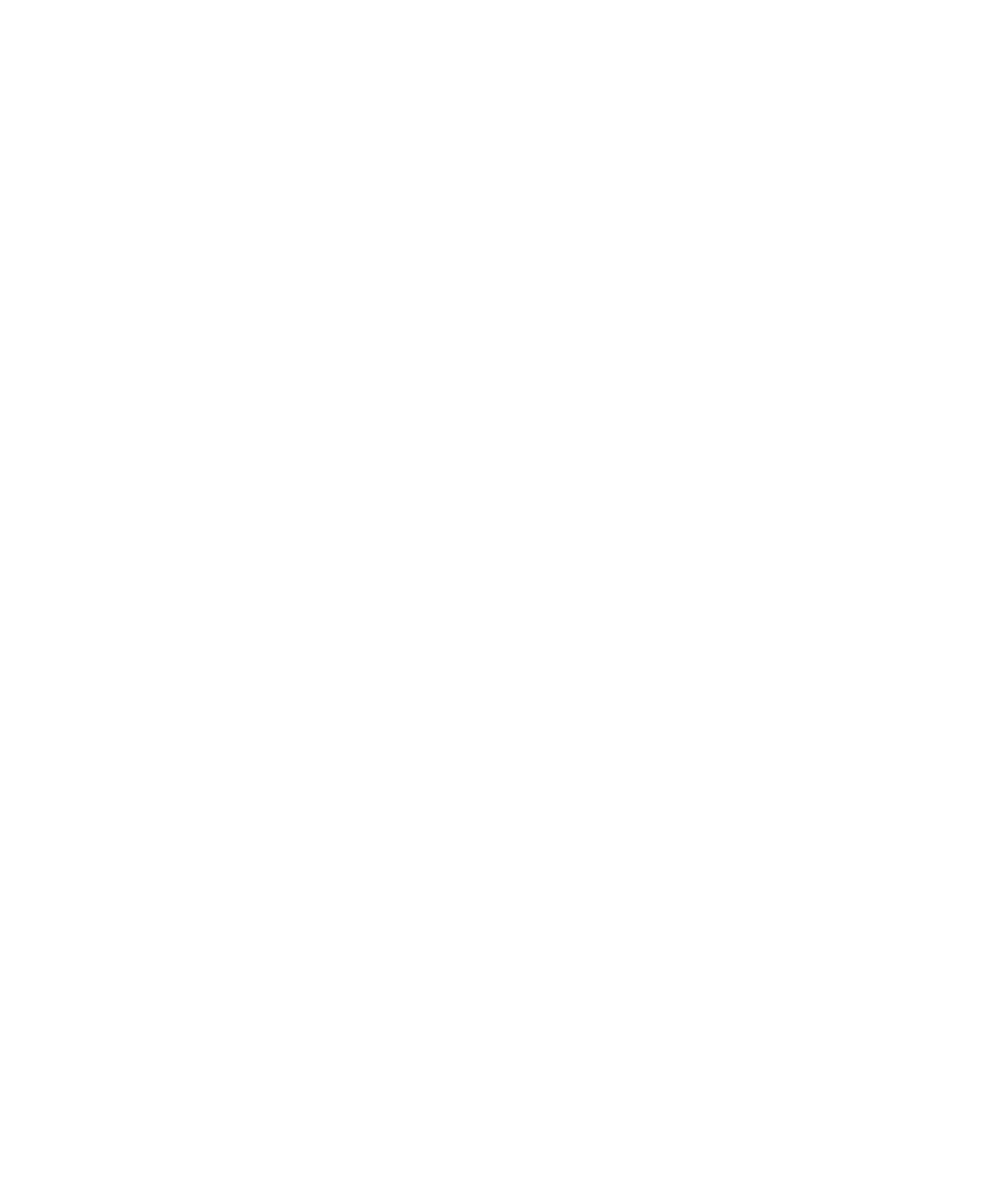

$\alpha$ New rod set July 20,1898

Discharge measurements of Stanislaus River at Parrots Ferry.

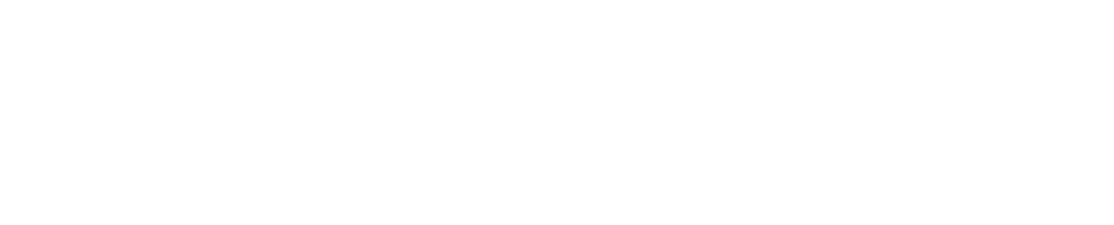


Estimated monthly discharge of Stanislaus River at Ortkdale, Stanislaus County." [Drainage area, 1,051 square miles.]

\begin{tabular}{|c|c|c|c|c|c|c|}
\hline \multirow[b]{2}{*}{ Month. } & \multicolumn{3}{|c|}{ Discharge. } & \multirow[b]{2}{*}{$\begin{array}{c}\text { Total } \\
\text { discharge. }\end{array}$} & \multicolumn{2}{|c|}{ Ruz-off. } \\
\hline & Maximum. & Minimnm. & Mean. & & $\begin{array}{l}\text { Per } \\
\text { square } \\
\text { mile. }\end{array}$ & Depth. \\
\hline 1878. & Sec-feet. & Sec.-feet. & Ser.ffet. & Acrefeet. & Sec.feet. & Inches. \\
\hline November ${ }^{k}$. - & 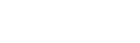 & & 42 & 2. 499 & 0.04 & 0.04 \\
\hline December $"$ & $\cdots \ldots$ & & 42 & $2, \tilde{5} 82$ & .04 & .05 \\
\hline $18 \% 9$. & & & & & & \\
\hline January $b \ldots$ & $\ldots \ldots$ & $\ldots \ldots$ & 525 & 32,281 & .50 & .58 \\
\hline February ..... & 9,830 & 350 & 1,994 & 110.741 & 1.89 & 1.97 \\
\hline March ........ & 6,960 & $\ldots \ldots$ & 4.523 & 278.108 & 4.30 & 4.96 \\
\hline April . . . . . . . & $\tau, 390$ & 3,260 & 4.307 । & 256,284 & 4.09 & 4.56 \\
\hline May . . . . . . . . . & 6,060 & 2,950 & 4,098 & 251,976 & 3.90 & 4.50 \\
\hline June . . . . . . . . & 6,720 & 3,160 & $4,38 \%$ & 261,044 & 4.17 & 4.65 \\
\hline July $\ldots \ldots \ldots$ & 2,230 & 1,320 & 1,584 & 97,396 & 1.51 & 1.74 \\
\hline August $b \ldots \ldots$ & & & 126 & 7.747 & .12 & .14 \\
\hline September $b$ & & & 21 & 1, 24.9 & .02 & .02 \\
\hline October $b \ldots$ & & & 21 & 1. 291 & .02 & .02 \\
\hline November " .. & & & 74 & 4,403 & .07 & .08 \\
\hline December ${ }^{b}$. & & & 630 & 38,737 & .60 & .69 \\
\hline The year & & & 1,858 & $1,341,25 \%$ & 1.77 & 23.91 \\
\hline 1880. & & & & & & \\
\hline January $b \ldots$ & & - & 315 & 19,369 & 0.30 & 0.35 \\
\hline February & & & 526 & 30,256 & .50 & .53 \\
\hline March $b \ldots$ & $\cdots+x_{1}$ & $\ldots$ & 630 & 38,737 & .60 & .69 \\
\hline April ${ }^{\prime} \ldots \ldots$ & $\ldots$. & - . . & 5. $781 ।$ & 343.993 & 5.50 & 6.14 \\
\hline May $\ldots \ldots \ldots$ & 10,980 & $4,3 \% 0$ & $\tau, 251$ & 445,846 & 6.90 & 7.96 \\
\hline June $\ldots \ldots \ldots . . . . . .$. & 10,820 & 5,240 & 5.742 & 460,681 & 7.37 & 8.22 \\
\hline July . & 4.630 & 1,680 & $3,25 \overline{1}$ & 200,142 & 3.10 & 3.57 \\
\hline August $\ldots . . .$. & & & 735 & 45,193 & .70 & .81 \\
\hline September & & & 74 & 4,403 & .07 & .08 \\
\hline October .... & & & 32 & 1,967 & .03 & .03 \\
\hline November $b$. & & & 21 & 1,249 & .02 & .02 \\
\hline December ${ }^{b}$. & & & 630 & 38,737 & .60 & .69 \\
\hline The year ....... & & & 2.949 & $1,630,573$ & 2.14 & 29.09 \\
\hline
\end{tabular}

a Authority: California State engineering department from November, 18\%8, to October, 1884; United States Geological Survey from June, 1895, to December, 1900.

$b$ Estimated from run-off of neighboring streams and from previous measurements. 
Estimuted momthly discharge' of Stanislaus River, ete.-Continued.

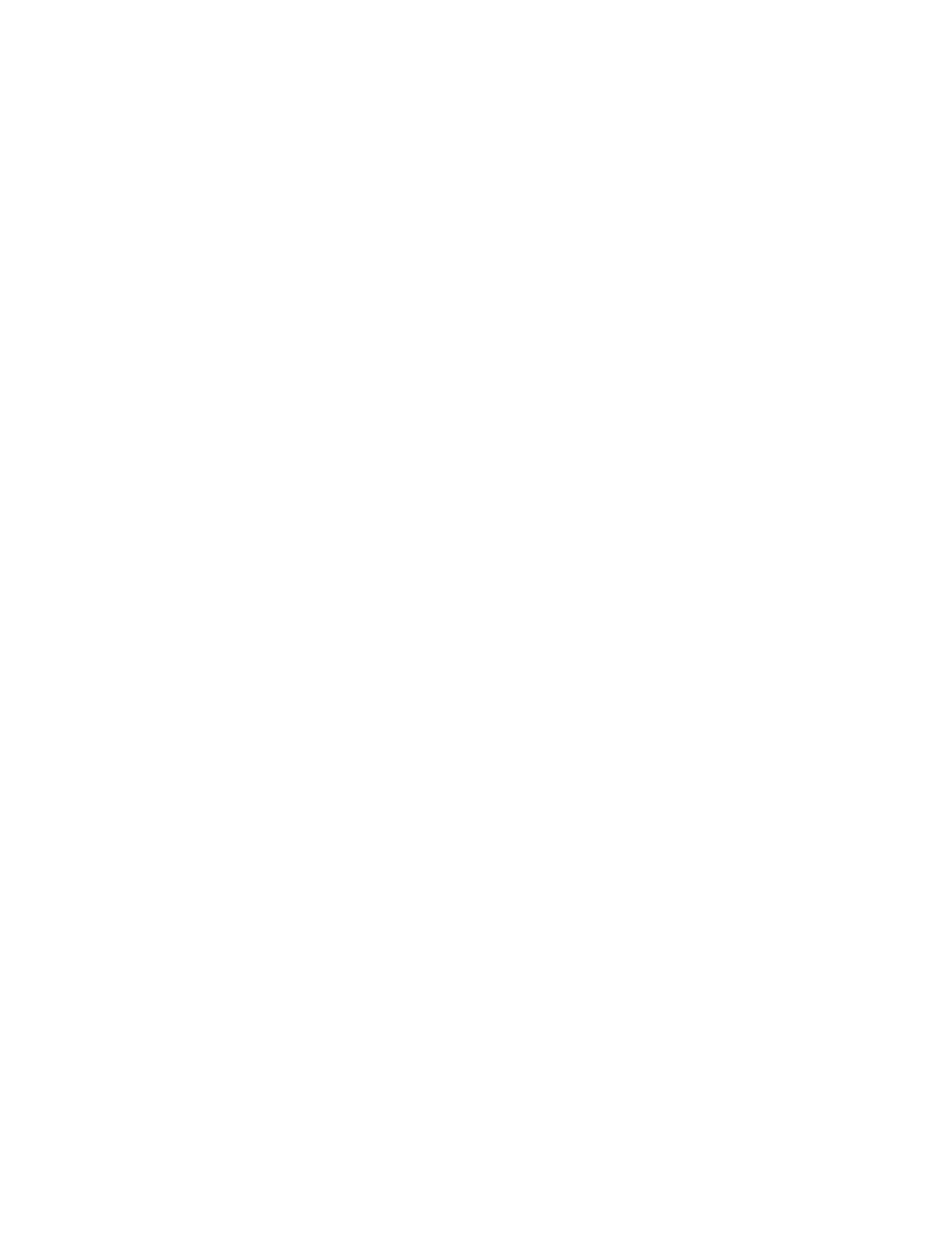

a Estimated from run-off of neighboring streams and from previous masurements. 
Estimated monthly diseharge of Stanislaus River, etc.-Continued.

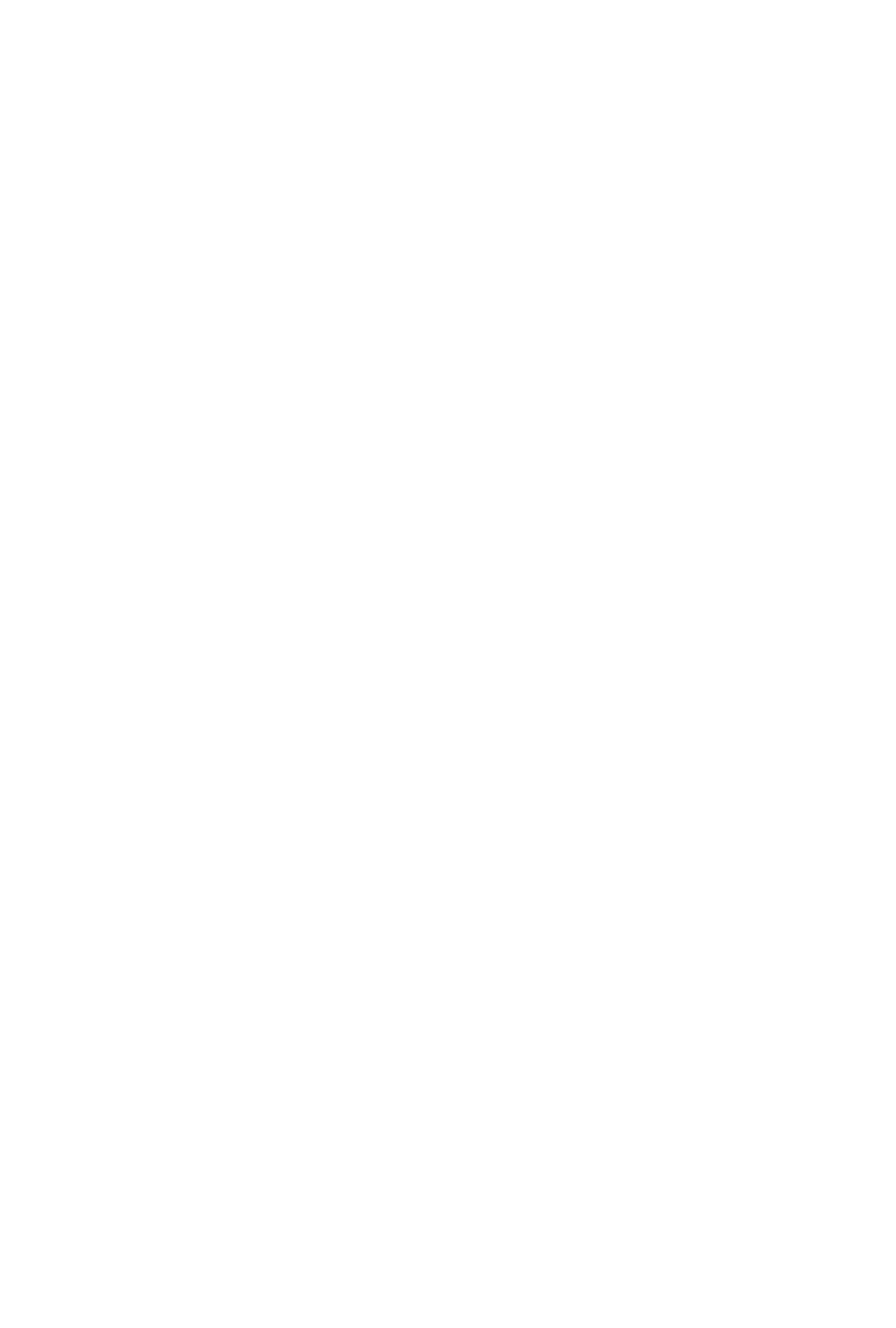


Estimuted monthly discharge of Stanislaus River, ete.-Continued.

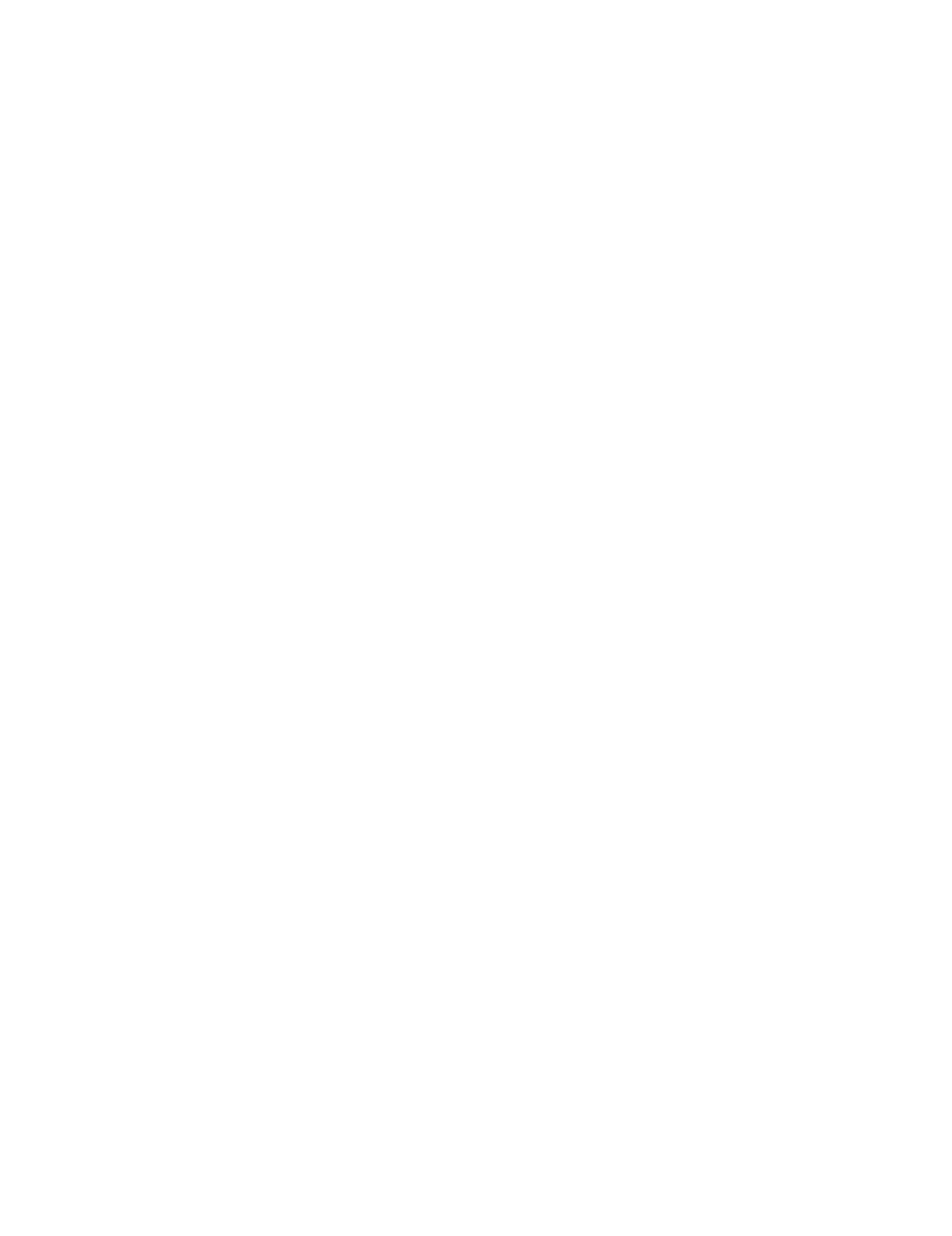


Estimated monthly discharge of Stanislaus River, ete.-Continued.

\begin{tabular}{|c|c|c|c|c|c|c|}
\hline \multirow[b]{2}{*}{ Month. } & \multicolumn{3}{|c|}{ Discharge. } & \multirow{2}{*}{$\begin{array}{c}\text { Total } \\
\text { discharge. }\end{array}$} & \multicolumn{2}{|c|}{ Rl' -off. } \\
\hline & Maximum. & Minimum. & Mean. & & $\begin{array}{l}\text { Per } \\
\text { square } \\
\text { mile. }\end{array}$ & Depth. \\
\hline 1898. & Sec.feet. & Sec.-feet. & Sec.feet. & Acrefeet. & Sec. feet. & Inches. \\
\hline January .... & 336 & 74 & $20 \pi$ & 12.728 & 0.20 & 0.23 \\
\hline February ... & 1,372 & 156 & 389 & 21,604 & $.3 r$ & .39 \\
\hline March - ... & 1,000 & 336 & $5 \% 2$ & 35,171 & .54 & .62 \\
\hline April . & 3.920 & 536 & 1,813 & 107,881 & 1.73 & 1.93 \\
\hline May ........ & 2,540 & 536 & 1,378 & 84,730 & 1.31 & 1.51 \\
\hline June ....... & 880 & 480 & 647 & 38,499 & .62 & .69 \\
\hline July . . . . . & 384 & 74 & $16 \tau$ & 10,268 & .16 & .18 \\
\hline Augast ... & 100 & 27 & 66 & 4,058 & .06 & .07 \\
\hline September . & 100 & 50 & 61 & 3,630 & .06 & .07 \\
\hline October.... & 100 & 74 & 77 & 4.735 & $.0 \%$ & .08 \\
\hline November & 100 & 50 & \%1 & 4,225 & .07 & .08 \\
\hline December ... & 315 & 74 & 139 & $8,54 \tau$ & .13 & .15 \\
\hline The year & 3,920 & 27 & 466 & 336,076 & .44 & 6.00 \\
\hline 1899 & $==$ & $==-=$ & & & & \\
\hline January ... & 1,240 & 70 & 457 & 28,100 & 0.44 & 0.51 \\
\hline February .... & 690 & 130 & 355 & 19,716 & .34 & $.3 \tilde{}$ \\
\hline March .... & 13,940 & 220 & 2,425 & 149,108 & 2.31 & 2.66 \\
\hline April ..... & 5,270 & 1.450 & 3,525 & 209,752 & $3: 35$ & 3.74 \\
\hline May ....... & 5,780 & 1.450 & 2,559 & 157,348 & 2.43 & 2.80 \\
\hline June...... & 4,632 & 1,045 & 2,663 & 158,459 & 2.53 & 2.82 \\
\hline July ....... & 1,120 & 175 & 502 & $30,86 \pi$ & .48 & .55 \\
\hline August ..... & 265 & 90 & 150 & 9,223 & .14 & .16 \\
\hline September - . & 130 & 50 & 85 & $5,0.58$ & .08 & .09 \\
\hline October.... & 1,200 & 90 & 309 & 19,000 & .29 & .33 \\
\hline November... & 2,340 & 90 & 1,092 & 64,978 & 1.04 & 1.16 \\
\hline December ... & 5,015 & 550 & 1,461 & 89,834 & 1.39 & 1.60 \\
\hline The year & 13,940 & 50 & 1,299 & 941,443 & 1.24 & $16.7 \%$ \\
\hline
\end{tabular}


Estimated monthly discharge of Stanislaus River, etc.-Continued.

\begin{tabular}{|c|c|c|c|c|c|c|}
\hline \multirow[b]{2}{*}{ Month. } & \multicolumn{3}{|c|}{ Discharge. } & \multirow{2}{*}{$\begin{array}{c}\text { Total } \\
\text { discharge. }\end{array}$} & \multicolumn{2}{|c|}{ Run-off. } \\
\hline & Maximum. & Minimum, & Mean. & & $\begin{array}{l}\text { Per } \\
\text { square } \\
\text { mile. }\end{array}$ & Depth. \\
\hline 1900. & Sec.feet. & Secr-feet. & Sec.feet. & Acre-feet. & sec.-feet. & Inches. \\
\hline January .... & 7,050 & 820 & 1,944 & 119,532 & 1.85 & 2.13 \\
\hline February & 1,100 & 540 & 700 & 38,873 & .67 & .70 \\
\hline March .... & 2,640 & 540 & 1,829 & 112,461 & 1.74 & 2. 01 \\
\hline April ... & 3,000 & 1,260 & 1,761 & $104,78 \%$ & 1.68 & 1.87 \\
\hline May ............. & 4,377 & 1.260 & 3,343 & 205,553 & 3.18 & 3.67 \\
\hline June _... . . . . . & 3,125 & 960 & 1,863 & 110,859 & 1. 78 & 1.97 \\
\hline July $\ldots . . . . . . . .$. & 960 & 70 & 349 & 21,459 & .33 & .38 \\
\hline August $\ldots . . . . . . .$. & 110 & 30 & 64 & 3,935 & .06 & $.0 \%$ \\
\hline September .... & 70 & 30 & 46 & 2,73 & .04 & .04 \\
\hline October .... & 2,760 & 70 & 448 & 27,545 & .43 & .49 \\
\hline November & 6,037 & 310 & 1,220 & 72,595 & 1.16 & 1.29 \\
\hline December . ......... & 1,640 & 610 & 871 & $53,5 \pi 5$ & .83 & .95 \\
\hline The year & 7,050 & 30 & 1,203 & 873,893 & 1.15 & 15.57 \\
\hline
\end{tabular}

Discharge measmrement of Cascade Crepk. Stanislaus River, Tuolumne County.

\begin{tabular}{|c|c|c|}
\hline Date. & Hydrographer. & $\begin{array}{l}\text { Dis- } \\
\text { charge. }\end{array}$ \\
\hline Oct. 21,1896 & J. B. Lippincott _. & $\begin{array}{r}\text { Sec.feet. } \\
0.0\end{array}$ \\
\hline
\end{tabular}

Discharge measurement of Cou Creek, Stanislaus River, Tholumne County.

\begin{tabular}{c|c|c|c|c} 
Date. & Hydrographer. & $\begin{array}{c}\text { Dis- } \\
\text { charge. }\end{array}$ \\
\hline Oct. 21,1896 & J. B. Lippincott & & & Sec.feet. \\
0.5
\end{tabular}


Discharge measurement of Stanislaus River, Main Fork, Eureka Ialley, Tuolumne County.

Date.

Hydrographer.

Discharge measurement of IIill C'reek. Stanislans: River, Tholumne County.

\begin{tabular}{c|c|c|c|}
\hline Date. & Hydrographer. \\
charge.
\end{tabular}$|+| \begin{array}{r}\text { Sec.feet. } \\
1.5\end{array} \mid$

Discharge measurement of Niagura C'reek, Stanislaus River. Tuolumne county.

\begin{tabular}{|c|c|c|c|c|}
\hline & Date. & Hydrographer. & $\begin{array}{l}\text { Dis- } \\
\text { charge. }\end{array}$ & Remarks. \\
\hline Oct. & 21,1896 & J. B. Lippincott. & $\begin{array}{c}\text { Sec-feet. } \\
1.5\end{array}$ & \\
\hline
\end{tabular}

Discharge measmement of Stanislaus River. Midalle Fork. Dounds Flut. near month of Niagame C'reek. Tuohume c'ounty.

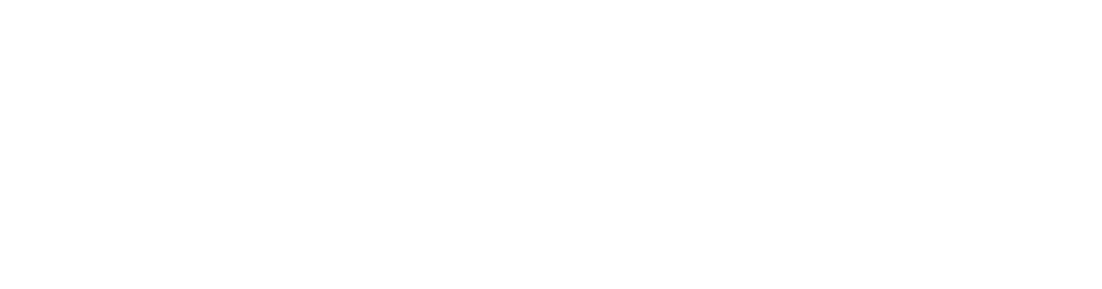

Discharge measurement of stanislans River. Widdle Fork, worth of shot Gun, Turolume County.

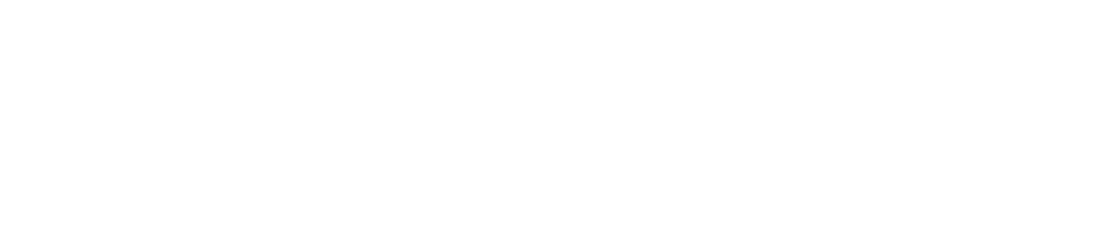

IRR $81-0: 3-28$ 
Dischnefy mensmrement uf Stunislaus River, Oakdale Ditch Crompany's Flumer. Stanislars County.

\begin{tabular}{|c|c|c|c|c|}
\hline Date. & Hydrographer. & $\begin{array}{c}\text { Gage } \\
\text { height. }\end{array}$ & $\begin{array}{c}\text { Dis- } \\
\text { charge. }\end{array}$ & Remarks \\
\hline 1899. & & Feet. & sec.-feet. & \\
\hline $\begin{array}{c}\text { May } 19 \\
190 \% .\end{array}$ & S. G. Bennett - & & 10.6 & \\
\hline May 12 & S. G. Bennett ... & 23 & 36.0 & $\begin{array}{l}\text { Flume No. 13, main canal be- } \\
\text { low head of Oakdale Canal. }\end{array}$ \\
\hline Do . & .....do . & & \%3.0 & $\begin{array}{l}\text { Flume No. 6, main canal be- } \\
\text { low head of Oakdale Canal. }\end{array}$ \\
\hline Do _ & ... do & & 13.71 & \\
\hline
\end{tabular}

Discharge measurements of Stanislaus Water Company's Canal. Stunislans River. near Knights Ferry, Stanislaus County.

\begin{tabular}{|c|c|c|c|c|}
\hline Date. & Hydrographer. & $\begin{array}{c}\text { Gage } \\
\text { height. }\end{array}$ & $\begin{array}{l}\text { Dis- } \\
\text { charge. }\end{array}$ & Remarks. \\
\hline 1896. & & Feet. & Sec-feet. & \\
\hline Sept. 8 & H. Crowe ....... & & 66 & \\
\hline Oct. 30 & J. B. Lippincott & & 38 & \\
\hline $189 \pi$ & & & & \\
\hline Feb. 16 & J. B. Lippincott - & & 26 & Below forks. \\
\hline Do . - & $\ldots$ do $_{2}$ & & 13 & Little Johr Canal. \\
\hline & Total & & 39 & \\
\hline \multirow{3}{*}{$\begin{array}{c}\text { May }: 30 \\
\text { Do }\end{array}$} & J, B. Lippincott . & & 54 & Main canal below forks. \\
\hline & $\ldots$... do ........ & & 12 & Little John Canal. \\
\hline & Total & & 66 & \\
\hline \multirow{3}{*}{$\begin{array}{l}\text { July } 1: 3 \\
\text { Do }\end{array}$} & A. Q. Campbell & & 36 & Below forks. \\
\hline & $\ldots$... do ........ & & 15 & Little Johr Canal. \\
\hline & Total & & 51 & \\
\hline \multirow{3}{*}{$\begin{array}{c}\text { Sept. }{ }^{6} \\
\text { Do }\end{array}$} & A. Q. Campbell & & 52 & Below forks. \\
\hline & .... do ......... & & 1 & Little Johr Canal. \\
\hline & Total & & 53 & \\
\hline \multirow{3}{*}{$\begin{array}{c}\text { Oct. } \quad 29 \\
\text { Do }-\end{array}$} & A. Q. Campbell & & 35 & Below forks. \\
\hline & .... do ........ & & 1 & Little Johr Canal. \\
\hline & Total ..... & & 36 & \\
\hline \multirow{3}{*}{$\begin{array}{l}\text { Dec. } 19 \\
\text { Do }\end{array}$} & J. B. Lippincott & & 17 & \multirow{3}{*}{$\begin{array}{l}\text { Below forks. } \\
\text { Little Johr Canal. }\end{array}$} \\
\hline & .. . do ......... & & 4 & \\
\hline & Total & & 21 & \\
\hline
\end{tabular}


Discharge measurements of Stanislaus Water Company's Canal. etc.-Continued.

\begin{tabular}{|c|c|c|c|c|}
\hline Date. & Hydrographer. & $\begin{array}{l}\text { Gage } \\
\text { height. }\end{array}$ & $\begin{array}{c}\text { Dis- } \\
\text { charge. }\end{array}$ & Remarks. \\
\hline 1898. & & Feet. & seci-feet. & -- \\
\hline Apr. 17 & J. B. Lippincott & & 58 & \\
\hline June 1 & $\ldots$ do $\ldots . . . .$. & $\ldots$ & $\because 2$ & Main canal flume No. 3. \\
\hline July 29 & $\ldots$. $d o \ldots . . . . . .$. & & 42 & Do. \\
\hline Oct. 5 & $\ldots$ do ....... & & 33 & \\
\hline Oct. 6 & $\ldots d 0 \ldots$ & & 33 & \\
\hline 1899. & & & & \\
\hline May 19 & S. G. Bennett - & & 74 & Do. \\
\hline June 6 & .... do ....... & & r1 & Do. \\
\hline 1900 & & & & \\
\hline May 9 & S. G. Bennett ..... & 2.79 & 95 & Do. \\
\hline Sept. $\quad \gamma$ & ... do ...... & & $8 \overline{5}$ & At headworks of canal. \\
\hline 1902. & & & & \\
\hline May 12 & S. G. Bennett . & 1.14 & 129 & Flume No. 3, main canal. \\
\hline Aug. 16 & E. T. Perkins ... & 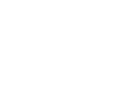 & 3.5 & $\begin{array}{l}\text { San Antonio Creek below } \\
\text { mouth of Big Tree Creek. }\end{array}$ \\
\hline Ang. 1i & . . do ..... & . & $6 \%$ & $\begin{array}{l}\text { Angel's ditch near head } \\
\text { North Fork Stanislaus. }\end{array}$ \\
\hline Do _. & ..... do ... & & 1 & $\begin{array}{l}\text { North Fork, } \notin 00 \text { feet below } \\
\text { suspension bridge. }\end{array}$ \\
\hline & Total & & 68 & \\
\hline Ang. 17 & E. T. Perkins & & 2.3 & $\begin{array}{l}\text { Mill Creek at junction Love } \\
\text { and Morgan creets. }\end{array}$ \\
\hline Aug. 20 & $\ldots$. . do & & 54 & $\begin{array}{l}\text { Power company's flume } \\
\text { above ditch tender's house, } \\
\text { South Fork. }\end{array}$ \\
\hline Do _ & $\ldots$. . do & & 16 & Do. \\
\hline Aug. 21 & ... do ...... & & 53 & $\begin{array}{l}\text { Clarks Fork at mouth Mid- } \\
\text { dle Fork. }\end{array}$ \\
\hline Do & $\ldots$. do & & $1: 6$ & $\begin{array}{l}\text { Middle Fork below month } \\
\text { of Clarks Fork. }\end{array}$ \\
\hline Do & ..... do & & i3 & $\begin{array}{l}\text { Middle Fork above mouth } \\
\text { of Clarks Fork. }\end{array}$ \\
\hline Aug. 14 & ..... do .. & & .53 & $\begin{array}{l}\text { Standard ditch at flume No. } \\
59 \text {. }\end{array}$ \\
\hline Aug. 22 & L. M. Lawson & 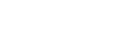 & 193 & Below Colliers. \\
\hline Aug. 24 & .... do & & 160 & Abbotts ferry. \\
\hline Aug. 21 & ..... do . . . . . . . & .6 & 168 & Parrotts ferry. \\
\hline Aug. 23 & . . . do ........ & & $1 \tilde{1} 1$ & Robinsons ferry. \\
\hline Aug. 19 & . . do . . . . . . . & & 166 & Knights ferry. \\
\hline Aug. 17 & .... do .......... & $\ldots \ldots$ & 154 & $\begin{array}{l}\text { Stanislaus Water Co.'s canal } \\
\text { below intake. }\end{array}$ \\
\hline
\end{tabular}


Discharge measmements of stamislans ITater ('ompany's r'anal, ete.-Continued.

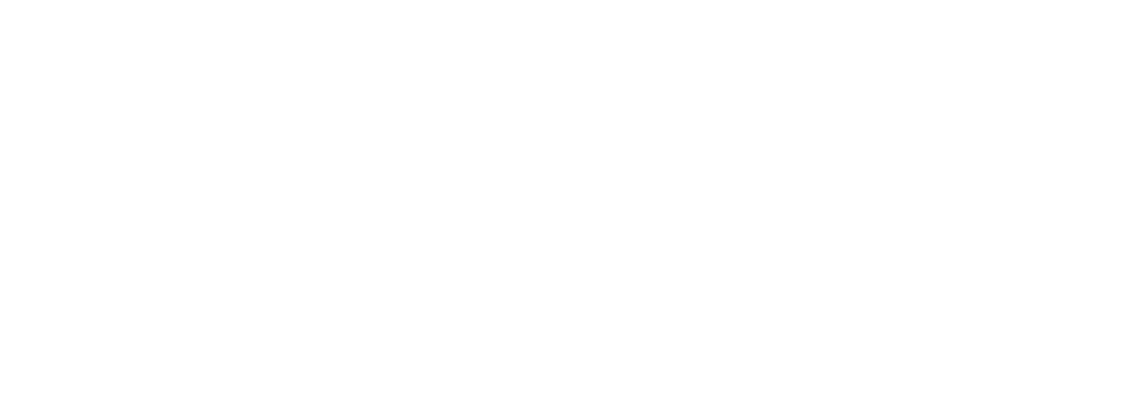

Discharye measurements of Stanislaus River. Tuolumne Connty.

\begin{tabular}{|c|c|c|c|c|}
\hline Date. & Hydrographer. & $\begin{array}{c}\text { Gage } \\
\text { height. }\end{array}$ & $\begin{array}{c}\text { Dis- } \\
\text { charge. }\end{array}$ & Locality. \\
\hline 1896 & & Feet. & Sec-feet. & \\
\hline Sept. 3 & J. B. Lippincott & & 60 & $\begin{array}{l}\text { South For' at Sugar Pine. } \\
\text { In flume; not entire flow of } \\
\text { river. }\end{array}$ \\
\hline 1901. & & & & \\
\hline Sept. 17 & C. E. Moore & & 300 & $\begin{array}{l}\text { Middle Fork, } 15 \text { miles above } \\
\text { junction with North Fork. }\end{array}$ \\
\hline
\end{tabular}

STONY CREEK.

This stream drains 700 square miles of the eastern slopes of the Coast Range. After reaching the Sacramento Valley it flows north for a number of miles, contrary to the general drainage, and then turns eastward and enters the Sacramento River 20 miles below Vina, Cal. A large portion of the basin near the heads of the stream is heavily covered with commercial timber. There are a number of good reservoir sites on this stream and its tributaries.

On January 30, 1901, a gaging station was established by Mr. Burt Cole at Julian's rauch, 6 miles northwest of the town of Fruto, Cal., to determine the amount of water available for storage.

For a description in detail of the reservoir sites and drainage basin of Stony Creek, see Water-Supply and Irrigation Paper No. 86. 
Discharge measurements of Stony Creek. Glenn County. Cal.

\begin{tabular}{|c|c|c|c|c|}
\hline Date. & Hydrographer. & $\begin{array}{l}\text { Gage } \\
\text { height. }\end{array}$ & Discharge. & Loeality. \\
\hline Ang.. $\quad 1900^{a}$ & & Feet. & Sier.foet. & \\
\hline Sept.. $\quad 1900$ e & Burt Cole ... & & 0.0 & $\left\{\begin{array}{l}\text { Grindstone Creek, } 4 \text { miles } \\
\text { above month. }\end{array}\right.$ \\
\hline Oct., $1900 "$ & & & & \\
\hline Nov. 22,1901 & H. E. Green & & 38.0 & $\begin{array}{l}\text { Grindstone Creek, point } \\
\text { above bridge. }\end{array}$ \\
\hline Aug. $\quad 3.19(100$ & Burt Cole. & & $1 . \tau$ & Hall ditch. \\
\hline Sept. 30,1900 & do . . & & 1.4 & $\begin{array}{l}\text { Hall ditch, } 10 \text { o feet above } \\
\text { head gate. }\end{array}$ \\
\hline July 28,1900 & $\ldots d 0 \ldots$ & & 2.3 & ()rland ditch. \\
\hline Aug. $\quad 3,1900$ & . . - do _ _..... & & 1.7 & Do. \\
\hline Sept. 30,1900 & $\ldots$ do ...... & $\ldots$. & 1.3 & Do. \\
\hline Sept. 22,1900 & S. G. Bennett & . & $\pi .7$ & I mile below Elk Creek. \\
\hline Aug., $\quad 1900 a$ & & & & \\
\hline Sept., $\quad 1900 q$ & Burt Cole. & - & .0 & Briscue Creek. at month. \\
\hline Oct.. $\left.\quad 1900^{a}\right]$ & & & & \\
\hline Nov. 22,1901 & H. E. Green & . & 10.4 & $\begin{array}{l}\text { Briscoe Creek, al sve dam } \\
\text { site. }\end{array}$ \\
\hline Sept. 21,1900 & Burt Cole ... & & 13.8 & Brown ditch. \\
\hline Sept. 1,1899 & W. W. Brier - & & 3.25 & $\begin{array}{l}\text { Thomas Creek, Tehama } \\
\text { County, at Richfield Sta- } \\
\text { tion. }\end{array}$ \\
\hline Nov. 11,1900 & Burt Cole - & & 69.0 & $\begin{array}{l}\text { Gaging station, Julian's } \\
\text { ranch. }\end{array}$ \\
\hline Feb. 19,1901 & $\ldots$ do & $\ldots$ & $18,000.0^{\prime \prime}$ & \\
\hline Feb. $2 \pi, 1901$ & $\ldots$ do ..... & 6.9 & 2.583 .0 & Do. \\
\hline Mar. 9,1901 & .... do ..... & 5.6 & 933.0 & Do. \\
\hline Apr. 30,1901 & S. G. Bennett & 4.9 & 382.0 & Do. \\
\hline Sept. $\quad 3,1901$ & .... do ....... & 3.17 & 3.4 & Do. \\
\hline Nov. 21,1901 & H. E. Green . - & 4.3 & 165.0 & Do. \\
\hline Jan. 26,1902 & S. G. Bennett & 3.9 & 126.0 & Do. \\
\hline Feb. 28.1902 & $\ldots$ do ....... & 10.0 & $7,336.0$ & Do. \\
\hline May 8,1902 & S. G. Bennett & 5.33 & $1,080.0$ & Do. \\
\hline Sept. 24,1902 & $\ldots$ do $\ldots$ & 3.00 & 14.0 & Do. \\
\hline Sept. 21.1900 & B. Cole - & & .3 & Laux ditch. \\
\hline Do $\ldots . .$. & $\ldots d_{0} \ldots$ & & 20.0 & $\begin{array}{l}\text { Stony Creek, near Stony } \\
\text { Fork, above Laux ditch. }\end{array}$ \\
\hline Sept. 26,1900 & .... do & & 6.2 & $\begin{array}{l}\text { Stony Ford ditcr, at head- } \\
\text { gate. }\end{array}$ \\
\hline Sept. $21,1900^{\prime}$ & do & & .3 & Welton ditch headgate. \\
\hline
\end{tabular}


Fistimutrel monthly discharge of Stony Creek at Juliun's ranch.

[Drainage area, 760 square miles.]

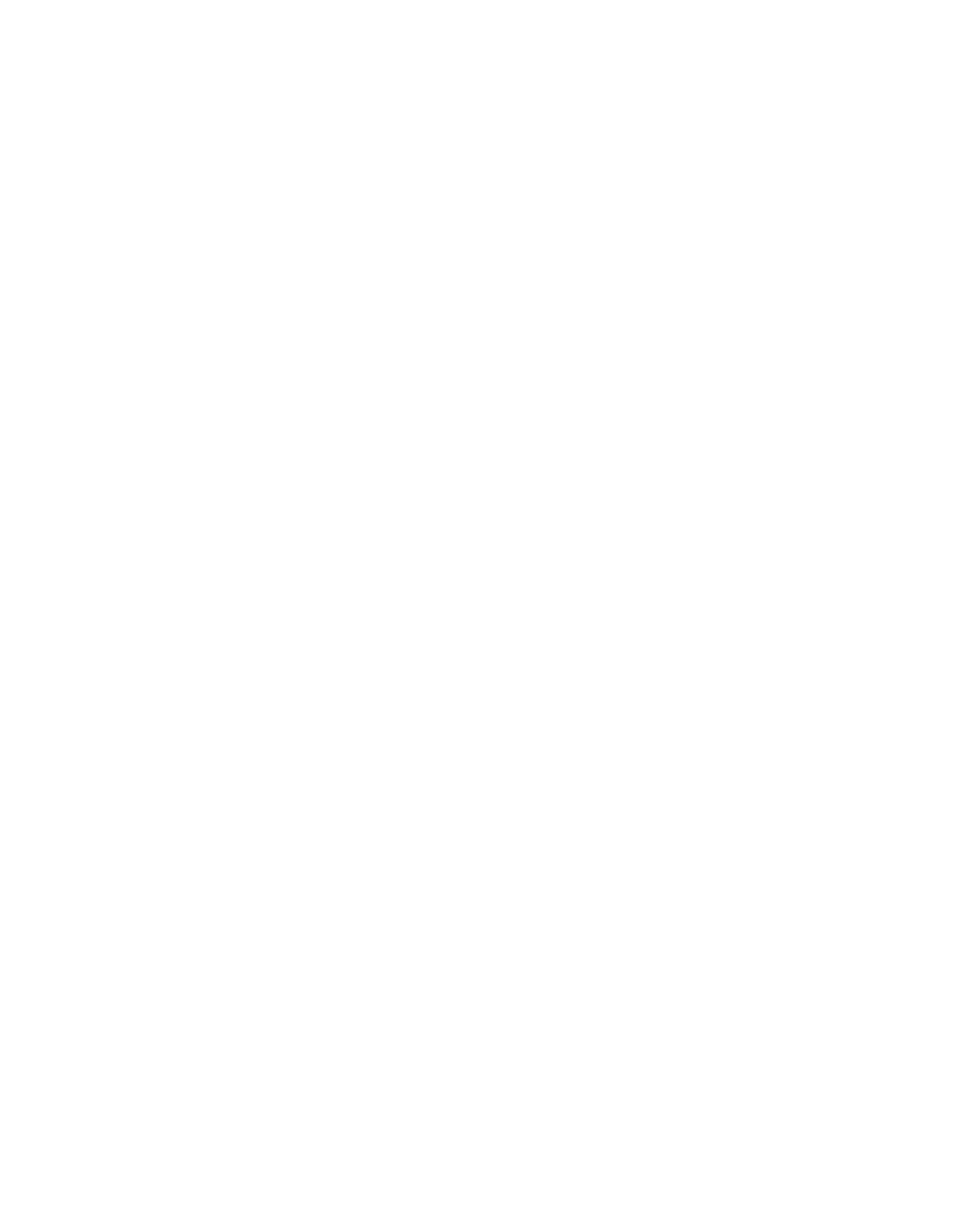


SUSAN RIVER.

Discharge measurements of Susan River at Honey Lake Basin, Lassen County.

\begin{tabular}{|c|c|c|c|c|}
\hline Date. & Hy̆drographer. & $\begin{array}{c}\text { Gage } \\
\text { height. }\end{array}$ & $\begin{array}{c}\text { Dis- } \\
\text { charge. }\end{array}$ & Lorality. \\
\hline 1899. & & Feet. & See -feet. & \\
\hline Apr. 18 & Albert Halen... . & & 25.0 & Mouth of Willow Creek. \\
\hline Apr. 18 & W.D. Minckler . . & & 25.0 & Do. \\
\hline Apr. 23 & Albert Halen .... & & 28.0 & Do. \\
\hline June 4 & $\ldots d 0 \ldots \ldots$ & $\ldots$. & 25.0 & Do. \\
\hline Apr. 24 & W. D. Minckler. . & & 28.0 & $\begin{array}{l}\text { Willow Creek, near Raven- } \\
\text { crofts. }\end{array}$ \\
\hline June 4 & $\ldots$ do ...... & & 24.0 & Do. \\
\hline June 11 & Albert Halen. ... & & 21.0 & Do. \\
\hline June 11 & W. D. Minckler... & & 21.0 & Do. \\
\hline 1900. & & & & \\
\hline June 4 & L. H. Taylor . . . . & 2.60 & 16.0 & Do. \\
\hline July 30) & $\ldots$ do ..... & 2.85 & 26.0 & Do. \\
\hline Oct. 10 & . do ........ & 2.80 & 20.0 & Do. \\
\hline 1899. & & & & \\
\hline Apr. 18 & Albert Halen .. & & 139.0 & $\begin{array}{l}\text { Main river. dam near mouth } \\
\text { of Willow Creek. }\end{array}$ \\
\hline Apr. 23 & . . . do & & 115.0 & Do. \\
\hline June 4 & $\ldots$ do .............. & $\ldots$. & $3 \pi .0$ & Do. \\
\hline June 11 & $\ldots d d_{0} \ldots . .$. & $\ldots$ & 33.0 & Do. \\
\hline June 11 & $\ldots$. . do ......... & & 34.0 & Main river, below dam. \\
\hline Apr. 18 & W. D. Minckler ... & $\ldots$. & 14.5 & Do. \\
\hline Apr. 23 & . . do . . . . . . & . & 41.0 & Do. \\
\hline June 11 & $\ldots$ do & . & 34.0 & $\begin{array}{l}\text { Main river, below Colony } \\
\text { dam. }\end{array}$ \\
\hline & $\ldots$ do. & & 23.0 & Do. \\
\hline 1900. & & & & \\
\hline June 30 & L. H. Taylor & 3.20 & 40.0 & Near Susanville. \\
\hline July $\quad \tilde{5}$ & $\ldots$ do ..... & 2.60 & 8.0 & Do. \\
\hline 1901. & & & & \\
\hline Mar. 16 & .. do & 4.30 & $2 \% 4.0$ & Do. \\
\hline Apr. $\tilde{j}$ & $\ldots$ do ......... & 4.00 & 178.0 & Do. \\
\hline May 20 & .... do ...... & 4.50 & 351.0 & Do. \\
\hline June $\tilde{\imath}$ & .....do & 3.60 & 84.0 & Do. \\
\hline
\end{tabular}


Dixcharge measurements of Susan River at Honey Lake Basin, etc.-Continned.

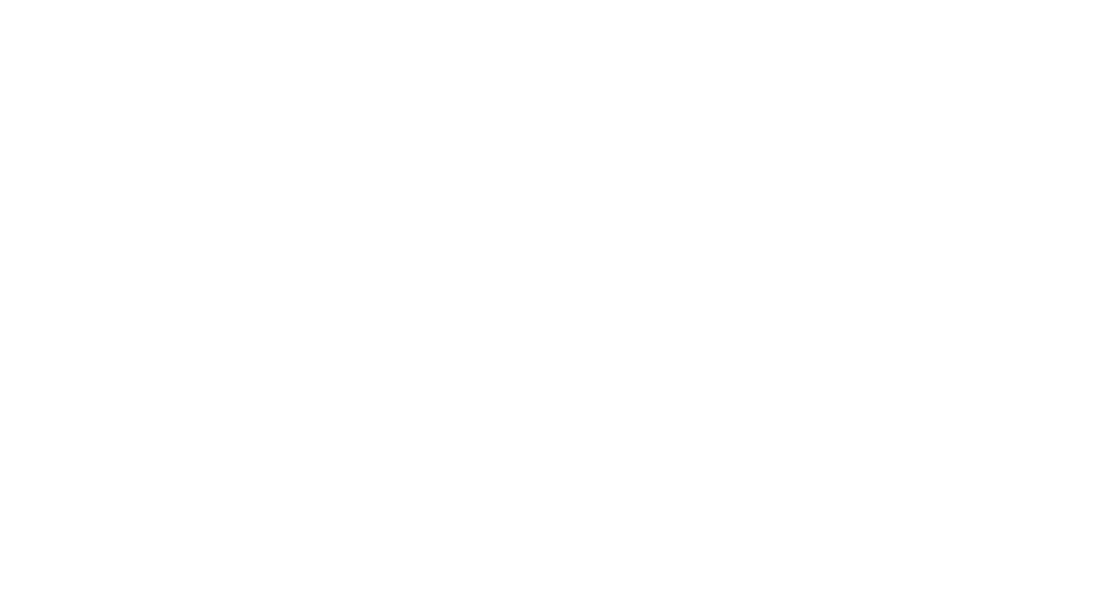

SUTTER RIVER.

Dischurge measurement of Sutter River. Amador County.

\begin{tabular}{|c|c|c|c|}
\hline Date. & Hydrographer. & $\begin{array}{c}\text { Dis- } \\
\text { charge. }\end{array}$ & Locality. \\
\hline 1899. & & sec-feet. & \\
\hline Sept. 18 & S. G. Bennett & 1.00 & At Sutter Creek (estimated). \\
\hline
\end{tabular}

SWEETWATER RIVER.

The drainage basin of Sweetwater River is in the extreme southwestern corner of the United States, being in San Diego County, Cal., adjacent to the Republic of Mexico. The river flows from the western slope of Cuyamaca Mountain, which rises to an elevation of 6,000 feet. The eity of San Diego, on the coast, is about 33 miles west and 12 miles south of this peak. The drainage basin is 34 miles in leugth by about 5 miles in width, its total area above the reservoir being $186 \mathrm{j}$ square miles, as determined in part from survey and in part from the county maps. This area is classified as follows:

Steep and rocky mountains favorable to large run-off Lower rolling mountains, usually covered with brush. . . . . . . . _ _... . . 99 Rolling hills, covered with soil and disintegrated granite $\ldots \ldots \ldots \ldots \ldots \ldots$ Agricultural lands (1\% per cent) and river bottom _............. 31

Total 186

The most noticeable topographic feature of this basin influencing the run-off is the abrupt flattening of the slopes at the base of the mountains into agricultural fields. The drainage lines deeply cut into the steep hillsides are quickly lost or are poorly defined in crossing the flat 
alluvial cones or partly filled valleys on the low grounds. In turn, the nearly level fields or parks drain into deep canyons. The occasional flood eaused by a heavy rain rushing down the mountain side spreads out over the flat lands, much of it disappearing before it can reach the lower eanyon. The steady percolation which might be expected at points below is to a large extent cut off by the high rate of evaporation, and thus the pereentage of run-off, taking the basin as a whole, is small. A more detailed description of this river is given in William Ham. Hall's report on irrigation in southern California.

The figures relating to the amount of water clraining from this basin and also the other details given in the following table have been eompiled from data obtained by $\mathrm{Mr}$. II. N. Savage, chief engineer, and Mr. James D. Schnyler, ronsulting engineer, of the San Dieg, Land and Town Conpany. The first column in the talle gives the evaporation from the surface of the Sweetwater reservoir in inches in depth per month. This was measured from a metallic pan exposed to the direct rays of the sum at a point near the dam, this being continued in use until May, 1893. Subsequently observations were made by means of a Piche evaporometer. ${ }^{a}$ This was placed in an instrument shelter of the ordinary type used by the Weather Bureau. This shelter is 15 feet above the ground and about 40 feet above the level of the lake, being locater 500 fect northeast from the gate tower. It has been noted that the records from the Piche evaporometer which cover the same months as those from the parr are in the ratio of 48 to 57 . It is believed that the exposed pan gives more nearly the evaporation from the water surface than the Piche evaporometer. If the evaporation were anmually 5 feet in depth from the surface of the reservoir-that is, from the 70 -foot level down to the 65 -foot level-the loss would amount to 24 per cent of the total amount stored. The area of the reservoir at the 70 -foot level is 721.86 acres.

The average wind velocity given in miles per hour is that noted at the city of San Diego, 12 miles from the reservoir, and under similar conditions. In this eonnection it may be well to note the results obtained by Prof. Thomas Russell as to the effect of velocity upon eraporation obtained br whirling the Piche evaporometer at varying rates.

Experiments were made which show that the effect of the wind on the evaporation from a vessel exposed in the open air is very great. Two Piche instruments were taken. one suspended in quiet air and the other fixed rigidly on the end of the 28-foot arm of the whirling machine set up in the inclosure of the Pension Office huilding. The whirling machine was the one used in standardizing anemometer.

The instruments, filled with water, were first weighed on a fine balance to the hundredth of a gram. The whirling arm was then turned so that the Piche on its end moved with a velocity of 5 miles an hour. The motion was continued for

a Described by Prof. Thomas Russell in the Monthly Weather Reriew for September, 1 $1 \times 88$, in connection with a report upon the depth of evaporation in the United States. 
half an hour. and at the end of the time both Piches were again weighed. Then the Piche that had been suspended in quiet air was put on the arm, and the one that lad been on the arm was put in its place. The whirling was then started again at the same velocity, and continued for another half hour. At the end of the time the Piches were again weighed. While this was being done the humidity of the air was determined from time to time by means of whirled wet and dry bulb thermometers.

Observations were also made in the same way with the Piche moving at velocities of $10,15,20,25$. and 30 miles per hour. At a velocity of is miles an hour the evaporation from a Piche was 2.2 times that from one in quiet air; at 10 miles, 3.8 times; at 15 miles, 4.9 times: at 20 miles, 5.7 times; at 25 miles, 6.1 times: and at 30 miles, 6.3 times. During the time the observations were made. June $2 \tilde{5}$ and 26,1888 , the average temperature of the air was 83.7 and the relative humidity 50 per cent.

Measurements were made of the relative humidity at the reservoir during 1893 and 1894 . When not obtained at this point they are given from the Weather Bureau figures for San Diego. The temperature of the air is taken as the average of the maximum and minimum daily readings. The temperature of the water in the lake and also in the pan was taken daily. That in the pan was observed at about 2 p. m., thus giving a reading slightly higher than that of the lake, as the pan under the hot sun caused the water to warm slightly. If two readings had been taken each day at intervals of twelve hours the average would probably have been very nearly that of the lake. It is noted that the water in the lake was usually a few degrees wrrmer than the atmospliere.

\section{RAINFALL IN SWEETWATER BASIN.}

The rainfall has been measured at two rain gages, ore at the reservoir and one at Descanso, 25 miles east of the reservoir and at an elevation of 3,500 feet. The Descanso gage is 3 miles to the east of the summit of a ridge which may act in such a manner as to cut off the precipitation, thus reducing it below a theoretical amount for this position. In addition to the two rain gages within the d rainage basin, the record from a third-that at the Cuayamaca reservoir-is given. This is at an eleration of 4,800 feet, and is only 3 miles distant from the divide between the drainage of Sweetwater and of San Diego River. The gage here is in a narrow valley or canyon, and the results obtained, being probably influenced by local topography, are regarded as excessive for this altitude and the locality. The rainfall at the dam in the winter of 1900-1901 was 11 inches.

The total amount of precipitation, as obtained at the reservoir and at Descanso, is not considered as showing the rainfall u pon the drainage basin as a whole. One of the gages is located tor high and the other too low to fairly represent the average conditions. In order, therefore, to obtain approximately the total amount of water falling upon the basin, certain assumptions are made and corrections are 
applied to the recorded precipitation. It is assumed that there is a regular increase in the rate of precipitation with altitude, and that this is at the rate of 0.6 inch of rain for each 100 feet increase in elevation. It is also assumed that the mean elevation of the whole basin is approximately 2,200 feet. Taking San Diego, which is nearly at sea level, as the base station, this, under the assumptions just given, would indicate that the rainfall on the basin should average 13.2 inches greater than that at San Diego. As the average rainfall at San Diego is 9.92 inches, the rainfall on the Sweetwater catchment area should be 9.92 plus 13.2 inches, or 23.12 inches.

In the same way the average rainfall is deduced from the measurements at the points within the basin. At Descanso the average rainfall is 26.38 inches. This point, having an altitude of 3,500 feet, is 1,300 feet above the assumed altitude of Sweetwater basin. Deducting, therefore, 7.8 inches leaves 18.58 inches as the average rainfall. Again, taking the results obtained at the rain gage at the Sweetwater reservoir, 12.01 inches, at an elevation of 250 feet, and adding to this the theoretical increase due to altitude of 11.70 inches, the sum 23.71 can be applied to the basin. The average of these two computations, based on the observations at Descanso and at the reservoir, is 21.14 inches for the basin. This method has been used in the following table, page 351 , in determining the average rainfall throughout the 186 square miles in the catchment basin for each year, additions being made to the rainfall recorded at the reservoir, and subtractiors from that at Descanso, the average of the two results thus obtained being given in the table.

\section{RUN-OFF FROM SWEETWATER BASIN.}

The discharge from this watershed, embracing 186 square miles, during the winter of $1900-1901$, was $280,000,000$ gallons, or 861 acrefeet.

The run-off shown in the table on page 351 has been computed by Mr. H. N. Savage. The stream usually ceased flowing about the 1st of June and remained dry throughout the summer, water flowing again in the fall or early winter after the rains began. At this latter time the reservoir is at a low stage, the water having been used for irrigation during the hot season. The flow into the reservoir, being wholly held, is therefore computed from the increase of height shown by the readings on the gage rod in the reservoir, due allowance being made for evaporation and the amount withdrawn. Later, whon the reservoir is full and some of the water overflows, an additional amount must be added. To obtain this amount is a somewhat difficult riatter, as the water flows out through a gate valve, over the waste weir, and also occasionally, during floods, over the top of the dam. 
Evaporation, temperature. and rainfall at Sueetumer resermoir, San Diego County.

\begin{tabular}{|c|c|c|c|c|c|c|c|c|}
\hline & & & & Tempe & rature. & & uainfall. & \\
\hline Month. & $\begin{array}{c}\text { Evapora- } \\
\text { tion. }\end{array}$ & $\begin{array}{l}\text { Wind } \\
\text { (miles } \\
\text { per } \\
\text { hour). }\end{array}$ & $\underset{\text { ity. }}{\text { Humid- }}$ & $\begin{array}{c}\text { Air, } \\
\text { degrees } \\
\text { Fahren- } \\
\text { heit. }\end{array}$ & $\begin{array}{c}\text { Water, } \\
\text { degrees } \\
\text { Fahren- } \\
\text { heit. }\end{array}$ & $\begin{array}{c}\text { At reser- } \\
\text { voir. }\end{array}$ & $\begin{array}{c}\text { At } \\
\text { Des- } \\
\text { canso. }\end{array}$ & $\begin{array}{l}\text { At } \\
\text { Cuya- } \\
\text { maca. }\end{array}$ \\
\hline 1888 & Inches. & & Percent. & & & Inches. & Thehes. & Inches. \\
\hline September & & & & 70 & & 0.00 & & 0.21 \\
\hline October & & & & 65 & & .36 & & 3.82 \\
\hline November & & & & 60 & & 2.81 & & 8.33 \\
\hline December & & & & 58 & & 3.20 & & 13.30 \\
\hline 1889 & & & & & & & & \\
\hline January .... & 1.990 & 4.8 & 80 & $\tilde{5}$ & & 1.56 & & 2.99 \\
\hline February & 3.336 & 5.7 & 74 & 56 & & .82 & & 4.70 \\
\hline March .... & 3.380 & 5.4 & 80 & б9 & & $3.8 \%$ & & 12.85 \\
\hline April .... & 4.961 & 5. 6 & 79 & 61 & & .36 & & 3.34 \\
\hline May ...... & 5.822 & 5.9 & 75 & 61 & & .21 & & 2.21 \\
\hline June . . . . . & 6.806 & 5.5 & 81 & 64 & & .33 & & .00 \\
\hline July . . . . . & $\tau .398$ & 5.1 & $\% 9$ & $6 \%$ & & .01 & & .00 \\
\hline August ..... & 8.253 & 5.0 & 69 & \%3 & & .00 & & 1.71 \\
\hline September & $\tau .360$ & 5.1 & & $\tau 1$ & & .00 & & .03 \\
\hline October ... & 2.998 & 4.7 & & 65 & & 2.22 & & 2.82 \\
\hline November & 4.800 & 4.4 & & 60 & & 1.08 & & 1.64 \\
\hline December & .246 & 4.7 & & 56 & & $7.0 \%$ & & 21.00 \\
\hline 1890 & & & & & & & & \\
\hline January .... & 1.588 & 5.0 & & 48 & & 2. 20 & & 11.02 \\
\hline February & 2. 214 & 5.2 & & 52 & & 2.07 & & 16.36 \\
\hline March .... & 3.280 & 4.9 & & 55 & & 1.30 & & 4.00 \\
\hline April .... & 4.141 & 5.1 & $\cdots$ & 58 & & .10 & & .97 \\
\hline May . . . . & 6.140 & 4.6 & $\ldots$ & 60 & & .41 & & .00 \\
\hline June $\ldots \ldots . . . .$. & 7.302 & 5.4 & $\ldots$ & 65 & & .00 & & .00 \\
\hline July . . . . . . . & $\tau .380$ & 4.7 & $\ldots$ & 70 & & .00 & & .09 \\
\hline August ..... & 9.020 & 4.6 & 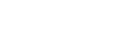 & 71 & & $.0 \pi$ & & .90 \\
\hline September & 6.482 & 4.3 & 69 & 72 & & .42 & & 1.40 \\
\hline October & 4.920 & 4.0 & 79 & 66 & & .45 & & .58 \\
\hline November... & 5.535 & 4.3 & ธ9 & 65 & & $.93^{\circ}$ & & 3.62 \\
\hline December & $1.84 \pi$ & 4.5 & 83 & 62 & & 2.29 & & 12.13 \\
\hline 1891 & & & & & & & & \\
\hline January .... . . & 3.608 & 4.4 & 58 & 55 & & .83 & & .00 \\
\hline February & 1.353 & 5.8 & 73 & 52 & & ว. 28 & & 34.70 \\
\hline March .... & 3.075 & 5.3 & 74 & 57 & & .23 & & 3.17 \\
\hline April .... & $3.70 \%$ & 4.9 & 76 & 581 & 70 & 1.27 & & 3.50 \\
\hline
\end{tabular}


Evaporation. temperature, and rainfall at Sweetucter reservoir, etc.-Continued.

\begin{tabular}{|c|c|c|c|c|c|c|c|c|}
\hline \multirow[b]{2}{*}{ Month. } & \multirow[b]{2}{*}{$\begin{array}{c}\text { Erapora- } \\
\text { tion. }\end{array}$} & \multirow[b]{2}{*}{$\begin{array}{c}\text { Wind } \\
\text { (miles } \\
\text { per } \\
\text { hour). }\end{array}$} & \multirow[b]{2}{*}{ Humid- } & \multicolumn{2}{|c|}{ 'Temperature. } & \multicolumn{3}{|c|}{ Rainfall. } \\
\hline & & & & $\begin{array}{c}\text { Air, } \\
\text { degrees } \\
\text { Fahren- } \\
\text { heit. }\end{array}$ & $\begin{array}{c}\text { Water, } \\
\text { degrees } \\
\text { Fahren- } \\
\text { heit. }\end{array}$ & $\begin{array}{c}\text { At reser- } \\
\text { voir. }\end{array}$ & $\begin{array}{c}\text { At } \\
\text { Des- } \\
\text { eanss. }\end{array}$ & $\begin{array}{l}\text { At } \\
\text { Cuya- } \\
\text { maca. }\end{array}$ \\
\hline$-{ }^{-}-$ & & - & & & & - - & --- & $\ldots$ \\
\hline 1891. & Inches. & & Percent. & 1 & & Inches. & Inches. & Inches. \\
\hline May . . & 5.599 & 5.4 & 75 & 61 & 69 & 0.83 & & 3.69 \\
\hline June ..... & 6.027 & 4.6 & it & 65 & 78 & .09 & & .00 \\
\hline July ..... & 6. 501 & 4.0 & is & i1 & 80 & .00 & & .04 \\
\hline August ... & 8.890 & 3.8 & $\%$ & 73 & $8 \dot{2}$ & .03 & & .30 \\
\hline September & 6.150 & 4.7 & 76 & 73 & 76 & .00 & & 2.67 \\
\hline October .... & 6.314 & 3.8 & 79 & 66 & $\tau_{2}$ & .00 & & .00 \\
\hline November... & 4.100 & 3.8 & 74 & 60 & 64 & .13 & & .45 \\
\hline December .... & 2.752 & 5.4 & 65 & 52 & 54 & .90 & & 6.75 \\
\hline 1892. & & & & & & & & \\
\hline January - - & 2.542 & 3.7 & 58 & 55 & 54 & 2.42 & & т. 23 \\
\hline February ... & 1,394 & 4.7 & 75 & 54 & 63 & 3.47 & & 6.47 \\
\hline March ....... & $3.0 \% 5$ & 4.8 & 73 & $\tilde{5} 6$ & 66 & .55 & & 7.76 \\
\hline April .... & 5.822 & 5.5 & 82 & $5 \pi$ & 70 & .93 & & 3.35 \\
\hline May ... . . & $4.6 \% 4$ & 5.7 & 68 & 61 & $\pi 1$ & 1.39 & & 5.90 \\
\hline June ..... & 6.478 & 5.6 & 69 & 63 & 74 & $.0 \%$ & & .67 \\
\hline July .... & 8.808 & 5.0 & 73 & $6 \tau$ & 78 & .00 & & .00 \\
\hline August ... - & 6.540 & 4.9 & $i 4$ & 68 & 78 & .02 & $\ldots$ & .00 \\
\hline September & 6.273 & 4.8 & 74 & 68 & 76 & .00 & 0.00 & .00 \\
\hline October... & 6.560 & 4. 2 & 65 & 64 & $a 68$ & .15 & .00 & .30 \\
\hline November. . & 4.766 & $3 . \tau$ & 50 & 62 & 60 & .04 & 1.50 & $2.8 \pi$ \\
\hline December. & 2.614 & 4.3 & 66 & 53 & 56 & 2.12 & 2.00 & 3.76 \\
\hline 1893. & & & & & & & & \\
\hline January ... & 2.768 & 4.0 & 51 & 571 & 58 & .22 & 3.01 & 5.55 \\
\hline February - & 2.214 & 5.1 & 67 & 54 & 59 & 1.96 & 2.64 & 9.13 \\
\hline March .... & $1.0 \% 6$ & 6.2 & $\approx 6$ & 51 & 60 & 6.50 & 14.07 & 15.60 \\
\hline April ....... & 5.002 & 5.3 & 73 & 581 & 64 & .27 & .50 & 1.00 \\
\hline May ... ... & 4.902 & 5.8 & 2 & 61 & 68 & .20 & .00 & 1.00 \\
\hline June . .. & 3.411 & 4.9 & $\pi$ & 65 & $\pi 6$ & .00 & .00 & .00 \\
\hline July ........ & 5.318 & 5.1 & $\pi$ & 69 & 81 & .16 & .75 & 1.20 \\
\hline August ..... & 4.693 & $\tilde{5} .0$ & 75 & i2 & 80 & .00 & .00 & .30 \\
\hline September _. _ & 4.864 & 5.1 & 75 & 66 & $7 \%$ & .00 & .25 & .00 \\
\hline October ...... & 4.586 & 4.6 & $6 \pi$ & 65 & 70 & .33 & 1.25 & 1.90 \\
\hline November _... & 4.513 & 4.5 & 65 & 58 & 60 & .84 & 3.15 & 3.30 \\
\hline December . . . & 6.283 & 4.5 & 60 & .38 & 58 & 2.08 & 4.38 & 6.05 \\
\hline
\end{tabular}

a End of measurements from pan and heginning of observations on Piche evaporometer. 
Evaporation, temperature, and rainfall at Sweetwater reservoir, etc.-Continued.

\begin{tabular}{|c|c|c|c|c|c|c|c|c|}
\hline \multirow[b]{2}{*}{ Month. } & \multirow[b]{2}{*}{$\begin{array}{c}\text { Evapora- } \\
\text { tion. }\end{array}$} & \multirow[b]{2}{*}{$\begin{array}{c}\text { Wind } \\
\text { (miles } \\
\text { per } \\
\text { hour). }\end{array}$} & \multirow[b]{2}{*}{$\underset{\text { ity. }}{\text { Humid- }}$} & \multicolumn{2}{|c|}{ Temperature. } & \multicolumn{3}{|c|}{ Rainfall. } \\
\hline & & & & $\begin{array}{c}\text { Air, } \\
\text { degrees } \\
\text { Fahren- } \\
\text { heit. }\end{array}$ & $\begin{array}{c}\text { Water, } \\
\text { degrees } \\
\text { Fahren- } \\
\text { heit. }\end{array}$ & $\begin{array}{l}\text { At reser- } \\
\text { voir. }\end{array}$ & $\begin{array}{c}\text { At } \\
\text { Des- } \\
\text { canso. }\end{array}$ & $\begin{array}{l}\text { At } \\
\text { Cuya- } \\
\text { maca. }\end{array}$ \\
\hline 1894. & Inches. & & Percent. & & & Inches. & Inches. & , Inches. \\
\hline January & 3.897 & 5.0 & 68 & 50 & 52 & 0.33 & 2. 10 & | $\quad 2.05$ \\
\hline February & 3.533 & 5.2 & 67 & 50 & 56 & .71 & 3.40 & 2.05 \\
\hline March ... & 3.008 & 5.8 & ז3 & 56 & 59 & 1.69 & 3.63 & 3.00 \\
\hline April & 3.634 & 5.4 & 70 & 59 & 65 & .04 & .13 & .00 \\
\hline May .... & 3.451 & 5.7 & 74 & 59 & 68 & .15 & .50 & 1.00 \\
\hline June . . . & 4.683 & 5.6 & 72 & 62 & 76 & .00 & .38 & .50 \\
\hline July & 3.161 & 5.2 & 75 & 67 & 80 & .00 & .12 & .00 \\
\hline August & 3.066 & 4.8 & 76 & 68 & 82 & .00 & .13 & 1.50 \\
\hline September. & 4.637 & 5.1 & 76 & 69 & $\% 5$ & .00 & .00 & .40 \\
\hline October & 3.232 & 3.8 & r2 & 64 & 70 & .04 & .00 & .00 \\
\hline November & 3.347 & 3.9 & $\tau 6$ & 59 & 64 & .00 & .00 & .00 \\
\hline December & 2.344 & 4.3 & 73 & 54 & 59 & 3.03 & ร. 62 & 12. 76 \\
\hline 1895 & & & & & & & & \\
\hline January .. & $2.35 \%$ & 6.0 & $\pi 4$ & 53 & & $9.6: 3$ & 19.52 & 28.43 \\
\hline February & 2.850 & 5.0 & & 54 & & 1.52 & 2.76 & 6.05 \\
\hline March & 3.121 & 5.3 & & 56 & & 1.18 & 3.13 & $5.5^{2}$ \\
\hline April .. & 3.939 & 5.2 & $\ldots$ & 58 & & .44 & .64 & 1.20 \\
\hline May .... & 4.119 & 5.8 & 77 & 63 & & .35 & .63 & .16 \\
\hline June ... & 3.188 & & & 66 & & .00 & .00 & .00 \\
\hline July ... & a 6.428 & & & 69 & & .00 & .00 & .00 \\
\hline August . & a 6.744 & & & 71 & $\ldots \ldots$ & .00 & .00 & .00 \\
\hline
\end{tabular}


The following table gives, for the period from 1888 to 1901, the estinated precipitation upon the catchment basin, obtained as stated on rage 347 , also the depth of run-off in inches and the relation which "his bears to the depth of rainfall, by years. The years chosen are not calendar years, but extend from Sieptember to August, inclusive, as this division is more in accordance with the distribution of rainfall and the discharge of the streams.

Estimated rainfall upon the Sueetwater atchment basin; also depth and percentage of run-off.

\begin{tabular}{|c|c|c|c|c|}
\hline \multirow{2}{*}{ Year. } & \multirow{2}{*}{ Rain. } & \multicolumn{2}{|c|}{ Run-off. } & \multirow{2}{*}{$P \Rightarrow \theta^{*}$ cent. } \\
\hline & & $\begin{array}{c}\text { Per square } \\
\text { mile. }\end{array}$ & Inches. & \\
\hline $188 \%-88 \ldots$ & Inche's. & $\begin{array}{c}\text { sec-feet. } \\
0.0524\end{array}$ & $\ldots \ldots$ & $\ldots$ \\
\hline $1888-89 \ldots$ & 21.00 & .1875 & 2.54 & 12.000 \\
\hline $1889-90 \ldots \ldots$ & 25.71 & .1525 & 3.71 & 14.000 \\
\hline $1890-91 \ldots \ldots$ & 23.40 & .1602 & $2.0 \%$ & 9.000 \\
\hline $1891-92 \ldots$ & 17.14 & .0460 & .62 & 4.000 \\
\hline $1892-93 \ldots \ldots \ldots$ & 20.00 & .1210 & 1.61 & 8.000 \\
\hline $1893-94 \ldots \ldots \ldots \ldots$ & 14.76 & .0099 & .14 & 1.000 \\
\hline $1894-95 \ldots \ldots$ & $2 \% .14$ & .5452 & T.12 & 26.000 \\
\hline $1895-96 \ldots \ldots \ldots$ & 19.54 & .0098 & .101 & .517 \\
\hline $1896-97 \ldots \ldots \ldots \ldots \ldots$ & 24.91 & .0512 & .665 & 2.67 \\
\hline $1897-98 \ldots \ldots \ldots$ & 18.18 & .00003 & .0005 & .003 \\
\hline $1898-99 \ldots \ldots$. & 18.51 & .0018 & .025 & .135 \\
\hline $1899-1900 \ldots \ldots$ & 19.10 & 0 & 0 & 0 \\
\hline $1900-1901 \ldots \ldots$ & 23.65 & .0063 & $.08 \pi$ & .368 \\
\hline $1901-1902 \ldots$ & 20.29 & 0 & 0 & 0 \\
\hline
\end{tabular}


The figures showing evaporation, wind movement, humidity, and temperature are brought together for comparison by years in the following table. In this case, as stated above, the years extend from September to August, inclusive, as this most nearly agrees with the natural division.

Anmal reaporation. temperature, etc, in sweetuater Basin.

[Elevation of reservoir, 250 feet ]

\begin{tabular}{|c|c|c|c|c|c|}
\hline Period. & Eraporation. & Wind. & Humidity. & $\begin{array}{l}\text { Tempera- } \\
\text { ture of air }\end{array}$ & $\begin{array}{l}\text { Tempera- } \\
\text { ture of } \\
\text { water. }\end{array}$ \\
\hline & hoches. & $\begin{array}{l}\text { Miles per } \\
\text { hour. }\end{array}$ & Per cent. & Deg. F: & Deg. F. \\
\hline $1889-90 \ldots$ & 56.47 & 4.9 & & & $\ldots \ldots$ \\
\hline $1890-91 \ldots \ldots$ &.$\% .54$ & 4.6 & $\ldots \ldots . . . . .$. & $\ldots \ldots$ & $\ldots \ldots$ \\
\hline $1891-92 \ldots \ldots \ldots . . . \ldots$ & 58.6 .5 & 4.8 & $\because 2$ & 61 & 68 \\
\hline $1892-93 \ldots \ldots$ & 49.60 & 4.9 & 68 & 61 & 67 \\
\hline $1893-94 \ldots \ldots$ & 48.68 & 5.1 & $\gamma_{0}$ & 60 & $6 \%$ \\
\hline $1894-9 \overline{9}_{\ldots} \ldots \ldots . . . .$. & 46.31 & 5.2 & $\because 9$ & 59 & $\ldots$ \\
\hline $1895-96 \ldots \ldots \ldots$ & $4 i j .18$ & 5.2 & $\pi 1$ & 61 & \\
\hline$\ldots \ldots \ldots$ & $a 41.24$ & 5. 3 & 76 & 61 & $\ldots \ldots$ \\
\hline $1897-98 \ldots \ldots \ldots \ldots$ & 61.93 & 5.9 & 73 & 60 & $\ldots$ \\
\hline $1898-99 \ldots \ldots \ldots$ & b 32.54 & 5.8 & $\pi 2$ & 59 & $\ldots \ldots$ \\
\hline $1899-1900 \ldots$ & & 5.7 & i.j) & 61 & \\
\hline $1900-1901 \ldots \ldots$ & & & - & $6:$ & \\
\hline
\end{tabular}

"Evaporation Jannary 1 to August 31.

b Evaporation Septemlier 1 to April 30.

FLOODS IN THE RIVER.

The Sweetwater, like the other rivers of southern California, is liable at times to extraordinary floods, due to heavy precipitation upon the catchment basin. In 1893 two floods furnished 70 per cent of the annual discharge of the river for that year. For the 24 hours ending March 24, 1893 , the river discharged 3,069 acre-feet. For the seven days ending March 27 , the total amount discharged was 7,980 acrefeet. In January, 1895, a flood was carefully watched and the flow computed at short intervals, as shown in the following table. The total run-off from 5 p. m. on January 14 to noon on January 22 was equivalent to a trifle over 4.70 inches over the whole drainage basin, or in all 46,670 acre-feet. This same storm gave a maximum discharge from Cedar, Boulder, and Colman creeks, aggregating 100 square miles within the drainage basin of San Diego River, of 13,000 second-feet. 
Rate of flow during flood of Jamuary, 1s\%, in Sweetwater River.

\begin{tabular}{|c|c|c|c|}
\hline Time. & $\begin{array}{l}\text { Second- } \\
\text { feet. }\end{array}$ & Time. & $\begin{array}{l}\text { Second- } \\
\text { feet. }\end{array}$ \\
\hline iry 14: & & January 17-Continued. & \\
\hline ip. $1 \mathrm{~m}$ & 0) & 3 p. m ... & 4,416 \\
\hline nuary 15: & & January 18: & \\
\hline ra. m. & 84 & s a. $\mathrm{m} \ldots$ & 3,331 \\
\hline $12 \mathrm{~m} \ldots$ & 1.855 & 9 a. $\mathrm{m} \ldots$ & 2.090 \\
\hline 3 p. $\mathrm{m} \ldots$ & 6,410 & 10 a. $\mathrm{m}$. & 2,048 \\
\hline 4 p. $\mathrm{m} \ldots$ & 5,214 & $\tau$ p. m... & 2,466 \\
\hline 5 p. $\mathrm{m} \ldots$ & 5. 262 & January 19: & \\
\hline $6 \mathrm{p} . \mathrm{m} \ldots$ & 4.152 & ja. m... & 1,532 \\
\hline ז p. $\mathrm{m} \ldots$ & 6.135 & 8.30 a. $\mathrm{nr}$ & 2,944 \\
\hline 9 p. $\mathrm{m} \ldots$ & 5.567 & 9.30 a. $\mathrm{m}$ & 2,888 \\
\hline 10 p. m $\ldots$ & 5.080 & 10.30 a. $\mathrm{m}$ & 3,068 \\
\hline nuary 16: & & 11.30 a. $\mathrm{m}$ & 3,470 \\
\hline ja. m. & 3,297 & 1.30 p. m . & 3,364 \\
\hline 6 a. $\mathrm{m} \ldots \ldots$ & 4.720 & $3 \mathrm{p} . \mathrm{m} \ldots$ & 3,968 \\
\hline ז & $3 . .585$ & $3.30 \mathrm{p} . \mathrm{m}$ & 4,692 \\
\hline 8.30 a. $\mathrm{m}$ & 5.316 & 4 p. m ... & 3,224 \\
\hline 9.30 a. $\mathrm{m}$ & $5.3 \% 0$ & $4.30 \mathrm{p} . \mathrm{m} \ldots$ & 3,230 \\
\hline 10.30 a. $\mathrm{m}$ & 6,602 & g. p. $\mathrm{m} \ldots$ & 3,$1 ; 6$ \\
\hline $11.30 \mathrm{a} . \mathrm{m}$ & 8.713 & January $20:$ & \\
\hline $12.30 \mathrm{p} . \mathrm{m} \ldots$ & 8,713 & ז & 3.314 \\
\hline $1.30 \mathrm{p.} \mathrm{m}$ & 13,684 & $9 \varepsilon \quad \mathrm{m} \ldots \ldots \ldots \ldots$ & 2.80 .5 \\
\hline 2 p. m ... & 13.000 & 10 a. $\mathrm{m} \ldots \ldots \ldots$ & $2,6 i 4$ \\
\hline 2.30 p. $1 \mathrm{~m}_{\ldots} \ldots$ & $15,14 \$$ & 11 a. $\mathrm{m} \ldots \ldots$ & 2,484 \\
\hline $3.30 \mathrm{p} . \mathrm{m} \ldots$ & 18.148 & 1 p. m $\ldots$ & 2,500 \\
\hline 4 p. $m \ldots$ & 14.0134 & 2 p. $m_{\ldots} \ldots \ldots \ldots$ & 2,136 \\
\hline $4.30 \mathrm{p.m} \ldots \ldots$ & 14,490 & January $21:$ & \\
\hline $5.30 \mathrm{p} . \mathrm{m} \ldots \ldots$ & $7.22 \%$ & э a. $\mathrm{m} \ldots \ldots$ & 1.880 \\
\hline $6.30 \mathrm{p}, \mathrm{m} \ldots \ldots$ & 9,420 & 10 a. $\mathrm{m} \ldots \ldots$ & 820 \\
\hline$\tau .30 \mathrm{p} . \mathrm{m} \ldots \ldots \ldots$ & 8,310 & $12 \mathrm{~m}, \ldots \ldots$ & 750 \\
\hline 8 1) m n $\ldots \ldots$ & 6.930 & $5.30 \mathrm{p} . \mathrm{m} \ldots \ldots$ & 800 \\
\hline antuary 1i: & & January 22: & \\
\hline 5 a. $\mathrm{m} \ldots \ldots$ & 5,302 & 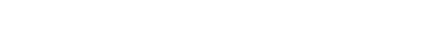 & 810 \\
\hline 6 a. $\mathrm{m} \ldots$ & 3,545 & $12 \mathrm{~m} \ldots \ldots \ldots$ & 530 \\
\hline 8 a. $\mathrm{m}$ & 3,954 & & \\
\hline
\end{tabular}

\section{INCREASE OF PRECIPITATION WITH AITITUDE.}

In connection with the above data concerning the rainfall and runa on the Sweetwater lrainage hasin, the writer has given a discusion of the precipitation in southern (alifornia, and has brought

IRR $\$ 1-03-23$ 
together figures showing the increase of rainfall with altitude. The following statement is quoted from a report made on this subject:

The warm, moisture-laden winds from the sea on their inland journey are driven up the slopes in the Coast Range. As they rise in elevation they expand under the lighter atmospheric pressure, become chilled, and are deprived of all moisture in excess of the point of saturation at that temperature and pressure. This lowering of temperature in their ascent is more pronounc 2 in winter than in summer, and, coupled with the fact that a high barometer is normal off the coast of southern California during the summer season, the winds yield much less rain.

The year in California is naturally divided into a wet and a dry season, the dry season beginning about the 1st of May. with little rain falling, except in thunderstorms in the high mountains, before the 1st of October. The rains then gradually increase, reaching their maximum in January. The records of the United States Signal Service and the Weather Bureau begin the year with the 1st of January. This is not a proper division in this region, as it will no ${ }^{+}$show either the maximum or minimum years of rainfall. Engineers divide the year either with the 1st of July or the 1st of September.

The effect of topography on rainfall is given in a report by Prof. G. E. Curtis $a$ in the following words:

"In general the amount of rain increases with the elevation above sea level up to a maximum plane, after which a decrease takes place. S. A. Hill has shown that in the northwest Himalayas, where the rainfall is most remarkable in amount and rate of variation, the observations can be represented by the following empirical formula: $R=1+1.92 h-0.40 h^{2}+0.02 h^{3}$, in which $\mathrm{R}$ represents the amount of rain and $h$ the relative height in units of 1,000 feet above the assumed plane, which is itself 1.000 feet above sea level. From this formula the height of maximum rainfall is computed to be 3.160 feet above the plane, or 4.160 feet above sea level. It is further shown that this elevation is that at which, according to the observed law of decrease of temperature, the southwest monson is cooled just below its dew-point. This point will be that at which in the mean we should expect the maximum precipitation to take place. *** A very rapid diminution takes place on the leeward side, where the stations recor only about half the amount of rainfall given by stations of equal elevation on the windward side."

Similar conditions prevail in California. In illustration the following table (p. 355) is given, in which the results obtained at a base station are compared with those from other stations in the vicinity and on that parallol. The base station in each case is one whose record is of long standing. In tho table the second column gives the period during which the record has been kept. The third shows the elevation of the station above sea. The fourth gives the annual average recorded rain at that station. The fifth gives the relation of the rainfall at the base station, during the years that rainfalls were actually recorded at the station under consideration, to the total average rainfall recorded at the base station during its entire period of observation. The record at the second station is then adjusted by this ratio and a probable average rainfall is determined for the station considered and entered in the sixth column under the head "Probable mean rain." $b$ For example, take the station Poway. The record at this point is for ten years. while the record at the base station, San Diego, has been kept for a period of

a Signal Service Notes. No. 16 The effect of wind currents on rainfall, by G E. Curtis, Washington, 1884, pamphlet, 11 pp., pp. 6-7.

$b$ See statement of Arthur Jacobs, late executive engineer for irrigation, Her Majesty's Bomhay Service, in Van Nostrand's Science Series, No. 6, p. 11. 
The stations of the first and second groups are located in San I iego County, and are all on the western slope of the Coast Range. Bear Valley is 80 miles east of Los Angeles on the same slope. The third group comprises the stations along the Central Pacific from Sacramento east to the summit, and the fourth those along the same line of road on the eastern slope 14,49 , and 83 miles by rail beyond the summit. This fourth group is given to show that wholly different conditions prevail on the eastern and on the western slope of the mountain.

All these records are seasonal, the year being divided at the 1 st of September when possible. Data are given from Signal Service and Weather Bureau reports, and from those of the California State engineer, the former keing accepted in cases of difference. Excepting the fourth or last group, which is given simply to show that the conditions prevailing on the eastern slope are dif erent from those of the western, it may be seen that the theoretical rain is very noarly the same as the probable mean rain. The instances where the widest variations exist usually can be explained.

In regard to the value of the theoretical rainfall, reference may again be made to the paper by Professor Curtis. He states (p. 8) that the Signal Service, in an investigation of the rainfall on the summit of Mount Washington to determine the local distribution and the average rainfall for the station, plesed five gages on the summit of the mountain. one in the center and four to the four points of the compass is feet distant from it. It has been known for a long time that a gage placed at an elevation above ground usually recorded less than one placed on the ground below, this difference being caused by wind currents. The increased velocities of the wind around the corners and over the tops of th: buildings. hills, or even the gage, tend to increase the slant of the falling rain at those points, and when just past the obstruction, the velocity of the wind being again reduced, a heavier fall of rain will be deposited. In this experiment on Mount Washington observations were made from September 1, 1882, to October 1, 1883. As the measurement of snow was reported as altogether unreliable, it was excluded. In the following table it is shown that the windward gages had received during this period 24.64 inches of rain and the leeward ones 28.43 inches, sinmle storms showing greater variation. The conclusion reached is that precipitation varies materially within distances of only 100 or 200 feet.

The most remarkable feature of the experiment is the different results obtained from gages with 3 -inch and 8 -inch catchment cups. The gages that were set to the four points of the compass had 3-inch cups and the regular station gage had one 8-inch cup. For the period in question the four exterior gag?s recorded 45.82, $51.19,45.40$, and 42.63 inches, respectively, while the regular station gage recorded $58 . \% 0$ inches of rain.

Comparative reading of 3 -inch and $s$-inch gages in wind.

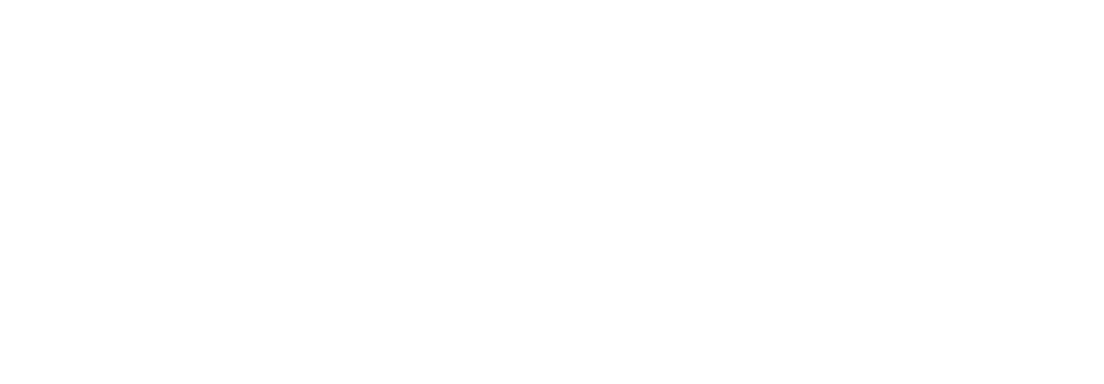


In view of these records, which are taken with experimental care. the stat mnent "ould be justified that the "Probable rainfall." as shown in the table on page 351, agrees with the " Theoretical rainfall " as closely as it can be measured, the gages eing of different makes and sizes.

The recorded rainfall of the Cuyamaca gage is probably in excess of the average in for this elevation and the locality, and it is so considered by engineers in San Diego. The gage is in a narrow valley or canyon. and is probably affected " the winds and the topography.

It will be seen that Cisco. with an elevation of 5,934 feet, has a rainfall of 56.28 $\because \gamma$ ches, while Summit, 13 miles heyond, with an elevation of 7,017 , has only 46.99 $\therefore$ clres of rain. It may be that this variation is due to the wind action, especially on the suow, which averages each year 31 feet in depth, or to the fact that Sum$n$ it is above the plane of maximum rainfall. as mentioned on page 354 .

\section{TECOLOTE CREEK.}

Discharge measurement of Tecolote Creek, Santa Barbara County.

\begin{tabular}{|c|c|c|}
\hline Date. & Hydrographer. & $\begin{array}{c}\text { Dis- } \\
\text { - ' harge. }\end{array}$ \\
\hline $\begin{array}{r}1899 . \\
\text { t ug. }\end{array}$ & G. F. Wright & $\begin{array}{l}\text { Ser.feet. } \\
\text { at } 0.27\end{array}$ \\
\hline
\end{tabular}

a Drainage area, 2 square miles.

TEJON CREEK.

See Fort Tejon Creek.

TEJON HOUSE CREEK. Discharge measurements of Tejon House Creek, at Tejon Ranch House, Kern
County.

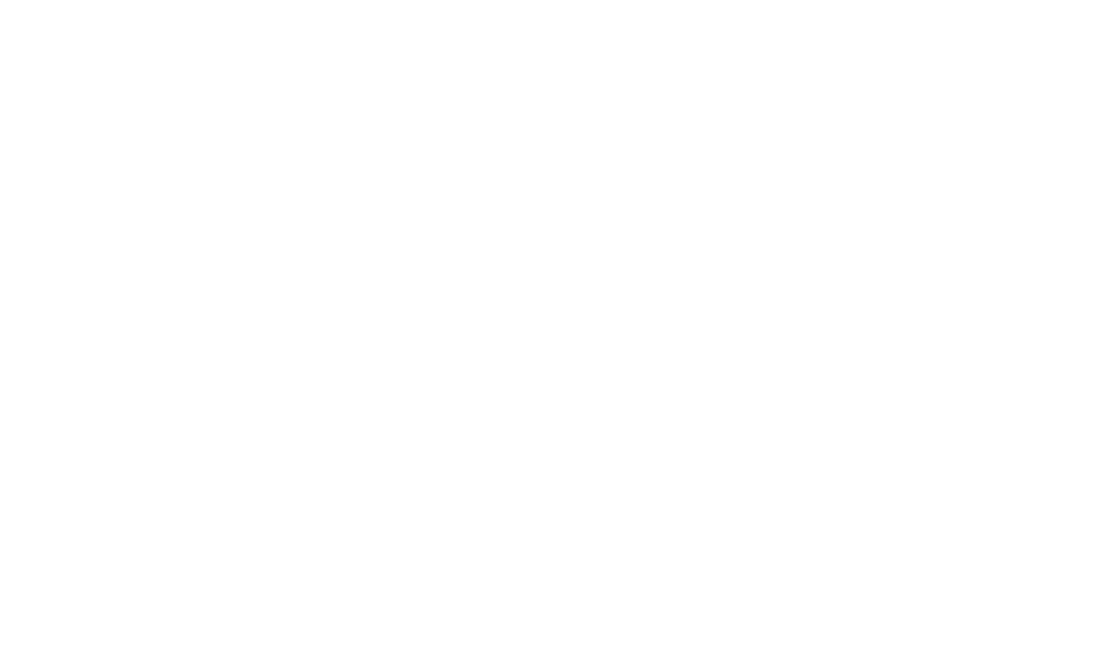


TEMESCAL CREEK.

Discharge measurements of Temescal creek at lower pipe line, Temescal Land and Water Company, Temescal, Riverside County, Cal.

\begin{tabular}{|c|c|c|}
\hline Date. & Hydrographer. & $\begin{array}{c}\text { Dis- } \\
\text { charge. }\end{array}$ \\
\hline 1899. & - & Sece-feet. \\
\hline Jan. 28 & F. Rolfe - & 0.66 \\
\hline Feb. 1 & $\ldots d o \quad$ & 0.00 \\
\hline Feb. 11 & $\ldots$ do .... & .31 \\
\hline Feb. 15 & $\ldots$ do $\ldots$ & 1.39 \\
\hline Feb. 20 & .... do & 1.56 \\
\hline Mar. 4 & .... do . . . & 4. 22 \\
\hline Mar. 12 & ....do & 3.55 \\
\hline Mar. 18 & ....do do & 2.69 \\
\hline Mar. 25 & .... do . ... & 2.91 \\
\hline Mar. 31 & . . . do ..... & 3.42 \\
\hline Apr. 14 & $\ldots$ do $\ldots$. & .89 \\
\hline Apr. 22 & .... do ..... & 2.28 \\
\hline Apr. 29 & $\ldots$ do . . . . & 2.28 \\
\hline May 6 & ... . do . . . . & 4.46 \\
\hline May 13 & .....do & 2.55 \\
\hline May 30 & $\ldots$ do ..... & 3.08 \\
\hline June 9 & $\ldots$ do . . . . . . & 3.10 \\
\hline June 15 & $\ldots$ do $\ldots .$. & 2.36 \\
\hline July 4 & $\ldots$ do ... & 2.87 \\
\hline July 19 & $\ldots$... do ... & 2.03 \\
\hline July 25 & $\ldots$ do $\ldots$ & 2.49 \\
\hline Ang. 5 & _. _ do _ _ _ & 1.12 \\
\hline Aug. 11 & - & 2.40 \\
\hline Ang. 21 & . do & 2.65 \\
\hline
\end{tabular}


Discharge measurements of Temescal Creek at upper pipe line, Temescal Land and Water Company, Temescal, Riverside County.

\begin{tabular}{|c|c|c|}
\hline Date. & Hydrographer. & $\begin{array}{l}\text { Dis- } \\
\text { (harge. }\end{array}$ \\
\hline 1899 . & & sec-feet. \\
\hline Jan. 4 & S. G. Cennett - & 0.99 \\
\hline Jan. $2 \tau$ & F. Rolfe $\ldots$ & .74 \\
\hline Feb. 4 & ... do & 1.62 \\
\hline Feb. 11 &.$d o \ldots$ & .87 \\
\hline Feb. 18 & ... do ... & $3.6 \%$ \\
\hline Feb. 24 & ... do . . & $3.3 \%$ \\
\hline Mar. :3 & $\ldots$... do ... & $3.8 \%$ \\
\hline Mar. 12 & .. & 5.10 \\
\hline Mtar. 16 & $\ldots$ do ........ & 3.56 \\
\hline Mar. 25 & do . & 3.74 \\
\hline Mar. 31 & . do... & 4.16 \\
\hline Apr. 14 & $\ldots$... do .... & 2.93 \\
\hline Apr. 22 & ... do .. & 3.71 \\
\hline Apr. 29 & .. do ... & 3.22 \\
\hline May 6 & . . do do & 2.80 \\
\hline May 13 & -. do & 4.02 \\
\hline May 18 & $\ldots$ do & 4.21 \\
\hline May 30 & $\ldots$... do ... & 4.01 \\
\hline June 9 & .. do ... & 3.36 \\
\hline June 16 & _ do & 3.52 \\
\hline July 10 & - . do .. & 3.21 \\
\hline Julÿ 19 & ... do ... & 3.20 \\
\hline July 25 & - do. & 3.67 \\
\hline Aug. 11 & $\ldots$......... & 1. 48 \\
\hline Aug. 11 & .... do ..... & 4.26 \\
\hline Aug. 21 & ...do . . do. & 3.84 \\
\hline
\end{tabular}

Discharge measurements of Evans ditch, Temescal C'reek, Temescal, Riverside County.

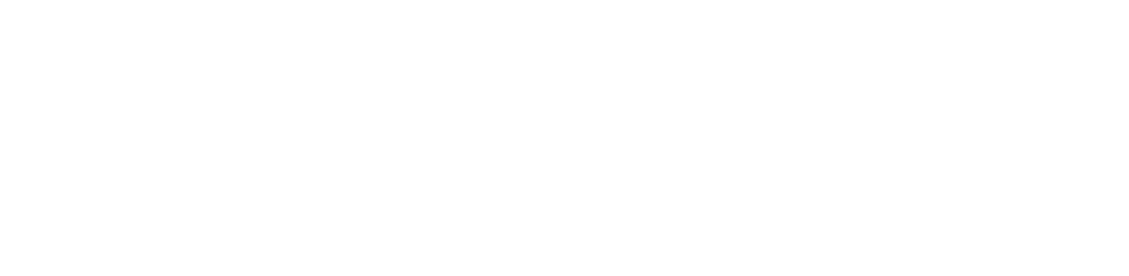


TORO CANYON.

Discharge mersurement of Toro C'anyon, Santa Barbara County.

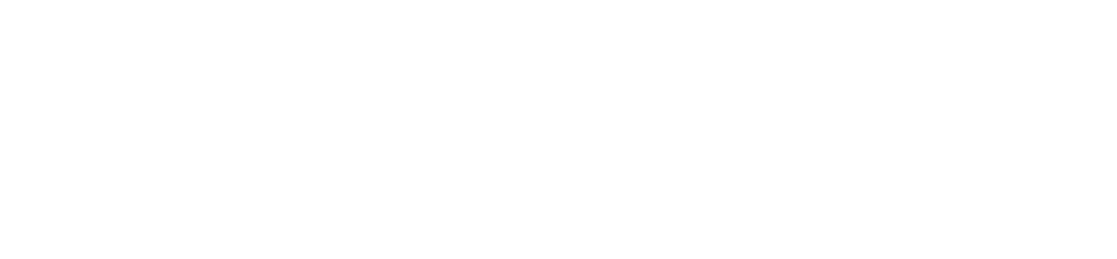

TRABUCO CREEK.

Discharge measurement of Trabuco ('reek, Orange county.

\begin{tabular}{|c|c|c|}
\hline Date. & Hydrographer. & $\begin{array}{c}\text { Dis- } \\
\text { rharge. }\end{array}$ \\
\hline$\ldots$ & $-\ldots-\cdots+\ldots-\ldots$ & $\ldots---$ \\
\hline 1899. & & sece-feet. \\
\hline May 24 & F. Rolfe & « 1.08 \\
\hline
\end{tabular}

"Ditch near San Juan Capistrano.

\section{TRUCKEE RIVER.}

TRUCKEE RIVER AT TAHOE, CAL.

Truckee River, the natural outlet of Lake Tahoe, leaves the lake at the city of 'Tahoe. About 500 feet from the lake there is a timber dam across the river, which has been maintained for more than twenty years for the purpose of eontrolling the discharge from the lake. During the early part of the year 1900 the gates in this dam were kept closed, not being opened until June 17, when a gage was placel in the stream for the purpose of recording the height of the water in the river. The gage is a vertical timber driven into the stream bed at the left bank, about 300 feet below the dam, and is spiked to the root of a tree growing on the bank. The bench mark is cut in the side of the tree, and is 4 feet above gage datum. The measurements are made from a cable and suspended car about onefourth of a mile below the gage, which was placed as near the city of Tahoe as possible for the convenience of the observer. At the point of measurement the right bank is low, and is subject to overflow at very high stages of the stream, but the left bank is rather high. The channel is nearly straight for a short distance above and below the station, and the berl of the river, which is of gravel and coarse sand, is smooth and stable. The purpose of the station is to ascertain the actual outflow from Lake Tahoe, with a view to determining its value as a storage reservoir. 
Dischurge measurements of Truckee River at outlet if Lake Tuhoe. Plarer c'onnty.

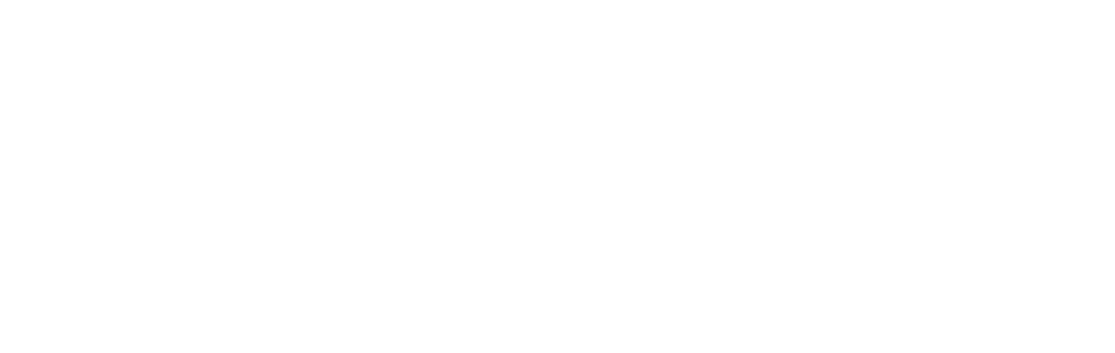

Inishenge measurements of Truckee River at Tahoe, Placer County.

\begin{tabular}{|c|c|c|c|}
\hline Date. & Hydrographer. & $\begin{array}{c}\text { Gaga } \\
\text { height. }\end{array}$ & $\begin{array}{c}\text { Dis- } \\
\text { rharge. }\end{array}$ \\
\hline 19011. & & Feet. & ser.-feet. \\
\hline June 18 & L. H. Taylor . .... & 0.75 & 92 \\
\hline June 30 & $\ldots$ do ....... & 1.45 & 2.40 \\
\hline July 12 & 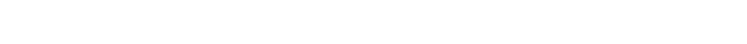 & 1.60 & $2.7 \%$ \\
\hline Sept. $\approx$ & $\ldots$ do ........ & 1.40 & 225 \\
\hline Oct. $\quad 23$ & ..... do ...... & .40 & 52 \\
\hline Oct. $2: 3$ & .... do ......... & .95 & 130 \\
\hline Oct. 23 & I... do . . & 1.15 & 158 \\
\hline 1901. & & & \\
\hline Sept. 5 & C. V. Taylor $\ldots \ldots$ & 1.94 & $3 \times 6$ \\
\hline Sept. 12 & 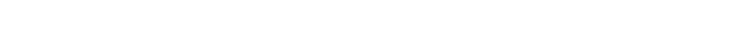 & 1.85 & 350 \\
\hline Nov. 11 & .... do ....... & $1.5 r$ & 296 \\
\hline Nov. 11 & $\ldots d_{0} \ldots \ldots \ldots$ & 1.23 & 187 \\
\hline $\begin{array}{c}\text { Nov. } 11 \\
1902 .\end{array}$ & do & 1.00 & 141 \\
\hline Oct. 22 & E. C. Murphy & & 320 \\
\hline
\end{tabular}

Discharge measurements of Truckee River one-half mile belou Truckee.

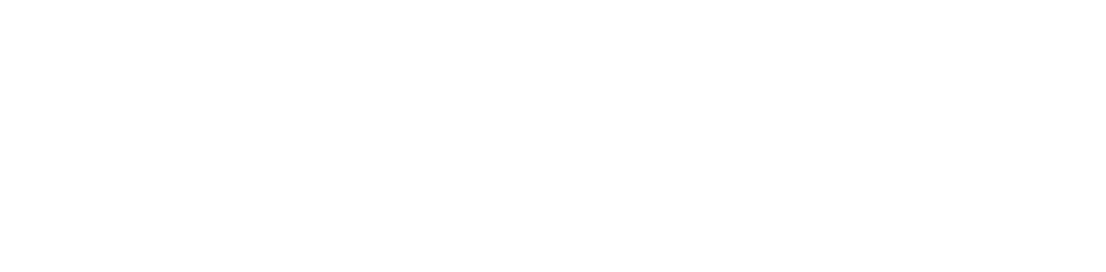


Estimated monthly discharge of Truckee River at Tahoe.

[Drainage area, 519 square miles.]

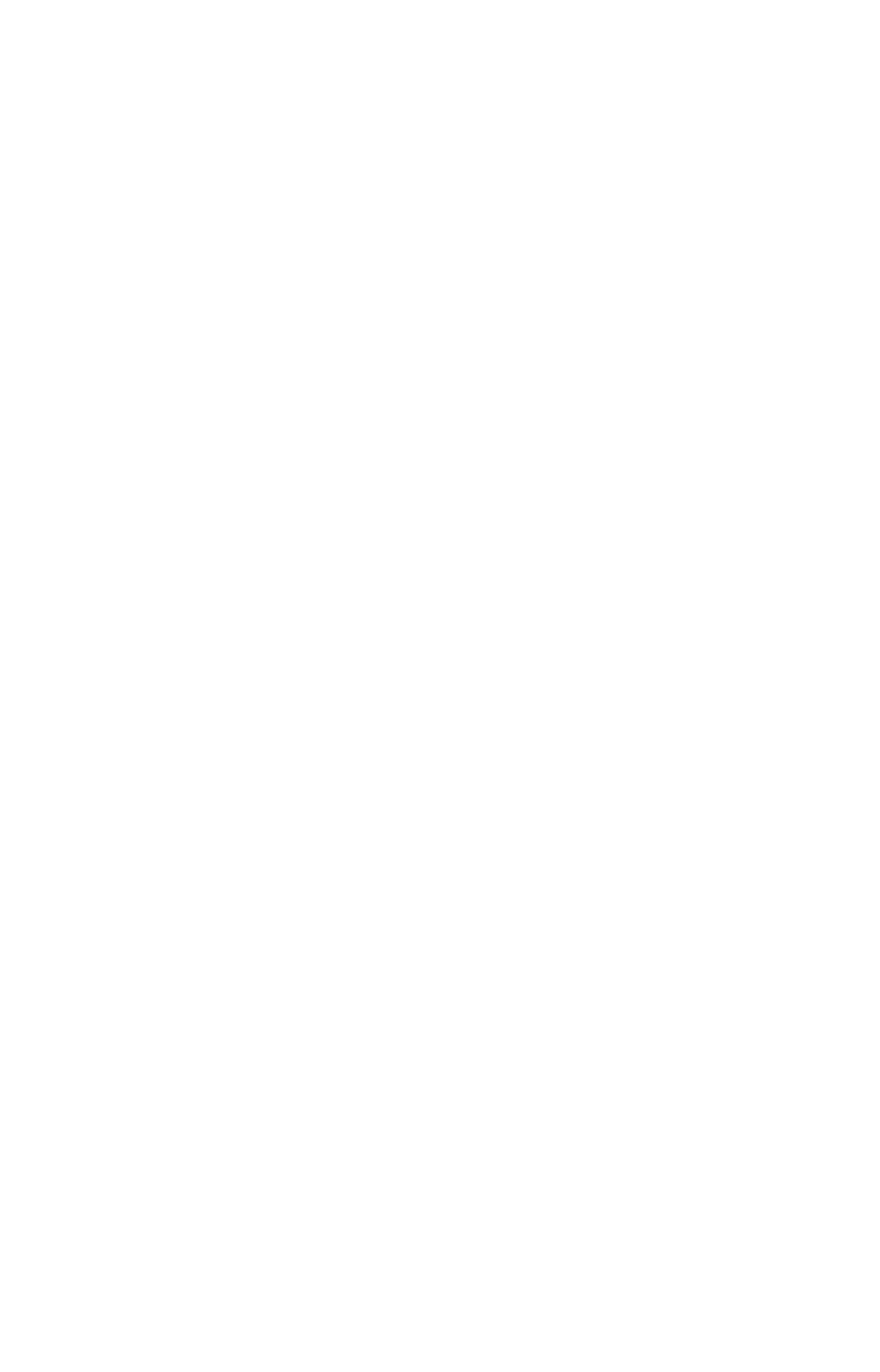


Discharge measurements of tributaries of Truckee River at carious points. DEER 'REKK, PJACER COUNTY.

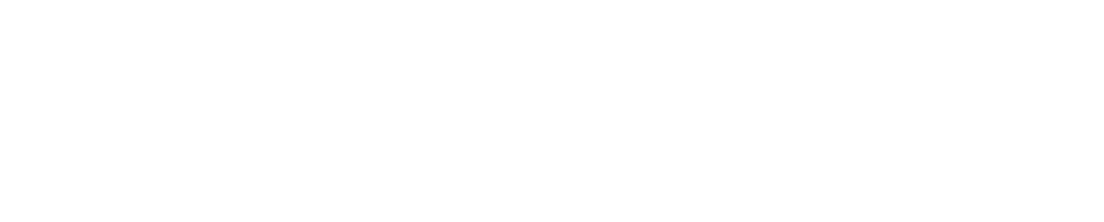

SQTAW CIREEK, I'IACER CUTNTY.

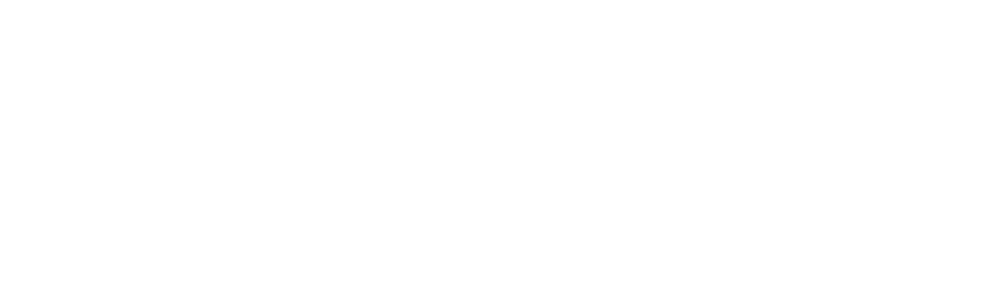

\begin{tabular}{|c|c|c|}
\hline \\
\hline 1900. & 1 & \\
\hline May 16 & .............. & $12 \pi .8$ \\
\hline May 29 & (2. & 73.4 \\
\hline July 13 & ( & 1.09 \\
\hline Aug. 20 & (n-1 & 69.0 \\
\hline Sept. 13 & 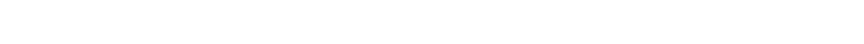 & 19.2 \\
\hline
\end{tabular}

LONNER CRELK, NEAR TRUCKEE RIVHR.

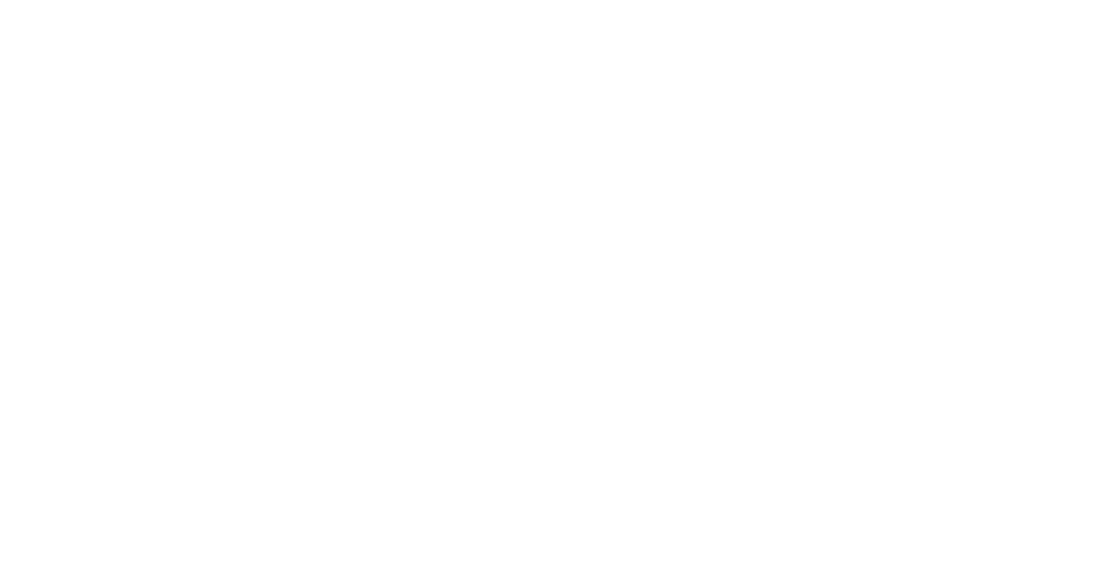


Discharge measurements of tributaries of Truckee River, ete - Continued. MAHTIS CHEKK.

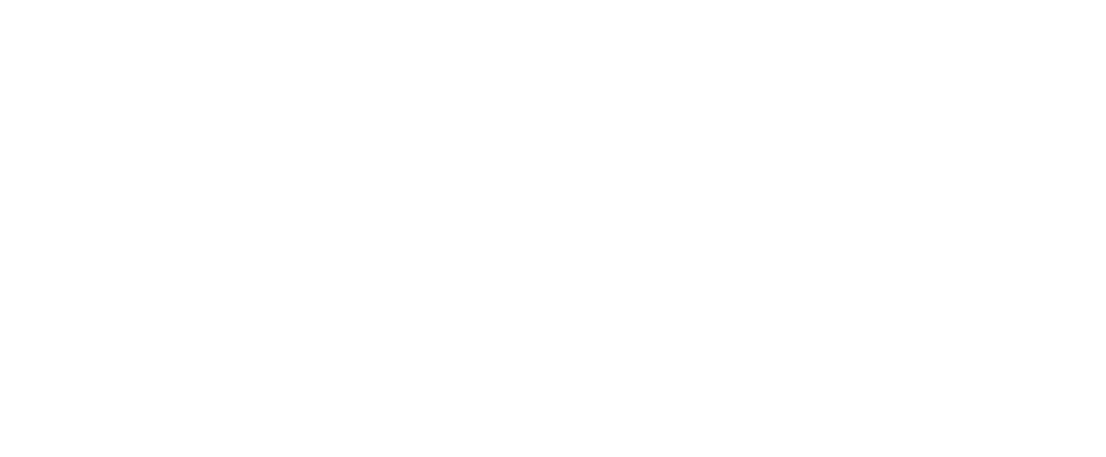

JUNIPER CREEK AT CLINTON.

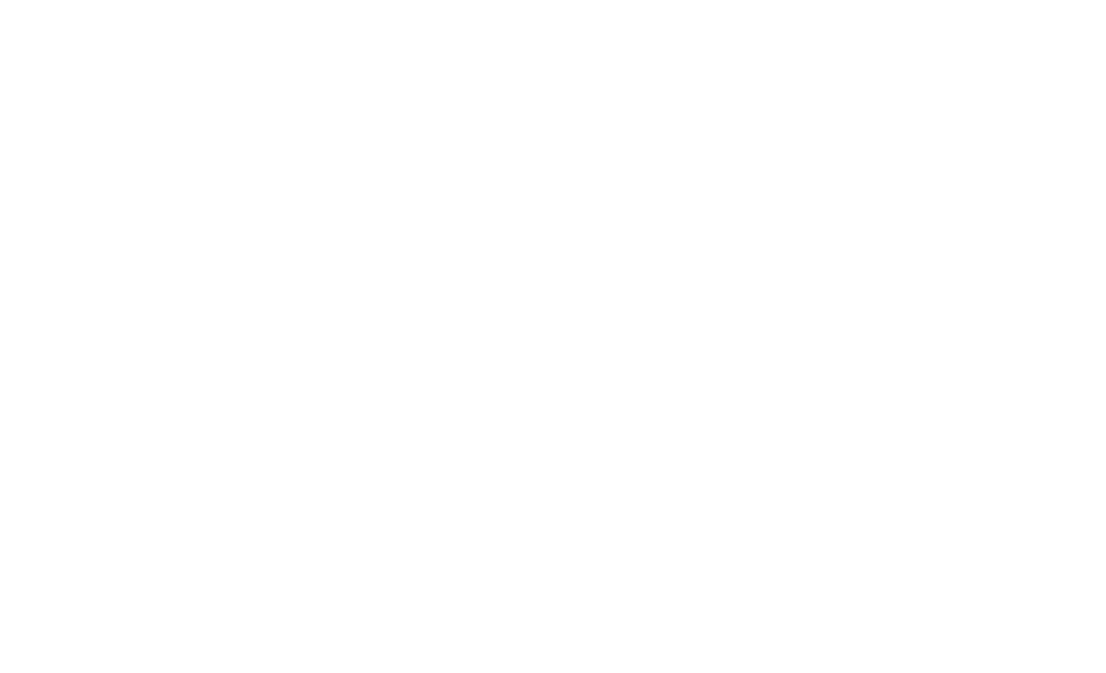

ALDER CREEK AT FLORISTON.

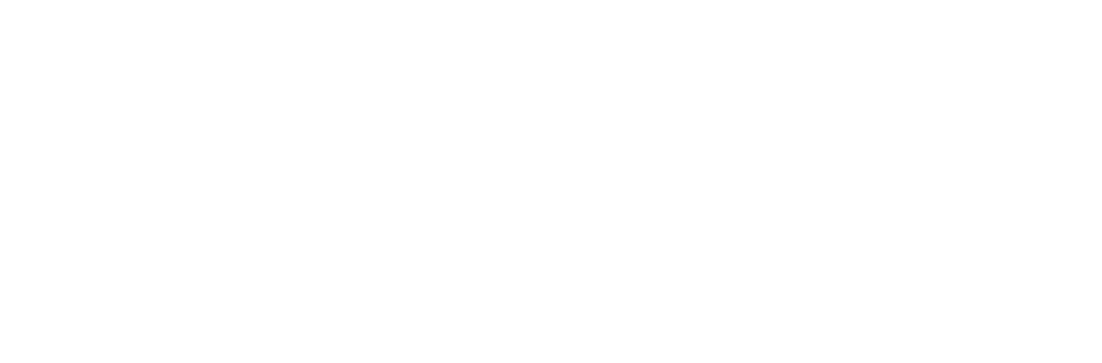


Discharge measurements of tributaries of Truckee River, ete-Continned. DOG VALLEY CAEEK AT VERDI.

\begin{tabular}{|c|c|c|}
\hline Date. & Hydrographer. & $\begin{array}{c}\text { Dic- } \\
\text { charge. }\end{array}$ \\
\hline 1889. & & Sec.feet. \\
\hline $\begin{array}{c}\text { May } 22 \\
1900 .\end{array}$ & & 7 \\
\hline July 26 & $\ldots \ldots \ldots$ & .40 \\
\hline $\begin{array}{c}\text { Sept. } 10 \\
1902 .\end{array}$ & 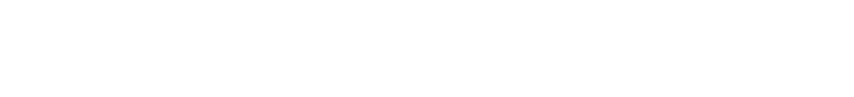 & .79 \\
\hline Oct. $\%$ & D. W. Hays $\ldots \ldots$ & 7.14 \\
\hline
\end{tabular}

TRUCKEE RIVER AT ESSEX, WASHOE COUNTY, NEV.

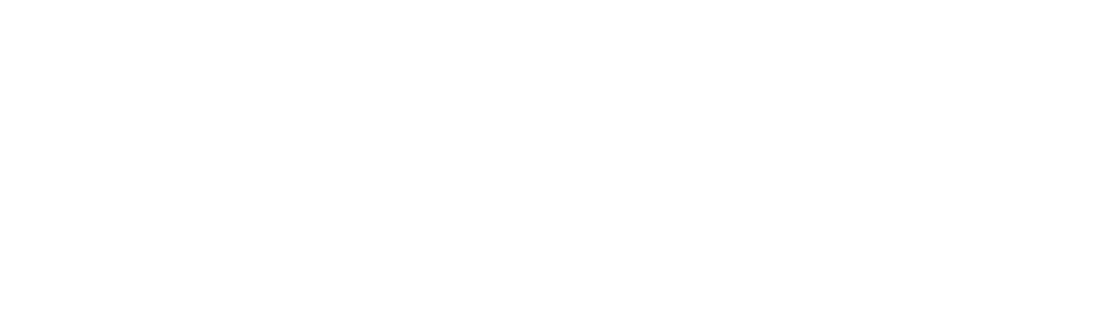

SQUAW CRELK ABOUT HALEWAY HROM LAKE TAHOK.

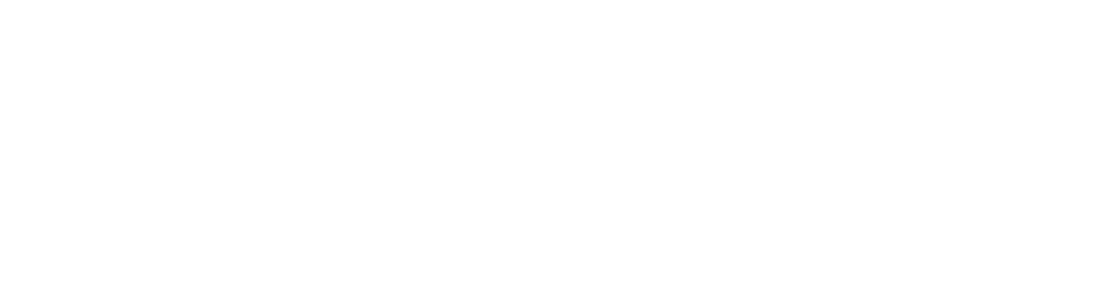

CREEK NEAR TAHOE TOLLGATE.

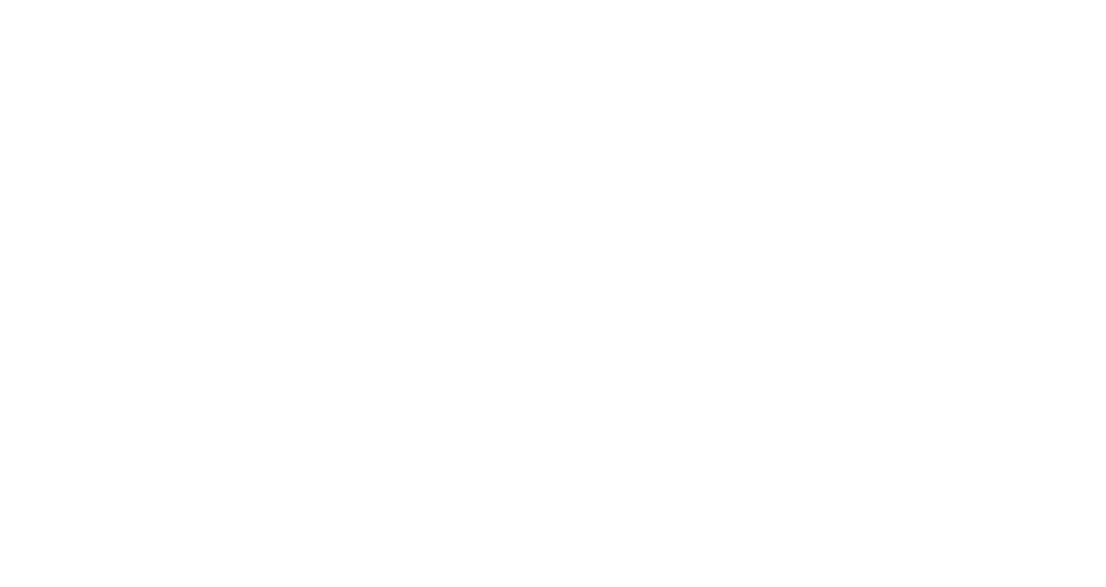


Inischurge messicrements of tributaries of Truckee River, etc-Continued.

COLD CREEK THREE-QUARTERS OF A MILE BELOW DONNER LAKE.

\begin{tabular}{|c|c|c|}
\hline Date. & Hydrographer. & $\begin{array}{c}\text { Dis- } \\
\text { charge. }\end{array}$ \\
\hline 1889. & & Sec.feet. \\
\hline June 28 & $\ldots$ & 11 \\
\hline July 3 & - & 10 \\
\hline July 6 & $\ldots$ & 5 \\
\hline July 11 & - & 1 \\
\hline Aug. 7 & $\ldots$ & 1 \\
\hline Aug. 10 & $\ldots \ldots \ldots$ & 1 \\
\hline Aug. 17 & $\ldots$ & .7 \\
\hline
\end{tabular}

PROSSER CREEK.

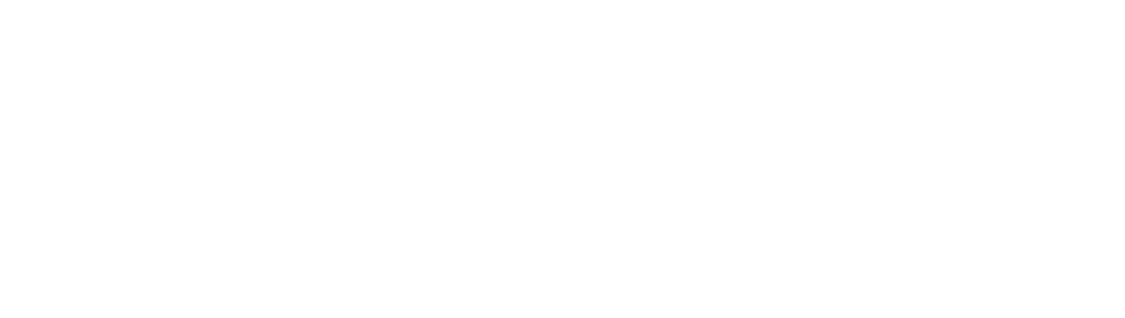

1'T'TLE TRUCKEE RIVER A'T BOCA.

\begin{tabular}{|c|c|c|}
\hline 1900 & & \\
\hline May 19 & $\cdots$ & $c 600$ \\
\hline June 6 & & 492 \\
\hline Aug. 16 & & 8.94 \\
\hline Sept. 15 & & $2 \pi .14$ \\
\hline
\end{tabular}

HUNTER CREEK.

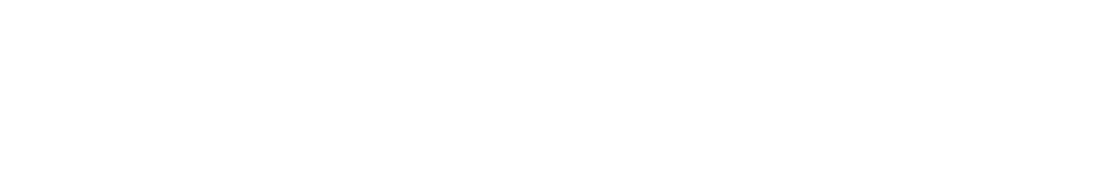

INDEPENDENCE CKEEK AT INDEPENDENGK LAKE.

1902.

Oct. 24 E. C. Murphy 
Discharge measurements of streams flowing into Lake Tahoe.

WARD CKEEK.

\begin{tabular}{|c|c|c|}
\hline Date. & Hydrographer. & $\begin{array}{l}\text { Dis- } \\
\text { charge. }\end{array}$ \\
\hline 1900 & & Sec.feet. \\
\hline May 5 & $\ldots \ldots \ldots$ & 147 \\
\hline
\end{tabular}

BLACK WOOD CREEK.

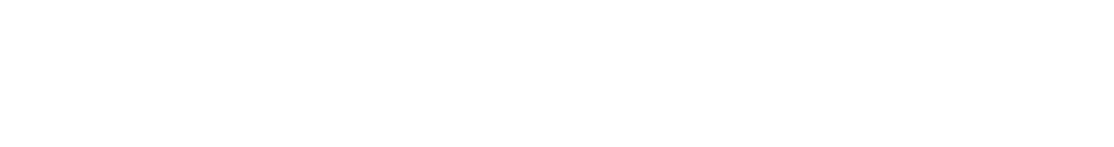

THREE SMALI, STREAMS BETWEEN IDLEWLLD AND MCKINNEY'A.

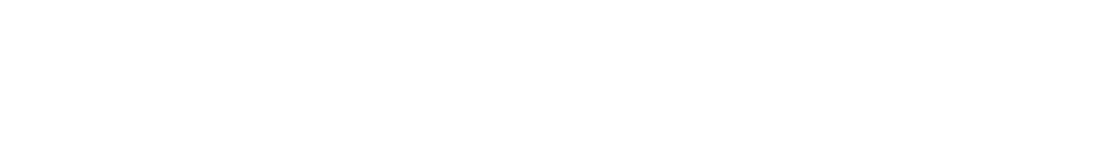

M'KINNHY CIREEK.

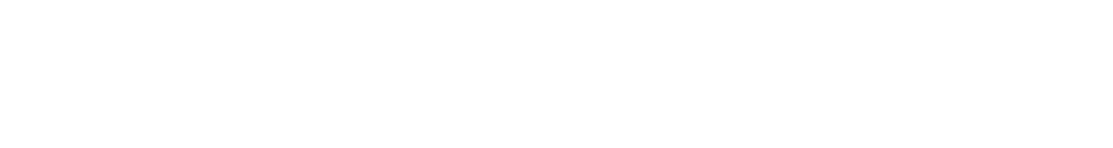

(iGNERAI, C'REEK.

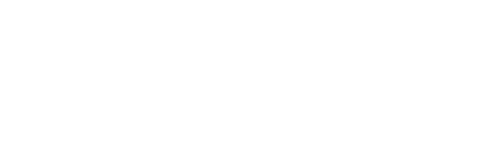

MEIGGS CREEK.

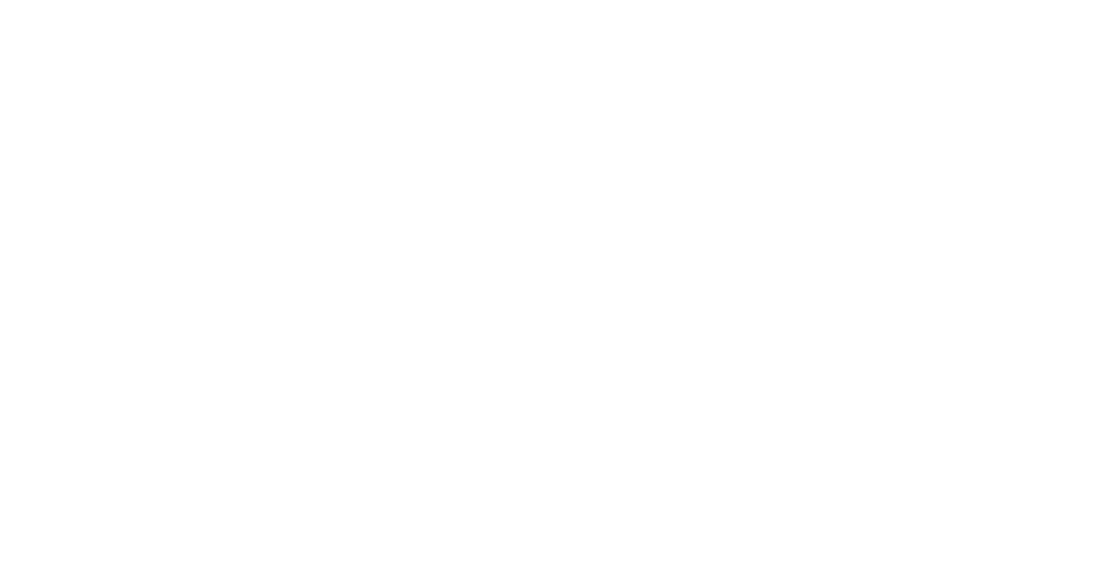

a Estimated. 
Discharge measurements of streams flowing into Lake Tahoe-Continued. (ASCADE CREEK.

\begin{tabular}{|c|c|c|}
\hline Date. & Hydrographer. & $\begin{array}{l}\text { Dis- } \\
\text { charge. }\end{array}$ \\
\hline 1900. & & Sec.-feet. \\
\hline May 8 & 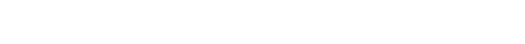 & 30 \\
\hline
\end{tabular}

TAYLOH CHEEK.

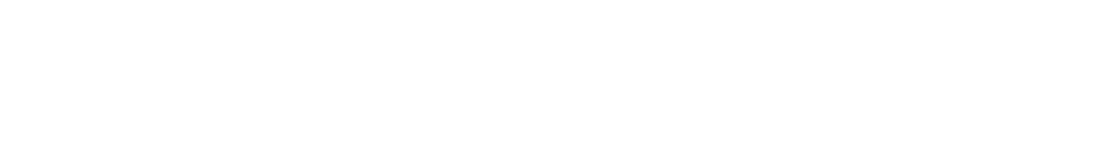

UPPER THUCKEE RIVER.

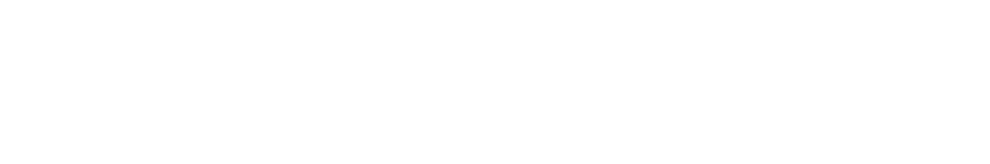

TEN SMALL, STRKAMS BETWEEN HIJOU AND GLEN BROOK IN NEYADA.

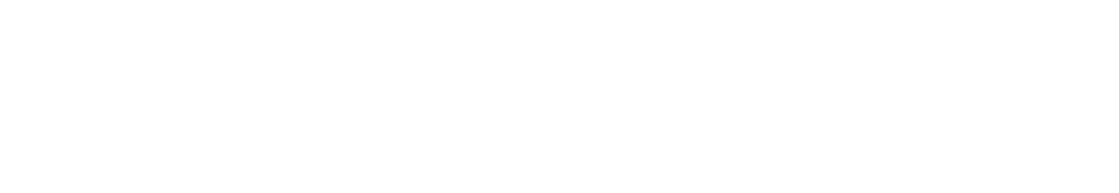

TRUCKEE RIVER AT NEVADA-CALIFORNIA STATE LINE.

This river has its source on the slopes of the Siema Nevada in eastern California and flows northward, entering Lake Tahoe. This lake is at an elevation of 6,225 feet, and is the largest body of fresh water in the United States at this considerable altitude. The area of the lake itself is 193 square miles. As the State line between Nevada and California passes through the lake, a portion of it is in each State. The outlet of the lake is at Tahoe, Cal, and Truckee River from this point has a general north ward course, rec?iving a number of important tributaries which contribute to its flow. There are a number of lakes at the headwaters of the branch stream, which have been surveyed and recommended as reservoir sites. The drainage area is mapped on the Pyramid Peak, Truckee, Carson, and Markleeville atlas sheets of the United States Geological Survey. The basin is now partially included in the Lake Tahoe forest reserve, set apart by Executive proclamation of April 13, 1899. September 7,1899 , a station was established on this river by L. H. Taylor, at the State line, 17 miles west of Reno, Nev. The gage is rertical, driven into the bed of the river and wired to a granite bowlder. The bench mark 
is the top of the rock to which the rod is fastened, and is at an elevation of 10 feet above gage datum. The channel is straigl t for a short distance above and below the station. The banks are not liable to overflow. The bed of the river is of gravel and cobbles and is quite stable.

Discharge measurements of Truckee River at State line.

\begin{tabular}{|c|c|c|c|}
\hline Date. & Hydrographer. & $\begin{array}{c}\text { Gage } \\
\text { height. }\end{array}$ & $\begin{array}{l}\text { Dis- } \\
\text { eharge. }\end{array}$ \\
\hline 1899. & & Feet. & Sec.feet. \\
\hline $\begin{array}{c}\text { Sept. } \\
1900 .\end{array}$ & L. H. Taylor . & 2.0 & 303 \\
\hline Apr. 10 & L. H. Taylor & 2.9 & กร8 \\
\hline May 15 & $\ldots$ do .......... & 4.1 & 1.493 \\
\hline May 22 & $\ldots$ do ....... & 4.3 & 1. 629 \\
\hline June 1 & .... do ... & 3.7 & 1,112 \\
\hline June 15 & $\ldots$ do $\ldots . .$. & 3.2 & 901 \\
\hline July 1 & $\ldots$ do $\ldots . .$. & 2.5 & 534 \\
\hline July 14 & $\ldots$ do _...... & 2.5 & 551 \\
\hline Sept. 6 & $\ldots$ do ....... & 2.3 & 447 \\
\hline $\begin{array}{l}\text { Oct. } 2 \\
1901 .\end{array}$ & $\ldots$ do $\ldots . . .$. & 1.9 & 318 \\
\hline Feb. 13 & C. V. Taylor ..... & 1.5 & 298 \\
\hline Feb. 27 & $\ldots$ do $\ldots . . . . .$. & 4.5 & 2,474 \\
\hline Mar. 11 & $\ldots \ldots d o \ldots \ldots$. . . & 3.4 & 1,262 \\
\hline June 9 & $\ldots$ do $\ldots . . . . . .$. & 3.9 & 1,741 \\
\hline July 13 & . . do _ _ _ _... & 2.6 & 811 \\
\hline Aug. 16 & 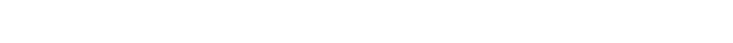 & 2.1 & 528 \\
\hline Sept. 3 & ... do .......... & 2.2 . & 570 \\
\hline Sept. 14 & 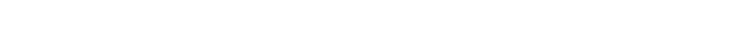 & 2.0 & 478 \\
\hline Nov. 9 & $\ldots$. . $d o \ldots \ldots$ & 1.95 & 437 \\
\hline $\begin{array}{c}\text { Dec. } 14 \\
1902 .\end{array}$ & $\ldots$ do $\ldots . . . . . . .$. & 1.75 & 353 \\
\hline Apr. 10 & C. V. Taylor $\ldots \ldots$ & & 1.492 \\
\hline May 10 & $\mid \ldots$ do $\ldots \ldots$. & & 2,384 \\
\hline
\end{tabular}

IRR $81-03-24$ 
Estimated monthly discharge of Truckee River at Nevada-California State line.

[Drainage area, 955 square miles.]

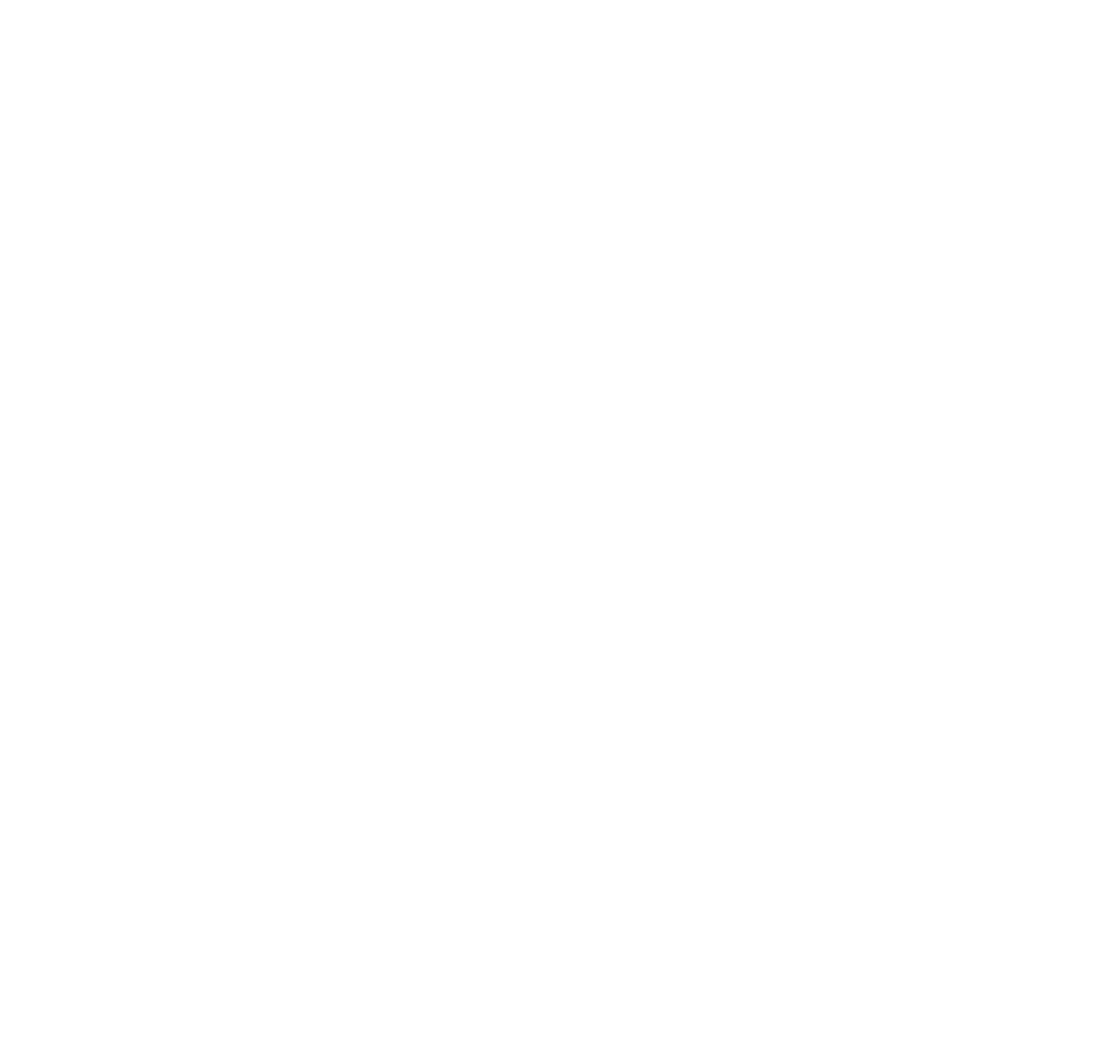

TRUCKEE RIVER AT VISTA, NEV.

On the lower courses of this river there are considers ble stretches of irrigable land which, however, have not yet been developed to their fullest extent. The drainage basin is peculiar in that its mountainous collecting area is located in the State of California, while the lands which cau be irrigated are situated in Nevada. This may lead in the future to certain legal difficulties, but not to the extent that it would if there were agricultural lands in both States. Truckes River, after entering Nevada, flows in a general easterly and then northerly direction, entytying into Pyramid Lake. The drainage area is mapped on the Pyramid Peak, Truckee, Markleeville, Carson, Reno, and Wadsworth atlas sheets of the United States Geological Survey. The station at Vista, Nev., was established August 18, 1899, by L. H. Taylor, and is located 7 miles east of Reno. The rod is spiked to posts driven into the bed of the river. The bench mark is on a bluff of rock 500 feet east of the gage, and is at an elevation of 17.50 feet 
above gage datum. A new bench mark was established March 14, 1901, on the top of a 2 by 2 inch plug driven 2 feet into the ground at the upper end of the inclined gage on the left bank. Its elevation is 9.60 feet above the datum of the gage. Both banks are high and not liable to overflow. The bed is rocky and not subject to change.

Discharge measurements of Truckee River at Vista, Nev.

[L. H. Taylor, hydrographer.]

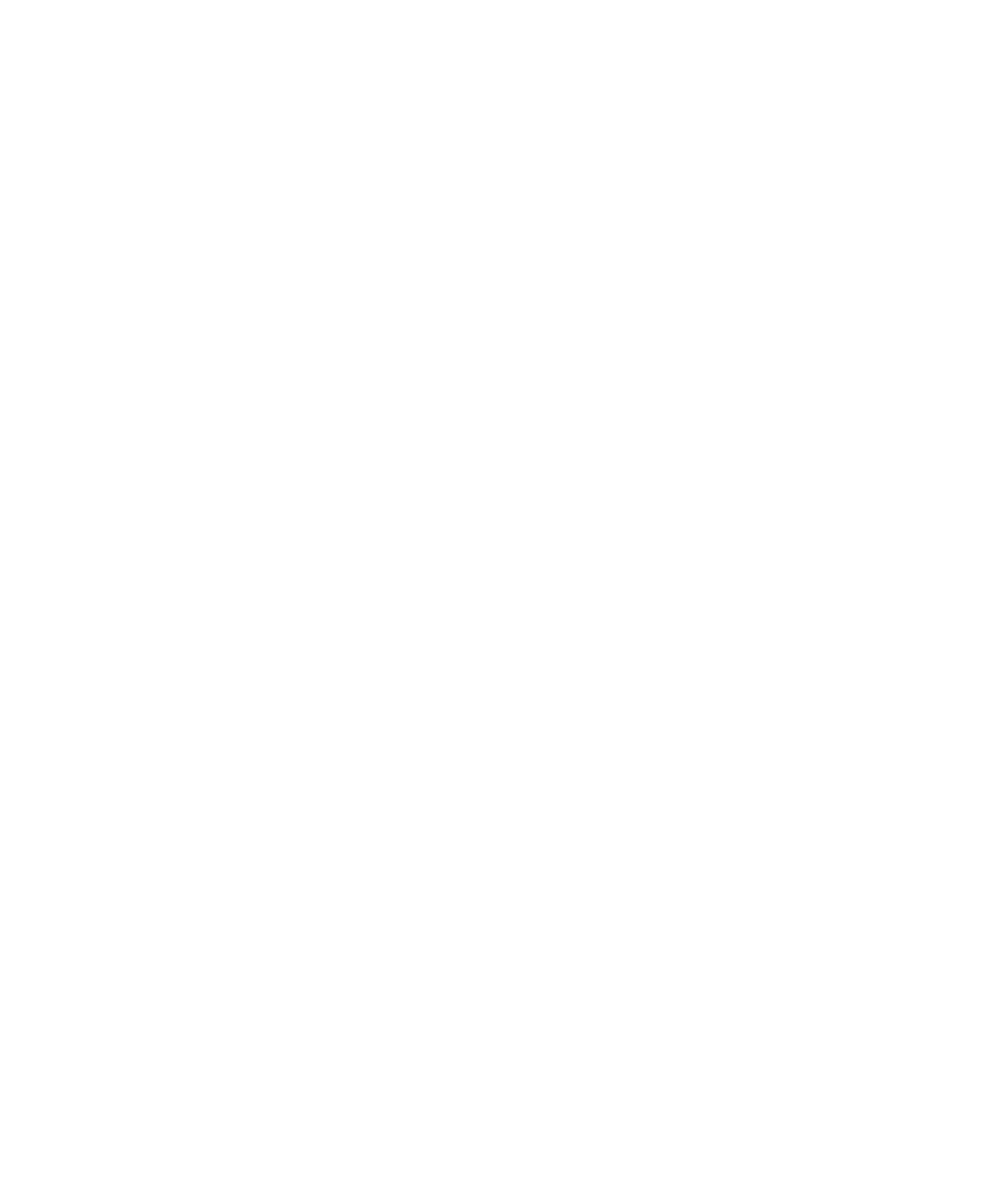

$a$ Results too small. 
Estimated monthly discharge of Truckee River at Vista, Nev.

[Drainage area 1,519 square miles.]

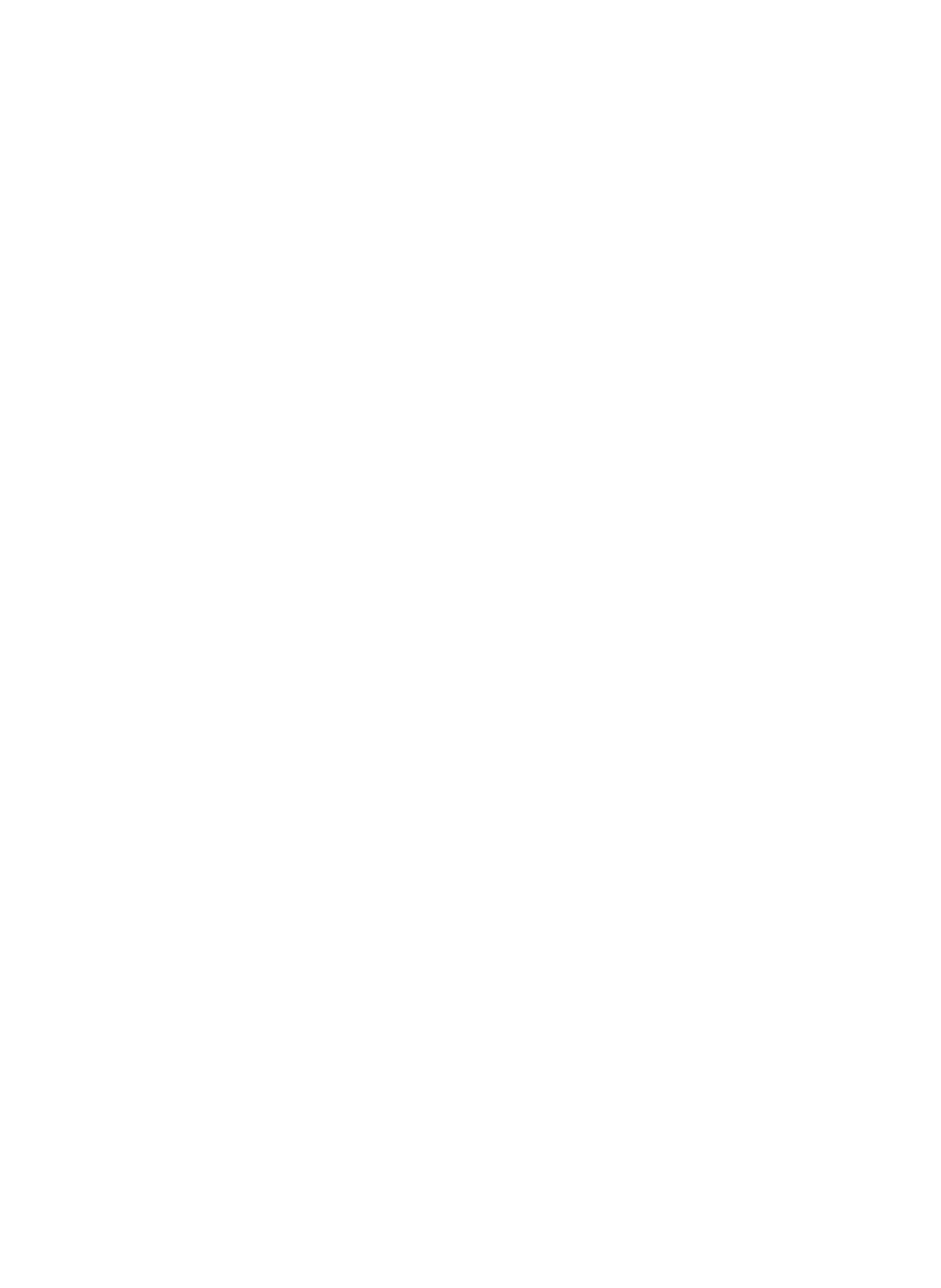

a Estimated, 
Estimated monthly discharge of Truckee River at Vista, Nev.-Continued.

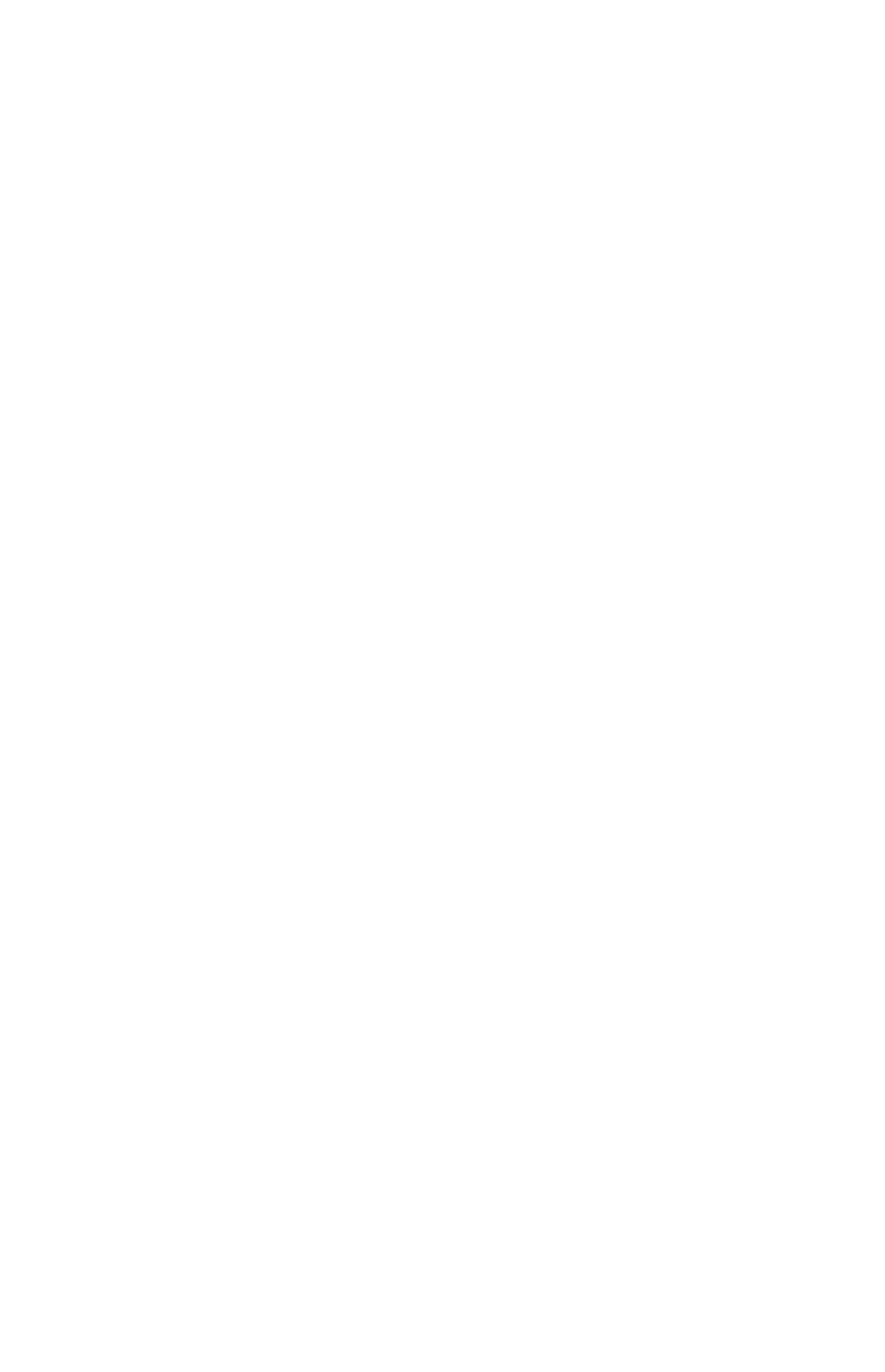


TULE RIVER.

Tule River drains a portion of the western slope of the Rierra Nevada. Its watershed is somewhat less productive of run-off than that of Kaweah River, which joins it on the north, and mnch less elevated and snow covered than Kings River basin.

The waters of this stream are all appropriated during the irrigation season, and a portion of them are used in irrigating valuable orange lands in the vicinity of Porterville, Cal.

The gaging station is located about 8 miles east of Porterville, at a point just below the wagon bridge near the MeFarland ranch, and about 1 mile above the mouth of the South Fork of Tule River. The station was established April 18, 1901. The gage rod is situated on the right bank of the river, 100 feet below the bridge. The zero of the gage is 8 feet below a spike driven into a large cottonwood tree. The area of the watershed above the gaging station is approximately 300 square miles.

Discharge measurements of Tule River.

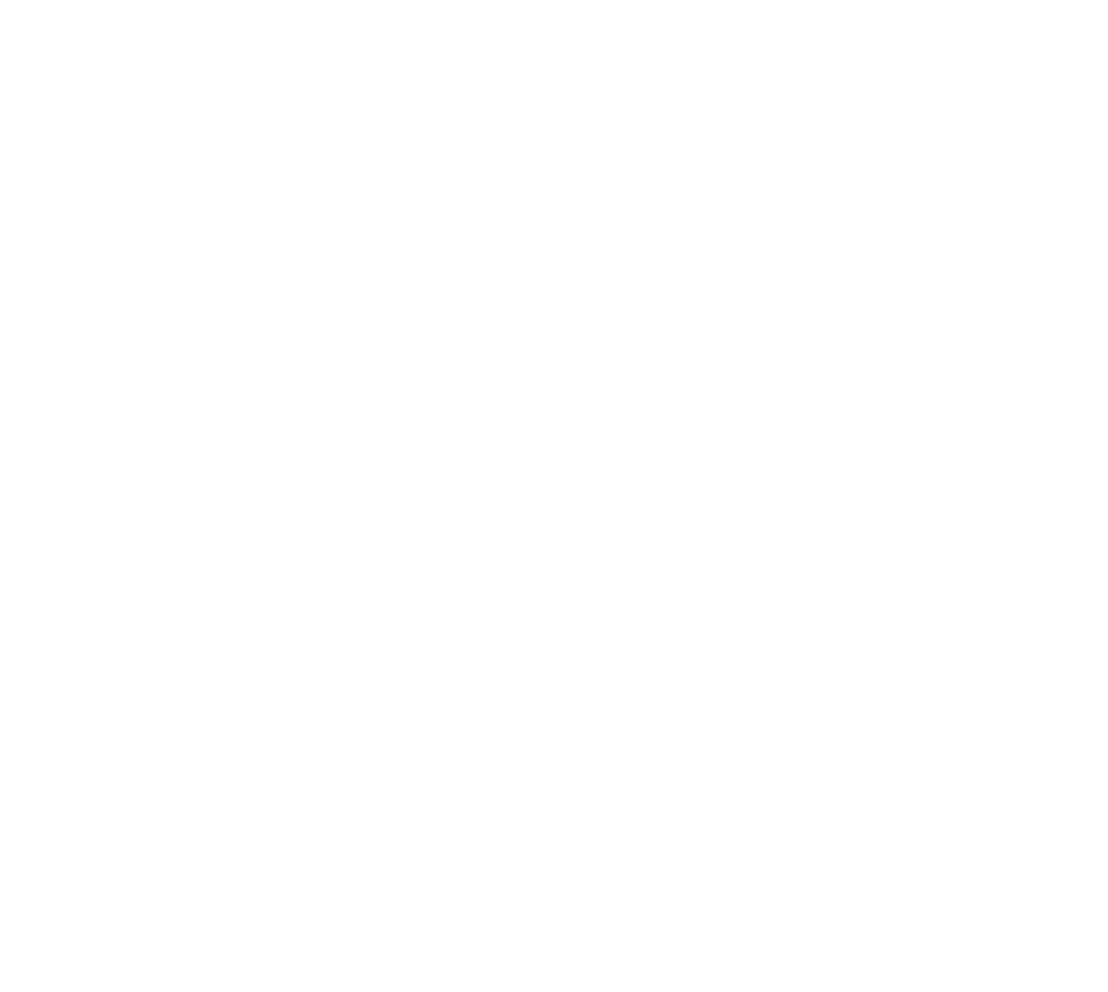


Discharge measurements of Tule River. Tulare County.

\begin{tabular}{|c|c|c|c|c|}
\hline \multicolumn{2}{|c|}{ Date. } & Hydrographer. & $\begin{array}{c}\text { Dis- } \\
\text { charge. }\end{array}$ & Location. \\
\hline 1902 & & & secefeet. & \\
\hline Sept. & 30 & E. T. Perkins $\ldots$ & 2.6 & $\begin{array}{l}\text { Middle Fork, trail crossing below lo- } \\
\text { cation of Doyle's headworks. }\end{array}$ \\
\hline Sept. & 30 & .... do ... & 14.0 & $\begin{array}{l}\text { Middle Fork } 100 \text { yards ahove head } \\
\text { Doyles ditch. }\end{array}$ \\
\hline Oct. & 1 & $\ldots$ do ... & 24.0 & $\begin{array}{l}\text { Middle Fork at trail crossing near } \\
\text { junction with East For?. }\end{array}$ \\
\hline Oct. & 1 & $\ldots$ do .... & 15.0 & East Fork 100 yards abova mouth. \\
\hline Oct. & 3 & .... do . & 10.0 & $\begin{array}{l}\text { East Fork at trail crossirg Nelsons } \\
\text { to Indian Reservation. }\end{array}$ \\
\hline Oct. & 2 & .... do . & 3.0 & $\begin{array}{l}\text { South Fork } 6 \text { miles below Indian } \\
\text { Agency. }\end{array}$ \\
\hline Oct. & 3 & ... . do _ & 3.2 & $\begin{array}{l}\text { South Fork near Tom Wheaton's } \\
\text { ranch. }\end{array}$ \\
\hline Oct. & 3 & L. M. Lawson . . . . & $(a)$ & $\begin{array}{l}\text { South Fork at junction of North } \\
\text { Fork. }\end{array}$ \\
\hline Oct. & 3 & . . . do & 4.0 & Pioneer canal at Porterville. \\
\hline
\end{tabular}

Discharge measurements of Tule River at McFarlands Bringe, above mouth of South Fork.

\begin{tabular}{|c|c|c|c|}
\hline Date. & Hydrographer. & $\begin{array}{c}\text { Gage } \\
\text { height. }\end{array}$ & $\begin{array}{c}\text { Dis- } \\
\text { charge. }\end{array}$ \\
\hline 1901. & & Feet. & Sec-feet. \\
\hline Apr. 18 & S. G. Bennett . & 2.5 & 233 \\
\hline May 22 & J.B. Lippincott & 2.85 & 338 \\
\hline June 10 & $\ldots$ do $\ldots . . .2$. & 2.65 & 311 \\
\hline June 28 & A.E. Chandler .... & 2.09 & 148 \\
\hline July 29 & S. G. Bennett . . . & 1.93 & 30 \\
\hline Oct. 18 & $\ldots$.... do ... & 1.09 & 18 \\
\hline $\begin{array}{c}\text { Dec. } \quad 9 \\
1902 .\end{array}$ & $\ldots$..... do ... & 1.44 & 58 \\
\hline Feb. 5 & . . do . & 1.33 & 43 \\
\hline Mar. 8 & $\ldots$ do $\ldots . .$. & 2.2 & 156 \\
\hline May 15 & $\ldots$. . do ........... & 3.03 & $3 r 1$ \\
\hline Oct. $\quad 2$ & L. M. Lawson .... & .93 & 15 \\
\hline
\end{tabular}


Discharge measurements of Lower Tule canal at Tulare Lake.

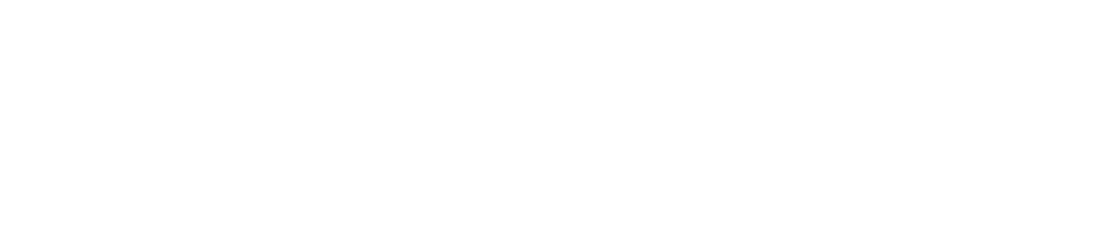

Discharge measurements of Pioneer canal, Tulare c'ounty.

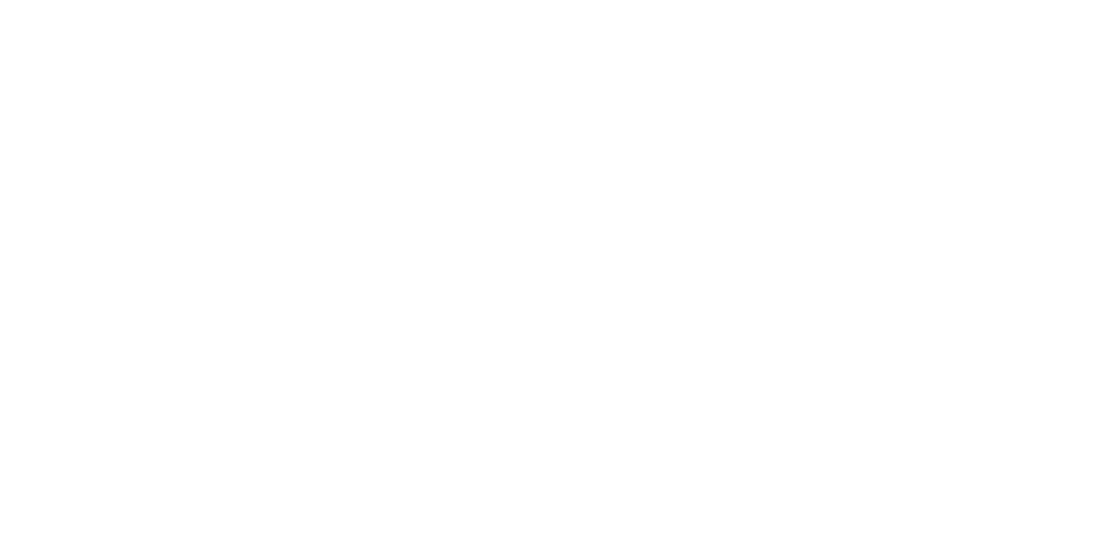

Discharge measurements of South Fork of Tule River at mouth, i miles east of Porterville, Tulare County.

\begin{tabular}{|c|c|c|}
\hline Date. & Hydrographer. & $\begin{array}{c}\text { Dis- } \\
\text { eharge. }\end{array}$ \\
\hline 1901. & & sec-feet. \\
\hline June 10 & J. B. Lippincott . . . & 47.3 \\
\hline $\begin{array}{c}\text { July } 29 \\
1902 .\end{array}$ & S. G. Bennett . ........ & ${ }^{a} .5$ \\
\hline May 15 & $\ldots$ do.. & 103.0 \\
\hline
\end{tabular}


Estimated monthly discharge of Tule River at Porterville.

[Drainage area, 437 square miles.]

\begin{tabular}{|c|c|c|c|c|c|c|}
\hline \multirow[b]{2}{*}{ Month. } & \multicolumn{3}{|c|}{ Discharge. } & \multirow[b]{2}{*}{$\begin{array}{l}\text { Total dis- } \\
\text { charge }\end{array}$} & \multicolumn{2}{|c|}{ Rur -off. } \\
\hline & Maximum. & Minimum. & Mean. & & $\begin{array}{l}\text { Per } \\
\text { square } \\
\text { mile. }\end{array}$ & Depth. \\
\hline $\begin{array}{r}1878 . \\
\text { November }\end{array}$ & sec-feet & sec-feet. & $\begin{array}{c}\text { Sec-feet. } \\
131\end{array}$ & $\begin{array}{r}\text { Acre-feet. } \\
7,795\end{array}$ & $\begin{array}{c}\text { sec.-feet. } \\
0.30\end{array}$ & $\begin{array}{l}\text { Inches. } \\
\quad 0.33\end{array}$ \\
\hline December - & & $\ldots \ldots$ & 131 & 8,055 & .30 & .35 \\
\hline $18 \div 9$. & & & & & & \\
\hline January. & & $\ldots$ & 57 & 3,505 & 0.13 & 0.15 \\
\hline February & & & $8 \%$ & 4,832 & .20 & .21 \\
\hline March & & - . . . & 61 & 3,751 & .14 & .16 \\
\hline April ..... & & ..... & 118 & 7,021 & .27 & .30 \\
\hline May ........ & & $\ldots$ & 105 & 6,456 & .24 & .28 \\
\hline June ....... & & & 350 & 20,826 & .80 & .89 \\
\hline July ... & & & 35 & 2,152 & . .08 & .09 \\
\hline August & & - & 26 & 1,599 & .06 & .07 \\
\hline September & & & 26 & 1,547 & .06 & .07 \\
\hline October ... & & & 74 & 4,550 & .17 & .20 \\
\hline November... & & & 140 & 8,330 & .32 & .36 \\
\hline December . . & & $\ldots \ldots$ & 271 & 16,663 & .62 & .71 \\
\hline The year & & & 113 & 81,232 & .25 & 3.49 \\
\hline 1880. & & & & & & \\
\hline January ... & & & $5 \%$ & 35,478 & 1.32 & 1.52 \\
\hline February .. & & & 1,040 & 59,821 & 2.38 & 2.57 \\
\hline March & & & 1,079 & 66,344 & 2.47 & 2.84 \\
\hline April . & & & 1,289 & 76,701 & 2.95 & 3.28 \\
\hline May .... & & & 1,040 & 63,946 & 2.38 & 2.75 \\
\hline June . . . & & & 721 & 42,902 & 1.65 & 1.84 \\
\hline July ....... & $\ldots$ & & 350 & 21,520 & .80 & .92 \\
\hline August & & & 87 & 5,349 & .20 & .23 \\
\hline September -. & & ... & 44 & 2,618 & .10 & .11 \\
\hline October. & & & 44 & 2,705 & .10 & .12 \\
\hline November & & & $8 \%$ & 5,177 & .20 & .22 \\
\hline December . . . . & $\ldots \ldots$ & $\ldots . . . .$. & 219 & 13,466 & .50 & .58 \\
\hline The year & $\ldots$ & & 548 & 396,027 & 1.25 & 16.98 \\
\hline
\end{tabular}

“A uthority, California State engineering department from November, 18\%8, to October, 1884. 
Estimated monthly discharge of Tule River at Porterville--Continued.

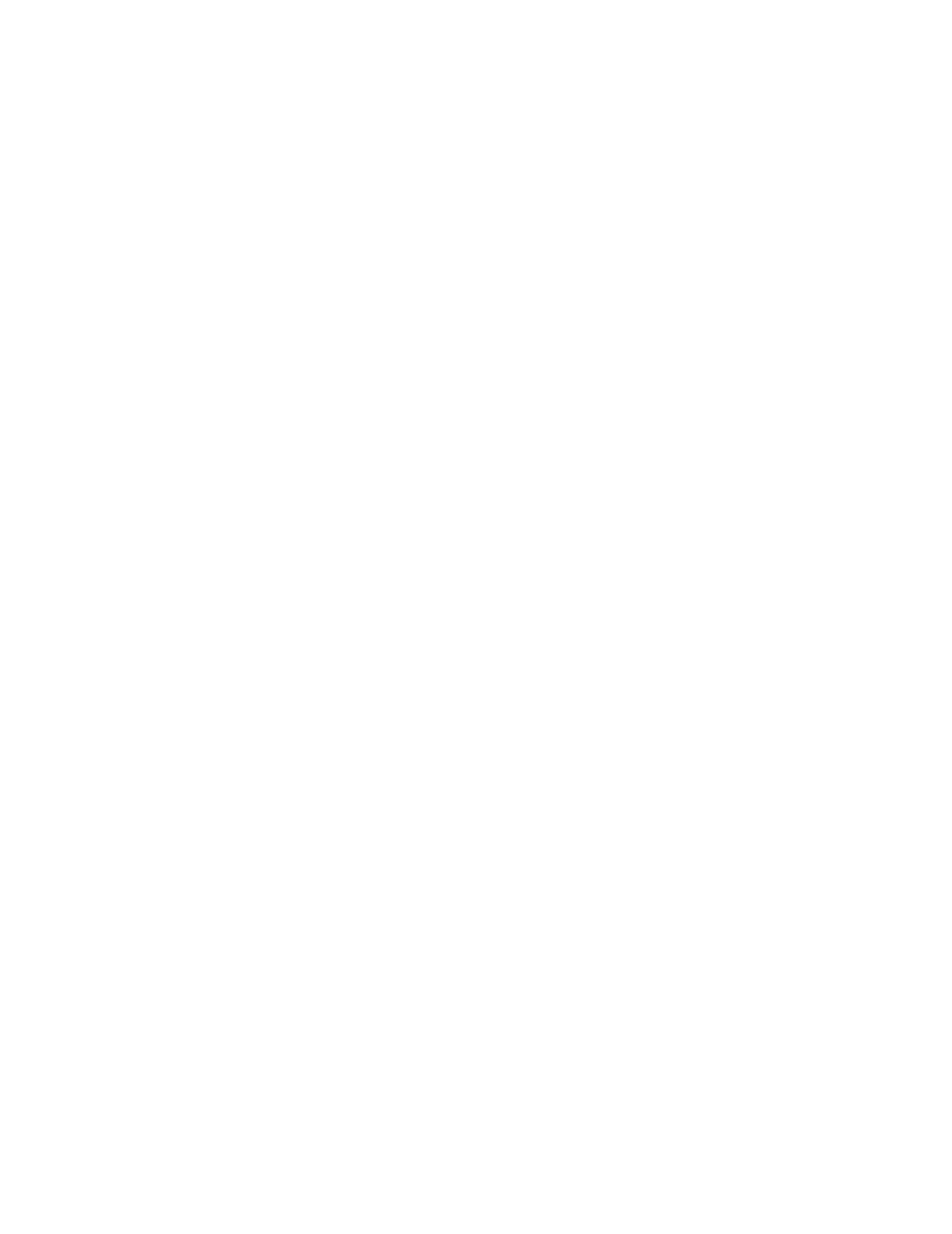


Estimated monthly discharge of Tule River at Porterville-Continued.

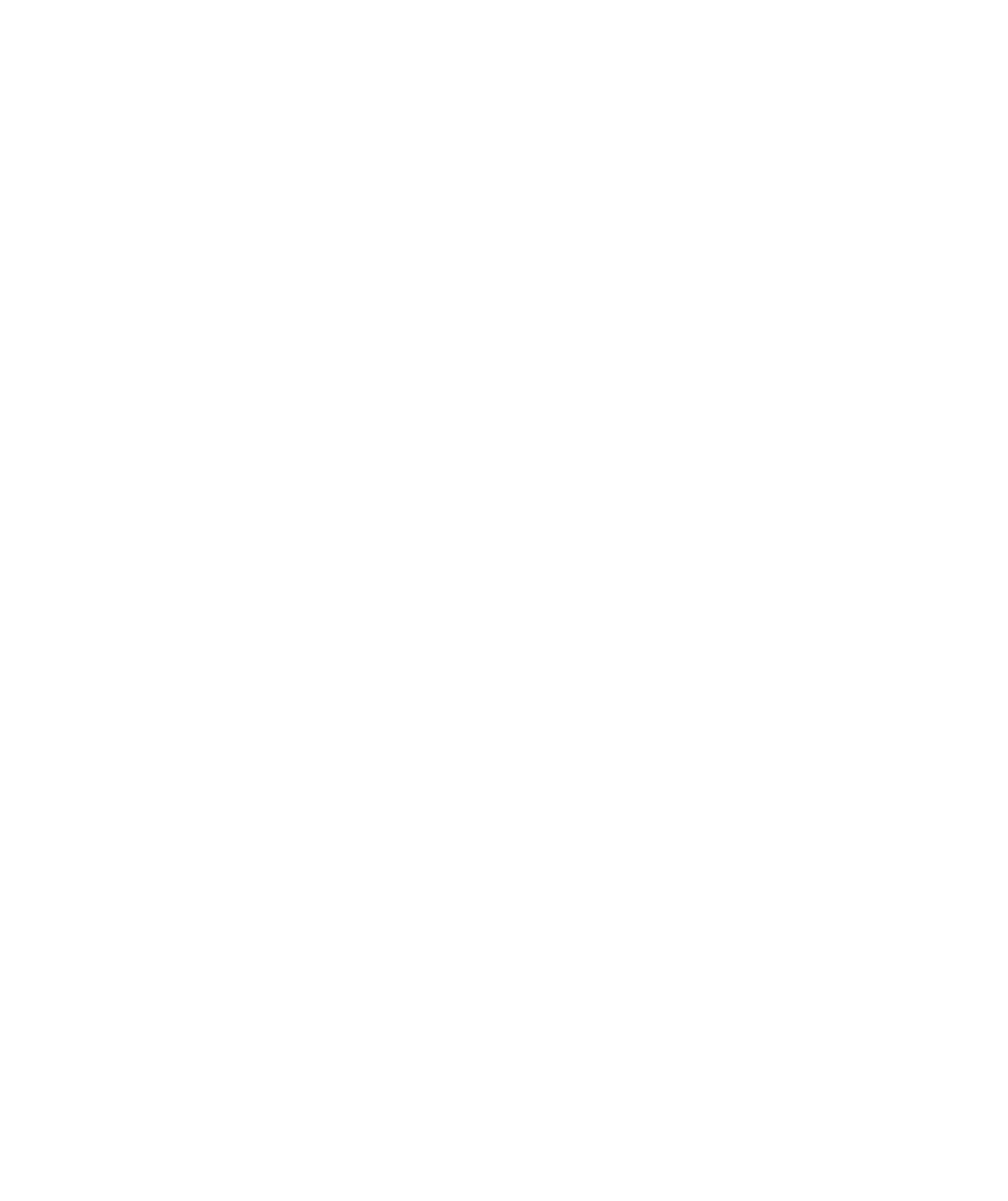


Estimated monthly discharge of Tule River at McFarlands Bridg: near Porterville, Tulare County.

[Drainage area, 437 square miles.]

\begin{tabular}{|c|c|c|c|c|c|c|}
\hline \multirow[b]{2}{*}{ Month. } & \multicolumn{3}{|c|}{ Discharge. } & \multirow[b]{2}{*}{$\begin{array}{l}\text { Total dis- } \\
\text { charge. }\end{array}$} & \multicolumn{2}{|c|}{ Run-off. } \\
\hline & Maximum. & Minimum. & Mean. & & $\begin{array}{l}\text { Per } \\
\text { square } \\
\text { mile. }\end{array}$ & Depth. \\
\hline 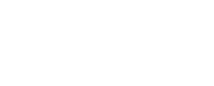 & $\begin{array}{r}\text { Sec.feet. } \\
875\end{array}$ & $\begin{array}{r}\text { sec. seet } \\
298\end{array}$ & $\begin{array}{r}\text { Sec.feet } \text {. } \\
418\end{array}$ & $\begin{array}{l}\text { Acre-feet. } \\
\quad 25,702\end{array}$ & $\begin{array}{r}\text { Sec.feet } \\
0.96\end{array}$ & $\begin{array}{r}\text { See -feet. } \\
1.10\end{array}$ \\
\hline June . . . . . . . & 408 & 126 & 240 & 14,281 & .55 & .61 \\
\hline July _...... & 126 & 30 & 61 & 3.751 & .14 & .16 \\
\hline August $\ldots$ & 30 & 18 & 19 & 1,168 & .04 & .04 \\
\hline September . . & 23 & 10 & 17 & 1,012 & .04 & .04 \\
\hline October ........ & 109 & 18 & 29 & 1,783 & .07 & .08 \\
\hline November... & 71 & 35 & 43 & 2,559 & .10 & .11 \\
\hline December .... & 64 & 39 & 50 & 3,074 & .11 & .13 \\
\hline 1902. & & & & & & \\
\hline January . . . . . & 51 & 34 & 45 & 2,767 & .10 & .12 \\
\hline February .... & 1.415 & 45 & 159 & 8,830 & .36 & .37 \\
\hline March & 2,735 & 144 & 362 & 22,259 & .83 & .95 \\
\hline April $\ldots . . .$. & 4,615 & 249 & 571 & 33,974 & 1.31 & 1.46 \\
\hline May - & 408 & 273 & 343 & 21,090 & .79 & .91 \\
\hline June $\ldots \ldots$ & 324 & 78 & 190 & 11,306 & .43 & .48 \\
\hline July .... & 78 & 26 & 43 & 2,644 & .10 & .12 \\
\hline August & 33 & 18 & 21 & 1,291 & .05 & .06 \\
\hline September - & 17 & 14 & 15 & 893 & .03 & .03 \\
\hline October..... & 93 & 14 & 24 & 1,476 & .05 & .06 \\
\hline November.... & 144 & 27 & 50 & 2,975 & .11 & .12 \\
\hline December ... - & 204 & 45 & 62 & 3,812 & .14 & .16 \\
\hline The year & 4.615 & 14 & 157 & 113,320 & .36 & 4.84 \\
\hline
\end{tabular}

TUMITUS CREEK.

Discharge measurement of Tumitus Creek, San Mateo County.

\begin{tabular}{|c|c|c|}
\hline Date. & Hydrographer. & $\begin{array}{c}\text { Dis- } \\
\text { charge. }\end{array}$ \\
\hline 1893. & & Sec.feet. \\
\hline Oct. $1 \pi$ & W. W. Brier . . . . . & $a 1.14$ \\
\hline
\end{tabular}


TUNIS CREEK.

Discharge measurement of Tunis Creek, Kern C'ounty.

\begin{tabular}{|c|c|c|}
\hline Date. & Hydrographer. & $\begin{array}{c}\text { Dis- } \\
\text { charge. }\end{array}$ \\
\hline $\begin{array}{l}1896 . \\
\text { ane } 4\end{array}$ & J. B. Lippincott . . . & $\begin{array}{r}\text { sec.feet. } \\
1.98\end{array}$ \\
\hline ec. 15 & $\ldots$.... do ..... & .7 \\
\hline
\end{tabular}

a At mouth.

\section{TUOLUMNE RIVER.}

\section{HETCH HETCHY DAM SITE, HETCH HETCHY VALLEY.}

The entire drainage of Tuolumne River above Lagrange is about l,500 square miles, some 400 square miles of which lie above the Hetch Hetchy dam site, the elevation of which is 3,630 feet above sea level. This upper drainage area consists of high granite mountains culminating in Mount Dana, Mount Gibbs, and Mount Lyell.

A gaging station was established at this point May 30, 1901, by J. B. Lippincott, for the city of San Franciseo.

For detailed description of Hetch Hetchy reservoir site see Twentyfirst Annual Report of U. S. Geological Survey, Part IV, page 450.

Discharge measurements of Tuolumne River. Hetch Hetchy Valley, Tuohmne. County.

\begin{tabular}{|c|c|c|c|c|}
\hline Date. & Hydrographer. & $\begin{array}{c}\text { Gage } \\
\text { height. }\end{array}$ & $\begin{array}{c}\text { Dis- } \\
\text { charge. }\end{array}$ & Location. \\
\hline 1899. & & Feet. & sec-feet. & \\
\hline July 31 & H. Ramel & & 238.0 & \\
\hline Ang. 5 & $\ldots$... do _.... & & 230.0 & \\
\hline Ang. 12 & .... do .... & & 131.0 & \\
\hline Aug. 19 & - do & $\ldots \ldots$ & 101.0 & \\
\hline Aug. 23 & ....do. & & 69.0 & \\
\hline 1901. & & & & \\
\hline Aug. 13 & $\begin{array}{l}\text { J. B. Lippincott and W. } \\
\text { W. Cockins, jr. }\end{array}$ & & 472.0 & $\begin{array}{l}\text { Ford in Hetch Hetchy Val- } \\
\text { ley. }\end{array}$ \\
\hline Aug. 29 & W. W. Cockins, jr . . . . & 12.93 & 190.5 & Do. \\
\hline Sept. 5 & $\ldots$. do . . . . . . . & 12.65 & 155.7 & Do. \\
\hline Sept. 14 & $\ldots$ do .......... & $: 2.42$ & $7 \pi .5$ & Do. \\
\hline Oct. 5 & $\ldots$. . do ......... & 12.92 & 115.6 & Do. \\
\hline Oct. 11 & . . . do ......... & 12.60 & 88.0 & Do. \\
\hline Aug. 25 & . . do ........ & 13.28 & 231.3 & 1,000 feet above dam site. \\
\hline $\begin{array}{l}\text { Sept. } 28 \\
1902 .\end{array}$ & $\ldots$ do $\ldots \ldots$ & 13.11 & 144.7 & Do. \\
\hline Ang. 29 & E. T.Perkins & & 66.0 & $\begin{array}{l}\text { Upper end Hetch Hetchy } \\
\text { Valley. }\end{array}$ \\
\hline
\end{tabular}


Dischargr measurements of Tuolumne River at Hetch lìetchy dam site.

\begin{tabular}{|c|c|c|c|}
\hline Date. & Hydrographer. & $\begin{array}{c}\text { Gage } \\
\text { height. }\end{array}$ & $\begin{array}{c}\text { Dis- } \\
\text { charge. }\end{array}$ \\
\hline 1901. & & Feet. & Sec,feet. \\
\hline June 29 & C. A. Miller and W. W. Cockins. jr & 36.00 & 7.621 .00 \\
\hline July 4 & C. A. Miller $\ldots$ & 30.00 & $3,296.00$ \\
\hline July 12 & $\ldots$ do ..... & 26.10 & 2.720 .00 \\
\hline July 21 & $\ldots$.... do ... & 24.17 & $1,886.00$ \\
\hline July 29 & W. W. Cockins. jr & 21.50 & $1,160.00$ \\
\hline Aug. $\quad 2$ & .... do ......... & 20.33 & 1.137 .00 \\
\hline Aug. 13 & J. B. Lippincott.... & 15.70 & 754.00 \\
\hline Sept. 20 & W. W. Cockins. jr. & 12.32 & 66.12 \\
\hline
\end{tabular}

Discharge measurements of Tuolumne River at old bridge above Rancheria Creek, Tuolumne County.

\begin{tabular}{|c|c|c|c|}
\hline Date. & Hydrographer. & $\begin{array}{c}\text { Gage } \\
\text { height. }\end{array}$ & $\begin{array}{c}\text { Dis- } \\
\text { charge. }\end{array}$ \\
\hline 1901. & & Feet. & Sec.-feet. \\
\hline July 13 & C. A. Miller.... & & 1,849 \\
\hline Aug. 26 & W. W. Cockins, jr . . . & & 160 \\
\hline Sept. 28 & do & $\ldots$ & 120 \\
\hline Oct, 11 & $\ldots$ do ....... & & 60 \\
\hline
\end{tabular}

Discharge measurements of Rancheria Creek (tributary to Tuolumne River) at old sheep bridge, Tuolumne County.

\begin{tabular}{|c|c|c|c|}
\hline Date. & Hydrographer. & $\begin{array}{c}\text { Gage } \\
\text { height. }\end{array}$ & $\begin{array}{c}\text { Dis- } \\
\text { charge. }\end{array}$ \\
\hline 1901. & & Feet. & Sec.feet. \\
\hline $\begin{array}{c}\text { Aug. } 26 \\
1902 .\end{array}$ & W. W. Cockins. jr & & 36.2 \\
\hline Aug. 29 & E.T.Perkins & & $a 7.0$ \\
\hline
\end{tabular}

"At head of falls.

CHERRY RIVER AT ELEANOR TRAIL CROSSING.

Cherry River is a tributary of the Tuolumne and enters that stream $12 \frac{1}{2}$ miles below Hetch Hetchy Valley. The area drained is 130 square miles.

A gaging station was eslablished at the point whare Eleanor trail crosses the river, on May 26, 1901, by J. B. Lippincott, for the city of San Francisco. 
ischarge measurements of C'herry Creek, a tributary of Tuolumne River. at Eleanor trail crossing.

\begin{tabular}{|c|c|c|c|}
\hline Date. & Hydrographer. & $\begin{array}{l}\text { Gage } \\
\text { height. }\end{array}$ & $\begin{array}{l}\text { Dis- } \\
\text { charge. }\end{array}$ \\
\hline 1901. & & Feet. & sec-feet. \\
\hline uly 8 & C. A. Miller .. & 11.40 & 915.0 \\
\hline uly 17 & $\ldots d o \quad \ldots . . .$. & 10.40 & 510.0 \\
\hline เug. 9 & W. W. Cockins, jr. & 8.75 & 112.0 \\
\hline sug. 19 & do $\ldots \ldots$ & 9.10 & 132.0 \\
\hline ıug. 20 & $\ldots$ do _. & 8.40 & 107.0 \\
\hline lug. 24 & $\ldots$. do _ . . & 8.10 & 43.0 \\
\hline jept. 1 & . . . & 7.80 & 17.5 \\
\hline jept. $\tau$ & $-\ldots n_{1}$ & 7.70 & 6.1 \\
\hline jept. 1 r & $\ldots$ do _.......... & T. 00 & 4.3 \\
\hline jept. 22 & (n. & 7.06 & 4.5 \\
\hline Sept. 26 & $\ldots$. do $\ldots . . . .$. & 9.05 & 141.0 \\
\hline Jct. 3 & $\ldots$ do $\ldots \ldots$...... & 8.96 । & 120.0 \\
\hline Jct. 10 & $\ldots$ do $\ldots . .$. & 8.001 & 43.0 \\
\hline 1902 & & & \\
\hline Aug. 30 & E. T. Perkins .... & & $" 4.4$ \\
\hline Aug. 30 & .... do ............ & & 6.0 \\
\hline
\end{tabular}

a 1,500 feet below trail crossing.

ELEANOR GREEK AT ELEANOR TRAIL CROSSING.

Eleanor Creek is a tributary of Cherry River and enters that stream 6 miles above its mouth. The elevation of the outlet of Lake Eleanor is 4,655 feet above sea level. The drainage area above the gaging station is 81 square miles, and consists of high granite mountains culminating in Richardson Peak, elevation 9,845 feet; Haystack Peak, elevation 9,966 feet; and an unnamed peak, elevation 10,510 feet. The average elevation of the drainage basin is probably 7,500 feet.

A gaging station was established at the outlet of Lake Eleanor June 1, 1901, by J. B. Lippincott, for the city of San Francisco.

For a detailed description of Lake Eleanor reservoir site see Thirteenth Annual Report of the U. S. Geological Survey, Part IIJ, page 402 . 
Discharge measurements of Eleanor Creek at inlet to Lake Eleanor, Tuolumne County.

\begin{tabular}{|c|c|c|c|}
\hline Date. & Hydrographer. & $\begin{array}{l}\text { Gage } \\
\text { height. }\end{array}$ & $\begin{array}{c}\text { Dis- } \\
\text { charge. }\end{array}$ \\
\hline 1901. & & Feet. & Sec-feet. \\
\hline June 11 & C. A. Miller. & & a 226.0 \\
\hline \multirow[t]{2}{*}{ Do } & do ........ & & $b 74.0$ \\
\hline & Total & & 300.0 \\
\hline \multirow{3}{*}{$\begin{array}{c}\text { July } 16 \\
\text { Do }\end{array}$} & C. A. Miller & & $a 121.0$ \\
\hline & ... do . . . . . . & & $b 23.0$ \\
\hline & Total. ............. & & 144.0 \\
\hline \multirow{3}{*}{$\begin{array}{c}\text { Aug. } 18 \\
\text { Do }\end{array}$} & W. W. Cockins, jr. & & a 75.0 \\
\hline & $\ldots$ do $\ldots \ldots$ & & $b 11.6$ \\
\hline & Total ........ & & 86.6 \\
\hline \multirow{3}{*}{$\begin{array}{c}\text { Aug. } 27 \\
\text { Do }\end{array}$} & W. W. Cockins, jr & & $x 8.3$ \\
\hline & $\ldots$ do $\ldots \ldots \ldots \ldots \ldots$ & & $b 1.5$ \\
\hline & Total . . . . . . . & & 9.8 \\
\hline \multirow{3}{*}{$\begin{array}{l}\text { Oct. } 1 \\
\text { Do }\end{array}$} & W. W. Cockins, jr .... & & 47.6 \\
\hline & do & & 67.4 \\
\hline & Total . - & & 55.0 \\
\hline
\end{tabular}

a West Branch.

b East Branch.

Discharge measurements of Eleanor C'reek at outlet of Lake Eleanor, Tuolumne county.

\begin{tabular}{|c|c|c|c|}
\hline Date. & Hydrographer. & $\begin{array}{c}\text { Gage } \\
\text { height. }\end{array}$ & $\begin{array}{l}\text { Dis. } \\
\text { charge. }\end{array}$ \\
\hline 1901. & & Feet. & Sec. feet. \\
\hline June 10 & C. A. Miller... & 8.67 & 411.0 \\
\hline June $2 \mathcal{2}$ & ..... do ..... & 9.76 & 793.0 \\
\hline July 8 & J. B. Lippincott .... & 8.57 & 310.0 \\
\hline July 16 & C. A. Miller .... & 7.92 & 263.0 \\
\hline July 18 & . do _........... & 7.80 & 225.0 \\
\hline July 27 & W. W. Cockins, jr. & 7.45 & 145.0 \\
\hline Ang. 3 & $\ldots$ do $\ldots \ldots$ & 7.10 & 84.0 \\
\hline Aug. 10 & .....do & 6.92 & 75.0 \\
\hline Aug. 17 & .... do & 6.48 & 30.0 \\
\hline Aug. 19 & .... do & 6.68 & 42.0 \\
\hline Ang. 23 & $\ldots$ do & $6.4 i$ & 32.0 \\
\hline Aug. 27 & $\ldots$ do .... & 6.26 & 17.8 \\
\hline Ang. 30 & $\ldots$....do & 6.05 & 13.9 \\
\hline
\end{tabular}


Discharge measurements of Eleanor ('reek, ete.-Continued.

\begin{tabular}{|c|c|c|c|}
\hline Date. & Hydrographer. & $\begin{array}{c}\text { Gag } 9 \\
\text { height. }\end{array}$ & $\begin{array}{c}\text { Dis- } \\
\text { charge. }\end{array}$ \\
\hline 1901. & & Feet. & Sec.-feet. \\
\hline Sept. 6 & 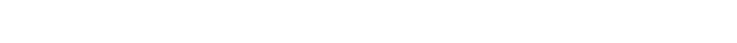 & 5.90 & 6.22 \\
\hline Sept. 14 & (.... do . . . . . . . . . . & 5.70 & 4.08 \\
\hline Sept. 21 & .... do .... & 5.72 & 5.02 \\
\hline Sept. 26 & .... do ...... & 5.85 & 5.77 \\
\hline Oct. 3 & $\ldots$. . do ..... & 6.40 & 34.5 \\
\hline Oct. 10 & ..... do _... & 6.21 & 21.2 \\
\hline
\end{tabular}

Discharge mensurements of Tuolumne River.

\begin{tabular}{|c|c|c|c|}
\hline Date. & Hydrographer. & $\begin{array}{l}\text { Dis- } \\
\text { charge. }\end{array}$ & Location. \\
\hline 1902. & & sec-foet. & \\
\hline Ang. 22 & E. T. Perkins. & 6.0 & $\begin{array}{l}\text { North Fork at headworks, Goldwin Min- } \\
\text { ing Co.'s canal. }\end{array}$ \\
\hline Aug. 2 r & $\ldots$ do . . & 152.0 & $\frac{1}{3}$ mile above junction of South Fork. \\
\hline Do & ..... do ... & 20.0 & $\begin{array}{l}\text { South Fork. } \frac{1}{3} \text { mile above junction of main } \\
\text { river. }\end{array}$ \\
\hline Ang. :29 & .....do & .5 & Tiltill Creek at trail crossing. \\
\hline Do - & $\ldots$ do ... & K2. 0 & Lower end Hetch Hetchy Valley. \\
\hline Aug. 31 & $\ldots . d o$ & 3.0 & 100 yards below bridge, Middle Fork. \\
\hline Sept. $\stackrel{2}{\sim}$ & -.... 10 - & 23.0 & $\begin{array}{l}\text { Above falls, lower end Tuolumne } \\
\text { Meadows. }\end{array}$ \\
\hline Aug. 25 & $\ldots$ do & 22.0 & Jacksonville. \\
\hline Aug. 26 & . . . (10 & 1.59 .0 & Ward s ferry. \\
\hline Aug. 28 & L. M. Lawson . & 1.50 .0 & Jacksonville. Tuolumne County. \\
\hline Aug. 27 & ..... de ....... & 4.0 & $\begin{array}{l}\text { Mining Company's ditch at Lagrange, } \\
\text { Stanislaus C'ounty. }\end{array}$ \\
\hline Do $\ldots$ & - - $_{\text {do }}$ & $10 . \overline{5} .0$ & Turlock canal. \\
\hline
\end{tabular}

Discharge measurements of Frog ('reek at inlet Eleanor Lakr. Tholnmne' Connty, Cal.

\begin{tabular}{|c|c|c|c|}
\hline Date. & Hydrographer. & $\begin{array}{c}\text { Dis- } \\
\text { charge. }\end{array}$ & Location. \\
\hline 1901 & & ser-fect. & \\
\hline June 12 & C. A. Miller . - & 116.0 & \\
\hline July 17 & $\ldots$ do $\ldots \ldots . . .$. & 33. & \\
\hline Aug. 18 & W. W, Cockins. jr. & 5.7 & \\
\hline Aug. $2 \pi$ & _ do & 1.0 & \\
\hline Oct. 1 & 1.... do .... & 4.9 & \\
\hline
\end{tabular}


Discharge measurements of Frolls ('reek at Lake Ternon (upper enr). Tuolumne cronty. Cul.

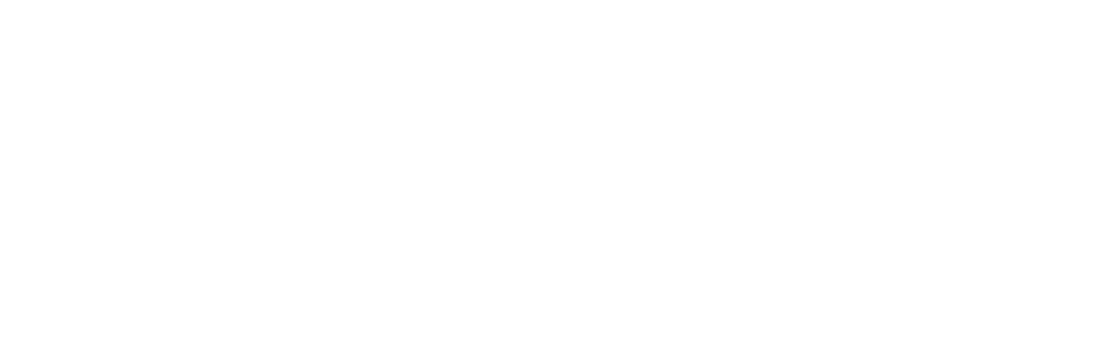

1902.

Ang. 29

E. T. Perkins .....

t. 0 100 yards above junction with Tuolumne.

TUOLUMNE RIVER AT LATRANGE.

This river rises on the western slope of the Sierra Nevada in California and drains the country located between Stanislaus River on the north and Merced River on the South. The northern half of the Yosemite National Park includes a portion of its drainege basin. The river is fer largely from small mountain lakes occurring high in the drainage basin, where snow remains on the mountain slopes throughout the year. The stream has a heary fall, and tre opportunities for power development are numerous. There are also a number of reservoir sites in the basin where water could be stored during the irrigation season. The gaging station, established August 29, 1895, is located at the wagon bridge in the town of Lagrange, Cal. The rod is vertical and is bolted to the right-hand pier of the bridge. The bench mark is a nail driven into the botton of the west post of the fifth bent south of the south iron cylinder, and is 1.5 .31 feet above gage datum. The station is located below the high dam of the Turlock and Modesto irrigation districts, and also below the head of the eanal of the Lagrange Hydraulic Mining Company. This latter canal diverts water from the left bank of the river 14 miles above Lagrange dam. This water is used for hydraulic mining, and partly returns above the gaging station, depending on the convenience of the miners. During 1898 water was first turned down the Turlock Canal in small quantity, and was used for puddling the banks and testing dams of certain reservoirs. Whenever measurements at the gaging station were made, the Turlock Canal and the mining company's canal were also measured. The channel at the station, both above and below the bridge, is straight for several hundred feet, and the velocity of the stream is rather uniform. Both hanks are high and not subject to overflow. 
Dischargr morsurements of Tuolumne River at Lagrange, Stanislaus c'onnty.

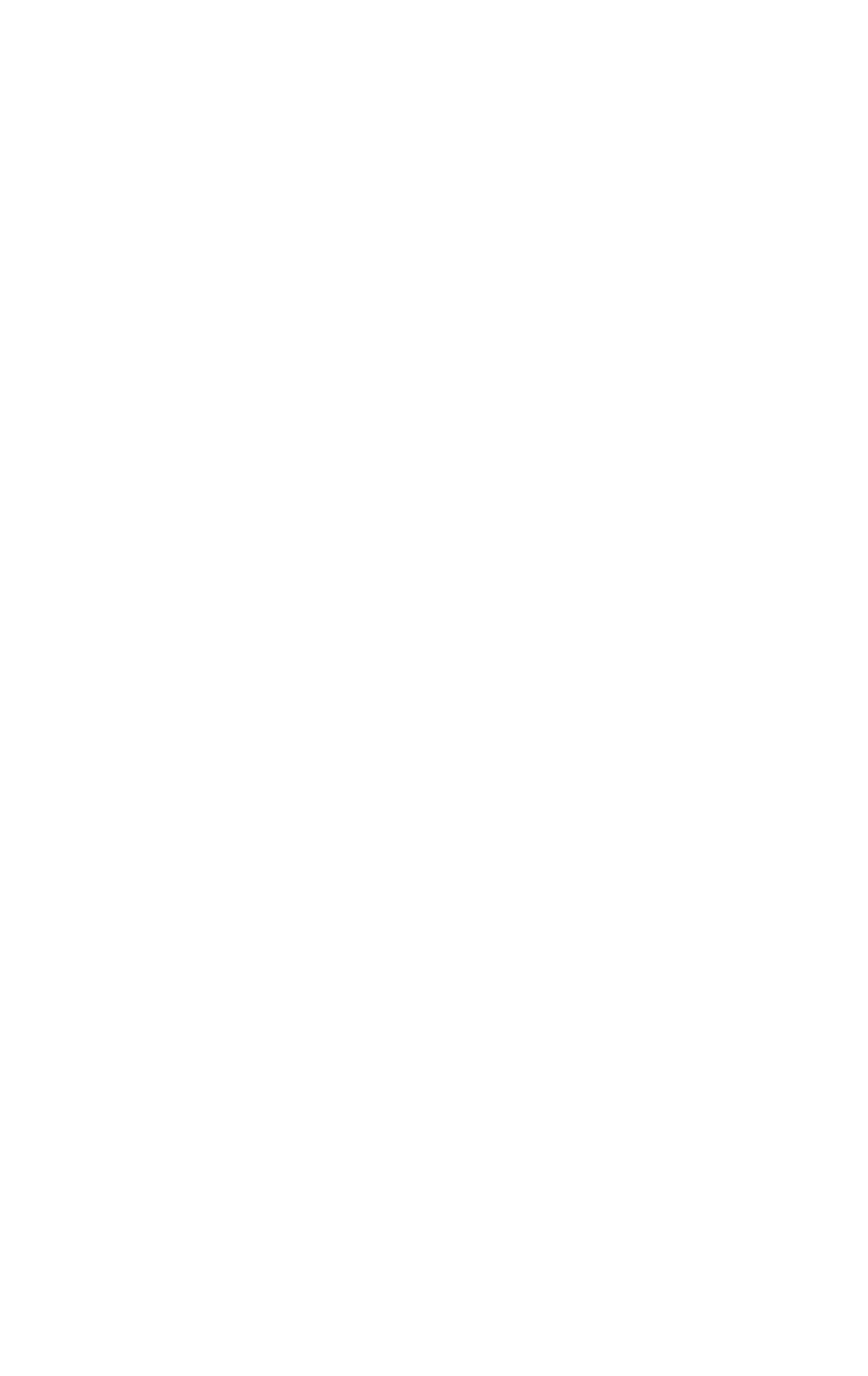

a Turlock Canal. "lat Grange Ditely and Hydraulic Mining Company's ('anal. "River. 


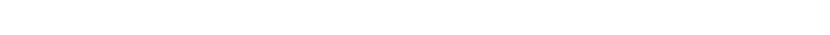

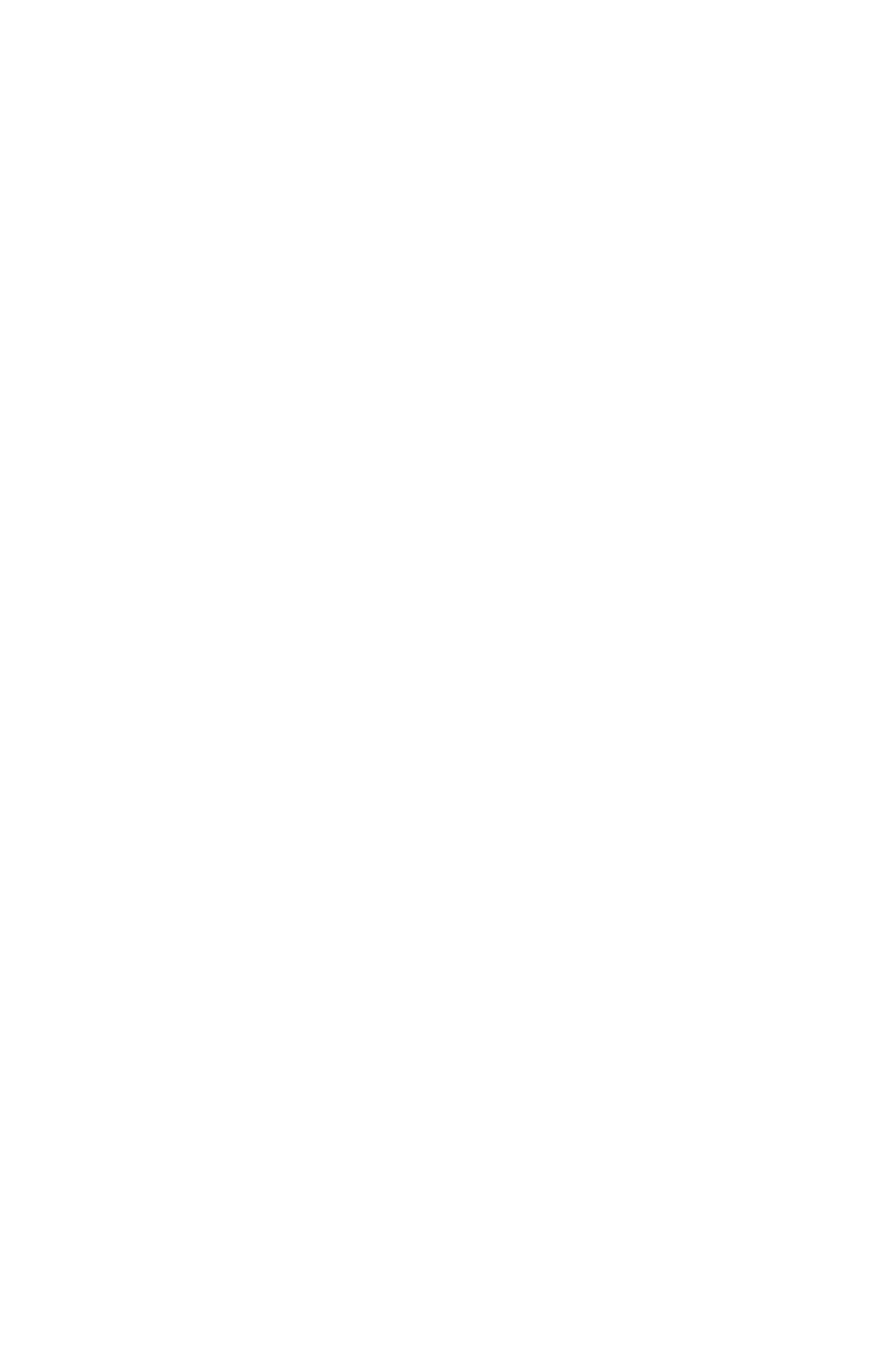

"River. "Turlock Canal. "La Grange Ditch and Hydraulic Mining Company's canal. 


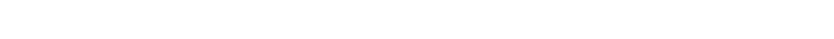

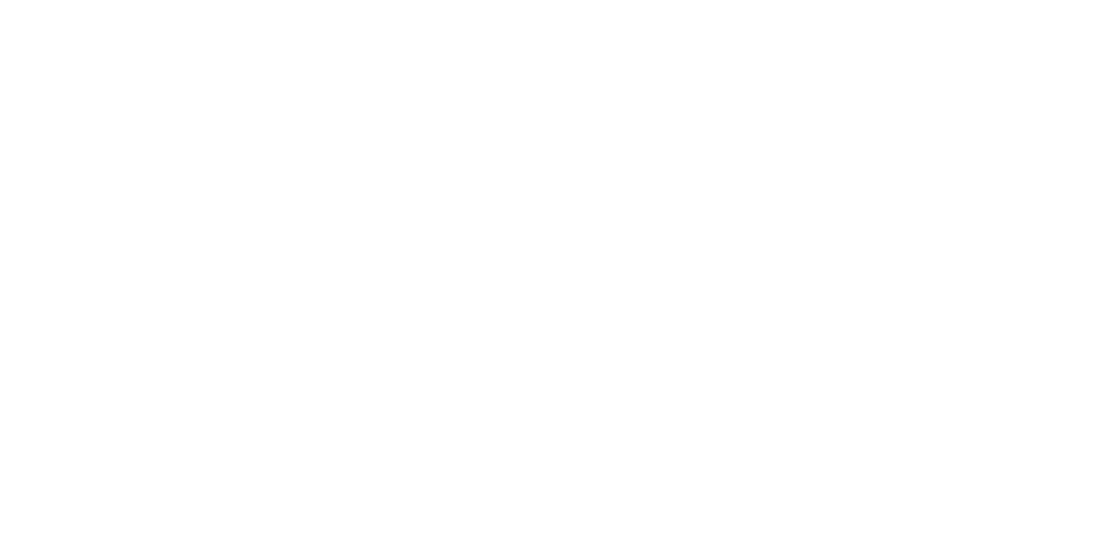

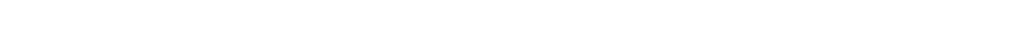

Estimater monthly discharge of Tuolumne River exchesive of anerls at Latgrenge, Stanislaus county.

[Drainage area $1.5111 \mathrm{~N}$ (1) ure miles.]

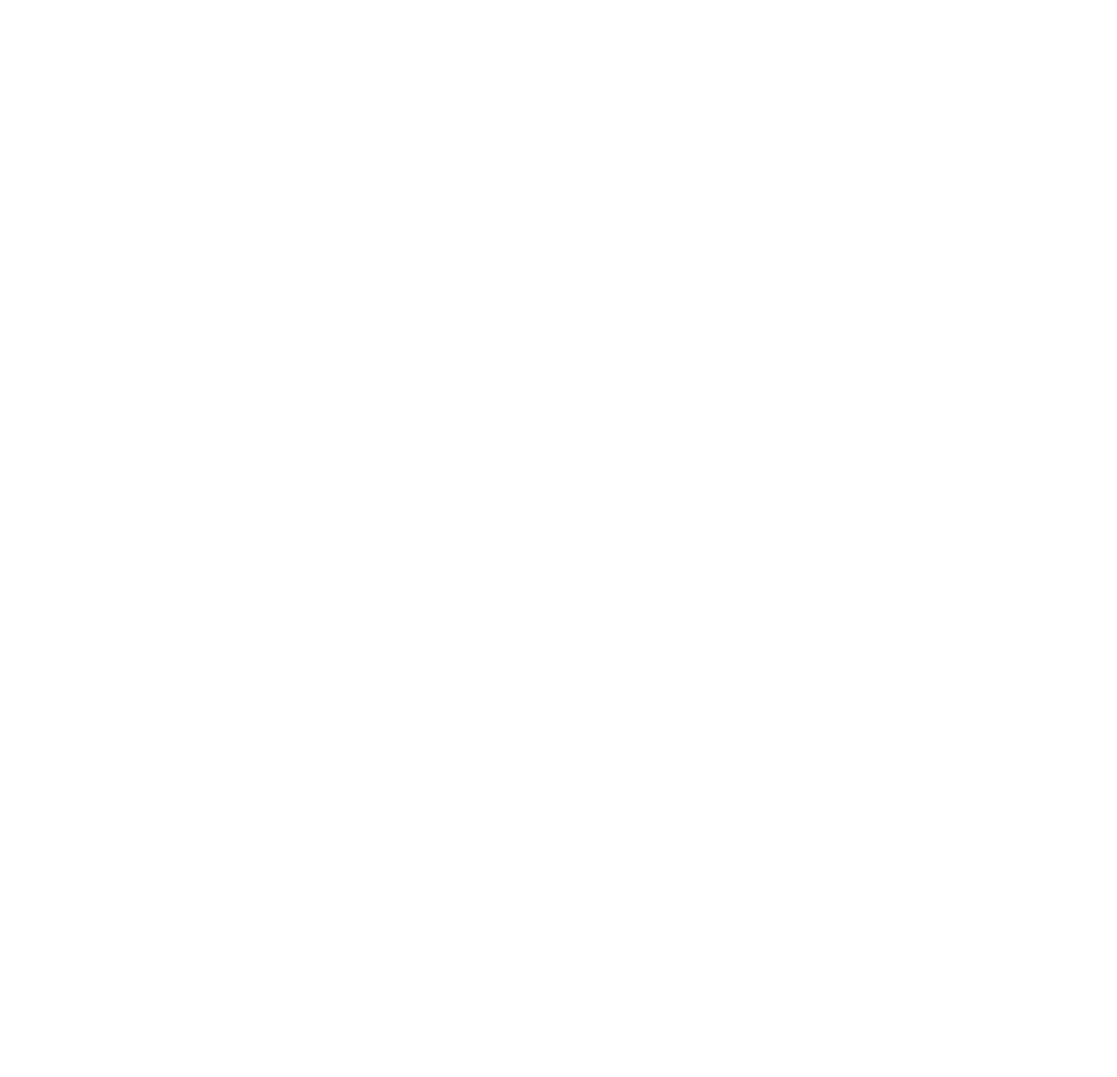

a During 1896 there was no water in the Turlock Canal, and the Lagrange Ditch and Hydraulic Mining Company's Canal was flowing 33 second-feet approximately. The Lagrange Ditch and Hydratulic Mining Conmpany's C'anal was flowing approximately 35 second-feet during 1895. 
Estimater monthly discherge of Tuolumme River. ote. - Continued.

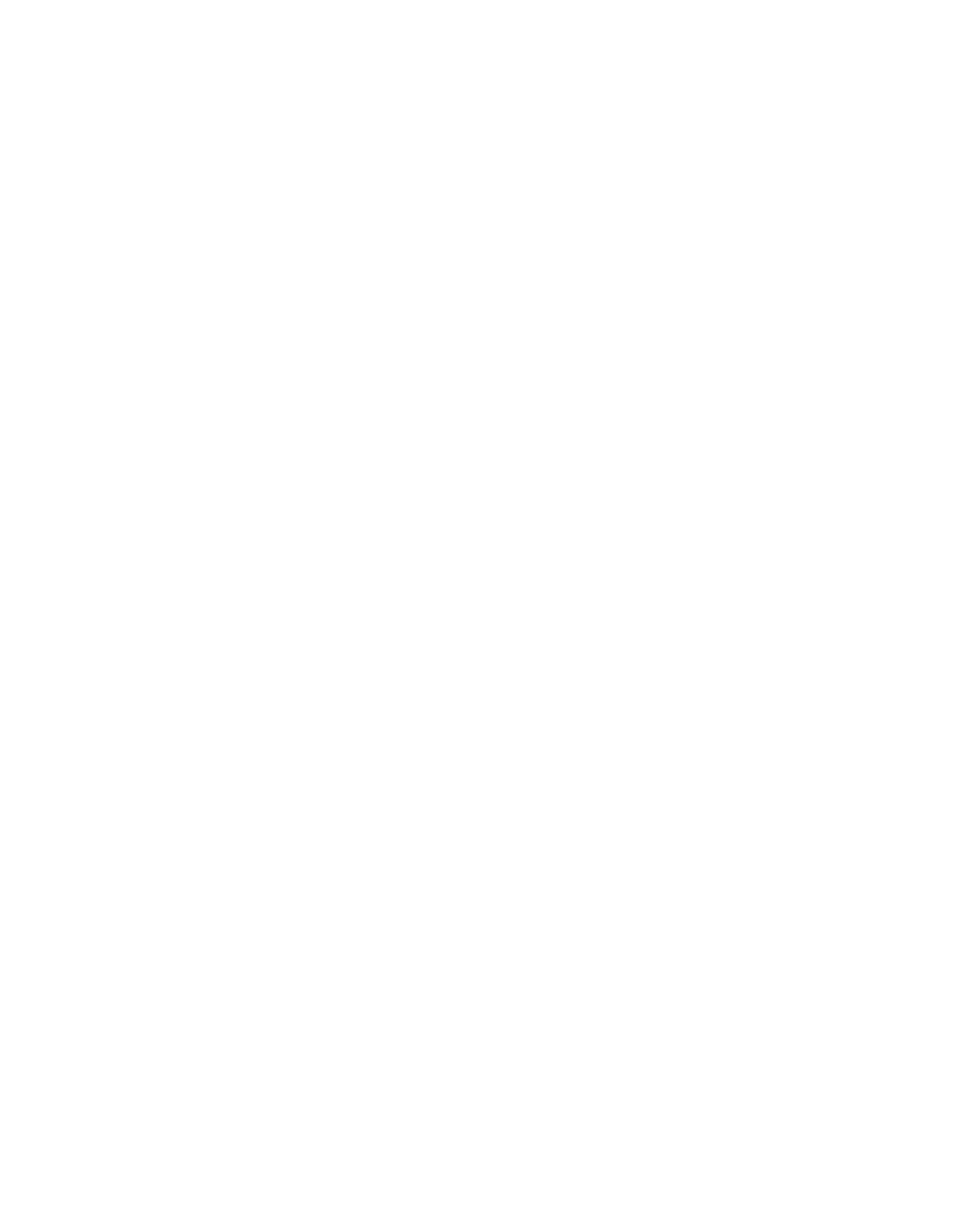

aThere was no dis harge from the Turlock Canal during the year 1897 past the Lagrange gaging station; it was wasted into the ricer above. For flow of the Lagrange Diteh and Hydranlic Mining Company"s Canal, sec special masurements of that eanal.

() During the year $1 \mathrm{kgs}$ the Turlock Canal was not disrhar ring any mat rial amount of water' past the Lagrange gagmg station. and the Lagrange Ditr.h aud Hydrauli. Mining ('ompany's Canal was rarrying about :4 seroud-feet. 
Estimeted monthly discherge of Twolnmme Rirer, etr.--Continued.

\begin{tabular}{|c|c|c|c|c|c|c|}
\hline \multirow[b]{2}{*}{ Month. } & \multirow[b]{2}{*}{ Maximum. } & Discharge. & & \multirow[b]{2}{*}{$\begin{array}{l}\text { Total dis- } \\
\text { charge. }\end{array}$} & \multicolumn{2}{|c|}{ Run-off. } \\
\hline & & : Minimum. & Meann. & & $\begin{array}{c}\text { Per } \\
\text { stuer, } \\
\text { mills. }\end{array}$ & Depth. \\
\hline 1899. & sire-ject. & sier -feet. & sierefiet. & Arre-feet. & sien-fotet. & Inches. \\
\hline January ..... & 1,940 & 110 & 487 & 29.945 & 0.32 & $0.3 \%$ \\
\hline February .... & 1,440 & 410 & T+1) & 41,098 & .49 & .51 \\
\hline March ...... & 21.800 & $5 \% 0$ & 3,616 & $\stackrel{222}{2}, 341$ & 2.41 & 2.78 \\
\hline April ...... & 8.040 & $2,2 \times, j$ & $\therefore, 199$ & 309,004 & 3.46 & 3.86 \\
\hline May _...... & $8,6 \times 0$ & 2,080 & t. $51 ; 3$ & $2 \pi \%, 49 \pi$ & 3.01 & $3.4 \pi$ \\
\hline June .... - . & 9.960 & 2.28 .5 & 6.660 & 360.594 & 4.04 & 4.51 \\
\hline July _.. . . & $?, 490$ & $3: 30$ & 1.010 & 62,103 & $.6 r$ &.$r \pi$ \\
\hline August .. .. & 530 & $4 i$ & $14 . ;$ & $\$, 916$ & .10 & .11 \\
\hline September ..... & 45 & 15 & 33 & 1.964 & .02 & .02 \\
\hline October .......... & 2.285 & 5 & 505 & 31,051 & .34 & .39 \\
\hline Norember... ... & 6,400 & 660 & 2,428 & 144,476 & 1.62 & 1.81 \\
\hline December & 8,040 & 8.50 & $3,04 i$ & $18 \pi, 3.54$ & 2.03 & 2.04 \\
\hline The year & 21,800 & $\pi$ & 2,31, & $1,676,341$ & 1.54 & 20.64 \\
\hline 1910. & & & & & & \\
\hline January ..... . & 13.160 & 1,060 & 2,384 & 146.586 & 1.59 & 1.83 \\
\hline February - & 1,300 & 750 & $96 \tau$ & .33 .704 & .64 & $.6 \tau$ \\
\hline March ... . & 8,100 & 9.50 & 2.343 & 144.065 & 1.56 & 1.80 \\
\hline April ..... & 4,320 & 1,440 & ?. $3 \$ 9$ & 142.15 .5 & 1.59 & $1 . \%$ \\
\hline May _... ... & $9,3: 0$ & 3,100 & 6.796 & $41 \%, 8 \% 0$ & 4.53 & 5.23 \\
\hline June ....... . . & $8.6 \times 0$ & 2.245 & 5,291 & 314,836 & 3.53 & 3.94 \\
\hline July _.... . . & 1.740 & 140 & 694 & $42,6 \div 2$ & .40 & .53 \\
\hline Angust $\ldots \ldots \ldots$ & 140 & 0 & 43 & 2.644 & .03 & .03 \\
\hline September.......... & 110 & 0 & 11 & 65.5 & .01 & .01 \\
\hline Octoher ...,$\ldots$. & 5.760 & 35 & 1,228 & $5.50 \%$ & .82 & .94 \\
\hline November .... - & 14,440 & 410 & 2,536 & $1.50,902$ & 1.69 & 1.89 \\
\hline December ... ........ & $2,0 \times 0$ & 850 & 1,332 & $\times 1,902$ & .89 & 1.02 \\
\hline The year "..... & 14,440 & $\begin{array}{l}0 \\
0=-=-1\end{array}$ & 2,160 & $1,573,498$ & $\begin{array}{c}1.45 \\
-==-\end{array}$ & $\begin{array}{r}19.66 \\
=-=\end{array}$ \\
\hline
\end{tabular}

a For record of discharge of Turlock Canal beginning July 1, 1899. see Turlock Car al. Lagrange Ditch and Hydraulic Mining Company's Canal discharged abut 24 second-feet during the year.

1. Fur discharge of Turlock (anal for 19n) see Turlock Canal. Lagrange Ditch and Hydraulic Mining Company is Canal. January 1 to Jume 23, 24 second-feet: from June 24 to October 20,12 second-feet; and from October 21 to December 31 , 10 second-feet. 
Estimated monthly discharye of Tuolumme River, etr.-Continued.

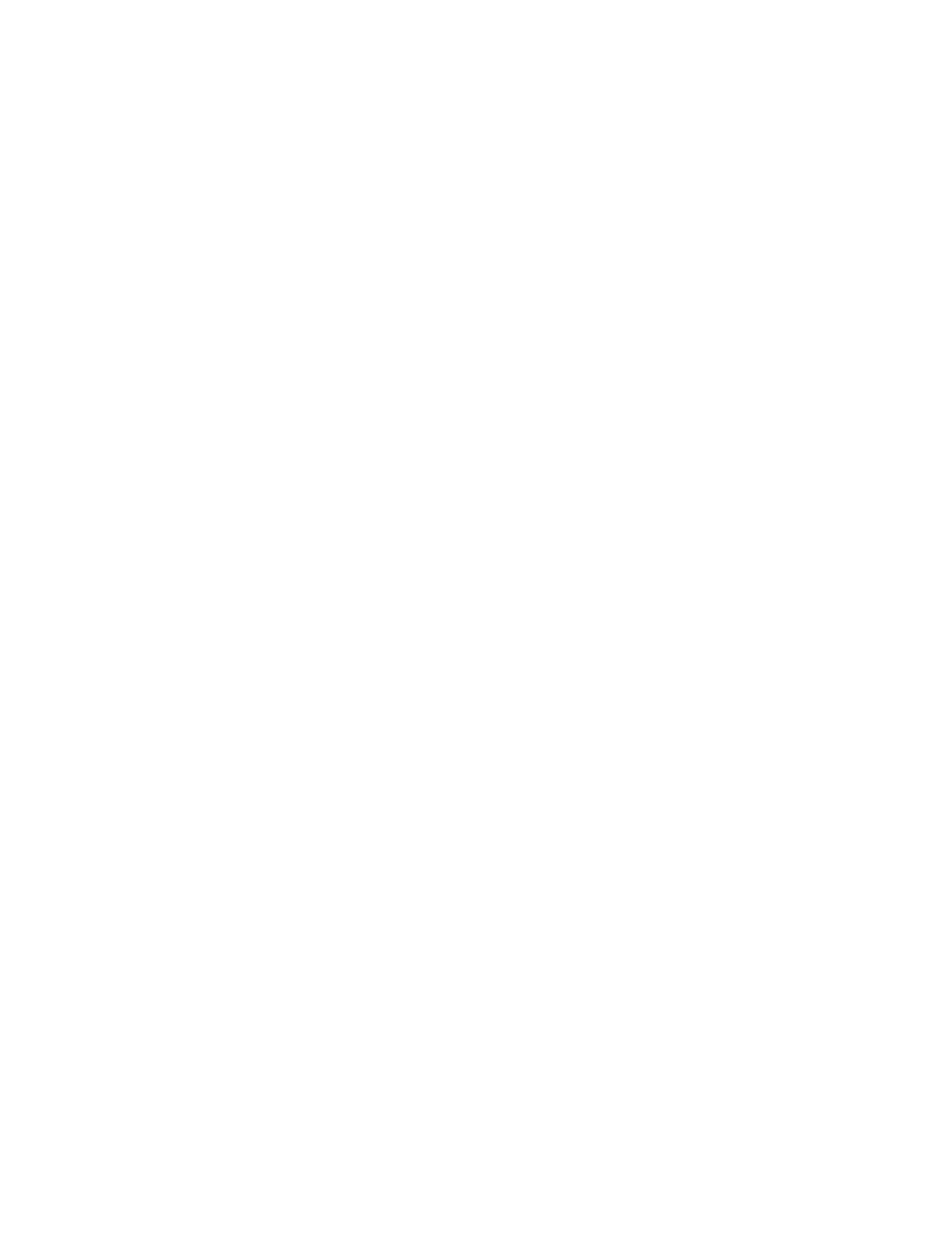

a Record for Turlock Canal for 1901 is incomplete. The Lagrange Ditc. and Hydraulic Mining Company's Canal discharged from January 1 to Mareh 31, 10 second-feet; April 1 to July 28 , 7 second-feet, and flow was not material after that. 


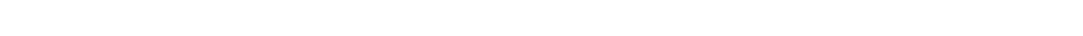
r'anal.

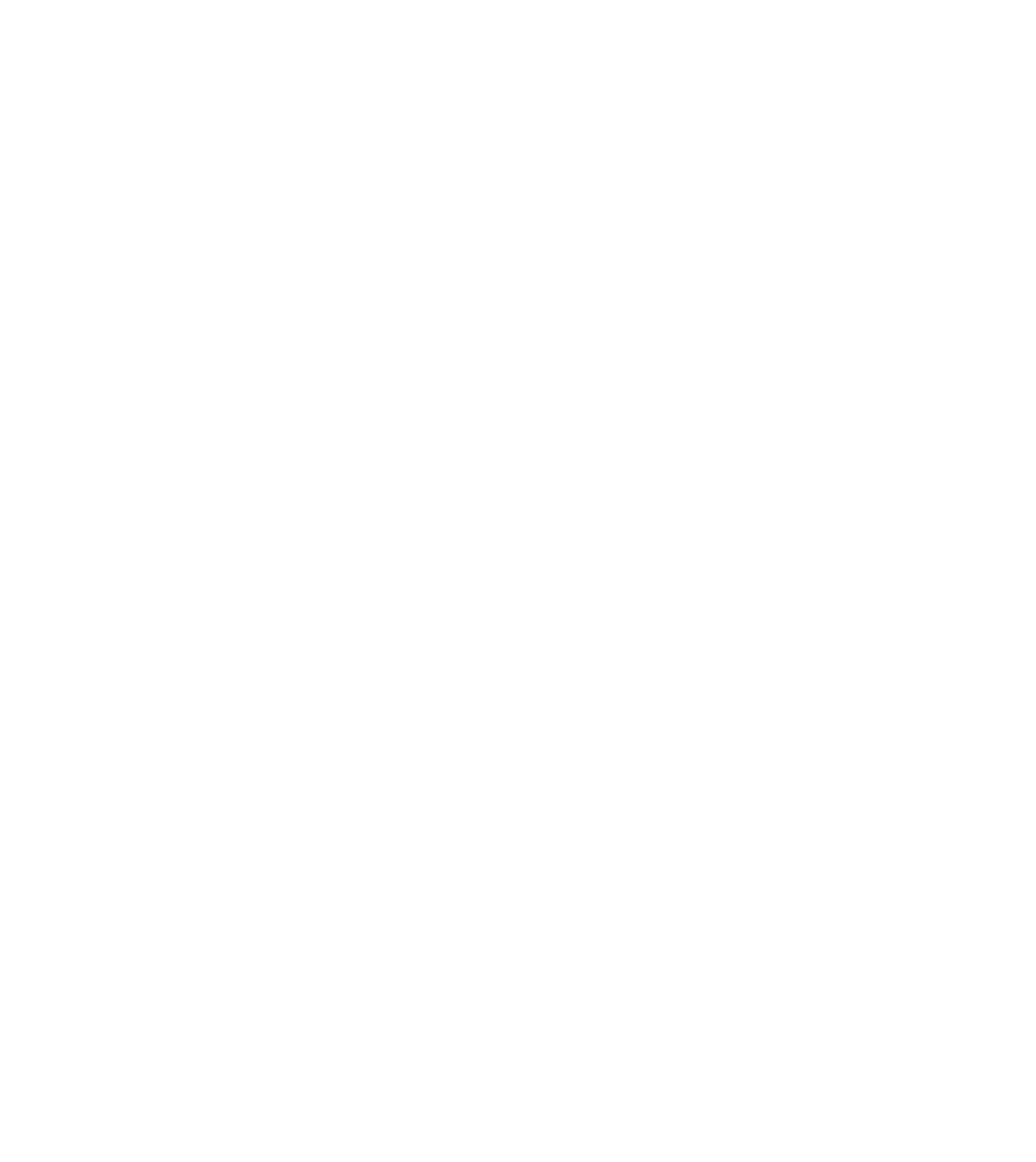


394

[No.81.

Dischurger measurements of Thrlowle canal, Lagrange, Stanislaus Comnty. C'al.

\section{Date.}

Sept. $\%$ A. Q. ('amploril

$189 \%$.

Oct. $\quad \tau$ J. B. Lippincott 1899.

Apr. :1

S. Ct. Dimnett

May $\because 0)$

Jume 6 - d do

June eg (.... do

Aug. 4 .....do

Sept. 9 do 1900.

Apr. (i । S. (*. Bennett

June 2: .... do

Aug. $11: \ldots$ do

Sept. $8: \ldots d t$

1901.

Aug. 31 S. (*. Bennett

1902.

May 1:3 S.G. Bennett

July 2:;

Ang. 2\% L. M. Lawson
Hydrogratpher.

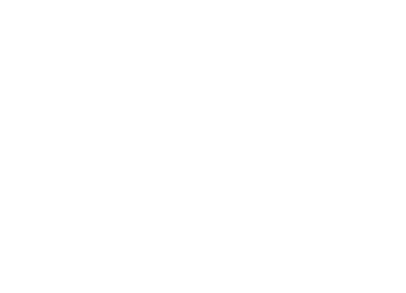

10.0

61.0

10.0

18.0

85.0

29.0

1.0

2.0

129.0

$.50 \quad 9.5$

$1.90 \quad 11 \% .0$

1.15

35.0

.0

2.92

253.0

\begin{tabular}{l|l}
3.0 & 260.0
\end{tabular}

\begin{tabular}{l|l}
2.6 & 105.0
\end{tabular} 


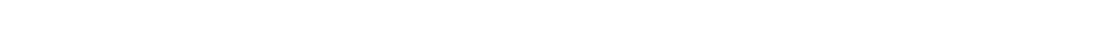

Discharge.

Month.

July

Angust

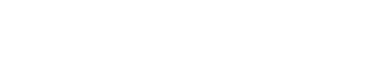

Serptemlier.

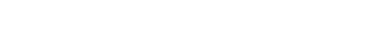

Octotier

Novemler

Decemlier

1!(1)

Jannary -

Felmuary -

March

April

10

May

Jume

July

Angrist

September

October

November

December

The year

\section{2.}

Tannary

February

March

April

May

June

July

August

September

October

November

December

The year

\begin{tabular}{|c|c|c|}
\hline 0 & 0 & 0 \\
\hline 1333 & so & $(i 2)$ \\
\hline 133 & 64 & 84 \\
\hline 1333 & 0 & 90 \\
\hline 183 & 133 & $13: 3$ \\
\hline 133 & 9 & i1 \\
\hline 133 & 0 & $1: 20$ \\
\hline 133 & 0 & 57 \\
\hline 36 & 0 & 26 \\
\hline 0 & 0 & 0 \\
\hline 0 & 0 & 0 \\
\hline 0 & 0 & 0 \\
\hline 133 & 0 & .54 \\
\hline & & \\
\hline 0 & 0 & 0 \\
\hline 0 & 0 & 0 \\
\hline 286 & 0 & זיאו \\
\hline 360 & 0 & $\because 69$ \\
\hline $3 \times 0$ & 0 & (205 \\
\hline 420 & 400 & +116 \\
\hline 460 & 215 & $40 . j$ \\
\hline $36 \%$ & 105 & 284 \\
\hline $4 i$ & 0 & 0 \\
\hline 0 & 0 & 0 \\
\hline 0 & 0 & 0 \\
\hline 0 & 0 & 0 \\
\hline 460 & 0 & 156 \\
\hline
\end{tabular}




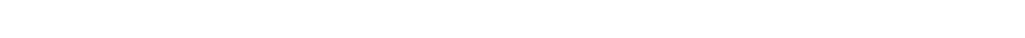

\begin{tabular}{|c|c|c|c|}
\hline Date. & Hydrongrapher. & $\begin{array}{c}\text { Gagr } \\
\text { height. }\end{array}$ & $\begin{array}{c}\text { Dis- } \\
\text { ،harge. }\end{array}$ \\
\hline $1 \times 95$. & & Feet. & seceft. \\
\hline Jan. $x$ & J. B. Lippinentt. & $\% .7$ & 3.003 \\
\hline Mar. 21 & $\ldots$ do $\ldots \ldots \ldots$ & 6.55 & 2,429 \\
\hline May 1 & .... do ........ & 10.25 & 6,078 \\
\hline May 2 & $\ldots$ do ...... & 12.9 & 13,546 \\
\hline June 27 & $\ldots$ do & 13.0 & 3,308 \\
\hline Aug. $2 \pi$ & A. P. Davis - & 4.0 & 294 \\
\hline $\begin{array}{c}\text { Nov. } 30 \\
1 \times 96 .\end{array}$ & .T. B. Tippineott … & 3.42 & 213 \\
\hline Apr. 14 & J. A. Vogleson . & 7.9 & 3,745 \\
\hline July 4 & C.C.Babl, - & 9.6 & 3,719 \\
\hline Sept. is & H. Crowe ............. & 4.5 & 362 \\
\hline Oct. :31 & J. B. Lipuincott $\ldots$ & 3.92 & $3 \% 5$ \\
\hline
\end{tabular}

Estimater menthly dischurge of Tuolumne Kiver at Modesto. Stanishus C'ounty."

[Drainage ar'a, 1,635 suruare miles.]

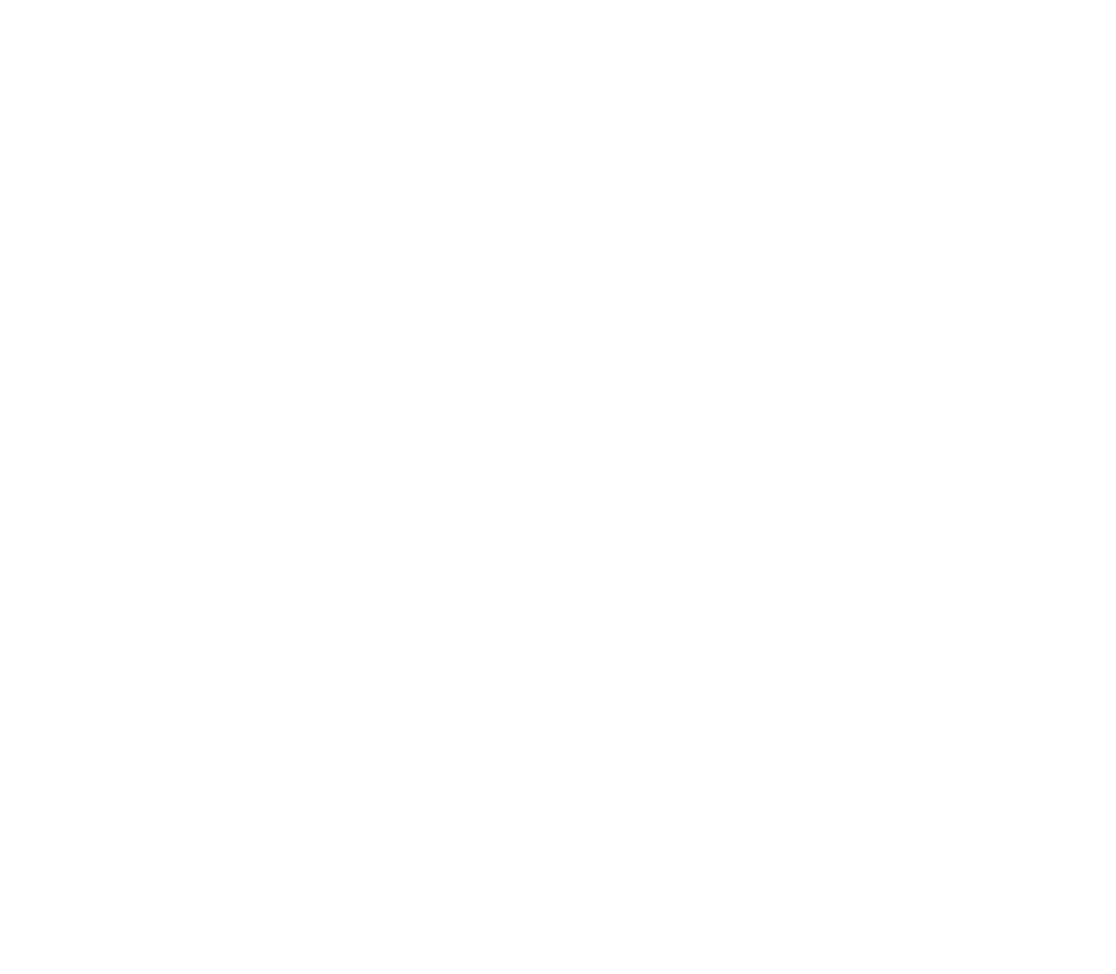

"Authority, ('alifornia state pugineering repartment from isis to lest. inclusive. 
Estimated monthly discharge of Tuolumm, River. etc-Continued.

\begin{tabular}{|c|c|c|c|c|c|c|}
\hline \multirow[b]{2}{*}{ Month. } & \multicolumn{3}{|c|}{ Discharge. } & \multirow[b]{2}{*}{$\begin{array}{l}\text { Toutal clis- } \\
\text { charge. }\end{array}$} & \multicolumn{2}{|c|}{ Run-off. } \\
\hline & Maximum. & Minimum. & Mean. & & $\begin{array}{c}\text { Per } \\
\text { scyure } \\
\text { mile. }\end{array}$ & Depth. \\
\hline 1880. & wereforet. & sires-fent. & Sierefiet. & fareforet. & Sefereforet. & Inches. \\
\hline January . . . . . . . . & 1.:290 & $1 \% 0$ & 409 & 25,148 & 0.25 & 0.29 \\
\hline February ......... & 5,150 & 130 & 625 & & .38 & 4 \\
\hline March ....... & 1,550 & $3 \% 0$ & 832 & $15 \%$ & .51 & .5 \\
\hline April ........ & 19.300 & \%ั) & $\tau, 141$ & 118 & 4.37 & $4.8 \%$ \\
\hline May . & 16.300 & 6.280 & $10.3 \% 1$ & $38 \%$ & 6.34 & ז.3 \\
\hline June ....... & 17.0 .50 & 10. 340 & $14,05 \pi$ & 21 & צ. 61 & 4). 61 \\
\hline July ....... & 13.290 & 3.295 & 7.618 & 412 & +66 & 5.3 \\
\hline Angust ...... & 2,960 & 300 & 1.233 & 75,814 & .75 & .8 \\
\hline September - & $\ldots$ & & 134 & & $.0 x$ &.$\theta$ \\
\hline eer .... & $\ldots$ & ....... & 56 & 3,443 & .013 & .0 \\
\hline mber . . . . & $\ldots$ & $\ldots$ & 35 & 2,082 & .02 & .0 \\
\hline Decembex'... & 5.020 & & 1,095 & 328 & $.6 i$ & .8 \\
\hline The year .... & - . & $\ldots . .$. & 3.63 .5 & $2,63 \pi, 433$ & 2.22 & 30. \\
\hline 1881 & & & & & & \\
\hline $\operatorname{ary} \ldots \ldots . . . .$. & 900 & $\therefore 640$ & 2.884 & 330 & $1 . r 6$ & 2.0 \\
\hline February ........ & $0 \geq 0$ & $\therefore .440$ & 6.7 .55 & .153 & 4.13 & 4.3 \\
\hline March ......... & $10.3+0$ & 3.290 & 2.879 & & 1.76 & 2.0 \\
\hline April ............. & 10,2003 & 4.790 & & & 3.53 & 4.2 \\
\hline May ........... & $\therefore .630$ & 3.540 & $\pi, 2 \pi t$ & & 4.45 & $\therefore .1$ \\
\hline June . . . . . . . . & $3.9 \% 0$ & 690 & 5,295 & 310.909 & 3.20 & 3.5 \\
\hline July .......... . & $1.3 \times 10$ & & 1,996 & 122,729 & 1.22 & 1.4 \\
\hline August . . ... & $\ldots$ & & 391 & 24.041 & .24 &.$\stackrel{2}{2}$ \\
\hline September . ....... & & & 19.5 & $7.43 \%$ & .018 & .0 \\
\hline October $\ldots \ldots$ & & $\ldots \ldots$ & 130 & $\because, 998$ & $.0 \mathrm{~s}$ & .0 \\
\hline November.... & & $\ldots$. & 193 & 11,484 & .12 & .1 \\
\hline December... & & $\ldots \ldots \ldots$ & $(030)$ & 38,122 & .38 & .4 \\
\hline The year & & $\ldots \ldots$ & 2.894 & $2,0 \pi 1,976$ & $1 . \%$ & $23 . \pi$ \\
\hline
\end{tabular}


Estimated monthly discharge of Tuolumne River. ete-Continued.

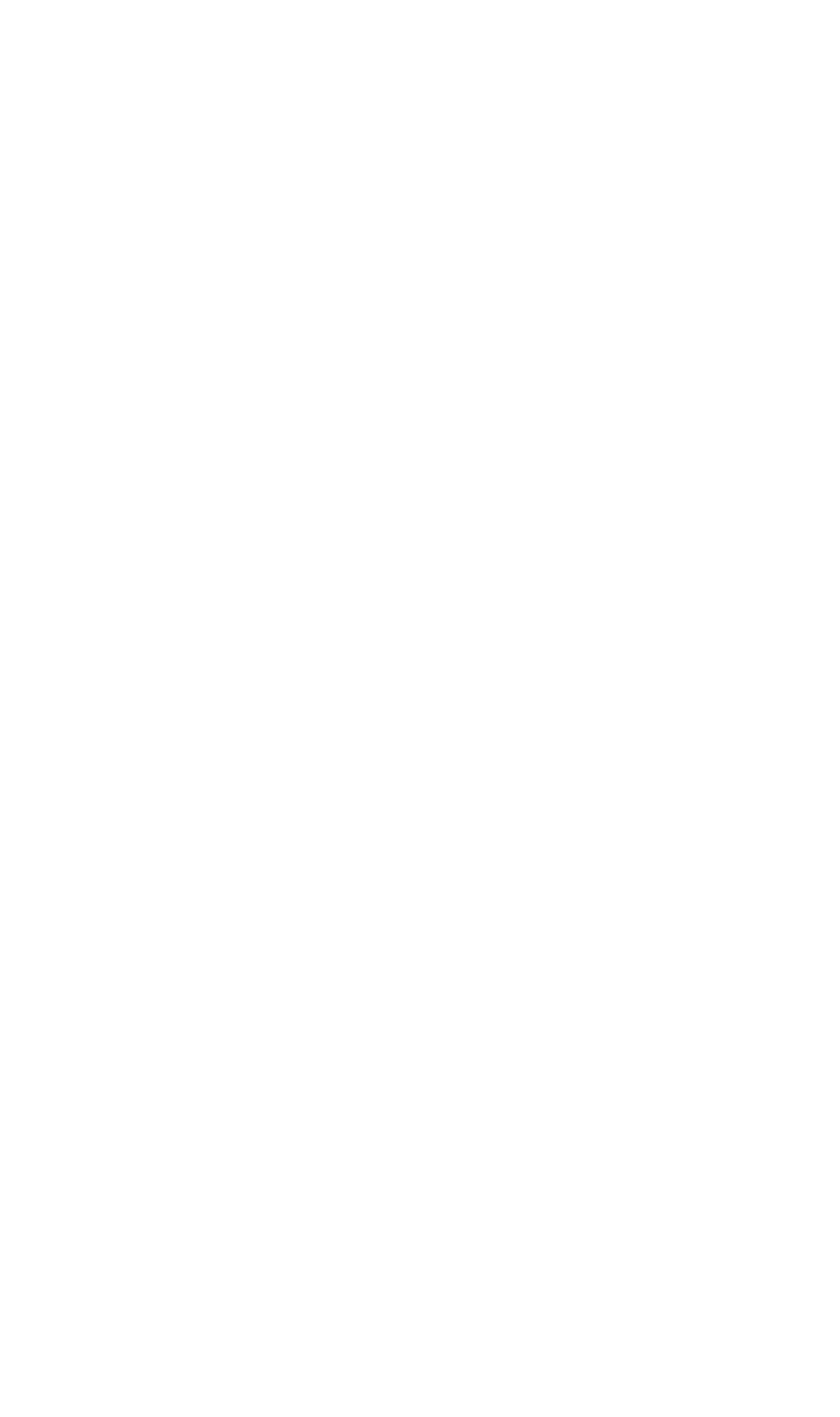


Estimated monthly discherge of Thol mmer River, stc.-Continned.

\begin{tabular}{|c|c|c|c|c|c|c|}
\hline \multirow[b]{2}{*}{ Momtli. } & \multirow[b]{2}{*}{ Maximum } & Discharge. & & \multicolumn{2}{|c|}{ Run-off. } \\
\hline & & $\int^{-}$Minimıun. & Mean. & $\begin{array}{l}\text { Total dis- } \\
\text { charge. }\end{array}$ & $\begin{array}{c}\text { Pev } \\
\text { square } \\
\text { nils. }\end{array}$ & De'puth. \\
\hline 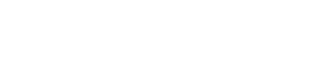 & $\begin{array}{l}\text { sies-fert. } \\
\quad 16,130\end{array}$ & $\begin{array}{l}\text { Sere-furt. } \\
1,39 x\end{array}$ & $\begin{array}{l}\text { serefiect. } \\
4 . \operatorname{sen}\end{array}$ & $\begin{array}{l}\text { frofetet. } \\
296,900)\end{array}$ & $\begin{array}{l}\text { Nerefiect. } \\
3.22\end{array}$ & $\begin{array}{l}\text { Iwrhess. } \\
\quad 3.70\end{array}$ \\
\hline February ..... & 19,650 & 1.392 & $3,91.5$ & 917.430 & 3.61 & 2.72 \\
\hline Mareh ....... & 10.785 & 1.710 & 3.16 .5 & 194,610 & 2.11 & 2.43 \\
\hline April . . $\quad \ldots . . . .$. & 10,012 & 3.25 & 5.824 & 346.570 & 3.84 & 4.33 \\
\hline May ............ & 16.000 & $6.09 i$ & 11. & 205.7110 & $7.8 \%$ & $9.0 \%$ \\
\hline June ............. & 12,530 & 5.616 & 9. 16:3 & $. j 4.5,110$ & 6.11 & 6.82 \\
\hline July $\ldots \ldots \ldots$ & 6.692 & $1,5.50$ & $3,4: 31$ & 235.540 & $2 . \pi j$ & 2.94 \\
\hline August ...... & 1.550 & 28.5 & 848 & 52.125 & $.5 \%$ & 6.5 \\
\hline Septemler... & 5,616 & 2011 & $61 \%$ & 36,600 & .41 & .46 \\
\hline October ......... & 200 & 120 & 152 & 9.346 & .10 & .12 \\
\hline November. . . . . . . . & 500 & 210 & $2 \pi 5$ & 14.98 .5 & $.1 \%$ & .19 \\
\hline December ....... & 330 & $1 \mathrm{HO}^{\circ}$ & $28: 3$ & $1 \% .411 .5$ & .19 & .23 \\
\hline The year - & 19,650 & 120 & 3,719 & $2.692,021$ & 2.45 & 33.65 \\
\hline $18 ! 6$. & & & & & & \\
\hline January ..... & $13, \mathrm{~s}$ (1) & 246 & $3.080 \vdots$ & $1 \times 9.380$ & 2.0 .5 & 2.37 \\
\hline February ....... & 1.880 & $9 \pi$ & $1,1 \times 2$ & $64.16) \%$ & .89 & .86 \\
\hline March ......... & $11 . i ! n$ & 1.0006 & 2.725 & 167 , in & 1.42 & 2.10 \\
\hline April _.. $\ldots \ldots . . . .$. & 14.873 & 1,970 & $3.5 \% 7$ & $212,42 x$ & 2.38 & 2.66 \\
\hline May ............. & 14.754 & 2.550 & 5,180 & $318.5(11)$ & $3.4 \pi$ & 3.98 \\
\hline June .... . . . . & 14.754 & 6.990 & 11.648 & 693,104 & $\approx .09$ & 7.87 \\
\hline July ........ & 8.735 & 1.3116 & +.121 & 953.418 & 2.55 & $3.1 \%$ \\
\hline August ....... & $1.11 \times$ & 300 & $5 \pi 5$ & $3 \overline{3} .: 39 \mathbf{2}^{\prime}$ & .38 & .44 \\
\hline September . . . . . . & 2.918 & $2: 3$ & $5 \pi+$ & 34.191 & $\therefore 4$ & .43 \\
\hline October & tit & $1 \times 0$ & 2041 & 13. $19 \%$ & .15 & .17 \\
\hline November. ... . . . & 7,802 & 23 & 1.210 & 72.012 &.$M 1$ & .90 \\
\hline December ..... & 3.560 & 516 & 1,028 & (6i3. 247 & .69 & .79 \\
\hline The year ..... & 14.7 .74 & 140 & $2.92 \pi$ & $2,121,434$ & 1.90 & 25.74 \\
\hline
\end{tabular}




\section{TWIN CREEKS.}

Inischurge measurements of Fast Twin Creek in C'anyon, San Bomardino County.

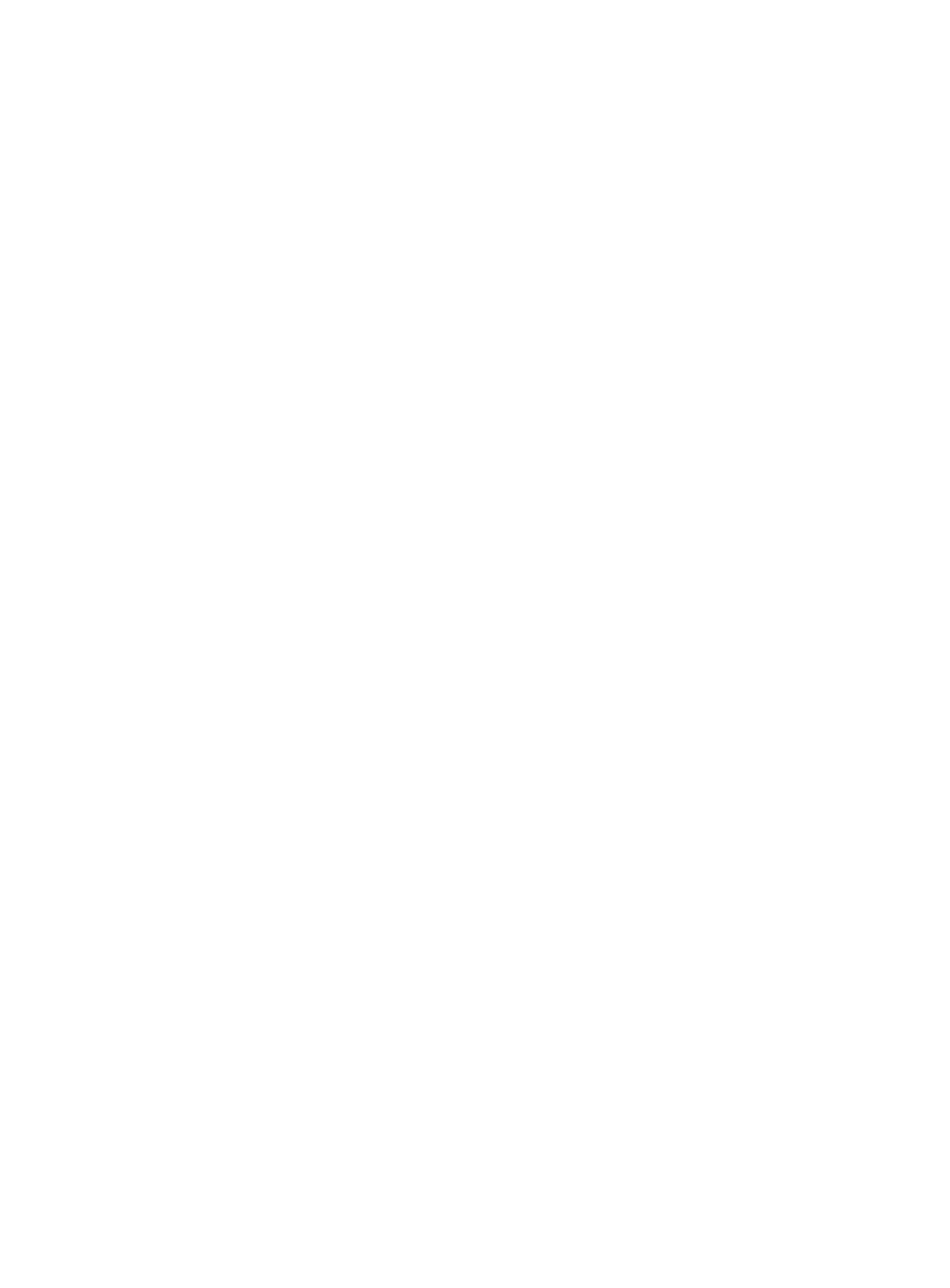


Discharge measurements of West Twin Creek in Canyon, San Bernardine County.

\begin{tabular}{|c|c|c|}
\hline Date. & Hydrographer. & $\begin{array}{c}\text { Dis- } \\
\text { charge. }\end{array}$ \\
\hline 1898. & & $\begin{array}{l}\text { Sec.-feet. } \\
\int^{a} 1.06\end{array}$ \\
\hline \multirow[t]{2}{*}{ June 11} & J. B. Lippincott. ..... & $\begin{array}{l}b .68 \\
c .40\end{array}$ \\
\hline & Total ........... & 2.14 \\
\hline $\begin{array}{c}\text { Sept. } 9 \\
1 \times 99 .\end{array}$ & J. B. Lippincott_ . . . & .38 \\
\hline Mar: 21 & S. G. Bennett $\ldots . . .6 \ldots$ & 3.00 \\
\hline $\begin{array}{c}\text { Aug. } 25 \\
1900 .\end{array}$ & 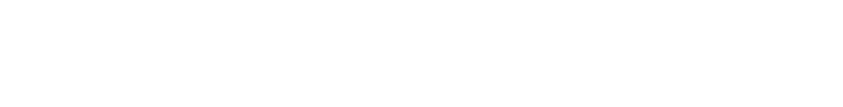 & .20 \\
\hline July 12 & $\ldots$... do ............. & .22 \\
\hline $\begin{array}{c}\text { Oct. } 1 \\
190^{\circ} .\end{array}$ & W. W. Cockins, jr .... & .16 \\
\hline Apr. 4 & S. (*. Bennett .... $\ldots \ldots \ldots$ & 3.20 \\
\hline Sept. 4 & W. B. Clapp $\ldots \ldots \ldots$ & .13 \\
\hline
\end{tabular}

WAL.KER RIVER.

I Hischarge measurements of Waller River. East Fork.

\begin{tabular}{|c|c|c|c|}
\hline Date. & Hydrographer. & $\begin{array}{c}\text { Dis- } \\
\text { charget. }\end{array}$ & Location. \\
\hline 1902. & & sect-fuet. & \\
\hline July 24 & L.H. Taylor - & 196.5 & 10) miles below Bridgeport. \\
\hline Aug. $: \tau$ & D. W. Hays - & 79.5 & Lower end Bridgeport Valley. \\
\hline Oct. 6 & $\ldots$ do $\ldots$. & 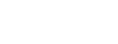 & Below all diversions in California. \\
\hline July 26 & F.H. Olmsterl & 119.8 & Robinson Creek below Twin Lakes. \\
\hline Aug. 21 & D. W. Hays... & $\pi \%$ & Do. \\
\hline Do $\ldots$ & . do .... & 43.2 & Buckeye Creek west of Bridgeport. \\
\hline Oct. 6 & . do & 24.0 & Robinsons Creek, Twin Lakes. \\
\hline Do & . . do .... & 20.0 & Buckeye Creek, Buckeye Springs. \\
\hline Oct. $\quad$ i & $\ldots$ do .... & 4.2 & Somers. southwest of Bridgeport. \\
\hline Do ... & .... do & $i .12$ & Green Creek above Standard Dam. \\
\hline Oct. $\quad \bar{s}$ & . . do & $\pi .7$ & $\begin{array}{l}\text { Virginia Creek bridge at Huntorm } \\
\text { Ranch. }\end{array}$ \\
\hline
\end{tabular}


Discharge measmorments of Walker River, West Fork.

\begin{tabular}{|c|c|c|c|}
\hline Date. & Hydrographer. & $\begin{array}{l}\text { Dis- } \\
\text { charge. }\end{array}$ & Location. \\
\hline 1902. & & Ser.-feet. & \\
\hline July 22 & F.H. Olmsted & $41 \% .0$ & 3 miles above Lalsons. \\
\hline Do & $\ldots$... do ....... & $15 . j$ & Silver Creek. \\
\hline July $2: 3$ & $\ldots$.... do .... & 10.5 & Quinton Creek. \\
\hline Do $\ldots$ & $\ldots$ do ........... & 71.5 & Leavitt. \\
\hline July 24 & $\ldots$ do ......... & 95.0 & At Middle Fork. \\
\hline July 25 & L.H. Taylor & 330.6 & Upper end Antelope Valley. \\
\hline Aug. 23 & D. W. Hays ...... & $69 . \tau$ & Do. \\
\hline Oct. $\quad 4$ & $\ldots d o \ldots . . . . . . .$. & 69.8 & Do. \\
\hline Ang. 8 & $\ldots . . .10$ & 221.8 & Bridge abuve tollhouse. \\
\hline
\end{tabular}

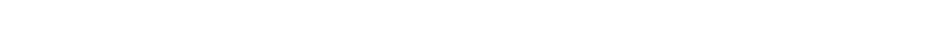

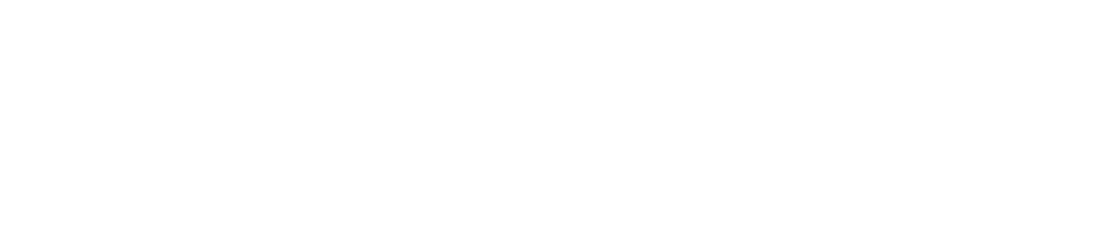

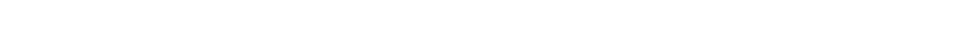

\begin{tabular}{|c|c|c|c|}
\hline Date. & Hydrographer. & $\begin{array}{l}\text { Dis- } \\
\text { charge. }\end{array}$ & Location. \\
\hline 1896. & & Sier frect. & \\
\hline Oct. $1 \%$ & J. B. Lippincott . . & 39 & \\
\hline 1902. & & & \\
\hline July 24 & F. H. Olmsted.... & 101.6 & Blacklurns Junction. \\
\hline
\end{tabular}

WARD AND WARREN DITCH.

See San Bernardino Valley.

WARM CREEK.

WARM CREEK, HAWES AND TALMADGE WTCH.

See San Bernarino Valley.

WARM ('REEK, M'KENZIE MTC'H.

See San Bernardino Valley. 
WARM C'REEK, MEEKS AND DAILY DITCH.

See San Bernardino Valley.

WARM (REEK, RABEL DITCH (DAM).

See San Bernarlino Valley.

WARM ('REEK, SHAY OR STOUT DITCH.

See San Bermardino Valley.

\section{WHITE CREEK.}

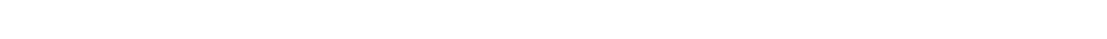

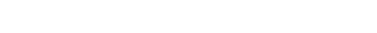

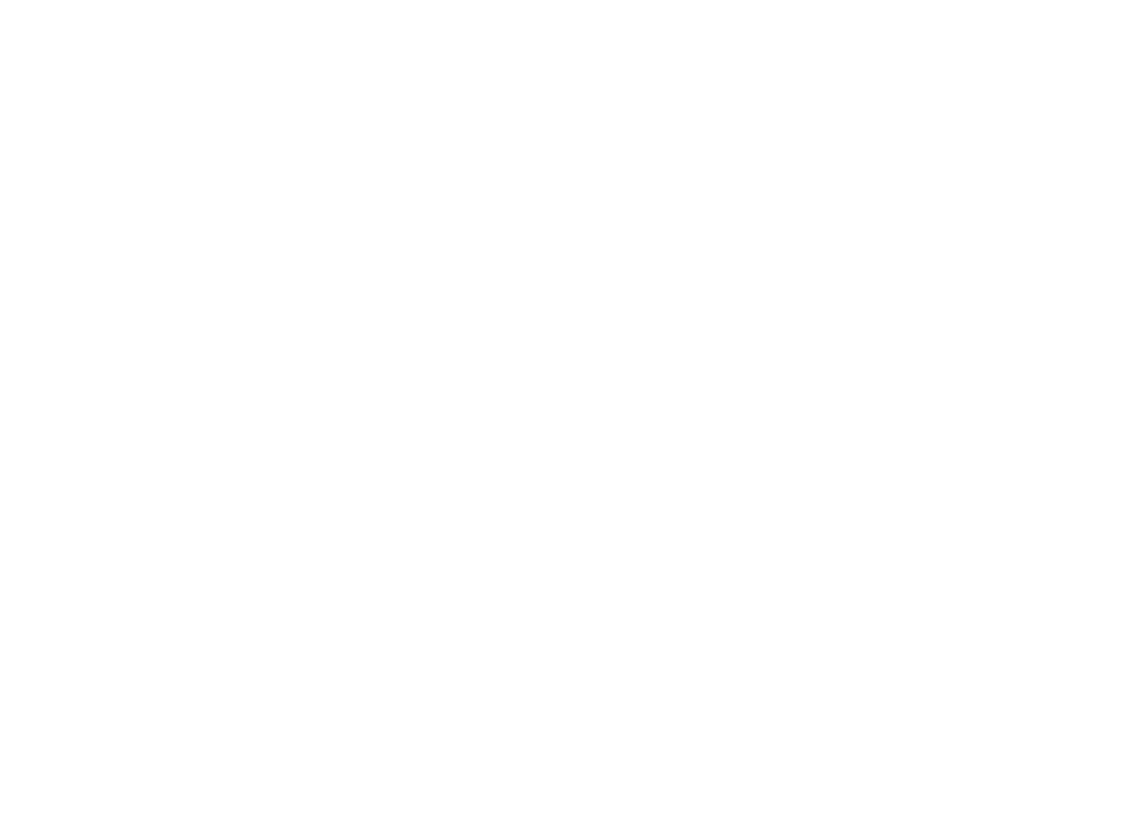

"The entire record is antimated from records of neighboring drainage basins. Authority, California State engineering department. 
Estimatrd monthly discharge of White Creek, ets.-Continued.

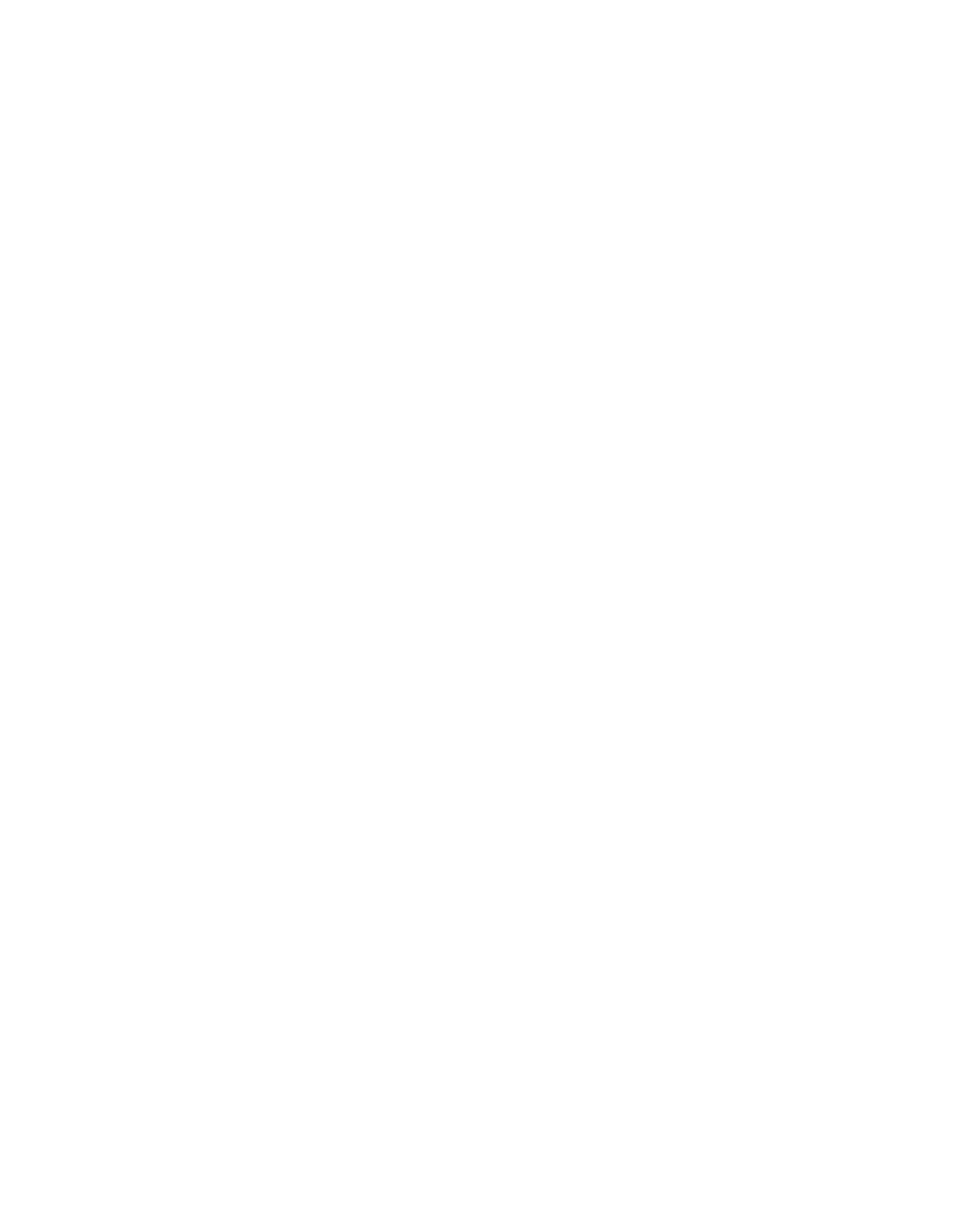


Estimuted monthly discharge of White crests, ste._Continued.

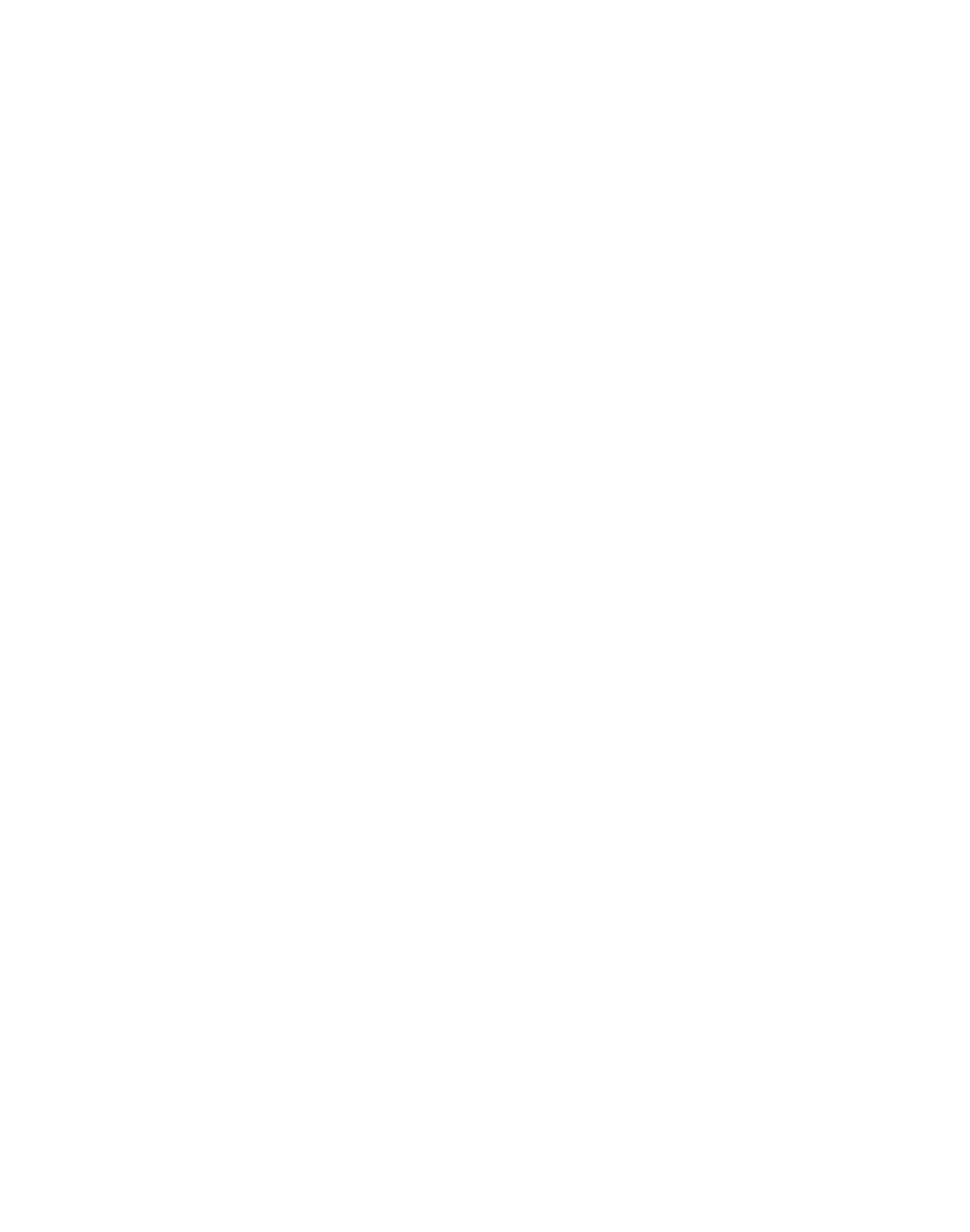




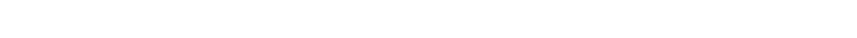

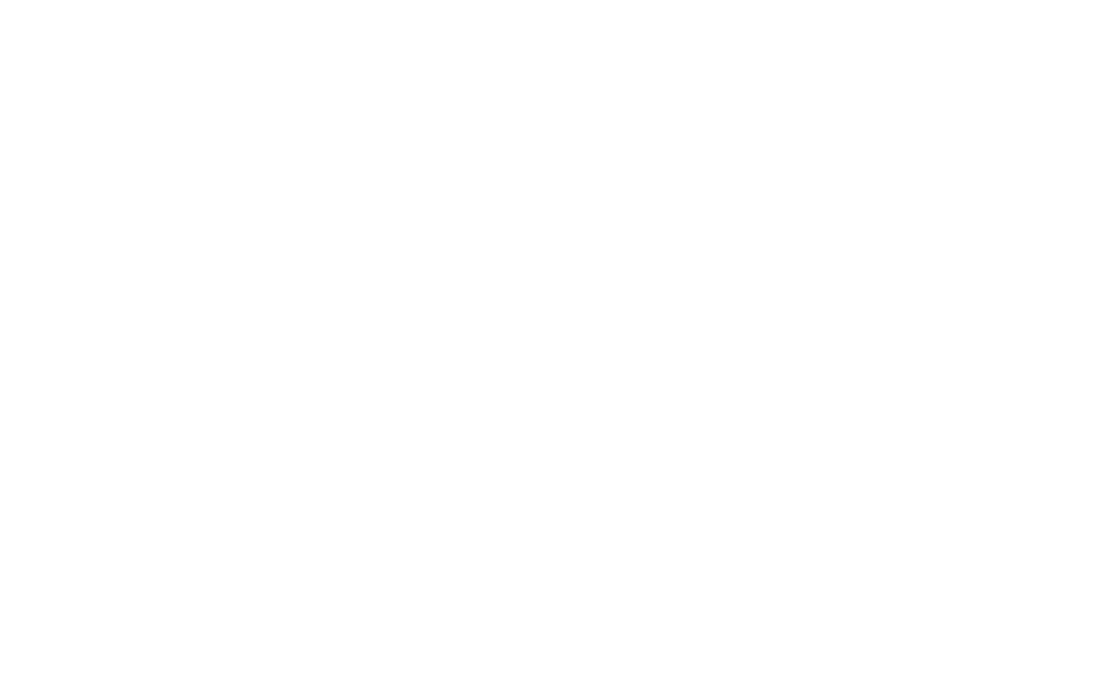

\section{WHITEWATER RIVER.}

Discharge measurements of Whitewater River and tributaries at arions points. San Bernardino and Riverside counties.

\begin{tabular}{|c|c|c|c|}
\hline Date. & Hydrographer. & $\begin{array}{c}\text { Dis- } \\
\text { r.harge. }\end{array}$ & Locality \\
\hline Feb. 15, 1s9s & J. B. Lippincott & $\begin{array}{l}\text { see. feet } \\
\text { T. } 42\end{array}$ & South Fork at tumnel. \\
\hline Mar. 4.1899 & .... do .. & 2.52 & Do. \\
\hline Feb. 16,1898 & .... do ... & 14. 24 & $\begin{array}{l}\text { Main river at fcot of Bear Val- } \\
\text { ley trail. }\end{array}$ \\
\hline Feb. 17,1898 & .....do .. & 4.64 & North Fork at routh. \\
\hline Do . . . . . & . do & .82 & Middle Fork at mouth. \\
\hline Do . & . do _... & $17 . \%$ & Main river $\cong$ miles above mouth. \\
\hline
\end{tabular}

Discharge measurements of Bear Valley Ditch, Riverside County.

\begin{tabular}{|c|c|c|c|}
\hline Late. & Hydrographer. & $\begin{array}{c}\text { Dis- } \\
\text { charge. }\end{array}$ & Locality. \\
\hline Feb. $1 \%, 1 s 98$ & J. B. Lippincott & $\begin{array}{r}\text { sec.-feet. } \\
3.05\end{array}$ & $\frac{1}{4}$ mile northeast of ranch house. \\
\hline Sept. $2 \times, 1899$ & $\ldots$. & 5. 20 & At headgate. \\
\hline Sept. :29, $1 \times 99$ & $\ldots$ rlo $\ldots \ldots$ & ?. 49 & 1 mile helow hearigate. \\
\hline
\end{tabular}


Discharge measurements of Bear Ialley and Palm Strming joint headuorks. month of c'anyon, Riverside commty.

Sept. \%. 1898

J. B. Lippinesott ....

Hydrographer.

Disrharge.

6.34

\section{WHITING DITCH.}

See San Bernardino Valley.

\section{WILLOW CREEK.}

See Fusan River.

\section{YUBA RIVER.}

Inscharge masemerments of Vube River.

\begin{tabular}{|c|c|c|c|}
\hline Dite. & Hydrographer. & $\begin{array}{l}\text { Dis- } \\
\text { (harge. }\end{array}$ & Lorality \\
\hline$-\cdots$ & - & $\cdots$ & $-\ldots \ldots$ \\
\hline 1878. & & Sire-feet. & \\
\hline Dec. 9 & $\begin{array}{l}\text { State engineering de- } \\
\text { partment. }\end{array}$ & .510 & Marysville. \\
\hline $\begin{array}{c}\text { Dec. } 12 \\
18 \% 9\end{array}$ & $\ldots d n \ldots \ldots . . . . . .$. & 510 & $\because$ miles below Smartsville. \\
\hline Feb. 14 & (du & $1 s,(1) 00$ & Marysville. \\
\hline Mar. 6 & do & 25.750 & Do. \\
\hline Mar. 9 & .... do & 11,500 & Do. \\
\hline Mar. 12 & .... do ......... & $9, \tilde{500}$ & Do. \\
\hline Mar. 19 & $\ldots$. do ......... & 7,000 & Do. \\
\hline Aug. 28 & $\ldots$... do ............... & 600 & Smartsville to Marysville. \\
\hline
\end{tabular}


Discharge measurements of Fuba River below Parks Bar Bringe, Smavtswille, Iuba County, Cal.

\begin{tabular}{|c|c|c|c|}
\hline Date. & Hydrographer. & $\begin{array}{l}\text { Gage } \\
\text { height. }\end{array}$ & $\begin{array}{c}\text { Dis- } \\
\text { charge. }\end{array}$ \\
\hline 1900. & & Feet. & ser.-feet. \\
\hline June 28 & H.D. H. Comnick . & 3.15 & 1,212 \\
\hline June 29 & .....do & 2.95 & 1,086 \\
\hline July 11 & $\ldots$...... & 2.65 & 820 \\
\hline July 12 & .....do. & 2.65 & 811 \\
\hline July 13 & $\ldots$. . do . . . . . & 2.60 & 274 \\
\hline July 22 & $\ldots$ do $\ldots \ldots$ & 2.42 & 622 \\
\hline July 23 & . . . . do . . . . . . & 2.50 & 686 \\
\hline July 24 & . & 2.50 & 673 \\
\hline Aug. $\tau$ & $\ldots$.... & 2.23 & $59 \%$ \\
\hline Aug. $\quad s$ & $\ldots$ & 2.30 & $5 \% 1$ \\
\hline Aug. 14 & $\ldots d o-\ldots . .$. & 2.25 & 534 \\
\hline Ang. 28 & $\ldots . . . . .$. & 2.20 & 474 \\
\hline $\begin{array}{c}\text { Sept. } 14 \\
1902 .\end{array}$ & 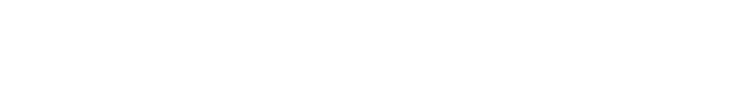 & 9.60 & 136 \\
\hline Sept. 1 & Chas. A. Miller -. & & 487 \\
\hline
\end{tabular}

Discharge measurements of I itba River, North Fork, abow poure rompany's drom, Tuba county, Cal.

\begin{tabular}{|c|c|c|c|}
\hline Date. & Hydrographer. & $\begin{array}{c}\text { Gage } \\
\text { height. }\end{array}$ & $\begin{array}{l}\text { Dis- } \\
\text { charge. }\end{array}$ \\
\hline 1900. & & Fieet. & Sec.feet. \\
\hline July 3 & H.D. H. Connick & 2.05 & 606 \\
\hline July 6 & $\ldots$. do ........ & 1.95 & 567 \\
\hline July $1 \%$ & $\ldots$ do $\ldots . . . . . . .$. & 1. 70 & 438 \\
\hline July 18 & $\ldots$. & 1.65 & 419 \\
\hline July $2 \tau$ & $\ldots$ & 1.65 & 366 \\
\hline July 29 & . . . . . . . . . . . . & 1.60 & $3 \% 1$ \\
\hline July 31 & $\ldots$.... do .. & 1.60 & 364 \\
\hline Aug. 9 & $\ldots$.... do ... & 1.55 & 328 \\
\hline Aug. 10 & $\ldots . . . d o \ldots$ & $1.5 \%$ & 322 \\
\hline Aug. 'Dy & . & 1.48 & 282 \\
\hline Aug. 30 & $\ldots$ do .............. & 1.48 & 285 \\
\hline
\end{tabular}




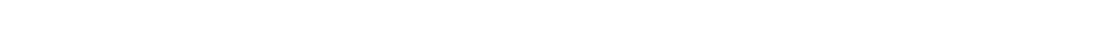
County, Cal.

\begin{tabular}{|c|c|c|c|}
\hline Date. & Hydrographer. & $\begin{array}{c}\text { ctage } \\
\text { height. }\end{array}$ & $\begin{array}{c}\text { Dis- } \\
\text { charge. }\end{array}$ \\
\hline 1900 . & & lisent. & wite-fert \\
\hline July & H. D. H. ('mmick & 2.40 & 191 \\
\hline July & -. de ....... & 2.35 & 180 \\
\hline July & ... do . & 2.30 & 185 \\
\hline July & $\ldots-d 11 \quad \ldots \ldots$. & $2.5 \%$ & 162 \\
\hline July : & ... . . d . . . . . . & 2.30 & 109 \\
\hline Aug. 1 & $\ldots d_{0} \ldots \ldots . . .$. & ?. $1 \%$ & 79 \\
\hline Ang. 1 & .... do ... & 2.1 .5 & 78 \\
\hline Ang. : & $\ldots$. . . . . . . & 9.20 & 69 \\
\hline Ang. : & ...... do ......... & 2.20 & 68 \\
\hline Sept. 1 & $\ldots \ldots \ldots \ldots \ldots \ldots \ldots \ldots$ & 2.1. & 64 \\
\hline
\end{tabular}

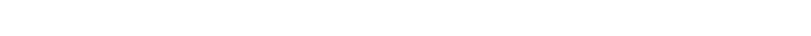

\begin{tabular}{|c|c|c|c|}
\hline Date. & Hydrographer. & $\begin{array}{l}\text { Dis- } \\
\text { "harge. }\end{array}$ & Luwality. \\
\hline 1902. & & Sec-feet. & \\
\hline Aug. 29 & S. G. Bennett & 58 & South Fork, at Eldorado bridge. \\
\hline Ang. 30 & Chas. A. Miller & 5.5 & Sonth Fork, at Bridgeport bridge. \\
\hline \multirow[t]{2}{*}{ Sept. 1} & $\ldots$ do ........ & 32 & $\begin{array}{l}\text { Excelsior Mining and Irrigation ca- } \\
\text { nal, at Pleasant Valley. }\end{array}$ \\
\hline & Total & $8 \%$ & \\
\hline Aug. 29 & S. G. Bennett. . & 58 & $\begin{array}{l}\text { South Fork, } 75 \text { feet above Edwards } \\
\text { bridge. }\end{array}$ \\
\hline Do ... & .....do. & 9.3 & $\begin{array}{l}\text { South Fork, North Columbia, Eirreka } \\
\text { Lake Company's canal. }\end{array}$ \\
\hline Do... & $\ldots$. . do & $\tau .0$ & South Fork, North Bloomfield ditch. \\
\hline Aug. 30 & . . . . do & 52 & $\begin{array}{l}\text { Middle Fork, } \frac{1}{4} \text { mile below Delihi } \\
\text { mine. }\end{array}$ \\
\hline Sept. 1 & .... do & 64 & $\begin{array}{l}\text { Middle Fork. } 300 \text { feet below Free- } \\
\text { mans bridge. }\end{array}$ \\
\hline Do . - & $\ldots$. do .. & 221 & $\begin{array}{l}\text { North Fork. Bay Counties Electric } \\
\text { Co.'s flume, below headgate. }\end{array}$ \\
\hline
\end{tabular}




\section{MAXIMUM FIOOD MEASUREMENTS.}

The following flool measurements are given as having probable interest to the engineer in connection with the designing of bridges and of spillways for reservoirs. It is not intended that these should be considered as the maximum floods that will ever occur on these drainage basins. They are rather given as a record of the largest observed volumes known to the author. It is, of course, exceedingly difficult to measure accurately a river in great flood, and it seldom falls to the fortune of a hydrographer to be present at the maximum flood wave, but it is believed that these data may be valuable for the purposes mentioned:

Gila River at Florence. Ariz., February, 1891: 17,750 square miles drainage area: discharge, 102,500 second-feet, or 7.5 second-feet per square mile.

Salt River, Arizona. February, 1891; area of drainage, 12,000 square miles; flood discharge, 300.000 second-feet, or 24.6 second-feet per square mile.

Gila River at Gila bend. Fehruary, 1891. probable flood dis`harge, 250,000 second-feet.

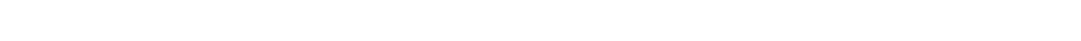
. from 1,009 to 3.800; flood discharge by Schuyler from 700 to 800 second-feet, or 48.5 second-feet per square mile.

Sweetwater River, 186 square miles drainage area; Jannary, 1895, 18,150 secondfeet, or 97.5 second-feet per square mile.

Tuolumne River at La Grange dam, drainage area, 1,501 square miles; elevations to 14,000 feet; flood discharge, 46.000 second-feet, or 30.6 second-feet per square mile.

Yuba River, South Fork. at Bowman dam, elevation, 5,500 feet; drainage area, 19 square miles: discharge, 5.000 to $\%, 000$ second-feet from meltirg snow, or 316 second-feet per square mile.

Cherry Creek, Colorado, area, 175 square miles; flood discharge, 10,000 secondfeet, or $5 \%$ second-feet per square mile. 
Haximum floods moasured by the Inited States Geological Srrvey. 189t-1901.

\begin{tabular}{|c|c|c|c|c|c|}
\hline Date. & Stream. & Jox:ality. & $\begin{array}{c}\text { Arca of } \\
\text { watershed }\end{array}$ & $\begin{array}{l}\text { Maximum } \\
\text { measure- } \\
\text { ments. }\end{array}$ & $\begin{array}{l}\text { I'scharge } \\
\text { per square } \\
\text { mile }\end{array}$ \\
\hline$\cdots$ & $--\square-\ldots-\cdots$ & - - & su miles & sec.foet & --- \\
\hline & $\begin{array}{l}\text { Arroyo Seco (Sali- } \\
\text { nas). }\end{array}$ & Above diversion & $21 R$ & $24.0 .31)$ & 110.23 \\
\hline 188.j & Ker'l . . . . . . . & Near Bakersfield . & $2,34 \pi$ & $9,: 380$ & 4.110 \\
\hline 1901. & King . . . . . & Rerl Mountain & 1.740 & $43,9: 30$ & 2.5 .21 \\
\hline 1901. & Mokelumne ... & Electra & 640 & 13,213 & 20.64 \\
\hline 1896 & Sacramento & Jellys Ferry - & 9,134 & $1: 30,050$ & $14.2: 3$ \\
\hline 1900 & San Antonio & $\begin{array}{l}\text { Near Jolon (ahove } \\
\text { Pinkerton d a m } \\
\text { site). }\end{array}$ & 322 & $15,31.5$ & $4 \pi .56$ \\
\hline 1901. & San Gtabriel & Azusa ........ & 222 & 6,250 & $25.1 j$ \\
\hline 1901. & San Joaquin. & Hermilon & 1,637 & 21,372 & 13.05 \\
\hline 1900 & San Lorenzo & $\ldots$ & 235 & 10,269 & 42.00 \\
\hline 1900 & Santa Ana ... & Warm Spring & 188 & 1,564 & $\$ .32$ \\
\hline 1899 . & Stanislaus. - & Oakdale ..... & 1,051 & 13,940 & 13.26 \\
\hline 1900 & Stony Creek... & Julian's ranch" & 760 & $" 18,000$ & $23.56+$ \\
\hline 1899. & Tuolnmme... & Lasrange. . . . . . . & 1,501 & $21 . \times 00$ & 14.52 \\
\hline
\end{tabular}

"(xage height, 14. February, 1902, gage height reashed 15.\%.

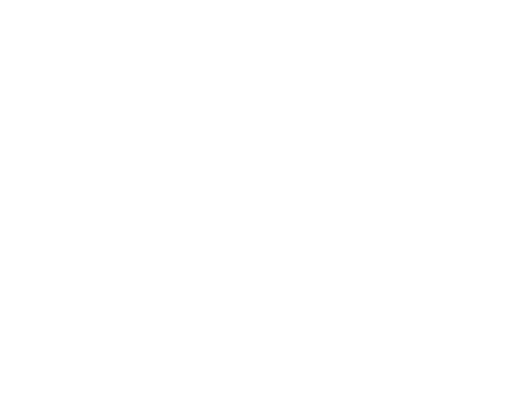

Fut. 4.-Figure showing construrtion of weir.

It has been found that the usual method of measuring the lead on weirs, as practiced by water companies and water users, is to use an ordinary foot rule divided into inches and sixteenths. As no general weir table is available for heads so measured, the following has been prepared. 
WHIR

'The following conditions should be olsserved in construction of weir: depth of box or canal, and distance $\cdot d$ of opening frort side of canal

Discharges in secomel-feet, rectangular meirs

[Formula $Q-3.33$

\begin{tabular}{|c|c|c|c|c|c|c|c|c|c|c|c|c|c|c|}
\hline & \multicolumn{2}{|c|}{ Hetal. } & \multicolumn{12}{|c|}{ Length of weir. } \\
\hline & 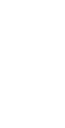 & 竞 & $\stackrel{\Xi}{\vec{H}}$ & $\stackrel{\nexists \approx}{=}$ & ت. & $\begin{array}{l}\vec{\nexists} \\
\overrightarrow{3}\end{array}$ & 音 & $\begin{array}{l}. \dot{\Xi} \\
\text { s. }\end{array}$ & 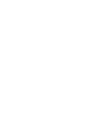 & 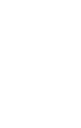 & $\underset{\infty}{\dot{4}}$ & 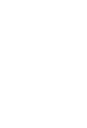 & $\underset{\rightarrow}{\sharp}$ & 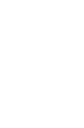 \\
\hline & 1! & 11.015 .5$. & & & & & & & & & & & & \\
\hline & 1 & . $1110^{\prime} 0$ & (1. & $0 .(6)+\frac{1}{1}$ & intor: & $0.1(k, 135,3)$ & & & & & & & & \\
\hline & 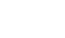 & .115 & .11121 & .00132 & (14)45 & . & & & & & & & & \\
\hline 4 & ! & )1 & . $013: 3$ & (4) (45t) & . & (1) & (1). & (1.1115) & 0. $022(201$ & (1. (12:50) & 0. $0.80 \%$ & $=10.113506$ & 0.0400 & (1). $14+.201$ \\
\hline : & $\frac{5}{36}$ & (1)66 & $.(K)+16$ & $\mid$.111699 & $.0114 !$ & . & | & . (18) & . (1279) & . (13549) & $.0+19$ & $.14 \times 9$ & (1).59 & .01629 \\
\hline (i & $\frac{2}{b}$ & .031 &.$(3) 60$ & $\mid(k+11$ & . & .011833 & 年 & .12255 & . 10346 & $.04,59$ & .0 .51 & .0643 & .0735 & $.11: 27$ \\
\hline$\tau$ & (u) & .036 & $.01 \%$ & .0114 & $.111 \% 2$ & . & $\left(6288 x^{\prime}\right.$ & $.0(33+f)$ & $.046 \%$ & .6 & . 1664 & . (1810) & (x)26 & .114 \\
\hline 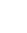 & 1 & .142 & (1) $1+92$ & . 11139 & . & (12)<1 & (1)3928 & $.01+22$ & .0 .664 & $.0 \% 116$ & . & (19869) & .113 & $.32 \%$ \\
\hline 9 & $\therefore$ & $.14 i$ & .0110 & .01616 & . (10:2) & . 113355 & .1419 & .05014 & $.063+3$ & $.04+2$ & .1111 & .118 & 135 & .152 \\
\hline 1) & $\frac{8}{8}$ & .052 & .11122 & . 0194 & . (1)243 & 18392 & .1491 & (15:5) & .1788 & .14 .4645 & .118 & $.13 \%$ & .158 & .178 \\
\hline 11 & $\frac{11}{10}$ & .0 .57 & $.014 \pi$ & $.102 \geq 3$ & . 01335 & . 0451 & $.0566 i$ & $.0(\log 40$ & (69) & .114 & .1336 & .159 & .142 & \% \\
\hline 12 & $\frac{8}{1}$ & . $1 \% 2$ & .0167 & . 1254 & (1534t & . 11514 & $.(6)+4$ & $.07 \pi 4$ & .1003 & $.1: 99$ & .155 & $.1 \times 1$ & .2\% & .233 \\
\hline $1: 3$ & $\begin{array}{c}13 \\
15 \\
10\end{array}$ & .0188 & . $018 \mathrm{~s}^{\circ}$ & .0285 & (143:3:2 & . 6579 & . & $.18 \% 2$ & $.11 \pi$ & .146 & $.1 \%$ & . & .234 & .263 \\
\hline 14 & $\frac{7}{3}$ & . 673 & (1)219 & .0318 & .0482 & $.06+6$ & . 1810 & $.09 \%$ & .130 & $16: 3$ & .196 & .2\% & .261 & 294 \\
\hline 15 & $\frac{15}{16}$ & .078 & .0231 & .0352 & (5) 634 & $.0 \% 16$ & .0897 & .108 & $.1 \pm 4$ & . 181 & $.21 \pi$ & .253 & .290 & .326 \\
\hline 16 & 1 & .083 & .0254 & .038 & $165 \%$ & . & .0988 & .119 & .159 & .199 & .239 & .79 & .319 & .359 \\
\hline $1 \%$ & $1_{10}^{1}$ & $.0 \times 8$ & $08 \pi$ & .0423 & . $1(15+2) 2$ & $.186 \%$ & .108 & .130 & $.1 \%$ & $\approx 1 x$ & .262 & .30\% & .349 & .393 \\
\hline 18 & $1 \frac{1}{5}$ & . 094 & .0301 & 0460 & (14999. & (1938. & .118 & .142 & .189 & (253 & .285 & .333 & .381 & .428 \\
\hline 19 & $1_{16}^{3}$ & . 099 & .1825 & .0498 & . & .102 & אנקו. & .153 & .205 & i & .309 & .361 & .413 & .464 \\
\hline 80 & $1 \frac{1}{4}$ & .104 & .0349 & .0536 & .0816 & .110 & .138 & .166 & . 2922 & .278 & .334 & .389 & .445 & .501 \\
\hline 21 & $1 \frac{5}{16}$ & .109 & .0875 & .0576 & .0877 & .118 & .148 & .178 & .238. & 298. & .359 & .419 & .479 & .539 \\
\hline 22 & $1 \frac{8}{8}$ & .115 & .0401 & .0616 & .0939 & .126 & .159 & .191 & .255 & .320 & .385 & .449 & .514 & .578 \\
\hline 23 & $1_{18}^{\frac{7}{16}}$ & .120 & $.042 \pi$ & .0657 & . 100 & .135 & .169 & .204 & .273 & .342 & . 411 & .480 & .549 & .618 \\
\hline 24 & $1 \frac{1}{2}$ & .125 & .0454 & .0699 & .107 & .144 & .180 & $.21 \%$ & .291 & .364 & .438 & .511 & .585 & .659 \\
\hline 25 & $1_{1 \mathrm{~g}}^{\frac{9}{16}}$ & .130 & .0481 & .0742 & . 113 & .152 & .192 & .231 & .309 & $.38 \pi$ & .465 & .544 & . 622 & .700 \\
\hline 26 & $1 \frac{5}{5}$ & .135 & .0508 & .0784 & . 1200 & .161 & .203 & .244 & $.32 \pi$ & .410 & .493 & .576 & .659 & .742 \\
\hline $2 \tilde{\imath}$ & $1 \frac{11}{12}$ & .140 & .0536 & .0829 & $.12 \%$ & .171 & .215 & .259 & .346 & .434 & $.52 \%$ & .610 & .698 & .785 \\
\hline 28 & $1 \frac{8}{x}$ & .146 & .0564 & .0873 & .134 & .180 & .226 & 273 & .365 & .458 & .551 & .644 & .736 & .829 \\
\hline 29 & $1 \frac{13}{16}$ & .151 & . 05993 & .0919 & .141 & .190 & .238 & .287 & .385 & .483 & .581 & $.6 \pi 8$ & . & .874 \\
\hline 30 & $1 \frac{\tilde{z}}{\xi}$ & .156 & .16622 & .0965 & .148 & .199 & .251 & $3(1) 2$ & $.40 \overline{0}$ & .508 & .611 & . 714 & .816 & .919 \\
\hline 31 & $1 \frac{15}{10}$ & .161 & .06651 & .101 & .155 & 2099 & 2633 & $.31 \%$ & .425 & .533 & 641 & .749 & .857 & .965 \\
\hline 3: & 2 & $.16 \%$ & .06880 & $.1(x ; j$ & .162 & .219 & $\dot{z}_{i}$ & . 33:2 & .446 & .559 & & .786 & .899 & 1.012 \\
\hline 33 & $*_{16}^{1}$ & $.1 \% 2$ & .010 & 111 & .170 & 淿 & $2 \times 8$ & & .456 & 585 & . .04 & $.8 * \pi$ & .941 & 1. 0610 \\
\hline 34 & $2 t$ & $.1 \%$ & (1) & .115 & $.17 \pi$ & .2399 & .3111 & .364 & .488 & .61\% & .736 & .860 & .984 & 1.108 \\
\hline 35 & $22_{16}^{3}$ & $.1 \% 2$ & .11769 & .120 & .185 & .250 & ת15. & yis. & $\therefore(19$ & . 6338 & .768 & .898 & $1.02 i$ & $1.15 \pi$ \\
\hline 36 & $2 \frac{1}{4}$ & $.18 \pi$ & . 10699 & (1\% & .193 & .260 & א. & .395 & .531 & .666 & .801 & .9866 & $1.0 \% 1$ & 1.2060 \\
\hline 37 & $2 \frac{5}{14}$ & .193 & $.0 \times 30$ & .130 & .201 & $2 \% 1$ & .341 & & .55 & .694 & 834 & .975 & 1.116 & 1. \\
\hline $3 x$ & 23 & .198 & .0868 & .135 & $20 R$ & . $2 \times 2 \times 2$ & .355 & .428 & .575 & .722 & . & 1.015 & 1.161 & 1. 308 \\
\hline 39 & $Z_{16}^{7}$ & $.2013^{4}$ & . 18993 & .140 & .216 & .293 & .369 & .445 & $.59 \%$ & . & .90? & 1.055 & 1.207 & 1. 359 \\
\hline 40 & 21 & 208 & .0924 & .145 & .224 & .303 & . 3883 & .462 & . 6200 & .788 & $.93 i$ & 1.095 & $1: 253$ & 1.412 \\
\hline 41 & $2 \frac{4}{10}$ & .213 & & .150 & .2333 & .315 & $.39 \pi$ & .479 & .6433 & . & .972 & 1.136 & 1. 300 & 1. 465 \\
\hline 4:2 & 28 & $.219^{\prime}$ & & .155 & .241 & .326 & .411 & .496 & .667 & .837 & 1.007 & 1.178 & 1. 348 & 1.518 \\
\hline 43 & $21 \frac{1}{16}$ & .224 & & .161 & .249 & (33i & .425 & .514 & .690 & $.86 \pi$ & 1.043 & 1.219 & 1. 396 & $1.57 \%$ \\
\hline 44 & 28 & |.2296 & & .166 & | & .349 & .440| & |. .531 & .714 & 897 & $|1.069|$ & $|1.262|$ & $|1.444|$ & 1.627 \\
\hline
\end{tabular}


TABLES.

The depth $a b$ of weir (fig. $t$, see 1.411 ) must not be over one-third must not be less than depth $a$ b.

with end contractions; original computation.

(L $-.2 \mathrm{H}) \mathrm{H}^{\frac{3}{2}}$.]

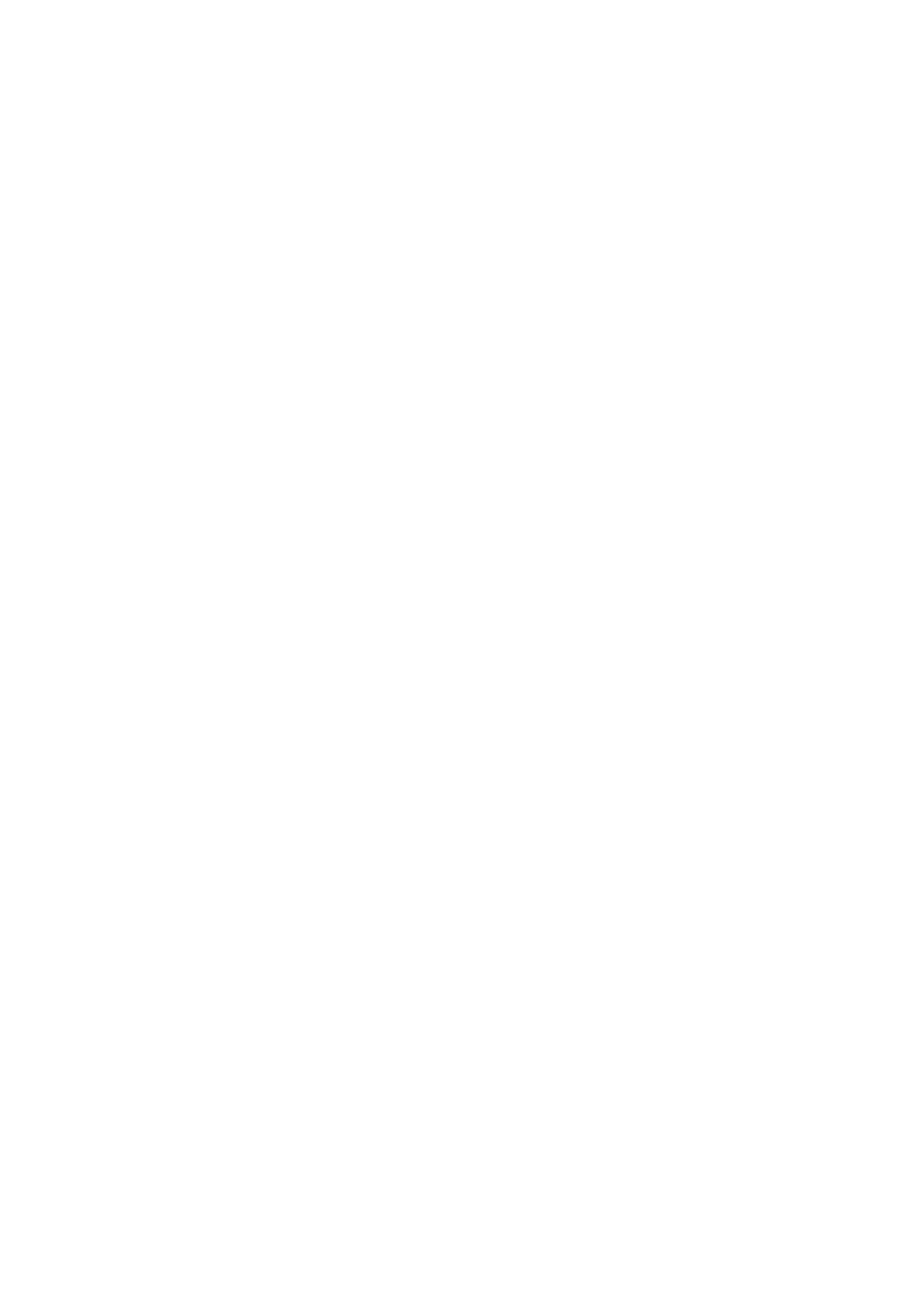


Discharges in second-feet, rectangular

\begin{tabular}{|c|c|c|c|c|c|c|c|c|c|c|c|c|c|c|}
\hline & Hea & & & & & & & & & & & & & \\
\hline & 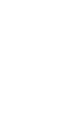 & 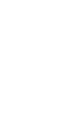 & & $\stackrel{\Xi}{g}$ & $\underset{\sigma}{\dot{E}}$ & $\begin{array}{l}\Xi \\
\Xi 2\end{array}$ & $\underset{20}{.2}$ & $\underset{\sim}{\approx}$ & $\frac{\dot{H}}{\Delta}$ & 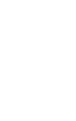 & 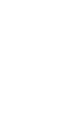 & 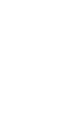 & 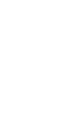 & 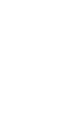 \\
\hline 45 & $22_{16}^{13}$ & 0.234 & & 0.171 & $0.2 \mathrm{~b}$ & 0.360 & 0.455 & 0.549 & 0.738 & 0.927 & 1.116 & 1.305 & 1.494 & 1. 683 \\
\hline 16 & 27 & .240 & & .177 & 254 & .372 & .469 & .567 & .762 & .958 & 1.153 & 1,348 & 1.543 & 1. 739 \\
\hline $4 \pi$ & $22_{16}^{15}$ & .245 & & .182 & $.2 \times 3$ & .384 & .484 & .585 & .787 & .989 & 1.190 & 1.392 & 1.594 & 1.795 \\
\hline 48 & 3 & .250 & & .187 & 291 & .3955 & . 499 & .604 & .812 & 1.020 & 1.228 & 1. 436 & 1.644 & 1. 852 \\
\hline 49 & $3 \frac{1}{16}$ & .255 & & .193 & .300 & $.40 \%$ & .515 & .622 & .837 & 1.051 & 1.266 & 1.481 & 1.695 & 1.910 \\
\hline 50 & $33 \frac{1}{5}$ & .260 & & .198 & 300 & $\begin{array}{l}.420 \\
\end{array}$ & .530 & .641 & .862 & 1.083 & 1.305 & 1.526 & $1 . \% 47$ & 1.968 \\
\hline 51 & $3 \frac{3}{1 \mathrm{E}}$ & .266 & & .204 & .318 & .432 & .546 & .660 & .888 & 1.116 & 1.343 & 1.571 & 1.799 & $2.02 \%$ \\
\hline 52 & $3 \frac{1}{3}$ & .271 & & .209 & $.32 \pi$ & .444 & .561 & .679 & .913 & 1.148 & 1. 383 & 1.617 & $1.85 \%$ & 2.087 \\
\hline 53 & $3 \frac{5}{16}$ & 276 & & .215 & . 336 & .456 & דשת & 698 & .939 & 1.181 & 1.422 & 1.664 & 1.905 & $214 \pi$ \\
\hline 54 & $3 s$ & 281 & & 10 & .345 & $\begin{array}{l}.469 \\
\end{array}$ & .593 & $.71 \%$ & .966 & 1.214 & 1. 462, & 1.711 & 1. 959 & 2.207 \\
\hline 55 & $3 \frac{7}{16}$ & .286 & & .226 & .354 & . 481 & .609 & .736 & .992 & 1.247 & 1.502 & 1.758 & 2.013 & $\therefore 268$ \\
\hline 56 & $3 \frac{1}{2}$ & .292 & & (2) & .363 & .494 & . 6255 & .756 & 1.018 & 1. 281 & 1. 543 & 1.805 & 2.068 & 2.330 \\
\hline $5 n^{\prime}$ & $33^{9}$ & $29 \%$ & & & $.3 i 2$ & $50 \%$ & .641 & $\pi 6$ & 1.045 & 1.315 & 1.584 & 1. 853 & 2.193 & 2.392 \\
\hline 5 & 3 & .3012 & & & . 381 & 280 & $\cos x$ & .796 & $1.0 \% 2$ & 1.349 & 1.625 & $1.90 \mathrm{R}$ & 2.178 & 2455 \\
\hline 59 & $33_{1 \frac{1}{6}}^{1}$ & . $30 \%$ & & & 391 & .539 & $.6 \pi 4$ & .816 & 1.100 & 1.383 & $1.667^{\circ}$ & $1.9 \div 0$ & 2.234 & 2.510 \\
\hline B) & 3 & .312 & & & .400 & .545 & 691 & .836 & $1.12 \%$ & $1.41 \mathrm{~s}$ & 1. $70 \%$ & $2.0(x)$ & 2.291 & 2.581 \\
\hline 61 & $3 \frac{13}{16}$ & . 318 & & & .409 & 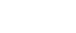 & $.711 x$ & (5.5. & 1.155 & 1.453 & 1.751 & $\because 049$ & 2.347 & $\therefore 64 t$ \\
\hline 62 & $3 \tilde{\xi}$ & . 325 & & & .419 & .572 & .724 & .877 & 1.183 & 1.488 & 1. 794 & :2.098 & $2.4(5)$ & 2.710 \\
\hline 63 & $3_{16}^{15}$ & .328 & & & .428 & .585 &.$\pi 11$ & .898 & 1.211 & 1.524 & 1.834 & 2.150 & 2.433 & 2.7\% \\
\hline 64 & 4 & .333 & & & .438 & .594 & $\pi 5 x$ & .919 & 1.239 & 1.5 .59 & 1.880 & 2.200 & $2.5 \% 1$ & 2.841 \\
\hline 65 & $4 . \frac{1}{16}$ & .338 & & & .448 & .612 & . & .940 & $1.26 \pi$ & 1.595 & $1.923^{\prime}$ & 2.251 & 2.579 & 2.907 \\
\hline 66 & $4 \frac{1}{3}$ & .344 & & & $.45 \pi$ & .625 & .793 & .961 & 1.296 & 1. 6392 & 1. $96 \%$ & 2. 3्रा 3 & 2.638 & 2.974 \\
\hline $6 i$ & $4_{18}^{a}$ & .349 & & & $46 \pi$ & . 638 & .810 & .982 & 1.325 & 1.668 & 2.011 & 2.355 & 2.698 & 3.041 \\
\hline 68 & 4 & .354 & & & $.4 \% \pi$ & 652 & היה & 1.003 & 1.354 & 1. 705 & 2.056 & $2.40 \%$ & 2. 758 & 3.109 \\
\hline 64 & $4 \frac{5}{16}$ & .359 & & & .486 & .666 & .845 & 1.025 & 1.383 & 1.742 & 2.101 & 2.459 & 2.818 & 3.177 \\
\hline 70) & $4 \frac{2}{6}$ & .365 & & & .496 & .680 & .863 & 1.046 & 1. 413 & 1. $\pi 9$ & 2.146 & 2.512 & 2.879 & 3.245 \\
\hline 11 & $4_{1 \mathrm{E}}^{7}$ & .370 & & & .506 & . 693 & .881 & 1. 068 & 1. $44 \mathrm{Z}$ & $1.81 \tau$ & 2.191 & 2.565 & 2.940 & 3.314 \\
\hline 2 & $4 \frac{1}{2}$ & .375 & & & .516 & . & .899 & 1.090 & 1.472 & 1.854 & 2.237 & 2.619 & 3.001 & 3.384 \\
\hline 83 & $4 \frac{9}{16}$ & .380 & & & & .721 & .917 & 1.112 & 1.502 & 1.892 & 2.283 & 2.673 & 3.063 & 3.454 \\
\hline 4 & 48 & .385 & & & & .735 & . 935 & 1.134 & 1.532 & 1.930 & 2. 328 & 2.797 & 3.126 & 3.524 \\
\hline 5 & $4 \frac{11_{1}^{3}}{3}$ & 390 & & & & .749 & .953 & 1.156 & 1.562 & 1.969 & 2.375 & $2.78 \%$ & 3.188 & 3. 59 \\
\hline 6 & 4 & .396 & & & & .764 & .971 & 1.178 & 1.593 & 2.008 & 2. 422 & 2.831 & 3.252 & 3.66 \\
\hline Ti & $4 \frac{1}{12} \frac{3}{6}$ & .401 & & & & . & .989 & 1.201 & 1.624 & $2.04 \%$ & 2. 469 & 2.892 & 3.315 & $\therefore 738$ \\
\hline 78 & $4 \frac{1}{\xi}$ & . $406 j$ & & & & .793 & 1.009 & 1.224 & 1.655 & 2.086 & 2.517 & 2.949 & 3.380 & 3.811 \\
\hline 79 & $4 \frac{15}{16}$ & .411 & & & & .807 & 1.028 & 1.246 & 1.686 & 2.125 & 2.565 & 3.004 & 344 & $3.880^{\circ}$ \\
\hline 8) & 5 & $.41 \%$ & & & & $.8 * 1$ & 1.045 & 1.269 & 1.717 & 2.164 & 2.612 & 3.060 & 3.508 & 3.956 \\
\hline 81 & $5_{1^{\frac{1}{6}}}^{\frac{1}{3}}$ & .422 & & & & .836 & 1.064 & 1. 292 & 1. 748 & 2.205 & 2.661 & 3.117 & $3.5 \% 3$ & t. 030 \\
\hline 82 & $5 \frac{1}{8}$ & . 427 & & & & .850 & 1.089 & 1.315 & 1. 799 & 2.244 & 2. 709 & 3.174 & 3.638 & t. 103 \\
\hline 83 & $5_{16}^{3}$ & . $432^{\prime}$ & & & & .864 & 1.101 & $1.363 \pi$ & 1.810 & 2.284 & 2.757 & 3.230 & 3.708 & $4.17 \%$ \\
\hline 84 & 5 & $43 \pi \tilde{T}$ & & & & . 879 & 1.120 & 1.361 & 1.843 & 2.324 & 2.806 & 3.248 & 3. $7 \%$ & 4.252 \\
\hline 85 & $5_{16}^{5}$ & . 4433 & & & & .893 & 1.138 & 1.38 .3 & 1.874 & 2.364 & 2.855 & 3.345 & 3.836 & 4.326 \\
\hline 86 & $5 \frac{3}{8}$ & .448 & & & & .9088 & 1.158 & 1. $40 \pi$ & 1.906 & 2.405 & 2.904 & 3.404 & 3.903 & 4.402 \\
\hline 1 & $\overline{\mathbf{s}}_{1 \overline{6}}^{\frac{\gamma}{6}}$ & . 4533 & & & & .983 & $1.1 \%$ & 1.431 & 1. 939 & $2.44 \pi$ & 2.954 & 3.462 & 3.970 & 4.478 \\
\hline 8 & $\delta_{1}$ & .458 & & & & $.93 \pi$ & 1.196 & 1.455 & $1.9 \% 1$ & 2.488 & 3,005 & 3.521 & 4.038 & 4.555 \\
\hline & $5 i$ & .463 & & & & 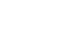 & 1.216 & 1.489 & $\because .004$ & 2.530 & 3. 055 & 3.581 & 4.306 & 4. 63 \\
\hline A) & $6 \frac{5}{x}$ & 469 & & & & $.96 z^{\prime}$ & 1.25 & 1. $\pi(t)$ & $2.013 \pi$ & 2.57 & 3.103 & 3.640 & t.174 & 4. 601 \\
\hline 1 & 516 & 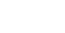 & & & & $.9 \times 3$ & 1.255 & $1.5 \mathrm{~g}+4$ & 2.170 & 2. 613 & $3.15 \mathrm{t}$ & 3. 6001 & 4.243 & 4.786 \\
\hline 2 & .3 & 97.4. & & & & איציו. & 1.254 & 1.550 & 2.103 & 2.655 & 3.2006 & 3. 760 & 4.312 & 4864 \\
\hline 33 & $5, \frac{13}{6}$ & .481 & & & & 1.014 & 1.295 & 1.575 & 2.13 & 2.698 & 3.259 & 3.821 & 4. $3 \times 2$ & 1. $44:$ \\
\hline 44 & $5 z^{z}$ & $4(x)$ & & & & 1.029 & 1.314 & 1. 599 & 2.170 & 2.740 & 3.310 & 3.881 & 4.451 & อ. \\
\hline
\end{tabular}




\begin{tabular}{|c|c|c|c|c|c|c|c|c|c|c|c|c|c|}
\hline \multicolumn{11}{|c|}{ Length of weir-Continued. } & \multicolumn{2}{|c|}{$\begin{array}{l}\text { Addition for } \\
\text { increase of } \\
\text { length. }\end{array}$} & \\
\hline $\begin{array}{l}+1 \\
10\end{array}$ & 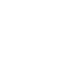 & $\sum_{i=1}^{ \pm}$ & $\begin{array}{l}+1 \\
\infty\end{array}$ & $\underset{\sharp}{\stackrel{\sharp}{\sigma}}$ & $\stackrel{ \pm}{\equiv}$ & 岸 & \pm & 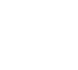 & 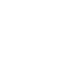 & $\stackrel{ \pm}{\mathrm{m}}$ & $\stackrel{1}{a}$ & $\stackrel{\dot{\pi}}{\check{\pi}}$ & \\
\hline 1.871 & 2.249 & 2.627 & $3.0 \times 15$ & 3.383 & 3. 761 & 4.516 & 5. $27 \%$ & 6.028 & 6.783 & .7 .539 & 0.0315 & 11. 378 & 45 \\
\hline 1.934 & $2.3 \% 4$ & 2.715 & 3.105 & 3.496 & 3.886 & $4.66 \%$ & 5.448 & 6. 229 & พ.010 & 7. 798 & .0325 & .391 & 46 \\
\hline 1.997 & 2.400 & 2.814 & $3.281 \%$ & 3.618 & 4.013 & 4.820 & อ. $62 \%$ & 6.433 & $\mp .240$ & S. 1447 & .0336 & .403 & 47 \\
\hline 2.060 & $2.4 \pi i$ & 2.893 & 3.309 & 3.725 & 4.162 & 4.974 & $5.800^{\circ}$ & (6. 6339 & i. $4 \%$ & 8.304 & $.034 \%$ & .416 & 48 \\
\hline 2.125 & 2.554 & 2.983 & 3.413 & $3.84 \%$ & $+.2 \%$ & 5.130 & 5.989 & $6.84^{\circ}$ & โ.706 & 8.565 & .0358 & .429 & 49 \\
\hline 2.190 & 2.632 & $3.0 \% 5$ & $3.51 \%$ & 3.960 & 4.402 & 5. $287^{4}$ & 6.172 & $7.058^{\prime}$ & ז. .943 & 8.828 & .0369 & .443 & 50 \\
\hline 2.255 & 2.711 & $3.16 \%$ & 3.623 & t.0\%9 & 4.535 & 5. 446 & 6. 358 & $\% 2 \% 0$ & $8.18 \%$ & 9.093 & .11380 & .456 & 51 \\
\hline 2.321 & 2.791 & 3.260 & 3. 729 & 4. 199 & 4.668 & $\therefore .60 \%$ & 6.546 & 7.484 & 8.423 & 9.342 & .0391 & .469 & 52 \\
\hline 2.384 & 2.871 & 3.354 & $3.83 \pi$ & 4.324 & 4. 813 & 5. 769 & 6. 735 & 7.701 & 8.666 & 9.632 & . (040? & .483 & 53 \\
\hline 2.455 & 2.952 & 3.449 & 3.946 & t. 442 & 4.939 & $5.932^{\prime}$ & 6.926 & $7.919^{\prime}$ & 8.913 & 9.906 & .0414 & $.49 \%$ & 54 \\
\hline 2,524 & 3.084 & 3.54 .5 & 4.055 & 4. .2664 & 5.076 & 6. 097 & ז.118 & $8.140^{\prime}$ & 9.161 & 10.182 & .0425 &. .511 & 55 \\
\hline 2.592 & $3.11 \%$ & 3.641 & 4.166 & 4. $69 x$ & 5. 215 & 6. 264 & ธ. 313 & 8. 362 & 9.411 & 10.460 & $.043 \%$ & 'ו's' & 56 \\
\hline 2. 661 & $3.21 m^{\prime}$ & 3. 739 & 4.27i & 4. 816 & 5. 355 & (6. 43\%? & 7.509 & 8.586 & 9.664 & 10. $r 41$ & .0449 & ו & 57 \\
\hline 2. 731 & 3.284 & $3.83 \pi$ & 4.390 & 4.943 & 5.495 & 6. 601 & 7.707 & 8. 813 & 9.918 & 11. 024 & .0461 & .503 & 58 \\
\hline 2.801 & 3. 369 & $3.934 i$ & 4.5103 & $5 .(1 \pi)$ & $5.63 x$ & b. พา2 & 7.907 & 9.041 & 10.166 & 11.310 & $.04 \% 3$ & .565 & 59 \\
\hline 2.89 & 3.454 & 4.0136 & เ.617 & 5. 199 & 5. 781 & 6. 944 & ×. 108 & 9.271 & 10.435 & 11.696 & $.114 \times 5$ & . nitis & (bi) \\
\hline 2.944 & 3.541 & 4. 13i & 4. 7.253 & 5. 329 & 5. 925 & $\% .118$ & 8.311 & 9.503 & 10.696 & 11. 889 & .049 & .596 & 61 \\
\hline 3.0116 & $3.62 \%$ & t.:30 & 4.849 & 5. $4(60)$ & 6. 011 & ᄃ.293 & $8.51 \%$ & $9.63 i$ & 10.960 & $12.1 \times 2$ & .0509 & $.611^{\prime}$ & 62 \\
\hline 3.1188 & 3. 714 & 4.2.201 & 4.966 & 5.592 & 6.218 & 5.470 & 8.722 & $9.9 \mathrm{ra}$ & 11.225 & 12.4is & $.052 ?$ & $.6 \% 25$ & 63 \\
\hline 3.162 & 3.802 & $4 .+43$ & 5.084 & 5. $(25)$ & 6.366 & 7.648 & 8.929 & 10.211 & 11. 493 & 19.274 & (15)34 & $.6+1$ & 64 \\
\hline 3,235 & $3 . \times 91$ & $4.5 \%$ & 5.2213 & 5.859 & (i. 515) & ‥82\% & 9.139 & 10.451 & 11. 763 & $13.0 \%$ & .054 & 676 & 65 \\
\hline 3.310 & 3.981 & $4.6 \pi 2$ & 5.323 & 5.994 & 6. 665) & $8.00 \%$ & 9.350 & 10,692 & 12.034 & $13.3 \% \mathrm{f}$ & (1):50) & $.67 \pi 1$ & 66 \\
\hline 3.384 & 4.0 .1 & 4. & 5.443 & f. 134 & 6. 816 & 8.189 & 9.562 & 10.935 & 12.308 & 13. 68$]$ & $.05 \%$ & $.6 \times 6$ & $6 t$ \\
\hline 3.460 & 4. 161 & 4.8633 & 5. 562) & $6.26 \%$ & 6. 969 & $\times .3 \% 3$ & 9. & 11.180 & 12.584 & 13.988 & .0 .585 & .702 & 68 \\
\hline 3.535 & 4.253 & $4.9 \% 0$ & .. 688 & 6. $4(15$ & 7.122 & $8.55 \%$ & 9.992 & $11.42 \pi$ & 12.862 & 14.296 & .0598 & $.71 i$ & 69 \\
\hline 3.612 & 4.345 & 5.078 & 5. 811 & 6.544 & $7.2 \%$ & 8. 743 & 10. 209 & 11.676 & 13.142 & 14.608 & .1611 & .733 & 70 \\
\hline 3.689 & 4.434 & 5.186 & 5.935 & (6. 684 & $\pi .433$ & 8.930 & 111.428 & 11.926 & 13.433 & $14.9: 1$ & .0621 & $\therefore 49$ & 71 \\
\hline 3. 766 & 4.531 & 5. 296 & 6. 1060 & ti. 825 & 7.590 & 9.119 & 10.648 & 12.158 & 13. 705 & $15.23 i$ & .16351 & .765 & 78 \\
\hline 3.844 & $4.6 \%$ & 万. 405 & 6. 186 & 6. 967 & 7.748 & 9.309 & 10.870 & 12.432 & 13.993 & 15. 554 & .0650 & .781 & 73 \\
\hline $3.92 \%$ & 4. 719 & $\tilde{\partial}, 516$ & 6. 313 & $\approx .110$ & 7.906 & 9.500 & 11.099 & 12.68 & 14.281 & $15.8 \mathrm{mit}$ & .0664 & .791 & 74 \\
\hline 4.1001 & 4. $814^{\prime}$ & 5. 628 & 15.440 & 5.253 & 8.066 & $9.69 \mathrm{z}$ & 11.318 & 12.944 & $14.5 \% 0$ & 16.196 & $.067 \%$ & .813 & 75 \\
\hline 4.0181 & 4.910 & 5. & $(3,569)$ & 7.395 & $8.22 \sigma^{\prime}$ & 9.886 & 11.545 & 13.203 & $14.86 \%$ & 16.520 & .0691 & .899 & 76 \\
\hline 4.161 & $.00 \%$ & 5.852 & (i. 698 & 7.544 & $\therefore .390$ & 10.081 & 11. $\% 2$ & 13.464 & 15.155 & 16.84 & .0705 & .846 & $\pi$ \\
\hline 4. $24 \%$ & 5.104 & 5.967 & (f. $x, 9 ?$ & ז. 691 & 8.553 & 10.288 & 12.002 & $13.72 \pi$ & 15.451 & $15.1 \% 6$ & .0419 & .862 & 78 \\
\hline $4.32: 3$ & 万. 201 & 6. 080 & 6. 459 & 7. $\times 34$ & 8. $71 \%$ & 10.475 & 12.233 & 13.990 & 15.748 & 17.506 & .0732 & .879 & 79 \\
\hline $4.4(1)$ & ธ. 299 & 6. 195 & $70(0)$ & $\because .986$ & $8.8 \times 2$ & $10.6 \% 8$ & 12.461 & 14.250 & $16.04 \%$ & $17.83 x$ & $.074 i$ & .896 & 80 \\
\hline 4.486 & 5.398 & 6.311 & 7.223 & ×. 1336 & 9.048 & 16).873 & 12.699 & 14.523 & 16.348 & 18.173 & .0760 & .912 & 81 \\
\hline $4.565^{5}$ & 5.497 & $6.42 \pi$ & 7.356 & S. $2 \times 5$ & 9.:215 & $11.0 \mathrm{~m} 4$ & 12.933 & 14.791 & 16.60 & $18.50)$ & .17675 & .420 & 82 \\
\hline 4.650 & 5.596 & $6.54: 3$ & i.489 & 8.436 & $9.3 \times 2$ & 11.25 & 13.168 & 15. 061 & 16.954 & $18.846^{\circ}$ & . Oons & .946 & 83 \\
\hline 4. 733 & $5.69 \%$ & fi. 66$]$ & ¿.62t & $8.5 \mathrm{ks}$ & $9.551^{1}$ & 11.469 & 13.4146 & 15. 3333 & $1 \% .260$ & $19.1 x_{i}$ & . (1803) & .964 & 84 \\
\hline 4.816 & .). 797 & 6.778 & โ. 599 & 8.740 & 9. & 11.682 & 13.64t & 15. 606 & $1 \% .56 \%$ & 19.520 & . (1817) & .981 & 85 \\
\hline 4.901 & .). 899 & $6.89 i^{n}$ & 7.895 & 8. 894 & 9. $\times 99$ & 11.888 & 13.885 & 15. 881 & $1 \pi .8 \%$ & 19. $87 t$ & .0832 & .994 & 86 \\
\hline 4.986 & $6 .(n+2)$ & i.01\% & $x .(133)$ & 9.04 & 10. (1)64 & 12.096 & 14.127 & 16.1 .99 & 18.190 & 2A). 221 & .0846 & 1.016 & 87 \\
\hline 5.071 & 6.105 & T.13n & 尺. 111 & 9.204 & 10. $: 23 k$ & 12.314 & 14.371 & 16.433 & 18. 514 & 21.57 & .0861 & 1.0834 & $8 x$ \\
\hline$\therefore .15 \%$ & 6. $20 \mathrm{~K}$ & i.250 & $x .310$ & 9.361 & 10. $41 \%$ & 12.514 & 14.6110 & 16. 718 & $18 . \times 21)$ & 21.992 & .1876 & 1.051 & 89 \\
\hline 5,243 & 6. $31 \%$ & 7.3800 & S. 449 & 9.518 & 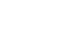 & 12. 724 & 14. $x(i]^{\prime}$ & 16. yeta' & $19.13 t i$ & & (1891 & 1.069 & $\$ 0$ \\
\hline 5.38, & (i. 416 & 7.5013 & $5,5 \times 9$ & 9.1566 & 10. $46 \%$ & 12.9346 & 15.104 & $17.2 \times 2$ & 19.455 & $21.6 \%$ & $.09066^{\prime}$ & 1.084 & 91 \\
\hline $5 .+16 j$ & (i. $.5: 21$ & ¿. $6 * t i$ & 8.730 & 9.8355 & 114.989 & 13.144 & 15.354 & $17.56 \%$ & 19. 776 & 21.385 & $\left(N_{1}\right): \geqslant 1$ & 1. 105 & 92 \\
\hline 5. 5nlt & ti. $6 \% \bar{F}$ & (7. & 8.872 & 9.995 & 11.117 & 13.363 & $15.60 \mathrm{~K}$ & $17,85.3$ & 2) (2) (18 & $=2-343$ &.$(x) 35$ & $1.12 \%$ & 93 \\
\hline .). 592 & 6. 6353 & 7.8\%3 & 9.014 & $10.15 \%$ & 11.295, & 13.5.5 & 15.858 & 18.140 & :20. $4: 21$ & 深 702 &.$(0951)$ & 1. 141 & 94 \\
\hline
\end{tabular}


Discharges in second-yeet, rectungular

\begin{tabular}{|c|c|c|c|c|c|c|c|c|c|c|c|c|c|c|}
\hline & \multicolumn{2}{|c|}{ Head. } & \multicolumn{12}{|c|}{ Length of weir. } \\
\hline & 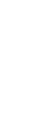 & $\begin{array}{l}\text { 㟧 } \\
\text { 焉 }\end{array}$ & $\exists$ & $\stackrel{\Xi}{0}$ & $\stackrel{s}{\sigma}$ & 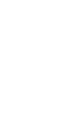 & 音 & $\underset{\infty}{\Xi}$ & 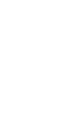 & 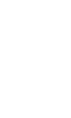 & $\underset{\infty}{ \pm}$ & $\begin{array}{l}\dot{\Xi} \\
0 \\
+ \\
\infty \\
\infty\end{array}$ & $\underset{J}{\stackrel{\rightleftarrows}{J}}$ & \begin{tabular}{l}
.$j$ \\
$\dot{j}$ \\
$\dot{3}$ \\
\multirow{+}{*}{}
\end{tabular} \\
\hline 95 & $5_{16}$ & 0495 & & & & 1.044 & 1.334 & 1.624 & 2.203 & 2. 783 & 3.362 & 3942 & $4.5 * 1$ & 5.101 \\
\hline 96 & 6 & $.5 k$ & & & & 1.060 & 1.354 & 1. 649 & 2.237 & 2.826 & 3.415 & 4.003 & 4.592 & 5.181 \\
\hline 97 & $6 \frac{1}{16}$ & $.50 \%$ & & & & & 1.374 & $1.6 \% 3$ & 2.271 & 2.869 & $3.46 \%$ & 4.065 & 4.662 & 5.260 \\
\hline 98 & $6 !$ & .510 & & & & & 1.394 & $1.69 \%$ & $2.3 n 4$ & 2.912 & 3.519 & 4.126 & 4. 733 & 5. 340 \\
\hline 99 & $6_{T_{16}^{3}}^{3}$ & .51 & & & & & 1.414 & 1. 202 & 2.339 & 2.955 & $3.5 \% 2$ & 4.188 & 4.805 & 5.421 \\
\hline 100 & $6+$ & .521 & & & & & 1.434 & 1. .40 & 2.372 & 2.999 & 3.624 & 4. 250 & 4.876 & 5.502 \\
\hline 101 & 65 & .526 & & & & & 1.45 & 1. $\approx 2$ & $2.40 \%$ & 3.043 & 3.678 & 4.313 & 4.948 & 5.584 \\
\hline 10: & $66_{3}^{R}$ & . & & & & & 1. $4 \pi$ & 1798 & 2.442 & $3.08 \mathrm{i}$ & 3.732 & $4.3 \pi \pi$ & ร. 0221 & 5. 666 \\
\hline $111 \% 3$ & $b_{\frac{7}{16}}$ & $.53 i t$ & & & & . & 1.495 & 1. $\times 22$ & 2.476 & 3.131 & 3.785 & 4.430 & 5093 & 5. 747 \\
\hline 104 & $6 !$ & .54 & & & & & 1.516 & 1.848 & 2511 & 8.155 & 3.839 & 4.505 & .ร. 166 & 5. 830 \\
\hline 10.5 & 69 & $3+2$ & & & & & 1.535 & $1.8 \% 3$ & $2.54 \pi$ & $3.2: 0$ & $3 \times 93$ & +.565 & .22840 & Б. .913 \\
\hline 1 CHi & 6 & $\alpha i$ & & & & 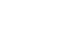 & 1. & 1. & 2.581 & 3.264 & 3.94\% & $4.6 ; 3$ & 5. 313 & 5. 996 \\
\hline $10 \%$ & $\theta_{i} \mid \frac{1}{15}$ & מ & & & & & $1 . \pi \%$ & 1,924 & 2.616 & 3.309 & +6012 & 4.695 & 5. 387 & 6. 080 \\
\hline $10: 4$ & (i) & $\pi \%$ & & & & & 1 int & 1.949 & 2652 & 3.354 & 4.057 & 4. .5 .5 & 5. 461 & (i. 161 \\
\hline 1119 & $b \frac{13}{1 *}$ & 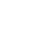 & & & & & J. 619 & 1.945 & $\because 6 \times 5$ & 3.400 & 4.112 & 4. $\times 24$ & 5.5335 & (i. 248 \\
\hline 110 & bi & $.5 \%$ & & & & & 1640 & 2001 & 2.723 & 3.445 & $4.16 i$ & 4. Sist, & ...1611 & 6.333 \\
\hline 111 & $b_{1} \frac{15}{16}$ & 50 & & & & & 1.661 & $2.02 \pi$ & ะ. 759 & 3.491 & 4. 283 & 4,95 & .j. risti & fi. 418 \\
\hline 11:2 & $i$ & $.5 \%$ & & & & & 1.682 & 2.053 & 2. 795 & 3.536 & $4.2 \pi 8$ & $5 .(2)$ & ก. 762 & 6.504 \\
\hline 113 & ${ }^{7} \frac{1}{L^{1}}$ & $.58 !$ & & & & & 1.703 & 2.079 & $2.830_{0}$ & $3.588^{\circ}$ & 4.334 & 5.086 & 5.834 & (6. $.589^{\prime}$ \\
\hline 114 & $i s$ & . & & & & & 1.8.25 & 2.106 & $2.86 \tilde{r}_{1}^{\prime}$ & 3.62 & 4.391 & 5. $1 \%$ & .5. 914 & 6.6\%6 \\
\hline 11.5 & $r_{16}^{3}$ & .594 & & & & & 1. 746 & $: 132$ & 2.904 & $3.6 \%$ & 4. $44 \pi$ & 5. 219 & 5. 991 & 1. 863 \\
\hline $116 i$ & $\tilde{i}_{t}^{1}$ & f(x) 14 & & & & & 1. & 2.158 & 2.941 & 3. 70 & 4.504 & 5.286 & B. 067 & 6.849 \\
\hline 117 & $i_{1} \bar{B}$ & .609 & & & & & 1. $78 \mathrm{~N}$ & 2. 184 & 2.976 & 3.768 & $4.560)$ & 5.352 & (i. 144 & 6. 936 \\
\hline 11 & $\tilde{i}_{3}$ & .61. & & & & & 1.819 & 2.210 & 3.012 & 3.815 & 4. 617 & 5.419 & 6.221 & $\pi .023$ \\
\hline 110 & $\tau_{16}$ & $6 \%$ & & & & & 1.8311 & 2.236 & 3.049 & 3.861 & 4.674 & 5. 486 & 6. 298 & $r .111$ \\
\hline 124 & $i \frac{1}{13}$ & .685 & & & & & 1.850 & 2.263 & 3.085 & 3.908 & 4. & 5.554 & 6. 376 & \%.199 \\
\hline 121 & $7_{16}^{\frac{1}{6}}$ & . $1: 31$ & & & & & & 2.290 & 3.123 & 3. 956 & 4. 589 & ธ. $6: 2$ & (i. 4559 & 7.288 \\
\hline 129 & $\gamma_{b}^{k}$ &.$B 3 ;$ & & & & & & 2. 316 & 3.160 & 4. 0013 & 4. 846 & 5.690 & 6.583 & 7.376 \\
\hline $12: 3$ & $\pi 11$ & .641 & & & & & & 2.343 & 3.196' & 4. 150 & $4.90 t$ & 5. 758 & 6.611 & 7. 465 \\
\hline $1 \% 4$ & $i$ & $.64 t$ & & & & & & 2.370 & 3.234 & 4.098 & 4.963 & 5. $82 \pi$ & (.. 691 & $7.5 \check{55}$ \\
\hline 1:25 & 713 & (ii) & & & & & & $\therefore 39 \%$ & 3.2\%1 & 4.146 & 5.021 & 5.895 & 6. & $\pi .64 \tilde{\Xi}$ \\
\hline 126 & $i$ & $.65 t$ & & & & & & 2.423 & 3.318 & 4.193 & 5. 079 & .5. 964 & 6. 449 & 7.734 \\
\hline $12 i$ & $7 \frac{15}{16}$ & $.66 ; 1$ & & & & & & $\therefore 451$ & 3.316 & 4.242 & 5.138 & L. 0.34 & 6.989 & โ.825! \\
\hline 123 & 8 & .667 & & & & & & :.4 & 3. 324 & 4.2011 & 5. 196 & 6.103 & 7.0098 & ส.915 \\
\hline 129 & $8_{1 q_{i}}^{1}$ & $.6 \%$ & & & & & & $\because 5015$ & 3.422 & 4. 3399 & ร. 256 & $6.1 \% 3$ & 7.0901 & $8.00 \pi \mid$ \\
\hline 131) & 然 & . & & & & & & 2.532 & 3.459 & $4.38 \%$ & 5.315 & 6.2.24 & $7.1 \% 0$ & 0998 \\
\hline $1: 31$ & $\begin{array}{r}x_{1}^{3} \\
\end{array}$ & . $6 x$ & & & & & & 2.5 .54 & 3. 498 & 4.436 & 5.344 & 6. 313 & 7.251 & 8. 189 \\
\hline 13: & $8 i$ & $.66 x$ & & & & & & 2.586 & 3.585 & 4.484 & 5.439 & 6.283 & 7,332 & 8.281 \\
\hline 1333 & $s_{i i:}$ & $6 \%$ & & & & & & $\therefore 614$ & $3.5 \pi$ & 4.534 & .). 494 & ti. 454 & 7.414 & 8.374 \\
\hline 1334 & $8 \frac{2}{s}$ & .69 & & & & & & 2.642 & 3.613 & 4.583 & 5.554 & 6. 625 & $\pi .496$ & 8. $46 \pi$ \\
\hline 185 & $\therefore_{16}^{7}$ & 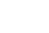 & & & & & & $\therefore 669$ & 3.650 & 4. 6332 & 5.614 & 6.596 & 7.507 & 8.559 \\
\hline 136 & 81 &.$\pi 18$ & & & & & & $2.69 \%$ & 3. 689 & 4. 688 & 5.674 & 0. 667 & 7.660 & 8.6.52 \\
\hline $1 \hat{3 \hat{\imath}}$ & $8 \frac{\pi}{16}$ & .71 & & & & & & 2.725 & 3. 208 & 4. 732 & 6. $73 n^{-1}$ & 6. 739 & $7.74:$ & 8. 746 \\
\hline $13 n$ & $8 \frac{5}{7}$ & \%1s & & & & & & $\therefore .752$ & $3 . \pi f 6$ & 4. $\% 81$ & 5. 7 & 6. 810 & 7.824 & 8.839 \\
\hline 134 & $>1 \frac{1}{16}$ & .80 & & & & & & $\because .801$ & $3 \times 50$ & 4. & 5.456 & 6.382 & 3.9.6. & 8.933 \\
\hline $1+1$ & $s_{1}$ & . & & & & & & 2.808 & 3.844 & 4. 481 & 5.918 & 6.955 & 7.991 & 9.028 \\
\hline 141 & $s_{11} ?$ & $\therefore 3$ & & & & & & 2.836 & $3.8 \times 4$ & +938 & 5.979 & $\tau .(2 \pi)$ & $8.0 \%$ & 9.125 \\
\hline 14:2 & $x ! 1$ & $i t 1$ & & & & & & 2.863 & $3.92: 2$ & 4.981 & $(6.0+1)$ & ช.0499 & $8.1 \mathrm{ing}$ & 9.216 \\
\hline 143 & 816 & . & & & & & & 2.891 & 3.961 & 5. 1038 & 6.11: & 7.162 & 8.242 & 9.312, \\
\hline 144 & 9 & .75 & & & & & & 2.919 & 4.(K)1 & 5. $18 \% 2$ & (i. $16 i t$ & 7.245 & 8.327 & 9.408 \\
\hline
\end{tabular}


woirs with oud contractions-c 'ontinned.

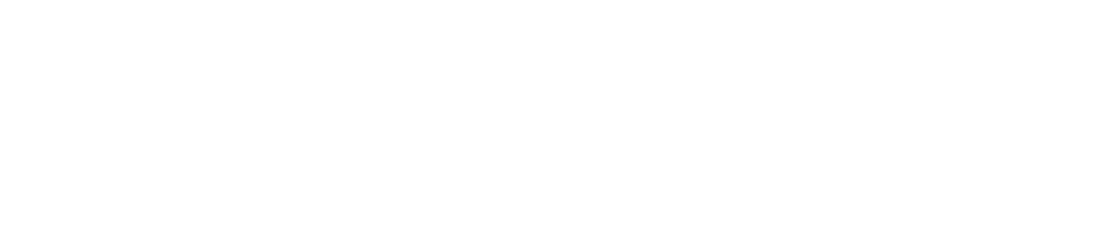

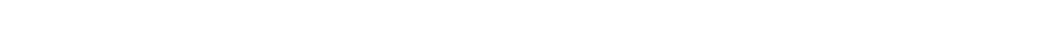

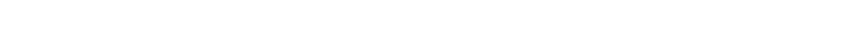

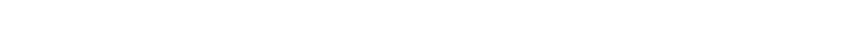

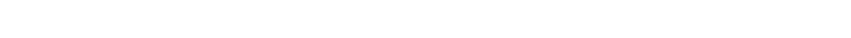

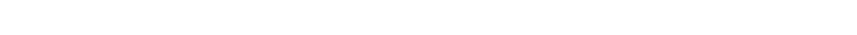

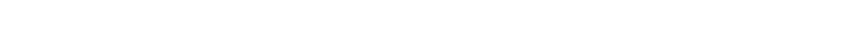
$6.219 \quad 5.490 \quad$ ห.

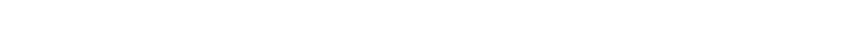

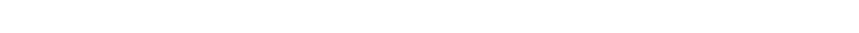

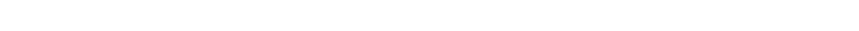

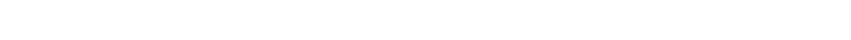

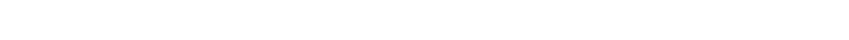

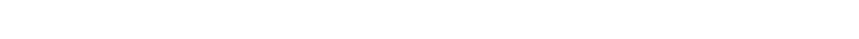

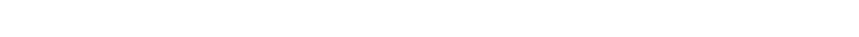

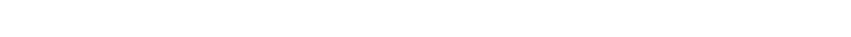

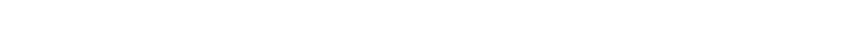

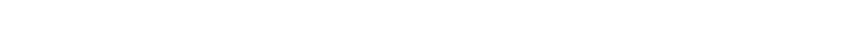

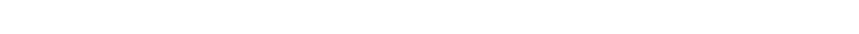

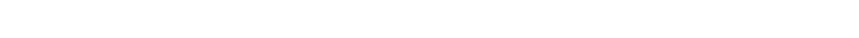

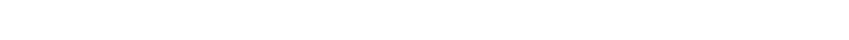

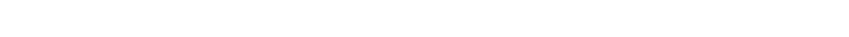

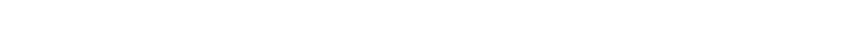

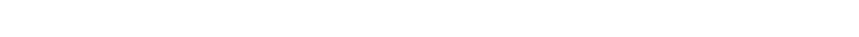

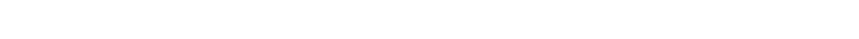

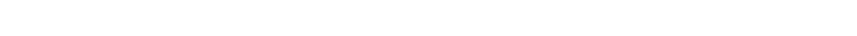

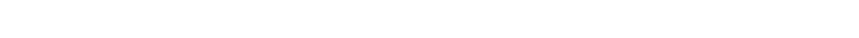

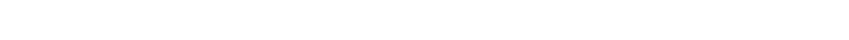

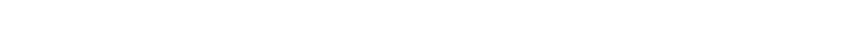

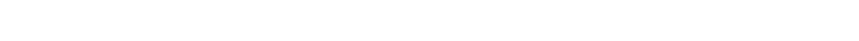

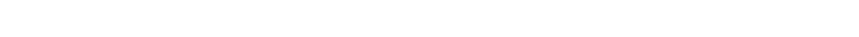

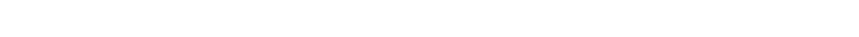

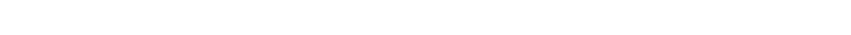

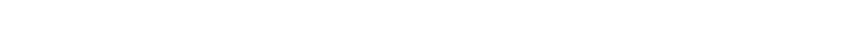

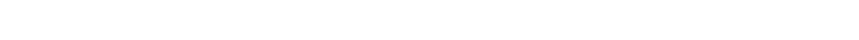

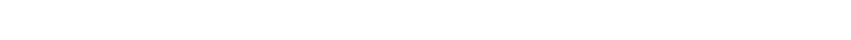

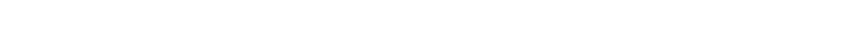

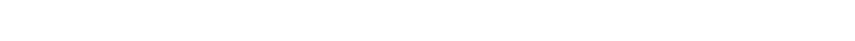

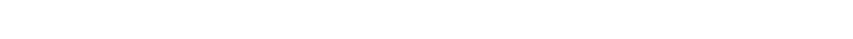

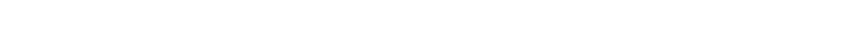

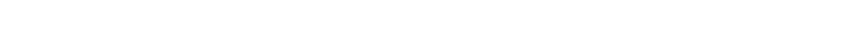

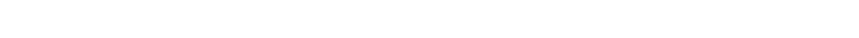

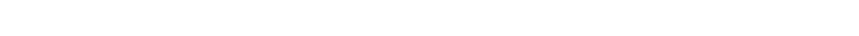

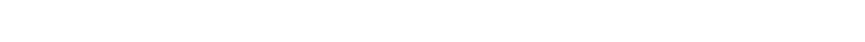

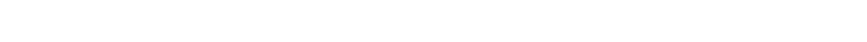

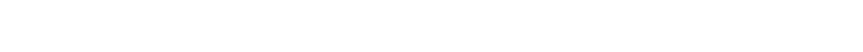

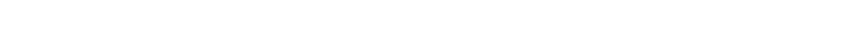

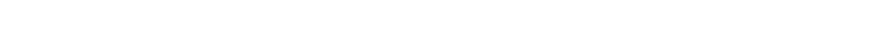

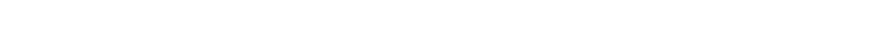

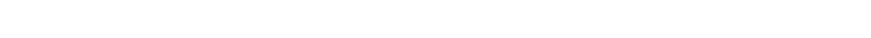

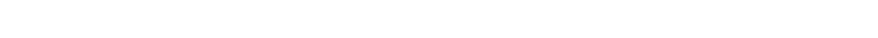

$.01381 \quad 1.1 \% 5$ $.009 \% 1.19 \% 9$ $.111,1.214 \quad 96$ 1113,1 , $1.23 \quad 99$ $.104 \quad 1.25100$ .106 1.2\%1 101 $.10 \%$ 1.2x! ]0स .1191 1. 3्रा5 103 111 1.30 104 $.112 \quad 1.397105$ $.114 \quad 1.356510 \mathrm{Ks}$ .115 $1.38510 \%$ . 117 1. 115i 108 $.119 \quad 1.429^{\prime} 109$ .121 1.111 110 ] 13:2 1.454 111 .1:4 1.44 11: .125 1.744113 $1 \%$ .1:日 $1.54+115$ 1301 1.56it 116 $.132 \quad 1.58411 \%$ $.1334 \quad 1.6014,118$ .135 1.1050 $.133^{2} \quad 1.645 \mid$ .139 1. rists 1:1 .141 1. kxit 182 $.14: 31.7180123$ .144 1. 120101 146 1.78 1980 $.11 x$ 1. Tral $1: 0$ .149 1.7.1 12\% $.151 \quad 1.813198$ \begin{tabular}{l|l|l}
.153 & 1.834 & 129
\end{tabular} $.155 \quad 1.855 \mid 130$ $\begin{array}{lll}15 \% & 1.86 \% & 131\end{array}$ $.15 \% \quad 1 . \times 9 \times 132$ 1601 1.9:21 $13: 3$ .162 1.94: 134 $.164 \quad 1.9633135$ .165 1.945130 $.16 \%$ 2.16\% $13 \%$ $.169 \quad 2029138$ $.1 \% 139$ 173 2.0\%3 141) .15.5 2.146 141 .17 $2.11814 \%$ .178 2.140143 $.180 \mid 2.163 .144$ 
Discharges in secomet-fert. resetmmgntar

\begin{tabular}{|c|c|c|c|c|c|c|c|c|c|c|c|c|c|c|}
\hline & \multicolumn{2}{|c|}{ Head. } & \multicolumn{12}{|c|}{ Length of weir. } \\
\hline & 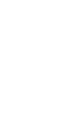 & 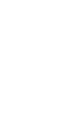 & $\underset{\forall}{\vec{H}}$ & $\stackrel{B}{=}$ & $\dot{\Xi}$ & $\begin{array}{l}\vec{\Xi} \\
\stackrel{\overrightarrow{0}}{-2}\end{array}$ & 音 & $\underset{x}{\vec{I}}$ & 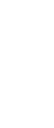 & 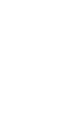 & $\underset{\infty}{\stackrel{4}{4}}$ & $\begin{array}{l}\dot{\Xi} \\
0 \\
\vdots \\
0 \\
0\end{array}$ & $\underset{ \pm}{+}$ & 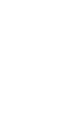 \\
\hline 145 & 9,1 & 0) & & & & & & & 4.04 & 5.133 & 6. 2266 & ๘.319 & $8.411^{\prime}$ & $9.504^{\prime}$ \\
\hline 146 & 9t & .769 & & & & & & & $4.0 \mathrm{~s}$ & 5.184 & 6. 288 & ז. 398 & $8.496^{\prime}$ & $9 . f(x)$ \\
\hline $14 \%$ & $9_{16}^{3}$ & .765 & & & & & & & 4.12 & 5. 2355 & 6. 351 & ז.466 & 8.581 & 9.697 \\
\hline 143 & 91 & . & & & & & & & 4.16 & 5.286 & 6.413 & 7.540 & 8.66" & 9. 794 \\
\hline 149 & $9_{16}^{5}$ & . 776 & & & & & & & 4.19 & 5. 338 & 6. 476 & ก.614 & 8. 753 & 9. 891 \\
\hline 150 & 98 & .781 & & & & & & & 4.23 & 5.389 & 6.539 & 7.689 & 8,839 & 9.988 \\
\hline 151 & $0 \frac{7}{16}$ & .786 & & & & & & & 4.28 & 5. 411 & 6. 602 & 7.763 & 8.925! & 10. 086 \\
\hline 152 & 92 & . & & & & & & & 4. 32 & 5.492 & 6. 665 & i. 838 & 9.011 & 10.184 \\
\hline 153 & $9_{1 \mathrm{a}}^{8}$ &.$\pi 9 \pi$ & & & & & & & 4.36 & 5.544 & 5. 729 & ז.913, & 9. 197 & 10.282 \\
\hline 154 & $9 \frac{5}{8}$ & .802 & & & & & & & 4.40 & 5. 596 & 6. 792 & ¡.988 & $9.18 t$ & 10.380 \\
\hline $15 \tilde{5}$ & $\begin{array}{l}91 \\
916\end{array}$ & $.80 \%$ & & & & & & & 4.44 & 5. 648 & 6. 856 & 8064 & 9.2 27 & 10.479 \\
\hline 156 & $99^{\prime}$ & .812 & & & & & & & 4. 48 & 5. 701 & 6.921 & 8140 & 9. 359 & 10.579 \\
\hline 157 & $4: 13$ & .818 & & & & & & . & 4.52 & .7. 764 & (6. 985 & 8216 & 9. 447 & 10. 678 \\
\hline 158 & $9 \frac{97}{4}$ & .823 & & & & & & & 4.56 & 5.806 & 7. 049 & 8.292 & 9.534 & 10. $\pi \sigma^{2}$ \\
\hline 159 & $9 \frac{1}{16}$ & .828 & & & & & & & 4.60 & 5. 858 & ־.113 & 8368 & 9.623 & 10. $47 \%$ \\
\hline 160 & 10 & . & & & & & & & 4.64 & 5. 911 & 7.177 & 8.444 & 9.711 & 10.977 \\
\hline
\end{tabular}


weirs neth rond antroctions-Continned.

\begin{tabular}{|c|c|c|c|c|c|c|c|c|c|c|c|c|c|}
\hline \multicolumn{11}{|c|}{ Length uf wir--continued. } & \multicolumn{2}{|c|}{$\begin{array}{l}\text { Addition for } \\
\text { increase of } \\
\text { length. }\end{array}$} & \\
\hline 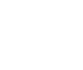 & $\underset{\uplus}{\sharp}$ & 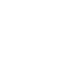 & $\underset{+}{ \pm}$ & $\stackrel{\leftrightarrows}{=}$ & $\stackrel{ \pm}{\equiv}$ & $\begin{array}{l}\stackrel{4}{4} \\
32\end{array}$ & $\stackrel{ \pm}{ \pm}$ & 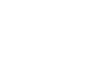 & 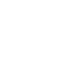 & $\begin{array}{l}\dot{4} \\
\overline{\overline{3}}\end{array}$ & $\stackrel{\dot{\Xi}}{\Xi}$ & $\dot{\sharp}$ & \\
\hline $1: 51 \%$ & $12.5 \times 2$ & 1t.SKii & $\mid 16.153$ & $1: 1,2328$ & a1..in & 25.614 & $3(1.265$ & :H4.6ists & ; & $43.3 \% 6$ & $0.18 \%$ & 2.18 .5 & 145 \\
\hline $10.71 H^{\prime}$ & $1 \% 913$ & 15.121 & $17.3: 9$ & 10,53 & 21. 14,5 & $2 i .16 i 1$ & $30.5 \%$ & & 39.411 & 43.8026 & .184 & 2.218 & 146 \\
\hline $111.81: \div$ & 13.04:3 & 15.20 & $15.5(1.5)$ & 19. & PL.SBiti & $26.4 \% 4$ & $: 30.869^{\prime}$ & 35.3 .51 & 39.:1:3 & 44.254 & $.1 \times 6$ & 2.231 & 147 \\
\hline 10.924 & $13.1 \% 4$ & 15.428 & $17.6 \times 1$ & 19.935 & 济 $1 \mathrm{ks}$ & 26.6945 & $31.20 \times 3^{\prime}$ & 35.711 & $40.21 \%$ & 44.724 & .188 & 2.254 & 148 \\
\hline 11.1193 & 13.8066 & $15.58 \%$ & 17.459 & 21). 135 & 22.412 & $26.96,5$ & $31.51 \%$ & $35.0 \% 1$ & 41.684 & $45.1 \%$ & .190 & $2.2 \%$ & 149 \\
\hline $11.134^{\circ}$ & 13. $433 x$ & 15. 73 & $18.033_{1}$ & : (1).3396 & $22.634 i$ & $2 \pi .2351$ & 31.434 & 365.433 & 41.032 & t5. $\operatorname{lin} 31$ & .192 & 2.300 & 150 \\
\hline $11 . \approx 4$ & $13.5 \%$ & 15. & $1: 215$ & 201.5:57 & 22. & $2 \pi .50 \%$ & 32.150 & 36.797 & 41. 441 & 46.08 .5 & .194 & 2.328 & 151 \\
\hline 11.356 & 13. & $16.04 x$ & $18.3 x 3$ & $20 . \pi 39$ & 23.084 & $2 \pi . \% 6$ & $32.46 \pi$ & 36.15 & 41.849 & 46.540 & .196 & 2.346 & $15:$ \\
\hline 11. $4\{t \mid x\}$ & $13.833^{-1}$ & 16.204 & 13.583 & $20.941_{1}^{\prime}$ & 23.310 & $2 \times .048$ & 39.785 & $3 i .523$ & 42.261 & 4li. 998 & 197 & 2.369 & 1.3 \\
\hline $11.5 \% 6 !$ & 13.969 & 16.361 & 18.753 & 21.145 & $23.53 \%$ & 29.321 & 33.105 & 37.890 & $42.6 i 1$ & ti. $45 \mathrm{~s}$ & . 1996 & 2.392 & 154 \\
\hline $11.68 \%$ & $14.102^{\prime}$ & 16.517 & 15.923 & $21.348^{\prime}$ & 23. 664 & 22.594 & 33.425 & 38.28k & 43.045 & 71.918 & .201 & 2.415 & 155 \\
\hline 11. 598 & $14.234^{\prime}$ & $16.6 \pi 6$ & $19.1+5$ & 21.573 & $23.9+2$ & $2 \pi .870$ & 33.747 & $34.6 \pm 5$ & 43.5113 & $48.3 \times 1$ & .2103 & 2.439 & 156 \\
\hline 11.9ng & 14.322 & 16.834 & $14.29+4$ & $21 . \pi 58$ & 24.221 & 29.145 & $34.0 \% 0$ & 38.995 & 43.919 & 48.844 & .215 & P. 462 & $15 i$ \\
\hline 12.020 & 14.506 & 16.992 & $19.4 \pi$ & 21.963 & 24.449 & 29.421 & 34.392 & 39.364 & 44.3336 & $49.301 \%$ & .207 & $2.4 \times 6$ & $15 \mathrm{~K}$ \\
\hline 12. 132 & $14.6 \pm 2$ & $1 \% .151$ & 19.661 & 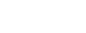 & 24.680 & $\approx 9.699$ & 34.718 & 30. 735 & 44.756 & 49. & 2019 & 2.510 & 159 \\
\hline 12.244 & 14. $\pi \%$ & 17.310 & $19.9_{43}$ & 20.316 & 24.911 & 29.976 & 35.1143 & 41.109 & 4.5. 175 & 50.242 & .211 & 2.533 & 160 \\
\hline
\end{tabular}




\section{TRIINFALI TABLES.}

The following records of precipitation are arranged alphabetically by comities:

Recomed of preripitation at Tramarack, Alpine Connty.

[Latitude, $33^{\circ}: 37^{\prime}$; longitude, $119^{\circ} 5 \mathrm{x}^{\prime}$; devation, $8,(13)$ feet. Authority, . . C. Huntington.]

\begin{tabular}{|c|c|c|c|c|c|c|c|c|c|c|c|c|c|}
\hline Yoar. & Sept. & oct. & Nov. & Doer. & Jant. & Fut. & Mar. & Apr. & May. & Jine. & July. & Ang. & Total. \\
\hline $1898-1899$ & & & & & & & $1: 2 \times 0$ & 2.50 & 1.75 & $0 .(n)$ & 0.00 & 0.001 & " 17.05 \\
\hline 1899-1900 & $0 .(4)$ & 6. 10 & 4.25 & $\therefore 10$ & $3 .(6)$ & 2.45 & 6.65 & 4. 60 & 0.65 & $0.00)$ & 0.00 & 0.00 & 36.20 \\
\hline 1900-1901 . & 0.1001 & 3.30 & 8.50 & 2.05 & 13. (its & 15.90 & 4.30 & 6. 40 & .95 & 0.39 & $\mathrm{~T}$ & 3.17 & 58.71 \\
\hline 1901-1902 & 1.60 & 2.69 & 3.22 & 2.38 & 3.37 & $13.00)$ & 11.35 & 4. 60 & 1. 68 & $0.00)$ & 0.00 & 0.00 & 43.89 \\
\hline$y e$ & & & & & & & & & & & & & 46.27 \\
\hline
\end{tabular}

"Year incomplete.

Recort of precipitation at Jackson, dmater county.

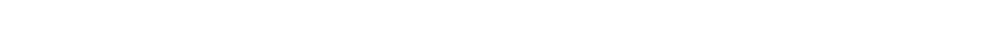

\begin{tabular}{|c|c|c|c|c|c|c|c|c|c|c|c|c|c|}
\hline Year & pt. & Oct. & Nov. & Dec. & Jan. & Feh. & Mar. & Apr. & & & July. & Ang. & Total. \\
\hline 7 & 0 & 0.70 & 2.010 & 1.45 & 8.45 & 13.104 & 5.55 & 1.97 & 0.24 & 014 & 0 & 0 & 33.44 \\
\hline & 0.05 & .97 & .86 & .70 & 5. $51 j$ & 5. 26 & 6. 97 & 4.97 & 2.10 & .25 & 0 & 0 & 27.78 \\
\hline & 0 & 2.92 & 4.33 & 5.38 & 2.30 & 3.44 & 3.51 & 13.59 & 2.41 & (i) & 0 & 0 & 37.88 \\
\hline & 0 & .15 & .60 & 10. 45 & 8.86 & $4 . \pi$ & 2.11 & 2.96 & 0 & .05 & 0 & 0 & 29.97 \\
\hline & א & 1.38 & 1.82 & 5. & 3.86 & 3.89 & 7.71 & 3. 52 & .49 & .10 & 0 & 0 & 88.87 \\
\hline & .75 & 5. 6: & 3.34 & 1.44 & 3.61 & 1.95 & 3.85 & 2.25 & 4.63 & 0 & 0 & 0 & ז. 44 \\
\hline & .90 & 1. 43 & 1.48 & 1.59 & 4.02 & 8.58 & 9.41 & T. 65 & .99 & 1.85 & 0 & 0 & 6.90 \\
\hline 1884 & .26 & 1.70 & .10 & 14.64 & 1.89 & $.2 \pi$ & .26 & 1.34 & .15 & .59 & 0 & 0 & 21.20 \\
\hline & .23 & 0 & 12.80 & 2.78 & $\tau .9 \%$ & .75 & 4.54 & 8.04 & 0 & 0 & .01 & 0 & $3 \pi .12$ \\
\hline & & & 1.118 & 8.113 & 3.21 & 3.03 & 4.89 & 2. 70 & 3.85 & .46 & 0 & & a 27.25 \\
\hline & .40 & & 7.48 & $5.5 \%$ & & & & & & 0 & .04 & 0 & "13.44 \\
\hline & 1.34 & .50 & 5.28 & 3.35 & 9.88 & 10.81 & ‥5? & 1.38 & 4.15 & 1.48 & $\mathrm{~T}$ & $\mathrm{~T}$. & 40.72 \\
\hline & 1.10 & 3,68 & 1.10 & $15.50)$ & 12.04 & 15.22 & 3.86 & 3.92 & 2.68 & 0 & .07 & $\mathrm{~T}$. & 50.17 \\
\hline & 1.14 & .28 & .93 & 3.97 & 8.79 & .43 & 5. 18 & 10.89 & 2.11 & 0 & .04 & $0.1 x$ & 33.64 \\
\hline & .23 & 1.35 & 8.78 & t. 611 & t. $\pi \%$ & 5.04 & 7.66 & 1.46 & .03 & 1.10 & 0 & .12 & 35. 15 \\
\hline & .19 & $3.0 \tilde{7}$ & 2.25 & 3.18 & 1.47 & 4.91 & 1.18 & 1.11 & 1.64 & .43 & 0 & 0 & 9.41 \\
\hline 0800 & .40 & 1.114 & 2.11 & 2.70 & 5.20 & $.5 \pi$ & 14.60 & 1. 49 & $1.0 \%$ & 1.00 & 0 & $.0 \pi$ & 30.25 \\
\hline 189 & 11 & 5. 86 & 5.81 & 7.45 & 2.37 & 2.15 & 4.37 & 3. 52 & 1.83 & .06 & 0 & 1) & 33.42 \\
\hline & .41 & 2.74 & 8.39 & 2.24 & $\gamma .13$ & 11.24 & 2.58 & 3.83 & 1.18 & .08 & T. & T. & 39.74 \\
\hline $1901-2 \ldots$ & 3.39 & 2.62 & 3.64 & 3.22 & 1.25 & 9.36 & 4.37 & 2.71 & 1.99 & .15 & n) & $\mathrm{T}$. & 32.70 \\
\hline & & & & & 3.82 & & & & & & & & 33.16 \\
\hline
\end{tabular}

a Year incomplete 
Record of precipitation at Little Stony, Coluse conty.

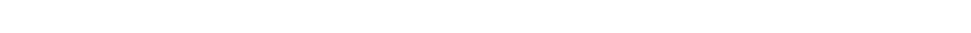

\begin{tabular}{|c|c|c|c|c|c|c|c|c|c|c|c|c|c|}
\hline Year. & Sept. & Oct. & Nor. & Dec. & Jan. & Feb. & Mar. & Apr. & May. & Jure. & July. & Aug. & Total. \\
\hline $1884-85$. & & & & S. 41 & 1.299 & 1.114 & 0 & 1.38 & 0 & 1.14 & 4) & 0 & a 13.30 \\
\hline $1885-86 \ldots \ldots$ & 1) & $0.2 \tau$ & 13.29 & 3.51 & 3.44 & 0 & 1.10 & 3.89 & & & & & (425.51) \\
\hline
\end{tabular}

"Year incomplete. L

Record of precipitation at ILome Diablo. Comtire Costa County.

Latitude, $37^{\circ} 5: 3^{\prime}$; longitude, $1: 21^{\circ} .5 t^{\prime}$; elevation, 3.848 feet. Authority, Par.jic Railway system. J. ... Hall.]

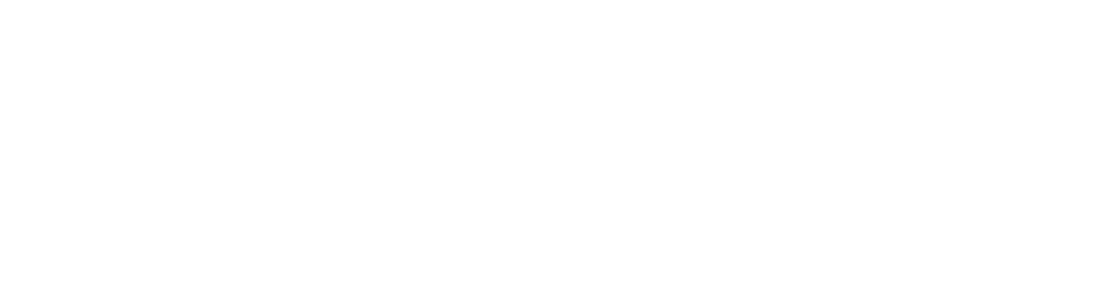

Record of precipitation at Eldorado, Eldorado C'ominty.

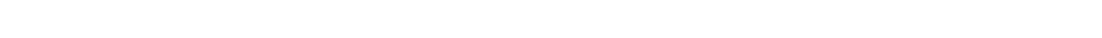

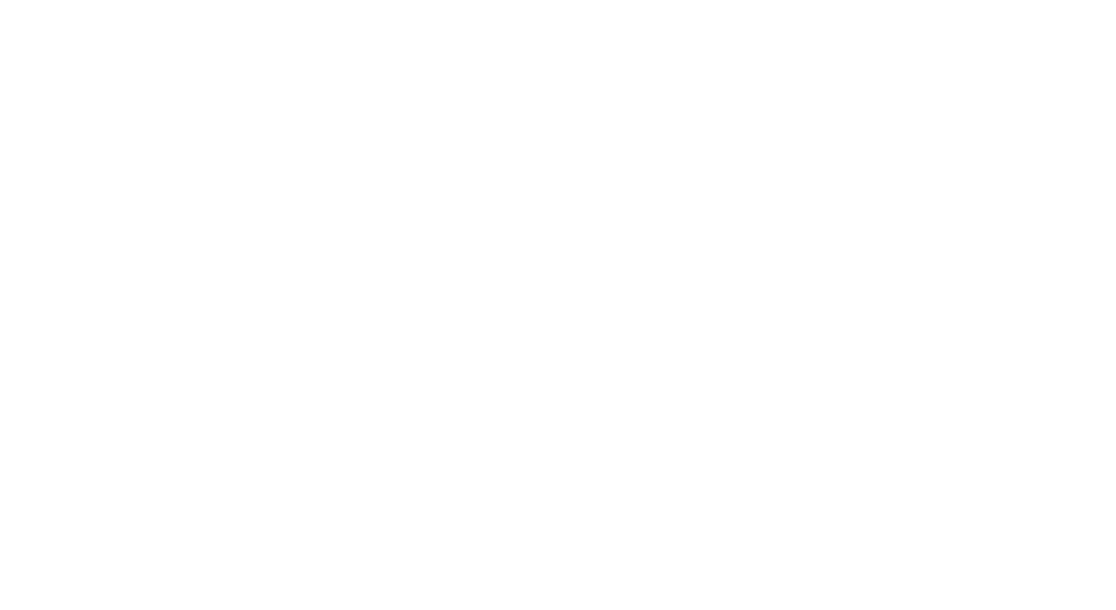

aYear incomplete. 


\section{Re'orr of precipitation at Georgetoun, Eldorado County.}

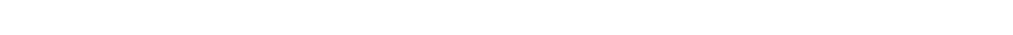

\begin{tabular}{|c|c|c|c|c|c|c|c|c|c|c|c|c|c|}
\hline $\begin{array}{c}\text { Year. } \\
-\end{array}$ & Sept. & Oct. & Nov. & Dec. & Jan, & Feb. & Mar. & Apr. & May & 'June. & July & Aug & Tot \\
\hline $72-733$ & (1) & 0 & 4. $3(3)$ & 14.20 & 4.08 & 13.45 & $3 .(5)$ & 3.11 & 0.12 & 0 & (1). 113 & 0 & \\
\hline $3-\pi 4$ & 0 & 0.61 & .55 & 16.6011 & 16.60 & 8.113 & 13.87 & 5.80 & 1.32 & .20 & 0 & & \\
\hline-75. & 11 & 3.86 & 14.60 & 1.24 & $17.8 \pi$ & .04 & 5.07 & .31 & 2.103 & 2.06 & 0 & & \\
\hline-7 & 0 & 1.90 & 24.12 & 10.85 & 13.1199 & 9.97 & 14.54 & 4. 78 & 1.22 & 0 & $\pi$ & & \\
\hline 66-ז6- & 4 & $11.4 \pi$ & 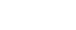 & 0 & 12.44 & 2.14 & $\tau .78$ & 1.74 & 3.87 & 24 & 0 & 0 & \\
\hline$\pi /-i \gamma$ & 0 & 1.03 & 4.30 & $1.9 \tilde{t}$ & 16. $: 1$ & 22.78 & 10. 92 & 2.93 & .94 & 12 & 0 & & \\
\hline i8-79. & .667 & 2.56 & 2.666 & .48 & 11. :34 & 12.41 & $1 \pi .57$ & 9.65 & 3. 39 & .34 & & & \\
\hline $69-8$ & 0 & 3. 85 & 1..25 & 11.73 & $5.4 \pi$ & 6.00 & 5.50 & 25.633 & 5.97 & 0 & 0 & 1 & \\
\hline $80-K 1$. & () & .18 & .37 & $22.6 \%$ & $20 . \times 3$ & 12.85 & & 2.40 & .40 & 2.28 & & & \\
\hline $1-82$ & $\therefore .013$ & 4,23 & 3.30 & 10.32 & 8,59 & 5.88 & 10. 44 & 7.11 & 2.46 & .18 & & & \\
\hline-83. & .16 & $\pi .05$ & $\pi .101$ & 3.31 & 4.70 & 3.18 & 8. & 3.87 & 6.8 & 0 & & & \\
\hline $33-8 t$ & 1. (ti) & 4.10 & 1.94 & 3.50 & 7.53 & 13.80 & 19.94 & $15.0 \pi$ & 1.52 & 3.65 & & & \\
\hline$f-85$ & .80 & 3.54 & .10 .3 & $33 . \pi 3$ & 436 & $.8 \%$ & .24 & 3.98 & .19 & 2.28 & 03 & 9 & \\
\hline $85-86$. & 116 & 1) & 20.7 & $\tau .113$ & 18.32 & 1.16 & 7.75 & $15 .(1)+$ & 1.76 & .116 & 0 & 0 & 73 \\
\hline $36-8{ }^{2}$ & 0 & 343 & 1. 79 & B. 90 & 3.36 & 15. 79 & 2.40 & 654 & .93 & .18 & 0 & 0 & \\
\hline & .53 & 0 & 1.44 & 7.666 & $14 . \approx 1$ & 3.14 & 6.02 & 1.18 & .38 & 1.56 & 144 & 0 & \\
\hline $88-89$ & .41 & 11 & $4.6 \%$ & 7.99 &.$t$ & .68 & $1: 2.29$ & $2 . \pi \pi$ & 7.0\% & 25 & 0 & & \\
\hline ). & 1) & 10.45 & 1.沙 & 22.94 & 19.90 & 8.96 & 14.7 & 3.86 & 4.66 & .10 & 11 & 1 & \\
\hline & 2.81 & 19 & $\mathrm{~T}$. & (7.65) & . & 10.39 & 10. & 3.99 & $\therefore .71$ & 2.22 & 42 & 8 & \\
\hline & $1 \pi$ & 1.80 & 1.59 & 3.74 & & x. 44 & & $4 \pi$ & is & 38 & & & \\
\hline & $.5 \pi$ & & & 15.76 & & & $1 \%$. & & & 0 & & T. & \\
\hline & $2.14 ;$ & 1. 60 & & 18 & & 16.25 & & HI & 五洗 & 1.61 & $\mathrm{~T}$. & & \\
\hline & 1. & (i. & & : 20.93 & & i. 69 & & & 4. 30 & 0 & .08 & & \\
\hline & 2.64 & (1) & & $\pi .2 \%$ & 19. & $\pi$ & 11. & 16.51 & $4.8 \mathrm{~L}$ & 0 & .20) & & \\
\hline & .83 & 1.76 & 16.18 & 6.37 & & 18. 26 & 13. & 2.411 & .20 & 1.00 & 0 & .144 & \\
\hline & .30 & & & $5.5 \tilde{z}$ & & 8.83 & & 9 & 2.78 & 1.23 & 11 & $\mathrm{~T}$ & \\
\hline & .53 & 2. $2 * 2$ & 4. 34 & 3.35 & & .61 & 21.39 & 1. 60 & $\therefore .3 \%$ & 1.61 & 0 & $.1 t$ & 5. \\
\hline & 0 & $9.8 \%$ & 10.33 & 11.91 & & 1.29 & & $5,1 t ;$ & 1.88 & .13 & .08 & 0 & \\
\hline & 1.00 & 5.4 & & 4.16 & 10. & & & 48 & .99 & 0 & $T$. & $T$ & \\
\hline $901-$ & 4.50 & 3. 32 & 4.72 & 5.51 & $1 .(n)$ & 1695 & $6.4 \tilde{i}$ & 3.64 & 1.44 & .56 & 0 & .05 & \\
\hline
\end{tabular}




\section{Record of precipitation at Placerville, Eldorabo county.}

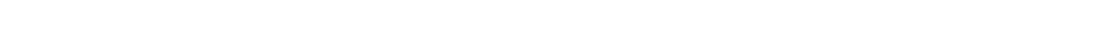
Railway system.]

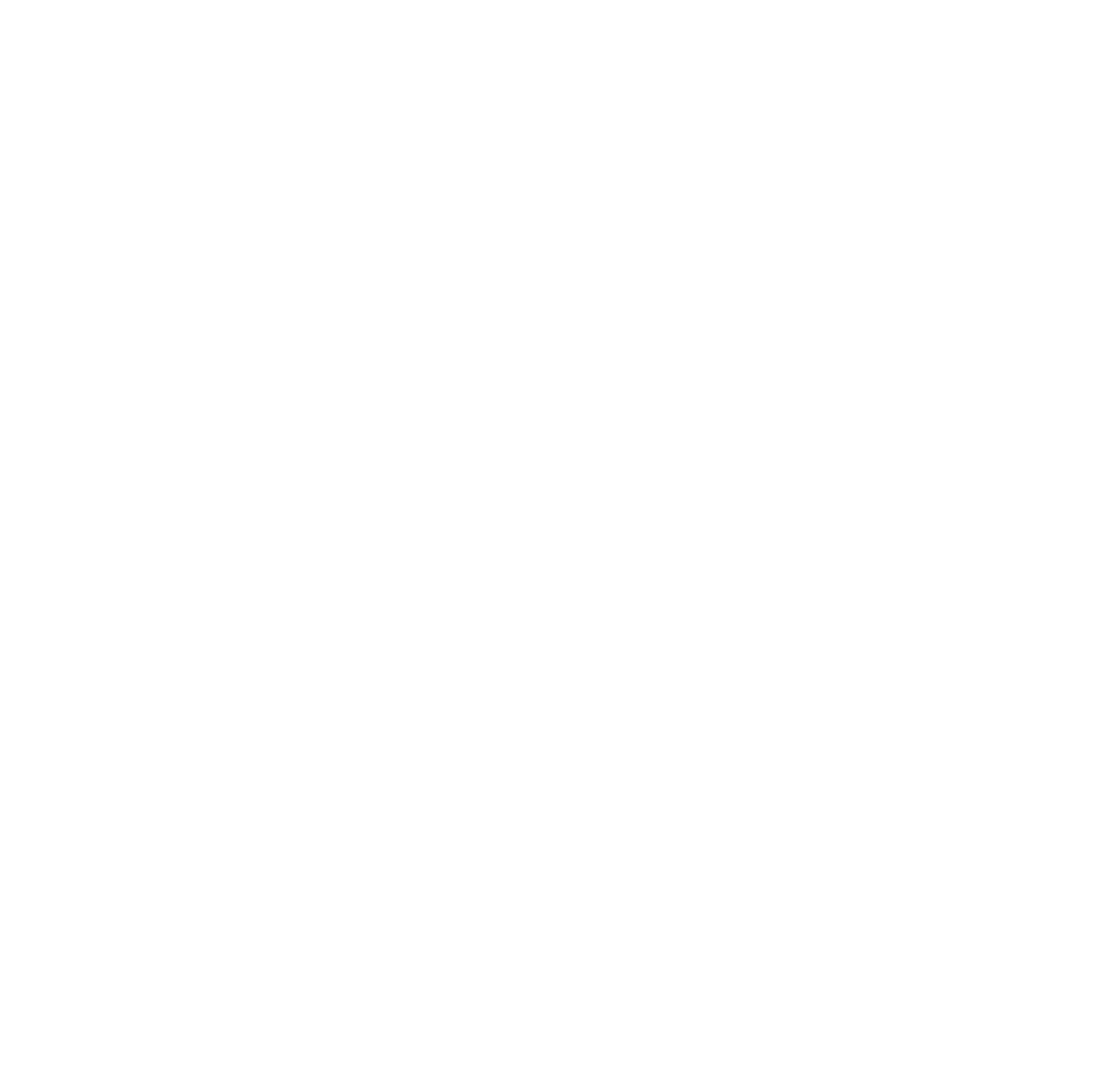


Reard of precipitation at Shingle Spuings, Eldorado Connty.

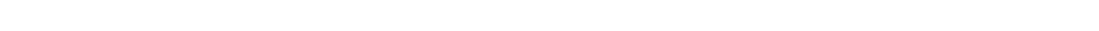
way fystem. 1

\begin{tabular}{|c|c|c|c|c|c|c|c|c|c|c|c|c|c|}
\hline Year. & sept. & oct. & Nor. & Deer. & Jan. & Feb & Mar. & Apr. & May. & June. & July & Aug. & Tot: \\
\hline $1849-50$. & 0 & 0.188 & . & 10.144 & 13.17 & 2.15 & 6. & 0.45 & 0.02 & 10 & 0 & 11 & 34.20 \\
\hline 185051. & 1.23 & 10 & (5i) & 2.70 & 4.80 & 40 & 2.111 & 4.80 & .40 & 0 & 0 & (1) & 16.18 \\
\hline $18.11-i):$ & .411 & (3) & $\therefore .5$ & 7.80 & 3.201 &. .50 & (9. (8) & ז & 1. (k) & 0 & 0 & "1 & 32.50 \\
\hline - & 11 & .50 & $\because 20$ & 11.40 & 13. $\tilde{* 0}$ & 2.40 & ‥21 & 8.101 & 1.10 & 0.0 .5 & 0 & 0 & 47.55 \\
\hline $1873-i 44$ & 1. 20 & . & 6. 41) & 4.10 & 4. 40 & 3.40 & 4.34 & 5.40 & .20 & .31 & 0 & ") & 1.45 \\
\hline $1854-5 \tilde{5}$ & 0 & 3.20 & 10.7) & 3.50 & 3.80 & 1.10 & 2.50 & 2.10 & .68 & 11 & 0 & 0 & 19.50 \\
\hline 185,566 & . & 17 & 2.41 & .711 & 4.10 & .80 & 3.41 & 1.90 & . & .10 & (1) & (1) & 8.6 \\
\hline $1856-64$ - & 0 & 11 & $\therefore .15$ & 6.35 & (i. .00$)$ & $\approx 05$ & 1.94 & 0 & $.4: 2$ & \%) & 0.35 & () & 9.1 \\
\hline $185 \%-5$ & 11 & .42 & t. 04 & 1.469 & 2.37 & : 69 & t. (1) & 1. 60 & 201 & . & 0 & 0 & 8.01 \\
\hline $1 \times 58-59 \ldots$ & 0 & 3.25 & . & $(1: 21)$ & 1.22 & $1: 2 .(x)$ & 5.81 & 1. $\$ 2$ & 1.51 & 0 & 0 & 1 & 2.3 \\
\hline $1859-60$ _ & 0 & .15 & 11.16 & $\therefore 411$ & $\therefore 231$ & $1.1 \%$ & 4. .1 & 3. 411 & 2.111 & . (1) & . & (1) & $8.10=$ \\
\hline $60-61-$ & 0 & 1. 20 & .511 & 7. 43 & $3 . \pi$ & 4.60 & R. 3 is & . & .15 & . 155 & 0 & 1 & b. \\
\hline $61-62-$ & 0 & ") & (i. (9) & 11.22 & $8+13$ & (6. $\pi$ & (6.9) & ia: & 4.10 & 1.90 & 2.54 & 1) & 1.4 \\
\hline $1862-163$. & 0) & is & $.3 \%$ & $\therefore .84$ & 1.4 .5 & 4. $\$ 4 ;$ & 4.01 & 2. & $\therefore 10$ & 0 & 0 & 1) & 9.2 \\
\hline $1863^{3}-1 j 4$ & 0 & 0 & 0.15 & 6.301 & 7.28 & 3.21 & $\{i 3$ & 3.4 & ...5 & 11 & () & 0 & 4.: $Z$ \\
\hline $1864-6 n$ & 0 & . lik & 9.94 & (9. 13 & 5. 13 & 5.63 & 1.13 & :.50 & .89 & 0 & () & (1 & 4.4 \\
\hline $1865-66 .$. & 1) & .45 & 6. .84 & 2.5 & 11.18 & 3.46 & 6.21 & 1.31 & $48 i$ & $.1 k$ & 1) & 0 & $6.98 \mathrm{C}$ \\
\hline $1866-61$. & 1) & 11 & 4.73 & $18 . i 7$ & 9.17 & 7.51 & +104 & ti. 19 & 111 & 11 & 0 & 1) & 1). \\
\hline $186-68$ & 列 & $\therefore 4$ & $i 1 i$ & 6 & 19.12 & 3. 3. & $1+.3: 4$ & & & & & & \\
\hline $1885-860^{6}$ & $\cdots$ & $\ldots$ & $\cdots$ & 4.99 & 10.7 & 69 & 3.84 & 9. & .11 & & & & $15 x_{1} .31$ \\
\hline $36-87$ & $\ldots \ldots$ & 1. 6 (iti & .93 & 3.50 & 1.67 & 12.21 & $1.4 \%$ & & $.16 \%$ & () & & & $4: 21.48$ \\
\hline $4-88 \ldots$ & $.4 !$ & T. & 1.014 & fi. 16 & $8.8 \%$ & 1. $10 \mathrm{x}$ & 4.泾 & 43 & .18 & 31 & 0 & 11 & 2.8 \\
\hline $1888-89 \ldots$ & 0 & 11 & 4.45 & 4. 4.i & .411 & (1) & 9.01 & $1.9 k$ & 7.80 & 1) & 0 & 0 & \\
\hline $1889-910 \ldots$ & () & 8.73 & i.xi & 17.35 & 13.50 & (6. 71$)$ & 10.48 & : is & 3.65 & 0 & 1) & 0 & \\
\hline $1 \times 90-91$ & 1 & .118 & 0 & 5. (1) & 1. 41 & $\pi(t)$ & $\pi .9 \pi$ & 3.80 & 1.60 & . & 0 & 11 & 1.11 \\
\hline $1891-92$ & .04 & (1) & 1.10 & $75 x$ & 2.5 & (i. 43 & 4.95 & 2.26 & 1.98 & (1) & 0 & 1 & \\
\hline 12-93. & .15 & 2.30 & $i x .5$ & 8.25 & +.97 & 4.17 & 9. ix & 2.95 & זיר & (1) & 0 & () & \\
\hline $1893-94$ & $.4 \pi$ & .411 & 4. 95 & $33(3)$ & $\therefore .0 \%$ & (1. 4) & 1. $\left(0^{0}\right)$ & 1.03 & 3 & דיבי. & 11 & 0 & \\
\hline . & 0 & 3.5 & 9 & 145 & 11.33 & 4.48 & 1.98 & $\because 200$ & $1 . \%$ & 0 & 11 & (1) & 1.7 \\
\hline & 1. +0 & .15 & 8.53 & 3.65 & $1+1 i$ & .30 & 16.3\% & 8.21 & 1. $\%$ & (1 & 0 & 11 & 4.5 \\
\hline & 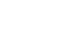 & 1.115 & $11 . \pi$ & 7.18 & 4 & 12.6 & 6.010 & 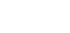 & . & .31 & 0 & 0 & 57 \\
\hline & 0 & 2.15 & $1 .+11$ & 3.25 & .93 & 3.80 & in & 40 & 210 & . 62 & 0 & (1 & 4.64 \\
\hline & 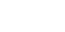 & .811 & 1.90 & 3.05 & $4 . N \pi$ & $3 x$ & 14.13 & firt & 1.08 & 1.2... & 0 & .15 & 8.65 \\
\hline $1 \times 99-1 !(k(1)$ & () & 6.25 & 6. 29 & 7.30 & & & & & & & & & a $19 \mathrm{xt}$ \\
\hline & & & & & & & & & & & & & 6.4 \\
\hline
\end{tabular}

"Year inromplete.

Recond of preceipitation at Jacinto, colemn comenty.

[Latiture, 390 35': longitude, 1:28' a1', elevation, 110 fect.]

\begin{tabular}{|c|c|c|c|c|c|c|c|c|c|c|c|c|c|}
\hline Yeatr. & Sept. & $(x+t$ & Nor: & Dete & Jan & Fel, & Nar. & $A_{1} r^{\prime}$ & May & June & July'. & Aug. & Total. \\
\hline $189: 2 ! 133_{2}$ & 11. 628 & 1.21 & (6.3: & 8.13 & t.211 & 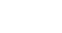 & 3.71 & $11.4 \pi$ & $1.4 t$ & 0 & (1) & 0 & 29.49 \\
\hline $1893-94$ & .4 & $.1 k_{i}$ & $2.6 \%$ & 1.til & 4.51 & $1+\pi$ & .89 & 51 & 1.24 & 0 & 0 & () & 13. $4:$ \\
\hline $1894-95$ & 1.31 & 1.33 & 35 & 869 & S. 83 & 1.86 & 174 & $24 !$ & $.2 \%$ & (1 & 0. .36 & 0 & 26.97 \\
\hline $1895-4$ & 2.33 & 0 & 1.10 & 94 & 9.37 & 24 & 2.92 & 410.3 & .69 & 0 & 0 & (1. .52 & 22.14 \\
\hline $1896-4$ & 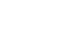 & .168 & 3. 06 & i). 20 & 3.48 & $3.5 t$ & $1 . \%$ & $\pi$ & (6) & 0. 44 & 1) & 0 & 200.5 \\
\hline $1897-$ & 11 & 3.12 & 1.16 & 1.411 & 6 6 & $3.4: 2$ & 31 & 200 & (1) & 0 & 0 & 0 & 11.24 \\
\hline $1898-6$ & .35 & .41 & 0. 4.9 & 1.34 & $6.3 t$ & 11 & 4. & .36 & 1.21 & .5.3 & 0 & () & 15. 39 \\
\hline $1899-$ & 0 & 2.64 & 4.411 & 3.41 & $3.14 \mathrm{i}$ & .16 & 1.25 & 168 & .72 & 0 & (1) & 0 & $17.3 \pi$ \\
\hline $19(\mathrm{~K})-1+\mathrm{k}) 1 \ldots$ & 13 & 242 & 5. (k) & & & & & & & & & & ' $\tilde{2} .42$ \\
\hline & & & & & & & & & & & & & 19.57 \\
\hline
\end{tabular}




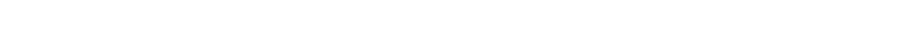

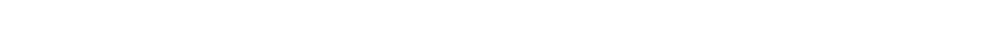

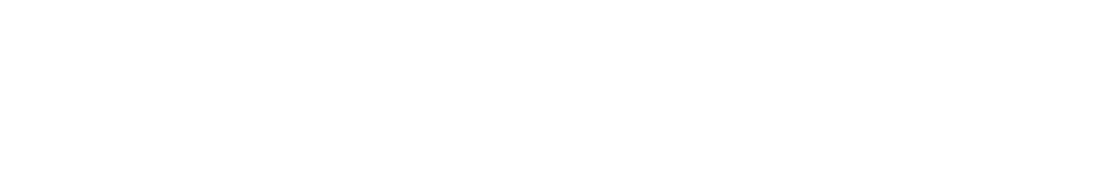

"Yuar incomplete.

Resom of precipitation at christmes. Prairie, Humboldt county.

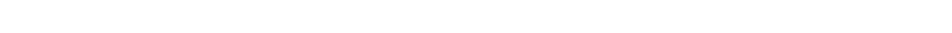

\begin{tabular}{|c|c|c|c|c|c|c|c|c|c|c|c|c|c|}
\hline Year. & SeIt. & (x.t. & Nor. & Dec & Jall. & Fel. & Mar. & Apr. & May. & Jume. & July. & Aug. & Total. \\
\hline $1883-84$. & & & & & & & & & & $1.5 \mathrm{t}$ & 11.24 & 0.011 & $\| 1.81$ \\
\hline $1884-85 \ldots$ & 3.23 & $2.1 i$ & $1: 3$ & 26.44 & 879 & 839 & 1.45 & 3.30 & 1.34 & $1.5 i$ & 0 & 01 & 58.05 \\
\hline $188 j-86 \ldots$ & .98 & $1 .(5.5)$ & 3189 & 18.85 & 16.59 & 6 31 & ti. 51 & 12.97 & 2.83 & 0 & 1.17 & (1) & 99.79 \\
\hline $1886-\kappa_{i} \ldots \ldots$. & 1 & 4. $\tilde{i z}$ & 3.93 & 19. & $15.9 \%$ & 冷 & $5 .(k)$ & & & & $-\ldots$ & & $a 64.27$ \\
\hline year m & & & & & & & & & & & & & 58.92 \\
\hline
\end{tabular}

"Year incomplete.

Record precipitation at Bishop ('reek, Inyo County.

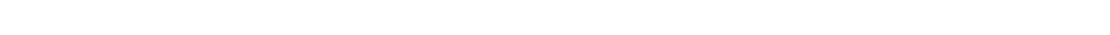

\begin{tabular}{|c|c|c|c|c|c|c|c|c|c|c|c|c|c|}
\hline Year. & Sept. & $(x) t$. & Noy. & Der. & Janl. & Feh. & Mar. & Apr. & May & June. & July. & Ang. & Total. \\
\hline $1883-84 \ldots$ & 0.12 & 0. 11 & 0 & 0.38 & 0.62 & (1. 64 & 0.94 & 0.05 & 0 & () & 0 & 0 & 2.86 \\
\hline $1884-85 \ldots$ & 0 & 11 & 0 & 1.001 & 0 & 0 & $.6 \%$ & .14 & 0 & 0 & 0 & () & 1.81 \\
\hline $1885-86$. & 0 & .02 & 0.35 & 0 & 1.08 & 0 & .001 & .38 & 0 & 0 & 0 & 0 & 2.28 \\
\hline $1886-8 \pi$. & 0 & 0 & 0 & 21 & .65 & $1 . \approx 5$ & 0 & .35 & 0.55 & 0.35 & 0 & 0 & 3.68 \\
\hline $1887-88$ & $.1 \%$ & .15 & (15.) & 1.10 & $1.3 \pi$ & .47 & .05 & 0 & 0 & .35 & 0.20 & 0 & 3.89 \\
\hline $1888-89 .$. & 0 & 0 & 1. $\%$ & .40 & .10 & . & 1. 46 & .12 & .30 & $\theta$ & 0 & $" 1$ & 4.60 \\
\hline $1889-9 x \ldots$ & 0 & . & .25 & 1. : & 4.5 & .301 & 0 & 0 & 0 & 0 & 0 & 0.50 & 7.13 \\
\hline $1890-91 . \ldots$ & 69 & 0 & 0 & 1.60 & 0 & 3.811 & $\therefore 8$ & 11 & 2.90 & 10 & 0 & .03 & 8. 60 \\
\hline $1891-92 \ldots$ & 19 & 11 & 11 & 3.59 & .10 & .70 & 1.10 & 0 & .25 & $\mathrm{~T}$. & 0 & 0 & 5.86 \\
\hline $1892-93 \ldots$ & 0 & 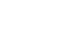 & $1.4 ?$ & 2.27 & 1.:2 & 1.12 & .15 & 0 & 11 & 0 & $1.0 \overline{5}$ & $\mathrm{~T}$. & 7.43 \\
\hline $1893-94$ & .19 & 11 & .10 & .49 & .30 & . & .09 & . 15,5 & $\mathrm{~T}$. & .25 & T. & .93 & 2.55 \\
\hline $1894-95$. & $\mathbf{T}$ & 1) & 0 & 1. & L. $10^{\circ}$ & . & Pי & 19: & .15 & .11 & $.2 \mathrm{~L}$ & $.0 \%$ & 3.83 \\
\hline $1895-96$ & $\mathrm{~T}$. & .16 & .15 & $\mathrm{~T}$ & $1.11 \%$ & 0 & .80 & . 11.5 & .03 & 0 & $.5 \pi$ & .06 & 2. 69 \\
\hline $1896-97 \ldots$ & .145 & $\mathrm{~T}$ & $T$ & $.16 i$ & $.3 x$ & $1 . t i \pi$ & 1.75 & 0 & .12 & $\mathrm{~T}$. & .01 & .15 & 4.13 \\
\hline $1897-98 \ldots$ & .09 & .34 & $\mathrm{~T}$. & .49 &.$(1.5)$ & .13 & $\mathrm{~T}$ &.$: 21$ & $\therefore \%$ & $\mathrm{~T}$. & $\mathrm{T}$ & $.196^{\circ}$ & 1.69 \\
\hline $1898-99$. & .41 & 0 & .21 & .11 & $1.6 \mathrm{3}$ & 11 & T. & .64 & $.0 \%$ & 0 & 0 & .0 .5 & 3.09 \\
\hline 1899-19(n). . & i) & .14 & .015 & 1.05 & .49 & .01 & .54 & .80 & .34 & .12 & $\mathrm{~T}$. & 0 & 3.34 \\
\hline $1900-1901$. & .39 & .03 & 2.69 & $.1 \%$ & 4.89 & 1.01 & $\mathrm{~T}$. & .50 & 1.29 & $\mathrm{T}$. & 0 & .93 & 11.90 \\
\hline $1401-2 \ldots$ & 0 & .81 & .61 & .12 & .01 & .5.5) & 1.53 & .61 & .066 & 0 & $\mathrm{~T}$. & .12 & 4.48 \\
\hline & & & & & & & & & & & & & $4.5 \%$ \\
\hline
\end{tabular}

" Year incomplete. 


\section{Recorr of mecipitution at Bear I'alley, Kern County.}

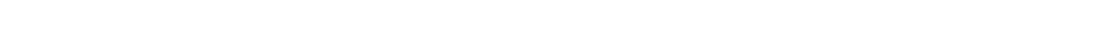

\begin{tabular}{|c|c|c|c|c|c|c|c|c|c|c|c|c|c|}
\hline Year. & Sept. & Oet. & Nov. & Der. & Jan. & Feb. & Mar. & Apr. & May. & June. & July & Aug. & Total. \\
\hline $1894-95$ & 1.48 & 6. 38 & 1.25 & $m .3 \pi$ & 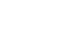 & ti. 154 & $i .42$ & 3.25 & $6.5 \tilde{\imath}$ & 0 & 0.04 & 0.21 & $84.8 \%$ \\
\hline $1895-96$ & 5. 18 & I.25 & 2.08 & 9.45 & 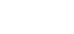 & 1.66 & $14.4 \%$ & 18.32 & 10.03 & 0 & .72 & .68 & 89.23 \\
\hline $1896-97$ & 2.13 & 2.57 & 18.35 & \$. 112 & 4.18 & 16.05 & 19.12 & 3.35 & .80 & & & & $\alpha 74.57$ \\
\hline $1 \times 97-9 \%$. & $\cdots$ & $\ldots$ & ...... & 5.96 & 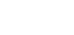 & 10.44 & ....... & 1.65 & 3.98 & 2 & 0 & T. & a26.98 \\
\hline $1898-99$ & .73 & $3.0 \%$ & 6.26 & 3.44 & 11.95 & 3.20 & 23.34 & 2.51 & 4 & 1.01 & 0 & .93 & 60.44 \\
\hline $1899-1900$. & 0 & 14.16 & 11.91 & 12.81 & 2.77 & 1.34 & 1 & 5.05 & 2.47 & $\theta$ & 0 & 0 & 51.51 \\
\hline $1900-190]$ & 0 & 1.76 & $2 \pi 1$ & .32 & 1.91 & 5. 30र & 2.75 & 1.77 & 1,43 & 0 & $\mathbf{T}$. & 0 & 17.95 \\
\hline $1901-2 \ldots$ & 0 & $1.2 \%$ & .56 & .90 & 3. 20 & 5 & 5. 36 & 3,48 & .75 & 0 & 0 & 0 & 20.52 \\
\hline 6-year $\mathrm{x}$ & & & & & & & & & & & & & 54.08 \\
\hline
\end{tabular}

"Year incomplete

\section{Record of meripitation at c'aliente, Kern county.}

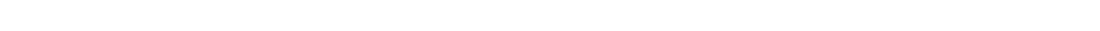

\begin{tabular}{|c|c|c|c|c|c|c|c|c|c|c|c|c|c|}
\hline Year & Sept. & $O x \cdot t$ & Nov. & Der. & Jan. & Feb. & Mar. & Apr. & May. & June. & July. & Aug. & Total. \\
\hline $1875-66$. & & & & - & ...... & 2.02 & 1.66 & (1..53 & T. & (1) & () & T. & " 4.21 \\
\hline $1876-77$ & 11 & 0.52 & $\mathrm{~T}$. & 0 & $1.0 \mathrm{~s}$ & $.4 \%$ & 1.08 & $1.2 \%$ & $(0.5 \%)$ & 0 & 0 & 0 & 4.94 \\
\hline $1877-78$. & 11 & 11 & 0.84 & 2.31 & $3 ., 1$ & $4.4 \pi$ & 2.69 & 3.20 & .03 & (1) & 0 & 0 & 17.35 \\
\hline $1878-79$ & 11 & $.4 \%$ & .10 & .10 & .20 & .34 & .33 & 1. 43 & .20 & 0.04 & 0 & 0 & 3.16 \\
\hline 1879-81। & 1) & 1.08 & 1. $\because 7$ & 3.46 & $2.3 \%$ & 1.51 & $1.0 y$ & 3.53 & .23 & 1) & 0 & 0 & 15.04 \\
\hline 1880-81. & 0 & 0 & 0.35 & 3.56 & 1.61 & 1.54 & 1.91 & .64 & .23 & 0 & 0 & 0 & 9.84 \\
\hline 1881-82. & 0.13 & 0.81 & .30 & .51 & 1.51 & 3.30 & .73 & 1.59 & .69 & .56 & 0 & 0 & 10.13 \\
\hline $1882-83$ & 0 & 1.01 & '69 & .37 & .04 & 1.76 & .82 & 2.42 & 1.07 & 0 & 0 & () & 8.18 \\
\hline 1883-84 & . 08 & .76 & .05 & (1.81) & 2.00 & 4.98 & 5.00 & 2.90 & 1.10 & 1.28 & 0 & (1) & 19.96 \\
\hline $884-85$ & 0 & $\therefore 2$ & .25 & 3.25 & .25 & 0 & .45 & 3,00 & 1.05 & 0 & 0.05 & 0 & 8.52 \\
\hline $1885-86$ & 0 & (0) & 3.88 & 1.33 & 1.59 & .66 & 2.62 & 2.65 & 0 & 1) & $\mathrm{T}$. & 0 & 12.78 \\
\hline $1886-87$. & 0 & $\mathbf{T}$. & 1.45 & 1.33 & .38 & 2. 79 & .07 & $\because 66$ & .21 & 0 & 0 & 0 & 8.89 \\
\hline $1887-88$ & 0 & .63 & .05 & 1. 43 & $.8 \pi$ & 1.14 & 1.50 & 0 & .81 & ( & 0 & 0 & 6.43 \\
\hline $1888-89$. & 0 & 0 & 6.14 & 2.18 & .59 & .20 & 3.15 & .601 & 11 & 0 & 0 & 0 & 12.86 \\
\hline 1889-90 & 0 & 1.35 & 1.05 & 3. 65 & (1.25) & 1.15 & 1.10) & 0 & 1. $6: 2$ & 0 & 0 & 0 & 11.17 \\
\hline $1890-91$ & .62 & 0 & 0 & 4.311 & .19 & 2.83 & .411 & 1.60 & 0 & 0 & 0 & 0 & 9.84 \\
\hline 1891-92. & $2 \pi$ & .15 & $\mathrm{~T}$. & 3. 73 & .75 & 1.00 & 4.25 & .30 & $1 .(0)$ & .50 & 0 & 0 & 11.85 \\
\hline $1892-93$ & 0 & 0 & 0 & 2.80 & $1 .(x)$ & 2.15 & 3,71 & . & 0 & 0 & 0 & 0 & 10.36 \\
\hline $1893-94$. & 0 & .10 & .20 & 3.45 & 3.30 & 1. 411 & 1.601 & .20 & .50 & .70 & 0 & 0 & 11.45 \\
\hline $1894-95$. & .6il & $\therefore)$ & 5 & 4.39 & 5.28 & 3.10 & $1.6 \%$ & .85 & .87 & 0 & 0 & 0 & 17.21 \\
\hline $1895-96$ & 0 & 2.31 & 1.51 & 1. (2) & 2.53 & .25 & 3.30 & 1.58 & .56 & 0 & .155 & .24 & 13.58 \\
\hline 189 & 11 & $1 .(k)$ & (6) & 3.55 & 1.25 & 4.96 & 3.41 & .35 & .13 & 0 & 0 & 0 & 14.20 \\
\hline $1897-98$. & 0 & 9) & 11 & 2.11? & 1.67 & .70 & 1.45 & .76 & 1. 40 & 0 & 0 & 0 & 8.90 \\
\hline $1898-99$ & .10 & 0 & .45 & .68 & 1. 73 & .41 & 3.26 & .28 & 1.13 & 0 & 0 & 0 & 8.04 \\
\hline $1899-1900$ & 0 & . 25 & 1.52 & .64 & 50 & .98 & .80 & 1.75 & 2.35 & 0 & 0 & 0 & 8.79 \\
\hline 1900-1901 . & 0 & 0 & 2.13 & 0 & .89 & 2.10 & .35 & 1.33 & 1.18 & 0 & 0 & 0 & 7.98 \\
\hline $1901-2 \ldots$ & 0 & 11 & 0 & () & 1.70 & 3.80 & 3. 65 & 2. 70 & .11 & (.12) & 0 & 0 & 12.08 \\
\hline & & & & & & & & & & & & & 10.91 \\
\hline
\end{tabular}

a Year incomplete. 
Record of precipitation at Fort Tejon, Kern County.

[Latitude, $34^{\circ} 55^{\prime}$; longitude, $118^{\circ} 44^{\prime}$; elovation, 3,245 feet. Authority, United States War Department, and J. (4. Stitt, Bakersfield.]

\begin{tabular}{|c|c|c|c|c|c|c|c|c|c|c|c|c|c|}
\hline Year. & Sept. & or.t. & Nov. & Der. & Jan. & Fell. & Mar. & Apr. & May & June & July & A ug. & Total. \\
\hline $1854-55$ & & & & & & & 1.58 & 3. & 0.61 & (1) & & 0 & a 5.97 \\
\hline $1855-56 \ldots$ & 0.99 & 0.0 .5 & 11 & $7.5 n$ & 4.41 & $\pi .88$ & 2.24 & $4.9 k$ & 4.62 & 0 & 0 & 0.30 & 32.97 \\
\hline $1856-5 \%$ & .08 & .05 & 3.12 & 6.54 & $.3 \pi$ & 75 & 0 & .04 & .63 & (1) & $.0 \%$ & .12 & 11.98 \\
\hline $1857-58 \ldots$ & 0 & 2.11 & 1.04 & 4. 50) & 2.100 & . is & ...39 & $5.3 \pi$ & .09 & 1.21) & 0 & .35 & 25.40 \\
\hline $1858-59$ & .44 & 2.62 & 具 & $3.0 \pi$ & $\approx 9$ & 1.69 & 1.22 & 2.37 & 11 & 0 & 0 & $.0 \tilde{\tau}$ & 12.02 \\
\hline $1850-6 x 1 \ldots$ & $8.5 x$ & .16 & 1.02 & 0 & .22 & ב & .201) & .60 & .2(3) & .21 & .01 & .16 & 11.61 \\
\hline $1860-61 \ldots$ & & $\cdots$ & & ...... & .7is & .31 & .26 & $\mathrm{~T}$. & .43 & & & $\mathrm{~T}$. & a1.73 \\
\hline 1861-62. & & & & & $\cdots$ & & & & & & & & 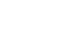 \\
\hline $1862-63$ & & & & & & & & & & & & $\mathrm{~T}$. & \\
\hline $1863-64 \ldots$ & 2.02 & 1. 10 & .71 & 4.32 &.$t^{2}$ & 0 & 1.84 & 1.80 & 1.09 & .04 & T. & .10 & 13.34 \\
\hline 1894-95_ _ & $\cdots$ & & & & & $3.1 \mathrm{k}$ & 2.14 & 1. 44 & 1.31 & 11 & 0 & 0 & $4 \pi .97$ \\
\hline $1895-96 \ldots$ & 0 & $1.4 \mathrm{i}$ & 1.42 & 1.25 & $3.0 \%$ & . 41 & 4.011 & 3.33 & 2.05 & נה: & .26 & .30 & 17.77 \\
\hline $1896-9 i \ldots \ldots$ & .53 & 1.63 & 1.74 & 4.47 & $3 . \tilde{x}^{\prime}$ & 5.14 & 3.63 & .95 & 0 & 0) & i) & 0 & 21.61 \\
\hline $189 \%-9 x-\ldots$. & (1) & 1.34 & 0 & 1. $\% 2$ & 1.49 & 1.55 & $1.36 \mathrm{i}$ & .40 & .3) & 11 & 1) & 0 & 8.61 \\
\hline $1898-99 \ldots$ & till & 0 & . (is) &.$\pi$ & $2.5 \%$ & וاNة. & $\because .99$ & .55 & 5 & . $x$ & 0 & 0 & 9.60 \\
\hline $1899-1900$ & 75 & $1.31)$ & 1. $\pi 1$ & 1.40 & 2.12 & .6 iti & .45 & $1 . \times 2$ & $1.5 \%$ & 0 & 11 & 0 & 11.2 \\
\hline $1900-1901 \ldots$ & $1.0 \% ;$ & 0 & $1 . \% 1$ & .511 & 1.80 & 5.86 & $1.9 \pi$ & .8 & .90 & 0 & 11 & $\mathrm{~T}$. & 14.58 \\
\hline $1901-2 \ldots \ldots \ldots$ & $.15)$ & 1.61 & .26 & $\mathrm{~T}$. & & 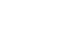 & $\cdots$ & & & & & & $" 1.92$ \\
\hline & & & & & & & & & & & & & 15.90 \\
\hline
\end{tabular}

" Tear incomplete.

\section{Recorel of precipitation at Isabella, Kern county.}

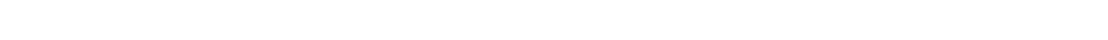

\begin{tabular}{|c|c|c|c|c|c|c|c|c|c|c|c|c|c|}
\hline Year. & Sept. & Ort. & Nov. & Dec'. & Jan. & Feb. & Mar. & A]נr. & May & June & July. & Aug. & Total. \\
\hline $1895-9 \mathrm{i}$ & & & & & & 0. 10 & 1.93 & 0.89 & 0.04 & $0.1 \mathrm{AB}^{\circ}$ & $2.5 \%$ & 0.01 & a 5.60 \\
\hline $1896-9 \pi \ldots \ldots$ & $0.32 \%$ & $1.1 \%$ & 0.48 & 0.70 & & & & & & & & - & a 2.67 \\
\hline $189 \%-9 k \ldots . .$. & .15 & 0 & 0 & 1. 24 & 0.54 & .99 & .58 & .06 & .54 & 0 & 0 & 0 & 4.10 \\
\hline $1898-99 \ldots$ & .114 & 0 & 0 & .33 & 1.95 & .19 & 1.89 & $.2 s$ & .25 & .45 & 0 & 0 & 5. $3 x$ \\
\hline 1899-19) . & 0 & .78 & .85 & . & 1.10 & .65 & $.0,5$ & .73 & 1. $(\mathrm{ki}$ & 0 & 1) & (12 & 6.62 \\
\hline $1900-1901 \ldots$ & .30 & .24 & 5. 53 & .115 & 1.201 & D. it & .33 & .36 & 1.98 & 1) & 0 & .99 & 13. 52 \\
\hline $1901-2 \ldots$ & 0 & .64 & .13 & (1) & .34 & (i. 115 & $2.2 i$ & 1. (1) & .15 & 0 & 0 & 0 & 10.50 \\
\hline 00 & & & & & & & & & & & & & 8.06 \\
\hline
\end{tabular}

$a$ Year incomplete. 


\section{Record of precipitation at Ke'ur, Kern c'onnty.}

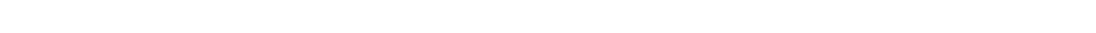

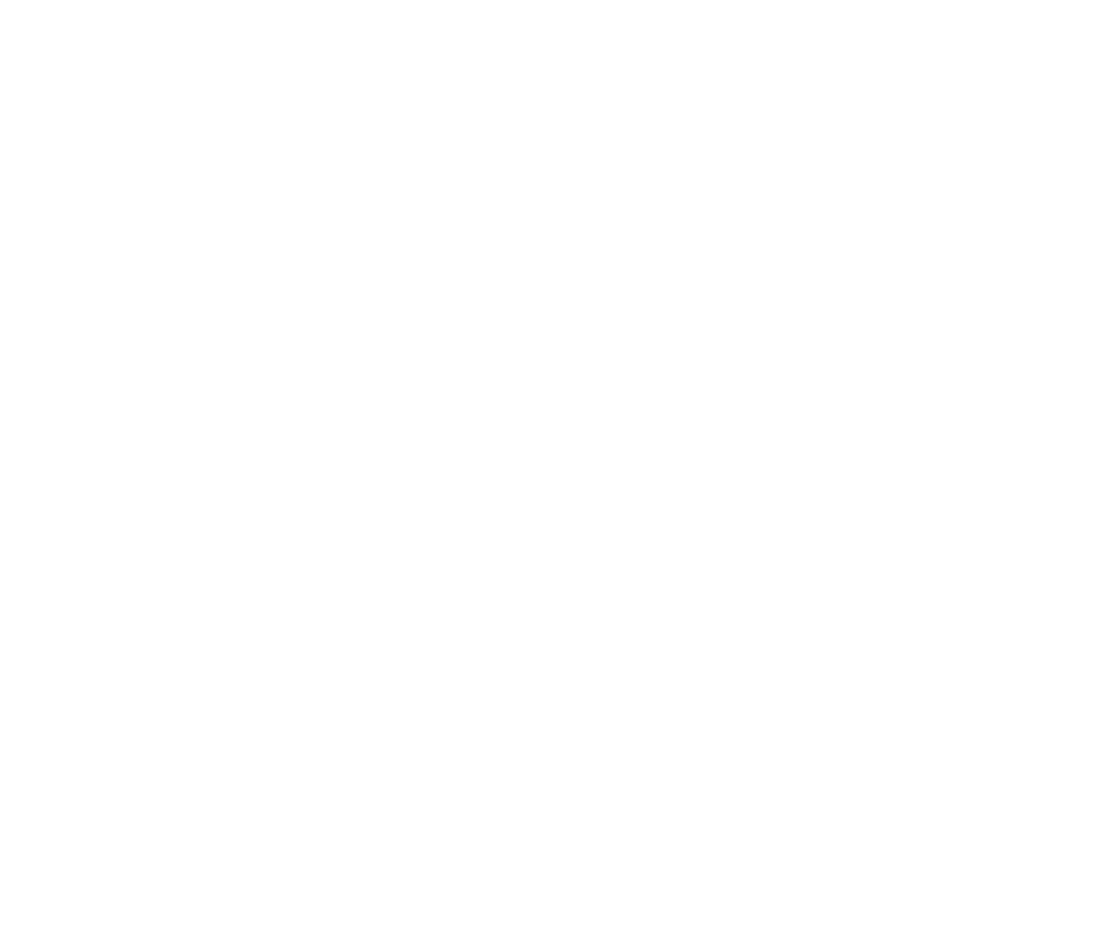

\section{Record of precipitation at Kerncille, Kern comnty.}

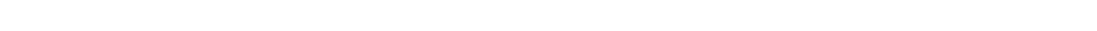
Brown, Kernville.]

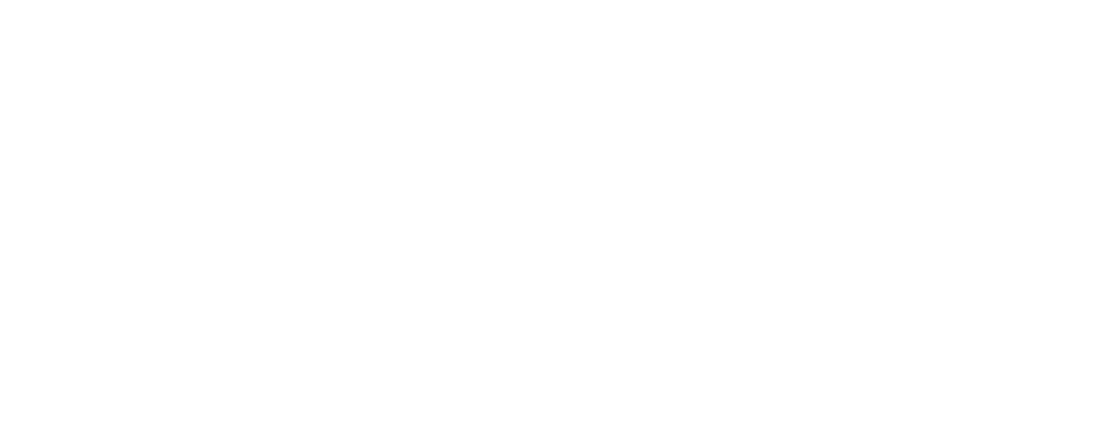

a Year incomplete. 
Recerd af precipitation at Mount Breckinrilge, Hanlon, Kern County.

[Latitude, $37^{\circ} 25$; longitude. 118 35'; elevatım, 6, 350 foet Authority G. otterman.]

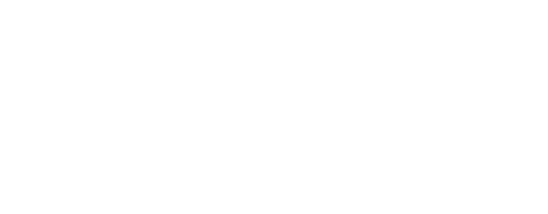

"Yair incomplete.

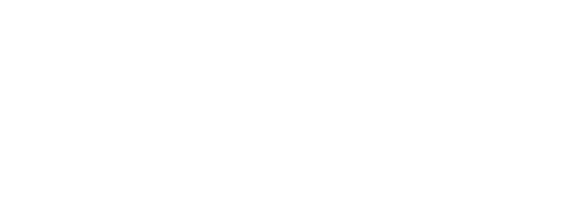

bN record kept in 1898 .

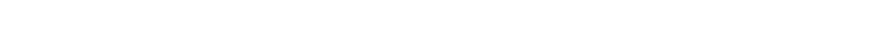

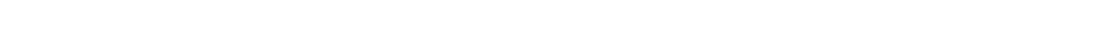
Alexander, Weldon

\begin{tabular}{|c|c|c|c|c|c|c|c|c|c|c|c|c|c|}
\hline Year. & Sept. & ort. & Nov. & Deen. & Tan. & Fell. & Mar. & $A_{1, r}$, & May. & June. & July. & Ang. & TotaI. \\
\hline $1899-1940)$. & & $\ldots . .$. & 11. & (1. titis & 0,01 & $0.4 \pi$ & (1.50) & 0.399 & 1. 82 & $0.0 \%$ & 0) & 0.03 & 114.38 \\
\hline $19(k)-1901$. & 11.62 & $0 .(\mathrm{r})$ & 4. 29 & 11 & 1. $14 \mathrm{i}$ & 1.96 & .05 & 41 & 1. 012 & 0 & 0 & 2. (i) & 12.03 \\
\hline $1901-2 \ldots$ & 0 & .39 & .12 & 11 & $\approx 6$ & $4: 3 \pi$ & 1.41 & .31 & 0 & () & (1) & 0 & 6.86 \\
\hline rear & & & & $\ldots$ & & & & & & & & & 9.45 \\
\hline
\end{tabular}

"Year incromplete.

\section{Record of previpitation at Tehacherpai, Kern county.}

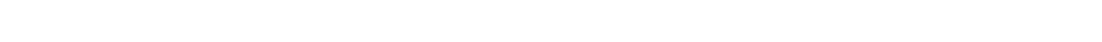

\begin{tabular}{|c|c|c|c|c|c|c|c|c|c|c|c|c|c|}
\hline Year. & Sept & (1)et. & Nor. & Dec. & Jan. & Feh. & Mar. & Apr & May & June. & & $\mathrm{ug}$ & otal. \\
\hline lxitb-ĩ. & 0.118 & 0.45 & 11 & 1) & 0.58 & 0.14 & 01. 89 & (1. (6) & 0.12 & 11 & $0 .(1)$ & 11 & 2.88 \\
\hline $1867-6$. & 11 & $\mathrm{~T}$ & $(15)$ & 2.91 & 2.59 & 6. $3: 8$ & 176 & 1.93 & .28 & (1. (1) & 0 & T. & 1638 \\
\hline $18,8-$ & 0 & , ; & .14 & .64 & 2102 & .45 & .19 & 1.34 & .09 & .12 & (1) & 0 & 5. 84 \\
\hline 1879 & 0 & .52 & 1.113 & $5 \%$ & 2.81 & 1.94 & 147 & 2.30 & 11 & 0 & ( & 0 & 15.59 \\
\hline $1880(1-81$ & 11 & .75 & .10 & 2.14 & 1. 69 & 2.05 & 3.15 & .50 & 11 & $n$ & 0 & 0 & 10. 48 \\
\hline $1881-8$ & $.3: 2$ & .10 & .31 & .12 & 1.1 & 2.117 & I. 45 & .63 & .21 & .15 & 0 & 0 & 6.59 \\
\hline $88:-8$ & 0 & it & .18 & .50 & 15 & 4.55 & 1.51 & 2.89 & $1 ; 3$ & 0 & 0 & () & 12.沙 \\
\hline $1883-84$ & 0 & . kl & 14 & $\because 2$ & 1.it & $\overline{1.5 i}$ & 3.48 & 185 & 1.26 & 1.0 .5 & 0 & 0 & 18.42 \\
\hline $1884-85$ & 0 & .13 & 䉡 & 396 & .10 & 11 & .26 & $14 x$ & $.30)$ & 0 & .115 & .31 & 6.88 \\
\hline 885 & 0 & 11 & 3.711 & $.5 \%$ & 1.58 & 6.1165 & 4.10 & $1.5 i$ & 11 & () & .10 & 11 & 20.63 \\
\hline $1.883-86$ & 11 & $\mathrm{~T}$. & 1.15 & (6) & .50 & 8.88 & .24 & 1. 9.5 & .26 & 0 & 11 & 0 & 13.58 \\
\hline $188 \pi-$ & 11 & .86 & $.26 \mathrm{i}$ & 1.44 & $2.5 \pi$ & $2(3)$ & 1.21 & 1.25 & .25 & 11 & 1) & (1 & $10.4: 3$ \\
\hline $888-8$ & 11 & 11 & 0 & 3.65 & .40 & .60 & 3.56 & 3.96 & $1.0 \%$ & 1) & 0 & 80 & 14. 04 \\
\hline $1889-90$ & (1) & $2 \approx 01$ & 30 & 5.30 & 1,15 & .80 & .301 & 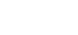 & 0 & (1) & $u$ & 0 & 1145 \\
\hline $1890-$ & .51 & 0 & 0 & 3.48 & .113 & 3.4 .5 & .80 & 90 & . & $(0 .(0))$ & 11 & 0 & $9.86^{\circ}$ \\
\hline $1891-$ & 1.17 & 11 & 0 & 3.111 & .8 & 9.68 & $2 . ; 2$ & .61 & . 03 & 0 & 0 & 0 & 1175 \\
\hline $1892-93 \ldots$ & 0 & 11 & 11 &.$+(1)$ & 85 & 3.61 & 5.00 & (is) & 0 & 0 & ( & 0 & 10.51 \\
\hline $893-$ & 1) & .50 & .50 & 5. & $\approx 80$ & 1.68 & 0 & $(.18)$ & .32 & זים & 0 & 0 & 11.60 \\
\hline & .111 & 0 & 0 & 3.5 & 3.21 & .69 & 1.118 & .51 & 7i) & 0 & 1) & 1) & 10.18 \\
\hline i. & 11 & .41 & (i) & .20 & $1.5 \%$ & $(1$ & 2.80 & .68 & 0 & 0 & ( & .85 & 7.15 \\
\hline $1896-9 i \ldots$ & 0) & 1.45 & .53 & 1.13 & 1. is & 2.03 & .18 & .25 & 0 & "1 & (i) & 11 & 7.35 \\
\hline & .12 & .32 & 11 & $1 .(x)$ & 1.21 & .34 & 1.35 & 111 & $.8: 2$ & 11 & 0 & 11 & 5.21 \\
\hline $1898-99$ & 0 & 0 & $\mathrm{~T}$. & $\therefore 20$ & . 68 & (b) & 1.60 & 0 & $\therefore$ & .38 & (1 & 0 & $3 . \%$ \\
\hline $1899-19 \times(1$ & 1 & $\therefore$ & 1.53 & .61 & .64 & $\therefore 9$ & $\therefore 9$ & 1.:39 & 50 & 23 & $T$ & 0 & 6.115 \\
\hline $19(x)-19 x) 1$ & 0 & $.4 t$ & 1.53 & 11 & $11 \%$ & 3.2 & .25 & $\therefore 8$ & in & $1)$ & 0) & 1.70 & $9.4 i$ \\
\hline $19011: 2$ & 11 & .51 & 1) & 11 & 80 & 3.911 & 1.115 & 1 is & 11 & (1) & 1) & a) & 7.18 \\
\hline & & & & & & & & & & & & & 0.23 \\
\hline
\end{tabular}


Record of precipitation at Tejon Ranch, Kern c'onnty.

[Latitude, 35` 01'; longitude, 11, 45'; elevation, 1,450 feet. Autbority, R. M. Pogson, Bakersfield.]

\begin{tabular}{|c|c|c|c|c|c|c|c|c|c|c|c|c|c|}
\hline Year. & sept. & onet & Noy & Der. & J:111. & $F(k)$ & Mar. & $A_{1} r$. & May & nne. & July. & Aug. & Total. \\
\hline $1 \times 94-95$ & & & $\cdots \ldots$ & & 5) 115 & 139 & 1. 70 & 1.11 & .49 & 0 & 0 & 0 & 09.74 \\
\hline $\begin{array}{l}1895-96 \ldots \\
1896-97 \ldots\end{array}$ & 0 & 213 & $\begin{array}{l}1.41 \\
\therefore .1: 2\end{array}$ & 106 & $1 !(n)$ & .37 & 4.22 & $1.6 \%$ & .48 & (0) & 0 & 0 & $\begin{array}{r}13.19 \\
42.12\end{array}$ \\
\hline $1897-98$ & & & & & 2.32 & 1.68 & .94 & .11 & .84 & 0 & 0 & 0 & “5.95 \\
\hline $1898-99$ & 0.34 & $.4 \div$ & .51 & .8 & 1. 300 & $\approx 10$ & 4.18 & .89 & 0 & 0 & () & 0 & $10.4 \tilde{5}$ \\
\hline 1899-190) & 11 & 1.31 & 18 & J. $6 \%$ & $1.1 \%$ & .35 & 41 & $1.9 \pi$ & $1.5 \pi$ & . 02 & 0 & 0 & 10.29 \\
\hline $1900-1901$. & 065 & $1 i \pi$ & 1.1165 & .31 & 1.28 & 4.69 & .95 & 1.36 & 1.28 & 0 & (1) & $\mathrm{T}$. & 11.69 \\
\hline $1901-2 \ldots$ & 0 & 41 & .17 & anl & 1. (i) & 1. $H i$ & 2.74 & 2.12 & .98 & (1) & 0 & 0 & 9. 98 \\
\hline yeal & & & & & & & & & & & & & 11.12 \\
\hline
\end{tabular}

"Year incomplete

Record of precipritation at Bartlett Springs, Lake Cor'nty.

[Latitude, 3: 11'; longitude, 1:30 45'. clevation, 2,375 feet. Authority, J. E. MeMahom.]

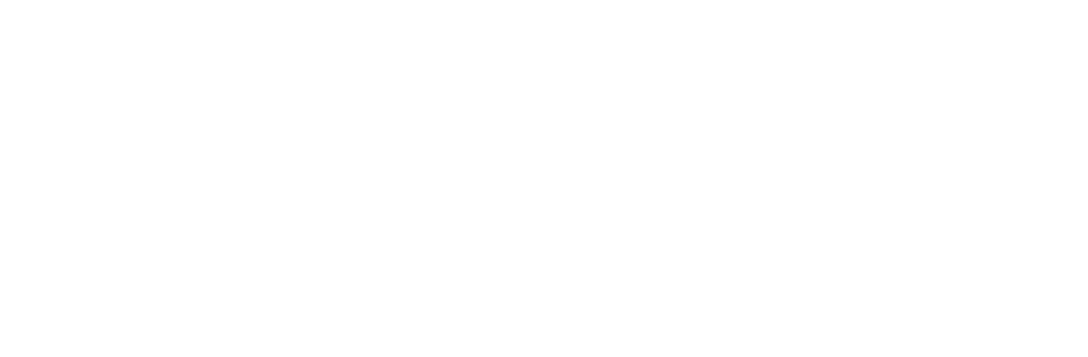

"Year incomplete.

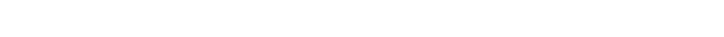

[Latitude. 396 5': longitude, 1:20 4:3'; ('Levation. 1,350 feet. Authority, F. S. Floyd.]

\begin{tabular}{|c|c|c|c|c|c|c|c|c|c|c|c|c|c|}
\hline Year. & I Sept. & ort. & Nov. & I)(x. & Jan. & Fers. & Mar. & Apr. & May. & June. & . July. & Aug. & Total. \\
\hline $873-74 \ldots$ & 1 & 0 & 0 & 18 & 1. $\mathrm{sk}$ & 8. (i) & 4.66! & 2.15 & (1). 45 & (1) & 0 & 0 & 12.60 \\
\hline $1874-75 \ldots$ & 0 & 3. & 6.25 & 0. & 9) 16 & $.3 x$ & (9) & 0 & .84 & (1. $4: 2$ & () & 0 & 21.96 \\
\hline $1 \times 75-76 \ldots$ & 0 & $1.1 \%$ & 6.96 & .5.1: & (6. 1.5 & 4. 湜 & 8. 34 & .110 & 0 & 0 & 0 & (1) & 31.96 \\
\hline $1876-\% \ldots$ & 0 & $\therefore$ & 3.50 & 11 & 3.17 & 2.41 & 1.411 & .51 & 0 & (w) & 0 & () & $12.0 \mathrm{k}$ \\
\hline $18 \pi \%-78 \ldots$ & 10.73 & 1.65 & $\therefore$. & 1.94 & $14.16 \mathrm{i}$ & 11.04 & 4.601 & 1. 43 & 0.79 & 45 & () & $0.0 \%$ & 39.13 \\
\hline $1 \% 78-79 \ldots$ & 0 &.+1 & $1.3 i$ & .333 & 3.11 & 3.41 & $9.1 \mathrm{i}$ & $.4 \pi$ & .6it & 0 & 0 & .155 & 18.84 \\
\hline $18 \% 9-80 \ldots$ & 0 & .91 & 3.54 & 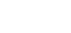 & 6. 24 & 3.85 & $4 . \pi 4$ & .48 & .25 & 0 & () & 0 & 25.76 \\
\hline $1880-81$. & 0 & 11 & 3.54 & $19 ?$ & 5. 50 & 6. 5 k & .64 & .95 & .12 & .85 & 0 & 0 & 19.50 \\
\hline $881-82 \ldots$ & 0 & .63 & 2.90 & 1. $\pi$ & $1 \%$ & 3.20 & 2.34 & 1.54 & .40 & 0 & 0 & 0 & 14.52 \\
\hline $1882-83 \ldots \ldots$ & .42 & 1.64 & 4.42 & .98 & 1.40 & .60 & $3 . \times 1$ & .95 & 2.41 & 0 & 0 & 0 & 16.63 \\
\hline 1883-84. & . & .99 & .39 & . & $4.1 \%$ & 1.91 & 5.35 & 3.88 & .06 & 4.118 & 0 & 0 & 22.23 \\
\hline $1892-933$ & .18 & .84 & 6.53 & $5.5 \pi$ & 3.84 & 4.15 & 5.41 & 2.06 & .66 & 0 & 0 & 11 & 29.84 \\
\hline $1893-94$. & .25 & .42 & 3.76 & 2. 34 & $6.9 \%$ & $4.3 \%$ & 1.11 & .91 & $.90^{\circ}$ & 1.64 & ध & $\mathrm{T}$. & $22.5 i$ \\
\hline $1 \times 44-95, \ldots \ldots$ & .50 & 1.22 & $.7 t$ & 111.70 & 14.45 & 2.32 & $3.13:$ & .98 & 1.14 & 11 & (1) & $\mathrm{T}$. & 35.18 \\
\hline $1895-96 \ldots$ & . 71 & 0 & 1.69 & 2.12 & 9. 42 & .25 & 231 & 4. 62 & $1.69 \mid$ & 45 & $\mathrm{~T}$. & $.2 \%$ & 23.53 \\
\hline $1896-97 \ldots \ldots$ & .29 & 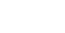 & 3.33 & 5.93 & 2.85 & 4.111 & 3.76 & .9M1 & .90 & .48 & (1) & 0 & 23.18 \\
\hline $1897-98 \ldots \ldots$. & (1) & 1.24 & 1.64 & $\therefore 1: 2$ & ד & 4.19 & .11 & .64 & 1. $6 \mathrm{iz}$ & .45 & 11 & (1) & $12 . \pi$ \\
\hline $1 \times 98-99 \ldots$ & .51 &.+16 & 1.15 & $1.2 \mathrm{~T}$ & 7.74 & $\mathrm{~T}$. & 5. 43 & io & 45 & . & .18 & $\mathrm{~T}$. & $18.1 \%$ \\
\hline $1899-19(1) \ldots \ldots$ & 11 & 3.8 & .56 & 4.14 & 3.10 & $1.2 \%$ & 2.89 & $2.3: 2$ &.$t i \pi$ & $\mathrm{T}$ & 0 & 0 & $23 . \pi 3$ \\
\hline $1900-1901 \ldots \ldots$ & $\mathrm{T}$ & 3.11 & 3.89 & 1.67 & $5.5 i$ & 4. 33 & 1.33 & 2.05 & .96 & .45 & 0 & T. & 23.36 \\
\hline $1901-2 \ldots$ & .54 & 1.04 & $3.4 \gamma$ & 1.19 & 1.31 & 10.28 & 3.85 & 2.4: & 1.59 & 0 & 0 & T. & 26.09 \\
\hline 1-year & & & & & & & & & & & & & 22.53 \\
\hline
\end{tabular}




\section{Record of precipitation at Azusa, Los Angeles County.}

[Latitude, $34^{\circ} 8^{\prime}$; longitude, $11 \%^{\circ} \mathrm{nt}$; elevation, 630 feet. Authority, H. F. Parkinson.]

\begin{tabular}{|c|c|c|c|c|c|c|c|c|c|c|c|c|c|}
\hline Year. & Sept. & Oct. & Nov. & Dec. & Jan. & Fels. & Mar. & Apr & May. & Juns. & July. & Aug. & Total. \\
\hline $1897-98$ & 0 & 4.25 & 0.25 & $\mathbf{T}$ & 1.75 & 1. 25 & 0.81 & 0.25 & 2.63 & $\mathbf{T}$. & $\mathrm{T}$. & 0 & 11.19 \\
\hline $1898-99 \ldots \ldots$ & .06 & $\mathrm{~T}$ & $\mathrm{~T}$ & 0.50 & 2.81 & $\mathrm{~T}$ & 2.49 & $\mathrm{~T}$ & $\mathrm{~T}$ & 1.25) & 0 & T. & 7.11 \\
\hline $1899-1900 \ldots$ & $\mathrm{T}$. & 2.55 & 1.79 & 1.00 & 1.31 & $\mathrm{~T}$. & 1.71 & 1.05 & 2.79 & 0 & 0 & 0 & 12.20 \\
\hline $1900-1901 \ldots$ & .13 & .34 & 10. 25 & 0 & $3.7 \%$ & 4.86 & .50 &.$\pi 3$ & 1.91 & $\mathrm{~T}$. & $\mathrm{T}$. & $\mathrm{T}$. & $\Rightarrow 29$ \\
\hline $1901-2$ & T. & 2.35 & $.6 r$ & $\mathrm{~T}$. & 2.24 & 2.84 & 3.99 & .38 & .18 & .09 & $\mathrm{~T}$. & 0 & 12.73 \\
\hline 5-yea & & & & & & & & & & & & & 13.14 \\
\hline
\end{tabular}

Record of precipitation at C'alabasas, Los Angeles Connty.

[Latitude, 34०09'; longitude, $118^{\circ} 38^{\prime}$; elevation, 925 feet. Authority, J. G. Chanman.]

\begin{tabular}{|c|c|c|c|c|c|c|c|c|c|c|c|c|c|}
\hline Year. & Sept. & Oet. & Nov. & Dee. & Jan. & Feb. & Mar. & Apt: & May & Jun 3. & July. & Aug. & Total. \\
\hline 1901-2 & & & & 0 & 1.28 & 4.35 & 2.17 & 0 & 0 & 0 & 0 & 0 & 7.80 \\
\hline
\end{tabular}

Record of precipitation at Colby's C'amp, Los Angeles County.

[Latitude, $118^{\circ} 05^{\prime}$; longitude, $34^{\circ} 15^{\prime}$; elevation, $3.8 \%$ feet. Authority, D. Wr. Colby, Pasadena.]

\begin{tabular}{|c|c|c|c|c|c|c|c|c|c|c|c|c|c|}
\hline Year. & Sept. & Oet. & Nor. & Dec. & Jan. & Feb. & Mar. & Apr. & May. & Juns, & July. & Aug. & Total. \\
\hline $1898-99$. & & . . . . . & & & 2.90 & 0.25 & 2.75 & 0.17 & 0.60 & 0.79 & 0 & 0 & $a 7.46$ \\
\hline 1899-1900 & 0 & 3.66 & 125 & 1.26 & 1.15 & 0 & $2 .(0)$ & 1.38 & 3.25 & 0 & 0 & 0 & 13.95 \\
\hline $1900-1901 \ldots$ & (1. 25 & .45 & 8.15 & 0 & 6.94 & 13.54 & $.6 \pi$ & 2.65 & 1.10 & .10 & 0 & 0.25 & 34.10 \\
\hline $1901-2 \ldots$ & .10 & 3.15 & 0 & 0 & 2.50 & 3.15 & 3.55 & 1.84 & $.20)$ & .10 & 0 & 0 & 14.59 \\
\hline year & & & & & & & & & & & & & 20.88 \\
\hline
\end{tabular}

a Year incomplete.

Record of precipitation at Follow's Camp) (Azusa). Lus Angeles County.

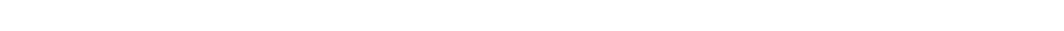

\begin{tabular}{|c|c|c|c|c|c|c|c|c|c|c|c|c|c|}
\hline Year. & Sept. & Ort. & Nov. & Dec. & Jan. & Feb. & Mar. & Apr. & May. & June. & July. & Aug. & Total. \\
\hline $1895-96$ & & & & 1.02 & $2 . \pi$ & $\mathbf{T}$ & 6.55 & 0.70 & 0.36 & 0 & $0,0 \%$ & 1.10 & a 12.57 \\
\hline $1896-97$. & $\mathrm{T}$ & 2.9 .5 & 1.03 & 1.61 & 5.43 & 10.39 & 8.25 & .15 & .28 & T. & 0 & 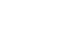 & 30.16 \\
\hline $1897-98$. & .45 & 7.85 & .20 & .27 & 0 & 9.80 & 0 & .85 & 6.16 & 1.03 & 0 & .53 & 27.14 \\
\hline $1898-99 \ldots \ldots$ & 0 & 0 & $1 . \% 0$ & \% & 3.59 & .84 & 2.49 & $.1 \%$ & 0 & .91 & 0 & 0 & 10.35 \\
\hline 1899-1900. & .12 & 3.03 & 1.64 & .44 & & $\mathrm{~T}$ & 2.40 & 1.76 & 2.98 & & & 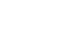 & “ 12.38 \\
\hline $1901-2 \ldots$ & & & .80 & 15 & ... & & $\ldots$ & 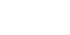 & & & & 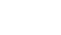 & 0.95 \\
\hline & & & & & & & & & & & & & 22.55 \\
\hline
\end{tabular}

a Year incomplete. 
Record of precipitation at La Liebre, Los Angeles County.

[Latitude, $34^{\circ} 46^{\prime}$; longitude, $118^{\circ} 16{ }^{\prime}$; elevation, $3,1 \% 0$ feet. Authority, J. W. Forbes, Neenack.]

\begin{tabular}{|c|c|c|c|c|c|c|c|c|c|c|c|c|c|}
\hline Year. & Sept. & Oct. & Nov & Der. & Jan. & $F(+b)$. & Mar. & Apr. & May. & June. & July. & A ug. & Total. \\
\hline & & & & & 3.67 & 4.01 & $\because 30$ & (0.10) & & & & & a 10.08 \\
\hline ـ & & 01.50 & $\ldots$ & 0. 40 & 53 & .35 & .81 & 0 & 0.45 & 0 & .0 & 0 & $a 3.0 t$ \\
\hline ـ & 0.20 & 0 & 0 & .66 & 1.79 & .04 & 2.26 & .09 & .04 & 11.27 & 0 & 0 & 5.35 \\
\hline 1899-190k. & .015 & $1.4 \pi$ & (1).?H) & .46 & 1.84 & & & & & & & & a4.12 \\
\hline
\end{tabular}

"Year incomplete.

Record of precipitation at Los Angeles, Los Angeles C'ounty.

[Latitudי, $34^{\circ}\left(13^{\prime} ;\right.$ longitude, $11 x^{\circ} 13^{\prime}$ : elcration, s30 feet. Authority, Signal Serrice anf Weather Bureau.]

\begin{tabular}{|c|c|c|c|c|c|c|c|c|c|c|c|c|c|}
\hline Year. & sept. & Oct. & Nov. & Dece. & Janr. & Fel. & Mar. & Apr. & May. & June & July & A tug. & Tot: \\
\hline $71-\gamma 2$ & & & & & & 2.25 & (1). 43 & (1.97 & $0.10^{1}$ & 0 & 11 & 11.22 & \\
\hline $62-63$ & 0 & 11 & 0 & 4. 42 & 2.18 & \%.19 & .05 & 0 & 0 & 0 & 0 & $1 .(\%)$ & \\
\hline $73-\tau 4 \ldots$ & 0 & 0 & $0.7 t$ & ก. 74 & 5. 51 & $9 . \pi$ & 1.08 & .4 .5 & $4: 2$ & 0 & 0 & (1) & \\
\hline $74-75$ & (1.). 16 & 1.81 & 1. 89 & .21 & 17.20 & .15 & .22 & .07 & .05 & 0 & 0 & 0 & \\
\hline $75-i f f \ldots$ & 0 & 11 & $\pi .5 \%$ & .89 & 6.54 & 7.92 & 3.41 & .45 & .1183 & 11 & 0 & 0 & \\
\hline $866-i \pi$ & () & 411 & 0 & 0 & 3.48 & .01 & .83 & .26 & .30 & 0 & 0 & 1 & \\
\hline $77-7$ & 0 & 86 & . 45 & 3.93 & 3.33 & 7.68 & 2.51 & 1. $\pi$ & .66 & $0.0 \%$ & 0 & & \\
\hline $78-7$ & () & .14 & (1) & 4. 80 & 3.59 & $.9 \%$ & .49 & 1. 19 & .24 & .0113 & 0 & & \\
\hline $79-8$ & 0 & 93 & 3.44 & 6.53 & 1. 33 & 1.56 & 1.4 .5 & 5.196 & .014 & 0 & T. & $\mathbf{T}$. & \\
\hline$(x)-$ & 0 & 14 & .67 & 841 & 1.43 & .36 & 1.66 & 46 & .011 & 1 & 11 & T. & \\
\hline$\delta 1-\gamma$ & $\mathrm{T}$. & $.8 \%$ & 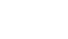 & .52 & & 266 & 2,66 & 1.83 & .63 & $\mathrm{~T}$. & 11 & & 10. \\
\hline $2 z$ & T. & .115 & $1.8 \%$ & .188 & 1.02 & 3.47 & 287 & 1.5 & 2.12 & . 1183 & $T$. & & 2. \\
\hline $85-\delta$ & 0 & 1.42 & 0 & 2.56 & 3.15 & $13.3 \pi$ & 12. 36 & 3.58 & .39 & 1. 39 & 0.02 & 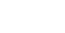 & 38. \\
\hline$t$ & T. & .39 & $1.0 \pi$ & 4.65 & 1. $1 k^{5}$ & .01 & .01 & 2. 01 & .176 & $\mathrm{~T}$ & $\mathrm{~T}$ & T. & \\
\hline $9=$ & . 155 & 3) & 5.5.5 & 1. 6.5 & 7.88 & 1.41 & $2.5 \%$ & 2.3 & , 111 & .11 & .27 & .21 & \\
\hline & .11 & (1) & 1.18 & 26 & .20 & 9.25 & .29 & 2.36 & .210 & .07 & $.0 \%$ & $\mathrm{~T}$. & 4. \\
\hline & .18 & $.1 \hat{~}$ & .80 & 2.64 & 6.01 & .80 & 3.17 & .12 & .05 & .01 & .14 & .10 & \\
\hline & . 113 &.+10 & 4.02 & 96 & 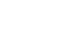 & .92 & 648 & .27 & .65 & (11 & T. & .28 & \\
\hline & .34 & 6.96 & 1.35 & $15.80)$ & โ..8B & 1.36 & .665 & . & .03 & .18 & 11 & .003 & \\
\hline & .06 & .03 & .13 & & 怘 & 8.56 & .41 & 1.26 & .31 & 0 & $\mathbf{T}$. & 0 & 3. \\
\hline & .165 & 0 & 0 & 99 & . & 3. 19 & 3.39 & .22 & 8.06 & $.066^{\circ}$ & 0 & .01 & 11. \\
\hline & 0 & .333 & 4. 41) & 18 & (5. 29 & 2.27 & $8.5 \%$ & 19 & $.06 ;$ & 03 & 0 & 0 & 6. \\
\hline & $\mathrm{T}$ & (5) & $.20)$ & & 94 & .49 & .37 & $.1: 3$ & .28) & T. & r. & .01 & \\
\hline & .73 & . 112 & 1) & 4.62 & & .46 & $3 . \pi$ & .46 & .19 & 01 & $\mathrm{~T}$. & T. & 16. \\
\hline & $\mathrm{T}$ & .24 & .81 & . & & $\mathbf{T}$ & 2.97 & .19 & .30 & T. & . & .01 & \\
\hline & $\mathrm{T}$ & 1.30 & 1. $66 \mathrm{i}$ & 212 & 3. $\%$ & $5.6 \%$ & 2.31 & . & .30 & $\mathrm{~T}$. & T. & 0 & \\
\hline & 0 & $2.4 \pi$ & .01 & 05 & 1.26 & .51 & 98 & .183 & 1. $\%$ & $\mathrm{~T}$. & .07 & $\mathbf{T}$. & \\
\hline & (1) & .119 & T. & 28 & 2.64 & .04 & 1.81 & .18 & .04 & .58 & 0 & .01 & \\
\hline & $\mathrm{T}$ & 1.59 & .90 & .90 & 1.17 & $\mathbf{T}$ & .99 & .54 & 1.81 & $\mathrm{~T}$. & T. & T. & \\
\hline 1)-1901 . & $\mathrm{T}$ & .26 & ti. 53 & $\mathrm{~T}$ & 249 & 4.34 & .45 & .68 & 1.50 & $\mathrm{~T}$. & $\mathbf{T}$. & .09 & \\
\hline $19012 \ldots \ldots \ldots$ & (it) & 1.58 & 46 & 0 & 1.62 & 3.35 & 2.98 & .16 & .113 & T. & 0 & 0 & 10.5 \\
\hline & & & & & & & & & & & & & \\
\hline
\end{tabular}

$a$ Year incomplete. 
Record of precipitation at Magic Hill, No. 1, Los Angeles County.

[Latitude, $34^{\circ} 23^{\prime}$; longitude, $118^{\circ} 22^{\prime}$; clevation, : 2.20 feet. Authority, B. L. Hutchins, Burbank.]

\begin{tabular}{|c|c|c|c|c|c|c|c|c|c|c|c|c|c|}
\hline Year. & Sept. & Oet. & Nov. & Dee. & Ja11. & Fub. & Mar. & Apr. & May. & June. & July. & Ang. & Total. \\
\hline $1897-98$ & & & 0.10 & 0.30 & 0.25 & 0.61 & 0 & 0.34 & 0.29 & 1.80 & 1.35 & 0.52 & a 5.56 \\
\hline $1898-99 \ldots$ & 3.12 & & - n.... & & 1.60 & 15 & $2.0 \%$ & .14 & 1.65 & .05 & 0 & 0 & a8. 78 \\
\hline $1899-19(x)$ & .07 & 2.25 & 1. 01 & 1.21 & 1.34 & 0 & 1.68 & 2.05 & 4.40 & .06 & .04 & 0 & 14.15 \\
\hline $1900-1901$ & .54 &.$\pi 1$ & 6.53 & 0 & 6.71 & 6. 68 & .78 & 1. 79 & .57 & & & & $b 24.31$ \\
\hline
\end{tabular}

a Tear incomplete.

${ }^{b}$ Record stopped.

Record of precipitation at Manzuna, Los Angeles County.

[Latitude, 340 45'; longitude, $118^{\circ} 3 \overline{5}^{\prime}$; elevation, 2,850 feet. Authol'ity, E. A. Silrey.]

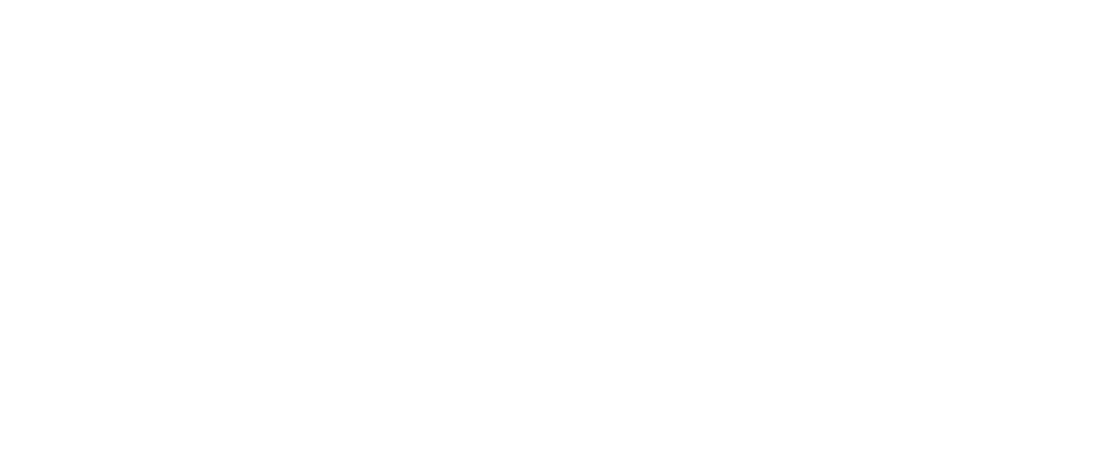

a Year incomplete.

Record of precipitation at Mount Lowe (Echo Mountain post-office), Los Angeles County.

[Latitude, $34^{\circ} 15^{\prime}$ : longitude, $118^{\circ} 0 \sigma^{\prime}$; elevation, 3,200 feet. Authority, Louis Swift and Edgar L. Larkin.]

\begin{tabular}{|c|c|c|c|c|c|c|c|c|c|c|c|c|c|}
\hline Year. & Sept. & Oct. & Nov. & Dec. & Jan. & Feb. & Mar. & Apr. & May & June. & July. & Aug. & Total. \\
\hline $1895-96$. & & 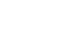 & $-\ldots . .$. & 1.35 & 2.85 & 0.10 & 4.10 & 0.60 & 0.30 & 0 & 0 & 0 & (19.30 \\
\hline $1896-97$ & 0 & 2.39 & 1.55 & 2.17 & 6.42 & 7.47 & $6.6 \pi$ & .19 & .87 & 0.10 & 0.15 & 0 & 27.98 \\
\hline $1897-98 \ldots$ & 0 & 2.57 & .40 & .22 & 1.55 & 2.22 & 1.65 & 2.70 & 2.17 & 0 & 0 & 0 & 13.48 \\
\hline $1898-99$ & 0.25 & .30 & 0 & .98 & 3.29 & 0 & 3.40 & .20 & 1.90 & .40 & 0 & 0 & $10.7 \%$ \\
\hline $1 \times 99-1900$. & (1 & 3.00 & 2.85 & & & $\ldots$. & 2.90 & 2.15 & 4.05 & .40 & T. & 0 & , a 15.35 \\
\hline $1900-1901 \ldots$ & .25 & 1.66 & 11.71 & 0 & 7.55 & 5.42 & 1.18 & 1.14 & 4.45 & .75 & 0 & 0 & 34.11 \\
\hline $1901-2 \ldots$. & 0 & 4.18 & 1.05 & .23 & 1.88 & 3.48 & 5.97 & 1.35 & .33 & .30 & 0 & 0 & 18.77 \\
\hline & & & & & & & & & & & & & 21.01 \\
\hline
\end{tabular}

a Year incomplete.

Record of precipitation at Mount Sister Elsie, Los Angeles County.

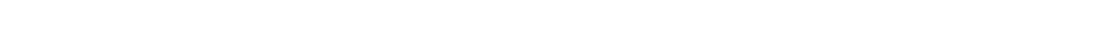

\begin{tabular}{|c|c|c|c|c|c|c|c|c|c|c|c|c|c|}
\hline Year. & Sept. & Oct. & Nor. & Dec. & Jan. & Feb. & Mar. & Apr. & May. & June & July & Aug. & Total. \\
\hline 189- & & & & & 2.95 & 0.12 & 3.37 & 0.58 & 0.08 & 0.78 & 0 & 0 & a 7.88 \\
\hline $1899-1900$. & 0.355 & 2.10 & 1.34 & 0.41 & .85 & 0 & 1.87 & 1.30 & 3.02 & 0 & 0 & $T$. & 11.24 \\
\hline $1900-1901 \ldots$. &.$(64)$ &.$M 1$ & 6. 70 & 0 & 8.92 & 12.13 & .95 & 3.60 & 1. 93 & & & ... & $c 35.13$ \\
\hline
\end{tabular}


Record of precipitation at Neuhall, Los Angeles County.

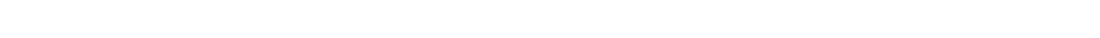

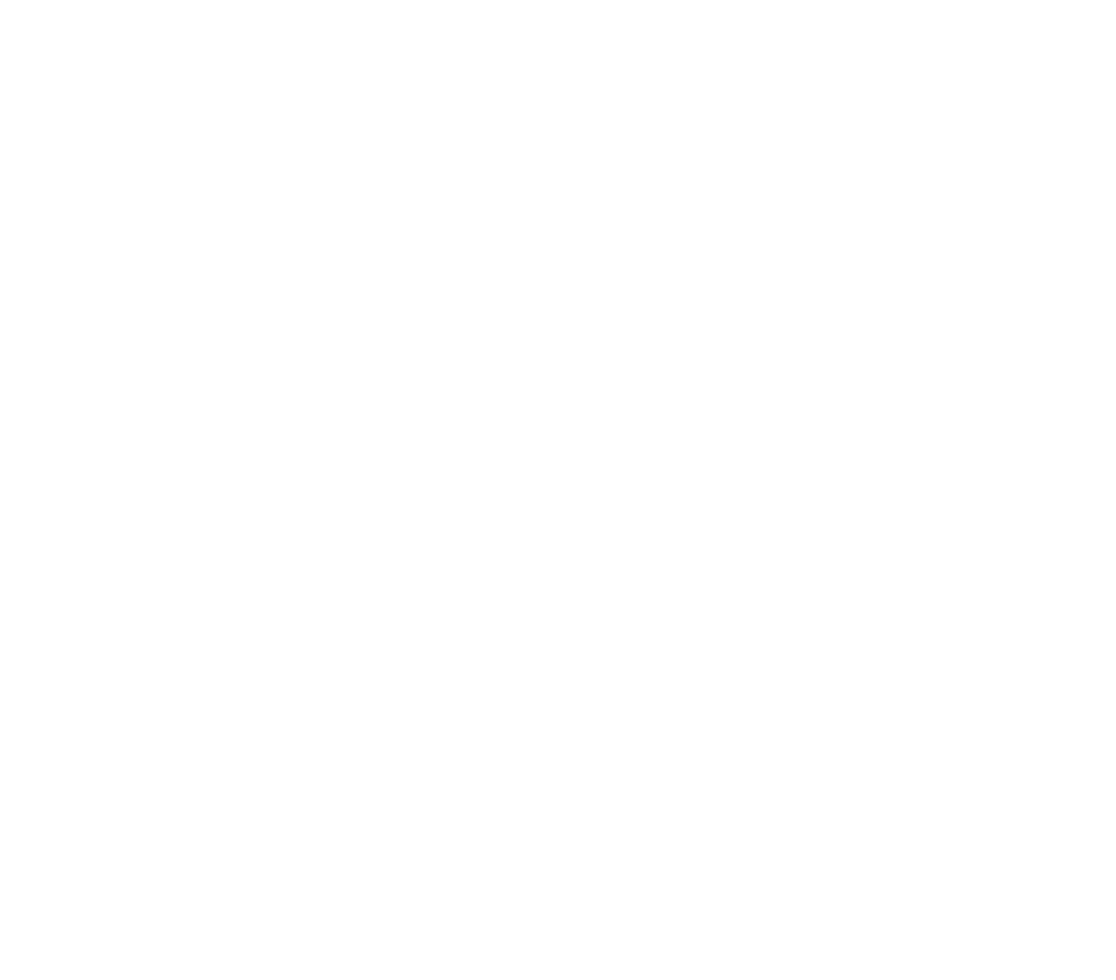

Note.-February and Oetober, 1884, and May, 1890, estimated by War Department.

Record of precipitution at Palmalale (Headurorks). Los Angeles County.

[Iatitude, 34 25'; longitude, 1180 18'; elevation, 3,299 feet. Anthority, Burt. Cole and A. T. Berkley.]

\begin{tabular}{|c|c|c|c|c|c|c|c|c|c|c|c|c|c|}
\hline Year. & Sept. & oct. & Nov. & Der. & Jan. & Fell. & Mar. & Apr. & May & June & July. & Aug. & Total. \\
\hline $189 \grave{a}-96$ & $\mathrm{~T}$. & $\mathrm{T}$. & (1. $5 \%$ & 0.10 & 1.00 & T. & $\therefore$ & T. & 0 & 0 & 0.25 & 1.33 & 5.95 \\
\hline $1896-97 \ldots$ & 0.32 & 1.42 & .43 & .98 & 3. 78 & 3. ${ }^{2} 1$ & 1.31 & 0.04 & 10.32 & 1) & .183 & $1.5 i$ & 13.91 \\
\hline $1897-98 \ldots$ & $\mathrm{T}$ & 1. .86 & 0 & .14 & 2.38 & $.1 \%$ & .90 & 0 & .21 & 0 & $.0 ?$ & .05 & 4. 6 \\
\hline 1898-99 _ . . & 0 & 0 & $\mathrm{~T}$. & $.8 \pi$ & 1.00 & .31 & $.9 \pi$ & 0 & 0 & 0 & 0 & 0 & 3.15 \\
\hline $1899-1900$ & 0 & $1.2 x$ & .27 & .33 & .65 & 0 & .80 & $.5 \%$ & .76 & () & 11 & 0 & 4.65 \\
\hline $1900-1901$. & 0) & : .20 & 1.79 & 0 & 1.34 & 4.501 & .38 & .15 & T. & 0 & 0 & .33 & 8.68 \\
\hline $1901-2$ & $\mathrm{~T}$. & .32 & .04 & 0 & $1.1 \%$ & 1.08 & 1.96 & .20 & 0 & $\mathrm{~T}$. & ( & a & $4.7 \%$ \\
\hline year me & & & & & & & & & & & & & 6.86 \\
\hline
\end{tabular}




\section{Record of precipitution at Sen Fernando, Los Angeles Connty.}

[Latitude, $34^{\circ} 16^{\prime}$; lomgitude, $13 \mathrm{R}^{\circ}: 26^{\prime}$; elevation. 1.14i6 foet. Authority, Pacific Railway Systom.]

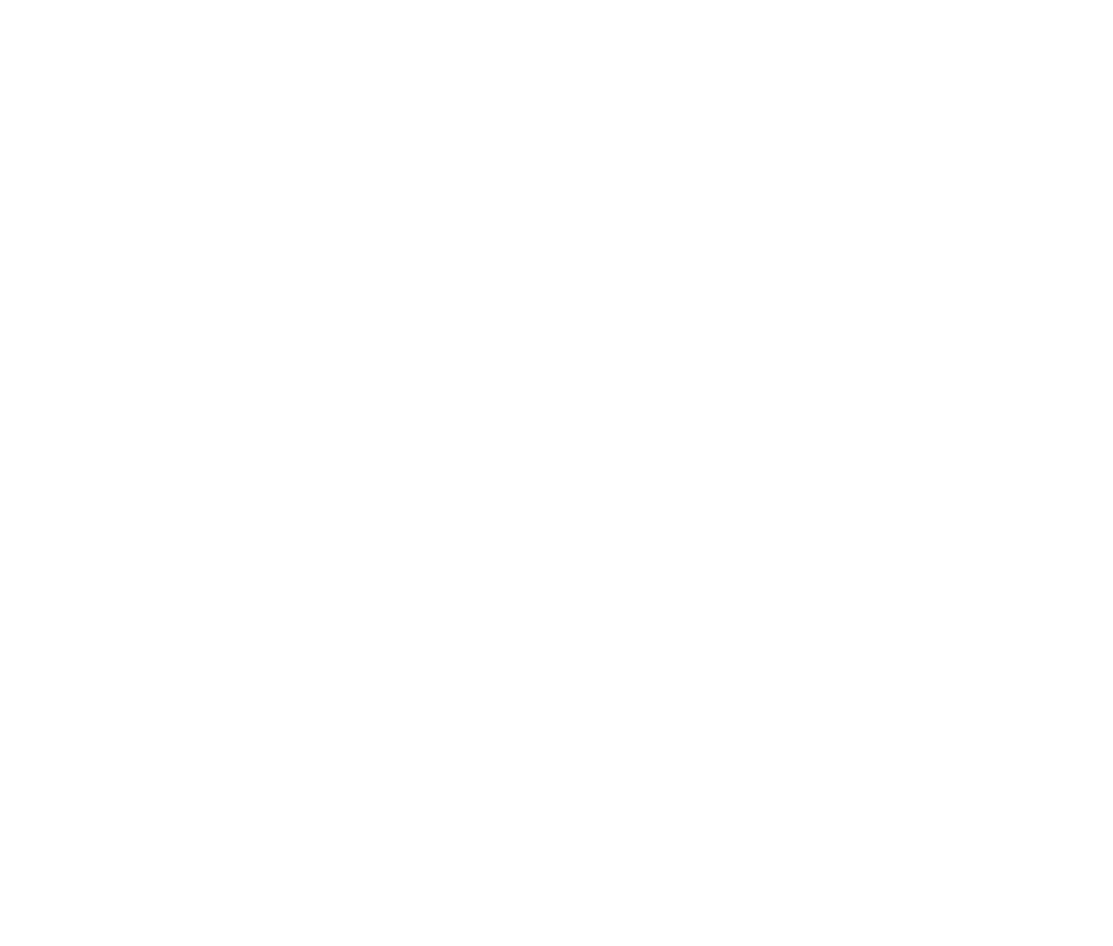

Recond of precipitation at San Gedriel Electric Company's pouer house, Azusa, Los Angeles, C'ounty.

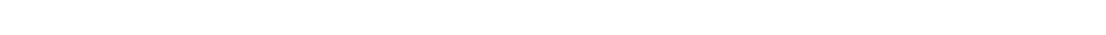
Company.]

\begin{tabular}{|c|c|c|c|c|c|c|c|c|c|c|c|c|c|}
\hline Year. & Sept. & ort. & Nov. & Der. & Jan. & Feb. & Mar. & Apr. & May. & June. & July. & Aug. & Total. \\
\hline $\begin{array}{l}1900-19011 \ldots \\
1901-2\end{array}$ & $\begin{array}{c}0.19 \\
0\end{array}$ & $\begin{array}{c}0 \\
3.1 \%\end{array}$ & $\begin{array}{r}9.76 \\
.64\end{array}$ & 1) & $\begin{array}{l}5.23 \\
1.98\end{array}$ & $\begin{array}{l}3.81 \\
3.03\end{array}$ & $\begin{array}{l}11.58 \\
4.69\end{array}$ & $\begin{array}{r}3.35 \\
.36\end{array}$ & $\begin{array}{r}1.87 \\
.23\end{array}$ & $\begin{array}{c}11 \\
0.14\end{array}$ & $\begin{array}{l}0 \\
0\end{array}$ & $\begin{array}{c}0.033 \\
0\end{array}$ & $\begin{array}{l}12.87 \\
14.22\end{array}$ \\
\hline "-year mean & & & & & & & & & & & & ..... & 13.55 \\
\hline
\end{tabular}

Record of precipitation at San Gabriel Electric ('ompany"s headg"te, Los Angeles County.

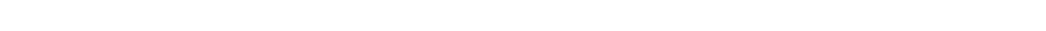
Company. J

\begin{tabular}{|c|c|c|c|c|c|c|c|c|c|c|c|c|c|}
\hline Year. & Sept. & oet. & Nov. & Der. & Jan. & Feb. & Mar. & Apr. & May. & June. & July. & Aug. & Total. \\
\hline 1900-1901 & 0.10 & 0 & 11.25 & 0 & 6.44 & 5. 09 & 0.48 & 1.15 & 2.90 & 0 & 0 & $0.0: 2$ & 27.43 \\
\hline $1901-2 \ldots .$. & 0 & 4.588 & 1.08 & .18 & 1.83 & 3.61 & 6.24 & 1.35 & .10 & .19 & 0 & 0 & 19.16 \\
\hline 2-year mean. & & & & & & . & & & & & & & 23.30 \\
\hline
\end{tabular}


Record of precipitation at Stan Gabriel Electric Company's Sierra porer house, Los Angeles C'ounty.

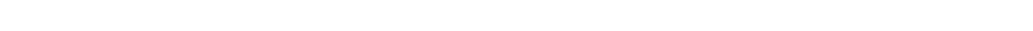
Company.]

\begin{tabular}{|c|c|c|c|c|c|c|c|c|c|c|c|c|c|}
\hline Year. & Sept. & oet. & Nov. & Dec & Jan. & Feb. & Mar. & Apr. & May. & June. & July & Aug. & Total \\
\hline $19(k)-16) 1$. & & & & & 10. 35 & 8.15 & 0.28 & 0.36 & 2.88 & 0.01 & 0 & 0 & a 22.43 \\
\hline $1901-z$ & 0 & 3.99 & $0.9 \pi$ & 0.24 & 2. 13 & 3.4 .5 & 7.53 & 1.13 & .20 & .11 & .03 & 0 & 19. 78 \\
\hline
\end{tabular}

« Year incomplete.

Record of precipitation at Coulterville, Mariposa C'ounty.

[Latitude, $3 \pi^{\circ} 43^{\prime}$; longitude, $120^{\circ} 12^{\prime}$, eleration, 1,660 feet. Authority, N. C. Pay.]

\begin{tabular}{|c|c|c|c|c|c|c|c|c|c|c|c|c|c|}
\hline Year. & Sept. & Oet. & Nov. & Dec. & Jan. & Feb. & Mar. & Apr. & May. & June. & July. & Aug. & Total. \\
\hline $1898-99 \ldots$ & 1) & 0 & 0.86 & $\because .04$ & 4.69 & 0.46 & 8.85 & 0.53 & 0.34 & $0.9 \pi$ & U & 1) & 18.64 \\
\hline $1899-1900) \ldots$ & 0 & $4.3 i$ & 5.70 & 3.32 & 2.01 & .60 & 1.47 & 2.90 & 1.14 & .33 & 0 & 0 & 21.84 \\
\hline $1900-1901$ & 0.18 & 3.82 & $8.2^{r}$ & 1.39 & 4.99 & 8.14 & $1.2 x$ & .66 & 3. $: 9$ & $T$ & T. & $\mathrm{T}$. & 31.92 \\
\hline $1901-2 \ldots$ & 1.35 & 1.92 & 2.09 & 1.39 & 0 & 0 & 0 & 0 & 0 & .09 & 0 & T. & 6.82 \\
\hline t-year' mean. & & & & & & & & & & & & & 19.81 \\
\hline
\end{tabular}

Record of precipitation at Yosemite, Mariposa Connty.

[Latitude, $35^{\circ} 45^{\prime}$ : longitude, $119^{\circ} 35^{\prime}$; elevation, 4,063 feet. Authority. Galen Clark.]

\begin{tabular}{|c|c|c|c|c|c|c|c|c|c|c|c|c|c|}
\hline Year. & Sept. & Ox.t. & Nov. & Dec. & Jan. & Feb. & Mar. & Apr. & May. & June. & July. & Aug. & Tota1. \\
\hline $1896-9 \pi$ & 085 & 1.36 & 6. 19 & 9.33 & 6. 62 & 11.53 & 16.32 & 0.40 & 062 & 0.16 & & & a 53.38 \\
\hline
\end{tabular}

$a$ Year incomplete.

Record of precipitation at Camp Wright, Mendocino County.

[Latitude, $39^{\circ} 45^{\prime}$; longitude, $1: 3^{\circ}\left(0 \sigma^{\prime}\right.$; elevation, 1,800 feet. Authority, U. S. War D spartment.]

\begin{tabular}{|c|c|c|c|c|c|c|c|c|c|c|c|c|c|}
\hline Year. & Sept. & Oet. & Nov. & Dec. & Jan. & Feb. & Mar. & Apr. & May. & June. & July & Aug. & Total. \\
\hline $864-65$. & 0.183 & 0.85 & 6.19 & 12.20 & 3.64 & 4.88 & 3.57 & 0.36 & 0.43 & 0 & 0 & 0 & 32.15 \\
\hline $1865-66 t^{2} \ldots$ & .81 & $.8 i$ & $16.6 \%$ & 2.05 & 15.83 & 4.30 & 11.80 & 1.05 & & & 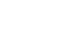 & $\cdots$ & a 53.38 \\
\hline $1866-6 t^{\prime} \ldots$ & 0 & 0 & 5.92 & $24.6 \pi$ & 8.92 & 7.85 & 2.38 & 3. 10 & .01 & 0 & 0 & 0 & 52.85 \\
\hline $1867-68$ & 1.56 & 3.75 & 6. $3 \hbar$ & 29.413 & 8.61 & 5. 89 & 9.11 & 3.25 & .71 & 1.58 & 0 & 0 & 9.87 \\
\hline $1868-69$. & .105 & .25 & 2. 79 & 6.63 & $13.5 \%$ & 4.13 & 3.80 & 4.51 & .55 & 0 & 0 & 0 & 36.28 \\
\hline $1869-70$. & 1. $4 \%$ & .84 & 5,38 & 8.106 & $\pi .03$ & 6.61 & 2.40 & 2.02 & 89 & 0 & 0 & 0 & 34.15 \\
\hline 18.0 & 0 & 0 & 1.28 & 1.19 & 2.66 & 4.60 & $\approx 10$ & $1.0 \%$ & 1.96 & 0 & 0 & 0 & 19.86 \\
\hline $18 \pi 1-\tau 2$. & . .7$)$ & .31 & 4.13 & 16.64 & 11.52 & 19.78 & 5. 34 & .66 & .12 & .04 & 0 & 0.20 & 59.14 \\
\hline $1 \times 72-73 \ldots$ & 0 & 36 & 5. 20 & 7.24 & 3.55 & 6.92 & 2.91 & 1.13 & .04 & .30 & 0.10 & 0 & $2 \pi .75$ \\
\hline $1873-74 \ldots$ & .05 & .34 & 4.98 & 15.50 & 12.94 & 5.46 & 7.26 & 3. $\% 2$ & 1.16 & .26 & .01 & 0 & 51.68 \\
\hline $18 \pi 4-75 \ldots \ldots$ & $1)$ & อ. 61 & 12.99 & 2.27 & 9.83 & 1. 06 & 1.76 & .59 & 2.32 & 0 & 0 & 0 & 36.43 \\
\hline & & & & & & & & & & & & & 42.02 \\
\hline
\end{tabular}

$a$ Year incomplete. 


\section{Record of precipitation at Alturas, Modoc County.}

[Latitude, 410 30': Iongitude, 1:20'30': "levation, 4,30) feet. Anthority, J. HI. Stewart.]

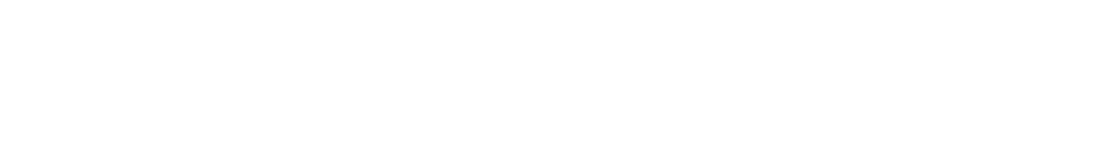

\section{Record of precipntation at Fort Biduell, Modoc Comnty.}

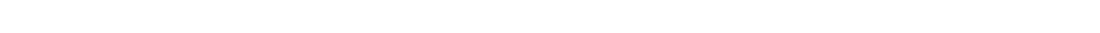

\begin{tabular}{|c|c|c|c|c|c|c|c|c|c|c|c|c|c|}
\hline Year. & Sept. & $O \cdot t$. & Nov. & Dec. & Jan. & Fel. I & Mar. & Apr. & May & June. & Tuly & Aug. & Total. \\
\hline $666-6 \pi$ & 0 & 1.001 & 3.50 & 5.80 & 12.00 & 4.80 & 6.70 & 1. 30 & 0 & 0.60 & 0.10 & 1. 40 & 37.20 \\
\hline $1867-68$ & 2.80 & .81 & 3.10 & $\therefore, 21)$ & 3.50 & .41 & 4.00 & .60 & 2.40 & 4.10 & .35 & 0 & 30.25 \\
\hline $1868-69$ & .20 & .50 & . & .90 & 2.50 & .40 & 2.36 & 1.55 & .60 & .20 & .70 & 0 & 10.41 \\
\hline $1869-70$. & .45 & 0 & $2.33^{\mu}$ & 2.30 & 19. 1 & 5.40 & 3.21 & 1.41 & 2.87 & 1.36 & .76 & .05 & 32.89 \\
\hline $1870-\pi$. & 11 & .113 & $2 .: 99$ & 9.10 & 1.23 & 3.26 & 3.21 & 0 & $.9 \pi$ & .16 & .38 & .02 & 20.65 \\
\hline $18 \% 1-\tau 2$ & .20 & .20 & .79 & 3.25 & 1.16 & 3.97 & 1.32 & .17 & 1.42 & .06 & 0 & .26 & 13.80 \\
\hline $1 \times 72-73$. & 1.18 & 46 & 1.169 & 1.94 & 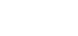 & 1.66 & . 60) & 2.06 &.$i n$ & .10 & .14 & .21 & 13.04 \\
\hline $1873-74$ & .40 & ti3 & 1.14 & 33.99 & 1.51 & $1.0 \mathrm{~s}$ & 1.15 & 1.12 & .64 & 1.106 & .05 & i & 12.24 \\
\hline $187+7.5$ & 0 & .99 & 2.44 & .13 & 2.10 & $.0 \pi$ & 2.15 & . 45 & 1. 30 & 1.00 & 0 & .0 .5 & .10 .98 \\
\hline $18 \% 5-76$. & 0 & 1.80 & $2.6 \%$ & 1.54 & $3.5 i$ & .39 & . $8(1)$ & .53 & .98 & .43 & 0 & 0 & 12.59 \\
\hline $66-7 \%$ & 1) & 1.99 & $4.3: 2$ & $\therefore .115$ & 9.365 & 3.30 & 4.10 & 2.14 & 4.66 & 2.10 & .10 & .35 & 34.47 \\
\hline $18 \pi 7-78$ & .10 & .80 & 3.113 & .35 & .75 & 46.5 & 2.35 & 1.05 & .82 & .20 & .25 & $.3 \%$ & 14. $\%$ \\
\hline $1878-\% 9$ & .70 & .30 & (:) & .20 & 3.00 & $: 2 .(i) 3$ & .95 & 1.00 & 1.40 & .15 & .15 & .30 & 11.93 \\
\hline & .10 & 1.34 & 1.5 & 6. 601 & 3.11 & 80 & 36 & 5.60 & 1.38 & $\therefore 6$ &.$i 2$ & .42 & .43 \\
\hline $18 \times 01-81$ & .05 & .50 & .26 & (i. 109 & 10.100 & 6. 011 & 1.50 & 3.02 & .84 & 1.59 & .32 & .10 & 30.54 \\
\hline $18+1-8 \%$. & .84 & 3.55 & ?.X. & 3.40 & 3.44 & 2.82 & 1.46 & 1. 42 & .64 & .38 & .16 & 0 & 20.68 \\
\hline $1889-83$ & .4 & 2.73 & .92 & 1. & 2.52 & .64 & .77 & 1.56 & 1.30 & $0^{\circ}$ & 0 & 0 & 12.69 \\
\hline 188384 & 11 & 1.18 & 1.14 & 1.166 & 1.14 & 2.96 & .82 & .68 & .40 & 4.29 & $.6 \%$ & .08 & 14.32 \\
\hline $1884-85$ & 1. 41 & .73 & $\mathrm{~T}$ & 6.81 & 2.09 & 1.82 & .04 & 3.45 & 1.99 & 1.05 & 1.38 & .17 & 20.98 \\
\hline $1885-86$ & .09 & .75 & ร. 46 & 3. 74 & 5. 38 & 2. 16 & 1.48 & 2.20 & 1.44 & .78 & .41 & .114 & 27.33 \\
\hline $1886-8 \%$ & 0 & $1.3 \mathrm{~b}$ & 1.06 & 4.25 & 3.31 & 4.85 & .97 & 1.96 & $1.4 \tau$ & .73 & .18 & .21 & 20.35 \\
\hline $1887-88$ & .05 & 0 & .38 & 2.40 & 3. 28 & 1.81 & 3. 28 & .16 & 1.50 & 2. 38 & .34 & .04 & 15.62 \\
\hline $888-89$ & .33 & .21 & $\therefore .03$ & 3.28 & 2.81 & .20 & 7. 31 & 1.08 & 1. 62 & .78 & 0 & 0 & 19.64 \\
\hline $1889-90$ & 0 & 3.61 & 2.20 & 3. 78 & 7.45 & 3.97 & $3.9 \%$ & .92 & $1.0 \%$ & .33 & .05 & .05 & 27.40 \\
\hline $1890-91$ & 1. 60 & .10 & 0 & 1.00 & .50 & 3.98 & 3.83 & 1.39 & 1.57 & 2. 73 & 155 & .19 & 18.44 \\
\hline $1891-92$. & .73 & .19 & I. $5 i$ & 2. $i f$ & .79 & 1.20 & .69 & 2.28 & $1.5 \pi^{\circ}$ & 1.46 & .15 & .02 & 12.81 \\
\hline 189?-93. & .91 & 1.28 & 3.12 & 2.64 & 2.60 & 2.92 & 1. $(6)$ & 1.88 & 1. 66 & .01 & .50 & .05 & 19.17 \\
\hline & & & & & & & & & & & & & 20.13 \\
\hline
\end{tabular}


Record of precipitation at Jolon, Monterey County.

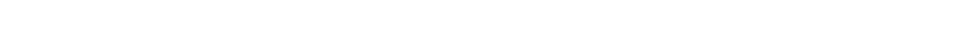

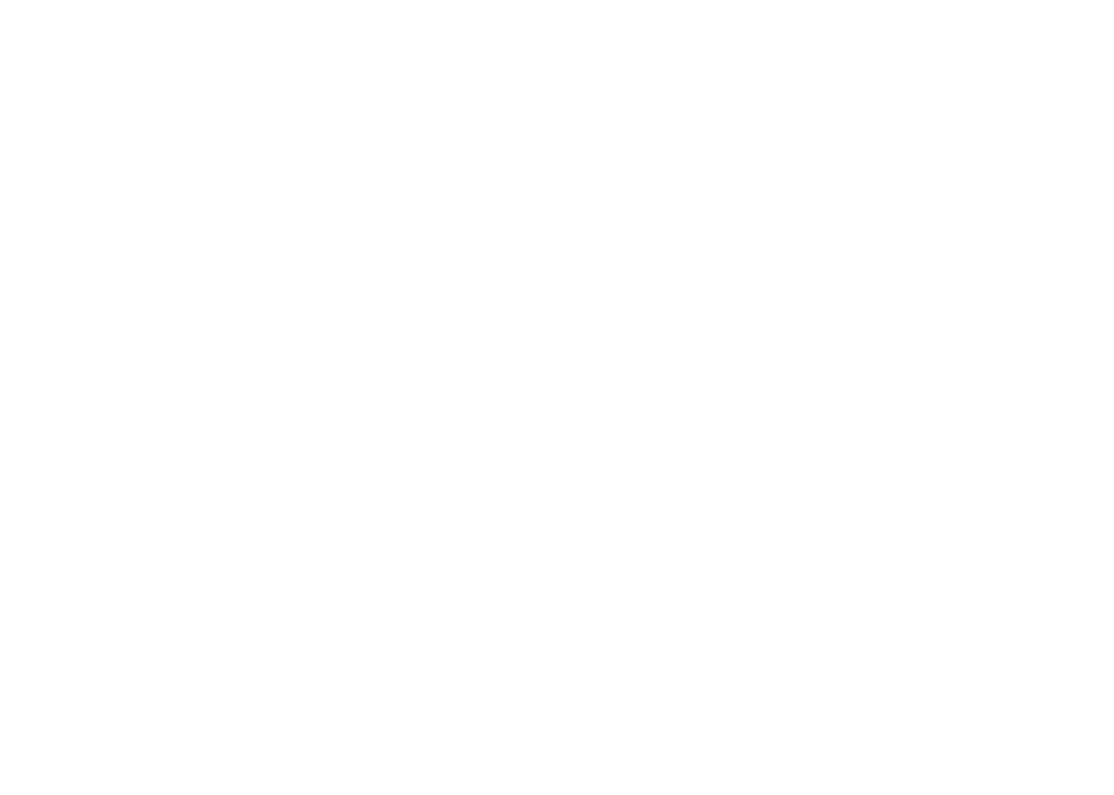

Reard of preapitation at Nattheus Rambh, near King City, Nomterey C'onnty.

[Latitudi‘, 34; 15'; longitude, $121^{\circ} u\left(\gamma^{\circ}\right.$ : elevation, 333 feet. Authority, J. I. Matthews.]

\begin{tabular}{|c|c|c|c|c|c|c|c|c|c|c|c|c|}
\hline Year. & Sept. & Or.t. & Nor. & Der. & Jan. & Feb. & Mar. & Apr. & May & June. & July. Aug. & Total. \\
\hline 1901-3 & & & 1.37 & 0.10 & 0.71 & 3.74 & 2.34 & 0.81 & & & & 9.11 \\
\hline
\end{tabular}

\section{Record of precipitation at Priests I'alley, Monterey county.}

[Latitude, 36' 12'; longitude, 121 45'; elevation, 2,:50 feet. Authority, A. J. Myers and Mrs. Martin Griffin, Soledad.]

\begin{tabular}{|c|c|c|c|c|c|c|c|c|c|c|c|c|c|}
\hline Year. & Sept. & Oet. & Not. & Dec. & Jan. & Feb. & Mar. & Apr. & May. & June. & July. & Aug. & Total \\
\hline $1898-99 \ldots$ & 0.13 & 0.17 & 0.36 & 0.34 & 4.111 & 0 & 5.) 30 & 1.33 & 0.52 & (1) & 0 & 0 & 12.16 \\
\hline $1899-1900$ & () & 3.61 & 1.80 & 2.81 & 2. 53 & 0.16 & $2.3 i$ & 1.17 & 1.23 & () & 0 & 0 & 15. 60 \\
\hline $1900-1901$ & (1) & 2.50 & 5.98 & .64 & 6. 27 & 9.51 & .80 & 2.44 & 1.59 & 0 & 0 & 0 & 31.13 \\
\hline $1901-2 \ldots$ & 0 & 2.57 & 2.118 & .66 & .70 & 5. $4: 2$ & 3.60 & 1.84 & .24 & 0 & 0 & 0 & $1 \% .11$ \\
\hline 4-year m & & & & & & & & & & & & & 19.18 \\
\hline
\end{tabular}


Record of precipitution at Salinas C'ity. Monterey Comnty.

[Latitude, $36^{\circ} 4 I^{\prime}$ : longitude. ]:2 :3i': clovatinn. 45 feet. Authority, Dr. E. K Abbott.]

\begin{tabular}{|c|c|c|c|c|c|c|c|c|c|c|c|c|c|}
\hline Year. & Sept. & $00 \mathrm{t}$. & Nov. & Des. & Jall. & F(t). & Nar. & Apr. & May. & June. & July. & Aug. & Total. \\
\hline & & & & & & & & & & & 0 & 0 & \\
\hline & 0.01 & 0 & 0 & 6.80 & 3.411 & 2.41 & $(0.80)$ & 0 & 1) & 0 & 0 & 0 & \\
\hline & .70 & 0.10 & 0. 20 & 4.25 & $3.4: 3$ & 11 & 2.15 & 0.95 & 0 & 0 & (1) & 0 & 11.17 \\
\hline & 0 & 1.83 & 1.42 & 0 & 4.50 & .15 & .69 & 0 & 0 & 0 & 0 & 0 & 8.59 \\
\hline & 0 & 0 & 5. 17 & 1.94 & (i. 16 & 3.55 & $4.5 \%$ & 1) & 0.111 & 0 & 1. 10 & 1) & 21.49 \\
\hline & .15 & 1.04 & (15) & 0 & 2.54 & .16 & .30 & .10 & .40 & 0 & & 0 & 4.64 \\
\hline & 0 & .12 & 1.001 & 2.39 & 7.15 & 8.77 & $\therefore .5 i$ & 1.93 & 0 & 0 & 0 & 0 & 23.83 \\
\hline &.$(15)$ & .60 & $\therefore 0$ & .35 & 2.42 & 2.81 & 1.85 & 1. 69 & .82 & (1. 15 & 0 & 0 & 10.94 \\
\hline & 0 & 1.45 & 1.08 & P.2A & $1.4 ; 5$ & 1.16 & 1.64 & 3.90 & .46 & 11 & 0 & 0 & 13.22 \\
\hline & 0 & 0 &.$\tilde{5} \tilde{\imath}$ & 5.53 & 3. $3:$ & 2. 32 & 1.26 & .665 & 0 & .38 & 0 & 0 & 14.07 \\
\hline & .10 & .28 & .65 & 1.24 & $1 . \pi$ & 法.31 & 4.86 & 1.01 & .49 & .19 & 0 & 0 & 2.93 \\
\hline & .38 & 1.43 & .6 .5 & 1.9 .5 & .91 & .95 & 2.26 & 1. 28 & 1.96 & 0 & 0 & 0 & .79 \\
\hline $1883-84 \ldots$ & .19 & 1.19 & (5) & .90 & $1 . \pi 1$ & 4.49 & 5.199 & 3.05 & .72 & 2.666 & 0 & 0.18 & $: 0.43$ \\
\hline & .11 & 1. 79 & .20 & 4.43 & 1.199 &.$(6)$ & .19 & 1. 21 & .12 & 0 & 0 & 0 & 9.30 \\
\hline & $.0 \%$ & $.0 x$ & (i. 60 & 1.301 & 5. 10 & 1.47 & 2.16 & 3.83 & 0 & 0 & 1) & 0 & 20. 56 \\
\hline & 0 & .62 & .80 & 20 & .5 & 4.73 & .54 & 1.63 & .01 & (1) & 1) & 0 & 9.88 \\
\hline & .11 & 0 & .98 & $\because .16$ & 4.15 & .53 & 3.28 & 0 & .89 & 0 & 0 & 0 & 12.70 \\
\hline & $.5 t^{\circ}$ & 11 & 1.64 & 2.211 & .64 & & 3. 31 & .95 & 68 & () & 0 & 0 & \\
\hline & $1)$ & 4.211 & 2.41 & 8.90 & 5.99 & 3.05 & 1. 79 & 60 & .655 & 0 & (1) & 0 & 27.59 \\
\hline $0-97$ & 0 & .29 & .44 & $\because(15)$ & .59 & 4. 41 & .43 & 2.53 & .33 & 0 & 0 & () & 11.06 \\
\hline & .12 & $.1 i$ & .31 & 4. 66 & .44 & & :2. 78 & .85 & .65) & 1) & 0 & 0 & \\
\hline & .08 & .066 & 4.03 & 2.13 & $1.0 \%$ & 2.91 & 5. 14 & .91 & $u$ & 0 & 0 & 0 & 16. 99 \\
\hline & 0 & .33 & .66 & $1 . \overline{3}^{\prime \prime}$ & 5. 17 & 3.36 & .82 & .53 & $1.5 \pi$ & .26 & 0 & 0 & 14.20 \\
\hline & 1.16 & .87 & .41 & 5.35 & 5.10 & 1.41 & $2.0 \%$ & .94 & .45 & 0 & 0 & 0 & 17.76 \\
\hline & 11 & .565 & .79 & .83 & 5.65 & .22 & 1.68 & 2.64 & .45 & 0 & 0 & . $4: 2$ & 13.24 \\
\hline & .0 .2 & 1.01 & 3.03 & $\therefore 02$ & .66 & 3.34 & 4.51 & .11 & .06 & .12 & 0 & 0 & 14.93 \\
\hline & .50 & $.7 x$ & .97 & .96 & .96 & 1.66 & 1.06 & $\therefore 3$ & 1. & .10 & 0 & 0 & 8.50 \\
\hline & $.1 \tau$ & .34 & .34 & 1.18 & 2.98 & .510 & 4.11 & .5 & .14 & 0 & (1) & 0 & 110.55 \\
\hline & 0 & 2.65 & 2.96 & 1.80 & .84 & .7 & 1. (x) & 141 & .25 & 0 & () & 0 & 11.68 \\
\hline & 0 & .69 & 5.65 &.$\approx 1$ & 1.69 & 5,44 & .50 & 148 & .35 & 1) & 0 & 0 & 16.51 \\
\hline & .38 & .50 & 1.27 & .20 & 1.01 & $3.5 !$ & 2.58 & .87 & $.2 \pi$ & (1 & 0 & 0 & 10.58 \\
\hline
\end{tabular}

"Year incomplete.

Recorl of precipitution at San Ardo, Honterey c'ousty.

[Latitude, 36० $03^{\prime}$; longitude, 1:2 $1^{\circ} 10^{\prime}$; elevation, 45: feet. Authority, Pacific Railway System.]

\begin{tabular}{|c|c|c|c|c|c|c|c|c|c|c|c|c|c|}
\hline Year. & Sept & $O(\cdot t$ & Nor. & Dec. & Jan. & Feb. & Mar. & Apr. & May. & June.' & July & Aug. & Total. \\
\hline $1886-8 \%$. & () & 0 & $0: 35$ & 0.17 & 0.5 & 5.58 & $0.1 \%$ & (1. 76 & 0.15 & 0.296 & 0 & (1) & 7.92 \\
\hline $188 \%-88$ & 1). 14 & 0.37 & $.3 \%$ & 2.147 & 3.44 & 2 & 2.91 & .11 & $.2 \pi$ & 0 & 0 & () & 9.91 \\
\hline $158 \times-89$ & 0 & 0 & 3.24 & 2.31 &.$\times 3$ & .80 & 6.16 & .49 & זّة & 0 & (1 & u & 14.10 \\
\hline $1889-90$ & 0 & 4.74 & 2.96 & 7.16 & 3.36 & 3.59 & .99 & 0 & .43 & () & 0 & 0.104 & ז \\
\hline $1890-91$ & 1.10 & 0 & .11 & 1.41 & .43 & 3.99 & .86 & 1.114 & .133 & 0 & 0 & 0 & 8.87 \\
\hline $1891-92$. & .14 & 0 & 0 & 1.5 & $.5 \%$ & .48 & $1.3 i$ & .08 & 1.61 & 0 & (1) & 0 & 5.83 \\
\hline $1 \times 92-93$. & 0 & .15 & 1.80 & 3.40 & 1.65 & 1.31 & 3.94 & .62 & .15 & 0 & 11 & () & 12.92 \\
\hline $1893-94 \ldots$ & 0 & 0 & .21 & 1.166 & 1.18 & .34 & .13 & .10 & .68 & Iis & 11 & 0 & 3.85 \\
\hline $1894-95$ & .65 & .25 & (r) & 4.42 & 3.98 & 33. & .94 & .41 & .012 & 0 & $\theta$ & 0 & 10.92 \\
\hline 1895-96 _. & 0 & 1.48 & 2.86 & .30 & 5.10 & 0 & 2.11 & $2.2 \pi$ & .25 & 0 & 0 &. & 14.59 \\
\hline $1896-97 \ldots$ & 0 & .45 & 2.73 & 1.54 & .89 & 1.18 & 2. 19 & .06 & 0 & 0 & 0 & .02 & 9.06 \\
\hline $1897-98 \ldots$ & 0 & .78 & 05 & $.4 \%$ & .38 & 89 & .0 & 0 & .43 & 11 & 0 & $\mathrm{~T}$ & 3.65 \\
\hline $1898-99 \ldots$ & $\mathrm{T}$. &, 15 & .243 & .15 & 3.24 & .03 & 2. 81 & .84 & $\mathrm{~T}$ & $\mathbf{T}$ & 0 & T. & 7.40 \\
\hline 1899-1900.. & 0 & 1.65 & 16 & 1.09 & 1.68 & 15 & 1.15 & .39 & .66 & $\mathrm{~T}$. & $\mathrm{T}$ & 0 & 7.73 \\
\hline $1900-1901$. & T. & .88 & 430 & .08 & 3.89 & 4.17 & .51 & .67 & 1. $: 0$ & 0 & 0 & 0 & 15. $\pi 0$ \\
\hline $1901-2 . .$. & .05 & .94 & 1.49 & 0 & .66 & 4.29 & 2.20 & .71 & $\mathrm{~T}$ & () & U & 0 & $10.3 \%$ \\
\hline $16-5$ ear me & & & & & & & & & & & & & 10.38 \\
\hline
\end{tabular}


Record of precipitation at Boca, Nevala c'muty.

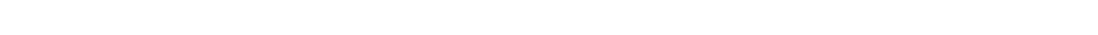

\begin{tabular}{|c|c|c|c|c|c|c|c|c|c|c|c|c|c|}
\hline Year & Sept. & oct. & Nov. & $D(2 x$. & Jan. & Fel, & Mal. & Apr. & May & June. & & Aug. & Total. \\
\hline$\sim 4$ & & & ...... & & & 3.85 & 1.82 & 0.81 & 0.5 .5 & (1. 26 & 11. 1\% & () & $t \div 41$ \\
\hline & 0 & 0.811 & 0.114 & 1.10 & 250 & 2.38 & $1.60)$ & .45 & i) & .10 & $\because(0)$ & 0 & 10.91 \\
\hline$\pi 1-\gamma 2$. & 0 & 0 & (i) & ז.301 & 3.001 & (9) & 10 & 1.50 & 10 & 11 & 0 & (1 & 1350 \\
\hline 1872 & 0 & 0 & .20 & 2. (6) & 1.80 & 4.111 & .10 & .10 & $\pi$ & 1) & 1) & 11 & 9.65 \\
\hline & 0 & 0 & 0 & 4.311 & 4.70 & $\because 40$ & 6.: & 80 & . (x) & 0 & 66 & 11 & (9., 60) \\
\hline & .10 & 2. 15 & 3. $\%$ & .60 & 6. 30) & 0 & .65 & (6) & 0 & 411 & $\mathrm{~T}$ & 0 & 14.50 \\
\hline & 0 & $\mathrm{~T}$ & 1.56 & 1.65 & & 3.60 & 4. & $\pi$ & .10 & $1)$ & ס & $1.01]$ & 20). $0^{30}$ \\
\hline $18 \%$ & .01 & .45 & 02 & 0 & 5.29 & 0 & .46 & .95 & .34 & .10 & 0 & 0 & 7. 37 \\
\hline & 0 & 0 & 1.50 & .31 & 3.94 & 6. $\pi 4$ & .86 & 1.30 & 0 & 13 & 0.8 & 0 & 34.85 \\
\hline & .17 & .99 & 1.60 & 0 & & & 4.80 & 08 & .45 & 0 & 0 & 1) & 3.45 \\
\hline & 11 & .20 & .98 & 4.18 & 11 & 3.001 & 290 & f. 45 & .75 & 0 & 0 & 0 & 18.96 \\
\hline & 0 & 0 & 0 & 3.74 & 0 & 0 & 12 & 0 & 0 & 1) & 11 & 0 & $3.8 \mathbf{b}^{\circ}$ \\
\hline & 14 & .10 & 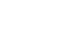 & & & 3.60 & I0 & 1.000 & 0 & 1) & 11 & 0 & 21.11 \\
\hline & 0 & .80 & .90 & (i) & 1. 15) & 2.21 & 1 \% & .90 & 1. 811 & 0 & "1) & 0 & 10.05 \\
\hline & .14 & B. 45 & .50 & & & 6. 30) & 5.10 & $1.9)$ & .30 & 140 & 0 & 1) & 3.29 \\
\hline & $\mathrm{T}$ & .80 & 0 & & & 10 & .116 & 1.54 & 0 & .310 & 0 & 0 & 2.00 \\
\hline$\cdots$ & 0 & 0 & 240 & 2.98 & 8. & .85 & 4.40 & 1.30 &.$\check{30}$ & 0 & .15 & 0 & 20). 93 \\
\hline & .10 & .70 &.$\pi 0$ & & & 12.70 & & 1.81 & $\mathrm{~T}$ & : 26 & .15 & $\mathrm{~T}$. & .51 \\
\hline & 0 & 0 & $.30 j$ & 3.74 & 4. 18 & 1.00 & 2.40 & .10 & .51 & . 10) & .15 & .31 & 12.92 \\
\hline & $.1 \%$ & 0 & .95 & 1.45 & 4.18 & 3.63 & 1.15 & .10 & 3.90 & 0 & 0 & 1) & J5. 48 \\
\hline & .14 & 1.50 & 4.5 & & 14. & & 5.45 & 50) & . & .265 & & 1) & 395 \\
\hline & 0 & .70 & 0 & & & & 2.50 & 1.70 & .84 & $.2 \mathrm{t}$ & .15 & & 22.85 \\
\hline & (6) & 0 & ד & 8.30 & .60 & 3.35 & 1.70 & 2.70 & 3.14 & . & 0 & 1) & 21.40 \\
\hline $1892-93$ & 0 & 1.50 & 8.35 & 6.95 & 4.5 & 8.90 & 4. (x) & 1.90 & 1.3.) & 11 & 0 & .05 & $3 \pi .55$ \\
\hline & 5) & . & $\approx 4:$ & & & $\tau .55$ & .7 .5 & 1.10 & .33 & $\mathrm{r}$ & ( & $\mathrm{T}$ & 21.65 \\
\hline $1894-95$ & $\mathrm{~T}$ & .61 &.$\check{x}$ & 11.80 & 8. 36 & 1.:20) & .45 & .70 & .90 & $\mathbf{T}$ & 0 & $\mathrm{~T}$ & 24.52 \\
\hline 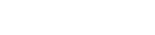 & $.9 \pi$ & .11 & .01 & & & .31 & 6.311 & 6.65 & 3.10 & 25 & 1.15 & .18 & 28.49 \\
\hline & .35 & 0 & 2.47 & & & 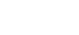 & 8.35 & 10 & .51 & .41 & 0 & .50 & 2302 \\
\hline & $\mathrm{T}$ & 2.10 & 2.80 & & & 2.919 & 2.50 & 1.30 & .85 & 1. (k) & 0 & 0 & 17.72 \\
\hline & (1) & 1. 28 & 1.84 & & & 1.8 .5 & $i .95$ & .85 & 2.40 & .10 & & 98 & 25.64 \\
\hline & 0 & $4.4 \%$ & 2.59 & & $1.5 \%$ & . (i) & $3.5 \%$ & $4.2 \tau$ & 1.10 & $2.6 \%$ & $\mathrm{~T}$. & 1.22 & 26.49 \\
\hline & .660 & 3.114 & 5.73 & & T.1T & 6. 66 & & 2.04 & 1.86 & 0 & 0 & .08 & 34.16 \\
\hline $1901-2 \ldots . . .$. & .40 & .80 & 1.15 & $3 . \pi$ & 1.34 & 2.50 & 2.70 & $\mathrm{~T}$ & $\Gamma$ & 11 & .10 & 0 & 12.72 \\
\hline & & & & & & & & & & & & & 13.33 \\
\hline
\end{tabular}

¿Year incomplete. 
Record of precipitation at Bouman's dam, Nevada County.

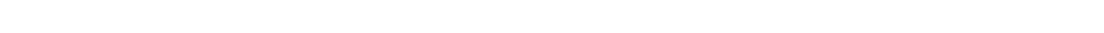
Radford.]

\begin{tabular}{|c|c|c|c|c|c|c|c|c|c|c|c|c|c|}
\hline Year. & Sept. & $0 \cdot t$ & Nov. & $D t^{*} \times$ & Jan. & Feth. & Mar. & Apr & May. & June. & July. & Aug. & Total. \\
\hline $18 \% 1-72$ & 0 & (1) 98 & i 88 & 38.20 & 12.98 & 25.08 & 7.52 & 4.57 & 1.09 & 1.04 & 0.88 & 0 & 102.2 \\
\hline 187273. & 025 & .73 & 5.43 & 17.41 & 5. 73 & 16.17 & 3.82 & 3.20 & 2. 65 & 0 & .06 & 0 & 55.45 \\
\hline $18 \div 3-74$ & 0 & 1.24 & $4.3 \pi$ & 23.47 & 21.53 & 9.98 & 16.73 & $5.4 \%$ & 3.93 & .45 & 0 & 0.08 & 88.25 \\
\hline $874-75$. & 0 & 4.54 & 15. 35 & 1.58 & 16.91 & .25 & 5. 18 & .83 & 2.85 & 2.38 & .25 & 1 & 50.12 \\
\hline $18 \% 5$ & (1 & 3.199 & 23.43 & $10.7 \pi$ & 17.62 & 11.70 & $18.0 \mathrm{I}$ & 5.92 & .99 & .36 & 1.28 & 0 & 3.17 \\
\hline $1876-$ & .41 & 111.76 & . 53 & 0 & 14.33 & 3.18 & 7.49 & $3.1 \%$ & 3. 33 & 1.17 & 0 & 0 & $44.3 \pi$ \\
\hline & 0 & $1,5 \%$ & 826 & $1 . \pi 1$ & 17.00 & 21.21 & 10.07 & 2.57 & 2.06 & .10 & .19 & .13 & 64.72 \\
\hline 87 & 0 & z 83 & 536 & 1.31 & 14.50 & 14.28 & 20.97 & $9.5 \pi$ & 3.93 & .71 & .05 & .10 & 73.60 \\
\hline & 0 & 341 & 9.62 & 15.01 & $9.2 \%$ & 8.17 & 9.51 & 31.72 & 8.90 & 0 & 0 & 0 & 5.60 \\
\hline & 0 & 0 & .65 & & & 15.0 & 7.29 & & 1.22 & 0 & 0 & 0 & .55 \\
\hline 881 & 2.33 & 609 & 4.25 & 10.78 & 11.46 & 7.45 & 15.17 & 7.96 & 1.16 & 0 & 0 & 0 & 66.67 \\
\hline & 2.94 & $11.4 \pi$ & 6.51 & 4.32 & 5.06 & 5.28 & 12.79 & 5.15 & 0 & 0 & 0 & 0 & $3.5 \%$ \\
\hline & 245 & 503 & 2.46 & & & 19.45 & 02 & 12.44 & 2.01 & 3.53 & 0 & 0 & .09 \\
\hline $884-8$ & 1.08 & 3.114 & 0 & $46.5 i$ & 4. 49 & 3.74 & .80 & 6.41 & $1.5 \%$ & 2.64 & 0 & 0 & 70.34 \\
\hline & 1.20 & 11 & 24.96 & S. 645 & $1 \% .84$ & 2.99 & 7.24 & 13.22 & 3.20 & 0 & 0 & 0 & 79.37 \\
\hline & 0 & 2.25 & & 6.95 & $\div .46$ & 21.60 & $2.2 \%$ & 5.81 & 1.93 & .76 & 0 & 0 & 79 \\
\hline & 0 & 0 & 1.25 & 8.97 & & & & & & & & & a 10.22 \\
\hline 1894 & & ..... & ..... & ....... & 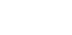 & $8.7 \%$ & 9.65 & & 9.15 & 0 & $\mathrm{~T}$. & .37 & a $2 \% .94$ \\
\hline $895-$ & $10.1 ?$ & .45 & 2.81 & 11.20 & 29.85 & 1.92 & 14.95 & 18.45 & 8.98 & .11 & .09 & 1.00 & 49.93 \\
\hline & 2.05 & 2.83 & 1940 & 10. 31 & 4.88 & 18.31 & 18.91 & 2.85 & .92 & 4.04 & 0 & $\mathrm{~T}$ & 84.50 \\
\hline $897-$ & .61 & 4 it & 5.35 & 5.31 & 3.01 & 12.23 & 2.63 & 2.10 & 3.95 & 2.12 & 0 & 0 & 42.05 \\
\hline & $.5 \overline{3}$ & 2.64 & 7.51 & 3. 22 & 14.11 & 2.54 & 26.31 & 1. 73 & 4.80 & 1.04 & 0 & 1.15 & 65.60 \\
\hline $1899-1$ & 0 & $162 \%$ & 12.53 & 15. \% & 9.60 & 4.44 & $10 . \%$ & 6.62 & $2.6 \%$ & .40 & .02 & 0 & 79.04 \\
\hline $1900-19011$ & 1.38 & 1\%. א & $11.4 \%$ & 8.15 & 14.30 & 18.79 & $4.6 \%$ & 5.99 & 1.73 & $T$ & T. & .05 & \%9.51 \\
\hline $1901-2 \ldots . . .$. & 412 & 4.28 & $\tau, 54$ & 8.01 & 2.40 & 21.08 & 9.26 & 5.96 & 2.76 & .46 & .09 & $\mathrm{~T}$. & 65.96 \\
\hline & & & & & & & & & & & & & 72.63 \\
\hline
\end{tabular}

a Year incomplete. 


\section{Recorl of precipitation at Grass I 'alley, Nevada C'ounty.}

[Latitude, $39^{\circ} 13^{\prime}$; longitude, $121^{\circ} 4^{\prime}$; elevation, 2,090 feet. Authority, Mr. Lontzerhuser and B. F. Berriman.]

\begin{tabular}{|c|c|c|c|c|c|c|c|c|c|c|c|c|c|}
\hline Year. & Sept. & Oct. & Nov. & Dec. & Jan. & Feb. & Mar. & Apr. & May. & & & Aug. & \\
\hline $1872-73$ & 0 & 0 & () & 13.13 & 4.01 & 12.52 & 1.39 & 2.32 & 2.56 & 1) & 11 & 0 & 35.93 \\
\hline $1873-7$ & 0 & 0.83 & 2.99 & 19.01 & 13. $\pi 1$ & 6.93 & 11. 11 & 3. 66 & 1.05 & 0.10 & 1) & 0 & 60.09 \\
\hline $18 \% 4-$ & 11 & 2.95 & 15. 91 & $1.0 \mathrm{~s}$ & 15.56 & 1.39 & 4.14 & .29 & 1.18 & 2.28 & 1) & 1) & 44.78 \\
\hline $1875-76$ & 0 & $.9 \%$ & 16.99 & 7.44 & 12.01 & 10. & 12.47 & 2.80 & 1.23 & 11 & .65 & 0 & 65.31 \\
\hline $1876-\tilde{i}$. & 0.06 & 8.72 & 62 & 0 & 10.18 & 2.44 & 4. $\% 9$ & 1.14 & 1.40 & .74 & 0 & 0 & 30.09 \\
\hline $18 \%$ & 11 & 1.21 & 3.78 & 1.74 & 15. 74 & 17.76 & 10.18 & 2.78 & .59 & 0 & 0 & 0 & 53.78 \\
\hline 1878 & .68 & 2.09 & 2.54 & .75 & 10.72 & 11.51 & $18.0 \%$ & $\tau .08$ & 3.08 & .30 & 0 & 0.08 & 56.90 \\
\hline 1879 & 0 & 2.79 & 6. 54 & 8. 86 & $6.4 n$ & 4. 83 & $4.0 \%$ & 2.33 & 6.23 & .09 & 0 & 0 & 42.14 \\
\hline & 0 & .04 & .30 & 29.69 & 19.21 & 8.50 & 3. 33 & 1.. 85 & .05 & 1.50 & 0 & 0 & $5 \% .46$ \\
\hline $1881-82$. & 1. 25 & 3. \%1 & 3.52 & 8.21 & (i. 103 & 6. 30 & 7.96 & 5. 25 & 1.18 & 0 & 0 & 0 & 43.43 \\
\hline 1882 & 1.88 & $7.8 x$ & 4. 78 & $2.8: 3$ & 3.155 & 2.97 & 9.25 & 2.38 & $5.7 \%$ & 0 & 0 & 0 & 40.79 \\
\hline $1883-84$ & 1.44 & 3.03 & 1.48 & 2.31 & 7.80 & $10.2 \%$ & 13.98 & 10.98 & 1.00 & 2.30 & 0 & 0 & 54.59 \\
\hline & .95 & 3.30 & .015 & 20.39 & 3.65 & 1. 76 & .83 & 3.17 & .16 & .90 & 0 & 0 & 43.19 \\
\hline $1885-8$ & 2.65 & 0 & $19.2 \%$ & ti. 36 & 12.40 & 1.43 & 4. $\times 3$ & 11.38 & 1.119 & $\theta$ & 0 & 0 & 59.41 \\
\hline 1886-87. & 0 & 1. $6 \mathrm{ti}$ & .65 & 5.46 & 3.38 & 15.72 & 1.69 & 6. 54 & .64 & .52 & 0) & 11 & 36.28 \\
\hline & .26 & 0 & 1.38 & 6.85 & 11.81 & 2.59 & 5. 22 & .50 & .38 & 2. 26 & $.0 R$ & 0 & 31.33 \\
\hline $1888-8$ & .55 & 0 & 4.29 & 8.70 & .64 & 1.08 & 12.95 & $3.8 i$ & 7.21 & .4) & 0 & 0 & 39.69 \\
\hline $1889-$ & 0 & 12. 49 & 8.76 & 21.08 & 18.64 & 10.02 & 13.69 & 3.52 & 3.10 & .112 & 1) & 0 & 91.32 \\
\hline & 1.85 & 11 & 0 & 5.51 & 1.54 & 13. 70 & 6.22 & 2.98 & 2.00 & $1.2 \%$ & .90 & 0 & 36.13 \\
\hline 1891-92 _ - & .21 & 1.00 & 1.76 & 10.26 & 4. 70 & 7.15 & 6.61 & 6. 37 & 6.49 & 0 & 0 & 0 & 44.55 \\
\hline $1892-93 \ldots$ & .23 & 2.12 & 13.44 & 11.22 & 7.31 & 6,83 & 12.40 & 5.80 & 1. 30 & 0 & $\mathrm{~T}$ & 0 & 61.25 \\
\hline $1893-94$ & 1.64 & 1. 49 & A. $7 \%$ & 5.55 & 11.24 & 11.12 & 2.96 & 1.67 & 3.46 & 2.05 & $\mathrm{~T}$ & .03 & 50.58 \\
\hline $1894-95$ & 1.01 & 4.91 & 1.38 & 16.55 & 22.26 & 6.18 & 5.01 & 3.38 & 3.46 & 0 & .25 & .24 & 64.63 \\
\hline $1895-96$. & $3.8 \%$ & .02 & $1.1 \%$ & $\tau .27$ & 20.34 & .93 & 6.94 & 12.47 & $4.8 \%$ & .13 & .02 & .13 & 58.16 \\
\hline $1896-97$ & 1. 53 & 1. $7^{2}$ & 13.65 & 5.78 & 3.65 & 14.40 & 8.47 & 2.25 & .10 & .62 & .04 & .03 & 52.24 \\
\hline $1897-98 \ldots$ & .51 & $3.0 \%$ & 4.56 & 3.97 & 1.44 & 8.36 & .52 & $(.90)$ & 2.53 & $1.2 \%$ & $\mathrm{~T}$ & $\mathbf{T}$ & $2 \% .13$ \\
\hline 1898-99 . & .01 & 2.08 & 4.31 & 2.73 & 10.76 & $.4 i$ & 19.60 & 1.70 & 2.72 & .83 & 0 & .42 & 46.23 \\
\hline $1899-1900$ & 0 & 10.33 & 11. 58 & 11.35 & 6.90 & 2.54 & T. 40 & 3.92 & 1.31 & .65 & .04 & .03 & 56.07 \\
\hline & & & & & & & & & & & & & 49. 41 \\
\hline
\end{tabular}

\section{Record of precipitation at Malakoff mine, Nevarda Connty.}

[Latitude, $39^{\circ} 22^{\prime}$; longitude, $120^{\circ} 5 y^{\prime}$; elevation, 3,20x) feet. Authority, R. D. Wheeler.]

\begin{tabular}{|c|c|c|c|c|c|c|c|c|c|c|c|c|c|}
\hline Year. & Sept. & Oet. & Nov. & Dec. & Jan. & Feb. & Mar. & Apr. & May. & June. & July. & Aug. & Total. \\
\hline $1886-8 \pi \ldots . .$. & 0 & 2.39 & 0.80 & 5. 32 & 5.06 & 18.12 & 2.27 & 7.52 & 0.89 & 0.49 & 0 & 0 & 42.86 \\
\hline $1887-88 \ldots$ & 0.64 & 0 & 1.68 & 8.26 & 12.14 & $2.6 r$ & & & & & & $\cdots$ & $a 25.39$ \\
\hline $1894-95 \ldots$ & $\ldots$ & $\ldots$ & 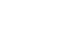 & $\ldots$ & 24.40 & 7.28 & 7.01 & ร. 18 & 6.03 & 0 & 0.14 & 0.41 & $a 50.45$ \\
\hline $1895-96 \ldots$ & 6.22 & .56 & 2.27 & ז. 36 & 24.11 & 1.36 & 10.21 & 17.78 & b. 61 & $\mathbf{T}$. & .06 & .15 & 76.68 \\
\hline $1896-97 \ldots \ldots$ & 1.90 & 2.33 & 17.42 & $7.0 \%$ & ...... & -....... & & & & & & $-\ldots$. & 428.67 \\
\hline 2-year mean. & & & & & & & & & & & & & 59.77 \\
\hline
\end{tabular}

a Year incomplete. 


\section{Record of precipitation at Neverda C'ity. Nevada Comnty.}

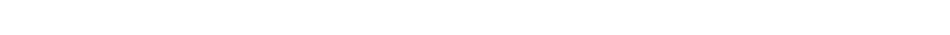

\begin{tabular}{|c|c|c|c|c|c|c|c|c|c|c|c|c|c|}
\hline Year & Sept. & Oct. & Nov. & Der. & Ta11. & Fell. & Mrar. & Apr. & May. & June. & July. & Ang. & Total. \\
\hline $1863-104$ & 0 & 0 & $1 .(60$ & 3.50 & (1. (M) & (0.5) & 5. 38 & 3.25 & 2.75 & 0 & 0 & 0.75 & $16 .(18$ \\
\hline $1864-65$ & 0 & 11 & $1 \% .05$ & $17.4 \%$ & 9.71 & $4.3 x$ & 2.19 & 1. & I. 31 & 11 & 0 & 0 & 53.71 \\
\hline $60-66$ & 11. 59 & $2.10 ; 3$ & 14.29 & 1.95 & $15.4 i$ & 5.60 & 14.24 & .59 & 4.50 & 0 & 0 & 0 & 9.26 \\
\hline . & 0 & 0 & 9.61 & 30.70 & 14.21 & 10.00 & 6.23 & 6.88 & 1.93 & 0 & 11 & 0 & 81.56 \\
\hline $186 \pi-68$ & 1.91 & 3.63 & 16.11 & 41.95 & 11.01 & 6.36 & 23.30 & 7.22 & 1.50 & $2.2 \%$ & 0 & 0 & 115.26 \\
\hline $68-69$ & .34 & .43 & 1. 49 & $10.6 \%$ & 16.85 & 12.62 & 6.96 & 5.72 & 1. $6 \mathrm{*}$ & .04 & () & 0 & 56.69 \\
\hline & .15 & .50 & 4.67 & 1..29 & 9.23 & 14.48 & 7.58 & 4.70 & .65 & .36 & 0.03 & 0 & 8.64 \\
\hline 1870 & 0 & $3.8 \%$ & 4. 32 & 5. 33 & 11.08 & 6.2 & 5.41 & 5.55 & 3.26 & .33 & 0 & 0 & 55.35 \\
\hline 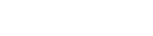 & 0 & .89 & 5.00 & 27.31 & 18.16 & $16.6 i$ & 5.28 & 3. 76 & .17 & 1.08 & 0 & 0 & 8.22 \\
\hline & 0 & .55 & 4.05 & 12.25 & 2.82 & 12.40 & .1 .96 & 2.47 & 2.2) & 0 & 0 & 0 & 8.70 \\
\hline & 0 & $.6 \%$ & 1.35 & $24.2 \%$ & 11.16 & 7.32 & 12.20 & 4.51 & 1.32 & .11 & 0 & 0) & 91 \\
\hline $18 \cdot 4^{-}$ & 0 & 3.06 & 15.08 & .90 & 16.57 & 2.11 & 3.97 & .27 & 1.56 & 2.43 & 0 & 0 & 5.95 \\
\hline & 0 & 1. 75 & 16.56 & 5. 91) & $12.4 \pi$ & 12.41 & 13.88 & 2.17 & 1.53 & 0 & 0 & 0 & 6.67 \\
\hline 187 &.+1 & 9.85 & 1.04 & 0 & 10.26 & 2.45 & & 1.43 & 1.97 & .72 & .71 & 0 & 02 \\
\hline & 0 & 1.35 & 4.31 & 3.65 & 17.62 & 16.61 & 10.11 .5 & 2.80 & 1.05 & 0 & 0 & 0 & 6.44 \\
\hline & 69 & 2.32 & 2.88 & .96 & 11.62 & 10.97 & 19.28 & 5.90 & 3.83 & .43 & 0 & .015 & .93 \\
\hline $1879-80$ & 0 & 315 & 5.50 & 8.76 & 6.67 & 5.45 & 5.09 & 22.54 & 5.58 & .15 & $(1$ & 0 & 62.92 \\
\hline & 0 & .06 & .28 & 24.78 & 18.88 & (i. $: 245$ & 4. 44 & 1. $\% 0$ & 0 & 1.47 & 0 & 0 & $57.8 \%$ \\
\hline $1881--8$ & 1.38 & 3.03 & 2.53 & 9.14 & 7.29 & $5.4 \%$ & 9.21 & 4.39 & .5 & 0 & 0 & 0 & $: .91$ \\
\hline $1882-83$. & 2.22 & i. 65 & 5.34 & $3,8 i$ & 2.39 & 3.06 & $14 .: 27$ & 2.98 & 6.92 & 0 & 0 & 0 & 8.70 \\
\hline $1883-84$ & 1.28 & 3.60 & 1.62 & 2.84 & 9.08 & 12.01 & 14.70 & $12.0 \%$ & $1.6 \tilde{i}$ & 2.47 & .01 & 0 & 61.41 \\
\hline 18 & $1.8 \%$ & 3. 61 & 0 & $2 \pi .92$ & 4.39 & 1.69 & .53 & 3.23 & .21 & 1.36 & 0 & 0 & 4.81 \\
\hline & I. 62 & 0 & 21.55 & $6 . \%$ & 13.66 & 1.54 & 6.92 & 12.49 & 1. 23 & 0 & 0 & .07 & 55.85 \\
\hline $1886-8{ }^{\circ}-$ & $\ldots$ & $\ldots$ & & & 3.51 & 12.64 & 4.80 & 7.24 & .70 & $.3 i$ & 0 & 0 & $a 29.26$ \\
\hline & .71 & 0 & 1. 70 & 7.53 & 11.32 & $3.5 \%$ & 7.14 & .68 &.+2 & 2.41 & 0 & 0 & 35.42 \\
\hline & .116 & 0 & 4.69 & 8.44 & $\mathbf{T}$ & 2.59 & 14.68 & 5.20 & 7.62 & .58 & & 0 & 13.94 \\
\hline $9-90$ & 0 & 13.15 & 8.55 & 24.50 & 24.05 & 10.07 & 13.40 & 3.11 & 3.35 & .01 & 0 & 0 & 100.09 \\
\hline J- & 2.04 & .04 & .04 & 6.34 & 2.18 & 18.66 & 3.64 & 2.93 & 1.92 & is & 0 & 0 & 38.56 \\
\hline & .04 & .90 & 1.49 & 9.56 & 6.48 & 6.04 & $\because .2 \pi$ & & 5.80 & .20 & & $\mathrm{~T}$. & 44.88 \\
\hline $1892-93$ & .26 & .95 & 13.87 & 14. 19 & 8.02 & 8.29 & 12.75 & (6.2: & 1.33 & 0 & $\mathrm{~T}$. & 0 & 65.88 \\
\hline 393-9 & 1. 71 & 1.25 & 5.78 & 5.23 & 11.71 & 10.85 & 3.26 & 2.17 & 3.54 & 1.85 & 0 & $\mathbf{T}$ & 9.35 \\
\hline 1894-95. & 1.21 & 4.83 & 1.38 & :20). 61 & 22.87 & 5.53 & 5. 12 & 3.82 & 3.42 & 0 & .15 & .29 & 69.23 \\
\hline $1895-96$. & 3.36 & 0 & 1.87 & 6.14 & 19.61 & .99 & 7. 39 & 13.63 & 4.88 & $\mathbf{T}$ & .05 & .05 & 57.97 \\
\hline $1896-9 \%$. & 1.55 & 2,18 & 12.63 & 6.46 & 4.38 & 13.63 & 9.13 & 2.08 & 22 & .82 & 0 & $\mathbf{T}$ & 53.08 \\
\hline & .60 & 3.36 & 4.34 & 3.17 & 1.92 & 9.91 & .87 & .95 & 2.73 & 1.27 & 1) & $\mathrm{T}$ & 29.16 \\
\hline $1898-99 \ldots$ & $.3 \pi$ & $1 . M$ & 3.49 & 2.27 & 9.12 & .49 & 15. 88 & 1.52 & 2.61 & .91 & 0 & 20 & 32.91 \\
\hline 1899-1900 & 1) & 10. 24 & 10.85 & 10. $2 \pi$ & 7.81 & 2. 36 & T..51 & 4.83 & 1.90 & .113 & $T$. & 11 & 55.80 \\
\hline $1900-1901$. & .5 & 5.52 & 9.22 & t. (x) & $11.5 t$ & 13.12 & 2.35 & 5. 69 & 1.29 & 0 & $\mathrm{~T}$. & .114 & $53 . ; 0$ \\
\hline $1901-2 \ldots \ldots . . . . .$. & 3.36 & 4.16 & 5.45 & 5. 35 & 1.91 & 18.28 & 5.02 & 4.66 & $1.4 \pi$ & .24 & 0 & 11 & 49.90 \\
\hline
\end{tabular}

a Year incomplete.

Note.-Record from January, 188\%, to February, 189:, inclusive, from J. F. Colley. 


\section{Record of precipitation at North Bloomfield, Nevadu County.}

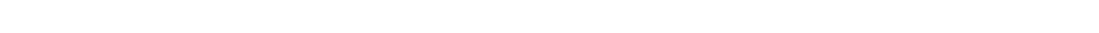
Radford.]

\begin{tabular}{|c|c|c|c|c|c|c|c|c|c|c|c|c|c|}
\hline Year & Sept. & $O * t$. & Nor. & Der. & Jan & Feh. & Mar. & Apr. & May & & July. & Atug. & Total \\
\hline $30-11 \ldots$ & (1) & 1.61 & $3 .: 24$ & 4.31 & 7.54 & 5.94 & 5.03 & 4.36 & 3.36 & (1. 12 & 1) & 0 & 35.51 \\
\hline $71-72$. & 11 & .83 & 15.21 & 25.19 & 12.71 & 18.22 & 5.73 & 3.84 & 1.39 & .41 & 0 & 0 & $74.5 \%$ \\
\hline $37:-73 \ldots$ & 0.16 & .53 & 4.4 & 11.7 & 4.16 & 11.09 & 2.50 & 9. 40 & $15 \tilde{r}$ & 11 & 0.10 & 0 & 8.7 \\
\hline $873-i 4 \ldots$ & 6) & $.0 \%$ & 3.37 & 19.00 & 15.15 & $3.0 k$ & 11.16 & 4.14 & 1. $7^{x}$ & 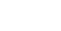 & () & 0.02 & 62.54 \\
\hline $67 t-i)$. & $.14 i$ & 4.88 & 13.52 & 1. 21 & .15 & .88 & 3.56 & .30 & 2.68 & 6.3 & (1) & 0 & 27.87 \\
\hline its. & () & 2.119 & 5. & 764 & $10.9 \mathrm{~K}$ & 10.21 & $13 .(v)$ & 4.03 & 1.06 & .111 & 1. 76 & .01 & 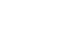 \\
\hline $76-77-$ & .31 & 10.46 & .85 & 0 & $9.9 k$ & 2.89 & .92 & $3.0 \%$ & 2.66 & .91 & (1 & 0 & \\
\hline $36-6 x-$. & () & 1.10 & 4.22 & 1.96 & 15. 72 & 16.97 & $9 . \nexists 3$ & 2.44 & .95 & (1) & 0 & 0 & 52.59 \\
\hline $38-69$. & () & 3.34 & 3.72 & 1.18 & $10 .(x)$ & 9.49 & 16.62 & 6.69 & 3.84 & .tit & (1 & .24 & 29). 16 \\
\hline & 0 & 3.03 & 43 & $13.5 \%$ & 5.96 & 5.66 & 45 & 23.31 & 5.63 & 0 & (1) & 0 & \\
\hline 81 & $1)$ & 0 & .41 & 21.10 & 19.45 & 12.13 & 4.92 & 2.59 & 1.33 & $1.5 i$ & (1) & 0 & 63.51 \\
\hline $881-82 \ldots$ & 1.35 & 3.86 & 4.05 & 8.73 & 8.12 & 6.76 & 10.12 & 5.39 & 1.82 & 0 & 0 & 0 & 50.41 \\
\hline $82-83$. & $\pi 4$ & 6.86 & .72 & 3.59 & 3.69 & 3.94 & .45 & 3.39 & 0 & 0 & () & () & \\
\hline $83-84 \ldots$ & 1.79 & 3.66 & 1. 48 & 2.84 & 9.21 & 10.02 & 15.65 & 10.31 & 2.6 & 4. 1 & 11 & & \\
\hline $1884-85$. & 1.98 & 3.43 & 0 & $3 \pi .21$ & 3.6 .5 & 1.91 & .79 & 3.62 & .71 & 2. 14 & () & 0 & 5.44 \\
\hline & 55 & 0 & 20,23 & 7.98 & 13,49 & 1.78 & 2.18 & 12.26 & 1. 15 & 11 & 11 & 0 & .62 \\
\hline $1896-9 \overbrace{}^{n}$ & 1.96 & 2.33 & 17.42 & T.10 & 5.06 & $16.5 i$ & 11.16 & 3.70 & . & 1.45 & (1) & .11 & $6 t$ \\
\hline $1897-9 \gamma^{-}$ & $.5 \%$ & 5.05 & 6. 12 & j). 41 & 2.28 & 13.03 & .79 & 1.18 & $4.4 i$ & 1. $\pi 11$ & $\mathrm{~T}$ & $\mathrm{~T}$ & 40.60 \\
\hline 88-9!) & .58 & $2.8 i$ & 5.61 & 4.10 & 10,88 & 1.01 & 18.24 & 1.98 & 3.91 & .65 & 0 & .67 & 50.55 \\
\hline $1899-1940$. & 11 & 14.52 & 13.33 & 13.161 & 9. 32 & .). 21 & 64 & 6.82 & 2.44 & $\mathbf{T}$ & .01 & 0 & .37 \\
\hline $1900-1961$. & .95 & 8.32 & 10. .99 & $4.9 \%$ & 7.73 & 13.46 & 2.97 & 6.21 & 1.73 & 1) & $\mathrm{T}$ & T. & 50.37 \\
\hline 1901- & 4.51 & 3.98 & 4.68 & $5.8 \tilde{i}$ & $1,6 ; 0)$ & $1 \times .04$ & 6.40 & 5. 29 & 1.70 & .19 & .09 & .04 & 52.39 \\
\hline & & & & & & & & & & & & & 54.28 \\
\hline
\end{tabular}




\section{Record of precipitation at Truckee, Nexada c'omety.}

[Latitude, $39^{\circ} 19^{\prime}$; longitude, $120^{\circ} 01^{\prime}$; elevation, 5, \$20 feet. Authority, Pacific Railway System.]

\begin{tabular}{|c|c|c|c|c|c|c|c|c|c|c|c|c|c|}
\hline Yeas & Sept. & Oet. & Nov. & Dec. & Jan. & Feb. & Mar. & $\mathrm{Apr}$. & May. & June. & July. & Aug. & Total. \\
\hline & & & & & & (i. 18 & & 0.12 & 2.40 & 0.80 & 1.30 & & .19 .10 \\
\hline & 0 & 0 & 0.51 & 1.67 & 4.80 & 4. 23 & 8 & & .28 & .35 & 0 & 0 & \\
\hline & 0.20 & 0.02 & 5.35 & 16.23 & 3.42 & 10.49 & 3.63 & 4.11 & .60 & . 30 & 0 & 0 & .35 \\
\hline 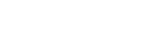 & 0 & .40 & .60 & 3.74 & 3.78 & 9.55 & 1.69 & 1.36 & .55 & 0 & $\mathrm{~T}$ & 0 & 1. 67 \\
\hline 8,3 & 0 & .11 & .42 & 8.70 & 9.54 & 6. 15 & 9.35 & 2.61 & .68 & .11 & .56 & $0.0 \%$ & 38.30 \\
\hline . & .014 & 2.44 & 3.54 & .60 & 8.50 & .21 & 1.20 & .90 & 0 & 1.81 & .40 & .03 & 19.66 \\
\hline & 'T. & .62 & 8.94 & 4.90 & 9.85 & 5. 50 & (6. 95 & 1.83 & .84 & .01 & .05 & .03 & .52 \\
\hline $376-71$. & .03 & 3.64 & .07 & .05 & 9.45 & .39 & 1.84 & 1.03 & 1.12 & .36 & 0 & 0 & \\
\hline$\ldots$ & .04 & 0 & 1. 66 & .24 & $5.97^{\prime}$ & 11.80 & $20 \%$ & .80 & $1.1 \%$ & .10 & 0 & 28 & 24.13 \\
\hline . & , & .65 & 2.14 & .50 & 7.70 & 2.68 & 5. 25 & 1.55 & .45 & 0 & 0 & 0 & 21.25 \\
\hline & $.0 \%$ & 1. 40 & 3.58 & 4.98 & 2.95 & 4.65 & 4. 65 & 12.74 & 2.50 & 0 & .16 & 0 & \\
\hline $880-81$ & 0 & $\theta$ & .45 & 9.51 & 5.71 & : 13 & 1.86 & .49 & .40 & 1. 26 & .18 & 0 & 21.99 \\
\hline$\ldots$ & .25 & 2.50 & 2. 0 & 3.80 & 6. 40 & 4.95 & 12.05 & 1.89 & .85 & .98 & $.60^{\circ}$ & 0 & 36.97 \\
\hline$\ldots$ & 0 & .85 & 1.04 & .80 & 1.55 & $3.0 \mathrm{5}$ & 1.0 & .19 & 1.13 & 0 & .53 & 0 & 2.79 \\
\hline & .28 & 2.46 & 2.50 & I. 62 & 6. 65 & 11.:20 & 5. 38 & 3.90 & .14 & $1.1 \mathrm{r} ?$ & 0 & .10 & 5.25 \\
\hline & .78 & 1. & 0 & 13.14 & 1.80 & .54 & .56 & 2.04 & .08 & 0 & 0 & .25 & 69 \\
\hline $1885-8$ & .47 & 0 & 6.95 & 2.22 & Fox & . & 2.90 & 1.78 & .60 & $.56 i$ & . 89 & 0 & 93.95 \\
\hline $886-8 \pi$ & $\mathrm{T}$ & .85 & 1. 10 & 2.29 & 3.43 & דים: יבי1 & .36 & 2.00 & 2.04 & $.3 \pi$ & .411 & $\mathrm{~T}$ & 25.09 \\
\hline & 0 & 0 & .30 & 4.80 & 2.35 & 0 & 11 & $\mathrm{~T}$ & .70 & .80 & .72 & . & 9.87 \\
\hline & $.2 x$ & 0 & 2.38 & 1.58 &.$k(1)$ & 1.40 & 2.51 & 1.01 & 4.51 & 0 & 0 & 0 & 4.4 \\
\hline 1889 & 0 & 3.13 & 3.29 & 2.51 & $16 .: 20$ & 8.90 & 7.29 & .45 & 1.44 & 0 & 0 & .22 & 43 \\
\hline . & . $8(1)$ & .45 & 11 & 3.70 & 1.22 & R. 36 & 3.92 & 2.17 & 2.!H) & .46 & 0 & 0 & 3.98 \\
\hline $1891-$ & .98 & .05 & .45 & 6.34 & 2. 65 & 2.80 & 3.00 & 2.96 & 4.20 & .95 & 0 & 0 & 4.38 \\
\hline & 29 & $.3 \%$ & 5. 73 & 8.15 & 5.44 & S. 0 & 5.18 & 3. & 1. $\% 9$ & 0 & 1) & 0 & 70 \\
\hline $893-94$ & 1.22 & .35 & 3.96 & 2.82 & 8.166 & 10.95 & 2.65 & 2.15 & 1.05 & T. & 0 & 0 & 3.21 \\
\hline $1894-95$ & .13 & 1.12 & .60 & 13.95 & 11.13 & 1.93 & $1 . \%$ & .50 & 2.40 & 0 & 0 & 0 & 3.47 \\
\hline $1895-96$ & 1.32 & .34 & .50 & 2.96 & $\tau .0 \%$ & .41 & 4.67 & 9.36 & 54 & 0 & .15 & .34 & 7.65 \\
\hline & .32 & .40 & 3.86 & 2.50 & 2.35 & 7.97 & 2.84 & .30 & $\mathrm{~T}$ & .18 & 0 & 0 & 1). 72 \\
\hline $189 \%$ & $\mathrm{~T}$ & .55 & 3.20 & 3.15 & 1.05 & 3.65 & 2.05 & .25 & .30 & 0 & 0 & 0 & 4.:30 \\
\hline & .40 & .06 & 2.95 & 1.50 & 7.80 & 2.70 & 9.50 & 1.10 & .75 & 0 & 0 & .92 & $\pi .68$ \\
\hline & 0 & 6.49 & 2.80 & 1.80 & 2.63 & .80 & & 1.90 & .80 & 1.01 & 0 & 0 & 22.43 \\
\hline $1900-1901$. & 0 & $1.0 \%$ & 2.50 & 2.70 & 5.00 & 7.96 & 2.50 & 1.80 & .70 & 0 & 0 & 0 & 24.19 \\
\hline $1901-2 \ldots$ & .50 & 2.78 & 3.63 & 1.55 & 1.10 & 3.30 & 5.60 & 1.28 & .55 & 0 & .45 & 1.10 & 21.84 \\
\hline & & & & & & & & & & & & & 26.21 \\
\hline
\end{tabular}

a Year incomplete.

Noww.-During July, 19x, there was also 3 feet of snow at Truckee.

Record of precipitation at Alta, Placer C'onnty.

[Latitude, 3: $13^{\prime}$; lon

\begin{tabular}{|c|c|c|c|c|c|c|c|c|c|c|c|c|c|}
\hline Year. & Sept. & Oet. & Now. & Dec. & Jan. & Feb. & Mar. & Apr. & May. & June. & July. & Aug. & Total. \\
\hline & & & & & & 13.75 & 6.56 & 3. $\% 3$ & $1.3 \%$ & 0.66 & & & a 26. 02 \\
\hline $0-11$. & ) & 0 & 2.75 & 3.94 & 5.21 & 5.4 .5 & $7.0 \mathrm{~J}$ & 3. 50 & 1.50 & 0 & 11 & 0 & 29.35 \\
\hline & 0 & 0 & $\mathrm{~T}$ & 6.50 & 11. 25 & 13.85 & .45 & .38 & 0 & 0 & 0 & 0 & 32.43 \\
\hline & 0 & 11.25 & .19 & 6.50 & 1.65 & 10.00 & .95 & 3.03 & 0 & 0 & 0 & 0 & 22.57 \\
\hline $373-74 \ldots$ & ( 1.40 & 0 & .90 & 1.). 59 & 12.66 & 7.17 & 3. 16 & 5. 65 & 1.2 & 0 & (1) & 0 & 47.50 \\
\hline$\ldots$ & 0 & 3.9 .2 & 12.86 & .09 & 13.17 & .01 & 3.40 & .40 & .12 & 2.00 & 0 & 0 & 35.97 \\
\hline $1875-i t$ & 0 & .02 & $18.5 \%$ & 830 & 7.70 & 4. $\%$ & 9.08 & $1.0 \%$ & 1.80 & 0 & $0.0 \%$ & 0 & 51.23 \\
\hline $1876-75$ & 0 & $\tau .00$ & .70 & 0 & 10.00 & 2.35 & 6.10 & 2.60 & 2. 61 & .80 & 0 & 0 & 39. 16 \\
\hline $877-78$ & 0 & 1. $\% 0$ & 3.90 & 1.00 & 9.10 & 14.80 & 11.65 & 2.50 & .33 & 0 & 0 & 0 & 44.98 \\
\hline $18 \% 6-7$ & .60 & 2.96 & 4.18 & 1.00 & 12.80 & 13.10 & 24.30 & 7.73 & 2.45 & 0 & ) & 0 & 69.12 \\
\hline $18 \% 9-80$ & 0 & 1.50 & 9.53 & 10. (1) & 2.70 & 4.90 & 3. 10 & 11.60 & 2.90 & 0 & 0 & 0 & 46.25 \\
\hline $1880-8$ & 0 & 0 & 1.00 & 13.80 & 21.00 & 11.80 & 3.50 & .511 & 0 & 0 & 0 & 0 & 51.60 \\
\hline $1881-8$ & 1.12 & 4.50 & 5. 60 & 13.60 & 5.93 & 6.40 & 15.40 & 3.20 & 1. 15 & .80 & 0 & 0 & 56.70 \\
\hline $1882-83$ & 2.70 & 7.65 & & 2.31 & 4.08 & 1. 60 & 9.06 & 3. 43 & 6. $0 \%$ & 0 & 0 & 0 & 42.54 \\
\hline $1883-84$ & .60 & 1. 60 & 2.15 & 3.10 & 3.50 & 8.60 & 7.00 & 5. 20 & .50 & 3.00 & 0 & 0 & 35.15 \\
\hline $1884-85$. & .12 & 1.00 & 0 & 14.08 & 1.50 & .60 & .10 & 2.48 & 0 & 1.00 & (b) & & 420.88 \\
\hline
\end{tabular}


Record of precipitation at Auburn, Placer County.

[Latitude, $38^{\circ} 53^{\prime}$; longitude, 121 05'; elevation, 1,36i3 feet. Authority, Pacific Railway System.]

\begin{tabular}{|c|c|c|c|c|c|c|c|c|c|c|c|c|c|}
\hline Year. & Sept. & Oct. & Nov. & Der. & Jan. & Feb. & Mar. & Apr. & May. & June. & July. & Aug. & Total. \\
\hline $1 \times 69-511$. & & & & & & 7. 31 & 3.92 & 2.63 & 0.45 & 10.81 & 0 & 11 & "15.12 \\
\hline 1 Kin-i1. & 0 & (1) & 0 & (1. 46 & ๆ.21 & 2.36 & 1.45 & $3 . \pi \%$ & 2.166 & 0 & 1) & 0 & 17.51 \\
\hline $1871-72$. & 0 & $(1.54$ & 2.80 & 13. ה5) & 6. 60 & 9.35 & 3.59 & 2.50 & .65 & .22 & 11 & 0 & 40. 00 \\
\hline $18 \% 2-83$. & 0 & .38 & 3.13 & 8.43 & 3.74 & 7.44 & .53 & 1.22 & .32 & (1) & "1 & 0 & 25.19 \\
\hline $18 \% 3-74$ & 0 & .34 & 1.25 & $11.9 \pi$ & 7.46 & 4.14 & 6. 26 & 2.56 & $\pi$ & 0 & 0 & 0 & 34.55 \\
\hline $18 \pi+75$ & 0 & $1.5 \%$ & 9.64 & . & 10. $(x)$ & .44 & 2.83 & .10 & .6il & 1. $8:$ & 11 & 1) & 27.73 \\
\hline $1 \times \% 5-76$ & 0 & $.8 \tilde{5}$ & 11.39 & 6.05 & 7.56 & .. 62 & 10.10 & 1. 44 & .61 & 0 & 11. 41 & 0.21 & 44.77 \\
\hline $8 \% 6-77$ & 0 & 4.52 & .65 & 0 & 6.94 & $1.4 \%$ & 2.14 & .82 & $1 . \pi 3$ & 2 & 0 & 0 & 18.24 \\
\hline $18 \%$ 16-is. & () & .99 & 2.46 & 1.5 & 10.61 & 10. 19 & i. foul & 1.75 & 98 & 0 & 0 & 0 & 36.13 \\
\hline io-79.. & 0.201 & .89 & 1.53 & .91 & 6. 34 & i. 16 & 8.88 & 5. 94 & 2.43 &.+6 & 0 & 0 & 34.94 \\
\hline $79-80$ & 0 & 2.83 & 3.82 & $\approx .84$ & 3.13 & +90 & $\therefore 62$ & 13.02 & 3.85 & 0 & 11 & 0 & 41.55 \\
\hline $80-81$. & (1) & 13 & .25 & 13.91 & 9.61 & $\therefore .20$ & $\because 43$ & 1.38 & $\theta$ & 1. 40 & 0 & n & 37.18 \\
\hline $8 \times 1-\$ 2$ & 92 & 2.02 & 3.111 & 3. & 4.6011 & +.99 & (i. 05 & 4.133 & .53 & $.2 k$ & $a$ & 0 & 33.60 \\
\hline $1882-83$ &.$x t$ & .. 19 & 4.08 & 1.6i) & 2.86 & 1.066 & 5.19 & (1) & $4.0 \tilde{\tau}$ & 0 & 0 & (1) & 25.64 \\
\hline $1883-84$. & 1. & 2.51 & 1.10 & 2.52 & ธ.. 33 & ๘.63 & $10.1 \%$ & $\therefore .02$ &.$x_{5}$ & 1.23 & 0 & 0 & 40.96 \\
\hline $1884-8$ & .56 & 2.25 & 0 & 16.37 & 1. & $1.2 \pi$ & $.5 \pi$ & 2.10 & 0 & 0 & 0 & 0 & 25.56 \\
\hline $1885-6$ & .64 & 0 & 15. 24 & 4.05 & 8.25 & 0 & 4.10 & 9.38 & .65 & 0 & 0 & 0 & 42.31 \\
\hline $18 \times 6-$ & 0 & .89 & 1.26 & 4.88 & 2.04 & 12.38 & 1.50 & 4.34 & .30 & 0 & 0 & $\mathrm{~T}$. & $2 \pi .59$ \\
\hline $188^{\prime \prime}-$ & 1.09 & 0 & 1.22 & 4. (91) & 7.07 & 1.40 & 3.25 & .80 & . (1) & $13 . .55$ & 0 & (T.) & 21. 68 \\
\hline $1888-89$ & .30 & 0 & 4. 20 & 5. $8: 2$ & .33 & .52 & $9.5 \pi$ & 1.36 & 4.65 & 0 & 0 & 0 & 26.75 \\
\hline $18 \times 9-9(4)$ & 0 & 5.5 & 4.85 & 11.94 & $8.9 \%$ & 3.96 & 8.08 & 2.83 & 2.30 & 1) & 1) & 0 & 48.68 \\
\hline 1890-91- & 2.693 & .14 & 0 & 5.13 & .88 & 6.80 & 5.40 & 2.23 & .88 & 69 & 11 & (1) & 24.78 \\
\hline $1891-9 ?$ & 11 & 1.33 & .95 & 7.3k & 4.00 & 4.91 & 5. 96 & 3.11 & 4.55 & 0 & 0 & a & 32.17 \\
\hline $1892-913$ & .15 & 1.76 & 6.13 & 8.99 & 5.33 & 4. 74 & 9.90 & 3.71 & . & 0 & 0 & 0 & 40.79 \\
\hline $1893-94$. & .80 & 1.11 & 5. & 3.88 & 6.96 & 9. 49 & 1.95 & $1.3 \tilde{5}$ & $2.7 \pi$ & 1.38 & $\mathrm{~T}$. & T. & 35.31 \\
\hline 1894 _. & $.6 \tilde{\imath}$ & $3.8 \%$ & 7.08 & 13.56 & 12.99 & 4.14 & 3.09 & 3.38 & 1.88 & 0 & $\mathrm{~T}$. & .13 & 夠. 80 \\
\hline $1895-96 \ldots$ & 2.04 & .12 & 1.04 & 3.39 & 11.88 & .49 & 6. 21 & ¿.66 & 2.42 & .43 & .14 & .25 & $36.1 \%$ \\
\hline $1896-8 \pi$ & & & & & $2.7 x$ & 11. 40 & 8.015 & 1.51 & . & $.1 \%$ & () & $\mathrm{T}$. & a 24.19 \\
\hline $1897-98$ & .20 & 2.83 & 2.22 & 3.50 & 1.13 & 6. 44 & .32 & .49 & 2206 & ז & T. & 0 & 20.36 \\
\hline $1898-4$ & .26 & 1.75 & 3.59 & 2. (j) & 4. & .17 & 13.25 & .51 & 1.28 & 1.43 & 0 & .03 & 29.80 \\
\hline 1899 & 0 & 5.94 & 9.00 & $5.4 \%$ & 5.47 & 2.11 & 3.69 & 3.42 & 2.19 & T. & 1) & $\theta$ & $3 \pi .29$ \\
\hline & .45 & 4.50 & b. 38 & 2.01 & $7.8^{\circ}$ & 8.84 & 1.25 & 4.83 & .48 & 0 & T. & 0 & 36.96 \\
\hline 1901-1R2 - & 2.39 & 5.51 & $4.8 b^{3}$ & $3.9 \breve{~}$ & 1.50 & 12.5 & 4.80 & 3.111 & .80 & $\therefore 0$ & $\mathrm{~T}$. & .02 & $40 . \tilde{5} \overline{3}$ \\
\hline & & & & & & & & & & & & & 33.40 \\
\hline
\end{tabular}

"Year incomplete.

IRR NI-U:3-2-2Y 


\section{Record of precipitation at Cisco, Placer County.}

[Latitude, 39० 19'; longitude, 1200 33'; elevation. 5,939 feet. Authority, Pacific Railway System.]

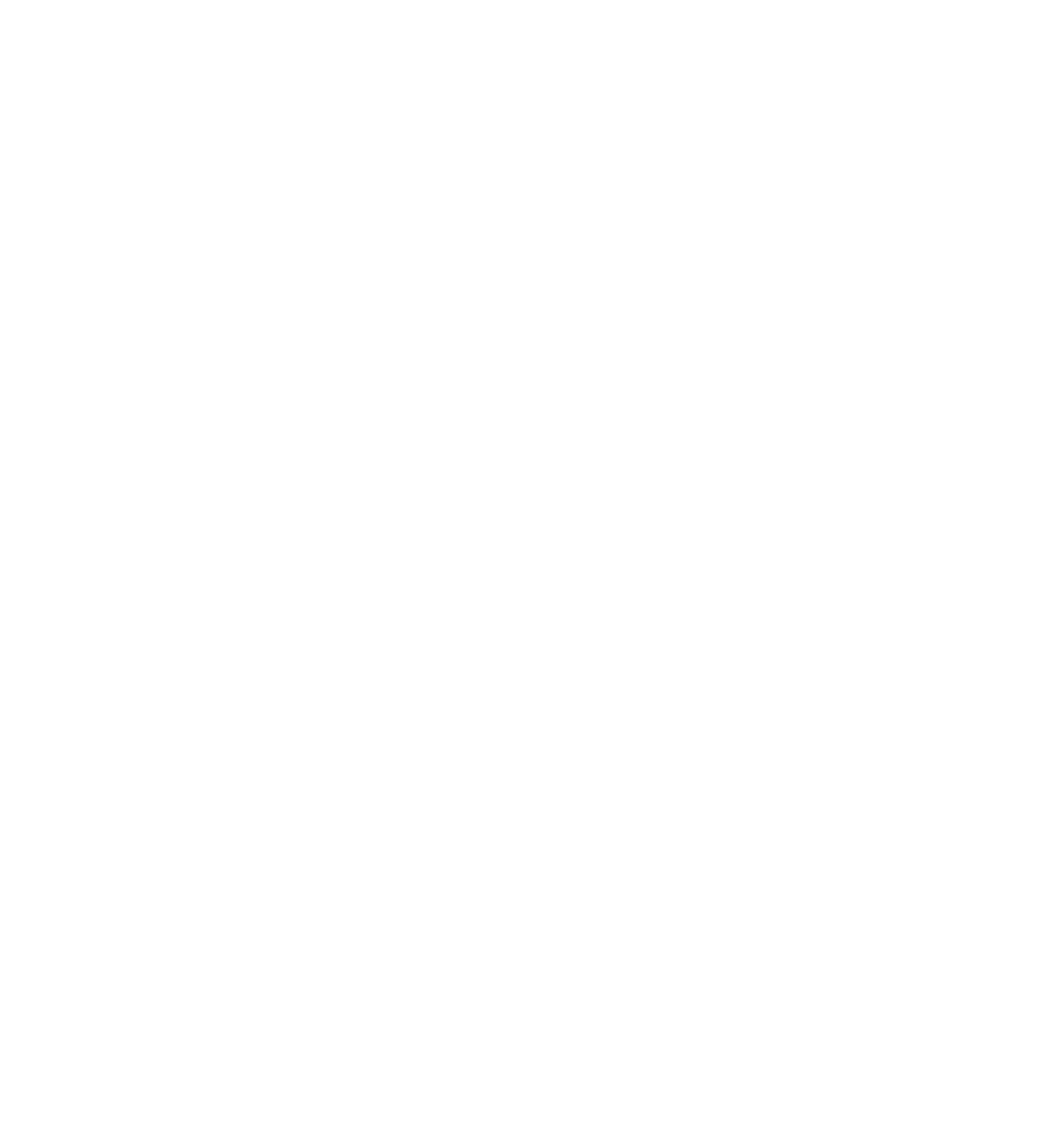

a Year incomplete. 


\section{Record of precipitation at Colfax, Placer c'ounty.}

[Latitude, $39^{\circ}\left(\mathrm{x}^{\prime}\right.$ : longitude, $1210^{\circ} 5 \tilde{\circ}^{\prime}$; elevation. 2,421 feet. Authority, Pacific Railway System.]

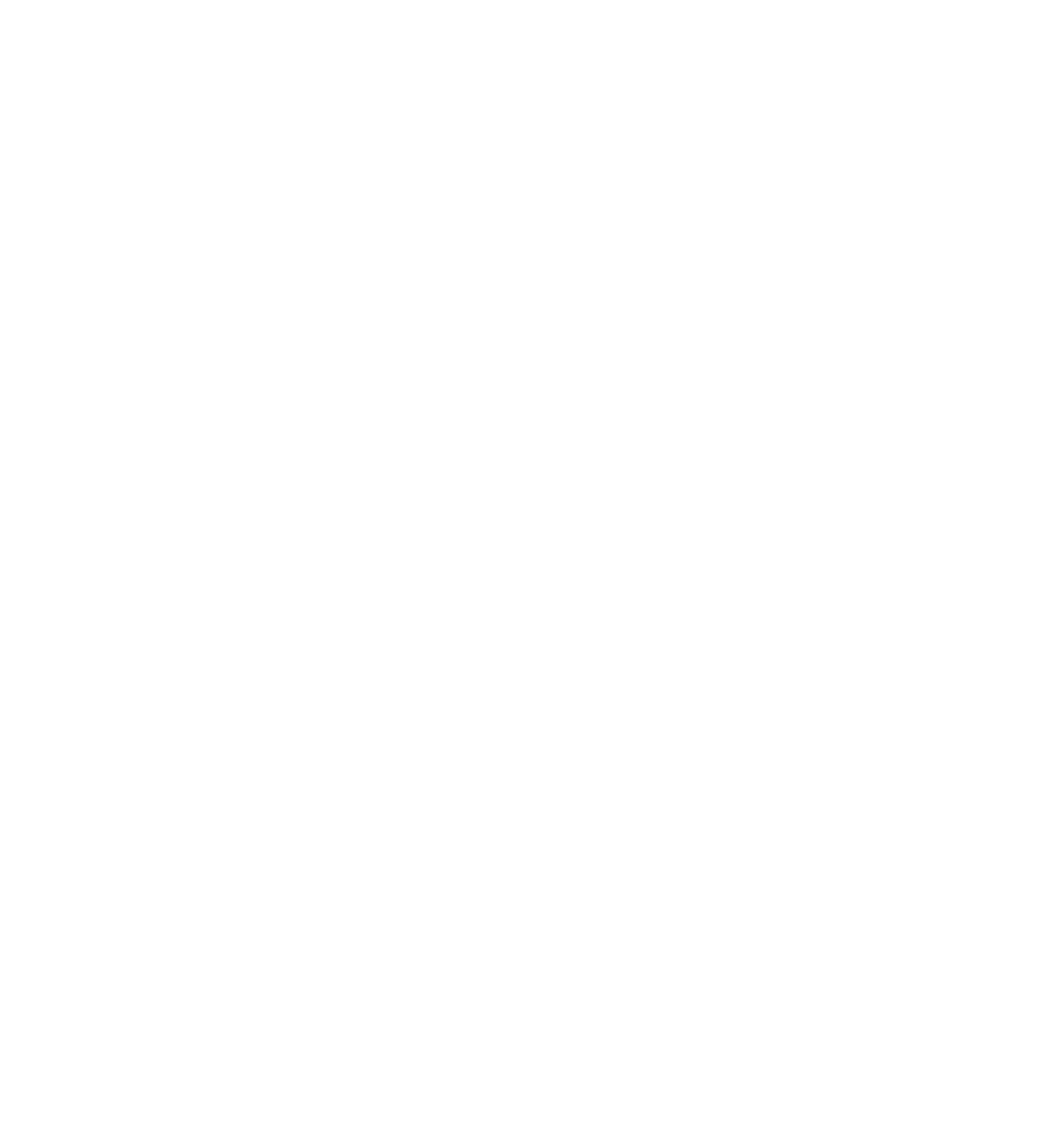

a Year incomplete. 


\section{Rerord of precipitation at Emigrent Gap, Placer County.}

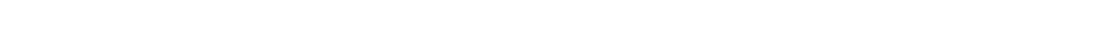

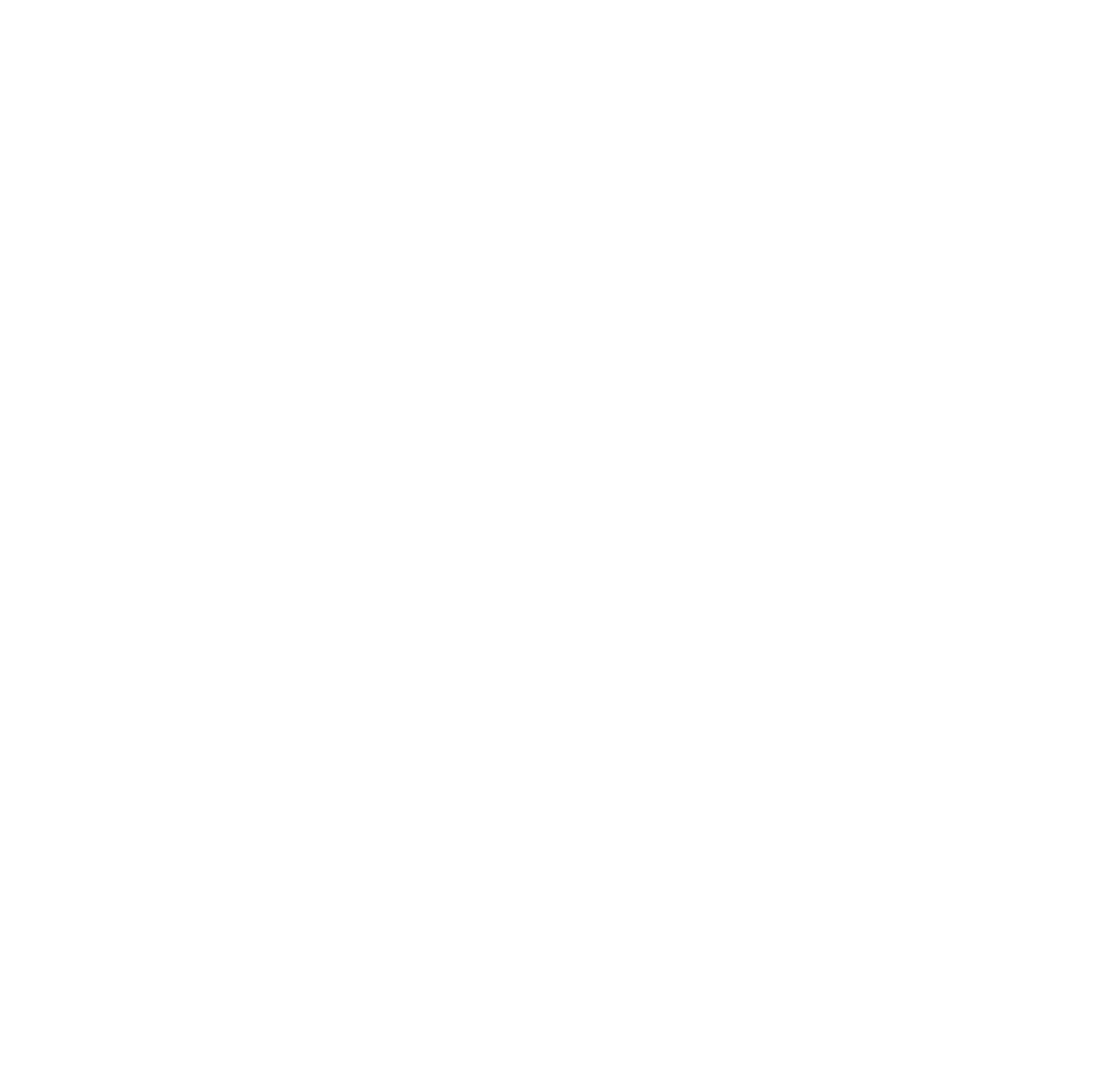

a Year incomplete. 
Record of precipitation at Ioum Hill (Strabbery Flat), Placer County.

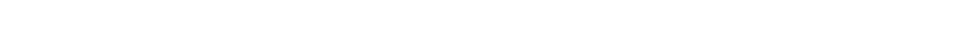

\begin{tabular}{|c|c|c|c|c|c|c|c|c|c|c|c|c|c|}
\hline Year. & Sept. & Oct. & Nov. & Dere. & Jan. & Feb. & Mar. & Apr. & May. & June. & July & ug. & Total. \\
\hline $36-59$ & $\cdots$ & $\cdots$ & $-\ldots$ & & 1:511 & $1: 3, x$ & 18.25 & $1.8 \%$ & 3.25 & 11. 饬 & 11 & 0 & $54 . t$ \\
\hline $679-$ & 0 & 3.54 & 3.63 & 13.35 & 5.51 & (i. 10 & T. $x$ & $18.8 \mathrm{i}$ & (6. 25$)$ & 11 & 0 & 0 & \\
\hline 1880$), 81 \ldots$ & 0 &.$\pi 5$ & .ii & 20.80 & 烄. & 111.511 & $4.6 \%$ & 3.15 & .13 & $: 2.12$ & 11 & (1) & 5 \\
\hline $8 \times 1-832 \ldots$ & (... & 4.25 & 3.91 & 111.50 & $\therefore .4 \%$ & (; $\mathrm{NI}$ & 111. 43 & 5.59 & 1.55 & .83 & 0 & 0 & \\
\hline $1882-83 \ldots$ & .35 & 8.50 & 6,63 & 2.69 & $4.3 \%$ & $4 . \therefore 4$ & 10.633 & 3.67 & T.:2: & 0 & 0 & 0 & .8 \\
\hline $1883-$ & .7 & 4.54 & 2.10 & 3.75 & 8.15 & $11: \approx 6$ & $16 . i x)$ & 13.29 & 1.till & $\because .5$ & 11 & 1 & 4. 21 \\
\hline 1884 & 1.60 & $\therefore 43$ & 0 & 24.22 & 3.113 & $1.4 k$ & is & 2.93 & .15 & 1.t(6) & 1) & 11 & $\therefore 112$ \\
\hline 188 & 1.90 & $\theta$ & $15 . x$ & 6.14 & 111. 89 & .68 & 6. 46 & 12.19 & $1 . \mathrm{ki}^{2}$ & 0 & 11 & $\because$. & 25 \\
\hline $18 \times 6$ & 0 & 2.28 & .811 & 5. 75 & 3.61 & 15.61 & 2.23 & 6.55 & $\tilde{x}$ & 0 & 0 & 110 & $6 t$ \\
\hline 1887 & $4 r$ & 0 & .95 & 6.52 & $11, \% 3$ & P. 41 & 4. 59 & 1.47 & 1.14 & 2.60 & 0.1165 & $\mathrm{~T}$ & .95 \\
\hline & $\therefore 35$ & 11 & 3. 5 & 8. 14 & אי & . & $12.1:$ & 4.20 & 8. 26 &.$\approx 2$ & & Int & \\
\hline 1889 & 0 & 9.31 & x. 49 & 21.04 & î & 111.74 & $14.1: 2$ & $3 .(1)^{2}$ & 3.48 & . $11 \mathrm{~K}$ & 11 & $\mathrm{~T}$ & 1.14 \\
\hline 1890 & 2.2. & .35 & 0 & 7.34 & 1.966 & 10.52 & s. & 3.55 & :. 03 & 2.13 & .83 & 0 & 9.28 \\
\hline 189 & .30 & .98 & 1.51 & .64 & 4.01 & 5. 36 & โ.11 & 6.10 & 6.56 &.$\$ 1$ & 0 & & \\
\hline $189 ?$ & .51 & 2.51 & $\therefore .21$ & 11. 8 ' & 6. 91 & $5 . \psi_{1}$ & 1\%.94 & 6,69 & 1. 44 & 0 & T. & 0 & 6.84 \\
\hline 1899 & 1.81 & 1.35 & 8.30 & 5.37 & 11.16 & נ:2:. & $4: 31$ & 2.10 & 4.03 & 1. fit & $\mathrm{T}$. & .51 & 68 \\
\hline & . & $4.16 j$ & $1.4 \mathrm{~K}$ & $1 \% .5 \%$ & 18.64 & $\therefore$ & 4.60 & 3,93 & 3.48 & 0 & .163 & $\therefore$ & \\
\hline & $\because .91$ & $.1 \%$ & 1.61 & 5.87 & 15.10 & .0 & 10.93 & 14.01 & 4.58 & (1 & .11 & .066 & 8.7. \\
\hline $1896-4$ & 1.00 & .49 & 13.42 & 5.13 & 3.44 & 15.83 & 11.33 & 2.15 & .15 & 1. 32 & 0 & 11 & 54.26 \\
\hline & .45 & 3.199 & & 5.31 & 2.01 & k. 10 & 1.68 & .99 & 2.83 & 1. 49 & $\mathrm{~T}$. & 0 & $29.4 \%$ \\
\hline & .44 & 1. & 4.03 & 2.84 & fi. 93 & .83 & 18.06 & 1.15 & 2.41 & 1.15 & 0 & .32 & (1), 05 \\
\hline & 11 & $9.1 \mathrm{~K}$ & 4.418 & 8.15 & 4.43 & 3.39 & 6.40 & 4.59 & 2. 59 & .101 & .015 & (1) & 6.96 \\
\hline & .49 & D.tit & 9.65 & & 9.94 & 12.61 & 1.98 & 6. 55 & .96 & 0 & $\mathrm{~T}$ & $.6 \pi$ & 1.5 \\
\hline $1901-2 \ldots$ & 4,12 & 3.98 & & (i, 08 & 1.1 .5 & 15. 75 & T.i4 & 3.90 & 1.04 & .66 & 0 & .15 & 49.08 \\
\hline
\end{tabular}

"Year incomplete. 
Record of precipitution at Summit, Placer County.

[Latitude, $39^{\circ} 19^{\prime}$; longitude, $120^{\circ} 22^{\prime \prime}$; eleration, \%,101\% feet. Authority, Pacific Railway System.]

\begin{tabular}{|c|c|c|c|c|c|c|c|c|c|c|c|c|c|}
\hline Year. & Sept. & Oet. & Nove. & Dec. & Jan. & Fets. & Mar. & Apr. & May. & June. & July. & Aug. & Total \\
\hline (ז) & 0 & 0.24 & 3.22 & 5.11 & $\therefore .44$ & 8.39 & 3.36 & $2 . \%$ & 11.31 & 0.89 & 0 & 0 & 32.7 \\
\hline (71-r\%. & 0.33 & $.41)$ & 9.33 & $8 x, 8 x^{\circ}$ & 4.44 & $1 \pi .61$ & 6.55 & 6.82 & .33 & 0 & 0 & 0 & 4.09 \\
\hline & 0 & 0 & 0 & 5.10 & 2.56 & $18 .(1)$ & 6.82 & 8.89 & 1.52 & 0 & 0 & 0 & .62 \\
\hline & 0 & 0 & 0 & 12.64 & 5.00 & 0 & 0 & 2.22 & 3.33 & .11 & 0 & 0 & .34 \\
\hline o. & 0 & 3.811 & 2.63 & .94 & 8.65 & 13.89 & 5. .22 & .89 & 1.58 & 2.6 & 0 & 0 & .24 \\
\hline & 0 & 0 & 7.22 & $\pi .78$ & 16.28 & 9.67 & & 3.33 & 11 & 0 & 0 & 0 & .72 \\
\hline & .56 & R. 18 & .53 & .22 & 17.89 & .64 & 82 & .31 & 4.03 &.$(\mathrm{H})$ & 1.:26 & 0.10 & .56 \\
\hline 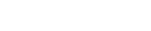 & .30 & .59 & 3.69 & 2.50 & 14.11 & 13.58 & & $2.6 t$ & 61 & 0 & 11 & .09 & .52 \\
\hline & .44 & 1.35 & .89 & 1.66 & 11.51 & 9.33 & $29.3 \pi$ & 5.02 & 2.83 & .11 & 0 & 0 & 6.51 \\
\hline & 1) & 1.5i) & 6.2: & $17 .(k)$ & 5.33 & 8.33 & 9.99 & 33.71 & .86 & 0 & 11 & 0 & .99 \\
\hline & 11 & 11 & .55 & f. 89 & 8.100 & 4.67 & 1.67 & 1.11 & .05 & .52 & 0 & (1) & 46 \\
\hline & .60 & $3.3 x$ । & $3.41)$ & 9.52 & 8.01 & 10.00 & & 3.61 & .66 & 0 & 0 & 0 & .51 \\
\hline 83. & . ii) & 13.26 & 4.39 & 5.50 & 1.11 & 2.88 & .50 & $3.7 i$ & 3.66 & 0 & 0 & 0 & .82 \\
\hline 44 & .10 & 1.06 & $1.33^{\prime}$ & 3.55 & 8.44 & 14.11 & 10.11 & 14.04 & .82 & 4.10 & 0 & 0 & ๘.62 \\
\hline & 1.10 & 3.13 & 0 & 9.40 & 1.40 & . $5 x$ & .10 & 4.88 & 1.00 & .80 & 0 & $\mathrm{~T}$. & .39 \\
\hline 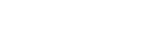 & .11 .5 & 11 & 13.60 & 3.00 & 13.90 & 1.411 & 80 & 6.40 & .95 & (I & 0 & 0 & 10 \\
\hline 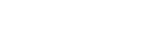 & 0 & 3.10 & 1.70 & $5 . \pi 5$ & 6.25 & 20.70 & 1.40 & 5.80 & .95 & 1.60 & .10 & $\mathrm{~T}$. & .35 \\
\hline & T. & $.0 \%$ & 1.50 & 11.60 & 9.20 & 1. 29 & 8.05 & 2.30 & 1.04 & 3.72 & 3.50 & .28 & .55 \\
\hline & 0 & 0 & 1.90 & 5.26 & 1.10 & 1.50 & & 1.90 & 6.30 & .2 & 0 & 0 & 63 \\
\hline & 0 & 5. 65 & 6.80 & 18.50 & $19.21)$ & 11.60 & 14.00 & 0 & .80 & 0 & 0 & 0 & 6.55 \\
\hline & 0 & 0 & 0 & $\tau .40$ & 1.50 & 1.5 & & 4.60 & & 0 & .0 & n & 08 \\
\hline & 1.2) & .05 & .30 & 11.90 & 4.00 & 3.40 & .40 & 4.50 & 6.30 & .20 & 0 & 0 & 25 \\
\hline & 11 & . 61$)$ & 8.80 & 9.50 & $\tau .90$ & 10.80 & 14.50 & 9. $: 20$ & 0 & 0 & 0 & 0 & 1.30 \\
\hline & 0 & .30 & 0 & 6.00 & 15.50 & 15.25 & & 4.30 & 2.40 & 0 & 0 & 0 & 7.15 \\
\hline & .95 & 1.28 & .53 & 9.53 & 25.80 & 4.2) & 4. 10 & 2.50 & 2.40 & 0 & 0 & 0 & 1.89 \\
\hline & .20 & 0 & 1.40 & 8.30 & 10.50 &.$\pi 0$ & 9. 70 & 18.20 & 5.40 & 0 & .21 & .02 & 4.63 \\
\hline & .40 & .90 & 12.30 & 4.10 & 4.15 & 14. 35 & & 1.25 & 0 & .70 & 0 & 0 & 6.05 \\
\hline & .03 & 2.50 & 26.50 & 4.20 & 4.00 & 7.10 & & .80 & 2.90 & .90 & 0 & 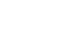 & 54.13 \\
\hline $1898-$ & 0 & 4.40 & 2.50 & 3.60 & 12.70 & 5.20 & 15.75 & 1.75 & 3.60 & .70 & 0 & 1.00 & 1.20 \\
\hline & 0 & 16.05 & 9.15 & 7.90 & 5.25 & 4.75 & & 4.80 & 3.9 & .50 & .25 & T. & 60.77 \\
\hline & .95 & 3.50 & 6.90 & 3.50 & 11.30 & 14.20 & 4.50 & 5.50 & & 0 & 0 & 0 & 51.35 \\
\hline $1901-2$ & 1.40 & 4.20 & 4. $\pi 0$ & 2.80 & 4.00 & 16.30 & 8.90 & 3.00 & 1.10 & .30 & 0 & 1.00 & 47.70 \\
\hline & & & & & & & & & & & & & 47.74 \\
\hline
\end{tabular}




\section{Record of precipitation at Toules. Placer County.}

[Latitude, 39० 18'; longitude, 120 38'; elevation, 3.7(14 feet. Authority, Pacific Railway System.]

\begin{tabular}{|c|c|c|c|c|c|c|c|c|c|c|c|c|c|}
\hline Year. & Sept. & Oet. & Nov. & Der. & Jan. & Feb. & Mar. & Apr. & May. & June. & July. & Ang & Total. \\
\hline $1885-86$ & 0.80 & (1 & 14.40 & $\approx .100$ & 9.40 & $(0.5 x)$ & 5. 10 & 3.80 & 0 & 0 & 0 & 0 & 41.40 \\
\hline $1886-8 i$. & 0 & 0.80 & . \$n & 3.10 & 4.35 & 11.60 & 1.10 & 1.20 & $\mathrm{~T}$. & 0 & $\mathbf{T}$. & 0 & 22.85 \\
\hline $1887-85$. & 0 & 0 & (k) & 1.06 & 20.11 & 1.71 & 11 & 0 & 0 & 1. (t) & 0.18 & 0 & 24.95 \\
\hline $1888-89$ & 0 & 1.11 & 1.08 & $1.0 \mathrm{l}$ & .45 & .9) & $.60)$ & 0 & 0 & 0 & 0 & 0 & 5. 15 \\
\hline $1889-90$ & 0 & 6.03 & 4. 11 & 11.40 & 19.4() & 14.60 & 3.00 & 0 & 1.00 & 0 & 1.00 & 0 & 60.54 \\
\hline $1890-91 \ldots \ldots$ & .10 & 1. 02 & 8.10 & 8.03 & 1.81 & 14.65 & 10.52 & 2.59 & 2.86 & 2.52 & 1.40 & 0 & 53.60 \\
\hline $1891-92$. & 1.118 & 1. 72 & 2.23 & 11.18 & 4.95 & 7.16 & 9.32 & 7.78 & 8.10 & (i) & 0 & 0 & 54.27 \\
\hline $1 \times 92-93$. & 93 & 2.74 & 12.54 & $1 \% .33$ & 9.06 & 8.65 & 16.61 & 7.98 & 2.34 & !! & 0 & 0 & 78.18 \\
\hline $1893-94$. & 2.75 & 1.76 & 10.62 & 6. 78 & 13.76 & 10. 10 & ธ.. 39 & 2.42 & 2.06 & 2.1 .5 & 11 & 0 & 57.79 \\
\hline $1894-95$ & 1.20 & 5.60 & 1. 80 & 13.85 & 19.15 & T.24 & 4.60 & s..15 & 4.76 & 0 & 11 & 0 & 63.08 \\
\hline $1895-96$ & 4.25 & .80 & 2.16 & 7.61 & 21.34 & $1.0 \alpha$ & 14.08 & 15.66 & โ. 21 & 0 & $\mathbf{T}$. & 0 & 74.14 \\
\hline $1896-9 \%$ & 8.04 & 1.08 & 3.12 & $6.0 \%$ & 5.25 & 13.34 & 5. 48 & 2.48 & .30 & 1.30 & 0 & 11 & 46.46 \\
\hline $189 \pi-98$ & .10 & 1.78 & 9.29 & 4.61 & 2.95 & 8.29 & .50 & .50 & 3.18 & 2.09 & 0 & (1) & 33.29 \\
\hline $1898-99 \ldots$ & .48 & 2.85 & 5.35 & 3.36 & 8.54 & .90 & 19.51 & 1.48 & 2.49 & 1.60 & 11 & 1.14 & $4 \pi .50$ \\
\hline $1899-1900 \ldots$ & 0 & 9.08 & 10.90 & 10.64 & 8.04 & 19.06 & $3.0 i$ & $1.0 \%$ & .10 & 0 & 0 & 0 & 61.91 \\
\hline $1900-1901 \ldots$ & .10 & 8.16 & 18.06 & 11.60 & 5.99 & 14.16 & 6.08 & 0 & 1.10 & 0 & 0 & 0 & 65. 25 \\
\hline $1901-2 \ldots$ & 20.01 & 1.10 & 19.10 & 15.91 & $1 . \pi 5$ & 22.25 & 1.11 & .50 & 1.52 & 0 & 0 & 0 & 82.95 \\
\hline 7 & & & & & & & & & & & & & .51 .54 \\
\hline
\end{tabular}

\section{Record of precipitation at Laporte, Plumas County.}

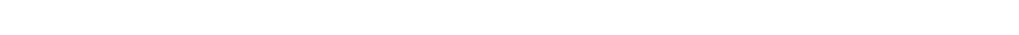

\begin{tabular}{|c|c|c|c|c|c|c|c|c|c|c|c|c|c|}
\hline Year. & Sept.' & Oct. & Nov. & Der. & Jan. & Feb. & Mar. & Apr. & May. & June. & July. & Ang. & Total. \\
\hline $1893-9$. & & & & & & & & 3.05 & 2.00 & 3.49 & $\mathrm{~T}$ & 0.17 & 48.71 \\
\hline $1894-95 .$. & 1.13 & $8.8 \%$ & 1.32 & $15.4 \%$ & 22.01 & 6.65 & 6.12 & 4.00 & 8.55 & 0 & 1. 41 & .29 & พ5. $8 \%$ \\
\hline $1895-96 \ldots$ & 8.42 & .69 & 3.35 & 9.98 & 32.43 & 2.84 & 16.20 & 16.63 & 9.32 & .09 &, 31 & .25 & 100.51 \\
\hline $1896-97 \ldots \ldots$ & 2.29 & 3.09 & 23.87 & 12.88 & 6.04 & 17.92 & 13.51 & 3.12 & 0.71 & 3.94 & 0 & $\mathrm{~T}$ & $8 \pi .3 \%$ \\
\hline $189 ;-98 \ldots \ldots$ & 1.26 & 4.84 & 9.34 & 6.63 & 2.53 & 13.04 & 1. 62 & 1. 49 & 4.64 & 2.73 & $\mathbf{T}$ & .04 & 48.16 \\
\hline $1898-99 \ldots$ & 0.94 & 3.31 & $6.6 \pi$ & 3.36 & 12.95 & 2.96 & 25.26 & 2.92 & 4. 43 & 1.48 & 0 & .82 & 64.83 \\
\hline $1899-1900 \ldots$ & 0 & 18.30 & 15.96 & 16.23 & 11.95 & 5.66 & 12.24 & 6.51 & 2.57 & .36 & 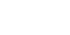 & $\mathrm{T}$ & 89.84 \\
\hline $1900-1901 \ldots$ & .61 & 13.02 & 14.37 & 8.79 & 17.25 & 18.35 & 6.24 & 7.48 & 2.09 & $\mathbf{T}_{3}$ & $\mathrm{~T}$ & .05 & 88.18 \\
\hline $1901-2 \ldots . . .$. & 5. 26 & 4.82 & 9.10 & 8.16 & 2.64 & 33.50 & 10.09 & 9.59 & 2.28 & .64 & (1) & $\mathrm{T}$. & 86.10 \\
\hline & & & & & & & & & & & & & 80.10 \\
\hline
\end{tabular}


Record of precipitation at Mrumford Hill. Plumas Cornty.

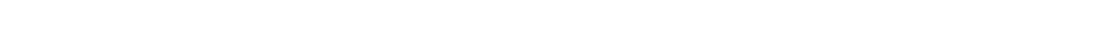
Talley.]

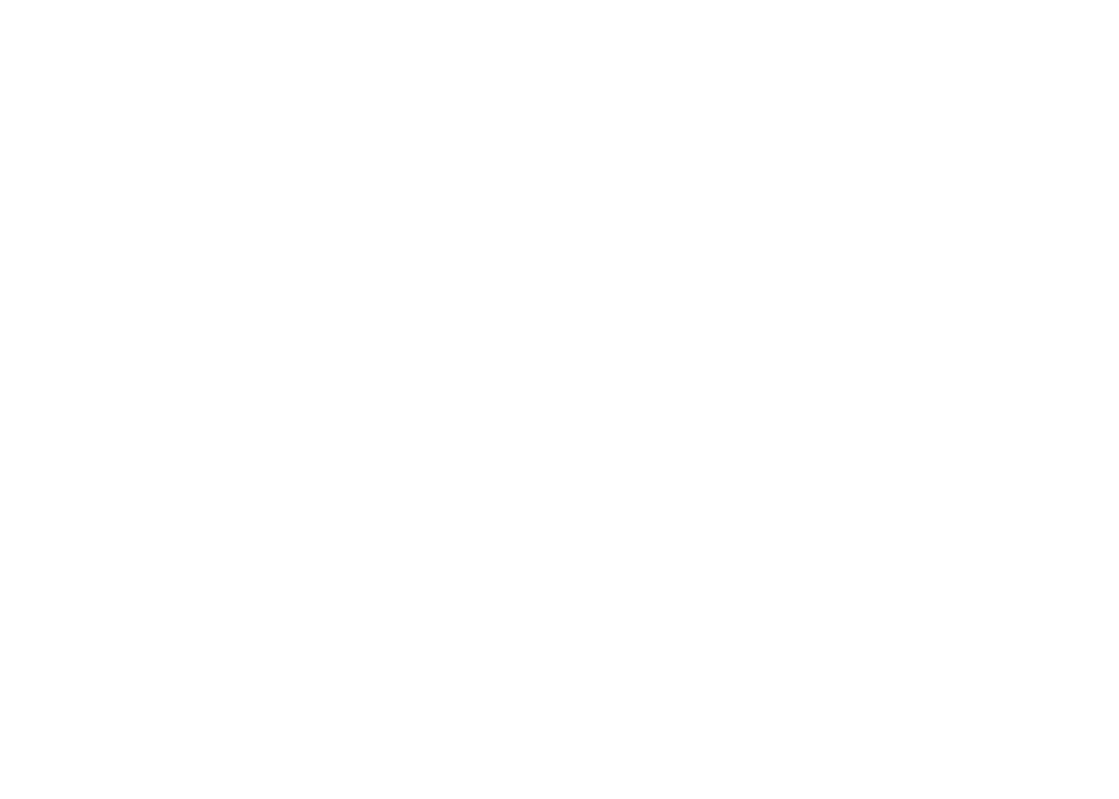

"Year incomplete.

Record of precipitation at Baming, Riverside County.

[Latitude, $33^{\circ} 5 t^{\prime}$; Iongitude, 1160 5.'; elevation 2,317 feet. A uthority. Par.ifi. Railway Systen.]

\begin{tabular}{|c|c|c|c|c|c|c|c|c|c|c|c|c|c|}
\hline Year. & Sept. & Oct. & Noy. & Dec. & Jan. & Feh, & Mar.' & Apr. & May. & June. & July. & Ang. & Tutal. \\
\hline $1878-79 \ldots . .$. & () & 1) & 0 & 1.08 & 2.37 & 1). $6 t^{6}$ & (1) & 1.48 & 0 & (1) & 0 & 0 & 5.59 \\
\hline $1879-80 \ldots \ldots$ & 11 & $0.12:$ & 2.44 & 4.55 & .75 & 1.59 & $2 \pi$ & :.411 & 0 & () & (1) & 1) & 14.992 \\
\hline $1880-81 \ldots \ldots$ & 0 & .58 & .87 & & & & & & & & & 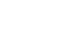 & (t. 1.34 \\
\hline $1898-49 \ldots$ & $\ldots$ & $\ldots$ & ....... & & 2.40 & .72 & 2.14 & .108 & 0.01 & 0. 48 & u & 1) & 12613 \\
\hline $1899-19(x) \ldots$ & 0 & .69 & 2.23 & .88 & 1.299 & .05 & 1.19 & 2.22 & 1.80 & 0 & 0 & 0 & 10.35 \\
\hline $1900-1901 \ldots$ & 0.10 & .47 & 3.94 & 11 & 4. 12 & ti. 46 & .81 & .00 & 1.21 & 0 & 0 & 1. 14 & 18.90 \\
\hline 1901-2........ & 0 & $1.1 \tilde{r}$ & .50 & 0 & 2.74 & 4. 83 & 4.63 & 1.00 & .06 & $\mathrm{~T}$. & $0.1 t$ & 11 & $15.0 \%$ \\
\hline 6-year $n$ & & & & & & & & & & & & & 11. $3: 2$ \\
\hline
\end{tabular}


Record of precipitation at Beaumont, Riverside County.

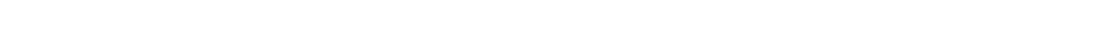

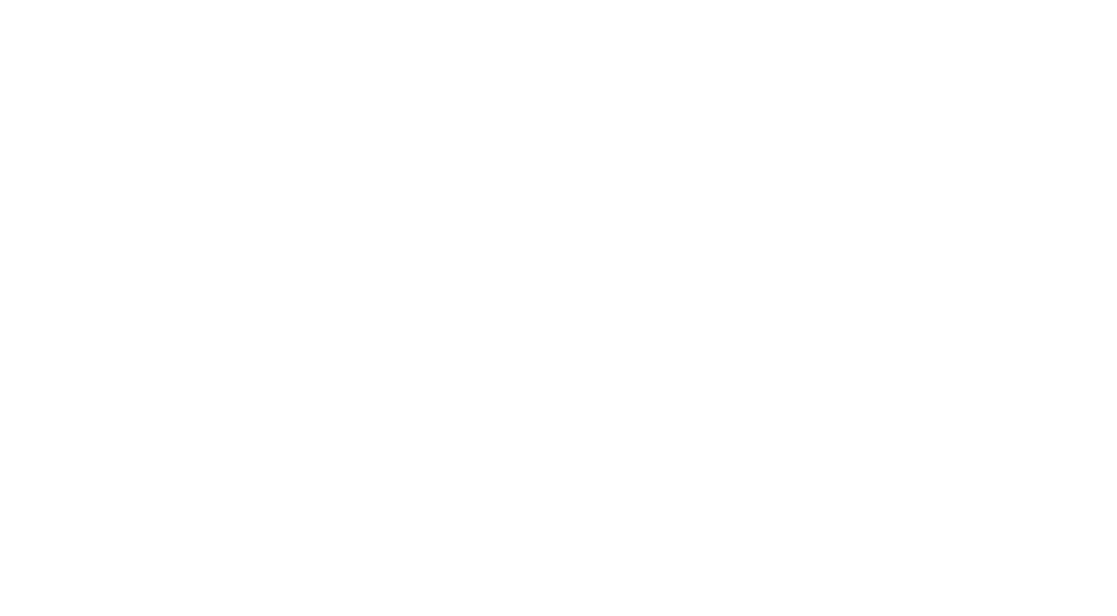

a Year incomplete.

Record of precipitaton at San Gorgonio Pass, Riverside C'ounty.

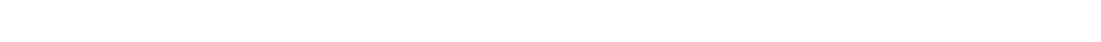

\begin{tabular}{|c|c|c|c|c|c|c|c|c|c|c|c|c|c|}
\hline Tealr. & sept. & oct. & Nor. & Der. & Jan. & Feb. & Mar. | & Apr. & May. & June. & July. & Aug. & Total. \\
\hline $180+\pi \% \ldots$ & $\ldots$ & & .... & (1. +1$)$ & $1 .(x)$ & (1. 60) & & & 1) & $\mathrm{T}$. & 0 & 0 & $4: 300$ \\
\hline 1875- & 0.03 & 1 & 1.33 & 1. 23 & 9.31 & 5.54 & 6. 26 & 0.99 & .20 & 1 & 0.03 & $11.1 \%$ & 25.04 \\
\hline $18 \pi(6-\pi) . . .$. & 19 & $.1 k$ & 0 & 0 & 5. 55 & 2.03 & 3.93 & 8.59 & 3.93 & 0 & .30 & $\mathrm{~T}$. & 18.70 \\
\hline 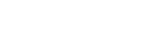 & .13 & 1.30 & . 801 & 4. : 2 x & 6.113 & 16. 49 & 4. 40 & 6. 81 & 1.33 & (1. 26 & . 03 & . & 35.96 \\
\hline $187 \times-79 \ldots$ & 0 & 0 & $.9 \pi$ & .92 & 2.88 & 1. $7 x$ & .55 & 3. 23 & .111 & 62 & 0 & .22 & 11.18 \\
\hline $\begin{array}{l}1 \times 79-80) \\
1880-81\end{array}$ & 0 & 1. (k) & 4. 111 & 9.33 & $1.7 \mathrm{x}$ & 2.81 & 3.114 & 6. 94 & .14 & 1) & T. & (199) & 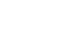 \\
\hline $1,841-\psi_{2} \ldots \ldots$ & 11 & .50 & 1.33 & $10.2 \pi$ & $\therefore 4 x$ & I. $\$ 6 ;$ & 3.39 & 3. $6: 2$ & .35 & 0 & . & 0 & 24.74 \\
\hline $1 \times 88-8 ; 3 \ldots$ & 0 & .53 & 1.333 & . 4: & 3.30 & 下准 & 4.38 & 4. .21 & 35 & 1. $3: 1$ & 11 & . 62 & 23.73 \\
\hline & $\ldots$ & & $\ldots$ & $\ldots$ & $\ldots$ & $\ldots$ & & & & & & & $\cdots-$ \\
\hline & & & & & & & & & & & & & $\ldots$. \\
\hline & & & & & $2.4 \pi$ & 1.73 & 3.17 & 1.24 & (1) & 0 & () & 0 & r9.41 \\
\hline $1886-8 ; \quad \ldots$. & 0 & (1) & .54 & 3.36 & $.1 \% 5$ & $5.6 \%$ & .108 & 2.94 & 14 & 0 & $.0 \%$ & 0 & 10.31 \\
\hline $18 x+-8 \pi . . . .$. & 0 & $1 .: 2: 3$ & 1.51 & & & & & & & & & $\cdots$ & u. $\pi 4$ \\
\hline & & & & & & & & & & & & & 22,62 \\
\hline
\end{tabular}

"Year incomplete.

Recorr af precipitation at Thhitemeter, Riverside comuty.

[Latitude, $33^{\circ} 5^{\prime} 4^{\prime}$; longitude, $116^{\circ}: 39^{\prime}$ : elevation. 1,12:3 feet. Authority, Parific Railw: 4 S System.]

Year. Sept. Oct. Nov. Dec. Jan. Feb. Mar. Ayr. May. June. July Aug. Total.

\begin{tabular}{|c|c|c|c|c|c|c|c|c|c|c|c|c|c|}
\hline $1 \times \pi-\tilde{\pi}, \ldots \ldots$ & 0 & (1) & 0 & 1.30 & 1.40 & 0.98 & (9. 45) & 2.35 & 0 & a & 0 & $(1$ & (i. 48 \\
\hline $1878-79 \ldots$ & 0 & $\mathrm{~T}$. & . 18 & .46 & 1.30 & $.2 k$ & .34 & .30 & 0 & (1) & () & (1) & 2.86 \\
\hline $18 \div 9-80 \ldots \ldots$ & 0 & 0 & 1.62 & 2.08 & .51 & $.4 \%$ & .20 & .12 & 11.01 & 0 & 0 & (1. 然 & 5.21 \\
\hline $1880-41 \ldots$ & 0 & (1) 15 & .34 & 1.70 & 0 & 0 & 2.25 & .171 & 0 & 0 & 11 & .46 & 4.97 \\
\hline $18+1-42$. & 0 & $\mathrm{~T}$ & 0 & 0 & 0 & $.4 K$ & .20 & .16 & 0 & 0 & 0 & 0 & .84 \\
\hline $1888-\times 3 \ldots$ & 0 & 0 & . & a 1 & .15 & .34 & .80 & .55 & 0 & 0 & 0 & (1) & 2.41 \\
\hline $1883-84 . \ldots . .$. & 0 &.$\pi k$ & 0 & 1.92 & 1.10 & 6.96 & 3.155 & 1 & 0 & 0 & (1) & 0 & 13.81 \\
\hline
\end{tabular}

Norw--Whitewater ceased reporting af ter August, last. 
Record of precipitation at Sucrumento, Sacramento County.

[Latitude, 3* 35': longitude, 121 30'; elevation, il feet. Authority, Signal Ser 7 ice and Weather Bureau.]

\begin{tabular}{|c|c|c|c|c|c|c|c|c|c|c|c|c|c|}
\hline Year & Sept & Or.t. & Now. & Dec. & Jan. & Fel. & Mar. & Apr & May. & June. & July. & Aug. & Total. \\
\hline $1849-54 \ldots$ & 1105 & $1.5 t$ & 2.25 & 12.50 & 4.54 & 050 & 10.00 & 4.25 & 0.25 & 0 & 0 & 0 & 36.00 \\
\hline $1850-51 \ldots$ & 0 & 0 & 0 & 0 & .65 & .33 & 1.88 & 1.14 & .69 & 0 & 0 & 0 & 4. $\pi 1$ \\
\hline $1851-52$. & 1.00 & .18 & 2.14 & $\pi .0 \%$ & .58 & .12 & 6.40 & .19 & .30 & 0 & 0 & 0 & 17.98 \\
\hline $1852-53 \ldots$ & 0 & 0 & $6.01)$ & 13.41 & 3.00 & 2.00 & 7.01) & 3.50 & 1.45 & 0 & 0 & 0 & 36.36 \\
\hline $1853-54 .$. & 0 & .01 & 1.50 & 1.54 & 3.25 & 8.50 & 3.25 & 1.50 & .21 & 0.31 & 0 & 0 & 20.07 \\
\hline $1854-55 \ldots$ & 0 & 1.01 & 65 & 1.15 & $2.6 \%$ & 3.46 & 4.20 & 4.32 & 1.15 & .01 & 0 & 0 & 18.62 \\
\hline $1855-56 .$. & 0 & 0 & 泣 & 2.00 & 4.92 & .69 & 1. 4 ) & 2.13 & 1.84 & .08 & 0 & 0 & 13.76 \\
\hline $1856-5 \% \ldots$ & (1 & .20 & .65 & 2.40 & 1.38 & $+.8 \mathrm{i}$ & .67 & 0 & 0 & .35 & 0.01 & 0 & 10. 46 \\
\hline $1857-58$ & (1) & .66 & $\therefore 41$ & 6. 63 & 2.44 & 2.46 & 2.88 & 1.21 & .30 & .10 & 0 & 11 & 18.99 \\
\hline $1858-59$ & () & 3.01 & .15 & 4.34 & .96 & 3.91 & 1.64 & .98 & 1.04 & 0 & .018 & 1 & 16.06 \\
\hline $1859-60$ & .112 & 0 & 6. 48 & 1.83 & 2. 31 & 93 & 5. 11 & 2.57 & 2.49 & .02 & .65 & 0 & 22.61 \\
\hline $1860-61$. & .166 & .91 & .18 & 4. $2 \mathrm{x}$ & $2.6 \%$ & 2.42 & 3. 32 & .48 & .59 & .13 & 0 & 0 & 15.54 \\
\hline $61-62$ & 0 & 0 & 2.17 & x. 64 & 15.04 & 4. 26 & 2.80 & . & 1.81 & 01 & 0 & 0.01 & 35.56 \\
\hline 1862-633 & (1 & $.34 j$ & 0 & 2.33 & 1.73 & 2.5 & 2.36 & 1.69 & .35 & 0 & () & 0 & 11.57 \\
\hline $63-64$. & 0 & 0 & 1.49 & 1.82 & $1.0 \mathrm{~s}$ & .19 & $1.30)$ & 1.08 &.$\tilde{4}$ & .09 & 0 & .08 & 7.87 \\
\hline $1864-(i)$ & 0 & .12 & 6. $\approx 2$ & $\pi .5 \%$ & $4 . \pi 8$ & $\pi$ & .48 & 1. $3 \pi$ & .46 & 0 & 0 & 0 & 22.51 \\
\hline $65-66 \%$ & .18 & .48 & 2.43 & .36 & 70 & $\approx .01$ & 2.02 & .48 & 2.25 & .10 & .02 & 0 & $1 \% .98$ \\
\hline $1866-6 \pi$. & 0 & 0 & 2.43 & 9.51 & 3.44 & ז.10 & 1.01 & 1.80 & .01 & 0 & 0 & 0 & 25.30 \\
\hline $1867-68$ & .01 & 0 & 3.81 & 12.85 & 6.04 & 3.15 & 4.35 & 2.31 & .27 & T. & 0 & 0 & 32.79 \\
\hline $1868-69$ & 0 & 0 & $.7 \%$ & 2.61 & 4.79 & 3.63 & 2.94 & 1.24 & .65 & .01 & 0 & 0 & 16.64 \\
\hline $1869-0$ & T. & 2.12 & .85 & 1.96 & 1.37 & 3. 24 & 1.64 & 2.12 & .27 & T. & T. & 0 & 13.57 \\
\hline $1870-71$ & 0 & .02 & 8 & .97 & 2.08 & 1.92 & .69 & 1.45 & .76 & T. & 0 & 0 & $8.4 \pi$ \\
\hline $1871-72$. & $\mathrm{T}$ & .21 & $1.2 \%$ & 10.59 & 4. 04 & 4.74 & 1.94 & .61 & .28 & .02 & 0 & 0 & 23.65 \\
\hline $1872-73$ & T. & ג2. & 1.93 & 5. 39 & 1.23 & t. 36 & .55 & .51 & 0 & $\mathrm{~T}$ & .02 & $\mathbf{T}$. & 14.21 \\
\hline 18 18-โ4. & 0 & .31 & 1. 21 & 10.01 & 5.20 & 1.86 & 3.15 & .89 & $.3 \pi$ & T: & T. & 1 & 22.90 \\
\hline $18 \% 4-65$ & .05 & 2.26 & 3.80 & .44 & 8.70 & .55 & .80 & T. & $\mathrm{T}$. & 1.10 & 0 & 0 & 17.70 \\
\hline $1875-76$ & 0 & .44 & 6. 20 & 5.32 & 4.99 & 3.75 & 4.15 & 2.10 & .15 & 0 & .21 & .02 & 26.53 \\
\hline & T. & 3.45 & .30 & 0 & $2 . \pi$ & 1.04 & .56 & .19 & .64 & $.01 \mid$ & $\mathrm{T}$. & $\mathbf{T}$ & 8.96 \\
\hline & 0 & .83 & $1.0 \pi$ & 1.43 & 9.26 & 8.04 & 3.09 & 1.07 & .17 & 0 & 0 & 0 & 24.86 \\
\hline & .29 & .55 & .51 & $.4 \pi$ & 3.18 & 3.88 & 4.88 & 2.66 & 1.30 & . 13 & T. & $\mathbf{T}$ & 17.85 \\
\hline & 0 & .88 & 2.05 & 3.41 & 1.64 & 1.83 & 1.70 & 14. 20 & .76 & 0 & T. & 0 & 26.47 \\
\hline & 1) & () & .0 .5 & 11.81 & 6.14 & 5.06 & 1.37 & 1.64 & T. & .50 & T. & 0 & 26.57 \\
\hline & .30 & .55 & 1. 88 & 3. $2 \pi$ & 1.89 & 2.40 & 3. 78 & 1.99 & .35 & .10 & T. & 0 & 16.51 \\
\hline & $\tilde{3}$ & 2.63 & 3.22 & 1.13 & 2.23 & 1.11 & 3. 70 & .67 & 2.85 & 0 & 0 & 0 & 18.11 \\
\hline $1883-84$ & .90 & .97 & .61 & .44 & 3.43 & 4. 46 & 8.14 & 4. 32 & .06 & 1.45 & 0 & $\mathbf{T}$. & 24.78 \\
\hline $1884-85$. & $.60)$ & 2.01 & 0 & 10.45 & 2.16 & .49 & .08 & .68 & $\mathrm{~T}$ & .11 & T. & 0 & 16.58 \\
\hline $1885-86$ & .08 & .02 & 11.34 & 5.76 & 7.95 & $\stackrel{20}{\sim 9}$ & 2.68 & 4. 08 & $.0 \%$ & 0 & 0 & 0 & 32.27 \\
\hline $1886-87 \ldots$ & 0 & .68 & .21 & 2.21 & 1.12 & 6.28 & .94 & 2.53 & $\mathrm{~T}$ & 0 & 0 & T. & 13.97 \\
\hline $1887-88 \ldots$ & . 02 & 0 & .45 & 2.09 & 4. 81 &.$\tilde{0} \tilde{\tau}$ & 3. 04 & .10 & .40 & .08 & T. & T. & 11.56 \\
\hline $1888-89 \ldots$ & .55 & 0 & 4.28 & t. 63 & .15 & .33 & 6.25 & .26 & 3.25 & .25 & 0 & 0 & 19.95 \\
\hline & 0 & 6. 02 & 3.15 & i. 82 & 6. 62 & 4.06 & 3.00 & 1.33 & 1.80 & 0 & 0 & $\mathrm{~T}$. & 33.80 \\
\hline & .80 & $\mathrm{~T}$ & 0 & 3.34 & .53 & 6.61 & 1.78 & 2.04 & .66 & .05 & T. & 0 & 15.81 \\
\hline 189 & .10 & .10 & .48 & 3.28 & 1.88 & 2.84 & 3.02 & 1.20 & 2.38 & T. & 0 & 0 & 15.18 \\
\hline 189 & .18 & .60 & 6. 60 & 4.90 & $3.2 \pi$ & 2.66 & 3.51 & 1.08 & 1.05 & 0 & $\mathrm{~T}$. & T. & 23.95 \\
\hline 189 & .22 & .12 & 2.92 & 1.76 & 4.17 & 3.9E & .74 & .34 & 1.70 & .46 & T. & T. & 16.35 \\
\hline & .88 & 1.06 & .48 & $8.8 ;$ & 8. 42 & 1. 84 & 1.20 & .845 & .51 & 0 & .04 & T. & 24.15 \\
\hline & 1. 26 & $.1 \tau$ & 1.54 & 1.54 & 9.76 & .09 & $2.5 i$ & 5.34 & .92 & .11 & $\mathrm{T}$ & .80 & 23.39 \\
\hline & .31 & .55 & 3.56 & 1. $\% 6$ & 3.66 & 4.15 & 2.54 & .25 & .30 & .04 & 0 & .01 & 17.13 \\
\hline & .16 & 1.96 & .61 & 1.64 & .98 & 3.19 & .04 & .28 & 1.50 & .14 & (1) & 0 & 10.50 \\
\hline & .36 & .64 & .61 & 2.30 & 3.94 & .04 & 6. 02 & .10 & .54 & .49 & 0 & .02 & 15.06 \\
\hline & (1 & 4. 46 & 2.62 & 2.91 & 3.54 & .32 & 1. 61 & 1.88 & 2.88 & $\mathrm{~T}$. & T. & 0 & 20.22 \\
\hline & 0 & 1. $\tau_{t}$ & 4.50 & 1.38 & 3.70 & ร. 32 & .48 & 2.23 & .80 & T. & T. & T. & 20.15 \\
\hline $1901-2 \ldots$ & .56 & 1.56 & 2.68 & 1. 19 & .95 & 6.52 & 1.99 & 1.36 & .45 & .01 & 0 & T. & 17.27 \\
\hline & & & & & & & & & & & & & 19.62 \\
\hline
\end{tabular}




\section{Recorrl of precipitation at Barston. San Bernardino County.}

[Latitude, $34^{\circ}, 51^{\prime}$ : longitude, $116^{\circ} 59^{\prime}$ : elevation, 2,15l feet. Authority, W. L. Burbeck. Geo. R. Gooding, G. W. Fetts. and others.]

\begin{tabular}{|c|c|c|c|c|c|c|c|c|c|c|c|c|c|}
\hline Year. & Sept. & ort. & Nov. & Der. & Jan. & Feh. & Mar. & Apr. & May. & June. & July. & Aug. & Total. \\
\hline $1888-89$ & & $\ldots . .$. & & & 11.14 & 0.014 & 11.43 & 0 & (1. 12 & 0 & 0 & 1). 13 & u 1.36 \\
\hline $1889-90$. & $0.01 \%$ & 1). 23 & 0.70 & $3.8 \pi$ & $.3 \%$ & .15 & $\mathbf{T}$ & $.0 \%$ & 0 & 0 & 0 & .15 & ธ. \\
\hline $1890 \Omega 1 \ldots$ & . & 0 & .0 .5 & .52 & 11 & 2.47 & $\mathbf{T}$. &.$(15)$ & $\mathrm{T}$. & 0 & $\mathrm{~T}$. & .06 & 3. 74 \\
\hline $1891-92 \ldots$ & .188 & $\theta$ & $\mathrm{T}$ & .25 & & & & & & & - - - & $\ldots$ & a. .33 \\
\hline $1892-93$ & & . & & $\ldots$ & .11 & $.2 \%$ &. & .06 & $\mathrm{~T}$. & 0 & 1.10 & 0 & a2.31 \\
\hline 1893-94. & 0 & .22 & $\mathrm{~T}$ & .72 & .02 & $\therefore 1$ & .116 & 11 & $.2 Z$ & $\mathrm{~T}$. & $\mathrm{T}$. & 0 & 1.45 \\
\hline 1894-95. & 0 & 0 & 0 & $.9 \%$ & 1.06 & 0 & .20 & 11 & 11 & 0 & 0 & 0 & 2.18 \\
\hline $1895-96$ & 0 & .83 & $\mathrm{~T}$. & 0 & .16 & () & .118 & 0 & 0 & 0 & $.0 \%$ & $.8 i$ & 1.51 \\
\hline $1896-9 r^{2} \ldots$ & 0 & 1.55 & 25 & .311 & 2.15 & $(t)$ & .11 & () & 0 & $\mathrm{~T}$. & 0 & .18 & 5. 19 \\
\hline $6-$ ye & & & & & & & & & & & & & 3.28 \\
\hline 1901-: & & & & & & & (1 & (1 & (1 & 4 & 0 & (1 & a) \\
\hline
\end{tabular}

"Year incomplete.

Record of precipitation at Deep ('reek. San Bernardino C'omty.

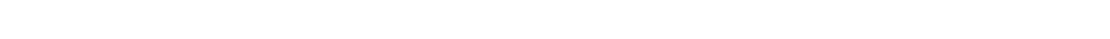
Company.1

\begin{tabular}{|c|c|c|c|c|c|c|c|c|c|c|c|c|c|}
\hline Year & Sept. & oct. & Nov. & Dec. & Jan. & Feb. & Mar. & Apr. & May. & June. & July. & Aug. & Total. \\
\hline $1893-94 \ldots \ldots$. & 1.95 & 1.19 & 1.20 & 4.16 & 1.94 & 1.89 & Q. 75 & 0.70 & 1.01 & 0.12 & 11.09 & 0.80 & $1 \% .80$ \\
\hline $1894-95 \ldots \ldots$ &.+9 & .30 & 0 & 18.41 & 13.14 & 2.13 & 7.21 & 1.36 & 0 & I 0 & 0 & 0 & 43.04 \\
\hline $1895-96 \ldots \ldots$ & 0 & 0 & 2.45 & 1.109 & 1.86 & .05 & 3.52 & 1.75 & .28 & 0 & 0 & .78 & 11. 18 \\
\hline $1896-9 \tau_{-} \ldots \ldots$ & 0 & 2.28 & 1.63 & 2.41 & 5. 43 & 13.03 & 7.59 & 11 & .19 & .10 & 0 & 0 & 32.68 \\
\hline $189 \%-98 \ldots$ & .28 & 3.92 & $1.1 \%$ & 1. 40 & 4. 20 & 1.10 & 1.89 & $.1 \%$ & 2.93 & 05 & .11 & 5) & 17.77 \\
\hline $1898-99 \ldots$ & 0 & 0 & .53 & .49 & & & & & & & & & $a_{1.02}$ \\
\hline $1899-1900)$ & & & & & 1. 40 & $.2 x$ & 3.07 & 2. & 4. 55 & & & - ...... & a 12.20 \\
\hline 5-year mean. & & & & & & & & & & & & & 24.61 \\
\hline
\end{tabular}

a Year incomplete.

Record of precipitation at Bear. Talley dam, Sam Beruardiun County.

[Latitude, $34^{\circ} 15^{\prime}$; longitude, $116^{\circ} 5 x^{\prime}$; elevation, 6,500 feet.]

\begin{tabular}{|c|c|c|c|c|c|c|c|c|c|c|c|c|c|}
\hline Year. & Sept. & Oct. & Nov. & Der. & Jan. & Feb. & Mar. & Apr. & May. & June. & July. & Aug. & Total. \\
\hline $1883-84$. & & & & & & & & & & & & & 94.60 \\
\hline $1884-85$ & & & & & & & & & & & & & 28.06 \\
\hline $1885-86$ & & & & & & & & & & & & & 65.51 \\
\hline $1886-8 \pi$ & & & & & & & & & & & & & 24.00 \\
\hline $1887-88$ & & & & & & & & & & & & & 62.30 \\
\hline $1888-89 \ldots$ & & & & & & & & & & & & & 46.0 .3 \\
\hline $1889-90 \ldots$ & & & & & & & & & & & & & 93.40 \\
\hline $1890-91 \ldots$ & & & & & & & & & & & & & 78.40 \\
\hline $1891-92 .$. & & & & & & & & & & & & & 38.00 \\
\hline 1892-93. . & & & & & & & & & & & & & 44.32 \\
\hline 10-year me & & & & & & & & & & & & & 57.46 \\
\hline
\end{tabular}


Record "f precipitation at Glen Ranch, San Bernardino County.

[Latitude, $34^{\circ}$. 201'; longitude, $11 \%^{\circ} 30^{\prime}$; elevation. 3.11: feet. Authority, Jas. M. Applewhite, C'ajon.]

\begin{tabular}{|c|c|c|c|c|c|c|c|c|c|c|c|c|c|}
\hline Year. & Sept. & Oet. & Nov. & Dec. & Jan. & Feb. & Mar. & Apr. & May. & June. & July. & Aug. & Total \\
\hline $1899-1 !(x) \ldots$ & 0.10 & 0.123 & 0.96 & $1 .(x)$ & 2.15 & 10. 11 & 8.84 & 1.35 & 1.69 & 0.02 & 0.01 & 0 & 11.25 \\
\hline $1900-19011 \ldots$ & .31 & $.4 t$ & 9.39 & 11 & 6.53 & $9 . \pi 8$ & .43 & 1.40 & .96 & 0 & 0 & 0 & 29.26 \\
\hline $1901-2 \ldots$ & 0 & 2.61 & .58 & .10 & 1.63 & $3.6 \pi$ & 5. 54 & .53 & 0 & .24 & 0 & 0 & 15.00 \\
\hline year $n$ & & & & & & & & & & & & & 18.50 \\
\hline
\end{tabular}

Record of precipitation at Holcomb Creek. San Bernardino County.

[Latitude, $34^{\circ} 1 \tilde{\imath}^{\prime}$; longitude, $117^{\circ} 05^{\prime}$; elevation, 5,220 feet. Authority, Ar'owhead Reservoir Company.]

\begin{tabular}{|c|c|c|c|c|c|c|c|c|c|c|c|c|c|}
\hline Year. & Sept. & Or.t. & Nov. & Dec. & Jan. & Feb. & Mar. & Apr. & May. & June. & July. & Ang. & Total. \\
\hline 1894-95. & & & & $\ldots$ & 10.06 & 11. 61 & 4.86 & 0.62 & 4 & 0 & 1 & (1) & t 16.15 \\
\hline $189596 \ldots$ & 0 & 0 & 1.66 & 0.41 & 1.56 & $\mathbf{T}$ & 3.24 & $1.0 \%$ & 0.25 & 0 & 0 & 0.47 & 8.61 \\
\hline $1896-97 \ldots$ & 0 & 1.70 & 1.05 & 1.82 & 3.35 & 7.89 & 3.42 & 0 & .11 & 0.20 & 0 & 0 & 19.54 \\
\hline $189 \pi-98 \ldots$ & 0.38 & 3.32 & 1.199 & .90 & 3.05 & .52 & $1.2 \pi$ & .10 & 1.46 & 0 & 0 & .66 & 12.75 \\
\hline $1898-99$ & 0 & 0 & $.5 \%$ & .48 & & & & 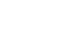 & - & & & & ‘ 1.05 \\
\hline $1899-1900$ & & & & & .38 & .21 & 1.14 & 1.25 & 1.20 & & & & a 4.18 \\
\hline year & & & & & & & & & & & & & 13.63 \\
\hline
\end{tabular}

a Year incomplete.

Record of precipitation at Little Bear Valley, San Bernardino County.

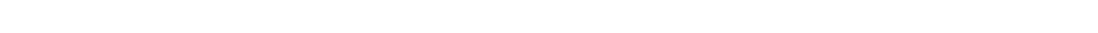
pany.]

\begin{tabular}{|c|c|c|c|c|c|c|c|c|c|c|c|c|c|}
\hline Year. & Sept. & ort. & Nov. & Dec. & Jan. & Feb. & Mar. & Apr. & May. & June. & Jvly. & Aug. & Total. \\
\hline 1898-94 & 1.21 & 1.49 & 2.55 & 7.61 & 2.48 & 2.25 & 3.16 & 0.62 & 1.34 & (1. $1 \%$ & (0. 144 & 0.31 & 23.18 \\
\hline $1894-95$ & .58 & .38 & 0 & 20.12 & & & & & & & & & ${ }^{\prime} 21.02$ \\
\hline $1896-97$ & & & & & & & & & & & & & - n..... \\
\hline $189 \%-98 \ldots$ & & & & & 3.80 & 1.38 & 2.49 & .25 & 4.56 & & 0 & & «12.48 \\
\hline $1898-99$. & & $\mathrm{T}$. & .62 & .74 & & & & & & & & & $u 1.36$ \\
\hline $1899-1900$ & ( & & & & 1.39 & .43 & $3.4 \%$ & 3.11 & 4. 63 & & & & a 12. 98 \\
\hline
\end{tabular}

a Year incomplete.

Record of precipitation at Mill ('reek "A," San Bernwdino C'onnty.

[Latitude, 34' $15^{\prime}$; longitude, 116 $54^{\prime}$; elevation, 5,000 feet. Author'1ty, Redland` Electrir Light and Power Company.]

\begin{tabular}{|c|c|c|c|c|c|c|c|c|c|c|c|c|c|}
\hline Year. & Sept. & Oct. & Nov. & Dec. & Jan. & Feb. & Mar. & Apr. & May. & June. & July & Ang. & Total. \\
\hline I899-1900. & & & & & 2.52 & 0.43 & 2.28 & 4.49 & & & & & a 9.72 \\
\hline $1900-19411$. & $\ldots$ & & 9.05 & & 4.32 & 6.00 & .71 & .39 & 1.85 & 0 & 0 & 1.20 & $a \geqq 3.5 \%$ \\
\hline 190I-: - - & 0 & 1.95 & $.8 \%$ & 0 & $\ldots$ & . n.... & . & 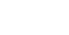 & - & $\ldots$ & - n. & & $a \% .7$ \\
\hline
\end{tabular}

« Year incomplete. 
Recowd of precipitation at Mill Creek "B." San Bernardino County.

[Latitude. $34^{\circ} 04^{\prime}$; longitude, $116^{\circ} 5 x^{\prime}$; elevation, 2.915 feet Authority, Redlands E'octric Light and Power Company:]

\begin{tabular}{|c|c|c|c|c|c|c|c|c|c|c|c|c|c|}
\hline Year. & Sept. & ret. & Nov. & Dec. & Jan. & Feb. & Mar. & Apr. & May. & June. & July. & Aug. & Total. \\
\hline 1899-1904. & & $\ldots$ & & $\cdots$ & 1.41 & $0.0 \%$ & 1.43 & 3. 14 & 3.31 & 0 & 0 & 0 & ?.9.96 \\
\hline $1900-1911$ & $1.1 t$ & 1. 1.5 & 4.96 & 0 & & & & ... & & & & $\cdots .$. & "ส:.25 \\
\hline
\end{tabular}

"Year incomplete

Record of precipitution at Morse's house. San Bernardino County.

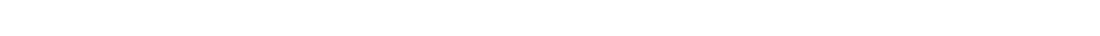
Company.]

\begin{tabular}{|c|c|c|c|c|c|c|c|c|c|c|c|c|c|}
\hline Year. & Sept. & act. & Now. & Dec. & Jan. & Feh. & Mar. & Apr. & May. & June. & July. & Aug. & Total. \\
\hline $1893-94 \ldots$ & 11.25 & 2.4t & 2.75 & 14. 73 & 4.78 & & 5. (k) & $1.3 \%$ & 2.118 & 0. 60 & 0.02 & 0.74 & 38.69 \\
\hline 1894-95. . . & $.6 \%$ & $.4 \pi$ & 0 & $26.7 \%$ & 15.00 & ล. 4.5 & 12.74 & 2.91 & 0 & 0 & 0 & 11 & $6 \% .21$ \\
\hline $1 \times 95-96$. & 0 & 0 & 4.18 & 3.11 & 5.95 & .08 & 7.90 & 2.63 & .89 & 0 & 0 & 46 & 25.20 \\
\hline $1896-97 \ldots \ldots$ & 1) & 3.83 & 1.96 & 2.73 & 9.34 & 20.14 & 15.61 & .15 & .18 & .40 & 0 & 0 & 54.34 \\
\hline $189 \pi-88 \ldots$ & .73 & 5.08 & 1.93 & 1.85 & $6.3 \%$ & 2.96 & 4.2 & .70 & 8.27 & .25 & .118 & .30 & 32.74 \\
\hline 1898-99_ & & .34 &.$\tilde{+\pi}$ & 1.28 & & & & $\cdots$ & . & & & & a.2.36 \\
\hline $1899-19010$. & & & & & 2.20 & 44 & 3.83 & 5. 81 & 8.64 & & & & $42(0.92$ \\
\hline ye & & & & & & & & & & & & & 43.64 \\
\hline
\end{tabular}

"Year incomplete

Record of preapitation at Rancho del Jurnpa, San Bernardina Comnty.

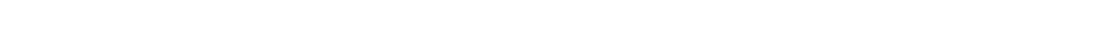
pital.]

\begin{tabular}{|c|c|c|c|c|c|c|c|c|c|c|c|c|}
\hline Year. & Sept. & Oet. & Nov. & Dec. & Jan. & Feb. & Mar. & Apr. & May. & June. July. & Aug. & Total. \\
\hline $188:-\times 3$. & 0 & 0 & 2.89 & 7.50 & (1. & 0.67 & 3.15 & 0.33 & 1.14 & 0 & $0.1 \%$ & 16.11 \\
\hline $1883-84 \ldots$ & () & 0 & .44 & 2.04 & 1. 64 & 2.34 & 3.09 & & & & $\cdots$ & $a 9.55$ \\
\hline
\end{tabular}

"Year incomplete.

Record of frecipitution at Redlands, San Bernardino C'ounty.

[Latitude, 34 103'; longitude, $117^{\circ}$ 11': elevation, 1.335 feet. Authority, Pacific Railvay Kystem.]

\begin{tabular}{|c|c|c|c|c|c|c|c|c|c|c|c|c|c|}
\hline Year. & Sept & Oet. & Nor. & Dece. & Jan. & Fel, & Mar & Apr & May. & June. & July. & Aug. & Total. \\
\hline $1888-89$. & (1) & 11.155 & 4. 12 & 4.64 & 0.68 & $1.4 \%$ & ร. 70 & 11. 59 & 0.58 & 0 & 1) & 11.28 & 18.51 \\
\hline 1889-9) . . & 0.31 & 1.50 & .52 & 13.72 & 4.69 & 3.03 & .89 & .16 & 68 & 0 & 0 & 216 & $2 \pi .66$ \\
\hline $1890-91 \ldots$ & .88 & 29 & () & 3.112 & i) & 9.28 & 1.19 & .91 & 1.10 & 10.23 & 0 & 1.63 & 18.53 \\
\hline 1891-92. & $9 \pi$ & 1) & 11 & 1.51 & $8 \pi$ & 4.37 & 2.06 & .13 & 0 & 0 & 0 & 11 & 9.91 \\
\hline $1892-93 \ldots$ & .113 & 0 & $.4 b^{\circ}$ & 1.14 & 2.39 & 2.65 & 6.26 & .0 .5 & 0 & 0 & .03 & 0 & 13.01 \\
\hline $1893-94 \ldots$ & .18 & 1.001 & .115 & $2.5 \theta$ & $.6 \tilde{i}$ & .90 & .59 & .31 & .62 & 0 & 0 & .11 & 7.02 \\
\hline $1894-95$ & .10 & .08 & 0 & 4.35 & 65 54 & 1.12 & $2 \% 4$ & 0 & .45 & 0 & 0 & 0 & 15. 38 \\
\hline $1895-96 \ldots$ & 0 & .03 & $1.1 \tilde{\pi}$ & 33 & 1. 24 & .06 & $2.4 i^{\prime \prime}$ & .43 & .85 & 0 & 0 & 1.03 & 7.66 \\
\hline 1896-9i & 0 & 1.12 & $20 \%$ & .16 & 4.33 & 3.89 & 1.92 & .10 & .19 & 0 & 0) & 0 & 14.38 \\
\hline $189 \tilde{i}-98$. & .83 & 192 &.$(r)$ & 51 & 2.56 & .60 & .84 & .18 & 1.59 & 0 & 1) & $\mathrm{T}$. & 9.10 \\
\hline $1898-99$ & .01 & .101 & .25 & .40 & 1.92 & 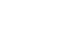 & 1.50 & .018 & .24 & $8 i$ & 0 & .04 & 6.03 \\
\hline $1899-1900$. & 05 & .65 & 1. 28 & $.46^{\circ}$ & 120 & $\mathrm{~T}$ & .78 & 2.03 & 1.41 & 0 &, 04 & 0 & 7.90 \\
\hline $1900-1901 \ldots$ & .50 & .53 & 3.48 & 0 & 2.25 & 3.79 & .16 & T. & 1.62 & .04 & 1) & 0 & 13. 07 \\
\hline $1901-2 \ldots . .$. & 11 & 92 & .119 & $\mathrm{~T}$ & 164 & 2.58 & 2.82 & .36 & .188 & .31 & $.0 \%$ & 0 & 8.87 \\
\hline & & & & & & & & & & & & & 12.64 \\
\hline
\end{tabular}


Reconel of precipitation at Rings Station, San Bernardino C'ounty.

[Latitude, :34 0:'; longitude, $116^{\circ} 46^{\prime}$; elevation. 4,310 feet. Authority, Jo'n J. Ring.]

\begin{tabular}{|c|c|c|c|c|c|c|c|c|c|c|c|c|c|}
\hline Year. & 'Sept. & Oct. & Nov. & Dee. & Jan.' & Fels. & Mar. & Apr. & May. & June. & July. & Aug. & Total. \\
\hline $18 \pi 4-75 \ldots \ldots$ & 0.09 & 0.61 & 2. 5i5 & 1. 78 & 5.64 & $\because 1 k$ & 11.28 & $11.3 \%$ & 0 & 0 & 0 & 0 & 12.7 \\
\hline $1865-76$ & .43 & $\mathbf{T}$ & 4.06 & .25 & 9.31 & 5.54 & 6.23 & .99 & (1. $\approx 0$ & 11 & 0.013 & 0 & 27.04 \\
\hline $1866-7 i$ & .19 & .18 & 0 & 11 & 5.75 . & 2.33 & 3.93 & 2.59 & 3.93 & 0) & .30 & $\theta$ & 19.:20 \\
\hline $18 \% 7-78 \ldots$ & 0 & 1.30 & (1. 80 & 4.03 & 6.183 & 11). 49 & 4.41 & 6.86 & 1.33 & $A, \approx b$ & .03 & $(1.20)$ & 35.74 \\
\hline $1878-79 \ldots$ & 0 & 0 & 9 & $1.5 \%$ & 2.84 & 5.11 & .55 & 3.23 & 0 & 0 & 0 & 0 & $14.2 b$ \\
\hline $18 \% 9-80$ & 0 & 1.60 & 4.10 & 9.39 & 1.78 & 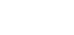 & 3.04 & 1.39 & .14 & 0 & 0 & .199 & 23.74 \\
\hline $1880 \_81 \ldots$ & 0 & . & 1.05 & $10.2 \%$ & $2.4 \times$ & 1.86 & 3.39 & 2.93 & .35 & 0 & 9.1 & 0 & $23.7 \%$ \\
\hline $1881-8 * \ldots . .$. & 0 & 1.30 & .08 & .42 & 3.30 & 7.:29 & 5. 38 & 4.21 & .35 & 1.30 & 0 & 0 & 23.63 \\
\hline
\end{tabular}

Record of precipitation at Santa Aud C'anyon. San Bernardino County.

[Latitude, $34^{\circ} 09^{\prime}$ : longitude. $11 \tilde{1}^{\circ} 0 \tau^{\prime}$ : elevation, 3,000 feet. A uthority, Edison Electric Company.]

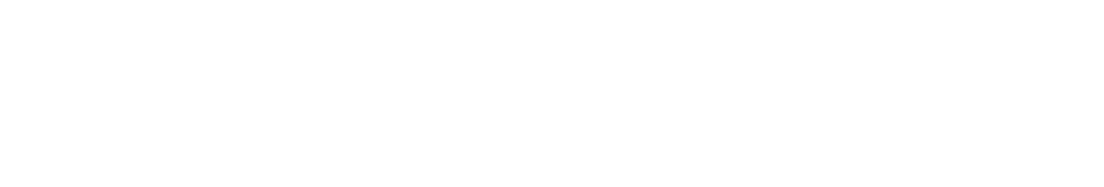

"Year incomplete.

Record of precipitation at Squirrel Inn, San Bernardino County.

[Latitude, 34० 12'; longitude. 11; 15'; elevation, 5.300 feet. Authority. Arrowhead Reservoir Company.]

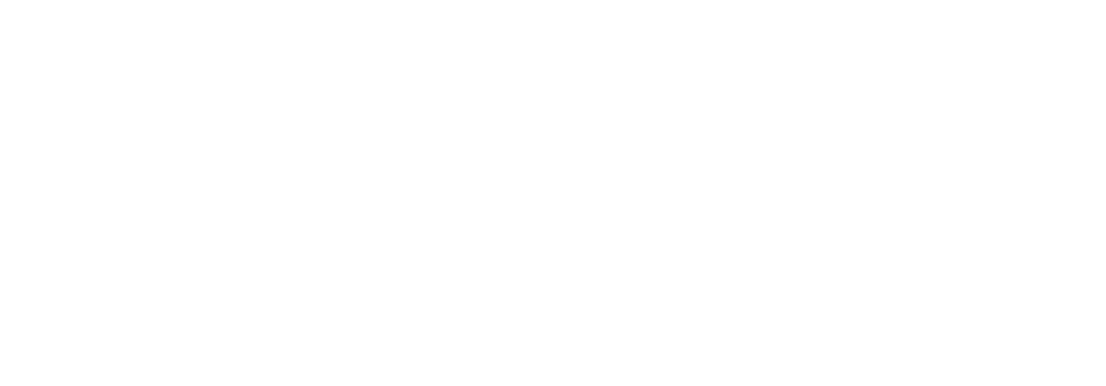

« Year incomplete.

Record of precipitation at Upper Holcomb Talley. San Bernarlino County.

[Latitude, 34 $18^{\prime}$; longitude, $116^{\circ}$ 5.'; elevation, 7 ; Company.]

\begin{tabular}{|c|c|c|c|c|c|c|c|c|c|c|c|c|c|}
\hline Year. & Sept. & Oct. & Nov. & Dec. & Jan. & Feb. & Mar. & Apr. & May & June & July. & Aug. & Total. \\
\hline $189 \%-98$. & & ...... & & & 2.60 & 0.40 & 1.50 & 0.50 & & & & & a 5. 00 \\
\hline
\end{tabular}

a Year incomplete. 
Record of precipitation at C'ampo, San Diego County.

[Latitude, 32० $37^{\prime}$; longitude, $116^{\circ} 30^{\prime}$; elevation, 2.660 feet. Authority, A. Campbell, Campo.]

\begin{tabular}{|c|c|c|c|c|c|c|c|c|c|c|c|c|c|}
\hline Year. & Sept & Oct. & Nov. & Dec. & Jan. & Feh. & Mar. & Apr. & May.' & June. & July. & Aug. & Total. \\
\hline $876-77$. & & & & & & & 2.29 & 1.08 & 0.91 & 0 & 0.50 & 0 & a 4. is \\
\hline $18.7-78$. & 0 & 0.35 & 1. 50 & 2.44 & 1. 79 & 5.45 & 1.84 & 5. $\%$ & .41 & 0 & 2.32 & 0.01 & 21.86 \\
\hline $1878-79$ & 0 & .31 & .55 & 1.29 & 2. 18 & 1.322 & .60 & 2.01 & 0 & 0 & 11 & 0 & 8.26 \\
\hline $18 \% 9-80 \ldots$ & 0 & 0 & 3.00 & 2.23 & 3.100 & 2.15 & 3.56 & 4. (k) & 0 & 0 & 12 & .41 & $18,4 \tilde{4}$ \\
\hline $8(8)-81$. & $0.0 \mathrm{~L}$ & 68 & .85 & 4.85 & $1.7 t$ & .53 & 5.01 & 1.52 & .12 & 0.04 & $.0 \%$ & 1.27 & 16.68 \\
\hline $881-8 \%$ & . & .73 & .11 & .24 & 3.10 & 4.5 & 1.01 & 1.10 & .18 & .26 & .62 & .53 & 12.47 \\
\hline $882-83$ & .02 & & & & & & & & & & & & $a .02$ \\
\hline 888-89. & $\cdots$ & $\ldots$ & & & ..... & 4.65 & 4.00 & & .45 & .10 & $\ldots$. & 2.50 & a 11.71 \\
\hline $889-90 \ldots$ & .50 & 1.10 & $1.6 \%$ & 9.34 & 2.40 & 7.25 & 1.69 & 1.86 & .90 & .16 & 2.26 & 2.67 & 31.81 \\
\hline $890-91$. & 1.80 & .44 & .95 & 2.80 & 0 & 13.30 & .50 & 1.20 & 50 & 0 & 0 & $b 16.10$ & 37.84 \\
\hline $1891-92$ & 0 & 0 & .25 & 3.21 & .75 & 4.55 & 3.30 & 1.25 & 2. & .35 & 0 & 0 & 16.41 \\
\hline $892-93$ & 0 & 12 & .71 & . & 3.55 & 3.6 .5 & 7.19 & 1.54 & .41 & 0 & 0 & 0 & 17.67 \\
\hline $893-6$ & זٓ & .11 & 3.38 & $2.18 \pi$ & 5.89 & 5.83 & 1.01 &.$\times(0)$ & 4.38 & 1. 26 & 0 & 0 & 25.31 \\
\hline $899-1$ & .24 & .60 & 1.61 & 1.15 & 2.65 & .10 & .55 & $2.0 \pi$ & 1.04 & .10 & 0 & 0 & 10.11 \\
\hline 1900-1901 & .15 & .28 & $4.4 i$ & 0 & 2.03 & 8.22 & .69 & .54 & 1.18 & 0 & .61 & .63 & 18.70 \\
\hline $1901-2$ & 0 & 1.02 & .43 & .23 & 4.28 & 4.72 & 4.00 & 1.33 & $.1 \%$ & .12 & 2.24 & 0 & 18.44 \\
\hline & & & & & & & & & & & & & 19. 54 \\
\hline
\end{tabular}

"Year incomplete. $\quad b$ Cloudburst; rain gage washed away. Record incormplete.

Record of precipitation at Cuyamaca Reservoir. San Diego County.

[Latitude, $33^{\circ}(\alpha)^{\prime}$; longitude. $116^{\circ} 4\left(\prime^{\prime}\right.$; eleration, $4.8(x)$ feet. Authority, San L: ego Flume Company.]

\begin{tabular}{|c|c|c|c|c|c|c|c|c|c|c|c|c|c|}
\hline Year. & Sept. & Oct. & Nor. & Dec. & Janl. & Feb. & Mar. & Apr. & May. & June & July. & Ang. & Total. \\
\hline $8 \%-88$. & 0 & 0.78 & 3.64 & 6.00 & 3.35 & 3.12 & 4.1: & 0.21 & 0 & () & 0.93 & 1). 04 & 22.19 \\
\hline $1888-89$ & 0.21 & $3.8 \%$ & 8,33 & 13. 30 & 2.99 & 4.70 & 12.85 & 3.44 & 2.22 & 0 & 0 & 1. it & $53 . \check{\jmath}$ \\
\hline $89-90 \ldots$ & .113 & 3.82 & 1. 64 & $: 0.96$ & 8.05 & 16.36 & 4.00 & 1.02 & 3.92 & 0 & .09 & .90 & 60.79 \\
\hline $1890-91 \ldots$ & 1.45 & .58 & 3.62 & 12.14 & 0 & 34.70 & $3.1 \%$ & 3.511 & 3.69 & 0 & .04 & .30 & 63.19 \\
\hline $1891-92 \ldots$ & .69 & 0 & .45 & 6. .5 & i.23 & 6.47 & 7.86 & 3. 35 & 5. 90 & $0.6 \bar{z}$ & 0 & 0 & $39.2 \pi$ \\
\hline $1892-93 \ldots$ & $n$ & .30 & $2.8 \%$ & $3 . \%$ & 5.55 & 9.13 & 1.5. $6 \mathrm{f}$ & 1. (1:6 & 1. 00 & 0 & 1. 20 & .30 & 40.71 \\
\hline $1893-94 \ldots$ & 0 & 1.90 & 3.30 & 2. & 2.05 & 2.05 & 0 & 11 & 1.00 & .511 & 0 & .50 & 14.05 \\
\hline $1894-95$ & .30 & 0 & 0 & 12.80 & 28.43 & 4.60 & 5. 89 & 3.10 & 1.16 & 0 & 0 & 0 & 54.28 \\
\hline $1895-96$ & 3.00 & 1.03 & 6.01 & 1.66 & $5 . \pi$ & .20 & 3.01 & 1.78 & .92 & a) & 1.29 & . $8 \pi$ & 25.54 \\
\hline $1896-97_{\ldots} \ldots$ & 1.06 & 4.93 & 3.45 & 3. $\pi 4$ & 6. 32 & 8.14 & 8.56 & .22 & .38 & 0 & 0 & 0 & 36.80 \\
\hline $1897-98 \ldots \ldots$ & .36 & 5.09 & $1.0 \pi$ & 2.46 & $5.4 \pi$ & $1.9 \%$ & $4.16 j \mid$ & 1.24 & 5.97 & 0 & 0 & 1.32 & 29.01 \\
\hline $1898-99 \ldots$ & 0 & 0 & .88 & .96 & ז.02 & 1.53 & 7.23 & .98 & .47 & 2.96 & .04 & T. & $28.0 \%$ \\
\hline _ _ _ & 0 & 4.51 & 3.45 & 2.49 & 3.62 & $2 \%$ & $2.5 \overline{1}$ & 6.69 & 2.81 & .10 & .28 & 0 & 26.72 \\
\hline 1 & .92 & .74 & 11.97 & .04 & $8.1 \%$ & 13.26 & 2.32 & 1.24 & $3.8 \%$ & 0 & $\mathrm{~T}$ & .09 & 12.62 \\
\hline $1901-2$ & . 188 & 1.94 & 1. 48 & .52 & $8.1 \%$ & ร..\% & 13.82 & 2.09 & .14 & 1\% & 1.54 & 0 & 35.65 \\
\hline & & & & & & & & & & & & & 37.66 \\
\hline
\end{tabular}

Record of precipitation at Descanso. San Diego C'ounty.

[Latitude, $32^{\circ} 50^{\prime}$; longitude, $116^{\circ} 4 \prime^{\prime}$ : elevation, 3,500 feet. Authority, E. W. Hulburd, Descanso.]

\begin{tabular}{|c|c|c|c|c|c|c|c|c|c|c|c|c|c|}
\hline Year. & Sept. & Oct. & Nov. & Dec. & Jan. & Feb. & Mar. & Apr. & May. & June. & July. & Aug. & Total. \\
\hline 895-96_. & T. & 0.38 & $4.3 \pi$ & 1.00 & 2.93 & 0.10 & 8.04 & 1.14 & 0.17 & 0 & 0.30 & 1.38 & 19.81 \\
\hline $1896-97 \ldots$ & 0.03 & $2 . \pi$ & 2.12 & 2.43 & 6.48 & 6.27 & 5.21 & 16 & .21 & 0.01 & .62 & .04 & 26.29 \\
\hline $1897-98 \ldots$ & .56 & 2.83 & 40 & 2.90 & 5. 28 & .89 & 4.11 & .90 & 2.35 & 0 & .15 & .83 & 21.20 \\
\hline 1898-99_. & 0 & 0 & .35 & 1.00 & 3.49 & 1.69 & 2.73 & .25 & 1.45 & 0 & .15 & .38 & 11.49 \\
\hline & 0 & 1.62 & .25 & 1.06 & 4.00 & .75 & 1.25 & 4. 25 & 2. 69 & .06 & 0 & $\mathbf{T}$ & 15.93 \\
\hline & | &.$t 33$ & 6. 50 & .15 & 3.5 & 11. & 1. 40 & $.5 \tau$ & 1.53 & 0 & T. & .78 & 26.06 \\
\hline $1901-2 \ldots \ldots \ldots$ & $\mathrm{T}$ & 1.25 & $.8 \pi$ & .12 & $4.4 \pi$ & $4.5 \%$ & $8 .(1)$ & 1.50 & .06 & 0 & .45 & 0 & 21.24 \\
\hline & & & & & & & & & & & & & 20. 29 \\
\hline
\end{tabular}




\section{Record of precipitation at Julian, Sam Diego Commty.}

[Latitude, $33^{\circ}\left(14^{\prime}\right.$; longitude, $116^{\circ} 36^{\prime}$; elevation, 4.5n feet. Anthorities, J. S. Berk and Mrs. A. L. Harritt.]

\begin{tabular}{|c|c|c|c|c|c|c|c|c|c|c|c|c|c|}
\hline Year. & Sept. & Oct. & Nor. & Dec. & Jan. & Feb. & Mar. & Apr. & May. & June. & July & Ang. & Total. \\
\hline $18 \% 9-81$. & 0 & 1) & 2.13 & 4.50 & 1.50 & $5 . \pi$ & 9. & 7.50 & (1) & 0 & 0 & 0 & 30.63 \\
\hline 1881L-81 . & 0 & 0 & 2.25 & 9.75 & 5.13 & 4.88 & 8.13 & 2.75 & 0 & 0 & 0 & 0 & 湓. 89 \\
\hline $1881-82$ & 0 & 0 & $1.8 x$ & (j. 88 & 5.13 & 3.38 & $\therefore .13$ & 4. 88 & " & 0 & 0 & (1 & 29.28 \\
\hline $1882-83 \ldots$ & 11 & 11 & .. 13 & 6.25 & 10.04 & 6.63 & 9.13 & 4.13 & 0 & 0 & 1) & 0 & 41.31 \\
\hline 1883-84. & 0 & 2.75 & 0 & 6.00 & 2.25 & 30.63 & 15.63 & 11). 63 & 3. $(* 3$ & () & 0 & 0 & 61. $5 \%$ \\
\hline ـ & 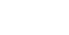 & & $\ldots$ & ..... & 6. 12 & 10.39 & 3.63 & 1.11 & P. & 0 & 0 & 1.25 & (125.04 \\
\hline $1890-91$ & 1.25 & (l) & $\geqslant .(x)$ & 6. $31 \mathrm{i}$ & $.1 \%$ & $19.32^{\prime}$ & 2.09 & 2.66 & 3.00 & 11 & 11 & 89 & $3 i .64$ \\
\hline $1 \times 91-92 \ldots$ & .81 & 11 & 2.25 & 8. 61 & $6.1 \%$ & 6.69 & 1.54 & 6. 11 & 3.55 & 0.41 & 0 & .11 & 36.25 \\
\hline $1892-93 \ldots$ & 0 & .50 & 1.53 & 2.81 & 3.76 & 3. $\% 2$ & 14.42 & .666 & 62 & 0 & 1.65 & .41 & 30.14 \\
\hline $1893-94 \ldots$ & .113 & $\because .20$ & 3,25 & $4 .(k)$ & 4.40 & 2.15 & 4. 19 & .38 & .68 & .04 & $.1 \%$ & .34 & 22.39 \\
\hline $1894-95 \ldots$ & .21 & T. & 0 & 93.36 & 16. 3\% & 3.80 & ว. 114 & s & .45 & $\mathbf{T}$ & $\mathbf{T}$ & .70 & 36.85 \\
\hline $1895-96 \ldots$ & 0 & .it & $\approx(6)$ & \% & 4.55 & .41 & 6.111 & I. 40 & .10 & (1) & .17 & .34 & $1 \% .11$ \\
\hline 11-year me & & & & & & & & & & & & & 33.55 \\
\hline
\end{tabular}

"Year incomplete.

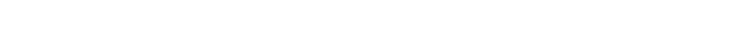

[Latitude, 3; in'; kongitude, 116 31': elevation, 5,440 feet. Authority, Arch. ('amphell, Campo.]

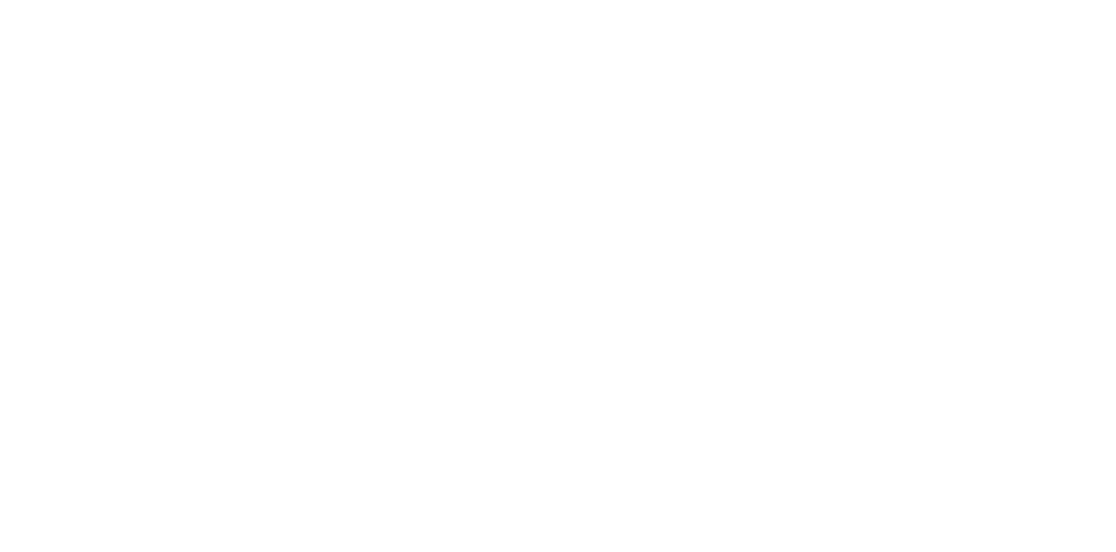

"Year incomplete.

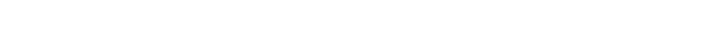

[Latitnde, $\left.33^{\prime \prime}: 21\right)^{\prime}:$ lomgitude. 116 .55'; elevation, 5.:240 feet. Authority, N. A. ('lark.]

\begin{tabular}{c|c|c|c|c|c|c|c|c|c|c|c|c|c|}
\hline Year. & Sept. crot. & Nov. & Dec. & Jan. & Feb. & Mar. & Apr. & May. June. July. Aug. Total. \\
\hline $1901-2$ & & 2.55 & 1.75 & 0.55 & 17.60 & 7.34 & 10.21 & 2.20 & 0.25 & 0 & 0.06 & 0 & $a 42.51$ \\
\hline
\end{tabular}

a Year incomplete. 


\section{Recurd of precipitation at San Diego, San Diego County.}

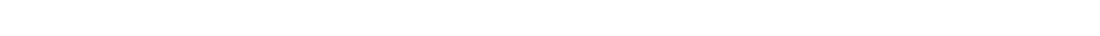
Weather Bureau.]

\begin{tabular}{|c|c|c|c|c|c|c|c|c|c|c|c|c|c|}
\hline Year. & Sept. & (x.t. & Nor. & Dec. & Jan. & Feth. & Mar. & Apr. & May & June. & July & Aug. & Total. \\
\hline $849-30 \ldots$ & & & & & 11 & 1. 13 & 1.00 & 0.119 & $n$ & 1). 68 & 11 & 0 & a2.c0 \\
\hline 41 & 0 & 0. 19 & $2.5 \%$ & 1.93 & 11. $11: 3$ & 1.51 & .34 & $.8 i^{\prime \prime}$ & 0.71 & .01 & 0 & c & 8.41 \\
\hline $11-92$ & 10.182 & .01 & 浩 & 3,74 & 8 & 1.84 & $1.8 \pi$ & .85 & .32 & 18 & 0 & 0.40 & 9.88 \\
\hline 1 & 10 & .06 & 1.45 & 4.511 & .00 & .20 & 1.52 & .25 & 2.10 & . 15 & 0 & .21 & 10.84 \\
\hline $53-34 \ldots$ & 11 & 11 & $1.2 x$ & 1. $\pi$ & .99 & 2.56 & 1.88 & .49 & .18 & .111 & $0.0)^{\circ}$ & 1.36 & 1.99 \\
\hline $54-5$ & .09 & .27 & .04 & 3. 29 & $1.9 \pi$ & 3.59 & 1.30 & 1.52 & .06 & 1) & 1) & .04 & 12.17 \\
\hline $5-56$ & 0 & .11 & 2.15 & .41 & $1.2 \%$ & 1. Kif & 1. 59 & 2.17 & 29 & (1) & 0 & 0 & 9.85 \\
\hline 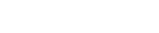 & $.16 \%$ & 0 & 1.22 & 1. 30$)$ & .26 & 1.76 & 0 & .04 & .08 & .103 & 0 & . 02 & 4. 78 \\
\hline $5 i-5+\ldots$ & .01 & $.4 !$ & 2.16 & 1. 30 & 1.52 & .44 & 1. 24 & $.1 \%$ & 0 & .19 & 0) & .04 & ז.56 \\
\hline $58-59+\ldots$ & .10 & $.4 \pi$ & 28 & 3.10 & 0 & 1.89 & .20 & .36 & $.1 \%$ & 0 & . 02 & 0 & 6. 58 \\
\hline $1859-60 \ldots$ & 01 & $.1 x$ & 1.49 & 1. 79 & 2 & 1. 49 & .15 & .65 & .04 & .05 & $.1 t$ & 0 & 6.70 \\
\hline $6(2-61 \ldots$ & 0 & 0 & 2.88 & 2.99 & . & . & .65 & .04 & 0 & .19 & 0 & 0 & 7.76 \\
\hline $61-6 z$ & 1.5! | & .05 & 1.19 & 3.31 & .5 .56 & 1.39 & $w_{i}$ & 1.05 & .16 & $.4 x$ & .11 & () & 15.75 \\
\hline $62-63$ & $0 \quad 1$ & . & $.1 \%$ & .918 & .32 & 1.09 & .33 & .13 & .02 & 0 & 0 & 0 & 3. 76 \\
\hline $3-64+$ & .36 & 0 & 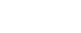 & .014 & .04 & 2.51 & $\therefore 0$ & .01 & 1.25 & .01 & .11 & 0 & 5. 25 \\
\hline $1-65$ & 0 & .144 & 2.41 & 1.04 & $1.2 x$ & 3.00 & () & . & 0 & .01 & 129 & & 9.6 \\
\hline $5-66 \ldots \ldots$ & 0 & (1) & .52 & .84 & 5.05 & $3 .+3$ & $1.4 \tilde{\imath}$ & .11 & 09 & 0 & 0 & .101 & 11.63 \\
\hline $66-6 i i \ldots$ & 0 & 0 & .24 & 1.82 & 9.32 & .85 & 7.88 & .48 & .04 & r & 0 & .30 & 13.93 \\
\hline $7-684 \ldots \ldots$ & 0 & .34 & .45 & 3. $0 k \mathrm{i}$ & 3.34 & 1. 63 & .73 & 1.20 & .15 & i & .51 & 0 & 11.44 \\
\hline $\left.1866^{\prime}-199\right) \ldots$ & $.0 .5)^{1}$ & (1) & $2 .(n)$ & 1.5 & 2.88 & 1.68 & 1.96 & .53 & .33 & 0 & $.0 \%$ & 0 & 11.22 \\
\hline 1869- "(1). & 01 & I. . & 法 & .94 &. .541 & $\pi$ & .33 & :20) & $.2 x$ & ( & .04 & $.0 \%$ & 5. 54 \\
\hline (10-i) & 11 & $1.5 t$ & .18 & .42 & $\tilde{n}^{2}$ & 1.35 & .01 & .70 & .34 & 0 & 1 & 0 & 5.06 \\
\hline $1871-i 2 \ldots$ & 11 & 0 & 1.33 & 1.3 & .99 & 2. & . ffi & .26 & .12 & & 1 & .18 & 6. 36 \\
\hline $180 \%-13$. & 0 & (1) & 11 & 1.411 & .44 & 4.1.5 & .11 & .10 & $.00^{\circ}-(x-1)$ & & 1) & 1.95 & 8.18 \\
\hline $18 \pi 34$ & 0 & 1) & $\pi$ & .7. 16 & 3.11 & 3.3 & 1.20 & .34 & 34 & 0 & & 0 & 15. 117 \\
\hline $18 \pi+4-5$. & .11 & .53 &.$x$ & .5 & 238 & $.3 \%$ & .45 & .12 & .20 & $(12$ & & .21 & 5.8 \\
\hline $18-5-66$ & .39 & (1) & :2.25 & .41 & 2.47 & 2.44 & 1.58 & $.14 \mathrm{i}$ & (1.5) & .05 & .113 & .06 & 9.9 \\
\hline $1876-76 \ldots$ & .03 & . & .194 & .15 & 1.05 & $.1 k$ & 1.44 & .26 & .43 & 0 & 0 & & 3.66 \\
\hline $1877-7 R_{\ldots} \ldots$ & 0 & & $.1 H \mathrm{i}$ & $3 . \times 14$ & 1. 45 & 4.83 & 1.41 & 2.91 & $.5 x$ & .14 & 0 & & 16.18 \\
\hline$-79-\ldots \ldots$ & $\theta$ & .96 & 0 & 1.55 & :3. 54 & 1.04 & .10 & .60 & $\mathrm{~T}$. & $.0 \pi$ & & & 7.88 \\
\hline $1879-80, \ldots \ldots$ & 11 & 24 & 2.7 & 6.30 & .61 & 1.50 & 1.43 & 1.34 & .16 & .06 & $(n)$ & . 32 & $14 . \pi$ \\
\hline & 11 & .33 & .28 & 4.15 & $.5 \%$ & .45 & $1.8 k$ & .35 & .04 & .65 & 11 & (11) & 9.26 \\
\hline & .184 & $\therefore 4$ & .12 & .30 & 4.53 & 2.5 & 1.18 & 4.5 & .18 & $.0 \pi$ & 0 & 1. & 9.511 \\
\hline . & .01 & .41 & . 39 & .13 & 1.099 & 5 & 41 & .31 & 1.14 & . & 0 & I & 4.92 \\
\hline $4+\ldots$ & 0 & | $: 2.01$ & .20 & & 34 & 9.115 & (5.2:3 & 2.44 & P. 17 & .31 & 0 & $\mathrm{~T}$. & 25.97 \\
\hline 18 & $.1 \%$ & 1.35 & .11 & 5.12 & & .02 & . is & :1) & .61 & .060 & $\mathrm{~T}$ & $1: 3$ & 8.80 \\
\hline & $\mathrm{T}$. & .31 & 1.36 & . & 6.95 & 1.51 & 3. 5 & .95 & .04 & . & T. & $\mathrm{T}$ & 16.83 \\
\hline & 18 & .05 & 5 & .10 & 44 & 4.51 & .1 & 2.14 & .4 & .04 & & $\therefore$ & 3.35 \\
\hline & $\mathrm{T}$. & $\mathrm{T}$. & 2.08 & & & 1.48 & & .10 &. & .04 & $.1)^{1}$ & $\mathrm{~T}$. & 9.82 \\
\hline & $.0 t$ & $\therefore 6$ & $1 . x 3$ & & 1.72 & 1.80 & 2.21 & .19 & .03 & .10 & T. & .04 & 11.05 \\
\hline $1889-91 \ldots$ & T. & 2. 12 & .12 & & 采 79 & 1. 70 & .4 & .05 & . (1) & 0 & 0 & 0 & 14.98 \\
\hline .. & $6 i$ & .01 &. & & & 4.84 & .2 & 海 & .3 & .05 & $\mathrm{~T}$. & & 10. 48 \\
\hline $92 \ldots \ldots$ & ה & .114 & .10 & 1.29 & 1.28 & 3.96 & .96 & .41 & 1.15 & .13 & (1) & S & 8.75 \\
\hline$-93 \ldots$ & T. & . & .91 & .69 & is & $.4 \tilde{\tau}$ & 5.50 & .22 & .39 & $\mathrm{~T}$. & $\mathrm{T}$. & ( & 9.21 \\
\hline $1893-94 \ldots$ & 11 & .11 & .91 & 1.91 & $\therefore 9$ & .49 & 1.05 & .11 & . 09 & .111 & 0 & .04 & 5. 61 \\
\hline $1894-95 \quad \ldots \ldots$ & .01 & $\mathrm{~T}$ & 0 & $\therefore .86$ & 6.33 & .53 & 1. 43 & .11 & .19 & 0 & 0 & 0 & 11.86 \\
\hline $1890-96 \quad \ldots$ & .01 & $.2 \pi$ & $1.1: 1$ & ז'. & $1.2 t$ & .021 & 2.89 & $2 \pi$ & .03 & .01 & $\mathrm{~T}$. & .13 & 6.34 \\
\hline & T. & ("9) & .98 & $\because 18$ & 3.13 & 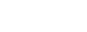 & 1.58 & . & .12 & $\mathrm{~T}$. & $.0^{\circ}$ & $\mathrm{T}$. & 11.71 \\
\hline . . . . . & $\mathrm{T}$. & $1.14 \mathrm{f}$ & . 02 & .32 & 1.71 & .0165 & .91 & 潜 & . 666 & 112 & 0 & 11 & 4.98 \\
\hline $3-991 \ldots$ & $\pi_{1}$ & 10 & .15 & .67 & 2.34 & .391 & (5) & .299 & .10 & ז 20 & 0 & $0 \pi$ & 5.31 \\
\hline $9-1901 \ldots 1 \ldots$ & 11 & . 35 &.$\times 6$ & . 6i5 & .69 &.$(B)$ & .53 & 1. 266 & 1.45 & . 18 & 0 & $\mathrm{~T}$. & $5 .(+1)$ \\
\hline (161-1911 . . . & $\mathrm{T}$. & 30 & 1.43 & 0 & $\approx .16$ & 4.7 & $1.1 \%$ & .01 &.$;$ & $.0 \%$ & $\mathrm{~T}$. & $\mathrm{T}$. & 10.45 \\
\hline $1901-2: \ldots$ & $.00 \mathrm{i}$ & $\therefore 8$ &.+1 & . 198 & 1. 60 & $1.5 \%$ & 1.86 & .21 & .06 & $\mathrm{~T}$. & .42 & $\mathrm{~T}$. & 6.194 \\
\hline & & & & & & & & & & & & & 9.50 \\
\hline
\end{tabular}




\section{Record of precipitation at Warners, San Diego County.}

[Latitude, $33^{\circ} 5^{\prime}$; longitude, $116^{\circ} 40^{\prime}$; elevation, 2,x94 feet. Authority, Charles E. McGary.]

\begin{tabular}{c|c|c|c|c|c|c|c|c|c|c|c|c|c|c|c|}
\hline Year. & Sept. & Oct. & Nor. & Dec. & Jan. & Feb. & Mar. & Apr. & May & June. July & Ang. & Total. \\
\hline $1900-1901$ & & & 1.93 & & 2.58 & 5.98 & 0.35 & 0.20 & 0.97 & & & & 012.01 \\
\hline
\end{tabular}

a Year incomplete.

Record of precipitation at Sunta Barbara, Santa Barbara County.

[Latitude, $34^{\circ} .5^{\prime}$; longitude, $119^{\circ} 40^{\prime}$; elevation, 100 feet. Authority, United States War Department and Weather Bureau.

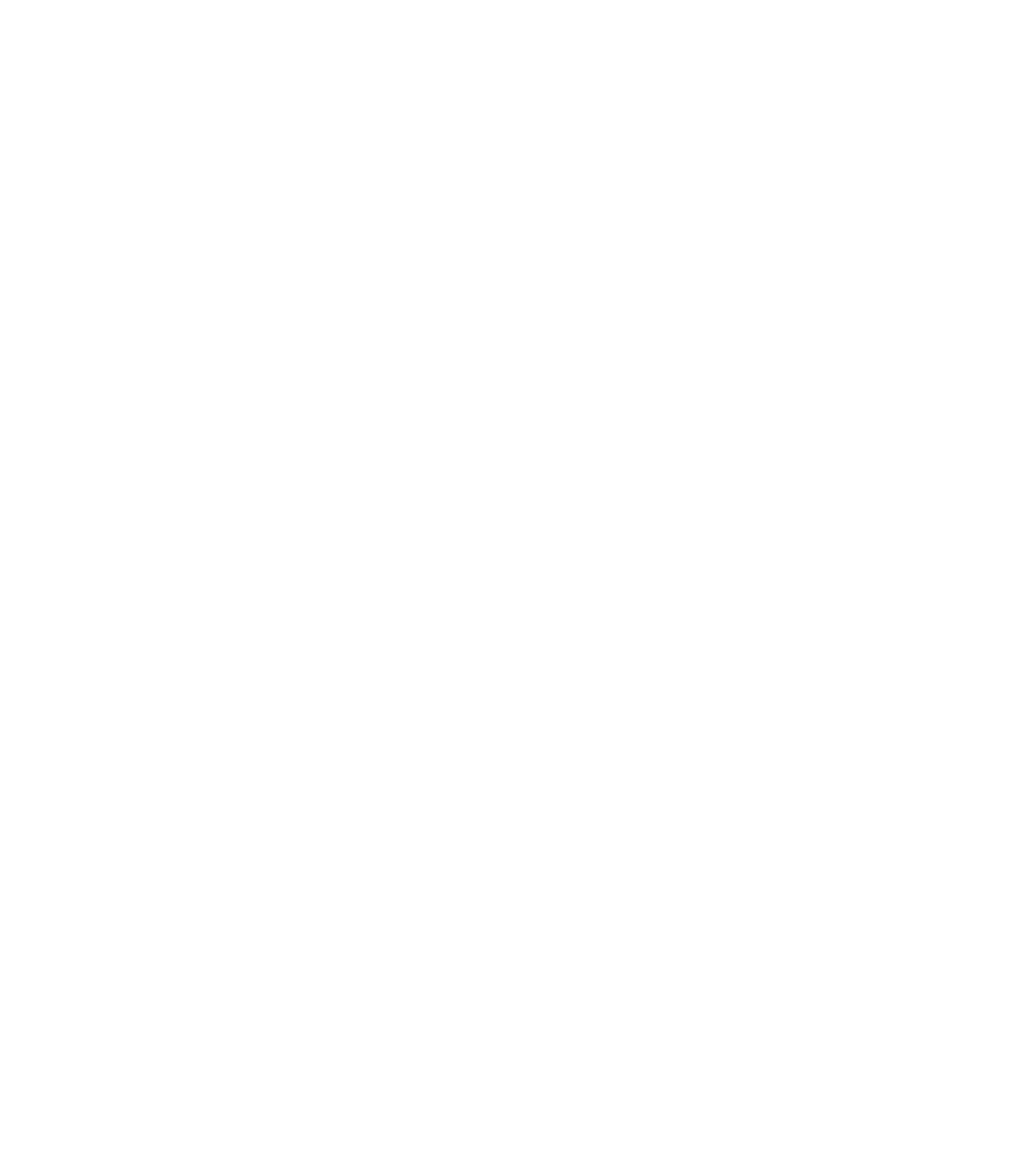




\section{Recom of precipitation at Monnt Hamilton (Lick Observatory), Santa Clara County.}

[Latitude, $37^{\circ} 2 \gamma^{\prime}$; longitude. 121 $31^{\circ}$; elevation, 4,440 feet. Authority, Lick Observatory.]

\begin{tabular}{|c|c|c|c|c|c|c|c|c|c|c|c|c|c|}
\hline $\mathrm{eal}$ & Sept. & Get. & Nuv. & Dec. & Jan. & Feb. & Mar. & Apr. & May. & & July. & Aug. & Total. \\
\hline $80-$ & & & & & 3.11 & 5.99 & .13 & 0.98 & 0.199 & 11. 33 & 0 & 0 & a 11.63 \\
\hline $81-$ & 0.10 & 0.33 & 0. 91 & 9.72 & 3.55 & 2.99 & 40 & 4. 70 & .48 & 1.06 & 0 & 1) & .15 \\
\hline & 0 & 6. 16 & 3.45 & 1.93 & 3.10 & 3. $\pi$ & 8. 66 & 2.66 & 7.56 & 0 & 0 & 0 & \\
\hline & .65 & 2. 60 & 1. $4 \mathrm{x}$ & 2.05 & 5. 60 & 12. 76 & 16.35 & 11.96 & 1.24 & 3. 45 & 0 & (1). 15 & \\
\hline & . (isi) & 3.71 & .111 & 33.84 & 1.99 & $.5 \tau$ & 1.15 & .08 & .16 & .36 & (1) & 0 & \\
\hline & .15 & .05 & 3.01 & 6.76 & 4. $\tilde{3} 3$ & 1.80 & 77 & 79 & .70 & 0 & 0 & () & \\
\hline 80 & 0 & .60 & 2.82 & 2.34 & 2.83 & 7.80 & 1.39 & 5.75 & . & .30 & 0.04 & 1) & 12 \\
\hline & .33 & .69 & .90 & 11.25 & 10.04 & 1.38 & 3.40 & .64 & 1.25 & 0 & 0 & $.0 \mathrm{~N}$ & \\
\hline & .49 & (08 & 3.25 & 4. 23 & 1.114 & 1. 42 & $6.1 \%$ & .92 & 3.21 & & $\theta$ & 0 & \\
\hline & 0 & 4.38 & 4.69 & 13.14 & 7.92 & 2.04 & 4.39 & 1. $\% 9$ & 2.42 & 0 & 0 & 0 & .82 \\
\hline & .80 & .12 & א. & 5. 39 & 1.38 & 6.52 & 4. $: 26$ & $3.0 \mathrm{~K}$ & 1.12 & ז̃ & 0 & 0 & .72 \\
\hline & .28 &.$t i 1$ & .38 & 9. 54 & $1.9 \%$ & 2.99 & איר. & 1.:(M) & 3.52 & .32 & 0 & $\mathrm{~T}$. & \\
\hline & .24 & .34 & $1(1.3)$ & 5.56 & 3.29 & 3.41 & .99 & 3.ti1 & .95 & $.166^{\prime}$ & 0 & 0 & \\
\hline 1 & .48 & .36 & 4. 111 & 3.35 & 8. $\pi 4$ & 10.52 & 2.54 & .89 & 2. $\pi x$ & .64 & (l) & $\mathrm{T}$. & 34.66 \\
\hline 804 & 1.64 & 2.98 & .84 & 11.90 & 10.10 & 3.18 & 46 & 2.311 & 2.39 & 0 & & 11 & 60 \\
\hline & .08 & .78 & 2.46 & -3.16 & 9.54 & 1. $(18$ & 3.83 & 6.70 & 2.10 &.$(\mathrm{~B})$ & $\mathrm{T}$. & א8.2. & \\
\hline $000-0$ & $.4 \pi$ & 1.91 & 5. & 4.93 & 3.50 & 5.92 & 3.40 & . & 2 & .89 & 6 & 0 & 27.34 \\
\hline & .07 & 1. 26 & 1.51 & 2.70 & 1.50 & 4.16 & 04 & .63 & 2. 41 & .34 & 0 & 0 & .86 \\
\hline$\ldots \ldots$ & .29 & 1,33 & 1.33 & 2.13 & 5.63 & .75 & 11.11 & 1.40 & $1.4 i$ & $.39^{\prime}$ & 0 & .12 & 25.95 \\
\hline 1899 & $\mathrm{~T}$ & $6.3 \pi$ & 4.92 & 4.16 & 3.26 & $1 . \%$ & $3.3 i$ & 4.166 & 1.35 & T. & .01 & .02 & 29.22 \\
\hline & .08 & 3.48 & $\pi \% 6$ & 2.21 & 5.74 & 5. 92 & $1.9 k$ & 3.33 & $1.0 \pi$ & .12 & 0 & .05 & 31.64 \\
\hline $1901-2$ & $1.0 \%$ & 2.29 & 2.49 & 1.61 & 1.4 & 9.25 & 5.18 | & 2.98 & 1.19 & 11 & 0 & 0 & $2 \pi .93$ \\
\hline
\end{tabular}

n Year incomplete.

Record of precipitation at Delta, Shasta County.

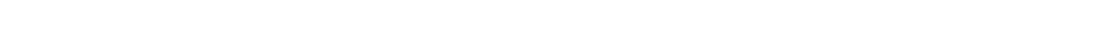

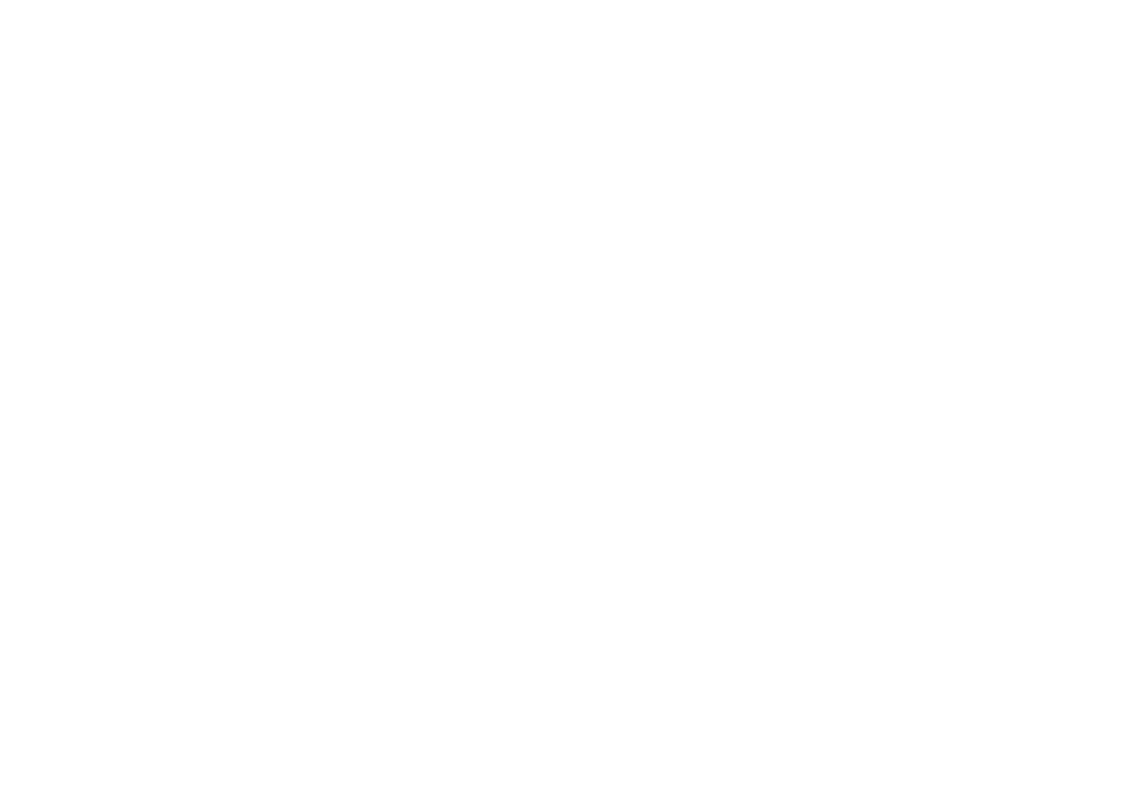




\section{Record of precipitation ent Fort ('reesh, Shasta ('om)ty.}

[Latitude, $40^{\circ} 10^{\prime}$ : longitude. $1: 1^{\circ}: 2 v^{\prime}$; elevation, $\left.3,3, n\right)$ feet. Anthority, U. S. War J)erartment.]

\begin{tabular}{|c|c|c|c|c|c|c|c|c|c|c|c|c|c|}
\hline Year. & Sept. & Oret. & Nor. & Der. & Jan. & Fr.t. & Mar. & Apr. & May. & June. & July. & Aug. & Total. \\
\hline $18.5 \pi-\pi_{4}$ & & & & & 2.23 & 4.38 & $2.5 i$ & 1. $2 x$ & 0. 13 & 0.34 & (1 & 0.013 & a 110.96 \\
\hline $1858-79$ & 0.04 & $3.6 \pi$ & 1. 32 & 6.39 & 1.81 & ..$\&$ & 4.165 & 1.26 & . 611 & 0 & 0 & .05 & 25.16 \\
\hline 18กัด-คด & 1.80 & 0 & $3.8 \mathrm{j}$ & $1 .(6)$ & 2.14 & $\therefore$ & .10 & 3.09 & 3.066 & .44 & 2.20 & 0 & 23.97 \\
\hline $8600-61$ & $\therefore 3$ & $2.9 \%$ & 1.33 & 5.104 & 1.:21) & +. $5 x$ & 4.03 & 1.82 & 1.33 & .665 & 0 & 0 & 23.39 \\
\hline $1861-62$ & 11 & .09 & 6. 18 & 9.75 & 8.22 & 4.89 & 3.53 & 2.64 & 2.59 & $2.4 ;$ & . (k) & 0) & 40.36 \\
\hline $1862-63$ & .40 & .199 & 0 & 1.81 & 3.60 & 3.09 & 2.80 & 1.00 & .41) & 0 & 0 & 0 & 13.19 \\
\hline 1863 & 0 & .39 &.$(16$ & 2.001 & 1.10 & 0 & .58 & 1.00 & 1.34 & 的 & (1) & 0 & .82 \\
\hline $1864-64$. & 0 & 1.115 & 5.00 & $7.4 \%$ & 3.16 & 2.16 & 2.23 & 1.:0) & 1.30 &.$(6)$ & 1) & (1) & 26.17 \\
\hline 1865-6iti & 1.11:? & 1.5.5 & 8.75 & & & & ‥25) & .87 & & & & 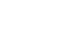 & a.20.44 \\
\hline $1866-65 i \ldots$ & 11 & 11 & .80 & $11 . \pi !$ & $5.2 \%$ & 4.44 &.$\pi 5$ & 1.86 & .50 & $.30)$ & () & 0 & 湆. 67 \\
\hline $186 \%-68$ & .40 & .73 & 1.12 & & & & & & & 1. $6 i i$ & .165 & 0 & (1 4.48 \\
\hline $1866-69 \ldots$ & 0 & .51) & .54 & 3.25 & 2.85 & & t. $x: 2$ & $1.5 f$ & & & & & a 13.54 \\
\hline & & & & & & & & & & & & & 29.9 \\
\hline
\end{tabular}

"Y ear incomplete.

\section{Recom of preapitation at Redding, Shasta conenty.}

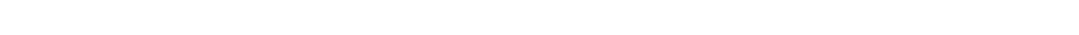

\begin{tabular}{|c|c|c|c|c|c|c|c|c|c|c|c|c|c|}
\hline Year. & Sept. & Oct. & Nor. & Dex. & Jan. & Feth. & Mar. & $A_{1}{ }^{\circ}$. & May. & June. & July. & Aug. & Total. \\
\hline 1890-91 & & & & & $1.6 \mathrm{n}$ & 9.45 & 3.015 & 2.31 & 3.17 & 1.91 & 0.75 & (1 & 122.82 \\
\hline $1891-92 \ldots$ & 0.13 & $0.12:$ & $11.11 \mathrm{~K}$ & 8.34 & $1.1 !$ & 1.32 & $1.4 \mathrm{I}$ & 9.31 & 3.23 & .201 & 0 & 0 & 18.25 \\
\hline $1892-93$. & 0 & 2.46 & 8.96 & $14.2 \%$ & 4.18 & 4.7 .5 & $9.1 \%$ & 3.94 & 1.35 & 1) & 1) & 0 & 49.08 \\
\hline $1898-94 \ldots$ & 3.15 & $.2 \gamma$ & i. (f) & 3.94 & 9. 69 & \%. 65 & 3.20 & 2.64 & 1.31 &.$(6.5)$ & 0 & $0.4 \%$ & 40.41 \\
\hline $1894-45 \ldots$ & 1.59 & 5.45 & .99 & 15.35 & 12.84 & 3.118 & 9.78 & .98 & ข. 61 & 0 & .95 & $\mathrm{~T}$ & $4 i .03$ \\
\hline $1895-96 \ldots$ & 3.24 & .01 & $2.1 \%$ & 4.36 & $14.5 \%$ & .79 & $4.1 \%$ & 4.015 & 8.97 & . & $\mathrm{T}$ & $.3 x$ & 42.96 \\
\hline $1896-9 i^{n} \ldots \ldots$ & .81 & 1.99 & 6. 301 & S.9. & t. $4: 2$ & (i. 81 & 5. 29 & 3.12 & 11 & 1.59 & 0 & 0 & 39.20 \\
\hline $1897-98 \ldots \ldots$ & .15 & 1.36 & 1.69 & 3. (61) & .54 & 3.77 & 0 & $.7 b$ & 3.84 & .15 & 0 & $\mathrm{~T}$. & 15.66 \\
\hline $1898-99$ & .13 & 1.56 & 2.23 & 2.35 & 9.66 & 1.04 & 8.865 & .61 & .82 & 2. $4 b^{\circ}$ & 0 & .18 & 29.80 \\
\hline 1899-190k . & 11 & 4.83 & 8.50 & $4.1 \mathrm{~s}$ & i. 4.5 & $2.84 i$ & 3.68 & 2.59 & 3.12 & 1.34 & $\mathrm{~T}$. & .16 & 37.75 \\
\hline $19(0)-19 n 1$ & 2.48 & ti. $4 \pi$ & 3.08 & 3.14 & 6i. $\$ 33$ & 5.52 & $.5 i$ & 5. 11 & .41 & T. & .01 & $\mathrm{~T}$ & 32. 07 \\
\hline $1901-2 \ldots$ & 3.11 & $3.11 \mathrm{k}$ & 6.45 & 4.37 & $1.3 \%$ & $19.9 \pi$ & 4.73 & 4.69 & 2.94 & (l) & .01 & .013 & . 5. \\
\hline $11-y$ & & & & & & & & & & & & & 36.72 \\
\hline
\end{tabular}

"Year incomplete.

\section{Record of precipitation at sims, shasted courety.}

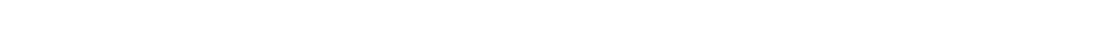

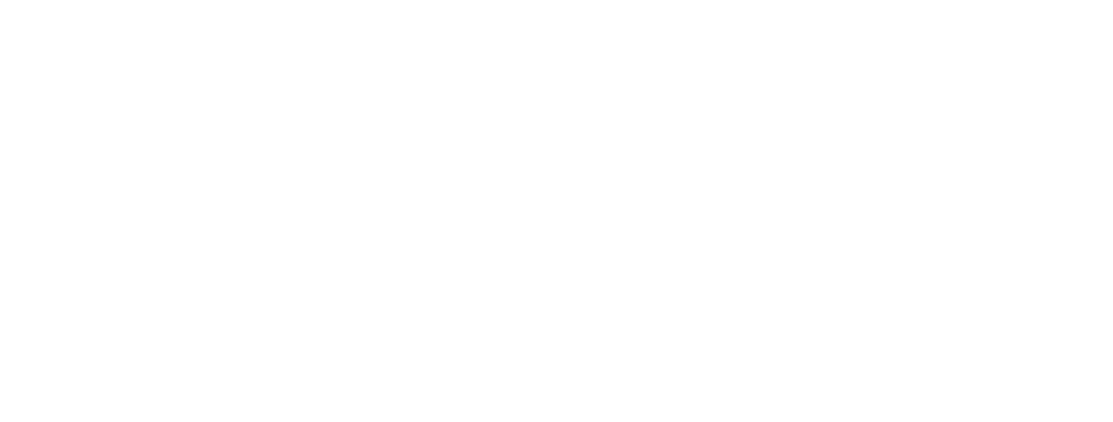




\section{Record of precipitation at C'oles, Siskiyou C'ounty.}

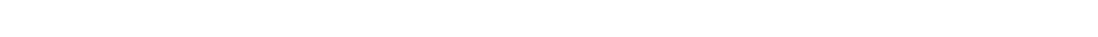

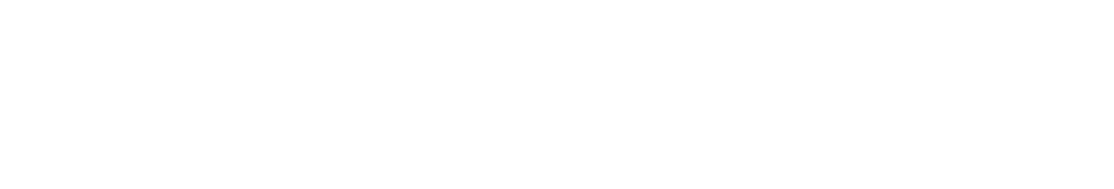

" Year incomplete.

\section{Record of precipitation et Inusmur. Sishiyou county.}

[Latitude, 41॰ 1:'; longitude. 1\% 16'; elevation, 2.285 feet. Authority, Pacifir Railway System.]

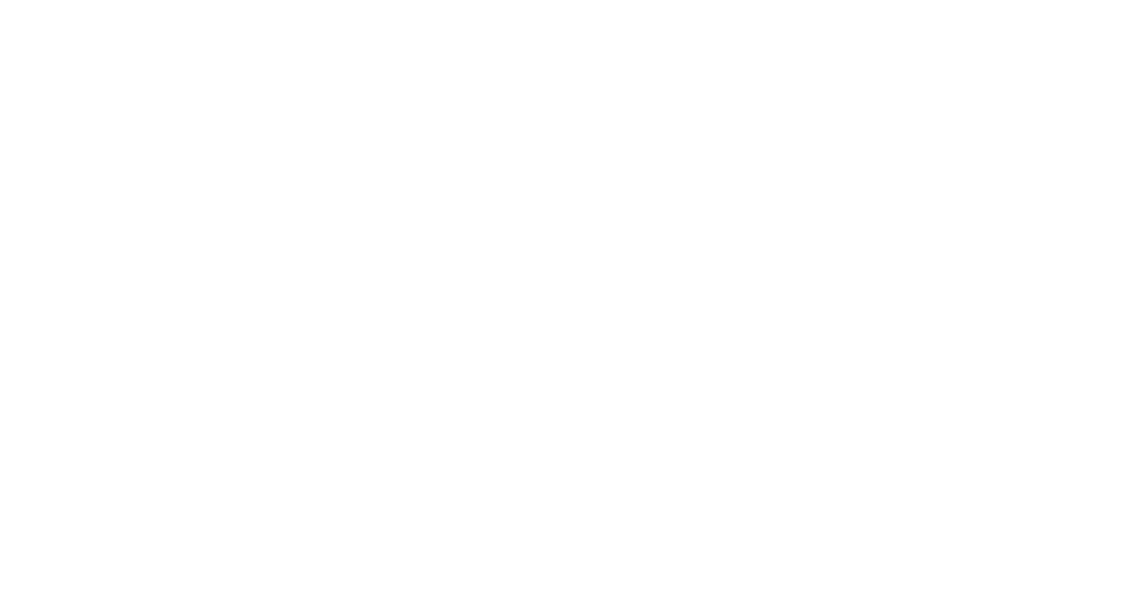

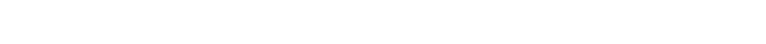

[Latitude, $41^{\circ} 2 \alpha^{\prime}$; longitude, 1:2: $22^{\prime}$ : elevation, :2,95 feet. Authority, Parific Railway System.]

\begin{tabular}{|c|c|c|c|c|c|c|c|c|c|c|c|c|c|}
\hline Year. & Sept. & $0 \times+$. & Nof. & Dece. & Jan. & Feb. & Mar. & Alr. & May & Trume. & July. & Aug. & Total. \\
\hline $1888-89$ & 11. 89 & 0. 15 & $\therefore(x)$ & 0.5 & (1).311 & 0.10 & 8.43 & 0.69 & 2.301 & 0.11 & (1. 33 & 0 & 16.015 \\
\hline & 0 & 7.80 & 2.35 & 5.31 & 5.616 & $5.9(1$ & 5.194 & .70 & 1. 180 & 1. $\%$ & 0 & (1. 4.) & 36.46 \\
\hline 189 & 1.15 & .22 & 0 & $3 .(\mathrm{k})$ & in & :.45, & .18 & 1.96 & 2.04 & 1.45 & $.6 i$ & .05 & 13.62 \\
\hline & .84 & .43 & .211 & 2.80 & .15 & $.1: 2$ & $2.6 \%$ & .46 & 1. 63 & .69 & .80 & 0 & 11.19 \\
\hline & 8. & $1.0 \%$ & 5.35 & T.N & .4 & 1 & 2.90 & 3.48 & .45 & .30 & .665 & 0 & 24.32 \\
\hline$\ldots$ & $1.5]$ &.$\approx 6$ & 2.65 & .85 & 5.13 & .50 & 1.83 & .1 & 3.56 & $.2 \%$ & 0 & .46 & 18.12 \\
\hline 1894 & .69 & $1 . \%$ &.$x^{\infty}$ & 9.55 & 4.56 & .334 & $: 2.84$ & .18 & .73 & 0 & 1) & .94 & $2 ; 3$ \\
\hline $1895-96$ & 1.59 & .115 & .75 & .51 & 6.64 & .31 & 2.68 & 4.666 & 1.35 & $.4: 2$ & $.11 \%$ &.$\pi$ & 19. $7 y$ \\
\hline & .71 & .41 & 3.45 & 5.16 & 1.18 & 1.133 & 1.5 .5 & .15 & 2.113 & 1.is & 1) & .35 & 18.69 \\
\hline & 11 & 1. $2 r$ & 1.94 & 2.68 & . & $4 . \%$ & .17 & 1.64 & 2. 49 & .51 & 0 & .99 & 17.30 \\
\hline $1898-49$ & $\mathrm{~T}$. & ris & 1.51 & 0 & 0 & .nis & 1. 67 & .14 & 1. 82 & .29 & 0 & 49 & 7.10 \\
\hline & $\|$ & $1.8 \%$ & 3.79 & 2. 21 & 3.37 & .91 & 1.8 .5 & $\therefore 25$ & 1.58 & .85 & .11 & .23 & $19.0:$ \\
\hline & .68 & $4.9{ }^{\circ}$ & .91 & ט. & 1.00 & 3.21 & .18 & 1.11:2 & .98 & 0 & .48 & .65 & 16.85 \\
\hline $1901-2$ & 1.16 & 0 & 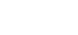 & 2.24 & $.3 \pi$ & 7.84 & 2.45 & 3.47 & .97 & .11) & .32 & .86 & 22.11 \\
\hline & & & & & & & & & & & & & 18.78 \\
\hline
\end{tabular}




\section{Record of precipitation at Fort Jomes. Siskigon c'onut!l.}

[Latitude, $41^{\circ} 35^{\prime}$; longitude, $122^{\circ} .51^{\prime}$; elevation, :2,50 feet. Authority, U. S. War Department.]

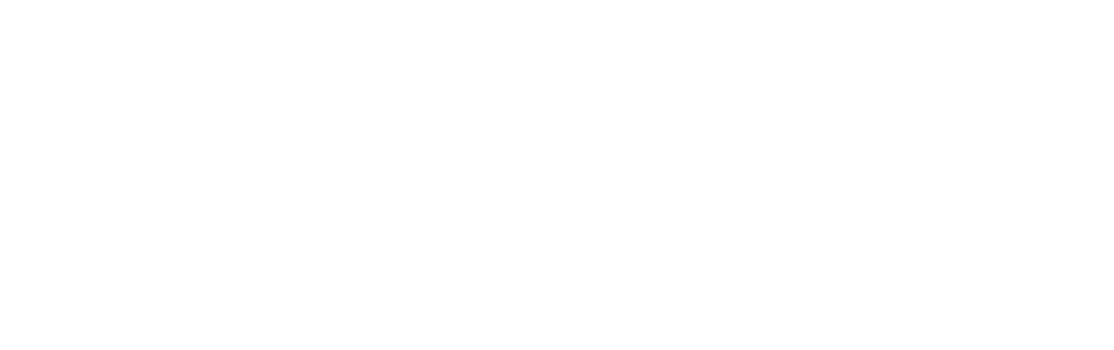

"Year incomplete.

Record of precipitation at Hombrook, siskigon county.

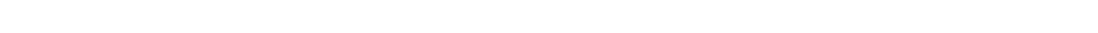

\begin{tabular}{|c|c|c|c|c|c|c|c|c|c|c|c|c|c|}
\hline Year. & sept. & (x)t. & Nor. & Ilece. & Jan. & Feh. & Mar. & Apr. & May. & June & July. & Aug. & Total. \\
\hline $188 r_{i}-68$. & 0.15 & $11.1: 2$ & 0.92 & 2.54 & 1.16 & 1.116 & 0.61 & T. & 2.58 & 2.74 & 10.15 & $0.1 \%$ & 12. 26 \\
\hline $1848-89$. & $.3:$ & 0 & $9.5 \pi$ & 2.94 & .60 & .10 & $2.0 \%$ & 0.43 & 2.34 & 11 & 0 & (1) & 11.37 \\
\hline $889-96) \ldots$ & 11 & 1. 45 & 293 & $\therefore 9$ & 6. (n) & 9.91 & .70 & .20 & .44 & .60 & .85 & .46 & 26.96 \\
\hline $1890-91 \ldots$ & 0 & 0 & 0 & 1.90 & .35 & 2.99 & $.6 \pi$ & .90 & 2.40 & 1.60 & .35 & 0 & 11.16 \\
\hline $1891-92$. & .5.5 & .65 & . 70 & 4. 55 & .70 & .55 & 1.40 & 1.50 & 㽞 & . 6nt & (1) & (1) & 11.50 \\
\hline 1892-93_. & i & .65 & 2.65 & $3.9 \mathrm{k}$ & 1.05 & 1.15 & .30 & 1.50 & 1.20 & $\mathrm{~T}$. & .65 & 0 & 13.91 \\
\hline $1893-94 \ldots$ & .80 & 1.60 & 4.17 & 3.33 & 3.20 & .70 & 1.50 & 0 & 3.78 & 1.12 & 0 & 0 & 20.20 \\
\hline $1894-95 \ldots$ & 0 & $1.3 \times 1$ & .70 & 2.30 & 2.40 &.$: 0$ & 2.69 & .20 & 1.20 & 1.50 & .60 & .60 & 13.69 \\
\hline $1895-96$ &.$\tilde{55}$ & 0 & .60 & 2.95 & 6.31 & ) & $2.4 \pi$ & 足. 00 & 1. 80 & 0 & 80 & $.5 \tilde{z}$ & 18.94 \\
\hline $1896-977_{-}$. & $.5 x$ & 2.02 & 6. 04 & 5.45 & .85 & 2.10 & .80 & .40 & 0 & 0 & 0 & 0 & 18.64 \\
\hline $1897-88$. & 0 & .60 & 4.48 & $3.1 \%$ & 2.95 & .10 & 0 & 0 & . .81 & 1) & 0 & 0 & 12.12 \\
\hline $1898-9$ & . $28 x$. & 1.4 .5 & 3.112 & $\pi$ & 2.17 & .63 & 3.90 & 0 & .10 & .10 & (1) & T. & 12.42 \\
\hline 1899-1 & 1) & 1.27 & 4. 66 & :.80 & 3.24 & .102 & 6.10 & $.5 \gamma$ & .46 & .55 & 0 & 0 & 19.67 \\
\hline & 0 & 3. 81 & 3.96 & 3.13 & 3. (6) & 2.13 & .10 & 0 & .13 & 0 & 0 & .10 & 16.96 \\
\hline $1901-2$ & 1.10 & .00 & 1.17 & .93 & 0 & 4.96 & .55 & 1.11 & 1.27 & .51 & T. & .60 & 12.90 \\
\hline & & & & & & & & & & & & & 15.51 \\
\hline
\end{tabular}

Record of preripitation at Montague, Siskiyou County.

[Latitude, $41^{\circ} 44^{\prime}$; longitude, 12\% 31'; elevation, $2,54 \%$ feet. Authority, Pacific Pailway System.]

\begin{tabular}{|c|c|c|c|c|c|c|c|c|c|c|c|c|c|}
\hline Year. & Sept. & Ort. & Now. & Dec. & Jan. & Feb. & Mar. & Apr. & May. & June. & etuly. & Aug. & Tota1. \\
\hline $88-89$ & 0.61 & 0.16 & 11.98 & 0.30 & 0.50 & 0.04 & 1. 78 & 0.55 & 1. 10 & 0.60 & (i & 0 & ז. 22 \\
\hline $1889-90$ & () & 3. 20 & 1.60 & 3. it & 3. 60 & 6.05 & 3.60 & .33 & .82 & 1.15 & 0 & 0.35 & 24.54 \\
\hline $1890(1-91$ & .90 & 0 & 0 & 1.40 &.$\pi$ & 2.33 & .75 & .45 & 1. 74 & 1.25 & .45 & 0 & 9.97 \\
\hline 1891-92. & .15 & $\therefore$ & .35 & 1.83 & .10 & $\mathrm{~T}$ & .75 & .40 & 1.40 & 0 & .35 & 0 & 5. 53 \\
\hline 1892-93 & 0 & 0 & 1.25 & 2.21 & .51 & 1.88 & .87 & 1.75 & 44 & 0 & 0 & 0 & 8.91 \\
\hline 1893-94 & .22 & .44 & 3.05 & 2.34 & 2. 20 & 8.13 & 2.28 & .05 & 2.50 & 1.04 & 0 & 0 & 17.27 \\
\hline $1894-95$ & 0 & 1.00 & .54 & $1 . \%$ & 2.25 & .55 & .40 & 0 & .81 & 0 & T. & 0 & 7.30 \\
\hline $1895-96 \ldots$ & .44 & 0 & .56 & $1 . \tilde{5} 8$ & 3. 40 & .40 & 1. 19 & .81 & .96 & 0 & 0 & .48 & 10.12 \\
\hline & 0 & 0 & 2.25 & 1.43 & 1.49 & 2.66 & 1. 35 & 0 & 0 & 1.11 & 0 & 0 & 10.29 \\
\hline $1897-98$ & 11 & (1) & .76 & 1.63 & .30 & 1.63 & .10 & 0 & .80 & 0 & 0 & 0 & 5.22 \\
\hline $1898-99 \ldots$ & 11 & .16 & $2.1 k$ & .20 &.$\% ?$ & . & 1.50 & .20 & .60 & .53 & 0 & .56 & $6.8 \pi$ \\
\hline $1899-1900$. & 11 & .90 & 3.15 & $\therefore .95$ & & & & & & & & & $a \% .00$ \\
\hline & & & & & & & & & & & & & 10. 29 \\
\hline
\end{tabular}

a Year incomplete. 
Recorrl of precipitation at Scott Talley, Siskiyou County.

[Latitude, $41^{\circ} 45^{\prime}$; longitude, $123^{\circ} 0 z^{\prime}$; elevation, $2.5 \% 0$ feet. Authority, Isaac Titcomb.]

\begin{tabular}{|c|c|c|c|c|c|c|c|c|c|c|c|c|c|}
\hline Year. & Sept. & Oct. & Nor. & Der: & Jan. & Feb. & Mar. & Apr. & May. & June. & July & Aug. & Total. \\
\hline $58-59$ & & & & & & & & & & & & 0.50 & $a 0.50$ \\
\hline $859-60$ & $0.8 \pi$ & $1 .(k)$ & 4.33 & 0.75 & 2.39 & 1.25 & 4. 12 & (0.75) & 2.1101 & 0.50 & 1.62 & .24 & 20.02 \\
\hline $86(1)-61$ & .49 & 2.23 & $\because(x)$ & 5. .4 & 1.12 & 8.50 & 2.50 & 3.001 & .54 & .30 & 0 & 0 & 20.41 \\
\hline $861-62$. & 0 & .51 & 11.56 & 110.63 & 9.29 & $3 . \pi 5$ & 1. 32 & 2.00 & 1.00 & . 80 & .10 & 0 & 40.96 \\
\hline $1862-63$. & . 02 & ז1. & .12 & $1.96)$ & 4.5 & 1. & 2.45 & 2.00 & .40 & $1.933^{\prime}$ & .25 & .09 & 15.81 \\
\hline $863-64 \ldots$ & .411 & .25 & 1.85 & ii. 17 & ז. & .43 & $.8 \%$ & 2.70 & .51 & .31 & 0 & .63 & 16.14 \\
\hline $1864-65$ & .04 & .31 & $(i,(x)$ & 12.55 & $1 . x \pi$ & 2.41 & 1.31 & .32 & 0.5 & . & .3 & .02 & 26.16 \\
\hline $865-66$ & 1. 1.5 & 1.33 & 9.79 & 1.21 & ti. 59 & 3.51 & 9. & 212 & 1. 1.0 & $6 \%$ & . & $4 i$ & 36.10 \\
\hline $866-6 \%$. & 0 & $.0 \mathrm{k}$ & 2.51 & $11 . \%$ & (1. 12 & 2.02 & .64 & 1.34 & .41 & . 114 & (1) & . & 28.17 \\
\hline $866-68$. & .411 & .88 & 1.\% & 9. 68 & 3.06 & 1.50 & 3.60 & 1.14 & .18 & 1. (k; & 0 & 0 & $23.3 \pi$ \\
\hline $1868-69$. & $.06 ;$ & . & $\pi$ & $2 . \times 11$ & 5. 76 & 1.13 & 1.32 & 3.61 & 1.52 & .69 & $.1: 3$ & () & 1 K..29 \\
\hline $869-70$ & $1.6 x$ & .11) & 3.04 & 3.54 & i. $(k)$ & $\therefore .11$ & 1.73 & $1.3 \%$ & 1.12 & .13 & 0 & 0 & $19 . \times 7$ \\
\hline $870-71$ & .01 & .198 & 1. (k) & 3.51 & $1 . \times 6$ & $\therefore .4 \pi$ & 1. $6 \%$ & 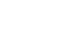 & .55 & .96 & .35 & (1) & 13.91 \\
\hline $8 \pi 1-72$. & .37 & ) & $1.6 \%$ & 7.65 & 4. 1 & 6. .94 & 1. 411 & .34 & (5) & .03 & .011 & .01 & 22.88 \\
\hline $72-73$ & .41 & .16 & 2,6 & $3.3 \%$ & 1.33 & $3 .(n)$ & 1.1 .5 & $1 . \tilde{x} 0$ & $.2 \%$ & . 183 & .013 & .05 & 13.88 \\
\hline $6+4$ & $.3 i$ & .94 & 1.11 & 4.49 & 6. 38 & 1.801 & 3.65 & 1.55 & . $\pi 1$ & .13 & .01 & . 09 & 21.83 \\
\hline & 11 & 1.25 & 4.33 & .43 & 3.13 & $1 \%$ & 1.79 & .35 & .5 & .12 & .38 & .05 & 13.05 \\
\hline & 0 & 4.45 & T.31 & 7.33 & 2.26 & 3.33 & 3. 94 &.$\pi 1$ & 1.19 & .18 & .34 & 1.50 & 32.54 \\
\hline $76-7$ & 1. 02 & 3. & .54 & .01 & 1.71 & 4. 23 & 3.10 & 1.23 & 1.48 & . 11 & .13 & .10 & 17.92 \\
\hline $77-i t$ & . (11 & .45 & $.6 \%$ & $1.6 \%$ & 9. $\%$ & 6.53 & 3.74 & $.2 \pi$ & .20 & .12 & .01 & .06 & 23.40 \\
\hline 79 & .36 & 2. $\$ 1$ & 2. 16 & 1.14 & 3.25 & 3.54 & 8.39 & 2.66 & 1.40 & $.2 i$ & .38 & .47 & 26.83 \\
\hline & .11 & .41 & 4.64 & 4.5x & $10.6 \%$ & 2.32 & 2.65 & 5. 39 & 1. 32 & $.0 \%$ & .37 & $.0 \%$ & 32.90 \\
\hline & () & $.1 \%$ & .32 & $6 . \pi 6$ & 13.95 & 6.53. & .79 & 1.19 & $.1 \tau$ & 1.04 & .54 & .144 & 31.51 \\
\hline &.$\approx 6$ & 3.53 & 2.40 & 4. 60 & 4.48 & 5. 69 & 2.22 & 2.45 & 1. 29 & . as & 2,49 & 0 & 29.99 \\
\hline $882-83$. & 1.44 & 2.86 & 2. .2 & $3 . \% 5$ & 2.58 & 1.51 & 1. 11 & 3 & 2.65 & 10 & .40 & .63 & 22.90 \\
\hline $883-84$ & .66 & 2.41 & 1.11 & 4.75 & 4.28 & 3.14 & 3.45 & 3. 16 & 1.65 & .87 & 1. 62 & .01 & $2 \pi .01$ \\
\hline $88 s-05$ & .60 & 1.04 & .16 & 8.18 & 2.50 & 3.49 & .11 & 1.98 & 1.40 & 1.40 & 1.16 & .01 & 22.03 \\
\hline $885-86$ & .83 & .53 & 111.24 & 3.26 & r.2.2 & 1.32 & 1.32 & 3.23 & $1 . \pi$ & .03 & 2.13 & .85 & 32.73 \\
\hline $886-8 \%$ & 0 & 1.85 & .88 & $6.6 \pi$ & 5. 18 & 4.96 & $1.0 \%$ & :. 63 & .94 & .36 & .37 & .18 & 24.99 \\
\hline $88{ }^{\pi}-88 \ldots$ & .36 & .09 & $1 . \%$ & 5.88 & 6.18 & $1.7 \%$ & 2.43 & .18 & 1.80 & 4. 21 & .60 & 11 & 25.36 \\
\hline $888-89 \ldots$ & .58 & .40 & 1.94 & 1.59 & 2.71 & .50 & 4.35 & 2.56 & 4. 71 & .19 & 1.11 & 0 & 201). 64 \\
\hline $1889-90 \ldots$ & 0 & 3. 95 & $3.3 \pi$ & 12.84 & 21.81 & 11.10 & & & & & & $\cdots$ & a $53.0 \%$ \\
\hline 30-year mean & & & & & & & & & & & & $\cdots$ & 24.05 \\
\hline
\end{tabular}

\section{a Year incomplete.}

Record of precipitation at Sissons, Siskiyou c'ounty.

[Latitude, $41^{\circ} 25^{\prime} ;$ longitude, $122^{\circ} 25^{\prime}$; elevation, 3,555 feet. Authority, Pacific Railway System.]

\begin{tabular}{|c|c|c|c|c|c|c|c|c|c|c|c|c|c|}
\hline Year. & Sept. & Oet. & Nov. & Dec. & Jan. & Fel, & Mar. & Apr. & May. & & July. & Aug. & Total. \\
\hline $1881-82$. & 0.99 & 2.53 & 3.34 & 8.54 & 6.35 & 2.90 & 1.74 & 1.65 & 0.60 & 0 & 0 & 0 & 28.64 \\
\hline $1882-83$ & 1.19 & 4.44 & 3.20 & 1.65 & .99 & 1.10 & 10.15 & 6.15 & 0 & $\theta$ & 0 & 0 & $28.8 \%$ \\
\hline $1888-89$ & .40 & 3. $\% 0$ & $2.1 \tau$ & 2.91 & .60 & .40 & 16.27 & .63 & 2.40 & 0.23 & 0 & 0 & 29.71 \\
\hline $1889-90 \ldots$ & 0 & 16.45 & 5.819 & 16.13 & 5. 69 & 9.33 & 5.30 & 2.98 & 2.75 & .44 & $\theta$ & 0 & 64.87 \\
\hline $1890-91 \ldots$ & 1.20 & .13 & 0 & 3.18 & .40 & 7.17 & .61 & 3.64 & 2.65 & .44 & 0.60 & 0 & 20.02 \\
\hline 1891-92. & .32 & .30 & .35 & 11.20 & 2.34 & .66 & t. 19 & 5. 38 & 3.74 & .39 & 0 & 0 & 28.87 \\
\hline 1892-93. & 1. $\% 1$ & 1.03 & $8 . \pi$ & $9.5 \%$ & 3.10 & 2.80 & $2 . \pi$ & 2.60 & 2.66 & .03 & 0 & 0 & 35.02 \\
\hline 1893-94. & .68 & .61 & 4.25 & $2.8 \pi$ & 10. .2 & 2.60 & 3.45 & .70 & 2.85 & 2.25 & 0 & 0 & 30.98 \\
\hline $1894-95$ & .99 & 3.65 & 1. 10 & 11.13 & 9.12 & 1.24 & 3.84 & $1.2 \%$ & 2.05 & 0 & .55 & 0 & 35.54 \\
\hline $1895-9$ & 4.6 .5 & 3. 80 & (10) & 4.31 & 21.09 & .21 & 4.16 & 3.55 & 3. 02 & 0 & .13 & 0.31 & 45.83 \\
\hline $1896-9 \%$. & & & & & 2.59 & 4.86 & .43 & .53 & 0 & .15 & 0 & 0 & a 8.56 \\
\hline $189 \pi-9$ & 0 & 2.31 & 2.62 & 3. $\tilde{n}_{2}$ & 0 & 10.45 & $4 . \% 0$ & $1.0 \%$ & 6.13 & 1.03 & .13 & 0 & 32.14 \\
\hline $1898-9$ & 0 & 0 & 1.70 & 2.10 & 5.55 & 1.03 & 2.98 & .23 & 1.32 & .89 & 11 & 1.32 & 1\%. 12 \\
\hline 1899-1900. & 0 & 4.01 & 10.83 & 5.67 & 8.64 & 1.04 & $9.9 \%$ & 3. 49 & 2.85 & 1.24 & 0 & .16 & 4.05 \\
\hline $1900-19011$ & .67 & 10.76 & 4.52 & 3.80 & 11.97 & 8.99 & .62 & 2.73 & .95 & 0 & 26 & .36 & 45. 63 \\
\hline $1901-2$ & 2.08 & 1.93 & 6.58 & 2.7 & 1. 83 & 21.73 & 4.14 & 5. 08 & $2.8 \%$ & $\mathrm{~T}$. & .38 & 4. 16 & 53.55 \\
\hline 15-yearn & & & & & & & & & & & & & 36.96 \\
\hline
\end{tabular}




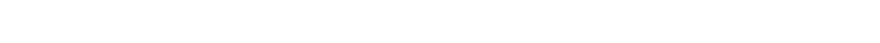

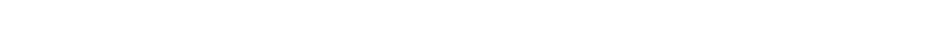

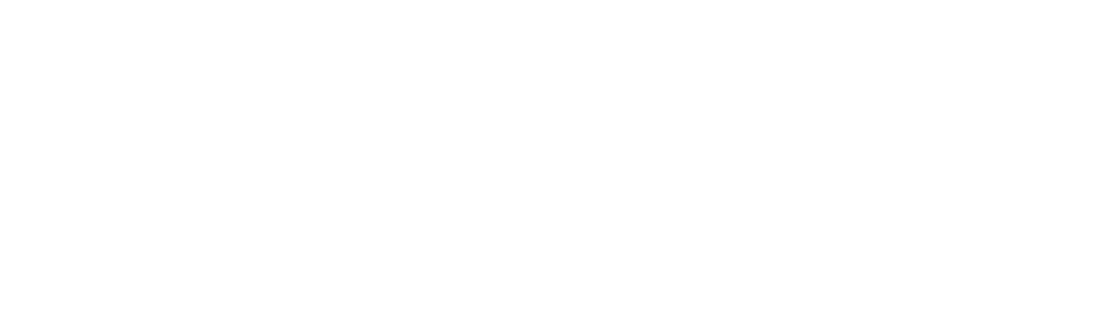

"Year inromplete.

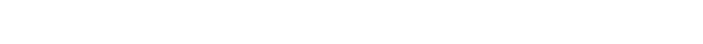

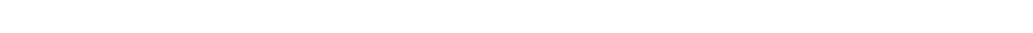

\begin{tabular}{|c|c|c|c|c|c|c|c|c|c|c|c|c|c|}
\hline $\begin{array}{l}\text { Year. } \\
-\end{array}$ & 'Sept.' & $(x \cdot t$. & Nor. & Der. & Jan. & Fek. & Mar. & Apr. & May. & & Jrly. & Aug.' & Total. \\
\hline $18.1-2.2$. & 11.333 & $1 . \approx t$ & או & $\because .61$ & 3.83 & 1.91 & 1.67 & $: .14$ & 0.44 & 6) & 11. 14 & 11 & 16.19 \\
\hline $18 \% 2-73.3$ & .85 & 1.5 .5 & $1.4: 3$ & 3.92 & 1.28 & $1.7 \%$ & .411 & .901 & .60 & () & 0 & 1) & 19.10 \\
\hline $18.3-74$ & .44 & .55 & 1.17 & :.2: & 3.58 & 1.62 & 1. 49 & .74 & .84 & 1). 44 & 11 & 0 & 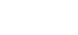 \\
\hline $187+5$ & 11 & 1.29 & 2.16 & 0 & 4.35 & .19 & $1.4 !$ & .17 & .51 & .30 & $.10 \%$ & 0 & 1).53 \\
\hline $18 \%$ & 0 & 3.34 & ธ. :9 & $6.0 \%$ & 2.00 & 1.43 & 2.16 & $.4 ;$ & .65 & .; & .83 & 1. 19 & 48 \\
\hline $1876-7$. & וח & 3.05 & .43 & .26 & $1 .: 00$ & 84 & 1. & .74 & 1.56 & . (is & . 18 & 0 & 3.69 \\
\hline $187 \%-78$ & .90 & .20 & 3.84 & . (4) & 6. 12 & 3. & 2.80 & $.3 \%$ & .56 & 0 & .75 & 0 & 1.40 \\
\hline $1878-79$ & 1.25 & .45 & 1.15 & .45 & 1. 53 & 1.41 & 3.96 & 1.56 & 1.42 & .39 & . $m$ & .15 & 2.94 \\
\hline 1879 & .25 &.$\pi$ & 2.32 & 7.23 & : 43 & .61 & 1.201 & $\therefore .23$ & .41 & .15 & 11 & 0 & $17 .(0)$ \\
\hline $1880-81$ & 0 & .13 & .10 & 2. 42 & 11.78 & 2.58 & .39 &.+8 & 0 & 1.23 & 11 & 0 & 4.91 \\
\hline $1881-8$ & .30 & 3.24 & .68 & 1.60 & 1.81 & 1.96 & .42 & 1. 20 & 1.118 & 0 & 0 & 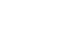 & 3.23 \\
\hline $1882-83 \ldots$ & .90 & 1.88 & 1. 89 & 2.09 & 1.38 & $.4 \%$ & .53 & 1.26 & 1.76 & 0 & .833 & . & 19.74 \\
\hline $1883-84$ & .33 & 1.35 & .66 & 2.95 & 2.10 & 1.20 & 8.34 & 1.41 & 1.40 & 1. $\pi \mathrm{s}$ & 1.33 & .51 & 17.36 \\
\hline & .33 & 0 & .79 & & 1.36 & & & 1. 12 & 3. 65 & 1. 66 & .58 & 0 & 42 \\
\hline 1885 & .49 & .29 & 9.98 & 2.10 & 4.03 & .91 &.$\pi 4$ & 1. 78 & 1. $(5)$ & 0 & 1.51 & .15 & 16.03 \\
\hline $18 \times 6-8$ & 0 & 1.69 & .30 & 4.14 & 3.21 & 3.01 & .41 & 2.35 & $1.4 \%$ & .84 & אי:2 & .31 & 1 18. 96 \\
\hline & .21 & 0 & 1.04 & 1.99 & 4.90 & & & .11 & 1.12 & 2.39 & .24 & 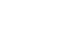 & 14.35 \\
\hline 188 & $.8 i$ & .34 & 1.13 & 0 & 1.30 & 1. & 2.12 & 1.3: & 1.70 & .10 & .94 & 0 & 11.12 \\
\hline 1889-91!. & 0 & 3.53 & 2.23 & 4.18 & 3.59 & 8.89 & 3.199 & & & & & & a:5. 41 \\
\hline $189 n$ & ...... & ....... & n...... & & & 3.59 & & .93 & 1.48 & 1.36 & .41 & () & a.8.92 \\
\hline $1891-92)$ & .82 & .43 & 2.20 & 3.92 & 1.65 & .1 & & 1. 12 & 1.20 & .87 & .31 & 0 & 3.59 \\
\hline $1892-$ & .61 & .05 & $3.3 \%$ & 3.64 & 1.20 & 2.5 & 1.53 & 2.10 & $.8 \tau$ & .32 & .58 & .08 & 16.88 \\
\hline & 1.12 & .54 & 7.83 & 2.11 & $\because .5$ & & & .10 & 3.31 & .70 &.$\pi$ & .41 & 1.02 \\
\hline $1894-95$ & .01 & 1.60 & .57 & 5.40 & 5. 30 & 1.03 & 2.26 & .81 & 1.59 & 0 & .43 & .68 & 19. 68 \\
\hline 1895 & .89 & $\mathbf{T}$ & .86 & 4.31 & 7.37 & 1.0 & 1.89 & 2.28 & 2.75 & .81 & .73 & 1.01 & 23.91 \\
\hline & .52 & .89 & 5.02 & 3.70 & $4 \%$ & 3.89 & 2.18 & .39 & .58 & 1.51 & 0 & .20 & 19.30 \\
\hline $1897-9 x$ & .12 & .68 & 2.94 & 3.76 & .83 & 1. 44 & & .48 & 2.08 & .10 & .02 & .05 & 19.92 \\
\hline $1898-4$ & .14 & .51 & 2.74 & 1.04 & 2.75 & 1.95 & $1.7 \pi$ & .21 & .02 & .61 & .03 & .12 & 19. 49 \\
\hline & .01 & $: 3.34$ & 5.00 & 3.80 & 1.35 & 2.1 & 1.1: & $4: 2$ & $.3 \%$ & 1.36 & 11 & 1.35 & 19.31 \\
\hline & .43 & 3.66 & 2.00 & 3.23 & 8.12 & 2.86 & & .41 & $.5 \%$ & 11 & .01 & .95 & $: 3.16$ \\
\hline $1901-2 \ldots$ & 1.24 & 1.28 & 1.81 & 3.119 & .39 & 6.68 & 1.53 & 1.21 & $1.1 \mathrm{~N}$ & .08 & .19 & .01 & 18.54 \\
\hline & & & & & & & & & & & & & \\
\hline
\end{tabular}

aYear incomplete. 
Record of precipitution at Hearereille. Trinity C'onnty.

[Latitude, $41^{\circ} 46^{\prime}$; longitude, 1:30.5': eleration, :.16:2 feet. A uthority, George E. Noonan.]

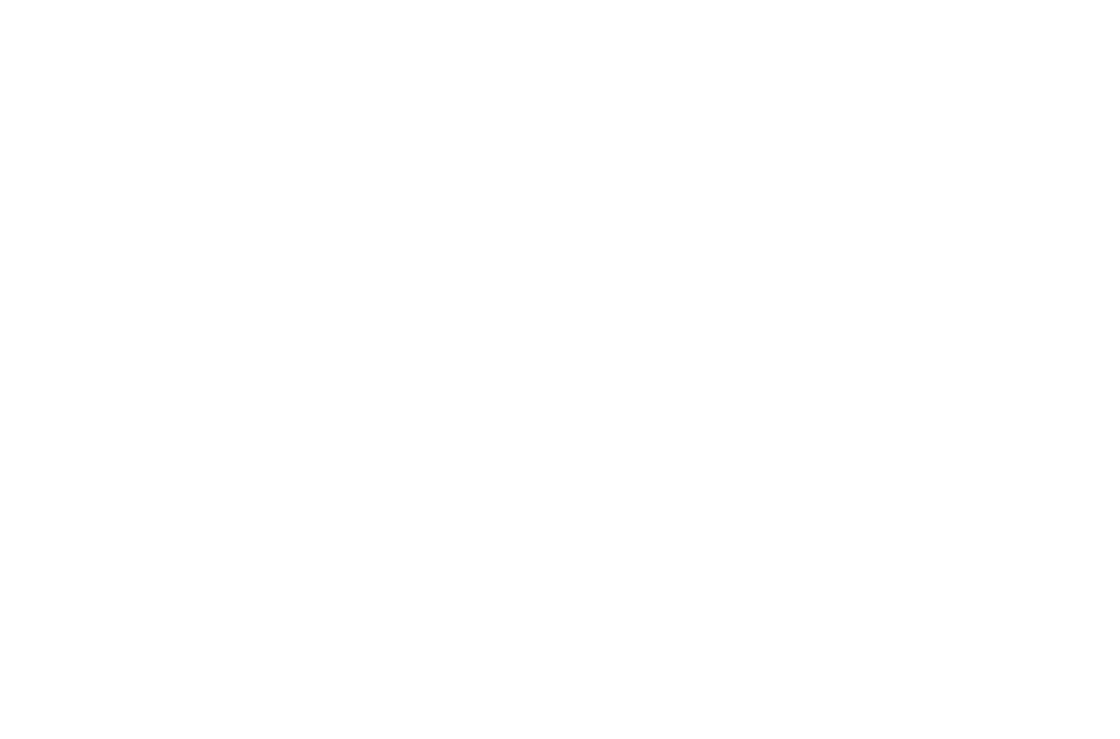

"Year incomplete.

\section{Reromel of prespipitation at Milo. Tulare ('omenty.}

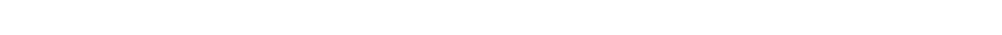

\begin{tabular}{|c|c|c|c|c|c|c|c|c|c|c|c|c|c|}
\hline Foar. & sitept. & (1).t. & Nor. & $D e c$. & Jan. & Feb. & Mar. & Apr. & May. & Tune & July. & Aug. & Total. \\
\hline 1900-1:2:1. & & & & . & 5. 74 & 4. 1 (Hi & 1.33 & 2.45 & 3.36 & (1) & 4) & 11 & a 16.94 \\
\hline 1901-2.2 & $\ldots|0 . . j|$ & 1.84 & $1.4 \pi$ & $0.2 \%$ & 1. (19) & $6.4 \pi$ & 4.233 & 1. 69 & .5t & 0 & $\mathrm{~T}$. & 0 & 18.08 \\
\hline
\end{tabular}

\section{Record of' precipitation at Momntain Home. Tulare c'omnty.}

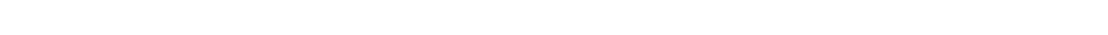
Bailey.]

\begin{tabular}{r|r|r|r|r|r|r|r|r|r|r|r|r|r|r|}
\hline Year. & Sept. Oct. & Nov. & Der. & Jan. & Fe.h. & Mar. & Apr. & May. June. July., Aug. Total. \\
\hline
\end{tabular}

a Year incomplete. 
Record of precipitation at Porterville. Tulare County.

[Latitude. 330; longitude, $119^{\circ}$; elevation, 461 feet. Authority, Southern Pacifi: Company, M. F. Murphy, agent.]

\begin{tabular}{|c|c|c|c|c|c|c|c|c|c|c|c|c|c|}
\hline Year. & Sept. & Oct. & Nov. & Der. & Jan. & Feb. & Mar. & Apr. & May. & June. & July. & Aug. & Total. \\
\hline $1892-93$. & & & 0.54 & 2.43 & $0.83^{1}$ & $1 . \times 5$ & $3.6 \mathrm{kr}$ & (1. 27 & 11 & 11 & 0 & 0 & a 9.60 \\
\hline $1893-94$ & 0 & 0 & $.0 \%$ & .61 & 1.52 & .83 & .70 & .32 & $0.4 \%$ & 1.09 & 11 & 0 & 5.56 \\
\hline $189+95$. & 0.43 & .15 & .04 & 3.13 & $3 . \$ 2$ & 1.54 & 1.10 & .41 & .35 & 0 & 0 & 0 & 10.97 \\
\hline $1895-96$ & 0 & .93 & 1.71 & .51 & 1.61 & $\mathrm{~T}$ & .67 & .82 & .13 & 0 & .69 & 0 & $6.3 \pi$ \\
\hline $1896-97 \ldots \ldots$ & 0 & .65 & .94 & .93 & 1.96 & 2.46 & $\therefore .00$ & .30 & .42 & 0 & 0 & 0 & 9.66 \\
\hline $189 \pi-9$ & 0 & 1.19 &..$\check{0} 0$ & .84 & .75 & 1.55 & .68 & 0 & .55 & $\theta$ & 0 & 0 & 6.11 \\
\hline $1898-99 \ldots$ & 2.10 & 0 & .27 & .35 & 1.01 & .77 & 2.92 & .19 & .10 & .85 & 0 & $\mathrm{~T}$. & 5.96 \\
\hline $1899-1900$ & 0 & ]. 08 & .88 & .91 & .97 & .16 & .89 & 1.94 & 2.41 & 0 & $\mathrm{~T}$ & 0 & 9.24 \\
\hline $1900-190 \mathrm{I}$. & $\mathrm{T}$. & .04 & 3.44 & $.31)$ & 2.74 & 1.78 & .30 & 2.19 & 1.97 & 0 & 0 & $\mathrm{~T}$. & 12.76 \\
\hline $19011-2$ & .41 & .45 &.$\pi 1$ & $\mathrm{~T}$ & .84 & 2.96 & 2.28 & 1.53 & .15 & 11 & $\mathrm{~T}$. & 0 & 9.33 \\
\hline$F=$ & & & & & & & & & & & & & 8.76 \\
\hline
\end{tabular}

"Year incomplete.

Record of precipitation at ('rockers (Sequoia post-office), Tuolumne County.

[Latitude, $3 \%^{\circ} 50^{\prime}$; longitude, $119^{\circ} 53^{\prime}$; elevation, 4,45\% feet. Authority, H. R. Crocker.]

\begin{tabular}{|c|c|c|c|c|c|c|c|c|c|c|c|c|c|}
\hline Year. & Sept. & oct. & Nov. & Dec. & Jan. & Feb. & Mar. & Apr. & May. & June. & July. & Aug. & Total. \\
\hline 1895-96. & & & & & & & & & & & & 3.10 & a 3.10 \\
\hline $1896-97 \ldots \ldots$ & 0.14 & 2.30 & 9.18 & 5.41 & 6.56 & $15.9 \%$ & 21.80 & 1.33 & 0 & 0.75 & 0 & 0 & 63.44 \\
\hline $189 i-98 \ldots$ & .45 & 6.09 & 2.70 & 3.80 & 2.60 & 5.15 & 3.74 & 1.10 & 3.74 & 0 & 0 & 0 & $31.3 \pi$ \\
\hline $1898-99 \ldots$ & 1.58 & 1.87 & 1.85 & 2.12 & 11.72 & 1.80 & 18.09 & 1.60 & .15 & 1.65 & 0 & 0 & 42.43 \\
\hline $1899-1900 \ldots$ & 0 & 11.50 & 7.45 & 12.18 & 5.98 & 1.18 & b 4.28 & 3.56 & 1. 80 & .47 & 0 & 0 & 48.40 \\
\hline $1900-1901 \ldots$ & .62 & 9.71 & 17.43 & 1.39 & 16.99 & 15.71 & 3.013 & 6.35 & $3 . \times 1$ & 0 & 0 & 0 & 75. 04 \\
\hline $1901-2 \ldots \ldots$ & 3.28 & 4.59 & 3.90 & 2.50 & 2.33 & 15.013 & $8 . \div 5$ & 6.54 & 1. 80 & 0 & 0 & .11 & 48.63 \\
\hline -year mean & & & & & & & & & & & & & 51.55 \\
\hline
\end{tabular}

a Year incomplete.

b March, 1900, violent hailstorm.

Record of precipitation at Dering Creek (3) miles east of Sonora), Tuolumne County.

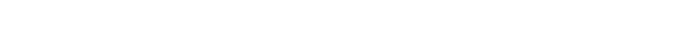

\begin{tabular}{c|c|c|c|c|c|c|c|c|c|c|c|c|c|c|}
\hline Year. & Sept. & Oct. & Nov. & Dec. & Jan. & Feb. & Mar. & Apr. May. June. July. Aug. Total. \\
\hline $1898-99$ & & 1.85 & 2.88 & 2.78 & 9.95 & 2.7 & 17.08 & 0.12 & & & & & T. \\
\hline
\end{tabular}

¿ Year incomplete. 
Kecord of precipitation at Second Garotte, Tuolumne County.

[Iatitude, $37^{\circ} 33^{\prime}$ N.; longitude, 1:310 $24^{\prime}$; elevation, 2,714 feet. Authority, J. P. Chamberlain.]

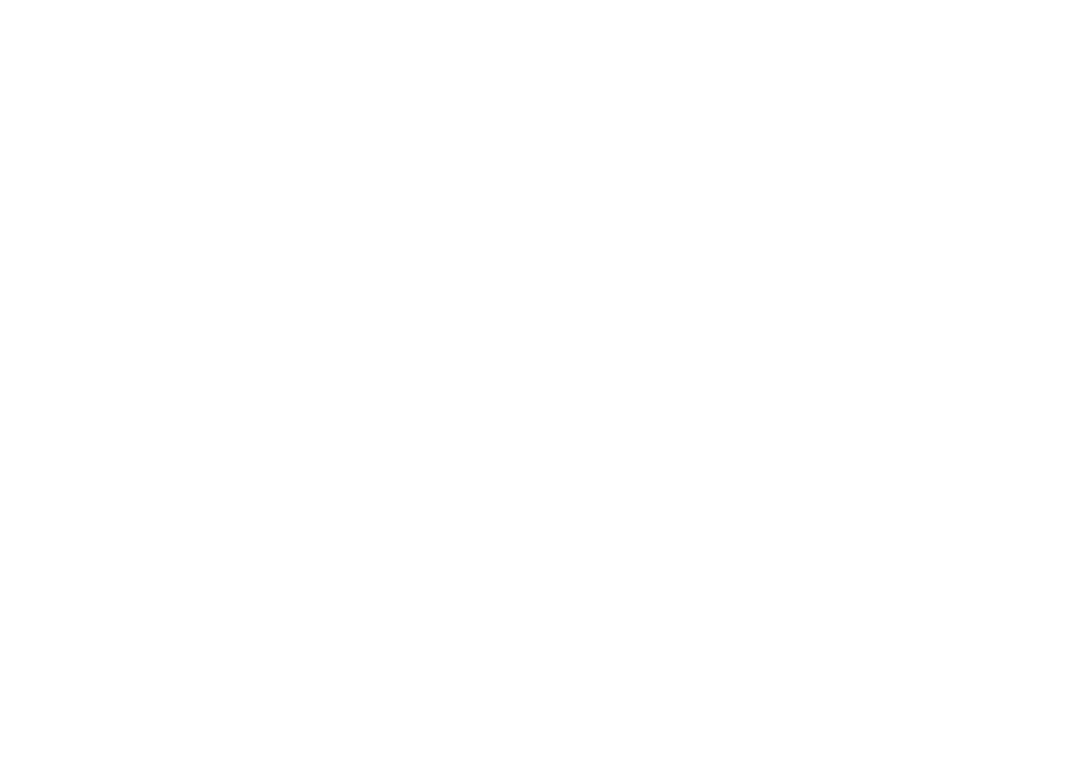

"Year incomplete.

\section{Record of precipitation at Sonora, Tuolnemne C'ounty.}

[Latitude, $37^{\circ} 5 \mathrm{x}^{\prime}$; longitude, 1:20:2, elevation, 1,9n feet. Authority, John Shaw.]

\begin{tabular}{|c|c|c|c|c|c|c|c|c|c|c|c|c|c|}
\hline Year. & Sept. & Oct. & Nor. & Der. & Jan. & Feb. & Mar. & Apr. & May. & 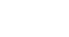 & July & Aug. & Total. \\
\hline $1887-88$. & 0. (it & 0 & 0.70 & 5. 76 & 7.99 & 1.32 & 3.91 & 0.25 & 1.02 & 0.23 & 11 & 11 & 21.75 \\
\hline $1888-89 \ldots \ldots$ & |.54 & 0 & 4.45 & 5.04 & $.8 x$ & 1.25 & $\pi .22$ & .96 & 4.77 & .615 & 11 & 0 & 25.66 \\
\hline $1889-90 \ldots$ & 0 & 6.83 & 7.04 & 18.25 & 13.59 & $9.2 \pi$ & $i+4)$ & 2.66 & 2.35 & 0 & 11 & 0 & 67.39 \\
\hline $1890-91$ & 1.69 & .09 & .10 & 10.23 & 1. 74 & 9.601 & 3.79 & $3 . \%$ & .60 & .68 & 0 & 0 & 32.29 \\
\hline $1891-92 \ldots$ & .36 & $.3 \pi$ & $.0 \mathrm{~s}$ & 9.10 & 1. 69 & 4. .9 & 6. 41 & 2.93 & 5. 18 & .09 & 0 & 0 & 30.40 \\
\hline $1892-9$ & .38 & 1.88 & 10.20 & 6. 52 & 4.88 & 5.93 & 11.11 & 2.51 & .27 & 0 & 0 & $\mathrm{~T}$ & 3. 76 \\
\hline $1893-94 \ldots$ & .53 & .35 & 3.39 & $3 . \times \tilde{~}$ & ห. 76 & 11.46 & 2.39 & 1.32 & 3.96 & 1.48 & $\mathrm{~T}$. & 0.012 & $3 \pi .53$ \\
\hline $1894-95$ & 1. 21 & 4. it & 0 & 14.53 & 11.19 & 4. 62 & 4.01 & 3.25 & 2.40 & 0 & 0 & 0 & 45.95 \\
\hline 1895-96 . - & .61 & .21 & .75 & 2.51 & 10.80 & .49 & 5.00 & 8.65 & 1.14 & 0 & 0.40 & .61 & 31.17 \\
\hline $1896-97 \ldots$ & הימה & 2.85 & 6.74 & 3.47 & 3.31 & 11.89 & 8.37 & .29 & .25 & .31 & 0 & 0 & 38.23 \\
\hline $1897-98$ & .10 & 3.35 & 2.15 & 2.53 & 1. 71 & 5. 79 & 1.96 & .60 & 2.70 & .15 & 0 & 0 & 21.04 \\
\hline $1898-99$. & $.8 i$ & .84 & 1.51 & 2.64 & 6.99 & .42 & 14.03 & 1.08 & 2.18 & 2.17 & 0 & .08 & 32.81 \\
\hline $1899-1900$ & 0 & 6.91 & 7.02 & 5. 38 & 3.20 & $1.3 \pi$ & $2 . \pi 5$ & 4.28 & 2.01 & .20 & 0 & .03 & 33.14 \\
\hline $1900-1901$ & .14 & 5.10 & 10.29 & 2.05 & 9.04 & 12.89 & 1. 23 & 4.73 & 1.18 & .07 & 0 & .04 & 46. 79 \\
\hline $1901-2 \ldots$ & 2.42 & 1.81 & 3.15 & 2.40 & 1.35 & \%.86 & 5.53 & 2.45 & 1.44 & 0 & 0 & .01 & 28.42 \\
\hline & & & & & & & & & & & & & 35.76 \\
\hline
\end{tabular}


Record of precipitation at Frezier mine, Ventura c'onnty.

[Latitude, $34^{\circ} 45^{\prime} ;$ longitude, $118^{\circ}$ (o' ; elevation. K.(x) feet. Authority. Harry C. Porter.]

\begin{tabular}{|c|c|c|c|c|c|c|c|c|c|c|c|c|c|}
\hline Year. & Sept. & Oct. & Nor. & Dec. & Jan. & $F(-b)$. & Mar. & Apr. & - May & June. & July. & Aug. & Total. \\
\hline 1894-95. & & & & & & & & $\ldots . . .$. & 0.40 & 0 & 0 & 0 & $a 0.40$ \\
\hline $1895-96$ & 0 & 0.30 & 0.90 & 0.68 & 2.94 & 0 & 3.12 & 2.2 & 1.03 & 0 & 0.15 & 3.73 & 15.07 \\
\hline $1896-9 \pi$. & 0 & $1.4 \%$ & 13 & 4.07 & $7.3 \%$ & 6.33 & 4.05 & .16 & .28 & 0 & .02 & .48 & 24.96 \\
\hline $1897-98 \ldots \ldots$ & 0.33 & 1.00 & $\mathrm{~T}$ & 1.35 & & & & & & 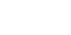 & .... & ...... & a 2.68 \\
\hline $1898-99$ & & & $\ldots$ & & & & & & & 0.60 & $\cdot 0$ & . & a. 60 \\
\hline & & & & & & & & & & & & & $: 0.02$ \\
\hline
\end{tabular}

a Year incomplete.

\section{Record of precipitation at Mutah Flat, Ventura County.}

[Latitude, $34^{\circ} 38^{\prime}$; longitude, $119^{\circ}\left(13^{\prime}\right.$; eleration, 4,450 feet. Authority, Burt Snedden Griffen.]

\begin{tabular}{|c|c|c|c|c|c|c|c|c|c|c|c|c|c|}
\hline Year. & Sept. & Oet. & Nov. & Dec. & Jan. & Feb. & Mar. & Apr. & May. & June. & July. & Aug. & . Total. \\
\hline $1893-94 \ldots$ & (1). $2: 2$ & 1.70 & 0 & 4.10 & 0.54 & 1.41 & 1). 30 & 0. 13 & 0.79 & () & 11 & (1) & 9.19 \\
\hline $189 t-95 \ldots$ & 0 & .85 & 0 & 7.33 & 9.80 & $.7 K$ & 2.95 & 0 & 0 & 0 & 0 & 0 & $21 . \% 1$ \\
\hline $1895-96 \ldots$ & 0 & 65 & 1.601 & 1.10 & 4.58 & 0 & 4. 79 & 3.50 & .52 & 0 & 030 & 0 & 17.04 \\
\hline $1896-9 \pi \ldots$. & 0 & 1. 65 & 1.50 & 2.80 & 9. 10 & B. & 3.54 & 0 & 11 & 0 & .30 & ( & 22. 54 \\
\hline $1897-98 \ldots . . .$. & 0 & 1.75 & 11 & .15 & .60 & $1 .(0)$ & .90 & 0 & . & (1. 411 & 0 & (1) & 5. 30) \\
\hline $1898-99 \ldots$ & 1.80 & 0 & 0 & .30 & 2.25 & 0 & 2.01 & $.51)$ & (t) & 0 & 0 & (1) & 7.35 \\
\hline 1899-1900. & 0 & $2 .(0)$ & 1.30 & 2.25 & 2.80 & 0 & 1.95 & .40 & 1.80 & 0 & 0 & u & 12.50 \\
\hline $1900-19 \times 11$. & 0 & 0 & 5.10 & 0 & 7.00 & 4.60 & .25 & 1.30 & .58 & 0 & 0 & 0 & 18.63 \\
\hline $1901-2 . \ldots . .$. & 0 & 2.85 & .65 & 0 & .75 & $3 .: 23$ & 2.80 & 1.41 & 0 & 0 & 0 & 0 & 11.69 \\
\hline & & & & & & & & & & & & & 13.99 \\
\hline
\end{tabular}

Record of precipitation at Nordloff, Venture ('ounty.

[Latitude, 34० $27^{\prime} ;$ l longitude, $119^{\circ} 06^{\prime}$; elevation, 1,200 feet. Authority, R. Robinson, J. W. Wolf, and $\mathrm{H}$. Lathrop.]

\begin{tabular}{|c|c|c|c|c|c|c|c|c|c|c|c|c|c|}
\hline Year. & Sept. & Oct. & Nor. & Der. & Jan. & Feb. & Mar. & Apr. & May. & June. & July. & Aug. & Total. \\
\hline $1886-87 \ldots$ & 0 & 0.36 & 1.10 & 0.78 & 0.92 & 16.81 & 0.44 & 1.88 & 0.18 & & 1 & & - 121.77 \\
\hline $188 i-88$. & ...... & ..... & 1.63 & 5. 29 & 7.46 & 1.28 & 5.47 & .54 & .26 & & & & " 21.93 \\
\hline $1888-89 \ldots$ & $\ldots$ & 0 & 5.96 & 7.22 & 0 & & & & & & & & a 13.18 \\
\hline $1890-91 \ldots$ & & $\ldots$ & $\ldots$ & $\ldots$ & ..... & . n & -..... & $\ldots$ & & & 0 & 0 & $a 0$ \\
\hline $91-92 \ldots \ldots$ & 0.25 & 0 & $\mathrm{~T}$ & 8.58 & .67 & 2.75 & 3.68 & $.4 \%$ & 1.39 & 0 & 0 & 0 & 11. 79 \\
\hline $1892-93 \ldots \ldots$ & 0 & 1.08 & 1.35 & 8.75 & 5. 80 & 3.64 & 7.75 & .45 & $\mathrm{~T}$ & 0 & 0 & 0 & $28.8 \%$ \\
\hline 1893-94 . & 0 & .61 & $\mathrm{~T}$ & 3.45 & .68 & .74 & .29 & .19 & $.9 \pi$ & 0 & 003 & 0 & 6.96 \\
\hline $1894-95 \ldots \ldots$ & .03 & .45 & 0 & 6.39 & 8.61 & .46 & 3.66 & .39 & 0 & 0 & 0 & 0 & 19.99 \\
\hline $1895-96 \ldots \ldots$ & 0 & .10 & 1.199 & 0 & 5. 78 & 0 & 3.42 & 1. $\% 2$ & 0 & 0 & .22 & $\mathrm{~T}$. & 12.33 \\
\hline $189697 \ldots \ldots$ & 11 & 1.38 & 1.03 & 3.00 & 4.11 & 7.16 & 2.91 & 0 & 0 & 0 & 0 & 0 & 19. 59 \\
\hline $189 \pi-98 \ldots$ & & $\cdots$ & & & & & .43 & 0 & & 0 & 0 & 0 & a.43 \\
\hline $1898-99 \ldots$ & 11 & .13 & & & 3.98 & & 2.71 & .27 & 0 & 0 & & 0 & a 7.09 \\
\hline 1899 & & & & & & & & & & & & & 17.13 \\
\hline $1900-1$ & & ....... & & & & & & & & & & & 36.37 \\
\hline $1901-2 \ldots$ & .25 & 4.36 & 1.25 & 0 & $1.3 \%$ & 5.50 & 4.13 & 2.50 & 0 & 0 & 11 & 0 & 19.38 \\
\hline 70 & & & & & & & & & & & & & 19.15 \\
\hline
\end{tabular}

“ Year incomplete. 
Recorl of precipitation at Smith's ranch, Ventura County.

[Latitude, $34^{\circ} 44^{\prime}$; longitude, $118^{\circ} 4 \tilde{\prime}^{\prime}$; elevation, 4.000 feet. Authority, William :'mith, Gorman Station.]

\begin{tabular}{|c|c|c|c|c|c|c|c|c|c|c|c|c|c|}
\hline Year. & Sept. & Oet. & Nov. & Dec. & Jan. & Feb. & Mar. & Apr. & May. & June. & July. & Aug. & Total. \\
\hline 1898-99_ _ _. & $-\ldots$. & $\ldots$ & $\ldots$ & ...... & 0.82 & 1.10 & 1.45 & 0 & 0 & 0 & 0 & t) & 03.27 \\
\hline $1899-190 \mathrm{~K}) \ldots$ & 0 & 0.95 & 0.65 & 0.35 & 1.2n & 0) & 1.12 & 0.12 & 0.75 & 0 & (1) & 0 & 5.14 \\
\hline $1900-1901 \ldots$ & 0.15 & (1 & 3.10 & 0 & 2.35 & 2.25 & .10 & .32 & .45 & 0 & () & 0.95 & 9.67 \\
\hline $1901 \div \ldots$ & .10 & 25 & .20 & (1) & 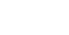 & & . & $\ldots$ & N & $\ldots$ & - & $\mid \cdots \ldots$ & $a .55$ \\
\hline 2-year mean. & & & & & & & & & & & & & 7.41 \\
\hline
\end{tabular}

\section{Record of precipitation at Snedden's ranch. Ventura Combly.}

[Latiturk, 34" $41^{\prime}$ : longitude, $119^{\circ} 113^{\prime}$; elevation, 4,90) feet. Authority, Burt Snedden (triffin.]

\begin{tabular}{|c|c|c|c|c|c|c|c|c|c|c|c|c|c|}
\hline Year. & Sept. & Oet. & Nov. & Der. & Jan. & Fet, & Mar. & Apr. & May. & June. & Jul:-. & Aug. & Total. \\
\hline $1892-93$ & & & & & & ....... & - n..... & & & & 0.14 & 0.02 & $a 0.16$ \\
\hline $189394 \ldots \ldots$ & 0.08 & 0.72 & 0 & 4.45 & 1.31 & 0.65 & 0.45 & 0.16 & 0.75 & 0 & 0 & 1.15 & 9.67 \\
\hline $1894-95$ & .75 & 0 & 0 & 6.99 & 6.31 & .49 & 1.50 & .11 & 0 & 0 & 1) & 0 & 16.15 \\
\hline $1895-96 \ldots$ & 0 & .16 & 0.91 & .55 & 3.47 & 0 & 5.02 & 3. 79 & $.5 \%$ & 0 & .25 & $\mathbf{T}$ & 14. \\
\hline $1896-9 i^{2} \ldots \ldots$ & .33 & 1.10 & 1.35 & 2.40 & 8.30 & 2.92 & 2.71 & .02 & 0 & 0 & .25 & .20 & 19.58 \\
\hline $1897-98 \ldots$ & .14 & .80 & 0 & .05 & .60 & .41 & .65 & $\theta$ & .54 & 0.35 & 0 & 0 & 3.44 \\
\hline $1898-99 . \ldots$ & 1.75 & 0 & 0 & .30 & 2. 65 & 0 & 1.50 & .50 & 0 & 0 & 0 & 0 & 6.70 \\
\hline $1899-19(x) \ldots$ & 0 & $1.50)$ & $.4 \pi$ & $.2 \pi$ & 1. 40 & $\mathbf{T}$. & 1.45 & .50 & 1. 40 & 11 & 11 & 0 & 6.99 \\
\hline $1900-1901$ & 11 & 11 & $4.5^{\circ}$ & 0 & 3.70 & 3.80 & .10 & 1.10 & $.4 \pi$ & 0 & 1) & 0 & 13.69 \\
\hline $1901-2 \ldots \ldots$ & 0 & 1.75 & 1. 75 & 0 & .56 & 2.95 & 1.85 & .50 & 0 & () & $1)$ & $(1$ & 9.36 \\
\hline & & & & & & & & & & & & & 11.14 \\
\hline
\end{tabular}

"Year incomplete.

\section{Record of precipitation at Uluper Lake, Fentura County.}

[Latitude, $34^{\circ} 41^{\prime}$; longitude, $119^{\circ} 133^{\prime}$; elevation, 4,90 feet. Authority, U. S. Weather Bureau.]

\begin{tabular}{|c|c|c|c|c|c|c|c|c|c|c|c|c|c|}
\hline Year. & sept. & Oct. & Nor. & Der. & Jan. & Fel, & Mar. & Apr. & Мау. & June. & Jul:" & Aug. & Total. \\
\hline (1) & & & & & & & & & & & & 0 & 10 \\
\hline $1891-9$ & 0.95 & 0.62 & 0.71 & 7.35 & 3.93 & 2.50 & $3.1 \mathrm{~s}$ & 2.84 & 3. 71 & 0.49 & 0 & (1) & 24.28 \\
\hline & $\mathrm{T}$. & 1.17 & .50 & 5.30 & $4.0 \mathrm{x}$ & 5. 19 & 5.47 & $2.3 i$ & 1.04 & 1) & $\mathrm{T}$. & 0 & 12 \\
\hline $93-$ & .85 & .47 & 4.83 & 2.82 & 10.43 & 6. 21 & 1.80 & 1.46 & 1.02 & 1.12 & 0 & $\mathrm{~T}$. & .01 \\
\hline $1 \times 94-$ & 53 & 2.05 & 1.13 & 11.62 & 14.92 & 4.15 & 3.20 & 1.41 & 1. 39 & 0 & 0.05 & $\mathbf{T}$ & 40.45 \\
\hline $1895-$ & .46 & $\mathrm{~T}$ & 3.50 & 5.30 & 11.18 & .80 & 2.39 & 6. 01 & 2.07 & 0 & $\mathbf{T}$ & $0.8 \%$ & 32.58 \\
\hline $1 \times 96$ & $4: 2$ & 1.04 & s. $6 \sigma^{\sigma}$ & 6.47 & 3.45 & 6. 35 & 4.58 & .42 & .29 & .97 & .05 & 0 & 9.114 \\
\hline 18 & .08 & 1.56 & 2.38 & 2.61 & .93 & $4.5 \%$ & .36 & .43 & 1.90 & .58 & 0 & $\mathrm{~T}$. & .51 \\
\hline $189 \times-99$ & .60 & 1.01 & 1.66 & 1.34 & ๙. 16 & .25 & 5. 59 & $.90)$ & 1.100 & .05 & 0 & .113 & 2). 59 \\
\hline $1899-1$ & 0 & 3.49 & 6.33 & 9.79 & 3.98 & 1.31 & 3.53 & 2.13 & .81 & .35 & $\mathrm{~T}$. & 0 & 31.72 \\
\hline 1900 & .03 & 3.96 & 5.08 & 3.63 & 6.44 & 4.75 & 1. In & 2.43 & .70 & 11 & T. & $\mathrm{T}$. & $2 \pi .08$ \\
\hline $1901-2 \ldots .$. & 1.11 & 1.199 & 4.35 & 2.09 & 1.35 & $12 . \times 2$ & 3.87 & $\because 3.5$ & 1. 60 & 0 & 0 & .07 & 31.20 \\
\hline & & & & & & & & & & & & & 28.60 \\
\hline
\end{tabular}

$a$ Year inconrplete. 


\section{Record of precipitation at Tentura, Ventura c'ounty.}

[Latitude, $34^{\circ} 20^{\prime}$; longitude, $119^{\circ} 20^{\prime}$; elevation, 50 feet. Authority, Mr. Suxby.]

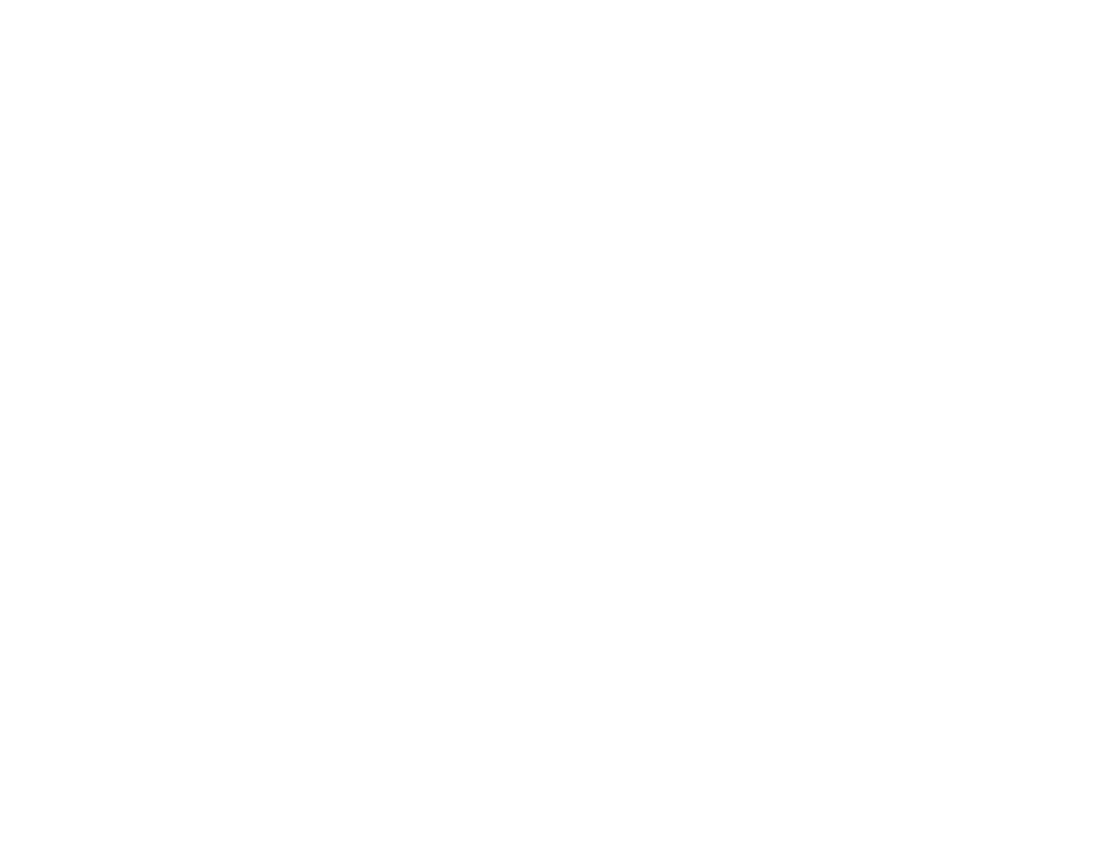

Rerord of precipitation at Rumsey, Folo C'ounty.

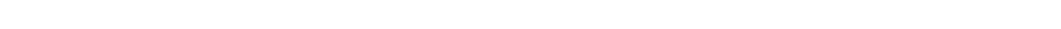

\begin{tabular}{|c|c|c|c|c|c|c|c|c|c|c|c|c|c|}
\hline Year. & Sept. & Oct. & Nox. & Der. & Jan. & Feh. & Mar. & Apr. & May. & June. & Ju. $1 y$. & Ang. & Total. \\
\hline $1888-89$ & 11.80 & n) & 6.55 & 5.15 & (1).95 & 1.35 & 8.20 & 1. 40 & 2. 45 & 0.15 & (1) & 11 & $2 \pi .(x)$ \\
\hline $1889-90 \ldots$ & 0 & $7.9)$ & 4.13 & 12.07 & 12.01 & 4.52 & 5.32 & 1.17 & 1.29 & 0 & 0 & 0 & 48.41 \\
\hline $189(0.91$. & .35 & 0 & 0 & 3.91 & .87 & 13.60 & 1.16 & 1.92 & 1.28 & 0 & 0 & 0 & 23.19 \\
\hline $1891-92$. & .85 & 0 & .25 & 4.98 & 3.49 & 2.81 & 3.02 & 1. 21 & 2.78 & 0 & 0 & 0 & 19.52 \\
\hline $1892-93$ & 0 & 1.183 & $10.5 \%$ & 11.37 & 4.80 & 5. 42 & $5.7 \%$ & 1.66 & .75 & 0) & 0 & 0 & 41. 49 \\
\hline 5-year'm & & & & & & & & & & & & & 31.90 \\
\hline
\end{tabular}

\section{Record of precipitation at Colyate, Fuba c'ounty.}

[Latitude, 39० 22'; longitude, $121^{\circ} 10^{\prime}$; elevation, 6on feet." Authrrity, Bay Connties Power Company.]

\begin{tabular}{|c|c|c|c|c|c|c|c|c|c|c|c|c|c|}
\hline Year. & Sept. & Oct. & Nov. & Der: & Jan. & Fel. & Mar. & Apr. & May. & June. & July. & Aug. & Total. \\
\hline - & 0 & 6.79 & 7.45 & 0 & 6.98 & อ.. $0 \%$ & 2.11 & 0 & 0.08 & 0 & 0 & 0 & 28.48 \\
\hline $1901-2$ & 1.48 & 3.61 & 4.39 & 5.31 & 1.44 & $18.2 \%$ & 4. $: 3$ & 4.10 & .80 & 0 & 0 & 0 & 43.58 \\
\hline & & & & & & & & & & & & & 36.03 \\
\hline
\end{tabular}

"Gage at botton of canyom 1,00) feet deep. 


\section{N J) E X .}

Page.

Abbotts Ferry, stream measurements at.... 339 Agricultural ditch, measurements of...... 244 Aguilar Creek, measurements of ........ 32, 321 Alameda Creek, measurements of. . . . . ... 32-39 Alder Creek, measurements of .......... 281,364 Alhambra Water Company, stream measurements at weirs of .......... 245

Aliso Creek, measurements of........... 40 Alsetrez ditch, measurements of ..... 22:1,299, 320 Alta, rainfall at ..................... 448 Alturas, rainfall at ..................... 440 Amador ditch, measurements of ........ 168-169 American River, measurements of ....... 40-42 American Valley, stream measurements at. $\quad 86$ Anaheim, stream measurements at ....... 320 Anaheim canal, measurements of ........ 310 Anaheim Union canal, measurements of... 309 Angel's ditch, measurements of........... $\quad 339$ Ant Creek, measurements of ............ 100 Antelope Valley, stream measurements i1. $\quad 402$ Armas Creek, measurements of........... 42,321 Armitas Creek, measurements of .......... 42 Arroso Burro, measurements of ......... 43,321 Arroyo Carnero, measurements of........ 43.321 Arroyo diteh, measurements of............ 244 Arroyo Grande, measurements at and near .................... 43,123

measurements of ................... 43

Arroyo Leon, measurements of .......... 43

Arroyo Seco, measurements of ..... 11-46, 2012-204

Arroyo Seco (Salinas River), flood measurements of

Artesian Belt Company, wells of, mean ments of................... 2ti

Auburu, rainfall at .................. $35 \bar{n}, 449$

stream measurements near............ 42, 46

Auburndale, stream measurements at and near.................. 309. 311,320

Azusa, flood measurements at........... 411 rainfall at ...................... 434 stream measurements at and near..... 226$230,231,248-258$

Azusa canal, measurements of .......... 228 Azusa city well, measurements of......... $\quad 246$ Baby Ruth weir, stream measurements at . $\quad 212$ Bakersfield, flood measurements near..... 411 Bald Mountain, stream measurements south of

Balls Ferry, stream measurements at ..... Banning, rainfall at................... Banta ditch, measurements of ........... Bards station, stream measurements at .... Barstow, rainfall at Bartlett springs, rainfall at .............
Basin Creek, measurements of ........... 100

Battle Creek, measurements of............ 199 Bay Counties Electric Company's flume, measurements of ........... 409

Beams ditch, measurements of ......... 215, 319 Bear Creek, measurements of .... 110, 242, 283-284 Bear River, measurements of . ........... 46,49 Bear Valley dam, rainfall at . ........... 459 Bear Valley ditch, measurements of ...... 406 Bear Valley headworks, measurements of Palm spring and ............ 407

rainfall at ..................... 355,428

Bear Valley trail, stream measurernents at foot of ..................... 406

Beardsley Water Company, streain measurements at station of ............ 245

Bearskin Meadow, stream measurements near ..................... 110

Beaumont, rainfall at ................. 45

Bellota, stream measurements at . . . . . . . . . 51-56

Benton Mills, stream measurements at .... 154

Bicknel, stream measurements at ........ $\quad 322$

Bieknell station, stream measurements at. $\quad 319$ Bidwell Bar bridge.stream measurementsat 81 Big Bend Tumnel. stram measurementsat. $\quad 86$ Big Canyon Creek, measurements of...... 41 Big Creek, measurements of .............. $\quad 261$ Big Meadows, stream measurements at .... $\quad 86$ Big Rock Creek, measurements of ........ $\quad 50$ Big Spring Branch, measurements of...... 86 Big Tree Creek, measurements below mouth of ....................... $\quad 339$

Big Walker River, measurements of ...... 402 Bijou, Nev., measurements of ter small streams hetween Glen Brook and ........................... 368

Bishop Creek, rainfall at................ $\quad 426$

Bishop road, stream measurements near... 173

Blaek, Mrs., weir of, stream measurements at .......................... 246

Blucklurus Junction, stream measurements at .......................... 402

Blackwod Creek, measurements of ..... 367 Blaney Meadows, stream mealsurementsat. 261 Bloody Canyon, stream measurements at.. 173 Bloomington flume, measurements of.... 215,319 Blue Canyon Creek, measurements of ..... 160 Boca, measurements at.................. 366 ruinfall at ..................... 443 Boulder Creek, measurements of ......... 110 Buwman dam, flood measurements of Yuba River at ................. $\mathbf{4 1 0}$ rainfall it ........................ 444 Bradbury ranch, stream measurements at.. $\quad 244$ 
Page.

Brannan slough, measurements of ........ 1s

Bridal Veil Creek, measurements of....... 154

Bridgeport, stream measurements at and near .................... 401,409

Bridgeport Valley, stream measurementsin.

Briscoe Creek, measurements of...........

Brown ditch, meastrement of...........

Brundege place, stream muasurements at..

Bruns Creek, measurements of ...........

Brush Creek, measurements of ........... Bryson, stream measurements at and near.

Bubbs Creek, measurements of.............

Buckeye Creek, measurements of ..........

Buckeyc Springs, stream measurements at .

Bull Run Creek, measurements of..........

Bulls Hearl Canyon, measurements at ....

Burnett Creek, measurements of ...........

Burney Creek, metsurements of ..........

Burney Falls, stream measurements below.

Burts Ferry, stream ineasurements at.....

Butano Creek, measurements of ...........

Butte ditch, measurements of............

Butte Valley, stream measurements at....

Butte Valley Crock, meaurements of.....

Caehe Creek, neasurements of ........... 51-53

Cajon ('reek, measurements of ............ 53

Cajon (reek Canyon, stream measurements

in........................... 318

Calabasas, rainfall at................... 434

Calaveras River, measurements of . ....... 53-56

Caliente, rainfall at .................. 428

Caliente Creck, measuruments of ........ . 56-59

California state enginecring department, acknowledgments to......... 12

Calloway canal, measurements of ....... 99-100

Cameron or Sheep Creek ditch, measurements of ................... 244

Camp Carlton diteh, measurements of ... 215,319

Camp Independenee, rainfall at ......... 427

Camp Mohave, stream measurements at... 69

Camp Tabeand, stream measurements at.. 168

Camp Wright, rainfall at............... 439

Campers station, stream measurements at.. 243

Campo, rainfull at .................... 163

Camulos, stream measurements 2 miles east of .......................

Camulos ditch, measurements of...........

Canyada del Corral Creek, measurements

of ..................... 60,321

Canyada Lares Creek, measurements of ... 60

Canyada Llaces Creek, measurements of... 321 Canyarla Refugio (reek, measurements of. 60,321 Canyada Verde Creek, measurements of. . 60,321 Capitan (El) Creek, measurements of ...... 60 Carbon Bridge, stream measurements at... 182 Carpenteria Creek, measurements of..... 61,321 Carson River, measurements of ........... 61-64 Carson River Basin, measurements in .... 64 Cascade creek, measurements of ........ 336, 368 Castill w ditch, measurements of ........... 309 Castle Crugs, stream measurements at.... 199 Cate diteh, measuruments of............. 24t Cattle Canyon, meisurements of........... 243 Chapman ranch, stream measurements at . 244 Chapman well, stream measurements of... 246 Chatsworth, stream measurements at.....
Cherokee, rainfall at.

Page.

Cherokee Pipe erossing, stream measurements at....................

('herokee reservoir, rainfall at ............ 421

cherry Creek, Colo., flood measurements of ......................... 410

('herry River, measurements of ......... 382-383

(hillie Bar, stream measuremen ts at...... 41

Chino Creek, measurements of...... . 30y-310,320

Chiquita San Joaquin River, measurements of ........................ 268

Chow chilla Creek, measuremerts of...... 65-67

Christmas Prairie, rainfall at........... $\quad 426$

Church diteh (Fresno Canal), measurements of.................... 110

Cisco, rainfall at ................... 355, 450

Citizens' Water Company's well, Covina, measurements of . . ........... 246

('ity Creek, measurements of........... 68,318

Claremont, strum measuremerts in...... 317

Clark Creek, measurements of............ 100

Clarks Fork, measurements of........... $\quad 339$

Clear Creek, measurements of . . . . . . ..... 101

Clear Lake, evaporation at.............. 31-32

Clements, stream measurements at ....... 169

Clinton, stream measurements at ......... 364

Colby's camp, rainfall at............... $43 \pm$

Cold Creek, measurements of .......... 363,366 Cold Spring Canyon, measurements of.... 68

Cold Stream Creek, measurementw of ..... 321

Coldwater Creek, measurements of . . 69, 236-241

Coles, rainfall at........................ 469

colfax, rainfall at................... 355,451 stream measurements near........... 42

Colgate, rainfall at.................. 478

Colliers, stream measnrements near ...... $\quad 339$

Collinsville, stream measurements at ... 18x-190

Colony dam, stream measurements near... 343

colorado River, measurements of........ 69- 61

Colton, measurements in canals above... 221-225 stream measurements in vicinity of.... 220 , $299,307-308,319$

Colton ditch, measurements of ........... 215

Colton Terrace Water Company, stream measurements at station of..... 215

('onsolidated Water Company's Pomona plant, weir of, measturements at.

Convict Creek, measurements of...........

Copper City, stream measurements near ...

Copper Creek, measurements of...........

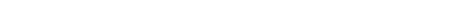

Cosumnes River, measurements of ......... 100

Coulterville, rainfall at ................. 439

Covina Irrigation Company, pumping plant of, stream measurements at....

Covina, well at, measurements of..........

Cow Creek, Tuolumne County, measurements of ......................

('rafton canal, measurements at headworks of . . . . . . . 16........... 159, 162

(rafton ditch, San Bernardino County, measurements at head of.......

Craftun Water Company's pumping plaut, stream measuremerts at ....... 
Page.

Crocker-Hoffman canal, measurements near ...................... 153

Crockers (sequoia post-office), rainfall at.. Crown Creek, measurements of ...........

Crown Meadow, stream measurements

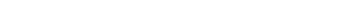

Cucamrmga Creek, measurements of .....

Cneamonga Land and Water Company, weir of. stream measurements of....

Currier's lam site, stream measurements above. ......................

Cuyamaca, rainfall at...................

Cuyamaca reservoir, rainfall at ............ run-off in watershed of..............

Daley ditch, measurements of........... 216, 319 Sce also Meeks \& Daley ditch.

Daniels \& Overholtzer well, measurements of.

Daty \& Sons, well of measurements of ....

Davis ranch, stream measurements at ....

Deacon well, measurements of............

Deep Creek, rainfall at .................. $\quad 459$

Deer Creek, measurements of ..... is-\$1,110. 363

Del Monte Water Company, weir of, stream measurements at .............

Del Rosa canal, measurements of ............

Delihi mine, stream measurements near...

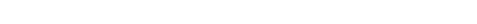

Democrat springs, measurements of ........

Dering Creek, rainfall at .............. 474

Descanso, rainfall at ................. 35.5, 463

Devils Gate, stream meusurements at and near ...................... 45,186

Dinkey creek, measurements of.......... 110

Dinsmore Creek, measurement of....... 81,321

Discharge tables, list of ............... 32-409

Dobbins Creek, measurement of.......... 81

Dog Valley Creek, measurements of ...... 365

Donner Creek, measurements of ....... 363,365

Donner Lake, measurements near.........

Dos Pueblos Creck, measurements of ....... s1, 321

Dotta, ur Lower Big spring Branch, measurements of ...................

Douglas and McQuilly well, measurements of.

Doyles diteh, measurements near ..........

Dry or Jackson Creek, measurements of ... \$2-81

Dry Meadows, stream measurements at.... 100

Duarte canal, measurement of .......... 2.28

Duarte Mutual Improvement and Canal Cumpany, strum ineasurements at station of .............

Dunsmuir, rainfall at ................ 469

Durkee ditch, measurements of ......... 300,320

Dusy Meadows, stream measurements at... 111

Dutton's, stream measurements near ...... 1s1

Eaton canyon, stream measurements in ...

East Riverside district, stream measurements in.

East Riverside ditch, measurements of .... East Twin Creek, measurements of ......... East Whittier ditch, measurements of .....

Eastwood, J. S., dam site of, stream measurements at ..................

Eaton Wash, measurements of wells in .... Edgewood, rainfall at
Edwards bridge, stream measurements near . ...................

El Capitan Creek, measurements of ....... 321

El Monte Narrows, stream measurements near .......................

El Monte road crossing, stream measurements at.................... $\quad 243$

Elrorado. rainfall at .................. 422

Eldorado bridge, stream measurements at.. $\quad 409$ Eldorado ditch, measurements of ......... 41

Eldorado flume, measurcments of......... $\quad 40$

Eleanor Creek, mcasurements of ........ 383-385

Eleanor Lake, measuremonts at.......... 385

Eleanor trail crossing, measurements at.. $3 \times 2-383$

Electra, flood measurements at .......... 411

stream measurements at .......... 168,173

Elevation, increased rainfall with, ciagram showing ................... 16

relation of rainfall to.............. $355-357$

Elk Creek, measurement below ......... 341

Emerald Bay, measurements of streams between Meeks Creek and ........ 367

Emerald Bay Creek, measurements of .... 367

Emigrant Gap, rainfall at ............. $\quad 452$

Enterprise, stream measurements at ...... $\quad 86$

Enterprise canal, measurements of........ 111

Eseondido Irrigation District canal, stream measirements at head works of.

Esperanza station, measurements opposite. Essex, Nev., stream measurements at ..... Eureka Lake Company's canal, reasurements at................... 409

Eureka valley, measurements in........ 337

Evans ditch, measurements of .......... 2:21,359

Evans Island ditch, measurements of ..... 221

Evans lower ditch, Riverside County, measurements if ................. 299

Evans upper diteh, measurements of..... 300,320

Evaproration at Sweetwater reservoi -..... 348

measurement of .................... $20-32$ methods of ................... 23

Excelsior Mining and Irrigation cane 1 ,measurements of ............... 409

Fall River, measurements of ............. Is?

Falls cretk, measurements of ............. 386

Farmers diteh, measurements of .......... 323

Farrell ditch. ice Logsdon de Farrell ditch .................... $\quad 217$

Ficuy (reek, measurements of ........... 87

Filmore, measurcments 1 mile eust of .... 323

Fish Fork, stream measurements near ..... 23í

Flouds, measurements of .............. 4J0-1J1

Florence, A riz., flood measurements of Gila

River at................... $\quad 410$

Floriston, stream measurements at....... 364

Feather River, measurements of .......... si -87

Follows Camp (Azusa), rainfall at ........ 434

Folsom, stream measurements at an near. 40,41

Fort Bidwell, rainfall at................ 440

Furt Crook, rainfall at.................. 468

Fort Jones, rainfall at ................. 470

244 Fort Mountain, stream measurements east

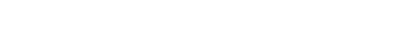

261 . Fort Tejon, rainfall at............... 429

8.5 Fort rejon Creek, measurements of....... 87

469 , Fosters, stream measurements near....... 203

IRR $81-1) 3-31$ 
Fonutain of Life Spring, stream measurement at................... 213,214

Fout s. springs, rainfull at .............. 421

Fowler switch canal, measurements of .... 110

Frazier mine, rainfall at ................. 4 tit $^{\circ}$

Freemans Bridge, Yuba River, measurements at .................. $40 y$

Freeport, stream measurements at ........ 1,4

French House, stream measurements at.... 1.81

Fresno Creek, measurements of .......... $88-90$

Frey's ranch, stream measurements at.... 31

Frog Creek, measurements of ........... 385

Fuller ditch, measurements of ........ 311,320

measurements above ............... 311

Fulton, D., well of, measurements of...... 247

Gage canal (Santa Ana River), measurements of ................. 216,319

Galligers Ford, stream neasurements at ... 308

Gardnerville, Nev., stream measurements at and near.................. $6_{2}^{2}$

Gato Creek, measurements of ........... 91-93

Gazoo Creek, measurements of........... 94

General Creek, measurements of ......... 36 i

Georgetown, rainfall at .............. 49.

Gila Bend, flood measurements of Gila River at ................... $\quad 410$

Gila River, Ariz., flood measurements of... $\quad 410$ Gilliland's ditch, measurements of...... 311,320 Glassell tributary, measurements of....... 133 Glen Brook, Ner., measurements of ten small streams between Bijou

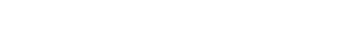

Glen ranch, rainfall at................

Glendora, stream meusurements at .......

Goodwin Mining Company's canal, measurements at ...................

Gorman Creek, measurements of.......... Gormanstation, stream measurements near. Gould canal, measurements of............ Granite Creek, measurements of ........ 110, 261 Grass Valley, rainfall at................ 4 . Graves and Bean tunnel, stream neasurements at....................

Gray and shaws, stream measurements at. Grease (Santa Clara) ditch, measurements of ........................

Green Creek, measurements of...

Green Spot pipe line (Santa Ana River), measurements of ........ 284-286,318

Grindstone Creek, measurements of....... 341

Gubernador Creek, measurements of...... 94, 321

Hackett Meadows, nt ream measurementsat. $\quad 96$

Half Hoon Bar, measurements near....... t3

Half Hom Bay, stream measurements atbove..................... $1 \times 1$

Hall ditch, measurements of............ 341

Hamptonville, stream measurements at.. 262-264 Harris Creek, measurements of........... 100 Harrey's ditch, measurements of ........ 64 Haskell well, measurements of ........... 317 Hat Creek, measurements of ........... 18. Hauser Brotliers well, 1nea-urements of ... 247 Hawkins Creek, measurements of ........ 64 Haws \& Talmage ditch, measmrement of. 217,319 Hays \& stratton well, measurements of.... 2t 24 Hennesseys, stream measurementis at..... d5
Page.

Herndon, flood measurement. at ......... 411 stream measurements at .... 259-260,2605-268 Hetrh Hetchy dam site. measurements at...................... $3 \times 1,3 \$ 2$

Hetch Hetchy Valley, stream m easurements in ....................... 391,385

Highland, W. A., stream measirements at. 244 Highlands canal, measurementi of ...... 287,318 Hirze Mountain, stream measurements at.. $1^{*} 2$ Holcomb Creek, rainfall at............... 460 Hollenbeck ranch, stream measurement. near..................... 207

Honey Lake, measurements of........... 94

Honey Lake Basin, measurements at .... 343.34

Hood, William, reference to.............. 14

Hooper ditch, measurements of .......... 101

Hornbrook, rainfall at ............... 470

Horse Creek, measurements of ............ $9 i$

Horse Meadows, stream measurements at.. 101 Horseshoe Bend, stream measurements at . $\quad 154$ Hot Springs, stream measurem`nts at..... 101 House Creek. Ser Tejon House Creek. Huffs Bar, stream measurements at ....... $\quad 86$ Hunter Creek, measurements of........... 316 Huntoon ranch, stream measu"ements at.. 401 Hydraulic Mining Company's canal, measurements of ................. 393

Iceland, stream measurements at .......... 364 Idlewild, measurements of streams between McKinney'sand............. 367

Illilonette River, measurements of......... 154 Independence Creek, measurements of .... 366 Independence Lake, measurements at ..... 366 Indian Creek, measurements of ........... 64,86 Indian Hill, stream measurements at ...... Indian Valley, stream measurements at ... 86 Iowa Hill (Strawberry Flat), rainfall at ... 453 Iron Canyon, stream measurements at... 191-192 Iron Fork, Sun Gubriel River, measurements near ............... $239-240$

Isabella, rainfall at.................. $\quad 429$

stream measurements at .............. 101 Jacinto, rainfall at .................... 425 Jarkass Creek, measurements of.......... 261 Jackson, rainfall at. .................... 420 Jackson Creek, measurement of ........ 82-84,100 Jacksonville, stream measurements at.... 385 Jelly: Ferry, flood meastirener ts at....... 411 stream measurements at ........... 193-198 Joe Gray Creek, measurements of ......... 364 Jolon, flood measurements near.......... 411 rainfall at ...................... 441 stream measurements at........... 206, 207 Julian, rainfall at ................... 355, 464 Julian $\&$ ranch, flood measuren ents at .... $\$ 11$ strcam measurements at ........... 342 rainfall at ...................... $\quad 426$ Juniper Creek, measurements of ......... 364 Jurupa canal, measurements $0 f^{*} \ldots \ldots \ldots \ldots . \quad 306$

Sie also North Riverside and Jurupa canal. Kansas City syndicate, deve'opment of, stream measurement-along.... $31 \%$

Kaweah ditch, measuremcnts of ......... 95

Kaweah River, measurements of ......... $95-99$ Keeler, rainfal] at.................... $4: 27$ Keene, rainfall at $\ldots \ldots \ldots \ldots \ldots \ldots \ldots \ldots . \quad 430$ 
Page.

Keenebrook station, stream measurements at ...........................

Keller Creek, measurements of ...........

Kern Comnty, evaporation in Tulare Comty and.

Kern Lake, evaporation at ................ strenm measurements below ...........

Kern River, evaporation at ............... flood measurements of ............... measurements of ................... 99-109

Kern River Power Company, stream meaurements above station of ......

Kernville, rainfall at. stream measurements near

Killion's pumping plant, stream measurements at...

King City, rainfall near ................. stream measurements at and near.... $20 \overline{7}, 208$

King River. evaporation at ............. 2i-31 flood measurements of ............... $\$ 11$ measurementio of .................... 109-119

King River Basin, rainfall in ............ 19

Kings River Canyon, stream measurements near .................... 110

Kingohury, evaporation at .............. 27-31 stream measurements at ............. 111

Kingsbury canal, measurements of ....... 110

Kiser well, measurements of ............ 247

Knights Ferry, measurements near ..... 338-340

Knights Landing, stream measurementsat. $\quad 187$

Kono Tayee, rainfall at................. 432

Kull well, measurements of.............. 247

La Liebre, rainfall at.................. 435

La Verne Land and Water Cn., well of, measurements of ...............

Lagrange, flood measurements at........ 411 stream measurements at . ........ 385, 386-392

Lagrange dam, flood measurements of Tuolumne River at ............

Lagrange ditch, measurements of........ 393

Laguna, rainfall at...................... 464

Lake Eleanor, stream measurements at.. 384-385

Lake Tahoe, evaporation at............. 20-21 mea-urements at outlet of ........... 361

of streams flowing into......... $367 t-369$

Lake Vernon, stream measurements at.... 346

Lakeport, evaporation at............... 31-32 rainfall at ........................ 433

Lamanda Park, stream measurements at..

Lancaster, c. L., weir of, stream measurements at.

Lancha Plana dam, measurements at.....

Laporte, rainfall at... .................

Larsens, stream measurements above......

Lathrop, stream measurements near.......

Latrobe, stream measurements at.........

Laux ditch, neasurements of ..............

Leavitt, stream measurements at ..........

Leerining, strean measurements at .......

Liddel, Robert, weir of, stream measurements of .....................

Little Bear Valley, rainfall at.

Little frass Valley, stream measurements

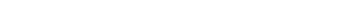

Little John canal, measurements of........
2.16 460

Page.

Little Kern River, measurements of ...... $\quad 100$

Little Lake, mersurements at............ 241

Little Rock Creek, measurements of...... 119

Little Rock irrigation district, stream measurcments in

Little Silver Crcek, measurements of ..... $\quad 40$

Little Stony, rainfall at ................. 422

Little Truckee River, measurements of .... 366

Little Walker River, measurements of .... 402

Live Oak Suspension Bridge, Sacramento County, stream measurements at.......................... $72-75$

Lobetus Creek, measurements of......... 119

Lodi, stream measurements at............ 168

Logsdon \& Farrell ditch, measurements of . . ..................... 21 21,319

Loma Abajo, measurements of......... 1:0-123

Lone Star Yills, stream measurements at. 170-172 Lone Star Spring pumping plant, measurements at....................

Long Valley, stream measurements at ..... Lopez Creek, measurements of ..... Lordsburg M[esa, stream measurements on. 247 Lns Angeles, rainfall at ............... 355, 435 Lns Angeles River, measurenients $o^{f} \ldots . .103-137$ Los Flores Canyon, stream measurements in...................... 13i-138

Los Gjitos dam site, stream measurements at ........................... 206

Los Frobles Water Company's reservoir, measurements in.............. $\quad 245$

Lougherydam site, stream measurements at. $\quad 46$ Lower Lake, stream meacurements at..... 52-53 Lower Murphy ditch, measurenents of .... 101 Lower Piru Creek, measurements of ....... 181 Lower Stafford ditch, measurements of .... 101 Lower Tule canal, measurements of....... 376 Lundy Lake, stream measurements near... 173 Lytle Creck, measurements of....... 139, 113,318 Lytle Creek canal, measurements of . . . . 141-146 Mccloud River, measurements of......... 152 MeFarlands Bridge, measurements at.... 375,380 McIntyre ditch, measurements of....... 217,319 Mr.Kenzie ditch, measurements of ....... 217,319 McKinney Creek, measurements of ....... 367 MrKinneys, measurement of streams bctween Idlewild and ........... $\quad 367$

Yagic Hill, Nn. 1, rainfall at............. 436

Main River, measurements of............ $\quad \downarrow 1$

Main Silyer Creek, measurements of $o^{f} . . . . \quad 41$

Malaknff mine, rainfall at............... 445

Mammoth Creek, measurements of ....... 173

Manache Yeadows, stream measurements at ......................... 99,100

Manzana, rainfall at .................. 436 Maria Ignacia Creek, measurements of... 148,321 Mariposa Creek, measurements of....... 149-151 Martis Creek, measurements of........... 364 ILarșille, stream measuremeuts at..... 8., 407 stream measurements between smartsville and ................... $40 \mathrm{i}$

Mas. $($ and $M$. Company's dam, measurements at................... 154

Massey wells, stream measurements of... 246-217 Yatthews ranch, rainfall at.............. 441 
Matthews ranch, stream measurements near.......................

Mayberry Canyon, measurements in...... Meeks \& Daley ditch, measurements of.... Meeks Creek, measurements of streams between Emerald Bay and ........

Meiggs Creek, measurements of........... Mendota, stream measurements at........ Merced Falls, stream measurements at and near ............. 153,155-157, 158 Merced River, measurements of ........ 152-15s Merced River M[ills canal, measurements of. 153 Middletown, rainfall at ................. 433 Mill Creek " $A, "$ rainfall at .............. 460 Mill Creek " B," rainfall at .............. 461 Mill Creek, measurements of..... 111, 173, 31s, 33 7 Mill Creek (Santa Ana River), measurements of ................. 158-163

Mill Creek, measurements of, at junction Love and Morgan reeks.......

Miller \& Lux canal, measurements of ..... 261 Miller Bridge, strenm measurements near . 2til Millers Narrows, atream measurements at, $117-148$ Milo, rainfall at .................... 473 Milton, measurements near.............. 208 Mission diteh, measurements of.......... 246 Mission Creek, measurements of ........ 163,321 Moresto, stream measurements at . ..... 396-399

Mohave River, measurements of ........ 164-167 meteorologicand hydrographie workat.

Mokelumne ditch, measurements of ...... 169 Mokelumne Hill, stream measurements at...................... 168-169

Mokelumne River, flond measurements of . 411 measurements of . ................ 16s-173

Mono Creek, measurements of . ..... 261,326-327 Mono Lake drainage basin, measurements

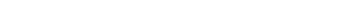

Mono tributary, measurements of Santa Inez River above junction with .................... 325-326

Monrovia Canyon, stream measurements at $\mathbf{2 4 5}$ Monrovia Water Company. stream measurements at weir of...............

Montague, rainfall at .................. stream mexsurement south of

Monte Vista eanal, measurements at head. works of .....................

Mcorwaw \& Son, well of, measurements of.

Morengo Canyon, streanı measurements at weir in ......................

Morengo Water Company, stream measurements at weir of................

Mormon Canyon, flood meaşurement of .. Morningside ranch, weir of, stream measurements at ...................

Morton Canyon, stream measurements at. Morton Canyon Water, measurements of... Mount Breckenridge, rainfall at ........... Mount Diablo, rainfall at ................ Mount Diablo meridian, stream measurements at....................

Mount Hamilton (Lick Observatory), rainfall at.

Mount Lowe (Echo Mountain post-office) rainfall at
Page.

Mount Sister Elsie, rainfall at........... 436

Mount Whitney Power Company flume, measurements at ..............

Mrount Whitney power plant, stream measurements near.............. 95

Mountain districts, gages used ........... 14

Mountain Home, rainfall at............. 473

stream measurements at ........... 160-161

Mullard well, stream measurements of .... 247

YIumford Hill. rainfall at .............. 456

IIutah Flat, rainfall at ............... 476

Myers ditch, measurements $o^{*} \ldots \ldots \ldots \ldots . \quad 95$

Nacimiento Creek, measurem ?nts of ....... 205

Nameless Mining Company's cam, measurements of ......................

Narrows fume, stream measurements at...

Natoma ditch, measurements of ...........

Teedles Peak, stream measurements at ....

Neil's ditch, measurements of ..............

Nellie, rainfall at. . . . . . . . . . . . . . . . . .

Nelson Creek. measurements of ............ Nelson's, stream measurements between Indian reservation and .........

Neuruff, stream measurements at .......... Nevada City, rainfall at.................. New Deal Water Compans, vell of, measurements of ................. 247

Newberry ditch, measuremerts of ....... 311, 320 Newberry's east line (Santa Ana River), measurements of ............ 311

Newell, F. H., letter of transmittal by .... $\quad 9$

Newhall, rainfall at ................... 437

Newhall ditch, measurement 3 of......... $\quad 322$

Newhall ranch, measurements on......... $\quad 322$

Newton ditch, measurements of .......... 311

Niagara Creek, measurements of......... 337 measurements near month of ......... 337

Nigger Hill ditch, mensurements of....... 41

Niles dam, measurements at ............ 34-39

Nordhoff, rainfall at................... 476

Norris well, stream measurements of...... 247

North Bloomfield, rainfall at........... 447

North Bloomfield ditch, measurements of . $\quad 409$

North Columbia, stream measurements at . $\quad 409$

North Fork canal, measurements of....... 42

Sorth Seedles Creek, measurements of .... 100

North Riverside and Jurupa canal, measurements of .............. 319,320

urements of ................. 319, 320
Oak Knoll Park, stream measurements at.. 245

Oakdale, flond meacurements at .......... 411 stream measurements at..... 329-330, 331-336 Oakdale canal, measurementsat flume near 338 Oakdale Ditch Company's flome, measureurements at ................ 338 (lld Mill Valley diteh, measurements of ... 153 Old Mission, stream measurements near ... 244 Old Ttmple ditch, measuremonts of ....... 244 One-mile Creck. measurements of......... 100 Ontario, stream measurements at .......... 78 Orland ditch, measurements of ........... 341 Oroville, stream measurements at. ........ 85-87 Owens River, measurements of ........... $\quad \mathbf{1 7 3}$ Pacific Improvement Company's tunnel, stream measurem ${ }^{\circ}$ ts at ....... $\quad \$ 3$

Pacoima, stream measuremerts at ....... 137 Padaro Creek, measurements of......... 174,321 
Hage.

Paine well, measurements of.......... 246

Pala, stream measurements ea-t of.......

Palermo canal, sonth fork. measurements

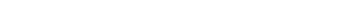

Pallett tributary, measurements on......

Palm arenue weir, stream measurement of .................... 216-217

Palm fipring. measurements of Bear Valley and.

Paim Valley, meawrements in...........

Palmdale (headworks), rainfall at .......

Panama Sloligh, evaporation at..........

Parker Creek, measurements of ..........

Parka Bar hrilge, Smartsville, measurements below.................

Parroti Ferry, measurements at....... 330,339

Pasadena, stream measurements at....... 245 well near, location of ............. 17

Pasadena Mesa, underground water (ittained from . . . . . . . . . . . . . 174-1>0

Pa-arlena weir, measurements uf......... 245

Pastoria Creek, measurements of......... 180

Patton tunnel. -trean measurement-at ...

Pattons East Canyon, stream measiurements in ...................

Peck-bridge, stream measurements at....

Pescadero Creek, measurements abore.....

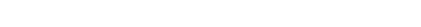

Pescadero, stream mensurements 6 miles

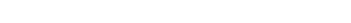

Petersuns Creek, measurementuof. . . . . . . Phillips: ranch, stream measurements at. . Pierce's ('aml, st ream measurements at.... Pilarcitos Creck, measurements of ........

Pinkertun clam site, stream measurement-

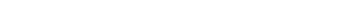

Pioneer canal, metsurements of . . . . . . 37t-376

Piru City. stream measurements at ....... 181

Piru Creek, measurements of ............. 1s1

Piru jipe line, stream measurements at

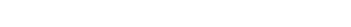

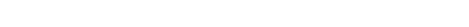
measurement of tributary of .........

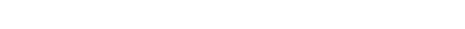
stream measurements 3 miles from ....

Placitas road, stream mea-urementsabove.

Pleasant Valley, stream measurementsat. .

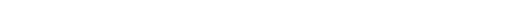

Pogues upper diti.h, measurements of. .... 9.

Pollacky, stream measurements at....... 261

Pollasky Bridge, strean measurements near 201

Pollasky Ford, stream measurements at ... ¿61

Pomona, stream measurements at ....... 317

Pomonacollege,stream measurementsnear 317

Pomona Land and Water Company, weir of, mensurements of...........

Pompronio Creek, measurements of .......

Portal, strean measurements at..........

Porterville. rainfall at. stream measuroments at and near .... 375, 37i, 377-379

Poso ('reek, measurements of .......... 183-18. Poway, rainfall at .................. $35 \overline{5}$

Powers diteh, measurements of ......... 101

Prattrille, stream measurements near .... 86 Precipitation, increace of with altitude . . 3.3-355
Page.

Priests Valley, rainfall at ............... $t 41$

Prosser Creek, measurements of.......... 366

Plente ditch, measurements of ........... 243

i) Purissima, stream measurements ahove.... 15\%

Purissima Creek, measurements of........ 195

Putah Creek, measurements of........... 186

Quinton Creek, measurements of ........ 402

Rabel ditch. measurements of ........... $\quad 319$

Rabel dam ditch, measurements of ........ 218

Rainfall at swcetwater reservoir.......... 348

diagrams and tables showing ......... 14-17

records of ......................... 13

relation of elevation to........... $352-357$

relation of run-off to ................ 14-20

tables showing amount of .......... $420-478$

Rancheria Creek, measurements of ....... 382

Ranchero ditch, measurements of........ 21s, 319

Rancho del Jurupa, rainfall at........... 461

Ravencrofts, stream measurements near... 343

Red Bluff, stream measurements at ........ 191

Red Hill, stream measurements at and

near ................... $76-78,317$

Red Iountain, flood measurements at.... 411 stream measurements at ..... 111-112,116-119

Redding, rainfall at................. $\quad 468$

Redlands, rainfall at................. 4 ti

Redlands canal, measurements of........ 318

Redland or Bolen tunnel, measurement

$$
\text { rif......................... } 291
$$

Redlanda or Soutl Fork (Santa Ana River). measurements of .......... 290-291

Redlands tunnel, stream measuremonts at. 318

Redlands Power Company, stream measure. ments at intake of............ 161

Reeder Lake, evaporation at ............. 24

Reedley, stream measurements north of ... 111

Remamettes, stream megsurements at .... 245

Reno, Ner., eraporation at.............. 21-22 rainfall at ........................ 355

Rhinedollar Lake, stream measurement; near ...................... 173

Rialto, stream measurement ahove..... 141-146 Richards, wells of, stream measurements of. $\quad 247$ Richfield station, stream measurements at. 341 Rincon, stream measurements at and near. 309

$313,314,315-316,320$

Rincon (reek, measurement of ........ 186,321 Rineon ditch, measurements of.......... 244

Rings station, rainfall at ................ 462

Rio Bravo ranch, evaporation at......... $\quad 26$

stream measurements at . . .......... 10:-105

Rin Honda or Old San Gabriel, measure. ments of.

Riverside, stream measurements in vicinity of........................ 215

$220,299,307-308$

Riverside county line, stream measurements at.................... 221

Riverside Mesa, stream measurements above........................

Rivervide Narrows, stream measurements

at and near $\ldots . . . \ldots . \ldots . .221$,
$309,314-315,320$

Riverside Water Company, lower canal of, measurements of . ....... 307,319,320 mill flume of, stream measurements at. $\quad 319$ 
Fiveroidr. Watır compans, mill wump of melsuremente uf ............ 819

-tation cif, itream mcasurements at . 218-214 ujper canal of, measurements of. $20,307,319$ Rivertum, stream measurements at....... 411 Ruaring creek, measurements of........ 110 Finhurs diteh. measurements of ......... 81 . Liohinson creek, measurements of......... $4(t)$ Rohertson mill, stream measurements at... 141 Robinsons Ferry, stream measurements at. $\quad 334$ Rockford bridge, stream measurements at. $\quad 37$ Rodgers wall, measurement of ......... 247 Rodney Soper well, measurements of ..... 24. Rodriguez diteh, measurement of........ 244 Rogers fumping plant, stream measurement<at.

Roubidux canal, measurements of ...... 2.21 Roubirloux ditch, measurements of. . 807, 319-820 measurements of Santa Ana River bo low

Rubicon River, measurements near...... 42 Ruddoek well, measurements of ......... uti Rumsey, rainfall at ................. th stream measurements at ......... in

Run-off, relation of rainfall to .......... 14-20 rclations of rainfall tr, diagramb ancl takles showing ............. 1t-17 table for converting depth of. in inches, into acre-feet per square mile.. 1i

Fush Creek, measurements of ......... 17:

Rutherford \& Co., well of, measurements of ..................... 24

Sacramento. rainfall at. . . . . . . . . . . . 3ñ. 45 stream measurements at .......4 41, 187, 199

Sacramento River, food measurements of . 411 measurements of . . . . . . . . . . . . . . . 180. 199 rainfall in ba in of . . . . . . . . . . . . . 17-14

Sacramento slough, measuremento of..... 187 Salina Valley vater Companys Arroro Seco ditch No. 2, measurements below headgate of . ........... 203

Salinas, rainfall at $\ldots \ldots \ldots \ldots \ldots \ldots \ldots \ldots .442$ strean meanurements near. . . . . . . . 200-201

Salinas River, measurements of . . . . . . . 192-20 tributaries of, measurements of . . . . 202-20s Salmon Creek, measurements of ........ 100-101

Salmon Falls, neasurements near ........ . 40-11 Salt River, Ariz., flood measurementi of... 410 Salt springs Valley, rainfall and run-nff in . 18-19 stream measurements in............. 208

San Andreas, stream measurements at.... 53 San Antorio Canyon, stream measurements in ...................... 317 San Antonio reek, measurements of..... 206 , $209-214,339$

San Antonio River, flond measurements of . 411 utilization of .................... 211-212

San Antonio tunnel, stream measurementsat $\quad 214$

San Antonio Water Company's wells, stream measurements at.............

San trdo, rainfall at ..........

San Bernardino, strean measurements noar ................. 215-2.21

San Bernardino Valley, stream measurementsin . ............... 215-225

San Diego, rainfall at. ............ 355, 465
Page.

San Tiemas Canyon, well in, measurement

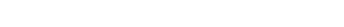

Sian Tijemas Irrigation Company, well of, measurements of ..............

-in Jirmals Wasb, wells in, measurements ،f . . . . . . . . . . . . . . . . 246

San Fernando, rainfall at ............... 438

-an Furmando Creek, measuremerts of..... 225

Sin Fernando Valley, measurements at... 40

Sin Francispuito Creek, measurements of.. 225

San tiahriel Electric Company, stream measurements at fiower house of ....

San (iabriel Power Company. Los Angeles ('ounty, measurements at intake of ................... 228, $281-293$

Fan crabriel River, flond measurementa of.. 411

measurements of . . . . . . . . . . . 225-258

Gal caliriel Sanitarium tumne1, stream measurementsat............. $\mathbf{2 4 t}$

San Gurgonio Pass, rainfall at . .......... 457

San (iregorio ('retk, measurements of ..... $\quad 259$

san Jomyuin River, flood measurement of . 411

measurements uf . . . . . . . . . . . . 259-268

-an Juaruin Electric Company, power house of, stream measurements at $\ldots \ldots \ldots \ldots \ldots \ldots \ldots \ldots \ldots . \ldots \ldots$

Gan Joaquin River Basin, rainfall in ...... 19 Fan Jose Creek, measurements of .... 2tit-2 74,321 Sin Lorenzo Creek, measurements of ..... 207 San Lırenzo River, flood measurements of. 411 Gan Luis Rey River, measurements of. . . . . 274 San Mateo Creek, meawurements of ... . . 275-276 rainiall and run-off in basin $0^{\circ} \ldots \ldots \ldots .18$ San Migulito ranch, measurements at ..... 205 San Perlro Creek, measurementc of... . . . . 321-322 San Rurui Creek, measurementa of ... 43, 276-279 San Timoteo Canyon ditch, measurements of ....................... $: 19$ Sam Timoteo Creek, measurenents of ..... San Ysidro Creck, neasurements of ....... 322 Fand Box, measurements at ........... 290-291 Santa Ana, stream measurements at ..... $\quad 320$ Santa Ana canal, measurements r plow .... 31\% measurements of . ............ 292-293, 310 Santa Ana Canyon, rainfall at ......... 462 Santa Ana River, flnod measurements of... 411 measurements in basin of . . . . . . . 317-320 measurements of . . . . . . . . . . . 221, 279-320 Santa Ana River flume, measurements at.. 221 Santa Ana Talley Irrigation Comoany"s canal, measurements of .........

Santa Avita Canyon, stream measurements

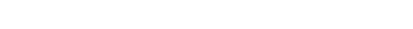

Santa Barbara, rainfall at............ 466

Atream neasurements near........... 321 Santa Barbara County, stream measurements in . ...........60-61,321-322 Santa Clara River, measurements of . . . . 32:-323 Santa Lucia, strean measurements near... 203 Santa Moniea Creek, measuremer ts of ... 321,323 Santa Paula, measurements near . . . . . . . 323-324 Santa Paula Rirer, measurements of ...... 324 Santa Ynez River, measurements of . . . . 324-327 Sawpit Creek, measurements of........ 328 Scott Valley, rainfall at ................ 471 Scoville, R. W., weir of, measurerzents at. . 246 
Pagt:

Seenni Garotte, rainfall at . ............ 4 . . .

Seerher ditch, measurements of ......... 310

Sequria National Park line. stream meanurements near. . . . . . . . . . . . 9.5 -90

Sespe Creek, metsin rement- of .......... 32

Sespe Land and Watercomplany canal, measurement at head of . . . . . . . . . Severity-six ianil. measurements of ...... 'seventy-six ditch, measurements of ...... Shasta River. measurementa of.......... Shay diteh, measurements of ............ Shay or stuut dam ditch, measurements of. Sheldun Bros. well, measurements of ..... Shingle Spring rainfall at . ............ Shorbes ranch, stream measurements at ... Shot Gun, measurements north of ........ Sierra Madre Water Company, stream measurements at weir of ...........

Signal Service and Weather Bureau, records of $\ldots \ldots \ldots \ldots \ldots \ldots \ldots \ldots \ldots \ldots \ldots$

Silver Creek, measurements of ... . . . 40.41.40.2 Silver Lake, stream measurements near ... 173 Silverthorn Ferry, stream measurements at. $\quad 1 * 2$ Simpson Meadow, stream measurements at. 110 sims, rainfall at . . . . . . . . . . . . . . 468 Sissons, rainfall at................. 471 Slate Point, stream measurements at.... 113-115 Sleider well, stream measurements of..... 247 Smartsville, stream measurements at und near ................ 407,408

Smith, F. D., well of, measurements of ... 246 Smith's, stream measurements at ........ 181 Smith s ranch, rainfall at ............ 47 Snedden's ranch, rainfall at $. . . . . . . \ldots . .47$ Suelling, stream measuremunts below .... 1, Snelling ditch, measurements of ......... 153 Snow Creek, measurements of ......... 32s Soda Creek, measurements of ............ Soldiers Camp, stream measurements below trail from Tar Gap to ...... Somers, stream measurements at.......... Sunora, rainfall at.

South Antelope Valley Water Company, stream measurements at headworks of.

South Seedles Creek, measurements of ... South Yuba Water Company, canal of. measurement of ..............

ditch of, measurements of............ Southern Pacific Railroad, records of ..... Spadra, stream measurement. near ....... Spanish Creek, measurement of ......... Spark's well, streim measurements of .... Spring Brook, stream measurements at . 308,330 spring Hill weir, stream measurements at. ...................... 214

Squaw creek. mea-urement $40 . \ldots \ldots, 152,363,365$ Squirrel Inn, raintall at . . . . . . . . . . . . . 46. Stafford and Neal diteh, measurements of . 101 Standard dain, stream measurements near. 401 standard ditch, measurements of ........ 339 Standard Power Canal, measurements of .. 169 Standifer diteh, measurementr of ........ 244 Stanislaus River, flood measurements oi... 411 measurements of . . . . . . . . . . . $329-\$ 10$ raiufall in basin of . ...............
Stanislaus Water Company's Caral, meas urtments of .............. $338-340$

Steres well, measurements of ........... 247 Stones Ferry, strean measurements at.... 69 stony Creek, foud measurementso*...... 411 measurements of . . . . . . . . . . . . . 310-342 rainfall $1, \ldots \ldots \ldots \ldots \ldots \ldots \ldots \ldots \ldots \ldots . \ldots .426$

stony ford ditch, measurements of ....... 311 stuwell, strean meanlurements at ........ 78 Stream meatsurements, methods of........ 11 record of . . .................... 11-1: sugar Pine, stream measurements at..... 310 Summit, rainfall at................... 35\%, 454 Sumner well, measurements of......... 247 Susan River, measurementi of . . . . . . . . 343-344 Susanville, rainfall at ................ 433 stream measurements near........... 343 sutter Creek, measurements of.......... 34 Sutter River, measurements of .......... 344 Swamp ditch, measurements of . ....... 219,319 Sweetwater, rainfall at ............. 355 Sweetwater Basin. evaporation in. . . . . . .2.2, 352 rainfall in . . . . . . . . . . . . . . . . . $340-347$ run-off from ..................... 347

Sweetwater reservoir, evapuration at .... $\boldsymbol{2}_{2}$ evaporation and run-off in basin oi.... 20 mea-urements at . . . . . . . . . . . . . . 348-350 Swcetwater River, floods in....... 3.52-353,410 measurements of . . . . . . . . . . . 34t-357 Sycamore Flat, stream measurements at. 23:-234 Tahoe, measurements at......... 360-361, 362 evaporation at...................... 21

Tahoe tollgate, measurements of cretek near ............................ 365

Talmage ditch, meavurements of $\mathrm{H}_{i}$ ws and. 217 Tamarack, rainfall at ................ 420 Tanners slough, measurements at........ 344 Taylor Creek, measurements of ......... 368 Tecolote Creek, measurements of ...... $3: 21,357$ , Teharhapai, rainfall at ............... 431 Tehipiti, stream measurements at........ 111 Tejon Creok. See Furt Tejon Creek.

Tejon House Creek, meavurements of..... 357

Tejon ranch, rainfall at .............. 432

119 Tejon ranch house, measurements at . . . . 357

100 Temescal, stream measurements at. . . . . 3.5-359 femescal Creek, measurements of . . . . . . $858-359$ Temple ditch, measurements of......... 243 I Tenaya River, meaturements of......... 154 Tenmile Creek, ineasurementsbelow...... 111 Thacker well, meaturements of .......... $240^{\circ}$ Thomas Creek, measurements of........ 341 Three Rivers, stream measurerients 3 milevabove................ 96

Tibbetts Creek. measurements of........ 100 Tiltill Crtek, measurements of .......... $3 \$ 5$ Timber ditch, measurements of ......... 319 Tubias C'reek, measurements of .......... 100) Toro Canyon, measurements of.......... 360 Tirwles, rainfull at ................ 45 Townsend ditch, measurements of . . . . . . 316,3:0) Trabuco Creek, measurementw of ........ 330 Trall crossing, stream measuremer ts at... 261 Trimmer springs, measurements o* . . . . 110-111 Truekee, measurements heluw......... 801 ratinfall at $\ldots \ldots \ldots \ldots \ldots \ldots \ldots \ldots \ldots \ldots . . \ldots 55,448$ 
Page.

Truckee River, measurements of........ 360-373 tributaries of, measurements of....... 363-366

True well, stream measurements of ....... 247

Trujillo ditch, measurements of...... $808,319-320$ measurements of Santa Ana River below

Tujunga, stream measurements at.........

Tujunga Railroad, stream measurements along.

Tulare County, evaporation in Kern County and $\ldots \ldots \ldots \ldots \ldots \ldots \ldots \ldots \ldots, 22-31$

Tulare Lake, measurements at ........... 376

Tule River, measurements of........... 374-380

Tumitus Creek, measurements of......... 380

Tunis Creek, measurements of ........... 381

Tuolumne Meadows, stream measurements at ........................... 385

Tuolumne River, flood measurements of... measurements of ............... $381-399,410$ rainfall in basin of ................... 19

Turlock canal, measurements of ..... 355,394-395

Twin Creeks, measurements of......... 400-401

Twin Lakes, stream measurements $\mathrm{tt} . . . . .401$

United States fishery, stream measurements at............................

Upper Holcomb Valley, rainfall at ......... Upper Lake, rainfall at.

Upper Truckee River, measurements of.... Ventura, rainfall at .....................

Verdi, stream measurements at ............

Victorville, stream measurements at ...... 166-167

Victorville Narrows, stream measurements at ......................... 164-165

Vineland canal, measurements of......... 227

Vineland tunnel, stream measurements at ....................... 226, 231

Virginia Creek, measurements of ........ 401

Vista, Ner., measurements at .......... $370-373$

Wachumna Hill, stream measurements at. 96-99

Wade Creek, measurements of ........... 100

Wadsworth, rainfall at ............... 355

Walker Creek, measurements of........... 173

Walker River, measurements of.......... $401-402$

Walkers Basin, stream measurements in ... 100

Walkers well, stream measurements cf.... 246

Walla Walla Creek, rainfall at........... $\quad 472$

Wallace well, measurements of .......... 247

Ward \& Warren ditch, measurements of . 219,319

Ward Creek, measurements of............ 367

Ward's ferry, stream measurements at.... 385
Page.

Warm spring, flood measurem ents at ..... 411 stream measurements at ..... 293-299,300-305

Warners, rainfall at ................... 466

Watumna Canal, measuremer ts of........ 95

Wawona, stream measurements at ........ 151

Weaverville, rainfall at ................. 473

Weir, tables showing measurements of .. 412-419

Weldon, rainfall at Taylor's ranch........ 431

stream measurements at .............. 101

Welton ditch, measurements at head-gate

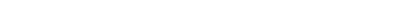

West Branch, measurements of ........... 86

West Point, stream measurements near.... 169

West Riverside bridge, stream measurements near ............... 308, 320

West Riverside pumping plant, stream measurements at ............. 221

West Twin Creek, measurements of....... 318

Wheatland, stream measurements at ..... 46

Whea ton ranch, stream measurements near. $\quad 375$

White Creek, measurements of..........403-406

Whitewater, rainfall at ............... 457

Whitewater River, measurements of..... 406-407

Whiting ditch, measurements of..... 219-220,319

Whitlock ditch, measurements of....... 220, 319

Whitney Creek, measurements of........ 100

Whittier ditch, measurements of......... 243

Wilbur ditch, measurements of .......... 316

William well, measurements of .......... 247

Williams River, Arizona, measurements of ......................... 50

Willow Creek, measurements of.......... 343

Winston ranch, stream measurements at .. 246

Winters, stream measurements above..... 186

Woodbridge, stream measurements at .... 169

Woodbridge canal, measurem onts of...... 169

Woodfords, stream measurements at and near ...................... 63,64

Yankee Hill Bridge, stream measurements at......................... 86

Yoakham's ranch, stream measurements at 246

Yorba ditch, measurements of ........... $\quad 316$

Yosemire, rainfall at .................. 499

Yosemite Valley, stream measurements in........................ 153-15̃

Yreka, rainfall at ...................... 472

Yuba River, measurements of.......... $407-109$ South Fork, flood measurements of .... 410 Yuma, Ariz., stream measurements at and near ................... 50, $69-71$ 


\section{LIBRARY CATALOGUE SLIPS.}

[Mount each slip upon a seprarate carrl, placing the subject at the top of the second slip. The name of the series should not be repeated on the series card, but the arditional numbers should be arderl as receired to the first entry.]

\section{Lippincott, Joseph Barlow.}

... California hydrography, by Joseph Barlow Lippincott. Washington, Gov't print. off., I903. th's p., 1 1. 1 17. (map), fig. $23 \frac{1}{2}{ }^{\mathrm{cm}}$. (U. S. Geological surrey. Water-supply and irrigation paper no. s1.)

subject series II, lieneral hydrographic investigations, 5 .

\section{Lippincott, Joseph Barlow.}

... California hydrography, by Joseph Barlow Lippincott. Washington, Gor"t print. off., I903. 48s p., 1 l. 1 1). (map), fig. $23 \frac{1}{2}$.' (C. S. (reological survey. Water-supply and irrigation paper no. 81.)

Subject series M, General hydrographic investigations, 5.

\section{U. S. Geological survey.} Water supply and irrigation papers no. SI. Lippincott, J. B. California hydrography. I9O3.

U. S. Dept. of the Interior. see also U. S. Geological survey. 




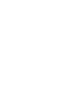

